\title{
JAZIDAS DE ESMERALDA DE CAPOEIRANA E BELMONT - MG: GEOLOGIA, PETROGÊNESE E METALOGÊNESE
}

Geysa Angelis Abreu Machado

Orientador: Prof. Dr. Johann Hans Daniel Schorscher

TESE DE DOUTORAMENTO

Programa de Pós-Graduação em Mineralogia e Petrologia

SẢO PAULO

1998 


\section{UNIVERSIDADE DE SÃO PAULO \\ INSTITUTO DE GEOCIENNCIAS}

\section{JAZIDAS DE ESMERALDA DE CAPOEIRANA E BELMONT - MG: GEOLOGIA, PETROGÊNESE E METALOGÊNESE}

\section{GEYSA ANGELIS ABREU MACHADO}

Orientador: Prof. Dr. Johann Hans Daniel Schorscher

TESE DE DOUTORAMENTO

COMISSÃO JULGADORA

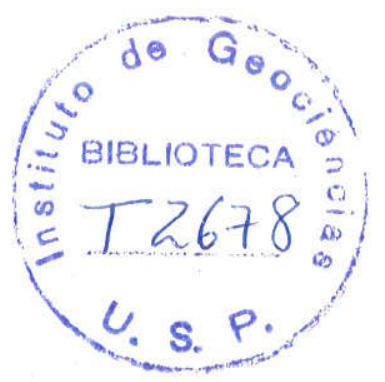

Nome

Presidente: Prof. Dr. Johann Hans Daniel Schorscher

Examinadores: Prof. Dr. Ian McReath

Prof. Dr. Jean Michel Legrand

Prof. Dr. José Marques Correia Neves

Prof. Dr. Léo Afraneo Hartmann

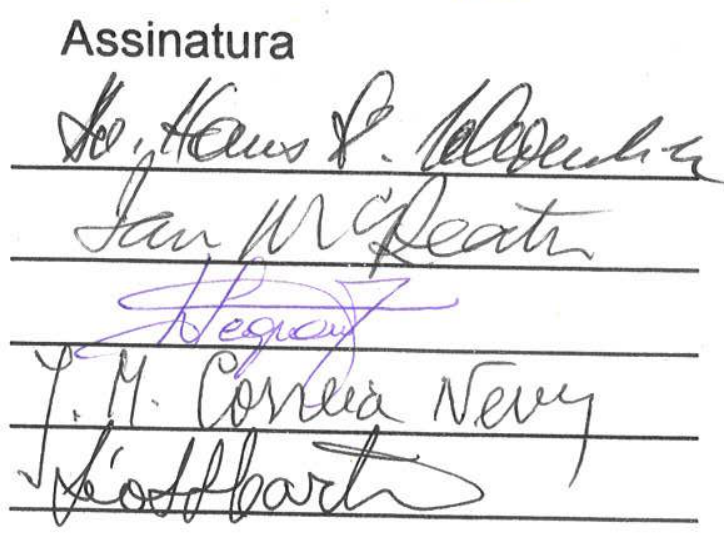

SÃO PAULO

1998 


\section{UNIVERSIDADE DE SÃO PAULO \\ INSTITUTO DE GEOCIÊNCIAS}

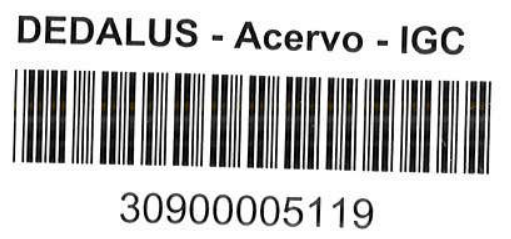

\section{JAZIDAS DE ESMERALDA DE CAPOEIRANA E BELMONT - MG: GEOLOGIA, PETROGÊNESE E METALOGÊNESE}

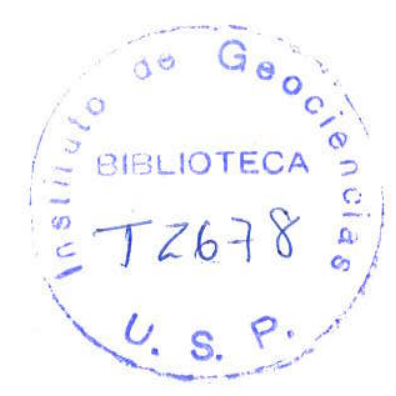

Orientador: Prof. Dr. Johann Hans Daniel Schorscher

TESE DE DOUTORADO

PROGRAMA DE PÓS-GRADUAÇÃO EM MINERALOGIA E PETROLOGIA 


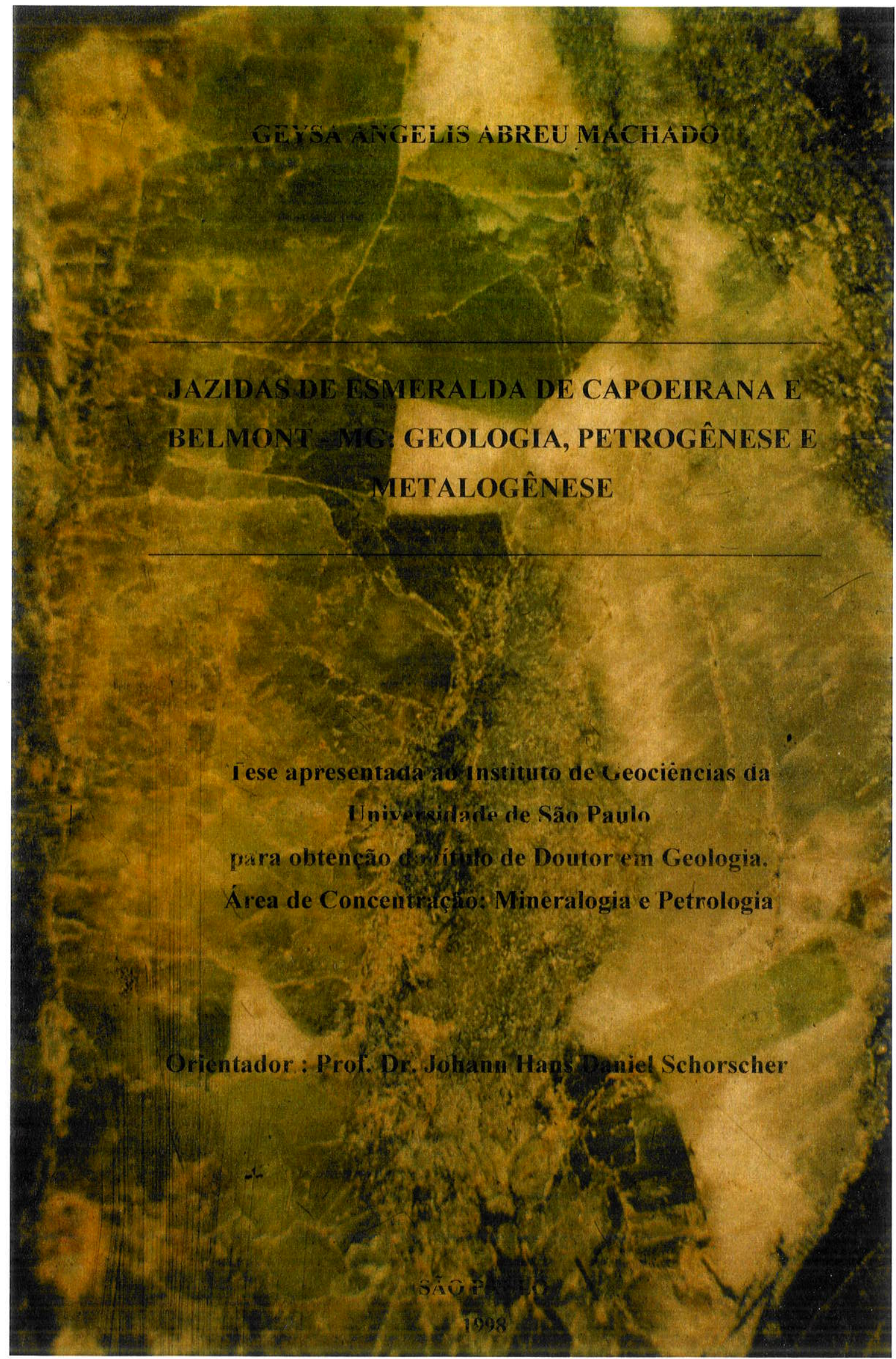

Esmeralda em veio pegmatóide de Capoeirana - Amostra NE-31 


\section{ÍNDICE}

ÍNDICE DE FIGURAS ...................................................................................................... V

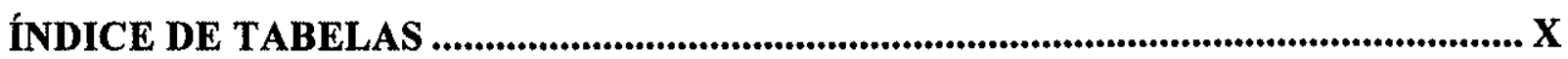

RESUMO ….............................................................................................................. XIII

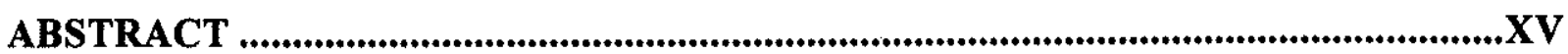

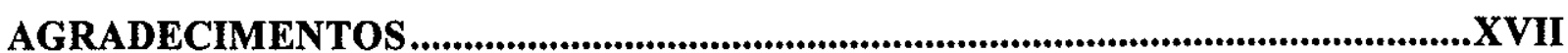

CAPÍTULO I - INTRODUÇÃO.......................................................................................... 1

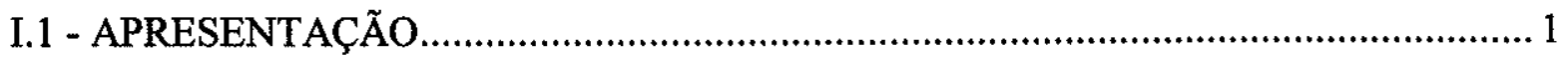

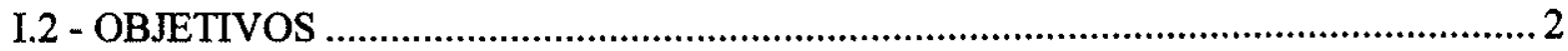

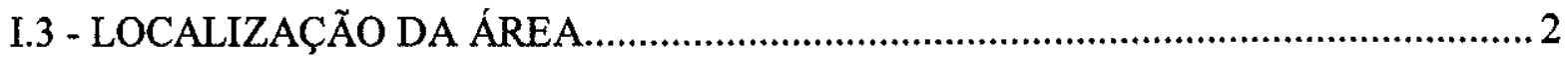

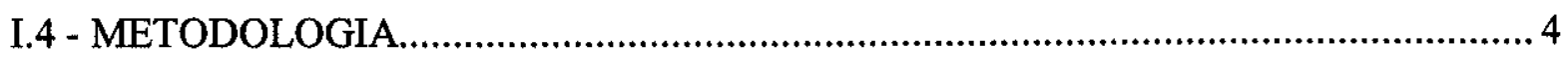

I.4.1 - Trabalhos Preliminares e de Suporte à Pesquisa ......................................... 4

I.4.2 - Análises e Estudos Litogeoquímicos...................................................... 5

I.4.3 - Estudos de Química Mineral ............................................................... 6

1.4.4 - Geotermobarometria ...................................................................... 8

I.4.5 - Geoquímica de Isótopos Estáveis .......................................................... 8

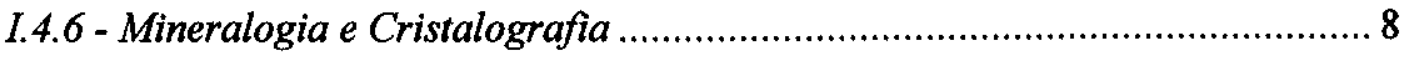

CAPÍTULO II - EVOLUÇÃo GEOLÓGICA E PETROGRAFIA...................................... 11

II.1- GEOLOGIA REGIONAL DO EXTREMO NE DO QUADRILÁTERO

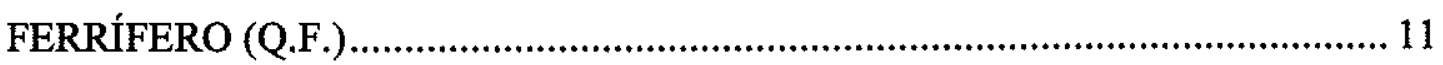

II.1.1- Sequências Supracrustais Metamórficas................................................ 11

II.1.2- Rochas Graniticas Regionais............................................................. 12

* Complexo Regional TTG Arqueano (TTG) ....................................................... 13

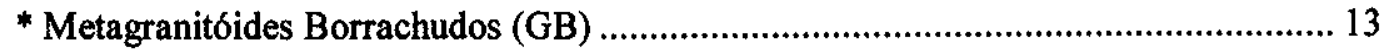

* Metagranitóides Foliados com Fluorita (MGF) ...................................................... 15

* Gnaisses Miloníticos de Derivação Incerta (GnM) ...................................................... 16

II.1.3- Tectônica e Metamorfismo - Evolução Geotectônica ……………….......... 16

II.2- GEOLOGIA DA REGIÃO DE CAPOEIRANA E BELMONT .............................. 19

II.2.1- Trabalhos Anteriores....................................................................... 19

II.2.2- Resultados deste Trabalho ............................................................... 20

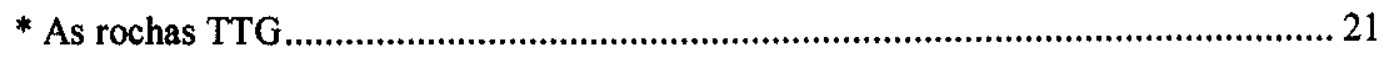


* A Sequência Metavulcano-Sedimentar (SVS) de Capoeirana e Belmont 21

* Os Metagranitóides Borrachudos (GB) e as Mineralizações de Esmeraldas Arqueanas

* Os Metagranitóides Foliados com Fluorita (MGF) e as Mineralizações Berilíferas Proterozóicas .......................................................................................... 22

* Os Gnaisses Miloníticos de Derivação Incerta (GnM) ............................................. 23

* A Evolução Neoproterozóica ................................................................................ 24

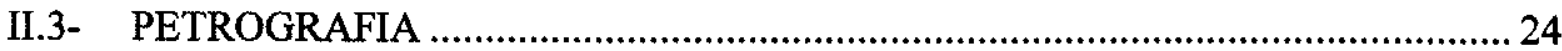

II.3.1- Metagranitóides e Veios Pegmatóides nos MGF e em Rochas da SVS ... 24

* Gnaisses TTG e Miloníticos de Derivação Incerta (GnM) .......................................... 24

* Metagranitóides Borrachudos (GB) e Metagranitóides Foliados com Fluorita

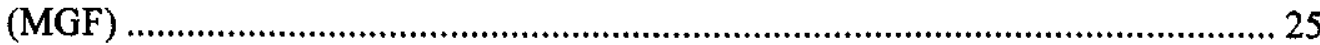

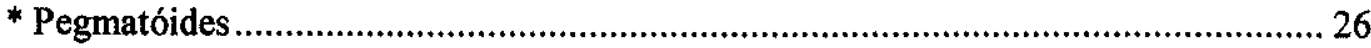

II.3.2- Sequência Metavulcano-Sedimentar ................................................... 27

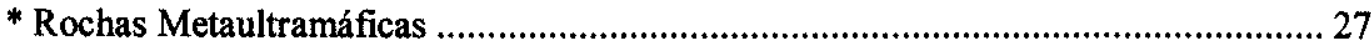

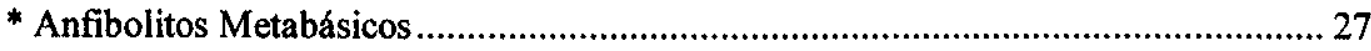

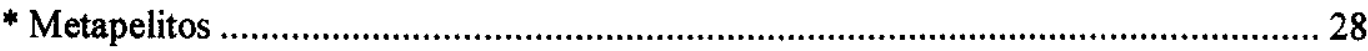

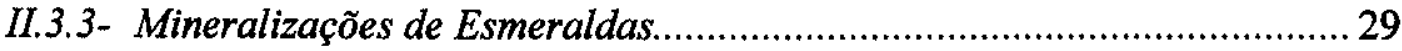

CAPÍTULO III: LITOGEOQUÍMICA .........................................................................35

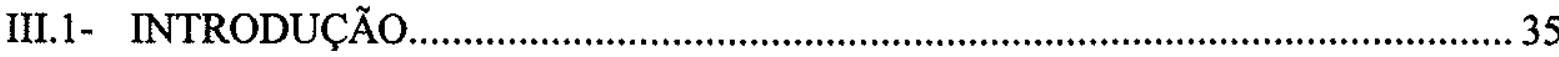

III.2- ROCHAS TTG E GNAISSES MILONÍTICOS DE DERIVAÇÃO

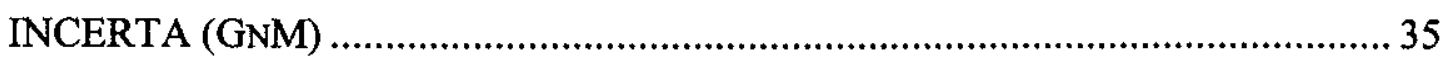

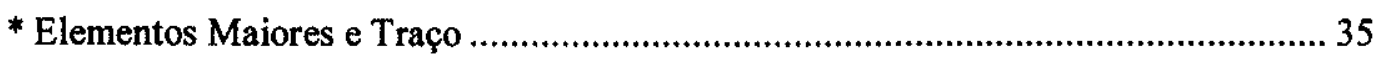

III.3- METAGRANITÓIDES BORRACHUDOS (GB) E METAGRANITÓIDES

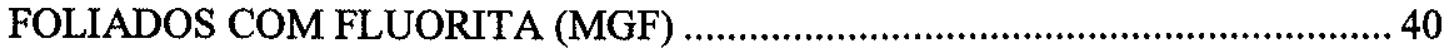

* Elementos Maiores e Traço …………….............................................................................. 40

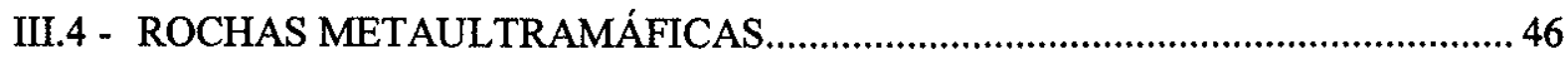

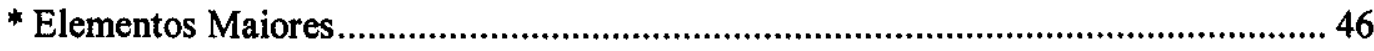

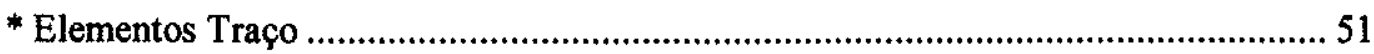

* Processo Metassomático Mineralizante.................................................................. 56

III.5 - ANFIBOLITOS METABÁSICOS E GNAISSES DE COMPOSIÇÃO

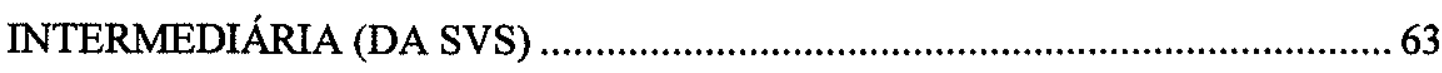

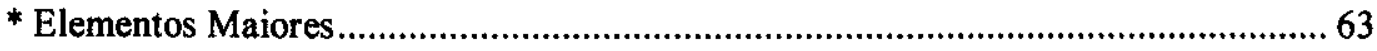

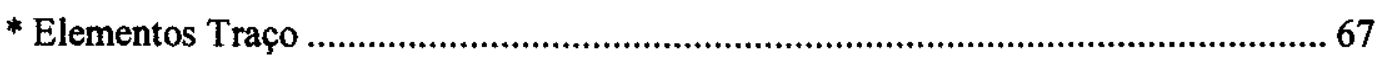


CAPÍTULO IV - QUÍMICA MINERAL .................................................................. 70

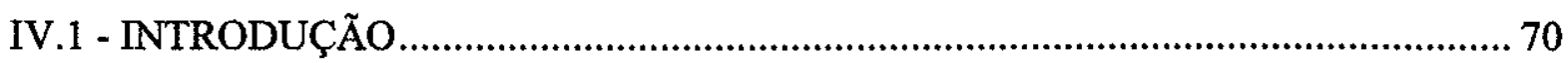

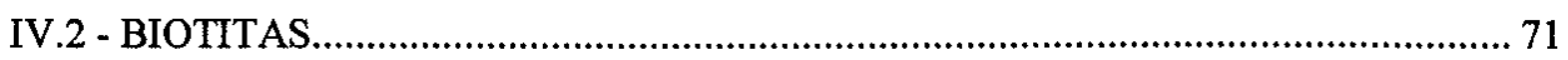

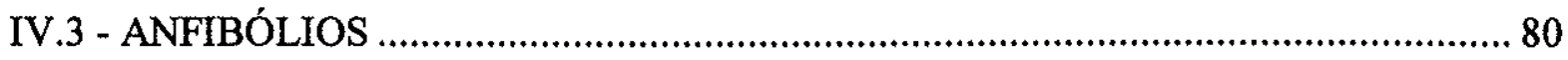

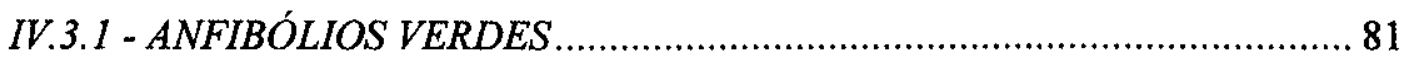

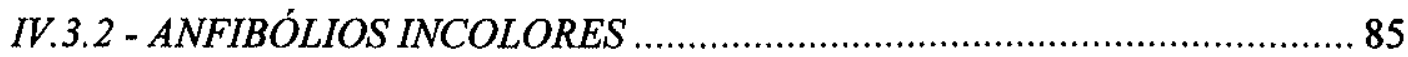

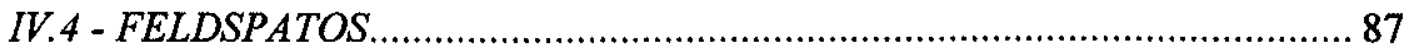

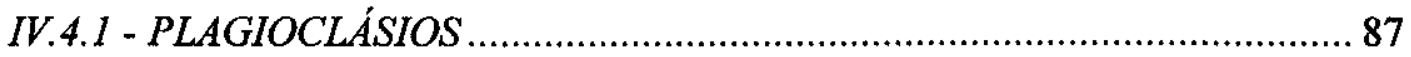

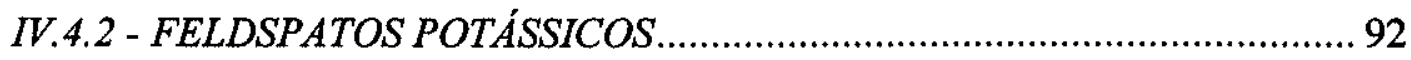

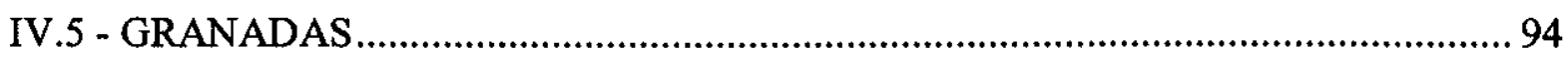

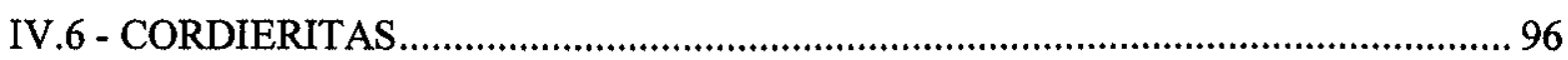

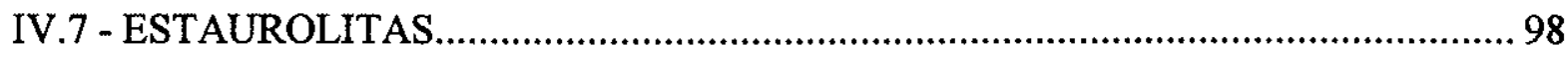

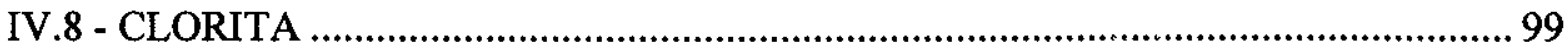

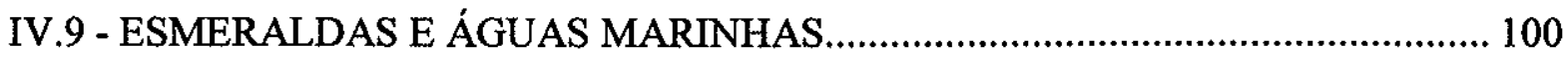

IV.10 - SINOPSE DOS ESTUDOS DE QUÍMICA MINERAL ................................... 109

\section{CAPÍTULO V - EVOLUÇÃO METASSOMÁTICA/ METAMÓRFICA}

- GEOTERMOBAROMETRIA ...................................................................... 113

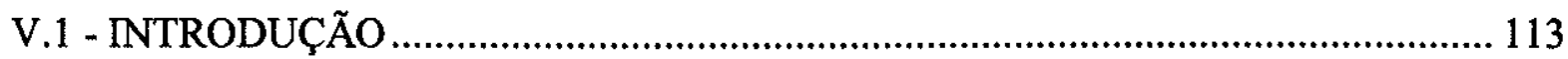

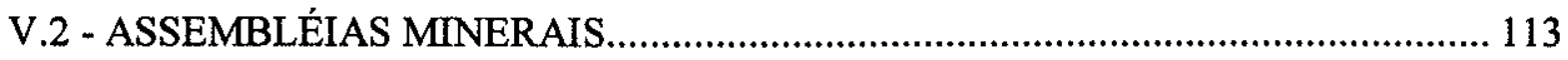

V.2.1 - Metapelitos (MP) ................................................................... 114

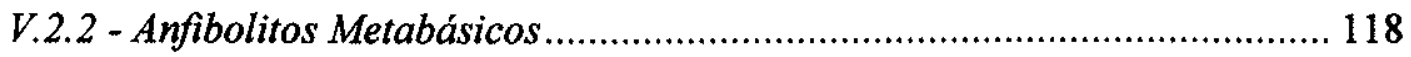

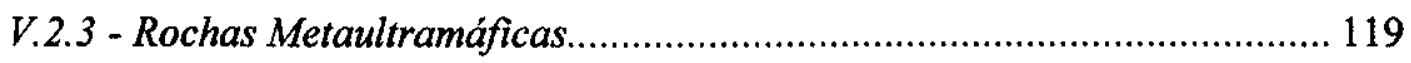

V.2.4 - Metagranitóides GB e MGF.................................................... 119

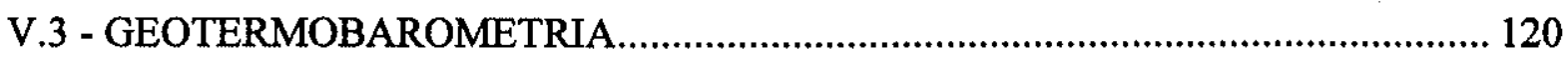

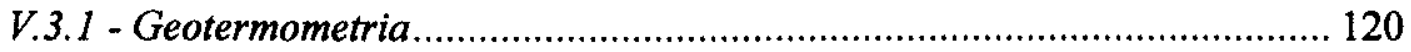

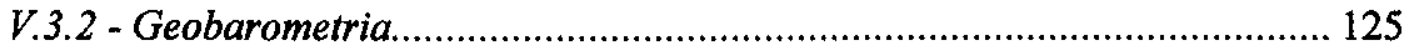

V.3.3 - Evolução Metamórfica ................................................................... 126

CAPÍtULO VI - ELEMENTOS TERRAS RARAS EM GB E MGF E EM ESMERALDAS E ÁGUAS MARINHAS ........................................................ 128 VI.1 - ETR: FUNDAMENTOS E APLICAÇÕES................................................. 128 
VI.2 - RESULTADOS 132

VI.2.1 - ETR em GB e MGF. 132

VI.5.2 - ETR em Esmeraldas e Águas Marinhas 138

CAPÍTULO VII - ISÓTOPOS ESTÁVEIS. 144

VII.1 - INTRODUÇÃO E FUNDAMENTOS 144

VII.2 - APLICAÇÕES FUNDAMENTAIS 147

* Geotermometria 147

* Interaçðes Fluidos-Rochas 147

VII.3 - RESULTADOS 149

VII.4 - CONCLUSÃO DOS ESTUDOS DE ISÓTOPOS ESTÁVEIS 157

CAPÍTULO VIII - EVOLUÇÃO GEOLÓGICA E PETRO-METALOGENÉTICA PRINCIPAIS CONCLUSÕES

ANEXO 1: MAPA E DESCRIÇÃO DE PONTOS/AMOSTRAS 183

ANEXO 2: LITOGEOQUÍMICA 197 ANEXO 3: ELEMENTOS TRAÇO, INCLUINDO ETR, DE METAGRANITÓIDES

GB E MGF E ESMERALDAS E ÁGUAS MARINHAS, POR ICP-MS 208 ANEXO 4: QUÍMICA MINERAL POR MSE E FRX. 213 ANEXO 5: CÁLCULOS GEOTERMOBAROMÉTRICOS 276 ANEXO 6: TERMOGRAVIMETRIA (TG) E ANÁLISE TÉRMICA DIFERENCIAL (DTA) DE ESMERALDAS. 280 


\section{ÍNDICE DE FIGURAS}

Figura 3.1: A maioria das rochas TTG $(+)$ e GnM (x), no diagrama de Garrels \& Mckenzie (1971), figuram no campo das rochas ígneas.

Figura 3.2: As rochas TTG $(+)$ e GnM (x) de características ígneas figuram no diagrama de Debon \& Le Fort (1983) nos campos 1, 2 e 3 de granito, adamelito e granodiorito. As duas análises externas aos campos das rochas ígneas representam mobilizado quartzo-feldspático perquartzoso no TTG (amostra G-144d).

Figura 3.3: As rochas TTG $(+)$ e GnM (x) de características ígneas figuram no diagrama de Middlemost (1985) nos campos 6 e 3 de granito e álcali-feldspato granito.

Figura 3.4: As rochas TTG (+) e GnM (x) no diagrama de Maniar \& Piccoli (1989) variam de metalumínicas a peralumínicas.

Figura 3.5: Variograma de elementos traço das rochas TTG $(+)$ e GnM $(x)$, normalizado em valores do manto primitivo - PRIM (Taylor \& McLennan, 1985).

Figura 3.6: GB (O) e MGF (O) nos diagramas $\mathrm{SiO}_{2}$ vs $\mathrm{Zr}$ (a), Y (b) e $\mathrm{Nb}$ (c) e Ga vs $\mathrm{Al}_{2} \mathrm{O}_{3}(\mathrm{~d})$.

Figura 3.7 (a,b): Os metagranitóides GB (O) e MGF (O) são ricos em $\mathrm{Rb}, \mathrm{Y}$ e $\mathrm{Nb}$, figurando no campo WPG (granitóides fanerozóicos intra-placas).

Figura 3.8: Diagramas multielementares de GB (O) e MGF(O), normalizados em: (a) valores do manto primitivo - PRIM e (b) crosta continental (Taylor \& McLennan, 1985); (c) granitóides de cadeia oceânica - ORG (Pearce et al. 1984).

Figura 3.9: Diagrama de perdas e ganhos dos elementos $\mathrm{Rb}, \mathrm{Ba}, \mathrm{Sr}, \mathrm{Nb}, \mathrm{Y}, \mathrm{Th}, \mathrm{U}, \mathrm{Cr}$, $\mathrm{Ni}, \mathrm{Co}, \mathrm{V}, \mathrm{Cu}$ e Pb em GB (amostra G-29d) relativo a TTG (amostra SC-136 de Schorscher, 1992) (cf.: Hildreth, 1981).

Figura 3.10: Diagramas de perdas e ganhos de elementos em MGF (amostra G-13a) relativo a GB (amostra G-29d): a) $\mathrm{Cs}, \mathrm{Rb}, \mathrm{Ba}, \mathrm{Sr}, \mathrm{Ga}, \mathrm{Ta}, \mathrm{Nb}, \mathrm{Hf}, \mathrm{Zr}, \mathrm{Y}$, Th e U; b) $\mathrm{Cr}, \mathrm{Ni}, \mathrm{Co}, \mathrm{Sc}, \mathrm{V}, \mathrm{Cu}, \mathrm{Pb}, \mathrm{Zn}, \mathrm{Cd}, \mathrm{Mo}, \mathrm{As}$, Se, Pd, Ag e Pt (cf.: Hildreth, 1981).

Figura 3.11: Diagramas de correlação Óxidos versus $\mathrm{MgO}$ para as rochas metaultramáficas, cromititos e equivalentes flogopitizados.

Figura 3.12: Diagramas de correlação Óxidos $v s \mathrm{~K}_{2} \mathrm{O}$ para as rochas metaultramáficas, cromititos e equivalentes flogopitizados.

Figura 3.13: Diagramas de correlação Óxidos $v_{s} \mathrm{Al}_{2} \mathrm{O}_{3}$ para as rochas metaultramáficas, cromititos e equivalentes flogopitizados.

Figura 3.14: As rochas metaultramáficas figuram nos campos dos komatiitos basálticos a peridotíticos (Jensen, 1976). Símbolos: AU (O), AFX ( $\square)$, TACX ( $\Delta$ ), CLT ( $\Delta$ ), CRT (X), CRTM $(+)$.

Figura 3.15: O diagrama AFM evidencia a natureza pouco diferenciada das rochas metaultramáficas não metassomatizadas [AU $(\mathrm{o}), \operatorname{TACX}(\Delta), \operatorname{CLT}(\Delta), \operatorname{CRT}(\mathrm{X})]$ e os enriquecimentos em $\mathrm{Na}_{2} \mathrm{O}+\mathrm{K}_{2} \mathrm{O}$ das rochas metaultramáficas metassomatizadas [AFX ( 
Figura 3.16: Diagramas de correlação de $\mathrm{K}_{2} \mathrm{O}$ com $\mathrm{Ba}, \mathrm{Y}, \mathrm{Rb} \mathrm{Zr}, \mathrm{Zn}$ e Be para as rochas metaultramáficas, cromititos e equivalentes metassomáticos. Símbolos: AU (O), $\operatorname{AFX}(\square), \operatorname{TACX}(\Delta), \operatorname{CLT}(\Delta), \operatorname{CRT}(\mathrm{X}), \operatorname{CRTM}(+)$

Figura 3.17: Diagramas de correlação de $\mathrm{Al}_{2} \mathrm{O}_{3}$ com $\mathrm{Rb}, \mathrm{Ba}, \mathrm{Y}$ e $\mathrm{Be}$ para as rochas metaultramáficas, cromititos e equivalentes metassomáticos. Símbolos: AU (O), $\operatorname{AFX}(\square), \operatorname{TACX}(\Delta), \operatorname{CLT}(\Delta), \operatorname{CRT}(X), \operatorname{CRTM}(+)$.

Figura 3.18: Variogramas de elementos menores e traço dos AU (a) e AFX (b), normalizados em PRIM (Taylor \& McLennan, 1985). Nota: Os valores analíticos nulos foram substituídos pelos limites de deteç̧ão dos respectivos elementos nos métodos utilizados.

Figura 3.19: Variograma de elementos menores e traço dos AFX, normalizados pela média dos AU. Nota: Os valores analíticos nulos foram substituídos pelos limites de deteç̧ão dos respectivos elementos nos métodos utilizados.

Figura 3.20: Variogramas de elementos menores e traço dos TACX ( $\Delta$ ) e CLT ( $\Delta)$ normalizados em (a) PRIM; e (b) nos valores médios dos AU.

Figura 3.21: Variograma de elementos menores e traço dos CRT (x) e CRTM (+), normalizados em PRIM (Taylor \& McLennan, 1985). Nota: Os valores analíticos nulos foram substituídos pelos limites de deteç̧ão dos respectivos elementos nos métodos analíticos utilizados.

Figura 3.22: Diagramas de ganhos e perdas de elementos maiores, no sentido da alteração metassomática: NE-29b (amostra menos modificada) $\rightarrow$ NE-8 $\rightarrow$ NE10.

Figura 3.23: Diagramas de ganhos e perdas de elementos maiores, no sentido da alteração metassomática: NE-29b(1) $\rightarrow$ NE-8(1) $\rightarrow$ NE-7.

Figura 3.24: Diagramas de ganhos e perdas de elementos maiores, no sentido da alteração metassomática: $6^{*} \mathrm{~m} \rightarrow$ Gal $1-5 \rightarrow 6^{*} \mathrm{v} \rightarrow$ Gal 1-6.....

Figura 3.25: Diagramas de ganhos e perdas de elementos maiores, no sentido da alteração metassomática: $\mathrm{I}-02 \mathrm{a} \rightarrow \mathrm{I}-02 \rightarrow \mathrm{I}-03$.

Figura 3.26: Diagramas de ganhos e perdas de elementos maiores, no sentido da alteração metassomática: A-13 $\rightarrow$ A-08 $\rightarrow$ A-7a.

Figura 3.27: Diagramas de ganhos e perdas de elementos maiores, no sentido da alteração metassomática: G-52e $\rightarrow$ G-52g $\rightarrow$ G-52f. .

Figura 3.28: Diagrama de ganhos e perdas de elementos maiores: a) na amostra $1^{*}$ b em relação a $1^{*}$; b) na média dos AFX (xistos com anfibólio e flogopita) em relação à média dos $\mathrm{AU}$ (anfibolitos não metassomatizados).

Figura 3.29: Diagramas de ganhos e perdas de elementos menores e traço, no sentido da alteração metassomática: a, b) NE-29b(1) $\rightarrow$ NE-8(1) $\rightarrow$ NE-7(1); c) G-52e $\rightarrow$ G$52 \mathrm{~g}$; d) média dos AU (anfibolitos metaultramáficos) $\rightarrow$ média dos AFX (anfibólio-flogopita-xistos).

Figura 3.30: Anfibolitos e gnaisses de composição básica a intermediária, da SVS, no diagrama TAS (Le Maitre, 1989). Símbolos: AB ( $)$; ABET ( $\nabla)$; ABG ( $\nabla)$; $\mathrm{Gn} / \mathrm{bag}(\triangleright)$ e AB/TTG $(+)$. 
Figura 3.31: As mesmas rochas da figura anterior, nos diagramas de Irvine \& Baragar (1971): (a) apresentam características subalcalinas; e (b) separam-se nos caminhos de diferenciação toleítica e cálcio-alcalina.

Figura 3.32 (a): Diagramas Óxidos vs $\mathrm{FeO}_{\mathrm{T}} /\left(\mathrm{FeO}_{\mathrm{T}}+\mathrm{MgO}\right)$ para os $\mathrm{AB}(\nabla)$, ABET $(\nabla)$, $\operatorname{ABG}(\nabla), \operatorname{AFF}(\diamond), \operatorname{AC}(0)$, Gn/bag $(\triangleright), \operatorname{AB} / T T G(+)$

Figura 3.33: Diagramas de correlação Elementos Traço $v s \quad \mathrm{FeO}_{\mathrm{T}} /\left(\mathrm{FeO}_{\mathrm{T}}+\mathrm{MgO}\right)$. Símbolos: AB ( $\nabla)$, AB/TTG $(+)$, ABET $(\nabla)$, ABG $(\nabla)$, AFF $(\diamond)$, AC $(O)$ e Gn/bag (b).

Figura 4.1: Biotitas/flogopitas das rochas: a) graníticas: $(\mathrm{GB}=\mathrm{O} ; \mathrm{MGF}=\Delta ; \mathrm{TTG}=\square$; PGD $=\diamond)$; b) metaultramáficas $(\nabla)$; c) anfibolitos metabásicos $(A B=\Delta ;$ ABET $=\nabla ; \mathrm{ABG}=0$ ); d) metapelíticas (amostras desta pesquisa $=0$; amostras de Schorscher, $1975=0$ ) e metagrauvaca $(\square)$. Cores: verde $=$ centro; azul $=$ parte intermediária; vermelha $=$ borda

Figura 4.2: Diagramas $\mathrm{Fe}^{+2}$ vs $\mathrm{Al}^{\mathrm{VI}}$ para as biotitas/flogopitas das rochas: a) graníticas: $(\mathrm{GB}=\mathrm{O} ; \mathrm{MGF}=\Delta ; \mathrm{TTG}=\square ; \mathrm{PGD}=0) ; \mathrm{b})$ metaultramáficas $(\nabla) ; \mathrm{c})$ anfibolitos metabásicos $(\mathrm{AB}=\Delta ; \mathrm{ABET}=\nabla ; \mathrm{ABG}=0) ; \mathrm{d})$ metapelíticas (desta pesquisa $=$ $O$; de Schorscher, $1975=0$ ) e metagrauvaca $(\square)$. Cores: verde $=$ centro; azul $=$ parte intermediária; vermelha $=$ borda .

Figura 4.3: Diagramas $\mathrm{Fe}^{+2} v s \mathrm{Al}^{\mathrm{IV}}$ para as biotitas/flogopitas das rochas: a) graníticas: $(\mathrm{GB}=\mathrm{O} ; \mathrm{MGF}=\Delta ; \mathrm{TTG}=\square ; \mathrm{PGD}=0) ; \mathrm{b})$ metaultramáficas $(\nabla) ; \mathrm{c})$ anfibolitos metabásicos $(\mathrm{AB}=\Delta ; \mathrm{ABET}=\nabla ; \mathrm{ABG}=\mathrm{O}) ; \mathrm{d})$ metapelíticas (desta pesquisa $=$ $O$; de Schorscher, $1975=\diamond$ ) e metagrauvaca $(\square)$. Cores: verde $=$ centro; azul $=$ parte intermediária; vermelha $=$ borda

Figura 4.4: Diagramas $\mathrm{Fe}^{+2}$ vs $\mathrm{Mg}$ para as biotitas/flogopitas das rochas: a) graníticas: $(\mathrm{GB}=\mathrm{O} ; \mathrm{MGF}=\Delta) ; \mathrm{b})$ metaultramáficas $(\nabla) ; \mathrm{c})$ anfibolitos metabásicos $(\mathrm{AB}=$ $\Delta ; \mathrm{ABET}=\nabla ; \mathrm{ABG}=0$ ); $\mathrm{d}$ ) metapelíticas (desta pesquisa $=0$; de Schorscher, $1975=\bigcirc$ ) e metagrauvacas $(\square)$. Cores: verde = centro; azul = parte intermediária; vermelha $=$ borda.

Figura 4.5: Diagramas de correlação $\mathrm{F}$ vs $\mathrm{TiO}_{2}$ (a) e $\mathrm{Al}_{2} \mathrm{O}_{3}$ (b), nas flogopitas das rochas metaultramáficas metassomatizadas. Cores: verde $=$ centro; vermelha $=$ borda.

Figura 4.6: Classificação dos anfibólios verdes dos GB (O) e MGF ( $\Delta$ ): a) geral; b) anfibólios cálcicos com $(\mathrm{Na}+\mathrm{K})_{\mathrm{A}} \geq 0.5 \mathrm{e} \mathrm{Fe}^{+3}>\mathrm{Al}^{\mathrm{VI}}$. Cores: verde = centro; azul $=$ parte intermediária; vermelha $=$ borda.

Figura 4.7: Diagramas de correlação para os anfibólios dos GB (O) e MGF $(\Delta)$ : a) $\mathrm{CMg} /\left(\mathrm{CMg}+\mathrm{CFe}^{+2}\right)$ vs soma cátions na posição $\mathrm{A}$; b) $\mathrm{CMg} /\left(\mathrm{CMg}+\mathrm{CFe}^{+2}\right)$ vs CAl . Cores: verde $=$ centro; azul $=$ parte intermediária; vermelha $=$ borda .

Figura 4.8: Classificação dos anfibólios verdes das rochas metaultramáficas: a) geral; b) $\left.(\mathrm{Na}+\mathrm{K})_{\mathrm{A}}>0.5 \mathrm{e} \mathrm{Fe}^{+3}<\mathrm{Al}^{\mathrm{Vl}} ; \mathrm{c}\right)(\mathrm{Na}+\mathrm{K})_{\mathrm{A}}<0.5$. Cores: verde $=$ centro; azul $=$ parte intermediária; vermelha $=$ borda

Figura 4.9: Classificação dos anfibólios verdes dos anfibolitos metabásicos: a) anfibólios cálcicos com $\left.(\mathrm{Na}+\mathrm{K})_{\mathrm{A}}<0.5 ; \mathrm{b}\right)$ anfibólios cálcicos com $(\mathrm{Na}+\mathrm{K})_{\mathrm{A}} \geq$ $0.5 \mathrm{e} \mathrm{Fe}^{+3}<\mathrm{Al}^{\mathrm{VI}}$. Símbolos: $\mathrm{AB}(\Delta)$, ABET $(\nabla), \mathrm{ABG}(\mathrm{O})$. Cores: verde = centro; azul $=$ parte intermediária; vermelha $=$ borda. 
Figura 4.10: Classificação dos anfibólios incolores de rochas da SVS. Símbolos: UM $(\nabla)$; MP $(\mathrm{O}) ; \mathrm{AB}(\mathrm{\vartheta})$. Cores: verde = centro; azul = parte intermediária; vermelha $=$ borda.

Figura 4.11: Plagioclásios das rochas graníticas: a) TTG (D) e GB (O); b) MGF ( $\Delta$ ). Cores: verde $=$ centro; azul $=$ parte intermediária; vermelha $=$ borda. 88

Figura 4.12: Plagioclásios de: a) veios pegmatóides não mineralizados (Símbolo: $\diamond$; Cores: verde $=$ centros, vermelha $=$ bordas); $b$ ) veios pegmatóides mineralizados (Símbolo: $\nabla$, Cores: verde $=$ centros; vermelha $=$ bordas $)$ e de lentes $\mathrm{em}$ biotitas/flogopitas esfoliadas (Símbolo: $\diamond$; Cores: verde - em flogopita de rochas metaultramáficas e lilás - em biotitas de GB).

Figura 4.13: Plagioclásios dos anfibolitos metabásicos dos subgrupos: a) AB; b) ABET; c) $\mathrm{ABG}$. Cores: verde $=$ centro; azul $=$ parte intermediária; vermelha $=$ borda.

Figura 4.14: Plagioclásios de metapelitos (Símbolo: O; Cores: vermelha $=$ amostra 286; verde = amostra AP-2) e metagrauvacas (Símbolo $\square$; Cores: verde = centro; vermelha $=$ borda)

Figura 4.15: Feldspatos potássicos de: a) GB e b) MGF. Cores: verde = centro; azul = parte intermediária; vermelha $=$ borda.

Figura 4.16: Feldspatos potássicos em: a) anfibolitos metabásicos (Cores: verde $=$ centros; vermelha = bordas; b) lentes em biotitas/flogopitas esfoliadas de TTG, anfibolitos metabásicos e metaultramáficas.

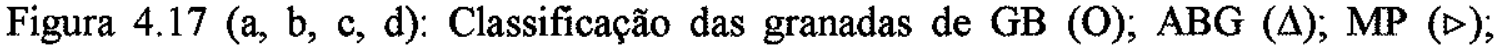
Cores: verde $=$ centro; azul $=$ parte intermediária; vermelha $=$ borda .

Figura 4.18: Diagramas $(\mathrm{CaO}+\mathrm{MnO})$ vs $(\mathrm{FeO}+\mathrm{MgO})$ (a) e $\mathrm{FeO} v s \mathrm{MgO}$ (b) para as granadas de GB (o); ABG $(\Delta)$; MP $(\triangleright)$.Cores: verde = centro; azul = parte intermediária; vermelha $=$ borda

Figura 4.19: Diagramas de correlação para as cordieritas: a) $\left(\mathrm{Fe}^{+2}+\mathrm{Mn}\right) v s \mathrm{Mg}$; b) $\mathrm{FeO}$ vs $\mathrm{MgO}$ vs $\mathrm{MnO}^{*} 100$; c) $\mathrm{Na}_{2} \mathrm{O}$ vs $\mathrm{Al}_{2} \mathrm{O}_{3}$. Símbolos : Amostras deste trabalho: G85a $(\Delta)$ e AP-3 $(\diamond)$; Amostra 286 ( $\triangleright$; médias de 04 análises). Cores: verde $=$ centro; azul $=$ parte intermediária; vermelho $=$ borda .

Figura 4.20: Diagramas de correlação para as estaurolitas de metapelitos de Capoeirana $(O)$ e Capoeirana do Meio $(\triangleright)$ e de um pegmatóide peralumínico $(\diamond)$ de Capoeirana. Cores: verde $=$ centro; vermelha $=$ borda

Figura 4.21: Classificação das cloritas de metapelitos $(\mathrm{O})$, metaultramáficas $(\nabla)$ e retrometamórficas de flogopitas $(\nabla)$.

Figura 4.22: Esmeraldas de diferentes associações genéticas das jazidas de Capoeirana e Belmont: $\mathrm{EX}=$ esmeraldas em xistos $(\nabla) ; \mathrm{EVQ}=$ esmeraldas em veios de quartzo $(\triangleright) ; \mathrm{EVP}=$ esmeraldas em veios pegmatóides $(\Lambda) ; \mathrm{E}-\mathrm{S} / \mathrm{ID}=$ esmeraldas sem identificação paragenética $(\diamond)$.

Figura 4.23: Composições médias das esmeraldas da área de estudo [EX ( $\nabla), \operatorname{EVQ}(\triangleright)$, EVP $(\Delta)$, E-S/ID $(\diamond)$ ] comparadas com as de outras localidades: Colômbia $(O$; Schwarz, 1992); Nigéria (, Schwarz et al., 1996); Áustria (O; Franz et al., 1986); Zâmbia ( $\diamond$; Graziani et al., 1983); Paquistão ( 0 ; Hussain et al., 1993); Urais (X; 
Schmetzer et al., 1991); Madagascar ( $\square$; Schwarz \& Henn, 1992); Carnaíba/Socotó (+; Schwarz \& Eidt, 1989; Schwarz et al., 1990).

Figura 4.24: Variogramas das esmeraldas de Capoeirana e Belmont, normalizados em:

(a) Condrito C1 (Sun \& McDonough, 1989) e (b) Condritos (Taylor \& McLennan, 1985). Símbolos: EX $(\nabla), \operatorname{EVQ}(\triangleright), \operatorname{EVP}(\triangle)$.

Figura 4.25: Variogramas das esmeraldas normalizados pelos valores médios das análises de GB e MGF: a) $\operatorname{EX~}(\nabla)$; b) $\operatorname{EVQ}(\triangleright)$; c) $\operatorname{EVP}(\Delta)$

Figura 4.26: Águas marinhas - AMQ $(\diamond)$ e AMP $(\diamond)$, normalizadas em: (a) Condrito C1 (Sun \& McDonough, 1989) e (b) Condritos (Taylor \& McLennan, 1985).

Figura 4.27: Águas marinhas - AMQ $(\diamond)$ e AMP $(\diamond)$, normalizadas em valores médios de GB e MGF.

Figura 6.1: Correlações do $\Sigma E T R P$ com: a) $\mathrm{SiO}_{2}$; e b) Y nos GB (•) e MGF (o).

Figura 6.2: a) Padrões de ETR dos GB (•) e MGF (o), normalizados segundo Sun \& McDonough (1989). A amostra G-29c (o) de GB com elevados teores de hastingsita apresenta teores mais elevados de ETR totais. b) Áreas de distribuição dos ETR dos GB (hachuras horizontais) e MGF (hachuras verticais).

Figura 6.3: Padrões de ETR de granitóides da Suíte Borrachudos com dados de: a,b Grossi Sad et al, 1990; c,d - Dussin, 1994; e,f - Fernandes et al., 1995a, em comparação com os valores médios dos GB (•) e MGF (o) desta pesquisa. Normalização: Sun \& McDonough (1989).

Figura 6.4: Variogramas de elementos menores e traço de granitóides da Suíte Borrachudos com dados de: a,b - Grossi Sad et al, 1990; c,d - Dussin, 1994; e,f - Fernandes et al., 1995a, em comparação com os valores médios dos GB (•) e MGF (o) desta pesquisa. Normalização: Taylor \& McLennan (1985)

Figura 6.5: Diagramas ETRP vs Y para: a) esmeraldas de diferentes associações genéticas e águas-marinhas; b) esmeraldas e águas-marinhas em conjunto com GB e MGF. Símbolos: EX $(\nabla)$, EVQ $(\triangleright)$, EVP $(\Delta)$, AMP $(\diamond)$, AMQ $(\diamond)$, GB $(\bullet)$ e MGF (O).

Figura 6.6: Padrões dos ETR de esmeraldas, normalizados em Condritos C1 (Sun \& McDonough, 1989): a,b) EX ( $\nabla)$; c,d) $\operatorname{EVQ~(\triangleright );~e,f)~} \operatorname{EVP}(\Delta)$

Figura 6.7: Padrões dos ETR de águas-marinhas, normalizados em Condritos C1 (Sun \& McDonough, 1989): AMP $(\diamond)$ e AMQ $(\diamond)$.

Figura 7.1: Teores (\% peso) e intervalos de $\delta \mathrm{D}$ da água das esmeraldas de Capoeirana e Belmont: (a) água das inclusões fluidas - IF $\left(<800^{\circ} \mathrm{C}\right)$; (b) água dos canais estruturais - $\mathrm{CE}\left(>800^{\circ} \mathrm{C}\right)$.

Figura 7.2: Composição isotópica de oxigênio e hidrogênio das esmeraldas e minerais associados de Capoeirana e Belmont: esmeralda: CE (O) e IF ( + ); quartzo: IF $(\Lambda)$; flogopita: $\mathrm{H}_{2} \mathrm{O}^{+}(\diamond)$. 


\section{ÍNDICE DE TABELAS}

Tabela 3.1: Be e Li nos GB e MGF (via absorção atômica). 41

Tabela 3.2: Valores médios de Be (ppm) nas rochas metaultramáficas: talco-anfibólioclorita-xistos (TACX), clorititos (CLT), anfibolitos (AU) e equivalentes flogopitizados (AFX), cromititos (CRT) e cromititos flogopitizados (CRTM).

Tabela 3.3: Ganhos (valores $>1$ ) e perdas (valores $<1$ ) de elementos maiores em séries selecionadas de transformação metassomática progressiva.

Tabela 3.4: Ganhos (valores $>1$ ) e perdas (valores $<1$ ) de elementos menores e traço em séries selecionadas de transformação metassomática progressiva.

Tabela 4.1: Litotipos com análises de biotitas. Símbolos: TTG = gnaisses da associação TTG; GB = Metagranitóides Borrachudos; MGF = Metagranitóides Foliados com Fluorita; $\mathrm{PGD}=$ pegmatóide; $\mathrm{UM}=$ metaultramáficas; $\mathrm{AB}=$ anfibolitos metabásicos; $\mathrm{ABET}=$ anfibolitos metabásicos com epidoto e titanita; $\mathrm{ABG}=$ anfibolitos metabásicos com granada; $\mathrm{MP}=$ metapelitos; $\mathrm{MG}=$ metagrauvaca da SVS; $(\mathrm{n})=$ número de análises.

Tabela 4.2: Variações dos teores de $F$ nas biotitas/flogopitas (analisadas por MSE). Símbolo: $\mathrm{TTG}=$ gnaisses da associação TTG; $\mathrm{GB}=$ Metagranitóides Borrachudos; $\mathrm{MGF}=$ Metagranitóides Foliados com Fluorita; UM = metaultramáficas; MP = metapelitos.

Tabela 4.3: Litotipos com análises de anfibólios. Abreviações: $\mathrm{AV}=$ anfibólios verdes; $\mathrm{AI}=$ anfibólios incolores; $\mathrm{GB}=$ Metagranitóides Borrachudos; $\mathrm{MGF}=$ Metagranitóides Foliados com Fluorita; PGDAl = Pegmatóide Peralumínico; UM $=$ Metaultramáficas; $\mathrm{AB}=$ Anfibolitos Metabásicos; $\mathrm{ABET}=$ Anfibolitos Metabásicos com Epidoto/Titanita; $\mathrm{ABG}=$ Anfibolitos Metabásicos com Granada; $\mathrm{MP}=$ Metapelitos. Símbolo: $(\mathrm{n})=$ número de análises.

Tabela 4.4: Litotipos com análises de plagioclásios. Abreviações: TTG = Gnaisses da Associação TTG; GB = Metagranitóides Borrachudos; MGF = Metagranitóides Foliados com Fluorita; PGD = Pegmatóides; $\mathrm{AB}=$ Anfibolitos Metabásicos; $\mathrm{ABET}=$ Anfibolitos Metabásicos com Epidoto/Titanita; $\mathrm{ABG}=$ Anfibolitos Metabásicos com Granada; MP = Metapelitos; $(n)=$ número de análises.

Tabela 4.5: Teores máximos de $\mathrm{FeO}, \mathrm{MnO}, \mathrm{MgO}$ e $\mathrm{BaO}$ (\% peso) em plagioclásios de rochas $s . l$. graniticas (TTG, GB e MG), lentes de albita em biotitas/flogopitas esfoliadas, veios pegmatóides (PGD), anfibolitos metabásicos ( $\mathrm{AB}, \mathrm{ABET}, \mathrm{ABG}$ ), metapelitos (MP) e metagrauvacas (MG); n.a.= não analisado.

Tabela 4.6: Litotipos com análises de feldspatos potássicos. Abreviaçð̃es: GB = Metagranitóides Borrachudos; MGF = Metagranitóides Foliados com Fluorita; $\mathrm{AB}=$ Anfibolitos Metabásicos; $\mathrm{ABG}=$ Anfibolitos Metabásicos com Granada; $\mathrm{UM}=$ metaultramáficas; TTG = Gnaisses da Associação TTG. Símbolos: $(\mathrm{n})=$ número de análises.

Tabela 4.7: Teores máximos de $\mathrm{FeO}, \mathrm{MnO}, \mathrm{MgO}$ e $\mathrm{BaO}$ (\% peso) em K-feldspatos de rochas graníticas (GB e $M G)$, de anfibolitos metabásicos $(A B, A B G)$ e de lentes em flogopitas/ biotitas esfoliadas; n.a.= não analisado. 
Tabela 4.8: Litotipos com análises de granadas. Abreviações: $\mathrm{GB}=$ Metagranitóide Borrachudos; $\mathrm{ABG}=$ anfibolito metabásico com granada; $\mathrm{MP}=$ metapelito. $(\mathrm{n})=$ número de análises.

Tabela 4.9: Relação das amostras por localidade com análises de estaurolitas. Símbolo: $\mathrm{PGDAl}=$ pegmatóide peralumínico; $\mathrm{MP}=$ metapelitos

Tabela 4.10: Relação das amostras com análises de esmeraldas e águas marinhas. EX = esmeraldas em xistos; $E V Q=$ esmeraldas em veios de quartzo; $E V P=$ esmeraldas em veios pegmatóides; E-S/ID = esmeraldas sem identificação paragenética, escolhidas segundo critérios de cor; $\mathrm{PGD}$ em $\mathrm{MGF}=$ veio pegmatóide em Metagranitóide Foliado com Fluorita; VQ em MGF = veio/mobilizado de quartzo associado a PGD em Metagranitóide Foliado com Fluorita; (n ) = número de análises.

Tabela 4.11: Composições médias (Med), mínimas (Min) e máximas (Max) das esmeraldas de diferentes associações genéticas das jazidas de Capoeirana e Belmont.

Tabela 5.1: Temperaturas médias de MP (metapelitos) e ABG (anfibolitos metabásicos com granada), obtidas à partir de diferentes geotermômetros, para $P=6 \mathrm{~kb}$, calculados segundo Rettinger (dados não publicados) e Reche \& Martinez (1996). Nota: GT = geotermômetros; Gr-Bt = granada-biotita; Gr-Stau = granadaestaurolita; Gr-Anf = granada-anfibólio.

Tabela 5.2: Temperaturas médias obtidas pelo geotermômetro de dois feldspatos a $6 \mathrm{~kb}$, para Metagranitóides Borrachudos - GB e Metagranitóides Foliados com Fluorita - MGF, utilizando-se o programa Solvcalc 2.0 (Wen \& Nekvasil, 1994).

Tabela 5.3: Algumas temperaturas médias, consideradas mais significativas, obtidas pelo geotermômetro (GT) granada-biotita (Gr-Bt), a $6 \mathrm{~kb}$, para Metagranitóides Borrachudos - GB, utilizando-se planilhas/programas específicas(os) (Rettinger, dados não publicados; Reche \& Martinez, 1996).

Tabela 6.1: Números atômicos, raios iônicos e configuração eletrônica dos ETR, Y e Sc, segundo Henderson (1984).

Tabela 6.2 :Valores de normalização para os ETR, segundo: (1) Haskin et al. (1968); (2) Wakita et al. (1971); (3) Nakamura (1974); (4) Evensen et al. (1978); (5) Sun \& McDonough (1989); (6) Masuda et al. (1973).

Tabela 6.3: Características de ETR dos GB e MGF (valores médios), incluindo coeficientes de fracionamento e valores $\mathrm{Eu} / \mathrm{Eu}^{*}$ ( $=$ Eu normalizado dividido por Eu interpolado entre Sm e Gd normalizados). Normalização: Condritos C1 de Sun \& McDonough (1989)

Tabela 6.4: Propriedades de ETR de esmeraldas EX (de xisto), EVQ (de veios de quartzo) e EVP (de veios pegmatóides) e de águas marinhas (AM) pegmatíticas dos MGF, incluindo coeficientes de fracionamentos e quantificações $\mathrm{Eu} / \mathrm{Eu}$ * (Eu normalizado dividido por $\mathrm{Eu}$ intrapolado entre o $\mathrm{Sm}$ e $\mathrm{Gd}$ normalizados). Normalização: Condritos C1 de Sun \& McDonough (1989).

Tabela 7.1: Padrões mais utilizados para medidas de isótopos estáveis.

Tabela 7.2: $\delta^{18} \mathrm{O}$ e $\delta \mathrm{D}$ (\% SMOW) de esmeraldas e minerais associados, de diferentes ambientes petro-metalogenéticos (xistos $=\mathrm{X}$; veios de quartzo polideformados $=$ 
$\mathrm{VQP}$; veios de quartzo pouco deformados $=\mathrm{VQ}$; veios pegmatóides $=\mathrm{VP}$ ) das jazidas de Capoeirana (C) e Belmont (B).

Tabela 7.3: $\delta^{18} \mathrm{O}$ e $\delta \mathrm{D}$ ( $\%$ SMOW) de esmeraldas de Belmont, sem identificação paragenética e separadas por critérios de cor: $1=$ verde grama; $2=$ verde acastanhado-amarelado ; $3=$ verde intenso; $4=$ verde claro; $\quad 5=$ verde azulado claro; 6 = verde azulado muito claro.

Tabela 7.4: $\delta^{18} \mathrm{O}$ e $\delta \mathrm{D}$ (\%o SMOW) de flogopita inclusa em esmeralda de Belmont, sem identificação de sua assembléia mineral.

Tabela 7.5: $\delta^{18} \mathrm{O}$ (\% SMOW) de quartzo de veios de quartzo não mineralizados de Belmont. 


\section{RESUMO}

Foram estudadas a evolução precambriana da região e as mineralizações de esmeraldas de Capoeirana e Belmont e de águas marinhas pegmatíticas. Essa região do extremo NE do Quadrilátro Ferrífero situa-se na borda SE do Cráton do São Francisco (MG), na zona de transição para o Cinturão Móvel Atlântico. Sua evolução compreende estágios arqueanos, representados por terrenos TTG e granito-greenstone belt, e retrabalhamentos tectonometamórficos proterozóicos dos cíclos Minas/Espinhaço e Brasiliano. As mineralizações beriliferas devem-se a processos arqueanos e proterozóicos.

Gnaisses, migmatitos e metagranitóides TTG são as rochas arqueanas mais antigas. Ocorrem como restos nos Metagranitóides Borrachudos (GB) e Metagranitóides Foliados com Fluorita (MGF) e ainda como gnaisses miloníticos em contato com as seqüências metavulcanosedimentares arqueanas (SVS). São polimetamórficos e sofreram enriquecimentos de álcalis (K, $\mathrm{Rb})$ e outros elementos incompatíveis nos retrabalhamentos proterozóicos.

A SVS de Capoeirana e Belmont é uma continuação do greenstone belt Rio das Velhas. Ocorre em zonas de cavalgamentos antitéticos num sistema regional de embricamento frontal; sofreu inversão, dobramentos superimpostos e repetições tectônicas pela principal orogênese proterozóica. A sucessão litoestratigráfica típica têm, na base, rochas metaultramáficas de natureza extrusiva. São anfibolitos, talco-anfibólio-clorita xistos (TACX), clorititos (CLT) e cromititos; sendo os TACX e CLT produtos de alterações aloquímicas premetamórficas. Têm características globais komatíticas com $\mathrm{Cr}$ e $\mathrm{Zn}$ variáveis em função dos teores e tipos de cromita e gradam para equivalentes flogopitizados/mineralizados, enriquecidos em $\mathrm{K}, \mathrm{Al}, \mathrm{Rb}$, $\mathrm{Ba}, \mathrm{Y}$ e Be em zonas de cisalhamento crustais profundas regionais $(\mathrm{ZC})$ da orogênese arqueana final do ciclo greenstone belt Rio das Velhas. Fluidos alcalinos-potássicos, ricos em $\mathrm{F}$ e elementos incompatíveis ( $\mathrm{Rb}, \mathrm{Zr}, \mathrm{Nb}, \mathrm{Be}, \mathrm{ETRL}$, entre outros) da degranitização/granulitização da crosta inferior, infiltrados nas ZC ativas, transformaram as rochas TTG em GB durante a milonitização, por reações fluidos-rochas hidrotermais-metassomáticas sinmetamórficas e flogopitizaram e mineralizaram as rochas metaultramáficas da SVS.

A evolução proterozóica compreendeu na orogênese do Cíclo Minas/Espinhaço o principal evento de metamorfismo regional, progressivo. Este causou, ainda, a transformação dos GB em MGF a partir da fácies anfibolito média. $O$ processo essencialmente mineralógicotextural e isoquímico quanto aos elementos principais, entretanto, acarretou mudanças menores, de elementos traço incompativeis (incluindo ETRL) condizentes com a anatexia inicial dos MGF. Cálculos geotermobarométricos para gradientes intermediários em paragêneses de minerais estáveis, como granada-estaurolita (metapelitos) e granada-anfibólio (anfibolitos metabásicos), forneceram temperaturas (T) máximas de $600-670^{\circ}$ e $600-630^{\circ} \mathrm{C}$, respectivamente. Com boa correlação nos valores absolutos e nas indicações do zoneamento, mostraram as $\mathrm{T}$ mais elevadas do ápice termal do metamorfismo nas bordas tardi-sin a póstectônicas. Retrometamorfismo é evidenciado por paragêneses de bordas de minerais menos estáveis com biotitas ou ainda pelo geotermômetro dos dois feldspatos (em GB e MGF). Forneceram T muito baixas e bastante variáveis de $260-430^{\circ} \mathrm{C}$ de reequilibrações variáveis no estágio final de soerguimento do próprio metamorfismo principal e/ou nos processos tectonotermais do Cíclo Brasiliano. 
A petro-metalogênese do Be foi também policíclica e originou duas gerações principais de mineralizações incluindo subtipos:

(1) Nas ZC, os fluidos alcalinos potássicos ricos em elementos incompatíveis, $\mathrm{F}$ e Be, ricos ainda em Al pela substituição dos plagioclásios dos TTG (na transformação em GB), reagiram com rochas metaultramáficas da SVS, causando flogopitização e as mineralizações de esmeraldas tipo xisto (EX) e tipo veio de quartzo (EVQ) polideformado, arqueanas. $O$ processo mineralizante é mais bem descrito como metamorfismo hidrotermal-metassomático em zona de cisalhamento ativa sob condições da fácies xistos verdes média/superior a anfibolito inferior, entretanto, com pressão (P) fluida variável e diferente da $\mathrm{P}$ sólida (e da $\mathrm{P}$ total), como é típico para sistemas abertos.

(2) O principal metamorfismo proterozóico com ápice termal tardi-sin a pós-tectônico e intensidade mais alta na região de Capoeirana, produziu ali, por fusões parciais dos MGF pegmatóides e pegmatitos pouco deformados, comumente mineralizados em águas marinhas; pegmatóides intrusivos nas rochas metaultramáficas da SVS são mineralizados em esmeraldas (tipo EVP). Em Capoeirana ocorrem ainda esmeraldas idiomórficas em veios/mobilizados de quartzo (tipo EVQ) pouco deformados. Conjuntamente representam um evento proterozóico de mineralizações berilif́reras, decorrente da anatexia inicial dos MGF.

Relações genéticas das mineralizações berilíferas (esmeraldas e águas marinhas) entre si, com os GB e MGF, são indicadas também pela correlação positiva contínua de Y e $\Sigma E T R P$, mostrando que os fluidos foram muito similares nos dois ciclos mineralizantes. Ou seja, que a segunda geração de mineralizações berilíferas originou-se por retrabalhamento e remobilização do reservatório químico-mineralógico fundamental gerado no ciclo anterior sem contribuições externas novas e de outras fontes.

As composições isotópicas $\delta^{18} \mathrm{O}$ e $\delta \mathrm{D}$ das esmeraldas são bem definidas na região de superposição dos campos de águas magmáticas e metamórficas. Aliadas aos dados de $\mathrm{Y}$ e ETRP, são condizentes com a formação conjunta dos GB e das mineralizações EX e EVQ, polideformados na orogênese arqueana do greenstone belt Rio das Velhas, pela reação dos fluidos crustais profundos, respectivamente, com quantidades grandes de rochas TTG e pequenas de rochas metaultramáficas mais impermeáveis. Os valores muito homogêneos de $\delta \mathrm{D}$ dos fluidos dos canais estruturais e de $\delta^{18} \mathrm{O}$ da estrutura cristalina dessas esmeraldas representam os sistemas mais resistentes às alterações polimetamórficas/retrometamórficas, caracterizando os fluidos da primeira fase arqueana de mineralizações. Os valores de $\delta^{18} \mathrm{O}$ pouco variáveis das gerações posteriores (EVP e EVQ pouco deformados) relacionadas ao metamorfismo proterozóico principal e a anatexia inicial dos MGF, confirmam suas origens por retrabalhamento do sistema geoquímico-isotópico anterior, sem contribuições significativas de fluidos de outras fontes. 


\section{ABSTRACT}

The emerald mineralizations of the Capoeirana and Belmont area and pegmatitic aquamarine occurrences were studied in the contxt of the regional Precambrian evolution. The area in question, in the extreme NE-Quadrilátero Ferrifero ('Iron Quadrangle'), is part of the SE-border of the São Francisco Craton (MG) in the transition zone to the Atlantic mobile belt. Its evolution comprises Archean stages represented by TTG grey gneisses and granitegreenstone terrains and Proterozoic tectono-metamorphic overprintings of the Minas/Espinhaço and Brasiliano cycles. The berylliferous mineralizations are due to Archean and Proterozoic processes.

TTG gneisses, migmatites and metagranitoids are the oldest Archean rocks. They occur as relics in the Borrachudos Metagranitoids (GB) and Foliated Fluorite-bearing Metagranitoids (MGF) and also as mylonitic gneisses were they are in contact with the metavolcanosedimentary Archean sequences (SVS). The TTG rocks are polymetamorphic and experienced enrichments in alkalis $(\mathrm{K}, \mathrm{Rb})$ and other incompatible elements in the course of the Proterozoic orogenies.

The SVS of Capoeirana and Belmont, an extension of the Rio das Velhas greenstone belt, was disrupted and strongly deformed during the main Proterozoic orogeny. It occurs in wedges beneath overthrusted granitic rocks in a zone of antithetic thrusts of a regional system of frontal imbrication; the SVS is overturned and suffered complex refolding and thrust-related repetitions. The typical lithostratigraphic succession comprises, at the base, metaultramafic rocks of volcanic origin, amphibolites, talc-amphibole-chlorite schists (TACX), chloritites (CLT) and chromitites. TACX and CLT originated from protoliths that underwent premetamorphic chemical alterations. Metaultramafics have overall komatiitic characteristics with variable $\mathrm{Cr}$ and $\mathrm{Zn}$ due to chromite contents and types. They grade into phlogopitized/ mineralized equivalents enriched in $\mathrm{K}, \mathrm{Al}, \mathrm{Rb}, \mathrm{Ba}, \mathrm{Y}$ and $\mathrm{Be}$ when involved in the regional deep-rooted crustal shear zones (ZC) that formed during the Archean orogeny at the end of the Rio das Velhas greenstone belt cycle. Alkaline potassic hydrous fluids, rich in $F$ and incompatible elements ( $\mathrm{Rb}, \mathrm{Zr}, \mathrm{Nb}, \mathrm{Be}, \mathrm{LREE}$, among others) due to degranitization/ granulitization of the lower crust, infiltrated into the active $\mathrm{ZC}$, transformed the TTG rocks into GB by simultaneous processes of synmetamorphic mylonitization and hydrothermalmetasomatic fluid-rock interactions and phlogopitized/mineralized the metaultramafics of the SVS.

The main event of progressive regional metamorphism occurred during the Minas/Espinhaço orogeny in the Proterozoic. It transformed the GB into MGF of middle amphibolite facies and higher. This process consisted essentially of mineralogical-textural changes and was isochemical with respect to the main elements. Smaller alterations however affected some of the incompatible trace elements (including LREE) and are consistent with the initial anatexis of the MGF. Geothermometric calculations considering intermediate pressure (P) gradients for parageneses of stable minerals, like garnet-staurolite (metapelites) and garnetamphibole (metabasic amphibolites), furnished maximum temperatures $(\mathrm{T})$ of 600-670 and 600$630^{\circ} \mathrm{C}$, respectively. Additional indications from mineral zoning showed the highest $\mathrm{T}$ of the metamorphic peak in the parageneses of the mineral-borders of late-syntectonic to post-tectonic growth. Retrometamorphic readjustments were indicated by border parageneses including less 
stable species, mainly biotites and by the 'two-feldspars' geothermometer (in GB and MGF). These furnished very low and largely variable $\mathrm{T}$ of $260-430^{\circ} \mathrm{C}$, indicating late-stage readjustments either of the main metamorphism itself during uplift and/or of the tectonothermal processes of the Brasiliano cycle.

The petro-metallogenesis of $\mathrm{Be}$ was also polycyclic and originated two main generations of mineralizations, including subtypes:

(1) In the crustal shear zones the alkaline potassic fluids, rich in incompatible elements, $\mathrm{F}$ and $\mathrm{Be}$, also rich in $\mathrm{Al}$ due to the replacement of the TTG rock plagioclases (during GBtransformation), reacted with the metaultramafics of the SVS causing phlogopitization and emerald mineralizations of both the schist type (EX) and the polydeformed quartz-vein type (polydeformed EVQ) of Archean age. The mineralizing process is best described as hydrothermal-metasomatic metamorphism in an active shear zone, under middle greenschist to lower amphibolite facies conditions yet under fluid pressures that were variable and different from the solid and total pressures, as are typical for open systems.

(2) The main Proterozoic metamorphism of late-syntectonic to post-tectonic thermal peak conditions and of higher intensity in the Capoeirana region, produced there, by partial fusion of the MGF, little-deformed pegmatoids and pegmatites commonly with aquamarine mineralizations; pegmatoids that intruded the metaultramafics of the SVS are mineralized in emeralds (EVP-type). In Capoeirana there still occur little-deformed quartz veins mineralized with idiomorphic emeralds (little-deformed EVQ-type). Together they represent a Proterozoic event of berylliferous mineralizations that occurred as a consequence of the initial anatexis of the MGF.

Genetic relationships of the the berylliferous mineralizations (emeralds and aquamarines) with each other, with the GB and MGF, are indicated too by the trace element geochemistry, as for instance, by the positive constant correlations of $\mathrm{Y}$ and $\Sigma \mathrm{HREE}$, showing that the fluids were very similar in the two mineralizing cycles. This means that the second generation of berylliferous mineralizations was formed by reworking and remobilization of the fundamental chemical-mineralogical reservoir generated in the preceding cycle, without new contributions from external sources.

The isotopic compositions $\delta^{18} \mathrm{O}$ and $\delta \mathrm{D}$ of the emeralds are well defined in the region of overlap of magmatic and metamorphic waters. Together with the REE data this suggests that the GB and the emerald mineralizations of the EX and polydeformed EVQ types formed jointly in associated processes during the orogenesis of the Archean Rio das Velhas greenstone belt through the reactions of the deep crustal fluids with, respectively, large and small amounts of TTG and metaultramafic rocks. The very homogeneous and constant values of $\delta \mathrm{D}$ of the channel fluids and of $\delta^{18} \mathrm{O}$ of the crystalline structure of these emeralds point to the fact that these variables may represent the systems most resistant to polymetamorphic/retrometamorphic alterations and may thus characterize the fluids of the first Archean mineralizing cycle. The later emerald generation of the little deformed EVP and EVQ types, related to the main Proterozoic metamorphism and initial anatexis of the MGF with little more variable values of $\delta^{18} \mathrm{O}$, confirms their origin through reworking/remobilization of the previou geochemical-isotopic system, without significant contributions of fluids from other sources. 


\section{AGRADECIMENTOS}

Ao concluir esta Tese, aproveito para expressar os meus mais sinceros agradecimentos a diversas pessoas e instituições, cuja colaboração foi decisiva para o desfecho deste trabalho.

Em especial, agradeço ao meu orientador, Prof. Dr. Johann Hans Daniel Schorscher, pelo acompanhamento crítico do trabalho e pela disposição, apoio e incentivo em todas as fases do trabalho. Acima de tudo, minha admiração pelo profissional que é.

Ao Sidney que qualquer palavra seria pouco para expressar meu reconhecimento pelo apoio irrestrito, carinho e companheirismo, sem os quais teria sido muito mais difícil terminar este trabalho.

Ao Luís Lutello, pela amizade e disponibilidade com a qual eu tive o privilégio de poder contar e pelas inúmeras horas desprendidas.

Ao amigo José Maria Leal que, com entusiamo, acompanhou-me em uma etapa de campo e auxiliou-me na digitalização do mapa.

À Empresa Penery Mineração, em nome do geólogo Wilson (Tonelada), que me concedeu apoio logístico.

Aos professores do DMP, Gergely Szabó, Francisco Alves, Excelso Ruberti, Rainer Schultz, Sívio Vlach, e todos os demais que viabilizaram análises imprescindiveis para o desenvolvimento desta pesquisa e estiveram sempre solícitos em esclarecer dúvidas.

Aos pesquisadores Dr. Norbert Miekeley e Dra. Carmem Porto da Silveira do EANA Espectrometria Atômica e Nuclear Aplicada, do Departamento de Química da PUC/RJ, pelas análises de ICP-MS; Dr. Antony Fallick do laboratório de Geoquímica Isotópica do SURRC, East Kilbride, Escócia, pelas análises de isótopos estáveis; e equipe do laboratório de Geoquímica da Universidade de Mainz, Alemanha.

À Adélia e Fátima do Laboratório de Análises Térmicas do IQ-USP, que me permitiram visualizar novos horizontes na Geologia e ao Prof. Dr. Vicentini do IQ-USP que me auxiliou no estudo de ETR. 
Aos técnicos dos laboratórios do IG-USP, Flávio Carvalho (Laboratório de DRX), Sandra, Inês e Ricardo (Laboratório de Química), Marcos Almeida (Laboratório de Microssonda), Verônica (Laboratório de Análises Mineralógicas) e Angélica (Laboratório de Ótica).

À Denise e ao Tadeu, pela atenção e suporte durante todas as fases deste trabalho.

Ao Sr. Cláudio Hopp e equipe do laboratório de laminação, pela confecção das seções delgadas para análises petrográficas e Aninha, pelas seções polidas para microssonda.

A todos os funcionários da biblioteca, em especial à Stela que gentilmente reviu as referências bibliográficas.

Ao Sr. José e demais funcionários da seção de xerox.

Ao Peter e à Gianna que auxiliaram na resolução de dúvidas referentes a programas/planilhas de computador.

Aos amigos Maria Mazzarello, Angela Pimenta, Alcina, Angela Menezes, Regina e Luis Jorge, Miriam Shinzato, Míriam Chilena, Gilson, Rosana, Fernando, Klaus, Xita, Inútil e demais colegas do DMP que mesmo não diretamente envolvidos com esta tese, dividiram comigo, nestes cinco últimos anos, alegrais e dificuldades. A eles todo meu carinho.

Ao CNPq pelo suporte financeiro concedido sob a forma de bolsa de doutorado.

De modo muito especial, agradeço a meus pais e irmãos que acreditaram quando eu mesma duvidava e apoiaram para que este trabalho fosse concretizado. 


\section{CAPÍTULO I - INTRODUÇÃo}

\section{I.1 - APRESENTAÇÃO}

Esta pesquisa .propõe-se ao estudo geológico multidisciplinar (petro-metalogenético, químico-mineralógico e cristalográfico-cristaloquímico) das jazidas de esmeraldas de Capoeirana e Belmont no contexto evolutivo de seu quadro regional, precambriano, policíclico, do extremo NE do Quadrilátero Ferrífero (Q.F.), MG, em continuação temática dos trabalhos de Mestrado (Machado, 1994).

As relações geológicas similares, sugerindo afinidades genéticas entre as duas jazidas, foram confirmadas por Machado (1994). No entanto, ainda, eram incompletos os conhecimentos regionais e específicos, necessários à melhor compreensão dos controles geológicos e origem das mineralizações, assim como da evolução petro-metalogenética regional dessa província berilífera, que abriga outras ocorrências de minerais gemas, importantes sob aspectos tanto científicos fundamentais quanto de aplicação.

Neste trabalho, destacam-se como inovadores os dados analíticos obtidos por ICP-MS em esmeraldas, águas-marinhas e rochas graníticas associadas (com cerca de 60 elementos traço por amostra, incluindo ETR, LILE e HFSE, entre outros), assim como os dados de isótopos estáveis $(\mathrm{O}, \mathrm{H})$ analisados em gerações distintas de esmeraldas (considerando, seletivamente, a fase sólida, os fluidos dos canais estruturais e os fluidos das inclusões fluidas) e em minerais associados (flogopita, quartzo e feldspato). Estes dados, em conjunto com os resultados geológicos, lito-estruturais, mineralógico-petrográficos, geoquímicos convencionais (elementos maiores e traço por FRX e ICP-AES), de química mineral por MSE e cristalográfico-cristaloquímicos, constituem um considerável acervo de dados sobre a petrometalogênese do Be em zonas de cisalhamento crustais profundas de terrenos precambrianos, polimetamórficos.

No âmbito desta tese, os resultados anteriores da Dissertação de Mestrado (Machado, 1994), com interpretações iniciais, constituíram-se num importante banco de dados. 


\section{I.2- OBJETIVOS}

Os objetivos gerais deste trabalho foram a definição e caracterização das unidades e associações lito-estruturais que compõem a área da pesquisa, dando ênfase ao detalhamento dos conjuntos litológicos envolvidos na gênese das mineralizações beriliferas. São essas as rochas sensu lato (s.l.) graníticas que compreendem continuações do Complexo Regional Arqueano TTG (tonalito-trondhjemito-granodiorítico), os Metagranitóides Borrachudos (GB), os Metagranitóides Foliados com Fluorita (MGF), e , evidentemente, as rochas das sequências metamórficas, supra-crustais, vulcano-sedimentares (SVS), que abrigam as mineralizações de esmeraldas.

Os objetivos temáticos-específicos, centrais deste trabalho, foram os estudos comparativos petro-metalogenéticos, químico-mineralógicos, geotermobarométricos, cristalográfico-cristaloquímicos e de isótopos estáveis das jazidas de esmeraldas de Capoeirana e Belmont, bem como de pegmatitos beriliferos com águas marinhas, no contexto da evolução geológica precambriana dessa parte do extremo NE do Q.F. Ainda, mais especificamente, no contexto das mineralizações, os estudos visaram: a melhor definição das associações genéticas das esmeraldas e berilos, em geral; a caracterização dos tipos de veios de quartzo e pegmatóides/pegmatitos; a composição e origem dos fluidos metassomáticos mineralizantes; e as mais prováveis idades geológicas dos depósitos de esmeraldas/águas marinhas.

Como resultado, objetivou-se, ainda, elucidar, questões científicas fundamentais dos processos petro-metalogenéticos de interação fluido-rochas em sistemas abertos de zonas de cizalhamento crustais profundas, com reativações tectono-metamórficas polifásicas e policíclicas.

\section{I.3- LOCALIZAÇÃO DA ÁREA}

A área da pesquisa, com extensão de cerca de $100 \mathrm{~km}^{2}$, localiza-se nos municípios de Nova Era e Itabira (MG) e inclui as jazidas de esmeraldas de Capoeirana e Belmont. A distância entre as duas jazidas de esmeraldas é de, aproximadamente, $4 \mathrm{~km}$. $\mathrm{O}$ acesso a partir de Belo Horizonte é feito através das rodovias BR-262 e BR-381 até a cidade de Nova Era, seguindo-se $10 \mathrm{~km}$ por estrada não pavimentada que liga Nova Era a Itabira, até chegar a jazida de Capoeirana (Fig. 1.1). 
FIGURA 1: LOCALIZAÇÃO E GEOLOGIA DAS JAZIDAS DE ESMERALDAS

CAPOEIRANA E BELMONT - MG
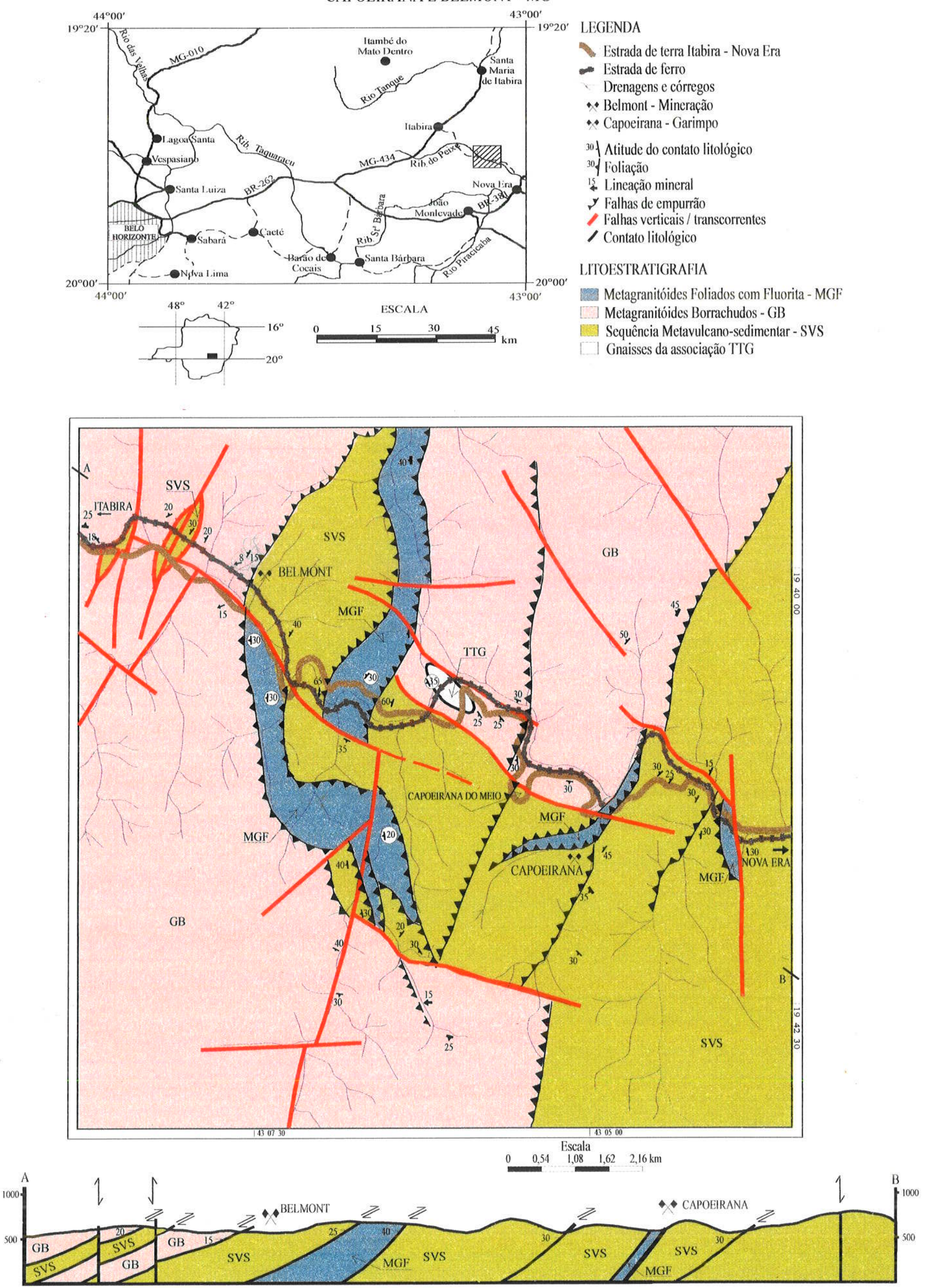


\section{I.4 - METODOLOGIA}

Os dados que sustentam esta pesquisa foram obtidos a partir de trabalhos agrupados e realizados em etapas subsequentes e/ou simultâneas, com o emprego de um amplo acervo metodológico.

\section{I.4.1 - Trabalhos Preliminares e de SuPorte À Pesquisa}

Incluiram a revisão bibliográfica segundo enfoques temáticos regionais e específicos (ver Cap. II), a sistematização dos dados anteriores do orientador (Schorscher, 1975, 1992) e próprios (Machado, 1994, 1996), levantamentos regionais e detalhados de campo e estudos petrográficos complementares.

O mapeamento geológico e os estudos petrográficos fundamentais foram de vital importância para a execução deste projeto. Realizado em escala aproximada 1:10.000, com apresentação final em escala 1:18.000, o mapeamento lito-estrutural abrangeu uma área de cerca de $100 \mathrm{~km}^{2}$ e foi, essencialmente, concluído no Mestrado (Machado, 1994).

Nesta pesquisa, foram complementadas as observações regionais e, principalmente, efetuados levantamentos detalhados de perfis de superfície e de galerias subterrâneas do garimpo de Capoeirana, com amostragens seletivas para estudos petrográfico-mineralógicocristaloquímicos de rochas e de esmeraldas/águas marinhas.

Estudos petrográficos foram efetuados em rochas não descritas anteriormente, como por exemplo, xistos/gnaisses metapelíticos e pegmatóides com cianita, cordierita e córindon, da SVS de Capoeirana; e ainda, em todos litotipos (incluindo aqueles já descritos) com o objetivo principal de reconstituir a evolução tectono-metamórfica-metassomática através das relações mineralógicas e texturais. Adicionalmente, as análises petrográficas foram imprescindíveis para a seleção das amostras e como estudos preliminares às análises de química mineral por microssonda eletrônica (MSE).

Para facilitar a leitura e, principalmente, a localização das amostras citadas no texto, são fornecidos o mapa de afloramentos/amostras e descriçôes suscintas no Anexo 1. 


\section{I.4.2 - ANÁLISES E ESTUDOS LITOGEOQUÍMICOS}

Esta pesquisa é baseada em:

- Análises globais multielementares por fluorescência de raios $\mathrm{X}$ (FRX) (30 elementos maiores e traço) de 81 amostras de diversos tipos litológicos. Os resultados analíticos e os limites de deteç̧ão encontram-se no Anexo 2;

- Análises de Be e Li por espectrometria de absorção atômica (AAS) de 12 amostras de rochas graníticas;

- Análises multielementares por espectrometria de emissão atômica com fonte de plasma indutivamente acoplado (ICP-AES) (25 elementos maiores e traço) de 71 amostras de litotipos diversos. $\mathrm{O}$ procedimento analítico foi descrito por Janasi et al. (1995). Os resultados e os limites de deteç̧ão encontram-se no Anexo 2;

- Análises multielementares de elementos traço incluindo terras raras (ETR), litófilos de raio iônico grande (LILE) e de alta força iônica (HFSE), por espectrometria de massa com fonte de plasma indutivamente acoplado (ICP-MS) (58 elementos) de 19 amostras de rochas graníticas (Anexo 3).

Dos vários métodos para a determinação de ETR em materiais geológicos, os dois mais usados são a análise instrumental por ativação neutrônica (INAA) e por ICP-AES. A ativação neutrônica é particularmente útil devido à sua alta sensibilidade e excelente precisão. As desvantagens principais são o tempo de execução e a necessidade de manusear material irradiado/ativo. O método ICP-AES é mais rápido, mas exige a separação seletiva, concentração e purificação dos ETR por troca iônica e demais tratamentos químicos especializados. A sensibilidade é suficiente para a determinação da maioria dos ETR no mesmo nível, ou mesmo abaixo da abundância condrítica.

O método ICP-MS é relativamente novo para análises de ETR, demais elementos traço e alguns isótopos (Rollinson, 1993). Tem como vantagens em relação ao ICP-AES maior sensibilidade (os limites de deteç̧ão para muitos elementos, incluindo os ETR, estão abaixo de nanograma), simplicidade analítica e do espectro de fundo (background) e menores efeitos de matriz. As amostras são analisadas diretamente após a digestão ácida, sem prévia separação ou concentração, com limites de deteção de 2 a $11 \mathrm{ng} / \mathrm{g}$ e precisão em torno de 2.5 vezes melhor do que por ICP-AES e INAA. 
As análises deste trabalho foram realizadas no Laboratório de ICP-MS do grupo de trabalho de Espectrometria Atômica e Nuclear Aplicada (EANA) do Departamento de Química da PUC-RJ, seguindo os procedimentos de rotina. Foram utilizados o equipamento de modelo Elan 5000A da Perkin Elmer Sciex e o programa analítico TotalQuant ${ }^{\circledast}$ (Perkin Elmer). Para quantificação, utilizou-se uma solução de calibração com 48 elementos de concentração conhecida (incluindo todos os ETR, platinóides e os mais relevantes elementos principais e traço), para atualização dos fatores de resposta (cps/ppb). Como padrões internos foram utilizados o In e $\mathrm{Tl}$. Desta forma a incerteza dos resultados analíticos dos elementos menores e traço é típicamente entre 10-30\%.

Nos tratamentos computacionais e modelagens de todos os dados geoquímicos (incluindo, ainda, dados de Schorscher, 1992) foram utilizados os programas Minpet 2.02 (Richard, 1995) e Newpet (Clarke, 1992, 1994). Parte das análises multielementares globais por FRX e as análises de Be por AAS já foram, inicialmente, exploradas no Mestrado (Machado, 1994).

Sob aspectos da preparação de amostras, foram tomados alguns cuidados com a moagem; para tanto, foram efetuados testes moendo alíquotas de uma mesma amostra em moinhos de ágata, WC (carbeto de tungstênio) e aço Fe-Cr. Os resultados indicaram contaminações apenas de Cr (na ordem de 250-330 ppm) e de Co (de cerca de 40-150 ppm), respectivamente, pelos moinhos de Fe-Cr e de WC.

\section{I.4.3 - ESTUDOS DE QUÍMICA MINERAL}

Análises quantitativas por MSE, FRX e ICP-MS foram efetuadas em minerais da mineralização e das rochas s.l. graníticas regionais e metamórficas da SVS, respectivamente, para caracterizar os tipos e as associações genéticas de esmeraldas/águas marinhas, assim como as condições geotermobarométricas e os padrões P-T-X-t da evolução polimetamórfica regional e dos processos mineralizantes.

Para análise por MSE, o material foi preparado em seções delgadas polidas cobertas com carbono. Um conjunto inicial foi analisado pelo orientador, através de convênio internacional, no Instituto de Geociências da Universidade de Mainz (Alemanha), com equipamento automático Camebax (4 espectômetros de cristais e sistema detector de estado sólido - EDS). A parte principal das análises foi realizada no Laboratório de Microssonda e Microscopia Eletrônica de Varredura do Departamento de Mineralogia e Petrologia/IG-USP. 
Neste caso, o equipamento foi uma microssonda automática JEOL modelo JXA 8600, com 5 espectrômetros de cristais (e EDS acoplado). As condições analíticas foram: voltagem de aceleração - $15 \mathrm{kV}$, corrente do feixe - $20 \mathrm{nA}$, diâmetro do feixe - $5 \mu \mathrm{m}$. Correções quantitativas de máquina (BG e tempo morto) e ZAF ( $\mathrm{Z}$ - $\mathrm{N}^{\circ}$ atômico, A - absorção, F fluorescência secundária) para efeitos de matriz foram executadas automaticamente através do programa Flextran PRZ (Noran Instruments 1990). Nessas condições, o erro analítico máximo estimado é de $\pm 3 \%$ para os elementos maiores. Foram utilizados os seguintes padrões minerais: Wollastonita: $\mathrm{Ca}$ e $\mathrm{Si}$; córindon: $\mathrm{Al}$; periclásio sintético: $\mathrm{Mg}$; rutilo: Ti; Ni-olivina: Ni; Cromita-53-IN-8: Cr; hematita-Elba: Fe; rodonita-660-388: Mn; andesina-AC-362: Na; microclina-USNM 143966: $\mathrm{K} ; \mathrm{BaF}_{2}: \mathrm{Ba}, \mathrm{F}$.

Foram realizadas mais de 800 análises pontuais de biotitas, anfibólios (verdes e incolores), feldspatos (plagioclásio e feldspatos potássicos), granada, cordierita, estaurolita, clorita e esmeraldas, detalhadamente tratadas, além de cianita, muscovita, apatita, titanita, epidoto, magnetita, ilmenita, rutilo e cromita, cujos resultados, embora incluídos no banco de dados, não serão discutidos nesta tese. No caso das esmeraldas, foram analisados cristais de xistos e veios de quartzo de Belmont e de xistos, veios de quartzo e veios pegmatóides de Capoeirana. Os dados de MSE são apresentados no Anexo 4.

As informações químicas das esmeraldas foram complementadas para os elementos maiores, exceto $\mathrm{Be}$, e alguns elementos traço (incompatíveis, por exemplo: $\mathrm{K}, \mathrm{Ba}, \mathrm{Rb}, \mathrm{Sr}$, e cromóforos, por exemplo: $\mathrm{Cr}, \mathrm{Ni}, \mathrm{V}, \mathrm{Fe}, \mathrm{Mn}$, etc.) por FRX em 16 amostras de fragmentos de cristais com peso individual de 300 a $600 \mathrm{mg}$, provenientes de Belmont. Estas esmeraldas, sem identificação de suas associações genéticas, foram selecinadas segundo critérios de cor. As análises de FRX foram realizadas com espectrômetro Philips sequencial automático no Instituto de Geociências da Universidade de Hamburgo (Alemanha). Os resultados das análises por FRX em esmeraldas encontram-se no Anexo 4.

Adicionalmente, foram efetuadas, também, em fragmentos de cristais de esmeraldas e de águas marinhas de diferentes associações genéticas, análises por ICP-MS de ETR, LILE e HFSE (58 elementos) no laboratório do grupo EANA do Departamento de Química da PUC, $\mathrm{RJ}$ (ver ítem I.4.2). Os resultados das análises por ICP-MS em esmeraldas e águas marinhas encontram-se no Anexo 3. 
Para o tratamento computacional e modelagem dos dados de química mineral foi utilizado o programa Minpet 2.02 (Richard, 1995).

\section{I.4.4 - GEOTERMOBAROMETRIA}

Estudos geotermobarométricos foram efetuados a partir de pares de minerais metamórficos regionais (granada-biotita, granada-estaurolita e granada-anfibólio em metapelitos e anfibolitos metabásicos com granada, e granada-biotita em metagranitóides GB/MGF), utilizando-se planilhas e programas de computador específicos (Rettinger, planilhas de cálculo não publicadas; Reche \& Martinez, 1996). Adicionalmente, foi utilizado o programa Solvcalc 2.0 (Wen \& Nekvasil, 1994) para cálculos do solvus e da temperatura de equilibrio de pares de feldspatos coexistentes em rochas graníticas (GB e MGF) e veio pegmatóide mineralizado. Resultados completos dos cálculos geotermobarométricos encontram-se no Anexo 5.

\section{I.4.5 - GEOQUIMICA DE ISÓTOPOS ESTÁVEIS}

Análises dos isótopos estáveis de $\mathrm{O}$ e $\mathrm{H}$ para a caracterização das ocorrências de esmeraldas e minerais associados, de ambientes petro-metalogenéticos diferentes (xistos metaultramáficos/metassomáticos, veios de quartzo e veios pegmatóides), foram realizadas em cooperação com o Prof. Dr. A. Fallick, no Laboratório de Geoquímica Isotópica do SURRC, East Kilbride, Escócia. As análises isotópicas foram efetuadas nos seguintes minerais: esmeralda, flogopita, quartzo e feldspatos coexistentes em tipos e associações distintas de mineralizações; no caso das esmeraldas foram analisados separadamente a fase sólida, os fluidos dos canais estruturais e das inclusões fluidas, segundo os procedimentos descritos por Fallick \& Barros (1987). Os resultados encontram-se no Cap. VII e foram utilizados na reconstrução das condições mineralizantes e em abordagens geotermométricas.

\section{I.4.6 - MinERALOGIA E CRISTALOGRAFIA}

Foram realizados os seguintes estudos:

* Espectroscopia no Infravermelho (IR) em cristais de esmeralda de diferentes tipos, associações e gerações de mineralizações (xistos, veios de quartzo e veios pegmatóides) das jazidas de Belmont e Capoeirana, para a identificação do tipo estrutural da água nos canais estruturais do mineral gema (nos laboratórios de IR do IG-USP e do CETEM-RJ). 
* Microtermometria de Inclusões Fluidas (IF) e complementos de Micro-Raman, para auxiliar na caracterização tipológica e genética das esmeraldas (no laboratório de IF do DMP-IG-USP e no Instituto de Física da UFMG, com auxilio e orientação da Prof. Rosa M.S. Bello e Prof. Kazuo Fuzikawa). As IF, em sua totalidade, são secundárias, rehomogeneizadas/contaminadas nos processos tectono-metamórficos proterozóicos, mesmo quando na forma de cristais negativos ou em réplicas microscópicas dos canais estruturais.

* Difratometria de Raios X (DRX) qualitativa e rotineira para identificação mineralógica complementar, por exemplo, de berilo/esmeralda, apatita, córindon, entre outros, e em estudos cristalográficos quantitativos para determinação da cela elementar de esmeraldas de diferentes tipos genéticos - xistos, veios de quartzo e veios pegmatóides (no laboratório do DMP-IG-USP).

* Catodoluminescência comparativa e exploratória visando testar o método e o equipamento disponível como uma nova aplicação na caracterização de gerações distintas de esmeraldas, tanto em ocorrências individuais, quanto nos diferentes tipos de mineralizações já identificadas. Os resultados, entretanto, não foram satisfatórios, uma vez que não foram observadas diferenças significativas e sistemáticas que pudessem denotar zoneamentos e/ou gerações distintas de esmeraldas. Com isto, estes estudos não tiveram prosseguimento. Trabalhos futuros deveriam incluir esmeraldas e outros minerais que ocorrem em mais de uma geração textural e/ou genética, tanto para completar a caracterização dos tipos de mineralizações já reconhecidos, quanto para verificar a presença e amplitude de outras mineralizações de potencial econômico (como por exemplo, a ocorrência já detectada de scheelita em anfibolitos e xistos máficos) e, ainda, para caracterizar minerais passíveis de datações geocronológicas (por exemplo, zircão, monazita). Para isto, entretanto, será necessário um equipamento mais potente, já que a principal limitação do equipamento utilizado (do laboratório de microscopia do DMP-IG-USP) constou na baixa voltagem de aceleração do feixe de elétrons de apenas $18 \mathrm{kV}$.

* Termogravimetria (TG) e Análise Térmica Diferencial (DTA) foram efetuadas em fragmentos de cristais de esmeraldas de xistos, veios de quartzo e veios pegmatóides, das jazidas de Capoeirana e Belmont (MG), após a moagem em cadinhos de cerâmica até granulometria silte $(<0.062 \mathrm{~mm}-2 \mu \mathrm{m})$. As curvas TG/DTA foram obtidas no sistema SDT 2960 da TA Instruments, sob atmosfera estática de ar, no intervalo de temperatura de 25 a $1100^{\circ} \mathrm{C}$, utilizando-se razão de aquecimento de $10^{\circ} \mathrm{C} \min ^{-1}$, massas de amostras da ordem de 
14 a $20 \mathrm{mg}$ e $\alpha-\mathrm{Al}_{2} \mathrm{O}_{3}$ altamente sinterizado como material de referência. Os aspectos analíticos e principais resultados obtidos foram descritos por Machado et al. $(1998 \mathrm{~b}, \mathrm{c})$.

Grande parte desses estudos, em particular aqueles de IR, microtermometria de IF e DRX cristalográfica das esmeraldas, foram realizados e essencialmente concluídos no Mestrado (Machado, 1994) e serão neste trabalho apenas mencionados. Os estudos de catodoluminescência foram relatados no texto do Exame de Qualificação (Machado, 1996) e as análises térmicas em publicações específicas (Machado, 1998b,c), constando o texto do trabalho completo como Anexo 6 neste volume. 


\section{CAPÍTULO II - EVOLUÇÃo GEOLÓGICA E PETROGRAFIA}

\section{II.1 - GEOLOGIA REGIONAL DO EXTREMO NE DO QUADRILÁTERO FERRÍFERO (Q.F.)}

A grande região que inclui as jazidas de esmeraldas de Capoeirana e Belmont continua pouco conhecida. Os mapeamentos mais detalhados devem-se, principalmente, a Dorr \& Barbosa (1963), Reeves (1966), Kehrer (1972), Schorscher (1973, 1975), Engesser (1974), Fontes et al. (1978), Guba (1982), Drumond (1985), Santos (1986), Chemale Jr. (1987a), Veneziani (1987) e Barbosa (1988), sendo ainda incompletos. Os mapas regionais foram compilados destes e outros autores (Dorr, 1969; Pflug \& Renger, 1973; Schobbenhaus et al., 1978, 1981, 1995; Machado Filho et al., 1983; Silva, et al., 1987; entre outros). Em geral, dispõe-se de mapas e/ou sínteses regionais onde foram consideradas as unidades maiores do Q.F. e dos terrenos de gnaisses polimetamórficos adjacentes à leste; estes incluem a região específica de interesse nesta pesquisa. Um esboço geológico do Q.F., Espinhaço Meridional, região de Itabira e adjacências, incluindo as jazidas de Belmont e Capoeirana, foi apresentado por Schorscher (1992) que também revisou a literatura e os mapeamentos até então existentes. Estes e outros trabalhos mais específicos, incluindo a Dissertação de Mestrado (Machado, 1994), serviram de base na presente pesquisa para a caracterização dos conjuntos litológicos, litoestratigráficos e/ou litoestruturais principais, com enfoque naqueles de interesse direto para a gênese das mineralizações de esmeraldas, quais sejam: as continuações do complexo regional arqueano TTG, os Metagranitóides Borrachudos (GB) e equivalentes de mais intenso retrabalhamento metamórfico regional proterozóico (Schorscher, 1992), denominados por Machado (1994) de Metagranitóides Foliados com Fluorita (MGF), e restos de sequências supracrustais, metavulcano-sedimentares, do tipo greenstone belt, arqueanas (SVS).

\section{II.1.1 - SEQUÊNCIAS SUPRACRUSTAIS METAMÓRFICAS}

Estas incluem restos de greenstones belts arqueanos (e, eventualmente, paleoproterozóicos) e coberturas proterozóicas. Restos de greenstones belts são de interesse particular no presente trabalho e ocorrem por todo o Cráton do São Francisco, como parte do embasamento arqueano do tipo TTG e granito-greenstone belt (Mascarenhas, 1973, 1976, 1979; Almeida, 1976, 1977; Schorscher, 1976, 1978; Teixeira, 1978; Sabóia, 1979; Schorscher et al., 1982; Inda et al., 1984; Marini et al., 1984; Schobbenhaus \& Campos, 
1984; Schrank et al., 1984; Schrank \& Silva, 1993; entre outros). Na porção E-SE do Cráton, incluindo as regióes do Q.F., da Serra do Espinhaço Meridional e da zona de transição para o Cinturão Atlântico, constituem o Supergrupo e greenstone belt homônimo Rio das Velhas (Schorscher, 1976, 1978, 1979, 1988, 1991, 1992; Ladeira, 1980; Schorscher et al., 1982; Padilha, 1984; Schrank et al., 1984; entre outros) e outras estruturas/conjuntos litológicos da mesma natureza, denominados formalmente e correlacionados entre si ou não (Uhlein et al., 1983; Fogaça et al., 1984; Inda et al., 1984; Souza, 1988; entre outros).

Nas regiões do extremo E-NE do Q.F., incluindo a área desta pesquisa, verificou-se que os restos das SVS, consideradas Rio das Velhas, ficam, em direção geral para leste, estratigraficamente menos completos, mais deformados e polimetamórficos, de grau médio a alto (Schorscher, 1992); sendo que, os levantamentos regionais e/ou de semi-detalhe, ainda incompletos, conseguiram estabelecer apenas em casos individuais, as continuidades físicas com as localidades tipo no Q.F. (por exemplo: Alves, 1986; Santos, 1986; Barbosa, 1988; Abreu, 1995; Mothé Filho, 1996; Schorscher et al., 1997a,b).

As coberturas proterozóicas compreendem metassedimentos dos supergrupos Minas principalmente e Espinhaço subordinadamente (Inda et al., 1984; Schorscher, 1992) que não ocorrem na área específica desta pesquisa. São, assim, considerados sem importância para a gênese das mineralizações de esmeraldas de Capoeirana e Belmont e, portanto, não serão mais aqui detalhados. Entretanto cabe ressaltar, que regionalmente são importantes como indicadores e marcos temporais relativos de processos geológicos. Em analogia ao que ocorre com os restos do greenstone belt arqueano Rio das Velhas, os metassedimentos proterozóicos também tornam-se, em direção geral para $\mathrm{E}$ estratigraficamente menos completos, mais deformados e metamórficos progressivos de grau médio a alto (Schorscher, 1975, 1992; Müller et al., 1982; Rettinger et al., 1994; Schorscher et al., 1997a,b; entre outros).

\section{II.1.2 - ROCHAS GRANÍTICAS REGIONAIS}

Essas compreendem, principalmente, gnaisses, migmatitos e metagranitóides intrusivos do complexo regional TTG arqueano, Metagranitóides Borrachudos (GB) e Metagranitóides Foliados com Fluorita (MGF), além de gnaisses graníticos e/ou metagranitóides sem definições mais específicas (litológica, estrutural, estratigráfica/cronológica); estes últimos, foram incluídos nesta pesquisa num grupo denominado de gnaisses miloníticos de derivação incerta (GnM). Ao contrário das sequências metamórficas supracrustais, as rochas graníticas aumentam em abundância e distribuição areal 
no sentido regional geral para E. Entretanto, também apresentam-se progressivamente mais metamórficas (de grau médio a alto) e deformadas, conforme evidenciado por fenômenos de migmatização/remigmatização e anatexia e aumento da intensidade da foliação principal associada.

\section{* Complexo Regional TTG Arqueano (TTG)}

É constituído por gnaisses, migmatitos e metagranitóides intrusivos bastante variáveis, entretanto, com predominância de composições tonalíticas, trondhjemíticas e granodioríticas hololeucocráticas. Rochas graníticas sensu stricto mais evoluídas, assim como rochas mais básicas e máficas, são raras. As rochas desse complexo foram consideradas como integrantes das partes mais antigas da crosta siálica arqueana da região, por critérios geológicos, em trabalhos desde clássicos a recentes (revisão em Schorscher, 1992) e assim confirmados por datações $\mathrm{U}-\mathrm{Pb}$ em zircões, que, embora, ainda, locais e isoladas, revelaram idades mínimas de até $\sim 3,4 \mathrm{Ga}$ (Carneiro, 1992, entre outros). A gênese dessas rochas e do complexo TTG como um todo foi considerada por processos superimpostos de formação, acreção e anatexia da crosta mais antiga siálica arqueana. Os processos tectono-metamórficos de retrabalhamento (progressivos, regionalmente para E) do principal evento orogênico Proterozóico supostamente Paleoproterozóico final - causaram desde retrometamorfismo a remigmatização e anatexia, acarretando, principalmente, em grau médio e alto, na potassificação/granitização das rochas TTG arqueanas, junto com o reajuste parcial a total dos principais sistemas isotópicos utilizados em geocronologia.

\section{* Metagranitóides Borrachudos (GB)}

O litotipo original foi descrito, definido e denominado Borrachudos Granite na região a NW de Itabira (Dorr \& Barbosa, 1963). Equivalentes ocorrem nas partes E-NE do Q.F., nas regiōes de Nova Era-Rio Piracicaba, Represa Petí-São Gonçalo do Rio Abaixo-João Monlevade, e a E de Itabira (Reeves, 1966; Dorr, 1969; Herz, 1970; Schorscher, 1973, 1975). Tratam-se, em todos os casos, de metagranitóides com composições de álcali-feldspato granitos com fluorita, ricos em quartzo, bastante homogêneos, hololeucocráticos, de granulação média a grossa, deformados - com os minerais máficos dispostos em agregados lineares orientados paralelamente, típicos para o litotipo. Sob aspectos das mineralizações de esmeraldas estudadas, são importantes litotipos controladores das mineralizações (Souza, 1988, 1990; Schorscher, 1988, 1992; Machado, 1994; Machado \& Schorscher, 1997). 
Quanto a gênese, idade e possíveis correlações regionais dessas rochas existe considerável controvérsia na literatura. Já foram consideradas como as rochas graníticas intrusivas ígneas tardi-orogênicas mais jovens da região do Q.F. incluindo Itabira, com base nas primeiras datações pelo método K-Ar que indicaram idades brasilianas (Dorr, 1969; Herz, 1970). Alternativamente, Schorscher (1975), por razões geológicas e petrográficas, enfatizou a importância de processos associados de milonitização, metassomatismo alcalino potássicosódico e metamorfismo regional na formação desses metagranitóides, que considerou originados em zonas de cisalhamento de raizes crustais profundas ativas durante o Ciclo Minas Paleoproterozóico. Chemale Jr. (1987) considerou os metagranitóides Borrachudos à NW de Itabira como granitos intrusivos alcalino-peralcalinos anorogênicos de idade arqueana. Com base em dados de mapeamento lito-estrutural regional de semi-detalhe, Guimarães \& Schorscher (1991, 1992) e Guimarães (1992) mostraram que os metagranitóides Borrachudos da região de Itabira/Morro do Pilar exerceram controle tanto na instalação, quanto na deformação dos depósitos daquela parte da bacia Minas, portanto reforçando uma idade préMinas, arqueana dos GB. Consequentemente, Schorscher (1992), integrando esses resultados de campo com novos dados litogeoquímicos e com base em comparações com outros terrenos granito-greenstone belt arqueanos, revisou os GB da região do Q.F. e demais partes da borda SE do Cráton do São Francisco por ele estudadas, como metagranitóides tardi-orogênicos do contexto evolutivo regional do greenstone belt arqueano Rio das Velhas (mantendo, entretanto, como modelo petrogenético, o condicionamento por processos associados tectonometamórfico-metassomáticos em zonas de cisalhamento crustais profundas). Os escassos dados geocronológicos dessas rochas não sustentam a idade arqueana geologicamente deduzida mas, tampouco delineiam uma idade alternativa de maneira coerente (Herz, 1970; Teixeira, 1982).

Mais recentemente, Grossi Sad et al. (1990) incluíram e relacionaram os GB da região aqui considerada (N-NE e do extremo NE do Q.F.) com outros granitóides e metagranitóides da região centro-leste de Minas Gerais, num conjunto que denominaram de "Suite Borrachudos" e distinguiram-na como de idade mesoproterozóica e originados por fusão crustal da "Suite Guanhães" arqueana e de origens metamórfico-metassomáticas. Complementações e/ou modificações desse conceito foram elaboradas por diversos autores. Dussin (1994) considerou a "Suite Borrachudos" (que subdividiu em um grupo plutônico e outro vulcânico e designou de "granitos e riolitos Borrachudos") representativa de um magmatismo granítico mesoproterozóico $(\sim 1,7 \mathrm{Ga})$ relacionado a fusão da crosta inferior. 
Posteriormente, Dussin et al. (1997), confrontados com as idades Sm-Nd $\mathrm{T}_{\mathrm{DM}}$ arqueanas (de 3,0 a 2,6 Ga) que encontraram nessas mesmas rochas, mantiveram a interpretação mesoproterozóica e explicaram as idades antigas como aparentes, resultado da assimilação significativa de material crustal mais velho e mais radiogênico, possivelmente arqueano, pelos magmas Borrachudos durante sua ascenção. Já Fernandes et al. (1995a,b) sustentaram que os granitos da "Suíte Borrachudos" na região por eles estudada intrudem gnaisses ortoderivados da "Suíte Guanhães" e rochas da sequência metavulcano-sedimentar nomeada "Grupo Guanhães" e que seriam granitos anorogênicos relacionados à abertura do rift Espinhaço.

Os dados da literatura permitem relacionar, conceitualmente, rochas da "Suite Guanhães" com gnaisses, migmatitos e metagranitóides intrusivos do complexo TTG arqueano (cf. Schorscher, 1992). Já para a "Suite Borrachudos" fica claro que, dependendo dos autores, foram incluídas no mesmo grupo rochas diferentes (plutônicas e vulcânicassubvulcânicas, ígneas e metaígneas, álcali-feldspato graníticas e alcalinas-peralcalinas, arqueanas e proterozóicas) que não necessariamente apresentam relações geológicas regionais e/ou locais, mineralógicas-texturais e geoquímicas análogas ou similares entre si e com os metagranitóides Borrachudos da região N-NE do Q.F. (Dorr \& Barbosa, 1963; Dorr, 1969; Herz, 1970; Schorscher, 1975, 1992; Chemale Jr., 1987a,b; Guimarães, 1992; entre outros).

\section{* Metagranitóides Foliados com Fluorita (MGF)}

A passagem gradativa dos GB a leste de Itabira para gnaisses graníticos granoblásticos subequigranulares de granulação média, hololeucocráticos, também de composição mineralógica álcali-feldspato granítica com fluorita, decorrente da progressão metamórfica regional do principal evento orogênico Proterozóico já foi constatada anteriormente (Schorscher, 1975, 1992; Guimarães, 1992). Machado (1994) também verificou essa transição e conseguiu ainda delinear algumas propriedades geoquímicas, principalmente, de elementos traço, distintas dos GB. Essas associadas às características mineralógico-texturais e relações metalogenéticas específicas, tanto com as ocorrências de esmeraldas (em veios pegmatóides) quanto de pegmatitos beriliferos regionais, justificaram a individualização dessas rochas com o nome próprio de Metagranitóides Foliados com Fluorita (MGF). Depreende-se que os MGF, como os GB, são importantes litotipos controladores das mineralizações de esmeraldas (Machado, 1994; Machado \& Schorscher, 1997). 


\section{* Gnaisses Miloníticos de Derivação Incerta (GnM)}

Nesse grupo foram incluídos gnaisses graníticos miloníticos, migmatitos e/ou metagranitóides diversos que não podem ser correlacionados com confiabilidade a nenhum dos grupos de rochas graníticas anteriores. Ocorrem, principalmente, nas partes orientais da área até então mapeada e representam, mais provavelmente, produtos de retrabalhamento metamórfico progressivo incluindo processos de granitização/potassificação de rochas s.l. graníticas do complexo TTG arqueano (Schorscher, 1975, 1992). Entretanto, ocorrem também, embora mais raramente, gnaisses miloníticos e demais rochas graníticas intimamente associadas com xistos e gnaisses metapelíticos de grau médio a alto. Podem-se tratar, nesses casos, de rochas graníticas para-derivadas seja de sequências supracrustais arqueanas, seja proterozóicas, como já foi proposto na literatura (por ex.: Pflug, 1965a,b; Reeves, 1966; Dorr, 1969; Pflug \& Renger, 1973; Schorscher, 1975; entre outros). Gnaisses miloníticos de derivação incera $(\mathrm{GnM})$ foram verificados na área específica desta pesquisa como rochas subordinadas nas zonas de contato tectônico da SVS com as rochas $s . l$. graníticas associadas.

\section{II.1.3 - TECTÔNICA E METAMORFISMO - EVOLUÇ̃o GEOTECTÔNICA}

Diversos eventos tectono-metamórficos, arqueanos e proterozóicos afetaram toda a região da borda SE do Cráton do São Francisco, incluindo as partes E-NE e do extremo NE do Q.F., superpondo-se uns aos outros, com intensidades, estilos deformacionais, propriedades $\mathrm{P}-\mathrm{T}-\mathrm{X}$ e polaridades diferentes entre si e regionalmente variáveis. Esses eventos imprimiram por toda a região características polideformacionais e polimetamórficas complexas, de difícil análise e interpretação, existindo apenas consensos parciais sobre a evolução geotectônica regional na região.

De um modo geral, devem ser considerados todos os eventos que também afetaram as partes adjacentes à W e SW, mais estáveis do Cráton, incluindo o Espinhaço Meridional (E.M.) e o Q.F., onde foram estabelecidos com maior precisão e melhor definidos. São estes, segundo Schorscher (1992):

(1) Um primeiro evento arqueano que incluiu metamorfismo de grau médio a alto causando migmatização e anatexia crustal generalizada, associado com magmatismo sensu lato (s.l.) granítico regionalmente expressivo e localmente processos de granulitização, originando o complexo regional TTG. A deformação, melhor observada nos gnaisses e migmatitos heterogêneos (bandados, dobrados, etc.) que são rochas menos abundantes quando comparadas aos equivalentes homogêneos hololeucocráticos, indica predominância de 
dobramentos isoclinais, com foliações de alto grau com direções, embora variáveis, com máximo em NNW e caimentos predominantementes para E. Este evento originou as rochas mais antigas da região, de idades mínimas de $\sim 3,4 \mathrm{Ga}$ (Carneiro, 1992).

(2) O segundo evento arqueano representa regionalmente o ciclo de evolução crustal de tipo greenstone belt Rio das Velhas. A orogênese deste evento foi acompanhada de metamorfismo regional brando, predominando condições de fácies dos xistos verdes, que causou retrometamorfismo nas rochas do complexo TTG de mais alto grau e metamorfismo progressivo nas sequências supracrustais vulcano-sedimentares. A deformação foi forte e imprimiu à região um estilo estrutural de domos TTG e sinclinórios a eles amoldados contendo as sequências greenstone belt, afetadas por dobramentos isoclinais apertados. Os metagranitóides Borrachudos também são considerados como produtos da orogênese Rio das Velhas arqueana. Datações indicam idades mínimas arqueanas superiores, de cerca de 2,7 Ga para a orogênese Rio das Velhas (Carneiro, 1992; Machado et al., 1989a,b, entre outros).

(3) O terceiro evento representa a evolução do ciclo Minas/Espinhaço Paleoproterozóico até, possivelmente, o início do Mesoproterozóico. Os metassedimentos do SGr. Minas com metaconglomerados de tipo quartz pebble conglomerates com ouro, uraninita e piritas detríticas, de águas rasas, seguidos de xistos grafitosos e itabiritos (i.e.: formações ferríferas de fácies óxido com hematita, de tipo Superior Province), assim como os vastos depósitos ortoquartzíticos do SGr. Espinhaço, também com pirita detrítica nas suas formações basais, são típicos para a época. Os resultados de trabalhos de datações mais recentes (por ex.: Machado et al., 1989a,b; 1996; Babinski et al., 1991; Noce, 1995; Rettinger, 1998, entre outros) confirmam cada vez mais a proveniência e evolução penecontemporânea conjunta, desde sedimentar a orogênica dos dois supergrupos como equivalentes laterais de fácies no Paleoproterozóico (cf.: Harder \& Chamberlin, 1915; Pflug, 1965, 1968; Pflug \& Renger, 1973). O modelo de uma plataforma continental consolidada no Arqueano, afetada por fraturamento, que evoluiu à partir de um estágio inicial de rift (acompanhado localmente de magmatismo diamantífero), para uma margem continental inicialmente passiva (com expressivas polaridades e diferenciação sedimentar clástica e química e do magmatismo sinsedimentar segundo ambientes de fácies proximais e distais e estruturais), e por final, para uma margem ativa com orogênese de tipo alpina, foi desenvolvido por Schorscher $(1975 ; 1992)$, que enfatizou ainda a importância dos processos associados de tectônica de nappes, obducção crustal e metamorfismo regional plurifacial progresivo. Resultou assim a estruturação da borda E-SE do Cráton do São Francisco num 
sistema frontal de embricamento, expondo progressivamente niveis crustais mais profundos no sentido regional E. As características do metamorfismo variaram de condições de mais alta P pré-a-sintectônicas (de tipo Barrow ou superiores) para mais elevadas $T$ tarde-sin a póstectônicas e intensidades (crescentes, regionalmente de $\mathrm{W}$ para $\mathrm{E}$ ) da fácies dos xistos verdes inferior a média até a fácies anfibolito superior e hidrogranulito. Para a região de Itabira, foi apresentado um mapa de isógradas e zonas minerais (Schorscher, 1975) completado com dados geotermobarométricos por Rettinger (1994) e Rettinger et al. (1996). Mais recentemente, ainda foi possível datar o metamorfismo (utilizando inclusões de monazita em bordas de granadas) obtendo idades de 1.9-2.0 Ga (Rettinger, 1998).

Este metamorfismo regional paleoproterozóico, final do ciclo Minas/Espinhaço foi o evento principal dessa natureza em toda a parte da borda $\mathrm{E}$ do Cráton do São Francisco aqui considerada e causou: (a) polimetamorfismo variável desde retrometamorfismo a remigmatização e anatexia nas rochas do complexo TTG arqueano; (b) polimetamorfismo, em geral, progressivo nas sequências de tipo greenstone belt arqueanas da região (apenas em poucos locais da região da borda W do Q.F., as rochas do SGr. Rio das Velhas apresentam grau metamórfico máximo, maior do que as rochas do SGr. Minas associadas), e (c) metamorfismo regional progressivo nos metassedimentos dos Supergrupos Minas e Espinhaço (ver também: Gorlt, 1972; Engesser, 1974; Hoefs et al., 1982; Müller et al., 1982, 1986a,b; Jordt Evangeslista, 1984, 1985; Jordt Evangeslista \& Müller, 1986; Teixeira et al., 1987, entre outros).

(4) O último evento diz respeito ao ciclo Brasiliano, com sedimentação clástica e química-carbonática do SGr. São Francisco, de mar epicontinental raso, sobre as partes internas estáveis do Cráton do São Francisco, com início no Mesoproterozóico Superior (Moeri, 1972) e sob influências glaciais continentais a marinhas em vastas partes da borda $\mathrm{E}$ da bacia (Hettich, 1977; Inda et al., 1984, entre outros). O fim orogênico desse ciclo constou de processos tectono-termais que ocorreram num intervalo amplo de tempo, de 650 a $450 \mathrm{Ma}$, causando na região considerada da borda leste do Cráton do São Francisco, apenas localmente, efeitos mais expressivos de metamorfismo termal associado a intrusões graníticas menores; entretanto, os efeitos de retrometamorfismo (em condições de fácies dos xistos verdes) são onipresentes e responsáveis pelos reajustes generalizados, parciais a totais dos principais sistemas isotópicos utilizados em geocronologia.

Modelos geotectônicos diferentes do acima exposto foram elaborados por diversos autores, tanto para litotipos individuais, conjuntos de litotipos e associações litoestruturais, 
como para a região integralmente. Revisões bastante abrangentes encontram-se em Barbosa (1954), Dorr (1969), Pflug (1965), Pflug \& Renger (1973), Inda et al. (1984), Schorscher (1992), entre outros. Trabalhos mais recentes sobre a evolução proterozóica devem-se, entre outros, a Trompette et al. (1992), Carneiro et al. (1995), Uhlein et al. (1995), Cunningham et al. (1996), Rettinger (1998), Alkmim \& Marshak (1998).

\section{II.2 - GEOLOGIA DA REGIÃO DE CAPOEIRANA E BELMONT}

\section{II.2.1 - TRABALHOS ANTERIORES}

Morfologicamente acidentada, de dificil acesso e profundamente intemperizada, principalmente, nas áreas metavulcano-sedimentares, a região das jazidas de esmeraldas de Capoeirana e Belmont impõe obstáculos naturais ao detalhamento geológico com métodos de campo convencionais. Assim, existem apenas os mapeamentos lito-estruturais, estratigráficos e metamórficos em escalas, respectivamente, de semidetalhe (1:20.000) e regional $(1: 70.000)$ (Schorscher, 1973; 1975), um mapeamento litológico (1:35.000) das imediações da jazida de Belmont (Souza, 1988), e o mapeamento litológico de semidetalhe (1:18.000) de Machado (1994). Estes permitiram verificar, como características gerais, a natureza de terreno policíclico, predominando rochas sensu lato graníticas que encerram restos de sequências supra-crustais, metavulcano-sedimentares (SVS) do tipo greenstone belt, polimetamórficas, de grau médio a alto. As SVS abrigam nas rochas metaultramáficas as mineralizações de esmeraldas de Capoeirana e Belmont e foram consideradas, com base em dados litoestruturais locais e regionais, como continuações do Supergrupo Rio das Velhas, embora disruptas e sem contatos conhecidos com as regiões-tipo deste Supergrupo no Q.F. (Schorscher, 1988; 1992; Souza, 1988; Machado, 1994).

Em escala de semidetalhe, estudos integrados, geológicos, petrográficos, geoquímicos e mineralógicos de toda a região compreendida entre Itabira e Nova Era, com ênfase na evolução crustal, petrogênese ígnea e polimetamórfica, metalogênese arqueana e proterozóica, incluindo considerações sobre as jazidas de esmeraldas, foram desenvolvidos por Schorscher (1975; 1988; 1991; 1992). Em escala de maior detalhe, estes estudos integrados foram continuados com ênfase nas jazidas de esmeraldas e tiveram seus resultados iniciais apresentados na Dissertação de Mestrado de Machado (1994).

Existe, ainda, um número considerável de trabalhos mineralógicos, petrográficos e geoquímicos de detalhe, além de notas geológicas locais, visando especificamente as 
ocorrências e determinação das propriedades das esmeraldas como mineral gema. No caso da jazida Belmont estes estudos se devem a Müller-Bastos (1981), Mendes et al (1985), Schwarz \& Mendes (1985a,b), Hänni et al. (1987), Souza \& Svizero (1987), Souza (1988;1990), Schwarz et al. (1988), Schorscher et al. (1990), entre outros; e da jazida Capoeirana a Epstein (1989), Souza et al. (1989), Souza et al. (1990) e Herrmann (1991). Estudos comparativos, principalmente mineralógicos e químicos, das esmeraldas brasileiras e suas ocorrências, incluindo dados sobre as jazidas de Belmont e/ou Capoeirana foram realizados por Sauer (1982), Cassedanne (1984), Souza \& Svizero (1987), Schwarz (1988; 1990), Giuliani et al. (1997a), entre outros. Estudos de isótopos estáveis foram realizados por Fallick et al. (1994) e Giuliani et al. (1997b), e de datações radiométricas (de esmeraldas) por Vidal et al. (1992) e Ribeiro-Althoff et al. (1997).

Os trabalhos de cunho mineralógico foram imprescindíveis para a caracterização precisa (cristalográfica, de química mineral, inclusões fluidas e cristalinas, entre outros) das esmeraldas das jazidas de Belmont e Capoeirana no quadro das demais ocorrências destas gemas no Brasil e no mundo. Estes trabalhos forneceram, ainda, valiosos dados sobre as rochas hospedeiras e encaixantes imediatas das mineralizações e revelaram similaridades muito grandes entre as duas jazidas, Belmont e Capoeirana, que sustentaram também, indubitavelmente, analogias e relacionamentos genéticos. Entretanto, têm sérias limitações no que diz respeito aos processos metalogenéticos e aos controles petrogenético-estruturais sugeridos para as mineralizações, que foram ora inferidos, ora adaptados da literatura. São, nestes aspectos, comumente, discordantes entre si e não correspondem às características geológicas da região.

\section{II.2.2 - RESUltADOS DESTE TRABALHO}

Como resultado dos estudos geológicos integrados do Mestrado (Machado, 1994), complementados com detalhamentos pontuais, é apresentado na Figura 1 um esboço do mapa geológico confeccionado com base em 260 afloramentos/perfis levantados e fotointerpretações geológicas; o mapa de localização $\mathrm{e}$ as descrições dos afloramentos/amostras constam no Anexo 1. Depreende-se que a área é constituída por rochas TTG, restos de uma sequência metavulcano-sedimentar (SVS), metagranitóides Borrachudos (GB), metagranitóides foliados com fluorita (MGF) e, como tipos litológicos menores, gnaisses de derivação incerta $(\mathrm{GnM})$ e diques básicos, estes últimos não sendo considerados nesta pesquisa. 
As rochas TTG são os litotipos arqueanos mais antigos da região. Ocorrem como restos preservados dos retrabalhamentos proterozóicos, com contatos gradacionais no interior dos corpos regionais de GB e MGF. Tratam-se de migmatitos, gnaisses metatéticos e metagranitóides intrusivos polimetamórficos, em geral, cinza claros, hololeucocráticos, mesmo os gnaisses e migmatitos apresentando homogeneização avançada.

\section{A Sequência Metavulcano-Sedimentar (SVS) de Capoeirana e Belmont é} considerada mais jovem que as rochas TTG e uma continuação tectonicamente disrupta do greenstone belt arqueano Rio das Velhas. Foi afetada por apenas um metamorfismo arqueano que não excedeu a fácies xisto verde superior/anfibolito inferior no final da evolução greenstone belt, seguido no Paleo a Mesoproterozóico, pelo principal metamorfismo regional progressivo, de grau variável - médio a alto - na área estudada. Compreende, essencialmente, xistos e anfibolitos metaultramáficos, anfibolitos básicos a intermediários, gnaisses e xistos vulcanoclásticos, calciossilicáticos e sedimentares clásticos (derivados de pelito/siltitos), arenitos líticos e quartzo-arenitos, assim como formações ferríferas bandadas e metacherts. As relações litoestruturais e estratigráficas são complexas, faltando, ainda, muitos conhecimentos de detalhe. No geral, a SVS ocorre em duas faixas principais, de Belmont na parte centrooeste da área e de Capoeirana na parte centro-leste, além de outras faixas menores e menos completas litologicamente (Fig. 1). Estas têm contatos tectônicos por falhas inversas entre si e com as rochas s.l. graníticas adjacentes, constituindo-se em escamas de dimensões variáveis, inseridas num sistema de cavalgamentos antitéticos (com caimentos baixos a médios, em geral para W). Internamente, sofreram inversão, dobramentos isoclinais e de arraste superimpostos e repetições tectônicas pela principal orogênese proterozóica Minas/Espinhaço. Destacam-se como características típicas de greenstone belt arqueano, além da sucessão litológica geral, a natureza extrusiva das rochas metaultramáficas que ocorrem na base da sequência em corpos/níveis delgados (submétricos a métricos), concordantes e finamente intercalados com xistos máficos, apresentando, às vezes, pequenas concentrações de cromititos disseminados. Seguem-se na sequência, anfibolitos básicos a intermediários, também intercalados com xistos máficos e metapelíticos. Os anfibolitos têm origens vulcânicas extrusivas e intrusivas subvulcânicas, de basaltos a andesitos toleíticos oceânicos. Alguns mostram evidências de alterações hidrotermais-metassomáticas, pré-metamórficas (de fundo oceânico), sendo cummingtonita-granada-cordierita anfibolitos. As rochas metassedimentares evoluem na sucessão lito-estratigráfica de composições imaturas, com 
considerável contribuição vulcanoclástica, para composições mais maturas, incluindo quartzomuscovita xistos a quartzitos.

Os Metagranitóides Borrachudos (GB) e as Mineralizações de Esmeraldas Arqueanas são alvos centrais desta pesquisa. Os GB são os litotipos mais abundantes na área, sendo metagranitóides fortemente deformados, hololeucocráticos, de granulação médiagrossa, ricos em quartzo, às vezes, com fluorita lilás macroscópica. A deformação inclui lineação dada por agregados de minerais máficos orientados, característica deste litotipo, de direções constantes $\mathrm{E}$, horizontal a subhorizontal, neste último caso caindo com ângulos baixos, ora para $\mathrm{E}$, ora para W. A foliação principal do metamorfismo regional Minas/Espinhaço proterozóico sobrepõe-se à lineação (arqueana), achatando os agregados de minerais máficos. Nos GB ocorrem ainda com grande freqüencia veios de quartzo posteriores à deformação principal; pegmatitos não foram observados e veios pegmatóides são muito raros ou mesmo ausentes.

Nos contatos tectônicos dos GB com as rochas metaultramáficas da SVS, estas apresentam-se flogopitizadas e mineralizadas por processos metassomáticos, sinmetamórficos e sin-tectônicos; assim, originaram-se as mineralizações de esmeraldas de tipo xisto e as mineralizações associadas de tipo veios de quartzo polideformados de idade arqueana. Nas zonas flogopitizadas e mineralizadas, que variam de espessuras de poucos metros a dezenas de metros, as rochas metaultramáficas foram transformadas em biotitaflogopita xistos por processos parciais a totais. Restos de anfibolitos metaultramáficos preservados da transformação ocorrem em corpos de tipo núcleos de boudins e são chamados, no jargão dos garimpeiros, de "rampa verde". Nos xistos metaultramáficos da zona mineralizada ocorrem, por vezes, cristais centimétricos de apatita, reconhecidos inclusive pelos garimpeiros como indicadores da proximidade da mineralização de esmeraldas. Sob aspectos quantitativos e qualitativos, as mineralizações de esmeraldas de tipo xisto e veios de quartzo polideformados, arqueanas, são as principais, tanto em Belmont quanto em Capoeirana, sendo as únicas que ocorrem em Belmont.

Os Metagranitóides Foliados com Fluorita (MGF) e as Mineralizações Beriliferas Proterozóicas devem-se à principal orogênese proterozóica do Ciclo Minas/Espinhaço. $O$ metamorfismo regional progressivo e deformações associadas deste evento causaram a progressão sistemática da fácies xistos verdes superior/anfibolito inferior nas extremidades $\mathrm{W}$ da área, para anfibolito médio na região de Belmont e anfibolito superior na região de Capoeirana e, em geral, na parte $\mathrm{E}$ da área. Essa progressão causou a transformação gradativa 
dos GB em MGF a partir da fácies anfibolito médio, por processos essencialmente mineralógico-texturais e isoquímicos. Os MGF típicos são gnaisses graníticos hololeucocráticos, homogêneos, granoblásticos, subequigranulares de granulação média, ricos em quartzo; sua foliação forte é macroscopicamente pouco expressiva, indicada apenas pela orientação das esparsas palhetas de biotita. $\mathrm{O}$ grau metamórfico maior a $\mathrm{E}$ da jazida Belmont, iniciou fusão parcial nos MGF, produzindo pegmatóides e pegmatitos tardi-sin a póstectônicos, pouco deformados em relação aos MGF encaixantes. Pegmatóides também ocorrem intrusivos na SVS em Capoeirana, onde próxima ou em contato com os MGF, sendo menos deformados que as encaixantes e com xenólitos destas em disposição aleatória. Quando intrusivos nas rochas metaultramáficas são, em geral, mineralizados em esmeraldas. Esses pegmatóides representam um evento proterozóico de mineralização de esmeraldas, metamórfico de médio/alto grau, relacionado a anatexia inicial dos MGF. Possivelmente, formaram-se, também, neste evento as alexandritas de Capoeirana, cujas ocorrências in situ, entretanto, ainda, não foram encontradas. Em Belmont não ocorrem mineralizações de esmeraldas de tipo veios pegmatóides e/ou pegmatitos; tampouco foram encontrados/mencionados alexandritas/crisoberilos. Estes fatos foram explicados pelo menor grau de metamorfismo regional proterozóico nesta região da área mapeada (Machado, 1994). Face à importância dos GB e MGF para as mineralizações de esmeraldas e defronto com a controvérsia existente na literatura, cabe ressaltar que as rochas denominadas Borrachudos de outras regiões do Espinhaço Meridional e do extremo NE do Q.F. (por ex.: Grossi Sad et al., 1990; Dussin, 1994; Fernandes et al., 1995a,b; entre outros) são aqui consideradas não necessariamente equivalentes aos GB e MGF desta pesquisa e, portanto, excluídas dos termos e vistas com restrições quanto as implicações geológicas, petro-metalogenéticas e geotectônicas.

Os Gnaisses Miloníticos de Derivação Incerta (GnM) ocorrem nas zonas de contato da SVS com as rochas s.l.graníticas, principalmente, na região de Capoeirana, em faixas de larguras consideráveis (de até várias centenas de metros). Trata-se de um grupo de rochas heterogêneas. Algumas foram derivadas por milonitização progressiva das rochas TTG típicas e apresentam-se com contatos gradacionais, como milonitos ou blastomilonito-gnaisses quartzo-feldspáticos bastante homogêneos, cinza-claros, que, às vezes, sofreram feldspatização potássica. Outros GnM são rochas de partes tectonicamente disruptas da SVS, incluindo milonito-gnaisses cinzentos de granulação e bandamento fino, mais ricos em filossilicatos, milonito-gnaisses félsicos de cor branca, ricos em feldspatos e muscovita, além 
de milonito-gnaisses e milonito-xistos com teores variáveis de quartzo e muscovita, principalmente, e feldspato subordinado. Esses GnM ocorrem como níveis e lentes concordantes na foliação milonítica, com espessura centimétrica a decamétrica e continuidade lateral variável (métrica a centena de metros), intercalados aos GnM homogêneos, quartzofeldspáticos, ficando mais freqüentes com a aproximação da SVS. Todos os GnM apresentam-se mais alterados/intemperizados do que seus prováveis equivalentes nãomiloníticos em condições similares.

A Evolução Neoproterozóica deixou como registros mineralógico-petrográficos apenas fenômenos locais de rehidratação e retrometamorfismo fracos, incluindo a formação de cloritas, epidotos, carbonatos e sericitas, principalmente, em zonas de reativação de falhas e fraturas.

\section{II.3 - PETROGRAFIA}

Os estudos petrográficos convencionais detalhados foram fundamentais para a definição e caracterização mineralógica-textural das principais unidades litoestratigráficas e litoestruturais, entre elas: as rochas sensu lato graníticas (incluindo TTG e GnM, GB e MGF e veios/corpos pegmatóides) e as rochas da SVS (incluindo anfibolitos metabásicos, rochas metaultramáficas e metapelitos), além dos diferentes tipos e gerações de mineralizações beriliferas, principalmente de esmeraldas, mas também de águas marinhas pegmatíticas. Esses estudos constituíram tópicos centrais do Mestrado (Machado, 1994). No que se segue, são resumidos os resultados principais anteriores completados pontualmente com dados novos.

\section{II.3.1 - METAGRANITÓIIDES E ROCHAS DE COMPOSIÇÃO S.L. GRANíTICA}

* Gnaisses TTG e Gnaisses Miloníticos de Derivação Incerta (GnM)

As rochas da associação TTG incluem gnaisses e migmatitos leucocráticos, homogêneos a fracamente bandados, com raros níveis anfibolíticos e biotíticos e sempre com foliação bem desenvolvida. São polimetamórficas, constituídas essencialmente por plagioclásio, quartzo, K-feldspato e biotita e pelos constituintes menores, acessórios e secundários, zircão, alanita, apatita, minerais opacos, muscovita, clorita, epidoto-clinozoizita, leucoxênio/rutilo e carbonato. O plagioclásio apresenta zonação metamórfica inversa e borda albítica quando em contato com microclínio. Este apresenta geminação típica e, localmente, junções tríplices em $120^{\circ}$. 
Os GnM ocorrem nas zonas miloníticas de contato das rochas TTG com xistos e gnaisses metapelíticos da SVS, sendo mais bem expostos na área do garimpo de Capoeirana. São, em geral, félsicos, constituídos por feldspatos (plagioclásio e microclínio), quartzo, biotita e muscovita (que varia desde traço a teores de muscovita $>$ biotita). Plagioclásio e quartzo ocorrem como cristais estirados na foliação e com extinção ondulante. Os feldspatos podem ocorrer, também, como porfiroclastos porfiroblásticos contornados pela foliação. Muscovita e biotita são fortemente orientadas e intercrescidas. Em quantidades maiores, a muscovita chega a formar níveis contínuos bem definidos e intercalados com níveis quartzofeldspáticos. Os minerais acessórios e secundários são, essencialmente, os mesmos dos TTG. Esses gnaisses representam equivalentes miloníticos e, eventualmente, metassomáticos por feldspatização potássica dos TTG. Outros GnM são tectonitos de partes diversas da SVS, incluindo milonito-gnaisses cinzentos, finos, bandados e milonito-gnaisses/milonito-xistos quartzo-muscovíticos com ou sem feldspatos (predominando feldspato alcalino) derivados de metassedimentos imaturos (tipo grauvacas, subgrauvacas, arenitos líticos e sedimentos finos em geral) e milonito-gnaisses brancos feldspato-muscovíticos com quartzo subordinado, representativos, possivelmente de metavulcanitos ácidos a ácido-intermediários da SVS.

* Metagranitóides Borrachudos (GB) e Metagranitóides Foliados com Fluorita (MGF)

Os GB são metagranitóides hololeucocráticos, de granulação média a grossa, constituídos, essencialmente, por quartzo, feldspato alcalino, plagioclásio, biotita, hornblenda, fluorita, epidoto-clinozoisita-alanita, zircão, monazita, minerais opacos (magnetita, ilmenita, sulfetos), titanita, apatita e, eventualmente, granada (Prancha 1, Foto 1).

O feldspato alcalino, constituinte principal e característico dos GB, é mesopertita de substituição parcial a completa do plagioclásio. Este, além da fase reliquiar em porfiroclastos parcialmente substituídos por feldspato alcalino, é também componente da matriz. Os feldspatos são afetados por recristalização e reequilibrações metamórficas progressivas. Mesopertitas e plagioclásios, saussuritizados em restos de substituição ocorrem apenas no extremo W da área, assim como nos corpos regionais de Itabira e São Gonçalo (Schoscher, 1992). A partir da fácies anfibolito inferior, as mesopertitas recristalizam para microclínios e plagioclásios albíticos granoblásticos em grãos separados (Prancha 1, Foto 2). Os plagioclásios, por ressorção progressiva de clinozoisita, desenvolveram zoneamento metamórfico inverso, evoluindo para oligoclásios (em geral, não geminados). Quando em contato com microclínio, desenvolvem bordas externas de albita virtualmente pura. 
Os minerais máficos principais (biotitas e, subordinadamente, hornblendas) encontram-se em agregados (macroscopicamente lineares) orientados (Prancha 1, Fotos 3 e 4); apresentam formas tardi-sin a pós-tectônicas e estão associados com zircão, alanita, epidoto-clinozoizita, monazita, minerais opacos, titanita e fluorita, entre outros. A granada, quando presente, ocorre em cristais isolados, com formas euédricas. $\mathrm{O}$ estado deformacional dos GB indica a lineação dos agregados de minerais máficos como elemento mais antigo; sobrepõe-se, com intensidade crescente, a foliação principal que acompanha a progressão metamórfica regional do principal evento proterozóico.

Os MGF são metagranitóides hololeucocráticos, granoblásticos subequigranulares, de granulação fina a média, com foliação bem desenvolvida. A composição mineralógica é similar a dos GB, destacando-se, porém, a ocorrência dos feldspatos, inicialmente, em agregados granoblásticos de microclínio e plagioclásio, passando para grãos maiores, isolados, produtos da recristalização metamórfica progressiva das mesopertitas dos GB, durante a deformação no curso do principal evento metamórfico regional dínamo-termal proterozóico. Analogamente, destaca-se, ainda, a distribuição em palhetas individualizadas da biotita que não chegam a formar os agregados máficos típicos dos GB. A hornblenda verdeazul-escura, tanto nos GB quanto nos MGF, é formada por metamorfismo progressivo em reações complexas que envolveram biotita e epidoto, entre outros (Schorscher, 1992).

Os MGF podem gradar, ainda, para ultramilonitos constituídos, essencialmente, de quartzo, microclínio, plagioclásio sódico, biotita, muscovita, granada e clorita e, como constituintes menores, apatita, fluorita, opacos e carbonatos. Estes ultramilonitos e as intercalações de quartzo-muscovita milonito-xistos (tanto em rochas sensu lato graníticas, quanto na SVS) estão orientados concordantemente com a estrutura geral das rochas sensu lato graníticas encaixantes.

\section{* Pegmatóides}

Abundantes mobilizados pegmatóides graníticos em veios e bolsões irregulares de dimensões decimétricas e pegmatitos em corpos maiores, com zonação mais ou menos bem desenvolvida ocorrem nos MGF, a partir da fácies anfibolito média, podendo ser portadores de águas marinhas.

Nas rochas da SVS de Capoeirana, próximas aos contatos com os MGF, ocorrem veios pegmatóides plagioclasíticos intrusivos nas rochas metaultramáficas, sendo mineralizados em esmeraldas, e veios pegmatóides peralumínicos com cianita, cordierita, córindon e 
plagioclásio (Prancha 1, Foto 5) intrusivos nos gnaisses metapelíticos. Todos os veios pegmatóides e pegmatitos graníticos dos MGF com ou sem berilos-águas marinhas e plagioclasíticos com esmeraldas e peralumínicos com córindon (quartzo-deficientes), respectivamente, das rochas metaultramáficas e metapelíticas da SVS, apresentam-se intrusivos, discordantes a pseudoconcordantes e menos deformados, tardi-sin a pós-tectônicos em relação a foliação principal de suas respectivas encaixantes.

\section{II.3.2 - SEQUÊNCIA METAVULCANO-SEDIMENTAR}

\section{* Rochas Metaultramáficas}

As rochas metaultramáficas, com cromita acessória ou cumulática, são representadas por xistos com proporções variáveis de talco, anfibólio e clorita (TACX) e anfibolitos constituídos quase que exclusivamente por anfibólios (AU). O anfibólio incolor nos TACX é suborientado a fibro-radial e cresce sobre a matriz talco-clorítica, crenulada, sendo tardi-sin a pós-tectônico em relação à foliação principal. $\mathrm{O}$ anfibólio verde nos $\mathrm{AU}$ é fortemente orientado na foliação e intercrescido/sobrecrescido por anfibólio incolor. As cromitas são os únicos minerais de origens magmáticas ainda preservados.

Nas áreas das mineralizações, as rochas metaultramáficas com ou sem cromititos associados são as hospedeiras das esmeraldas. Nestas áreas, o aparecimento e os teores crescentes de flogopita caracterizam a alteração metassomática mineralizante, causando a transição das rochas metaultramáficas para flogopititos.

\section{* Anfíbolitos Metabásicos}

Os anfibolitos metabásicos distribuem-se por toda a área, onde ocorrem como intercalações pseudoconcordantes e concordantes, em corpos tabulares de espessuras até métricas nas rochas da SVS. Podem ser divididos em subgrupos petrográficos caracterizados pelas seguintes assembléias minerais:

(I) anf + plag $+q z \pm$ op (anfibolitos metabásicos - AB);

(II) anf + plag $+q z \pm$ ep-clz \pm tit \pm op (anfibolitos metabásicos com epidoto e/ou titanita - ABET);

(III) anf + plag + qz + gr (anfibolitos metabásicos com granada - AG).

Em todos estes subgrupos, o anfibólio verde dispõe-se em arranjos nematoblásticos, dobrados. É comum a substituição de anfibólio verde por incolor, este tardi-sin a póstectônico em relação à foliação principal. O plagioclásio é fortemente estirado na foliação ou 
granoblástico, poligonal, com junções tríplices; via de regra, apresenta zonação inversa e, ainda, saussuritização parcial a avançada por processos retrometamórficos e de hidratação local, tardios.

Nos ABET, a titanita e o epidoto concentram-se em bandas. Já a granada dos ABG é poiquiloblástica, com inclusões de quartzo, plagioclásio, opacos e biotita em estrutura helicítica. Às vezes, é fraturada e sutilmente contornada pela foliação sugerindo crescimento pré- a sin-tectônico. Mais raramente, pode também apresentar aspecto deformado/dobrado sugerindo seu crescimento durante ou posterior a deformação, em bandas com controle composicional químico-mineralógico específico.

A biotita nos anfibolitos metabásicos em geral, embora um constituinte menor, pode ocorrer esfoliada com lentes de feldspato potássico, similar às flogopitas das rochas metaultramáficas. $\mathrm{O}$ mineral opaco predominante dos anfibolitos é a ilmenita.

\section{* Metapelitos}

Os xistos/gnaisses metapelíticos apresentam texturas variáveis desde maciças ou foliadas a homogêneas ou bandadas. A mineralogia, também, é bastante variável, podendo ocorrer quartzo, plagioclásio, biotita, muscovita, clorita, granada, estaurolita, cordierita, cummingtonita, anfibólios verdes, cianita e sillimanita, e ainda, rutilo, minerais opacos (ilmenita, magnetita, sufetos), zircão, apatita, fluorita, entre outros.

A biotita foi formada em gerações distintas, sendo pré- a sin-tectônica (orientada na foliação) e pós-tectônica (discordante). Apresenta diferenças não sistemáticas nas cores de pleocroismo.

O anfibólio incolor cummingtonita exibe hábito desde fibro-radial a prismáticoidioblástico, crescendo, em geral, sobre a foliação e associado à estaurolita, granada ou cordierita (Prancha 1, Fotos 6,7 e 8). O anfibólio verde é raro e, quando presente, é substituído/sobrecrescido por anfibólio incolor.

A granada pode ocorrer como cristais xenomórficos com formas alongadas e com inclusões de quartzo, plagioclásio, biotita/clorita e opacos, orientadas segundo o alongamento do cristal; como porfiroblastos sub- a idioblásticos, de dimensões até centimétricas, sem e com inclusões, neste caso em estrutura helicítica (sintectônica) e, ainda, como cristais esqueléticos, intergranulares, preenchendo interstícios entre quartzo e plagioclásio; em geral, encontra-se em equilíbrio com rutilo e contém inclusões corroídas de estaurolita. 
A estaurolita é xenomórfica e ocorre associada à cummingtonita e fibrolita, sobrecrescendo granada e inclusa em cordierita (Prancha 2, Fotos 9 a 11); pode, ainda, ocorrer com formas subédricas em reações mútuas de contato com cianita (Prancha 2, Foto 12).

A cianita ocorre com a muscovita em veios de quartzo cizalhados, apresentando-se fortemente deformada (os cristais são dobrados e com forte extinção ondulante); ocorre, ainda, associada à biotita, estaurolita, cordierita, fibrolita e córindon; algumas vezes, observam-se reações de contato com estaurolita (Prancha 2, Fotos 12 a 14).

A cordierita ocorre como porfiroblastos com inclusões de opacos (com reações para rutilo), anfibólio incolor e estaurolita corroída, ou, ainda, nos interstícios da cianita/fibrolita, biotita, quartzo, plagioclásio, anfibólio incolor ou granada (Prancha 2, Fotos 10 e 15); via de regra, apresenta-se geminada e pinitizada (transformada em clorita) por processos retrometamórficos tardios (Prancha 2, Foto 16).

\section{III.3.3 - MINERALIZAÇÕES DE ESMERALDAS}

As mineralizações de esmeraldas na região de Belmont estão associadas a TACX e na região de Capoeirana a AU e TACX, sempre parcial a totalmente flogopitizados. Nos flogopititos ocorrem apatitas em cristais até centimétricos, pré a tardi-sin e pós-tectônicos em relação à foliação principal. Nos processos metassomáticos mineralizantes, a cromita é também atacada, sofrendo corrosão. A flogopita pode ocorrer esfoliada, com lentes interfoliares de albita e feldspato potássico metassomáticos, e alterar-se em clorita em processos retrometamórficos tardios.

A esmeralda ocorre em três tipos principais de mineralizações: tipo xisto (EX), tipo veio de quartzo (EVQ) e tipo veio pegmatóide (EVP).

Nas mineralizações de tipo xisto (EX), a esmeralda ocorre como porfiroblastos xenoblásticos a subidioblásticos de dimensões centimétricas, preferencialmente orientados na foliação principal, sendo envolvida por esta. Pode, ainda, ocorrer associada ao quartzo com contatos irregulares, em charneiras de micro-dobras (Prancha 3, Fotos 17 e 18). Exibe sombras de pressão e lamelas de deformação (Prancha 3, Fotos 19 e 20). Estas características indicam uma origem pré-tectônica em relação ao evento metamórfico deformacional principal proterozóico. 
As mineralizações de tipo veios de quartzo (EVQ) podem ser agrupadas em subtipos:

- Veios de quartzo polideformados, finos, de espessuras centimétricas a milimétricas, concordantes com a foliação principal. Nestes, a esmeralda é facoidal ou porfiroblástica porfiroclástica a subidioblástica e com sombras de pressão de quartzo; os contatos com o quartzo são irregulares (Prancha 3, Fotos 21 a 23); apresenta inclusões de flogopita, quartzo e esmeralda idiomórfica de uma geração anterior;

- Veios de quartzo polideformados, espessos (decimétricos $a \leq 2 \mathrm{~m}$ ), pseudoconcordantes com a foliação principal. Estes contém fragmentos (porfiroclastos) angulosos a deformados de esmeraldas apenas em suas bordas (de no máximo $10-15 \mathrm{~cm}$ de largura). $\mathrm{Na}$ esmeralda foram observadas inclusøes de flogopita, quartzo e esmeralda. Estes veios só foram observados em Belmont (Prancha 3, Foto 24);

- Veios de quartzo menos deformados que os anteriores, contendo esmeraldas idiomórficas. Estes só foram observados em Capoeirana.

Em afloramentos subterrâneos de shafts e galerias de garimpos em Capoeirana, os veios de quartzo polideformados com mineralizações de esmeraldas nos xistos metaultramáficos metassomatizados da SVS e as deformações análogas nas demais rochas da SVS, evidenciam uma e, provavelmente, até três fases deformacionais, posteriores às deformações nos migmatitos (TTG) e anteriores à $D_{n}$ principal proterozóica (cf.: Abreu, 1995).

As mineralizações de tipo veio pegmatóide (EVP) somente foram observadas em Capoeirana. Estes pegmatóides apresentam composição plagioclasítica, sendo intrusivos em rochas metaultramáficas flogopitizadas; são menos deformados que as encaixantes e contém xenólitos desta (Prancha 4, Foto 25). Os cristais de esmeralda são idiomórficos a subidiomórficos (Prancha 4, Fotos 26 a 28). Seus contatos com o plagioclásio são retilíneos ou de imposição mútua de idiomorfismo, e irregulares com o quartzo (Prancha 4, Fotos 29 e 30). A esmeralda é fraturada e exibe lamelas de deformação (Prancha 4, Fotos 31 e 32). As inclusões comumente observadas são de quartzo, carbonatos, muscovita e biotita, esta última fortemente orientada (Prancha 4, Foto 32). Em alguns casos, observam-se duas gerações de fraturas que podem estar preenchidas por quartzo, feldspato potássico e minerais micáceos tardios (Prancha 4, Foto 31). 


\section{PRANCHA 1}

Foto 1: Metagranitóides Borrachudos (GB) hololeucocráticos, de granulação média a grossa, com agregados de minerais máficos (biotitas e, subordinadamente, hornblendas) lineares, orientados. Amostra 03.

Foto 2: Plagioclásios e microclínios granoblásticos, em grãos separados, em GB. Microclínio envolve plagioclásio zonado. Na porção inferior, um cristal de granada hipidioblástica, sobrecresce biotita. (pol.+; comprimento da foto 2,80mm). Amostra G-166b.

Foto 3: GB com agregado orientado de minerais máficos, constituído por biotita, zircão, alanita, epidoto-clinozoizita, monazita, titanita, opacos e fluorita; biotita apresenta formas tardi-sin a pós-tectônicas. Na porção superior, feldspatos alcalinos contendo restos de plagioclásios (pol. +; comprimento da foto 2,80mm). Amostra G-29a.

Foto 4: GB com hornblenda em agregado orientado de minerais máficos, associada à biotita, zircão, epidoto-alanita e titanita. Os feldspatos estão alongados na foliação (pol. +; comprimento da foto 2,80mm). Amostra G-29c.

Foto 5: Veio pegmatóide (PGD) deformado, peralumínico com cianita, córindon e plagioclásio alongado, orientados. Plagioclásio apresenta-se fortemente sericitizado nos contatos com cianita. Estes pegmatóides ocorrem intrusivos em gnaisses metapelíticos de Capoeirana. (pol. +; comprimento da foto 1,39mm). Amostra M-5.

Foto 6: Gnaisse metapelítico (MP) de Capoeirana, com estaurolita xenomórfica e anfibólio incolor, fibro-radial, na matriz quartzo-feldspática ou sobrecrescido às bordas de granada idiomórfica (pol. //; comprimento da foto 1,39mm). Amostra G-52c.

Foto 7:. MP do centro da área, com anfibólio incolor, prismático, sobrecrescendo cordierita xenoblástica (pol.+; comprimento da foto 2,80mm). Amostra G-85a.

Foto 8: MP do centro da área, com anfibólio incolor idioblástico sobre a matriz biotítica com opacos esparsos, foliada (pol. +; comprimento da foto 2,80mm). Amostra G-85a 
PRANCHA 1

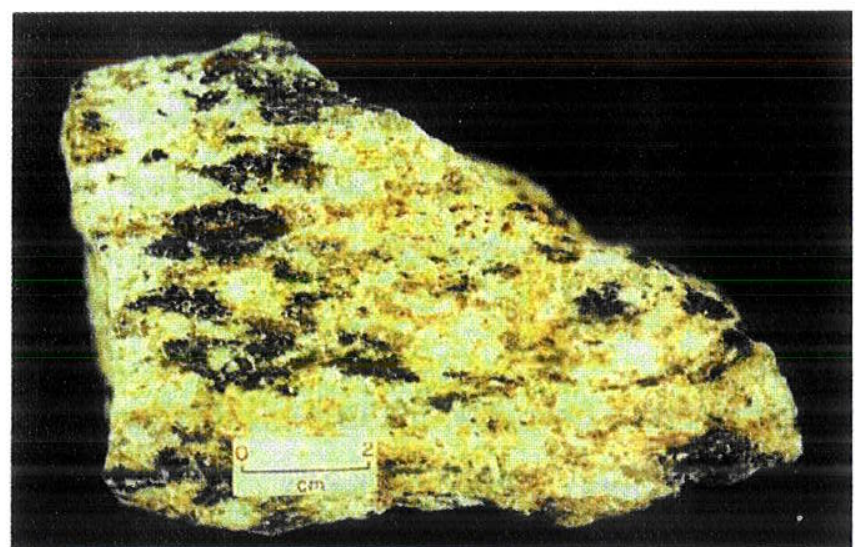

Foto 1

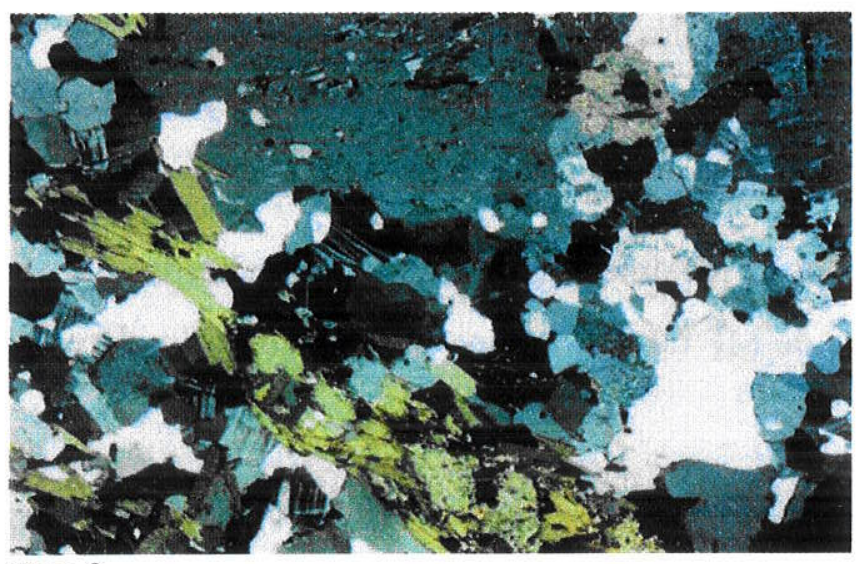

Foto 3

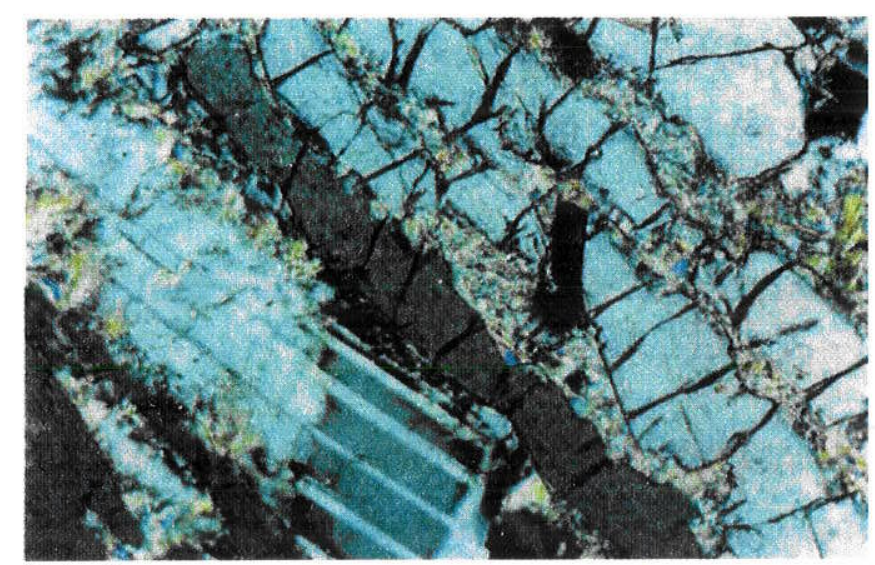

Foto 5

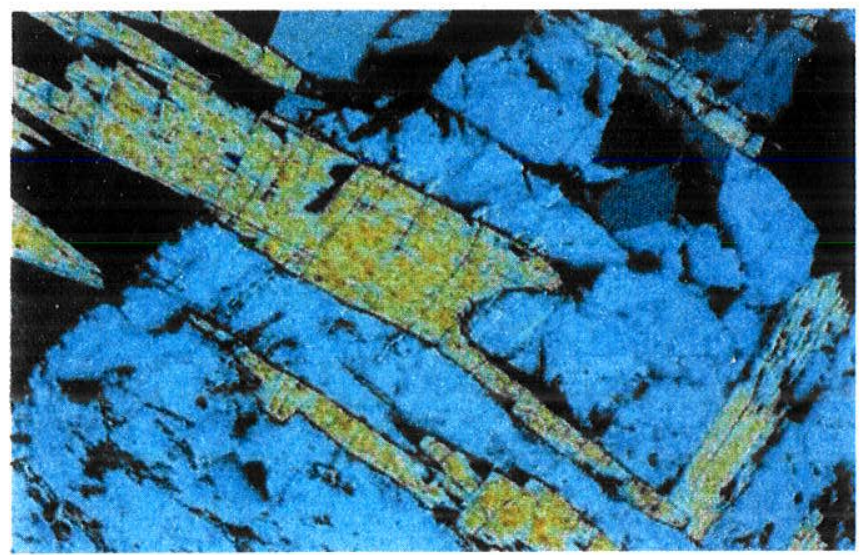

Foto 7

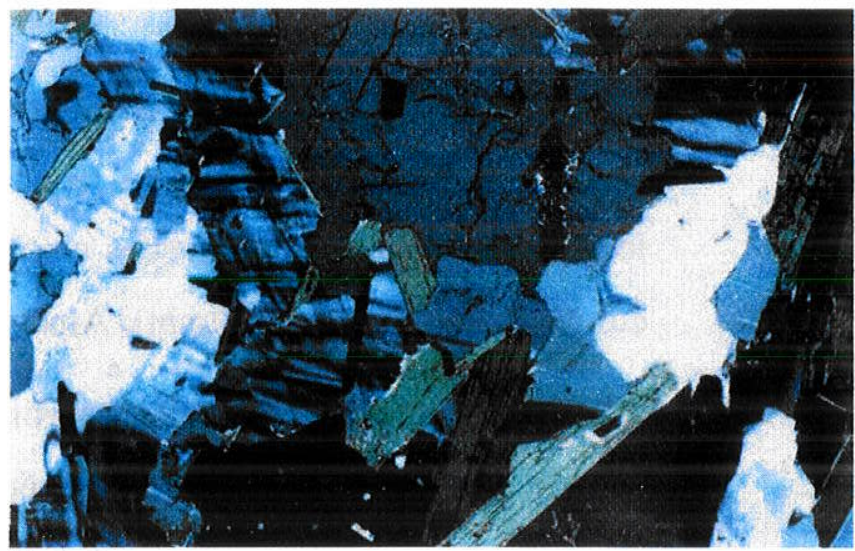

Foto 2

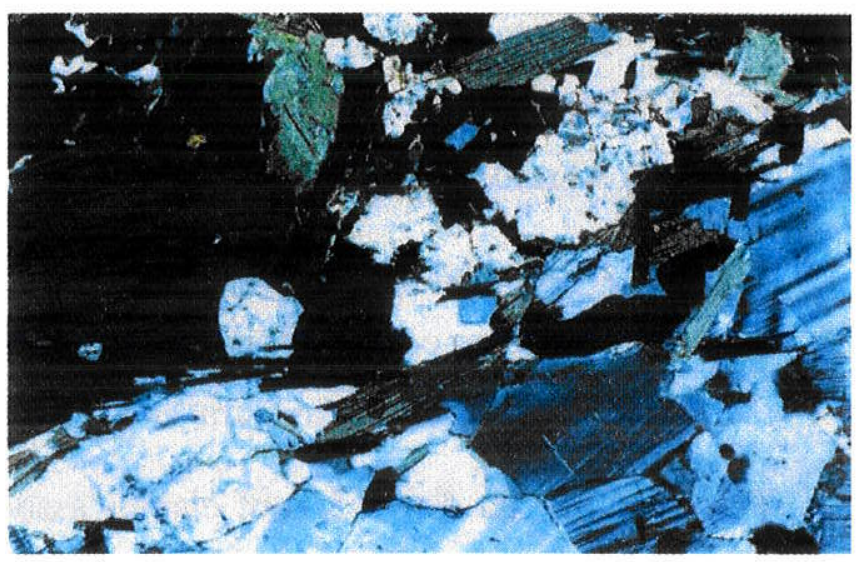

Foto 4

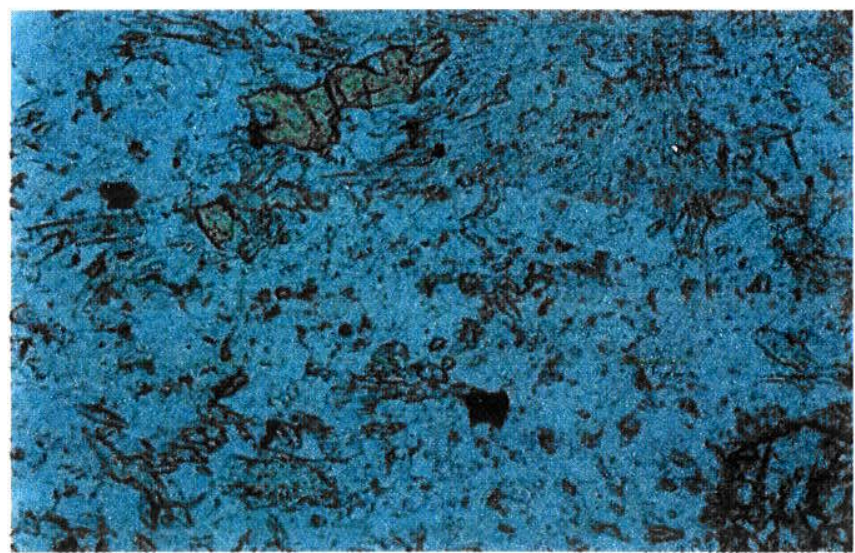

Foto 6

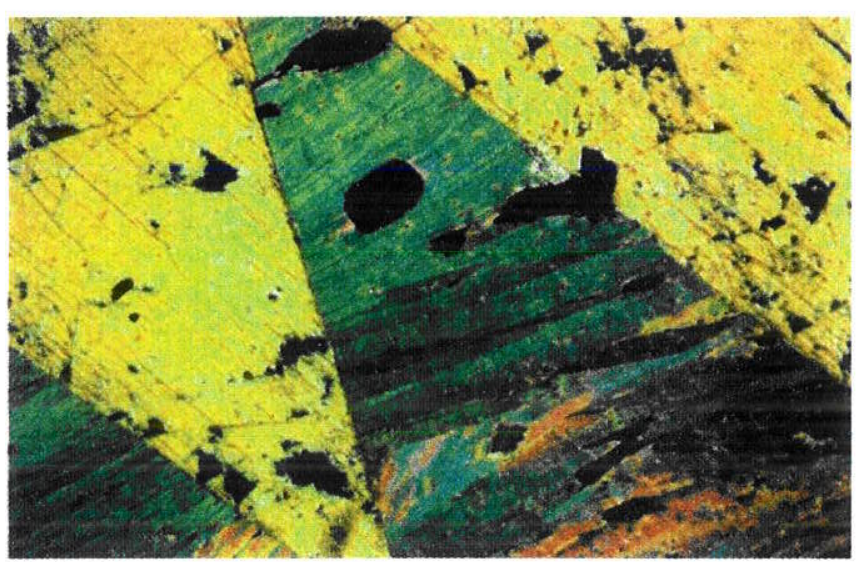

Foto 8 


\section{PRANCHA 2}

Foto 9: Gnaisse metapelítico (MP) de Capoeirana do Meio com estaurolita poiquiloblástica, granada e biotita. A granada ocorre em níveis preferenciais, é subidiomórfica a idiomórfica, isenta de inclusões e sobrecrescida pela estaurolita xenomórfica (pol. //; comprimento da foto 2,80mm). Amostra G-89.

Foto 10: MP do centro da área, com estaurolita xenomórfica e corroída, inclusa em cordierita zonada e pinitizada (pol.+; comprimento da foto $2,80 \mathrm{~mm}$ ). Amostra G-85a.

Foto 11: MP do centro da área com xenoblasto de estaurolita poiquiloblástica com inclusões diminutas e orientadas de biotita, quartzo plagioclásio. A biotita é intercrescida com fibrolita, indicativo da gênese da fibrolita a partir da biotita (pol.; comprimentò da foto 2,80mm). Amostra G-85a.

Foto 12: Estaurolita em cristais subédricos isolados e, localmente, em contatos por bordas de reação com cianita em porção pegmatóide de MP de Capoeirana (pol. //; comprimento da foto $1,39 \mathrm{~mm}$ ). Amostra M-5.

Foto 13: MP da foto 12 com cianita associada à fibrolita (pol. +; comprimento da foto 5,50mm). Amostra M-5.

Foto 14: MP de Capoeirana com cianita associada à biotita, cordierita intersticial (parte superior da foto) e clorita secundária a partir da biotita (pol. //; comprimento da foto $2,80 \mathrm{~mm})$. AP-5.

Foto 15: Cordierita intersticial com bordas pinitizadas em MP do centro da área (pol.t; comprimento da foto $2,80 \mathrm{~mm}$ ). Amostra G-85a.

Foto 16: Porfiroblasto de cordierita geminada simples, pinitizada nas bordas, sobrecrescendo biotita em MP do centro da área. Observa-se um cristal idiomórfico de fluorita na parte central-direita (pol.+; comprimento da foto 2,80mm). Amostra G-85a. 
PRANCHA 2

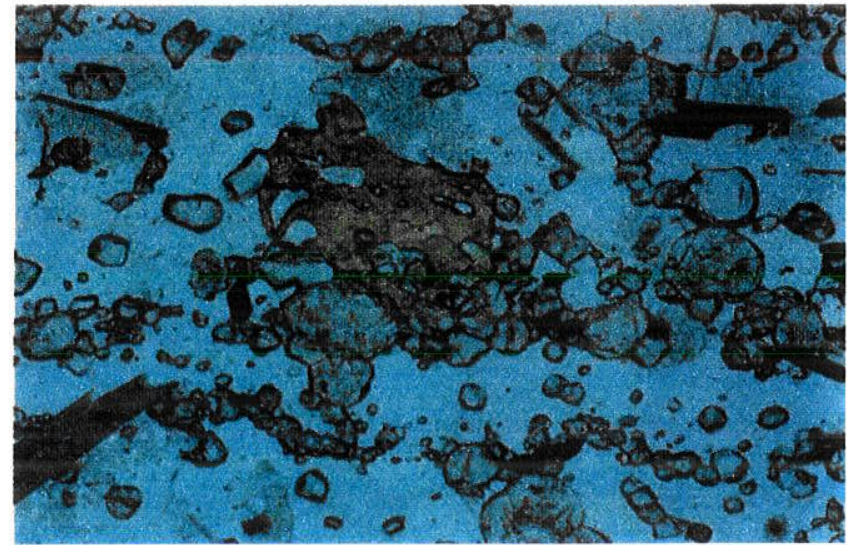

Foto 9

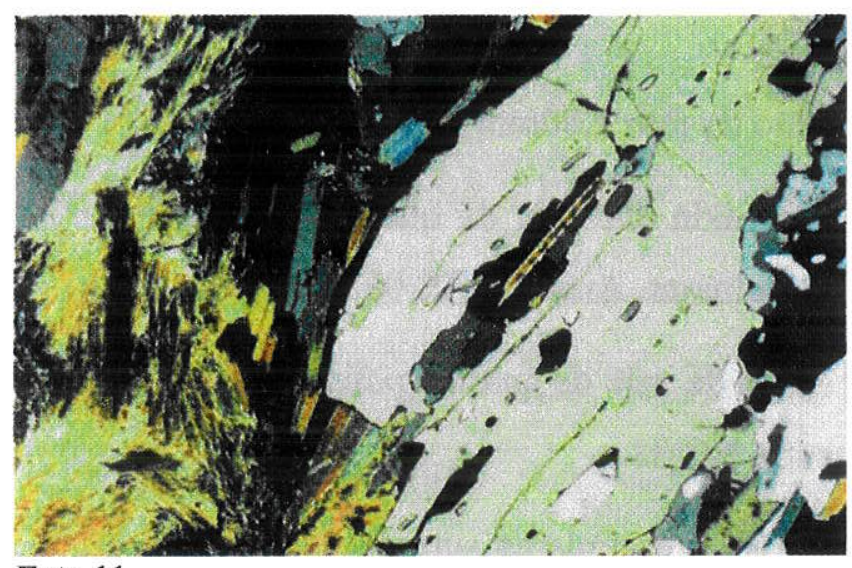

Foto 11

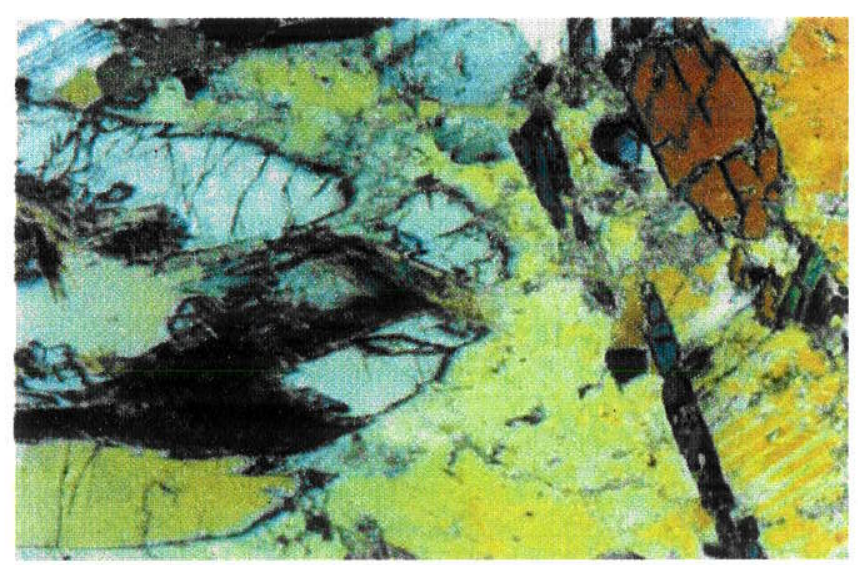

Foto 13

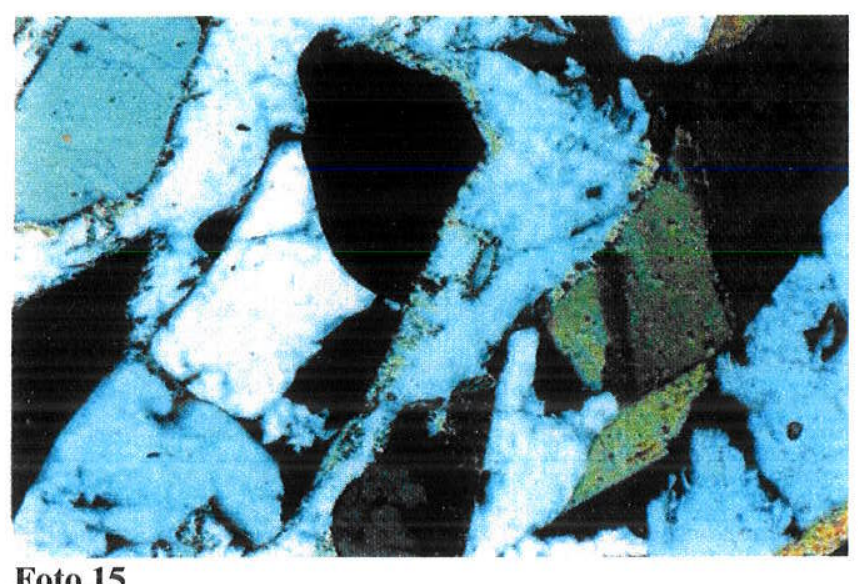
Foto 15

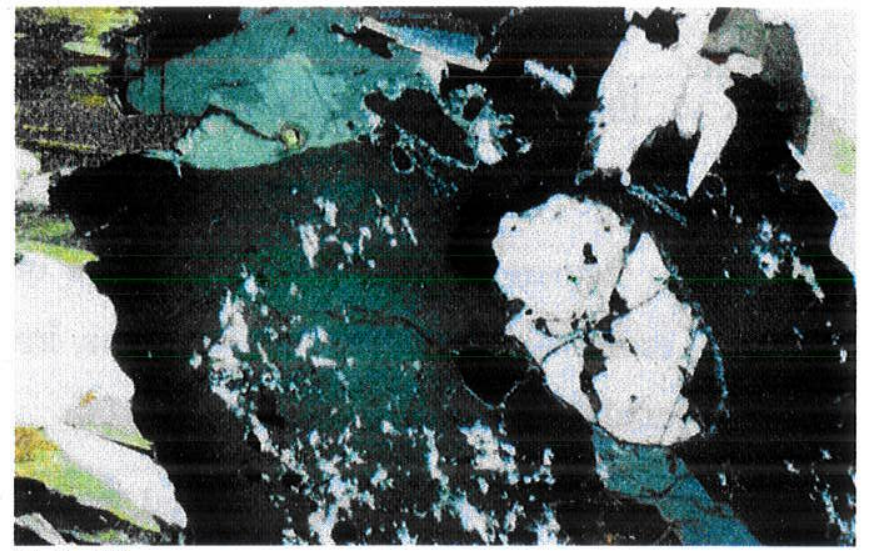

Foto 10

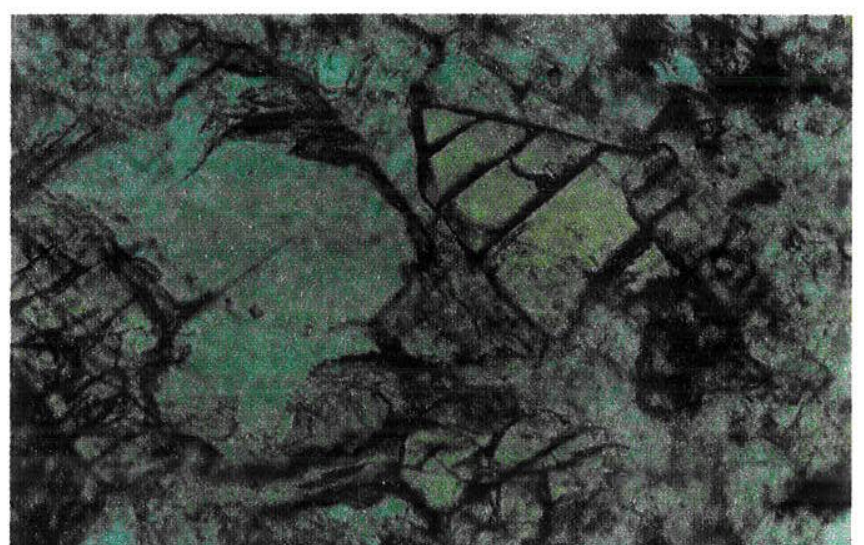

Foto 12

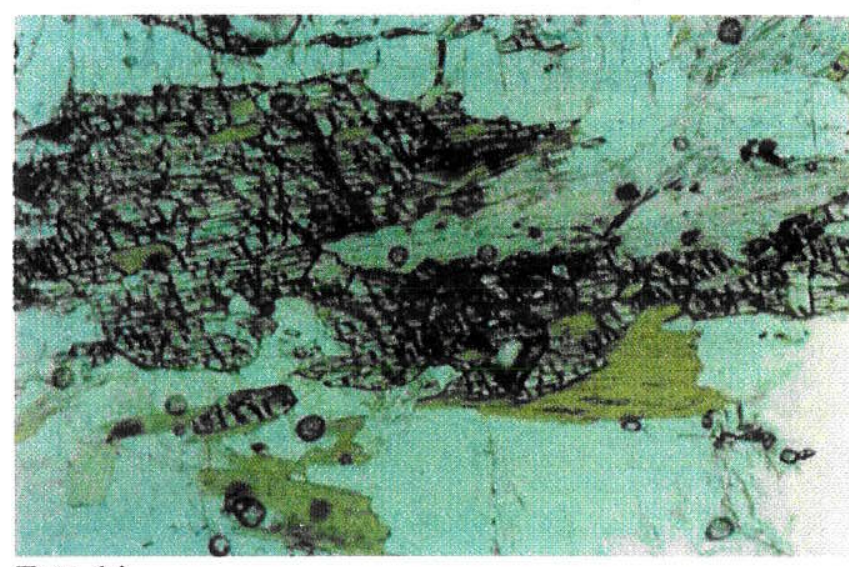

Foto 14

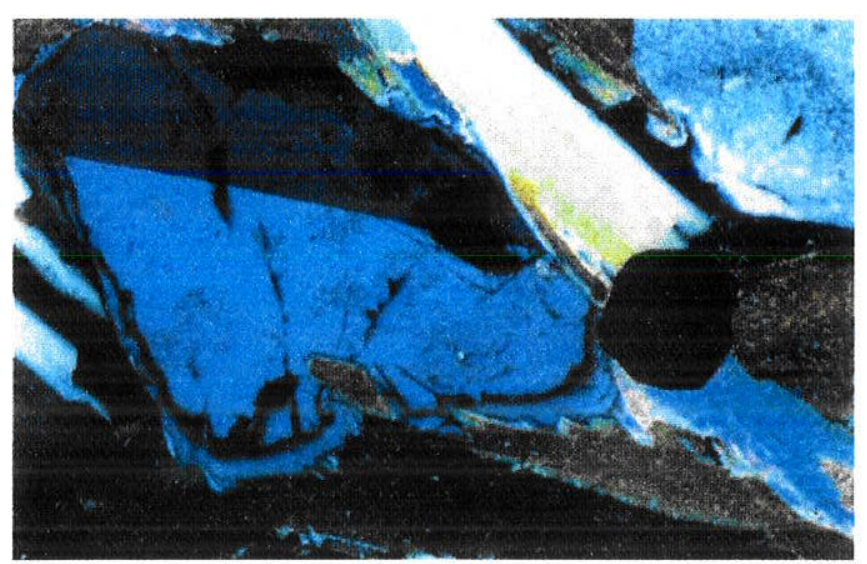

Foto 16 


\section{PRANCHA 3}

Foto 17: Esmeralda deformada em xisto (tipo EX) associada a quartzo em ápices de dobra. Amostra BE-06.

Foto 18: Esmeralda tipo EX associada a quartzo em ápices de dobra; os contatos entre esmeralda e quartzo são suturados, irregulares (pol.+; comprimento da foto $2,80 \mathrm{~mm}$, cunha de quartzo ). Amostra BE-06.

Foto 19: Esmeralda tipo EX, facoidal, exibe lamelas de deformação, sendo envolvida pela foliação, em anfibólio-flogopita-xisto (pol. //; comprimento da foto 2,80mm). Amostra BE-06

Foto 20: Mesma foto anterior com pol. + (comprimento da foto 2,80mm). Amostra BE-06.

Foto 21: Fragmentos angulosos e fraturados de esmeralda em veio de quartzo (tipo EVQ) polideformado, de espessura centimétrica, de Belmont. Amostra BE-05.

Foto 22: Esmeralda (tipo EVQ) subidioblástica na borda de veio de quartzo polideformado, de espessura centimétrica, de Capoeirana. Amostra NE-38.

Foto 23: Esmeralda e quartzo deformados, com contatos irregulares suturados, em veio de quartzo polideformado (tipo EVQ) (pol.+; comprimento da foto $2,80 \mathrm{~mm}$; cunha de quartzo). Amostra 21

Foto 24: Fragmentos de esmeralda tipo EVQ polideformado, da borda do veio de dimensões métricas. Amostra B-24 
PRANCHA 3

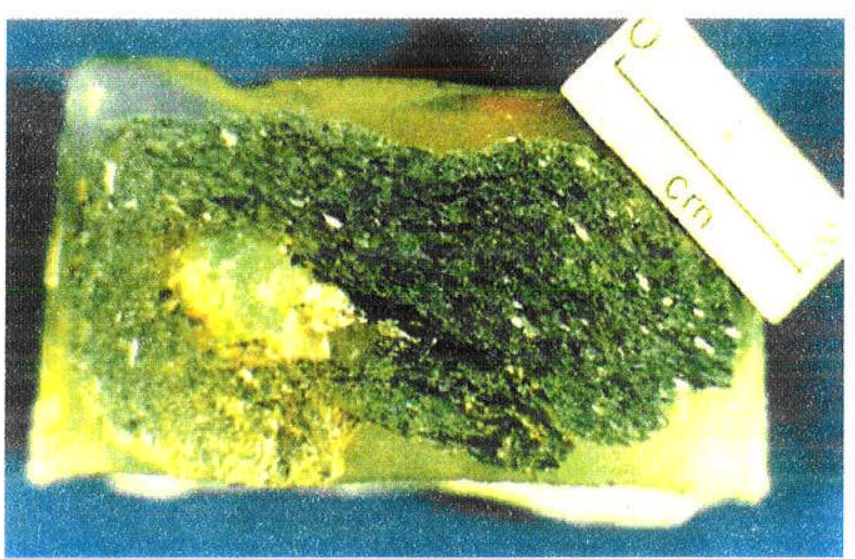

\section{Foto 17}
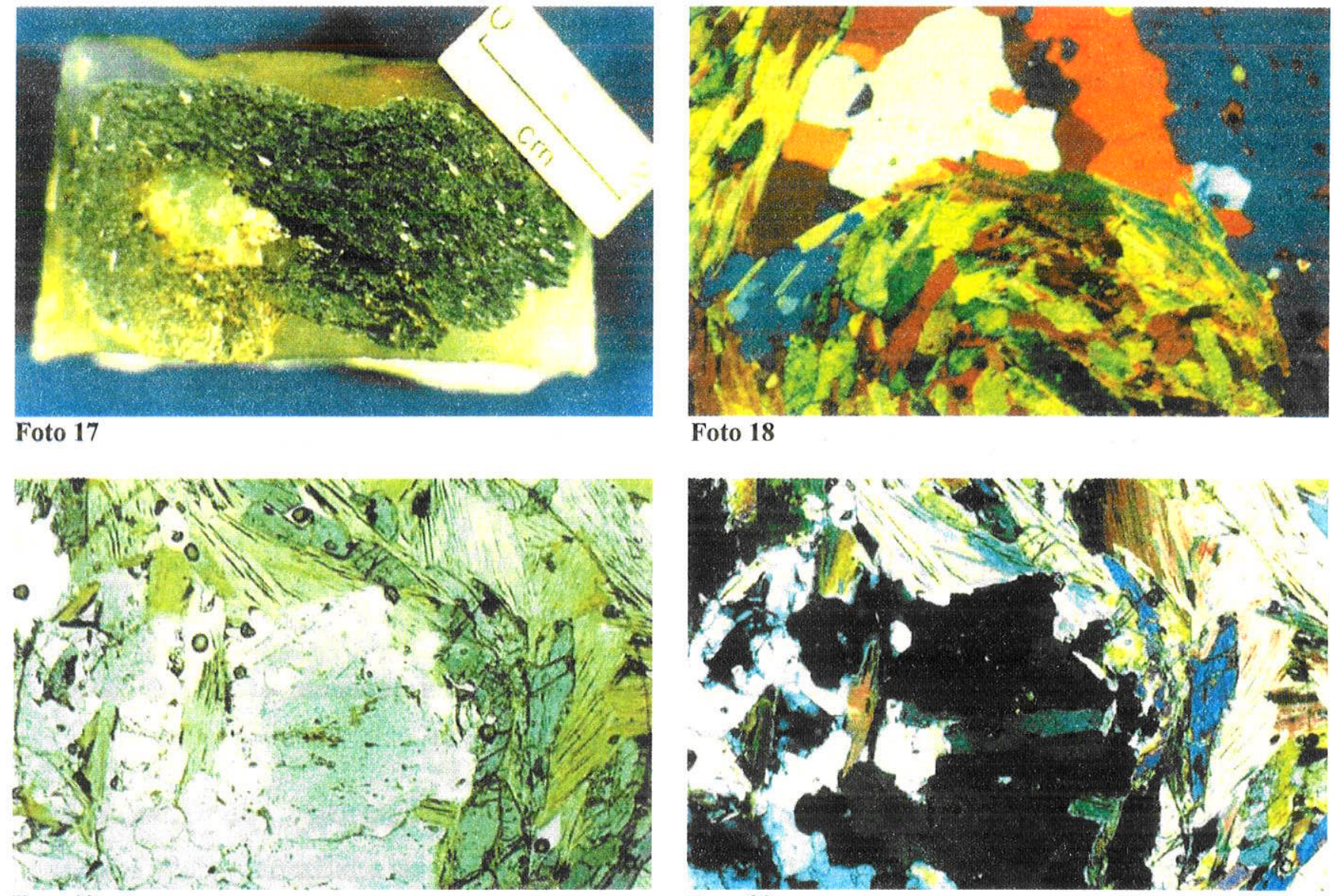

Foto 19

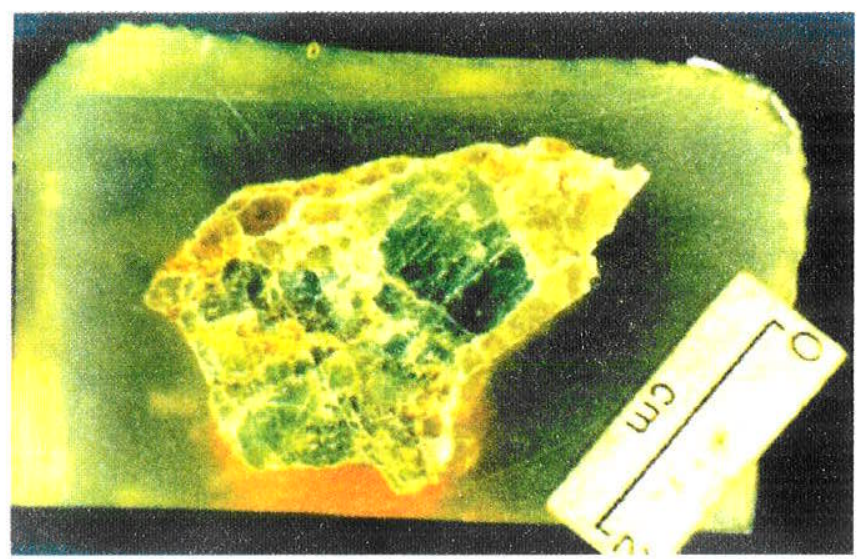

Foto 21

Foto 18

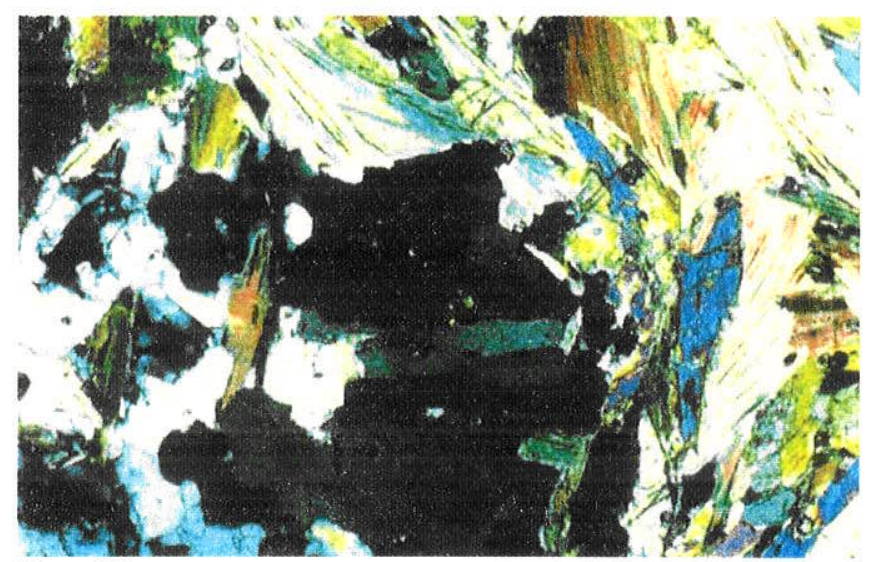

Foto 20

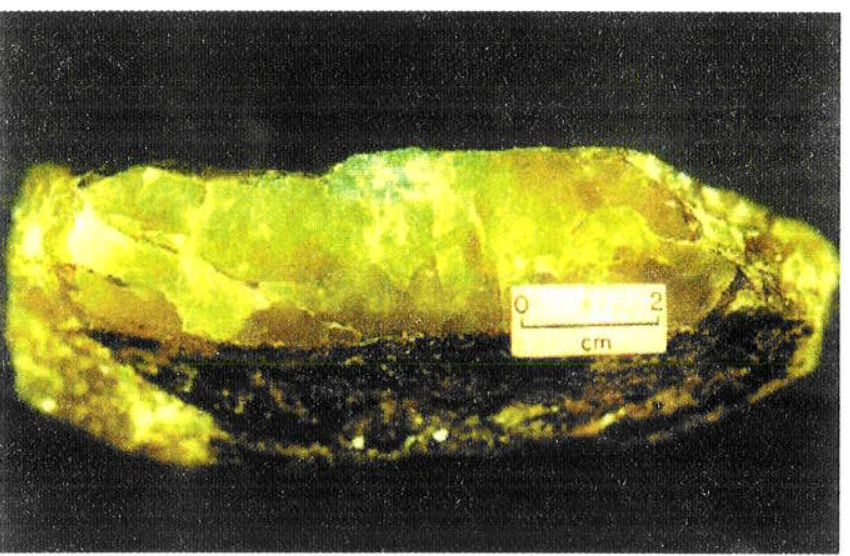

Foto 22

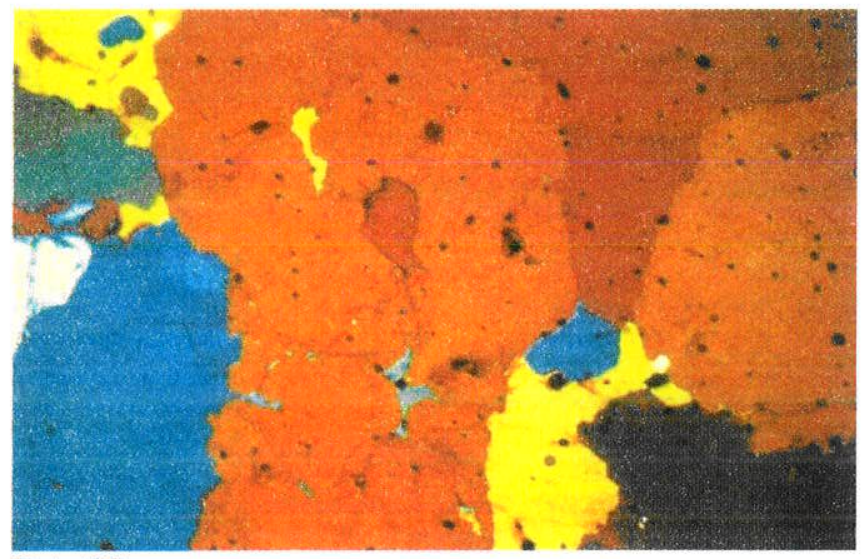

Foto 23

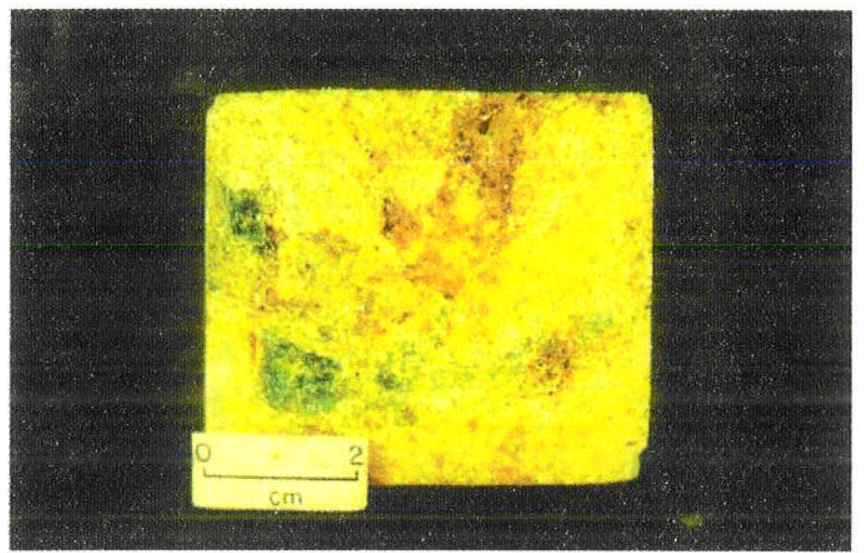

Foto 24 


\section{PRANCHA 4}

Foto 25: Esmeralda idiomórfica em veios pegmatóides (EVP) plagioclasíticos, pouco deformados com microxenólito do xisto metaultramáfico encaixante (largura do cristal $\sim 1 \mathrm{~cm})$. Amostra NE-31-07.

Foto 26: Esmeraldas idiomórficas (tipo EVP) com contatos retilíneos com o plagioclásio (largura da face do cristal $\sim 1 \mathrm{~cm}$ ). Amostra NE-31.

Foto 27: Esmeralda (tipo EVP) na borda do veio, mostrando idiomorfismo e contatos retilíneos com o plagioclásio do lado interno do veio e base irregular de crescimento sobre a parede - flogopitito - (largura da face do cristal $\sim 1 \mathrm{~cm}$ ). Amostra NE-33.

Foto 28: Cristal deformado de esmeralda cortado por veio microgranítico/aplogranítico pouco deformado (comprimento do cristal $\sim 3 \mathrm{~cm}$ ). Amostra NE-31-03.

Foto 29: Esmeralda tipo EVP esquelética, idioblástica, em intercrescimento com plagioclásio (pol. +; comprimento da foto 2,80mm). Amostra NE-31-01

Foto 30: Esmeralda tipo EVP com contatos retilíneos com plagioclásio saussuritizado e menos regulares com quartzo. Fraturas na esmeralda caracterizam a deformação posterior de natureza rúptil desses veios (pol. +; comprimento da foto $2,80 \mathrm{~mm}$ ). Amostra NE-31-06

Foto 31: Duas gerações de fraturas em esmeralda tipo EVP preenchidas, a primeira por material micáceo e a segunda por quartzo e, eventualmente, feldspato potássico (pol. + ; comprimento da foto $2,80 \mathrm{~mm}$ ). Amostra NE-30.

Foto 32: Esmeralda tipo EVP exibindo lamelas de deformação e inclusões de biotita com orientações ortogonais (pol. +; comprimento da foto 2,80mm). Amostra NE-31-02. 


\section{PRANCHA 4}

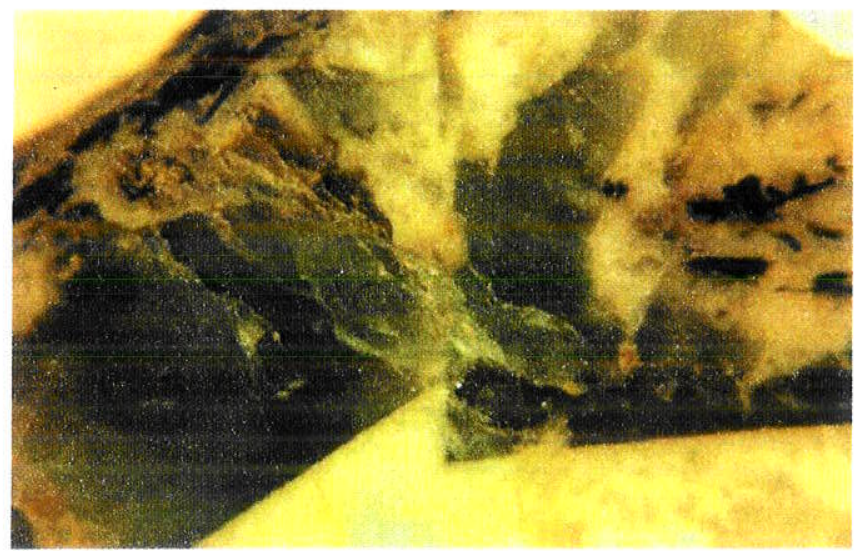

Foto 25

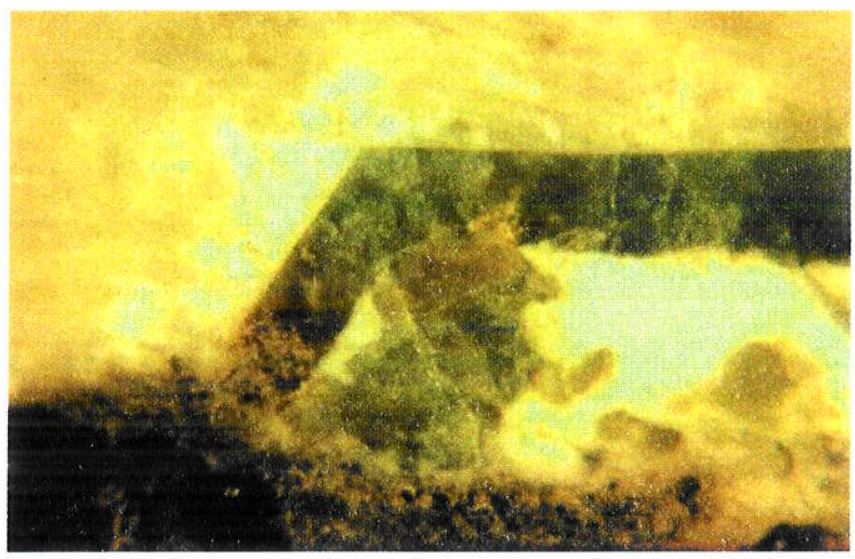

Foto 27

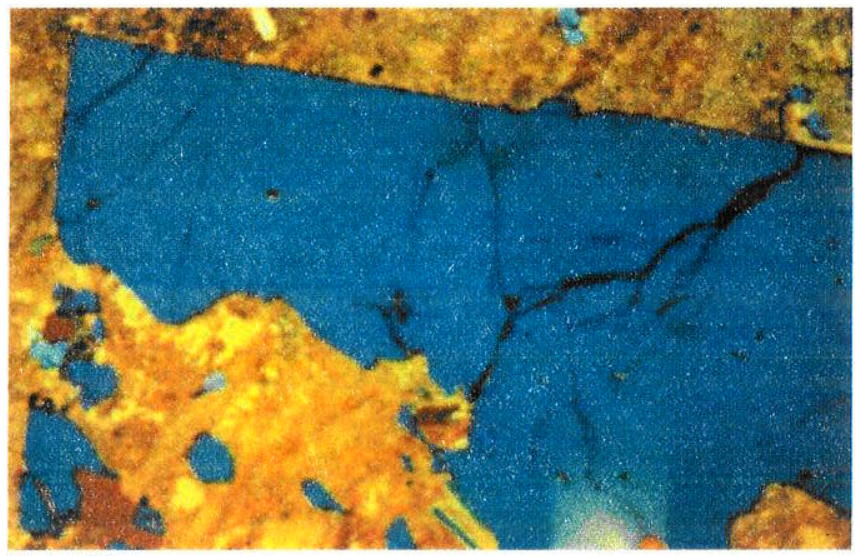

Foto 29

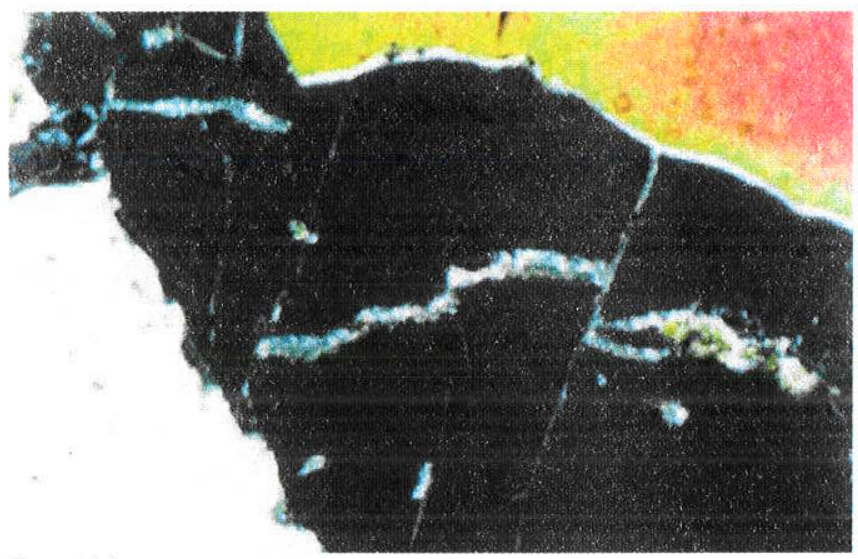

Foto 31

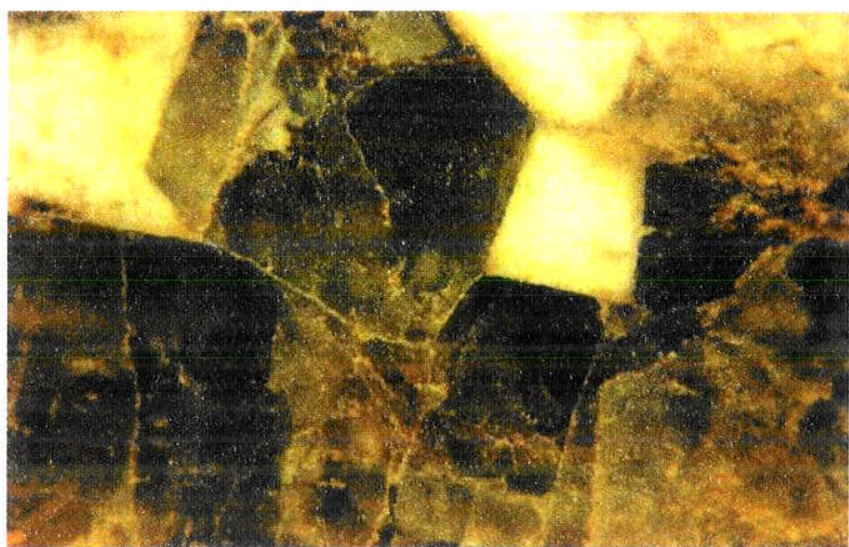

Foto 26

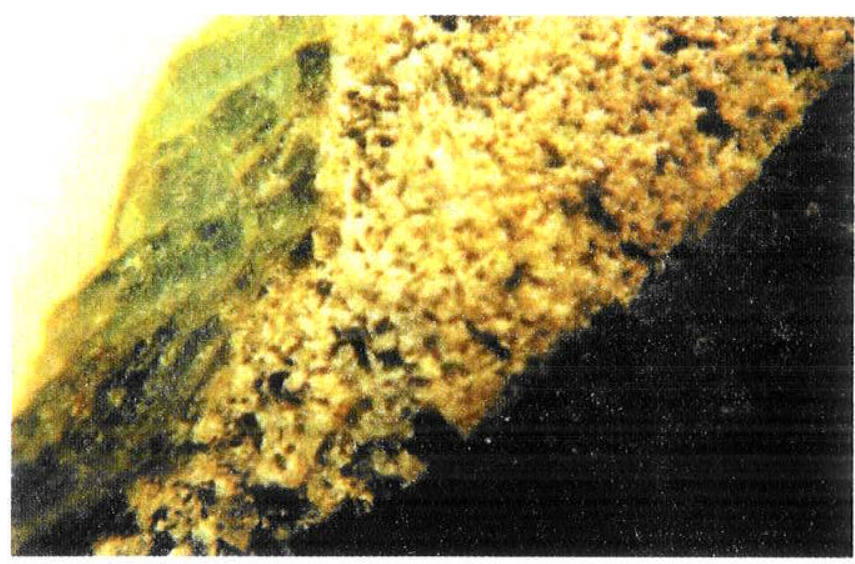

Foto 28

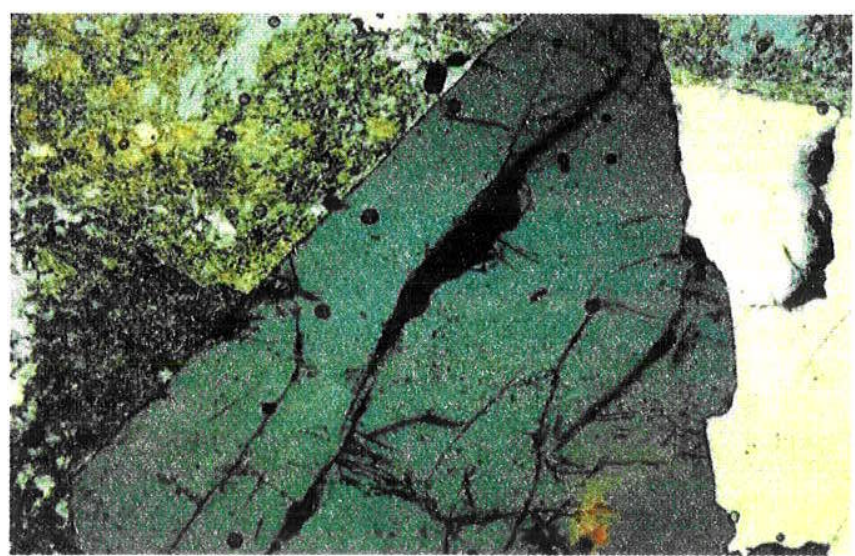

Foto 30

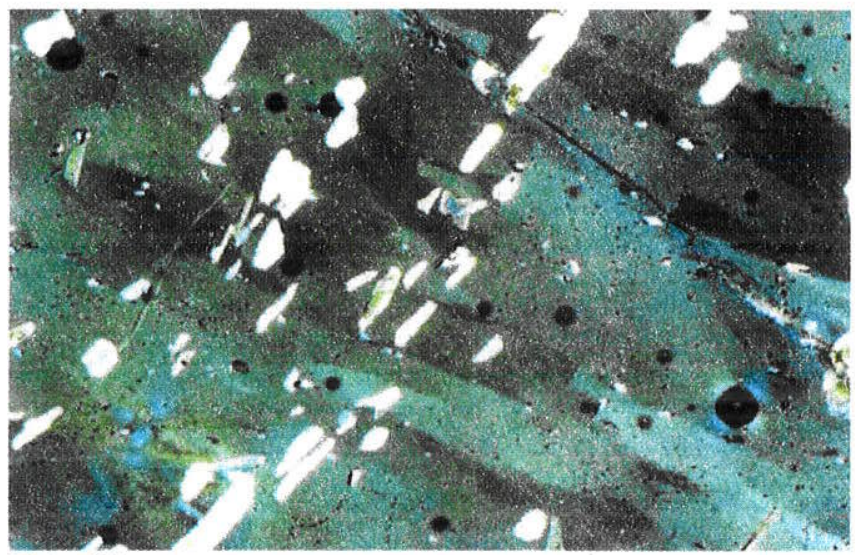

Foto 32 


\section{CAPÍTULO III - LITOGEOQUÍMICA}

\section{III.1 - INTRODUÇÃO}

Nesse capítulo serão tratadas as rochas TTG e gnaisses miloníticos de derivação incerta - GnM, os metagranitóides GB e MGF, os anfibolitos metabásicos e as rochas metaultramáficas, onde se situam as principais contribuições analíticas desse trabalho. Nos diagramas representativos foram incluídos todos os dados, inclusive aqueles do Mestrado (Machado, 1994).

\section{III.2 - ROCHAS TTG E GNAISSES MILONÍTICOS DE DERIVAÇÃO INCERTA (GnM)}

Essas rochas serão tratadas em conjunto, uma vez que as relações de campo e petrográficas sustentaram, em parte, suas relações de equivalência por processos associados polimetamórficos e de milonitização progressiva nas imediações dos contatos com a SVS, especialmente, na região de Capoeirana. Entretanto, cabe ressaltar que tratam-se de litotipos subordinados na área da pesquisa, desprovidos de relações genéticas diretas com as mineralizações de esmeraldas. Ademais, apresentam-se sempre em condições de afloramentos e preservação bastante precárias para estudos geoquímicos. Esses fatores limitaram as pesquisas realizadas a um número relativamente pequeno de amostras e em níveis básicos de análises e interpretações petrogenéticas, embora, sejam, especificamente os $\mathrm{GnM}$ derivados dos TTG, rochas importantes como protólitos no contexto dos processos generativos arqueanos dos GB. Os tratamentos tiveram por fim comparações dos TTG e GnM e inferências sobre os possíveis protólitos orto e/ou paraderivados dos GnM. Os dados analíticos encontram-se no Anexo 2 (Tab. A2.2).

\section{* Elementos Maiores e Traço}

As razões de álcalis/alumina, segundo Garrels \& Mckenzie (1971), mostram a grande maioria das rochas TTG e GnM agrupadas no campo de rochas ígneas (Fig. 3.1). Três análises de rochas TTG (amostra G-144a) e outras três de GnM (amostras G-103a e G-123) externas a este campo são, respectivamente, mobilizados neossomáticos da remigmatização proterozóica ricos em feldspato alcalino e gnaisses miloníticos ricos em córindon normativo podendo-se 
tratar ou de milonito-gnaisses TTG e/ou de rochas paraderivadas da SVS que sofreram mais fortes alterações aloquímicas.

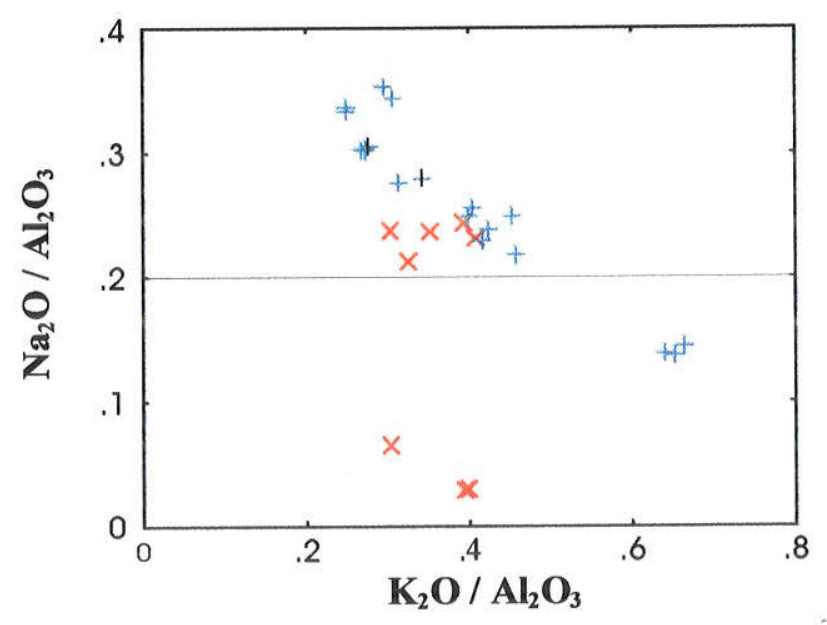

Figura 3.1: A maioria das rochas TTG (+) e GnM (x), no diagrama de Garrels \& Mckenzie (1971), figuram no campo das rochas ígneas.

As rochas com características ígneas foram representadas em diagramas convencionais de classificação, onde figuram nos campos das rochas graníticas normais (Fig. 3.2 e 3.3), levemente peraluminosas (Fig. 3.4), com exceção de duas análises de mobilizados quartzofeldspático, perquartzoso $\left(\mathrm{SiO}_{2}>85 \%\right)$ em TTG.

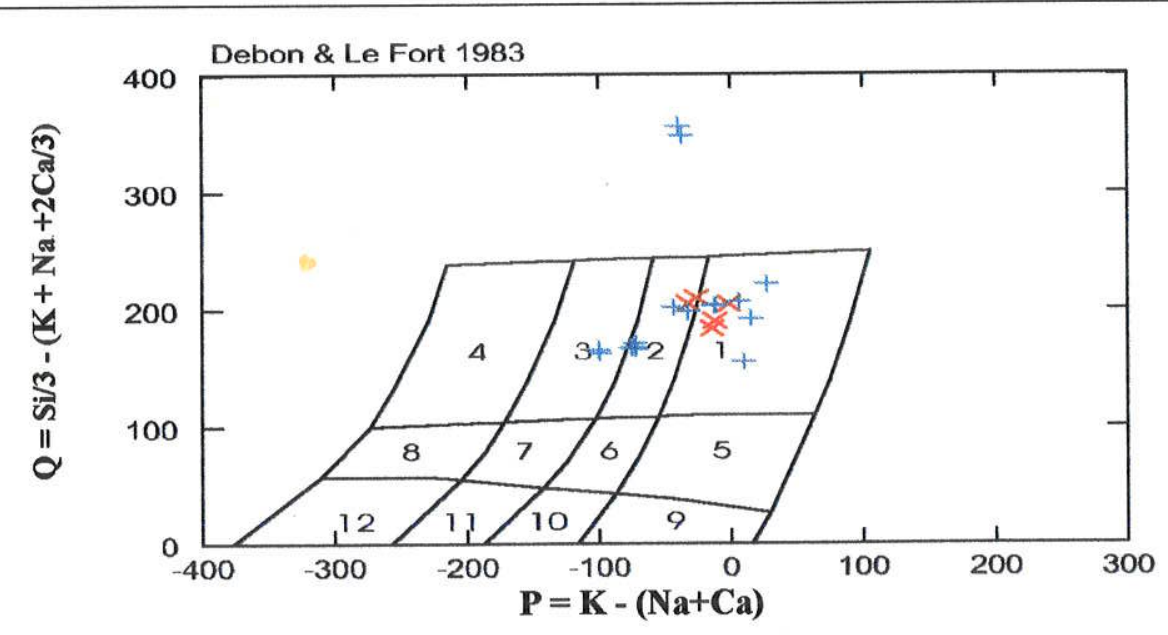

Figura 3.2: As rochas TTG $(+)$ e $\mathrm{GnM}(\mathrm{x})$ de características ígneas figuram no diagrama de Debon \& Le Fort (1983) nos campos 1, 2 e 3 de granito, adamelito e granodiorito. As duas análises externas aos campos das rochas ígneas representam mobilizado quartzo-feldspático perquartzoso no TTG (amostra G-144d). 


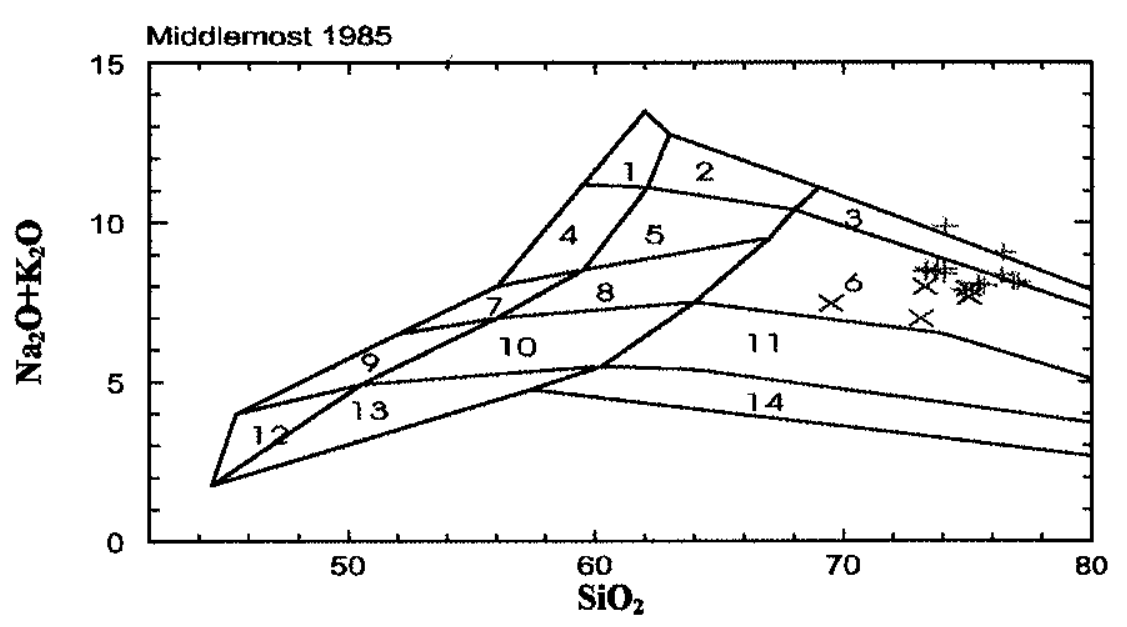

Figura 3.3: As rochas TTG $(+)$ e $\mathrm{GnM}(\mathrm{x})$ de características igneas figuram no diagrama de Middlemost (1985) nos campos 6 e 3 de granito e álcali-feldspato granito.

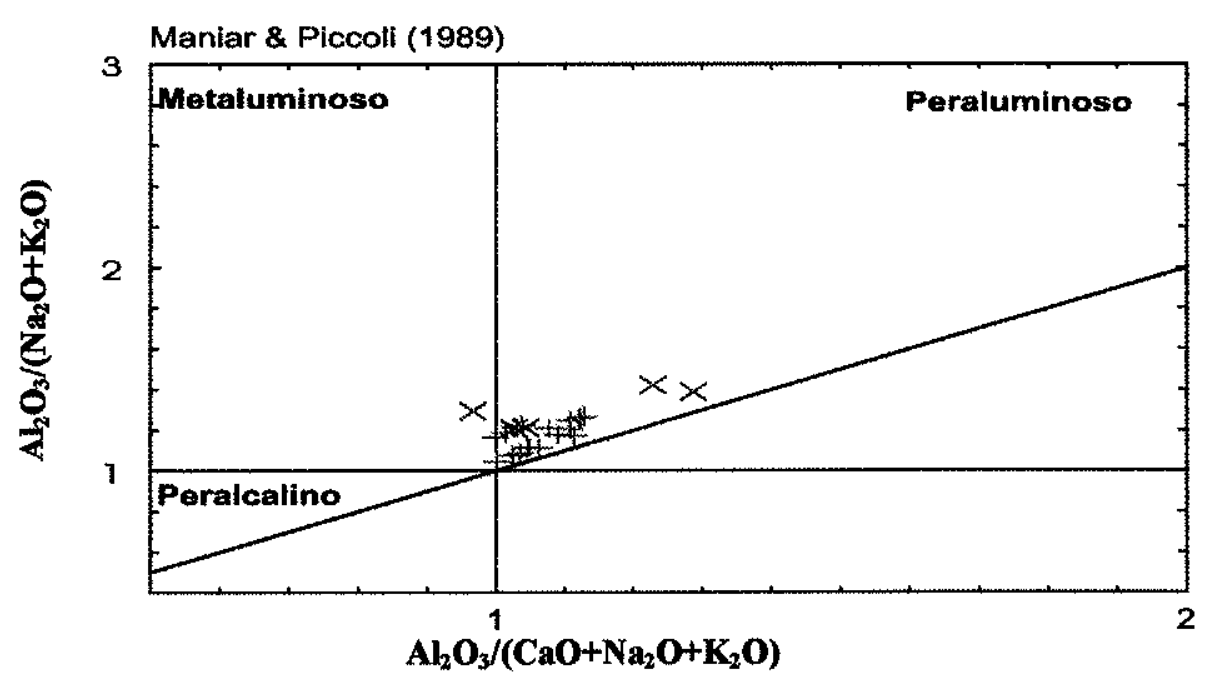

Figura 3.4: As rochas TTG (+) e GnM (x) no diagrama de Maniar \& Piccoli (1989) variam de metalumínicas a peralumínicas.

As análises dos elementos traço, representadas em diagramas multielementares normalizados em valores do manto primitivo - PRIM (Taylor \& McLennan, 1985), indicam para os GnM teores mais elevados em praticamente todos os elementos traço incompatíveis e compatíveis (desde o $\mathrm{Ba}$ ao $\mathrm{Cr}$ ), com exceção apenas do $\mathrm{Sc}, \mathrm{V}$ e $\mathrm{Cu}$ que correspondem a média dos gnaisses TTG (Fig. 3.5). Em relação às rochas TTG com razões $\mathrm{Na}_{2} \mathrm{O} / \mathrm{K}_{2} \mathrm{O}>1.5$ de Schorscher (1992), os TTG e GnM desta pesquisa apresentam-se enriquecidos nos principais elementos incompatíveis, incluindo os elementos Terras Raras Leves (ETRL). 


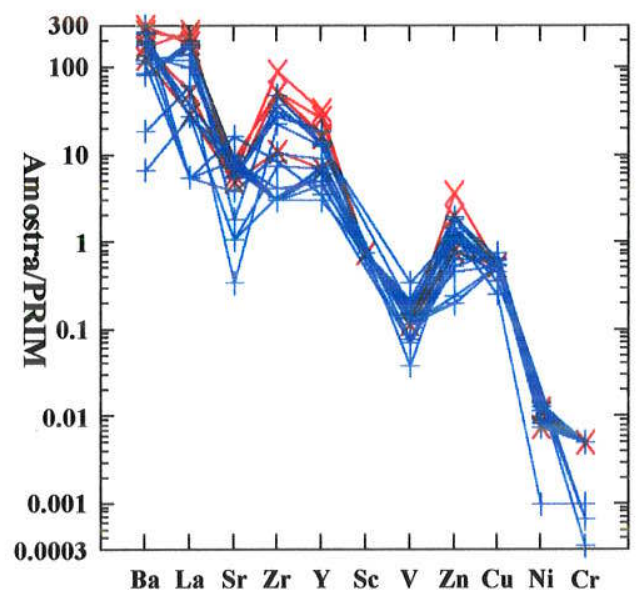

Figura 3.5: Variograma de elementos traço das rochas TTG $(+)$ e $\mathrm{GnM}(\mathrm{x})$, normalizado em valores do manto primitivo - PRIM (Taylor \& McLennan, 1985).

Com relação ao Be, os teores nos TTG e GnM são, em geral, baixos ( $<5$ ppm), com exceção de duas amostras (G-240a e G-240b) das fácies transicionais de TTG para GB com teores mais elevados, de 13 a 32 ppm (Anexo 2, Tab. A2.2).

Por fim, conclui-se que a população de amostras analisada, bastante restrita, inclui gnaisses e migmatitos TTG, com estruturas macroscópicas/de campo típicas que sofreram remigmatização e princípio de anatexia no principal evento metamórfico proterozóico e mobilizados neossomáticos e quartzo-feldspáticos decorrentes deste evento, assim como gnaisses miloníticos $(\mathrm{GnM})$ diversos.

As rochas TTG típicas tem derivação ígnea e composições, em geral, graníticas, variáveis de granodioríticas a álcali-feldspato-graníticas, perquartzosas, levemente peralumínicas. Em relação às outras rochas TTG (médias globais e da região do Q.F.) que não sofreram remigmatização e inícios de anatexia proterozóica apresentam enriquecimentos em $\mathrm{K}_{2} \mathrm{O}$ e nos principais elementos incompatíveis, inclusive ETRL, decorrentes dos processos metamórficos regionais de grau médio-alto.

Os gnaisses miloníticos $(\mathrm{GnM})$ ortoderivados tem composições muito similares aos TTG típicos. São considerados como equivalentes destes que sofreram transformações aloquímicas metamórfico-metassomáticas durante a milonitização, incluindo concentração residual de elementos traço compatíveis (como $\mathrm{Ni}$ e $\mathrm{Cr}$ ) e enriquecimentos de elementos traço incompatíveis (especialmente $\mathrm{Ba}, \mathrm{La}, \mathrm{Zr}$ e Y) relacionados a feldspatização potássica. Já os GnM com características de paragnaisses miloníticos são aqui admitidos como partes 
metassedimentares da SVS, tectonicamente disruptas, conforme indicam também as relações de campo.

Assim, a formação dos GnM deve ser atribuída a processos superimpostos arqueanos e proterozóicos: tiveram sua origem nos processos arqueanos de milonitização e transformações mineralógicas aloquímicas associadas ao soerguimento dos terrenos TTG em relação à SVS, quando foram geradas as zonas de contato tectoníticas; essas foram retrabalhadas nos processos proterozóicos metamórficos de grau médio-alto, incluindo remigmatização e início de anatexia. 


\section{III.3 - METAGRANITÓIDES BORRACHUDOS (GB) E METAGRANITÓIDES FOLIADOS COM FLUORITA (MGF)}

Essas rochas são importantes no contexto das mineralizações de esmeraldas, controlando sua formação quando em contato com rochas metaultramáficas da SVS. Portanto, foram detalhadamente estudadas, a partir de um grande número de dados analíticos produzidos por FRX, AAS e ICP-MS. A íntegra dos resultados analíticos encontram-se nos Anexos 2 e 3 (Tab. A2.3 e Tab. A3.1). Uma parte dos dados, incluindo os elementos maiores, já foram tratados no mestrado (Machado, 1994); esses resultados serão, aqui, apenas citados.

\section{* Elementos Maiores e Traço}

Inicialmente, serão brevemente discutidos os princípios de classificação genética de rochas graníticas de tipo álcali-feldspato granitos félsicos, perquartzosos e metalumínicos a levemente peralumínicos, grupo petrogeneticamente problemático no qual se encaixam os GB e MGF. Em seguida, serão examinados os dados analíticos novos de elementos menores e traço, por ICP-MS, considerando os resultados anteriores dos elementos maiores. Face ao grande número de elementos analisados, de cerca de 40 elementos por amostra (sem os ETR que serão tratados à parte, no Cap. VI), optou-se, principalmente, por representações em diagramas binários específicos e multielementares que permitem caracterizar, comparativamente, a natureza geoquímica geral dessas rochas e os processos que nelas atuaram.

Os metagranitóides GB e MGF são, praticamente, homogêneos mineralógica e quimicamente. Apresentam composição de álcali-feldspato granitos perquartzosos com fluorita, com altos teores de $\mathrm{SiO}_{2}(>72 \%)$ e altas razões de $\mathrm{K}_{2} \mathrm{O} / \mathrm{Na}_{2} \mathrm{O}(1.0-3.2)$ e $\mathrm{FeO} /(\mathrm{FeO}$ $+\mathrm{MgO})(0.9-1.0)$ e baixos teores de $\mathrm{CaO}$. Comumente, apresentam pequenos teores de córindon normativo, sendo isentos de minerais normativos alcalinos (Schorscher, 1992; Machado, 1994), diferentemente do que constatou Chemale Jr.(1987a,b) numa parte de suas análises da ocorrência de Itabira. São, ainda, ricos em Be (média de 8.4 ppm) e Li (média de 24 ppm). Segundo Wedepohl (1969), o teor médio de Be em rochas silícicas (com $\mathrm{SiO}_{2}$ entre 60 e $78 \%$ ) é de 6.5 ppm (Tab. 3.1). Essas propriedades geoquímicas relacionam os GB e MGF com o grupo de granitos Tipo A que no Fanerozóico, mais comumente, são encontrados em 
ambientes anorogênicos; entretanto, no Precambriano não são restritos a tais ambientes (Whalen et al., 1987).

Segundo King et al. (1997), granitos Tipo A félsicos e perquartzosos, apresentam composições químicas e mineralógicas que sobrepõem àquelas dos Tipo I análogos, sendo necessário comparar suítes maiores de rochas para a caracterização de granitos félsicos. As dificuldades interpretativas aumentam quando as rochas foram alteradas, como é o caso dos metagranitóides GB e MGF por processos tectono-metamórficos posteriores.

\begin{tabular}{|l|l|l|l|}
\hline Litotipos & Amostras & Be (ppm) & Li (ppm) \\
\hline \multirow{4}{*}{ GB } & 03 & 13.0 & 13.8 \\
\cline { 2 - 4 } & G-26 & 6.3 & 27.9 \\
\cline { 2 - 4 } & G-29a & 6.6 & 25.6 \\
\cline { 2 - 4 } & G-29b & 5.0 & 22.1 \\
\cline { 2 - 4 } & G-29c & 6.3 & 27.9 \\
\cline { 2 - 4 } & G-31 & 4.9 & 17.3 \\
\hline \multirow{4}{*}{ MGF } & G-2a & 5.5 & 13.5 \\
\cline { 2 - 4 } & G-2b & 10.2 & 7.6 \\
\cline { 2 - 4 } & G-3a & 8.3 & 33.3 \\
\cline { 2 - 4 } & G-11a & 12.8 & 27.3 \\
\cline { 2 - 4 } & G-11d & 13.8 & 29.3 \\
\cline { 2 - 4 } & G-13a & 8.1 & 42.4 \\
\hline \multirow{4}{*}{} & & & \\
\hline
\end{tabular}

Tabela 3.1: Be e Li nos GB e MGF (via absorção atômica).

Granitos Tipo A ocorrem em todos os tempos e em qualquer ambiente geológico (Whalen et al., 1987) e, uma vez que, em qualquer suíte granítica, o aumento de $\mathrm{SiO}_{2}$ está associado a um aumento de $\mathrm{Na}_{2} \mathrm{O}+\mathrm{K}_{2} \mathrm{O}$, estes elementos não são considerados diagnósticos da alcalinidade destes granitos (King et al., 1997).

Com base no trabalho de King et al. (1997) que considera as composições mineralógicas e de elementos maiores similares em granitos félsicos Tipo I e Tipo A, foram, então, considerados alguns elementos menores e traço na tentativa de discriminar a natureza dos metagranitóides em estudo:

- $\mathrm{O} \mathrm{Zr}$ é alto (> $200 \mathrm{ppm}$ ), mas diminui com o aumento de $\mathrm{SiO}_{2}$ (Fig. 3.6a), o que pode ocorrer tanto em granitos Tipo I como Tipo A. Comparando com as análises apresentadas por aqueles autores, as concentrações dos GB e MGF estão mais próximas dos granitos Freycinet, Tipo I, da Tasmânia;

- Y e Nb são relativamente abundantes e aumentam com o aumento de $\mathrm{SiO}_{2}$ (Fig. 3.6b,c), feição mais comum em granitos Tipo I; 
- As razões $\mathrm{Ga} / \mathrm{Al}_{2} \mathrm{O}_{3}$ nos $\mathrm{GB}$ e MGF são relativamente altas, com correlações negativas entre o $\mathrm{Ga}$ e o $\mathrm{Al}_{2} \mathrm{O}_{3}$ (Fig. 3.6d); granitos Tipo I félsicos podem apresentar razões $\mathrm{Ga} / \mathrm{Al}$ sobrepondo os campos de granitos Tipo A (Whalen et al., 1987).

- Os teores de Sc dos metagranitóides desta pesquisa variam de 33 a 54 ppm, faixa considerada diagnóstica de granitos Tipo A por Collins et al. (1982); porém, o Sc de granitos Tipo A varia, geralmente, no intervalo dos granitos Tipo I com o mesmo teor de $\mathrm{SiO}_{2}$ (King et al., 1997).

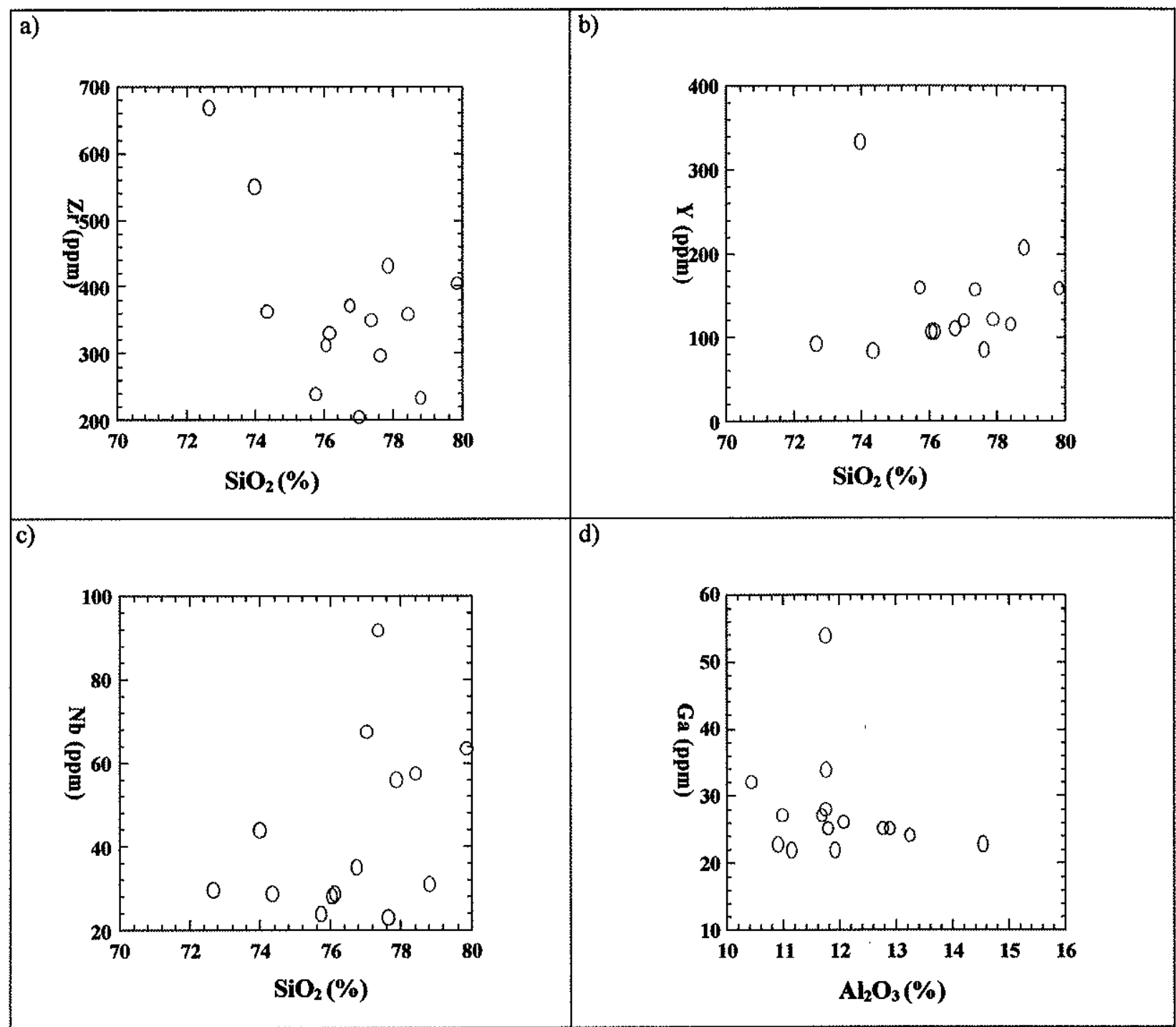

Figura 3.6: GB (O) e MGF (O) nos diagramas $\mathrm{SiO}_{2}$ vs $\mathrm{Zr}(\mathrm{a}), \mathrm{Y}(\mathrm{b})$ e $\mathrm{Nb}$ (c) e Ga vs $\mathrm{Al}_{2} \mathrm{O}_{3}$ (d).

Nos diagramas de discriminação geotectônica de Pearce et al. (1984), os GB e MGF figuram no campo dos granitóides intra-placa (WPG), conforme já demonstrado por Schorscher (1992) e Machado (1994). Entretanto, esses diagramas foram construídos para granitos Fanerozóicos e, especificamente limitados em relação a rochas arqueanas; foram aqui 
utilizados, sobretudo, para mostrar as relações de $\mathrm{Y}, \mathrm{Nb}$ e $\mathrm{Rb}$ nos metagranitóides GB e MGF, comparativamente (Fig. 3.7).
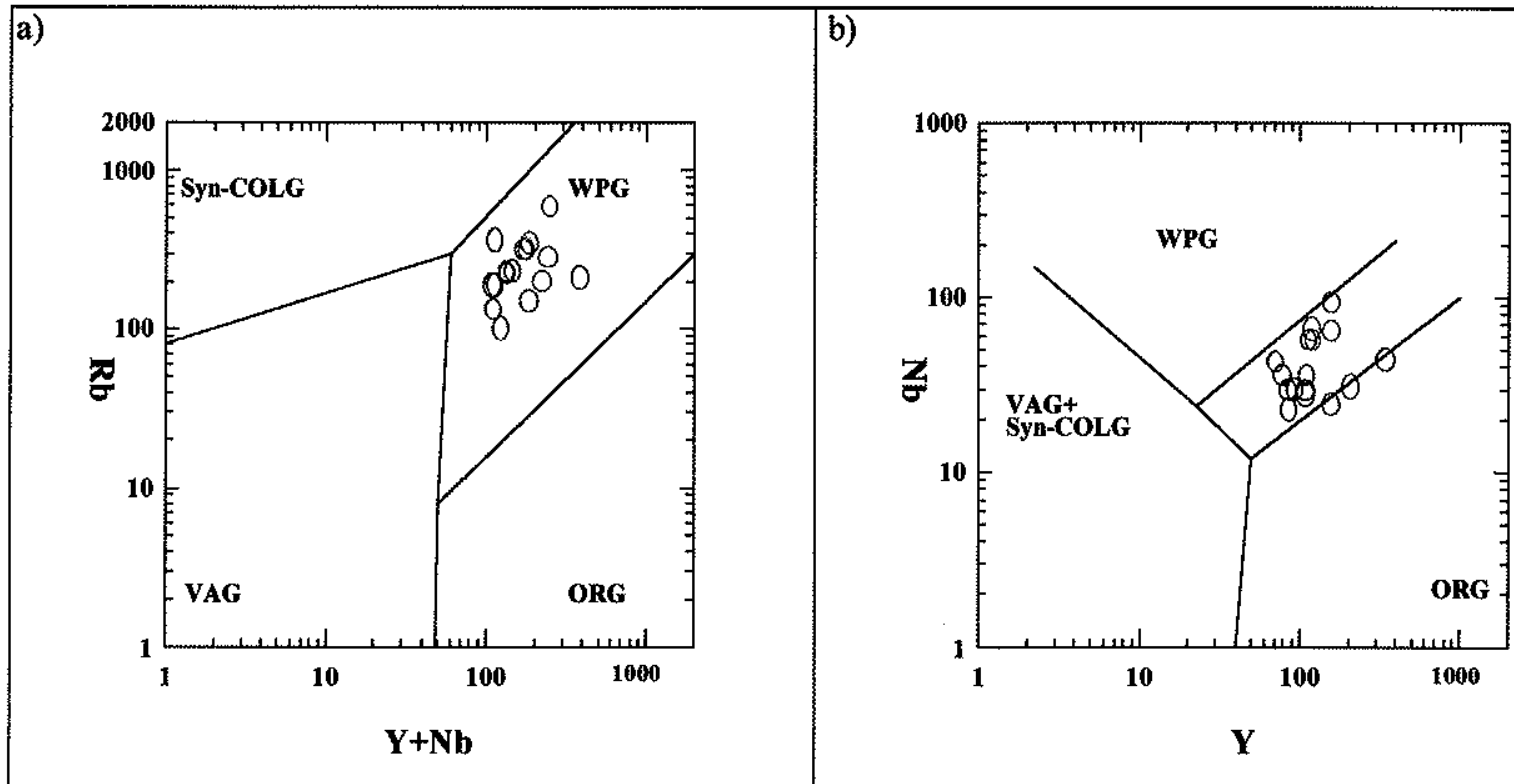

Figura $3.7(a, b)$ : Os metagranitóides GB (O) e MGF (O) são ricos em $\mathrm{Rb}, \mathrm{Y}$ e $\mathrm{Nb}$, figurando no campo WPG (granitóides fanerozóicos intra-placas).

Em diagramas multielementares nomalizados em manto primitivo - PRIM e crosta continental (Taylor \& McLennan, 1985) e em granitóides de cadeia oceânica - ORG (Pearce et al., 1984), os GB e MGF exibem padrões geoquímicos muito bem definidos e praticamente idênticos, caracterizados por enriquecimentos de $\mathrm{Rb}, \mathrm{Ba}, \mathrm{Sr}, \mathrm{Ta}, \mathrm{Nb}, \mathrm{Th}, \mathrm{U}, \mathrm{Zr}, \mathrm{Y}, \mathrm{Pb}$ e $\mathrm{Zn}$ e empobrecimentos de V, Cr e Ni (Fig. 3.8a,b,c). Já os elementos Sc, Mo, As e W apresentam teores variáveis, próximos dos padrões. Anomalias positivas maiores de $\mathrm{Pb}$ e $\mathrm{Zn}$ devem-se a mineralizações de galena e esfalerita (Schorscher, 1975; Machado, 1994) (Fig. 3.8a,b). Os diagramas normalizados em ORG (Pearce et al., 1984) revelaram anomalias positivas fortes de $\mathrm{Rb}$ e $\mathrm{Th}$, fracas de $\mathrm{Ce}$ e $\mathrm{Sm}$ e enriquecimentos variáveis, fracos a médios, de Ba (Fig. 3.8c), devendo ser lembrado que os resultados dos ETR serão mais detalhadamente discutidos no Capítulo VI. Os valores de $\mathrm{Hf}$ e $\mathrm{Zr}$ são próximos do padrão. Comparativamente, os MGF são enriquecidos em $\mathrm{Ta}, \mathrm{Nb}$ e $\mathrm{Y}$ e empobrecidos em $\mathrm{Ba}, \mathrm{Hf}$ e $\mathrm{Zr}$ em relação aos $\mathrm{GB}$. As razões $\mathrm{Hf} / \mathrm{Zr}$ variam no intervalo de 0.029 a 0.036 para os GB e de 0.030 a 0.042 para os MGF. 


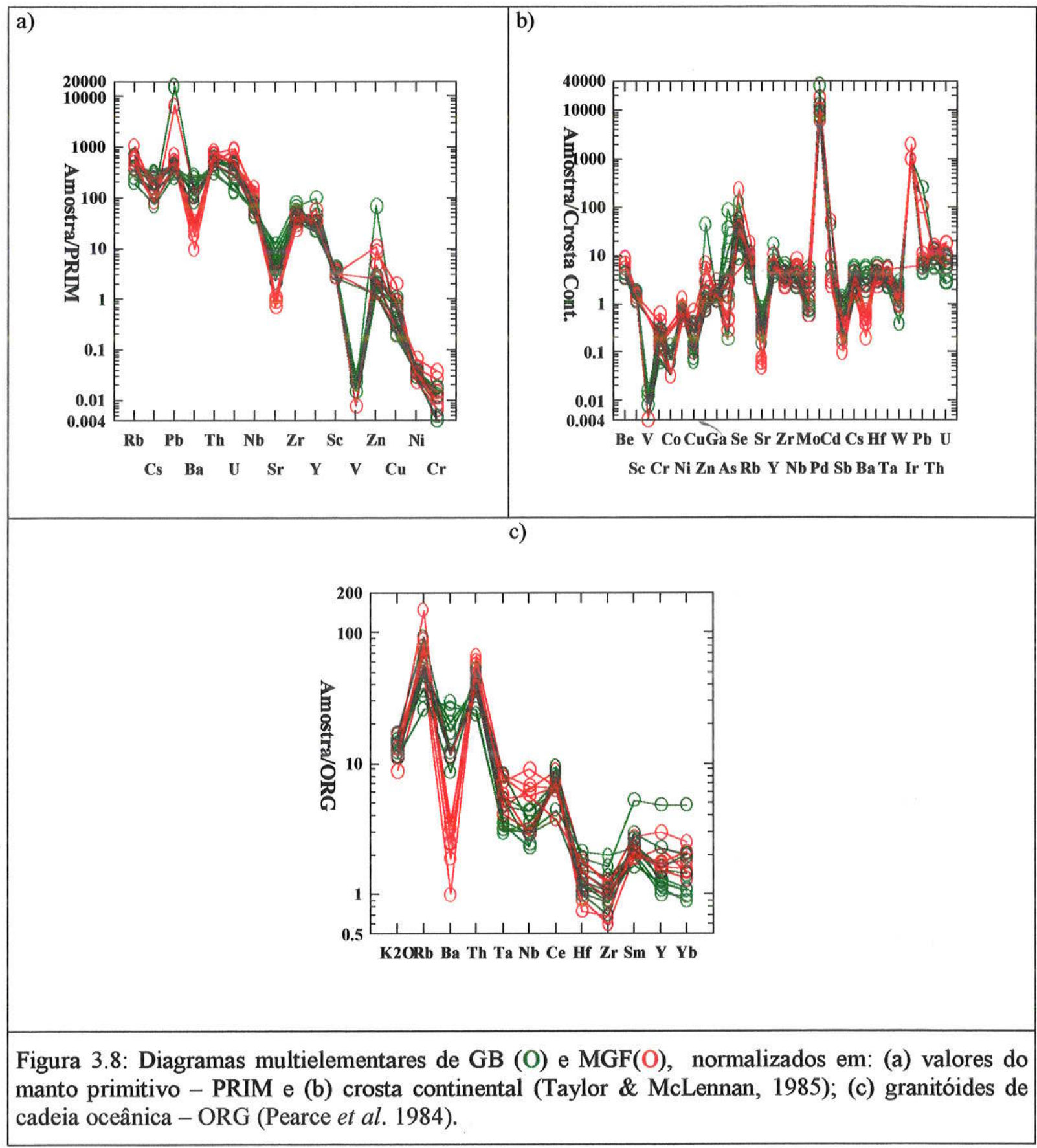

Para comparações geoquímicas entre GB e MGF e entre TTG e GB, foram representadas nos diagramas de Hildreth (1981) amostras típicas de GB e MGF da área de estudo e de um TTG menos transformado (amostra 136 de Schorscher, 1992). Resultaram, assim, para os GB enriquecimentos em $\mathrm{Y}, \mathrm{Nb}, \mathrm{Th}, \mathrm{U}, \mathrm{Cr}$, $\mathrm{Ni}$ e $\mathrm{Cu}$ e empobrecimentos em Co, V e Ba em relação aos TTG (Fig. 3.9), atribuídos por Schorscher (1992) a processos metassomáticos; para os MGF em relação aos $\mathrm{GB}$, enriquecimentos em $\mathrm{Rb}, \mathrm{Ga}, \mathrm{Nb}, \mathrm{Y}$ e $\mathrm{Zn}$ e empobrecimentos em Cs, Ba, Sr, Hf e Zr (Fig. 3.10), atribuídos a processos de metamorfismo 
regional de grau médio a alto e processos correlacionados de fusão parcial incipiente nos MGF.

a)

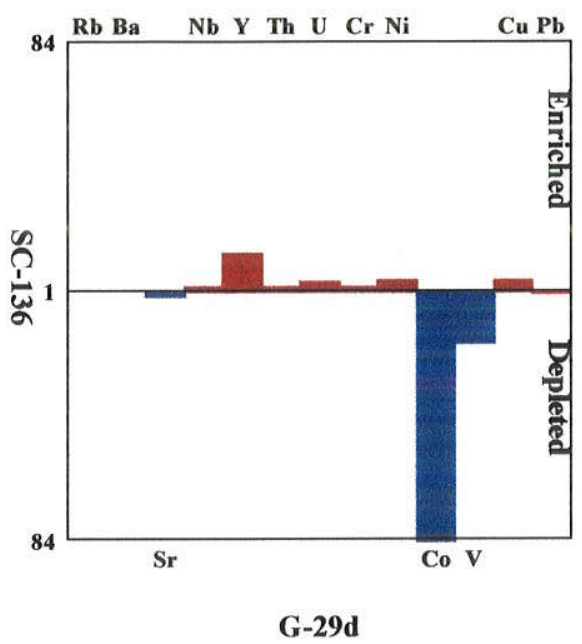

Figura 3.9: Diagrama de perdas e ganhos dos elementos $\mathrm{Rb}, \mathrm{Ba}, \mathrm{Sr}, \mathrm{Nb}, \mathrm{Y}, \mathrm{Th}, \mathrm{U}, \mathrm{Cr}, \mathrm{Ni}, \mathrm{Co}, \mathrm{V}, \mathrm{Cu}$ e Pb em GB (amostra G-29d) relativo a TTG (amostra SC-136 de Schorscher, 1992) (cf.: Hildreth, 1981).

b)

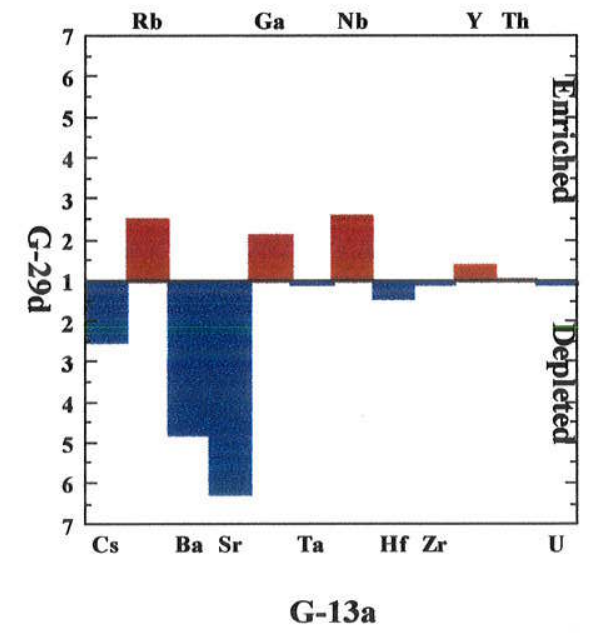

c)

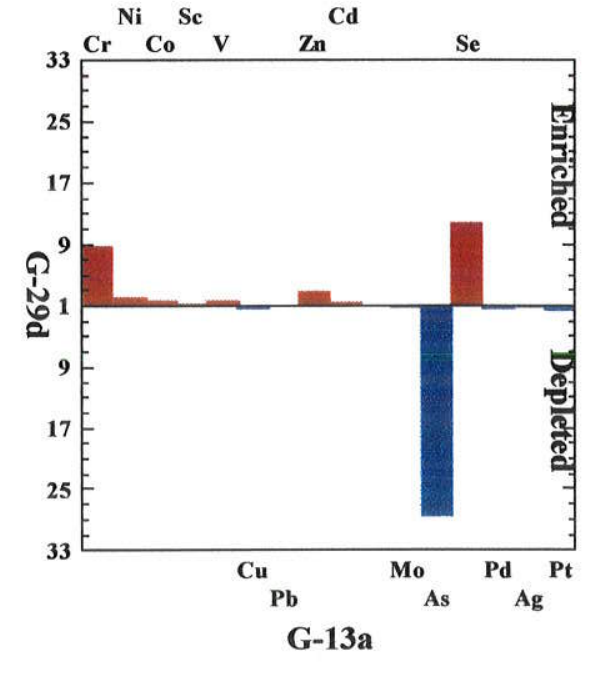

Figura 3.10: Diagramas de perdas e ganhos de elementos em MGF (amostra G-13a) relativo a GB (amostra G-29d): a) Cs, Rb, Ba, Sr, Ga, Ta, Nb, Hf, Zr, Y, Th e U; b) Cr, Ni, Co, Sc, V, Cu, Pb, Zn, Cd, Mo, As, Se, Pd, Ag e Pt (cf.: Hildreth, 1981). 


\section{III.4 - ROCHAS METAULTRAMÁFICAS}

As rochas metaultramáficas, hospedeiras das mineralizações, foram classificadas petrograficamente em: 1) anfibolitos $(\mathrm{AU})$ constituídos essencialmente por anfibólios verdes (>95\%) e com cromitas acessórias; 2) talco-anfibólio-clorita xistos (TACX) com cromitas acessórias ou cumuláticas, passando para cromititos disseminados (CRT); e 3) equivalentes flogopitizados (AFX), incluindo flogopita-anfibolitos, anfibólio-flogopita-xistos e flogopititos, com respectivamente, $5-45 \%$ de flogopita, $45-80 \%$ e $>80 \%$, além de cromititos flogopitizados (CRTM).

O estudo geoquímico destas rochas teve como objetivos principais: 1) avaliar as modificações composicionais ao longo da sua evolução tectono-metamórfica, procurando reconhecer padrões distintos que possam ser correlacionados a processos pós-magmáticos, metamórficos e metassomático-mineralizantes, estes últimos responsáveis pela flogopitização incipiente a total das rochas metaultramáficas e formação dos depósitos de esmeraldas; 2) procurar caracterizar um possível conjunto de amostras menos modificadas, que possa preservar algo do padrão geoquímico original. Para tanto, foram efetuadas 63 análises de elementos maiores, menores e traço, por FRX e ICP-AES (Anexo 2, Tab. A2.4).

\section{* Elementos Maiores}

As variações composicionais são analisadas em diagramas dos óxidos principais versus $\mathrm{MgO}, \mathrm{K}_{2} \mathrm{O}$ e $\mathrm{Al}_{2} \mathrm{O}_{3}$. O Fe foi tratado como FeO total. Em relação ao $\mathrm{MgO}, \mathrm{SiO}_{2}$ e $\mathrm{FeO}_{\mathrm{T}}$ não apresentam correlações bem definidas. $\mathrm{Al}_{2} \mathrm{O}_{3}, \mathrm{CaO}$ e $\mathrm{Na}_{2} \mathrm{O}$ apresentam tendências de correlação negativa (Fig. 3.11). Nos diagramas óxidos versus $\mathrm{K}_{2} \mathrm{O}$ indicativos dos processos metassomáticos de flogopitização, observam-se enriquecimentos de $\mathrm{K}_{2} \mathrm{O}$ com valores constantes de $\mathrm{SiO}_{2}, \mathrm{MgO}$ e $\mathrm{FeO}_{\mathrm{T}}$ e correlações gerais negativas com $\mathrm{CaO}$ e $\mathrm{Na}_{2} \mathrm{O}$. Entretanto, observam-se variações consideráveis desses óxidos nas rochas não metassomatizadas $\left(\mathrm{K}_{2} \mathrm{O} \leq\right.$ $0.5 \%$ peso), indicando as variações composicionais dos protólitos (Fig. 3.12). Notam-se, ainda, evoluções diferentes para $\mathrm{CaO}$ e $\mathrm{Na}_{2} \mathrm{O}$, com o enriquecimento de $\mathrm{K}_{2} \mathrm{O}$ : nas rochas com alto $\mathrm{CaO}$ e $\mathrm{Na}_{2} \mathrm{O}$, estes óxidos diminuem; nas rochas com mais baixo $\mathrm{CaO}$, o enriquecimento de $\mathrm{K}_{2} \mathrm{O}$ não exerce efeito; porém, nas rochas de mais baixo $\mathrm{Na}_{2} \mathrm{O}$, observa-se o fraco enriquecimento deste para teores crescentes de $\mathrm{K}_{2} \mathrm{O}$ (Fig. 3.12). Os diagramas óxidos versus $\mathrm{Al}_{2} \mathrm{O}_{3}$ mostram, com o aumento de $\mathrm{Al}_{2} \mathrm{O}_{3}$, diminuições de $\mathrm{SiO}_{2}, \mathrm{CaO}$ e $\mathrm{FeO}_{\mathrm{T}}$ (fraca) e aumentos de $\mathrm{Na}_{2} \mathrm{O}$ e $\mathrm{K}_{2} \mathrm{O}$ (Fig. 3.13). Todas as variações nas rochas com $\mathrm{K}_{2} \mathrm{O} \geq 0.5 \%$ peso são atribuíveis a processos metassomáticos. 


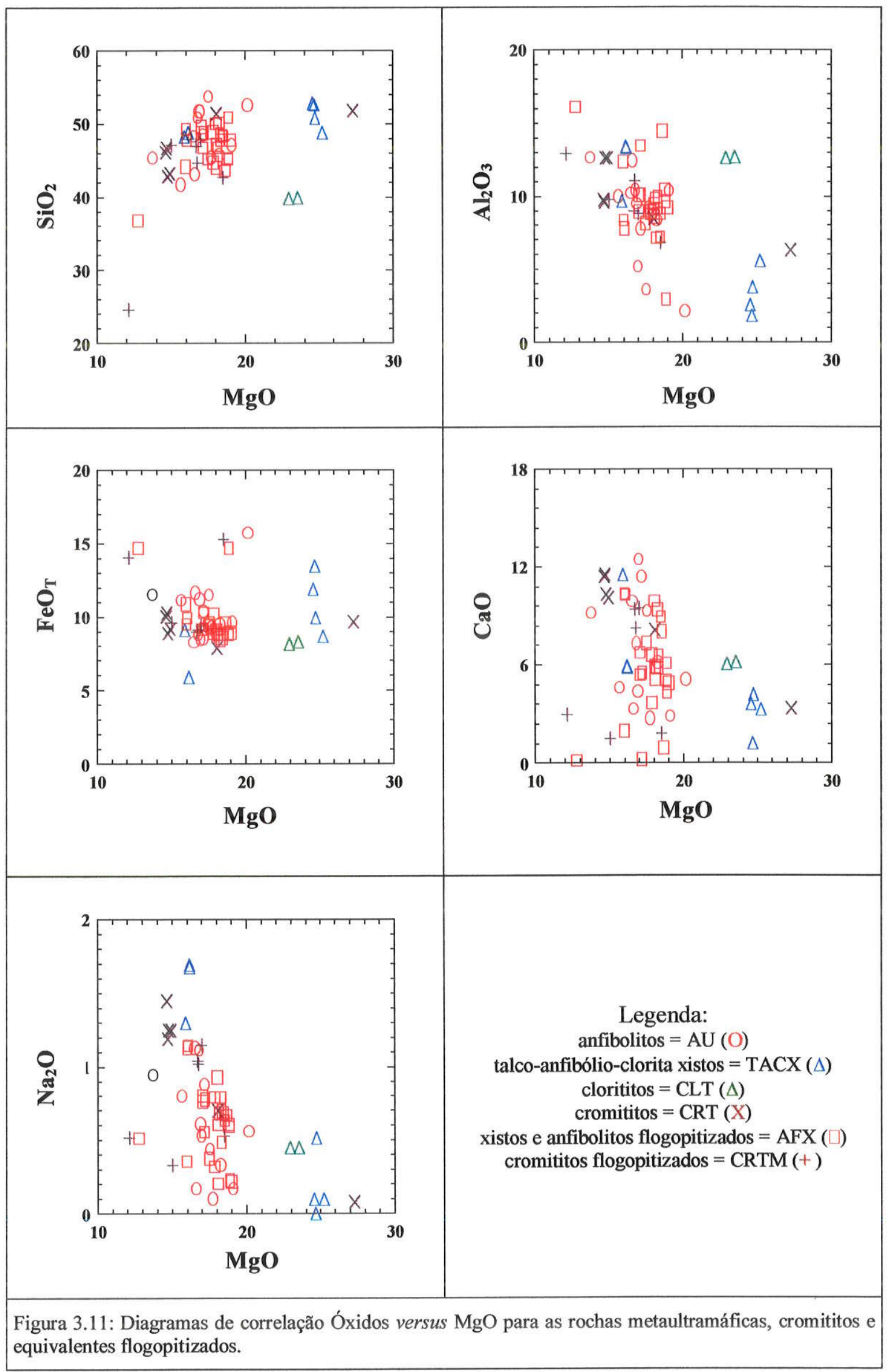




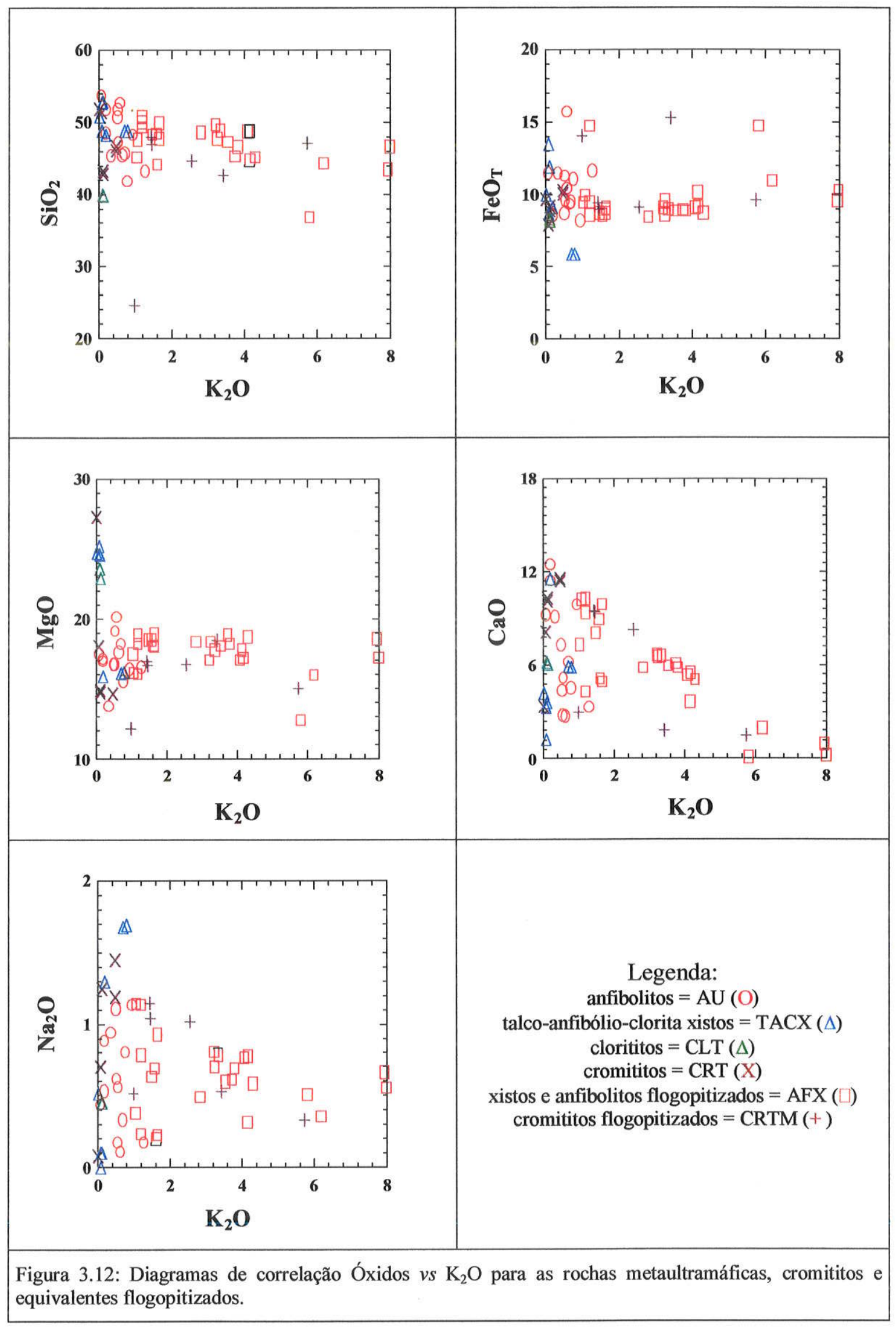




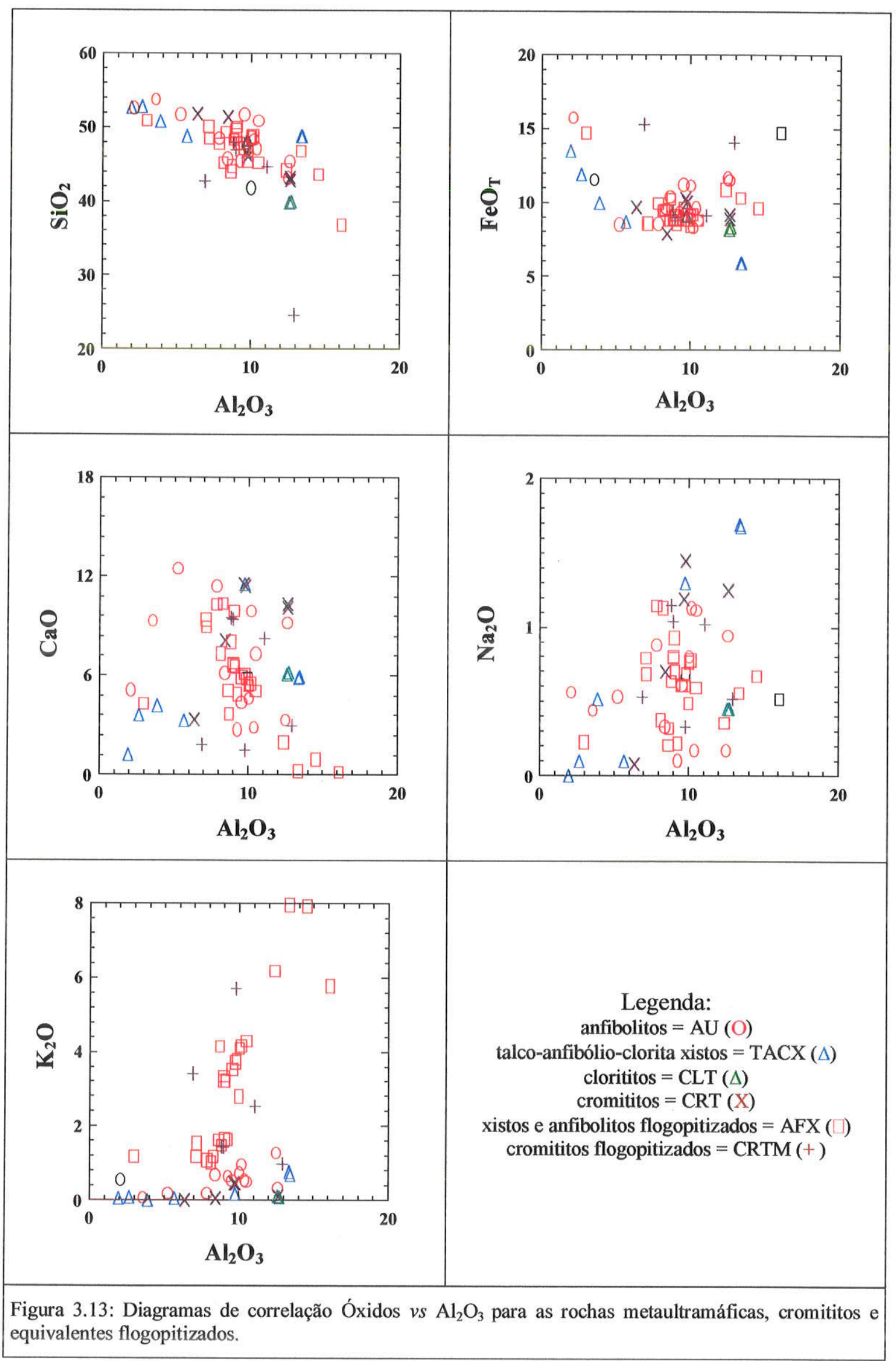


Sob aspectos de classificação, o diagrama de Jensen (1976) confirma a natureza komatiítica de todas as rochas metaultramáficas estudadas (cf.: Machado, 1994) (Fig. 3.14).

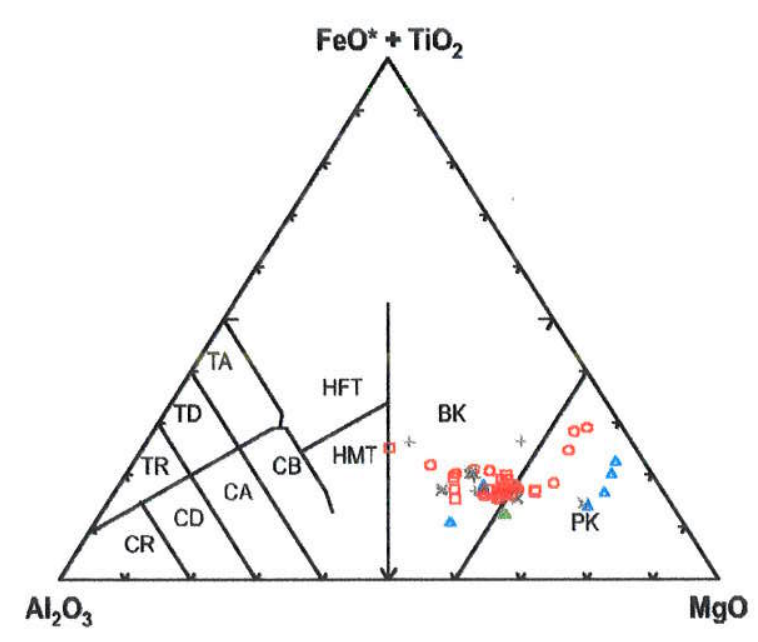

Figura 3.14: As rochas metaultramáficas figuram nos campos dos komatiitos basálticos a peridotíticos (Jensen, 1976). Símbolos: AU (O), AFX ( $\square)$, TACX $(\triangle)$, CLT $(\triangle)$, CRT (X), CRTM (+).

O diagrama AFM (Irvine \& Baragar, 1971) evidencia a natureza pouco diferenciada das rochas metaultramáficas não metassomatizadas que se concentram mais próximas à linha FeO*-MgO na origem do campo toleítico, enquanto que os processos metassomáticos com enriquecimentos em álcalis são responsáveis por deslocamentos em direção ao vértice $\mathrm{K}_{2} \mathrm{O}+\mathrm{Na}_{2} \mathrm{O}$ no campo das rochas cálcio-alcalinas (Fig. 3.15).

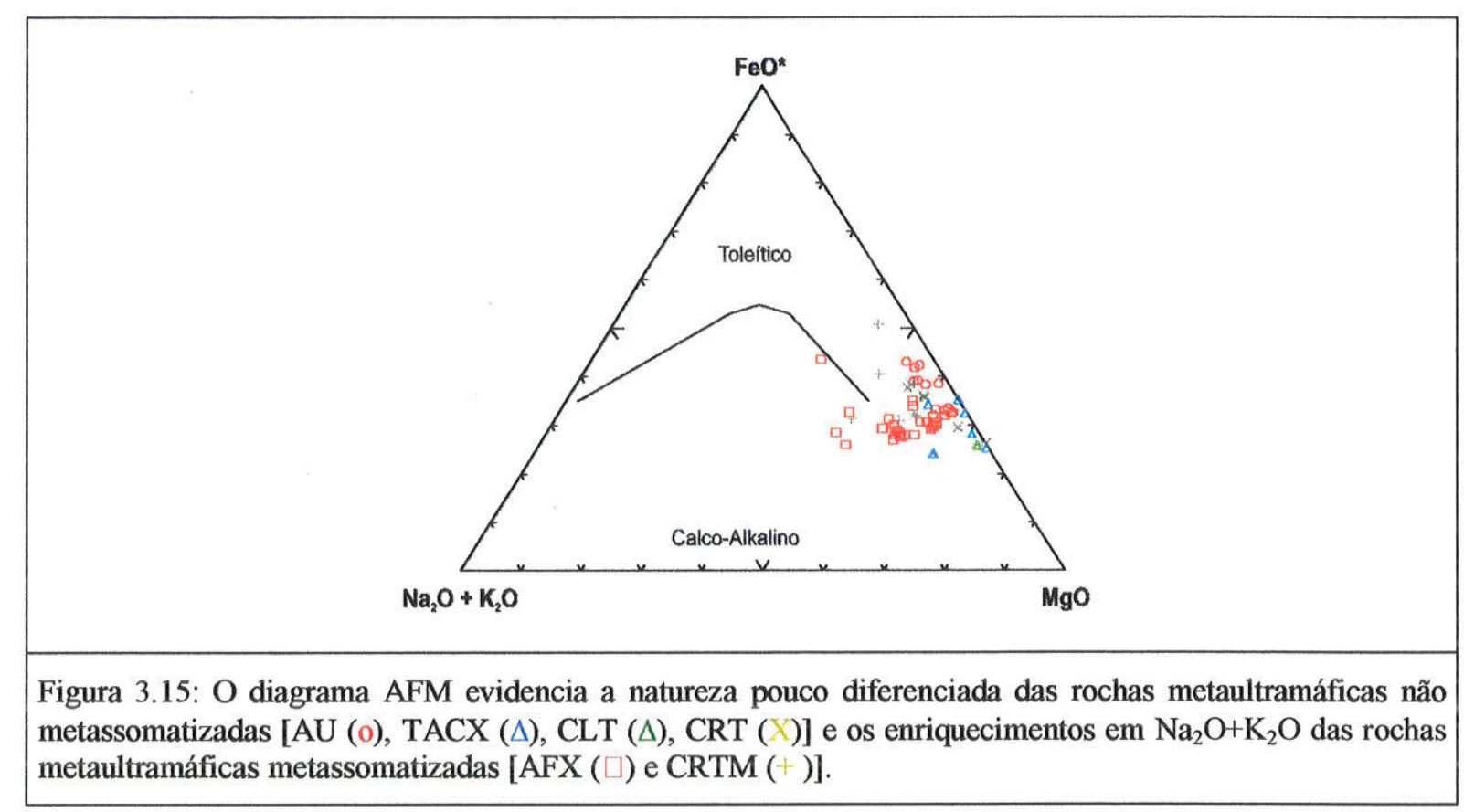


Todos os dados foram, ainda, analisados nos diagramas $\mathrm{SiO}_{2}$ versus $\mathrm{CaO} / \mathrm{Al}_{2} \mathrm{O}_{3}$ e $\mathrm{CaO} / \mathrm{Al}_{2} \mathrm{O}_{3}$ versus $\mathrm{Al}_{2} \mathrm{O}_{3} / \mathrm{TiO}_{2}$, propostos por Nesbitt et al. (1979) para distinguir tipos genéticos de komatiitos (cf.: Szabó, 1996, entre outros). A distribuição dos pontos, embora mostre eventuais similaridades às tendências definidas pelas rochas de Barbenton (cf.: Herzberg, 1992), são consideradas, principalmente, como resultados da mobilidade de $\mathrm{Si}, \mathrm{Al}$ e Ca nos processos metassomáticos, não permitindo, assim, aprofundar a discussão sobre a natureza e origem mais específica dos protólitos.

\section{* Elementos Traço}

Os elementos menores e traço $(\mathrm{Ba}, \mathrm{Y}, \mathrm{Rb} \mathrm{Zr}, \mathrm{Zn}$ e $\mathrm{Be}$ ) das rochas metaultramáficas, cromititos e equivalentes metassomáticos foram representados em diagramas de correlação com o $\mathrm{K}_{2} \mathrm{O}$ (Fig. 3.16). Observam-se correlações positivas de $\mathrm{K}_{2} \mathrm{O}$ com Ba, $\mathrm{Y}$ e Rb, tanto para as rochas metaultramáficas, quanto para os cromititos. $\mathrm{O} \mathrm{Zn}$ apresenta teores constantes nas rochas metaultramáficas e crescentes nos cromititos de acordo com os teores e a composição da cromita (cf.: Schorscher, 1992). Os teores de $\mathrm{Zr}$ (e de $\mathrm{Cr}, \mathrm{Ni}, \mathrm{Co}, \mathrm{V}, \mathrm{Cu}$ e La não representados na Fig. 3.16) permanecem, aproximadamente, constantes. $O$ Be não mostra relação bem definida com $\mathrm{K}_{2} \mathrm{O}$; porém, considerando-se os valores médios nos anfibolitos (AU) e cromititos (CRT) e nos seus equivalentes metassomáticos (AFX e CRTM), observa-se uma relação direta com o metassomatismo (Tab. 3.2). Em geral, o teor de Be nas rochas metaultramáficas e equivalentes metassomáticos varia até $97 \mathrm{ppm}$ Segundo Wedepohl (1969), o Be nas rochas ultramáficas não excede $1 \mathrm{ppm}$, sendo os teores $>10 \mathrm{ppm}$ causados por processos metassomáticos.

\begin{tabular}{|c|c|c|}
\hline Sub-Grupas & $\begin{array}{c}\text { Média de Be (ppm) } \\
\text { ICP-AES }\end{array}$ & $\mathbf{N}^{\circ}$ de análises \\
\hline TACX & 3.17 & 06 \\
\hline CLT & 3.5 & 02 \\
\hline AU & 12.43 & 07 \\
\hline AFX & 30.87 & 08 \\
\hline CRT & 3.3 & 03 \\
\hline CRTM & 87.00 & 01 \\
\hline
\end{tabular}

Tabela 3.2: Valores médios de Be (ppm) nas rochas metaultramáficas: talco-anfibólio-clorita-xistos (TACX), clorititos (CLT), anfibolitos (AU) e equivalentes flogopitizados (AFX), cromititos (CRT) e cromititos flogopitizados (CRTM).

As tendências de correlação dos mesmos elementos menores e traço com o $\mathrm{Al}_{2} \mathrm{O}_{3}$, indicam, analogamente, aumento nos teores de $\mathrm{Rb}, \mathrm{Ba}$ e $\mathrm{Y}$; os demais elementos (inclusive o Be) não apresentam correlações bem definidas com este óxido (Fig. 3.17). 


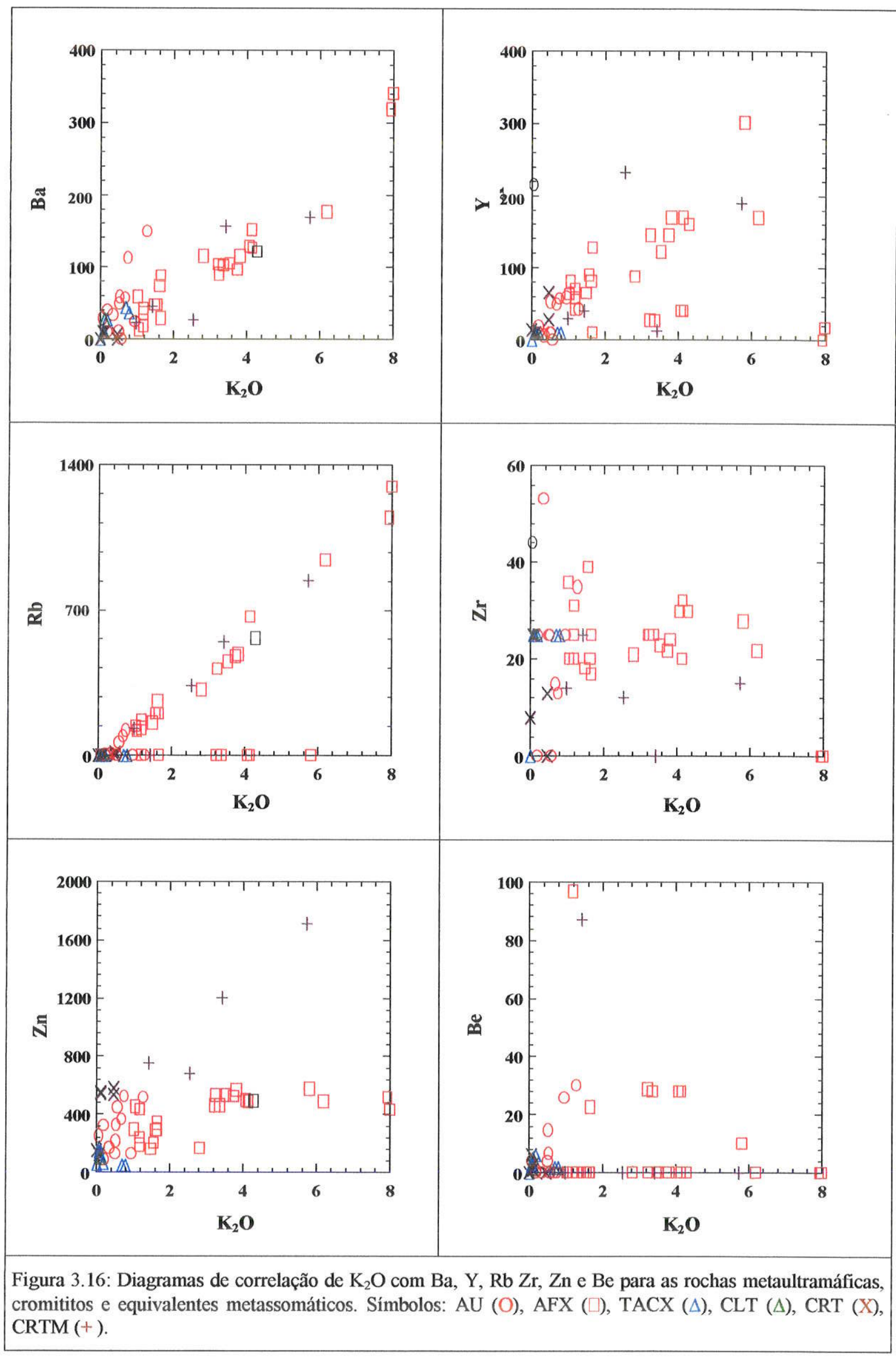




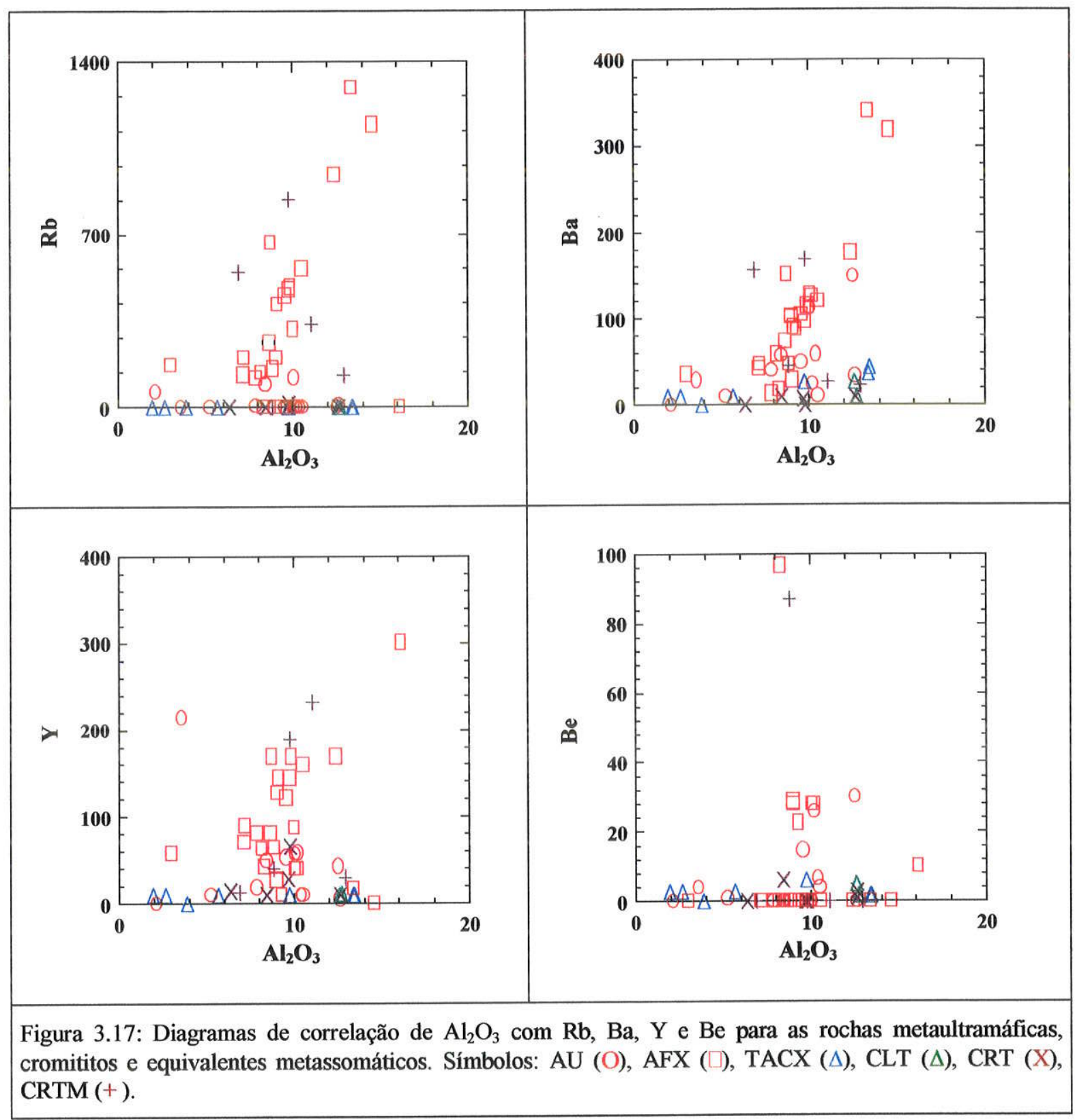

Os elementos menores e traço dos anfibolitos não metassomatizados (AU) e seus equivalentes metassomáticos (AFX) foram representados em diagramas multielementares normalizados em valores do manto primitivo - PRIM (Taylor \& McLennan, 1985) (Fig. 3.18). Tanto nos AU, quanto nos AFX, observam-se enriquecimentos sistemáticos (e variáveis) dos elementos incompatíveis, com anomalias positivas fortes de $\mathrm{Rb}, \mathrm{La}, \mathrm{Y}$ e $\mathrm{Zn}$, e anomalias negativas fortes de $\mathrm{Sr}$ e fracas de $\mathrm{Ni}$. Os elementos compatíveis $\mathrm{Zr}, \mathrm{Sc}, \mathrm{V}, \mathrm{Cu}$ e $\mathrm{Cr}$ apresentam valores próximos ao padrão. Fatores magmáticos são os responsáveis pelos teores elevados em Zn que se encontra na estrutura da cromita (Schorscher, 1992). 
a)

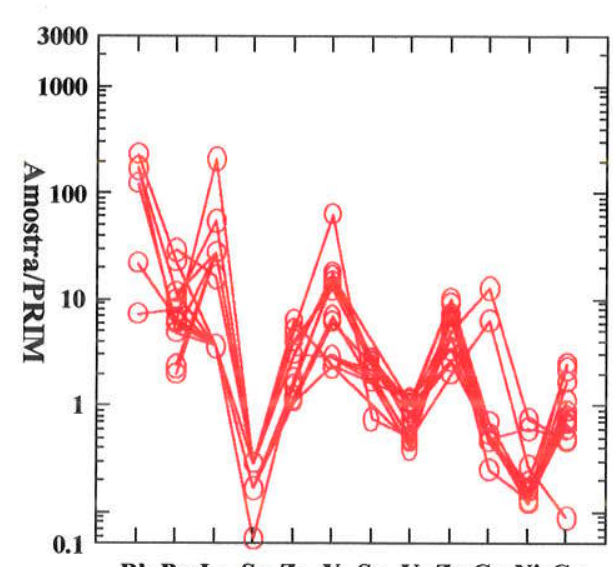

Rb Ba La Sr Zr Y Se V Zn Cu Ni Cr b)

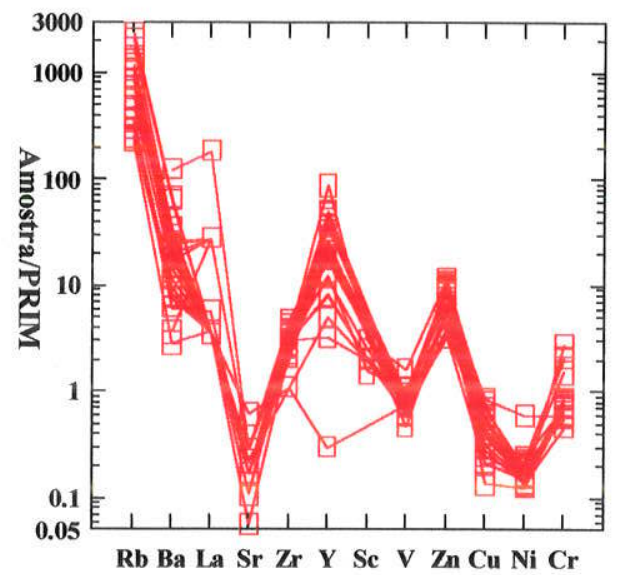

Figura 3.18: Variogramas de elementos menores e traço dos AU (a) e AFX (b), normalizados em PRIM (Taylor \& McLennan, 1985). Nota: Os valores analíticos nulos foram substituídos pelos limites de detecção dos respectivos elementos nos métodos utilizados.

Para melhor visualisar as modificações químicas dos processos de flogopitização metassomáticos/mineralizantes, foram utilizados em diagramas multielementares os valores médios dos anfibolitos não metassomáticos (AU) como dados de normalização para as rochas metaultramáficas metassomáticas (AFX) (Fig. 3.19). Os resultados indicam enriquecimentos em $\mathrm{Rb}, \mathrm{Ba}$ e Y e empobrecimentos em $\mathrm{La}, \mathrm{Cu}$ e $\mathrm{Cr}$ (fracos) nos processos metassomáticos. Os elementos Sr, Zr, Sc, V, Zn e Ni são praticamente imóveis e seus valores variam próximos da normalização.

Os xistos metaultramáficos com talco, anfibólio incolor e clorita (TACX) e clorititos (CLT) foram representados, conjuntamente, em variogramas multielementares normalizados em PRIM (Taylor \& Mclennan, 1985). Estes indicam enriquecimentos fortes de La, fracos a moderados e bastante variáveis de $\mathrm{Ba}$ e fracos de $\mathrm{Zr}$, Y e $\mathrm{Zn}$, e empobrecimentos de $\mathrm{V}$ e Ni; no caso do $\mathrm{Sr}$ predominam enriquecimentos fracos e os elementos $\mathrm{Sc}, \mathrm{Cu}$ e $\mathrm{Cr}$ mantêm-se próximos aos valores padrão (Fig. 3.20a). Quando normalizados nos valores médios dos anfibolitos metaultramáficos não metassomatizados (AU), os TACX e CLT apresentam enriquecimento em Sr e empobrecimentos em La e Y (Fig. 3.20b). 


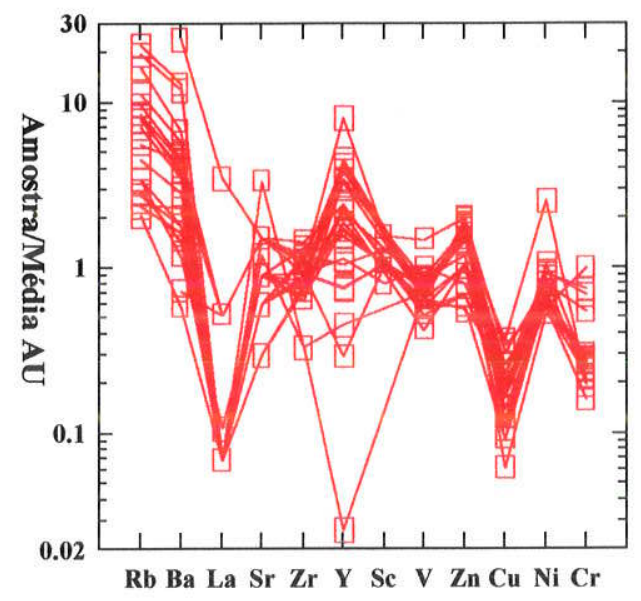

Figura 3.19: Variograma de elementos menores e traço dos AFX, normalizados pela média dos AU. Nota: Os valores analíticos nulos foram substituídos pelos limites de detecção dos respectivos elementos nos métodos utilizados.

a)

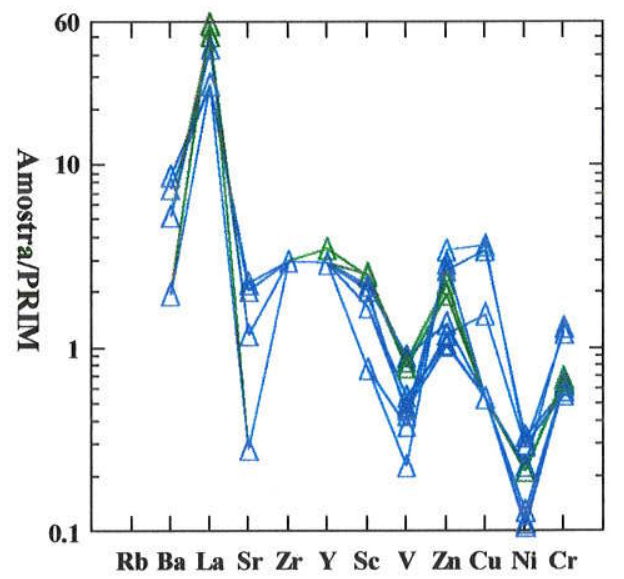

b)

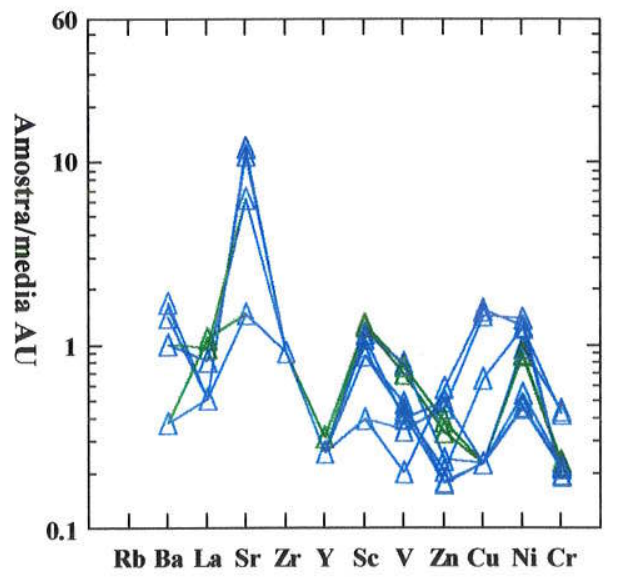

Figura 3.20: Variogramas de elementos menores e traço dos TACX $(\triangle)$ e CLT $(\Delta)$ normalizados em (a) PRIM; e (b) nos valores médios dos AU. 
As características químicas dos TACX e CLT em relação aos AU apontam para alterações aloquímicas premetamórficas específicas (cf.: Schorscher, 1992), anteriores e, portanto, não relacionados aos processos metassomáticos mineralizantes.

Os cromititos (CRT) e cromititos metassomáticos (CRTM) foram representados em diagramas multielementares, normalizados em manto primitivo - PRIM (Taylor \& McLennan, 1985) (Fig. 3.21). De modo similar às rochas metaultramáficas, estes litotipos são enriquecidos em $\mathrm{Rb}, \mathrm{Ba}$, La, Y e Zn e Cr e empobrecidos em $\mathrm{Sr}, \mathrm{Cu}$ e $\mathrm{Ni}$. Os elementos $\mathrm{Zr}$ e $\mathrm{V}$ estão próximos aos valores do padrão. Novamente, os enriquecimentos conjuntos em $\mathrm{Cr} \mathrm{e}$ Zn devem-se a fatores magmáticos (Schorscher, 1992), ou seja, teores variáveis de cromita com zinco nos cromititos. Comparativamente aos CRT, os CRTM exibem enriquecimentos de Rb, Ba e Y.

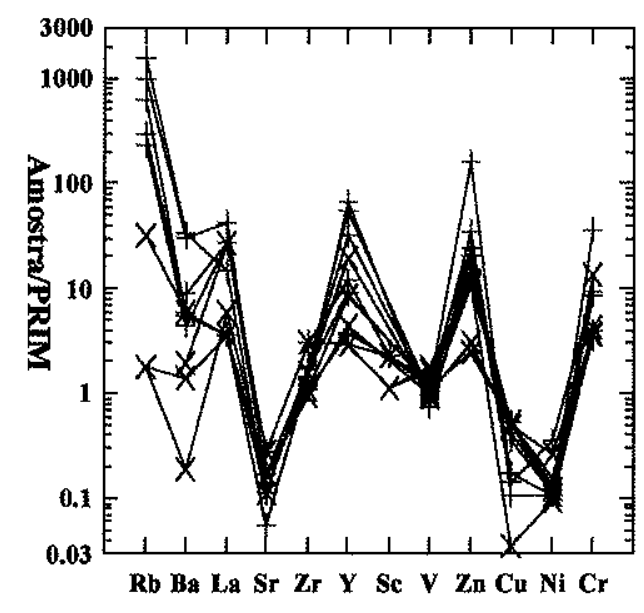

Figura 3.21: Variograma de elementos menores e traço dos CRT (x) e CRTM (+), normalizados em PRIM (Taylor \& McLennan, 1985). Nota: Os valores analíticos nulos foram substituídos pelos limites de detecção dos respectivos elementos nos métodos analíticos utilizados.

\section{* Processo Metassomático Mineralizante}

Esse atuou em zonas específicas onde afetou todos os litotipos metaultramáficos e cromititos (AU, TACX, CLT, CRT), independentemente das alterações aloquímicas anteriores, transformando-os em equivalentes variavelmente flogopitizados (AFX e CRTM). As características geoquímicas desse processo foram analizadas em diagramas de ganhos e perdas, segundo Hildreth (1981), em amostras de séries de transformação metassomática progressiva selecionadas. Para tanto, têm-se os valores numéricos nas Tabelas 3.3 e 3.4 e os diagramas nas Figuras 3.22 a 3.29 . 


\begin{tabular}{|c|c|c|c|c|c|c|c|c|c|c|}
\hline & $\mathrm{SiO}_{2}$ & $\mathbf{T i O}_{2}$ & $\mathbf{A l}_{2} \mathbf{O}_{3}$ & $\mathrm{FeO}_{\mathrm{T}}$ & MnO & $\mathrm{MgO}$ & $\mathrm{CaO}$ & $\mathrm{Na}_{2} \mathrm{O}$ & $\mathbf{K}_{2} \mathbf{O}$ & $\mathbf{P}_{2} \mathbf{O}_{5}$ \\
\hline $\mathrm{NE}-29 \mathrm{~b}$ & \multicolumn{10}{|c|}{ ROCHA ORIGINAL } \\
\hline NE-8 & 1.05 & 1.80 & 0.98 & 0.93 & 1.14 & 1.03 & 2.35 & 6.36 & 5.13 & 2.00 \\
\hline NE -10 & 0.99 & 1.02 & 1.05 & 0.95 & 1.05 & 1.06 & 2.16 & 5.54 & 5.90 & 1.00 \\
\hline NE-29b(1) & \multicolumn{10}{|c|}{ ROCHA ORIGINAL } \\
\hline NE-8(1) & 1.04 & 1.76 & 0.86 & 0.93 & 1.29 & 0.93 & 2.34 & 4.65 & 6.18 & 0.22 \\
\hline $\mathrm{NE}-7(1)$ & 1.03 & 1.76 & 0.97 & 0.95 & 1.14 & 0.90 & 1.95 & 4.59 & 7.70 & 1.00 \\
\hline $6 * \mathrm{~m}$ & \multicolumn{10}{|c|}{ ROCHA ORIGINAL } \\
\hline Gal 1-5 & 1.14 & 0.59 & 0.78 & 0.89 & 1.52 & 1.03 & 2.24 & 1.42 & 1.32 & 0.25 \\
\hline $6 * V$ & 1.05 & 0.76 & 0.85 & 0.79 & 0.80 & 1.15 & 1.11 & 0.25 & 2.10 & 0.50 \\
\hline Gal 1-6 & 1.07 & 0.88 & 0.87 & 0.92 & 1.16 & 1.14 & 0.81 & 0.40 & 5.43 & 0.50 \\
\hline $1-02^{\mathrm{a}}$ & \multicolumn{10}{|c|}{ ROCHA ORIGINAL } \\
\hline $\mathrm{I}-02$ & 0.96 & 1.07 & 1.37 & 0.94 & 0.98 & 0.94 & 0.82 & 0.41 & 2.13 & 0.50 \\
\hline $1-03$ & 0.89 & 0.48 & 6.25 & 0.66 & 0.18 & 0.85 & 0.05 & 0.98 & 14.49 & 0.00 \\
\hline A-13 & \multicolumn{10}{|c|}{ ROCHA ORIGINAL } \\
\hline A-08 & 0.94 & 2.00 & 1.07 & 1.11 & 0.85 & 1.06 & 0.56 & 0.39 & 4.00 & 0.50 \\
\hline$\overline{\mathrm{A}-7^{\mathrm{a}}}$ & 0.93 & 2.00 & 1.05 & 1.10 & 0.89 & 1.02 & 0.64 & 0.43 & 6.06 & 0.50 \\
\hline G-52e & \multicolumn{10}{|c|}{ ROCHA ORIGINAL } \\
\hline G-52g & 0.93 & 0.70 & 1.07 & 0.73 & 0.62 & 0.98 & 2.23 & 1.82 & 1.81 & 0.67 \\
\hline G-52f & 0.95 & 0.63 & 0.87 & 0.84 & 0.90 & 0.95 & 2.34 & 1.82 & 2.27 & 1.33 \\
\hline 1* & \multicolumn{10}{|c|}{ ROCHA ORIGINAL } \\
\hline $1 * b$ & 0.94 & 1.68 & 1.48 & 0.96 & 0.43 & 1.27 & 0.09 & 0.46 & 16.89 & 5.00 \\
\hline
\end{tabular}

Tabela 3.3: Ganhos (valores > 1) e perdas (valores < 1) de elementos maiores em séries selecionadas de transformação metassomática progressiva. 

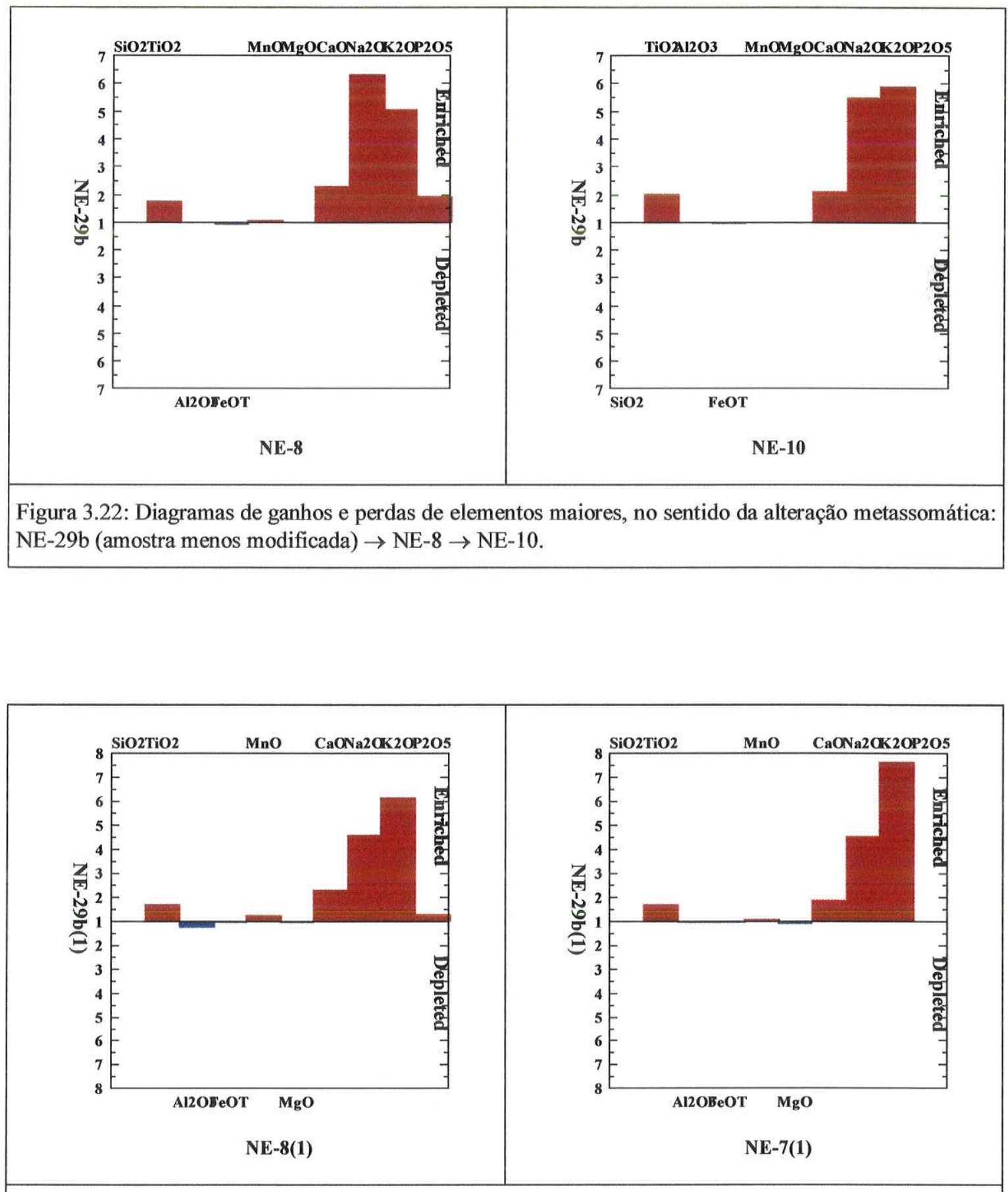

Figura 3.23: Diagramas de ganhos e perdas de elementos maiores, no sentido da alteração metassomática: $\mathrm{NE}-29 \mathrm{~b}(1) \rightarrow \mathrm{NE}-8(1) \rightarrow \mathrm{NE}-7$. 


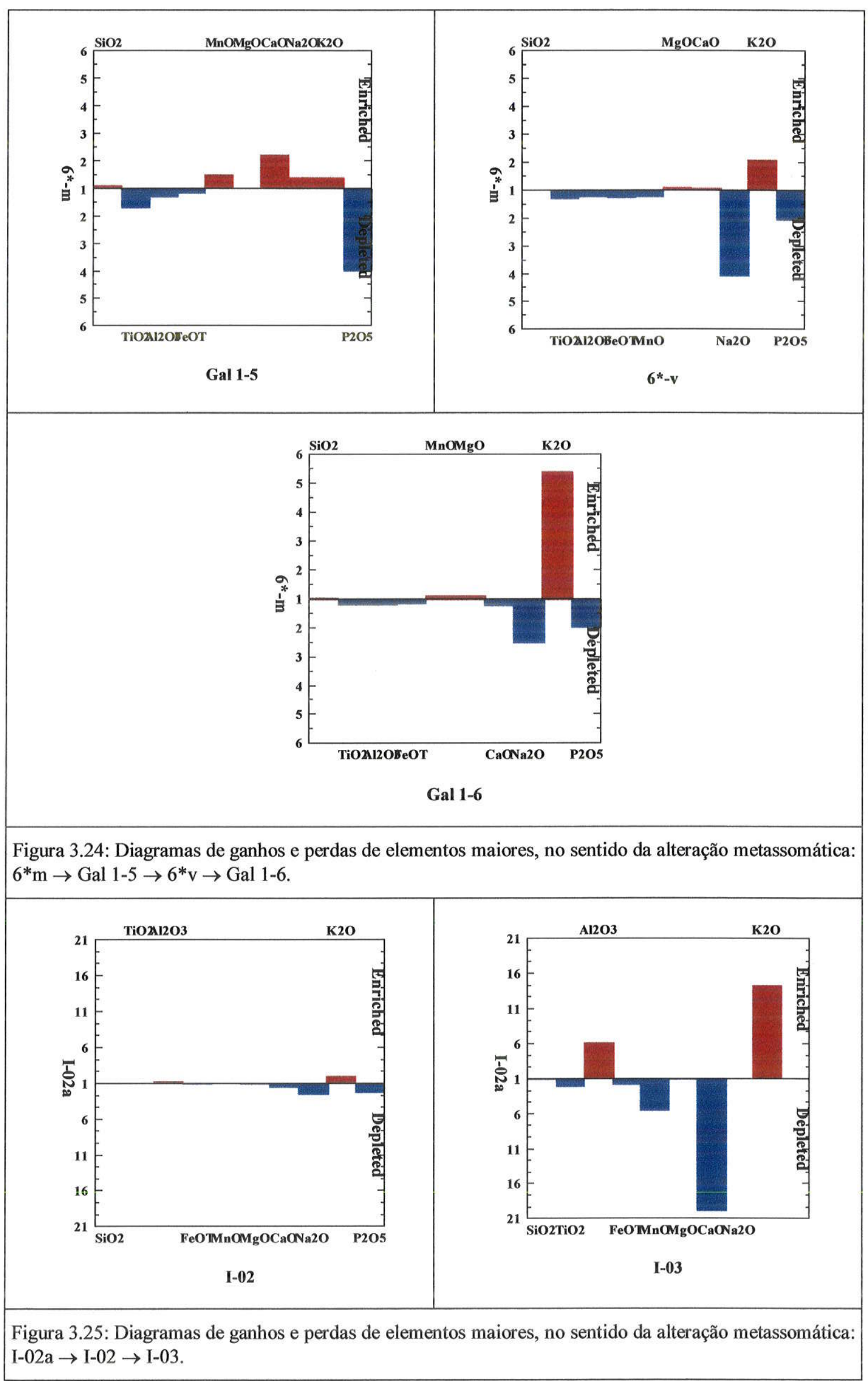



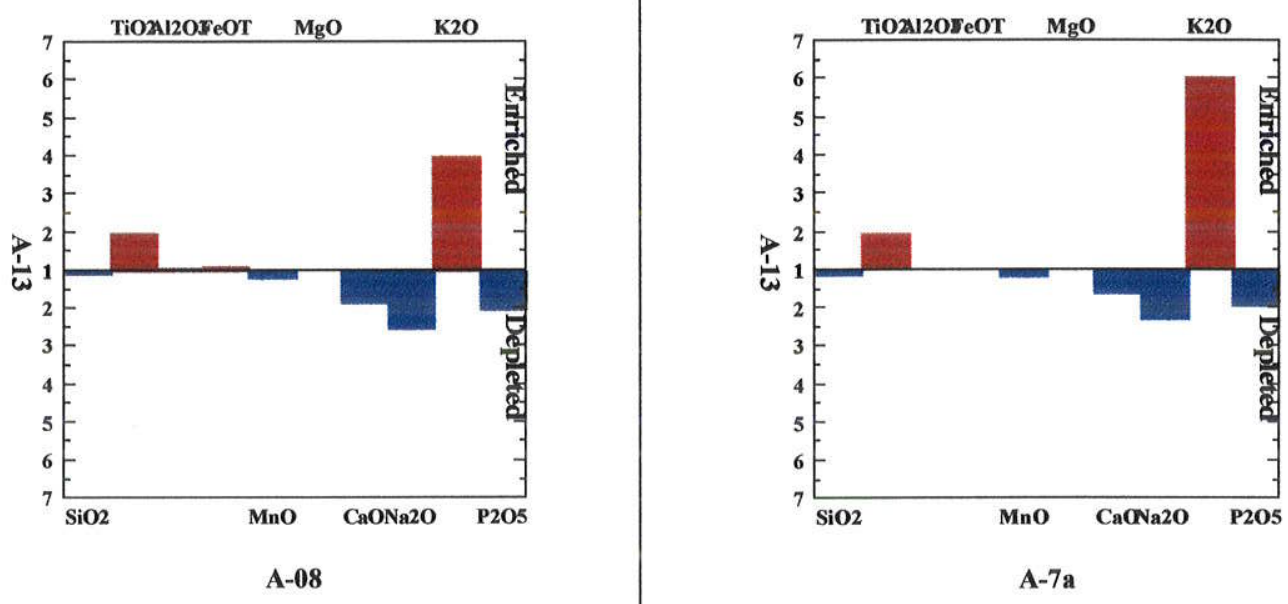

Figura 3.26: Diagramas de ganhos e perdas de elementos maiores, no sentido da alteração metassomática: A-13 $\rightarrow$ A-08 $\rightarrow$ A-7a.
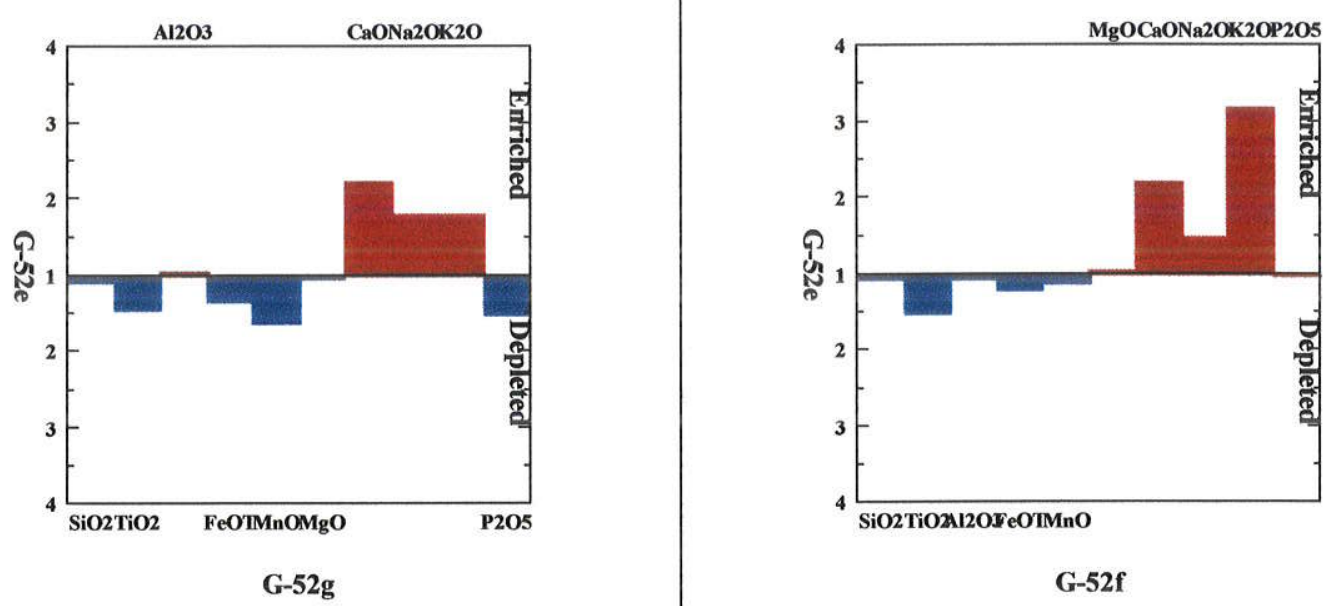

Figura 3.27: Diagramas de ganhos e perdas de elementos maiores, no sentido da alteração metassomática: G-52e $\rightarrow$ G-52g $\rightarrow$ G-52f.

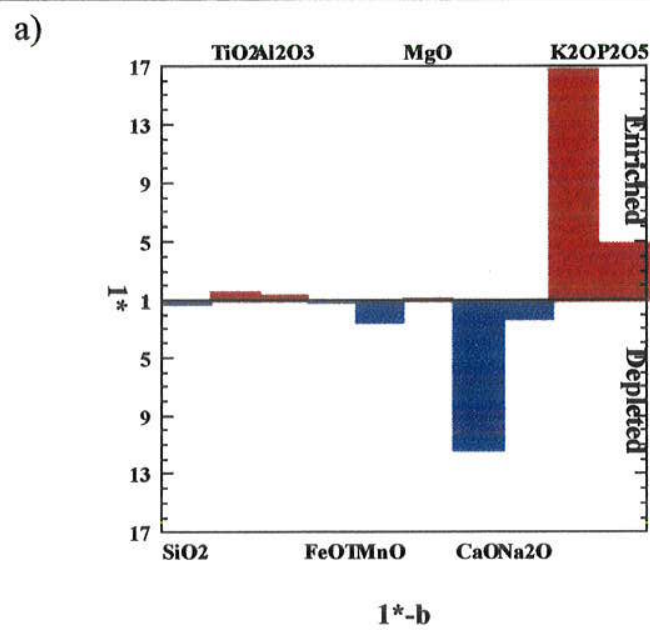

b)

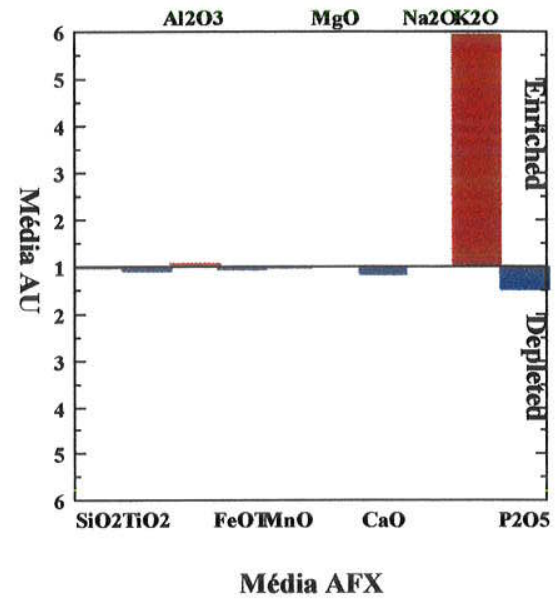

Figura 3.28: Diagrama de ganhos e perdas de elementos maiores: a) na amostra $1^{*}$ b em relação a $1^{*}$; b) na média dos AFX (xistos com anfibólio e flogopita) em relação à média dos AU (anfibolitos nao metassomatizados). 


\begin{tabular}{|c|c|c|c|c|c|c|c|c|c|c|}
\hline & $\mathbf{R b}$ & $\mathbf{B a}$ & $\mathbf{Z r}$ & $\mathbf{Y}$ & $\mathrm{Cr}$ & $\mathbf{N i}$ & $\mathbf{V}$ & $\mathrm{Cu}$ & $\mathbf{Z n}$ & Be \\
\hline NE-29b & \multicolumn{10}{|c|}{ ROCHA ORIGINAL } \\
\hline NE-8 & 4.38 & 3.68 & 2.50 & 6.08 & 0.01 & 1.13 & 1.81 & 1.57 & 1.51 & - \\
\hline NE-10 & 5.08 & 3.84 & 2.20 & 6.12 & 1.15 & 1.11 & 1.90 & 3.14 & 1.46 & - \\
\hline $\mathrm{NE}-29 \mathrm{~b}(1)$ & \multicolumn{10}{|c|}{ ROCHA ORIGINAL } \\
\hline $\mathrm{NE}-8(1)$ & - & 1.70 & 1.00 & 2.8 & 1.08 & 1.04 & 1.79 & 1.00 & 1.41 & 4.00 \\
\hline NE-7(1) & - & 2.10 & 1.28 & 4.00 & 1.07 & 1.05 & 2.02 & 1.00 & 1.49 & 4.00 \\
\hline $\mathrm{I}-02 \mathrm{a}$ & \multicolumn{10}{|c|}{ ROCHA ORIGINAL } \\
\hline $\mathrm{I}-02$ & 2.50 & - & - & - & 1.17 & 0.96 & 1.81 & - & 0.94 & - \\
\hline $\mathrm{I}-03$ & 19.00 & - & - & - & 0.90 & 0.22 & 1.71 & - & 0.95 & - \\
\hline A-13 & \multicolumn{10}{|c|}{ ROCHA ORIGINAL } \\
\hline $\mathrm{A}-08$ & 24.50 & 1.41 & - & 2.38 & 0.31 & 1.26 & 0.61 & - & 1.13 & - \\
\hline A-7a & 5.80 & 1.46 & - & 3.00 & 0.28 & 1.14 & 0.71 & - & 0.92 & - \\
\hline G-52e & \multicolumn{10}{|c|}{ ROCHA ORIGINAL } \\
\hline G-52g & - & 0.50 & 1.00 & 1.11 & 2.17 & 0.75 & 1.32 & 1.00 & 0.59 & 1.73 \\
\hline G-52f & - & 0.38 & 1.00 & 0.78 & 2.74 & 1.35 & 1.37 & 1.00 & 1.05 & 6.47 \\
\hline $1^{*}$ & \multicolumn{10}{|c|}{ ROCHA ORIGINAL } \\
\hline $1 * a$ & 0.05 & - & - & 0.44 & 0.87 & 0.76 & 1.36 & 0.07 & 1.08 & - \\
\hline $1 * b$ & 63.88 & - & - & 0.01 & 0.16 & 1.38 & 0.83 & 0.73 & 0.40 & - \\
\hline
\end{tabular}

Tabela 3.4: Ganhos (valores $>1$ ) e perdas (valores $<1$ ) de elementos menores e traço em séries selecionadas de transformação metassomática progressiva. 


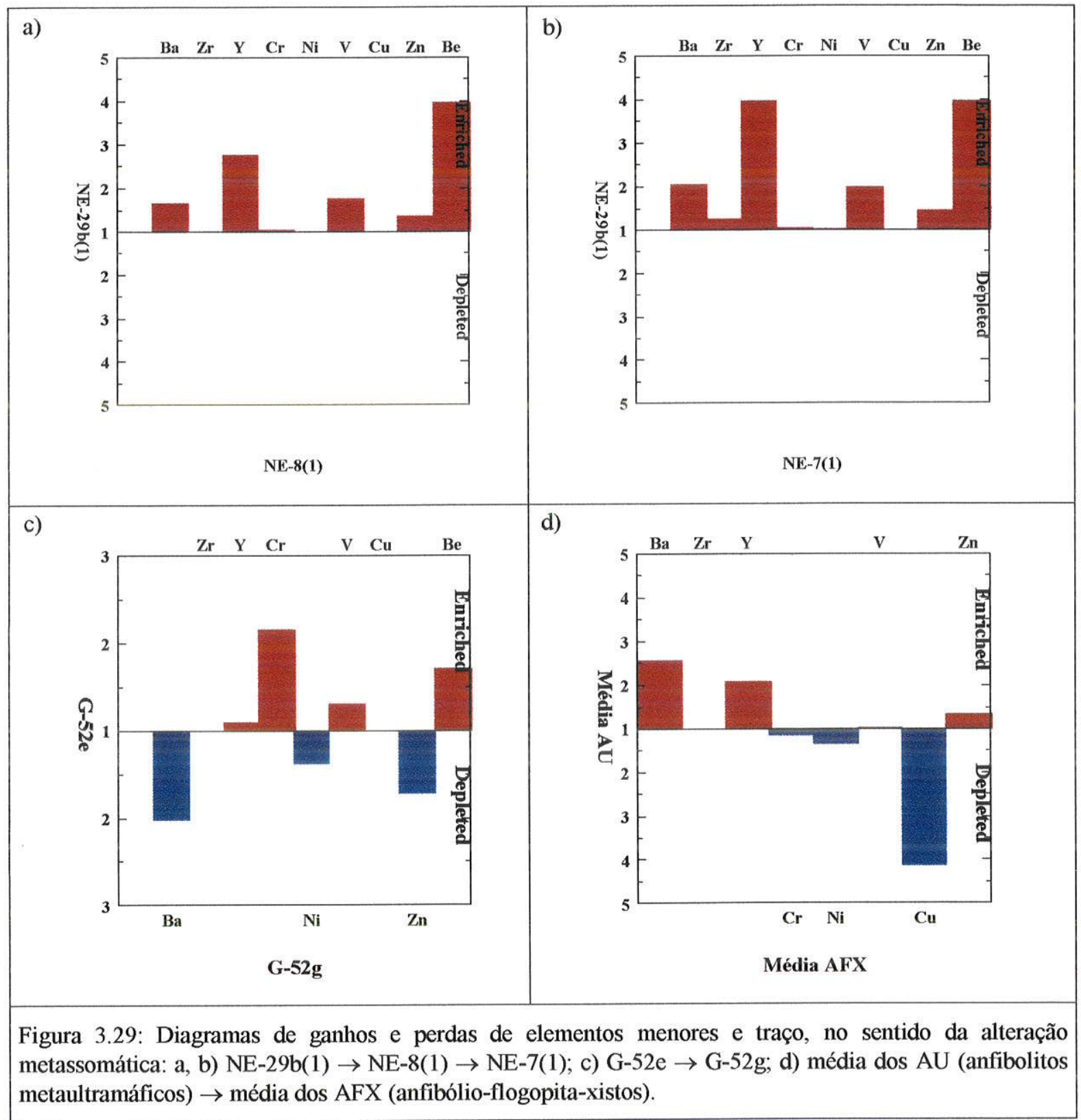

Os diagramas de ganhos e perdas dos elementos maiores, tanto nas séries individuais, quanto nas composições médias das amostras modificadas em relação às não modificadas, confirmam os enriquecimentos sistemáticos em $\mathrm{K}_{2} \mathrm{O}$ e $\mathrm{Al}_{2} \mathrm{O}_{3}$ indicativos da flogopitização. Já para os elementos menores e traço, exemplificados apenas em três séries individuais e pelas médias nas amostras transformadas em relação às não transformadas, são confirmados os enriquecimentos de $\mathrm{Rb}, \mathrm{Ba}, \mathrm{Y}$ e $\mathrm{Be}$, sugerindo ainda, o empobrecimento de $\mathrm{Cu}$. Todos os demais elementos menores e traço apresentam variações pequenas e irregulares. 


\section{III.5 - ANFIBOLITOS METABÁSICOS E GNAISSES DE COMPOSIÇÃO INTERMEDIÁRIA (DA SVS)}

$O$ acervo de dados inclui um total de 33 análises de: 1) anfibolitos metabásicos (AB); anfibolitos metabásicos com epitodo e titanita (ABET); anfibolitos metabásicos com granada (ABG); gnaisses com biotita, granada e, eventualmente, anfibólio ( $\mathrm{Gn} / \mathrm{bag}$ ); anfibolitos calciossilicáticos (AC); anfibolitos de formações ferríferas (AFF); e anfibolitos tectonicamente intercalados em TTG (AB/TTG) fortemente milonitizados, em contato com a SVS. O resultado destas análises encontram-se no Anexo 2 (Tab. A2.5), onde a razão $\mathrm{Fe}_{2} \mathrm{O}_{3} / \mathrm{FeO}$ foi calculada com o valor de 0.20 (Middlemost, 1989).

\section{* Elementos Maiores}

Em diagramas de classificação de rochas ígneas, foram representados, apenas, os anfibolitos do tipo $\mathrm{AB}, \mathrm{ABET}$ e $\mathrm{ABG}$ (derivados de vulcanitos máficos/básicos), $\mathrm{Gn} / \mathrm{bag}$ (possíveis metavulcanitos intermediários) e, para comparação, três análises de AB/TTG (anfibolitos intercalados em TTG).

No diagrama TAS (Le Maitre, 1989), estas rochas apresentam composições de basaltos, andesitos basálticos, traquiandesito basáltico (amostra G-37b de ABG), andesito (amostra C-1a de ABG) e dacitos (Gn/bag) (Fig. 3.30).

A filiação magmática dos anfibolitos metabásicos já foi definida como subalcalina por Machado (1994) e é, a presente, confirmada para os demais anfibolitos e gnaisses, com exceção de uma única amostra de $\mathrm{ABG}$ (G-37b), com características alcalinas (Fig. 3.31a). Os anfibolitos, em geral, seguem o trend de diferenciação toleítica, ao contrário dos gnaisses (Gn/bag) e da amostra G-37b de ABG que tendem para diferenciação cálcio-alcalina (Fig. 3.31b). 


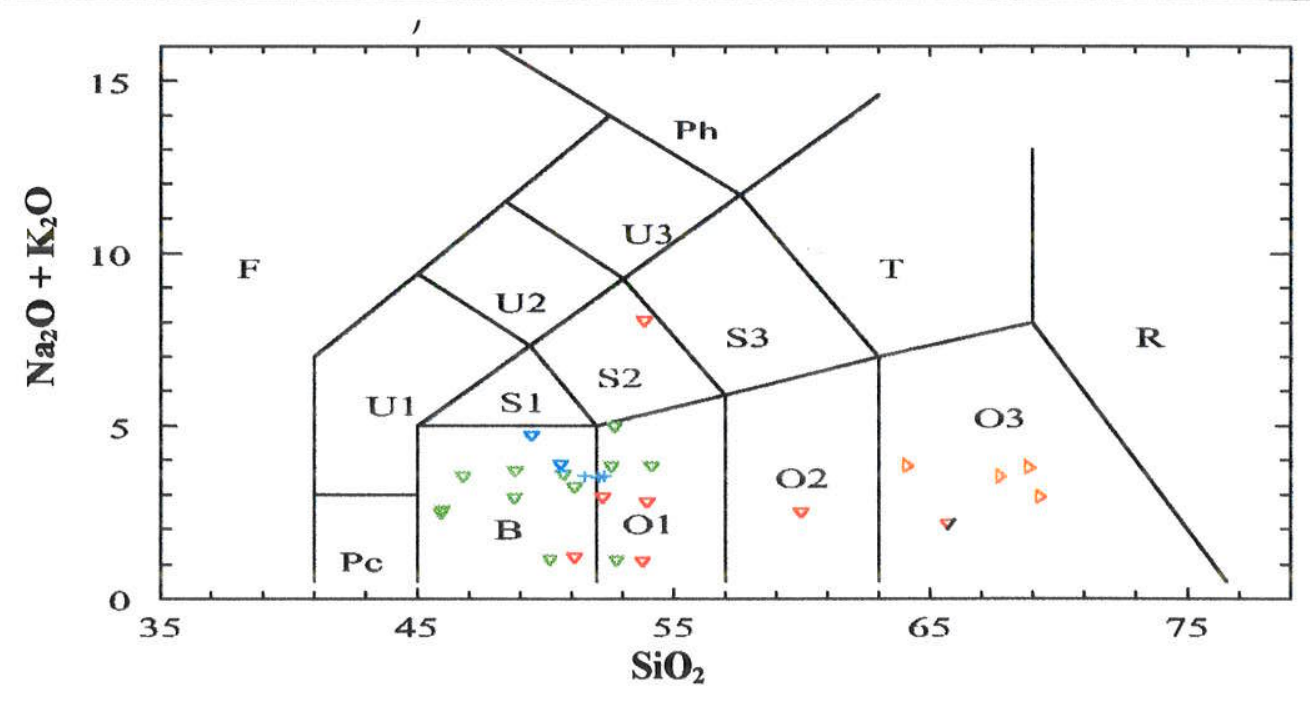

Figura 3.30: Anfibolitos e gnaisses de composição básica a intermediária, da SVS, no diagrama TAS (Le Maitre, 1989). Símbolos: AB ( $\nabla)$; ABET ( $\nabla) ; \operatorname{ABG}(\nabla) ; \mathrm{Gn} / \mathrm{bag}(\triangleright)$ e AB/TTG (+).

a)

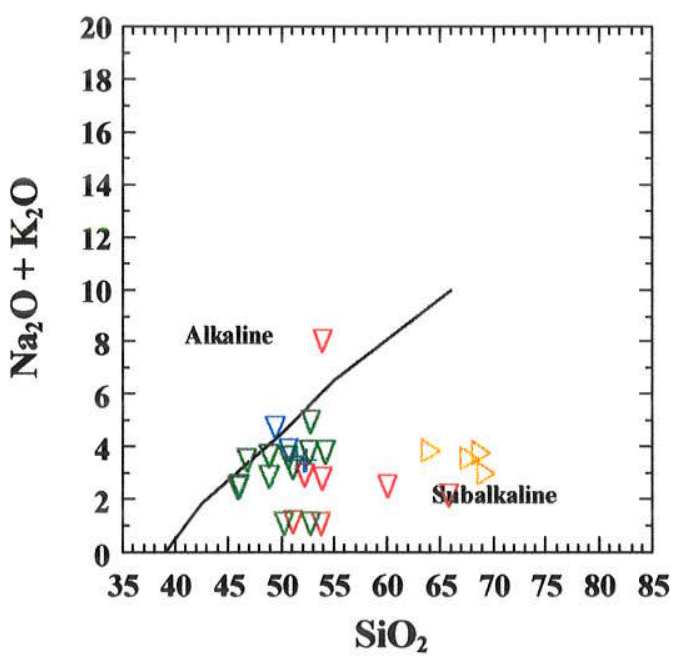

b)

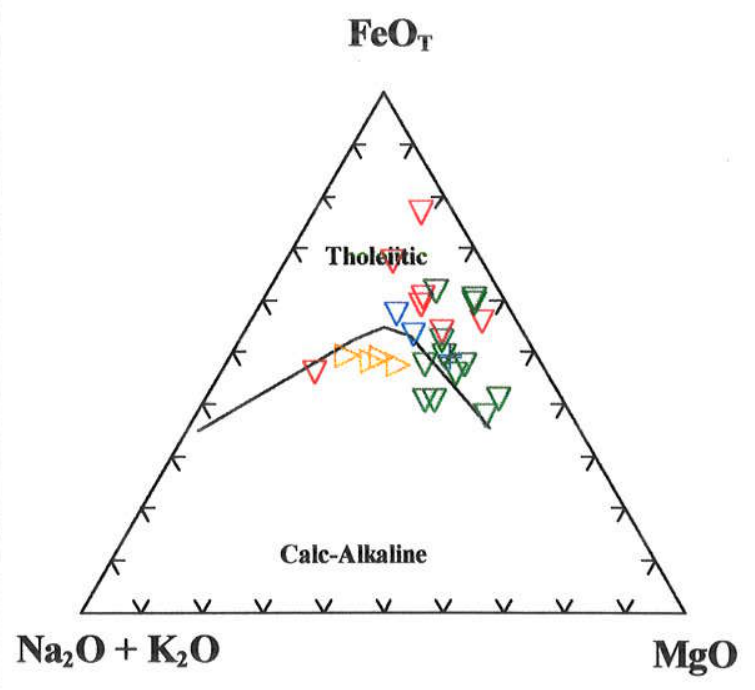

Figura 3.31: As mesmas rochas da figura anterior, nos diagramas de Irvine \& Baragar (1971): (a) apresentam características subalcalinas; e (b) separam-se nos caminhos de diferenciação toleítica e cálcio-alcalina.

Os valores de $\mathrm{MgO}$ para todo o acervo analítico, incluindo anfibolitos de formações ferríferas (FF) e anfibolitos cálciossilicáticos (AC), situam-se entre 1 e $11 \%$ em peso, o que sugere, pelo menos para os anfibolitos metaígneos, um fracionamento significativo. Essas tendências foram estudadas em diagramas binários Óxidos versus $\mathrm{FeO}_{\mathrm{T}} / \mathrm{FeO}_{\mathrm{T}}+\mathrm{MgO}(\# \mathrm{FeO})$ (Fig. 3.32). 


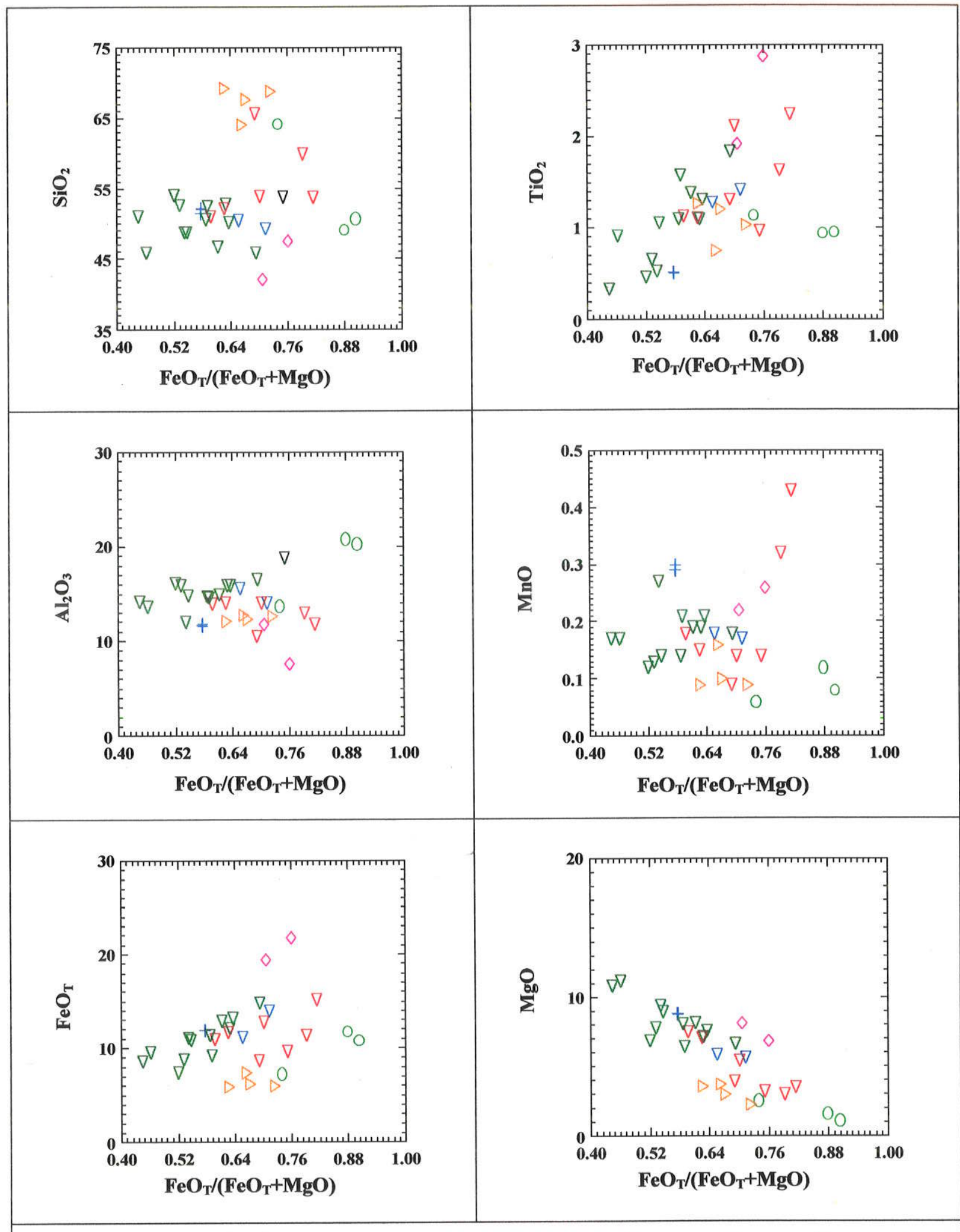

Figura 3.32 (a): Diagramas Óxidos vs $\mathrm{FeO}_{\mathrm{T}} /\left(\mathrm{FeO}_{\mathrm{T}}+\mathrm{MgO}\right)$ para os $\mathrm{AB}(\nabla)$, $\operatorname{ABET}(\nabla), \operatorname{ABG}(\nabla)$, $\operatorname{AFF}(\diamond), \mathrm{AC}$ $(\mathrm{O}), \mathrm{Gn} / \mathrm{bag}(\triangleright), \mathrm{AB} / \mathrm{TTG}(+)$. 


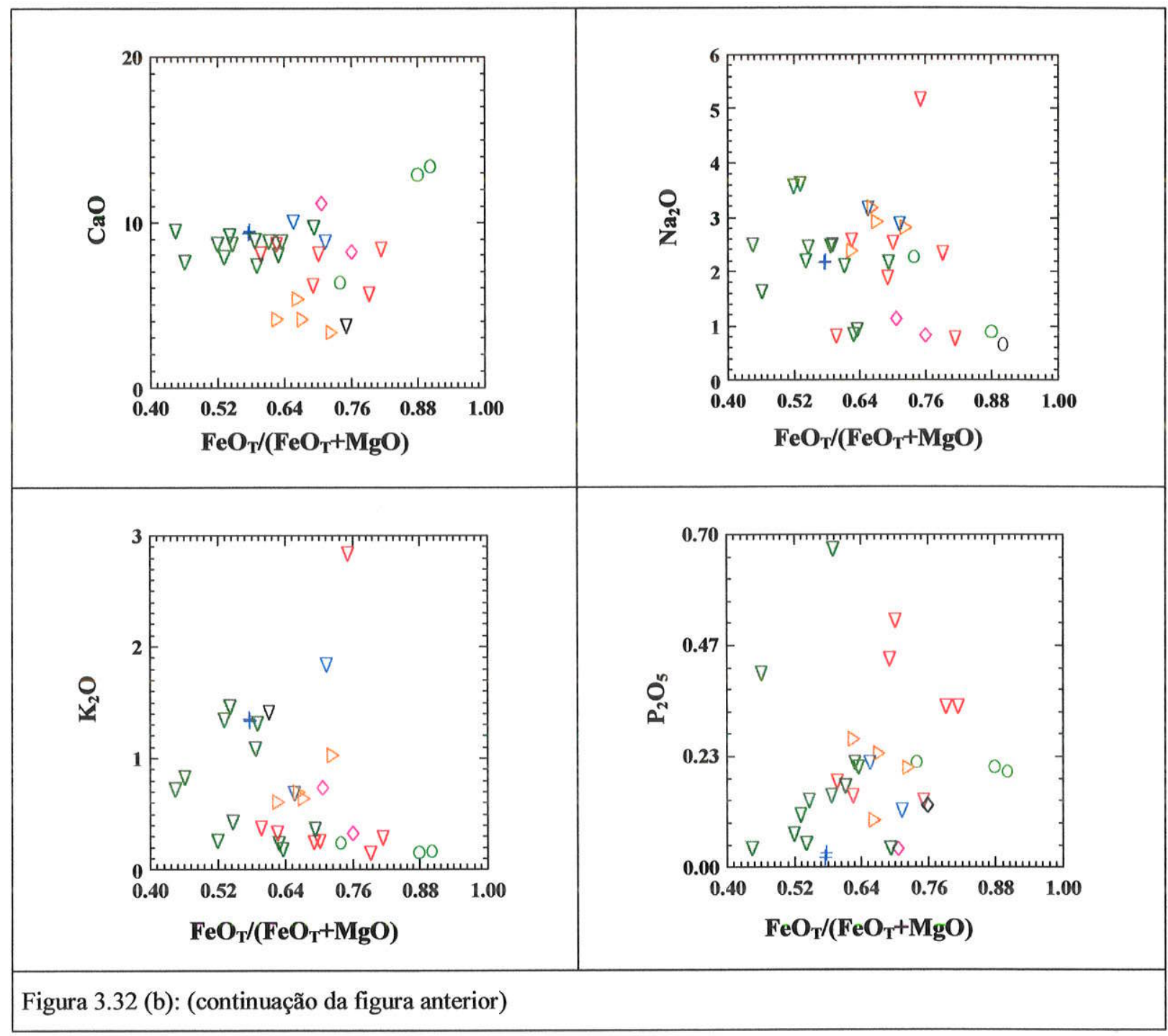

Para as rochas de derivação ígnea, observam-se nos $\mathrm{AB}$ e $\mathrm{ABET}$ teores mais baixos de $\mathrm{SiO}_{2}$, constantes ou levemente decrescentes com o aumento do \#FeO. Já os $\mathrm{ABG}$ e os $\mathrm{Gn} / \mathrm{bag}$ apresentam teores, respectivamente, intermediários e mais altos de $\mathrm{SiO}_{2}$ de evolução progressiva, independentemente de variações maiores de \#FeO. Outros elementos que, analogamente, apresentam evoluções distintas para essas rochas são o $\mathrm{MnO}, \mathrm{CaO}, \mathrm{Na}_{2} \mathrm{O}$ e $\mathrm{P}_{2} \mathrm{O}_{5}$. Dentre estes, o valor mais alto de $\mathrm{Na}_{2} \mathrm{O}$ que ocorre em um ABG (amostra G-37b), indica tratar-se, eventualmente, de processos de espilitização decorrentes de alterações pósmagmáticas (de fundo oceânico) pré-metamórficas. $\mathrm{CaO}, \mathrm{MnO}$ e $\mathrm{P}_{2} \mathrm{O}_{5}$ sobrepõem-se, parcialmente; no entanto, indicam as características próprias dos $\mathrm{AB}$ e $\mathrm{ABET}$, por um lado, e dos $\mathrm{ABG}$ e $\mathrm{Gn} /$ bag por outro. 
Os elementos $\mathrm{TiO}_{2}, \mathrm{Al}_{2} \mathrm{O}_{3}, \mathrm{MgO}$ e $\mathrm{K}_{2} \mathrm{O}$ indicam evolução contínua dos $\mathrm{AB}, \mathrm{ABET}$ (com exceção da amostra G-37a, quanto ao $\mathrm{K}_{2} \mathrm{O}$ ) e dos $\mathrm{ABG}$, neste sentido, com constância de $\mathrm{Al}_{2} \mathrm{O}_{3}$, correlação positiva de $\mathrm{TiO}_{2}$ e $\mathrm{FeO}$ e negativa do $\mathrm{MgO}$ em relação ao \# FeO. Já os Gn/bag situam-se à parte, indicando, eventualmente, sua natureza de derivação cálcioalcalina.

Os anfibolitos de formação ferrífera (AFF) e cálciossilicáticos (AC), em quase todos os diagramas, destacam-se em grupos específicos, não relacionados com as tendências dos anfibolitos metaígneos.

Por fim, menciona-se, ainda, a muito boa inserção dos anfibolitos AB/TTG, conjuntamente com os $\mathrm{AB}$ e $\mathrm{ABET}$, o que pode indicar que, nos casos analisados, tratam-se, de fato, de rochas anfibolíticas metaígneas em diques milonitizados ou corpos tectonicamente disruptos da SVS em gnaisses TTG.

\section{* Elementos Traço}

Dos elementos menores e traço analisados, foram escolhidos para representação em diagramas de correlação com \#FeO e discussão petrogenética $\mathrm{Zr}, \mathrm{Y}, \mathrm{Cr}, \mathrm{Ni}, \mathrm{V}$ e $\mathrm{Th}$ (Fig. 3.33). De um modo geral, observam-se o empobrecimento de $\mathrm{Cr}$ e $\mathrm{Ni}$ e o enriquecimento de $\mathrm{Zr}$, V e Th nos anfibolitos metaígneos. O Y, apesar de não apresentar uma correlação bem definida, exibe uma tendência de enriquecimento com o aumento de \#FeO.

Analogamente às considerações dos elementos maiores, observam-se comportamentos similares e de evolução contínua dos $\mathrm{AB}$ e $\mathrm{ABET}$, incluindo os $\mathrm{AB} / \mathrm{TTG}$, para os $\mathrm{ABG}$, representando a evolução das rochas toléticas da SVS. Os Gn/bag apresentam-se em grupos, em geral, próximos, mas individualizados em relação às rochas anfibolíticas toleiticas, o que é melhor observado nos casos do $\mathrm{Zr}$, $\mathrm{Cr}$ e $\mathrm{Ni}$.

Apesar do restrito número de análises, também, os AC e AFF caracterizam grupos com comportamentos distintos das rochas metaígneas (Fig. 3.33). 


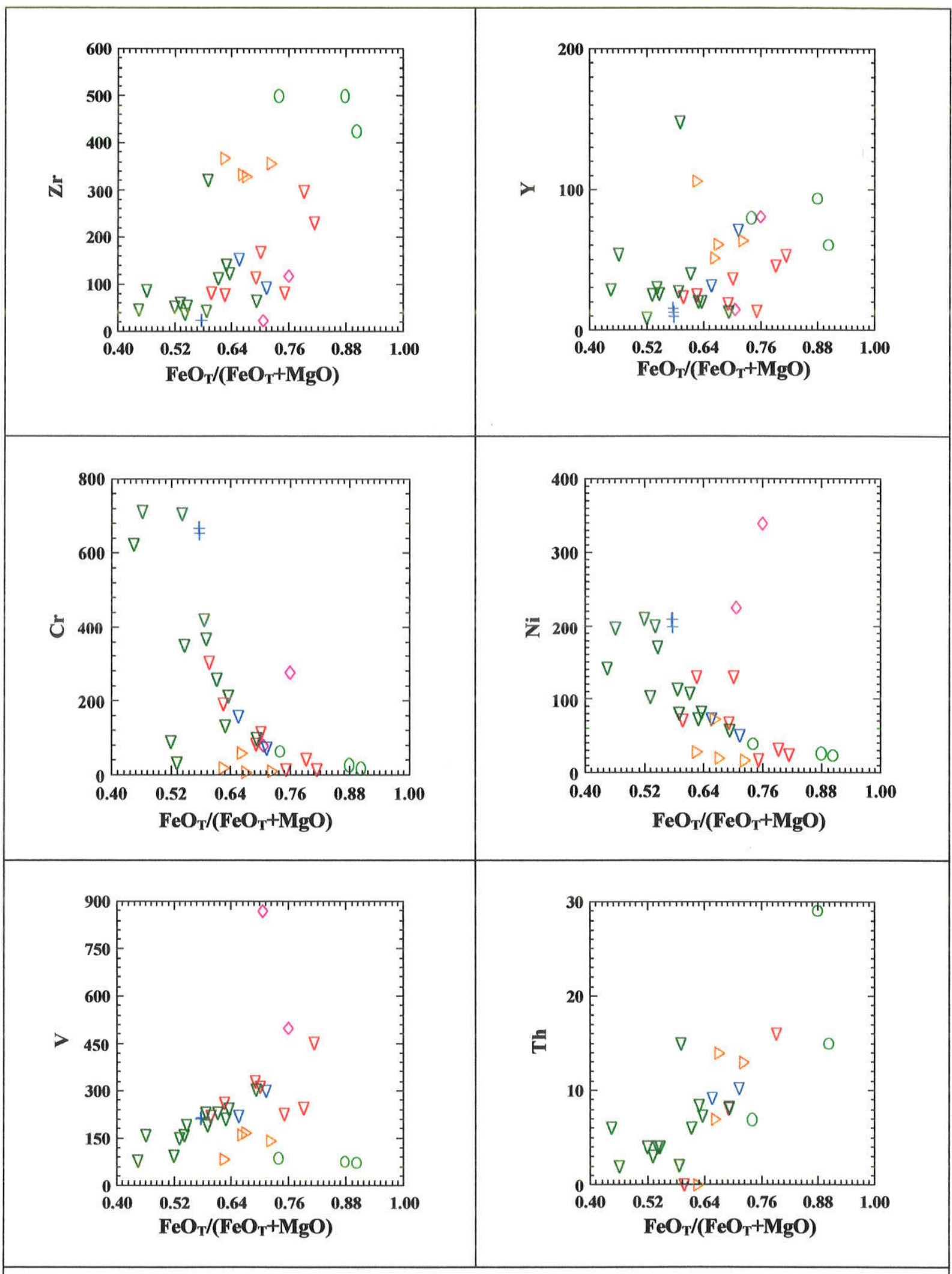

Figura 3.33: Diagramas de correlação Elementos Traço vs $\mathrm{FeO}_{\mathrm{T}} /\left(\mathrm{FeO}_{\mathrm{T}}+\mathrm{MgO}\right)$. Símbolos: $\mathrm{AB}(\nabla), \mathrm{AB} / \mathrm{TTG}$ $(+), \operatorname{ABET}(\nabla), \operatorname{ABG}(\nabla), \operatorname{AFF}(\bullet), \operatorname{AC}(O)$ e $\mathrm{Gn} /$ bag $(\triangleright)$. 
Destacam-se, ainda, os teores mais elevados de:

- $\mathrm{Zr}(426-502 \mathrm{ppm}), \mathrm{Sr}(457-715 \mathrm{ppm})$ e Ga (46-61 ppm) em AC (amostras NE-23a,b,c);

- $\mathrm{Rb}(327 \mathrm{ppm})$ e $\mathrm{Pb}$ (72 e 86 ppm) em ABET (amostras G-37a e G-56);

- $\mathrm{Nb}(67 \mathrm{ppm})$ e $\mathrm{Y}$ (148 ppm) em AB (amostra NE-26);

- V (872 ppm), Ni (339 ppm), Cu (279 ppm) e La (229 ppm) em AFF (amostras G$231 c$ e G-250a);

- Cr (622 a 712 ppm) em AB (amostras BT-03, HC-03 e A-7b) e em AB/TTG (amostra G-168a).

$\mathrm{O}$ acervo de dados químicos indica teores de $\mathrm{Be}<5$ ppm (Anexo 2, Tab. A2.5). Para Wedepohl (1969), rochas básicas e intermediárias têm, respectivamente, $<2.6$ e $<3.9$ ppm de Be.

Os anfibolitos e os gnaisses básicos a intermediários são importantes para a caracterização da evolução magmática e, em geral, lito-estratigráfica e estrutural da SVS, contribuindo na sua identificação como de tipo greenstone belt arqueano. Possíveis relações e potencialidades metalogenéticas são indicadas pela presença de scheelita em anfibolitos e sulfetos em anfibolitos e gnaisses (Machado, 1994). Entretanto, não foram encontrados quaisquer indícios de relações diretas com as mineralizações de esmeraldas e, em geral, berilíferas. 


\section{CAPÍTULO IV - QUÍMICA MINERAL}

\section{IV.1 - INTRODUÇÃO}

As análises de minerais dos litotipos principais e das mineralizações de berilos/esmeraldas da região de estudo objetivaram a caracterização das fases presentes e, principalmente, das reações metamórficas e metassomáticas-mineralizantes, considerando as condições de temperatura e pressão dos eventos atuantes.

Foram realizadas análises pontuais quantitativas por MSE de centros e bordas em todas as fases minerais, onde se procurou investigar zoneamentos químicos e cristais em situações texturais diversas. As variações observadas em grãos individuais foram, em geral, muito pequenas. Cabe ressaltar que nos dados brutos todo o ferro foi calculado como $\mathrm{Fe}^{+2}$. Para o tratamento computacional e modelagem de todos os dados de química mineral foi utilizado o programa Minpet 2.0 (Richard, 1995) (Anexo 4).

Foram analisados:

A) minerais constituintes das rochas graníticas (GB, MGF e TTG) e das rochas da SVS (metaultramáficas, metabásicas e metapelíticas): biotitas, anfibólios (verdes e incolores), granadas, plagioclásios, K-feldspatos, estaurolitas, cordieritas, cloritas, muscovitas, epidotos, titanitas, cianita, magnetitas, ilmenitas, rutilos e cromitas; e

B) minerais das mineralizações: esmeraldas, anfibólios (verdes e incolores), plagioclásios, biotitas, cloritas, talcos, cromitas e apatitas.

Adicionalmente e para complementar as informações de MSE com dados de elementos menores e traço, foram realizadas apenas em esmeraldas e águas marinhas análises por FRX e ICP-MS em fragmentos de cristais individuais.

Os resultados são apresentados a seguir. 


\section{IV.2 - BIOTITAS}

O grupo das micas escuras é composto por minerais com fórmula geral $\mathrm{X}_{2} \mathrm{Y}_{6} \mathrm{Z}_{8} \mathrm{O}_{20}(\mathrm{OH}, \mathrm{F})_{4}$, onde: $\mathrm{X}=\mathrm{K}, \mathrm{Y}=\mathrm{Fe}, \mathrm{Mg}$ e subordinadamente, $\mathrm{Al}$, Ti e $\mathrm{Mn}$, e $\mathrm{Z}=\mathrm{Si}$ e $\mathrm{Al}$ (Deer et al.1962).

A ocupação da posição $Y$ por 6 cátions diferenciam-nas das micas claras e permite classificá-las como micas trioctaédricas. $O$ grupo das micas trioctaédricas pode ser representado em termos de quatro membros finais - anita, siderofilita, flogopita e eastonita sendo a biotita, o tipo mais comum, uma mica com composição intermediária entre os termos puros.

Foram realizadas 186 análises de biotitas de rochas graníticas e da sequência mevulcano-sedimentar (SVS) (Tab. 4.1) e, ainda, consideradas 09 análises da amostra 286 (Schorscher, 1975) de um xisto/gnaisse metapelítico, da porção centro-norte da área, cujo protólito sofreu alteração hidrotermal pré-metamórfica.

\begin{tabular}{|c|c|}
\hline Litotipos & Amostras \\
\hline MG (2) & Cap-3 \\
\hline MP (30) & AP-2; AP-3; \\
& G-52c; G-85a; G-89 \\
\hline ABG (17) & I-01 \\
\hline ABET (14) & G-37a; G-56 \\
\hline AB (10) & Cap-4; HC-3a \\
\hline & $\begin{array}{c}\text { *; BE-06; BE-08; Cap-5; } \\
\text { UM (49) }\end{array}$ \\
& NE-3; NE-12; NE-30; NE- \\
& NE-31-06; Sul 01 \\
\hline PGD não mineralizado da & Astro 01; M-5 \\
\hline SVS (04) & G-2a; G-2b; G-3a; \\
\hline MGF (33) & G-68; G-11a \\
\hline GB (23) & 03; G-26; G-29c; \\
\hline GTG (04) & G-29d; G-113; G-166b \\
\hline
\end{tabular}

Tabela 4.1: Litotipos com análises de biotitas. Símbolos: TTG = gnaisses da associação TTG; $\mathrm{GB}=$ Metagranitóides Borrachudos; $M G F=$ Metagranitóides Foliados com Fluorita; PGD = pegmatóide; UM = metaultramáficas; $\mathrm{AB}=$ anfibolitos metabásicos; $\mathrm{ABET}=$ anfibolitos metab́ásicos com epidoto e titanita; $\mathrm{ABG}=$ anfibolitos metabásicos com granada; $\mathrm{MP}=$ metapelitos; $\mathrm{MG}=$ metagrauvaca da $\mathrm{SVS} ;(\mathrm{n})=$ número de análises.

Procurou-se caracterizar biotitas de metamorfismo regional (isoquímico) visando cálculos geotermobarométricos e biotitas das mineralizações (metamórfico-metassomáticas) de modo a caracterizar os processos metassomático-mineralizantes indicados pela petrografia. 
A fórmula estrutural da biotita foi recalculada considerando todo o ferro como $\mathrm{Fe}^{+2} \mathrm{e}$ admitindo-se 24(O+OH+F) (cf.: Deer et al., 1962) (Anexo 4, Tab. A4.1).

As biotitas definem grupos distintos segundo os tipos litológicos; porém, dentro destes grupos ocorrem, ainda, variações, principalmente, de $\mathrm{Al}^{\mathrm{IV}}$ :

1 - Rochas Graníticas ( Fig. 4.1a):

* GB: anita;

* MGF: mica intermediária entre anita e siderofilita;

* TTG: mica intermediária entre flogopita e anita;

* Pegmatóides (PGD) não mineralizados da SVS; distinguindo-se dois sub-grupos:

a) pegmatóides graníticos (PGDGr) com mica intermediária entre flogopita e anita;

b) pegmatóides peralumínicos (PGDAl) com córindon e cianita, cuja mica apresenta composição intermediária entre flogopita e eastonita;

2 - Rochas Metaultramáficas Metassomatizadas (Fig. 4.1b):

* Mica com composição da flogopita;

3 - Anfibolitos Metabásicos (Fig. 4.1c):

* AB, ABET e ABG: mica com teores variáveis de $\mathrm{Al}^{\mathrm{IV}}$ e constantes de \#Fe $\mathrm{Fe}^{+2}$ composições intermediárias entre flogopita-anita até eastonita-siderofilita;

4 - Rochas Metapelíticas (Fig. 4.1d): as variações composicionais estão relacionadas à variação na composição dos protólitos e, ainda, à distribuição das amostras na área, ou seja:

* na porção central e centro-norte da área (amostras: G-85a; e 286 - Schorscher, 1975), a mica tem composição flogopítica, com teores de $\mathrm{Fe}^{+2}$ puco variáveis; trata-se nos dois casos de protólitos magnesianos de alteração hidrotermal premetamórfica;

* no garimpo de Capoeirana, no leste da área, a mica varia mais amplamente na transição dos campos entre biotita e flogopita (amostras AP-2, AP-3, G-52c), sendo metapelitos máficos ferromagnesianos da parte basal da SVS;

* no garimpo de Capoeirana do Meio, no centro-leste da área, a mica apresenta teores mais elevados de $\mathrm{Al}^{\mathrm{IV}}$ e de $\# \mathrm{Fe}^{+2}$, sendo biotita com composição intermediária entre os quatro membros finais (amostra G-89), indicando maior contribuição terrígena no protólito. 
5 - Metagrauvaca (Fig. 4.1d):

* Mica cuja composição figura na transição dos campos da biotita e flogopita; foi representada conjuntamente com a mica dos metapelitos (amostra Cap-3; Anexo 4, Tab. A4.1).

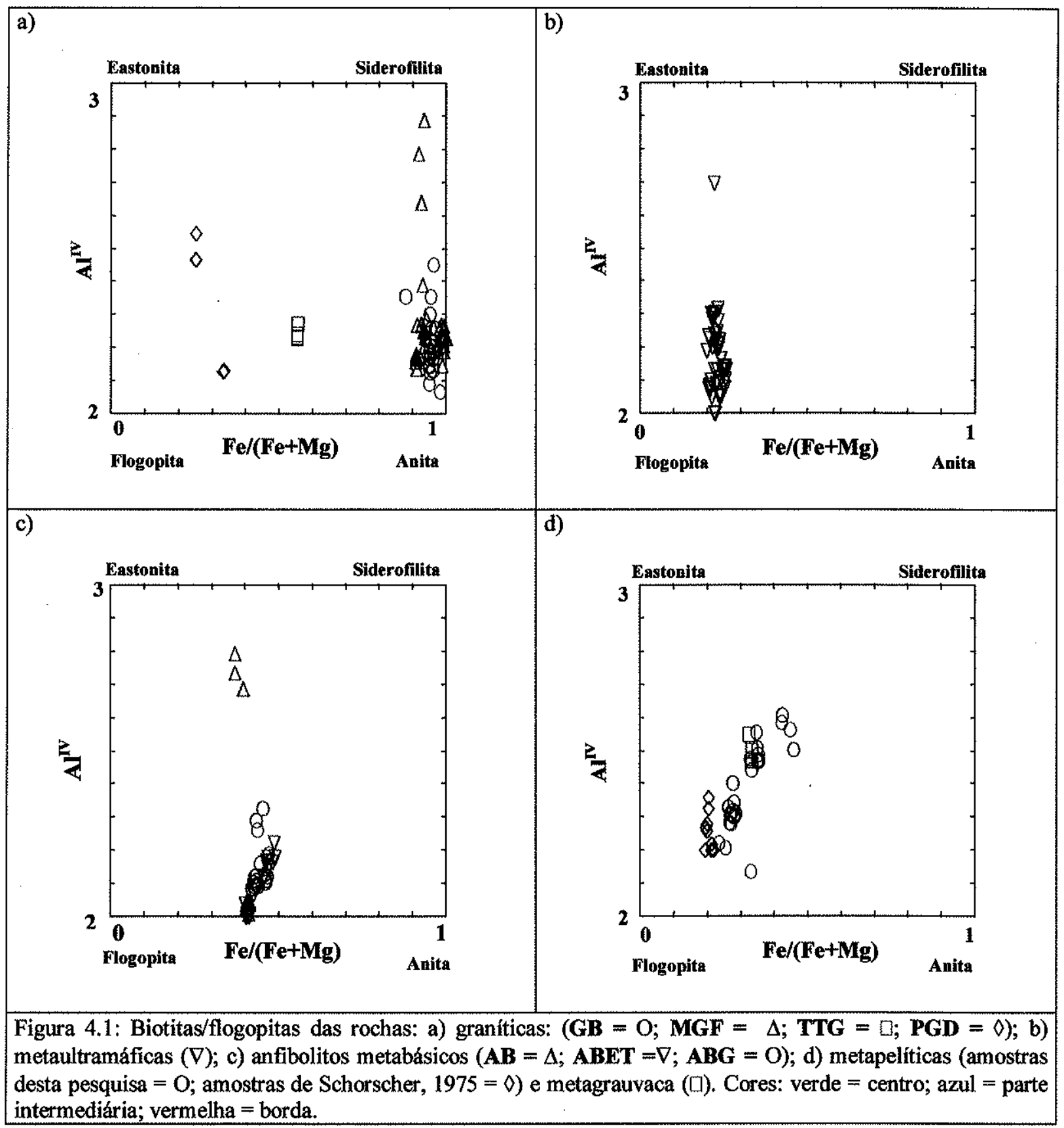


Para melhor elucidar as relações de substituição, foram elaborados diagramas de correlação de $\mathrm{Fe}^{+2}$ versus $\mathrm{Al}^{\mathrm{VI}}$, $\mathrm{Al}^{\mathrm{IV}}$ e $\mathrm{Mg}$ (Fig. 4.2 a 4.4).

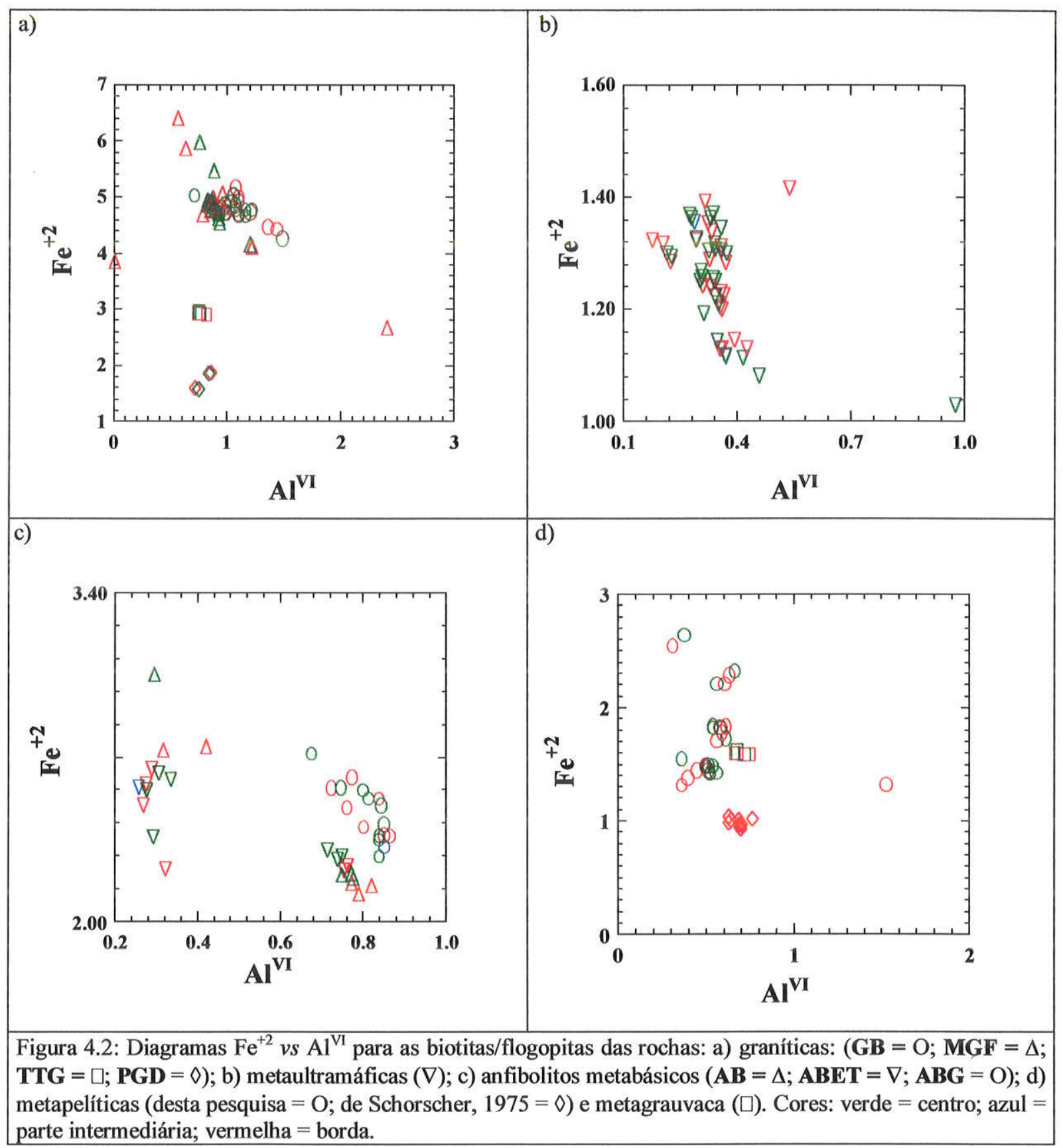

Nos diagramas da Figura 4.2, observa-se uma clara correlação negativa entre $\mathrm{Fe}^{+2}$ e $\mathrm{Al}^{\mathrm{VI}}$ nas biotitas/flogopitas de todos os tipos litológicos, com exceção dos pegmatóides (Fig. 4.2a) e dos metapelitos (Fig. 4.2d) que apresentam ou correlações positivas ou constância de $\mathrm{Fe}^{+2}$. De um modo geral, $\mathrm{Al}^{\mathrm{VI}}$ aumenta de centros para bordas, mas esta variação não é sistemática nas amostras de um mesmo grupo, da mesma forma que não é sistemática a variação de $\mathrm{Fe}^{+2}$. 


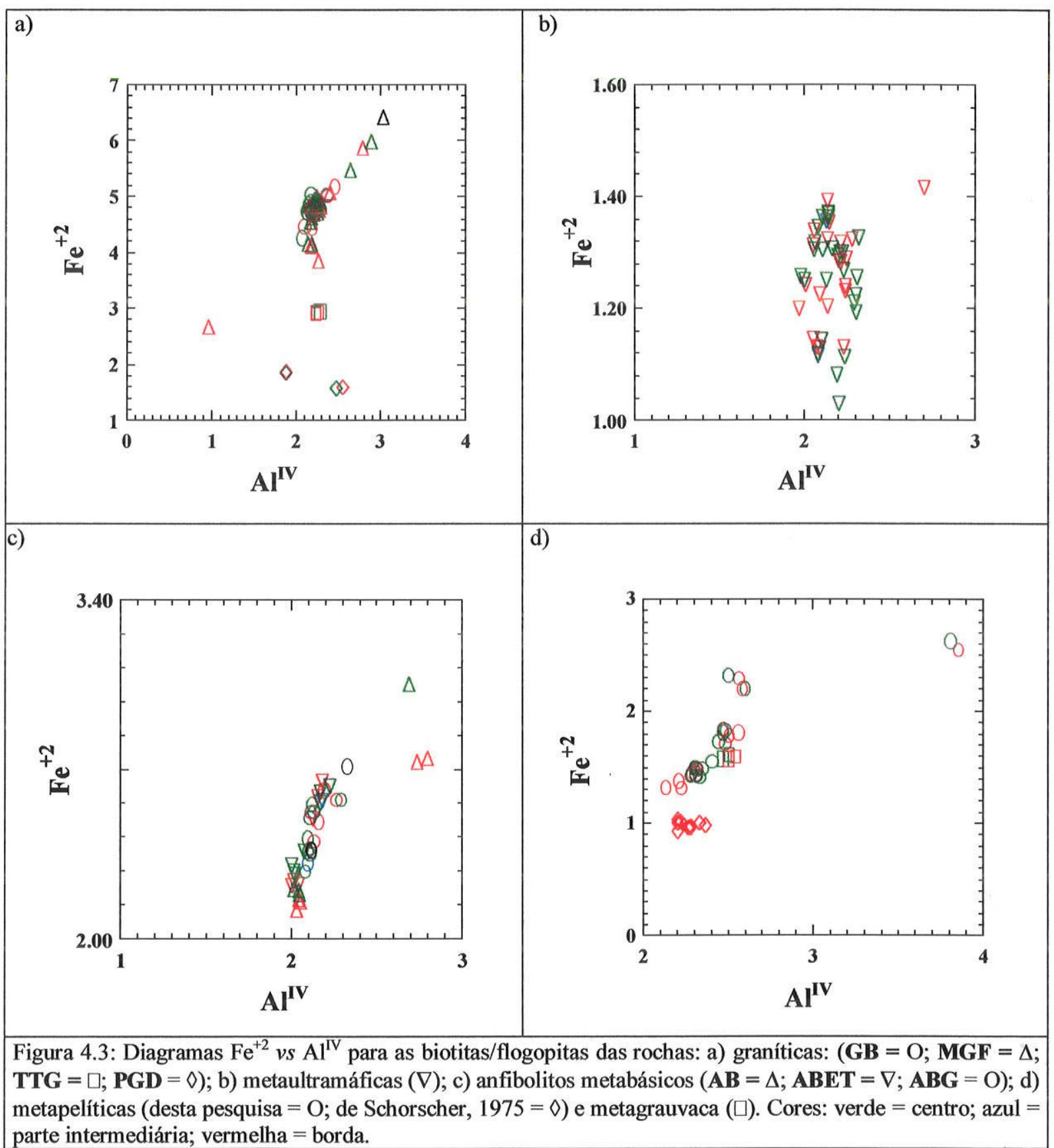

Quanto a relação de $\mathrm{Fe}^{+2}$ e $\mathrm{Al}^{\mathrm{IV}}$, observa-se uma clara correlação positiva nas biotitas dos GB e MGF, com exceção das biotitas com os valores mais baixos de $\mathrm{Fe}^{+2}(<4.6$ átomos/fórmula unitária) (Fig. 4.3a). Para os anfibolitos metabásicos e os metapelitos, esta correlação é também positiva (Fig. 4.3c e 4.3d). Já nas biotitas das rochas metaultramáficas a variação de $\mathrm{Fe}^{+2}$ ocorre com $\mathrm{Al}^{\mathrm{IV}}$ constante (Fig. $4.3 \mathrm{~b}$ ). 


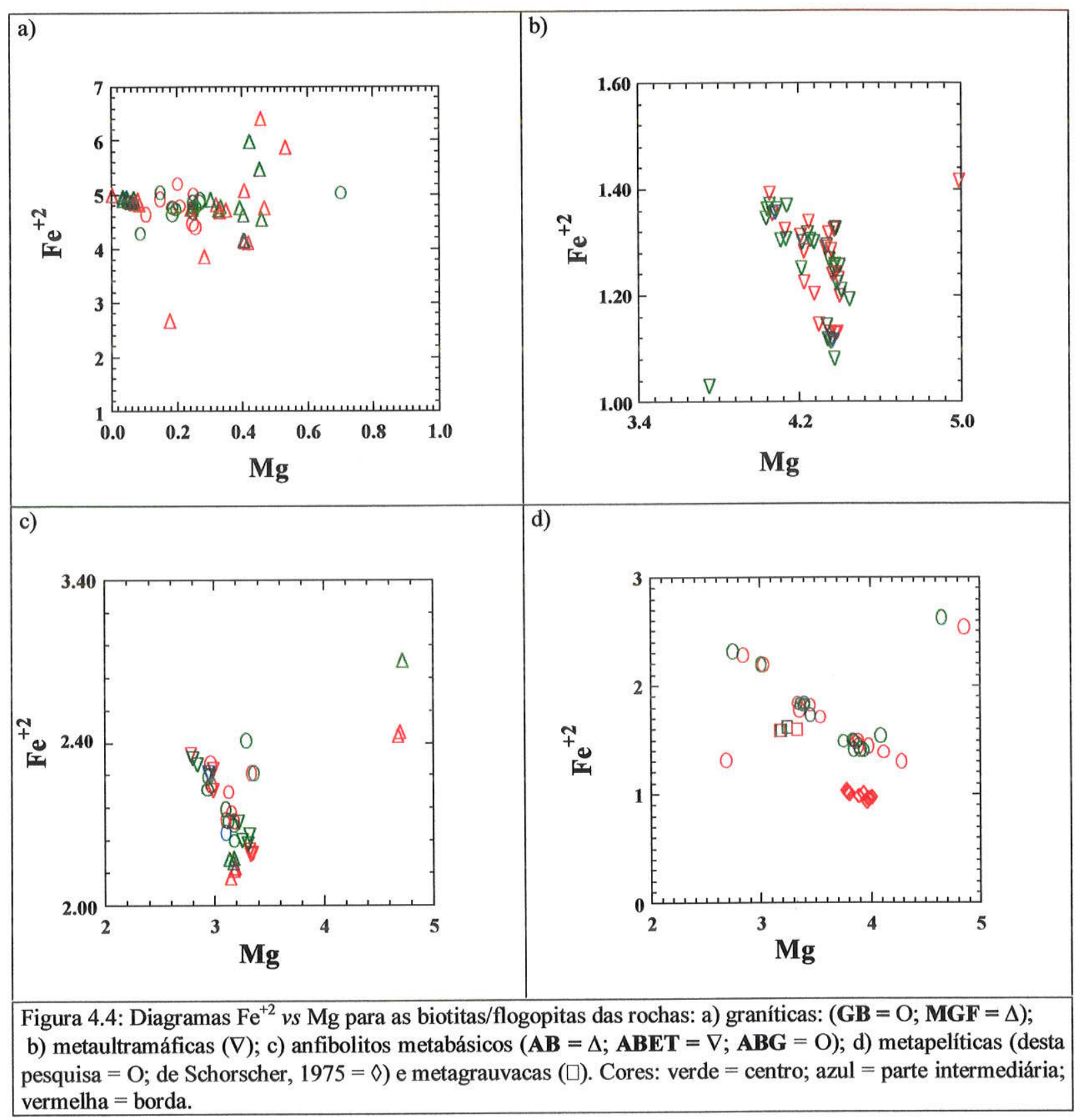

A correlação entre $\mathrm{Fe}^{+2}$ e Mg é complexa nos GB e MGF (Fig. 4.4a), notando-se padrões que podem ser tratados em dois grupamentos: o primeiro, com mais ampla variação de $\mathrm{Mg}$ e com $\mathrm{Fe}^{+2}$ essencialmente constante (de 4 a 5 átomos/fórmula unitária), comprende GB e MGF; o segundo, com correlação positiva de $\mathrm{Mg}$ e $\mathrm{Fe}^{+2}$ e com forte crescimento de $\mathrm{Fe}^{+2}$, compreende apenas MGF. Nas rochas da SVS, essa correlação é, em geral, negativa (Figs. 4.4b, c, d).

As relações observadas indicam substituições de $\mathrm{Fe}^{+2}$ por $\mathrm{Al}^{\mathrm{VI}}$ e/ou $\mathrm{Mg}$, em proporções variáveis, nas biotitas dos litotipos estudados, com exceção das rochas 
metapelíticas, em que um aumento de $\mathrm{Fe}^{+2}$ é acompanhado de um aumento de $\mathrm{Al}^{\mathrm{VI}}$ e, ainda, em parte dos MGF, em que um aumento de $\mathrm{Fe}^{+2}$ é acompanhado de um aumento de $\mathrm{Mg}$. Consta, ainda, que em todas as biotitas analisadas, a correlação $\mathrm{Fe}^{+2}$ versus $\mathrm{Al}^{\mathrm{VI}}+\mathrm{Mg}+\mathrm{Ti}$ é negativa; a correlação $\mathrm{Fe}^{2+}$ versus $\mathrm{Al}^{\mathrm{IV}}+\mathrm{Mg}+\mathrm{Ti}$ é também negativa, exceto para os MGF com correlação $\mathrm{Fe}^{+2}$ versus $\mathrm{Mg}$ positiva.

Valores discrepantes ocorrem nas seguintes amostras, sendo o número das respectivas análises colocados entre parênteses (Anexo 4, Tab. A4.1; Fig. 4.2 a 4.4):

a) G-2b (4/1/16), com teores mais baixos em $\mathrm{Fe}^{+2}$ e $\mathrm{Al}^{\mathrm{VI}}$, que representa a borda de um cristal de biotita de MGF reagindo para anfibólio (Fig. 4.2a);

b) NE-31 (6/3/62) e NE-31-06 (3/4/30) de flogopititos intrudidos por veios pegmatóides mineralizados; a primeita com flogopita parcialmente cloritizada, dai seus teores mais elevados de $\mathrm{Al}^{\mathrm{VI}}, \mathrm{Al}^{\mathrm{IV}}$ e $\mathrm{Mg}$ (Figs. 4.2b, 4.3b e 4.4b), e a segunda, cuja flogopita esfoliada, de mais baixo $\mathrm{Mg}$, inclui lentes de albita metassomática (Fig. 4.4b);

c) Cap-4 (28/1B1.1, 28/1B2.1 e 28/3B1.1) de anfibolito metabásico (AB), cujas biotitas de menor $\mathrm{Al}^{\mathrm{VI}}$ podem ser restos de reações formadoras de $\mathrm{K}$-feldspato + ilmenitas ou produtos de alteração metassomática (Fig. 4.2c); e

d) G52c (2/1/29 e 2/1/30), respectivamente, análises de centro e borda de uma biotita parcialmente cloritizada, com teores mais altos de $\mathrm{Fe}^{+2}, \mathrm{Al}^{\mathrm{IV}}$ e $\mathrm{Mg}$, em contato com granada (Figs. 4.2d, 4,3d, 4,4d) e G-85a (3/3/73), cuja biotita também parcialmente cloritizada ocorre na borda de cristais de cordierita (Figs. 4.2d e 4.4d), ambas de metapelitos.

Zoneamentos são mais evidentes nas biotitas das rochas metapelíticas e anfibolitos metabásicos tipo $\mathrm{AB}$ e $\mathrm{ABET}$, nitidamente mais magnesianas e empobrecidas $\mathrm{em}^{\mathrm{FeO}} \mathrm{T}$ nas bordas do que nos centros, e ainda, nas biotitas dos MGF, com bordas mais magnesianas e enriquecidas em $\mathrm{Al}^{\mathrm{IV}}$. Já as flogopitas das rochas metaultramáficas metassomatizadas destacam-se por apresentarem zoneamento composicional fraco, com bordas ligeiramente enriquecidas em $\mathrm{MgO}$.

Nas rochas metaultramáficas, observam-se, ainda, variações amplas de $\mathrm{F}(0.1$ a $1.9 \%$ peso) que se correlaciona positivamente com $\mathrm{Ti}$ e negativamente com $\mathrm{Al}$ (Fig. 4.5). 

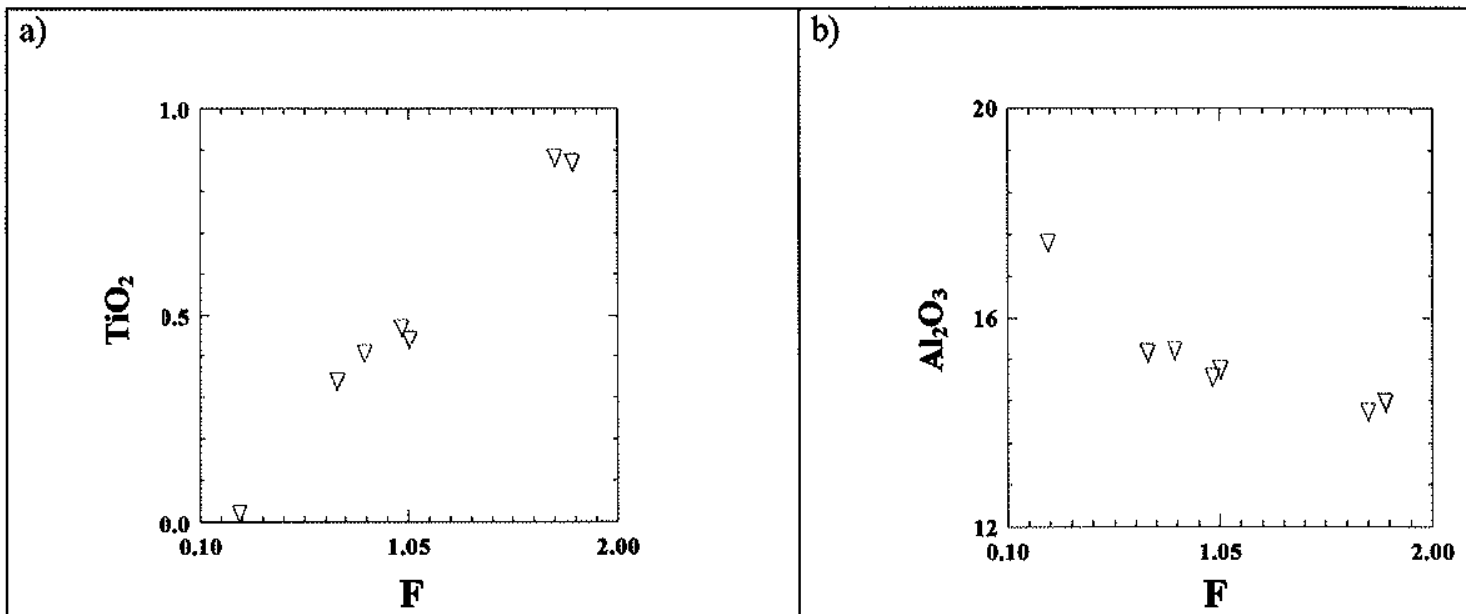

Figura 4.5: Diagramas de correlação $\mathrm{F}$ vs $\mathrm{TiO}_{2}$ (a) e $\mathrm{Al}_{2} \mathrm{O}_{3}$ (b), nas flogopitas das rochas metaultramáficas metassomatizadas. Cores: verde = centro; vermelha $=$ borda.

A partir da análise petrográfica minuciosa das biotitas dos diversos litotipos, procurouse estabelecer correlações entre a localização das amostras em campo, as cores de pleocroismo e os teores de Fe, Mg, Ti e F. A princípio, esperava-se que, de W para $\mathrm{E}$, com o aumento do grau metamórfico determinado regionalmente (Schorscher, 1975; 1992), poderiam ser caracterizadas variações sistemáticas desses elementos, com consequente mudança das cores de pleocroismo das biotitas. No entanto, estas mudanças não são sistemáticas apenas em função do metamorfismo; a associação, no mesmo afloramento e no mesmo litotipo, de biotitas de cor ora verde escura (mais ricas em Fe), ora castanhoavermelhada (mais titaníferas), indica a importância das variações químicas nos protólitos. Estas controlaram também os teores de $\mathrm{F}$ nas micas escuras dos diferentes litotipos, cujas variações de centro para borda em uma mesma amostra, entretanto, são insignificantes, com exceção talvez do metapelito G-52c (Tab. 4.2).

\begin{tabular}{|c|c|c|c|}
\hline \multirow{2}{*}{ Litotipos } & \multirow{2}{*}{ Amostras } & \multicolumn{2}{|c|}{ Teor de F (\% em peso) } \\
\cline { 3 - 4 } & & Centro & Borda \\
\hline \multirow{2}{*}{ MP } & G-52c & 1.53 & 1.75 \\
& G-85a & 0.82 & 0.83 \\
\hline \multirow{3}{*}{ UM } & BE-06 & 1.79 & 1.71 \\
& NE-30 & 0.72 & 0.84 \\
& NE-31 & 0.34 & 0.28 \\
& Sul-01 & 1.05 & 1.01 \\
\hline \multirow{2}{*}{ MGF } & G-11a & 0.90 & 0.82 \\
& & 0.83 & 0.91 \\
\hline GB & G-29c & 0.29 & 0.15 \\
\hline \multirow{2}{*}{ TTG } & G-168g & 0.19 & 0.14 \\
& & 0.10 & 0.26 \\
\hline
\end{tabular}

Tabela 4.2: Variações dos teores de F nas biotitas/flogopitas (analisadas por MSE). Símbolo: TTG $=$ gnaisses da associação TTG; GB = Metagranitóides Borrachudos; MGF = Metagranitóides Foliados com Fluorita; UM = metaultramáficas; MP = metapelitos. 
Em geral, as biotitas são minerais bastante sensíveis ao metamorfismo, destacando-se, sob este aspecto, principalmente, as biotitas das rochas metapelíticas. No entanto, as relações entre as composições das biotitas/flogopitas e as ocorrências geológicas descritas a seguir aproximam-se daquelas estabelecidas por Heinrich (1946; In: Deer et al., 1962), confirmando, assim, o predomínio das composições químicas globais dos protólitos sobre as variações de temperatura nas composições das biotitas dos litotipos estudadas.

* As biotitas dos gnaisses TTG apresentam teores variáveis e relativamente elevados de $\mathrm{FeO}( \pm 22 \%$ em peso) e $\mathrm{MgO}( \pm 10 \%$ em peso);

* As biotitas das rochas graníticas (GB e MGF) são caracterizadas pelo alto teor de FeO (21 a $40 \%$ em peso). Este, porém, em geral, diminui dos centros para as bordas, ao contrário do $\mathrm{MgO}$ (que aumenta dos centros para as bordas) especialmente nos MGF como já mencionado. Estas observações estão de acordo com a hipótese de que, na região de Itabira, as biotitas mais ferriferas dos GB originaram-se a partir de biotitas retrometamórficas, mais magnesianas dos TTG (Schorscher, 1992) e, com o aumento do grau metamórfico mais elevado na área de estudo, voltam a adquirir novamente composições mais magnesianas;

* As micas escuras das rochas metaultramáficas metassomatizadas são flogopitas típicas (com $\mathrm{FeO}<12 \%$ e $\mathrm{MgO}$ entre 17 a $21 \%$ em peso). As variações centros/bordas muito pequenas e irregulares, neste caso, de fato não obedecem a uma sistemática regular de metamorfismo regional progressivo e sim, retratam a estabilidade da flogopita, desde a formação metassomática até o pico do metamorfismo, com eventuais pequenos reajustes parciais progressivos e retrometamórficos finais.

* As composições das biotitas dos anfibolitos metabásicos em geral aproximam-se daquelas dos gnaisses TTG;

* A biotitas das rochas metapelíticas destacam-se pelos seus teores baixos de $\mathrm{FeO}$ (< $20 \%$ em peso) e altos de $\mathrm{MgO}$ (12 a 20\% em peso), aproximando-se de composições flogopíticas. Os enriquecimentos em $\mathrm{MgO}$ e empobrecimentos em $\mathrm{FeO}_{\mathrm{T}}$ dos centros para as bordas são efeitos do metamorfismo regional progressivo.

Eventuais bordas externas mais ricas em $\mathrm{FeO}$ nas biotitas de todos os litotipos estudados devem-se a reajustes retrometamórficos locais, finais, associados a fraturamento e hidratação, incluindo cloritização e argilitização, podendo ser correlacionados à fase final, retrometamórfica, do metamorfismo regional progressivo, ou ainda, aos efeitos tectonotermais do ciclo Brasiliano. 


\section{IV.3 - ANFIBÓLIOS}

A fórmula estrutural dos anfibólios pode ser escrita como $\mathrm{A}_{0-1} \mathrm{~B}_{2} \mathrm{C}_{5} \mathrm{~T}_{8} \mathrm{O}_{22}(\mathrm{OH}, \mathrm{F})_{2}$, onde os cátions $\mathrm{A}, \mathrm{B}, \mathrm{C}$ e T estão, respectivamente, nas posições $\mathrm{A}, \mathrm{M} 4, \mathrm{M} 1+\mathrm{M} 2+\mathrm{M} 3$ e $\mathrm{T}$, na seguinte forma: $\mathrm{A}(\mathrm{M} 4)_{2}(\mathrm{M} 1)_{2}(\mathrm{M} 3)_{1}(\mathrm{M} 2)_{2}(\mathrm{~T} 1)_{4}(\mathrm{~T} 2)_{4} \mathrm{O}_{22}(\mathrm{OH})_{2}$. Existem seis tipos de recálculos (ou restrições estequiométricas) que podem ser aplicadas, baseadas na fórmula estrutural:

1) $\mathrm{Si}=8$; assume nenhum $\mathrm{Al}$ tetraédrico;

2) $\mathrm{Si}+\mathrm{Al}=8$; assume nenhum Al octaédrico;

3) $\mathrm{Si}+\mathrm{Al}+\mathrm{Ti}+\mathrm{Mg}+\mathrm{Fe}+\mathrm{Mn}=13$; não permite $\mathrm{Mg}$, Fe ou $\mathrm{Mn}$ no sítio M4;

4) $\mathrm{Si}+\mathrm{Al}+\mathrm{Ti}+\mathrm{Mg}+\mathrm{Fe}+\mathrm{Mn}+\mathrm{Ca}=15$; coloca todo $\mathrm{Na}+\mathrm{K}$ no sítio $\mathrm{A}$ (nenhum Na em M4);

5) $\mathrm{Si}+\mathrm{Al}+\mathrm{Ti}+\mathrm{Mg}+\mathrm{Fe}+\mathrm{Mn}+\mathrm{Ca}+\mathrm{Na}=15$; coloca todo o $\mathrm{Na}$ em $\mathrm{M} 4$ (nenhum Na no sítio A);

6) $\mathrm{Si}+\mathrm{Al}+\mathrm{Ti}+\mathrm{Mg}+\mathrm{Fe}+\mathrm{Mn}+\mathrm{Ca}+\mathrm{Na} \mathrm{K}=16$; assume que o sítio $\mathrm{A}$ é completamente preenchido.

Os anfibólios metamórficos são subdivididos em três grupos, baseados nos tipos de cátions no sítio M4: os ferromagnesianos (Fe e Mg em M4), os cálcicos (Ca em M4) e os sódicos (Na em M4).

Nesta pesquisa, foram efetuadas 211 análises pontuais de anfibólios de diversos litotipos (Tab. 4.3). Os resultados foram recalculados, segundo Spear (1993), com base em 23 oxigênios e considerando, respectivamente, as opções (expressas acima): 3 - para as rochas graníticas; 4 - para as rochas metaultramáficas e metabásicas; e 5 - para os metapelitos (Anexo 4; Tab. A4.2).

Os anfibólios compreendem dois grupos petrográficos: anfibólios verdes e anfibólios incolores, sendo os primeiros cálcicos e os segundos ferromagnesianos; com exceção de um anfibólio incolor da amostra 32,20 que é cálcico (cf. pág. 86). 


\begin{tabular}{|c|c|c|c|}
\hline \multirow{2}{*}{ Litotipo } & \multirow{2}{*}{ Amostra } & \multicolumn{2}{|c|}{$N^{\circ}$ de Análises } \\
\hline & & AV & Al \\
\hline MP & G-52c;G-85a & & (19) \\
\hline $\mathrm{ABG}$ & $\begin{array}{l}\text { C-1a; B-10; } \\
\text { G-54b; } 1-01\end{array}$ & (55) & (08) \\
\hline ABET & 32,$20 ; \mathrm{G}-37 \mathrm{a} ; \mathrm{G}-56$ & (18) & $(01)$ \\
\hline $\mathbf{A B}$ & Cap-4;HC-3a & $(16)$ & \\
\hline UM & $\begin{array}{c}\text { 1* NE-3; NE-12; } \\
\text { B-11; B-18; } \\
\text { BE-06; BE-08 }\end{array}$ & (49) & $(12)$ \\
\hline PGDAl & M-5 & (01) & \\
\hline MGF & G-2a; G-2b; G-68 & (22) & \\
\hline GB & $03 ; \mathrm{G}-26 ; \mathrm{G}-29 \mathrm{c}$ & $(10)$ & \\
\hline
\end{tabular}

Tabela 4.3: Litotipos com análises de anfibólios. Abreviações: $\mathrm{AV}=$ anfibólios verdes; $\mathrm{Al}=$ anfibólios incolores; $\mathrm{GB}=$ Metagranitóides Borrachudos; MGF = Metagranitóides Foliados com Fluorita; PGDAl = Pegmatóide Peralumínico; UM = Metaultramáficas; $\mathrm{AB}=$ Anfibolitos Metabásicos; $\mathrm{ABET}=$ Anfibolitos Metabásicos com Epidoto/Titanita; $\mathbf{A B G}=$ Anfibolitos Metabásicos com Granada; $\mathbf{M P}=\mathbf{M e t a p e l i t o s}$. Símbolo: (n) = número de análises.

Nas rochas graníticas ocorrem, somente, anfibólios verdes e nas rochas da SVS (metaultramáficas e metabásicas) ocorrem, às vezes associados, anfibólios verdes e incolores (Tab. 4.3). Nos metapelitos, anfibólios verdes são raros, sendo muito freqüentes os incolores. Os anfibólios verdes e incolores serão tratados separadamente.

\section{IV.3.1 - ANFIBÓLIOS VERDES}

\section{* GB e MGF}

Nos GB e MGF, os anfibólios verdes são cálcicos, ricos em $\mathrm{Fe}$ e, de acordo com a classificação de Leake (1978), são hastingsitas com Si = 6.0-6.25 átomos/fórmula (Fig. 4.6).

A ocupação do sítio A é alta (GB: > 0.63; MGF: > 0.57) refletindo os teores elevados de $\mathrm{K}_{2} \mathrm{O}$ (GB: 1.72-2.20; MGF: 1.87-2.22) e relativamente elevados de $\mathrm{Na}_{2} \mathrm{O}$ (GB: 1.32-2.31; MGF: 1.35-2.15). As correlações entre \#Mg e a ocupação do sítio A e entre o \#Mg e $\mathrm{Al}^{\mathrm{VI}}$ são positivas (Fig. 4.7).

De um modo geral, dos centros para as bordas dos anfibólios verificam-se: uma menor ocupação do sítio $A$ nos MGF; empobrecimentos e enriquecimentos em $\mathrm{Al}^{\mathrm{VI}}$, respectivamente, nos GB e nos MGF; empobrecimentos em $\mathrm{Al}^{\mathrm{IV}}$ nos MGF; enriquecimentos em $\mathrm{MgO}$ nos GB e empobrecimentos em $\mathrm{TiO}_{2}$ e $\mathrm{MgO}$ nos MGF (Anexo 4, Tab. A4.2). 
a)

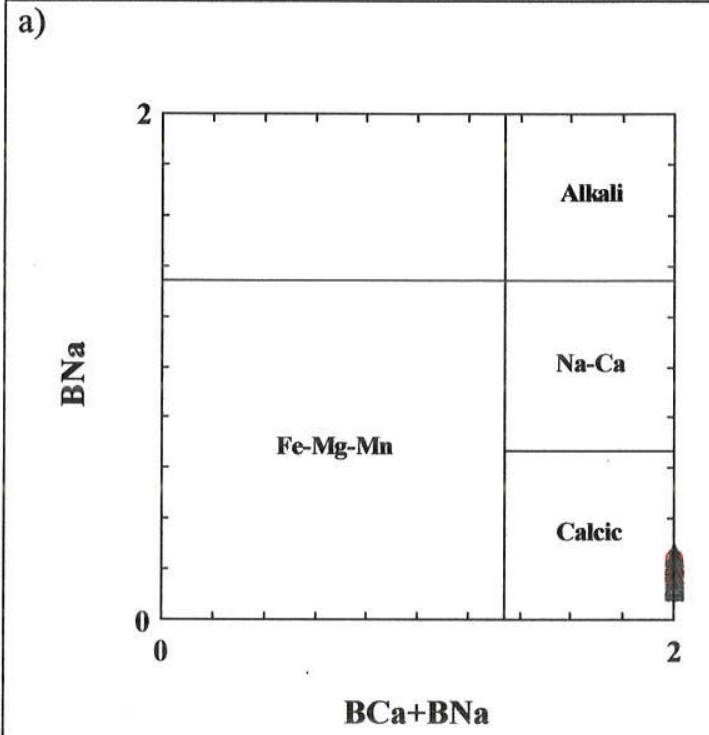

b)

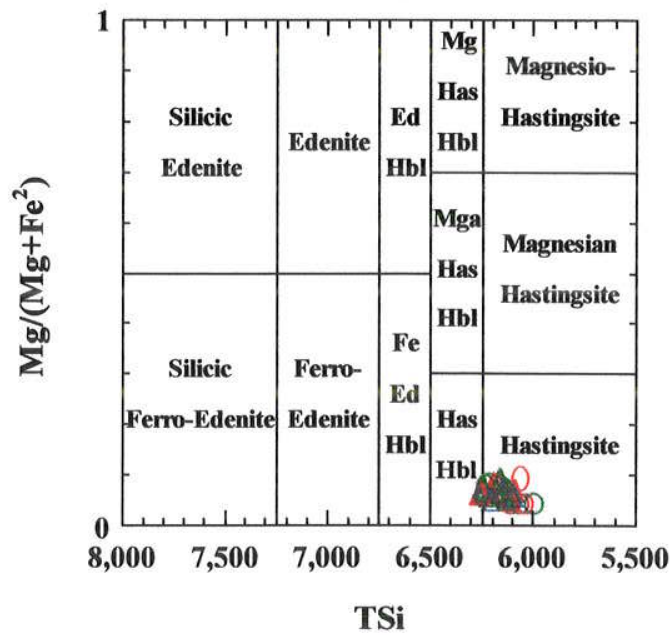

Figura 4.6: Classificação dos anfibólios verdes dos GB $(\mathrm{O})$ e MGF $(\Delta)$ : a) geral; b) anfibólios cálcicos com $(\mathrm{Na}+\mathrm{K})_{\mathrm{A}} \geq 0.5$ e Fe${ }^{+3}>\mathrm{Al}^{\mathrm{VI}}$. Cores: verde = centro; azul = parte intermediária; vermelha = borda.

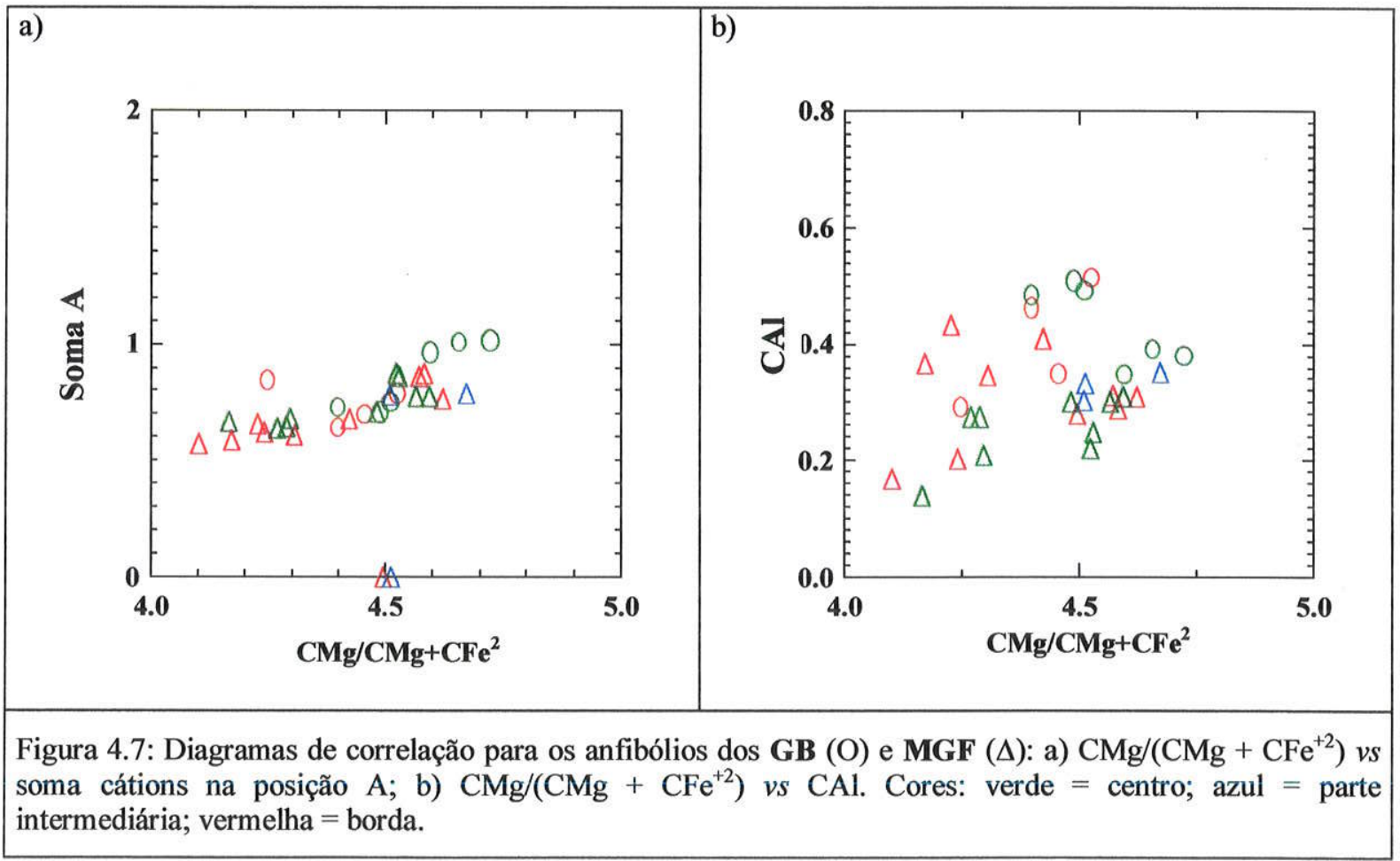




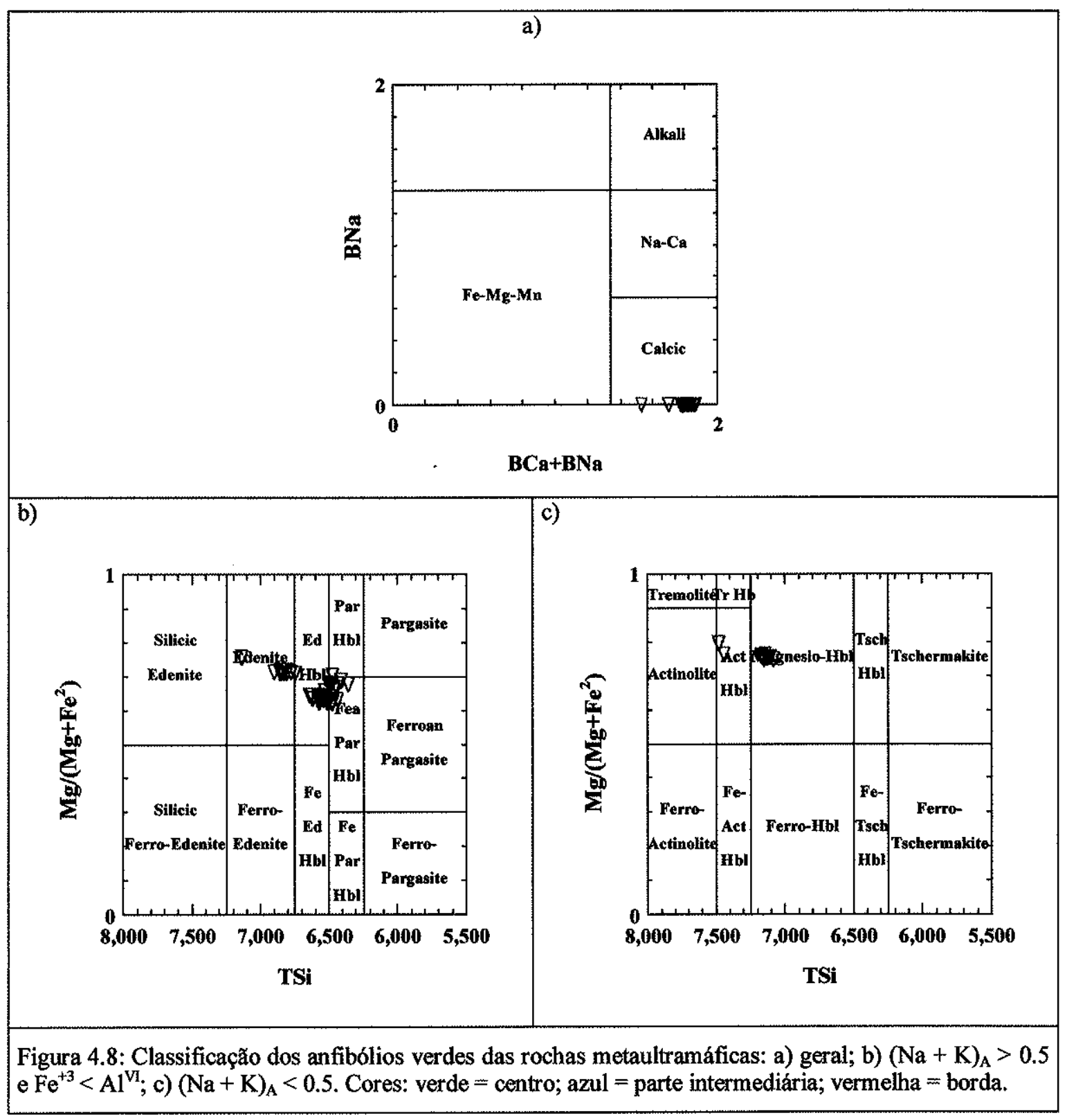

\section{* Rochas Metaultramáficas}

Os anfibólios verdes das rochas metaultramáficas, incluindo AU, AFX, CRT e CRTM, são cálcicos, diferindo dos anfibólios das rochas graníticas, principalmente, pelo teor de $\mathrm{Na}=$ 0 no sítio B (Fig. 4.8a). Suas composições variam desde hornblendas pargasíticas ferrosas, a hornblendas edeníticas e edenitas (Fig. 4.8b). Como exceção, nas amostras NE-3 e NE-12 os anfibólios são, respectivamente, $\mathrm{Mg}$-hornblendas e hornblendas actinolíticas, com relação (Na $+\mathrm{K})_{\mathrm{A}}<0.5$ (Fig. 4.8c). 


\section{* Anfibolitos Metabásicos}

Os anfibólios verdes dos anfibolitos metabásicos, representados na Figura 4.9, também são cálcicos e caracterizados por $\mathrm{Na}=0$ na posição $\mathrm{B}$. Nos anfibolitos tipo $\mathbf{A B}$ (comuns, com anfibólio verde, plagioclásio, quartzo e opacos), variam amplamente, desde hornblendas tschermakíticas, Mg-hornblendas, hornblendas actinolíticas, hornblendas pargasíticas ferrosas a edenitas, podendo, inclusive, ocorrer associados numa mesma amostra (ex.: Cap-4 e HC-03, Anexo 4, Tab. A4.2). Nos anfibolitos ABET (com epidoto/titanita), apresentam relação (Ca + $\mathrm{Na})_{\mathrm{B}}>1.86$ alta e $(\mathrm{Na}+\mathrm{K})_{\mathrm{A}}>0.59$, sendo hornblendas pargasíticas ferrosas com os mais baixos teores de \#MgO de todos os anfibolitos metabásicos estudados. Nos anfibolitos (ABG) com granada os anfibólios são, essencialmente, hornblendas pargasíticas ferrosas com ( $\mathrm{Na}+$ $\mathrm{K})_{\mathrm{A}}>0.5$; exceção é feita para a amostra B-10, onde hornblendas pargasíticas ferrosas ocorrem associadas com horblendas tschermakíticas com $(\mathrm{Na}+\mathrm{K})_{\mathrm{A}}<0.5$.

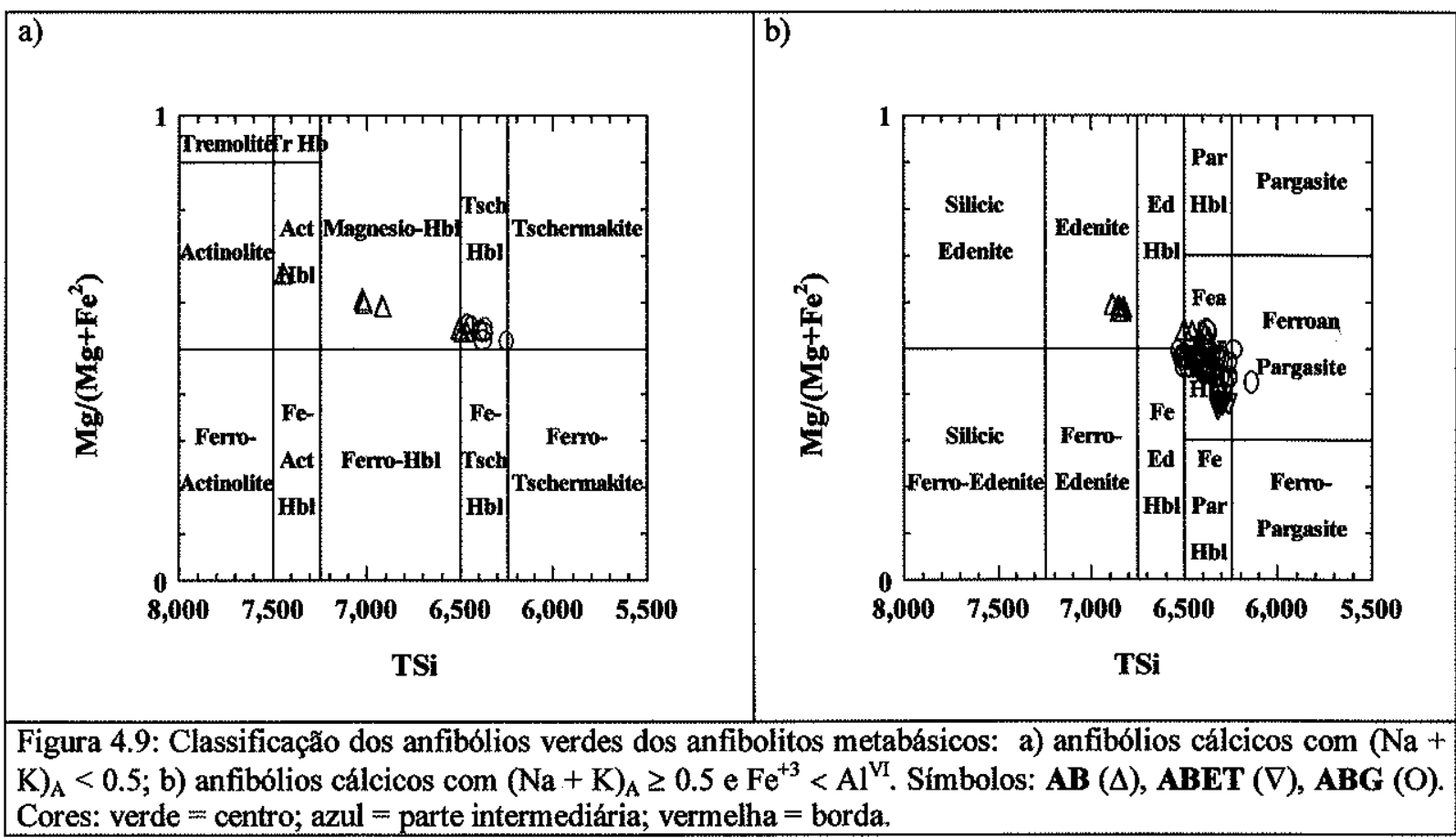

\section{* Veio Pegmatóide Peralumínico}

Vale citar a ocorrência de um caso único de anfibólio verde incluso em plagioclásio de veio pegmatóide com cianita, cordierita, estaurolita e córindon, intrusivo em gnaisse metapelítico da SVS (amostra M-5). Este anfibólio tem ocupação $\mathrm{BNa}=0$ e $(\mathrm{Ca}+\mathrm{Na})_{\mathrm{B}} \cong 1.6$ e composição intermediária entre Mg-hornblenda e hornblenda tschermakítica (Anexo 4, Tab. A4.2). 
Como observação final para os anfibólios verdes das rochas da SVS, ressaltam-se a maior frequêência de aumento de $\mathrm{MgO}$ e diminuição de $\mathrm{FeO}$ e as variações muito restritas de centros para bordas, respectivamente, nos anfibólios verdes dos $\mathrm{AB}$ e das rochas metaultramáficas; nos demais subgrupos (ABET e $\mathrm{ABG}$ ) de rochas da SVS, as variações centros-bordas de cristais não são sistemáticas.

\section{IV.3.2 - ANFIBÓLIOS INCOLORES}

Os anfibólios incolores das rochas metaultramáficas, metapelitos e anfibolitos metabásicos são ferromagnesianos. Nas rochas metaultramáficas (UM) apresentam BNa igual a zero e um valor máximo de BCa igual a 0.8. Já nos metapelitos (MP) caracterizam duas populações distintas: a) com $\mathrm{BNa}$ e $\mathrm{BCa}$, respectivamente, igual e próximo de zero, sendo representada pela amostra G-52c do garimpo de Capoeirana; b) com $\mathrm{BNa} \cong 0.55$ e $\mathrm{BCa} \cong 0.0$, sendo representada pela amostra G-85a, um xisto metapelítico (de protólito hidrotermalizado) com cordierita, granada, estaurolita e anfibólios incolores, do centro da área de estudo (Fig. 4.10a).

Os anfibólios das UM figuram nos campos das antofilitas e Mg-cummingtonita, sendo nitidamente separados dos anfibólios dos MP por razóes mais altas de $\mathrm{Mg} /\left(\mathrm{Mg}+\mathrm{Fe}^{+2}\right)$ e $\mathrm{TSi}$ $\cong 8.0$ (Fig. $4.10 \mathrm{~b}, \mathrm{c})$.

Os anfibólios dos MP típicos mostram um espalhamento maior de TSi, sendo representados nos campos das antofilitas e cummingtonitas. Já os anfibólios dos MP (de protólitos hidrotermalizados) apresentam valores de TSi aproximadamente constantes e próximos de 6.0, situando-se nos campos das gedritas e Mg-cummingtonitas (Fig. 4.10b,c).

O habitus acicular, o caráter geminado e a ausência de extinção reta dos anfibólios incolores das UM e MP e, adicionalmente, o sinal óptico positivo dos anfibólios dos MP indicam tratar-se mais provavelmente de cummingtonitas/Mg-cummingtonitas, não podendo ser descartada a possibilidade de ocorrerência de antofilitas/gedritas.

Nos anfibolitos metabásicos (ABG), os anfibólios incolores estão intercrescidos com anfibólios verdes. Nos diagramas de classificação, sobrepõem-se aos anfibólios das UM e dos MP de baixo BNa e BCa (respectivamente, igual e próximo de zero) (Fig. 4.10a) e, ainda, aos anfibólios dos MP de mais alto TSi, sendo cummingtonitas nos casos opticamente verificados (Fig. 4.10b,c). 
Em uma amostra de ABET de testemunho de sonda da Penery Mineração (Capoeirana), anfibólios incolores substituem os anfibólios verdes onde em contato com um micro-veio de zeólitas (amostra 32,20, Anexo 4, Tab. A4.2, análise 6/1/42). Estes anfibólios incolores apresentam composição cálcica da ferro-actinolita e representam uma fase metaestável de alteração hidrotermal dos anfibólios verdes, cálcicos, no contato com o veio. Ressalta-se, ainda, que as zeólitas têm teores elevados de $\mathrm{CaO}$ e composições próximas da heulandita (cf.: Deer et al., 1992) (Anexo 4, Tab. A4.10).

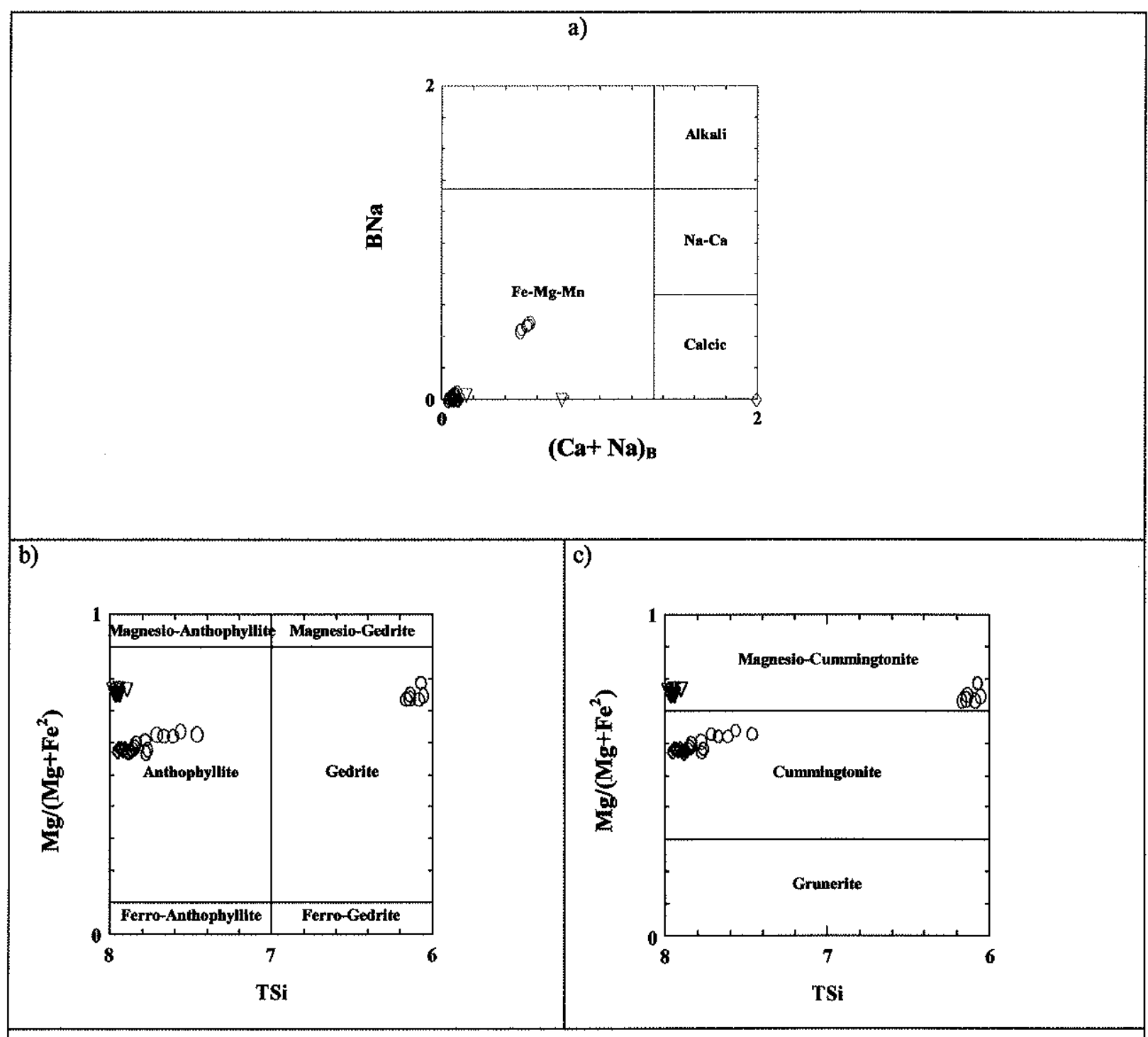

Figura 4.10: Classificação dos anfibólios incolores de rochas da SVS. Símbolos: UM (V); MP (O); AB (৩). Cores: verde $=$ centro; azul $=$ parte intermediária; vermelha $=$ borda. 
A análise de centros e bordas de cristais individuais permitiu constatar a falta de zoneamentos significativos nos anfibólios incolores. Pode-se dizer que em todos os litotipos (UM, ABG e MP) suas composiçð̃es são relativamente homogênas, apenas com tendências de aumento de $\mathrm{MgO}$ em direção às bordas externas nas UM e nos $\mathrm{ABG}$; já nos $\mathrm{MP}$, a tendência é inversa (de diminuição de $\mathrm{MgO}$ ).

\section{IV.4 - FELDSPATOS}

Os feldspatos são constituintes principais dos TTG, GB, MGF e dos anfibolitos metabásicos. Ocorrem, ainda, nas mineralizações de esmeraldas de tipo veios pegmatóides (EVP) e em gnaisses da SVS. Foram, assim, estudados plagioclásios e K-feldspatos visando a caracterização dos protólitos e a geotermometria pelo método dos "dois feldspatos" (Cap. V).

Nas análises por MSE foram consideradas tanto as substituições principais entre $\mathrm{K}, \mathrm{Na}$ e $\mathrm{Ca}$, quanto possíveis teores subordinados de $\mathrm{Ba}, \mathrm{Fe}$ e $\mathrm{Mg}$ dentre os elementos que introduzem pequenas modificações composicionais que podem ser correlacionadas à temperatura de cristalização ou recristalização dos feldspatos e/ou à composição do protólito.

\section{IV.4.1 - PLAGIOCLÁSIOS}

Foram efetuadas 168 análises de plagioclásios de diferentes litotipos (Tab. 4.5) e os resultados das análises, recalculadas com base em 32 oxigênios, encontram-se no Anexo 4 (Tab. A4.3).

\begin{tabular}{|c|c|}
\hline Litotipos & Amostras \\
\hline MG (4) & Cap-3 \\
\hline MP (10) & $286 ;$ AP-2 \\
\hline ABG (40) & C-1a; G-54b; I-01 \\
\hline ABET (24) & G-37a; G-56 \\
\hline AB (13) & Cap-4; HC-3a \\
\hline $\begin{array}{c}\text { PGD não mineralizado em } \\
\text { rochas da SVS (13) }\end{array}$ & Astro 01; M-5 \\
\hline $\begin{array}{c}\text { PGD mineralizado em rochas } \\
\text { metaultramáficas (10) }\end{array}$ & $\begin{array}{c}\text { NE-30; NE-31; } \\
\text { NE-31-06; Sul-01 }\end{array}$ \\
\hline MGF (32) & $\begin{array}{c}\text { G-2a; G-2b; G-3a; } \\
\text { G-11a; G-68 }\end{array}$ \\
\hline GB (20) & $\begin{array}{c}03 ; \text { G-113; G-166b; } \\
\text { G-26; G-29c; G-29d }\end{array}$ \\
\hline TTG (02) & G-168g \\
\hline
\end{tabular}

Tabela 4.4: Litotipos com análises de plagioclásios. Abreviaçães: TTG = Gnaisses da Associação TTG; GB = Metagranitóides Borrachudos; MGF = Metagranitoides Foliados com Fluorita; PGD = Pegmatóides; AB = Anfibolitos Metabásicos; ABET = Anfibolitos Metabásicos com Epidoto/Titanita; ABG = Anfibolitos Metabásicos com Granada; MP = Metapelitos; $(n)=$ número de análises. 
A Figura 4.11 sumariza os dados químicos dos plagioclásios das rochas s.l. graníticas estudadas.

Das rochas TTG apenas uma foi analisada para plagioclásios, sendo de uma fase mais máfica, cujos plagioclásios apresentam zoneamento normal, fraco, com centros $\mathrm{Ab}_{69}-\mathrm{An}_{30} \mathrm{e}$ bordas $\mathrm{Ab}_{72}-\mathrm{An}_{26}$ (Fig. 4.11a; Anexo 4, Tab. A4.3).

Nos GB e MGF os plagioclásios são muito similares; a variação total é de oligoclásio a albita, com tendências algo mais albíticas nos MGF do que nos GB (Fig. 4.11a,b). Os zoneamentos, conforme constatados microscopicamente, são inversos dos centros para as bordas internas e normais até albitas virtualmente puras para as bordas mais externas. Nos GB ocorre, ainda, biotita esfoliada com lente microscópica interfoliar de albita muito pura, representada na Figura 4.12 b e interpretada como produto de metasomatismo sódico tardio em relação ao principal metamorfismo regional proterozóico.

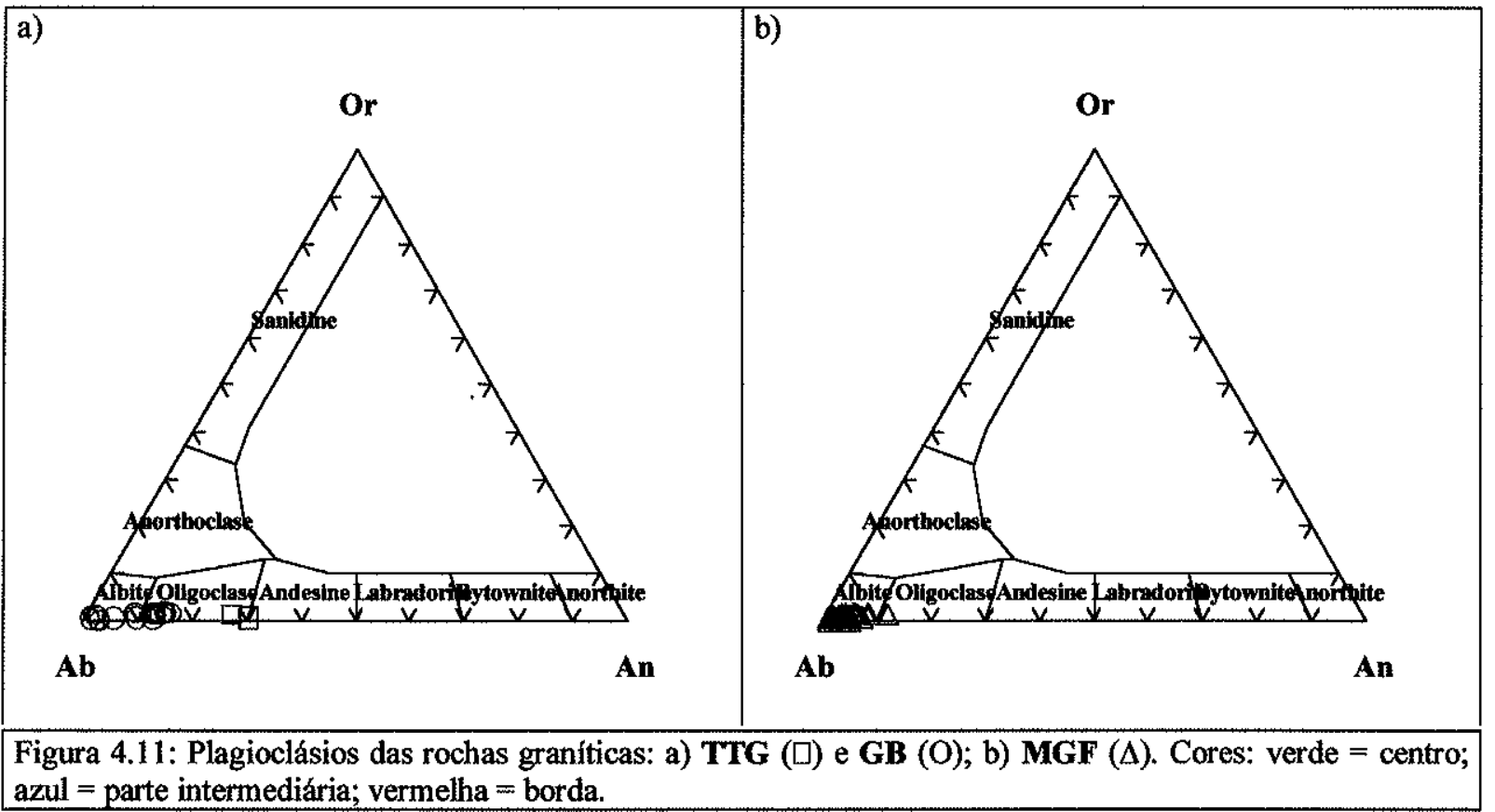

Nos veios pegmatóides não mineralizados intrusivos em rochas metaultramáficas flogopitizadas (amostra Astro 01) e peralumínicos em metapelitos (amostra M-5) e nos veios pegmatóides mineralizados (Tab. 5.4) em rochas metaultramáficas flogopitizadas, os plagioclásios têm composição andesina-oligoclásio e zoneamento normal restrito, também indicado microscopicamente pelas partes centrais saussuritizadas (Fig. 4.12a,b). Flogopitas 
das bordas dos veios pegmatóides nas rochas metaultramáficas flogopitizadas encaixantes, podem apresentar-se esfoliadas, com lentes microscópicas, interfoliares, de albita virtualmente pura (Fig. 4.12b; Anexo 4, Tab. A4.3, amostras NE-31-06, análise 3/4/29 e Sul 01, análise 2/1/9); essas albitas resultam de processo metassomático de albitização.

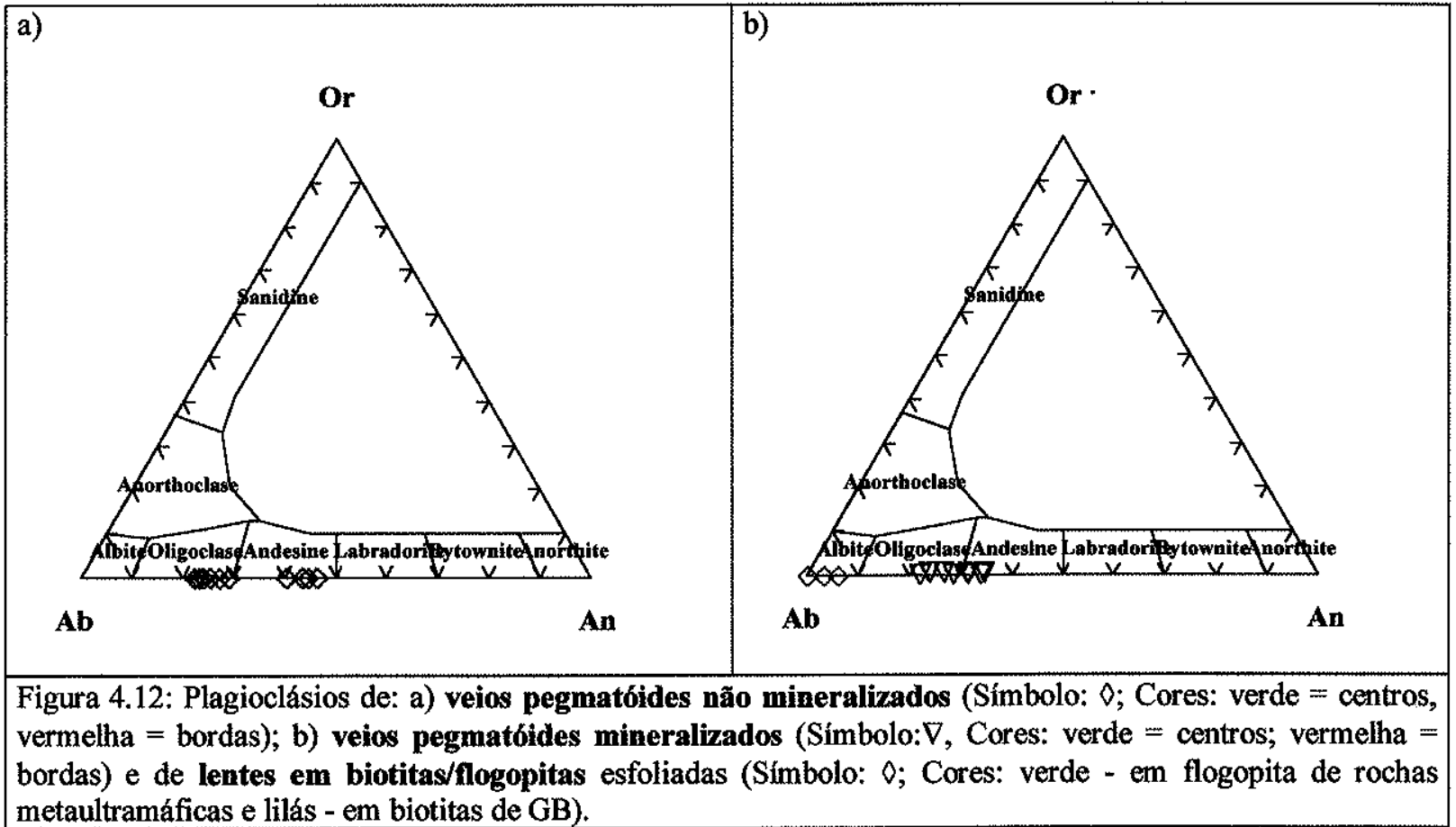

Os anfibolitos metabásicos dos subgrupos $A B, A B E T$ e $A B G$ mostram variações composicionais de seus plagioclásios na faixa oligoclásio/andesina, com exceção da amostra Cap-4 (AB) de variação ainda maior, de albita a andesina (Fig. 4.13). De um modo geral, os plagioclásios desses litotipos exibem um zoneamento inverso, metamórfico, do centro até a borda interna, com reequilibração albítica da borda mais externa, o que está de acordo com as evidências petrográficas. 


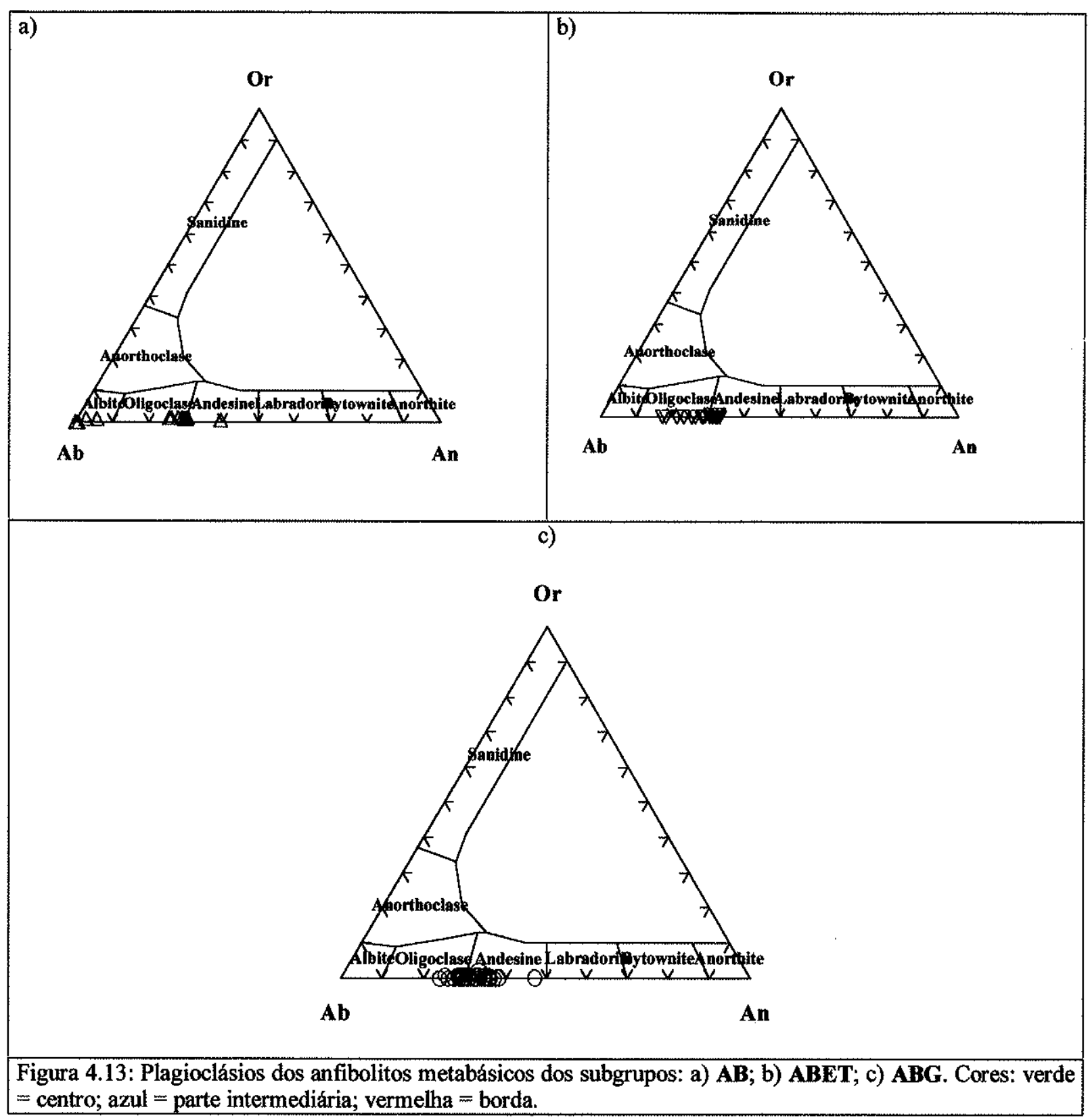

Nos metapelitos da porção central da área (amostra 286 - Schorscher, 1975) e do garimpo de Capoeirana (AP-2 e Cap-3), os plagioclásios são oligoclásios bastante homogêneos, porém, com diferentes teores de An (Fig. 4.14) decorrentes das variações na natureza e na composição dos protólitos. Tratam-se de um metapelito de protólito hidrotermalizado (amostra 286), de um metapelito epiclástico (AP-2) e de uma metagrauvaca (Cap-3).

Os teores de molécula ortoclásio em todos os plagioclásios são baixos; os valores mais elevados foram observados em ABG (até 2.2\% Or). Efeito do zoneamento metamórfico 
principal inverso foram observados somente nos plagioclásios de $\mathrm{AB}$, caracterizados por aumentos simultâneos de Or e An nas bordas dos cristais. Com o zoneamento normal externo para albitas puras ocorre, em geral, decréscimo de Or; este efeito é melhor observado nos GB e MGF. Nos plagioclásios de veios pegmatóides com zoneamento normal os teores de Or são muito baixos (até $0.6 \%$ Or).

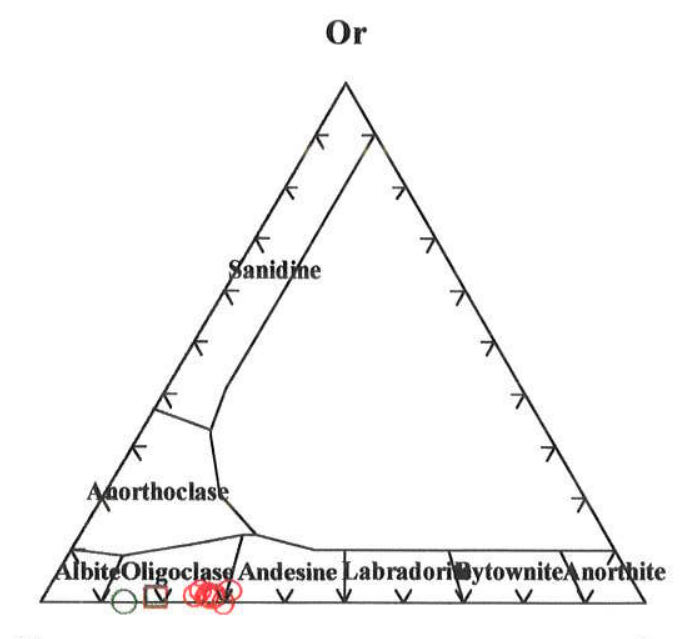

Ab

An

Figura 4.14: Plagioclásios de metapelitos (Símbolo: $\mathrm{O}$; Cores: vermelha $=$ amostra 286; verde $=$ amostra AP2) e metagrauvacas (Símbolo $\square$; Cores: verde $=$ centro; vermelha $=$ borda).

Foram efetuadas, ainda, análises de alguns elementos menores, tais como $\mathrm{Fe}, \mathrm{Mn}$ e $\mathrm{Mg}$ (e Ba em parte das análises). Observa-se, com uma maior constância a presença de $\mathrm{FeO}$, cujos teores acima de $0.2 \%$ peso em albitas com $\mathrm{An}<5$ devem ser considerados como efeitos de contaminação/interferência de opacos finamente disseminados (como ocorrem em albitas em lentes nas biotitas esfoliadas) ou de minerais máficos associados/inclusos. Nos demais casos, os teores maiores de $\mathrm{Fe}, \mathrm{Mn}, \mathrm{Mg}$ ocorrem, em geral, nos plagioclásios mais cálcicos. $\mathrm{Ba}$ tem ocorrência esporádica com teores muito baixos ( $\mathrm{BaO} \leq 0.04 \%$ peso), limítrofes da faixa de confiabilidade do método (Tab 4.6).

\begin{tabular}{|c|c|c|c|c|c|c|c|}
\hline & TTG & GB & MGF & $\begin{array}{c}\text { Lente em } \\
\text { Bt/Flog. }\end{array}$ & PGD & $\begin{array}{c}\text { AB/ABET/ } \\
\text { ABG }\end{array}$ & MP/MG \\
\hline $\mathrm{FeO}$ & 0.07 & 0.25 & 0.45 & 0.59 & 0.30 & 0.32 & 0.17 \\
\hline $\mathrm{MnO}$ & 0.0 & 0.13 & 0.15 & 0.0 & 0.16 & 0.18 & 0.03 \\
\hline $\mathrm{MgO}$ & 0.03 & 0.02 & 0.02 & 0.02 & 0.02 & 0.01 & 0.06 \\
\hline $\mathrm{BaO}$ & 0.02 & 0.02 & 0.04 & 0.01 & 0.02 & n.a. & n.a. \\
\hline
\end{tabular}

Tabela 4.5: Teores máximos de $\mathrm{FeO}, \mathrm{MnO}, \mathrm{MgO}$ e $\mathrm{BaO}$ (\% peso) em plagioclásios de rochas s.l. graníticas (TTG, GB e MG), lentes de albita em biotitas/flogopitas esfoliadas, veios pegmatóides (PGD), anfibolitos metabásicos (AB, ABET, ABG), metapelitos (MP) e metagrauvacas (MG); n.a.= não analisado. 


\section{IV.4.2 - FELDSPATOS POTÁSSICOS}

Foram analisados 65 pontos em feldspatos potássicos dos metagranitóides GB e MGF, anfibolitos metabásicos e em lentes em flogopitas/biotitas esfoliadas (Tab. 4.7), cujos resultados incluindo os cálculos da fórmula estrutural (base de 32 oxigênios), encontram-se no Anexo 4 (Tab. A4.4).

\begin{tabular}{|c|c|}
\hline Litotipos & Amostras \\
\hline $\begin{array}{c}\text { UM, TTG e ABG (em lentes em } \\
\text { flogopitas/biotitas esfoliadas ) (08) }\end{array}$ & BE-04; NE-31-06 (UM) \\
\hline G-168g (TTG) e 1-01 (ABG) \\
\hline MG/ABG (13) & Cap-4; I-01 \\
\hline GBF (27) & G-2a; G-2b; G-3a; G-11a; G-68 \\
\hline GB (17) & $03 ;$ G-26; G-29c; G-113; G-166b \\
\hline
\end{tabular}

Tabela 4.6: Litotipos com análises de feldspatos potássicos. Abreviaçães: $\mathrm{GB}=$ Metagranitóides Borrachudos; MGF $=$ Metagranitóides Foliados com Fluorita; $\mathrm{AB}=$ Anfibolitos Metabásicos; $\mathrm{ABG}=$ Anfibolitos Metabásicos com Granada; UM = metaultramáficas; TTG = Gnaisses da Associação TTG. Símbolos: $(\mathrm{n})=$ número de análises.

Os feldspatos potássicos, em geral, apresentam composições poucas variáveis e puras (Or $>92 \%$ ), exibindo fracos zoneamentos com bordas externas mais ricas em Or (Fig. $4.15 \mathrm{e}$ 4.16).

Comparativamente, os feldspatos potássicos dos MGF $\left(\mathrm{Ab}_{1.2-6.2}\right.$ Or 98.8-93.8 ) são algo mais puros do que os dos GB ( Ab $_{3.1-7.7}$ Or $_{96.9-92.3}$ ) (Fig. 4.15), o que reforça a petrogênese dos MGF a partir dos GB e a formação de pegmatóides por fusão incipiente dos MGF.

Os feldspatos potássicos mais puros e de menor variação composicional ocorrem em rochas mais máficas: em anfibolitos $\mathrm{AB}$ e $\mathrm{ABG}$, tanto livres na matriz, quanto em lentes microscópicas em biotitas esfoliadas; e ainda, em lentes em biotitas esfoliadas num caso de um TTG mais máfico (amostra G-168g) e flogopitas de rochas metaultramáficas mineralizadas (Fig. 4.16, Anexo 4, Tab. A4.4). A pureza, a pequena variabilidade composicional, as características texturais e a ocorrência incomum em rochas metamáficas de composições e origens ígneas normais apontam para a natureza metassomática tardi-sin a pósmetamórfica em relação ao evento regional principal desses feldspatos potássicos. 


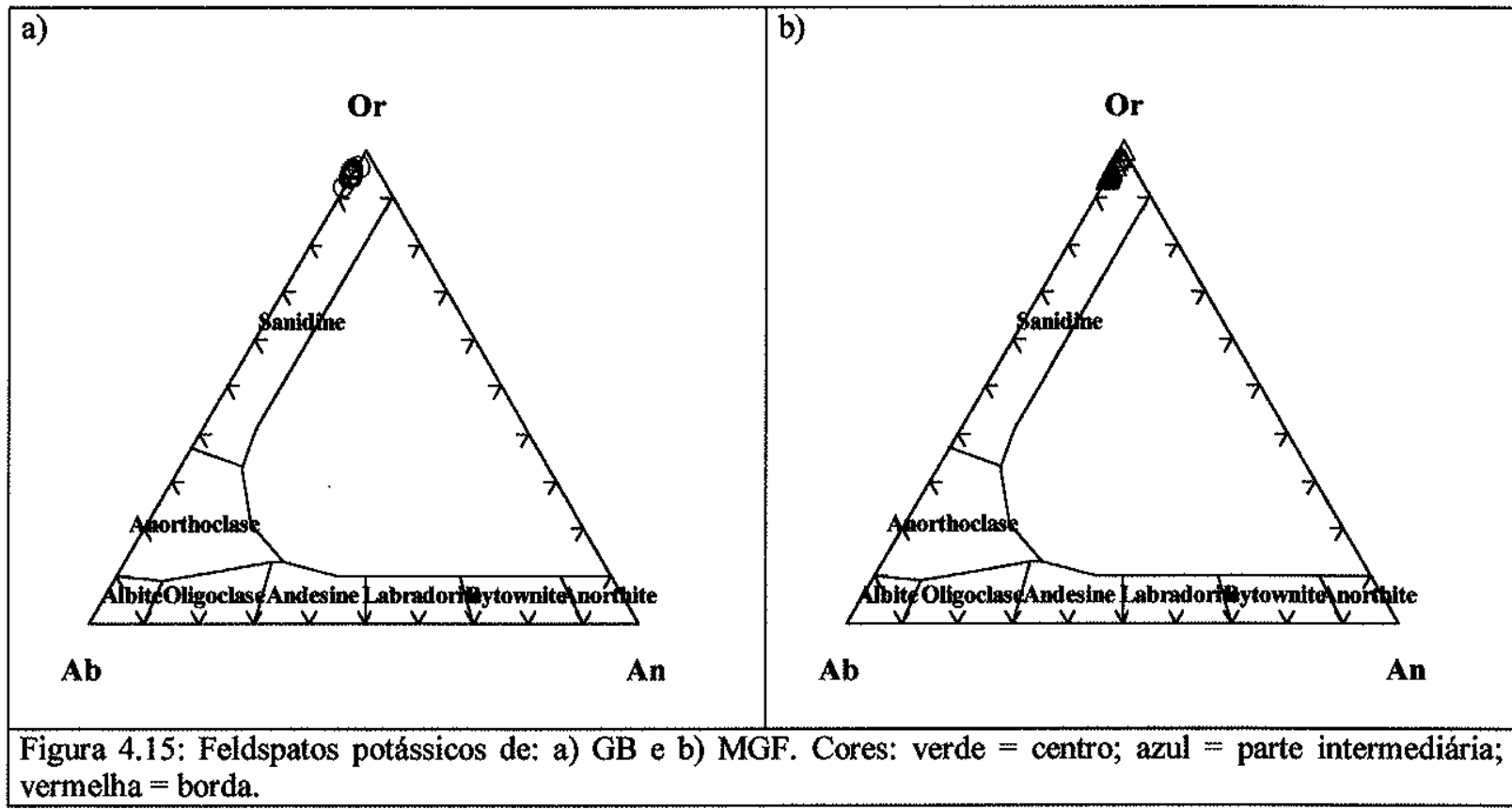

a)

b)

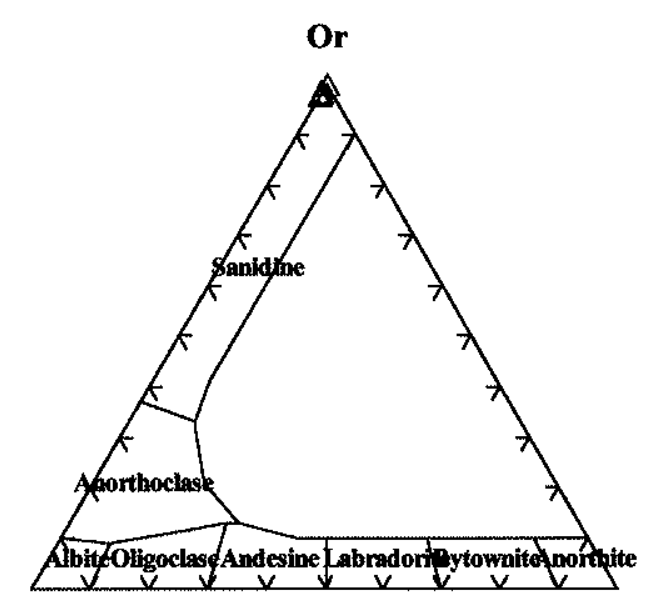

$\mathbf{A b}$

An

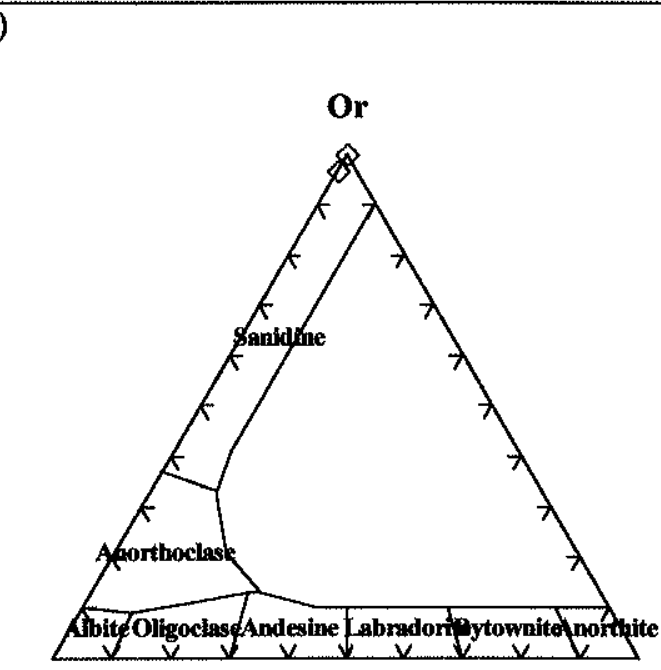

Ab

An

Figura 4.16: Feldspatos potássicos em: a) anfibolitos metabásicos (Cores: verde $=$ centros; vermelha $=$ bordas; b) lentes em biotitas/flogopitas esfoliadas de TTG, anfibolitos metabásicos e metaultramáficas.

Foram feitas também nesses feldspatos análises dos elementos menores $\mathrm{Fe}, \mathrm{Mn}$ e $\mathrm{Mg}$ em todos os casos e Ba em parte das análises. Observam-se, com maior freqüência, a presença de $\mathrm{Fe}$ e $\mathrm{Ba}$. Teores de $\mathrm{FeO}$ acima de $0.3 \%$ peso em $\mathrm{K}$-feldspatos com $\mathrm{Ab}<5$, outrossim puros, foram considerados, em função da variabilidade analítica geral, como efeitos de contaminação/interferência de opacos finamente disseminados (por ex.: em lentes de $\mathrm{K}$ feldspatos em biotitas/flogopitas) ou de minerais máficos associados/inclusos (Tab 4.7). 


\begin{tabular}{|c|c|c|c|c|}
\hline & GB & MGF & AB/ABG & Lentes em Bt/Flog. \\
\hline FeO & 0.22 & 1.12 & 0.49 & 0.36 \\
\hline $\mathrm{MnO}$ & 0.03 & 0.03 & 0.0 & 0.02 \\
\hline $\mathrm{MgO}$ & 0.03 & 0.01 & 0.0 & 0.02 \\
\hline $\mathrm{BaO}$ & 0.47 & 0.27 & n.a. & 0.42 \\
\hline
\end{tabular}

Tabela 4.7: Teores máximos de $\mathrm{FeO}, \mathrm{MnO}, \mathrm{MgO}$ e $\mathrm{BaO}$ (\% peso) em $\mathrm{K}$-feldspatos de rochas graníticas (GB e $\mathrm{MG})$, de anfibolitos metabásicos (AB, $\mathrm{ABG}$ ) e de lentes em flogopitas/ biotitas esfoliadas; n.a.= não analisado.

\section{IV.5 - GRANADAS}

Os minerais do grupo das granadas têm a fórmula geral $\mathrm{X}_{3} \mathrm{Y}_{2} \mathrm{Z}_{3} \mathrm{O}_{12}$, que, em função das ocupações de X e Y, foram divididos em duas séries isomorfas (Whinchell, 1933), denominadas ugrandita e piralspita.

\begin{tabular}{c|c|c|c}
\hline \multicolumn{2}{c|}{ Série Ugrandita } & \multicolumn{2}{c}{ Série Piralspita } \\
\hline Uvarovita & $\mathrm{Ca}_{3} \mathrm{Cr}_{2} \mathrm{Si}_{3} \mathrm{O}_{12}$ & Piropo & $\mathrm{Mg}_{3} \mathrm{Al}_{2} \mathrm{Si}_{3} \mathrm{O}_{12}$ \\
\hline Grossulária & $\mathrm{Ca}_{3} \mathrm{Al}_{2} \mathrm{Si}_{3} \mathrm{O}_{12}$ & Almandina & $\mathrm{Fe}_{3} \mathrm{Al}_{2} \mathrm{Si}_{3} \mathrm{O}_{12}$ \\
\hline Andradita & $\mathrm{Ca}_{3} \mathrm{Fe}_{2} \mathrm{Si}_{3} \mathrm{O}_{12}$ & Espessartita & $\mathrm{Mn}_{3} \mathrm{Al}_{2} \mathrm{Si}_{3} \mathrm{O}_{12}$ \\
\hline
\end{tabular}

Por tratar-se de importantes indicadores metamórficos, foram efetuadas 61 análises de granadas de GB, ABG e MP (Tab. 4.8). Para verificar zoneamento composicional foram feitas, em média, 2 a 3 análises por cristal entre centros e bordas.

\begin{tabular}{|c|c|}
\hline Litotipos & Amostras \\
\hline MP (16) & G-52c; G-89 \\
\hline ABG (35) & B-10; C-1a; G-54b; I-01 \\
\hline GB(10) & G-113; G-166b \\
\hline
\end{tabular}

Tabela 4.8: Litotipos com análises de granadas. Abreviaçðes: $\mathrm{GB}=$ Metagranitóide Borrachudos; $\mathrm{ABG}=$ anfibolito metabásico com granada; $\mathrm{MP}=$ metapelito. $(\mathrm{n})=$ número de análises.

Os dados analíticos, as formulas estruturais com base em $12(\mathrm{O})$ e o Fe recalculado segundo Droop (1987), bem como os membros finais recalculados segundo Rickwood (1968) são apresentados no Anexo 4 (Tab. A4.5). Os resultados mostram que as granadas são almandinas, em geral, homogêneas, com pequenas variaçð̃es dos teores de grossulária, piropo e espessartita (Fig. 4.17 a,b,c,d). Porém, nos três litotipos as granadas são distintas entre si. 


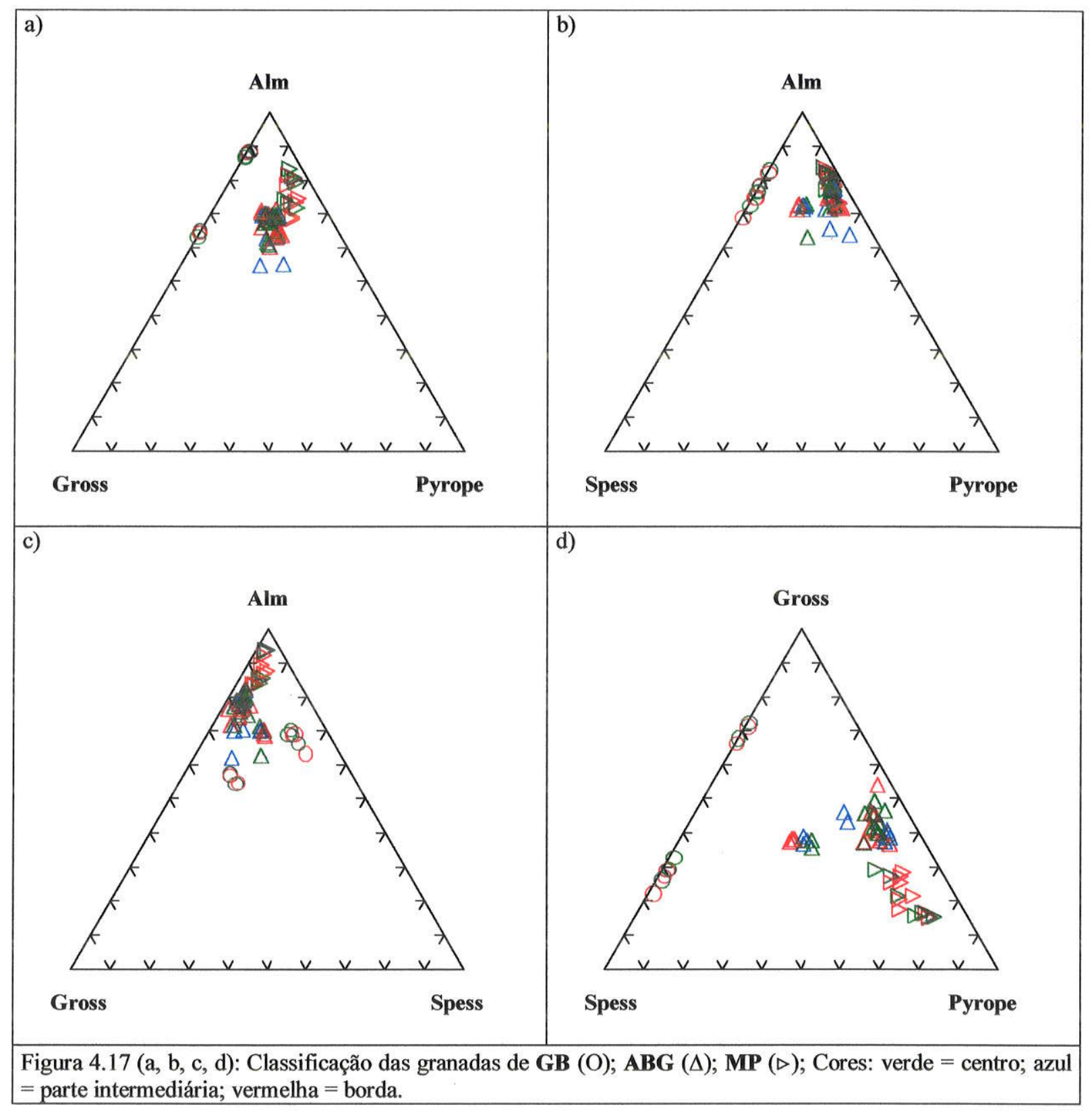

As composições obtidas definem:

* dois grupos distintos para as amostras dos GB, principalmente, quanto aos componentes almandina, grossulária e espessartita (Fig. 4.17a,c,d);

* dois grupos distintos para as amostras dos $\mathrm{ABG}$, principalmente, quanto aos componentes espessartita e piropo (Fig. 4.17b,d);

* para os MP, composições homogêneas, mais ricas nos componentes almandina e piropo (Fig. 4.17a,b,c,d). 
Quando representadas no diagrama $(\mathrm{CaO}+\mathrm{MnO})$ versus $(\mathrm{FeO}+\mathrm{MgO})$, as granadas caracterizam uma tendência evolutiva de teores mais altos em $\mathrm{CaO}+\mathrm{MnO}$ para mais altos em $\mathrm{FeO}+\mathrm{MgO}$, na sequência GB, ABG e MP (Fig. 4.18a). Na Figura 4.18b, são caracterizados grupos mais e menos ferro-magnesianos, constando as granadas dos GB como virtualmente isentas de $\mathrm{MgO}$. Comportamento similar do $\mathrm{MgO}$ já foi observado nas biotitas desses mesmos tipos litológicos.

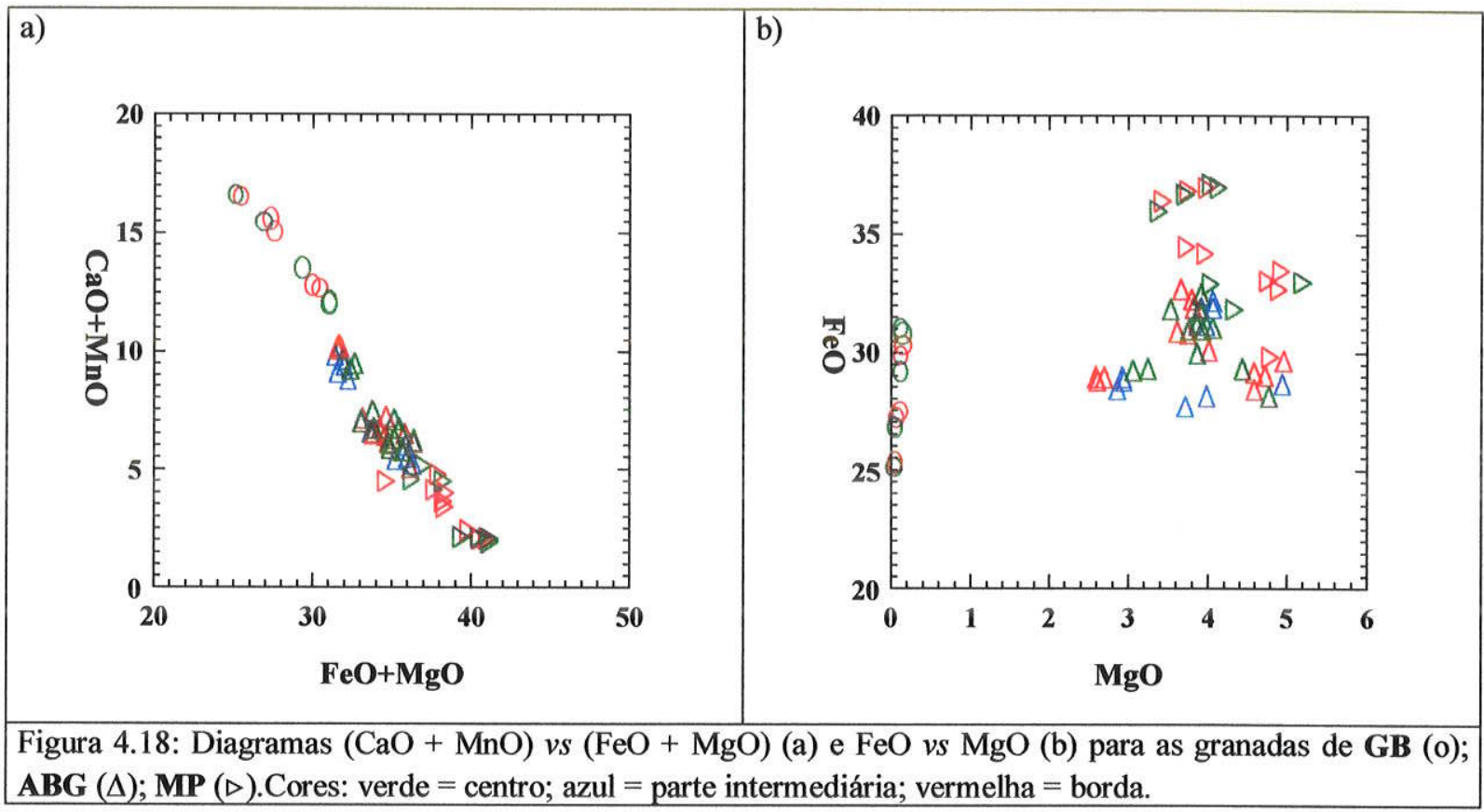

As diferenças que originam subgrupos de granadas nos $\mathrm{GB}$ e nos $\mathrm{ABG}$ devem-se, mais provavelmente, a pequenas variações na química global dos protólitos. Dentro de um mesmo grupo/subgrupo litológico, no entanto, ocorrem, ainda, variações composicionais não sistemáticas entre centros e bordas de cristais individuais.

\section{IV.6 - CORDIERITAS}

Foram efetuadas 19 análises de cordieritas de metapelitos do centro da área (amostra G-85a) e da porção leste (garimpo de Capoeirana - amostra AP-3), sendo adicionalmente consideradas 09 análises da amostra 286 (Schorscher, 1975) da porção centro-norte. Os dados que incluem recálculos da fórmula estrutural com base em 18(O), encontram-se no Anexo 4 (Tab. A4.6). 
As cordieritas apresentam variações composicionais restritas por amostra e algo maiores entre amostras. $\mathrm{SiO}_{2}$ e $\mathrm{MgO}$ são, em geral, constantes em todas as amostras (Anexo 4, Tab. A4.6). As pequenas variações de $\mathrm{Fe}^{+2}$ e $\mathrm{Mn}$ indicam, principalmente, controles composicionais dos protólitos (Fig. 4.19a,b).

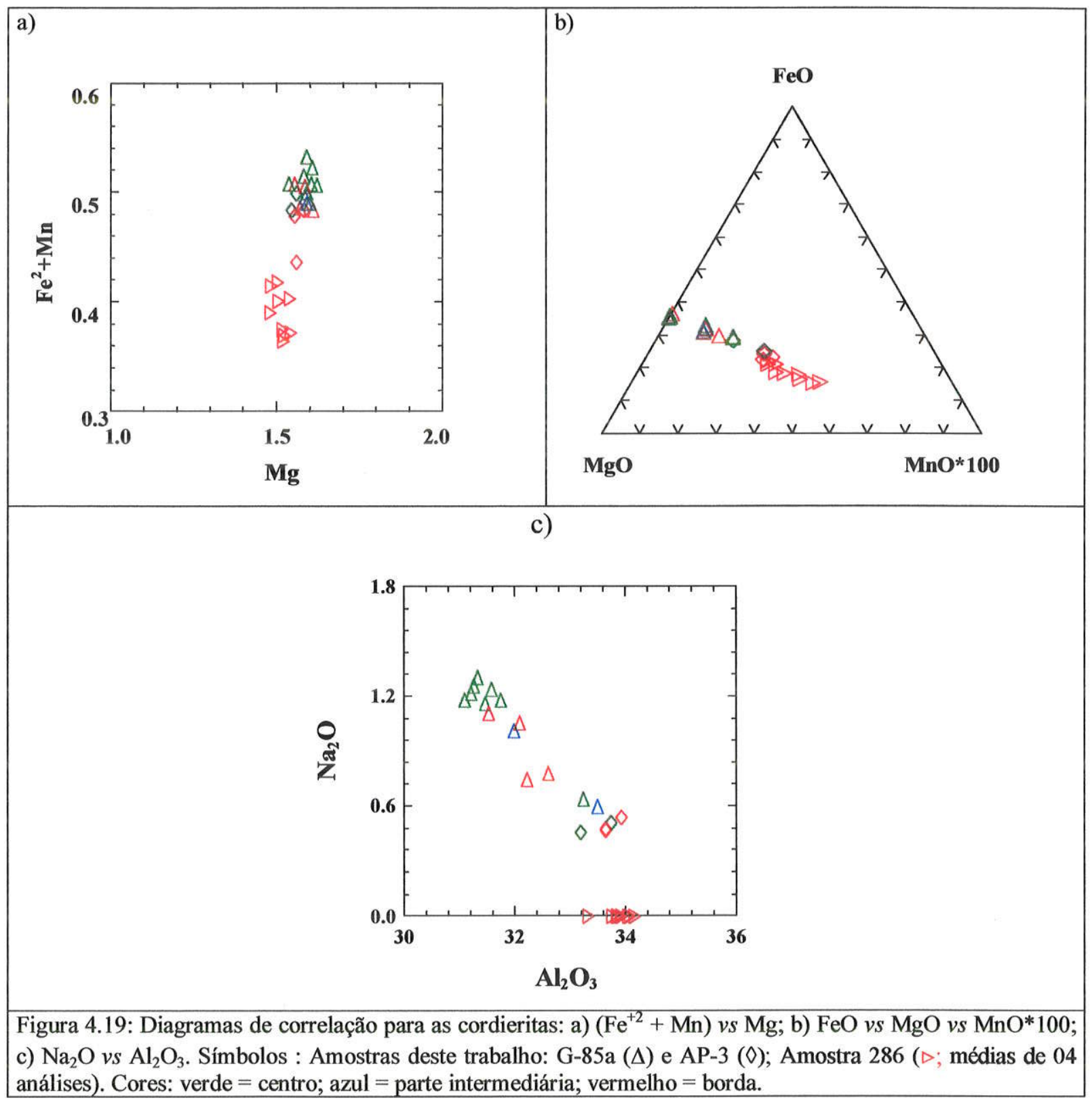

Zoneamentos químicos, mais evidentes na amostra G-85a com bordas empobrecidas em $\mathrm{Na}_{2} \mathrm{O}$ e enriquecidas em $\mathrm{Al}_{2} \mathrm{O}_{3}$, associam-se à correlação geral negativa entre estes óxidos: a amostra G-85a exibindo valores máximos de $\mathrm{Na}_{2} \mathrm{O}$ e mínimos de $\mathrm{Al}_{2} \mathrm{O}_{3}$, a amostra $\mathrm{AP}-3$ com valores mínimos de $\mathrm{Na}_{2} \mathrm{O}$ e intermediários de $\mathrm{Al}_{2} \mathrm{O}_{3}$ e a amostra 286 com valores 
máximos de $\mathrm{Al}_{2} \mathrm{O}_{3}$ foi representada com valores nulos de $\mathrm{Na}_{2} \mathrm{O}$ que não foram analisados no trabalho origianl (Fig. 4.19c). Adicionalmente, observam-se de centros para as bordas de cristais, decréscimos e aumentos sistemáticos, embora pequenos, respectivamente, de $\mathrm{FeO}$ e $\mathrm{MgO}$ como efeito do metamorfismo progressivo.

\section{IV.7 - ESTAUROLITAS}

Foram efetuadas 17 análises de estaurolitas dos garimpos de Capoeirana e de Capoeirana do Meio, no primeiro caso, em metapelitos e em pegmatóide peralumínico com córindon, cianita, cordierita, estaurolita e plagioclásio, e no segundo em metapelito (Tab. 4.9). Os resultados das análises recalculadas com base em 48 oxigênios estão contidos no Anexo 4 (Tab. A4.7).

\begin{tabular}{|c|c|c|}
\hline Litotipos & Amostras & Local \\
\hline PGDAl & M-5 & \multirow{2}{*}{ Capoeirana } \\
\hline MP & AP-2; AP-3; G-52c & Capoeirana do Meio \\
\hline MP & G-89 & Can \\
\hline
\end{tabular}

Tabela 4.9: Relação das amostras por localidade com análises de estaurolitas. Símbolo: PGDAl = pegmatóide peralumínico; $\mathrm{MP}=$ metapelitos

Observam-se fracas correlações negativas entre $\mathrm{Al}_{2} \mathrm{O}_{3}$ e $\mathrm{FeO}$ e entre $\mathrm{Al}_{2} \mathrm{O}_{3}$ e $\mathrm{MgO}$ e correlação positiva entre $\mathrm{FeO}$ e $\mathrm{MgO}$ nas estaurolitas de metapelitos de Capoeirana (Fig. $4.20 \mathrm{a}, \mathrm{b}, \mathrm{c})$. Estas estaurolitas são mais ricas em $\mathrm{MgO}$ e $\mathrm{FeO}$ do que as de Capoeirana do Meio, que por sua vez, tem os mais elevados teores de $\mathrm{Zn}(\mathrm{ZnO}= \pm 3 \%)$ (Fig. 4.20d; Anexo 4, Tab. A4.7). As estaurolitas da amostra M-5 (pegmatóide peralumínico) destacam-se pelos teores mais baixos de $\mathrm{FeO}$ e mais elevados de $\mathrm{Al}_{2} \mathrm{O}_{3}(\sim 57 \%)$ e $\mathrm{Cr}_{2} \mathrm{O}_{3}(\sim 0.2 \%)$ (Fig. 4.20a, b, c; Anexo 4, Tab. A4.7).

De modo geral, as estaurolitas apresentam bordas enriquecidas em $\mathrm{SiO}_{2}$ e $\mathrm{Al}_{2} \mathrm{O}_{3}$ e empobrecidas em $\mathrm{MgO}$.

Como resultado geral, conclui-se que as variações das estaurolitas entre amostras, principalmente, em relação aos teores de $\mathrm{Fe}, \mathrm{Mg}$ e $\mathrm{Zn}$ são controladas por variações químicas nos protólitos. Teores mais elevados de $\mathrm{Al}$ parecem ser característicos de estaurolitas de pegmatóides peralumínicos. 


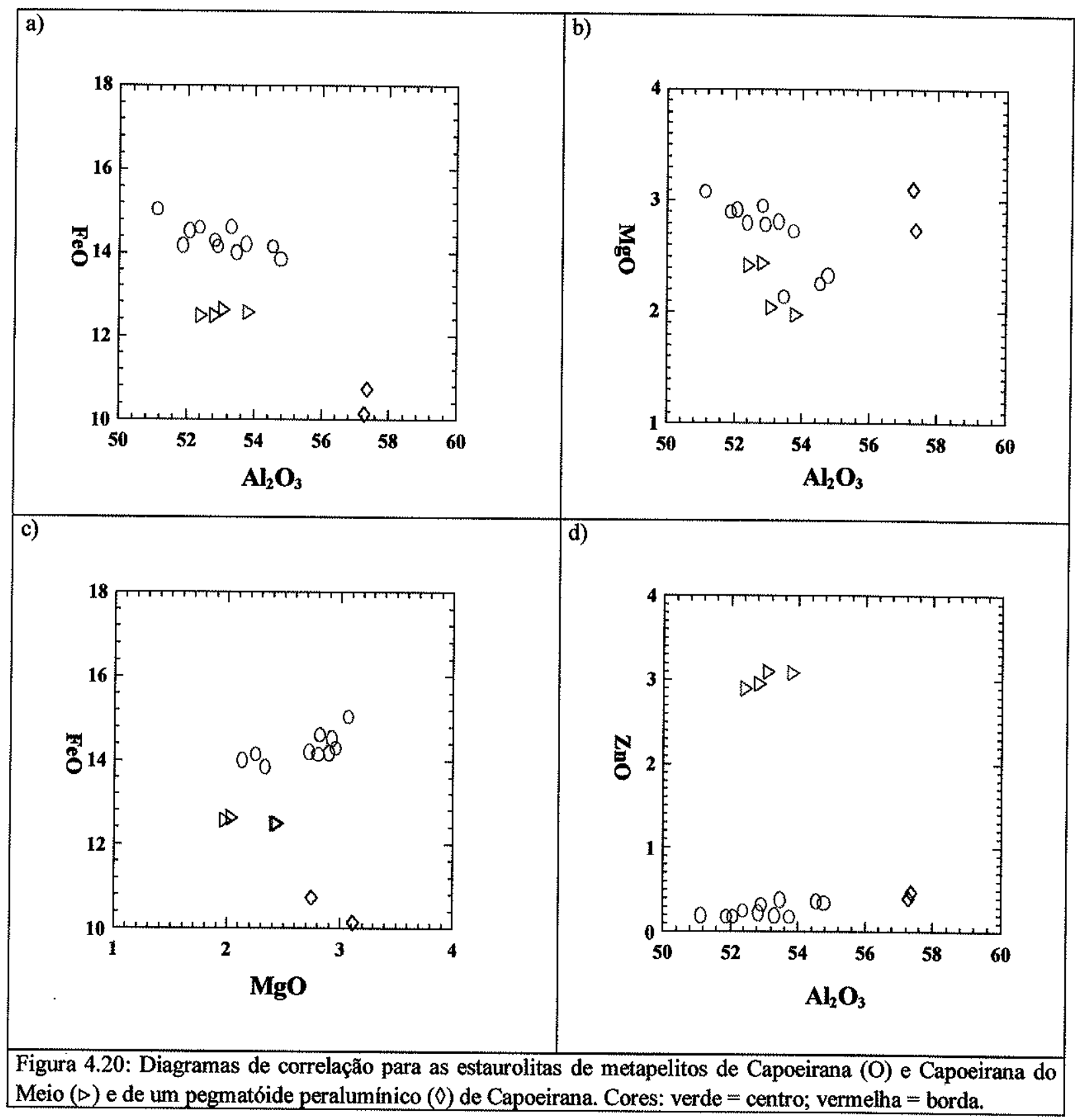

\section{IV.8 - CLORITA}

Foram efetuadas 13 análises de cloritas de rochas metaultramáficas/cromititos (amostras B-11 e B-18) de metamorfismo progressivo, e 03 análises de cloritas retrometamórficas da transformação das flogopitas das mineralizações de esmeraldas (amostras NE-31 e Sul-01). Os resultados recalculados com base em 36 oxigênios, encontram-se no Anexo 4 (Tab. A4.8). Adicionalmente, foram consideradas 09 (nove) análises de cloritas de metamorfismo progressivo de metapelito (de protólito hidrotermalizado) da amostra 286 (Schorscher, 1975) da porção centro-norte da área. 


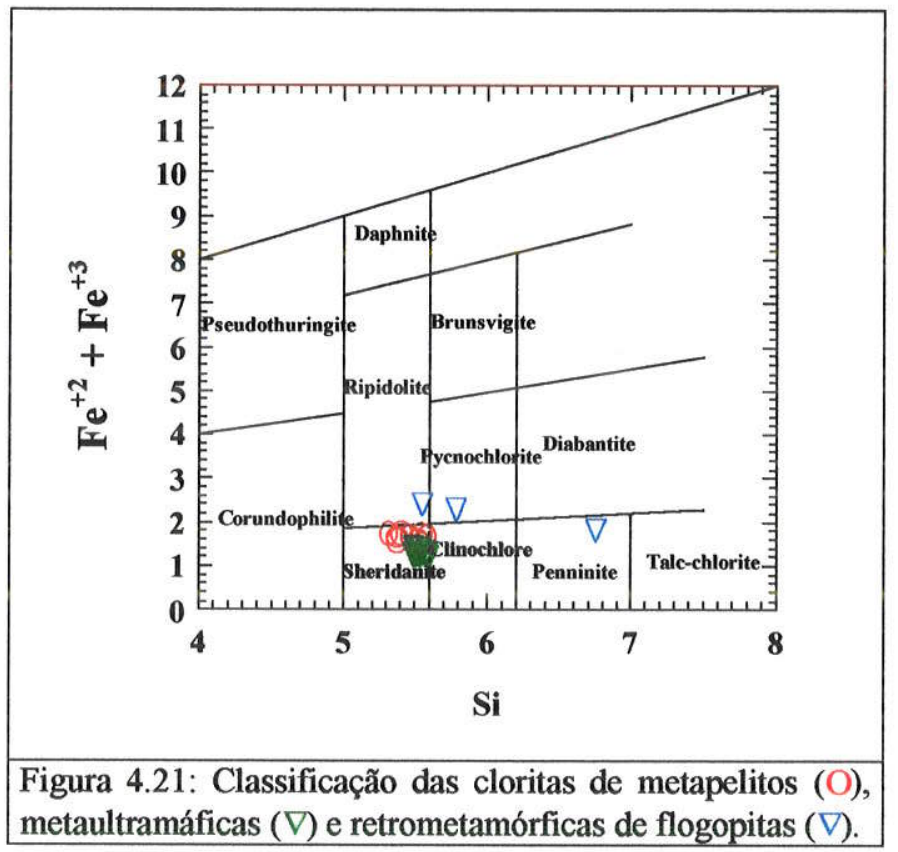

As cloritas dos metapelitos e das rochas metaultramáficas são as mais magnesianas ( $\mathrm{MgO}$, respectivamente, 24-29\% e 27-30\%). No diagrama de classificação, figuram no campo das sheridanitas, ao passo que as cloritas retrometamórficas, mais ricas em $\mathrm{Si}$ e $\mathrm{Fe}^{+2}$, apresentam espalhamento nos campos da ripidolita, pycnoclorita e penninita (Fig. 4.21). Cr ocorre em teores de 1.58 a $1.88 \%$ de peso nas cloritas das rochas metaultramáficas de metamorfismo progressivo. As demais cloritas são isentas ou têm baixos teores de $\mathrm{Cr}\left(\mathrm{Cr}_{2} \mathrm{O}_{3}\right.$ de 0.1 a $0.3 \%$ peso), ou não foram analisadas para $\mathrm{Cr}$ como é o caso da amostra 286 de Schorscher (1975).

\section{IV.9 - ESMERALDAS E ÁGUAS MARINHAS}

Foram analisadas esmeraldas de diferentes associações genéticas (mineralizações tipo xistos, veios de quartzo e veios pegmatóides) das jazidas de Capoeirana e Belmont, totalizando 85 análises pontuais via MSE e 13 análises por FRX e 17 por ICP-MS (estas últimas incluem 03 de águas-marinhas) em fragmentos de cristais (Tab. 4.10). Os dados foram tratados separadamente: os elementos principais (excluindo $\mathrm{BeO}$ ), alguns cromóforos e demais elementos menores e traço (sem ETR) no que se segue e os ETR em capítulo à parte (Cap. VI). 


\begin{tabular}{|c|c|c|c|c|c|}
\hline \multirow{2}{*}{$\begin{array}{c}\text { Tipos de } \\
\begin{array}{c}\text { Mineralização de } \\
\text { Esmeraldas }\end{array} \\
\end{array}$} & \multirow{2}{*}{ Amostras } & \multicolumn{3}{|c|}{ Métodos Analíticos } & \multirow{2}{*}{ Localidades } \\
\hline & & MSE & FRX & ICP-MS & \\
\hline $\begin{array}{c}\text { EX } \\
\text { (44: MSE; 03: ICP-MS) }\end{array}$ & $\begin{array}{l}\text { BE-04 } \\
\text { BE-08 } \\
\text { BE-06 } \\
\text { G-260 } \\
\end{array}$ & $\begin{array}{l}\mathrm{X} \\
\mathrm{X} \\
\mathrm{X}\end{array}$ & & $\begin{array}{l}\mathrm{X} \\
\mathrm{X} \\
\mathrm{X} \\
\end{array}$ & $\begin{array}{c}\text { Belmont } \\
\text { Belmont } \\
\text { Belmont } \\
\text { Cap. do Meio }\end{array}$ \\
\hline $\begin{array}{c}\text { EVQ } \\
\text { (20: MSE; 07: ICP-MS) }\end{array}$ & $\begin{array}{c}\text { B-21 } \\
\text { B-22 } \\
\text { BE-05 } \\
\text { NE-34 } \\
\text { NE-36a } \\
\text { NE-36b } \\
\end{array}$ & $\begin{array}{l}\mathrm{X} \\
\mathrm{X} \\
\mathrm{X} \\
\mathrm{X}\end{array}$ & & $\begin{array}{l}X \\
X \\
X \\
X \\
X \\
\end{array}$ & $\begin{array}{c}\text { Belmont } \\
\text { Belmont } \\
\text { Belmont } \\
\text { Capoeirana } \\
\text { Capoeirana } \\
\text { Capoeirana } \\
\end{array}$ \\
\hline $\begin{array}{c}\text { EVP } \\
\text { (21: MSE; 06: ICP-MS) }\end{array}$ & $\begin{array}{c}\text { NE-30 } \\
\text { NE-31 } \\
\text { NE-31-01 } \\
\text { NE-31-02 } \\
\text { NE-31-03 } \\
\text { NE-31-06 } \\
\text { Sul-01 } \\
\text { Gal } 1 / 2 \mathrm{a} \\
\end{array}$ & $\begin{array}{l}\mathrm{X} \\
\mathrm{X} \\
\mathrm{X} \\
\mathrm{X} \\
\mathrm{X} \\
\mathrm{X}\end{array}$ & & $\begin{array}{l}X \\
X \\
X \\
X \\
X \\
\\
X\end{array}$ & $\begin{array}{l}\text { Capoeirana } \\
\text { Capoeirana } \\
\text { Capoeirana } \\
\text { Capoeirana } \\
\text { Capoeirana } \\
\text { Capoeirana } \\
\text { Capoeirana } \\
\text { Capoeirana }\end{array}$ \\
\hline E-S/ID (13) & B-28 & & $\mathrm{X}$ & & Belmont \\
\hline Águas-Marinhas (4) & $\begin{array}{l}\text { G-39a } \\
\text { G-39b } \\
\text { G-39c }\end{array}$ & & & $\begin{array}{l}\mathrm{X} \\
\mathrm{X} \\
\mathrm{X}\end{array}$ & $\begin{array}{l}\text { PGD em MGF } \\
\text { PGD em MGF } \\
\text { VQ em MGF }\end{array}$ \\
\hline
\end{tabular}

Tabela 4.10: Relação das amostras com análises de esmeraldas e águas marinhas. EX = esmeraldas em xistos; $E V Q=$ esmeraldas em veios de quartzo; $\mathrm{EVP}=$ esmeraldas em veios pegmatóides; $\mathrm{E}-\mathrm{S} / \mathrm{ID}=$ esmeraldas sem identificação paragenética, escolhidas segundo critérios de cor; $\mathrm{PGD}$ em MGF $=$ veio pegmatóide em Metagranitoide Foliado com Fluorita; VQ em MGF = veio/mobilizado de quartzo associado a PGD em Metagranitóide Foliado com Fluorita; $(\mathrm{n})=$ número de análises.

\section{* Elementos principais e alguns cromóforos}

Os resultados das análises dos elementos principais, incluindo os recálculos da fórmula estrutural com base em 36 oxigênios, estão contidos no Anexo 4 (Tab. A4.9). Os teores médios, mínimos e máximos desses elementos nas esmeraldas de xistos (EX), esmeraldas de veios de quartzo (EVQ) e esmeraldas de veios pegmatóides (EVP) estão representados na Tabela 4.11. Comparativamente, as EX apresentam teores mais elevados $\mathrm{SiO}_{2}, \mathrm{Al}_{2} \mathrm{O}_{3}$ e $\mathrm{Cr}_{2} \mathrm{O}_{3}$ e os mais baixos de $\mathrm{MgO}$ e $\mathrm{Na}_{2} \mathrm{O}$; por outro lado, as EVP exibem os teores mais elevados de $\mathrm{MgO}$ e $\mathrm{Na}_{2} \mathrm{O}$ e os mais baixos de $\mathrm{Al}_{2} \mathrm{O}_{3}$ e $\mathrm{Cr}_{2} \mathrm{O}_{3}$; as EVQ apresentam composições intermediárias entre estes dois grupos.

Correlações negativas de $\mathrm{Al}_{2} \mathrm{O}_{3}$ com $\mathrm{MgO}$ e $\mathrm{Na}_{2} \mathrm{O}$ e positiva de $\mathrm{Na}_{2} \mathrm{O}$ com $\mathrm{MgO}$ são evidentes em diagramas binários (Fig. 4.22a,c,d). FeO não apresenta nenhuma correlação clara com estes óxidos, quando considerada a população analítica integral (Fig. $4.22 \mathrm{~b}, \mathrm{e}, \mathrm{f}$ ). No entanto, nas EX nota-se uma correlação positiva com o MgO (Fig. 4.22f). Esses diagramas confirmam, ainda, que as $\mathrm{EX}$, em geral, apresentam os teores mais elevados de $\mathrm{Al}_{2} \mathrm{O}_{3}$ e mais baixos de $\mathrm{MgO}$ e $\mathrm{Na}_{2} \mathrm{O}$. 


\begin{tabular}{|c|c|c|c|c|c|c|c|c|c|}
\hline \multirow{2}{*}{ Oxidos } & \multicolumn{3}{|c|}{ EX } & \multicolumn{3}{c|}{ EVQ } & \multicolumn{3}{|c|}{ EVP } \\
\cline { 2 - 11 } & Med & Min & Max & Med & Min & Max & Med & Min & Max \\
\hline $\mathrm{SiO}_{2}$ & 65.84 & 62.50 & 67.90 & 65.28 & 63.67 & 66.49 & 65.53 & 64.60 & 66.86 \\
\hline $\mathrm{TiO}_{2}$ & 0.00 & 0.00 & 0.02 & 0.01 & 0.00 & 0.04 & 0.01 & 0.00 & 0.10 \\
\hline $\mathrm{Al}_{2} \mathrm{O}_{3}$ & 16.88 & 15.16 & 17.82 & 15.67 & 14.23 & 16.88 & 15.59 & 14.88 & 16.09 \\
\hline $\mathrm{Cr}_{2} \mathrm{O}_{3}$ & 0.23 & 0.00 & 0.66 & 0.16 & 0.04 & 0.33 & 0.12 & 0.00 & 0.23 \\
\hline $\mathrm{ZnO}$ & 0.00 & 0.00 & 0.01 & 0.02 & 0.00 & 0.06 & 0.01 & 0.00 & 0.07 \\
\hline $\mathrm{FeO}$ & 0.64 & 0.38 & 1.03 & 0.72 & 0.48 & 0.90 & 0.67 & 0.52 & 0.96 \\
\hline $\mathrm{MnO}$ & 0.01 & 0.00 & 0.18 & 0.01 & 0.00 & 0.04 & 0.01 & 0.00 & 0.05 \\
\hline $\mathrm{MgO}$ & 1.51 & 1.20 & 1.95 & 2.09 & 1.15 & 3.08 & 2.15 & 1.80 & 2.59 \\
\hline $\mathrm{NiO}$ & 0.00 & 0.00 & 0.02 & 0.01 & 0.00 & 0.04 & 0.01 & 0.00 & 0.03 \\
\hline $\mathrm{CaO}$ & 0.02 & 0.00 & 0.13 & 0.06 & 0.01 & 0.11 & 0.04 & 0.01 & 0.08 \\
\hline $\mathrm{Na}_{2} \mathrm{O}$ & 1.21 & 0.85 & 1.61 & 1.34 & 0.76 & 1.88 & 1.46 & 1.25 & 1.76 \\
\hline $\mathrm{K}_{2} \mathrm{O}$ & 0.01 & 0.00 & 0.10 & 0.05 & 0.0 & 0.14 & 0.05 & 0.02 & 0.12 \\
\hline $\mathrm{P}_{2} \mathrm{O}_{5}$ & 0.01 & 0.00 & 0.14 & - & - & - & - & - & - \\
\hline $\mathrm{BaO}^{2} \mathrm{O}$ & - & - & - & - & - & - & 0.00 & 0.00 & 0.07 \\
\hline $\mathrm{F}$ & - & - & - & - & - & - & 0.01 & 0.00 & 0.10 \\
\hline $\mathrm{Cl}$ & 0.00 & 0.00 & 0.05 & - & - & - & - & - & - \\
\hline $\mathrm{SO}_{3}$ & 0.00 & 0.00 & 0.14 & - & - & - & - & - & - \\
\hline
\end{tabular}

Tabela 4.11: Composiçães médias (Med), mínimas (Min) e máximas (Max) das esmeraldas de diferentes associaçðes genéticas das jazidas de Capoeirana e Belmont.

As EVQ dividem-se em dois grupos composicionais, um representado pela amostra NE-36a (de Capoeirana) com os teores mais elevados de $\mathrm{MgO}$ e $\mathrm{Na}_{2} \mathrm{O}$ e mais baixos de $\mathrm{Al}_{2} \mathrm{O}_{3}$ de todas as amostras analisadas e outro pelas amostras B-21, B-22 e BE-05 (de Belmont) com teores elevados de $\mathrm{Al}_{2} \mathrm{O}_{3}$ e baixos de $\mathrm{MgO}$ e $\mathrm{Na}_{2} \mathrm{O}$, próximos daqueles das $\mathrm{EX}$ (Fig. 4.22a,c,d,f). Cabe ressaltar que as amostras destes dois grupos são, também, petrograficamente diferentes, sendo a primeira de veio de quartzo pouco deformado com esmeralda idiomórfica e as demais de veios de quartzo polideformados com esmeraldas deformadas, xenoblásticas a subidioblásticas.

As esmeraldas do lote B-28 de Belmont (sem identificação paragenética) obedecem a correlação FeO versus $\mathrm{MgO}$ das $\mathrm{EX}$, com exceção de duas análises com teores mais baixos de $\mathrm{MgO}$ e $\mathrm{Na}_{2} \mathrm{O}$ e mais altos de $\mathrm{Al}_{2} \mathrm{O}_{3}$ (Fig. 4.22f).

As esmeraldas são, em geral, homogêneas quimicamente. Porém, nas análises de centros e bordas observam-se algumas variações químicas mais freqüentes, embora nem sempre sistemáticas, tanto entre os tipos genéticos, quanto em uma mesma amostra. São estas:

* nas EX: diminuição de $\mathrm{Al}_{2} \mathrm{O}_{3}$ e aumento de $\mathrm{MgO}, \mathrm{FeO}$ e $\mathrm{Na}_{2} \mathrm{O}$;

* nas EVQ: aumento de $\mathrm{Al}_{2} \mathrm{O}_{3}$ e diminuição de $\mathrm{MgO}, \mathrm{FeO}$ e $\mathrm{Na}_{2} \mathrm{O}$;

* nas EVP: diminuição de $\mathrm{Al}_{2} \mathrm{O}_{3}$ e $\mathrm{FeO}$ e aumento de $\mathrm{MgO}$ e $\mathrm{Na}_{2} \mathrm{O}$.

Estas observações sugerem, pelo menos para as EX e EVP, a seguinte relação de substituição: $\mathrm{Al}^{+3(\mathrm{VI})}=\mathrm{Mg}^{+2(\mathrm{VI})}+\mathrm{Na}^{+ \text {(canal) }}$. 


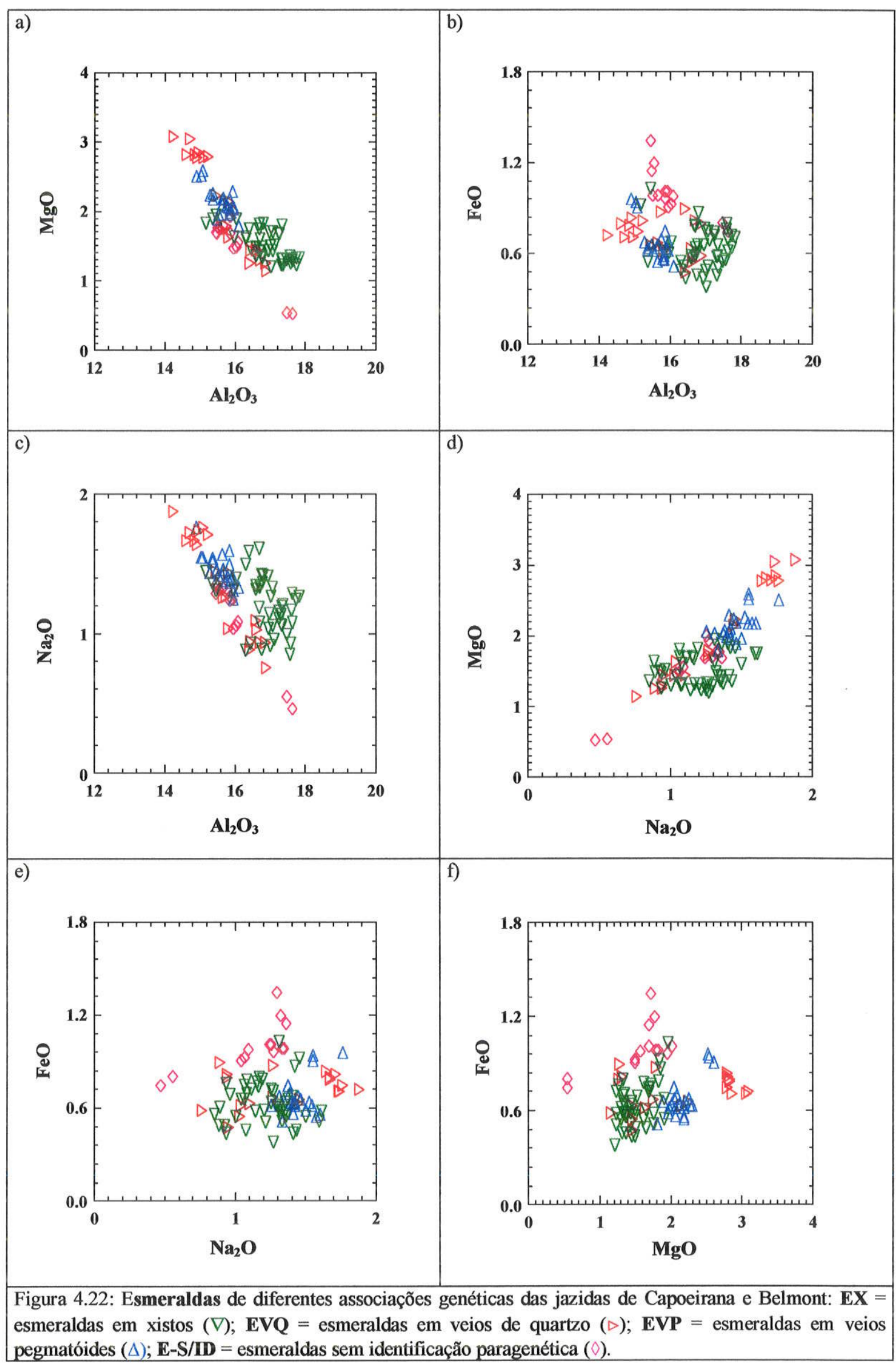


As rochas metaultramáficas flogopitizadas, hospedeiras das mineralizações, apresentam, para o litotipo, teores médios de $\mathrm{MgO}$ (16-19\% peso) e altos de $\mathrm{Na}_{2} \mathrm{O}(0.2-1.2 \%$ peso). Em decorrência, a concentração desses elementos nas esmeraldas é também média a alta $\left(\mathrm{MgO}=0.5\right.$ a $3.1 ; \mathrm{Na}_{2} \mathrm{O}=0.5$ a $1.9 \%$ peso) para o tipo mineral (cf.: Deer et al., 1992). A incorporação de $\mathrm{Na}^{+}$nos canais estruturais da esmeralda não depende só da disponibilidade deste elemento nos fluidos mineralizantes, mas principalmente, da compensação da deficiência de carga causada pela entrada de cátions bivalentes, na posição octaédrica. Isto significa que, a concentração de $\mathrm{Na}^{+}$nos canais varia proporcionalmente com os valores de $(\mathrm{Mg}, \mathrm{Fe})^{+2}$ da estrutura cristalina.

Nas análises do lote B-28, cujas esmeraldas foram separadas segundo critérios de cor, existe uma forte correlação entre intensidade da cor e aumento do teor de $\mathrm{Cr}_{2} \mathrm{O}_{3}$; no entanto, nenhuma correlação segura pode ser feita entre a cor e o teor de $\mathrm{FeO}$ ou $\mathrm{MgO}$ (Anexo 4, Tab. A4.9).

As esmeraldas das jazidas de Capoeirana e Belmont foram comparadas com as de outras localidades e revelaram teores médios em $\mathrm{Al}_{2} \mathrm{O}_{3}, \mathrm{FeO}, \mathrm{MgO}$ e $\mathrm{Na}_{2} \mathrm{O}$, sendo mais similares às esmeraldas de Carnaíba (Schwarz \& Eidt, 1989), Socotó (Schwarz et al., 1990) e da Zâmbia (Graziani et al., 1983) (Fig. 4.23).

\section{*Elementos Menores e Traço (sem ETR)}

As propriedades químicas são sensíveis indicadores genéticos e da procedência do berilo (esmeralda/água-marinha) e foram correlacionadas com suas propriedades físicas, especialmente, cor, índice de refração e peso específico (Schaller et al., 1962).

Para melhor caracterização da composição química das esmeraldas de Capoeirana e Belmont e de alguns cristais de águas marinhas de pegmatitos dos MGF, foram efetuadas análises multielementares por ICP-MS (58 elementos por amostra, incluindo ETR). As amostras analisadas são listadas na Tabela 4.10 e os resultados no Anexo 3 (Tab. A3.2). Neste capítulo, serão considerados somente os elementos menores/traço, sendo os ETR tratados em um capítulo próprio (Cap. VI). 

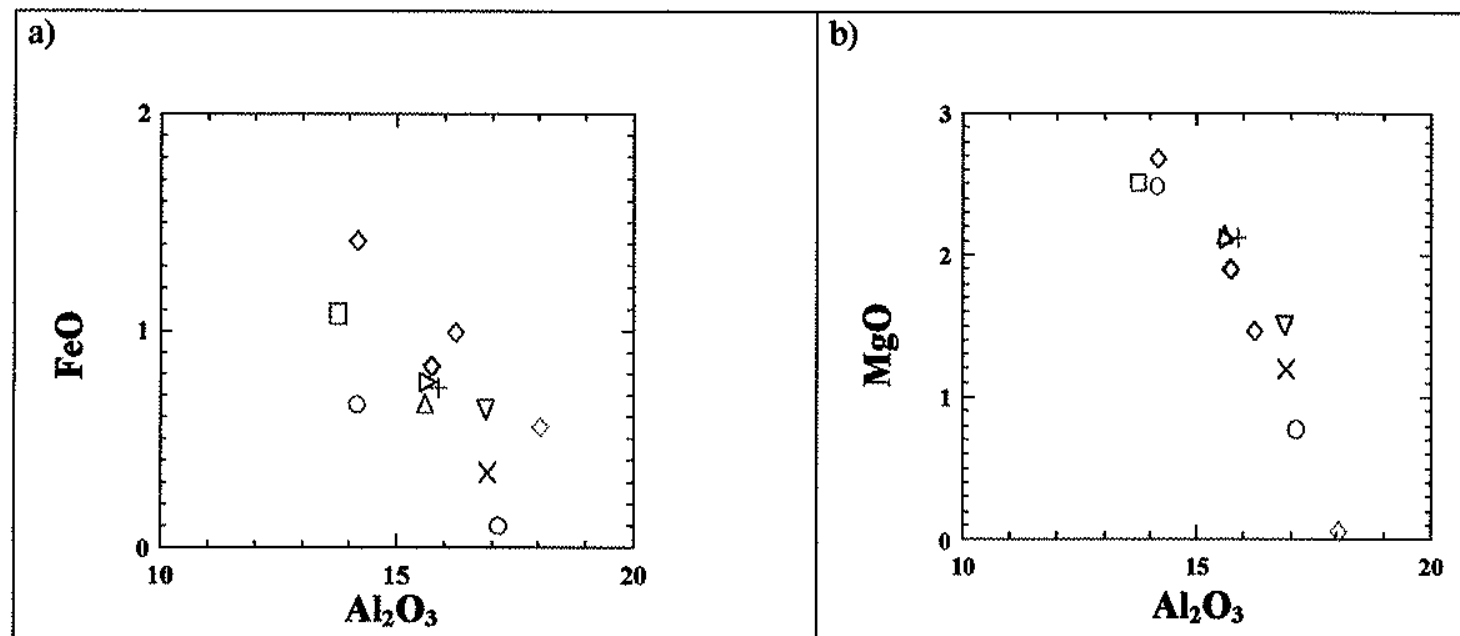

c)

d)

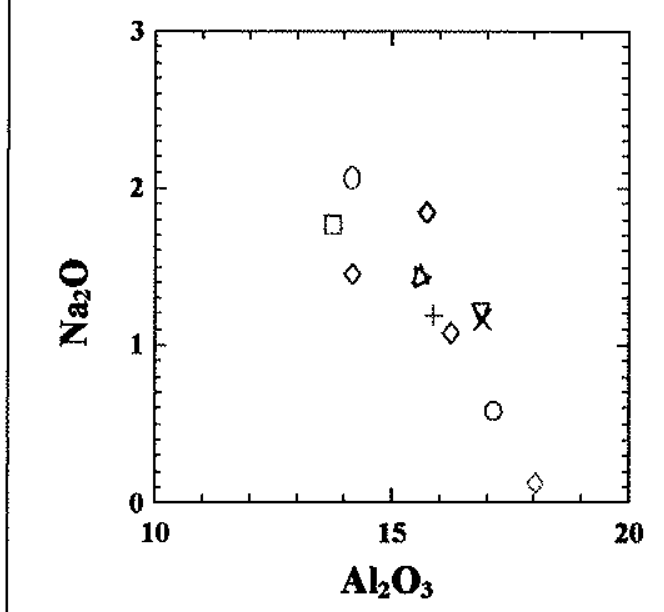

e)
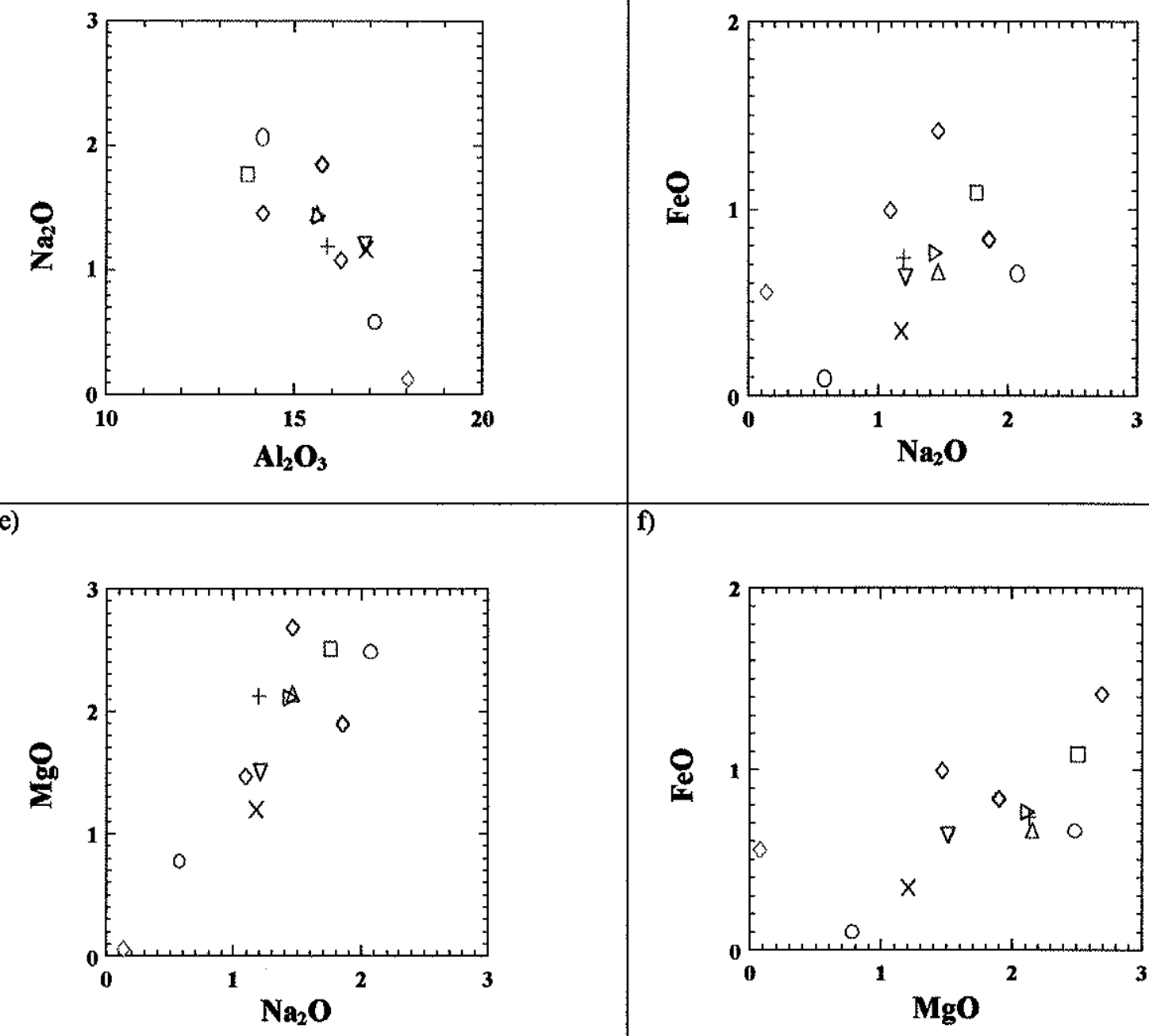

f)

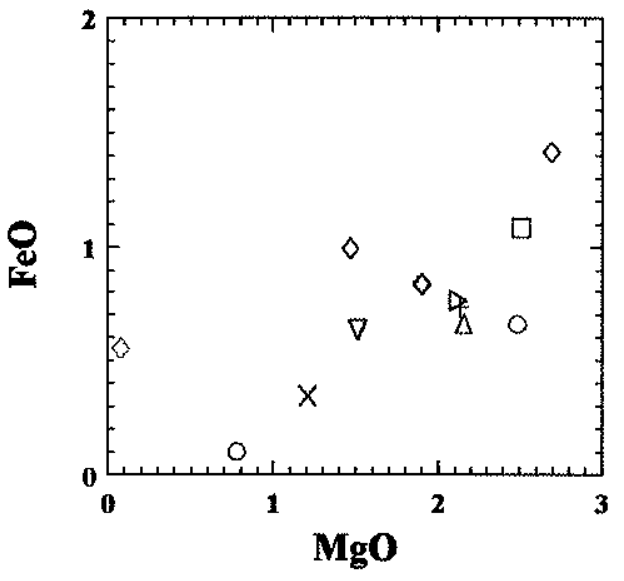

Figura 4.23: Composições médias das esmeraldas da área de estudo [EX $(\nabla)$, EVQ $(\triangleright)$, EVP $(\Delta)$, E-S/ID $(\diamond)]$ comparadas com as de outras localidades: Colômbia (O; Schwarz, 1992); Nigéria ( $)$; Schwarz et al., 1996); Áustria (O; Franz et al., 1986); Zâmbia ( $($; Graziani et al., 1983); Paquistão ( $\diamond$; Hussain et al., 1993); Urais (X; Schmetzer et al., 1991); Madagascar ( $\mathrm{\square}$; Schwarz \& Henn, 1992); Carnaíba/Socotó (+; Schwarz \& Eidt, 1989; Schwarz et al., 1990). 
Representadas em variogramas multielementares com normalizações condríticas (Sun \& McDonough, 1989; Taylor \& McLennan, 1985), as esmeraldas, em geral, são caracterizadas por enriquecimentos variáveis de $\mathrm{Cs}, \mathrm{Ba}, \mathrm{Rb}, \mathrm{Th}, \mathrm{U}, \mathrm{W}, \mathrm{Ta}, \mathrm{Nb}$ e $\mathrm{Sc}$ e empobrecimentos em $\mathrm{Mo}, \mathrm{Sr}, \mathrm{Cu}, \mathrm{Zn}, \mathrm{Ni}$ e $\mathrm{Cr}$. Os teores de $\mathrm{Pb}, \mathrm{Sn}$ e $\mathrm{V}$ estão próximos aos valores condríticos. Os elementos $\mathrm{Hf}, \mathrm{Zr}$ e $\mathrm{Y}$ apresentam variações consideráveis e irregulares, sendo desde empobrecidos a enriquecidos (Fig. 4.24).

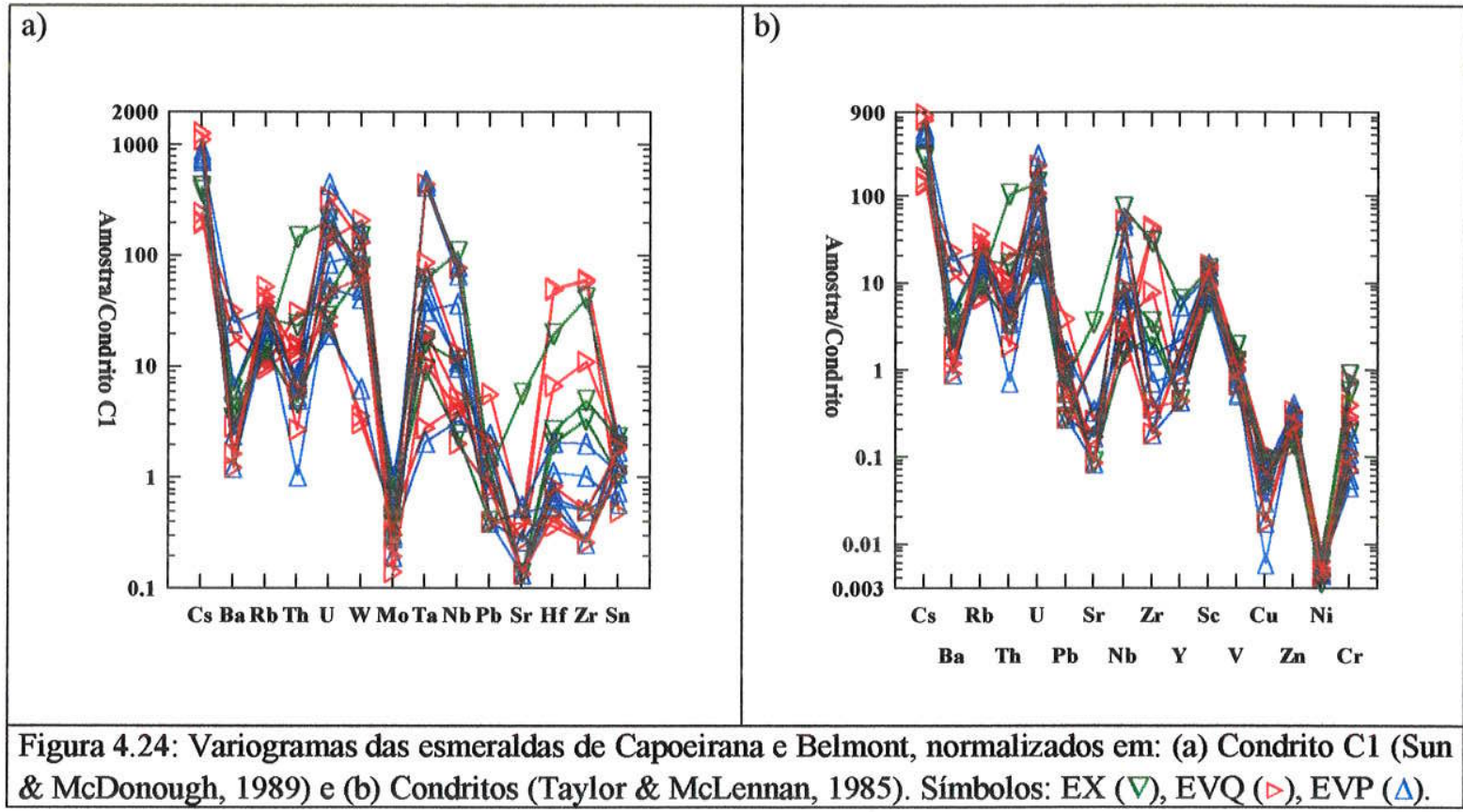

A concentração dos elementos litófilos $\mathrm{K}, \mathrm{Cs}, \mathrm{Ba}, \mathrm{Rb}$ e $\mathrm{Sr}$, considerados como móveis (Rollinson, 1993) em processos de interação fluidos-rochas, em geral, é uma função da fase fluida, enquanto que a concentração dos elementos de alta força de campo - HFSE (high field strengh elements) $\mathrm{Th}, \mathrm{U}, \mathrm{Zr}, \mathrm{Ta}, \mathrm{Nb}, \mathrm{Hf}$, entre outros, é, comumente, controlada pela química das rochas envolvidas no sistema mineralizante.

Em variogramas normalizados pelos valores médios das análises de GB e MGF, as esmeraldas, em geral, exibem enriquecimentos fortes de $\mathrm{Cs}, \mathrm{V}$ e $\mathrm{Cr}$ e fracos de $\mathrm{W}$ e Co e empobrecimentos em $\mathrm{Ba}, \mathrm{Rb}, \mathrm{Th}, \mathrm{U}, \mathrm{Pb}, \mathrm{Sr}, \mathrm{Y}, \mathrm{Zn}$ e Mo. Dos elementos enriquecidos, o Cs é um típico íon alcalino dos canais estruturais; $\mathrm{Cr}, \mathrm{V}$ e Co são elementos cromóforos e a posição do $\mathrm{W}$ é, ainda, desconhecida. Os teores de $\mathrm{Ga}, \mathrm{Sc}, \mathrm{Cu}$ e $\mathrm{Ni}$ estão próximos do padrão e os de $\mathrm{Ta}, \mathrm{Nb}$, Hf e $\mathrm{Zr}$ são variáveis, com tendências de empobrecimento (Fig. 4.25). 


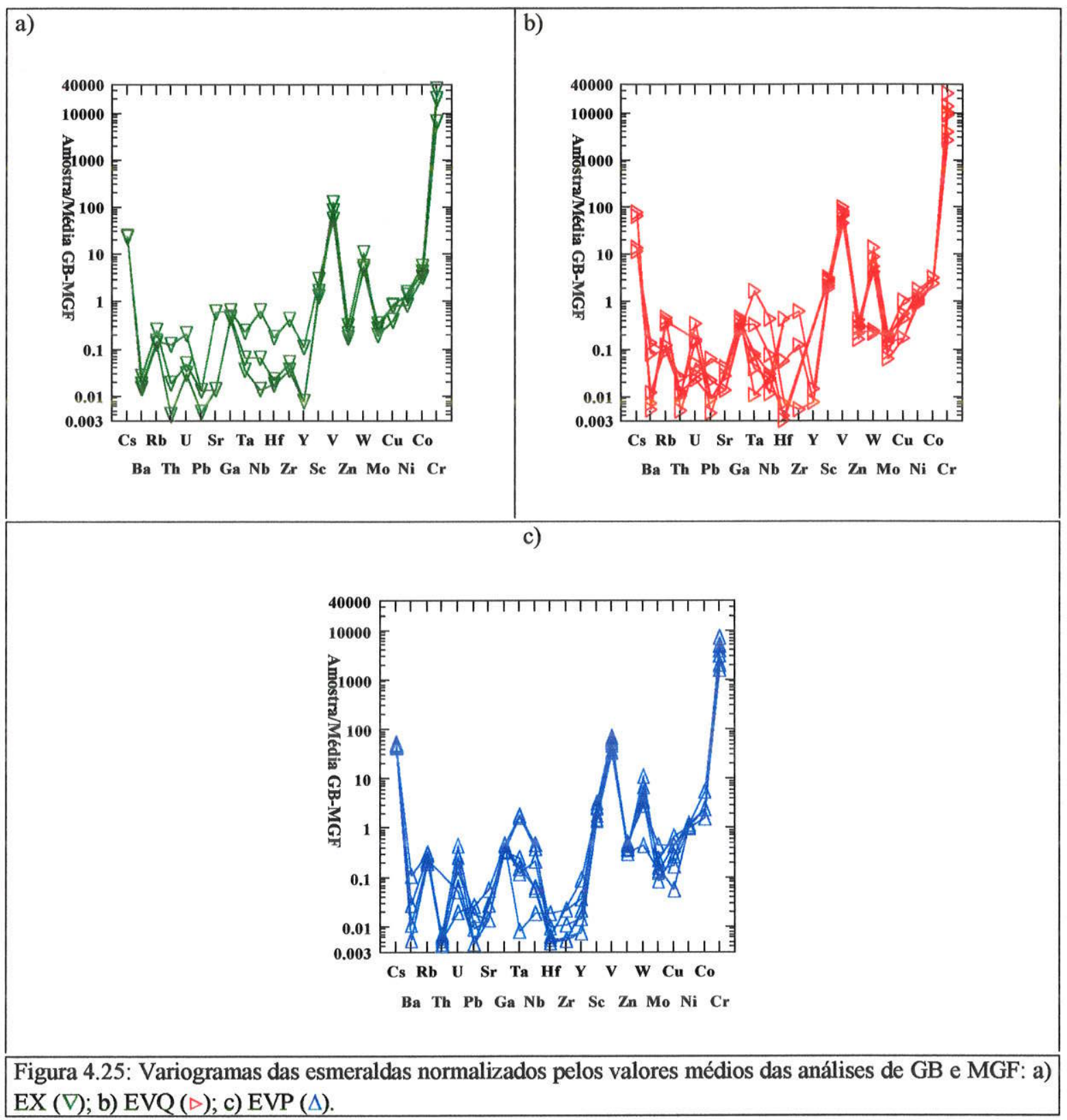

Comparativamente, as EVP são empobrecidas (fracamente) em $\mathrm{Hf}, \mathrm{Zr}, \mathrm{V}$ e $\mathrm{Cu}$ e (fortemente) em $\mathrm{Cr}$ em relação às EX e EVQ (Fig. 4.25). As EVQ são divididas em dois subgrupos representados por amostras ora enriquecidas (NE-34, NE-36a,b), ora empobrecidas (B-21 e B-22), principalmente, nos elementos Cs, Ba, Rb e W. Ressaltam-se, ainda, os elevados teores de $\mathrm{Y}$ e $\mathrm{Nb}$ da amostra G-260 (EX) em relação às demais amostras de esmeraldas (Anexo 4, Tab. A4.9).

As águas-marinhas são provenientes das porções pegmatóides - feldspáticas (AMP) e quartzosas (AMQ) de um pegmatito nos MGF. Apresentam composições distintas das esmeraldas, principalmente, quanto aos teores mais baixos de $\mathrm{Cs}$ e $\mathrm{Cr}$ e distintas entre si. Em variogramas com normalizações condríticas (Sun \& McDonough, 1989; Taylor \& McLennan, 
1985), as AMP são enriquecidas em $\mathrm{Cs}, \mathrm{Ba}, \mathrm{Rb}$, Th, U, W, Ta, Pb e Sc e empobrecidas em Sr, $\mathrm{Cu}, \mathrm{V}, \mathrm{Ni}$ e Cr. Os teores de $\mathrm{Mo}, \mathrm{Hf}, \mathrm{Zr}, \mathrm{Sn}, \mathrm{Nb}, \mathrm{Y}$ e $\mathrm{Zn}$ estão próximos do padrão. A única amostra de AMQ apresenta um padrão anômalo, com enriquecimentos, em parte, muito fortes de todos os elementos, exceto $\mathrm{Sn}$ com valores próximos do padrão e $\mathrm{Mo}, \mathrm{V}, \mathrm{Cu}, \mathrm{Zn}, \mathrm{Ni}$ e $\mathrm{Cr}$ empobrecidos (Fig. 4.26).

Normalizadas pela média de GB e MGF, as AMP exibem padrões similares às esmeraldas, diferindo, porém, por enriquecimentos menores de $\mathrm{Cs}, \mathrm{Sc}, \mathrm{Co}, \mathrm{Zn}$ e, sobretudo, V e Cr (cf. Fig. 4.25). A amostra de AMQ tem composição anômala representada, entre outros, pelos enriquecimentos em $\mathrm{Ba}$ e $\mathrm{Pb}$ e empobrecimentos em $\mathrm{Cs}$ e Zn (Fig. 4.27, cf.: Fig. 4.25).

a)

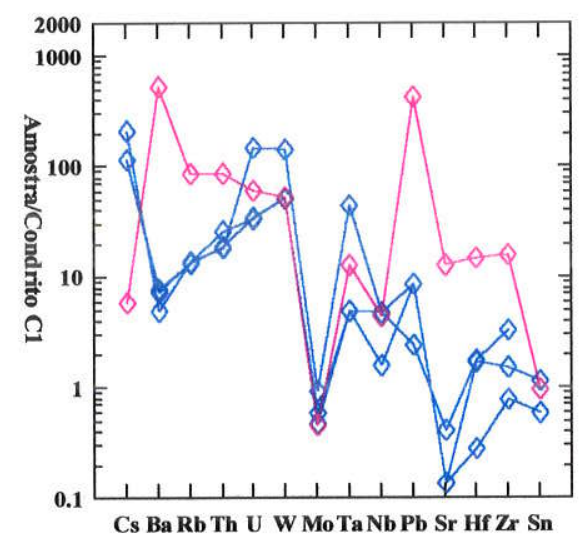

b)

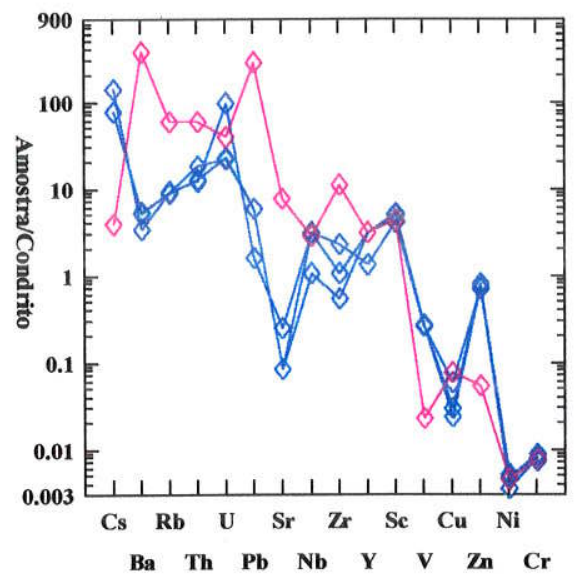

Figura 4.26: Águas marinhas - AMQ $(\diamond)$ e AMP $(\diamond)$, normalizadas em: (a) Condrito C1 (Sun \& McDonough, 1989) e (b) Condritos (Taylor \& McLennan, 1985).

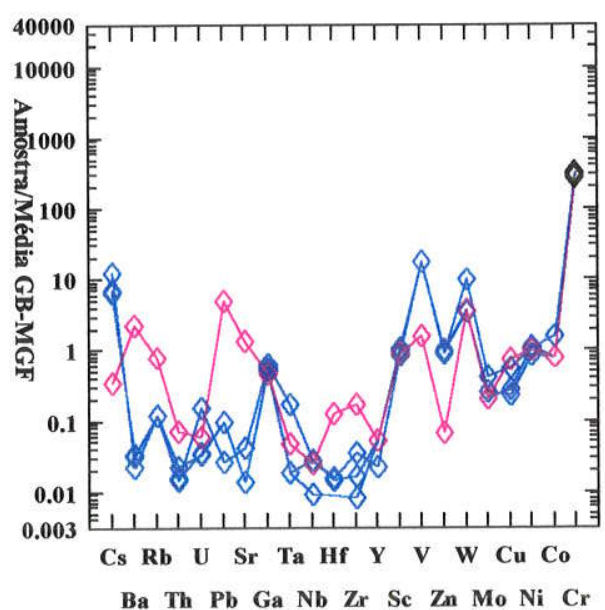

Figura 4.27: Águas marinhas - AMQ $(\diamond)$ e AMP $(\diamond)$, normalizadas em valores médios de GB e MGF. 


\section{IV.10 - SINOPSE DOS ESTUDOS DE QUÍMICA MINERAL}

Dos estudos de química mineral dos constituintes principais das rochas sensu lato graníticas TTG, GB e MGF e das rochas da SVS e, ainda, das mineralizações berilíferas da região de Capoeirana e Belmont resumem-se alguns resultados principais, a seguir descritos por grupos de minerais.

- As biotitas apresentam composições distintas nos diferentes tipos litológicos, sendo nos GB e MGF as mais ricas em Fe e nas rochas metaultramáficas e em alguns metapelitos (de protólitos hidrotermalizados) as mais ricas em magnésio; em cada grupo observam-se variações de $\mathrm{Al}^{\mathrm{IV}}$ para valores constantes de $\# \mathrm{Fe}^{+2}$. As substituções verificadas são de $\mathrm{Fe}^{+2}$ por $\mathrm{Al}^{\mathrm{VI}}$ e/ou Mg, em proporções variáveis, com exceção das rochas metapelíticas, em que um aumento de $\mathrm{Fe}^{+2}$ é acompanhado de um aumento de $\mathrm{Al}^{\mathrm{VI}} \mathrm{e}$, ainda, em parte das amostras dos MGF, em que um aumento de $\mathrm{Fe}^{+2}$ é acompanhado de um aumento de $\mathrm{Mg}$. Os zoneamentos foram melhores observados nas biotitas dos MGF e, ainda, dos anfibolitos $\mathrm{AB} / \mathrm{ABET}$ e metapelitos (MP), sendo caracterizados por: aumento de $\mathrm{MgO}$ e $\mathrm{Al}^{\mathrm{lV}}$ nos MGF e aumento de $\mathrm{MgO}$ e dimuição de $\mathrm{FeO}$ nos $\mathrm{AB} / \mathrm{ABET}$ e MP. As flogopitas das rochas metaultramáficas metassomatizadas mostram zoneamento composicional fraco, com bordas ligeiramente enriquecidas em $\mathrm{MgO}$. Eventuais bordas externas mais ricas em $\mathrm{FeO}$ nas biotitas de todos os litotipos devem-se a reajustes retrometamórficos locais, finais, associados a fraturamento e hidratação, incluindo cloritização e argilitização.

- Os anfibólios compreendem dois grupos petrográficos: anfibólios verdes e anfibólios incolores. Nas rochas graníticas ocorrem somente anfibólios verdes e nas rochas metaultramáficas e metabásicas da SVS ocorrem, às vezes associados, anfibólios verdes e anfibólios incolores; nos metapelitos, anfibólios verdes são raros, sendo comuns os anfibólios incolores. Os anfibólios verdes são cálcicos, predominando hastingsitas nos GB e MGF e hornblendas edeníticas/hornblendas pargasíticas ferrosas nas rochas da SVS; os anfibólios incolores são ferromagnesianos, predominando cummingtonitas/Mgcummingtonitas. Zoneamentos nos anfibólios verdes são caracterizados, comparativamente, nos GB por maior ocupação do sítio A e por enriquecimentos em $\mathrm{MgO}$ e nos MGF por empobrecimentos em $\mathrm{TiO}_{2}$ e $\mathrm{MgO}$; nos $\mathrm{AB}$ da SVS, nota-se, com maior freqüência, aumento de $\mathrm{MgO}$ e diminuição de FeO. Os anfibólios incolores têm composições relativamente homogênas nos litotipos analisados (UM, ABG e MP), com 
tendências de aumento de $\mathrm{MgO}$ nas bordas mais externas nas UM e nos $\mathrm{ABG}$; já nos MP, observa-se uma tendência inversa de diminuição de $\mathrm{MgO}$.

- Os plagioclásios nos GB e MGF são muito similares; a variação total é de oligoclásio a albita, com tendências algo mais albíticas nos MGF. Os zoneamentos são inversos dos centros para as bordas internas e normais até albitas virtualmente puras nas bordas externas. Nos GB ocorre, ainda, biotita esfoliada com lentes interfoliares de albita pura, produto de metasomatismo sódico tardio em relação ao principal metamorfismo regional proterozóico. Os plagioclásios dos veios pegmatóides intrusivos na SVS têm composição andesina-oligoclásio e zoneamento normal restrito, também indicado microscopicamente pela distribuição da saussuritização. Nos anfibolitos metabásicos $A B, A B E T$ e $A B G$ as variações são na faixa oligoclásio/andesina; de um modo geral, esses plagioclásios exibem zoneamento inverso, metamórfico progressivo, dos centros até as bordas internas, com reequilibração albítica das bordas externas. Nos metapelitos da porção central da área e do garimpo de Capoeirana, os plagioclásios são, em geral, oligoclásios bastante homogêneos, porém, com diferentes teores de An decorrentes das variações na composição global dos protólitos. Os teores de ortoclásio em todos os plagioclásios são baixos; os valores mais elevados ocorrem nos $\mathrm{ABG}$ (Or $\leq 2.2$ ). Efeitos do zoneamento metamórfico principal inverso foram observados somente nos $\mathrm{AB}$, caracterizados por aumentos simultâneos de Or e An dos centros para as bordas internas; nas bordas externas, a reequilibração para albitas puras é, em geral, acompanhada de decréscimo de Or. Este efeito é também e ainda melhor observado nos GB e MGF. Nos plagioclásios (com zoneamento normal) dos veios pegmatóides, os teores de Or são sempre muito baixos (Or $\leq 0.6$ ). Dos elementos menores, ocorre, com maior frequência, o FeO, entretanto, os teores $\geq 0.2 \%$ peso em albitas puras (com An $<5$ ) foram considerados como efeitos de contaminação/interferência. Nos demais casos, os teores maiores de Fe, $\mathrm{Mn}, \mathrm{Mg}$ ocorrem, em geral, nos plagioclásios mais cálcicos.

- Os feldspatos potássicos apresentam composições muito puras (Or $>92)$ e fracos zoneamentos com bordas mais ricas em Or. Nos MGF são algo mais puros do que nos GB, reforçando a petrogênese dos MGF a partir dos GB e a formação de pegmatóides por fusão incipiente dos MGF. Em alguns $\mathrm{AB}$ e $\mathrm{ABG}$ ocorrem feldspatos potássicos praticamente puros livres/intersticiais na matriz e em lentes em biotitas esfoliadas. Feldspatos potássicos puros em lentes em biotitas esfoliadas ocorrem, ainda, nas rochas 
TTG e em flogopitas esfoliadas de rochas metaultramáficas. A pureza, a pequena variabilidade composicional, as características texturais e a ocorrência incomum em rochas metamáficas apontam para as origens metassomáticas tardi-sin a pós-metamórficas em relação ao evento regional principal, desses minerais. Teores de $\mathrm{FeO}$ acima de $0.3 \%$ peso em feldspatos potássicos outrossim puros $(\mathrm{Ab}<5)$ foram considerados, em função da variabilidade analítica geral, como efeitos de contaminação/interferência analítica (de opacos finamente disseminados nas lentes de feldspato potássico e/ou das biotitas/flogopitas e demais minerais máficos associados ou inclusos.

- As granadas nos GB, ABG e MP são, em geral, almandinas, homogêneas, com pequenas variações dos teores de grossulária, piropo e espessartita. Caracterizam-se, na sequência de GB para $A B G$ e MP, por teores decrescentes de $\mathrm{CaO}+\mathrm{MnO}$ e crescentes de $\mathrm{FeO}+$ $\mathrm{MgO}$, ressaltando-se as granadas dos GB como virtualmente isentas de $\mathrm{MgO}$. Tanto nos GB quanto nos $A B G$ ocorrem subgrupos com variações composicionais menores que se devem a pequenas diferenças nos protólitos. Os zoneamentos entre centros e bordas, considerando-se os elementos individuais, não são sistemáticos entre os grupos litológicos e mesmo nas amostras de um mesmo grupo/subgrupo.

- As cordieritas dos MP apresentam variaçóes composicionais restritas com teores de $\mathrm{SiO}_{2}$ e $\mathrm{MgO}$, em geral, constantes. Pequenas variações de $\mathrm{Fe}^{+2}$ e $\mathrm{Mn}$ indicam os controles composicionais dos protólitos. Os zoneamentos são caracterizados por decréscimos e aumentos sistemáticos, embora pequenos, respectivamente, de $\mathrm{FeO}$ e $\mathrm{MgO}$, sendo efeitos do principal metamorfismo regional progressivo.

- As estaurolitas dos MP de Capoeirana (leste da área) são mais ricas em MgO e FeO do que as de Capoeirana do Meio (centro da área) que, por sua vez, tem teores elevados de $\mathrm{Zn}(\mathrm{ZnO} \cong 3 \%)$ As variações expressivas de $\mathrm{Zn}$ denotam as variações nos protólitos; seu significado petrometalogenético não foi verificado. As estaurolitas de um pegmatóide peralumínico destacam-se por teores mais baixos de $\mathrm{FeO}$ e mais elevados em $\mathrm{Al}_{2} \mathrm{O}_{3}$. Em geral, as estaurolitas apresentam bordas enriquecidas em $\mathrm{SiO}_{2}$ e $\mathrm{Al}_{2} \mathrm{O}_{3}$ e empobrecidas em $\mathrm{MgO}$, indicativas da sua substituição progressiva por cordieritas.

- As cloritas dos metapelitos e das rochas metaultramáficas são magnesianas (MgO, respectivamente, $24-29 \%$ e $27-30 \%$ ), tendo sido classificadas como sheridanitas; cloritas retrometamórficas têm menor $\mathrm{MgO}$ e são mais ricas em $\mathrm{FeO}$. Cr ocorre em teores de 1.58 
a $1.88 \%$ de peso nas cloritas das rochas metaultramáficas de metamorfismo progressivo; as demais cloritas são isentas ou têm baixos teores de $\mathrm{Cr}\left(\mathrm{Cr}_{2} \mathrm{O}_{3}<0.3 \%\right.$ peso).

- As esmeraldas foram analisadas por grupos, segundo suas paragênese minerais. As EX apresentam os teores mais elevados de $\mathrm{SiO}_{2}, \mathrm{Al}_{2} \mathrm{O}_{3}$ e $\mathrm{Cr}_{2} \mathrm{O}_{3}$ e mais baixos de $\mathrm{MgO}$ e $\mathrm{Na}_{2} \mathrm{O}$; diferentemente, as EVP exibem os teores mais elevados de $\mathrm{MgO}$ e $\mathrm{Na}_{2} \mathrm{O}$ e mais baixos de $\mathrm{Al}_{2} \mathrm{O}_{3}$ e $\mathrm{Cr}_{2} \mathrm{O}_{3}$. Já as EVQ têm composições intermediárias entre estes dois grupos e caracterizam, ainda, duas populações genéticas distintas. Uma de esmeraldas idiomórficas em veios de quartzo pouco deformados (só observadas em Capoeirana), com teores mais elevados de $\mathrm{MgO}$ e $\mathrm{Na}_{2} \mathrm{O}$ e mais baixos de $\mathrm{Al}_{2} \mathrm{O}_{3}$ e a outra de esmeraldas fortemente deformadas em veios de quartzo polideformados (observados tanto em Belmont, quanto em Capoeirana), com teores elevados de $\mathrm{Al}_{2} \mathrm{O}_{3}$ e baixos de $\mathrm{MgO}$ e $\mathrm{Na}_{2} \mathrm{O}$, próximos daqueles das EX. As variações químicas, embora muito restritas e não sistemáticas, sugerem, pelo menos para as EX e EVP, a substituição de $\mathrm{Al}^{3+(\mathrm{VI})}=\mathrm{Mg}^{2+(\mathrm{VI})}$ $+\mathrm{Na}^{+ \text {(canal) }}$. Isso indica que a concentração de $\mathrm{Na}^{+}$nos canais varia proporcionalmente com os valores de $(\mathrm{Mg}, \mathrm{Fe})^{+2}$ da estrutura cristalina. As composições das esmeraldas exibem, em relação aos valores médios dos GB e MGF, em geral, enriquecimentos fortes de $\mathrm{Cs}, \mathrm{V}$ e $\mathrm{Cr}$ e fracos de $\mathrm{W}$ e Co e empobrecimentos em $\mathrm{Ba}, \mathrm{Rb}, \mathrm{Th}, \mathrm{U}, \mathrm{Pb}, \mathrm{Sr}, \mathrm{Y}, \mathrm{Zn}$ e $\mathrm{Mo}$, sendo o Cs um típico íon alcalino dos canais estruturais de todos os berilos e $\mathrm{Cr}, \mathrm{V}$ e Co elementos cromóforos da variedade esmeralda.

- As águas-marinhas provenientes das porções pegmatóides (AMP) e quartzosas (AMQ) de um pegmatito nos $\mathrm{MGF}$, apresentam composições distintas entre si e das esmeraldas (especialmente, quanto aos teores mais baixos de $\mathrm{Cs}$ e $\mathrm{Cr}$ ). Em relação aos valores médios dos GB e MGF, as AMP exibem padrões similares às esmeraldas, diferindo, porém, por enriquecimentos menores de $\mathrm{Cs}, \mathrm{Sc}, \mathrm{Co}, \mathrm{Zn}$ e, sobretudo, $\mathrm{V}$ e $\mathrm{Cr}$; a amostra de AMQ tem composição anômala caracterizada por enriquecimentos em $\mathrm{Ba}$ e $\mathrm{Pb}$ e empobrecimentos em Cs e Zn.

Esses resultados sutentam a evolução petrograficamente reconstruída para o polimetamorfismo proterozóico, incluindo um evento principal progressivo de grau médioalto que causou avançada homogeneização de todos os minerais metamórficos principais com reequilibrações retrometamórficas finais e/ou posteriores subordinadas. Já as variações nas esmeraldas e águas marinhas corroboram e contribuem na distinção dos diferentes tipos/gerações de mineralizações e respectivos processos mineralizantes. 


\section{CAPÍTULO V - EVOLUÇÃO METASSOMÁTICA/ METAMÓRFICA - GEOTERMOBAROMETRIA}

\section{V.1 - INTRODUÇÃO}

As rochas TTG, da SVS e os GB foram transformadas, afetadas e/ou geradas no final da evolução do ciclo greenstone belt regional Rio das Velhas, por metamorfismo de grau fraco a médio, tectonismo e metassomatismo localmente forte, incluindo a evolução de zonas de cizalhamento crustais de extensões regionais e profundas em processos arqueanos relacionados à orogênese do greenstone belt. Seguiu-se, no final do Paleoproterozóico a início do Mesoproterozóico, o principal evento tectono-metamórfico regional progressivo do Ciclo Minas/Espinhaço (Schorscher, 1992) de grau médio a forte por toda a área, que resultou inclusive na transforção dos GB em MGF. Por último, a área foi afetada no Neoproterozóico por reativações e retrabalhamentos tectono-termais, fracos, do Ciclo Brasiliano que proporcionou reequilibrações retrometamórficas locais e reajustes gerais, parciais a totais, dos principais sistemas isotópicos utilizados em geocronologia.

Neste capítulo, serão tratadas as condições dos processos polimetamórficos com enfoque no principal evento de metamorfismo regional dínamo-termal porgressivo paleo a mesoproterozóico e nos processos metamórficos e metassomáticos geradores e transformadores das mineralizações de esmeraldas de Belmont e Capoeirana e, em geral, das demais mineralizações berilíferas regionais.

\section{V.2 - ASSEMBLÉIAS MINERAIS}

Os estudos de petrografia metamórfica por grupos litológicos visaram reconstruir a evolução polimetamórfica, estabelecendo as assembléias minerais e principais reações, com enfoques naquelas para as quais já existem calibrações geotermobarométricas na literatura. Para isto, foram selecionadas as rochas metapelíticas (MP), os anfibolitos metabásicos com granada ( $A B G$ ), as rochas metaultramáficas e os metagranitóides (GB e MGF).

Serão utilizadas as seguintes abreviações para os minerais das assembléias encontradas e consideradas: alm (almandina), an (anortita), antf (antofilita), ap (apatita), bt (biotita), ky (cianita), clo (clorita), clz (clinozoizita), crn (córindon), cord (cordierita), cum (cummingtonita), ep (epidoto), fibrol (fibrolita), gr (granada), gross (grossulária), hb (hornblenda), kf (feldspato potássico), mu (muscovita), op (minerais opacos), plag 
(plagioclásio), qz (quartzo), ru (rutilo), sil (silimanita), srp (serpentina), stau (estaurolita), tc (talco), tit (titanita) e tscher (tschermakita).

\section{V.2.1 - METAPELITOS (MP)}

Os pelitos respondem mais sensivelmente as mudanças de $\mathrm{P}$ e $\mathrm{T}$, sendo, portanto, bons indicadores do metamorfismo. As principais assembléias minerais verificadas nos xistos/gnaisses metapelíticos, ordenadas de mais baixo para mais alto grau metamórfico, são:

(I) $\mathrm{qz}+\mathrm{mu} \pm \mathrm{bt}$;

(II) $\mathrm{plag}+\mathrm{qz}+\mathrm{bt}+\mathrm{clo}+\mathrm{gr}+\mathrm{op} \pm \mathrm{kf} \pm \mathrm{mu} \pm \mathrm{ap} \pm \mathrm{ru}$;

(III) $p l a g+q z+g r+c u m+o p \pm h b \pm b t \pm c l o$;

(IV) $g r+s t a u+b t+p l a g+q z+o p \pm c u m \pm c l o ;$

(V) $\mathrm{ky}+\mathrm{mu}+\mathrm{qz}$;

(VI) stau $+\mathrm{ky}+\mathrm{bt}+\mathrm{clo}+\mathrm{qz}+$ plag \pm cum $\pm \mathrm{hb} \pm \mathrm{ru} \pm$ fibrol;

(VII) sil $+\mathrm{ky}+\mathrm{bt}+\mathrm{clo}+\mathrm{qz} \pm$ plag;

(VIII) cum $+\mathrm{stau}+\operatorname{cord}+\mathrm{q} z+\mathrm{bt}+\mathrm{clo}+\mathrm{ru}+\mathrm{op}$;

(IX) bt + stau + cum + gr + cord + sil + clo + qz + ru + op \pm fluorita;

$(\mathrm{X}) \mathrm{ky}+\mathrm{stau}+$ cord $+\mathrm{crn} \pm$ plag \pm qzo.

Destas, apenas aquelas de maior importância petrogenética serão, brevemente, discutidas.

A primeira ocorrência de granada nas rochas metapelíticas estudadas verifica-se na porção centro-oeste da área mapeada (Ponto 110 deste trabalho e 232 de Schorscher, 1975); porém, sua presença extende-se além dos limites W e E (Schorscher, 1975).

As associações do tipo (II) são caracterizadas pela presença da granada em equilíbrio com biotita e rutilo, sendo típicas do intervalo de temperatura mais elevada do metamorfismo de grau fraco, conhecido em metapelitos como zona da granada (Barrow, 1912; Winkler, 1976). No gnaisse metapelítico G-203, os cristais xenomórficos de granada tem formas alongadas e contém inclusões de quartzo, plagioclásio, biotita/clorita e opacos, orientadas segundo o alongamento do cristal. Estas características aliadas à presença de rutilo associado sugerem que a reação (5.1) pode ter se processado.

$$
* \mathrm{mu}+\mathrm{clo}+\mathrm{plag}+\mathrm{il}+\mathrm{qz}=\mathrm{alm}+\mathrm{bt}+\mathrm{ru}+\mathrm{H}_{2} \mathrm{O} \text { (Trzcienski Jr., 1977) }
$$

Para produzir granada devem ser ultrapassadas as pressões de $4 \mathrm{~kb}$ a $500^{\circ} \mathrm{C}$ e de $5 \mathrm{~kb}$ a $600^{\circ} \mathrm{C}$; porém, se a granada contém quantidade apreciável do componente espessartita, os 
valores de pressão serão menores, estimados em $2 \mathrm{~kb}$ (cf.: Winkler, 1976), o que não é o caso das granadas almandinas dos metapelitos estudados com teores de espessartita $<4.8 \%$ moleculares (ver Cap. IV, item IV.5 e Anexo 4, Tab. A4.5).

A zona da granada é, ainda, marcada por uma mudança na composição do plagioclásio metamórfico (tanto em metapelitos e outros metassedimentos, como em rochas metaígneas), sendo que, em graus mais baixos ocorre albita e na zona da granada, oligoclásio ou andesina. Os plagioclásios das rochas da SVS apresentam composições intermediárias entre oligoclásio e andesina (com exceção de algumas albitas quase puras, metassomáticas, que ocorrem em lentes de flogopitas esfoliadas em rochas metaultramáficas, entre outras).

Assembléias de tipo IV (gr + stau $+b t+$ plag $+q z+o p \pm$ cum \pm clo) são caracterizadas pela presença de estaurolita e granada, podendo o anfibólio ocorrer em algumas amostras (Pontos 52 e 89). Zoneamentos texturais em granadas são, por vezes, acompanhados de zoneamentos químicos representados por um aumento de $\mathrm{FeO}$ e diminuição de $\mathrm{CaO}$ e $\mathrm{MnO}$ do centro para borda (por ex.: G-52c; Anexo 4). Estes zoneamentos resultam, segundo Woodsworth (1977) e Anderson \& Olimpio (1977), da progressão metamórfica. Entretanto, as granadas estudadas são, com maior freqüência, homogêneas ou as variações químicas são muito pequenas, insuficientes para caracterizar zoneamento (Anexo 4). Para Anderson \& Olimpio (1977), a homogeneização das granadas ocorre em altas temperaturas (nas zonas da cianita, da silimanita ou da cordierita) em função do gradiente químico e dos processos de difusão intracristalina do interior para as bordas do mineral.

Comumente, as granadas apresentam inclusões de estaurolitas e as estaurolitas inclusões de granadas, quartzo e biotita. Muitas reações foram sugeridas para explicar a formação da estaurolita. Chinner (1967) considerou ser o cloritóide um importante mineral formador de estaurolita. Hoschek $(1967 ; 1969)$ demonstrou que tanto o cloritóide quanto a estaurolita somente se formam em litotipos com composições químicas específicas. $O$ cloritóide não foi observado em nenhuma amostra dos metapelitos analisados, o que pode indicar que ele tenha sido consumido para formação da estaurolita. Neste sentido, é de interesse mencionar que na região de Itabira, a W e NW, em continuidade física com a área dessa pesquisa, Schorscher $(1975 ; 1976)$ descreveu paragêneses com cloritóide que ocorre como relictos armados em granadas de metapelitos, tanto da fácies dos xistos verdes superior como, analogamente, em associações com gr + stau $+\mathrm{ky}$, da fácies anfibolito inferior. Ademais, como já observado por Winkler (1976), a estaurolita é mais comum em rochas de médio-grau do que o cloritóide em rochas de baixo-grau. Consequentemente, reações 
adicionais de formação da estaurolita não envolvendo cloritóide devem ser consideradas. No caso das rochas metapelíticas estudadas, as inclusões corroídas/arredondadas de estaurolita em granada e vice-versa, assim como a ausência de muscovita e a falta quase completa de clorita sugerem, entre outras, as reações (5.2), (5.3) e (5.4).

* $12 \mathrm{stau}+23 \mathrm{bt}+4 \mathrm{qz} \leftrightarrow 31 \mathrm{alm}+23 \mathrm{mu}+6 \mathrm{H}_{2} \mathrm{O}$ (Ganguly, 1968)

$* \mathrm{gr}+\mathrm{clo} \leftrightarrow \mathrm{stau}+\mathrm{bt}+\mathrm{H}_{2} \mathrm{O}$ (Spear, 1993)

$*$ clo $+\mathrm{mu}+\mathrm{alm}=\mathrm{stau}+\mathrm{bt}+\mathrm{qz}+\mathrm{H}_{2} \mathrm{O}$ (Albee, 1965; Carmichael, 1970)

A formação da estaurolita e biotita a partir de assembléias com clorita, conforme as reações (5.3) e (5.4), requer, como condições mínimas, $\mathrm{P}=4 \mathrm{~kb}$ e $\mathrm{T}=540 \pm 15^{\circ} \mathrm{C}$ à $\mathrm{P}=7 \mathrm{~kb}$ e $\mathrm{T}=565 \pm 15^{\circ} \mathrm{C}$ (Hoschek, 1969). Assim, o surgimento da estaurolita não pode ser definido por condições de $\mathrm{P}$ e $\mathrm{T}$ precisas, e sim por faixas de $\mathrm{P}$ e $\mathrm{T}$, estimadas em $\mathrm{P}=3-5 \mathrm{~kb}$ e $\mathrm{T}=$ $510-550^{\circ} \mathrm{C}$, de acordo com as composições dos protólitos (Winkler, 1976). A estaurolita, em geral, persiste até a parte baixa da zona da silimanita (Hoschek, 1967, 1969; Ganguly, 1968, 1969; Ganguly \& Newton, 1968 e Richardson, 1968a,b), sendo seu limite superior estabelecido por Ganguly (1971) em $687,5 \pm 37,5^{\circ} \mathrm{C}$ a $10 \mathrm{~kb}$.

Assembléias $\mathrm{ky}+\mathrm{mu}+\mathrm{qz}$ são raras e ocorrem em veios de quartzo cisalhados e xistos associados da parte estratigráfica superior da SVS, na porção central da área mapeada (Pontos $77,76,96,97$ e 110). A cianita pode se formar desde o início da fácies anfibolito, sob condições de pressão relativamente altas, caso contrário, formar-se-ia andaluzita e estaurolita apareceria antes da cianita na transição para a fácies anfibolito; a estabilidade superior da cianita é delimitada pela zona da silimanita (Miyashiro, 1973; Winkler, 1976; Turner, 1981; Deer et al.,1982).

A associação VI (stau $+\mathrm{ky}+\mathrm{bt}+\mathrm{clo}+\mathrm{qz}+\mathrm{plag} \pm \mathrm{ru} \pm \mathrm{cum} \pm \mathrm{hb} \pm$ fibrol) foi encontrada na parte SE da área mapeada, regionalmente de mais alto grau metamórfico (amostras G-116 e M-5). Anfibólios verdes são raros e substituídos por cummingtonita. A cianita apresenta-se deformada (cristais dobrados, com extinção ondulante), associa-se a biotita e fibrolita e contém inclusões de rutilo; em certos casos, verificam-se reações mútuas nos contatos com estaurolita, possivelmente, segundo a reação (5.5).

$$
{ }^{*} \mathrm{mu}+\mathrm{stau}+\mathrm{clor} \leftrightarrow \mathrm{bt}+\mathrm{ky}+\mathrm{qz}+\mathrm{H}_{2} \mathrm{O} \text { (Yardley, 1989) }
$$

A $\mathrm{fO}_{2}$ controla a formação adicional ou substitutiva da estaurolita/cianita (Guidotti, 1970), podendo ocorrer ky + stau estáveis ou só a cianita formando-se às custas da estaurolita ou vice-versa, respectivamente, em condições oxidantes ou redutoras. Assim, a presença ou 
não de estaurolita pode ser explicada pelo quimismo das rochas, pela $\mathrm{PO}_{2}$ durante o metamorfismo ou pela sua transformação através das reações anteriormente consideradas.

A primeira ocorrência de rochas contendo a associação VIII (cum $+\mathrm{stau}+\operatorname{cord}+\mathrm{qz}+$ $b t+c l o+r u+o p)$ foi observada na porção central da área (Ponto 85) e na região do garimpo de Capoeirana. Nestas, a cordierita se forma a partir da estaurolita, provavelmente, segundo a reação (5.6).

$*$ stau $+\mathrm{bt}+\mathrm{qz}=$ cord $+\mathrm{gr}+\mathrm{mu}+\mathrm{H}_{2} \mathrm{O}$ (Winkler, 1976)

A associação (IX), representada por bt $+\mathrm{gr}+\mathrm{stau}+\mathrm{cum}+\mathrm{cord}+\mathrm{sil}+\mathrm{clo}+\mathrm{qz}+\mathrm{ru}+$ op \pm plag \pm ap \pm fluorita, é também caracterizada pela presença da cordierita, diferindo da anterior pela presença de granada e silimanita. Ocorre na porção central da área (Ponto 85), na região do garimpo de Capoeirana e na porção E da área mapeada (Ponto 367, Schorscher, 1975) e pode ser relacionada a zona da silimanita de Barrow (1912).

A estaurolita é substituída por cordierita e contém inclusões de rutilo, opacos, granada e estaurolita. A cordierita ocorre como porfiroblastos geminados, pinitizados por retrometamorfismo e com inclusões de estaurolita corroída, ou ainda, como cristais intersticiais (amostra G-239a); encontra-se em equilíbrio com cummingtonita, e contém inclusões vermiformes de quartzo. Porfiroblastos centimétricos de granada helicítica (sintectônica) estão associados com cordierita e fibrolita e contém abundantes inclusões orientadas de quartzo, opacos e rutilo (este último, menos freqüente), e raras de apatita. Estas granadas contém, também, inclusões corroídas de estaurolita, o que vem confirmar a quebra da estaurolita originando granada e cordierita, possivelmente, através das reações (5.7) e (5.8).

* $6 \mathrm{stau}+4 \mathrm{mt}=8 \mathrm{alm}+19 \mathrm{cord}+3 \mathrm{H}_{2} \mathrm{O}+2 \mathrm{O}_{2}$ (Ganguly, 1972)

${ }^{*}$ stau $+\mathrm{qz}=\mathrm{Al}_{2} \mathrm{SiO}_{5}+\mathrm{alm}+$ cord $+\mathrm{H}_{2} \mathrm{O}$ (Winkler, 1976)

As granadas destas rochas são almandinas que, segundo Winkler (1976), coexistem com cordierita somente em altas temperaturas de metamorfismo de grau médio e em um intervalo restrito de pressão intermediária (na zona da cordierita-almandina do grau médio). Hutcheon et al. (1974) encontraram para as rochas com quartzo-silimanita-granada-cordierita, condições de formação de $\mathrm{T}=610-760^{\circ} \mathrm{C}$ e $\mathrm{P}=5,3-6,6 \mathrm{~kb}$. 


\section{V.2.2 - ANFIBOLITOS METABÁSICOS}

Os anfibolitos metabásicos da SVS compõem, petrograficamente, três subgrupos: anfibolitos metabásicos $(\mathrm{AB})$, anfibolitos metabásicos com epidoto e/ou titanita (ABET) e anfibolitos metabásicos com granada (ABG).

Os $\mathrm{AB}$ distribuem-se, em geral, por toda a área onde ocorrem como intercalações normalmente estreitas (métricas) nas rochas da SVS.

Os plagioclásios destes litotipos apresentam, em sua maioria, zonação inversa e composição variável entre oligoclásio e andesina, às vezes com alterações retrometamórficas para albitas em bordas externas finas (Cap. IV, ítem IV.4.1). Segundo Liou et al. (1974), a partir de $475^{\circ} \mathrm{C}$, já na zona da granada, a albita reage para oligoclásio-andesina pela ressorção de minerais cálcicos, principalmente, clinozoizita.

Entre os anfibólios verdes predominam, amplamente, a hornblenda pargasítica e, subordinadamente, a tschermakítica. É comum a substituição dos anfibólios verdes por antofilitas/cummingtonitas. Segundo Miyashiro (1968) e Yardley (1989), a cummingtonita pode se formar pelo consumo de hornblendas tschermackíticas e de quartzo, em temperaturas e pressões da fácies anfibolito, segundo a reação (5.9).

* 7 tscher $+10 \mathrm{qz}=3 \mathrm{cum}+14 \mathrm{an}+4 \mathrm{H}_{2} \mathrm{O}$ (Miyashiro, 1968; Yardley, 1989)

A paragênese plag + hb sem clorita e epidoto nos $\mathrm{AB}$ pode indicar que condições entre $550^{\circ} \mathrm{C} / 2 \mathrm{~kb}$ e $575^{\circ} \mathrm{C} / 5 \mathrm{~kb}$ foram alcançadas (Liou et al, 1974).

Os ABET foram encontrados em apenas quatro ocorrências (Amostras G-37, G-56, G-240 e 32,20) sem correlação com a progressão metamórfica na área. Suas paragêneses com abundante titanita e epidoto, outrossim, minerais indicativos de mais baixo grau de metamorfismo, são aqui consideradas como resultado conjunto da composição dos protólitos e da composição e $\mathrm{fO}_{2}$ do fluido metamórfico local.

Os $\mathrm{ABG}$ apresentam plagioclásios e hornblendas/cummingtonitas como os $\mathrm{AB}$ e ABET. Suas granadas são almandinas, com inclusões helicíticas de quartzo, plagioclásio, biotita e opacos; às vezes, mostram-se fraturadas e sutilmente contornadas pela foliação sugerindo crescimento pré- a sin-tectônico.

A formação de granadas almandinas em anfibolitos depende, essencialmente, do teor algo mais elevado de $\mathrm{Fe}^{+2}$ nos protólitos com composições basálticas a gabróicas e ocorre por todo a fácies anfibolito de tipo Barrow (Winkler, 1976). 


\section{V.2.3 - ROCHAS METAULTRAMÁFICAS}

As rochas metaultramáficas da área são talco-Mg-cummingtonita/antofilita-clorita xistos (TACX) e anfibolitos metaultramáficos (AU) constituídos predominantemente por anfibólios verdes. Ambos, podem conter cromitas acessórias.

Nos TACX, talco e clorita formaram-se em reações pré-anfibólio, o talco, possivelmente, segundo a reação (5.10).

$* 1 \operatorname{srp}+2 \mathrm{qz}=1 \mathrm{tc}+1 \mathrm{H}_{2} \mathrm{O}$ (Winkler, 1976)

O anfibólios ferromagnesianos são sub-orientados a fibro-radiais sobre a matriz talcoclorítica, crenulada, sugerindo crescimento tardi-sin a pós-tectônico pela reação (5.11).

$* 7 \mathrm{tc}=3$ antf $+4 \mathrm{qz}+4 \mathrm{H}_{2} \mathrm{O}$ (Winkler, 1976)

A cummingtonita presente nas rochas metaultramáficas estudadas pode ter-se formado a partir da antofilita, durante o metamorfismo progressivo.

As cloritas nos xistos metaultramáficos apresentam composições magnesianas (Cap. IV, ítem IV.8); essas, segundo Winkler (1976), são estáveis em metamorfismo de grau médio e forte, excedendo o seu limite de estabilidade a temperatura de $800^{\circ} \mathrm{C}$.

Nos $\mathrm{AU}$, os anfibólios verdes variam de edenitas (predominantes) a hornblendas pargasíticas ferrosas (Cap. IV; ítem IV.3), sendo parcialmente substituídos por antofilita/cummingtonita.

\section{V.2.4 - METAGRANITÓIDES GB E MGF}

Corpos de metagranitóides Borrachudos a W de Itabira e E de São Gonçalo do Rio Abaixo encontram-se na fácies xisto verde do metamorfismo regional, principal, Proterozóico e preservaram melhor suas características petrogenéticas, originais, arqueanas, (Schorscher, 1975, 1992),. Na área desta pesquisa, os GB sofreram metamorfismo proterozóico mais intenso, gradando para os MGF (Machado, 1994).

Sob aspectos da progressão metamórfica, destacam-se a formação de hornblendas hastingsitas a partir de, principalmente, biotita e epidoto, a ocorrência de granadas almandinas com teores de grossulária e espessartita algo maiores em relação às granadas dos metapelitos e anfibolitos ABG (Fig. 4.17c) e as reações e composições dos feldspatos, incluindo zoneamento metamórfico inverso do plagioclásio. 


\section{V.3 - GEOTERMOBAROMETRIA}

A geotermobarometria visa os cálculos das temperaturas e pressões de reações metamórficas assumindo equilíbrio termodinâmico. Os geotermômetros são reações que mostram considerável sensitividade de temperatura (grande $\Delta \mathrm{S}, \Delta \mathrm{H}$ ) e pequena de pressão (pequeno $\Delta \mathrm{V}$ ) e os geobaromêtros são reações que resultam em grandes mudanças de volume. Os valores de $\Delta \mathrm{H}, \Delta \mathrm{S}, \Delta \mathrm{Cp}$ e $\Delta \mathrm{V}$ são conhecidos de calibrações experimentais ou tabelas termodinâmicas e o valor da constante de equilíbrio/coeficiente de distribuição é obtido a partir das composições dos minerais coexistentes.

Os geotermômetros disponíveis são baseados em reações de troca catiônica em posições estruturais definidas como, por exemplo, a substituição de $\mathrm{Fe}^{+2}$ e $\mathrm{Mg}$ entre granadas e biotitas coexistentes, ou ainda, nas composições de fases de soluções sólidas num sistema de solvus como, por exemplo, a distribuicão da molécula albita entre feldspatos alcalinos e plagioclásios coexistentes. Reações de troca, muitas vezes, são bons geotermômetros, pois tipicamente tem pequeno $\Delta \mathrm{V}_{\text {reaçăo }}$ (Spear, 1993).

Um grande número de geotermômetros e geobarômetros e respectivas calibrações existem na literatura. Uma revisão de cada um destes foge ao escopo deste trabalho. Nesta pesquisa, procurou-se utilizar aqueles que mais se adequam à assembléias minerais identificadas nas rochas da área de estudo, isto é, os geotermômetros granada-biotita, granadaestaurolita, granada-anfibólio e de dois feldspatos e o geobarômetro granada-alumossilicatosílica-plagioclásio (GASP), considerando as composições dos centros e das bordas dos minerais coexistentes. Para os cálculos foram empregadas(os), comparativamente, três planilhas/programas de computador (Rettinger, dados não publicados; Reche \& Martinez, 1996; Wen \& Nekvasil, 1994), sendo os resultados completos apresentados no Anexo 5.

\section{V.3.1 - GEOTERMOMETRIA}

Foram efetuados cálculos geotermométricos em: a) 10 pares de granada-biotita de MP e 08 pares de GB; b) 06 pares de granada-estaurolita de MP ; c) 02 pares de granada-anfibólio de MP e 05 pares de ABG ; d) 08 pares de feldspatos coexistentes de GB e 12 pares de MGF. Foi, ainda, considerado 01 par de feldspatos coexistentes em uma amostra da mineralização (NE-31-06: veio pegmatóide com esmeralda, contendo K-feldspato em lentes de flogopitas esfoliadas na borda do veio) (Anexo 5). As amostras consideradas para os cálculos são provenientes de diferentes afloramentos, desde o $\mathrm{W}$ ao $\mathrm{E}$ da área. 
Os geotermômetros empregados são listados a seguir.

\begin{tabular}{|c|c|}
\hline granada-biotita & 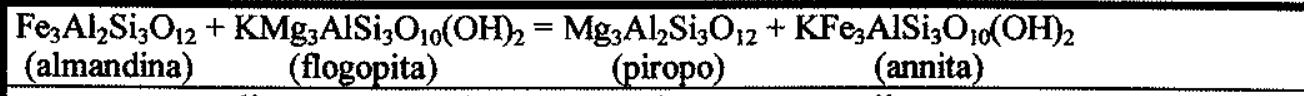 \\
\hline granada-staurolita & estaurolita $_{(\mathrm{Mg})}+$ granada $_{(\mathrm{Fe})}=$ granada $_{(\mathrm{Mg})}+$ estaurolita $_{\mathrm{Mgg})}$ \\
\hline granada-anfibólio & $4 \mathrm{Mg}_{3} \mathrm{Al}_{2} \mathrm{Si}_{3} \mathrm{O}_{12}+\mathrm{NaCa}_{2} \mathrm{Fe}_{4} \mathrm{Al}_{3} \mathrm{Si}_{6} \mathrm{O}_{22}(\mathrm{OH})_{2}=4 \mathrm{Fe}_{3} \mathrm{Al}_{2} \mathrm{Si}_{3} \mathrm{O}_{12}+3 \mathrm{NaCa}_{2} \mathrm{Mg}_{4} \mathrm{Al}_{3} \mathrm{Si}_{6} \mathrm{O}_{22}(\mathrm{OH})_{2}$ \\
\hline dois feldspatos & baseada na distribuição de $\mathrm{K}$ e Na entre álcali-feldspato e plagioclásio coexistentes. \\
\hline
\end{tabular}

O geotermômetro granada-biotita é o mais usado para estimar as condições de temperatura em xistos e gnaisses metapelíticos de médio a alto grau. Foi definido por Ferry \& Spear (1978) e, posteriormente, recalibrado por diversos autores, por exemplo: Goldman \& Albee (1977), Hodges \& Spear (1982), Perchuk \& Lavrent'eva (1983), Indares \& Martingnole (1985), entre outros. A primeira calibração de Ferry \& Spear (1978) foi feita experimentalmente para o sistema Fe-Mg puro e, portanto, o emprego deste termômetro para soluções sólidas mais complexas deve implicar em erros maiores. Para adequar o geotermômetro às associações naturais, foram feitos estudos visando os efeitos de $\mathrm{Ca}, \mathrm{Mn}, \mathrm{Ti}$ e Al (Goldman \& Albee, 1977). Ainda assim, estes efeitos não são bem conhecidos, tornandose difícil a opção por qualquer uma das calibrações existentes.

Uma análise comparativa dos cálculos geotermométricos efetuados nesta pesquisa indica valores muito próximos para calibrações correspondentes do termômetro granadabiotita nas duas planilhas utilizadas para os cálculos (Rettinger, dados não publicados; Reche \& Martinez, 1996). Cabe ainda ressaltar que, inicialmente, foram efetuados os cálculos em $P$ $=5,6$ e $7 \mathrm{~kb}$; porém, como esperado, a análise dos resultados confirmou que a pressão pouco influencia nas temperaturas obtidas por uma determinada calibração, sendo a partir daí, considerada, somente, $P=6 \mathrm{~kb}$.

Conforme discutido no ítem V.2 (Assembléias Minerais), as temperaturas máximas estimadas pelas paragêneses minerais dos MP deveriam variar entre 610 e $760^{\circ} \mathrm{C}$, para pressões de 5,3 a 6,6 kb, considerando, por exemplo, a coexistência de gr + cord (cf.: Hutcheon et al., 1974). No entanto, os resultados indicam temperaturas médias mais baixas, de 450 a $610^{\circ} \mathrm{C}$ e de 540 a $670{ }^{\circ} \mathrm{C}$, respectivamente, pelos geotermômetros granada-biotita e granada-estaurolita (Tab. 5.1). No geotermômetro granada-biotita, as temperaturas médias mais elevadas ( $\mathrm{T}$ entre 490 e $610^{\circ} \mathrm{C}$ ), foram obtidas pelas calibrações de Battacharya et al. (1992), Perchuk \& Lavrent'eva (1983) e de Perchuk et al. (1985). 


\begin{tabular}{|c|c|c|c|c|c|c|c|}
\hline \multirow[b]{2}{*}{ GT } & \multirow[b]{2}{*}{ Calibrações } & \multicolumn{6}{|c|}{ Temperaturas Médias $\left({ }^{\circ} \mathbf{C}\right)$} \\
\hline & & $\begin{array}{c}\text { MP } \\
\text { G-89 (C) }\end{array}$ & $\begin{array}{c}\text { MP } \\
\text { G-89 (B) }\end{array}$ & $\begin{array}{c}\text { MP } \\
\text { G-52c (C) }\end{array}$ & $\begin{array}{c}\text { MP } \\
\text { G-52c (B) }\end{array}$ & $\begin{array}{c}\mathrm{ABG} \\
\mathrm{C}-1 \mathrm{a}(\mathrm{C})\end{array}$ & $\begin{array}{c}\text { ABG } \\
\text { C-1a (B) }\end{array}$ \\
\hline \multirow{8}{*}{ Gr-Bt } & Battacharya et al., $1992^{2}$ & 606.0 & 590.0 & 606.5 & 571.0 & - & - \\
\hline & Perchuk \& Lavrent'eva, $1983^{1}$ & 555.5 & 536.0 & 532.0 & 493.5 & - & - \\
\hline & Perchuk et al., 1985 & 571.9 & 552.0 & 571.4 & 528.1 & - & - \\
\hline & Indares \& Martignole, $1985^{2}$ & 478.5 & 451.3 & 530.4 & 449.6 & - & - \\
\hline & Ganguly, 1979 & 558.5 & 524.0 & 552.5 & 489.5 & - & - \\
\hline & Pigage \& Greenwood, 1982 & 558.5 & 523.7 & 555.2 & 482.2 & - & - \\
\hline & Ganguly \& Saxena, 1984 & 475.5 & 449.1 & 433.1 & 369.1 & - & - \\
\hline & Williams \& Grembling, 1990 & 563.5 & 526.0 & 550.9 & 475.9 & - & - \\
\hline Gr-Stau & Perchuk, 1991 & 550.55 & 540.3 & 596.8 & 666.2 & - & - \\
\hline Gr-Anf & Graham \& Powell, 1984 & - & - & 468.0 & 483.0 & 603.3 & 634.5 \\
\hline
\end{tabular}

Tabela 5.1: Temperaturas médias de MP (metapelitos) e ABG (anfibolitos metabásicos com granada), obtidas à partir de diferentes geotermômetros, para $P=6 \mathrm{~kb}$, calculados segundo Rettinger (dados não publicados) e Reche \& Martinez (1996). Nota: GT = geotermômetros; Gr-Bt = granada-biotita; Gr-Stau = granada-estaurolita; Gr-Anf = granada-anfibólio.

Os valores máximos calculados mais baixos do que os valores máximos estimados e as diferenças observadas entre as diversas calibrações do geotermômetro granada-biotita para uma mesma amostra, são os limites ainda existentes na geotermometria metamórfica. Já as comparações das temperaturas obtidas para centros e bordas de pares minerais apresentam variações mais sistemáticas, ou seja: para os pares envolvendo biotitas, as bordas externas indicam temperaturas mais baixas do que as respectivas partes internas; dos centros às bordas internas. (Tab. 5.1). Isto é um um efeito do retrometamorfismo sobre as bordas das biotitas muito susceptíveis a tais processos. Para o par granada-estaurolita da amostra G-52c com baixos teores de $\mathrm{Zn}(\mathrm{ZnO} \cong 0.38 \%)$, ao contrário, as temperaturas obtidas para assembléias de borda são mais elevadas, em até $70^{\circ} \mathrm{C}$, em relação às de centro, indicando neste caso, mais coerentemente, a progressão metamórfica do principal evento Proterozóico, preservada em bordas de minerais mais estáveis. Indicações diferentes pelo par granada-estaurolita na amostra G-89 (Tab. 5.1) devem ser consideradas com reservas, visto tratar-se de estaurolitas com elevados teores de $\mathrm{Zn}(\mathrm{ZnO} \cong 3 \%)$, sendo que o efeito deste, ainda, não foi avaliado com finalidades geotermométricas no termômetro usado.

Para finalizar as considerações sobre os MP, deve ser mencionado que amostras diferentes de um mesmo litotipo, mesmo quando proximamente associadas no campo, podem apresentar diferenças nas temperaturas calculadas. Isto pode ser efeito de: (1) diferenças químicas, principalmente, de constituintes menores das rochas e de suas biotitas e granadas, não consideradas nas calibrações; (2) diferenças nas composições dos fluidos metamórficos com efeitos sobre as condições de oxi-redução; e (3) diferenças entre o tipo de mistura (ideal versus não ideal) existente na granada e aquela usada nas calibrações. Assim, vale acrescentar 
que a calibração de Perchuk \& Lavrent'eva (1983) inclui correções para o componente grossulária na granada, conhecido por formar mistura não ideal com piropo. $\mathrm{O}$ modelo de Ganguly \& Saxena (1984) inclui duas correções, uma para a mistura não ideal do componente espessartita e outra para $\mathrm{Fe} / \mathrm{Mg}$ na granada. Porém, os resultados ainda não são sempre coerentes para suites de rochas comparáveis e diferentes também daqueles obtidos por outras calibrações (Spear, 1993). Indares \& Martignole (1985) adicionam uma correção para os teores de $\mathrm{Ti}$ e $\mathrm{Al}^{\mathrm{VI}}$ da biotita que fornece temperaturas menores do que aquelas obtidas sem estas correções (Spear, 1993).

A aplicação do geotermômetro granada-anfibólio em MP e ABG de Capoeirana mostrou claramente que o uso deste termômetro, desenvolvido para assembléias metamáficas, definitivamente resulta em valores baixos demais quando aplicado para pares granadaanfibólios de MP. Comparando-se os resultados deste geotermômetro nos ABG com aqueles de granada-estaurolita nos MP, observa-se boa correlação, tanto nos valores absolutos, quanto nas indicações de zoneamento (Tab. 5.1).

As temperaturas máximas obtidas nos MP $\left(490\right.$ a $610^{\circ} \mathrm{C}$ pelo par granada-biotita e 540 a $670^{\circ} \mathrm{C}$ pelo par granada-estaurolita) e nos $\mathrm{ABG}\left(600\right.$ a $635^{\circ} \mathrm{C}$ pelo par granada-anfibólio) estão próximas das $\mathrm{T}$ médias obtidas por Rettinger $(1994 ; 1998), \mathrm{T}=530$ a $650^{\circ} \mathrm{C}$, para a região entre Itabira, Nova Era e Piçarrão.

Os metagranitóides GB e MGF, também, foram considerados nos cálculos geotermométricos, com $\mathrm{P}=6 \mathrm{~kb}$, utilizando-se os pares de feldspato alcalino-plagioclásio e granada-biotita e diferentes calibrações (Anexo 5). Algumas temperaturas médias, consideradas mais significativas, estão representadas nas Tabelas 5.2 e 5.3

As temperaturas médias máximas dos GB e MGF obtidas pelo geotermômetro de dois feldspatos são, em geral, muito baixas, inclusive muito inferiores àquelas obtidas pelo geotermômetro granada-biotita para os $\mathrm{MP}$ da mesma região (Tab. 5.2); entretanto, são similares às temperaturas obtidas pelo mesmo geotermômetro em uma amostra (NE-31-06) de veio pegmatóide mineralizado com plagioclásio saussuritizado e feldspato potássico em lentes de flogopitas esfoliadas na borda do veio $\left(T=390,0^{\circ} \mathrm{C}\right.$, segundo Nekvazil \& Burnham, 1987 ; e $\mathrm{T}=340,0^{\circ} \mathrm{C}$, segundo Ghiorso, 1984). 


\begin{tabular}{|c|c|c|c|c|c|c|c|c|c|c|}
\hline $\begin{array}{c}\text { Geotermômetro } \\
\text { Dois Feldspatos }\end{array}$ & \multicolumn{10}{|c|}{ Temperaturas Médias ( $^{\circ} \mathrm{C}$} \\
\hline Calibrações & $\begin{array}{c}\text { G-26 } \\
\text { (C) }\end{array}$ & $\begin{array}{c}\text { G-26 } \\
(\mathrm{B})\end{array}$ & $\begin{array}{c}\text { G-166b } \\
(\mathrm{C})\end{array}$ & $\begin{array}{c}\text { G-166b } \\
(\mathrm{B})\end{array}$ & $\begin{array}{c}\text { G-113 } \\
(\mathrm{C})\end{array}$ & $\begin{array}{c}\text { G-113 } \\
(\mathrm{B})\end{array}$ & $\begin{array}{c}\text { G-2b } \\
(\mathrm{C})\end{array}$ & $\begin{array}{c}\text { G-2b } \\
(\mathrm{B})\end{array}$ & $\begin{array}{c}\text { G-11a } \\
(\mathrm{C})\end{array}$ & $\begin{array}{c}\text { G-11a } \\
(\mathrm{B})\end{array}$ \\
\hline $\begin{array}{c}\text { Nekvazil \& } \\
\text { Burnham, 1987 }\end{array}$ & 394.6 & - & 339.3 & 330.1 & 427.5 & 418.7 & 406.8 & 373.4 & 382.4 & 383.0 \\
\hline $\begin{array}{c}\text { Elkins \& Grove, } \\
\text { 1990 }\end{array}$ & 290.5 & 319.9 & 313.7 & 260.8 & 425.4 & 323.0 & 324.2 & 297.7 & 325.5 & 317.3 \\
\hline Ghiorso, 1984 & 346.0 & 314.7 & 393.8 & 283.2 & 396.6 & 390.3 & 409.8 & 363.6 & 379.6 & 383.7 \\
\hline
\end{tabular}

Tabela 5.2: Temperaturas médias obtidas pelo geotermômetro de dois feldspatos a $6 \mathrm{~kb}$, para Metagranitóides Borrachudos - GB e Metagranitóides Foliados com Fluorita - MGF, utilizando-se o programa Solvcalc 2.0 (Wen \& Nekvasil, 1994).

Considerando essas temperaturas não condizentes com as observações paragenéticas, foi, então, tentativamente, utilizado o geotermômetro granada-biotita em duas amostras de $\mathrm{GB}$, sendo uma dos arredores de Belmont (G-113) e outra da região à $\mathrm{E}$ de Capoeirana (G-116). As temperaturas obtidas são elevadas na amostra G-113, aivançando nas associações de borda até $100^{\circ} \mathrm{C}$ a mais do que os MP (Tab. 5.3 cf Tab. 5.1). Já na amostra G-166b, os resultados são mais compatíveis com os dos MP da mesma região. Neste caso, também, as temperaturas mais elevadas das associações de bordas podem indicar a progressão metamórfica regional do principal evento Proterozóico.

\begin{tabular}{|c|c|c|c|c|c|}
\hline \multirow{3}{*}{ GT } & \multirow{4}{*}{ Calibrações } & \multicolumn{4}{|c|}{ Temperaturas Médias ( ${ }^{\circ}$ C) } \\
\cline { 2 - 6 } & & \multicolumn{3}{|c|}{ Metagranitóides Borrachudos (GB) } \\
\cline { 2 - 6 } & & G-113(C) & G-113 (B) & G-166b(C) & G-166b (B) \\
\hline \multirow{5}{*}{ Gr-Bt } & Battacharya et al., 1992 & 552,0 & 613,5 & 475,0 & 476,0 \\
\cline { 2 - 6 } & Perchuk \& Lavrent'eva, 1983 & 510,5 & 548,0 & 526,0 & 529,5 \\
\cline { 2 - 6 } & Perchuk et al., 1985 & 648,8 & 683,6 & 569,4 & 572,6 \\
\cline { 2 - 6 } & Indares \& Martignole, 1985 & 573,3 & 652,1 & 577,8 & 581,5 \\
\cline { 2 - 6 } & Ganguly, 1979 & 678,0 & 759,5 & 628,5 & 637,0 \\
\cline { 2 - 6 } & Pigage \& Greenwood, 1982 & 670,4 & 749,0 & 628,2 & 632,2 \\
\cline { 2 - 6 } & Ganguly \& Saxena, 1984 & 604,1 & 676,8 & 622,0 & 626,3 \\
\cline { 2 - 6 } & Williams \& Grembling, 1990 & 686,6 & 769,3 & 683,7 & 643,2 \\
\hline
\end{tabular}

Tabela 5.3: Algumas temperaturas médias, consideradas mais significativas, obtidas pelo geotermômetro (GT) granada-biotita (Gr-Bt), a $6 \mathrm{~kb}$, para Metagranitóides Borrachudos - GB, utilizando-se planilhas/programas específicas(os) (Rettinger, dados não publicados; Reche \& Martinez, 1996).

As temperaturas em geral muito baixas fornecidas pelo geotermômetro dos dois feldspatos podem ser indicativas de reajustes térmicos durante o soerguimento na fase final do evento proterozóico principal e, ainda, no Ciclo Brasiliano, conforme indicam também as temperaturas sistematicamente mais baixas das associações das bordas externas. 
Todas as temperaturas dos GB e MGF deste trabalho, independentemente dos geotermômetros utilizados, são bem inferiores àquela obtida por Fernandes et al. (1995b), de cerca de $840^{\circ} \mathrm{C}$, que consideraram como temperatura de cristalização magmática dos granitos da região de Dores de Guanhães por eles denominados Borrachudos.

\section{V.3.2 - GEOBAROMETRIA}

A partição de Ca entre plagioclásio e granada na reação (5.12) é dependente da pressão.

* $3 \mathrm{CaAl}_{2} \mathrm{Si}_{2} \mathrm{O}_{8}=\mathrm{Ca}_{3} \mathrm{Al}_{2} \mathrm{Si}_{3} \mathrm{O}_{12}+2 \mathrm{Al}_{2} \mathrm{SiO}_{5}+\mathrm{SiO}_{2}$

anortita grossulária cianita/sil

Esta reação foi estudada e calibrada por Ghent (1976), sendo de fato um geotermobarômetro dada, também, sua forte dependência da temperatura.

Vários argumentos contrários à aplicação deste geobarômetro, como por exemplo, a influência da temperatura, os erros oriundos dos teores geralmente baixos de grossulária na granada e de anortita no plagioclásio, e mesmo, as incertezas decorrentes da formulação das atividades destes componentes nos minerais, foram discutidos por Bucher \& Frey (1994).

Nas rochas MP da área de estudo, é comum a ocorrência de granada, plagioclásio, cianita e sillimanita. Porém, ainda, não se dispõe de dados químicos de granada e plagioclásio na mesma amostra. Por outro lado, a estimativa das pressões metamórficas a partir dos metagranitóides $\mathrm{GB}$ e dos $\mathrm{ABG}$, a princípio, parecia ser possível, uma vez que tanto os $\mathrm{GB}$ quanto os ABG encontram-se intercalados com rochas da SVS, inclusive com MP portadores de alumossilicatos. Assim, apesar das restrições consideradas no parágrafo anterior foi, tentativamente, aplicado o geotermobarômetro GASP.

Com base nas temperaturas máximas calculadas para os $\mathrm{MP}$ e $\mathrm{ABG}\left(490\right.$ e $610^{\circ} \mathrm{C}$ pelo geotermômetro granada-biotita, 540 a $670^{\circ} \mathrm{C}$ pelo geotermômetro granada-estaurolita e 460 a $630^{\circ} \mathrm{C}$ pelo geotermômetro granada-anfibólio), assumiu-se uma temperatura de $600^{\circ} \mathrm{C}$ para calcular as pressões do pico do metamorfismo regional principal. Os cálculos geobarométricos forneceram pressões, em geral, extremamente elevadas $(>9 \mathrm{~kb})$, à exceção de alguns valores próximos de $7 \mathrm{~kb}$ para os $\mathrm{ABG}$ (ver calibração de Hodges \& Spear, 1982) (Anexo 5). Estes resultados elevados demais podem ter sidor causados, no caso dos GB, pelos erros oriundos dos teores muito baixos de anortita no plagioclásio e altos de grossulária na granada (até $23 \%$ nos ABG e $31 \%$ nos GB) (cf.: Bucher \& Frey, 1994). Todas as calibrações 
utilizadas para o geotermômetro GASP usam modelos de atividade para granadas que incorporam a mistura não ideal do componente grossulária (Spear, 1993), resultando, assim, nos valores bastante elevados calculados.

\section{V.3.3 - EVOLUÇÃo METAMÓRFICA}

$\mathrm{Na}$ área foram reconhecidos:

(1) Um ciclo metamórfico mais antigo de grau médio-alto caracterizado pela natureza migmatítica e processos ígneos graníticos intusivos de níveis crustais médios a profundos associados, que conduziu a formação das rochas TTG. Este ciclo foi de mais alto grau e anterior a orogênese da SVS também arqueana de tipo greenstone belt conforme os critérios petrográficos e estruturais. Valores numéricos termobarométricos deste evento não foram obtidos nem de pargêneses minerais e nem das composições gerais das rochas TTG em relação a eutéticos graníticos, pelas alterações polimetamórficas aloquímicas posteriores (arqueanas e proterozóicas).

(2) Um segundo ciclo arqueano representado pela orogênese da SVS incluindo a formação dos $\mathrm{GB}$ e das mineralizações de esmeraldas tipo xistos (EX) e tipo veios de quartzo polideformados (EVQ). As condições P-T desse evento podem ser apenas estimadas pelas paragêneses de centros de minerais do principal evento metamórfico regional posterior paleomesoproterozóico, indicando condições P-T arquenas máximas de fácies xisto verde superior transicional para anfibolito inferior. Informações adicionais sobre os regimes de fluidos na zona de cisalhamento formadora dos GB (a partir dos TTG) e das mineralizações de esmeraldas arqueanas foram obtidas dos estudos litogeoquímicos, de química mineral e isótopos estáveis que serão apresentados e discutidos em seção própria.

(3) Para as assembléias minerais do principal metamorfismo regional paleomesoproterozóico foram apresentados e discutidos acima as condições de T e P com base em estudos petrográficos e geotermobarométricos. Entretanto, é preciso acrescentar que, embora a teoria termodinâmica que fundamenta a termobarometria seja clara, a aplicação prática às rochas, ainda, não o é, devido às consideráveis incertezas dos dados termodinâmicos e modelos de atividade aplicados a cada caso. Assim, até que sejam propostas novas calibrações, mais adequadas para os litotipos estudados, e efetuadas novas análises de pares de minerais e cálculos geotermobarométricos específicos, serão consideradas como características mais prováveis do metamorfismo regional, principal, paleoproterozóico final sua evolução progresiva em condições de pressão de 5,3 a $6,6 \mathrm{~kb}$, em associação com a 
formação de zonas de cisalhamento predominantemente dúcteis que também indicam níveis crustais médios transicionais a profundos e, temperaturas dadas pela coexistência de $\mathrm{gr}+$ cord em MP (cf. Hutcheon et al., 1974) e cálculos geotermométricos de 460 a $670^{\circ} \mathrm{C}$, compatíveis com a evolução regional nas zonas da cianita transicional para sillimanita (cf. Schorscher,1975,1992; Rettinger, 1994,1998; Rettinger et al., 1996).

Esse evento metamórfico e orogênico principal causou, ainda, a transformação dos GB em MGF progressiva de $\mathrm{W}$ para $\mathrm{E}$ e fusões parciais incipientes nos MGF que originaram veios pegmatóides e pegmatitos portadores de uma geração proterozóica de mineralizações berilíferas: de esmeraldas em veios pegmatóides e veios quartzo pouco deformados intrusivos nas rochas metaultramáficas flogopitizadas da SVS e de águas marinhas análogas em mobilizados pegmatóides e de quartzo intrusivos nos MGF (ausentes nos GB).

(4) Reajustes térmicos e reequilibrações retrometamórficas das paragêneses anteriores de bordas de minerais menos estáveis (incluindo, por exemplo, biotitas e também feldspatos) devem-se tanto a fase final de soerguimento do evento orogênico e metamórfico regional principal paleoproterozóico final, quanto a processos tectono-metamórficos regionais fracos neoproterozóicos do Ciclo Brasiliano. 


\section{CAPÍTULO VI - ELEMENTOS TERRAS RARAS EM GB E MGF E EM ESMERALDAS E ÁGUAS MARINHAS}

\section{VI.1 - ETR: FUNDAMENTOS E APLICAÇÕES}

Os elementos terras raras ou lantanídios (ETR) foram estudados em GB e MGF e em esmeraldas, pois são considerados excelentes indicadores de processos geológicos, petrogenéticos e metalogenéticos. Constituem uma família de 15 elementos, do $\mathrm{La}(Z=57)$ ao Lu $(Z=71)$, que por suas características geoquímicas, são nitidamente litófilos (Smirnov, 1976). As pequenas diferenças de raios iônicos e o estado trivalente predominante dos ETR explicam suas semelhanças químicas e físicas e, consequentemente, porque os ETR ocorrem na natureza, em geral, associados.

O Y e o Sc, de números atômicos 39 e 21, com propriedades químicas análogas, ocorrem intimamente associados aos lantanídeos e, sob o ponto de vista mineralógico, são considerados em conjunto com os ETR. Estes podem ser subdivididos em dois grupos: os ETR leves (ETRL) ou do grupo do $\mathrm{Ce}$, com baixo número atômico, do $\mathrm{La}$ ao $\mathrm{Eu}$, e os ETR pesados (ETRP) ou do grupo do Y, com maior número atômico, do $\mathrm{Gd}$ ao $\mathrm{Lu}$. Às vezes, é útil dividir os ETR em três subgrupos: do lantânio ou leves (La-Nd), do ítrio ou intermediárias (Sm-Ho) e do escândio ou pesados (Er-Lu).

Os raios iônicos dos ETR, em relação aos elementos maiores de rochas silicáticas, são comparáveis ao do $\mathrm{Ca}^{+2}$ e do $\mathrm{Na}^{+}$. São superiores ao do $\mathrm{Si}^{+4}, \mathrm{Al}^{+3}, \mathrm{Fe}^{+2}$ e $\mathrm{Fe}^{+3}$, não permitindo aos ETR substituir estes íons em posições octaédricas ou tetraédricas. São também nitidamente superiores àqueles dos elementos de transição da primeira série (do $\mathrm{Sc}$ ao $\mathrm{Zn}$ ).

A configuração eletrônica (Tab. 6.1) faz com que os ETR tenham todos, preferencialmente, valência +3. As exceções geológicas mais importantes são o Eu e o Ce, que podem, respectivamente, ter as valências +2 (sob condições redutoras) e +4 (sob condições altamente oxidantes). A proporção de Eu e Ce nos diferentes estados de oxidação, em qualquer sistema, é função da temperatura, pressão, composição e condições redox. Outra característica cristaloquímica importante é a contração lantanídica, ou seja, a redução progressiva dos raios iônicos com números atômicos crescentes, o que torna os ETR pesados mais compatíveis com estruturas silicáticas. 


\begin{tabular}{|c|c|c|c|c|}
\hline Elemento & Símbolo & $\mathbf{N}^{0}$ Atômico & Raio Iônico (nm) & Configuração \\
\hline Escândio & $\mathrm{Sc}$ & 21 & 8.1 & {$[\mathrm{Ar}] 3 \mathrm{~d}^{1} 4 \mathrm{~s}^{2}$} \\
\hline Ítrio & $\bar{Y}$ & 39 & 9.00 & {$[\mathrm{Kr}] 4 \mathrm{~d}^{1} 5 \mathrm{~s}^{2}$} \\
\hline Lantânio & $\overline{\mathrm{La}}$ & 57 & 10.32 & {$[\mathrm{Xe}] 5 \mathrm{~d}^{1} 6 \mathrm{~s}^{2}$} \\
\hline Cério & $\mathrm{Ce}$ & 58 & 10.10 & {$[\mathrm{Xe}] 4 \mathrm{f}^{2} 6 \mathrm{~s}^{2}$} \\
\hline Praseodímio & $\operatorname{Pr}$ & 59 & 9.90 & {$[\mathrm{Xe}] 4 \mathrm{f}^{3} 6 \mathrm{~s}^{2}$} \\
\hline Neodímio & $\mathrm{Nd}$ & 60 & 9.83 & {$[\mathrm{Xe}] 4 \mathrm{f}^{4} 6 \mathrm{~s}^{2}$} \\
\hline Prométio & $\mathrm{Pm}$ & 61 & Nd. & {$[\mathrm{Xe}] 4 \mathrm{f}^{3} 6 \mathrm{~s}^{2}$} \\
\hline Samário & Sm & 62 & 9.58 & $\mathrm{Xe}] 4 \mathrm{f}^{6} 6 \mathrm{~s}^{2}$ \\
\hline Európio & $\mathrm{Eu}$ & 63 & 9.47 & {$[\mathrm{Xe}] 4 \mathrm{f}^{7} 6 \mathrm{~s}^{2}$} \\
\hline Gadolínio & $\mathrm{Gd}$ & 64 & 9.38 & {$[\mathrm{Xe}] 4 \mathrm{f}^{\prime} 5 \mathrm{~d}^{1} 6 \mathrm{~s}^{2}$} \\
\hline Térbio & $\mathrm{Tb}$ & 65 & 9.23 & {$[\mathrm{Xe}] 4 \mathrm{f}^{9} 6 \mathrm{~s}^{2}$} \\
\hline Disprósio & $\overline{\text { Dy }}$ & 66 & 9.12 & {$[\mathrm{Xe}] 4 \mathrm{f}^{10} 6 \mathrm{~s}^{2}$} \\
\hline Hólmio & Ho & 67 & 9.01 & {$[\mathrm{Xe}] 4 \mathrm{f}^{\mathrm{T}} 6 \mathrm{~s}^{2}$} \\
\hline Érbio & Er & 68 & 8.90 & {$[\mathrm{Xe}] 4 f^{12} 6 s^{2}$} \\
\hline Túlio & $\mathrm{Tm}$ & 69 & 8.80 & {$[\mathrm{Xe}] 4 \mathrm{f}^{3} 6 \mathrm{~s}^{2}$} \\
\hline Itérbio & $\mathrm{Yb}$ & 70 & 8.68 & $\mathrm{Xe} / 4 \mathrm{f}^{4} 6 \mathrm{~s}^{2}$ \\
\hline Lutécio & $\mathrm{Lu}$ & 71 & 8.61 & {$[\mathrm{Xe}] 4 \mathrm{f}^{4} 5 \mathrm{~d}^{1} 6 \mathrm{~s}^{2}$} \\
\hline
\end{tabular}

Tabela 6.1: Números atômicos, raios iônicos e configuração eletrônica dos ETR, Y e Sc, segundo Henderson (1984).

$\mathrm{Na}$ análise e representação dos ETR em sistemas petro-metalogenéticos, magmáticos/pós-magmáticos, os parâmetros mais importantes são a abundância geral dos ETR nestes sistemas, suas analogias geoquímicas e substituições com outros elementos.

As abundâncias dos ETR, em geral, baixas fazem com que a freqüência cósmica tenha grande influência em suas concentrações absolutas num determinado composto; ou seja, existem grandes variações entre ETR de números atômicos consecutivos pares e ímpares. Este efeito é compensado por representações normalizadas, tendo sido propostos na literatura vários padrões (Tab. 6.2). Os valores de Sun \& McDonough (1989) serão usados para a normalização dos dados nesse trabalho.

O modo de ocorrência de ETR num sistema petrogenético depende da abundância total

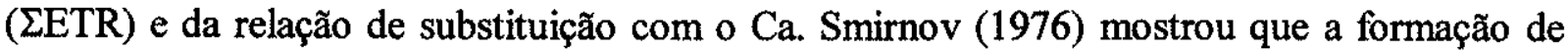
minerais de ETR (sendo os três principais a monazita, o xenotímio e a bastnaesita) nas rochas depende da razão $100\left(\mathrm{TR}_{2} \mathrm{O}_{3} / \mathrm{Ca}\right)$ : quando $>1$ é possível formar minerais de ETR e para valores $<1$ os ETR ocorrem dispersos nos minerais essenciais das rochas ocupando posições compatíveis com seu raio iônico (mormente, do $\mathrm{Ca}$ ). 


\begin{tabular}{|c|c|c|c|c|c|c|}
\hline & $\begin{array}{c}\text { Média de 09 } \\
\text { Condritos }^{(1)}\end{array}$ & $\begin{array}{c}\text { Média de 12 } \\
\text { Condritos }^{(2)}\end{array}$ & $\begin{array}{c}\text { Média de 10 } \\
\text { Condritos }^{(3)}\end{array}$ & $\begin{array}{c}\text { Média de } \\
\text { Condritos C1 }^{(4)}\end{array}$ & $\begin{array}{c}\text { Média de } \\
\text { Condritos C1 }^{(5)}\end{array}$ & $\begin{array}{c}\text { Condrito de } \\
\text { Leedey }^{(6)}\end{array}$ \\
\hline $\mathrm{La}$ & 0.330 & 0.34 & 0.329 & 0.2446 & 0.237 & 0.378 \\
\hline $\mathrm{Ce}$ & 0.88 & 0.91 & 0.865 & 0.6379 & 0.612 & 0.976 \\
\hline $\mathrm{Pr}$ & 0.112 & 0.121 & - & 0.09637 & 0.095 & - \\
\hline $\mathrm{Nd}$ & 0.60 & 0.64 & 0.630 & 0.4738 & 0.467 & 0.716 \\
\hline $\mathrm{Sm}$ & 0.181 & 0.195 & 0.203 & 0.1540 & 0.153 & 0.230 \\
\hline $\mathrm{Eu}$ & 0.069 & 0.073 & 0.0770 & 0.05802 & 0.058 & 0.0866 \\
\hline $\mathrm{Gd}$ & 0.249 & 0.26 & 0.276 & 0.2043 & 0.2055 & 0.311 \\
\hline $\mathrm{Tb}$ & 0.047 & 0.047 & - & 0.03745 & 0.0374 & - \\
\hline $\mathrm{Dy}$ & - & 0.30 & 0.343 & 0.2541 & 0.2540 & 0.390 \\
\hline $\mathrm{Ho}$ & 0.070 & 0.078 & - & 0.05670 & 0.0566 & - \\
\hline $\mathrm{Er}$ & 0.200 & 0.20 & 0.225 & 0.1660 & 0.1655 & 0.255 \\
\hline $\mathrm{Tm}$ & 0.030 & 0.032 & - & 0.02561 & 0.0255 & - \\
\hline $\mathrm{Yb}$ & 0.200 & 0.22 & 0.220 & 0.1651 & 0.170 & 0.249 \\
\hline $\mathrm{La}$ & 0.034 & 0.034 & 0.0339 & 0.02539 & 0.0254 & 0.0387 \\
\hline
\end{tabular}

Tabela 6.2 :Valores de normalização para os ETR, segundo: (1) Haskin et al. (1968); (2) Wakita et al. (1971); (3) Nakamura (1974); (4) Evensen et al. (1978); (5) Sun \& McDonough (1989); (6) Masuda et al. (1973).

De modo geral, tem sido constatado que minerais como zircão, granada, anfibólio e piroxênio são concentradores, particularmente eficientes, de ETRP. Apatita, titanita, monazita e allanita retém preferencialmente os ETRL. $\mathrm{O} \mathrm{Eu}$, dada a sua tendência de ocorrência no estado divalente, aparece, geralmente, em maiores teores em minerais cálcicos, sendo suas anomalias em rochas silicáticas controladas pelo feldspato, especialmente, plagioclásio, uma vez que $\circ \mathrm{Eu}^{+2}$ é compatível com o $\mathrm{Ca}^{+2}$ destes minerais, mas também com o $\mathrm{K}^{+}$nos feldspatos alcalinos (em analogia ao $\mathrm{Ba}^{+2}$ ). Assim, uma anomalia positiva de Eu pode resultar da concentração de plagioclásio cálcico, hornblenda, clinopiroxênio, granada e apatita nas rochas, enquanto que a remoção dos feldspatos dos magmas félsicos durante a sua cristalização fracionada ou a retenção dos feldspatos nos resíduos de fusão parcial da rocha pretérita (protólito) produzirão anomalias negativas de Eu nas fusões. O comportamento dos ETR em minerais de diferentes tipos de rochas foi resumido por Clark (1984), sendo que as rochas ígneas podem conter várias centenas de ppm de lantanídeos, distribuídos nos minerais principais e/ou acessórios. Em rochas graníticas, os ETR estão concentrados, sobretudo, em minerais acessórios, como titanita, zircão, apatita, alanita e monazita. A contração dos lantanídeos é responsável pela entrada preferencial dos ETRP (cátions com raios menores) nas posições do $\mathrm{Ca}$, o que faz com que os ETRL fiquem concentrados nas frações tardias da cristalização fracionada, nos líquidos residuais e fluidos pós-magmáticos, ou então, nos fluidos/líquidos iniciais da fusão parcial. 
As propriedades geoquímicas dos ETR são, em geral, descritas em termos de valores normalizados: o grau de fracionamento dos ETRP em relação aos ETRL pelas razões $\mathrm{La} \mathrm{a}_{\mathrm{N}} / \mathrm{Lu} \mathrm{u}_{\mathrm{N}}$ ou $\mathrm{Ce}_{\mathrm{N}} / \mathrm{Yb} \mathrm{b}_{\mathrm{N}}$; e o comportamento do $\mathrm{Eu}$ relativo às freqüentes anomalias positivas ou negativas pela relação $\mathrm{Eu} / \mathrm{Eu}^{*}$, onde o Eu representa o teor real normalizado e o Eu* é um valor obtido por interpolação linear entre o Sm e Gd no padrão da amostra analisada. $\mathrm{O}$ mesmo princípio pode ser utilizado na quantificação das anomalias de $\mathrm{Ce}$, usando-se, então, a interpolação linear entre o La e o Nd.

Estudos sobre o comportamento geoquímico dos ETR em petrogênese ígnea de rochas graníticas foram feitos por Drury (1979), Condie (1981), Cullers \& Graf (1984), Taylor \& McLennan (1985), entre outros (ver também: Figueiredo, 1985; Formoso et al, 1989). A metalogenia dos ETR em processos metassomáticos, em função das condições de temperatura, pressão, alcalinidade, composição da rocha mãe e das encaixantes, foi estudada por vários autores, sendo um assunto de importância, inclusive, para a migração desses elementos em soluções (Mineyev, 1963; Kovalenko et al., 1966; Hildreth, 1981; ver ainda: Formoso et al., 1989).

A mobilidade dos ETR por longo tempo desconsiderada, vem sendo reconhecida cada vez mais como fenômeno-chave na compreensão e interpretação petrogenética e metalogenética de sistemas de interação fluidos-rocha, tardi a pós-magmáticos (pegmatíticos, pneumatolíticos a hidrotermais), metamórfico-metassomáticos e supergênico-intempéricos (Mineyev, 1963; McLennan \& Taylor, 1979; Hellman et al., 1979; Beswick, 1982; Humphris (1984); Sverjensky, 1984; Michard, 1989; Rollinson, 1993; Banks et al., 1994; Wood \& Williams-Jones, 1996; ver também: Figueiredo, 1985; Formoso et al., 1989, entre outros). Assim, distinguem-se processos CHARAC controlados por carga e raio iônico dos ETR, nos quais continuam válidos os coeficientes de fracionamento magmáticos e metamórficos, de processos em fases fluidas, controlados pela especiação em íons complexos por ligantes específicos dos ETR; estes são caracterizados pelo efeito tetrádico (dos ETR) em seus depósitos.(Masuda et al., 1987; McLennan, 1994; Bau, 1996) Para as finalidades deste trabalho são de interesse especial as relações dos ETR em fases fluidas com elementos tais como $\mathrm{Al}, \mathrm{Be}, \mathrm{Fe}, \mathrm{Zr}, \mathrm{Ti}, \mathrm{F}, \mathrm{Cl}, \mathrm{CO}_{2}$, entre outros, e suas interações com as rochas, especialmente TTG e metaultramáficas, em condições pós-magmáticas até hidrotermais metamórfico metassomáticas (Mineyev, 1963; McLennan \& Taylor, 1979). 


\section{VI.2 - RESULTADOS}

Os ETR foram utilizados nesta pesquisa para a avaliação dos processos petrogenéticos e metalogenéticos atuantes na evolução das rochas graníticas e dos fluidos metamórficos/metassomáticos/mineralizantes berilíferos. Para isto, foram efetuadas análises de ETR em: a) Metagranitóides Borrachudos (GB) e Metagranitóides Foliados com Fluorita (MGF); e b) em esmeraldas e águas marinhas (subordinadamente) das mineralizações associadas.

\section{VI.2.1 - ETR EM GB E MGF}

Foram analisados, por ICP-MS, em torno de 60 elementos traço, incluindo ETR, de 16 amostras de metagranitóides GB e MGF (Anexo 3, Tab. A3.1). Os elementos maiores, menores e traço convencionais dessas amostras já foram discutidos no Capítulo 3 (ver também Machado, 1994).

Teores totais de ETR ( $\Sigma$ ETR) maiores em rochas graníticas indicam a tendência para termos mais evoluídos por processos magmáticos e pós-magmáticos (Smirnov, 1976) e os enriquecimentos de ETRP e $\mathrm{Y}$ em relação aos ETRL indicam acidez progressiva, considerando, ambos, os teores de $\mathrm{SiO}_{2}$ e F (Kovalenko et al., 1966). Banks et al. (1994) e Wood \& Williams-Jones (1996) sugeriram que Y e ETRP são transportados e enriquecidos nos fluidos metassomáticos como complexos F-ETRP.

Nas rochas estudadas observam-se elevados teores de $\Sigma E T R$, com nítidos enriquecimentos dos GB para os MGF. As razões Y/LETR assim como $\Sigma E T R P / \Sigma E T R L$ aumentam no mesmo sentido, enquanto $\Sigma E T R L / \Sigma E T R P$ diminuem (Tab. 6.3).

\begin{tabular}{|c|c|c|}
\hline Razóes & GB & MGF \\
\hline$\overline{\Sigma E T R}(\mathrm{ppm})$ & 559.71 & 699.25 \\
\hline Y/IETR & 0.16 & 0.23 \\
\hline 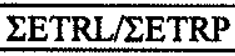 & 7.14 & 5.30 \\
\hline 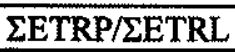 & 0.14 & 0.19 \\
\hline$(\mathrm{La} / \mathrm{Sm}) \mathrm{N}$ & $2.81-4.97$ & $3.96-5.85$ \\
\hline$(\mathrm{Gd} / \mathrm{Lu}) \mathrm{N}$ & $1.22-2.64$ & $1.13-1.69$ \\
\hline$(\mathrm{La} / \mathrm{Lu}) \mathrm{N}$ & $5.58-16.45$ & $5.48-8.95$ \\
\hline $\mathrm{Eu} / \mathrm{Eu}^{*}$ & 0.06 ( constante) & $0.06-0.08$ \\
\hline
\end{tabular}

Tabela 6.3: Características de ETR dos GB e MGF (valores médios), incluindo coeficientes de fracionamento e valores $\mathrm{Eu} / \mathrm{Eu}^{*}$ (= Eu normalizado dividido por Eu interpolado entre $\mathrm{Sm}$ e Gd normalizados). Normalização: Condritos C1 de Sun \& McDonough (1989). 
As relações $\Sigma$ ETRP versus $\mathrm{SiO}_{2}$ e $\mathrm{Y}$ são mostradas na Figura 6.1, com correlações positivas e valores crescentes dos GB para os MGF, o que indica um aumento na acidez da paragênese mineral (cf.: Kovalenko et al., 1966); a presença de fluorita sugere que o Y e os ETRP foram transportados e enriquecidos por complexos flúor-ETRP nos fluidos metamórfico-metassomáticos (Banks et al., 1994; Wood \& Williams-Jones, 1996). Uma amostra anômala, com enriquecimento extremo de ETRP, representa uma variedade petrográfica de GB com elevados teores de hornblenda hastingsita.

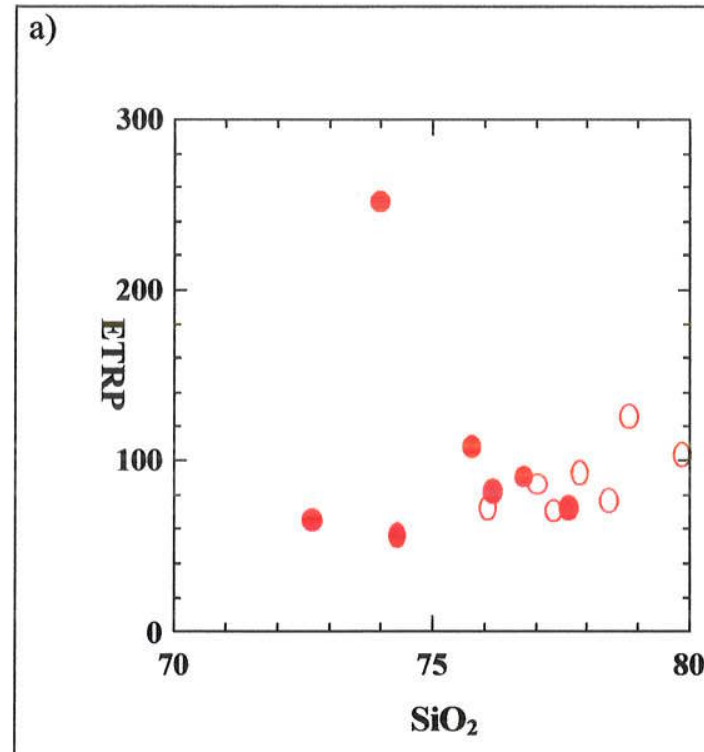

b)

Figura 6.1: Correlações do $\Sigma E T R P$ com: a) $\mathrm{SiO}_{2}$; e b) Y nos GB (•) e MGF (o).

Os padrões de distribuição dos ETR normalizados são muito homogêneos nos GB e MGF. Apresentam enriquecimento pronunciado dos ETRL em relação aos ETRP $\left(\mathrm{La}_{\mathrm{N}} / \mathrm{Sm}_{\mathrm{N}}\right.$ entre 2.81 e $5.85, \mathrm{Gd}_{\mathrm{N}} / \mathrm{Lu}_{\mathrm{N}}$ entre 1.13 e 2.64 e $\mathrm{La}_{\mathrm{N}} / \mathrm{Lu}_{\mathrm{N}}$ entre 5.48 e 16.45 ), alcançando valores superiores a $1.000 \mathrm{X} \mathrm{C1}$ para o La e abundância total dos ETRP variando entre $40 \mathrm{e}$ $120 \mathrm{X} \mathrm{C1}$ e fortes anomalias negativas de Eu (Tab. 6.3 e Fig. 6.2). As razões $\mathrm{La}_{\mathrm{N}} / \mathrm{Sm}_{\mathrm{N}}$ e as anomalias negativas de Eu aumentam sistematicamente dos GB para os MGF, enquanto as razões $\mathrm{Gd}_{\mathrm{N}} / \mathrm{Lu}_{\mathrm{N}}$ e $\mathrm{La}_{\mathrm{N}} / \mathrm{Lu}_{\mathrm{N}}$ diminuem. Os padrões evidenciam, ainda, e de forma bastante clara o efeito tetraédico (Masuda et al., 1987; McLennan, 1994; Bau, 1996) tanto nos GB como nos MGF. 
Granitos potássicos, tardi-arqueanos, ígneos ou metassomáticos, de outras localidades, apresentam características similares, especialmente, no que diz respeito às altas razões $\mathrm{La}_{\mathrm{N}} / \mathrm{Lu}_{\mathrm{N}}$, os padrões planos a moderadamente inclinados de ETRP e a significante depauperação de Eu (McLennan \& Taylor, 1979; Taylor \& McLennan, 1985; ver também Figueiredo, 1985); entretanto, o efeito tetraédrico foi verificado apenas em depósitos pósmagmáticos, pegmatíticos a hidrotermais, ou em rochas ígneas que sofreram alterações dessa natureza (Masuda et al., 1987; McLennan, 1994; Bau, 1996).

a)

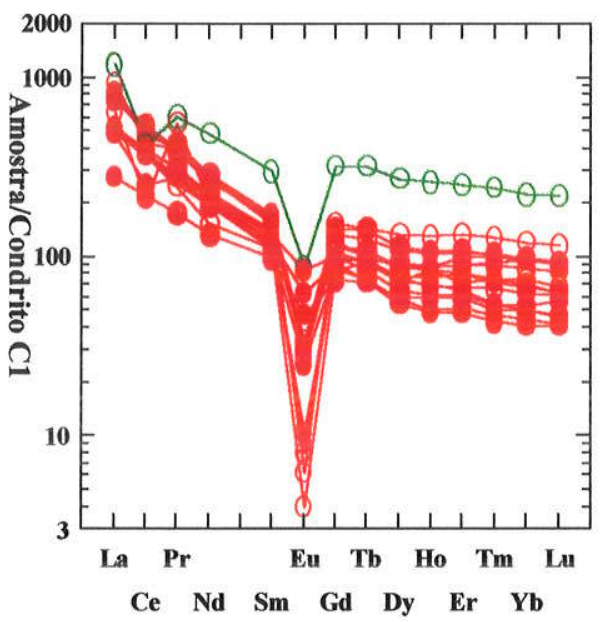

b)

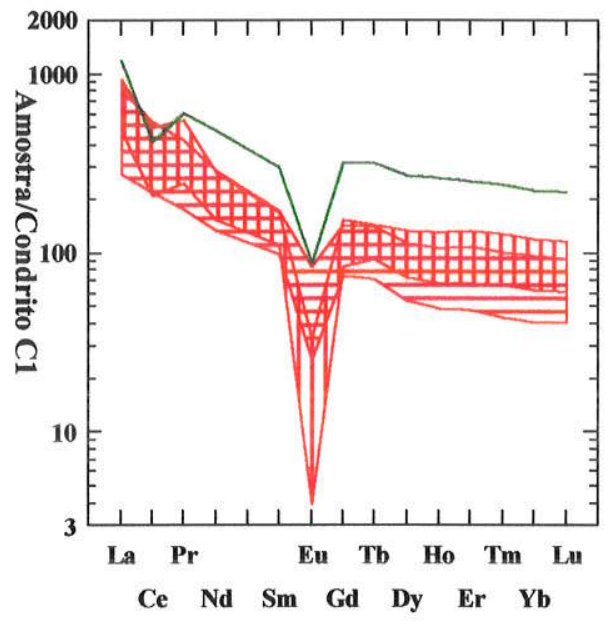

Figura 6.2: a) Padrões de ETR dos GB (•) e MGF (o), normalizados segundo Sun \& McDonough (1989). A amostra G-29c (o) de GB com elevados teores de hastingsita apresenta teores mais elevados de ETR totais. b) Áreas de distribuição dos ETR dos GB (hachuras horizontais) e MGF (hachuras verticais).

Uma análise dos valores absolutos dos ETR (Anexo 3, Tab. A3.1) e da Figura 6.2 permite concluir que os GB apresentam características que evidenciam a importância de processos metassomáticos de fluidos potássicos e ricos em $\mathrm{F}$ e $\mathrm{Si}$ (entre outros) na sua formação. Essa análise confirma, ainda, a relação genética entre os GB e MGF, por metamorfismo regional progressivo de grau médio a alto, que resultou em processos iniciais de fusão parcial. A progressão metamórfica foi responsável pelas anomalias negativas de Eu mais fortes e enriquecimentos parciais em ETRL e gerais em ETRP nos MGF em relação aos GB. O enriquecimento em ETRL originou anomalias negativas fracas de Ce nos MGF e ocorre de forma análoga, embora mais forte, também numa amostra de GB que apresenta elevados teores de hornblenda hastingsita (G-29c). 
A anomalia negativa de Eu é considerada consensualmente uma indicação de mudança episódica sofrida pela crosta continental no final do Arqueano, quando teria passado a conter volumosos corpos de granitos potássicos (McLennan \& Taylor, 1979; Taylor \& McLennan, 1985). Nos GB, a ausência de fluorescência nos feldspatos verificada em testes de espectrofluorescência, indica que todo o Eu estaria presente como $\mathrm{Eu}^{+2}$ que é isomorfo com o $\mathrm{Ca}^{+2}$ e neste caso não fluoresce. Isto significa que as anomalias negativas Eu podem ter sido produzidas pelas reações metassomáticas de substituição do plagioclásio (com $\mathrm{Eu}^{2+} \mathrm{em}$ sua estrutura) por K-feldspato e perdas decorrentes de Eu. Já o desenvolvimento da anomalia negativa de Eu dos GB para os MGF sugere, ainda, diferentes condições físico-químicas dos fluidos-metamórficos causando perdas de $\mathrm{Eu}$ relacionadas em parte a anatexia inicial e formação dos abundantes veios pegmatóides nos MGF.

Alguns corpos de granitóides do extremo NE do QF, mais especificamente, da região compreendida à leste da Serra do Espinhaço Meridional entre Itabira e Guanhães, foram considerados por outros autores como granitos ígneos mesoproterozóicos da Suíte Borrachudos (Grossi Sad et al., 1990; Dussin, 1994; Fernandes et al., 1995a,b), com base em dados de elementos menores/traço e ETR. A análise comparativa desses dados em conjunto com a média dos GB e MGF dessa pesquisa mostra nítidas diferenças nos espectros de ETR, especialmente das anomalias de Eu e dos teores de ETRP (Fig. 6.3). Também notam-se diferenças quanto aos demais elementos traço com destaque para $\mathrm{Pb}, \mathrm{V}, \mathrm{Zn}, \mathrm{Ni}$ e $\mathrm{Cr}$ (Fig. 6.4). Neste sentido, vale acrescentar que, segundo Taylor \& McLennan (1985), a crosta arqueana é similar àquela da média das rochas cálcio-alcalinas modernas, exceto que são mais abundantes em $\mathrm{Cr}$ e $\mathrm{Ni}$. Estas diferenças sustentam a posição deste trabalho de separar os $\mathrm{GB}$ e MGF desta pesquisa dos outros granitóides da Suíte Borrachudos de Grossi Sad et al. (1990) e demais autores. 
a)

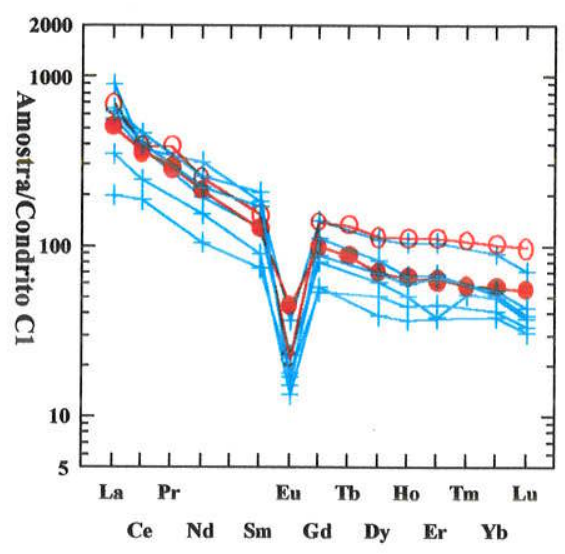

c)

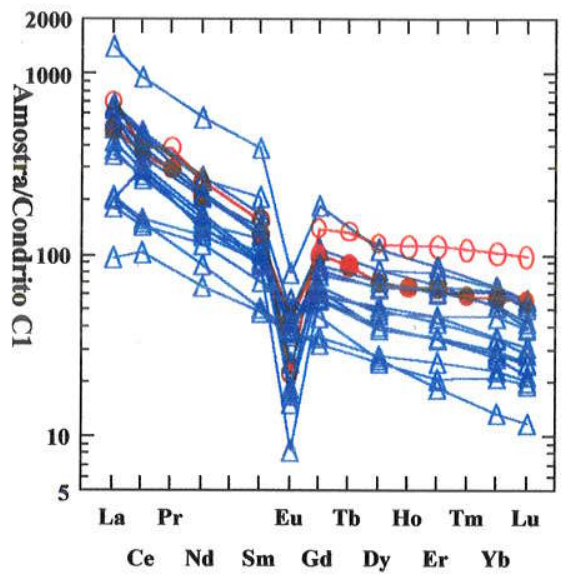

e)

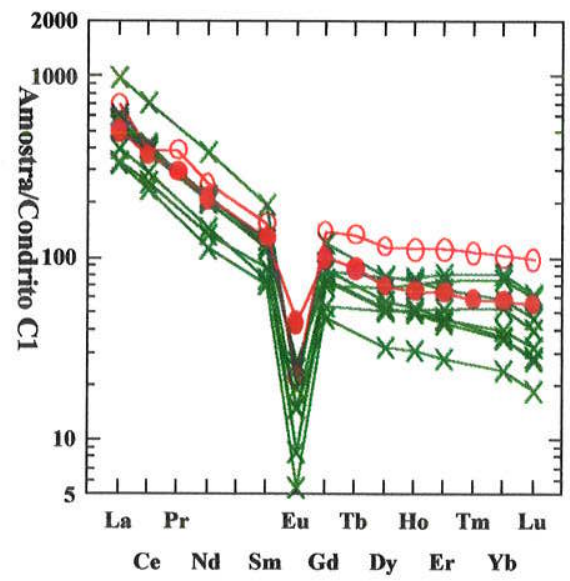

b)

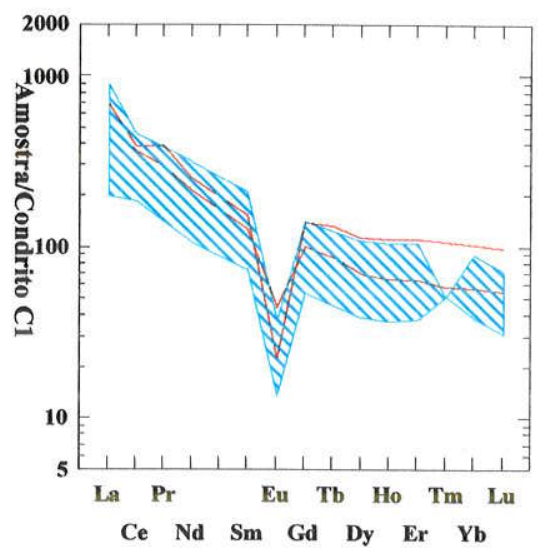

d)

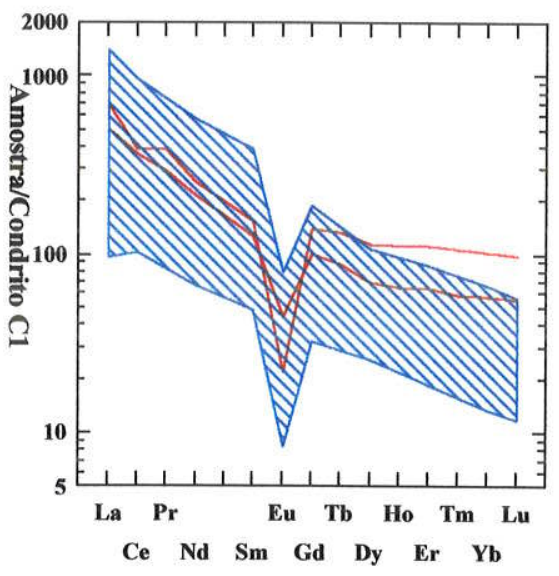

f)

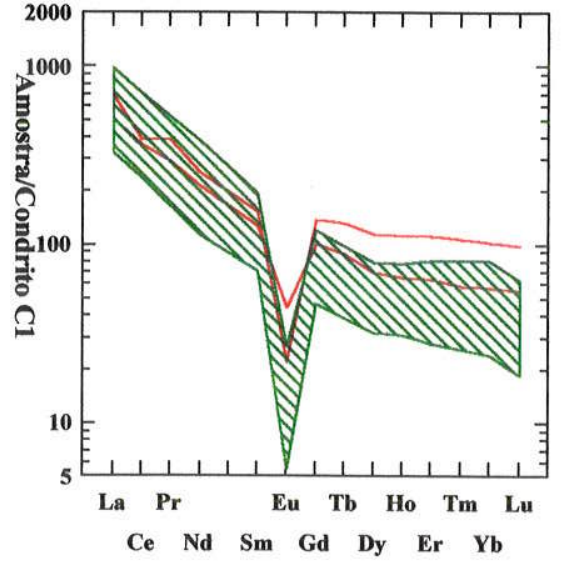

Figura 6.3: Padrões de ETR de granitóides da Suíte Borrachudos com dados de: a,b - Grossi Sad et al, 1990; c,d - Dussin, 1994; e,f - Fernandes et al., 1995a, em comparação com os valores médios dos GB (॰) e MGF (o) desta pesquisa. Normalização: Sun \& McDonough (1989). 


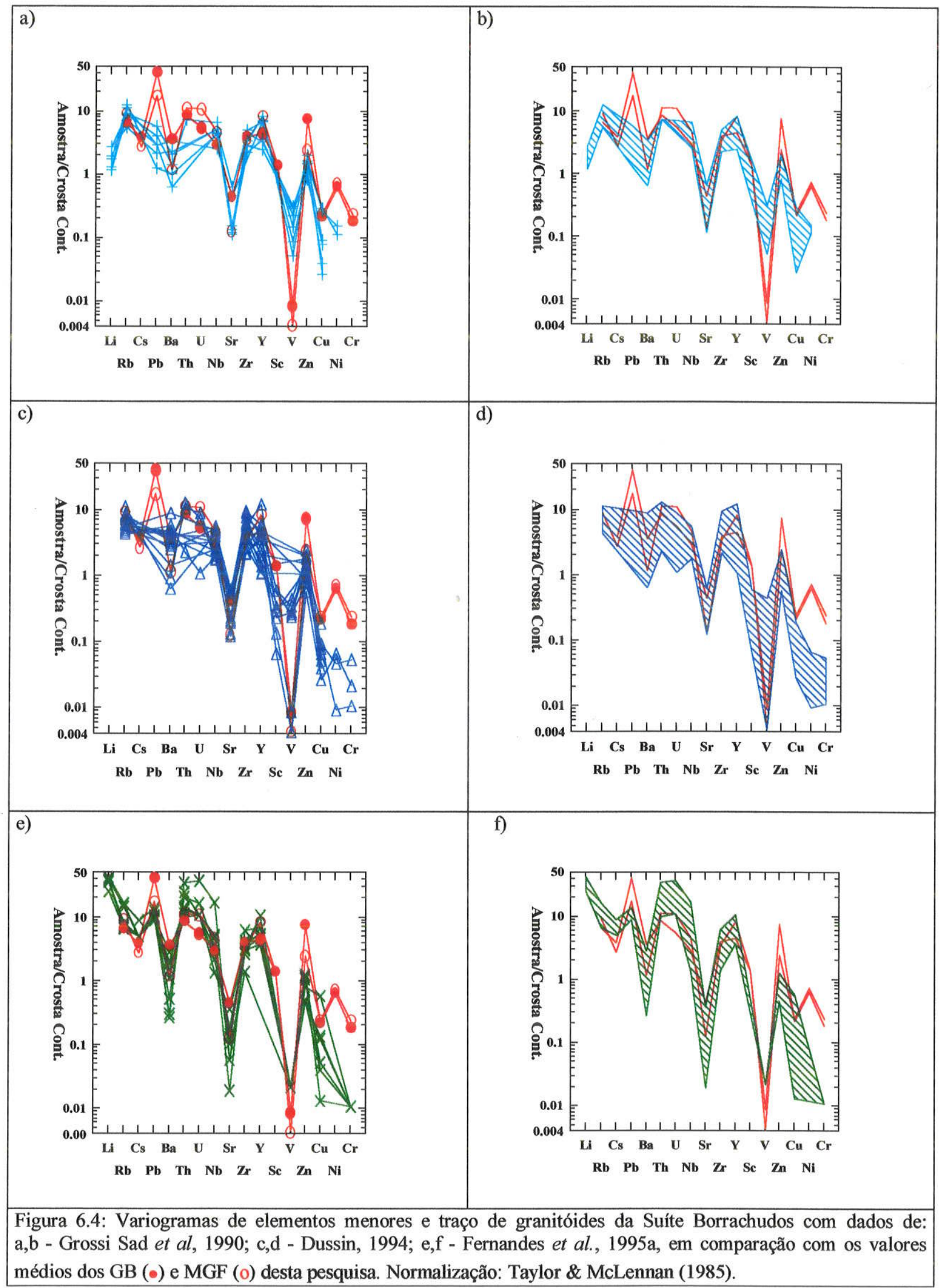




\section{VI.5.2 - ETR EM ESMERALDAS E ÁGUAS MARINHAS}

Para melhor caracterização das mineralizações berilíferas da região de Capoeirana e Belmont foram analisados, via ICP-MS, os ETR em 14 amostras de esmeraldas de Capoeirana e Belmont, considerando as diferentes associações genéticas (EX, EVQ, EVP) e 03 de águasmarinhas que ocorrem na parte pegmatóide (AMP) e em veios/mobilizados de quartzo do núcleo de um corpo pegmatítico métrico (AMQ) nos MGF. Os resultados das análises encontram-se no Anexo 3 (Tab. A3.2).

Os valores de $\Sigma E T R$ absolutos nas esmeraldas e águas marinhas são, em geral, baixos para a maioria dos casos estudados. Das esmeraldas, 06 análises apresentam $\Sigma E T R<10$ ppm, 09 entre 10 e 20 ppm e 01 (amostra G-260) tem $\Sigma E T R>100$ ppm. Os valores de $\Sigma E T R$ nas EVQ são mais homogêneos (sempre abaixo de $10 \mathrm{ppm}$ ), ao passo que nas EX variam consideravelmente. De modo similar às EX, as águas-marinhas provenientes de um único pegmatito apresentam $\Sigma E T R$ bastante variáveis (respectivamente, abaixo de 20 ppm nas AMP e de 95 ppm em uma única amostra de $A M Q$ do núcleo pegmatítico).

\begin{tabular}{|c|c|c|c|c|}
\hline Razðes & EX & EVQ & EVP & $\mathbf{A M}$ \\
\hline EETR (ppm) & 10.0 & 5.0 & 5.0 & 51.0 \\
\hline Y/LETR & 0.09 & 0.26 & 0.55 & 0.17 \\
\hline$\Sigma E T R L / \Sigma E T R P$ & 14.86 & 3.89 & 1.42 & 6.54 \\
\hline 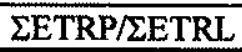 & 0.07 & 0.26 & 0.70 & 0.15 \\
\hline$(\mathrm{La} / \mathrm{Sm}) \mathrm{N}$ & $3.80-10.58$ & $1.85-18.12$ & $0.94-7.24$ & $1.06-2.84$ \\
\hline$(\mathrm{Gd} / \mathrm{Lu}) \mathrm{N}$ & $0.49 \cdots 2.05$ & $0.03-0.91$ & $0.07-0.36$ & $1.48-5.66$ \\
\hline$(\mathrm{La} / \mathrm{Lu}) \mathrm{N}$ & $1.61-21.95$ & $0.07-4.72$ & $0.10-0.79$ & $3.69-18.0$ \\
\hline $\mathrm{Eu} / \mathrm{Eu}^{*}$ & $0.07-0.08$ & $0.04-0.12$ & $0.05-0.29$ & $0.03-0.06$ \\
\hline
\end{tabular}

Tabela 6.4: Propriedades de ETR de esmeraldas EX (de xisto), EVQ (de veios de quartzo) e EVP (de veios pegmatóides) e de águas marinhas (AM) pegmatíticas dos MGF, incluindo coeficientes de fracionamentos e quantificaçðes $\mathrm{Eu} / \mathrm{Eu}^{*}$ (Eu normalizado dividido por $\mathrm{Eu}$ intrapolado entre o $\mathrm{Sm}$ e $\mathrm{Gd}$ normalizados). Normalização: Condritos $\mathrm{Cl}$ de Sun \& McDonough (1989).

Os fracionamentos de ETRL são maiores nas EVQ (com razões $\mathrm{La}_{\mathrm{N}} / \mathrm{Sm}_{\mathrm{N}}$ variando até 18.12). As EX são caracterizadas pelos maiores fracionamentos de $\mathrm{ETRP}\left(\mathrm{Gd}_{\mathrm{N}} / \mathrm{Lu}_{\mathrm{N}}\right.$ até 2.05) e de ETR totais $\left(\mathrm{La}_{N} / \mathrm{Lu}_{\mathrm{N}}\right.$ até 21.95) (Tab. 6.4). As EVP, à exceção das razões Eu/Eu*, apresentam os menores coeficientes de fracionamentos. Os cristais de águas-marinhas, comparativamente às esmeraldas, apresentam altos fracionamentos de ETRP e de ETR totais. 
As razões $\mathrm{Y} / \Sigma E T R$ e $\Sigma E T R P / \Sigma E T R L$ aumentam das EX para EVP, o que indica um aumento na acidez das paragêneses consecutivas (cf.: Kovalenko et al., 1966), em analogia aos GB e MGF. O comportamento do Y em relação aos ETRP é mostrado na Figura 6.5a, indicando, como no caso dos metagranitóides, correlação positiva. Isto sugere que o $\mathrm{Y}$ e os ETRP foram transportados por complexos flúor-ETRP (Banks et al., 1994; Wood \& Williams-Jones, 1996) nos fluidos metassomáticos mineralizantes que, por sua vez, indicam composição similar àquela dos fluidos que agiram nos GB e MGF (Fig. 6.5b).

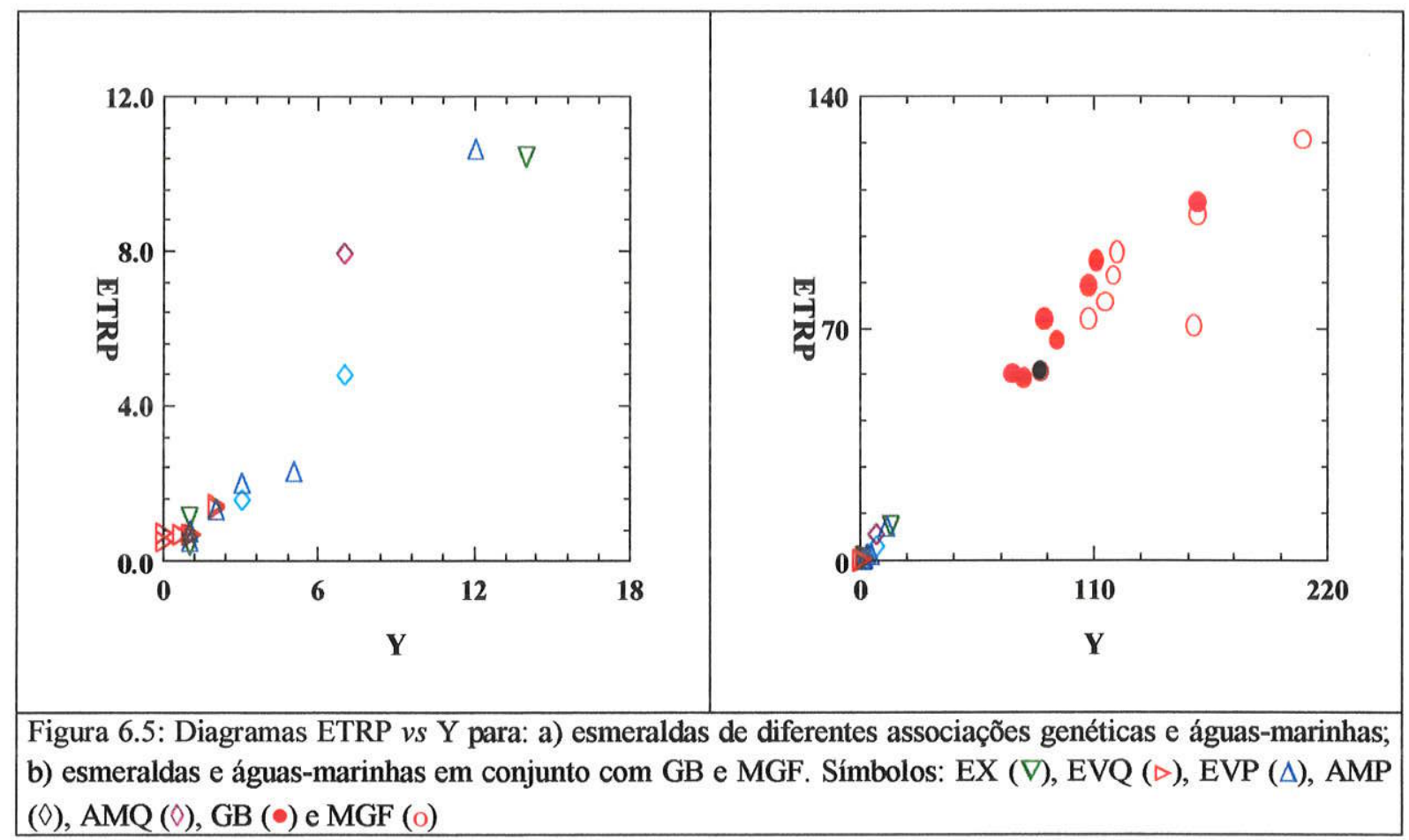

Representadas em diagramas multielementares com normalização de condritos C1 (Sun \& McDonough, 1989), as esmeraldas são caracterizadas, em geral, por um padrão dos ETR relativamente plano ou em forma de ' $u$ ' aberto (Fig. 6.6). São enriquecidas em ETRL (La varia entre 0.4 e 200 X C1) e pobres em ETRP, com exceção do Yb e Lu que se apresentam variavelmente enriquecidos ( $\mathrm{Lu}$ varia entre 0.8 e $20 \mathrm{X} \mathrm{C1}$ ). Exibem, também, nitidamente efeito tetrádico (Masuda et al., 1987; McLennan, 1994; Bau, 1996) e maiores fracionamentos em ETRL (Tab. 6.4). Nestes diagramas podem também ser observadas diferenças nos ETR entre os grupos genéticos individuais de esmeraldas, tais como: 
- EX: apresentam os mais variados teores em ETRL, alcançando valores máximos superiores a $200 \mathrm{X} \mathrm{C1}$ para o La. Ce apresenta anomalias fracas, ora positivas, ora negativas. Eu e $\mathrm{Tm}$ exibem anomalias negativas, variáveis. $\mathrm{Er}, \mathrm{Yb}$ e $\mathrm{Lu}$ apresentam anomalias positivas, mais evidentes para os elementos mais pesados (Fig. 6.6a,b);

- EVQ: são caracterizados dois subgrupos distintos: o primeiro (amostras B-21 e B-22 de veios polideformados de Belmont) com teores mais elevados em todos os ETR (exceto $\mathrm{Lu}$ ), apresenta anomalias negativas de $\mathrm{Ce}, \mathrm{Eu} \mathrm{e}$, eventualmente, Dy, assim como fraco enriquecimento de Lu; o segundo subgrupo (amostras NE-34, NE-36a e NE-36b de veios pouco deformados de Capoeirana) exibe padrões planos, anomalias positivas eventuais de Pr e negativas de Eu e forte enriquecimento dos ETRP do Tm ao Lu (Fig. 6.6c,d); ressaltase, de um modo geral, uma maior similaridade do primeiro subgrupo com as EX.

- EVP: são, também, caracterizados dois subgrupos distintos: o primeiro (amostras Gal 1/2a e NE-31-01) com teores de ETR, em geral, mais elevados, apresenta anomalias positivas, fracas, de Ce e negativas de Eu, assim como enriquecimentos de ETRP, do Yb ao Lu; o segundo (amostras NE-31-02, NE-31-03 e NE-31-06) apresenta anomalias negativas de Sm e enriquecimentos mais fortes de ETRP, do Er ao Lu. A amostra NE-30 exibe um padrão de ETR distinto, com anomalias positivas de Ce e Sm e negativas de Eu, assim como o mais forte enriquecimento de ETRP de todas as amostras analisadas; entretanto, no seu padrão geral, assemelha-se mais ao primeiro subgrupo (Fig. 6.6e,f).

Os subgrupos de EVQ e EVP, caracterizados por composições químicas distintas, representam diferentes gerações de esmeraldas, sendo os subgrupos mais ricos em ETR de ambos, veios de quartzo e veios pegmatóides, mais similares as EX. 
a)

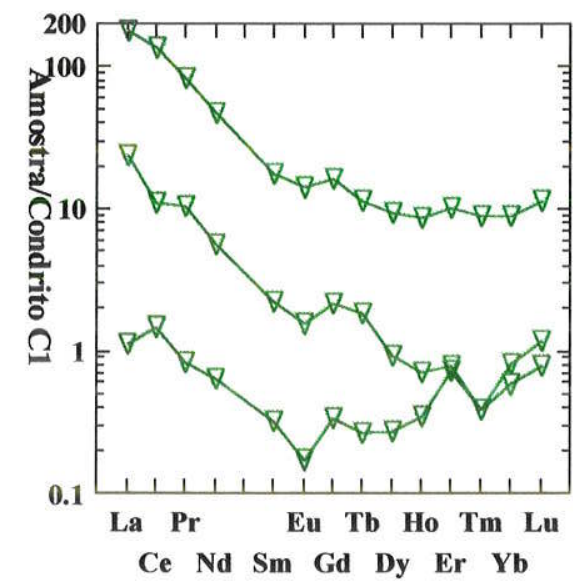

c)

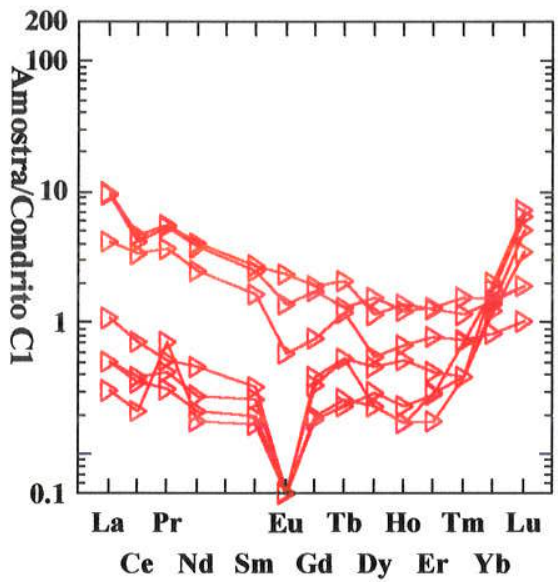

e)

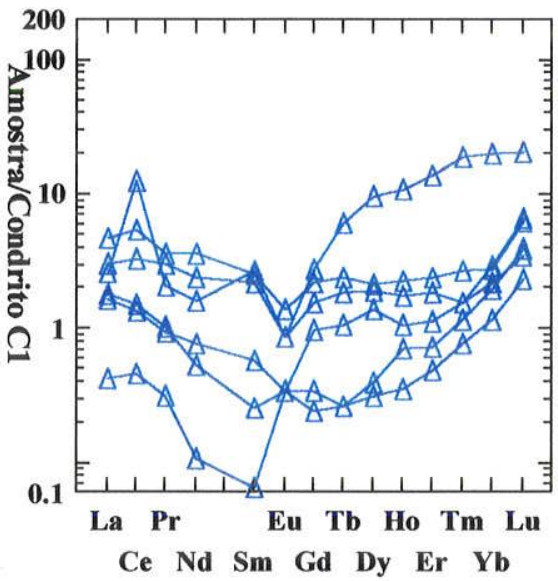

b)

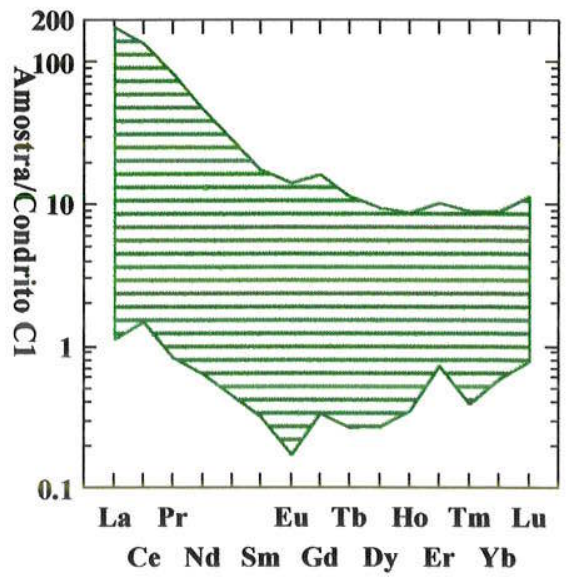

d)

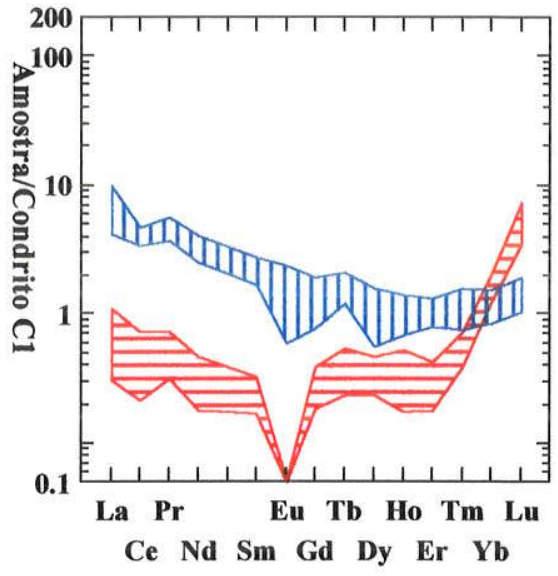

f)

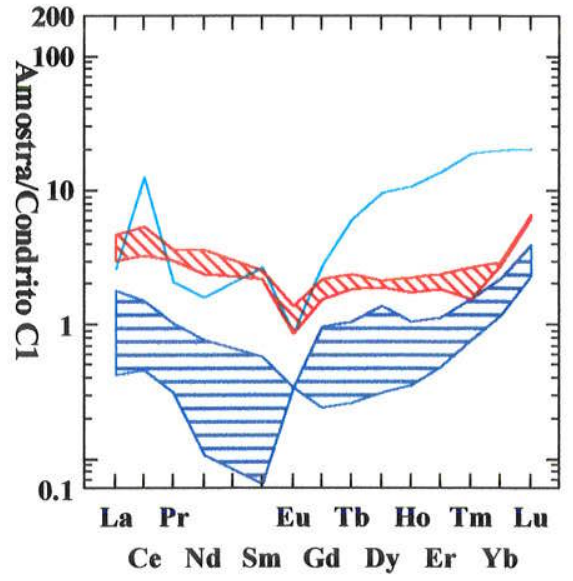

Figura 6.6: Padrões dos ETR de esmeraldas, normalizados em Condritos C1 (Sun \& McDonough, 1989): a,b) $\operatorname{EX~}(\nabla)$; c,d) $\operatorname{EVQ}(\triangleright)$; e,f) $\operatorname{EVP}(\Delta)$. 
Os cristais de água-marinha analisados, provenientes de um veio pegmatítico em MGF, respectivamente, de sua porção pegmatóide (amostras G-39a e G-39b) e quartzosa (amostra G-39c), apresentam composições distintas entre si. Nas águas-marinhas das porções pegmatóides (AMP), o padrão de distribuição dos ETR é homogêneo, com declive suave do La ao Sm e plano para os ETRP, destacando-se a anomalia negativa forte de Ce e sutil empobrecimento em Eu. Já o cristal de água-marinha da porção quartzosa (AMQ) apresenta um padrão muito diferente, com enriquecimentos em ETRL, forte anomalia positiva de Eu e Sm e empobrecimento mais acentuado em ETRP do que as AMP, com exceção de um fraco enriquecimento de $\mathrm{Yb}$ e $\mathrm{Lu}$; todas as águas-marinhas apresentam, ainda, nítidos efeitos tetraédricos (Fig. 6.7).

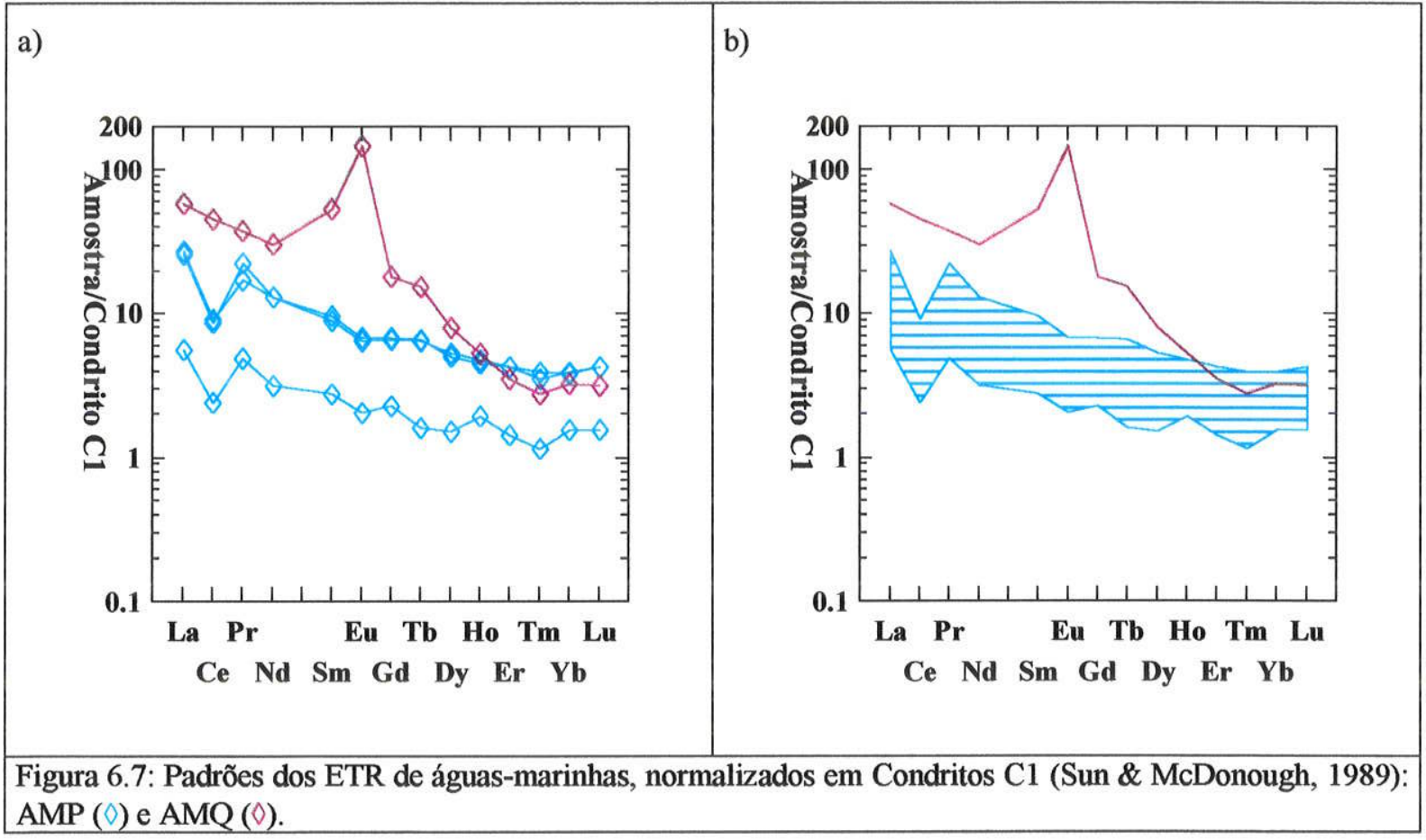

Nos diagramas EETR versus $\mathrm{Y}$, entretanto, as águas-marinhas alinham-se com as esmeraldas e com os GB e MGF (Fig. 6.5), indicando também tratar-se, mais provavelmente, do ciclo metassomático-metamórfico que originou os GB-MGF e não de um processo pegmatítico geneticamente independente.

Os processos de complexação e de precipitação dos ETR são, ainda, pouco conhecidos, com variações dependendo das condições físico-químicas ( $\mathrm{pH}$, temperatura, 
pressão, ligantes específicos e salinidade), do sistema fluido-rocha, da porosidade e composições mineralógica e química original da rocha, da sequência de desenvolvimento das fases secundárias metamórficas-metassomáticas, do tempo de atuação do processo, entre outros. A complexidade das combinações possíveis no quadro dos processos petrometalogenéticos envolvidos aumentou ainda mais a dificuldade de utilizar os ETR como indicadores petro-metalogenéticos nesta pesquisa, que, no entanto, se destaca, ainda, como uma das primeiras a detalhar o comportamento desses elementos em esmeraldas e suas mineralizações naturais. Em consequência, as modelagens realizadas não permitiram explicar todas as variações nos trends observados, tais como as anomalias de $\mathrm{Ce}$ e enriquecimento relativo dos ETRP e todas as anomalias negativas e positivas de Eu. Entretanto, destacam-se como resultado talvez mais importante, as correlações positivas contínuas e constantes $\Sigma E T R$ versus $\mathrm{Y}$ e os efeitos tetrádicos; consideradas conjuntamente para as esmeraldas dos diversos tipos genéticos, as águas marinhas, os GB e os MGF, as correlação $\Sigma E T R$ versus $\mathrm{Y}$ indicam as origens consanguíneas desse sistema fluidos-rochas-mineralizações. As gerações distintas de esmeraldas e águas marinhas devem-se a retrabalhamentos e remobilizações de um reservatório químico-mineralógico único, sem contribuições externas novas e de outras fontes. 


\section{CAPÍTULO VII - ISÓTOPOS ESTÁVEIS}

\section{VII.1 - INTRODUÇÃO E FUNDAMENTOS}

O princípio deste estudo é o fracionamento, por processos fisicos, de isótopos de elementos leves com massa atômica menor do que 40 (mais leves do que o Ca); já no caso dos isótopos de elementos com número atômico maior, a diferença de massa relativa é, em geral, pequena demais para permitir que os fracionamentos fisicos naturais sejam eficientes.

Os isótopos estáveis mais frequentemente utilizados são os de $\mathrm{H}, \mathrm{C}, \mathrm{N}, \mathrm{O}$ e S devido a fatores, tais como os supra-citados, sua abundância na natureza e participação na constituição dos materiais terrestres. Nesta pesquisa foram utilizados apenas os isótopos dos elementos $\mathrm{O} e$ H, que segundo Rollinson (1993), tem as seguintes abundâncias naturais:

$$
\begin{array}{ll}
{ }^{16} \mathrm{O}=99.763 \% & { }^{1} \mathrm{H}=99.9844 \% \\
{ }^{17} \mathrm{O}=0.0375 \% & { }^{2} \mathrm{D}=0.0156 \% \\
{ }^{18} \mathrm{O}=0.1995 \% &
\end{array}
$$

Por serem sempre os principais constituintes dos fluidos geológicos aquosos, o estudo da composição isotópica destes elementos permite a análise da natureza dos fluidos e dos processos petro-metalogenéticos de interação fluidos-rochas, objeto desta pesquisa.

Os principais fatores que controlam o fracionamento de isótopos (FI) são: temperatura, composição química, força de ligação, estrutura cristalina e processos de transição de fase, tais como evaporação e condensação, fusão e cristalização, difusão, entre outros.

Como regra geral, os isótopos mais leves formam ligações mais fracas do que os isótopos pesados. Daí, durante uma reação química, moléculas com isótopos leves, em geral, reagem ligeiramente mais rápido do que aquelas com isótopos pesados.

Ligações com íons de alto potencial iônico e baixo número de massa estão associadas com frequências vibracionais altas e têm tendências a incorporar preferencialmente o isótopo pesado, pois este tende a reduzir o componente vibracional. Por exemplo:

$\mathrm{O}+\mathrm{Si}^{4+} \rightarrow$ quartzo (mineral enriquecido em ${ }^{18} \mathrm{O}$ em relação ao $\mathrm{O}$ disponível); e $\mathrm{O}+\mathrm{Fe}^{2+} \rightarrow$ magnetita (mineral empobrecido $\mathrm{em}^{18} \mathrm{O}$ ). 
Os isótopos pesados concentram-se nas estruturas mais densamente empacotadas ou bem ordenadas (este efeito pode ser grande, como por exemplo, entre grafita e diamante) e em moléculas com maior estado de oxidação.

Moléculas contendo os isótopos leves são mais facilmente extraídas de um material durante processos como fusão ou evaporação. No caso dos isótopos de $\mathrm{H}$, os principais mecanismos de fracionamento são as diferenças na pressão de vapor da água e no ponto de congelamento, sendo a concentração do D maior na fase líquida do que na fase vapor.

O fracionamento de um isótopo entre duas substâncias A e B pode ser definido pelo fator de fracionamento $(\alpha)$ :

$$
\alpha_{A-B}=R_{A} / R_{B} \text { ou } \alpha=K^{1 / n}
$$

Onde: $R_{A}=$ razão entre dois isótopos em um composto $A$;

$R_{B}=$ razão entre dois isótopos em um composto $B$

$\mathrm{K}=$ constante de equilíbrio;

$\mathrm{n}=$ número de átomos trocados.

Por exemplo, em uma reação em que ${ }^{18} \mathrm{O}$ e ${ }^{16} \mathrm{O}$ são trocados entre o quartzo e magnetita, o fracionamento de ${ }^{18} \mathrm{O} /{ }^{16} \mathrm{O}$ entre o quartzo (qzo) e magnetita (mg) é expresso como:

$$
\alpha_{\mathrm{qzo}-\mathrm{mg}}=\frac{\left({ }^{18} \mathrm{O} /{ }^{16} \mathrm{O}\right) \mathrm{qzo}}{\left({ }^{18} \mathrm{O} /{ }^{16} \mathrm{O}\right) \mathrm{mg}}
$$

Os valores de $\alpha$ são sempre muito próximos da unidade e tipicamente variam na terceira casa decimal. Consequentemente, apresentam a forma $1.00 \mathrm{~N}$; por exemplo: o $\alpha$ para ${ }^{18} \mathrm{O}$ entre o quartzo e magnetita a $500^{\circ} \mathrm{C}$ é 1.009 (Javoy, 1977). Uma aproximação matemática para o fator de fracionamento provém de:

$$
1000 \ln (1.00 \mathrm{~N}) \cong \mathrm{N}
$$

No exemplo acima, onde $\alpha=1.009$, tem-se que: $1000 \ln \alpha=9$.

As razões de isótopos estáveis são medidas em relação a um padrão (Tab. 7.1) e são expressas como um valor $\delta$ em partes por mil (\%o):

$$
\delta(\%)=\underline{R(a m o s t r a)-R(\text { padrão) }} \times 1000
$$


Amostras com valores positivos de $\delta$ são isotopicamente pesadas (enriquecidas no isótopo pesado em relação ao padrão) e amostras com valores negativos de $\delta$ são isotopicamente leves.

\begin{tabular}{|c|c|c|}
\hline Elemento & Padrão & Abreviatura \\
\hline $\mathrm{H}$ & Standard Mean Ocean Water & SMOW \\
\hline $\mathrm{C}$ & $\begin{array}{c}\text { Peedde Formation - } \\
\text { Belemnitella }\end{array}$ & PDB \\
\hline $\mathrm{O}$ & Standard Mean Ocean Water & SMOW \\
\hline $\mathrm{S}$ & $\begin{array}{c}\text { Troilita do meteorito Canyon } \\
\text { Diablo }\end{array}$ & $\mathrm{CD}$ \\
\hline $\mathrm{N}$ & $\mathrm{Ar}$ & $\mathrm{N}_{2}$ \\
\hline
\end{tabular}

Tabela 7.1: Padrões mais utilizados para medidas de isótopos estáveis.

Estudos experimentais tem mostrado que $1000 \ln \alpha$ é uma função linear de $1 / \mathrm{T}^{2}$ para pares mineral-mineral e mineral-fluido, o que permite definir a relação geral para o fator de fracionamento:

$$
1000 \ln \alpha_{\text {minerall-mineral } 2}=\mathrm{A}\left(10^{6} / \mathrm{T}^{2}\right)+\mathrm{B}
$$

Bottinga e Javoy (1973) mostraram que o fracionamento de isótopos entre pares de minerais anidros, em $\mathrm{T}>500^{\circ} \mathrm{C}$, pode ser expresso pela equação (7.6), onde $\mathrm{A}=0.97$ para $\mathrm{o}$ par quartzo-albita.

$$
1000 \ln \alpha=\mathrm{A}\left(10^{6} / \mathrm{T}^{2}\right)
$$

Uma outra aproximação mais usual é a relação entre $1000 \ln \alpha$ e as razões de isótopos medidas, expressas como valores $\delta$. A diferença entre os valores $\delta$ para dois minerais A e B é expressa como $\Delta$, que se aproxima de $1000 \ln \alpha$ quando os valores $\delta$ são menores do que 10:

$$
\Delta_{\mathrm{A}-\mathrm{B}}=\delta_{\mathrm{A}^{-}} \delta_{\mathrm{B}}=1000 \ln \alpha_{\mathrm{A}-\mathrm{B}}
$$

Se, por um lado, a temperatura é um importante controle no fracionamente de isótopos, por outro lado, as mudanças de volume em reações de troca isotópica são muito pequenas, exceto para os isótopos de hidrogênio, e consequentemente, a partição de isótopos é mais ou menos independente da pressão. Graças a isto, os termômetros de isótopos estáveis são particularmente atrativos em estudos de processos crustais profundos e em vantagem sobre os geotermômetros convencionais. 
Embora os termômetros de isótopos de oxigênio sejam menos sensíveis em altas temperaturas, uma vez que o fracionamento isotópico diminui com aumento da temperatura, os estudos experimentais são mais precisos e termômetros confiáveis foram calibrados para aplicação em temperaturas ígneas e metamórficas.

A condição necessária para aplicar os diferentes geotermômetros é o "equilíbrio entre os isótopos". Em uma assembléia mineral de $n$ fases, podemos obter $n$-1 temperaturas independentes, uma temperatura para cada par mineral. Se cada par mineral fornece temperaturas concordantes, o equilíbrio isotópico foi alcançado na mesma temperatura (em cada par) e mantido.

\section{VII.2 - APLICAÇÕES}

Dos princípios básicos da geoquímica de isótopos estáveis originaram duas aplicações geológicas principais: a geotermometria isotópica e o estudo de processos petrometalogenéticos de interação fluidos-rochas.

\section{* Geotermometria}

A geotermometria isotópica basea-se no fracionamento isotópico do oxigênio que é uma função da temperatura. Uma revisão completa do método e suas aplicações foi apresentada por Clayton (1981). Na região E-NE e do extremo NE do Quadrilátero Ferrífero (Q.F.), tais estudos foram realizados por Hoefs et al. (1982) e Müller et al. (1982; 1986a,b) em formações ferríferas e tiveram resultados regionalmente concordantes com os desta pesquisa (Cap. V.3 - Geotermobarometria). Entretanto, as aplicações em geotermometria isotópica necessitam de calibrações experimentais de pares minerais específicos para cada sistema estudado. Tais calibrações, ainda, não são disponiveis para as assembléias com esmeraldas/berilos e portanto, não serão aqui aplicadas. Uma tentativa de estimar a temperatura de formação de veios pegmatóides mineralizados em esmeraldas foi feita a partir do par quartzo-plagioclásio para o qual existem calibrações experimentais.

\section{* Interações Fluidos-Rochas}

Mais importante no contexto desta pesquisa, entretanto, foi a aplicação visando os processos petro-metalogenéticos de interação fluidos-rochas que originaram as mineralizações de esmeraldas, com base no estudo conjunto de isótopos de $\mathrm{O}$ e $\mathrm{H}$ que tem-se revelado como 
uma poderosa ferramenta na investigação dos processos geológicos envolvendo água, como é o caso dos processos hidrotermais, metassomáticos e metamórficos mineralizantes em questão.

O hidrogênio é um componente menor nas rochas e assim, apenas quando a razão fluido/rocha é muito baixa, sua composição isotópica nas rochas (e minerais) influencia na composição dos isótopos de $\mathrm{H}$ dos fluidos coexistentes. $\mathrm{O}$ oxigênio, por outro lado, perfaz $50 \%$ de peso nas rochas (e minerais) comuns e daí, é menos sensível às razões de isótopos de O dos fluidos coexistentes, exceto em condições de altas razões fluido/rocha (Rollinson, 1993).

As composições isotópicas da água de diferentes ambientes geológicos podem ser medidas diretamente da água preservada como inclusões fluidas (Richardson et al., 1988) e, eventualmente, da água estrutural dos minerais (Fallick \& Barros, 1987).

A composição dos isótopos estáveis de uma rocha metamórfica e seus minerais é controlada por quatro fatores principais: a) composição do protólito; b) composições dos fluidos e razão fluido/rocha $(\mathrm{F} / \mathrm{R})$; c) perdas por volatilização em sistemas abertos; e d) condições de temperatura do sistema. O metamorfismo progressivo causa a liberação dos elementos voláteis, mais comumente, por reações de desidratação, e mais raramente, de decarbonatação. Como regra geral, as razões F/R diminuem com o metamorfismo progressivo por reações de desidratação e perdas por volatilização.

A migração de fluidos é altamente variável em rochas metamórficas e sua influência depende, além da quantidade de fluido, do tipo de fluxo se canalizado ou pervasivo em decorrência das propriedades estruturais e texturais. Quando o fluxo é pervasivo ao longo das bordas de grãos e/ou de planos mecanicamente ativos estreitamente espaçados, a razão $\mathrm{F} / \mathrm{R}$ será alta e tenderá a homogeneizar quaisquer diferenças isotópicas na rocha (e em seus minerais). Diferentemente, quando por fluxo canalizado os fluidos concentram-se, sobretudo, em falhas, fraturas e sistemas de veios, então, localmente, a razão $F / R$ pode ser alta, mas as rochas fora destes sistemas serão pouco influenciadas pelo fluido. Cabe ressaltar nesse contexto que heterogeneidades texturais em sistemas, outrossim, pervasivos surtem efeitos análogos nas rochas menos permeáveis. Processos de difusão intra cristalina ou nos fluidos de poros e intergranulares, podem também ser responsáveis por diferenças na composição isotópica; contudo, estes processos são pouco eficientes e ocorrem, em geral, em escala de 
poucos centímetros ou menos, sendo maiores apenas em sistemas que foram mantidos em altas temperaturas por longos períodos de tempo. Em especial, os processos de difusão intracristalina, entretanto, podem ser efetivamente incrementados por gradientes geoquímicos de elementos, por exemplo de álcalis contrastantes na fase fluida e cristalina (O'Neil \& Taylor, 1967).

\section{VII.3 - RESULTADOS}

Para os estudos de isótopos estáveis dessa pesquisa são importantes: a natureza de zona de cisalhamento tectonicamente ativa com características pervasivas ao transporte e migração de fluidos do sistema geológico que gerou os GB e as mineralizações de esmeraldas arqueanas; os gradientes geoquímicos entre os fluidos potássicos, ricos em $\mathrm{F}, \mathrm{Si}, \mathrm{Al}, \mathrm{Be}$, entre outros, que reagiram, por um lado, com os TTG sódicos originando os GB e, por outro, com as rochas metaultramáficas ferro-magnesianas, insaturadas em sílica, da SVS gerando as mineralizações de esmeraldas; as características de metamorfismo regional progressivo dos processos mineralizantes proterozóicos ligados a transformação GB $\rightarrow$ MGF e a anatexia incipiente destes últimos; e, especialmente, as características da estrutura cristalina dos berilos/esmeraldas/águas marinhas que os tornam de particular importância para a aplicação do estudo de isótopos estáveis. Tratam-se de ciclossilicatos cujos tetraedros de $\mathrm{SiO}_{4}$ formam anéis hexagonais, e o empilhamento sucessivo destes ao longo do eixo "c" do cristal produz canais estruturais, nos quais, água, $\mathrm{CO}_{2}$ e íons de metais alcalinos $(\mathrm{Na}+, \mathrm{K}+, \mathrm{Cs}+, \mathrm{Rb}+)$ são aprisionados (Wood \& Nassau, 1968; Aines \& Rossman, 1984; ver, também, Machado, 1994). A água aprisionada nos canais estruturais da esmeralda pode ser uma amostra do fluido original de formação do mineral e, neste caso, terá sua razão $\delta \mathrm{D}$ original preservada (Fallick \& Barros, 1987; Waldron et al, 1990; Sullivan et al., 1993; Fallick et al., 1994; Giuliani et al., 1997b). Tão somente, acima de $800^{\circ} \mathrm{C}$, os íons de metais alcalinos que aprisionam os voláteis nos canais estruturais são expelidos e a água desprendida.

Nesta pesquisa, foram efetuadas análises de isótopos estáveis de $\mathrm{O}$ e $\mathrm{H}$ para a caracterização geoquímica isotópica das ocorrências de esmeraldas e minerais associados, de ambientes petrogenéticos diferentes (xistos metaultramáficos/metassomáticos, veios de quartzo e veios pegmatóides) das jazidas de Capoeirana e Belmont. No caso das esmeraldas, foram analisados separadamente a fase sólida, os fluidos dos canais estruturais e das inclusões fluidas. No total, foram obtidas 62 análises de isótopos de $\mathrm{O}$ da estrutura silicática de esmeraldas, flogopitas, quartzos e plagioclásios, 27 de isótopos de $\mathrm{H}$ da água das inclusões 
fluidas (IF) e dos canais estruturais (CE) da esmeralda, 15 de isótopos de $\mathrm{H}$ da água das IF de quartzo (de veios) e 02 de isótopos de $\mathrm{H} \mathrm{da}_{2} \mathrm{O}^{+}$da flogopita. Os resultados são apresentados nas Tabelas 7.2 a 7.5 .

\begin{tabular}{|c|c|c|c|c|c|c|c|c|}
\hline \multirow{2}{*}{ Jazida } & \multirow{2}{*}{ Amostra } & \multirow{2}{*}{ Tipo } & \multirow{2}{*}{ Mineral } & \multirow{2}{*}{$\delta^{18} \mathrm{O}$} & \multicolumn{2}{|c|}{ Água $<800^{\circ} \mathrm{C}$} & \multicolumn{2}{|c|}{ Água $>800^{\circ} \mathrm{C}$} \\
\hline & & & & & (\% em peso) & $\delta \mathrm{D}$ & (\% em peso) & $\delta \mathrm{D}$ \\
\hline \multirow{2}{*}{ B } & BE-06-01 & \multirow{2}{*}{$X$} & esmeralda & 5.8 & & & & \\
\hline & BE-06-03 & & flogopita & 3.8 & & & & \\
\hline C & $\mathrm{I}-05-01$ & $\mathrm{X}$ & esmeralda & 6.1 & & & & \\
\hline \multirow{2}{*}{ B } & B-24-01 & \multirow{2}{*}{ VQP } & esmeralda & 6.1 & & & & \\
\hline & B-24-02 & & quartzo & 5.6 & & & & \\
\hline \multirow{2}{*}{ B } & BE-05-01 & \multirow{2}{*}{ VQP } & esmeralda & 6.3 & & & & \\
\hline & BE-05-02 & & quartzo & 6.9 & & & & \\
\hline \multirow{3}{*}{$\mathrm{C}$} & Gal $1 / 2-01$ & \multirow{3}{*}{ VQP } & esmeralda & 7.0 & & & & \\
\hline & Gal $1 / 2-02$ & & quartzo & 6.9 & & & & \\
\hline & Gal $1 / 2 m 03$ & & flogopita & 6.9 & & & & \\
\hline \multirow{3}{*}{$\mathrm{C}$} & NE-38-01 & \multirow{3}{*}{ VQP } & esmeralda & 6.7 & & & & \\
\hline & NE-38-02 & & quartzo & 8.4 & & & & \\
\hline & NE-38-03 & & flogopita & 6.0 & & & & \\
\hline \multirow{3}{*}{$\mathrm{C}$} & NE-34-01 & \multirow{3}{*}{ VQ } & esmeralda & 4.1 & 0.09 & -102 & 2.16 & -43 \\
\hline & NE-34-02 & & quartzo & 6.3 & & & & \\
\hline & NE-34-03 & & flogopita & 4.9 & & & & \\
\hline \multirow{5}{*}{$\mathrm{C}$} & NE-36b-01 & \multirow{5}{*}{ VQ } & esmeralda & 5.0 & 0.108 & -40 & 1.98 & -47 \\
\hline & NE-36b-02 & & flogopita & 5.6 & & & & \\
\hline & NE-36b-03 & & esmeralda & 6.2 & & & & \\
\hline & NE-36b-04 & & quartzo & 7.8 & & & & \\
\hline & NE-36b-05 & & flogopita & 4.9 & & & & \\
\hline $\mathrm{C}$ & $\mathrm{NE}-36-02-01$ & $\mathrm{VQ}$ & esmeralda & 7.1 & & & & \\
\hline \multirow{3}{*}{$\mathrm{C}$} & $\mathrm{C} 03-01$ & \multirow{3}{*}{ VP } & esmeralda & 5.9 & & & & \\
\hline & $\mathrm{C} 03-02$ & & feldspato & 6.8 & & & & \\
\hline & $\mathrm{CO3-03}$ & & flogopita & 4.0 & & & & \\
\hline \multirow{5}{*}{$\mathrm{C}$} & NE-30-01 & \multirow{5}{*}{ VP } & esmeralda & 5.1 & & & & \\
\hline & NE-30-02 & & esmeralda & 6.2 & & & & \\
\hline & NE-30-02 & & feldspato & 6.1 & & & & \\
\hline & NE-30-03 & & flogopita & 4.4 & & & & \\
\hline & NE-30-04 & & quartzo & 9.0 & & & & \\
\hline \multirow{4}{*}{$\mathrm{C}$} & NE-31-02-01 & & esmeralda & 6.3 & 0.072 & & 2.16 & -41 \\
\hline & $\mathrm{NE}-31-02-02$ & $\mathrm{IT}$ & feldspato & 7.4 & & & & \\
\hline & NE-31-02 03 & VP & flogopita & 5.5 & & & & \\
\hline & NE-31-02-04 & & quartzo & 7.2 & & & & \\
\hline C & NE-31-07-01 & VP & esmeralda & 5.3 & 0.054 & & 1.98 & -43 \\
\hline $\mathrm{C}$ & NE-33-01 & VP & esmeralda & 8.8 & 0.162 & -78 & 1.08 & -47 \\
\hline
\end{tabular}

Tabela 7.2: $\delta^{18} \mathrm{O}$ e $\delta \mathrm{D}(\% \mathrm{O}$ SMOW) de esmeraldas e minerais associados, de diferentes ambientes petrometalogenéticos (xistos $=\mathrm{X}$; veios de quartzo polideformados $=\mathrm{VQP}$; veios de quartzo pouco deformados $=$ VQ; veios pegmatóides = VP) das jazidas de Capoeirana (C) e Belmont (B). 


\begin{tabular}{|c|c|c|c|c|c|c|}
\hline \multirow{2}{*}{ Amostra } & \multirow{2}{*}{ Cor } & \multirow{2}{*}{$\delta^{18} \mathrm{O}$} & \multicolumn{2}{|c|}{ Água $<800^{\circ} \mathrm{C}$} & \multicolumn{2}{|c|}{ Água $>800^{\circ} \mathrm{C}$} \\
\hline & & & (\% em peso) & $\delta \mathrm{D}$ & (\% em peso) & $\delta \mathrm{D}$ \\
\hline B-27a & \multirow{2}{*}{1} & 7.0 & 0.13 & -59 & 2.16 & -43 \\
\hline B-27b & & 7.2 & 0.40 & -60 & 2.12 & -46 \\
\hline B-29a & \multirow{2}{*}{2} & 6.3 & 0.14 & -108 & 2.05 & -44 \\
\hline B-29b & & 6.1 & 0.23 &.-55 & 2.20 & -44 \\
\hline B-30 & 3 & 6.1 & 0.09 & -107 & 2.09 & -42 \\
\hline $\mathrm{B}-31$ & $\overline{4}$ & 7.1 & 0.07 & -103 & 2.11 & -43 \\
\hline B-32a & \multirow{3}{*}{5} & 7.2 & 0.11 & -111 & 2.30 & -45 \\
\hline $\mathrm{B}-32 \mathrm{~b}$ & & 7.1 & 0.09 & -48 & & -45 \\
\hline B-32c & & 6.9 & & & & \\
\hline B-33a & \multirow{2}{*}{6} & 6.9 & 0.09 & -113 & 2.32 & -49 \\
\hline B-33b & & 7.4 & & & 2.11 & -47 \\
\hline
\end{tabular}

Tabela 7.3: $\delta^{18} \mathrm{O}$ e $\delta \mathrm{D}$ ( \% SMOW) de esmeraldas de Belmont, sem identificação paragenética e separadas por critérios de cor: $1=$ verde grama; 2 = verde acastanhado-amarelado ; $3=$ verde intenso; 4 = verde claro; $5=$ verde azulado claro; $6=$ verde azulado muito claro.

\begin{tabular}{|c|c|c|c|}
\hline \multirow{2}{*}{ Amostra } & \multirow{2}{*}{$\delta^{18} \mathrm{O}$} & \multicolumn{2}{|c|}{$\mathrm{H}_{2} \mathrm{O}^{+}$} \\
\cline { 3 - 4 } & & (\% em peso) & $\delta \mathrm{D}$ \\
\hline \multirow{2}{*}{$\mathrm{B}-27$} & 7.7 & 4.32 & -83 \\
\cline { 2 - 4 } & & 3.42 & -77 \\
\hline
\end{tabular}

Tabela 7.4: $\delta^{18} \mathrm{O}$ e $\delta \mathrm{D}(\%$ SMOW) de flogopita inclusa em esmeralda de Belmont, sem identificação de sua assembléia mineral.

\begin{tabular}{|c|c|c|c|}
\hline \multirow{2}{*}{ Amostra } & \multirow{2}{*}{$\delta^{18} \mathrm{O}$} & \multicolumn{2}{|c|}{ Água de Inclusóes Fluidas } \\
\cline { 3 - 4 } & & (\% em peso) & $\delta \mathrm{D}$ \\
\hline $\mathrm{B}-1$ & 7.3 & 0.04 & -87 \\
\hline $\mathrm{B}-2$ & 6.7 & 0.05 & -57 \\
\hline B-3 & 7.2 & 0.02 & -83 \\
\hline B-4 & 6.7 & 0.02 & -86 \\
\hline B-5 & 6.8 & 0.04 & -78 \\
\hline \multirow{2}{*}{ B-6 } & 7.0 & 0.05 & -60 \\
\hline & & 0.05 & -56 \\
\hline \multirow{2}{*}{ B-7 } & 6.4 & 0.04 & -83 \\
\hline & 6.4 & & \\
\hline \multirow{2}{*}{ B-9 } & 7.8 & 0.22 & -69 \\
\hline B-13 & 7.4 & 0.02 & -81 \\
\hline B-14a & 7.1 & 0.02 & -98 \\
\hline B-14b & 6.4 & 0.04 & -97 \\
\hline B-14c & 6.2 & 0.07 & -114 \\
\hline B-16 & 6.7 & 0.02 & -88 \\
\hline
\end{tabular}

Tabela 7.5: $\delta^{18} \mathrm{O}$ (\% SMOW) de quartzo de veios de quartzo não mineralizados de Belmont. 
A água desprendida durante $\mathrm{o}$ aquecimento das esmeraldas apresenta duas composições isotópicas distintas. Abaixo de $800^{\circ} \mathrm{C}$ é considerada água das inclusões fluidas (cf.: Fallick et al., 1994) e os valores de $\delta \mathrm{D}$ (SMOW) variam amplamente (-113 a - $40 \%$ ), indicando águas de várias fontes nas diferentes gerações de inclusões fluidas (Tab. 7.2 e 7.3; Fig. 7.1a) (para estudos de inclusões fluidas ver Machado, 1994). A água liberada acima de $800^{\circ} \mathrm{C}$, considerada como a água de formação aprisionada nos canais estruturais das esmeraldas, apresenta valores de $\delta \mathrm{D}$ extremamente uniformes (- $49 \mathrm{a}-41 \%$ ) (Tab. 7.2 e 7.3 ; Fig.7.1b) (cf.: Sullivan et al., 1993).

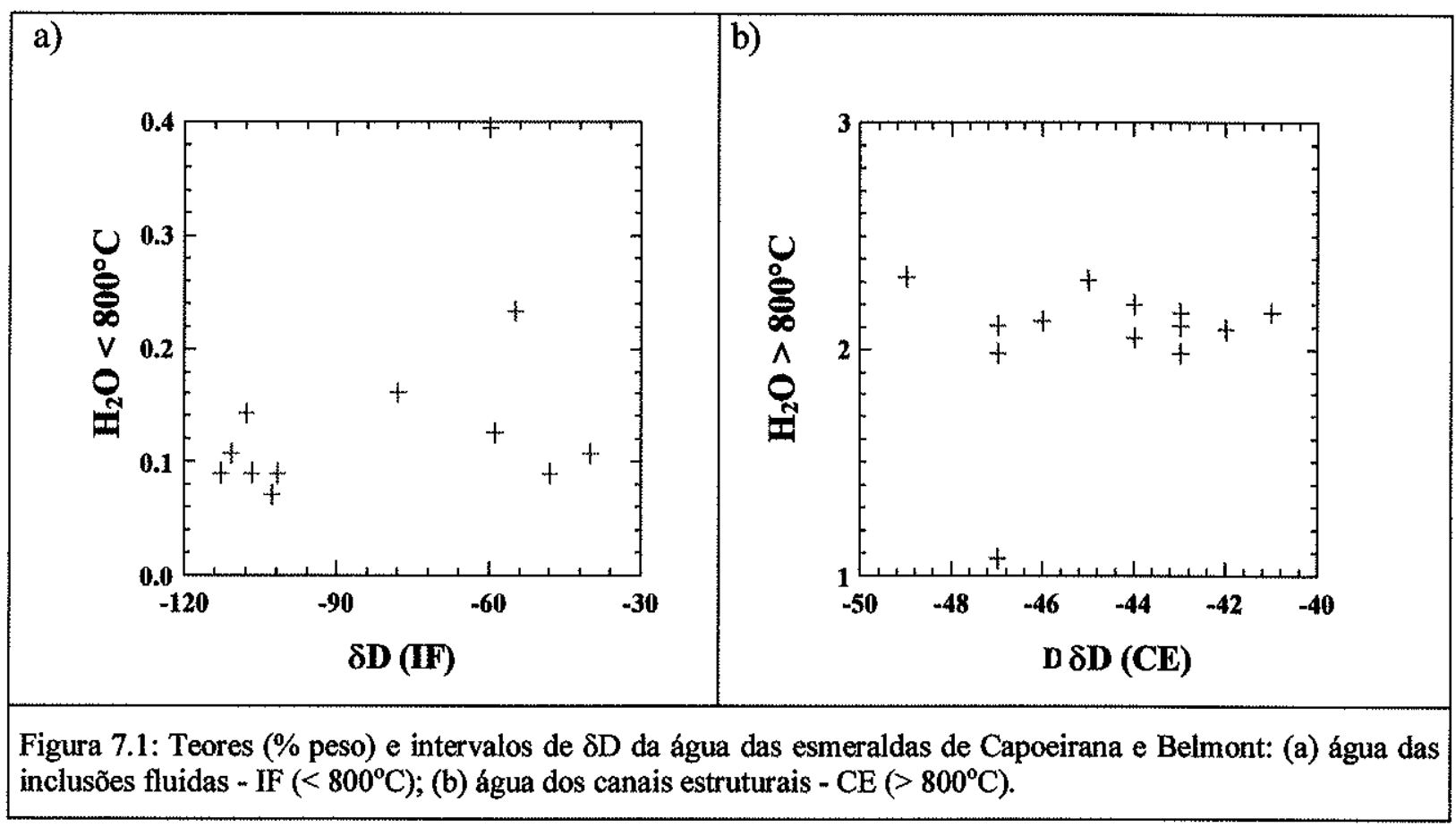

Os teores de água desprendidos abaixo de $800^{\circ} \mathrm{C}$ variam de 0.05 a $0.40 \%$ em peso, sendo muito inferiores àqueles dos canais estruturais, de 1.08 a $2.32 \%$ em peso (Fig. 7.1a,b; ver também Anexo 6). A amostra NE-33 (EVP) tem baixo teor de água em comparação com as demais esmeraldas, o que poderia ser explicado pela gênese em um sistema ligeiramente mais seco ou pela perda de voláteis.

A análise das condições de formação das esmeraldas a partir das composições e quantidade de fluidos usando-os como estimativas de $\mathrm{P}$ de fluidos não é segura, devido às possíveis perdas de voláteis em processos geológicos posteriores e a eventual presença de $\mathrm{CO}_{2}$ (Vry et al., 1990). No caso estudado, a presença de $\mathrm{CO}_{2}$ é menos importante como mostraram os estudos de espectroscopia no infravermelho - IR (Machado, 1994). 
Zimmermann et al. (1997) ressaltam ainda que, para esmeraldas cristalizadas em sistemas hidrotermais abertos, o aumento do teor de água nos canais estruturais está diretamente relacionado às substituições isomorfas, especialmente em posições octaédricas $\left(\mathrm{Al}^{+3, \mathrm{VI}}=\right.$ $\mathrm{Mg}^{+2, \mathrm{VI}}+\mathrm{Na}^{+, \text {canal }}$, conforme discutido no Cap. IV, ítem IV.9), que requer de íons alcalinos, além de $\mathrm{H}_{2} \mathrm{O}$ e $\mathrm{CO}_{2}$ nos canais estruturais para manter a neutralidade de carga.

Os valores de $\delta^{18} \mathrm{O}$ das esmeraldas de Capoeirana variam de 4.1 a $8.8 \%$, num intervalo mais amplo do que das esmeraldas de Belmont, de 5.8 a 7.4 (Tab. 7.2 e 7.3). Por outro lado, considerando as diferentes associações genéticas, notam-se valores mais homogêneos de $\delta^{18} \mathrm{O}$ nas esmeraldas de xistos $(5.8$ a $6.1 \%$ ) e de veios de quartzo polideformados $(6.1 \mathrm{a}$ $7.0 \%$ ) e valores um pouco mais amplos nas esmeraldas de veios de quartzo pouco deformados com esmeraldas idiomórficas $(4.1$ a $7.1 \%$ ) e veios pegmatóides $(5.3$ a $8.8 \%$ ) (Tab. 7.2).

A análise individual das composições isotópicas dos minerais nos veios de quartzo polideformados indicam valores médios de $\delta^{18} \mathrm{O}$ do quartzo $(7 \%$ ), esmeralda $(6.5 \%)$ e flogopita (6.5\%) muito próximos (Tab. 7.2); porém, isto não se verifica nos veios de quartzo pouco deformados, com um valor médio de $\delta^{18} \mathrm{O}$ de $7.1 \%$ para o quartzo e de 5.6 e $5.1 \%$, respectivamente, para a esmeralda e a flogopita.

Nos veios pegmatóides, os valores médios de $\delta^{18} \mathrm{O}$ da flogopita (4.6\%), do quartzo $(8.1 \%)$, do feldspato $(6.8 \%)$ e da esmeralda $(6.3 \%)$ sugerem o envolvimento de um fluido isotopicamente distinto na evolução desta paragênese num processo retrometamórfico, destacando-se a saussuritização e sericitização dos plagioclásios e alterações de cloritização incipiente das flogopitas. Nos xistos/flogopititos, o valor médio de $\delta^{18} \mathrm{O}$ da esmeralda (6\%) é muito elevado em relação ao único $\delta^{18} \mathrm{O}(3.8 \%)$ obtido para a flogopita.

O $\delta^{18} \mathrm{O}$ de $7.7 \%$ da flogopita incluida em esmeralda de Belmont sem identificação mais precisa de sua paragênese (mais provavelmente, de tipo xisto) é bem superior àqueles das flogopitas dos xistos (3.8\%), dos veios de quartzo em geral (de 4.9 a $6.9 \%$ ) e veios pegmatóides (de 4.0 a 5.5\%) (Tab. 7.2 e 7.4).

$\mathrm{O}$ intervalo de $\delta \mathrm{D}$ das inclusões fluidas do quartzo, de -114 a $-56 \%$ (Tab. 7.5), coincide com o dos fluidos desprendidos das esmeraldas abaixo de $800^{\circ} \mathrm{C}$, de -113 a $-40 \%$ 
(Tab. 7.2 e 7.3), podendo ser atribuído à natureza secundária das principais inclusões fluidas das esmeraldas (cf.: Machado, 1994; Fallick et al., 1994).

Embora os valores de $\delta \mathrm{D}$ das IF em esmeraldas sejam variáveis, os valores de $\delta^{18} \mathrm{O}$ da estrutura silicática e de $\delta \mathrm{D}$ da água dos canais são, respectivamente, uniformes e notadamente uniformes (Tab. 7.2 e Fig. 7.2). Este fato, entretanto, não é suficiente para descartar as evidências geológicas, petrográficas e geoquímicas quanto à história polimetamórfica e poligenética dos tipos individuais de mineralizações de esmeraldas. Apesar do número, ainda, reduzido de análises, sobretudo, quando consideradas as esmeraldas por diferentes associações genéticas, conclui-se, como hipótese hipótese mais provável, que os valores de $\delta^{18} \mathrm{O}$ da estrutura silicática (em especial, das EX e EVQP) e de $\delta \mathrm{D}$ dos fluidos dos canais estruturais são tão marcantemente uniformes por se tratarem de fluidos de uma fonte única reciclados em processos mineralizantes consecutivos que ocorreram em períodos específicos num amplo intervalo tempo, entretanto, repetindo condições físico-químicas, entre si, essencialmente análogas.

Os dados de $\delta \mathrm{D}$ das águas dos canais estruturais e de $\delta^{18} \mathrm{O}$ das esmeraldas foram comparados com valores da literatura para águas metamórficas que variam, respectivamente, de -70 a $0 \%$ e +3 a $+20 \%$ (Sheppard, 1986), águas magmáticas de -80 a $-40 \%$ e +5.5 a +10\% (Sheppard e Epstein, 1970) e, ainda, para águas magmáticas associadas a granitos produzidos por fusão intracrustal com $\delta \mathrm{D}$ de -65 a $-40 \%$ e $\delta^{18} \mathrm{O}$ de +9.5 e $+13 \%$ (Sheppard, 1977). Os dados desta pesquisa são típicos do campo de superposição de águas magmáticas e metamórficas; não são, portanto, conclusivos quanto à gênese das esmeraldas e a derivação magmática ou metamórfica dos fluidos originais (Fig. 7.2). Descarta-se, porém, claramente, a sua formação a partir de granitos produzidos por fusão intracrustal. Como interpretação preferida nessa pesquisa corroborada também pela composição de $\delta \mathrm{D}$ da flogopita incluída em esmeralda (Tab. 7.4), a origem da água e sua composição isotópica são consideradas como resultados da granulitização/degranitização da crosta profunda/inferior arqueana nos processos tectono-metamórficos que originaram as zonas de cisalhamento regionais causando, inclusive, a transformação tectono-metamórfica-metassomática dos TTG em GB. 


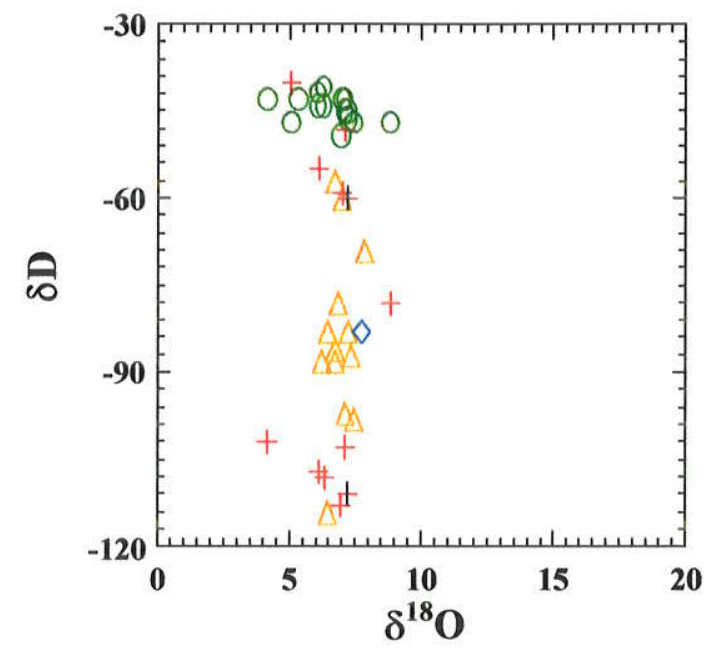

Figura 7.2: Composição isotópica de oxigênio e hidrogênio das esmeraldas e minerais associados de Capoeirana e Belmont: esmeralda: CE (O) e IF (+); quartzo: IF ( $\triangle)$; flogopita: $\mathrm{H}_{2} \mathrm{O}^{+}(\diamond)$.

Tentativamente, foram efetuados cálculos de fracionamento isotópico para a associação esmeralda-flogopita de mineralizações de xistos e de termometria isotópica para um veio pegmatóide mineralizado de Capoeirana, a partir do par plagioclásio-quartzo. Como ponto de partida nos cálculos de fracionamento isotópico, admitiu-se uma temperatura mínima de $350^{\circ} \mathrm{C}$ para formação das esmeraldas de xistos segundo estudos de inclusões fluidas (Machado, 1994).

Com base na equação (7.8) proposta por Taylor et al. (1992), foi feito o cálculo para o fracionamento esmeralda-água para as esmeraldas de xistos, formadas nesta temperatura $\left(350^{\circ} \mathrm{C}=623^{\circ} \mathrm{K}\right)$ :

$$
10^{3} \ln \propto_{\text {esmeralda-água }}\left(250-500^{\circ} \mathrm{C}\right)=1.579\left(10^{6} / \mathrm{T}^{2}\right)-0.645\left(10^{3} / \mathrm{T}\right)-2.522
$$

$\mathrm{T}=$ temperatura de formação em ${ }^{\circ} \mathrm{K}$.

$$
\begin{aligned}
& 10^{3} \ln \propto_{\text {esmeralda-água }}=\delta^{18} \mathrm{O}_{\text {esmeralda }}-\delta^{18} \mathrm{O}_{\text {água }}=1.579\left(10^{6} / 623^{2}\right)-0.645\left(10^{3} / 623\right)-2.522 \\
& \delta^{18} \mathrm{O}_{\text {esmeralda }}-\delta^{18} \mathrm{O}_{\text {água }}=4.07-1.04-2.522=0.51
\end{aligned}
$$

$$
\delta^{18} \mathrm{O}_{\text {água }}=\delta^{18} \mathrm{O}_{\text {esmeralda }}-0.51
$$


Considerando que as flogopitas e esmeraldas de xistos são cogenéticas e supondo que estejam em equilibrio isotópico, foram efetuados cálculos do fracionamento flogopita-água utilizando-se a mesma temperatura do fracionamento esmeralda-água $\left(350^{\circ} \mathrm{C}\right)$. Cabe lembrar que este cálculo é somente tentativo e ressaltar que a equação (7.9) aqui utilizada para o fracionamento flogopita-água foi calibrada por Bottinga \& Javoy (1973) no intervalo de temperatura de $400-700^{\circ} \mathrm{C}$.

$$
\begin{aligned}
& 10^{3} \ln \alpha_{\text {flogopita-água }}=0.4\left(10^{6} / \mathrm{T}^{2}\right)-3.1 \\
& \mathrm{~T}=\text { temperatura de formação em }{ }^{0} \mathrm{~K} . \\
& 10^{3} \ln \alpha_{\text {flogopita-água }=} \delta^{18} \mathrm{O}_{\text {flogopita }}-\delta^{18} \mathrm{O}_{\text {agua }}=0.4\left(10^{6} / 623^{2}\right)-3.1 \\
& \delta^{18} \mathrm{O}_{\text {flogopita }}-\delta^{18} \mathrm{O}_{\text {agua }}=1.03-3.1=-2.07 \\
& \delta^{18} \mathrm{O}_{\text {agua }}=2.07+3.8 \\
& \delta^{18} \mathrm{O}_{\text {agua }}=5.9 \%
\end{aligned}
$$

Assim, para as esmeraldas de xistos, os valores de $\delta^{18} \mathrm{O}$ analisados de 5.8 e $6.1 \%$ estão próximos daqueles de $\delta^{18} \mathrm{O}$ calculados da água da esmeralda (respectivamente, 5.3 e 5.6\%); entretanto, o valor calculado para a água da flogopita $\left(\delta^{18} \mathrm{O}=5.9 \%\right)$ não corresponde ao valor analisado da flogopita de $\delta^{18} \mathrm{O}=3.8 \%$. Este desequilíbrio isotópico pode ser o efeito de processos retrometamórficos tardios, incluindo cloritização incipiente, mais efetivos nas flogopitas do que nas esmeraldas (ver Cap. IV: Química Mineral).

Os amplos intervalos de temperatura obtidos das inclusões fluidas das esmeraldas de veios de quartzo e veios pegmatóides (Machado, 1994) não permitem os cálculos dos fracionamentos mineral-água destes sistemas.

Os dados isotópicos foram, ainda, utilizados numa tentativa de termometria isotópica em uma amostra de veio pegmatóide com esmeralda (NE-30), uma vez que para o par quartzo-plagioclásio já existem calibrações experimentais. Para tanto utilizou-se a equação (7.6):

$1000 \ln \alpha_{\text {qzo-plag }}=\mathrm{A}\left(10^{6} / \mathrm{T}^{2}\right)$ sendo $A=0.97$ (Bottinga e Javoy, 1975).

Assim, resulta que: $1000 \ln \alpha_{\mathrm{qzo}-\mathrm{plag}}=0.97\left(10^{6} / \mathrm{T}^{2}\right)$. 
Para a amostra NE-30-01, tem-se $\delta^{18} \mathrm{O}_{\mathrm{qzo}}=9.0$ e $\delta^{18} \mathrm{O}_{\text {plag }}=6.1$. Segundo Rollinson (1993), quando $\delta<10$ é válida a expressão:

$\delta^{18} \mathrm{O}_{\mathrm{qzo}}-\delta^{18} \mathrm{O}_{\text {plag }}=1000 \ln \alpha_{\mathrm{qzo}-\mathrm{plag}}$

Assim: $9.0-6.1=1000 \ln \alpha_{\text {qzo-plag }}=0.97\left(10^{6} / \mathrm{T}^{2}\right)$,

resultando:

$$
\mathrm{T}=578 \mathrm{~K} \text { ou } 305^{\circ} \mathrm{C}
$$

A temperatura de $305^{\circ} \mathrm{C}$ é muito aquém da temperatua de cristalização de veios pegmatóides em sistemas de anatexia de rochas graníticas. Entretanto, deve-se destacar que os plagioclásios dos veios pegmatóides são saussuritizados e os resultados obtidos, novamente, parecem indicar o processo retrometamórfico.

\section{VII.4 - CONCLUSÃO DOS ESTUDOS DE ISÓTOPOS ESTÁVEIS}

Mediante o estudo de isótopos estáveis, pode-se concluir que os valores de $\delta \mathrm{D}$ das inclusões fluidas de esmeraldas e das inclusões fluidas de quartzo e os valores de $\delta^{18} \mathrm{O}$ das flogopitas, quartzos e plagioclásios são amplamente variáveis e indicam desequilibrios, ressaltando-se que estes sistemas são mais susceptíveis a efeitos polimetamórficos e retrometamórficos. Neste quadro, destacam-se os valores mais homogêneos de $\delta \mathrm{D}$ dos fluidos dos canais estruturais das esmeraldas. Estes, em conjunto com o $\delta^{18} \mathrm{O}$ da estrutura das esmeraldas, representam os sistemas mais resistentes em relação às alterações polimetamórficas e retrometamórficas. Os valores de $\delta^{18} \mathrm{O}$ mais homogêneos nas esmeraldas de xistos e de veios de quartzo polideformados devem ser considerados como característicos da primeira fase, arqueana, de mineralizações. As gerações posteriores, indicam uma origem por retrabalhamento dos sistemas geoquímicos-isotópicos anteriores, sem contribuição de fluidos de outras fontes. 


\section{CAPÍTULO VIII - EVOLUÇÃO GEOLÓGICA E PETRO- METALOGENÉTICA - PRINCIPAIS CONCLUSÕES}

Dentro dos objetivos propostos, esta pesquisa contribuiu, especialmente, nos seguintes aspectos:

- Geologia e petrografia regional;

- Evolução metamórfica;

- Tópicos específicos de geoquímica de ETR e de isótopos estáveis;

- Metalogênese das jazidas de esmeraldas.

A evolução geológica da área de estudo compreende estágios arqueanos, representados por associações de rochas TTG e terrenos granito-greenstone belt e estágios de retrabalhamentos tectono-metamórficos proterozóicos. As mineralizações de esmeraldas devem-se a processos arqueanos e proterozóicos.

As rochas TTG, gnaisses, migmatitos e metagranitóides polimetamórficos com estruturas típicas, são os litotipos arqueanos mais antigos da região. Na área da pesquisa, ocorrem em corpos restritos no interior dos GB e MGF, ou ainda, como gnaisses miloníticos no contato com as rochas da SVS. As composições químicas sugerem enriquecimentos em álcalis, em especial $\mathrm{K}_{2} \mathrm{O}$, nos retrabalhamentos metamórficos regionais Proterozóicos. Alguns gnaisses miloníticos ortoderivados das proximidades dos contatos com a SVS são problemáticos; apresentam-se, em geral, mais peralumínicos e enriquecidos em elementos traço do que as rochas TTG típicas, sendo, mais provavelmente, produtos de alteração aloquímica dos TTG.

A sequência metavulcano-sedimentar de Capoeirana e Belmont é considerada mais joven que as rochas TTG, sendo parte tectonicamente disrupta do greenstone belt arqueano Rio das Velhas (SGr. Rio das Velhas). Compreende uma grande variedade de litotipos: xistos/anfibolitos metaultramáficos, anfibolitos metabásicos a metaintermediários, anfibolitos de formações ferríferas, xistos/gnaisses vulcanoclásticos, anfibolitos/gnaisses calciossilicáticos e xistos/gnaisses metassedimentares clásticos. Como características típicas de greenstone belt arqueano destacam-se a sucessão litológica e a natureza extrusiva das rochas metaultramáficas. 
A despeito da complexidade estrutural incluindo dobramentos isoclinais apertados e possíveis repetições locais e das condições de afloramentos que não permitiram estudos estruturais de detalhe, foi possível reconstruir a sucessão litoestratigráfica e as principais características estruturais regionais que indicam para as jazidas de Belmont e Capoeirana, sequências litológicas similares de direção principal NNE e caimentos, em geral, suaves para W. Assim, encontram-se em contato direto a WNW, por falhas inversas, com as rochas graníticas regionais, especialmente, GB em Belmont e MGF em Capoeirana, as rochas metaultramáficas mineralizadas, seguidas para ESE, de rochas máficas, anfibolitos, paragnaisses e metassedimentos mais maturos. Define-se, assim, uma sequência litológica típica de greenstone belt, invertida estruturalmente e repetida por cavalgamentos.

As rochas metaultramáficas são de interesse maior entre as rochas da SVS, pois são hospedeiras das mineralizações. Ocorrem na base da sequência, sendo representadas por anfibolitos metauitramáficos (AU), talco-anfibólio xistos, anfibólio-clorita xistos e tremolititos (TACX), clorititos (CLT) e cromititos (CRT), sendo que os TACX e CLT devemse a alterações aloquímicas pre-metamórficas específicas, não relacionados aos processos metassomáticos mineralizantes. Todas as rochas metaultramáficas apresentam composições komatiíticas, sendo que as variabilidades do $\mathrm{Cr}$ e $\mathrm{Zn}$ retratam os teores primários, bastante variáveis de cromita. Os enriquecimentos em $\mathrm{Sr}$ e empobrecimentos em La e Y dos TACX e CLT em relação aos AU devem-se às alterações pré-metamórficas específicas. As rochas metaultramáficas podem gradar na continuidade do mesmo corpo para equivalentes flogopitizados/mineralizados, evidenciando enriquecimentos sistemáticos $\mathrm{em}_{2} \mathrm{O}, \mathrm{Al}_{2} \mathrm{O}_{3}, \mathrm{Rb}$, $\mathrm{Ba}$ eY e, eventualmente, Be. Os elementos $\mathrm{Zr}, \mathrm{Sc}, \mathrm{V}, \mathrm{Zn}, \mathrm{Cr}$ e $\mathrm{Ni}$, entretanto, permaneceram praticamente constantes.

Os anfibolitos metabásicos e anfibolitos/gnaisses metaintermediários apresentam filiação magmática, sub-alcalina, toleiítica, com evolução dos anfibolitos metabásicos (AB) mais primitivos para os anfibolitos metabásicos com epidoto-titanita (ABET) e para os anfibolitos metabásicos com granada $(\mathrm{ABG})$, também indicada pelo comportamento dos elementos traço $\mathrm{Zr}, \mathrm{Y}, \mathrm{Cr}, \mathrm{Ni}, \mathrm{V}$ e Th. A afirmação de que os ABG são rochas paraderivadas (por ex.: Rettinger, 1998) é aqui descartada. Já os gnaisses com biotita, anfibólio e granada (Gn/bag) apresentam composições distintas, indicando derivação cálcio-alcalina.

Os anfibolitos de formação ferrífera (AFF) e cálciossilicáticos (AC) representam, inclusive quimicamente, grupos específicos, quase nunca relacionados com as tendências dos 
anfibolitos metaígneos, sendo os primeiros caracterizados por altos teores de $\mathrm{V}, \mathrm{Ni}, \mathrm{Cu}$ e $\mathrm{La} \mathrm{e}$ os segundos por altos teores de $\mathrm{Zr}, \mathrm{Sr}$ e $\mathrm{Ga}$.

Ainda como litotipos essenciais da SVS, destacam-se os xistos e gnaisses vulcanoclásticos de alterações hidrotermais-metassomáticas pré-metamórficas, com cummingtonita, granada, cordierita e estaurolita, e as rochas metassedimentares que evoluem na sucessão litoestratigráfica de composições imaturas, com considerável contribuição vulcanoclástica (grauvacas), para composições mais maturas, incluindo quartzo-muscovitaxistos e raros quartzitos.

No final da evolução do greenstone belt, a área sofreu em toda a sua extensão retrabalhamentos estruturais e metamorfismo de baixo a, eventualmente, médio grau, e metassomatismo forte nas zonas de cisalhamento crustais profundas, de dimensões regionais, onde circularam fluidos alcalinos (potássicos) ricos em $\mathrm{F}$, elementos incompatíveis $(\mathrm{Rb}, \mathrm{Zr}$, $\mathrm{Nb}, \mathrm{Y}, \mathrm{Be}, \mathrm{ETRL}$, entre outros) de origens profundas, derivados, mais provavelmente, de processos de granulitização da crosta inferior (Mehnert, 1971). Estes fluidos, por reações fluidos-rochas, transformaram as rochas TTG, durante sua milonitização, em Granitóides Borrachudos (GB) e flogopitizaram e mineralizaram as rochas metaultramáficas da SVS.

Os GB são metagranitóides, hololeucocráticos a leucocráticos, com composição de álcali-feldspato granitos com fluorita. Os feldspatos alcalinos são os constituintes principais e característicos dos GB, sendo representados por pertitas ricas em inclusões fluidas na fase potássica, formadas pela substituição incompleta de plagioclásios dos TTG, (Schorscher, 1992).

A evolução proterozóica compreende o principal metamorfismo regional progressivo e deformações associadas do Ciclo Minas/Espinhaço (Paleoproterozóico final) e o Ciclo Brasiliano (Neoproterozóico). O primeiro foi um episódio plurifacial, no início marcado por gradientes tipo Barrow de mais baixas temperaturas e altas pressões passando, no final, para gradientes de mais altas temperaturas (Schorscher, 1975; 1992; Rettinger, 1998).

Os resultados geotermométricos indicam temperaturas médias máximas de 450 a 610 ${ }^{\circ} \mathrm{C}$ e de 540 a $670{ }^{\circ} \mathrm{C}$, respectivamente, pelos geotermômetros granada-biotita e granadaestaurolita em metapelitos, e de 475 a $770^{\circ} \mathrm{C}$ pelo geotermômetro granada-biotita nos GB. Entre os geotermômetros utilizados, os que forneceram temperaturas mais compatíveis com as assembléias minerais das rochas em estudo foram: granada-estaurolita em MP, para 
estaurolitas com baixos teores de $\mathrm{Zn}(\mathrm{ZnO} \cong 0.38 \%)$, e granada-anfibólio em ABG. Entre estes dois pares existe boa correlação, tanto nos valores absolutos, quanto nas indicações de zoneamento, cujas temperaturas obtidas para assembléias de borda são mais elevadas em "relação às de centro, indicando a progressão metamórfica do principal evento Proterozóico, preservada em bordas de minerais mais estáveis.

A evolução geológica do Meso a Neoproterozóico deixou poucos registros mineralógico-petrográficos na área de estudo, tais como processos locais de rehidratação e retrometamorfismo, incluindo a formação de cloritas, sericitas, epidoto e carbonatos. Efeitos do retrometamorfismo são também indicados pelas composições de mais baixas temperaturas nas bordas do que nos respectivos centros de biotitas de metapelitos. De modo similar, as temperaturas, em geral, muito baixas, com mínimos nas associações de bordas, fornecidas pelo geotermômetro dos dois feldspatos $\left(260\right.$ a $\left.430^{\circ} \mathrm{C}\right)$ em GB e MGF podem, também, indicar reequilíbrios retrometamórficos finais do principal metamorfismo regional Paleo a Mesoproterozóico e/ou ainda, os efeitos tectono-termais do Ciclo Brasiliano.

Os MGF formaram-se pelo metamorfismo progressivo dos GB a partir de condições P$\mathrm{T}$ da fácies anfibolito médio, no evento principal Paleo a Mesoproterozóico. As transformações foram essencialmente texturais e mineralógicas, incluindo o desenvolvimento progressivo da foliação até sua predominância sobre a lineação e a recristalização granoblástica das mesopertitas para microclínios e plagioclásios. Nesses processos, foram preservadas as características geoquímicas globais, sobretudo, dos elementos maiores: $\mathrm{SiO}_{2}>$ $72 \%$; altas razões de $\mathrm{K}_{2} \mathrm{O} / \mathrm{Na}_{2} \mathrm{O}(1.0$ a 3.4) e $\mathrm{FeO} / \mathrm{FeO}+\mathrm{MgO}(1.0-1.2)$; baixos teores de $\mathrm{CaO}(<1.73 \%)$; e, ainda, altos teores de Be (média de $8.4 \mathrm{ppm}$ ) e Li (média de $24 \mathrm{ppm}$ ). Contudo, foram encontradas evidências de mudanças geoquímicas menores, mas sistemáticas de elementos traço, incluindo elementos incompatíveis e ETRL que acompanharam a transformação dos GB para os MGF, tais como: enriquecimentos em $\mathrm{Rb}, \mathrm{Ga}, \mathrm{Nb}, \mathrm{Y}$ e $\mathrm{Zn}$ e empobrecimentos em $\mathrm{Cs}, \mathrm{Ba}, \mathrm{Sr}, \mathrm{Hf}$ e $\mathrm{Zr}$; aumento das razões $\mathrm{Hf} / \mathrm{Zr}$ (de 0.029 a 0.036 nos

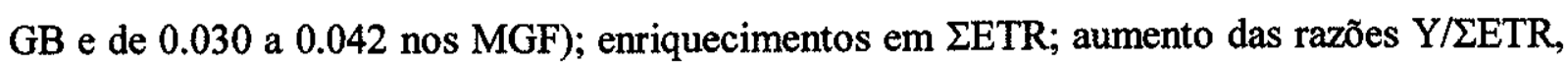
$\Sigma E T R P / \Sigma E T R L$ e $\mathrm{La}_{\mathrm{N}} / \mathrm{Sm}_{\mathrm{N}}$ e das anomalias negativas de Eu e diminuição das razões $\mathrm{Gd}_{\mathrm{N}} / \mathrm{Lu}_{\mathrm{N}}$ e $\mathrm{La}_{\mathrm{N}} / \mathrm{Lu}_{\mathrm{N}}$. Estas mudanças, porém, não apagaram as características geoquímicas de granitos potássicos tanto dos GB quanto dos MGF e confirmaram a relação genética entre estes metagranitóides por metamorfismo regional progressivo de grau médio a alto, que resultaram em processos iniciais de fusão parcial. 
Granitos potássicos, tardi-arqueanos, ígneos ou metassomáticos, de outras localidades, apresentam características de ETR similares aos $\mathrm{GB} / \mathrm{MGF}$, especialmente, no que diz respeito às altas razões $L a_{N} / L u_{N}$, aos efeitos tetrádicos nos padrões globais, planos a moderadamente inclinados de ETRP, assim como a significante depauperação de Eu (McLennan \& Taylor, 1979; Taylor \& McLennan, 1985). A anomalia negativa de Eu é considerada quase que consensualmente, uma indicação de mudança episódica sofrida pela crosta continental no final do Arqueano, quando passou a conter volumosos corpos de granitos potássicos (McLennan \& Taylor, 1979; Taylor \& McLennan, 1985; Figueiredo, 1985). Nos GB, pode ter sido produzida pelas reações metassomáticas de substituição do plagioclásio (com $\mathrm{Eu}^{+2} \mathrm{em}$ sua estrutura) por K-feldspato. A ausência de fluorescência nos feldspatos dos GB indica que todo o Eu estaria presente como $\mathrm{Eu}^{+2}$ que é isomorfo com o $\mathrm{Ca}^{+2}$ e neste caso não fluoresce. Já o desenvolvimento da anomalia negativa de Eu dos GB para os MGF, indica perdas de Eu nos processos de fusão parcial.

A análise comparativa dos dados de elementos traço e ETR dos GB/MGF desta pesquisa e de outros corpos de granitóides do extremo NE do QF, mais especificamente, da região compreendida entre Itabira e Guanhães estudados e denominados como "Borrachudos" por outros autores (Grossi Sad et al., 1990; Dussin, 1994; Fernandes et al., 1995) mostra nítidas diferenças nos espectros de ETR, tanto nas anomalias de Eu, quanto dos teores de ETRP, bem como dos demais elementos traço com destaque para $\mathrm{Pb}, \mathrm{V}, \mathrm{Zn}, \mathrm{Ni}$ e Cr. Estas diferenças sustentam a posição deste trabalho de separar os GB e MGF desta pesquisa dos outros granitóides da Suíte Borrachudos de Grossi Sad et al. (1990) e demais autores.

Sob aspectos metalogenéticos, além das mineralizações berilíferas, foram observadas e merecem menção pequenas ocorrências de cromita nas rochas metaultramáficas e de scheelita nos anfibolitos metabásicos e nos xistos/gnaisses que sofreram alteração hidrotermal prémetamórfica (com cummingtonita, granada, cordierita e estaurolita), assim como, anomalias geoquímicas de Zn em metapelitos da SVS e de ETR nos metagranitóides GB e MGF. Os traçadores geoquímicos $\mathrm{W}$ e $\mathrm{Zn}$ indicam, ainda, o potencial metalogenético em Au da SVS na área de estudo. Porém, no contexto da metalogênese do Be, destacam-se as mineralizações de esmeraldas e de águas marinhas, sendo as primeiras foco desta pesquisa.

As mineralizações de esmeraldas ocorrem em diferentes gerações e tipos genéticos distintos. Nas zonas de cisalhamento rúptil-dúctil, ativas, envolvendo associações de rochas TTG e da SVS, fluidos alcalinos, potássicos, ricos em $\mathrm{Be}$ e Al, interagiram simultaneamente: 
(a) com os TTG transformando-os em GB e liberando, entre outros, Al (da substituição do plagioclásio) para o fluido; e (b) com as rochas metaultramáficas da SVS causando as alterações metassomáticas de flogopitização e as mineralizações de esmeraldas de tipo xisto (EX) e tipo veio de quartzo polideformado (EVQP), consideradas de idade arqueana.

O metamorfismo regional progressivo, paleoproterozóico final, alcançou o ápice termal em estágio tardi a pós-tectônico e intensidade, em geral, algo mais alta na região de Capoeirana em relação à de Belmont. Causou, ainda, fusão parcial incipiente dos MGF produzindo pegmatóides e pegmatitos; os primeiros, quando intrusivos nas rochas metaultramáficas podem ser mineralizados em esmeraldas e os últimos, intrusivos nos próprios MGF podem ser portadores de águas marinhas.

As EX ocorrem, geralmente, como porfiroblastos orientados segundo a foliação principal da rocha, sendo envolvidos pela flogopita. Os veios de quartzo polideformados com esmeraldas são concordantes/pseudoconcordantes com as foliações principais dos xistos e/ou formam concentrações lenticulares também deformadas e, às vezes, contorcidas de tipo "toalha molhada" nas charneiras de micro-dobras, o que indica cristalização em condições pré-cinemáticas em relação ao evento principal de deformação. Nesses veios, as bordas de grãos de quartzo com esmeralda são, geralmente, de suturação metamórfica; ambos os minerais apresentam ainda lamelas de deformação intracristalina. As características petrográficas, mineralógicas e cristalográficas das EX e EVQP são similares (Machado, 1994).

Os pegmatóides intrusivos nas rochas metaultramáficas e mineralizados em esmeraldas, formam corpos pseudoconcordantes e discordantes, com formas predominantemente irregulares e dimensões métricas, sendo claramente menos deformados que as encaixantes. As esmeraldas nestes pegmatóides são idiomórficas e apresentam bordas retilíneas e de imposição mútua de idiomorfismo com os plagioclásios e irregulares com o quartzo.

Ressalta-se, ainda, a ocorrência em Capoeirana de veios de quartzo pouco deformados contendo esmeraldas idiomórficas. Assim, tanto as EVP e as EVQ em veios pouco deformados (restritos a Capoeirana), quanto as águas marinhas de pegmatitos dos MGF representam um evento proterozóico de mineralizações berilíferas, relacionado ao metamorfismo regional principal de médio/alto grau e à anatexia inicial dos MGF. Essas 
observações levam a rejeitar todas as interpretações que, com base em datações radiométricas e outros métodos essencialmente laboratoriais e teóricos, enfatizam para a região uma fase única de mineralização de esmeraldas de idade Brasiliana ligada a intrusões graníticas magmáticas (por ex.: Ribeiro-Althoff et al., 1997; Giuliani et al., 1997a).

Quimicamente, as EX e as EVQP apresentam teores, em geral, mais elevados de $\mathrm{Al}_{2} \mathrm{O}_{3}$ e $\mathrm{Cr}_{2} \mathrm{O}_{3}$ e mais baixos de $\mathrm{MgO}$ e $\mathrm{Na}_{2} \mathrm{O}$; as EVQ pouco deformados exibem os teores mais elevados de $\mathrm{MgO}$ e $\mathrm{Na}_{2} \mathrm{O}$ e mais baixos de $\mathrm{Al}_{2} \mathrm{O}_{3}$ e $\mathrm{Cr}_{2} \mathrm{O}_{3}$; as EVP apresentam composições intermediárias entre estes dois grupos. As esmeraldas não mostram significantes zoneamentos composicionais; porém, as variações químicas de centros e bordas de esmeraldas, sugerem, pelo menos para as EX e EVP, a reação de substituição $\mathrm{Al}^{3+(\mathrm{VI})}=\mathrm{Mg}^{2+(\mathrm{Vl})}+\mathrm{Na}^{+(\text {canal })}$.

Existe uma forte correlação entre intensidade da cor e aumento do teor de $\mathrm{Cr}_{2} \mathrm{O}_{3}$; no entanto, nenhuma correlação segura pode ser feita entre a cor e os teores de $\mathrm{FeO}$ e/ou $\mathrm{MgO}$.

Comparativamente, as EX e EVQP exibem os teores mais elevados de $\mathrm{Cr}, \mathrm{V}, \mathrm{Hf}, \mathrm{Zr}$ e Th e mais baixos de $\mathrm{Cs}, \mathrm{Rb}, \mathrm{Zn}$, enquanto que as EVQ pouco deformados detém os teores mais elevados de Cs e Rb.

As esmeraldas são, ainda, caracterizadas por enriquecimentos variáveis de $\mathrm{Cs}, \mathrm{Ba}, \mathrm{Rb}$, $\mathrm{Th}, \mathrm{U}, \mathrm{W}, \mathrm{Ta}, \mathrm{Nb}$ e Sc e empobrecimentos em $\mathrm{Mo}, \mathrm{Sr}, \mathrm{Sb}, \mathrm{Ti}, \mathrm{Cu}, \mathrm{Zn}, \mathrm{Ni}$ e $\mathrm{Cr}$ em relação aos valores condríticos. Os elementos $\mathrm{Hf}, \mathrm{Zr}$ e $\mathrm{Y}$ apresentam variações consideráveis, sendo desde empobrecidos a enriquecidos. Em relação aos valores médios de GB e MGF, exibem enriquecimentos fortes de $\mathrm{Cs}, \mathrm{V}$ e $\mathrm{Cr}$ e fracos de $\mathrm{W}$ e Co e empobrecimentos em $\mathrm{Ba}, \mathrm{Rb}, \mathrm{Th}$, $\mathrm{U}, \mathrm{Pb}, \mathrm{Sr}, \mathrm{Y}$ e $\mathrm{Mo}$. Dos elementos enriquecidos, o Cs é um típico íon alcalino dos canais estruturais; Cr, V e Co são elementos cromóforos e a posição do W é, ainda, desconhecida.

Em geral, todas as esmeraldas são pobres em ETR. Em relação aos condritos, são enriquecidas em ETRL e empobrecidas em ETRP, com exceção do Yb e Lu que se apresentam variavelmente enriquecidos. As EX são caracterizadas pelos maiores fracionamentos de ETRP e de ETR totais e as EVQ pelos maiores fracionamentos de ETRL. Ressaltam-se, ainda, tanto nas EVQ quanto nas EVP, subgrupos com composições químicas distintas, confirmando diferentes gerações de esmeraldas. No caso das EVQ, associam-se às variações químicas diferenças estruturais; trata-se de EVQP nos xistos por um lado e de EVQ pouco deformados, com esmeraldas idiomórficas, por outro. Quanto às EVP, os subgrupos carecem, ainda, de caracterizações complementares. 
As águas-marinhas provenientes das porções pegmatóides e quartzosas de pegmatitos nos MGF, apresentam composições distintas entre si e das esmeraldas, tanto nos mais altos teores de $\mathrm{Pb}$ e mais baixos de $\mathrm{Cs}, \mathrm{Cr}, \mathrm{V}, \mathrm{Sc}$ e $\mathrm{Co}$, quanto nos mais altos teores de $\Sigma \mathrm{ETR}$ e mais fortes fracionamentos de ETRP.

As correlações positivas entre o $\mathrm{Y}$ e os ETRP nas esmeraldas e nos metagranitóides GB e MGF sugerem que estes elementos foram transportados por complexos flúor-ETRP nos fluidos metassomáticos mineralizantes de composição similar àquela dos fluidos que agiram na formação dos GB (MGF). As águas-marinhas provenientes das porções pegmatóides e quartzosas de um pegmatito em MGF, apresentam composições de ETR distintas entre si e das esmeraldas; porém, em relação ao Y e ETRP, alinham-se com as esmeraldas e com os GB e MGF, indicando também tratar-se, mais provavelmente, do ciclo metassomáticometamórfico que originou os GB-MGF e não de um processo pegmatítico geneticamente independente. Ou seja, as gerações mais novas de esmeraldas (EVP e EVQ menos deformados) e as águas marinhas devem-se a retrabalhamentos e remobilizações pelo metamorfismo regional principal proterozóico do reservatório químico-mineralógico original, arqueano (das EX e EVQP), sem contribuições externas novas e de outras fontes.

As composições isotópicas das esmeraldas situam-se no campo de superposição de águas magmáticas e metamórficas, sendo condizentes com a origem, mais provável, das EX e EVQP, relacionada à orogênese do greenstone belt e à formação metassomática dos GB a partir de fluidos crustais profundos, de granulitização/degranitização da crosta inferior. Por outro lado, as EVP, as EVQ pouco deformados e as águas marinhas originaram-se de fluidos da anatexia e fusão parcial incipiente dos MGF.

Os valores muito homogêneos de $\delta \mathrm{D}$ dos fluidos dos canais estruturais das esmeraldas e de $\delta^{18} \mathrm{O}$ de sua estrutura cristalina representam os sistemas mais resistentes às alterações polimetamórficas e retrometamórficas. Estes valores e sua homogeneidade representam assinaturas que devem ser consideradas como características originais que permaneceram constantes desde a primeira fase arqueana de mineralizações (tipo EX e EVQP) e foram reproduzidas por todas as gerações posteriores, confirmando, assim, os retrabalhamentos dos sistemas geoquímicos-isotópicos anteriores, sem contribuição de fluidos de outras fontes. 


\section{REFERÊNCIAS BIBLIOGRÁFICAS}

ABREU, G.C. (1995) Geologia e metalogênese do ouro da mina do Pari, NE do Quadrilátero Ferrifero - MG. São Paulo, 162p. (Dissertação de Mestrado) - Instituto de Geociências, Universidade de São Paulo.

AINES, R.D. ; ROSSMAN, G.R. (1984) The high temperature behavior of water and carbon dioxide in cordierite and beryl. American Mineralogist, v.69, p. 319-327.

ALBEE, A.L. (1965) A petrogenetic grid for Fe-Mg silicates of pelitic schists. American Journal of Science, v. 263, p. 512-536.

ALKMIM, F.F.; MARSHAK, S. (1998) Transamazonian orogeny in the Southern São Francisco Craton Region, Minas Gerais, Brazil: evidence for paleoproterozoic collision and collapse in the Quadrilátero Ferrífero. Precambrian Research, v.90, p. 29-58.

ALMEIDA, F.F.M. (1976) Estruturas do Pré-Cambriano Inferior brasileiro. In: CONGRESSO BRASILEIRO DE GEOLOGIA, 29., Ouro Preto, 1976. Boletim de Resumos. Ouro Preto, SBG. p.201-202.

ALMEIDA, F.F.M. (1977) O Cráton do São Francisco. Revista Brasileira de Geociências, v.7, p. 349-364.

ALVES, M.G. (1986) Técnicas de sensoriamento remoto e obtenção de dados litoestruturais de detalhe na região NE do Quadrilátero Ferrífero - $M G$. São José dos Campos, 103p. (Dissertação de Mestrado) - Instituto de Pesquisas Espaciais, Sensoriamento Remoto, INPE/São Paulo.

ANDERSON, D.E. ; OLIMPIO, J.C. (1977) Progressive homogenization of metamorphic garnets, South Morar, Scotland: evidence for volume diffusion. Canadian Mineralogist, v.15, part 2, p. 205-216.

BABINSKI, M.; CHEMALE Jr, F.; VAN SCHMUS, W.R. (1991) Geocronologia Pb/Pb em rochas carbonáticas do Supergrupo Minas, Quadrilátero Ferrifero, Minas Gerais, Brasil. In: CONGRESSO BRASILEIRO DE GEOQUÍMICA, 3., São Paulo, 1991. Anais. São Paulo, SBGq. v.2, p. 628-631.

BANKS, D.A.; YARDLEY, B.W.D.; CAMPBELL, A.R.; JARVIS, K.E. (1994) REE composition of an aqueous magmatic fluid: a fluid inclusion study from the Capitan Pluton, New Mexico, U.S.A. Chemical Geology, v.113, p. 259-272.

BARBOSA, O. (1954) Évolution du Géosynclinal Espinhaço. In: INTERNATIONAL GEOLOGICAL CONGRESS, 19., Alger, 1952. Comptes Rendus. v.14, part 2, p. 17-36.

BARBOSA, M.P. (1988) Estudo do relacionamento genético das feições geológicas na região do Espinhaço Meridional e adjacências, Minas Gerais. São Paulo, 237 p. (Tese de Doutorado) Instituto de Geociências, Universidade de São Paulo.

BARROW, G. (1912) On the geology of the lower Dee-side and the southern highland border. Proceedings of the Geologists Association, v.23, p. 268-284.

BATTACHARYA, A.; MOHANTY, L.; MAJI, A.; SEN, S.K.; RAITH, M. (1992) Non-ideal mixing in the phlogopite-annite binary: constraints from experimental data on $\mathrm{Mg}$-Fe partitioning and a reformulation of the biotite-garnet geothermometer. Contributions to Mineralogy and Petrolology, v. 111, n.1, p.87-93.

BAU, M. (1996). Controls on the fractionation of isovalent trace elements in magmatic and aqueous systems: evidence from $\mathrm{Y} / \mathrm{Ho}, \mathrm{Zr} / \mathrm{Hf}$, and lanthanide tetrad effect. Contributions to Mineralogy and Petrology, v.123, p.323-333. 
BESWICK, A.E. (1982) Some geochemical aspects of alteration and genetic relations in komatiitic suites. In: ARNDT, N.T. ; NISBET, A.E. (eds) Komatiites. London, Allen and Unwin. p. 16061628 .

BOTTINGA, Y. ; JAVOY, M. (1973) Comments on oxygen isotope geothermometry. Earth and Planetary Science Letters, v. 20, p. 250-265.

BOTTINGA, Y. ; JAVOY, M. (1975) Oxygen isotope partitioning among the minerals in igneous and metamorphic rocks. Reviews of Geophysics ans Space Physics, v.13, p. 401-418.

BUCHER, K. ; FREY, M. (1994) Petrogenesis of metamorphic rocks: complete revision of Winkler's text book. 6.ed. Berlin, Springer. 318p.

CARMICHAEL, D.M. (1970) Intersecting isograds in the Whetstone Lake area, Ontario. Journal of Petrology, v.11, n. 1, p. 147-181.

CARNEIRO, M.A. (1992) O complexo metamórfico Bonfim Setentrional (Quadrilatero Ferrifero, Minas Gerais): litoestratigrafia e evolução geológica de um segmento de crosta continental do arqueano. São Paulo, 226 p.(Tese de Doutorado) - Instituto de Geociências, Universidade de São Paulo.

CARNEIRO, M.A.; NOCE, C.M.; CUNHA, E.M.; FERNANDES, R.A. (1995) Afinidades geoquímicas entre gnaisses arqueanos dos complexos metamórficos Bonfim e Belo Horizonte. In: SIMPOSIO DE GEOLOGIA DE MINAS GERAIS, 8., Diamantina, 1995. Anais. Belo Horizonte, SBG-Nucleo Minas Gerais. Boletim n.13, p. 50-52.

CASSEDANNE, J.P. (1984) As esmeraldas do Brasil. Brasil Relojoeiro e Joalheiro, v.25, n. 283, p. 76-82.

CHEMALE Jr., F. (1987a) Tektonische, lagerstät tenkundliche und petrographische Untersuchungem im Eisenerzrevier Itabira, Minas Gerais, Brasilien. Clausthal-Zellerfeld, 140p. (Doktorarbeit ) Geologisch-Paläontologisches Institut, Technische Universität Clausthal.

CHEMALE Jr., F. (1987b) Gênese das rochas graniticas do tipo Borrachudo. In: CONGRESSO BRASILEIRO DE GEOQUIMICA, 1., Porto Alegre, 1987. Porto Alegre, SBGq. v.1, p. 171186.

CHINNER, G.A. (1967) Chloritoid, and the isochemical character of Barrow's zones. Journal of Petrology, v.8, n. 2, p.268-282.

CLARK, A.M. (1984). Mineralogy of the rare earth elements. In: HENDERSON, P.(ed.). Rare earth element geochemistry. Amsterdam, Elsevier. p.31-61. (Developments in Geochemistry, 2).

CLARKE, D. (1992) Newpet 1987-1992: programa livre para microcomputador (IBM - PC e compatíveis), para cálculos petroquímicos e representações gráficas. St. John's, Memorial University of Newfoundland, Department of Earth Sciences.

CLARKE, D. (1994) Newpet 1987-1994: programa livre para microcomputador (IBM - PC e compatíveis), para cálculos petroquímicos e representações gráficas. St. John's, Memorial University of Newfoundland, Department of Earth Sciences.

CLAYTON, R.N. (1981) Isotope thermometry. In: NEWTON, R.C.; NAVROTSKY, A.; WOOD, B.J. (eds.) Thermodynamics of minerals and melts. New York, Springer. p.85-109.

COLLINS, W.J.; BEAMS, S.D.; WHITE, A.J.R.; CHAPPELL, B.W. (1982) Nature and origin of Atype granites with particular reference to southeastern Australia. Contributions to Mineralogy and Petrology, v.80, p. 189-200.

CONDIE, K. C. (1981) Archaean greenstone belts. Amsterdam, Elsevier. 434 p. (Developments in Precambrian Geology, 3). 
CULLERS, R.L.; GRAF, J.L. (1984) Rare earth elements in igneous rocks of the continental crust: intermediate and silic rocks ore petrogenesis. In: HENDERSON, P. (ed.) Rare earth element geochemistry. Amsterdam, Elsevier. p. 275-316. (Developments in Geochemistry, 2 ).

CUNNINGHAM, W.D.; MARSHAK, S.; ALKMIM, F.F. (1996) Structural style of basin inversion at mid-crustal levels two transects in the internal zone of the Brasiliano Araçuaí Belt, Minas Gerais, Brazil. Precambrian Research, v.77, p. 1-15.

DASGUPTA, S.; SENGUPTA, P.; GUHA, D.; FUKUOKA, M. (1991) A refined garnet-biotite Fe-Mg exchange geothermometer and its application in amphibolites and granulites. Contributions to Mineralogy and Petrololgy, v.109, n.1, p. 130-137.

DEBON, F. ; LE FORT, P. (1983) A chemical-mineralogical classification of common plutonic rocks and associations. Transactions Royal Society Edinburgh. Earth Sciences, v.73, p. 135-149.

DEER, W.A.; HOWIE, R.A. ; ZUSSMAN, J. (1962) The rock-forming minerals: sheet silicates. New York, John Wiley. v.3, 270p.

DEER, W.A.; HOWIE, R.A.; ZUSSMAN, J. (1982) An introduction to the rock-forming minerals: orthosilicates. 2.ed. London, Longman . v.1A, 919p.

DEER, W.A.; HOWIE, R.A.; ZUSSMAN, J. (1992) An Introduction to the rock forming minerals. 2.ed. London, Longman. $695 \mathrm{p}$.

DERBY, O.A. (1906) The Serra do Espihaço, Brazil. Journal of Geology, v.14, n.3, p. 374-401.

DORR, J.V.N. (1969) Physiographic, stratigraphic and structural development of the Quadrilátero Ferrifero, Minas Gerais. U.S.Geological Survey Professional Paper, v.641-A, p. 110p.

DORR, J.V.N.; GAIR, J.E.; POMERENE, J.B.; RYNEARSON, G.A. (1957) Revisão da estratigrafia Pré-Cambriana do Quadrilátero Ferrífero. Avulso. DNPM.DFPM, n.81, p.1-31.

DORR, J.V.N. ; BARBOSA, A.L.M. (1963) Geology and ore deposits of the Itabira District, Minas Gerais, Brazil. U.S. Geological Survey Professional Paper, v.341-C, p.1-108.

DRAKE, A.A.; MORGAN, B.A. (1980) Precambrian plate tectonics in the Brazilian shield: evidence from the pre-Minas rocks of the Quadrilátero Ferrifero, Minas Gerais. U.S. Geological Survey Professsional Paper, v. 1119, p. B1-B19.

DROOP, G.T.R. (1987) A general equation for estimating $\mathrm{Fe}^{3+}$ concentrations in ferromagnesian silicates and oxides from microprobe analyses using stoichiometric criteria. Mineralogical Magazine, v.51, p. 431-435.

DRURY, S.A. (1979) Rare earth and other trace element data bearing on the origin of Archaean granitic rocks from Yellowknife, Northwest Territories. Canadian Journal of Earth Sciences, v.16, p. 809-815.

DRUMOND, J.B.V. (1985). Projeto mapas metalogenéticos e de previsão de recursos minerais. Folha Se.23-Z-D Ipatinga - Escala 1:250.000. Brasilia, DNPM/CPRM. 15 p.

DUSSIN, T.M. (1994) The Borrachudos Suite, Mesoproterozoic A-type granitic magmatism in the southeastern São Francisco Craton (SE Brazil). In: DUSSIN, T.M. (1994). Associations volcanoplutoniques de l'Espinhaço Meridional (SE-Brésil). Orleans, 23-52. (Doctoral Thesis) - Universite d'Orleans.

DUSSIN, T.M.; DUSSIN, I.A.; NOCE, C.M.; ROSSI, P.; CHARVET, J. (1997) Tectonic setting and origin of the Mesoproterozoic Borrachudos granites (MG, Brazil). In: SOUTH-AMERICAN SYMPOSIUM ON ISOTOPE GEOLOGY, Campos de Jordão, 1997. Extended Abstracts. p.104106.

ELKINS, L.T. ; GROVE, T.L. (1990) Ternary feldspar experiments and thermodynamic models. American Mineralogist, v.75, n. 5-6, p. 544-559. 
ENGESSER, W. (1974). Geologie, petrographie und altersstellung der Gesteine der sudlichen Serra do Espinhaço, Minas Gerais, Brasilien. Baden-Wurtemberg, 37 p. (Doktorarbeit) Geowissenschaftlichen Fakultat, Albert - Ludlwigs University Freiberg.

EPSTEIN, D.S. (1989) The Capoeirana Emerald deposit near Nova Era, Minas Gerais, Brazil. Gems and Gemology, v.25, n. 3, p. 150-158.

EVENSEN, N.M.; HAMILTON, P.J.; O'NIONS, R.K. (1978) Rare earth abundances in chondritic meteorites. Geochimica et Cosmochimica Acta, v. 42, p. 1199-1212.

FALLICK, A.E. ; BARROS, J.G. (1987) A stable-isotope investigation into the origin of beryl and emerald from the Porangatu deposits, Goias State, Brazil. Chemical Geology, v.66, p. 293-300.

FALLICK, A.E.; SCHORCHER, H.D.; MACHADO, G.A.A.; MONTEIRO, M.M.G.; ELLAM, R.M. (1994) A review of stable isotope $\left({ }^{18} \mathrm{O}, \mathrm{D}\right)$ studies of emerald deposits in Brazil. In: MINERAL DEPOSITS STUDIES GROUP, Exeter, 1994. Annual Meeting. Camborne, Geological Society.

FERNANDES, M.L.S.; MARCIANO, V.R.P.R.O.; OLIVEIRA, R.C.; CORREIA NEVES, J.M.; DILÁSCIO, M.V. (1995a) Granitos borrachudos: um exemplo de granitogênese anorogênica na porção central do Estado de Minas Gerais. Geonomos, v.2, n.2, p. 23-29.

FERNANDES, M.L.S.; BILAL, E.; CORREIA NEVES, J.M.; GIRET, A.; COSTA, K.V. (1995b) Estimativa das condições de cristalização do granito borrachudos na região de Dores de Guanhães, MG. In: SIMPOSIO DE GEOLOGIA DE MINAS GERAIS, 8., Diamantina, 1995. Anais. Belo Horizonte, SBG-Núcleo Minas Gerais. Boletim n. 13, p. 64-66.

FERRY, J. M.; SPEER, F.S. (1978) Experimental calibration of partitioning of Fe and $\mathrm{Mg}$ between biotite and garnet. Contibutions to Mineralogy and Petroology, v.66, p. 113-117.

FIGUEIREDO, M.C.H. (1985) Introdução à geoquímica dos elementos terras raras. Boletim. IG-USP. Série Científica, v.16, p. 15-31.

FOGAÇA, A.C.C.; ALMEIDA ABREU, P.A.; SCHORSCHER, H.D. (1984) Estratigrafia da sequência supra-crustal arqueana na porção mediana-central da Serra do Espinhaço, Minas Gerais. In: CONGRESSO BRASILEIRO DE GEOLOGIA, 33., Rio de Janeiro, 1984. Anais. Rio de Janeiro, SBG. v.6, p.2654-2667.

FONTES, C. Q.; NETTO, C.; COSTA, M.R.A.; BALTAZAR, O.F.; SILVA, S.L.; VIEIRA, V.S. (1978) Projeto Jequitinhonha - Relatório Final. Belo Horizonte, DNPM/CPRM. v.1, 543p.

FORMOSO, M.L.L.; NARDI, L.V.S. ; HARTMANN, L.A. (1989) Geoquímica dos elementos terras raras no Brasil. Rio de Janeiro, CPRM/DNPM. 152p.

FRANZ, G.; GRUNDMANN, G.; ACKERMAND, D. (1986) Rock forming beryl from a regional metamorphic terrain (Tauern Window, Austria): parageneses and crystal chemistry. Tschermaks Mineralogische und Petrographische Mitteilungen, v.35, p. 167-192.

FUHRMAN, M.L. ; LINDSLEY, D.H. (1988) Ternary-feldspar modeling and thermometry. American Mineralogist, v.73, n.3.4, p. 201-215.

GANGULY, J. (1968) Analysis of the stabilities of chloritoid and staurolite and some equilibria in the system $\mathrm{FeO}-\mathrm{Al}_{2} \mathrm{O}_{3}-\mathrm{SiO}_{2}-\mathrm{H}_{2} \mathrm{O}-\mathrm{O}_{2}$. American Journal of Science, v.266, n.4, p. 277-298.

GANGULY, J. (1969) Chloritoid stability and related parageneses: theory, experiments, and applications. American Journal of Science, v.267, n.8, p. 910-944.

GANGULY, J. (1971) A reply to Hoschek's criticisms of Ganguly (1968), and Ganguly and Newton (1968) in his article "The stability of staurolite and chloritoid and their significance in metamorphism of pelitic rocks". Contributions to Mineralogy and Petrology, v.31, n.2, p. 166167. 
GANGULY, J. (1972) Staurolite stability and related parageneses: theory, experiments and applications. Journal of Petrology, v.13, n.2, p.335-365.

GANGULY, J. (1979) Garnet and clinopyroxene solid solutions, and geothermometry based on Fe-Mg distribution coefficient. Geochimica et Cosmochimica Acta, v.43, n.7, p. 1021-1029.

GANGULY, J. ; NEWTON, R.C. (1968) Thermal stability of chloritoid at high pressure and relatively high oxygen fugacity. Journal of Petrology, v.9, p. 444-466.

GANGULY, J.; SAXENA, S.K. (1984) Mixing properties of alumino-silicate garnets: constraints from natural and experimental data and applications to geothermometry. American Mineralogist, v.69, n.1-2, p. 88-97.

GARRELS, R.M.; MCKENZIE, F.T. (1971) Evolution of sedimentary rocks. New York, W. W. Norton . 397p.

GHENT, E.D. (1976) Plagioclase-garnet- $\mathrm{Al}_{2} \mathrm{SiO}_{5}$ quartz: a potential geobarometer-geothermometer. American Mineralogist, v.61, p. 710-714.

GHIORSO, M.S. (1984) Activity-composition relations in ternary feldspars. Contributions to Mineralogy and Petrology, v.87, p. 282-296.

GIULIANI, G.; CHEILLETZ, A.; ZIMMERMANN, J.L.; RIBEIRO-ALTHOFF, A.M.; FRANCELANORD, C.; FERAUD, G. (1997a) Les gisements d'émeraude du Brésil: genèse et typologie. Chronique de la Recherche Miniere, n.526, p. 17-61.

GIULIANI, G.; FRANCE-LANORD, C.; ZIMMERMANN, J.L.; CHEILLETZ, A.; ARBOLEDA, C.; CHAROY, B.; COGET, P.; FONTAN, F.; GIARD, D. (1997b) Composition of fluids, (D of channel $\mathrm{H}_{2} \mathrm{O}$ and $\left({ }^{18} \mathrm{O}\right.$ of lattice oxygen in beryls genetic implications for Brazilian, Colombian and Afghmstani emerald deposits. International Geology Review, v.39, p. 400-424.

GOLDMAN, D.S. ; ALBEE, A.L. (1977) Correlation of Mg/Fe partitioning between garnet and biotite with partitioning between quartz and magnetite. American Journal of Science, v.277, n.6, p. 750767

GORLT, G. (1972) Fazieswechsel und Metamorphose in der westlichen Serra Negra (Espinhaço-Zone, Minas Gerais, Brasilien). Geoogische Rundschau, n.61, p. 166-201.

GRAHAM, C.M. ; POWELL, R. (1984) A garnet-hornblende geothermometer: calibration, testing, and application to the Pelona Schist, Southern California. Journal of Metamorphic Geology, v. 2, p. 13-31.

GRAZIANI, G.; GÜBELIN, E.; LUCCHESI, S. (1983) The genesis of an emerald from the Kitwe District, Zambia. Neues Jarbuch Mineralogische.Monatshefte, n.4, p. 175-186.

GROSSI SAD, J.H.; CHIOD FILHO, C.; FONTANA DOS SANTOS, J.; MAGALHÃES, J.M.M.; CARELOS, P.M. (1990) Duas suítes graníticas do bordo sudeste do Cráton San franciscano em Minas Gerais: petroquímica e potencial metalogenético. In: CONGRESSO BRASILEIRO DE GEOLOGIA, 36., Natal, 1990. Anais. Natal, SBG. v.4, p.1836-1848.

GUBA, I. (1982) Tektonik, Texturen und Mineralogie der präkambrischen Eisenerze und Nebengesteinsserien der Lagerstätte Morro Agudo im NE des Quadrilátero Ferrífero/Minas Gerais, Brasilien. Clausthal-Zellerfeld, 342p. (Doktorarbeit) - Technische Universität Clausthal.

GUIDOTTI, C.V. (1970) The mineralogy and petrology of the transition from the lower to upper sillimanite zone in the Oquossoc area, Maine. Journal of Petrology, v.11, n.2, p. 277-336.

GUIMARÃES, M.L.V. (1992) Petrogenese das rochas precambriana da região Itabira-Morro do Pilar, borda SE da Serra do Espinhaço Meridional, Minas Gerais. São Paulo, 138 p. (Dissertação de Mestrado ) - Instituto de Geociências, Universidade de São Paulo. 
GUIMARÃES, M.L.V. ; SCHORSCHER, H.D. (1991) Evolução crustal precambriana da região Itabira/Morro do Pilar, borda SE do Espinhaço Meridional, MG. In: RELATÓRIO CIENTIFICO, 1., São Paulo, FAPESP/IG-USP. Processo n ${ }^{0}$ 89/3835-5. 82 p.

GUIMARÃES, M.L.V. ; SCHORSCHER, H.D. (1992) Evolução crustal precambriana da região Itabira/Morro do Pilar, borda SE do Espinhaço Meridional, MG. In: RELATÓRIO CIENTIFICO, 2., São Paulo, FAPESP/IG-USP. Processo nº 89/3835-5.

HÄNNI, H.A.; SCHWARZ, D. ; FISCHER, M. (1987) The emeralds of the Belmont Mine, Minas Gerais, Brazil. Journal of Gemmology, v.20, n.7/8, p. 446-456.

HARDER, E.C. ; CHAMBERLIN, R.T. (1915) The geology of Central Minas Gerais, Brazil - Part l. Journal of Geology, v.23, n.4, p. 341-378.

HARDER, E.C. ; CHAMBERLIN, R.T. (1915). The geology of Central Minas Gerais, Brazil - Part II. Journal of Geology, v.23, n.5, p.385-424.

HASKIN, L.A.; HASKIN, M.A.; FREY, F.A.; WILDMAN, T.R. (1968) Relative and absolute terrestrial abundances of the rare earthe. In: AHRENS, L.H. (ed.) Origin and distribution of the element. Oxford, Pergamon. v.1, p. 889-911.

HELLMAN, P.L.; SMITH, R.E.; HENDERSON, P.(1979) The mobility of the rare earth elements: evidence and implications from selected terrains affected by burial metamorphism. Contributions to Mineralogy and Petrology, v.71, p.23-24.

HENDERSON, P. (1984) Rare earth element geochemistry. Amsterdam, Elsevier. 510p. (Developments in geochemistry, 2).

HERRMANN, J. R. (1991) Geologie, Mineralogie, Geochemie und Genese der Smaragdlagerstätte Capoeirana, Minas Gerais, Brasilien. Mainz, 84 p. (Diplomarbeit zur Erlangung des Grades eines Diplom) - Geologisch Institut für Geowissenschaften Johannes Gutenberg Universität.

HERZ, N. (1970) Gneissic and igneous rocks of the Quadrilátero Ferrífero, Minas Gerais, Brazil. U.S.Geological Survey Profissional Paper, v. 641-B, p.1-58.

HERZ, N. (1978) Metamorphic rocks of the Quadrilátero Ferrífero, Minas Gerais, Brazil. U. S. Geological Survey Profissional Paper, v. 641-C, p.1-81.

HERZBERG, C. (1992) Depth and degree of melting of komatiites. Journal Geophysical Research, v. 97, n.4, p. 4521-4540.

HETTICH, M. (1977) A glaciação proterozóica no centro-norte de Minas Gerais. Revista Brasileira de Geociências, v.7, p. 87-101.

HILDRETH, W. 1981. Gradients in silicic magma chambers: implications for lithospheric magmatism. Journal Geophysical Research. Section B, v.86, p. 10153-10192.

HODGES, K.V. ; SPEAR, F.S. (1982) Geothermometry, geobarometry and the $\mathrm{Al}_{2} \mathrm{SiO}_{5}$ triple point at Mt. Moosilauke, New Hampshire. American Mineralogist, v.67, n.11-12, p. 1118-1134.

HODGES, K.V. ; CROWLEY, P.D. (1985) Error estimation and empirical geothermobarometry for pelitic systems. American Mineralogist, v.79, n.7-8, p. 702-709.

HOEFS, J.; MÜLLER, G.; SCHUSTER, A.K. (1982) Polymetamorphic relations in iron ores from the Iron Quadrangle. Brazil: the correlation of oxygen isotope variations with deformation history. Contributions to Mineralogy and Petrology, v.79, p. 241-251.

HOINKES, G. (1986) Effect of grossular content in garnet on the partitioning of $\mathrm{Fe}$ and $\mathrm{Mg}$ between garnet and biotite. Contributions to Mineralogy and Petrology, v.92, n.3, p. 393-399. 
HOLDAWAY, M.J.; LEE, S.M. (1977) Fe-Mg cordierite stability in high grade pelitic rocks based on experimental, theoretical and natural observations. Contributions to Mineralogy and Petrology, v.63, n.2, p. 175-198.

HOSCHEK, G. (1967) Untersuchungen zum stabilitätsbereich von chloritoid und staurolith. Contributions to Mineralogy and Petrology, v.14, p. 123-162.

HOSCHEK, G. (1969) The stability of staurolite and chloritoid and their significance in metamorphism of pelitic rocks. Contributions to Mineralogy and Petrology, v.22, p. 208-232.

HUMPHRIS, S.E. (1984). The mobility of the rare earth elements in the crust. In: HENDERSON, P. (ed.). Rare earth element geochemistry. Amsterdam, Elsevier. p.317-342. (Developments in Geochemistry, 2).

HUSSAIN, S.S.; CHAUDHRY, M.N.; DAWOOD, H. (1993) Emerald mineralization of Barang, Bajaur Agency, Pakistan. Journal of Gemmology, v.23, n.7, p. 402-408.

HUTCHEON, I.; FROESE, E.; GORDON, T.M. (1974) The assemblage quartz-sillimanite-garnetcordierite as an indicator of metamorphic conditions in the Daly Bay Complex, N.W.T. Contributions to Mineralogy and Petrology, v. 44, p. 29-34.

INDA, H.A.V.; SCHORSCHER, H.D.; DARDENNE, M.A.; SCHOBBENHAUS, C.; HARALYI, N.L.E.; BRANCO, P.C.A.; RAMALHO, R. (1984) O Cráton do São Francisco e a faixa de dobramentos Araçuaí. In: SCHOBBENHAUS, C.; CAMPOS, D.A.; DERZE, G.R.; ASMUS, H.E. (coords.). Geologia do Brasil: texto explicativo do mapa geológico do Brasil e da área oceânica adjacente incluindo depósitos minerais. Escala 1:2500 000. Brasília, MME/DNPM. p.193-248.

INDARES, A. ; MARTINGNOLE, J. (1985) Biotite-garnet geothermometry in the granulite facies: the influence of Ti and $\mathrm{Al}$ in biotite. American Mineralogist, v.70, n.3-4, p.272-278.

IRVINE, T.N. ; BARAGAR, W.R.A. (1971) A guide to the chemical classification of the common volcanic rocks. Canadian Journal Earth Sciences, v.8, p. 523-548.

JANASI, V.A.; ANDRADE, S.; ULBRICH, H.H.G.J. (1995) A correção do drift instrumental em ICP-AES com espetrômetro seqüencial e a análise de elementos maiores, menores e traços em rochas. Boletim. IG-USP. Série Científica, v.26, p. 45-58.

JAVOY, M. (1977) Stable isotopes and geothermometry. Journal of Geological Society. London, v.133, p. 609-636.

JENSEN, L.S. (1976) A new cation plot for classifying sub-alkalic volcanic rocks. Miscellaneous Paper. Ontario Division of Mines, n.66.

JORDT-EVANGELISTA, H. (1984) Petrologische Untersuchungen im Gebiet zwischen Mariana und Ponte Nova, Minas Gerais, Brasilien. Clausthal-Zellerfeld, 183p. (Doktorarbeit) - Technische Universität Clausthal.

JORDT-EVANGELISTA, H. (1985) Petrologia de fases, geotermometria e geobarometria do Complexo Granulítico de Acaiaca, sudeste do Quadrilátero Ferrífero, MG. In: SIMPOSIO DE GEOLOGIA DE MINAS GERAIS, 3., Belo Horizonte. Anais. Belo Horizonte, SBG. v. 5, p. $165-$ 179.

JORDT-EVANGELISTA, H. , MÜLLER, G. (1986) Petrology of a transition zone between the Archean Craton and the Coast Belt, SE of the Iron Quadrangle, Brazil. Chemie Erde, v.45, p. 129-145.

KEHRER, P. (1972) Zur Geologie der Itabirite in der südlichen Serra do Espinhaço (Minas Gerais, Brasilien). Geologische Rundschau, v.61, n.1, p. 216-249. 
KING, P.L.; WHITE, A.J.R.; CHAPPEL, B.W.; ALLEN, C.M. (1997) Characterization and origin of Aluminous A-type Granites from the Lachlan Fold Belt, Southeastern Australia. Journal of Petrology, v.38, n. 3, p. 371-391.

KOVALENKO, V. I.; ZNAMENSKAYA, A. S.; AFONIN, V.P.; PAVLINSKIY, G.V.; MAKOV, V. M. (1966) Behavior of rare-earth elements and Yttrium in metassomatically altered alkalic granites of the Ognitsk Complex (East Sayan). Geochemistry International, v. 3, p. 406-418.

KOZIOL, A.M. (1989) Recalibration of the garnet-plagioclase- $\mathrm{Al}_{2} \mathrm{SiO}_{5}$-quartz (GASP) geobarometer and applications to natural parageneses. EOS, v.70, n.15, p. 493.

KOZIOL, A.M.; NEWTON, R.C. (1988) Redetermination of the anorthite breakdown reaction and improvement of the plagioclase-garnet- $\mathrm{Al}_{2} \mathrm{SiO}_{5}$-quartz barometer. American Mineralogist, v.73, n.3-4, p. 216-223.

LADEIRA, E.A. (1980) Gênese do ouro na mina de Morro Velho e no Distrito de Nova Lima, Minas Gerais, Brasil. In: CONGRESSO BRASILEIRO DE GEOLOGIA, 31., Camboriú, 1980. Boletim de Resumos. Camboriú, SBG. p.371.

LAVRENT'EVA, I.V. ; PERCHUK, L.L. (1981) Phase correspondence in the system biotite-garnet: experimental data. Doklady Akademie Nauk SSSR, v. 260, p. 731-734.

LEAKE, B.E. (1978) Nomenclature of amphiboles. Mineralogical Magazine, v.42, p. 533-563.

LE MAITRE, R.W. (1989) A classification of igneous rocks and glossary of terms: recommendations of the IUGS subcommission on the systematics of igneous rocks. Oxford, Blackwell. 193p.

LINDSLEY, D.H. ; NEKVASIL, H. (1989) A ternary feldspar model for all reasons (abst.). EOS, v. 70, n. 15, p. 506.

LIOU, J.G.; KUNIYOSHI, S. ; ITO, K. (1974) Experimental studies of the phase relations between greenschist and amphibolite in a basalt system. American Journal of Science, v.274, p. 613-632.

MACHADO, G.A.A. (1994) Geologia da região e aspectos genéticos das jazidas de esmeraldas de Capoeirana e Belmont, Nova Era - Itabira, MG. São Paulo, 134p. ( Dissertação de Mestrado) Instituto de Geociências, Universidade de São Paulo.

MACHADO, G.A.A. (1996) Geologia da região e aspectos mineralógicos das jazidas de esmeraldas de Capoeirana e Belmont, Nova Era-Itabira (NG). São Paulo, 70p. ( Exame de Qualificação de Doutorado) - Instituto de Geociências, Universidade de São Paulo.

MACHADO, G.A.A ; SCHORSCHER, H.D. (1997) Geologia da região e aspectos genéticos das jazidas de esmeraldas de Capoeirana e Belmont, MG. In: SIMPOSIO DE GEOLOGIA DE MINAS GERAIS, 9., Ouro Preto, 1997. Anais. SBG, Núcleo Minas Gerais. Boletim n. 14, p.4749.

MACHADO, G.A.A. ; SCHORSCHER, H.D. (1998) Rochas metaultramáficas nas jazidas de esmeraldas de Capoeirana e Belmont (Estado de Minas Gerais - Brasil). In: CONGRESO URUGUAYO DE GEOLOGÍA, 2., Punta del Leste, 1997. Uruguay, Sociedad Uruguaya de Geología. Faculdad de Ciencias.

MACHADO, G.A.A.; SCHORSCHER, H.D.; MIEKELEY, N.F. (1998a) Elementos terras raras em esmeraldas das jazidas de Capoeirana e Belmont (MG). In: CONGRESSO BRASILEIRO DE GEOLOGIA, 40., Belo Horizonte, 1998. p. 463.

MACHADO, G.A.A.; SCHORSCHER, H.D.; SILVA, A.M.L. (1998b) Termogravimetria (TG) e análise térmica diferencial (DTA) em esmeraldas das jazidas de Capoeirana e Belmont (MG). In: CONGRESSO BRASILEIRO DE ANÁLISES TÉRMICAS E CALORIMETRIA, 1., Poços de Caldas, 1998. Livro de Resumos. Minas Gerais, ABRATEC. p.82. 
MACHADO, G.A.A. ; SILVA, A.M.L.; SCHORSCHER, H.D. (1998c) Termogravimetria (TG) e análise térmica diferencial (DTA) em esmeraldas das jazidas de Capoeirana e Belmont (MG). Revista da Associação Brasileira de Química. (no prelo).

MACHADO, N.; NOCE, C.M.; BELO DE OLIVEIRA, O.A.; LADEIRA, E.A. (1989a) Evolução geológica do Quadrilátero Ferrífero no Arqueano e Proterozóico Inferior, com base em Geocronologia U-Pb. In: SIMPOSIO DE GEOLOGIA DE MINAS GERAIS, 5./SIMPÓSIO DE GEOLOGIA DE BRASÍLIA, 1., Belo Horizonte, 1989. Anais. Belo Horizonte, SBG. Boletim n.10, p.1-5.

MACHADO, N.; SCHRANK, A.; ABREU, F.R. de; KNAUER, L.G.; ALMEIDA-ABREU, P.A. (1989b) Resultados preliminares da geocronologia U/Pb na Serra do Espinhaço Meridional. In: SIMPOSIO DE GEOLOGIA DE MINAS GERAIS, 5. / SIMPÓSIO DE GEOLOGIA DE BRASILIA, 1., Belo Horizonte, 1989. Anais. Belo Horizonte, SBG. Boletim, n. 10, p.171-174.

MACHADO, N.; SCHRANK, A.; NOCE, C.M.; GAUTHIER, G. (1996) Ages of detrital zircon from Archean-Paleoproterozoic sequences: implications for greenstone belt setting and evolution of a Transamazonian foreland basin in Quadrilatero Ferrifero, southeast Brazil. Earth and Planetary Science Letters, v.141, p. 259-276.

MACHADO FILHO, L. ; RIBEIRO, M.V.; GONZALEZ, S.R.; SCHENINI, C.A.; SANTOS NETO, S.A.; PALMEIRA, R.C.B.; PIRES, J.L.; TEIXEIRA, W.; CASTRO, H.E.F. (1983). Projeto RADAMBRASIL. Folhas SF.23/24 Rio de Janeiro/Vitória. Rio de Janeiro, MME. 780p. (Levantamentos de Recursos Naturais, v.32).

MANIAR, P.S. ; PICCOLI, P.M. (1989) Tectonic discrimination of granitoids. Geological Society American Bulletin, v.101, p. 635-643.

MARINI, O.J.; FUCK, R.A.; DANNI, J.C.M.; DARDENNE, M.A.; LOGUERCIO, S.O.C.; RAMALHO, R. (1984) As faixas de dobramentos Brasília, Uruaçu e Paraguai-Araguaia e o Maciço Mediano de Goiás. In: SCHOBBENHAUS, C.; CAMPOS, D.A.; DERZE, G.R.; ASMUS, H.E. (coords.). Geologia do Brasil: texto explicativo do mapa geológico do brasil e da área opceânica adjacente incluindo depósitos minerais, escala 1:2500 000. Brasília, MME/DNPM. p.251-303.

MASCARENHAS, J.F. (1973) A geologia do centro-leste do Estado da Bahia. In: CONGRESSO BRASILEIRO DE GEOLOGIA, 27., Aracaju, 1973. Anais. Aracaju, SBG. p.35-66.

MASCARENHAS, J.F. (1976) Estruturas do tipo greenstone belt no leste da Bahia. In: CONGRESSO BRASILEIRO DE GEOLOGIA, 27., Ouro Preto, 1973. Anais. Ouro Preto, SBG. v.4, p.25-50.

MASCARENHAS, J.F. (1979) Evolução geotectônica do Pré-Cambriano do Estado da Bahia. In: INDA, H.A.V. (coord.). Geologia e recursos minerais do Estado da Bahia. Salvador, Secretaria de Minas e Energia do Estado da Bahia. p.55-165. (Textos Básicos, v.2).

MASUDA, A.; KAWAKAMI, O.; DOHMOTO, Y.; TAKENAKA, T. (1987). Lanthanide tetrat effects in nature: two mutually opposite types, W and M. Geochemical Journal, v.21, p.119-124.

MASUDA, A.; NAKAMURA, N.; TANAKA, T. (1973) Fine structures of mutually normalised rareearth patterns of chondrites. Geochimica et Cosmochimica Acta, v.37, p.239-248.

MCLENNAN, S.M. ; TAYLOR, S.R. (1979) Rare earth element mobility associated with uranium mineralization. Nature, v. 282, p. 247-260.

MCLENNAN, S.M. (1994). Rare earth element geochemistry and the "tetrad" effect. Geochimica et Cosmochimica Acta, v.58, p.2025-2033.

MEHNERT (1971) Migmatitos and the origin of granitic rocks. Amsterdam, Elsevier. 403p. (Developments in Petrology, 1). 
MENDES, J.C.; SCHWARZ, D.; SVIZERO, D.P. (1985). Geologia e mineralização da jazida de esmeralda de Itabira: correlação com as demais jazidas brasileiras. In: SIMPÓSIO DE GEOLOGIA DE MINAS GERAIS, 3., Belo Horizonte, 1985. Anais. Belo Horizonte, SBG. Boletim n. 5, p. 240-250.

MICHARD, A. (1989) Rare earth element systematics in hydrothermal fluids. Geochimica et Cosmochimica Acta, v.53, p. 745-750.

MIDDLEMOST, E.A.K. (1985) Magmas and magmatic rocks. London, Longmam. 266p.

MIDDLEMOST, E.A.K. (1989) Iron oxidation ratios, norms and the classification of volcanic rocks. Chemical Geology, v.77, p. 19-26.

MINEYEV, D.A. (1963) Geochemical differentiation of rare-earth elements. Geochemistry, n.12, p.1129-1149.

MIYASHIRO, A. (1968) Metamorphism of mafic rocks. In: HESS, H.H.; POLDERVAART, A. (eds.) Basalts: the poldervaart treatise on rocks of basaltic composition. New York, Interscience. v.2, p. 799-834.

MIYASHIRO, A. (1973 Metamorphism and metamorphic belts. London, George Allen \& Unwin. $492 p$.

MOERI, E. (1972) On a columnar stromatolite in the precambrian Bambui Group of Central Brazil. Eclogae Geologicae Helvitae, v.65, n.1, p.185-195.

MOTHÉ FILHO, H.F. (1996) Contribuição à geologia da região de Florália/MG. Rio de Janeiro, 189p. (Disssertação de Mestrado) - Instituto de Geociências, Universidade Federal do Rio de Janeiro.

MÜLLER-BASTOS, F (1981). Emeralds from Itabira, Minas Gerais, Brazil. Lapidary Journal, v.35 n.9, p. 1042-1848.

MÜLLER, G.; HÖHNDOR, A.; LAUENSTEIN, H.-J.; LENZ, H. (1986a) Petrological and geochemical data on a high-metamorphic archean BIF-bearing rock sequence near Guanhães, Minas Gerais, Brazil. Geologische Jahrbuch. Série D, v.79, p. 3-20.

MÜLlER, G.; LAUENSTEIN, H.-J.; HOEFS, J. (1986b) Sauerstoff und Kohlenstoff Isotopenuntersuchungen an Mineralen aus gebänderten Eisenerzen und Metamorphen Gesteinen nordöstlich des Eisernen Vierecks in Brasilien. Geologische Jahrbuch. Série D, v. 79, p. 21-40.

MÜLLER, G.; SCHUSTER, A.; HOEFS, J. (1982) Oxygen isotope variations in polymetamorphic iron ores from the Quadrilátero Ferrífero, Brazil. Revista Brasileira de Geociências, v.12, p.348355.

NAKAMURA, N. (1974) Determination of REE, $\mathrm{Ba}, \mathrm{Fe}, \mathrm{Mg}, \mathrm{Na}$ and $\mathrm{K}$ in carbonaceous and ordinary chondrites. Geochimica et Cosmochimica Acta, v. 38, p. 757-775.

NEKVAZIL, H. ; BURNHAM, C.W. (1987) The calculated individual effects of pressure and water content on phase equilibria in the granite system. In: MYSEN, B.O. (ed.) Magmatic Processes physicochemical principles. Pennsylvania, Geochemical Society. p.433-445. (Pennsylvania Special Publication, n.1).

NESBITT, R.W.; SUN, S.S.; PURVIS, A.C. (1979) Komatiites: geochemistry and genesis. Canadian Mineralogist, v.17, p. 165-186.

NEWTON, R.C.; HASELTON, H.T. (1981) Thermodynamics of the garnet-plagioclase- $\mathrm{Al}_{2} \mathrm{SiO}_{5}$-quartz geobarometer. In: NEWTON, R.C.; NAVROTSKY, A.; WOOD, B.J. (eds.) Thermodynamics of minerals and melts. New York, Springer. p.131-147. (Advances in Physical Geochemistry, 1). 
NOCE, C.M. (1995) Geocronologia dos eventos magmáticos, sedimentares e metamórficos na região do Quadrilátero Ferrifero, Minas Gerais. São Paulo, 128 p. (Tese de Doutorado) - Instituto de Geociências, Universidade de São Paulo.

O'NEIL, J.R. ; TAYLOR, H.P.Jr. (1967) The oxygen isotope and cation exchange chemistry of feldspars. American Mineraogist, v. 52, p.1414-1437.

PADILHA, A.V. (1984) Formação Córrego dos Boiadeiros - uma sequência komatiítica na base do Grupo Nova Lima, Supergrupo Rio das Velhas, Quadrilátero Ferrífero, MG. In: CONGRESSO BRASILEIRO DE GEOLOGIA, 33., Rio de Janeiro, 1984. Anais. Rio de Janeiro, SBG. v.6, p.2668-2679.

PEARCE, J.A.; HARRIS, N.B.W.;TINDLE, A.G. (1984) Trace element discriminations diagrams for the tectonic interpretation of granitic rocks. Journal of Petrology, v.25, n.4, p. 956-983.

PERCHUK, L.L (1991) Derivation of a thermodynamically consistent set of geothermometers and geobarometers for metamorphic and magmatic rocks. In: PERCHUK, L.L. (ed.) Progress in metamorphic and magmatic petrology - a memorial volume in Honor of D. S. Korzhinskiy. Cambridge, Cambridge University. p. 93-112.

PERCHUK, L.L. ; LAVRENT'EVA, I.V. (1983) Experimental investigation of exchange equilibria in the system cordierite-garnet-biotite. In: SAXENA S.K. (ed.) Kinetics and equilibrium in mineral reaction. Berlin, Springer. p. 199-239.

PERCHUK, L.L.; ARANOVICH, L.Y.; PODLESSKII, K.K.; LAVRENT'EVA, I.V. ; GERASIMOV, V.Y.; FED'KIN, V.V.; KITSUL, V.I.; KARASAKOV, L.P.; BERDNIKOV, N.V. (1985) Precambrian granulites of the Aldan shield, eastern Siberia, USSR. Journal Metamorphic Geology, v.3, n.3, p. 265-310.

PFLUG, R. (1965a) A geologia da parte meridional da Serra do Espinhaço e zonas adjacentes, Minas Gerais. Boletim. DNPM-DGM. Rio de Janeiro, n. 226, p. 1-55.

PFLUG, R. (1965b) Zur geologie der südlichen Espinhaço - Zone und ihrer präkambrischen Diamantvorkommen, Minas Gerais, Brasilien. Zeitschrifte der Deutschen Geologischen Gesellschaft, v.115, p. 177-215.

PFLUG, R. (1968) Observações sobre a estratigrafia da Série Minas na região de Diamantina, Minas Gerais. Notas Preliminares e Estudos.DNPM-DGM, n. 142, p. 1-20.

PFLUG, R. ; RENGER, F. (1973) Estratigrafia e evolução geológica da margem SE do cráton San Francisco. In: CONGRESSO BRASILEIRO DE GEOLOGIA, 27., Aracaju. Anais. Aracaju, SBG. v. 2, p. 5-19.

PIGAGE, L.C. ; GREENWOOD, H.J. (1982) Internally consistent estimates of pressure and temperature. The staurolite problem. American Journal of Science, v.282, n.7, p. 943-969.

RECHE, J. ; MARTINEZ, F.J. (1996) GPT: an excel spreadsheet for thermobarometric calculations in metapelitic rocks. Computers \& Geosciences, v.22, n.7, p. 775-784.

REEVES, R.G. (1966) Geology and mineral resources of the Monlevade and Rio Piracicaba quadrangles, Minas Gerais, Brazil. U.S.Geological Survey Profissional Paper, v.341-E, p. 1-58.

RETTINGER, R. (1994) Geothermobarometrisch-petrologische Untersuchungen am SE-Raund des Eisernen Vierecks, Minas Gerais, Brasilien. Mainz, 79 p. ( Diplomarbeit) - Institut für Geowissenschaften Johannes Gutenberg, Universität Mainz.

RETTINGER, R. (1994) Planilhas EXCEL para cálculos geotermobarométricos. . (Dados não publicados). 
RETTINGER, R. (1998) Thermometamorphic characterisation of the transition zone between the Archean São Francisco Craton and the Proterozoic mobile belt, Minas Gerais, Brazil. 116p. (Dissertation zur Erlangung des akademischen Grades Doktor) Naturwissenschaften - Universität Potsdam.

RETTINGER, R.; SCHORSCHER, H.D.; OBERHÄNSLI, R. (1996) Geothermobarometric correlation of geothermobarometers and petrogenetic modelling in NE-Quadrilátero Ferrifero, Minas Gerais, Brazil. Zentralblatt für Geologie und Paläontologie. Teil 1, n.7/8, p. 613-625.

RETTINGER, R.; OBERHÄNSLI, R. ; SCHORSCHER, H.D. (1994) Geothermobarometric investigation in the north-eastern part of the Quadrilátero Ferrifero. Terra Nostra, v.2, n.94, p. 62.

RIBEIRO-ALTHOFF, A.M.; CHEILLETZ, A.; GIULIANI, G.; FÉRAUD, G.; ZIMMERMANN, JL.; BARBOSA CAMACHO, G.; ROBERT, P. (1996) Datações K-Ar e ${ }^{40} \mathrm{Ar} /{ }^{39} \mathrm{Ar}$ de mineralizações de esmeralda do Brasil. In: CONGRESSO BRASILEIRO DE GEOLOGIA, 39., Salvador, 1996. Anais. Salvador, SBG. v. 7, p. 324-328.

RIBEIRO-ALTHOFF, A.M.; CHEILLETZ, A.; GIULIANI, G.; FÉRAUD, G.; BARBOSA CAMACHO, G.; ZIMMERMANN, J-L. (1997) ${ }^{40} \mathrm{Ar} /{ }^{39} \mathrm{Ar}$ and K-Ar Geochronological evidence for two periods $(\sim 2 \mathrm{Ga}$ and 650 to $500 \mathrm{ma})$ of emerald formation in Brazil. International Geology Review, v.39, p. 924-937.

RICHARD, L. R. (1995) Minpet - version 2,0: reference manual. Quebec, Minpet Geological Software.

RICHARDSON, S.W. (1968a) The stability of Fe-staurolite + quartz. Annual Report of the Geophysical Laboratoty. Carnegie Institution of Washington, 1966-67, p. 398-402.

RICHARDSON, S.W. (1968b) Staurolite stability in a part of the system Fe-Al-Si-O-H. Journal of Petrology, v.9, n.3, p. 467-488.

RICHARDSON, C.K.; RYE, R.O.; WASSERMAN, M.D. (1988) The chemical and thermal evolution of the fluids in the Cave-in-rock fluorspar district, Illinois: stable isotope systematics at the deardorff mine. Economic Geology, v.83, p. 765-783.

RICKWOOD, P.C. (1968) On recasting analyses of garnet into end-member molecules. Contributions to Mineralogy and Petrology, v.18, p. 175-198.

ROLLINSON, H. R. (1993) Using geochemical data: evaluation, presentation, interpretation. New York, Longmam. 352p.

SABÓIA, L.A. (1979) Os greenstone belts de Crixás e Goiás - GO. Boletim da Sociedade Brasileira de Geologia. Núcleo Centro-Oeste, n. 9, p.44-72.

SANTOS, A.R. (1986) Estudos sobre a tectônica de fraturamento na região do Quadrilátero Ferrifero e em partes do Complexo Migmatítico-Granulitico de Minas Gerais com base em sensoriamento remoto. São Paulo, 172p. (Tese de Doutorado) - Instituto de Geociências, Universidade de São Paulo.

SAUER, D.A. (1982) Emeralds from Brazil. In: PROCEEDINGS OF THE INTERNATIONAL GEMOLOGICAL SYMPOSIUM, Santa Monica, USA 1982. Santa Monica, Gemological Institute America. p. 357-377.

SCHALLER, W.T.; STEVENS, R.E.; JAHNS, R.H. (1962) An unusual beryl from Arizona. Ameican Mineralogist, v. 47, p. 672-699.

SCHMETZER, K.; BERNHARDT, H-J.; BIEHLER, R. (1991) Emeralds from the Ural Mountains, USSR. Gems \& Gemmology, v.27, p.86-99. 
SCHOBBENHAUS, C.; CAMPOS, D.A.; DERZE, G.R.; ASMUS, H.E. (1981) Mapa geológico do Brasil e da área oceânica adjacente, incluindo depósitos minerais, escala 1:2.500.000. Brasília, MME/ DNPM. (4 folhas).

SCHOBBENHAUS, C. ; CAMPOS, D.A. (1984) A evolução da plataforma sul-americana no Brasil e suas principais concentrações minerais. In: SCHOBBENHAUS, C.; CAMPOS, D.A.; DERZE, G.R.; ASMUS, H.E. (coords.) Geologia do Brasil: texto explicativo do mapa geologico do Brasil e da area oceânica adjacente incluindo depósitos minerais, escala 1:2500000. Brasilia, MMM/DNPM. p.9-53.

SCHOBBENHAUS, C.; CAMPOS, D.A.; DERZE, G.R.; ASMUS, H.E. (1995). Mapa geológico do Brasil e da área oceânica adjacente, incluindo depósitos minerais, escala 1:2.500.000. 2.ed. Brasília, MME/DNPM.

SCHOBBENHAUS, C. ; SILVA, A.S.D.; MIGNON, R.A.; NEVES, S.P.; LEÃO, E.; PIMENTEL, E.D.C.; DERZE, G.R. (1978). Carta geologica ao milionésimo - Folha Belo Horizonte. Brasilia, MME/DNPM.

SCHORSCHER, H.D. (1973). Levantamento geológico da região de Itabira - Relatório final 1:20.000. Heidelberg, Mineralogisch-Petrographisches Institut/Instituto Eschwege/CVRD. 48p.

SCHORSCHER, H.D. (1975) Entwicklung des polymetamorphen präkambrischen Raumes Itabira, Minas Gerais, Brasilien. Heidelberg, 302p. Ruprecht-Karl Universität.

SCHORSCHER, H.D. (1976) Polimetamorfismo do Pré-Cambriano na região de Itabira, Minas Gerais, Brasil. In: CONGRESSO BRASILEIRO DE GEOLOGIA, 29., Ouro Preto, 1976. Boletim de Resumos. Ouro Preto, SBG. p.194-195.

SCHORSCHER, H.D. (1978) Komatiitos na estrutura "Greenstone Belt" Série Rio das Velhas, Quadrilátero Ferrífero, Minas Gerais, Brasil. In: CONGRESSO BRASILEIRO DE GEOLOGIA, 30., Recife, 1978. Boletim de Resumos. Recife, SBG. p.292-293.

SCHORSCHER, H.D. (1979) Evolução geotectônica e petrogenética do embasamento arqueano do Quadrilátero Ferrífero. Anais da Academia Brasileira de Ciências, v.51, p. 767-768.

SCHORSCHER, H.D. (1980b) Geotectonic evolution of the Quadrilatero Ferrifero, Brazil. In: INTERNATIONAL GEOLOGICAL CONGRESS, 26., Paris, 1980. Résumés. Paris, BRGM. v.2, p. 613.

SCHORSCHER, H.D. (1988) NE Quadriláteo Ferrífero and adjacent areas. In: INTERNATIONAL CONFERENCE GEOCHEMICAL EVOLUTION OF THE CONTINENTAL CRUST, Poços de Caldas, 1988. Guidebook. São Paulo, IG-USP. p.96.

SCHORSCHER, H.D. (1991). Quadrilátero Ferrífero e Espinhaço Meridional. In: CONGRESSO BRASILEIRO DE GEOQUÍMICA, 3., São Paulo, 1991. Guia das Excurções. São Paulo, SBGq / Sociedade de Geologia de Portugal/IG-USP. p.37-87.

SCHORSCHER, H.D. (1992) Arcabouço petrográfico e evolução crustal de terrenos precambrianos do sudeste de Minas Gerais: Quadrilátero Ferrifero, Espinhaço Meridional e domínios granitognáissicos adjacentes. São Paulo, 274 p. (Tese de Livre-Docência) - Instituto de Geociências, Universidade de São Paulo.

SCHORSCHER, H.D.; ALVES, M.G.; DAVIES, H-P.K. (1997a) Geologia da quadrícula São Gonçalo do Rio Abaixo 1:25.000, parte nordeste do Quadrilátero Ferrífero, MG. In: SIMPOSIO DE GEOLOGIA DE MINAS GERAIS, 9., Ouro Preto, 1997. Anais. Ouro Preto, SBG-Núcleo Minas Gerais. Boletim, n.14, p.50-52. 
SCHORSCHER, H.D.; MOTHÉ FILHO, H.F.; ABREU, G.C.; ALVES, M.G.; DAVIES, H-P.K.; QUEIROGA, N.C.M. (1997b) Geologia da quadrícula Florália 1:25.000, borda leste do Quadrilátero Ferrífero, MG. In: SIMPOSIO DE GEOLOGIA DE MINAS GERAIS, 9., Ouro Preto, 1997. Anais. Ouro Preto, SBG-Núcleo Minas Gerais. Boletim n.14, p. 53-55.

SCHORSCHER, H.D.; SANTANA, F.C.; POLONIA, J.C.; MOREIRA, J.M.P. (1982) Quadrilátero Ferrífero - Minas Gerais: Rio das Velhas Greenstone Belt and Proterozoic rocks. In: INTERNATIONAL SYMPOSIUM ON ARCHEAN AND EARLY PROTEROZOIC GEOLOGIC EVOLUTION AND METALLOGENESIS, Salvador, 1982. Abstracts and Excursions. Salvador, SME/BA. 44p.

SCHORSCHER, H.D. ; SVISERO, D.P. ; SOUZA, J.L. (1990) Aspectos genéticos da jazida de esmeralda da Itabira, Minas Gerais. In: CONGRESSO BRASILEIRO DE GEOLOGIA, 36. Natal, 1990. Resumos. Natal, SBG. p. 126-127.

SCHRANK, A.; PADILHA, A.V.; SICHEL, S.; SZABÓ, G.J.A. (1984) Komatiitos de Minas Gerais. In: CONGRESSO BRASILEIRO DE GEOLOGIA, 33., Rio de Janeiro, 1984. Anais. Rio de Janeiro, SBG. v.12, p.5335-5378.

SCHRANK, A. ; SILVA, M.G. (1993) Greenstone Belts do Cráton do São Francisco, Brasil. In: DOMINGUEZ, J.M.L.; MISI, A(eds.). O Cráton do São Francisco. Salvador, SBG-Núcleo Bahia-Sergipe. p.85-118.

SCHWARZ, D. (1988) As propriedades químicas das esmeraldas brasileiras. In: CONGRESSO BRASILEIRO DE GEOLOGIA, 35. Belém, 1988. Anais. Belém, SBG. v.1, p.348-362.

SCHWARZ, D. (1990) Die chemischen Eigenschaften der Smaragde. I. Brasilien. Zeitschrift der Deutschen Gemmologischen Gesselschaft, v.38, n.4, p. 233-272.

SCHWARZ, D. (1992) The chemical properties of Colombian emeralds. Journal of Gemmology, v.23 n.4, p. 225-233.

SCHWARZ, D.; EIDT, T. (1989) The brazilian emeralds and their occurrences: Carnaiba, Bahia. Journal of Gemmology, v.21, n.8, p. 474-486.

SCHWARZ, D.; EIDT, T.; COUTO, P.A. (1990) The brazilian emeralds and their occurrences: Socotó, Bahia. Journal of Gemmolgy, v.22, n.3, p. 147-163.

SCHWARZ, D.; HÄNNI, H.A.; MARTINS Jr., F.L. ; FISCHER, M. (1988) The emeralds of Fazenda Boa Esperança, Tauá, Ceará, Brazil: occurrence and properties. Journal of Gemmolog, v.21, n.3, p. 168-178.

SCHWARZ, D.; HENN, U. (1992) Emeralds from Madagascar. Journal of Gemmology, v.23, n.3, p. 140-149.

SCHWARZ, D.; KANIS, J.; KINNAIRD, J. (1996) Emeralds and green beryl from Central Nigeria. Journal of Gemmology, v.25, n.2, p. 117-141.

SCHWARZ, D. ; MENDES, J.C. (1985a) Estudo comparativo das inclusões nas esmeraldas de Itabira/Minas Gerais e Santa Terezinha/Goiás. In: SIMPOSIO DE GEOLOGIA DE MINAS GERAIS, 3., Belo Horizonte, 1985. Anais. Belo Horizonte, SBG. v. 5, p. 154-164.

SCHWARZ, D. ; MENDES, J.C. (1985b). Classificação das inclusões nas esmeraldas brasileiras de Socotó/Bahia e Itabira/Minas Gerais. In: CONGRESO LATINOAMERICANO DE GEOLOGIA, 6., BOGOTÁ, 1985. Memorias. Bogotá, Consejo Consultivo de Directores de Serviços Geologicos de Latino America y el Caribe. v.1, p.477-491.

SHEPPARD, S.M.F. (1977) The Cornubian batholith, SW England: $\mathrm{D} / \mathrm{H} \mathrm{e}{ }^{18} \mathrm{O} /{ }^{16} \mathrm{O}$ studies of kolinite and other alteration minerals. Journal of Geological Society. London, v.133, p. 573-591. 
SHEPPARD, S.M.F. (1986) Characterisation and isotopic variations in natural waters. Reviews in Mineralogy, v.16, p. 165-183.

SHEPPARD, S.M.F. ; EPSTEIN, S. (1970) D/H and ${ }^{18} \mathrm{O} /{ }^{16} \mathrm{O}$ ratios of minerals of possible mantle or lower crustal origin. Earth Planetary Science Letters, v.9, p. 232-239.

SILVA, J.M.R.; LIMA, M.I.C.; VERONESE, V.F.; RIBEIRO Jr., R.N. ; ROCHA, R.M.; SIGA JR., O. (1987). Projeto RADAMBRASIL. Folhas SE.24 Rio Doce. Rio de Janeiro, IBGE. 547p. (Levantamentos de Recursos Naturais, v.34).

SMIRNOV, V.I. (1976). Geology of mineral deposits. Moskow, Mir. 520p.

SOUZA, J.L. (1988) Mineralogia e geologia da esmeralda da jazida de Itabira - Minas Gerais. São Paulo, 198p. (Dissertação de Mestrado) - Instituto de Geociências, Universidade de São Paulo.

SOUZA, J.L. (1990): A jazida de esmeralda de Itabira, Minas Gerais. In: SCHOBBENHAUS, C.; QUEIROZ, E.T. de ; COELHO, C.E. (coords.). Principais depositos minerais do Brasil. Brasilia, DNPM/ CPRM. v. 4-A, p. 223-243

SOUZA, J.L.; MENDES, J.C.; GARIBALDI, E.; SVISERO, D.P. (1989): Aspectos geológicos da área do garimpo de Capoeirana, Nova Era: uma nova ocorrência de esmeralda em Minas Gerais. In: SIMPOSIO DE GEOLOGIA NÚCLEO MINAS GERAIS, 5./ SIMPOSIO DE GEOLOGIA NUCLEO BRASILIA, 1., Belo Horizonte, 1989. Anais. Belo Horizonte, SBG-Núcleo Minas Gerais. Boletim n. 10, p. 94-98.

SOUZA, J.L.; MENDES, J.C.; BELLO, R.M.S.; SVISERO, D.P.; VALARELLI, J.V. (1990) Estudos petrográficos, mineralógicos e microtermométrico da esmeralda do Garimpo de Capoeirana, Nova Era, Minas Gerais. In: CONGRESSO BRASILEIRO DE GEOLOGIA, 36., Natal, 1990. Anais. Natal, SBG. v. 3, p.1389-1402.

SOUZA, J.L. ; SVISERO, D.P. (1987): Estudo óptico e roentgenográfico de inclusões de esmeraldas da jazida de Itabira, Minas Gerais. In: SIMPOSIO DE GEOLOGIA DE MINAS GERAIS, 4., Belo Horizonte, 1987. Anais. Belo Horizonte, SBG-Núcleo Minas Gerais. Boletim, n. 7, p. 329-342.

SPEAR, F.S. (1993) Metamorphic phase equilibria and pressure-temperature-time paths. Washington, Mineralogical Society of America. 799p. (Monograph Mineralogical Society of America).

SULLIVAN, G.B.; FALLICK, A.E.; SCHORSCHER, H.D. (1993) A stable isotopic study of emeralds and their host minerals from the Belmont Mine, Itabira, Brazil. Abstracts with Programs. Geological Society of America, v. 25, n.6, p. A-80.

SUN, S. S.; MCDONOUGH, W.F. (1989). Chemical and isotopic systematics of oceanic basalts: implications for mantle composition and processes. In: SAUNDERS, A. D. ; NORRY, M. J. (eds.). Magmatism in the ocean basins. Oxford, Blackwell. p.313-345. (Geological Society Special Publication, n. 42).

SVERJENSKY, D.A. (1984) Europium redox equilibria in aqueous solution. Earth Planetary Science Letters, v.67, p. 70-78.

SZABÓ, G.A.J. (1996) Petrologia da suite metaultramáfica da sequência vulcano-sedimentar Morro do Ferro na região de sul a oeste de Alpinópolis, MG: domínio norte do Complexo Campos Gerais. São Paulo, 354 p. (Tese de Doutorado) - Instituto de Geociências, Universidade de São Paulo.

TAYLOR, H.P. ; EPSTEIN, S. (1962): Relationship between $\mathrm{O}^{18} / \mathrm{O}^{16}$ ratios in coexisting minerals of igneous and metamorphic rocks. Part 1: principles and experimental results. Geological Society of America Bulletin, v.73, p.461-480. 
TAYLOR, H.P. ; EPSTEIN, S. (1963): $\mathrm{O}^{18} / \mathrm{O}^{16}$ ratios in rocks and coexisting minerals of the Skaergaard intrusion. Journal of Petrology, v.4, p.51-74.

TAYLOR, R.P.; FALLICK, A.E.; BREAKS, F.W. (1992) Volatile evolution in Archean rare-element granitic pegmatites: evidence from the hydrogen-isotopic composition of channel $\mathrm{H}_{2} \mathrm{O}$ in beryl. Canadian Mineralogist, v.30, p. 877-893.

TAYLOR, S.R. ; MCLENNAN, S.M. (1985) The continental crust: its composition and evolution. Oxford, Blackwell. 312 p.

TEIXEIRA, N.A. (1978) Geologia, petrologia e prospecção geoquímica da sequência vulcanosedimentar Morro do Ferro, Fortaleza de Minas (MG). Brasília, 202p. (Dissertação de Mestrado) - Instituto de Geociências, Universidade de Brasilia.

TEIXEIRA, W. (1982) Geochronology of the southern part of the São Francisco Craton. Revista Braileira de Geociências, v.12, n.1-3, p. 268-277.

TEIXEIRA, W.; EVANGELISTA, H.J.; KAWASHITA, K. ; TAYLOR, P.N. (1987) Complexo granulítico de Acaiaca, MG: idade, petrogênese e implicações tectônicas. In: SIMPOSIO DE GEOLOGIA DE MNAS Gerais, 4., Belo Horizonte, 1987. Anais. Belo Horizonte, SBG-Núcleo Minas Gerais. Boletim n.7, p. 58-71.

TEIXEIRA, W.; DOSSIN, I.A.; DOSSIN, T.M.; SALVADOR, E.D.; SIGA Jr., O. ; SATO, K. (1990) Interpretação do contexto geotectônico do embasamento na borda leste do sistema Espinhaço, região de Guanhães e Gouveia - MG, com base numa integração do seu conjunto geocronológico $\mathrm{U} / \mathrm{Pb}, \mathrm{Rb} / \mathrm{Sr}$ e K/Ar. In: CONGRESSO BRASILEIRO DE GEOLOGIA, 36., Natal. Anais. Natal, SBG. v. 6, p. 2711-2722.

THOMPSON, A.B. (1976) Mineral reactions in pelitic rocks: II. Calculation of some P-T-X (Fe-Mg) phase relations. American Journal of Science, v.276, n.4, p. 425-454.

TROMPETTE, R.; UHLEIN, A.; da SILVA, M.E.; KARMANN, I. (1992) The Brasiliano São Francisco craton revisited (central Brazil). Journal of South American Earth Science, v.6, p. 4957.

TRZCIENSKI JR, W.E. (1977) Garnet zoning - product of a continuous reaction. Canadian Mineralogist, v.15, Part II, p. 250-256.

TURNER, F.J. (1981) Metamorphic petrology. 2.ed. New York, MacGraw-Hill. 524p.

UHLEIN, A.; ASSIS, L.C.; DARDENNE, M.A. (1983) As mineralizações de ouro e cromita da sequência vulcano-sedimentar do Serro, MG. In: SIMPOSIO DE GEOOGIA DE MINAS GERAIS, 2., Belo Horizonte, 1983. Anais.Belo Horizonte, SBG/NMG. p.306-320.

UHLEIN, A.; TROMPETTE, R.; EGYDIO-SILVA, M. (1995) Rifteamentos superpostos e tectônica de inversão na borda sudeste do Cráton do Sao Francisco. Geonomos, v.3, p. 99-107.

VENEZIANI, P.(1987) Análise dos movimentos da tectônica rúptil e rúptil-dúctil através da interpretação de produtos de sensores remotos na região do Espinhaço Meridional (MG): uma correlação com processos evolutivos. São Paulo, 186p. (Tese de Doutorado) - Instituto de Geociências, Universidade de São Paulo.

VIDAL, Ph.; LASNIER, B.; POIROT, J-P. (1992) Determination of the age and origin of emeralds using rubidium-strontium analysis. Journal of Gemmology, v.23, n.4, p. 198-200.

VRY, J.K.; BROWN, P.E.; VALLEY, J.W. (1990) Cordierite volatile content and the role of $\mathrm{CO}_{2}$ in high-grade metamorphism. American Mineralogist, v.75, p. 71-88. 
WAKITA, H.; REY, P.; SCHMITT, R.A. (1971) Abundances of the 14 rare-earth elements and 12 other trace elements in Appolo 12 samples: five igneous and one breccia rocks and four soils. In: PROCEEDINGS LUNAR SCIENCE CONFERENCE, 2., Houston, 1971. Cambridge, Lunar Science Institute. p.1319-1329.

WALDRON, S.; FALLICK, A.; SCHORSCHER, H. (1990) A stable isotope investigation of emeralds from the Itabira Belmont Deposit, State of Minas Gerais, Brazil. In: MINERAL DEPOSITS STUDIES GROUP, Dublin, 1990. Programme \& Abstracts. Dublin, p.29.

WHALEN, J.B.; CURRIE, K.L.; CHAPPELL, B.W. (1987) A-type granites: geochemical characteristics, discrimination and petrogenesis. Contributions to Mineralogy and Petrology, v.95, p. 407-419.

WEDEPOHL, K.H. (1969) Handbook of geochemistry. Berlin, Springer. v. II/1.

WEN, S. ; NEKVASIL, H. (1994) SOLVCALC 2.0: an interactive graphics program package for calculating the ternary feldspar solvus and for two-feldspar geothermometry. Computers \& Geosciences, v.20, n.6, p. 1025-1040.

WHINCHELL, A. N. (1933) Elements of optical mineralogy: an introduction to microscopic petrography. 3. ed. New York, John Wiley. Part II, p.174-183.

WHITNEY, J.A. ; STORMER, J.C. (1977) The distribution of $\mathrm{NaAlSi}_{3} \mathrm{O}_{8}$ between coexisting microcline and plagioclase and its effect on geothermometric calculations. American Mineralogist, v. 62 , p. $687-691$.

WILLIAMS, M.L. ; GRAMBLING, J.A. (1990) Manganese, ferric iron and the equilibrium between garnet and biotite. American Mineralogist, v.75, n.7/8, p. 886-908.

WINKLER, H.G.F. (1976) Petrogenesis of metamorphic rocks. 4.ed. New York, Springer. 334p.

WOOD, D.L.; NASSAU, K. (1968) The characterization of beryl and emerald by visible and infrared absorption spectroscopy. American Mineralogist, v.53, n.5-6, p. 777-800.

WOOD, S.A. ; WILLIANS-JONES, A. E. (1994) The agneous geochemistry of the elements and yttrium, 4. Monazite solubility and REE mobility in exalative massive sulphide-depositing enviroments. Chemical Geology, v.115, p. 47-60.

WOODSWORTH, G.J. (1977) Homogenization of zoned garnets from pelitic schists. Canadian Mineralogist, v.15, Part 2, p. 230-242.

YARDLEY, B.W.D. (1989) Introdução à petrologia metamórfica. Brasilia, EDUNB. 340p.

ZIMMERMANN, J.L.; GIULIANI, G.; CHEILLETZ, A. (1997) Mineralogical significance of fluids in channels of Colombian emeralds: a mass-spectrometric study. International Geology Review, v.39, p. 425-437. 
Anexo 1: Mapa e Descrição de Pontos/Amostras. 


\section{Legenda}

\section{DESCRIÇÃO DOS AFLORAMENTOS}

$\mathrm{S}=$ Plano de foliação

$\mathrm{S}_{\mathrm{cr}}=$ Plano de crenulação

$\mathbf{P A}_{\mathrm{cr}}=$ Plano Axial das crenulaçðes

$\mathrm{L}_{\mathrm{er}}=$ Lineaça de crenulação

$\mathrm{Lm}=$ Lineação mineral

$\mathrm{F}=$ Plano de Falha

$\mathrm{Fr}=$ Fratura

$\mathrm{C} \approx$ Atitude do contato litológico

Dn $=$ Eixo de dobra

$\mathrm{Fl}=$ Flanco de dobra

\section{Abreviaçes}

Litotipos: MGF - Metagranitóide Foliado com Fluorita; GB - Metagranitóide Borrachudos; TTG - Rochas sensu lato (s...l.) graníticas, gnaisses e migmatitos polimetamórficas, da associação tonalito-trondhjemito-granodiorítica regional arqueana; SVS - Sequência metavulcano-sedimentar arqueana;

Minerais: anf - anfibólio; ap - apatita; bt - biotita; clo - clorita; cord - cordierita; cum - cummingtonita; ep - epidoto; felds feldspato; fluo - fluorita; gr - granada; kf - feldspato potássico; mag - magnetita; mu - muscovita; op - opaco; qzo - quartzo; ru - rutilo; sil -sillimanita; spha - esfalerita; stau - estaurolita; tit - titanita; zi - zircão;

\section{Afloramentos Regionais (de superficie)}

\begin{tabular}{|c|c|c|c|}
\hline $\begin{array}{l}\text { Aflora- } \\
\text { mento (A) }\end{array}$ & $\begin{array}{l}\text { Amostra } \\
(\mathrm{Am})\end{array}$ & $\begin{array}{l}\text { Dados estru- } \\
\text { turais }\end{array}$ & Descrição sumária dos afloramentos e da amostragem \\
\hline 1 & - & - & Gnaisse félsico, fino, homogêneo, intemperizado, com bolsð̃es pegmatóides. \\
\hline \multirow[t]{2}{*}{2} & G-2a & - & MGF, com veios de quartzo discordantes. \\
\hline & $\mathrm{G}-2 \mathrm{~b}$ & - & MGF. \\
\hline \multirow[t]{2}{*}{3} & G-3a & - & MGF, com veios pegmatóides. \\
\hline & $\mathrm{G}-3 \mathrm{~b}$ & 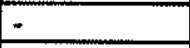 & MGF. \\
\hline 4 & - & - & GB de granulometria média típico (com nódulos de biotita). \\
\hline 5 & $=$ & - & Gnaisse bandado, com níveis quartzo-feldspáticos e biotíticos. \\
\hline 6 & - & - & $\begin{array}{l}\text { Gnaisse bandado (cf. A-5), com mobilizados pegmatóides e veios de quartzo } \\
\text { deformados. }\end{array}$ \\
\hline 7 & - & - & $\begin{array}{l}\text { Gnaisse granítico semi-alterado a alterado, granulometria fina-média, finamente } \\
\text { foliado, com veios de quartzo (discordantes) deformados. }\end{array}$ \\
\hline 8 & - & - & Gnaisse granitico de granulometria fina-média. \\
\hline 9 & G-9 & $\mathrm{S}=250 / 28$ & $\begin{array}{l}\text { Gnaisse-granítico pouco alterado, com veios de quartzo (pseudoconcordantes) } \\
\text { deformados. }\end{array}$ \\
\hline 10 & - & $\mathrm{S}=222 / 30$ & $\begin{array}{l}\text { MGF com níveis félsicos e máficos (biotita) e pegmatóides pseudoconcordantes } \\
\text { deformados. }\end{array}$ \\
\hline \multirow[t]{4}{*}{11} & G-11a & - & MGF, com veio pegmatóide. \\
\hline & $\mathrm{G}-11 \mathrm{~b}$ & - & Pegmatóide com cristais grandes de feldspato róseo (até $\sim 5 \mathrm{~cm}$ ) e biotita (até $\sim 2 \mathrm{~cm}$ ). \\
\hline & G-11c & - & Biotitas separadas do veio pegmatóide. \\
\hline & G-11d & - & MGF. \\
\hline 12 & - & $\mathrm{S}=292 / 25$ & Gnaisse-granítico semi-homogêneo, com biotita de granulometria fina e orientada. \\
\hline 13 & G-13 & $\begin{array}{l}S=325 / 25 \\
S=98 / 20\end{array}$ & $\begin{array}{l}\text { Transiçăo MGF (com granulometria fina, félsico, homogêneo)/GB; ocorrem veios } \\
\text { pegmatóides discordantes. }\end{array}$ \\
\hline 14 & G-14a & $\begin{array}{l}S=310 / 20 \\
S_{\mathrm{cr}}=148 / 75\end{array}$ & Gnaisse da SVS, bandado, leucocrático, rico em granada e com veios pegmatóides. \\
\hline 15 & - & $\begin{array}{l}S=290 / 18 \\
S_{c r}=170 / 74\end{array}$ & $\begin{array}{l}\text { Gnaisse metapelítico da SVS, intemperizado, de granulometria fina, com } \\
\text { microdobras e veios de quartzo de espessura milimétrica a centimétrica, } \\
\text { pseudoconcordantes. }\end{array}$ \\
\hline 16 & - & $S=290 / 15$ & $\begin{array}{l}\text { Gnaisse metapelítico, intemperizado, com estruturas pinch and swell e/ou de boudins } \\
\text { deformados; contém níveis finos anfibolíticos intercalados, intemperizados, de } \\
\text { coloraça ocre. }\end{array}$ \\
\hline 17 & - & $\mathrm{S}=310 / 15$ & Gnaisse félsico, de granulometria fina, homogêneo. \\
\hline 18 & G-18 & - & Gnaisse félsico, de granulometria fina, homogêneo, com gzo + felds + bt (tipo TTG). \\
\hline 19 & - & - & $\begin{array}{l}\text { Rocha muito intemperizada, argilosa, de coloração amarelada, provável anfibolito da } \\
\text { alterado da SVS. }\end{array}$ \\
\hline 20 & G-20 & $\begin{array}{l}\mathrm{S}=300 / 40 \\
\mathrm{~F}=78 / 50\end{array}$ & $\begin{array}{l}\text { Gnaisse metapelítico com intercalaçðes de xisto metapelítico (de coloração } \\
\text { arroxeada, com } \mathrm{mu}+\mathrm{gr}+\mathrm{sil} \text { ) e de anfibolitos; verificam-se falhas e fraturas nos } \\
\text { níveis anfibolíticos. }\end{array}$ \\
\hline
\end{tabular}




\begin{tabular}{|c|c|c|c|}
\hline 21 & - & - & Gnaisse metapelítico, bandado. \\
\hline 22 & - & $\begin{array}{l}\mathrm{C}=260 / 30 \\
\mathrm{~S}=288 / 10\end{array}$ & $\begin{array}{l}\text { Contato de dique de basalto (intemperizado e com esfoliação esferoidal) com } \\
\text { gnaisse-granítico (granulometria fina, homogêneo, leucocrático, com mu }+\mathrm{kf}+ \\
\text { mag). }\end{array}$ \\
\hline 23 & $\mathrm{G}=23$ & $\mathrm{~S}=300 / 25$ & $\begin{array}{l}\text { Gnaisse metapelítico, de granulometria fina, coloraçấo cinza, bastante foliado, com } \\
\text { veios pegmatóides pseudoconcordantes. }\end{array}$ \\
\hline $\begin{array}{l}24(\mathrm{cf} . \\
\mathrm{A}-152)\end{array}$ & G-24 & $\mathrm{S}=320 / 25$ & $\begin{array}{l}\text { Gnaisse metapelítico com granada, com intercalações de anfibolitos metabásicos } \\
\text { com granada (amostra G-24). }\end{array}$ \\
\hline 25 & - & - & $\begin{array}{l}\text { Gnaisse-granítico (félsico), fino, homogêneo, intemperizado, com muscovita e pouca } \\
\text { biotita. }\end{array}$ \\
\hline 26 & G-26 & - & GB típico. \\
\hline 27 & - & - & $\begin{array}{l}\text { Gnaisse bandabo de cor clara, intemperizado, contendo cristais alongados de quartzo } \\
\text { e intercalacões de xistos metapelíticos de coloraçao arroxeada. }\end{array}$ \\
\hline 28 & - & - & Solo de coloração ocre com granada limonitizada. \\
\hline \multirow[t]{5}{*}{29} & G-29a & - & GB típico. \\
\hline & G-29b & - & GB típico. \\
\hline & G-29c & - & GB típico. \\
\hline & G-29d & - & GB típico. \\
\hline & $\mathrm{G}-29 \mathrm{e}$ & - & GB típico. \\
\hline 30 & - & $S=222 / 10$ & Gnaisse metapelítico (foliado), intemperizado, de coloração arroxeada. \\
\hline 31 & G-31 & $\begin{array}{l}\mathrm{S}=262 / 30 \\
\mathrm{~L}_{\mathrm{m}}=248 / 15\end{array}$ & GB - fácies mais rica em máficos e mais foliada. \\
\hline 32 & - & $\mathrm{S}_{\mathrm{ct}}=160 / 87$ & $\begin{array}{l}\text { Gnaisse félsico intemperizado de cor branca, com muscovita e intercalações de } \\
\text { níveis milimétricos de biotitito/flogopitito crenulado. }\end{array}$ \\
\hline 33 & G-33 & $S=262 / 20$ & $\begin{array}{l}\text { Gnaisse com muscovita milonítico (amostra), intercalado em gnaisse bandado da } \\
\text { SVS mais máfico, de coloração avermelhada (por intemperismo). Este está em } \\
\text { contato com gnaisse félsico, homogêneo, fino, com biotita disseminada, fortemente } \\
\text { foliado, intemperizado (rico em caolim) e que transiciona para um fácies de } \\
\text { granulação média/grossa. O gnaisse félsico possui composição granitica, é rico em } \\
\text { feldspato e tem biotita que predomina sobre muscovita mas não perfaz mais de } 10 \% \text { - } \\
\text { vol. da rocha. }\end{array}$ \\
\hline 34 & 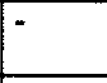 & $\mathrm{S}=260 / 20$ & $\begin{array}{l}\text { Gnaisse bandado fino da SVS, com niveis milimétricos ora mais ricos em biotita, ora } \\
\text { em muscovita, intemperizado, de coloracáa ocre. }\end{array}$ \\
\hline 35 & - & $\mathrm{S}=295 / 20$ & Continuação do gnaisse da SVS do A-34. \\
\hline 36 & G-36 & $\mathrm{S}=310 / 30$ & $\begin{array}{l}\text { Gnaisse hololeucocrático, fino; possui extensão maior (extendendo-se até o ponto } \\
\text { 181). }\end{array}$ \\
\hline \multirow[t]{2}{*}{37} & G-37a & $S=298 / 60$ & Anfibolito metabásico com epidoto. \\
\hline & G-37b & $S=280 / 60$ & Anfibolito metabásico com granada. \\
\hline 38 & 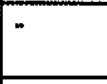 & $S=260 / 35$ & $\begin{array}{l}\text { Xisto de coloração ocre, crenulado, intercalado em gnaisse metapelítico de coloração } \\
\text { arroxeada da SVS, intemperizados. }\end{array}$ \\
\hline \multirow[t]{4}{*}{39} & & & $\begin{array}{l}\text { Pegmatito pouco deformado em MGF, intemperizado; o corpo foi lavrado para } \\
\text { águas-marinhas e feldspato/caolim. }\end{array}$ \\
\hline & G-39a & - & $\begin{array}{l}\text { Cristal prismático de água marinha }(2 \mathrm{~cm}) \text { associado a feldspato alterado }+ \text { qzo } \\
\text { anguloso (amostragem da zona pegmatóide quartzo-feldspática). }\end{array}$ \\
\hline & $\mathrm{G}-39 \mathrm{~b}$ & - & $\begin{array}{l}\text { Fragmentos de cristais de água marinha associados a zona pegmatóide (mesmo corpo } \\
\text { do A-39). }\end{array}$ \\
\hline & G-39c & 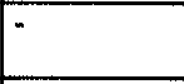 & $\begin{array}{l}\text { Fragmentos de cristais de água marinha associados a mobilizado/veio de quartzo } \\
\text { fraturado (mesmo corpo do A-39). }\end{array}$ \\
\hline 40 & G-40 & - & Pegmatóide com amazonita intrusivo em gnaisse-anfibolítico com granada da SVS; \\
\hline 41 & $\mathrm{G}-41$ & $\begin{array}{l}S=270 / 45 \\
C=270 / 45\end{array}$ & $\begin{array}{l}\text { Gnaisse anfibolítico (mesocrático) de granulação fina, rico em biotita (de granulação } \\
\text { fina) (amostra), em contato com xisto/gnaisse metapelítico com granada da SVS. }\end{array}$ \\
\hline 42 & - & - & $\begin{array}{l}\text { Anfibolito com granada, intemperizado, de coloração ocre, intercalado em xisto } \\
\text { metapelítico, crenulado, com muscovita. }\end{array}$ \\
\hline$\overline{43}$ & G-43 & $\begin{array}{l}S=298 / 35 \\
S=300 / 40\end{array}$ & $\begin{array}{l}\text { Xisto metapelítico com quartzo, muscovita e biotita, com veio de quartzo } \\
\text { pseudoconcordante possante (de espessura métrica). }\end{array}$ \\
\hline 44 & G-44 & $\begin{array}{l}S=340 / 35 \\
S=345 / 55\end{array}$ & $\begin{array}{l}\text { Nível de muscovita-quartzo-xisto (amostra) de aproximadamente } 7 \mathrm{~m} \text { de espessura, } \\
\text { em gnaisse félsico de granulação fina, intemperizado, coloração rósea e com } \\
\text { muscovita. }\end{array}$ \\
\hline 45 & - & $\mathrm{S}=302 / 25$ & $\begin{array}{l}\text { Gnaisse leucocrático de granulaçăo fina, milonítico, com biotitas esparsas e } \\
\text { disseminadas (em grâos individuais). }\end{array}$ \\
\hline 46 & $\mathrm{G}-46$ & $\begin{array}{l}\mathrm{S}=290 / 30 \\
\mathrm{~L}_{\mathrm{cr}}=166 / 65\end{array}$ & $\begin{array}{l}\text { Gnaisse metapelítico da SVS, quartzoso, de coloração arroxeada (amostra) em } \\
\text { contato com gnaisse félsico, de granulaçđo fina, mais feldspático; próximo ao } \\
\text { contato, ocorrem xistos metapelíticos de coloraçâo ocre. }\end{array}$ \\
\hline
\end{tabular}




\begin{tabular}{|c|c|c|c|}
\hline $\begin{array}{l}47 \text { (cf. A- } \\
195)\end{array}$ & - & $\begin{array}{l}\mathrm{S}=282 / 30^{\mathrm{K}} \\
\mathrm{Fl}_{1}=140 / 60 \\
\mathrm{Fl}_{2}=270 / 35\end{array}$ & $\begin{array}{l}\text { Xistos/gnaisses metapelíticos* de coloração arroxeada (intemperizados) com } \\
\text { intercalaç̃es de anfibolitos metaultramáficos dobrados; (ver tb. A-195/Am G-195). }\end{array}$ \\
\hline 48 & - & - & $\begin{array}{l}\text { Gnaisse metapelítico intemperizado, de coloração arroxeada, com intercalaçőes de } \\
\text { anfibolitos decimétricas. }\end{array}$ \\
\hline$\overline{49}$ & - & $\begin{array}{l}S=300 / 30^{*} \\
S=294 / 55^{* 2} \\
S_{n+1}=300 / 28\end{array}$ & $\begin{array}{l}\text { Quartzo-muscovita-xisto }{ }^{* 1} \text { e anfibolitos }{ }^{* 2} \text { metabásico com granada intercalados em } \\
\text { gnaisses metapelíticos de coloração arroxeada; ocorrem indicadores cinemáticos de } \\
\text { movimento dextral no anfibolito e dobras suaves, abertas, nos gnaisses. }\end{array}$ \\
\hline 50 & $\begin{array}{l}\text { G-50a } \\
\text { G-50b }\end{array}$ & $\mathrm{S}=298 / 50$ & $\begin{array}{l}\text { Quartzo-muscovita-xistos e anfibolitos metabásicos (com alofana) (Am G-50a) em } \\
\text { xistos/gnaisses metapelíticos de coloração arroxeada, intemperizados, com granada } \\
\text { limonitizada e opacos (Am G-50b), da SVS. }\end{array}$ \\
\hline $\begin{array}{l}51 \text { (cf. A- } \\
124)\end{array}$ & G-51 & $\bar{*}$ & $\begin{array}{l}\text { Anfibólio-flogopita-xisto com cristais aciculares de anfibólio (metaultramáfica } \\
\text { flogopitizada da SVS da jazida Belmont). }\end{array}$ \\
\hline \multirow[t]{14}{*}{52} & várias & - & Jazida de esmeralda de Capoeirana: amostragem de diversos garimpos subterrâneos \\
\hline & G-52a & $\div$ & Anfibolito metabásico com veios de quartzo discordantes. \\
\hline & G-52b & - & Biotita-anfibólio-gnaisse bandado. \\
\hline & G-52c & - & Gnaisse metapelítico com gr + stau $+\mathrm{sil}+\mathrm{bt}+\mathrm{clo}+\mathrm{mu}+\mathrm{qzo}+/-\mathrm{Kf}$. \\
\hline & G-52d & - & Flogopita-anfibolito metaultramáfico; \\
\hline & G-52e & $\mathrm{S}=318 / 458$ & Flogopitito com esmeralda; \\
\hline & G-52f & - & $\begin{array}{l}\text { Anfibolito metaultramáfico dobrado e com fraturas muito finas, preenchidas por } \\
\text { material argiloso. }\end{array}$ \\
\hline & G-52g & - & $\begin{array}{l}\text { Anfibolito de metaultramáfica dobrado (amplitude da dobra } \sim 6 \mathrm{~cm} \text { ) envolvido por } \\
\text { flogopitito. }\end{array}$ \\
\hline & G-52h & - & Veio pegmatóide não mineralizado, intrusivo na SVS. \\
\hline & G-52i & 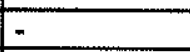 & Anfibolito metabásico. \\
\hline & $G-52 j$ & - & Granada-gnaisse metapelítico. \\
\hline & G-521 & - & Gnaisse bandado da SVS, com dobras assimétricas. \\
\hline & G-52m & & Flogopitito com um cristal de apatita de $2 \mathrm{~cm}$ de diâmetro. \\
\hline & G-52n & & Fragmentos de cristais de esmeralda sem identificacão precisa de sua paragênese. \\
\hline 53 & - & $\because$ & $\begin{array}{l}\text { Xistos/gnaisses metapelíticos de coloração arroxeada, com pegmatóides intrusivos } \\
\text { intemperizados; cava para garimpo. }\end{array}$ \\
\hline \multirow[t]{2}{*}{54} & G-54a & - & Pegmatóide com mica verde. \\
\hline & G-54b & - & Anfibolito metabásico com granada. \\
\hline 55 & $\mathrm{G}-55$ & - & Gnaisse metapelítico com muscovita de coloração arroxeada, intemperizado. \\
\hline 56 & G-56 & - & $\begin{array}{l}\text { Anfibolito metabásico com epidoto e titanita; ocorrem lentes pegmatóides } \\
\text { centimétricas, deformadas em dobras intrafoliais. }\end{array}$ \\
\hline 57 & - & - & $\begin{array}{l}\text { Gnaisse da SVS de granulação fina, coloração cinza, intemperizado, com dobras } \\
\text { intrafoliais e mobilizados pegmatóides; cava para garimpo. }\end{array}$ \\
\hline 58 & 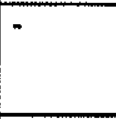 & - & $\begin{array}{l}\text { Gnaisse da SVS de granulação fina, coloração cinza, com biotita disseminada, semi- } \\
\text { alterado em contato com gnaisse félsico feldspático com pouca biotita, de granulação } \\
\text { média, coloração branca. }\end{array}$ \\
\hline 59 & $\overline{-}$ & - & $\begin{array}{l}\text { Gnaisse metapelítico com baixo teor de muscovita intemperizado de coloração } \\
\text { arroxeada, intrudido por pegmatóides de dimensóes métricas, intemperizados com } \\
\text { caolim }+ \text { mu }+ \text { qzo e veios de quartzo pseudo-concordantes. }\end{array}$ \\
\hline 60 & $\mathrm{G}-60$ & - & $\begin{array}{l}\text { Blastomilonito-gnaisse granítico de granulação média/grossa transicional para GB, } \\
\text { às vezes com concentrações de biotita em agregados, mas sem formar nódulos } \\
\text { típicos. }\end{array}$ \\
\hline 61 & - & - & Xistos/gnaisses metapelíticos, foliados, intemperizados. \\
\hline 62 & G-62 & - & $\begin{array}{l}\text { Gnaisse/migmatito TTG de granulaçăo fina/média, com bandamento composicional } \\
\text { fraco e veio pegmatóide pseudoconcordante. }\end{array}$ \\
\hline 63 & - & $S=258 / 40$ & $\begin{array}{l}\text { Gnaisse félsico, homogêneo, de granulação fina, coloração cinza com biotita (de } \\
\text { granulação fina) disseminada, pouco alterado. }\end{array}$ \\
\hline \multirow[t]{2}{*}{64} & G-64a & - & Quartzo-clorita-xisto crenulado. \\
\hline & $\mathrm{G}-64 \mathrm{~b}$ & - & Anfibolito metabásico. \\
\hline 65 & G-65 & - & Gnaisse TTG com muscovita notável, de granulação fina. \\
\hline 66 & $=$ & $\mathrm{S}=276 / 30$ & Gnaisse félsico, de granulação fina com biotita (de granulação fina) disseminada. \\
\hline 67 & - & - & Gnaisse da SVS alterado, arroxeada com níveis ocres, rico em biotita. \\
\hline 68 & $\mathrm{G}-68$ & - & MGF. \\
\hline 69 & - & - & Gnaisse com níveis muscoviticos, intemperizado. \\
\hline 70 & - & - & $\begin{array}{l}\text { Xistos/gnaisses metapelíticos de coloração arroxeada, com lentes milimétricas de } \\
\text { quartzo de veio. }\end{array}$ \\
\hline 71 & - & $S=260 / 20$ & $\begin{array}{l}\text { Gnaisse félsico, semi-alterado, com qzo }+ \text { felds }+ \text { mu }+/- \text { biotita; muscovita } \\
\text { concentra-se nos planos da foliaçăo. }\end{array}$ \\
\hline
\end{tabular}




\begin{tabular}{|c|c|c|c|}
\hline 72 & G-72 & $\mathrm{S}=260 / 40$ & $\begin{array}{l}\text { Quartzito quase puro, fortemente foliado (ou veio de quartzo impuro muito } \\
\text { cizalhado). }\end{array}$ \\
\hline 73 & - & $\mathrm{C}=200 / 40$ & $\begin{array}{l}\text { Contato por falha inversa entre rochas da SVS (anfibolitos ocres e xistos } \\
\text { metapeliticos) e GB (de coloração rósea), intemperizados. }\end{array}$ \\
\hline 74 & G-74 & $\cdot$ & $\begin{array}{l}\text { Gnaisse milonitico, leucocrático, granulação fina/média, coloração cinza, fracamente } \\
\text { bandado, pouco alterado. }\end{array}$ \\
\hline 75 & 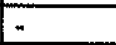 & - & Xistos/gnaisses metapelíticos. \\
\hline 76 & G-76 & $\mathrm{S}=342 / 37$ & Quartzo-cianita-muscovita-xisto com estaurolita. \\
\hline 77 & G-77 & - & $\begin{array}{l}\text { Xisto metapelítico crenulado, de coloração arroxeada, com muscovita e } \\
\text { lentes/mobilizados de quartzo. }\end{array}$ \\
\hline 78 & G-78 & - & $\begin{array}{l}\text { Gnaisse milonítico, feldspático, leucocrático, de granulação fina intemperizado, com } \\
\text { feldspato fortemente alterado, quartzo e muscovita (ca. de 5\%-vol.). }\end{array}$ \\
\hline 79 & G-79 & - & $\begin{array}{l}\text { Gnaisse milonítico, leucocrático, de granulaçào média, pouco alterado, com } \\
\text { feldspato }(\sim 50) \text {, quartzo }(\sim 30) \text { e biotita orientada }(\sim 15 \% \text {-modais }) \text {. }\end{array}$ \\
\hline 80 & & - & Solo de coloração arroxeada contendo fragmentos de veio de quartzo. \\
\hline 81 & G-81 & 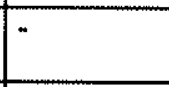 & $\begin{array}{l}\text { Gnaisse homogêneo, granulação fina/média, coloração cinza com biotita disseminada } \\
\text { (fina, orientada na foliação) pouco alterado. }\end{array}$ \\
\hline 82 & G-82a & - & $\begin{array}{l}\text { Gnaisse milonítico, félsico, de granulaçáo fina, alterado, com feldspato caolinizado } \\
(\sim 50) \text {, quartzo }(\sim 20) \text {, biotita }(\sim 20) \text { e muscovita }(\sim 10 \% \text {-modais }) \text {. }\end{array}$ \\
\hline & G-82b & - & Gnaisse cf. anterior, porém de granulacão média. \\
\hline & G-82c & - & Gnaisse cf. anterior, porém de granulação grossa e com muscovita $>$ biotita. \\
\hline 83 & 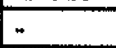 & - & Solo arroxeado, localmente com resquícios saprolíticos de uma rocha xistosa/foliada. \\
\hline 84 & 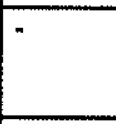 & $\begin{array}{l}\mathrm{S}=350 / 20 \\
\mathrm{~S}=320 / 25 \\
\mathrm{~S}=318 / 30\end{array}$ & $\begin{array}{l}\text { Contato entre gnaisse fino da SVS com biotita (fina) disseminada e porç̃̃es com } \\
\text { cores de intemperismo lilás e gnaisse félsico muscovítico, homogêneo, de granulação } \\
\text { fina. }\end{array}$ \\
\hline 85 & G.85a & - & Granada-estaurolita-anfibólio-quartzo-cordierita-biotita-xisto. \\
\hline & G-85b & - & $\begin{array}{l}\text { Anfibolio-gnaisse com stau }+ \text { cord }+a n f+g x+b t+q z o+/- \text { ap; anfibólios são radiais } \\
\text { e centimétricos. }\end{array}$ \\
\hline & G-85c & - & $\begin{array}{l}\text { Xisto com bt }+ \text { anf }+\mathrm{gr}+\mathrm{ru}+\mathrm{sil}+\text { cord }+/-\mathrm{qzo}+/-\mathrm{Kf} \text {; anfibolios crescem sobre a } \\
\text { foliação. }\end{array}$ \\
\hline 86 & - & - & $\begin{array}{l}\text { Anfibolito metabásico intrudido por veio pegmatóide intemperizado; cava para } \\
\text { garimpo. }\end{array}$ \\
\hline 87 & - & - & $\begin{array}{l}\text { Gnaisse metapelítico semi-alterado, de coloração acastanhada com "pintas" de } \\
\text { caolim; presença de veios de quartzo centimétricos. }\end{array}$ \\
\hline 88 & G-88 & - & $\begin{array}{l}\text { Gnaisse TTG félsico de granulaçåo fina, com feldspato }(\sim 50) \text {, quartzo }(\sim 40) \text {, biotita } \\
(\sim 3) \text {, e muscovita }(\sim 1 \% \text {-modais }) \text {, sendo as micas orientadas e dispostas em níveis } \\
\text { descontínuos. }\end{array}$ \\
\hline 89 & G-89 & - & Gnaisse metapelítico com bandamento composicional, rico em granada. \\
\hline 90 & - & - & Gnaisse cf. A-89. \\
\hline 91 & - & $=$ & $\begin{array}{l}\text { Gnaisse cf. A-89 e anterior, porém, mais rico em biotita e com veios de quartzo } \\
\text { deformados. }\end{array}$ \\
\hline 92 & $\mathrm{G}-92$ & - & GB com porfiroblastos de magnetita, de coloração rósea, intemperizado. \\
\hline 93 & - & - & $\begin{array}{l}\text { Gnaisse-granítico esbranquiçado com foliação fraca, lineação de biotita e alteração } \\
\text { incipiente. }\end{array}$ \\
\hline 94 & - & - & $\begin{array}{l}\text { Gnaisse-granítico esbranquiçado com foliação fraca, lineação de biotita e alteração } \\
\text { incipiente. }\end{array}$ \\
\hline 95 & $\overline{-}$ & - & $\begin{array}{l}\text { Gnaisse-granítico fracamente foliado, semi-alterado, com lentes pegmatóides } \\
\text { pseudoconcordantes. }\end{array}$ \\
\hline 96 & $\overline{-}$ & $\begin{array}{l}\text { Direç̃o= } \\
\text { NE }\end{array}$ & Veios de quartzo muito cizalhados com cianita e muscovita. \\
\hline 97 & - & - & $\begin{array}{l}\text { Quartzo-cianita-muscovita-xisto em contato com gnaisse metapelítico intemperizado } \\
\text { de coloração arroxeada; próximo ao contato ocorrem veios de quartzo. }\end{array}$ \\
\hline 98 & G-98 & - & Gnaisse milonitico, félsico, de granulação fina com muscovita. \\
\hline 99 & - & - & Colúvio/talus de gnaisse félsico, de granulação fina com muscovita. \\
\hline 100 & - & - & Solo ocre. \\
\hline 101 & G-101 & - & $\begin{array}{l}\text { SVS com intercalaç̃es de quartzo-muscovita-xistos (amostra), gnaisses } \\
\text { metapelíticos (intemperizados, coloração arroxeada) e anfibolitos (intemperizados, } \\
\text { coloração ocre). }\end{array}$ \\
\hline $\begin{array}{l}102 \text { (cf. } \\
\mathrm{A}-221)\end{array}$ & - & $\mathrm{S}=255 / 30$ & $\begin{array}{l}\text { Gnaisse quartzo-feldspático de granulação média, transicional para gnaisse félsico, } \\
\text { quartzo-feldspático de granulação fina com muscovita contem niveis de quartzo- } \\
\text { muscovita-xisto; na encosta, do outro lado do vale, ocorre solo de coloração } \\
\text { avermelhada da SVS indicando contato por falha no vale. }\end{array}$ \\
\hline 103 & G-103 & $\mathrm{S}=258 / 35$ & Gnaisse-granítico facoidal blastomilonitico, muito foliado, com estrutura de fluxão. \\
\hline 104 & - & - & Gnaisse cf. anterior (A-103), intemperizado de coloração lilás. \\
\hline
\end{tabular}




\begin{tabular}{|c|c|c|c|}
\hline 105 & G-105 & $L_{m}=264 / 15$ & $\begin{array}{l}\text { MGF, às vezes, com nódulos de biotita e com minerais granulares arredondados, } \\
\text { limonitizados (sulfetos e/ou granada). }\end{array}$ \\
\hline 106 & G-106 & - & MGF em bloco rolado cf, anterior (A-105). \\
\hline $\begin{array}{l}107 \text { (cf. } \\
\mathrm{A}-231)\end{array}$ & G-107 & $\cdot$ & $\begin{array}{l}\text { Contato SVS com GB; cava para garimpo na SVS expð̃e anfibolito metaultramáfico } \\
\text { e flogopitito. }\end{array}$ \\
\hline 108 & G-108 & - & $\begin{array}{l}\text { MGF facoidal apresenta dobras locais centimétricas e veios de quartzo deformados } \\
\text { pseudoconcordantes e discordantes. }\end{array}$ \\
\hline 109 & $\cdot$ & - & $\begin{array}{l}\text { Talus com fragmentos de rochas da SVS (anfibolitos e xistos metapelíticos); poucos } \\
\text { metros abaixo aparece um solo argiloso (sem quartzo) de coloração amarelada, } \\
\text { possivelmente, da alteração de anfibolito metaultramáfico. }\end{array}$ \\
\hline 110 & - & - & $\begin{array}{l}\text { Contato entre quartzo-cianita-muscovita-xisto e xisto metapelítico com granada de } \\
\text { até } 3 \mathrm{~cm} \text { de diâmetro de coloração ocre; no contato, presença de veios de quartzo. }\end{array}$ \\
\hline $\begin{array}{l}111 \text { (cf. } \\
\text { A-208) }\end{array}$ & G-111 & - & $\begin{array}{l}\text { Gnaisse-milonítico de granulação fina, homogêneo, com biotita e muscovita de } \\
\text { granulação fina disseminadas. }\end{array}$ \\
\hline 112 & G-112 & - & MGF foliado, facoidal, de granulacão grossa. \\
\hline 113 & G-113 & $\mathrm{S}=328 / 35$ & $\begin{array}{l}\text { GB de granulação média fracamente foliado, com nódulos de biotita e feldspatos } \\
\text { facoidais. }\end{array}$ \\
\hline 114 & G. 114 & - & $\begin{array}{l}\text { GB transicional de milonitico-fina, com foliação bem desenvolvida, lineação de } \\
\text { agregados de anfibólio e biotita e porfiroblastos de feldspatos rotacionados, para } \\
\text { granulação média, com foliação menos evidente e estrutura facoidal. }\end{array}$ \\
\hline 115 & $\mathrm{G}-115$ & - & GB. \\
\hline 116 & G-116 & - & Gnaisse quartzoso com biotita; foliado. \\
\hline 117 & $\mathrm{G}-117$ & - & MGF com alto teor de biotita fina e orientada, em níveis descontínuos. \\
\hline 118 & G-118 & - & Anfibolito metabásico foliado, em bloco rolado. \\
\hline \multirow[t]{3}{*}{119} & várias & - & $\begin{array}{l}\text { Jazida de Capoeirana: amostragem de boca de galeria de garimpo subterrâneo, de } \\
\text { material retirado da galeria (não-in situ). }\end{array}$ \\
\hline & G-119a & - & $\begin{array}{l}\text { Gnaisse metapelítico, bandado/foliado, com } \mathrm{Kf}+\text { spha }+ \text { mica verde }+ \text { mica branca }+ \\
\text { gr verde }+ \text { gr comum, com porçסes mais ricas em granada, biotita e/ou anfibólio; às } \\
\text { vezes, gradando para níveis biotititicos pretos; com pegmatódes intrusivos em veios } \\
\text { e níveis lit par lit, pseudoconcordantes. }\end{array}$ \\
\hline & $\mathrm{G}-119 \mathrm{~b}$ & - & $\begin{array}{l}\text { Anfibolito metabásico, foliado, com anf }+ \text { plag }+ \text { qzo }+ \text { op }+ \text { tit }+ \text { ap; intrudido por } \\
\text { veio pegmatóide pseudoconcordante. }\end{array}$ \\
\hline 120 & - & - & $\begin{array}{l}\text { Bloco rolado (de } \sim 15 \times 15 \mathrm{~m} \text { ) de qzo-bt-mu-xisto com níveis intercalados de quartzo } \\
\text { e mica, e estruturas de foliaçẫo milonítica-sc; lentes de qzo pseudoconcordantes } \\
\text { deformadas. }\end{array}$ \\
\hline 121 & - & - & Quartzo-biotita-xisto intemperizado. \\
\hline 122 & G-122 & - & $\begin{array}{l}\text { MGF de granulação fina/média, com quartzo e feldspato facoidais e biotita, às vezes, } \\
\text { concentrada em nódulos. }\end{array}$ \\
\hline 123 & $\mathrm{G}-123$ & - & Gnaisse granítico foliado, fino, semi-alterado, com plag + micr $+\mathrm{gzo}+\mathrm{mu}+/=$ bt. \\
\hline 124 & G-124 & - & $\begin{array}{l}\text { GB típico com nódulos de biotita e porfiroblastos facoidais de feldspato contornados } \\
\text { pela foliação em estrutura de fluxão. }\end{array}$ \\
\hline 125 & $\mathrm{G}-125$ & - & Basalto com esfoliacão esferoidal; próximo, bloco rolado (de $\sim 2 \times 2 \mathrm{~m}$ ) de GB típico. \\
\hline 126 & - & - & MGF mais feldspático, intemperizado e de coloração cinza. \\
\hline 127 & $\mathrm{G}-127$ & - & Basalto microgábrico. \\
\hline 128 & $\mathrm{G}-128$ & - & MGF com biotita fina - disseminada, orientada na foliacão. \\
\hline 129 & G-129 & - & MGF. \\
\hline 130 & - & $\mathrm{S}=300 / 45$ & GB. \\
\hline 131 & G-131 & & MGF de granulacảo média, foliado, com anfibólio e magnetita milimétricos. \\
\hline 132 & - & $\mathrm{S}=320 / 50$ & GB de fácies de granulacão fina, fortemente foliado. \\
\hline 133 & - & $\mathrm{Lm}=250 / 20$ & GB. \\
\hline 134 & $=$ & - & No ponto mais alto da trilha, solo de intemperismo de GB. \\
\hline 135 & - & - & $\begin{array}{l}\text { GB de granulação fina, intemperizado, de coloração rósea, transicional para MGF; } \\
\text { com bolsðes pegmatóides, de dimensðes centimétricas. }\end{array}$ \\
\hline 136 & - & - & $\begin{array}{l}\text { GB de fácies fina intemperizado, transicional para MGF leucocrático, apresenta } \\
\text { bolsóes pegmatóides. }\end{array}$ \\
\hline \multirow[t]{2}{*}{137} & G-137a & - & Gnaisse metapelítico, intemperizado. \\
\hline & $\mathrm{G}-137 \mathrm{~b}$ & - & Quartzito ferruginoso, intemperizado. \\
\hline 138 & + & - & Contato entre GB intemperizado e rochas da SVS. \\
\hline 139 & + & $\mathrm{S}=315 / 50^{\top}$ & $\begin{array}{l}\text { Contato entre gnaisse metapelítico da SVS de granulação média, equigranular, } \\
\text { coloração cinza, intemperizado e com veios pegmatóides e GB de granulação média, } \\
\text { foliado, intemperizado e com veios pegmatóides* } \\
\text { pseudoconcordantes. }\end{array}$ \\
\hline
\end{tabular}




\begin{tabular}{|c|c|c|c|}
\hline 140 & - & - & 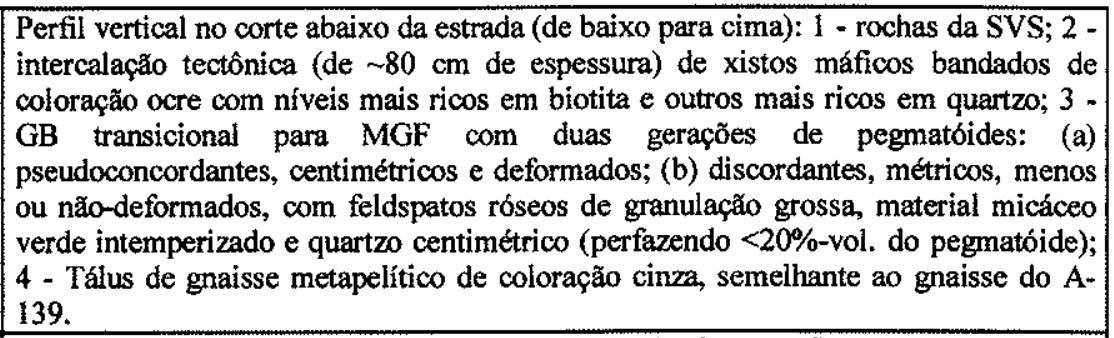 \\
\hline 141 & G-141 & $\begin{array}{l}S=318 / 38 \\
\text { no gnaisse } \\
\text { da SVS }\end{array}$ & $\begin{array}{l}\text { Perfil vertical do leito do rio do Peixe até o nível de xistos máficos e horizontal até o } \\
\text { dique de basalto microgábrico (amostra G-141); ocorrem: rochas da SVS sotopostas } \\
\text { por gnaisses miloniticos, félsicos, quartzo-feldspáticos com pouca biotita (fina e } \\
\text { disseminada), contendo niveis de gnaisses muscovíticos e veios de quartzo, ora } \\
\text { concordantes e milonitizados, ora discordantes (cortando a foliação em baixo ângulo) } \\
\text { e menos deformados. }\end{array}$ \\
\hline 142 & $\cdot$ & - & $\begin{array}{l}\text { Gnaisse da SVS de coloração cinza com níveis de quartzo-muscovita-xisto e veios } \\
\text { pegmatóides. }\end{array}$ \\
\hline 143 & - & - & $\begin{array}{l}\text { Anfibolito de granulaçăo fina, foliado, intemperizado, de coloração ocre, com lentes } \\
\text { concordantes de quartzo. }\end{array}$ \\
\hline \multirow[t]{5}{*}{144} & G-144a & - & $\begin{array}{l}\text { TTG de fácies migmatítica com predomínio da fase félsica; essa transiciona para as } \\
\text { fases mais ricas em minerais máficos. }\end{array}$ \\
\hline & $\mathrm{G}-144 \mathrm{~b}$ & - & TTG da porçăo mais máfica, fina e homogênea. \\
\hline & G-144c & - & $\begin{array}{l}\text { Gnaisse mais máfico de granulaçăo mais grossa que as fácies anteriores, homogêneo, } \\
\text { foliado com estrutura flaser. }\end{array}$ \\
\hline & G-144d & $=$ & intrusivo. \\
\hline & G-144e & $=$ & Basalto \\
\hline 145 & & $=$ & asalto microgábrico. \\
\hline 146 & G-146 & - & Morrote de basalto microgábrico. \\
\hline 147 & - & $\mathrm{S}=298 / 35$ & $\begin{array}{l}\text { Intercalaç̋̃es de gnaisses/xistos metapelíticos com silimanita, intemperizados, de } \\
\text { coloração arroxeada, com anfibolitos metabásicos com granadas alteradas. }\end{array}$ \\
\hline 148 & G-148 & $\mathrm{S}=310 / 25^{\mathrm{T}}$ & $\begin{array}{l}\text { Intercalaç̃es de anfibolitos metabásicos com granada }{ }^{* 1} \text { (amostra) e gnaisses } \\
\text { biotíticos, foliados, de granulaça fina/média bandados (níveis com teores distintos } \\
\text { de biotita). }\end{array}$ \\
\hline 149 & - & - & $\begin{array}{l}\text { GB típico; uma falha vertical colocou rochas da SVS (na outra margem do rio do } \\
\text { Peixe em justaposicấo no mesmo nível topográfico dos GB. }\end{array}$ \\
\hline \multirow[t]{4}{*}{150} & G-150a & - & Anfibolito metaultramáfico em bloco rolado. \\
\hline & G-150b & 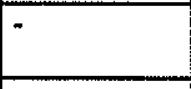 & $\begin{array}{l}\text { Talco-tremolita-xisto com tremolita radial, centimétrica -pós-tectônica em bloco } \\
\text { rolado. }\end{array}$ \\
\hline & G-150c & - & Anfibolito metaultramáfico dobrado em bloco rolado. \\
\hline & G-150d & $\mathrm{S}=315 / 30^{\mathrm{T}}$ & $\begin{array}{l}\text { Gnaisse*1 bandado quartzoso rico em muscovita de coloração cinza, intemperizado } \\
\text { ("arenoso"); o ponto é localizado na linha ferrea, abaixo da galeria do garimpo de } \\
\text { esmeralda, onde foram coletadas as amostras anteriores. }\end{array}$ \\
\hline 151 & G-151 & " & $\begin{array}{l}\text { Dique de basalto (com matriz fina e fenocristais milimétricos de minerais máficos) } \\
\text { cortando gnaisse metapelítico, bandado da SVS. }\end{array}$ \\
\hline $\begin{array}{l}152 \quad \text { (cf. } \\
\text { A-24) }\end{array}$ & - & $\mathrm{S}=320 / 25$ & Intercalaç̧es de gnaisses metapelíticos e anfibolitos metabásicos da SVS. \\
\hline 153 & - & $\mathrm{S}=320 / 30$ & Gnaisse g \\
\hline 154 & - & $S=296 / 35^{\top}$ & Nível de anfibolito metabásico sobre gnaisse granatifero*! \\
\hline \multirow[t]{2}{*}{155} & G-155a & - & Gnaisse milonitico da SVS de granulação fina/média, com muscovita $>$ biotita \\
\hline & G-155b & $\mathrm{S}=255 / 20$ & Gnaisse milonítico da SVS com biotita e muscovita, alterado. \\
\hline 156 & - & $\begin{array}{l}S=180 / 30 \\
S=160 / 20 \\
D_{2}=160 / 05 \\
S=100 / 05^{* 1} \\
F r=190 / 75^{* 1}\end{array}$ & $\begin{array}{l}\text { Gnaisse metapelítico de granulação fina, com biotita, muscovita e granada, foliação } \\
\text { milonitica sc; intrudido por veios pegmatódes dobrados intrafoliares; amostra } \\
\text { orientada*!. }\end{array}$ \\
\hline 157 & - & - & Solo acastanhado com fragmentos de gnaisses metapelíticos com granada alterados. \\
\hline \multirow[t]{3}{*}{158} & & - & Basalto de granulação fina, bloco rolado. \\
\hline & G-158b & - & Anfibolito metabásico, bloco rolado. \\
\hline & G-158c & & Anfibolito metaultramáfico, bloco rolado. \\
\hline
\end{tabular}




\begin{tabular}{|c|c|c|c|}
\hline 159 & $\mathrm{G}=159 \mathrm{a}$ & - & $\begin{array}{l}\text { Flogopitito crenulado, de cor marron-arroxeada, com palhetas grandes de flogopita e } \\
\text { pontos amarelos de alteração, bloco rolado. }\end{array}$ \\
\hline & $\mathrm{G}-159 \mathrm{~b}$ & - & Tremolitito de cor acinzentada, com porçoes amareladas (oxidadas), bloco rolado. \\
\hline & $\mathrm{G}-159 \mathrm{c}$ & 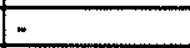 & Bloco rolado de muscovita-biotita-quartzo-xisto com epidoto e opacos. \\
\hline & G-159d & - & Cloritito de cor verde-acinzentada, crenulado; bloco rolado. \\
\hline & $\mathrm{G}-159 \mathrm{e}$ & $=$ & Anfibólio-clorita-xisto fino crenulado de cor verde-acinzentada; bloco rolado. \\
\hline & G-159f & - & $\begin{array}{l}\text { Talco-tremolita-xisto de cor amarelo-acinzentada, com cristais de tremolita de } \\
\text { granulação grossa }(1,5 \mathrm{~cm}) \text { sem orientaçao; bloco rolado. }\end{array}$ \\
\hline 160 & - & - & Gnaisse com biotita disseminada, pouca muscovita, semi-alterado. \\
\hline 161 & G-161 & $\cdot$ & $\begin{array}{l}\text { Gnaisse milonítico, leucocrático, homogêneo, de granulaçâo fina, com pouca biotita } \\
\text { (fina e disseminada), intemperizado. }\end{array}$ \\
\hline 162 & - & - & GB. \\
\hline 163 & - & - & GB. \\
\hline 164 & - & $\mathrm{S}=318 / 15$ & GB com veios de quartzo fortemente milonitizados. \\
\hline 165 & - & - & GB de fácies de granulação mais grossa. \\
\hline \multirow[t]{4}{*}{166} & G-166a & - & $\begin{array}{l}\text { GB típico (amostra G-166a) com mobilizados pegmatóides, bolsões/veios de quartzo } \\
\text { e niveis de biotitito granatifero (amostra G-166c). }\end{array}$ \\
\hline & G-166b & - & $\begin{array}{l}\text { Fácies transicional } \mathrm{GB} / \text { biotitito granatífero com quartzo, feldspatos, biotita e } \\
\text { granada. }\end{array}$ \\
\hline & $\mathrm{G}-166 \mathrm{c}$ & - & Biotitito granatífero. \\
\hline & G-166d & - & GB intemperizado, com porfiroblastos de magnetita; bloco rolado. \\
\hline 167 & - & 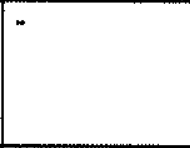 & $\begin{array}{l}\text { Gnaisse-milonítico de granulação fina, intemperizado, com níveis caolínicos ricos } \\
\text { em muscovita e níveis biotitíticos quase monominerálicos disruptos, sendo fácies } \\
\text { atípica de GB e/ou fácies milonítica de gnaisse quartzo-feldspático a metapelítico da } \\
\text { SVS; presença de cava para garimpo. }\end{array}$ \\
\hline \multirow[t]{8}{*}{168} & várias & $\begin{array}{l}\mathrm{Fr}_{1}=184 / 65 \\
\mathrm{Fr}_{2}=278 / 70 \\
\mathrm{D}_{\mathrm{n}+2}=236 / 10 \\
\mathrm{D}_{\mathrm{n}+3}: \mathrm{Fl}_{1}= \\
148 / 85 ; \quad \mathrm{Fl}_{2} \\
=320 / 30 \\
\end{array}$ & $\begin{array}{l}\text { Milonito-gnaisse (TTG), com níveis ora mais félsicos, ora mais máficos bititicos e } \\
\text { anfibolíticos, fortemente dobrados e com dobras intrafoliais. }\end{array}$ \\
\hline & G-168a & - & Gnaisse anfibolítico com dobras intrafoliais. \\
\hline & $\mathrm{G}-168 \mathrm{~b}$ & 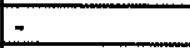 & Milonito-gnaisse félsico, com níveis biotíticos. \\
\hline & $\mathrm{G}-168 \mathrm{c}$ & $\cdot$ & $\begin{array}{l}\text { Gnaisse de fácies intermediária, de granulação fina, bandado, que transiciona para } \\
\text { fácies mais leucocráticas. }\end{array}$ \\
\hline & G-168d & - & Gnaisse de fácies mais leucocrática, dobrada. \\
\hline & G-168e & - & Gnaisse de fácies mais máfica biotítica, bandada. \\
\hline & $\mathrm{G}-168 \mathrm{f}$ & - & Gnaisse de fácies mais biotítica, bandada, com níveis pegmatóides. \\
\hline & $\mathrm{G}-168 \mathrm{~g}$ & - & Gnaisse de fácies mais máfica com porções félsicas. \\
\hline \multirow[t]{2}{*}{169} & G-169 & - & $\begin{array}{l}\text { Pegmatóide (amostra) de dimensões métricas, zonado, com muscovita de granulação } \\
\text { grossa (até } 5 \mathrm{~cm} \text { de tamanho); intrude gnaisse de granulação fina, bandado, da SVS. }\end{array}$ \\
\hline & G-169a & - & Basalto microgábrico; bloco rolado. \\
\hline 170 & & - & Tálus com fragmentos de xistos metapelíticos. \\
\hline 171 & & - & Pegmatóide com ametista, intrusivo na SVS. \\
\hline 172 & G-172 & - & $\begin{array}{l}\text { Basalto microgábrico (amostra); forma dique em gnaisse fino, bandado com níveis } \\
\text { biotiticos, fracamente foliado, intemperizado da SVS. }\end{array}$ \\
\hline 173 & - & - & $\begin{array}{l}\text { Gnaisse com estrutura flaser incipiente, granulação média/grossa, de coloração rósea, } \\
\text { intemperizado, apresenta níveis de minerais quartzo-feldspáticos e raros pegmatóides } \\
\text { centimétricos discordantes e concordantes. }\end{array}$ \\
\hline \multirow[t]{3}{*}{174} & $\mathrm{G}-174 \mathrm{a}$ & $\mathrm{L}_{m}=85 /$ horiz. & MGF. \\
\hline & $\mathrm{G}-174 \mathrm{~b}$ & - & MGF de fácies máfica, com hornblenda e magnetita grossas. \\
\hline & $\mathrm{G}-174 \mathrm{c}$ & - & $\begin{array}{l}\text { MGF de fácies transicional félsica para máfica; apresenta uma banda/faixa contendo } \\
\text { gzo + horn + mag. }\end{array}$ \\
\hline 175 & - & $S=190 / 30$ & GB típico. \\
\hline 176 & - & $S=256 / 30$ & GB intemperizado. \\
\hline 177 & - & $\mathrm{S}=210 / 25$ & GB. \\
\hline $\begin{array}{ll}178 \\
A-94)\end{array}$ & - & $S=225 / 25$ & GB típico, intemperizado. \\
\hline $\begin{array}{ll}179 \quad \text { (cf. } \\
\mathrm{A}-95)\end{array}$ & - & $S=240 / 40$ & GB foliado, com cores lilás de intemperismo. \\
\hline 180 & - & - & $\begin{array}{l}\text { Brusca mudança de coloração do solo passando para marron avermelhado típico da } \\
\text { SVS (contato GB/SVS). }\end{array}$ \\
\hline
\end{tabular}




\begin{tabular}{|c|c|c|c|}
\hline 181 & - & - & $\begin{array}{l}\text { Início da zona de transição da SVS para gnaisses leucocráticos graníticos (cf. } \\
\text { descritos no A-36) indicada pela mudança na cor e composição do solo. }\end{array}$ \\
\hline 182 & - & - & $\begin{array}{l}\text { Gnaisse de granulação fina, bandado da SVS, às vezes, bastante micáceo; } \\
\text { intemperizado, de coloração rósea. }\end{array}$ \\
\hline 183 & - & - & Xistos/gnaisses metapelíticos da SVS. \\
\hline 184 & - & - & Xistos/gnaisses metapelíticos da SVS. \\
\hline 185 & G-185 & - & Talco-tremolita-xisto fino de cor cinza-amarelada. \\
\hline 186 & - & $\begin{array}{l}\mathrm{S}=305 / 15 \\
\mathrm{~L}_{m}=255 / 8\end{array}$ & GB típico. \\
\hline 187 & - & $S=330 / 25$ & $\begin{array}{l}\text { GB milonitizado, intemperizado, com inúmeros veios de quartzo variavelmente } \\
\text { deformados; }\end{array}$ \\
\hline 188 & - & $\begin{array}{l}S=280 / 35 \\
S=270 / 30 \\
S=260 / 35\end{array}$ & $\begin{array}{l}\text { SVS: milonito-gnaisse de granulação fina bandado intemperizado de cor rósea- } \\
\text { avermelhada, com níveis anfibolíticos decimétricos de granulação fina } \\
\text { intemperizados de coloração ocre e níveis com granatíferos, pretos quando } \\
\text { intemperizados. }\end{array}$ \\
\hline 189 & - & - & $\begin{array}{l}\text { Tálus com fragmentos de gnaisse granatífero da SVS de granulação fina e de GB } \\
\text { foliado e rico em minerais máficos. }\end{array}$ \\
\hline 190 & G-190 & $S=275 / 10$ & Ultramilonito-gnaisse perquartzoso fino e finamente foliado, muito homogêneo. \\
\hline 191 & - & - & $\begin{array}{l}\text { Quartzo-muscovita-xisto intercalado em gnaisse de granulacãa fina, foliado, } \\
\text { intemperizado e de coloração rósea. }\end{array}$ \\
\hline 192 & G-192 & - & Milonito-gnaisse quartzo-feldspático, de granulação fina, foliado. \\
\hline 193 & - & $\begin{array}{l}\mathrm{S}=284 / 40 \\
\mathrm{~S}=278 / 30\end{array}$ & $\begin{array}{l}\text { Intercalaçðes de rochas da SVS: anfibolitos e xistos/gnaisses metapelíticos, } \\
\text { intemperizados com muscovitanquartzitos milonitizados. }\end{array}$ \\
\hline 194 & - & - & $\begin{array}{l}\text { Intercalaçóes de rochas da SVS: anfibolitos e xistos/gnaisses metapelíticos com } \\
\text { lentes/níveis decimétricos de quartzo-muscovita-xistos que gradam para muscovita- } \\
\text { quartzitos. }\end{array}$ \\
\hline $\begin{array}{ll}195 \quad(\mathrm{cf} . \\
\mathrm{A}-47)\end{array}$ & G-195 & $\begin{array}{l}\mathrm{Fl}_{1}=140 / 60 \\
\mathrm{Fl}_{2}=270 / 35\end{array}$ & $\begin{array}{l}\text { Anfibolito metaultramáfico (nível de } \sim 30 \mathrm{~cm} \text { de espessura) fino de cor cinza-escura, } \\
\text { com dobras locais. }\end{array}$ \\
\hline $\begin{array}{ll}196 & \text { (cf. } \\
\mathrm{A}-46)\end{array}$ & - & - & Gnaisse metapelítico da SVS (cf. A-46). \\
\hline 197 & - & - & Quartzo-muscovita-xisto com nódulos de biotita em gnaisse félsico com muscovita. \\
\hline $\begin{array}{ll}198 \quad \text { (cf. } \\
\mathrm{A}-45)\end{array}$ & - & - & $\begin{array}{l}\text { Gnaisse milonítico leucocrático, de granulação fina, quartzo-feldspático, com biotita } \\
\text { esparsa disseminada. }\end{array}$ \\
\hline 199 & - & $S=310 / 40$ & $\begin{array}{l}\text { Contato milonítico entre SVS e GB constituído por intercalaçðes de gnaisses } \\
\text { (miloníticos) e quartzo-muscovita-xistos da SVS e GB intemperizado. }\end{array}$ \\
\hline $\begin{array}{ll}200 \quad \text { (cf. } \\
\mathrm{A}-44)\end{array}$ & - & - & SVS com gnaisses e xistos metapelíticos muscoviticos (cf. A-44). \\
\hline 201 & - & $\begin{array}{l}\mathrm{S}=292 / 40^{* 1} \\
\mathrm{~S}=310 / 40^{* 2} \\
\mathrm{D}_{\mathrm{n}}=302 / 30\end{array}$ & $\begin{array}{l}\text { Contato entre gnaisse félsico*1, quartzo-feldspático, de granulação fina, } \\
\text { intemperizado de coloração rósea e gnaisse metapelítico*2, foliado com dobras } \\
\text { intrafoliais, fino, intemperizado, de coloração arroxeada. }\end{array}$ \\
\hline 202 & - & - & Niveis decimétricos de quartzo-clorita-xisto em gnaisses da SVS. \\
\hline $\begin{array}{ll}203 \quad \text { (cf. } \\
A-41)\end{array}$ & G-203 & - & Gnaisse metapelítico com granada. \\
\hline 204 & - & $\begin{array}{l}\mathrm{C}=205 / 35 \\
\mathrm{~L}_{m}=240 / 35 \\
\mathrm{~L}_{\mathrm{m}}=240 / 25\end{array}$ & $\begin{array}{l}\text { Contato tectônico entre a SVS e gnaisse milonítico, quartzo-feldspático, de } \\
\text { granulação fina, intemperizado, de coloração branca, com niveis mais micáceos e } \\
\text { pintas disseminadas de caolim. }\end{array}$ \\
\hline 205 & - & - & $\begin{array}{l}\text { Contato tectônico entre a SVS e milonito-gnaisse quartzo-feldspático leucocrático; } \\
\text { próximo ao contato, com inúmeros veios de quartzo de dimensðes até métricas. }\end{array}$ \\
\hline 206 & 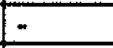 & - & Na encosta, solo de coloração esbranquiçada - de gnaisse quartzo-feldspático. \\
\hline 207 & - & - & Na encosta, solo de coloração avermelhada - de rochas da SVS. \\
\hline 208 & - & - & Paredăo de GB. \\
\hline 209 & - & - & Na encosta, com solo de coloracão esbranquicada - de gnaisse quartzo-feldspático. \\
\hline 210 & - & - & Solo de coloração avermelhada - de rochas da SVS. \\
\hline 211 & $\overline{-}$ & - & Solo de coloracăo esbranquicada - de gnaisse quartzo-feldspátivo. \\
\hline 212 & - & - & $\begin{array}{l}\text { Tálus de coloração avermelhada, com fragmentos de rochas da SVS: xistos/gnaisses } \\
\text { metapelíticos, anfibolitos e quartzo-muscovita-xisto com nódulos de biotita. }\end{array}$ \\
\hline 213 & 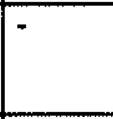 & - & $\begin{array}{l}\text { Zona de contato indicada pela mudança na coloração do solo, entre as partes mais } \\
\text { altas da encosta com solo avermelhado de rochas da SVS e as partes mais baixas } \\
\text { com solo esbranquiçado de gnaisse quartzo-feldspático. }\end{array}$ \\
\hline 214 & - & - & Solo de coloracão esbranquicada de gnaisse quartzo-feldspático. \\
\hline 215 & - & - & $\begin{array}{l}\text { Tálus com fragmentos de rocha da SVS: xistos/gnaisses metapelíticos, anfibolitos e } \\
\text { quartzo-muscovita-xisto com nódulos de biotita. }\end{array}$ \\
\hline 216 & - & - & Encosta com solo avermelhado de rochas da SVS. \\
\hline
\end{tabular}




\begin{tabular}{|c|c|c|c|}
\hline 217 & - & - & $\begin{array}{l}\text { Encosta com solo branco-róseo - de gnaisse quartzo-feldspático (ou leucognaisse da } \\
\text { SVS). }\end{array}$ \\
\hline 218 & - & - & Faixa estreita de solo esbranquicado, em solos típicos avermelhados da SVS. \\
\hline $\begin{array}{l}219 \text { (cf. } \\
\text { A-109) }\end{array}$ & $\overline{-}$ & - & Talus da SVS (cf, A-109). \\
\hline 220 & $\cdot$ & - & $\begin{array}{l}\text { Brusca mudança na coloração do solo, passando de solo avermelhado típico da SVS } \\
\text { (a W) para solo esbranquiçado típico de gnaisse quartzo-feldspático (a E). }\end{array}$ \\
\hline $\begin{array}{l}221 \text { (cf. } \\
\mathrm{A}-102)\end{array}$ & - & - & Gnaisse quartzo-feldspático em contato tectônico com a SVS (cf. A-102). \\
\hline 222 & - & - & Encosta com solo de coloracão avermelhada típico da SVS. \\
\hline 223 & - & $\begin{array}{l}\mathrm{S}=300 / 20 \\
\mathrm{~S}=305 / 15\end{array}$ & $\begin{array}{l}\text { Quartzito muscovítico de granulação fina, finamente foliado, contendo veios de } \\
\text { quartzo de dimensões métricas. }\end{array}$ \\
\hline 224 & - & $\begin{array}{l}S=208 / 35^{* 1} \\
S=232 / 35^{* 2} \\
S=240 / 30^{* 3}\end{array}$ & $\begin{array}{l}\text { Quartzito muscovitico (topo*!, } \text { base }^{*^{2}} \text { ) intercalado em xisto metapelítico com } \\
\text { granada*3. }\end{array}$ \\
\hline 225 & G-225 & - & $\begin{array}{l}\text { Anfibolito cálciossilicático, homogêneo, de granulação fina e coloração cinza- } \\
\text { azulada. }\end{array}$ \\
\hline 226 & 7 & $=$ & Tálus de solo de coloraçáo avermelhada e fragmentos de rocha da SVS. \\
\hline 227 & - & - & GB. \\
\hline 228 & - & $\mathrm{S}=200 / 25$ & $\begin{array}{l}\text { GB intemperizado e de coloração lilás; numa porção pegmatóide com mica de } \\
\text { granulação grossa existe uma galeria para lavra de garimpo. }\end{array}$ \\
\hline 229 & - & - & GB. \\
\hline 230 & - & - & Solo de coloração avermelhada com raros fragmentos de rocha da SVS. \\
\hline \multirow[t]{4}{*}{231} & G-23la & - & Anfibolito cálciossilicático, foliado, de granulação fina e coloração cinza-azulada. \\
\hline & G-23lb & - & Anfibolito metabásico com dobra isoclinal. \\
\hline & G-231c & - & Anfibolito de formação ferrifera, semi-alterado de coloração escura. \\
\hline & G-23ld & - & Anfibolito de metaultramáfica. \\
\hline 232 & - & - & Solo de coloracão avermelhada da SVS. \\
\hline 233 & - & $\mathrm{C}=200 / 40$ & $\begin{array}{l}\text { Contato de falha entre rochas da SVS (xistos metapelíticos com intercalações de } \\
\text { anfibolitos de coloraça ocre) e GB (intemperizado de coloração rósea). }\end{array}$ \\
\hline 234 & - & - & Encosta com solo de coloração branco-rósea. \\
\hline 235 & - & $\mathrm{S}=204 / 30$ & Xisto metapelítico muscovitico, crenulado. \\
\hline 236 & - & - & GB. \\
\hline 237 & - & - & Tálus de cor avermelhada com fragmentos de xistos máficos e metapelíticos da SVS. \\
\hline 238 & G-238 & $\overline{-}$ & $\begin{array}{l}\text { Tálus com fragmentos de rochas da SVS: xistos/gnaisses metapelíticos, quartzo- } \\
\text { muscovita-xistos e anfibolitos metabásicos com granada (com fraturas mineralizadas } \\
\text { com sulfetos (amostra). }\end{array}$ \\
\hline \multirow[t]{4}{*}{\begin{tabular}{ll|}
239 \\
$\mathrm{~A}-85)$
\end{tabular}} & G-239a & - & $\begin{array}{l}\text { Granada-cordierita-cummingtonita-biotita-xisto com cummingtonita radial; apresenta } \\
\text { nivel milimétrico com predominância de granada vermelha e biotita. }\end{array}$ \\
\hline & G-239b & - & Amostra da porção anfibolítica com granada helicítica. \\
\hline & G-239c & - & $\begin{array}{l}\text { Amostra do nivel biotítico com granada de granulaçăo grossa e veios de quartzo } \\
\text { deformados. }\end{array}$ \\
\hline & G-239d & - & $\begin{array}{l}\text { Amostra do nível biotítico com granada de granulação grossa, cordierita, estaurolita, } \\
\text { opacos, rutilo, clorita e veios de quartzo deformados. }\end{array}$ \\
\hline \multirow[t]{6}{*}{240} & - & - & Zona de contato SVS/GB \\
\hline & G-240a & - & $\begin{array}{l}\text { GB de fácies fina milonítico, com biotita disseminada e concentrą̧̃es de fluorita } \\
\text { lilás. }\end{array}$ \\
\hline & $\mathrm{G}-240 \mathrm{~b}$ & - & GB de fácies rica em muscovita e nódulos de biotita. \\
\hline & G-240c & - & $\begin{array}{l}\text { Anfibolito metabásico com epidoto-clinozoizita-titanita, e níveis mais ricos em } \\
\text { biotita. }\end{array}$ \\
\hline & G-240d & - & $\begin{array}{l}\text { Anfibolito metabásico com epidoto-clinozoizita, com dobras locais grada para } \\
\text { quartzo-biotita-xisto de coloração preta, não alterado. }\end{array}$ \\
\hline & G-240e & - & $\begin{array}{l}\text { Biotita-xisto de coloraçåo preta, com epidoto-clinozoizita-titanita-plagioclásio-rutilo- } \\
\text { opacos-anfibólio-apatita e fluorita. }\end{array}$ \\
\hline 241 & - & - & Tálus com fragmentos de xistos/gnaisses metapelíticos. \\
\hline $\begin{array}{l}242 \text { (cf. } \\
\mathrm{A}-36)\end{array}$ & - & $\mathrm{S}=310 / 45$ & $\begin{array}{l}\text { Contato cisalhado entre a SVS (com intercalaçós de xisto/gnaisse metapelítico e } \\
\text { quartzo-muscovita-xisto) a SE e gnaisse milonítico félsico, de granulação fina, a } \\
\text { NW. }\end{array}$ \\
\hline 243 & - & & $\begin{array}{l}\text { Gnaisse metatético, intemperizado, com estruturas schlieren, apresenta veios } \\
\text { pegmatóides pseudoconcordantes e dobras locais. }\end{array}$ \\
\hline 244 & - & $\begin{array}{l}S=210 / 20^{* 1} \\
S=190 / 37^{* 2}\end{array}$ & $\begin{array}{l}\text { Veio de quartzo com cianita ocorre encaixado em zona de cisalhamento NW em } \\
\text { biotita-gnaisses }{ }^{1} \text { da SVS; } 50 \mathrm{~m} \text { à frente, seguindo a trilha do córrego do Mamão, } \\
\text { afloram qzo-plag-bt-mu-xistos }{ }^{2} \text {. }\end{array}$ \\
\hline
\end{tabular}




\begin{tabular}{|c|c|c|c|}
\hline 245 & - & - & $\begin{array}{l}\text { Próximo a captação d'água da Penery Mineração ocorre um veio pegmatóide com } \\
\text { manchas de Mn encaixado em rocha xistosa, alterada e de coloração cinza- } \\
\text { esverdeada da SVS; subindo a drenagem, ocorrem blocos de rochas da SVS, com } \\
\text { predominio de gnaisses. }\end{array}$ \\
\hline 246 & - & - & $\begin{array}{l}\text { Biotita-gnaisse de granulação fina, cor cinza, com niveis de biotita e dobras locais é } \\
\text { intrudido por veios pegmatóides; foi inicidao a abertura de uma galeria de garimpo. }\end{array}$ \\
\hline 247 & $\cdot$ & - & $\begin{array}{l}\text { Solo de SVS na trilha aberta pela Penery Mineracão para sondagem (um furo atingiu } \\
200 \mathrm{~m} \text { ). }\end{array}$ \\
\hline 248 & - & - & $\begin{array}{l}\text { Biotita-gnaisse da SVS, fino, muito alterado, de coloração arroxeada, com boudins } \\
\text { de gzo; existe uma galeria desmoronada atrás do local da sondagem da Penery. }\end{array}$ \\
\hline 249 & G-249 & - & $\begin{array}{l}\text { Cloritito com flogopita e cristais pseudomorfizados por óxidos de Fe, no local do } \\
\text { poco }(\text { de } 32 \mathrm{~m}) \text { acima da casa de máquinas da Penery Mineração. }\end{array}$ \\
\hline 250 & G-250a,b & " & $\begin{array}{l}\text { Atrás da casa de máquinas da Penery Mineração ocorrem intercalaçóes de anfibolito } \\
\text { de formação ferrífera (BIF) }{ }^{* 1} \text { semi-alterado, preto-azulada com porçôes ocre (Am. } \\
\text { G-250a) e de anfibolito metabásico com granada, alterado, de cor lilás/ocre (Am. G- } \\
250 \text { b). }\end{array}$ \\
\hline 251 & $\mathrm{G}-251$ & $\cdot$ & $\begin{array}{l}\text { Atrás do almoxarifado da Penery Mineração ocorre um nivel de } \sim 15 \mathrm{~m} \text { de espessura } \\
\text { de anfibolito de BIF alterado, com anf }+ \text { gzotop. }\end{array}$ \\
\hline 252 & - & - & Gnaisse metapelítico alterado de coloração arroxeada. \\
\hline 253 & - & $\begin{array}{l}\mathrm{S}=105 / 45^{* 1} \\
\mathrm{~L}_{\min }=70 / 30^{* 2} \\
\mathrm{~F}=230 / 90\end{array}$ & $\begin{array}{l}\text { Veio de gzo cisalhado }{ }^{\prime !} \text { de direção N-S com } \sim 50 \mathrm{~m} \text { de largura, em muscovita-biotitam } \\
\text { gnaisse* }{ }^{2} \text { de coloração arroxeada. }\end{array}$ \\
\hline 254 & - & - & Biotita-gnaisse em blocos rolados ora frescos, ora alterados (na grota). \\
\hline 255 & - & $n$ & Bloco rolado de biotita-gnaisse, pouco alterado, de $\sim 1 \mathrm{~m}$. \\
\hline 256 & - & - & $\begin{array}{l}\text { Na drenagem, blocos e fragmentos de rochas rolados diversos: biotita-gnaisse fino, } \\
\text { veio de qzo cisalhado e anfibolito metabásico. }\end{array}$ \\
\hline 257 & - & $S=180 / 25$ & Qzo-bt-xisto com granada e lentes de qzo recristalizado. \\
\hline 258 & - & - & Solo de coloração rosácea, com qzo e mu. \\
\hline 259 & 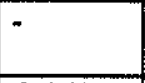 & - & $\begin{array}{l}\text { Na trilha do córrego do Mamão, a } \sim 150 \mathrm{~m} \text { atrás da captação d'água da Penery } \\
\text { Mineração ocorre biotita-gnaisse da SVS. }\end{array}$ \\
\hline 260 & $G-260$ & - & $\begin{array}{l}\text { Fragmentos de cristais de esmeralda de cor verde-clara, ligeiramente azulada, } \\
\text { associados a talco-anfibólio-xisto. }\end{array}$ \\
\hline
\end{tabular}

\section{Galerias Subterrâneas da Área de Garimpo de Capoeirana}

\section{Garimpo do Afonso Paulino (AP)}

\begin{tabular}{|l|l|}
\hline Dados estruturais & Descrição geral \\
\hline $\mathrm{S}=\mathrm{N} 15 \mathrm{E} / 31 \mathrm{NW}$ & Clor-bt-anf gnaisse gradando para gr-anf gnaisse; ocorrem concentraçðes em níveis só de anfibólio \\
$\mathrm{S}=\mathrm{N} 55 \mathrm{E} / 22 \mathrm{NW}$ & próximo à lentes deformadas de qzo recristalizado como perturbaç̃es locais no regime de pressão. \\
$\mathrm{S}=\mathrm{N} 40 \mathrm{E} / 69 \mathrm{NW}$ & \\
$\mathrm{L}_{\text {qañ }}=250 / 05$ & \\
\hline
\end{tabular}

\begin{tabular}{|l|l|}
\hline No. das Amostras & Descrição das Amostras \\
\hline AP-1 & Gnaisse com níveis mais félsicos intercalados com niveis mais máficos, com bt + gr \pm clo. \\
\hline AP-2 & Gnaisse metapelítico com bt + stau + cord + plag + qzo + ru + op \pm clo \\
\hline AP-3 & Gnaisse metapelítico com plag + qzo + stau + cord + bt $+\mathrm{ru}+$ ep + clo \\
\hline AP-4 & Clorita-anfibólio-gnaisse. \\
\hline AP-5 & Gnaisse metapelítico com bt + ky + fibrolita. \\
\hline AP-6 & Anfibólio gnaisse com níveis pegmatóides pseudoconcordantes e dobras locais. \\
\hline
\end{tabular}

\section{Garimpo do Marte (M)}

\begin{tabular}{|l|l|}
\hline Dados estruturais & Descriçåo Geral \\
\hline $\mathrm{L}_{\mathrm{cr}}=303 / 12^{* 1}$ & Intercalaçð̌es de anfibolitos metaultramáficos* flogopitizados e anfibolitos metabásico ${ }^{* 2} ;$ mobilizados \\
$\mathrm{PA}_{\mathrm{cr}}=205 / 65^{* 1}$ & pegmatoides deformados indicam sentido de movimento para NE; sigmóides de quartzo no \\
$\mathrm{S}=220 / 35^{* 2}$ & flogopitito*3 indicam direção N80W. \\
$\mathrm{S}=203 / 35^{* 3}$ & \\
$\mathrm{Fr}=175 / 80$ & \\
\hline
\end{tabular}




\begin{tabular}{|l|l|}
\hline Amostras & Descrição das Amostras \\
\hline M1 & Pegmatóide com corindon azulado e estaurolita intrusivo em biotitito. \\
\hline M2 & $\begin{array}{l}\text { Veio de quartzo em contato com um estreito nivel de anfibolito; próximo ao contato, na borda do veio, ocorre } \\
\text { concentração de cianita azul. }\end{array}$ \\
\hline M3 & $\begin{array}{l}\text { Veio pegmatóide com plag }+\mathrm{ky}+\text { corn } \pm \text { qzo; ocorrem ainda cianita e córindon, geralmente, próximos ao } \\
\text { contato com um nfvel de anfibolito. }\end{array}$ \\
\hline M4 & Veio pegmatóide com ky + stau; com enclaves lenticulares de biotita xisto. \\
\hline M5 & $\begin{array}{l}\text { Pegmatóide com ky (de até 3cm) + córindon; ocorrem porçóes com ky + plag + cord + stau + anf. verde + anf. } \\
\text { incolor, proximo ao contato com um nível constituído por anf }+ \text { bt } \pm \text { plag } \pm \text { qzo; na extremidade oposta do veio } \\
\text { ocorre um nível constituído só por anfibólios. }\end{array}$ \\
\hline M6 & Pegmatóide com ky + córindon + stau, em anfibolito. \\
\hline M7 & Veio lenticular de pegmatóide com núcleo de quartzo recristalizado intrusivo em anfibolio-biotita-xisto. \\
\hline M8 & Lente pegmatóide deformada com granada (de até 3cm) em anfibolito. \\
\hline M9 & Pegmatóide com cianita, córindon vermelho (rubi) e estaurolita. \\
\hline
\end{tabular}

\section{Penery Mineracăo}

\begin{tabular}{|l|l|}
\hline $\begin{array}{l}\text { Dados } \\
\text { estruturais }\end{array}$ & Descrição Geral \\
\hline $\mathrm{S}=180 / 15^{\circ}$ & $\begin{array}{l}\text { A } 50 \mathrm{~m} \text { de profundidade, contato* litológico na SVS, de gnaisse com anfibolito metabásico contendo níveis de } \\
\text { clorita orientada na foliação e tension gashes indicando sentido E de movimento; próximo ao contato, no } \\
\text { anfibolito ocorrem níveis de pegmatóide com amazonita. }\end{array}$ \\
\hline
\end{tabular}

\begin{tabular}{|l|l|}
\hline Amostras & Descrição das Amostras \\
\hline P1 & Clorita-biotita-gnaisse (com tit/leuc + ep). \\
\hline P2 & Veio pegmatóide com cordierita (granular, cor azulada). \\
\hline P3 & Pegmatóide. \\
\hline P6 & Pegmatóide com biotita; shaft - profundidade $=65,50 \mathrm{~m}$. \\
\hline 65,30 & Pegmatóide com K-feldspato idiomórfico incluido em quartzo e enclaves de biotita xisto da SVS. \\
\hline 61,95 & Biotita-anfibólio-gnaisse com titanita-epidoto. \\
\hline 57,15 & Anfibolito metabásico com opacos (provável metatufo básico) \\
\hline 47,70 & Gnaisse com bt + clo + cum + ru + ap + zir + ep + fluo. \\
\hline 47,00 & Gnaisse com bt + anf + op + clo + alan + ap + ep + zir. \\
\hline 45,00 & Anfibolito rico em epidoto com anf. verde + anf. incolor + op + bt + ep. \\
\hline 44,00 & Anfibolito metabásico com opacos. \\
\hline 42,75 & Anfibolito metabásico com anf. verde + anf. incolor + op + alan + fluo + ap. \\
\hline 41,30 & Clorita-biotita-gnaisse. \\
\hline 39,90 & Gnaisse metapelítico com bt + sil/fibrolita + gr + stau + clo + mu. \\
\hline 38,40 & Gnaisse metapelítico com biotita e muscovita. \\
\hline 36,50 & Biotita-granada-gnaisse com clorita e opacos. \\
\hline 35,50 & Anfibolito com bt + op + ap + gr. \\
\hline 33,40 & Anfibolito metabásico com biotita, opacos e granada. \\
\hline 32,20 & Anfibolito metabásico com titanita; no microscópio, nota-se um veio discordante de zeólitas pós-metamórfico. \\
\hline 31,40 & Anfibolito. \\
\hline 14,30 & Anfibolito de BIF com anf + qzo + op + ru + fluo + tit + ep + zir. \\
\hline
\end{tabular}

\section{Garimpo do Suíco}

\begin{tabular}{|l|l|}
\hline Amostras & Descrição das Amostras \\
\hline NE-1 & Anfibolito metaultramáfico gradando para flogopitito. \\
\hline NE-2 & Flogopitito. \\
\hline NE-3 & Flogopita-anfibolito (metaultramáfico). \\
\hline NE-4 & Flogopitito com lentes de quartzo. \\
\hline NE-5 & Flogopitito friável com lentes de quartzo. \\
\hline NE-6 & Quartzo-flogopita-xisto (quartzo 10\%). \\
\hline NE-7 & Anfibólio-flogopita-xisto com nivel quartzoso-flogopitico. \\
\hline NE-8 & Anfibólio-flogopita-xisto grada para flogopita-anfibólio-xisto. \\
\hline NE-9 & Flogopita-anfibólio-xisto. \\
\hline NE-10 & Flogopita-anfibólio-xisto. \\
\hline NE-11 & Flogopita-anfibólio-xisto grada para flogopitito. \\
\hline NE-12 & Flogopita-anfibólio-xisto com apatita e lentes de quartzo. \\
\hline NE-13 & Quartzo-flogopita-xisto (quartzo 10\%). \\
\hline
\end{tabular}




\begin{tabular}{|c|c|}
\hline NE-14 & Contato quartzo-flogopita-xisto com flogopita-anfibólio-xisto. \\
\hline NE-15 & Flogopitito com lentes de quartzo. \\
\hline NE-16 & Flogopitito. \\
\hline NE-17 & Flogopita-anfibólio-xisto. \\
\hline NE-18 & Gnaisse da SVS. \\
\hline NE-19 & Flogopitito com quartzo $(<10 \%)$ \\
\hline NE-20 & Flogopita-anfibólio-cromita-xisto com níveis de flogopitito. \\
\hline $\mathrm{NE}-21$ & Anfibolito metabásico. \\
\hline NE-22 & Contato biotita-anfibólio-gnaisse com anfibólio-granada-biotita-gnaisse. \\
\hline NE-23 & Gnaisse calciossilicático. \\
\hline $\mathrm{NE}-24$ & Quartzo-flogopita-anfibólio-xisto $(\sim 10 \%$ quartzo). \\
\hline $\mathrm{NE}-25$ & Flogopita-anfibolio-xisto. \\
\hline NE-26 & Niveis intercalados de biotita-gnaisse, biotita-anfibólio-gnaisse e anfibolito metabásico. \\
\hline NE-27 & Níveis de granada-biotita-gnaisse em granada-biotita-anfibolio-gnaisse. \\
\hline NE-28 & Veio de quartzo. \\
\hline NE-29 & Veio pegmatóide em flogopitito. \\
\hline NE-29b & Flogopita-anfibólio-xisto com lentes pseudoconcordantes de quartzo recristalizado. \\
\hline NE-30 & $\begin{array}{l}\text { Flogopitito com veios de quartzo e pegmatóide com esmeralda e plagioclásio; cristais centimétricos de apatita } \\
\text { ocorrem no flogopitito (Am. NE-30a). }\end{array}$ \\
\hline NE-31 & Veio pegmatóide com esmeralda em flogopitito. \\
\hline NE-31-01 & Veio pegmatóide com esmeralda em flogopitito. \\
\hline NE-31-02 & Veio pegmatóide com esmeralda de cor verde-azulada, transparente, em flogopitito. \\
\hline NE-31-03 & Veio pegmatóide com esmeralda em flogopitito. \\
\hline $\mathrm{NE}-31-04$ & Veio pegmatóide com esmeralda em flogopitito. \\
\hline NE-31-05 & Veio pegmatóide com esmeralda em flogopitito. \\
\hline NE-31-06 & Veio pegmatóide com esmeralda verde-amarelada, fraturada, transparente, em flogopitito. \\
\hline NE-31-07 & Veio pegmatóide com esmeralda em flogopitito. \\
\hline NE-32 & Veios pegmatóide com esmeralda em flogopitito. \\
\hline NE-33 & Veios pegmatóides com esmeralda e apatita em flogopitito. \\
\hline NE-34 & $\begin{array}{l}\text { Veio de quartzo com esmeralda idiomórfica (prismática hexagonal, de } \sim 6 \mathrm{~mm} \text { de comprimento, verde-água, } \\
\text { transparente). }\end{array}$ \\
\hline NE-35a & Cristais de fluorapatita (caracterização por DRX) em flogopitito. \\
\hline NE-35b & Cristais de esmeralda de cor verde ligeiramente azulada em flogopitito. \\
\hline NE-36a & Cristais de esmeralda de veio de quartzo em flogopitito. \\
\hline NE-36b & Fragmento de esmeralda (de $\sim 2 \mathrm{~cm}$ ) verde-azulada, translúcida, de veio de quartzo. \\
\hline NE-37a & Veio de quartzo muito fraturado com esmeralda. \\
\hline NE-38 & Veio de quartzo com esmeralda (verde-azulada, translúcida) na borda do veio, em flogopitito. \\
\hline
\end{tabular}

\section{Garimpo do André}

\begin{tabular}{|l|l|}
\hline A-7a & Flogopita-anfibolito. \\
\hline A-7b & Biotita-gnaisse alterado com biotita grossa e pintas de caolim. \\
\hline A-7c & Gnaisse de granulometria fina alterado da SVS. \\
\hline A-8 & Flogopita-anfibolito. \\
\hline A-12 & Anfibolito metaultramáfico. \\
\hline A-13 & Flogopita-anfibolito com fraturas preenchidas por material fibroso, de cor verde clara. \\
\hline A-15a & Flogopitito. \\
\hline A-15b & Flogopitito. \\
\hline A-16a & Veio pegmatoide com fluorapatita (caracterização por DRX), em flogopitito. \\
\hline A-16b & Flogopitito com fluorapatita (caracterizacåa por DRX). \\
\hline A-16c & Anfibolito metaultramáfico intercalado com flogopitito. \\
\hline A-16d & Cristal de fluorapatita (caracterizacão por DRX) em flogopitito. \\
\hline
\end{tabular}

(Primeira Galeria)

\begin{tabular}{|l|l|}
\hline Gal 1 & Flogopitito com veio pegmatóide com fluorapatita (caracterizacão por DRX). \\
\hline Gal 1/2 & Dois fragmentos de esmeralda associados a veios de quartzo em flogopitito. \\
\hline Gal 1/2a & Esmeralda verde azulada de pegmatóide (com feldspato alterado e quartzo xenomórfico) em flogopitito. \\
\hline Gal 1-1 & Contato gradacional entre biotitito (amostra) e biotita-gnaisse. \\
\hline Gal 1-2 & Gnaisse da SVS, alterado. \\
\hline Gal 1-3 & Veio pegmatóide muito alterado (totalmente caolinizado). \\
\hline Gal 1-4 & Gnaisse da SVS muito alterado (caolim + mu + qzo). \\
\hline Gal 1-5 & Anfibolito metaultramáfico intercalado em flogopitito. \\
\hline Gal 1-6 & Flogopitito (< 10\% de quartzo), \\
\hline
\end{tabular}


\begin{tabular}{|l|l|}
\hline $1^{*}$ & Anfibolito metaultramáfico com cromita grada para flogopitito. \\
\hline $6^{*} \mathrm{~m}$ & Flogopita-anfibólio-xisto. \\
\hline $6^{*} \mathrm{v}$ & Anfibólio-flogopita-xisto. \\
\hline
\end{tabular}

(Segunda Galeria)

\begin{tabular}{|l|l} 
Gal 2a & Flogopitito com veios de quartzo e pegmatóides. \\
\hline
\end{tabular}

\begin{tabular}{|l|l}
\hline Gal $2 b$ & Flogopitito com veio pegmatóide com fluorapatita. \\
\hline
\end{tabular}

Gal 2c $\quad$ Anfibolito metaultramáfico.

\begin{tabular}{l|l} 
Gal $2 \mathrm{~d}$ & Flogopitito com veio pegmatoide com fluorapatita.
\end{tabular}

(Galeria Capoeirana)

\begin{tabular}{|l|l}
\hline Cap 1 & Anfibólio-flogopita-xisto.
\end{tabular}

\begin{tabular}{l|l} 
Cap 2 & Gnaisse da SVS. \\
\hline
\end{tabular}

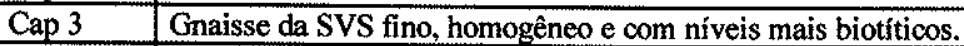

\begin{tabular}{l|l} 
Cap 4 & Anfibolito metabásico com biotita. \\
\hline
\end{tabular}

\begin{tabular}{l|l}
\hline Cap 5 & Contato entre quartzo-flogopita-cromita-anfibólio-xisto e quartzo-cromita-flogopita-xisto. \\
\hline
\end{tabular}

\section{Garimpo do ldeu}

\begin{tabular}{|l|l|}
\hline $\mathrm{I}-01$ & Contato entre granada-biotita-gnaisse e anfibolito metabásico. \\
\hline $\mathrm{I}-02$ & Flogopita-anfibolito. \\
\hline $\mathrm{I}-03$ & Flogopitito crenulado com lentes de quartzo recristalizado. \\
\hline $\mathrm{I}-04$ & Veio pegmatóide em flogopitito. \\
\hline $\mathrm{I}-05$ & Cristais de esmeralda sem caracterização mais precisa da procedência no garimpo. \\
\hline
\end{tabular}

\section{Garimpo do Boto}

\begin{tabular}{l|l}
\hline BT-01 & Flogopita-anfibólio-xisto
\end{tabular}

\begin{tabular}{|l|l}
\hline BT-02 & Flogopitito com lentes de quartzo. \\
\hline
\end{tabular}

\begin{tabular}{l|l}
\hline BT-03 & Biotita-gnaisse com anfibolito metabásico intercalado.
\end{tabular}

\begin{tabular}{|l|l|}
\hline BT-04 & Flogopita-anfibólio-xisto. \\
\hline
\end{tabular}

\section{Amostras coletas no Rio do Poixe}

\begin{tabular}{|l|l|}
\hline HC-01 & Gnaisse da SVS. \\
\hline HC-02 & Gnaisse da SVS. \\
\hline HC-03 & Anfibolio-gnaisse da SVS. \\
\hline HC-3a & Anfibolito metabásico; \\
\hline HC-06 & GB com magnetita. \\
\hline
\end{tabular}

\section{Garimpo do Alfredo}

\begin{tabular}{|l|l|}
\hline Sul 01 & Veio pegmatoide com esmeralda em flogopitito. \\
\hline
\end{tabular}

\section{Astro Mineracão}

\begin{tabular}{|l|l|}
\hline Astro 01 & Veio pegmatóide em flogopitito. \\
\hline
\end{tabular}

\section{Garimpo do Cósar}

\begin{tabular}{|l|l|}
\hline C-01 & Anfibolito metabásico. \\
\hline C-01a & Granada-anfibólio-gnaisse com opacos. \\
\hline C-02 & Flogopita-anfibólio-xisto. \\
\hline C-03 & Veio pegmatóide com esmeralda, deformado. \\
\hline 03 & GB com fluorita lilás e verde. \\
\hline
\end{tabular}

\section{Mina Bolmont}

\begin{tabular}{|l|l|}
\hline B-1 & Veio de quartzo. \\
\hline B-2 & Veio de quartzo. \\
\hline B-3 & Veio de quartzo. \\
\hline B-4 & Veio de quartzo. \\
\hline B-5 & Veio de quartzo. \\
\hline
\end{tabular}




\begin{tabular}{|c|c|}
\hline B-6 & Veio de quartzo. \\
\hline B-7 & Veio de quartzo. \\
\hline B-8 & Anfibolito. \\
\hline B-9 & Veio de quartzo. \\
\hline B-10 & Anfibolito metabásico com granada. \\
\hline $\mathrm{B}-11$ & Talco-anfibólio-clorita-xisto. \\
\hline $\mathrm{B}-12$ & Anfibolito metabásico. \\
\hline $\mathrm{B}-13$ & Veio de quartzo. \\
\hline $\mathrm{B}-14 \mathrm{a}$ & Veio de quartzo. \\
\hline $\mathrm{B}-14 \mathrm{~b}$ & Veio de quartzo. \\
\hline B-14c & Veio de quartzo. \\
\hline $\mathrm{B}-15$ & Anfibólio-flogopita-xisto avermelhado. \\
\hline $\mathrm{B}-16$ & Veio de quartzo (bloco rolado). \\
\hline $\mathrm{B}-17$ & Centro do bloco rolado. \\
\hline B-18 & Contato entre talco-anfibólio-clorita-xisto e cromitito. \\
\hline B-19 & Talco-anfibólio-clorita-xisto. \\
\hline B-20 & GB foliado; biotita envolve o felspato potássico com estrutura de fluxão. \\
\hline B-21 & Veio de quartzo fraturado, com esmeralda verde, transparente, fraturada. \\
\hline B-22 & Veio de quartzo com esmeralda. \\
\hline B-23 & Veio de quartzo com esmeralda. \\
\hline B-24 & Veio de quartzo com esmeralda. \\
\hline B-25 & Veio de quartzo com esmeralda. \\
\hline B-26 & Veio de quartzo com esmeralda. \\
\hline B-27 & Cristais de esmeralda em flogopitito. \\
\hline B-27a & Cristais de esmeralda em flogopitito. \\
\hline $\mathrm{B}-27 \mathrm{~b}$ & Cristais de esmeralda em flogopitito. \\
\hline B-28 & Cristais de esmeralda sem identificaça mais precisa da procedência no garimpo. \\
\hline B-29 & Cristais de esmeralda sem identificação mais precisa da procedência no garimpo. \\
\hline $\mathrm{B}-29 \mathrm{~b}$ & Cristais de esmeralda sem identificação mais precisa da procedência no garimpo e associação. \\
\hline B-30 & Cristais de esmeralda de cor verde intensa. \\
\hline$\overline{\mathrm{B}-31}$ & Cristais de esmeralda de cor verde clara. \\
\hline B-32 & Cristais de esmeralda de cor verde azulada. \\
\hline B-33 & Cristais de esmeralda de cor verde muito clara. \\
\hline BE-01 & Talco-anfibólio-clorita-xisto com opacos. \\
\hline BE-02 & Anfibolito metabásico. \\
\hline BE-03 & Flogopita-anfibolito com lentes de quartzo. \\
\hline BE-04 & Esmeralda verde grama, transparente, em flogopitito. \\
\hline $\mathrm{BE}-05$ & Esmeraldas de veio de quartzo. \\
\hline BE-06 & Anfibolito metaultramáfico dobrado com esmeralda. \\
\hline BE-08 & Esmeralda verde grama transparente, em flogopitito. \\
\hline
\end{tabular}


Mapa de Afloramentos da Região das Jazidas de Esmeraldas Capoeirana e Belmont-MG
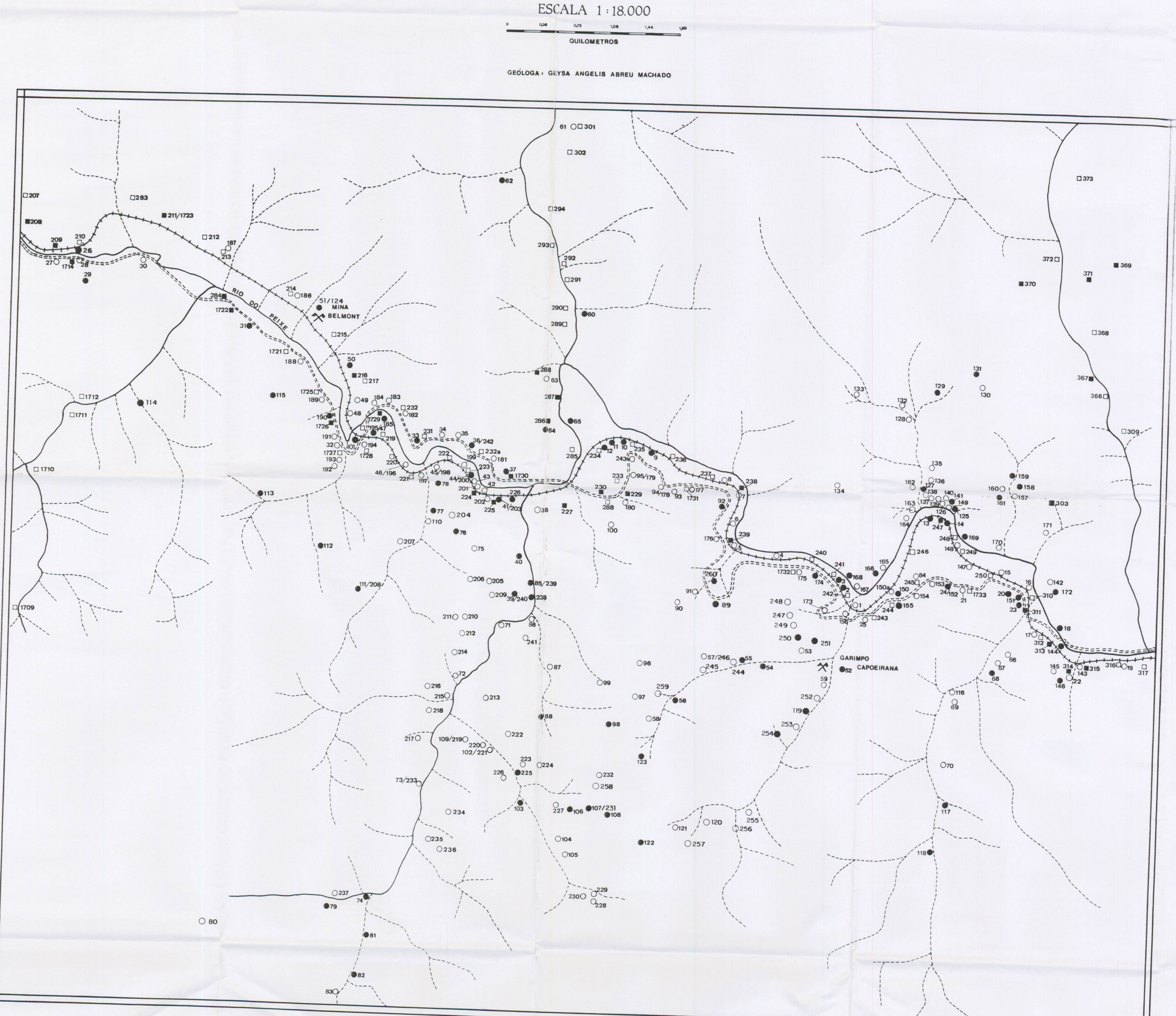

LEGENDA
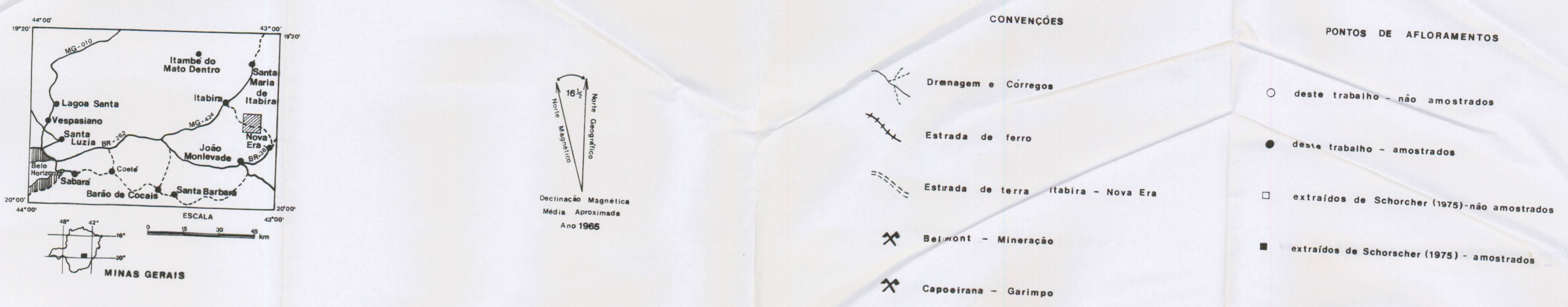


\section{ANEXO 2: Litogeoquímica}

* TABELA 2.1: Limites de Deteç̧ão e Quantificação de FRX e ICP-AES.

* TABELA 2.2: Dados analíticos de TTG e GnM.

* TABela 2.3: Dados analíticos de GB e MGF.

* TABELA 2.4: Dados analíticos de Rochas Metaultramáficas, Cromititos e Equivalentes Metassomáticos.

* TABELA 2.5: Dados analíticos de Anfibolitos (AB, ABET, ABG, AB/TTG, AFF, AC) e Gnaisses da SVS.

* TABELA 2.6: Normas CIPW de TTG, GnM, GB e MGF.

Abreviações: TTG $=$ Gnaisse da Associação TTG; GnM = Gnaisse Milonítico de Derivação Incerta; $\mathrm{GB}=$ Metagranitóide Borrachudos; $\mathrm{MGF}=$ Metagranitóide Foliado com Fluorita; $\mathrm{AU}$ = Anfibolito Metaultramáfico Não Flogopitizado; AFX = Anfibólio-Flogopita-Xisto; FAX = Flogopita-AnfibólioXisto; $\mathrm{TAX}=$ Talco-Anfibólio xisto; $\mathrm{ACX}=$ Anfibólio-Clorita Xisto; $\mathrm{CLT}=$ Cloritito; $\mathrm{CRT}=$ Cromitito CRTM $=$ Cromitito Flogopitizado; $\mathrm{AB}=$ Anfibolito Metabásico; $\mathrm{ABET}=$ Anfibolito Metabásico com Epidoto e/ou Titanita; $\mathrm{ABG}=$ Anfibolito Metabásico com Granada; $\mathrm{AB} / \mathrm{TTG}=$ Anfibolito Metabásico intercalado em Gnaisse TTG; AFF = Anfibolito de Formação Ferrífera; AC = Anfibolito Calciossilicático; Gn/SVS = Gnaisse da Sequência Metavulcano Sedimentar; FRX = Fluorescência de Raios X; ICP-AES = Espectrometria de Emissão Etômica com Fonte de Plasma Indutivamente Acoplado; n.a. = não analisado; n.d. = não detectado. 
Tabela A2.1.1: Limites de Detecção e Quantificação para ICP-AES

\begin{tabular}{|l|c|c|c|c|c|}
\hline Elemento & L.D. (\%) & L.Q. (\%) & Elemento & L.D. (ppm) & L.Q.(ppm) \\
\hline $\mathrm{SiO}_{2}$ & 0.024 & 0.10 & $\mathrm{Ba}$ & 10 & 30 \\
\hline $\mathrm{Al}_{2} \mathrm{O}_{3}$ & 0.008 & 0.04 & $\mathrm{Sr}$ & 5 & 15 \\
\hline $\mathrm{CaO}$ & 0.001 & 0.01 & $\mathrm{Zr}$ & 25 & 50 \\
\hline $\mathrm{MgO}$ & 0.005 & 0.03 & $\mathrm{~V}$ & 15 & 50 \\
\hline $\mathrm{Fe}_{2} \mathrm{O}_{3}$ & 0.001 & 0.01 & $\mathrm{Ni}$ & 15 & 50 \\
\hline $\mathrm{Na}_{2} \mathrm{O}$ & 0.006 & 0.03 & $\mathrm{Cr}$ & 15 & 50 \\
\hline $\mathrm{K}_{2} \mathrm{O}$ & 0.032 & 0.15 & $\mathrm{La}$ & 15 & 50 \\
\hline $\mathrm{P.F}$ & 0.01 & 0.10 & $\mathrm{Y}$ & 10 & 30 \\
\hline $\mathrm{H}_{2} \mathrm{O}^{-}$ & 0.01 & 0.10 & $\mathrm{Zn}$ & 10 & 30 \\
\hline $\mathrm{MnO}$ & 0.0001 & 0.0005 & $\mathrm{Cu}$ & 15 & 50 \\
\hline $\mathrm{TiO}_{2}$ & 0.0006 & 0.003 & $\mathrm{Sc}$ & 10 & 30 \\
\hline $\mathrm{P}_{2} \mathrm{O}_{5}$ & 0.009 & 0.05 & $\mathrm{Co}$ & 15 & 50 \\
\hline & & & $\mathrm{Be}$ & 1 & 5 \\
\hline
\end{tabular}

Símbolo: L.D. = limite de detecção real; L.Q. = limite de quantificação. Nota: abaixo dos limites de quantificą̧ão os valores são semi-quantificativos.

Tabela A2.1.2: Limites de Deteç̧ão para FRX

\begin{tabular}{|l|c|c|c|c|}
\hline \multicolumn{1}{|c|}{ Elemento } & L.D. (\%) & Elemento & L.D. (ppm) & D.P. \\
\hline $\mathrm{SiO}_{2}$ & 0.004 & $\mathrm{Cr}$ & 10 & 8 \\
\hline $\mathrm{Al}_{2} \mathrm{O}_{3}$ & 0.004 & $\mathrm{Ni}$ & 7 & 4 \\
\hline $\mathrm{CaO}$ & 0.0004 & $\mathrm{Co}$ & 7 & 10 \\
\hline $\mathrm{MgO}$ & 0.1 & $\mathrm{~V}$ & 15 & 7 \\
\hline $\mathrm{Fe}_{2} \mathrm{O}_{3}$ & 0.002 & $\mathrm{Cu}$ & 14 & 4 \\
\hline $\mathrm{Na}_{2} \mathrm{O}$ & 0.3 & $\mathrm{Zn}$ & 5 & 3 \\
\hline $\mathrm{K}_{2} \mathrm{O}$ & 0.0003 & $\mathrm{Rb}$ & 3 & 2 \\
\hline $\mathrm{MnO}^{\mathrm{TiO} O}$ & 0.002 & $\mathrm{Ba}$ & 30 & 18 \\
\hline $\mathrm{P}_{2} \mathrm{O}_{5}$ & 0.0001 & $\mathrm{Sr}$ & 3 & 4 \\
\hline & 0.007 & $\mathrm{Ga}$ & 6 & 2 \\
\hline & & $\mathrm{Nb}$ & 7 & 3 \\
\hline & & $\mathrm{Zr}$ & 9 & 6 \\
\hline & & $\mathrm{Y}$ & 8 & 5 \\
\hline
\end{tabular}

Símbolo: L.D. = limite de detecção; D.P. = desvio padrão. Nota: Os dados dos elementos não listados, contidos nas Tabelas A.2.2 a A.2.5 (Anexo 2) representam a análises semiquantitativas. 


\begin{tabular}{|c|c|c|c|c|c|c|c|c|c|c|c|c|c|c|c|c|c|c|c|c|}
\hline Amostra & G-18 & $G-18(1)$ & $\mathrm{G}-18(2)$ & $G-\infty$ & $G-62$ & $G-65$ & G-74 & G-88 & G-144a(1) & $G-144 a(2)$ & G-144a(3) & G-144d(1) & $\mathrm{G}-144 \mathrm{~d}(2)$ & G.240a(1) & $G-240 a(2)$ & $G-240 b(1)$ & $G-240 \mathrm{~b}(2)$ & $\mathrm{G}-24 \mathrm{Ob}(3)$ & $G-240 b(4)$ & $\mathrm{G}-103 \mathrm{a}$ \\
\hline Litotipo & TTG & TTG & TTG & ITG & $\pi G$ & ITG & TTG & TTS & $\pi \mathrm{TG}$ & TTG & TIG & TIG & TTG & TTG & TTG & TTG & TTG & TTO & TTG & GnM \\
\hline Análise & FRX & ICP-AES & CP-AES & FRX & FRX & FRX & $F R X$ & FRX & ICP-AES & ICP-AES & ICP-AES & ICP-AES & ICP-AES & ICPAAES & ICP-AES & ICP-AES & ICP-AES & CP-AES & ICP-AES & ICP-AES \\
\hline Moinho & Agata & Agata & WC & Agata & Ágata & Agata & Bgata & Agata & $W C(B r)$ & $\mathrm{Cr}-\mathrm{Fe}(\mathrm{Br})$ & $\mathrm{C}_{r}-\mathrm{Fe}(\mathrm{Br})$ & WC & $\mathrm{Cr}_{\mathrm{r}-\mathrm{F}_{\theta}}$ & WC & $\mathrm{Fe}-\mathrm{Cr}$ & WC & Angata & $\mathrm{Cr}_{\mathrm{r}-\mathrm{F}_{\theta}}$ & $\mathrm{Cr}-\mathrm{Fe}(\mathrm{Br})$ & WC \\
\hline $\mathrm{SiO}_{2}$ & 75.36 & 74.82 & 75.65 & 76.35 & 74.08 & 76.26 & 76.85 & 76.79 & 73.88 & 75.36 & 74.36 & 86.78 & 87.31 & 74.02 & 73.66 & 73.37 & 73.76 & 74.03 & $\begin{array}{r}73.29 \\
\end{array}$ & 75.01 \\
\hline $\mathrm{TiO}_{2}$ & 0.28 & 0.27 & 0.26 & 0.07 & 0.02 & 0.08 & 0.21 & 0.03 & 0.06 & 0.06 & 0.07 & 0.03 & 0.04 & 0.10 & 0.10 & 0.09 & 0.09 & 0.08 & 0.09 & 0.30 \\
\hline $\mathrm{Al}_{2} \mathrm{O}_{3}$ & 12.52 & 11.93 & 12.36 & 12.91 & 14.94 & 13.43 & 12.04 & 13.85 & 13.14 & 13.38 & 13.38 & 7.41 & 7.10 & 14.30 & 14.45 & 14.68 & 15.01 & 14.80 & 14.71 & 12.38 \\
\hline $\mathrm{Fe}_{2} \mathrm{O}_{3 \mathrm{~T}}$ & 2.99 & 2.60 & 2.63 & 1.17 & 0.37 & 1.08 & 2.38 & 0.36 & 0.59 & 0.97 & 0.95 & 0.35 & 0.80 & 0.79 & 1.09 & 0.70 & 0.70 & 1.06 & 1.07 & 2.71 \\
\hline MnO & 0.06 & 0.04 & 0.04 & 0.01 & 0.02 & 0.03 & 0.01 & 0.01 & 0.01 & 0.01 & 0.01 & 0.02 & 0.02 & 0.01 & 0.01 & 0.01 & 0.01 & 0.01 & 0.01 & 0.06 \\
\hline $\mathrm{MgO}$ & 0.16 & 0.20 & 0.20 & 0.12 & 0.12 & 0.16 & 0.04 & 0.03 & 0.08 & 0.09 & 0.09 & 0.03 & 0.04 & 0.22 & 0.22 & 0.15 & 0.15 & 0.14 & 0.14 & 0.10 \\
\hline $\mathrm{CaO}$ & 0.71 & 0.95 & 0.99 & 0.31 & 0.56 & 0.55 & 0.31 & 0.75 & 0.32 & 0.34 & 0.34 & 0.23 & 0.22 & $\$ .18$ & 1.17 & 0.82 & 0.83 & 0.82 & 0.81 & 0.93 \\
\hline $\mathrm{Na}_{2} \mathrm{O}$ & 2.87 & 3.05 & 3.08 & 3.22 & 3.56 & 3.75 & 2.63 & 3.82 & 1.90 & 1.84 & 1.86 & 2.55 & 2.51 & 4.81 & 4.82 & 4.48 & 4.54 & 4.47 & 4.46 & 2.87 \\
\hline $\mathrm{K}_{2} \mathrm{O}$ & 5.20 & 4.82 & 4.93 & 5.84 & 6.32 & 4.60 & 5.50 & 4.34 & 8.71 & 8.72 & 8.55 & 2.27 & 2.09 & 3.56 & 3.59 & 4.06 & 4.02 & 4.03 & 4.00 & 5.05 \\
\hline $\mathrm{P}_{2} \mathrm{O}_{5}$ & 0.06 & 0.04 & 0.03 & 0.01 & 0.01 & 0.05 & 0.02 & 0.03 & 0.12 & 0.11 & 0.11 & 0.01 & 0.01 & 0.04 & 0.03 & 0.02 & 0.02 & 0.02 & 0.04 & 0.02 \\
\hline $\mathrm{H}_{2} \mathrm{O}$ & 0.78 & 0.11 & 0.23 & 0.47 & 0.68 & 0.55 & 0.60 & 0.80 & 0.16 & 0.25 & 0.25 & 0.15 & 0.12 & 0.08 & 0.14 & 0.18 & 0.09 & 0.23 & 0.23 & 0.09 \\
\hline LOI & 0.93 & 0.60 & 0.65 & 0.71 & 0.91 & 0.73 & 0.90 & 1.06 & 0.43 & 0.59 & 0.59 & 0.35 & 0.22 & 0.34 & 0.42 & 0.91 & 0.66 & 0.87 & 0.86 & 0.40 \\
\hline Total & 101.92 & 99.43 & 101.05 & 101.19 & 101.59 & 101.27 & 101.49 & 101.87 & 99.40 & 101.72 & 100.56 & 100.18 & 100.48 & 99.45 & 99.70 & 99.47 & 99.88 & 100.56 & 99.71 & 99.92 \\
\hline $\mathrm{Cl}$ & 2.0 & 15.0 & 15.0 & 3.00 & 1.00 & n.d. & n.d. & n.d. & 15.00 & 300.00 & 309.00 & 15.00 & 352.00 & 15.00 & 270.00 & 15.00 & 15.00 & 332.00 & 333.00 & 15.00 \\
\hline $\mathrm{Ni}$ & n.d. & 15.0 & 15.0 & 2.00 & n.d & n.d. & n.d. & n.d. & 26.00 & 15.00 & 15.00 & 15.00 & 15.00 & 18.00 & 18.00 & 17.00 & 19.00 & 29.00 & 24.00 & 25.00 \\
\hline$C_{0}$ & n.d. & 15.0 & 172.0 & n.d. & n.d. & n.d. & 7.00 & 1.00 & 74.00 & 15.00 & 15.00 & 129.00 & 15.00 & 54.00 & 15.00 & 148.00 & 15.00 & 16.00 & 15.00 & 44.00 \\
\hline$S c$ & n.a. & 10.0 & 10.0 & n.a. & n.a. & n.a. & n.a. & n.a. & 10.00 & 10.00 & 10.00 & 10.00 & 10.00 & 10.00 & 10.00 & 10.00 & 10.00 & 10.00 & 10.00 & 10.00 \\
\hline $\mathrm{V}$ & 44.0 & 15.0 & 15.0 & 9.00 & 9.00 & 10.00 & 23.00 & 9.00 & 15.00 & 15.00 & 17.00 & 15.00 & 15.00 & 19.00 & 28.00 & 15.00 & 24.00 & 20.00 & 23.00 & 15.00 \\
\hline $\mathrm{Cu}$ & 10.0 & 15.0 & 15.0 & 7.00 & 21.00 & 13.00 & 16.00 & 17.00 & 15.00 & 15.00 & 15.00 & 15.00 & 15.00 & 15.00 & 18.00 & 15.00 & 15.00 & 15.00 & 15.00 & 15.00 \\
\hline $\mathrm{Pb}$ & 38.0 & n.a. & ก.a. & 63.00 & 65.00 & 41.00 & 47.00 & 45.00 & n.a. & n.a. & n.a. & n.a. & n.a & n.a. & n.a. & n.a. & n.a. & n.a. & n.a. & n.a. \\
\hline $\mathrm{Zn}$ & 61.0 & 56.0 & 51.0 & 58.00 & 26.00 & 39.00 & 53.00 & 32.00 & 10.00 & 12.00 & 10.00 & 12.00 & 23.00 & 93.00 & 98.00 & 72.00 & 73.00 & 66.00 & 60.00 & 100.00 \\
\hline$R b$ & 252.0 & n.a. & n.a. & 343.00 & 291.00 & 237.00 & 236.00 & 124.00 & n.a. & n.a. & n.a. & n.a. & n.a. & n.a. & n.a. & n.a. & n.a. & n.a. & n.a. & n.a. \\
\hline $\mathrm{Ba}$ & 705.0 & 636.0 & 622.0 & 95.00 & 1514.00 & 564.00 & 419.00 & 951.00 & 1309.00 & 1239.00 & 1285.00 & 34.00 & 34.00 & 452,00 & 432.00 & 1034.00 & 1036.00 & 986.00 & 1028.00 & 888.00 \\
\hline $\mathrm{Sr}$ & 98.0 & 100.0 & 98.0 & 6.00 & 148.00 & 70.00 & 33.00 & 292.00 & 133.00 & 124.00 & 130.00 & 19.00 & 19.00 & 149.00 & 146.00 & 173.00 & 173.00 & 164.00 & 170.00 & 87.00 \\
\hline $\mathrm{Ga}$ & 17.0 & n.a. & n.a. & 20.00 & 14.00 & 16.00 & 23.00 & 14.00 & n.a. & n.a. & n.a. & n.a. & n.a. & n.a. & n.a. & ก.a. & n.a. & n.a. & n.a. & n.a. \\
\hline $\mathrm{Nb}$ & 25.5 & n.a. & n.a. & 55.30 & 8.10 & 20.10 & 38.40 & 10.20 & n.a. & n.a. & n.a. & n.a. & na. & n.a. & n.a. & ก.a. & n.a. & n.a. & n.a. & n.a. \\
\hline $\mathrm{Zr}$ & 308.0 & 257.0 & 232.0 & 191.00 & 34.00 & 84.00 & 390.00 & 71.00 & 25.00 & 25.00 & 25.00 & 62.00 & 27.00 & 25.00 & 25.00 & 25.00 & 25.00 & 25.00 & 25.00 & 445.00 \\
\hline $\bar{Y}$ & 45.0 & 63.0 & 64.0 & 43.00 & 17.00 & 30.00 & 48.00 & 12.00 & 15.00 & 24.00 & 25.00 & 24.00 & 24.00 & 20.00 & 10.00 & 10.00 & 10.00 & 10.00 & 10.00 & 88.00 \\
\hline Th & 37.7 & n.a. & ก.a. & 27.15 & 0.02 & 18.06 & 48.75 & 3.05 & n.a. & n.a. & n.a. & n.a. & n.a. & n.a. & n.a. & n.a. & n.a. & n.a. & B.a. & n.a. \\
\hline$U$ & 13.2 & n.a. & n.a. & 8.05 & 1.01 & 5.01 & 3.12 & 4.07 & n.a. & n.a. & n.a & n.a. & n.a. & n.a. & n.a. & n.a. & n.a. & n.a. & ก.a. & n.a. \\
\hline $\mathrm{La}$ & 55.0 & 69.0 & 77.0 & 34.18 & 3.02 & 3.01 & 109.97 & 3.05 & 15.00 & 15.00 & 15.00 & 15.00 & 15.00 & 100.00 & 97.00 & 15.00 & 15.00 & 15.00 & 21.00 & 140.00 \\
\hline $\mathrm{Ce}$ & 188.3 & n.a. & n.a. & 72.39 & 2.02 & 30.10 & 237.56 & 35.64 & n.a. & n.a. & n.a. & n.a. & n.a. & n.a. & n.a. & n.a. & n.a. & n.a. & n.a. & n.a. \\
\hline Nd & 60.1 & n.a. & n.a. & 21.11 & ก.d. & 10.04 & 54.98 & 10.18 & n.a. & n.a. & n.a. & n.a. & n.a. & n.a. & n.a. & n.a. & n.a. & n.a. & ก.a. & n.a. \\
\hline Be & n.a. & 1.0 & 2.0 & n.a. & n.a. & n.a. & n.a. & n.a. & 1.00 & 1.00 & 1.00 & 2.00 & 2.00 & 32.00 & 31.00 & 13.00 & 13.00 & 13.00 & 13.00 & 5.00 \\
\hline
\end{tabular}

Tabela A2.2: Dados analíticos de TTG e GnM. 


\begin{tabular}{|c|c|c|c|c|c|c|c|}
\hline Amostra & G-103b & $G-103 b$ & $G-106$ & G-111 & $\mathrm{G}=112$ & G-113 & $G-123$ \\
\hline Litotipo & GnM & $\mathrm{GnM}$ & $\mathrm{GnM}$ & GnM & GRM & GnM & $\mathrm{GnM}$ \\
\hline Análise & ICP-AES & ICP-AES & ICP-AES & ICP-AES & ICP-AES & ICP-AES & ICP-AES \\
\hline Moinho & $\mathrm{WC}^{\prime}(\mathrm{Br})$ & WC & WC & WC & WC & WC & WC \\
\hline $\mathrm{SiO}_{2}$ & 71.51 & 72.66 & 73.27 & 75.03 & 73.11 & 69.49 & 83.26 \\
\hline $\mathrm{TO}_{2}$ & 0.30 & 0.29 & 0.29 & 0.13 & 0.45 & 0.51 & 0.08 \\
\hline $\mathrm{Al}_{2} \mathrm{O}_{3}$ & 13.87 & 13.89 & 12.56 & 14.24 & 11.89 & 13.87 & 9.25 \\
\hline $\mathrm{Fe}_{2} \mathrm{O}_{3 \mathrm{~T}}$ & 3.42 & 3.57 & 3.41 & 1.07 & 4.67 & 6.15 & 1.07 \\
\hline $\mathrm{MnO}$ & 0.03 & 0.03 & 0.04 & 0.01 & 0.06 & 0.06 & 0.02 \\
\hline $\mathrm{MgO}$ & 0.02 & 0.02 & 0.05 & 0.18 & 0.14 & 0.51 & 0.30 \\
\hline $\mathrm{CaO}$ & 0.01 & 0.01 & 1.02 & 0.46 & 1.73 & 0.85 & 0.21 \\
\hline $\mathrm{Na}_{2} \mathrm{O}$ & 0.41 & 0.42 & 3.07 & 3.39 & 2.82 & 2.96 & 0.61 \\
\hline $\mathrm{K}_{2} \mathrm{O}$ & 5.46 & 5.53 & 4.93 & 4.30 & 4.18 & 4.51 & 2.80 \\
\hline $\mathrm{P}_{2} \mathrm{O}_{5}$ & 0.01 & 0.01 & 0.02 & 0.01 & 0.09 & 0.04 & 0.17 \\
\hline $\mathrm{H}_{2} \mathrm{O}$ & 0.55 & 0.55 & 0.22 & 0.27 & 0.24 & 0.38 & 0.51 \\
\hline $\mathrm{LO}$ & 3.86 & 3.96 & 0.66 & 1.23 & 0.50 & 1.32 & 1.96 \\
\hline Total & 99.45 & 100.94 & 99.54 & 100.32 & 99.88 & 100.65 & 100.24 \\
\hline $\mathrm{C}_{\mathrm{r}}$ & 15.00 & 15.00 & 15.00 & 15.00 & 15.00 & 45.00 & 15.00 \\
\hline $\mathrm{Ni}$ & 29.00 & 23.00 & 15.00 & 22.00 & 15.00 & 15.00 & 29.00 \\
\hline Co & 60.00 & 63.00 & 110.00 & 78.00 & 91.00 & 46.00 & 286.00 \\
\hline Sc & 10.00 & 40.00 & 10.00 & 10.00 & 10.00 & 10.00 & 10.00 \\
\hline $\mathrm{V}$ & 15.00 & 15.00 & 15.00 & 15.00 & 15.00 & 15.00 & 15.00 \\
\hline $\mathrm{Cu}$ & 16.00 & 16.00 & 15.00 & 15.00 & 15.00 & 15.00 & 15.00 \\
\hline $\mathrm{Pb}$ & n.a. & n.a. & n.a. & n.a. & n.a. & n.a. & n.a. \\
\hline$Z_{n}$ & 125.00 & 133.00 & 102.00 & 40.00 & 101.00 & 183.00 & 44.00 \\
\hline $\mathrm{Rb}_{\mathrm{b}}$ & n.a. & n.a. & n.a. & n.a. & n.a. & n.a. & n.a. \\
\hline $8 a$ & 909.00 & 908.00 & 924.00 & 669.00 & 1490.00 & 1342.00 & 321.00 \\
\hline $\mathrm{Sr}$ & 40.00 & 41.00 & 86.00 & 88.00 & 160.00 & 109.00 & 39.00 \\
\hline $\mathrm{Ga}$ & n.a. & n.a. & n.a. & n.a. & n.a. & n.a. & n.a. \\
\hline $\mathrm{Nb}$ & n.a. & n.a. & n.a. & n.a. & n.a. & n.a. & n.a. \\
\hline $\mathrm{Zr}$ & 440.00 & 483.00 & 446.00 & 91.00 & 438.00 & 745.00 & 25.00 \\
\hline $\bar{Y}$ & 101.00 & 100.00 & 55.00 & 24.00 & 58.00 & 109.00 & 10.00 \\
\hline Th & n.a. & n.a. & n.a. & n.a. & n.a. & n.a. & n.a. \\
\hline $\mathrm{U}$ & n.a. & n.a. & n.a. & n.a. & n.a. & n.a. & n.a. \\
\hline La & 104.00 & 103.00 & 29.00 & 16.00 & 103.00 & 122.00 & 38.00 \\
\hline $\mathrm{Ce}$ & ก.a. & ก.a. & n.a. & n.a. & ก.a. & n.a. & n.a. \\
\hline Nd & ก.. & n.a. & n.a. & n.a. & ก.a. & n.a. & n.a. \\
\hline$\overline{B e}$ & 1.00 & 1.00 & 3.00 & 4.00 & 2.00 & 3.00 & 2.00 \\
\hline
\end{tabular}

Tabela A2.2: Dados analíticos de TTG e GnM 


\begin{tabular}{|c|c|c|c|c|c|c|c|c|c|c|c|c|c|c|c|}
\hline Amostra & 03 & G-26 & $\mathrm{G}-29 \mathrm{a}$ & G-29b & $G-29 c$ & G-29d & G-31 & $\mathrm{G}-29 \mathrm{e}$ & G-2a & $G=2 b$ & G-3a & G-3b & G-11a & G-11d & G-13a \\
\hline Litotipo & $\mathrm{GB}$ & GB & $\mathrm{GB}$ & GB & $\mathrm{GB}$ & $\mathrm{GB}$ & GB & $G B$ & MGF & MGF & MGF & MGF & MGF & MGF & MGF \\
\hline Análise & FRX & FRX & FRX & FRX & FRX & FRX & $F R X$ & FRX & FRX & FRX & FRX & FRX & FRX & FRX & FRX \\
\hline Moinho & Agata & Agata & Agata & Agata & Agata & Agata & Agata & Agata & Agata & Agata & Agata & Agata & Agata & Agata & Agata \\
\hline $\mathrm{SiO}_{2}$ & 51.86 & 74.34 & 75.76 & 76.15 & 73.96 & 76.77 & 72.64 & 77.64 & 78.91 & 70.64 & 78.42 & 76.06 & 79.83 & 77.01 & 77.36 \\
\hline $\mathrm{TiO}_{2}$ & 0.32 & 0.24 & 0.14 & 0.19 & 0.22 & 0.21 & 0.49 & 0.21 & 0.14 & 0.22 & 0.15 & 0.17 & 0.14 & 0.16 & 0.11 \\
\hline $\mathrm{Al}_{2} \mathrm{O}_{3}$ & 14.54 & 12.90 & 12.77 & 11.92 & 13.25 & 11.79 & 12.07 & 11.15 & 10.91 & 14.53 & 10.97 & 11.74 & 10.44 & 11.75 & 11.74 \\
\hline $\mathrm{Fe}_{2} \mathrm{O}_{3 \uparrow}$ & 2.00 & 0.73 & 0.43 & 0.63 & 0.68 & 0.64 & 1.43 & 0.64 & 0.49 & 0.77 & 0.54 & 0.59 & 0.59 & 0.60 & 0.46 \\
\hline $\mathrm{FeO}$ & 5.25 & 1.90 & 1.13 & 1.65 & 1.77 & 1.67 & 3.74 & 1.67 & 1.27 & 2.03 & 1.43 & 1.55 & 1.55 & 1.58 & 1.20 \\
\hline $\mathrm{MnO}$ & 0.20 & 0.03 & 0.02 & 0.02 & 0.03 & 0.03 & 0.07 & 0.03 & 0.03 & 0.13 & 0.03 & 0.09 & 0.03 & 0.03 & 0.01 \\
\hline $\mathrm{MgO}$ & 0.36 & 0.04 & n.d. & n.d. & 0.03 & 0.02 & 0.14 & n.d. & n.d. & 0.09 & n.d. & 0.14 & 0.02 & 0.03 & 0.12 \\
\hline $\mathrm{CaO}$ & 10.05 & 1.35 & 0.65 & 0.94 & 1.09 & 1.19 & 1.47 & 0.97 & 0.55 & 1.73 & 0.59 & 0.81 & 0.50 & 0.55 & 0.66 \\
\hline $\mathrm{Na}_{2} \mathrm{O}$ & 2.81 & 3.31 & 2.93 & 2.70 & 3.09 & 3.02 & 2.88 & 2.76 & 3.11 & 4.41 & 3.21 & 2.04 & 3.13 & 3.55 & 2.89 \\
\hline $\mathrm{K}_{2} \mathrm{O}$ & 6.83 & 4.91 & 6.02 & 5.60 & 5.66 & 4.45 & 4.52 & 4.70 & 4.55 & 5.20 & 4.50 & 6.61 & 3.58 & 4.54 & 5.31 \\
\hline $\mathrm{P}_{2} \mathrm{O}_{5}$ & 0.03 & 0.04 & 0.02 & 0.02 & 0.04 & 0.03 & 0.12 & 0.03 & 0.01 & 0.02 & 0.01 & 0.02 & 0.02 & 0.02 & 0.01 \\
\hline Total & 94.25 & 99.80 & 99.88 & 99.83 & 99.83 & 99.83 & 99.57 & 99.79 & 99.98 & 99.78 & 99.85 & 99.83 & 99.83 & 99.83 & 99.88 \\
\hline $\mathrm{H}_{2} \mathrm{O}$ & 0.34 & 0.56 & 0.62 & 0.59 & 0.46 & 0.51 & 0.24 & 0.43 & 0.38 & 1.22 & 0.36 & 0.49 & 0.41 & 0.02 & 0.52 \\
\hline LOI & 3.88 & 0.59 & 0.65 & 0.59 & 0.54 & 0.70 & 0.34 & 0.63 & 0.43 & 1.30 & 0.42 & 0.64 & 0.51 & 0.10 & 0.52 \\
\hline $\mathrm{Cr}$ & 9.00 & n.d. & n.d. & n.d. & n.d. & n.d. & n.d. & n.d. & n.d. & n.d. & n.d. & 3.01 & n.d. & n.d. & n.d \\
\hline $\mathrm{Ni}$ & 9.00 & n.d. & n.d. & n.d. & n.d. & n.d. & n.d. & n.d. & n.d. & n.d. & n.d. & n.d. & n.d. & n.d. & n.d \\
\hline Co & 6.42 & 15.03 & 8.01 & n.d. & n.d. & n.d. & n.d. & 8.99 & n.d. & 9.02 & n.d. & n.d. & 8.01 & n.d. & n.d \\
\hline $\mathrm{V}$ & 14.00 & 31.07 & 15.02 & 24.04 & 30.06 & 25.05 & 62.27 & 26.97 & 14.02 & 21.05 & 20.03 & 20.04 & 17.03 & 14.03 & 11.01 \\
\hline $\mathrm{Cu}$ & 23.00 & 18.04 & 12.02 & 23.04 & 7.01 & 14.03 & 25.11 & 13.99 & 19.02 & 26.06 & 16.03 & 7.01 & 14.02 & 10.02 & 10.01 \\
\hline $\mathrm{Pb}$ & 1118.00 & 53.11 & 41.05 & 44.08 & 47.09 & 38.07 & 30.13 & 35.96 & 52.07 & 18230.00 & 55.09 & 657.00 & 46.08 & 60.11 & 48.06 \\
\hline $\mathrm{Zn}$ & 4126.00 & 123.26 & 55.07 & 65.12 & 74.15 & 70.13 & 135.00 & 80.92 & 122.16 & 20529.00 & 155.25 & 598.00 & 377.00 & 145.26 & 82.11 \\
\hline$S$ & 0.01 & 0.02 & 0.02 & 0.02 & 0.01 & 0.02 & 0.02 & 0.01 & 0.02 & 0.04 & 0.02 & 0.02 & 0.02 & 0.02 & 0.01 \\
\hline $\bar{K}$ & 56698.00 & 40738.00 & 49970.00 & 46454.00 & 46878.00 & 36975.00 & 37498.00 & 39033.00 & 37787.00 & 43146.00 & 37322.00 & 54851.00 & 29732.00 & 37661.00 & 44082.00 \\
\hline $\mathrm{Rb}$ & 367.00 & 195.41 & 228.30 & 233.42 & 236.47 & 206.37 & 110.48 & 205.79 & 308.40 & 217.00 & 320.00 & 283.00 & 241.41 & 347.00 & 397.00 \\
\hline $\mathrm{Ba}$ & 531.00 & 1130.00 & 672.00 & 630.00 & 1278.00 & 628.00 & 1762.00 & 599.00 & 118.15 & 898.00 & 117.19 & 766.00 & 32.05 & 120.22 & 51.07 \\
\hline $\mathrm{Sr}$ & 45.00 & 134.28 & 75.10 & 78.14 & 118.24 & 77.14 & 198.00 & 76.92 & 6.01 & 70.16 & 8.01 & 60.11 & 13.02 & 9.02 & 6.01 \\
\hline $\mathrm{Ga}$ & 74.00 & 22.05 & 22.03 & 18.03 & 16.03 & 18.03 & 15.06 & 17.98 & 18.02 & 193.44 & 18.03 & 17.03 & 18.03 & 22.04 & 22.03 \\
\hline $\mathrm{Nb}$ & 32.00 & 31.40 & 35.55 & 34.40 & 52.90 & 36.50 & 35.80 & 33.37 & 59.50 & 53.60 & 58.60 & 54.00 & 57.80 & 68.70 & 69.00 \\
\hline $\mathrm{Zr}$ & 375.00 & 379.00 & 304.40 & 332.00 & 364.00 & 333.00 & 589.00 & 350.65 & 333.43 & 345.00 & 360.00 & 316.00 & 333.00 & 431.00 & 306.40 \\
\hline $\mathrm{Ti}$ & 1918.00 & 1456.00 & 850.00 & 1153.00 & 1342.00 & 1277.00 & 2948.00 & 1276.00 & 847.00 & 1312.00 & 908.00 & 1037.00 & 851.00 & 969.00 & 669.00 \\
\hline $\bar{Y}$ & 191.00 & 59.12 & 93.12 & 83.15 & 179.36 & 84.15 & 66.29 & 80.92 & 96.12 & 200.46 & 99.16 & 166.30 & 112.19 & 96.17 & 119.15 \\
\hline Th & 55.00 & 25.30 & 39.52 & 36.45 & 25.44 & 33.48 & 16.39 & 41.55 & 37.34 & 296.53 & 43.44 & 39.71 & 66.96 & 45.47 & 44.67 \\
\hline $\mathrm{U}$ & 9.00 & 3.04 & 12.16 & 4.05 & 7.12 & 7.10 & 6.15 & 11.15 & 9.08 & 5.47 & 15.15 & 9.16 & 29.42 & 10.10 & 16.25 \\
\hline La & 132.00 & 63.75 & 237.13 & 129.53 & 246.24 & 134.94 & 92.18 & 138.83 & 80.74 & 172.89 & 142.45 & 292.20 & 253.65 & 162.68 & 104.58 \\
\hline $\mathrm{Ce}$ & 287.00 & 142.67 & 314.15 & 270.19 & 210.62 & 254.67 & 135.20 & 266.52 & 170.57 & 579.93 & 247.52 & 187.33 & 414.98 & 268.77 & 173.62 \\
\hline Nd & 111.00 & 71.84 & 144.91 & 111.31 & 179.08 & 98.42 & 100.38 & 111.47 & 64.59 & 157.57 & 95.98 & 159.85 & 151.18 & 106.09 & 72.09 \\
\hline
\end{tabular}

Tabela A2.3: Dados analíticos de GB e MGF. 


\begin{tabular}{|c|c|c|c|c|c|c|c|c|c|c|c|c|c|c|c|c|c|c|c|c|}
\hline Amostra & A-08 & $\mathrm{A}-13$ & $\sigma^{2}-m$ & $6^{*} M$ & BE-03 & G-520 & G-52g & G-150a & G-195 & G-231d & $1-02 a$ & NE-29b & NE-29o(1) & A-7a & BT-01 & $\mathrm{C}-02$ & Gal 1-5 & Gal 1-6 & NE-7 & NE-7(1) \\
\hline Litotipo & $A U$ & $\mathrm{AU}$ & $\mathrm{AU}$ & $A U$ & $\mathrm{AU}$ & $A U$ & $A U$ & $\mathrm{AU}$ & $A U$ & $\mathrm{AU}$ & $A U$ & $\mathrm{AU}$ & $\mathrm{AU}$ & AFX & AFX & AFX & AFX & AFX & AFX & AFX \\
\hline Análise & $F R X$ & ICP-AES & FRX & ICP-AES & $F R X$ & ICP-AES & ICP-AES & \begin{tabular}{|l|} 
ICP-AES \\
\end{tabular} & ICP-AES & ICP-AES & $F R X$ & FRX & ICP-AES & FRX & FRX & FRX & FRX & FRX & FRX & ICP-AES \\
\hline Moinho & Agata & WC & Agata & WC & Agata & WC & WC & $w C$ & WC & Wc & Aga过a & Ágata & WC & Agata & Agata & Acata & Ágała & Acata & Ágata & WC \\
\hline $\mathrm{SiO}_{2}$ & 45.86 & 48.58 & 41.84 & 43.22 & 45.41 & 51.82 & 48.25 & 50.76 & 53.66 & 51.85 & 52.63 & 45.59 & 47.30 & 45.11 & 48.41 & 50.17 & 47.65 & 44.80 & 46.68 & 48.83 \\
\hline $\mathrm{TiO}_{2}$ & 0.28 & 0.14 & 0.34 & 0.47 & 0.65 & 0.27 & 0.19 & 0.26 & 0.67 & 0.10 & 0.44 & 0.16 & 0.17 & 0.28 & 0.20 & 0.23 & 0.20 & 0.30 & 0.28 & 0.30 \\
\hline $\mathrm{Al}_{2} \mathrm{O}_{3}$ & 8.39 & 7.81 & 10.07 & 12.50 & 12.59 & 9.47 & 10.18 & 10.44 & 3.58 & 5.17 & 2.14 & 9.27 & 10.40 & 8.18 & 7.16 & 7.08 & 7.84 & 8.73 & 9.83 & 10.13 \\
\hline $\mathrm{Fe}_{2} \mathrm{O}_{3 \mathrm{~T}}$ & 10.59 & 9.54 & 12.34 & 12.98 & 12.73 & 12.50 & 9.14 & 9.71 & 12.71 & 9.47 & 17.41 & 10.37 & 10.72 & 10.48 & 9.53 & 9.57 & 10.99 & 11.32 & 9.82 & 10.23 \\
\hline Mno & 0.23 & 0.27 & 0.25 & 0.21 & 0.21 & 0.29 & 0.18 & 0.17 & 0.25 & 0.17 & 0.61 & 0.22 & 0.21 & 0.24 & 0.22 & 0.23 & 0.38 & 0.29 & 0.25 & 0.24 \\
\hline $\mathrm{MgO}$ & 18.20 & 17.12 & 15.63 & 16.58 & 13.75 & 16.84 & 16.46 & 16.83 & 17.54 & 16.97 & 20.11 & 17.71 & 19.12 & 17.50 & 18.51 & 18.21 & 16.11 & 17.83 & 18.15 & 17.20 \\
\hline $\mathrm{CaO}$ & 6.23 & 11.40 & 4.57 & 3.31 & 9.17 & 4.42 & 9.88 & 7.36 & 9.31 & 12.42 & 5.18 & 2.80 & 2.84 & 7.33 & 8.93 & 9.44 & 10.26 & 3.70 & 5.81 & 5.53 \\
\hline $\mathrm{Na}_{2} \mathrm{O}$ & 0.34 & 0.88 & 0.80 & 0.17 & 0.94 & 0.62 & 1.13 & 1.11 & 0.44 & 0.54 & 0.56 & 0.11 & 0.17 & 0.38 & 0.69 & 0.79 & 1.14 & 0.32 & 0.69 & 0.78 \\
\hline $\mathrm{K}_{2} \mathrm{O}$ & 0.68 & 0.17 & 0.76 & 1.27 & 0.32 & 0.52 & 0.94 & 0.48 & 0.07 & 0.17 & 0.55 & 0.63 & 0.54 & 1.03 & 1.56 & 1.18 & 1.08 & 4.13 & 3.79 & 4.16 \\
\hline $\mathrm{P}_{2} \mathrm{O}_{5}$ & 0.01 & 0.02 & 0.04 & 0.04 & 0.11 & 0.03 & 0.02 & 0.04 & 0.05 & 0.03 & 0.02 & 0.01 & 0.03 & 0.01 & 0.01 & 0.02 & 0.01 & 0.02 & 0.01 & 0.03 \\
\hline $\mathrm{H}_{2} \mathrm{O}$ & 4.41 & 1.35 & 6.58 & 7.70 & 2.27 & 3.14 & 0.20 & 0.03 & 0.04 & 0.31 & 0.87 & 6.73 & 6.95 & 3.57 & 0.42 & 0.33 & 0.34 & 2.27 & 0.48 & 0.39 \\
\hline $\mathrm{LO}$ & 9.25 & 1.51 & 13.00 & 8.45 & 3.05 & 3.86 & 1.63 & 1.31 & 1.52 & 2.15 & 0.96 & 12.92 & 7.25 & 8.13 & 2.64 & 2.12 & 1.57 & 6.77 & 3.24 & 1.56 \\
\hline Tokal & 104.47 & 98.79 & 106.22 & 106.90 & 101.20 & 103.78 & 98.20 & 98.50 & 99.84 & 99.35 & 101.48 & 106.52 & 105.70 & 102.24 & 98.28 & 99.37 & 97.57 & 100.48 & 99.03 & 99.38 \\
\hline $\mathrm{Cr}$ & 2292.00 & 7490.00 & 2351.00 & 2671.00 & 6965.00 & 2356.00 & 5119.00 & 3380.00 & 1480.00 & 272.00 & 1539.00 & 1978.00 & 2059.00 & 2078.00 & 2120.00 & 1693.00 & 8556.00 & 2354.00 & 2222.00 & 2214.00 \\
\hline $\mathrm{Ni}$ & 342.00 & 272.00 & 321.00 & 331.00 & 385.00 & 325.00 & 243.00 & 273.00 & 1524.00 & 552.00 & 1267.00 & 266.00 & 343.00 & 311.00 & 493.00 & 416.00 & 271.00 & 330.00 & 298.00 & 330.00 \\
\hline $\mathrm{Co}$ & 53.00 & 42.00 & 56.00 & 69.00 & 61.00 & 65.00 & 51.00 & 61.00 & 201.00 & 111.00 & 77.00 & 39.00 & 58.00 & 57.00 & 60.00 & 40.00 & 79.00 & 57.00 & 79.00 & 54.00 \\
\hline Sc & n.a. & n.a. & n.a. & 31.00 & n.a. & 34.00 & 37.00 & 29.00 & 10.00 & 23.00 & n.a. & n.a. & 26.00 & n.a. & n.a. & n.a. & n.a. & n.a. & n.a. & 32.00 \\
\hline $\mathrm{V}$ & 79.00 & 130.00 & 136.00 & 143.00 & 151.00 & 102.00 & 135.00 & 108.00 & 67.00 & 67.00 & 59.00 & 52.00 & 61.00 & 92.00 & 74.00 & 81.00 & 114.00 & 94.00 & 95.00 & 123.00 \\
\hline $\mathrm{Cu}$ & 13.00 & n.d. & 20.00 & 15.00 & n.d. & 15.00 & 15.00 & 15.00 & 360.00 & 177.00 & n.d. & 7.00 & 15.00 & 6.00 & 11.00 & 12.00 & 17.00 & 7.00 & 13.00 & 15.00 \\
\hline $\mathrm{Pb}$ & 7.00 & n.d. & 3.00 & n.a. & 8.00 & n.a. & n.a. & n.a. & ก.a. & n.a. & 3.00 & 6.00 & n.a. & 14.00 & 11.00 & 14.00 & 13.00 & 11.00 & 13.00 & n.a. \\
\hline $\mathrm{Zn}$ & 366.00 & 324.00 & 521.00 & 520.00 & 175.00 & 224.00 & 133.00 & 128.00 & 257.00 & 97.00 & 455.00 & 357.00 & 332.00 & 299.00 & 199.00 & 498.00 & 458.00 & 499.00 & 574.00 & 495.00 \\
\hline $\mathrm{Rb}$ & 98.00 & 4.00 & 128.00 & n.a. & 12.00 & n.a. & n.a. & n.a. & n.a. & ก.a. & 68.00 & 95.00 & n.a. & 142.00 & 199.00 & 138.00 & 120.00 & 667.00 & 492.00 & n.a. \\
\hline $\mathrm{Ba}$ & 58.00 & 41.00 & 114.00 & 149.00 & 34.00 & 50.00 & 25.00 & 12.00 & 31.00 & 10.00 & n.d. & 25.00 & 60.00 & 60.00 & 48.00 & 43.00 & 15.00 & 152.00 & 117.00 & 126.00 \\
\hline St & 1.00 & n.d. & n.d. & 5.00 & 5.00 & 5.00 & 5.00 & 5.00 & 5.00 & 5.00 & n.d. & n.d. & 5.00 & n.d. & 5.00 & 1.00 & n.d. & n.d. & 2.00 & 5.00 \\
\hline $\mathrm{Ga}$ & 16.00 & 8.00 & 24.00 & n.a. & 16.00 & n.a. & n.a. & n.a. & n.a. & n.a. & 5.00 & 6.00 & n.a. & 15.00 & 21.00 & 19.00 & 32.00 & 15.00 & 22.00 & n.a. \\
\hline $\mathrm{Nb}$ & 21.00 & 10.00 & 3.00 & n.a. & 7.00 & n.a. & n.a. & n.a. & n.a. & n.a. & 14.00 & 7.00 & n.a. & & 14.00 & & 15.00 & 25.00 & 28.00 & n.a. \\
\hline $\mathrm{Zr}$ & 15.00 & n.d. & 13.00 & 35.00 & 53.00 & 25.00 & 25.00 & 25.00 & 44.00 & 25.00 & n.d. & 10.00 & 25.00 & 36.00 & 39.00 & 20.00 & 20.00 & 20.00 & 24.00 & 32.00 \\
\hline $\bar{Y}$ & 50.00 & 21.00 & 57.00 & 45.00 & 8.00 & 55.00 & 61.00 & 40.00 & 215.00 & 10.00 & n.d. & 24.00 & 10.00 & 63.00 & 91.00 & 71.00 & 82.00 & 170.00 & 170.00 & 40.00 \\
\hline$T h$ & 4.00 & n.d. & 3.00 & n.a. & 4.00 & n.a. & ก.a. & n.a. & n.a. & n.a. & n.d. & 3.00 & n.a. & 2.00 & 2.00 & 2.00 & 1.00 & 3.00 & 3.00 & n.a. \\
\hline $\mathrm{U}$ & 6.00 & n.d. & 2.00 & n.a. & n.d. & ก.a. & ח.a. & ก.a. & n.a. & n.a. & n.d. & n.o. & n.a. & 4.00 & 7.00 & 1.00 & 9.00 & n.d. & 11.00 & n.a. \\
\hline La & n.d. & n.d. & ก.d. & 9.00 & B.d. & 31.00 & 15.00 & 15.00 & 119.00 & 15.00 & n.d. & n.d. & 15.00 & n.d. & n.d. & n.d. & n.d. & n.d. & n.d. & 15.00 \\
\hline $\mathrm{Ce}$ & n.d. & n.d. & n.d. & n.a. & n.d. & n.a. & n.a. & n.a. & n.a. & n.a. & n.d. & 17.00 & n.a. & 11.00 & 15.00 & n.d. & 28.00 & 10.00 & 16.00 & n.a. \\
\hline Nd & 26.00 & ก.d. & 8.00 & n.a. & n.d. & n.a. & n.a. & n.a. & ก.a. & n.a. & n.d. & 30.00 & n.a. & 35.00 & 40.00 & 30.00 & 51.00 & 31.00 & 32.00 & n.a. \\
\hline $\mathrm{Be}$ & n.a. & n.a. & n.a. & 30.00 & n.a. & 15.00 & 26.00 & 4.00 & 4.00 & 3.00 & ก.a. & n.a. & 7.00 & n.a. & n.a. & n.a. & n.a. & n.a. & n.a. & 28.00 \\
\hline
\end{tabular}

Tabela A2.4: Dados analíticos de rochas metaultramáficas, cromititos e equivalentes metassomáticos. 


\begin{tabular}{|c|c|c|c|c|c|c|c|c|c|c|c|c|c|c|c|c|c|c|c|c|}
\hline Amostra & NE-7(2) & NE-8 & NE-8(1) & $N E-8(2)$ & NE-9 & NE-10 & NE-11 & $1-02$ & NE-25 & NE-24 & Cap-1 & $1-03$ & $1^{*}-b$ & G-51 & G-52f & $G-52 f(1)$ & $6^{*} \mathrm{v}$ & $\sigma^{*} V$ & B-19 & G-150b(1) \\
\hline Litotipo & FAX & AFX & FAX & FAX & AFX & AFX & AFX & AFX & AFX & $A F X$ & AFX & AFX & AFX & AFX & $A F X$ & AFX & AFX & AFX & TAX & TAX \\
\hline Análise & ICP-AES & $F R X$ & ICP-AES & ICP-AES & FRX & $F R X$ & FRX & $F R X$ & FRX & $F R X$ & FRX & FRX & $F R X$ & ICP-AES & FRX & ICP-AES & FRX & ICP-AES & FRX & ICP-AES \\
\hline Moinho & WC & Agata & WC & WC & Ágata & Agata & Ágata & Agata & Ágata & Agata & Agata & Ágata & Agata & WC & Ágata & WC & Agata & WC & Ágata & Agata \\
\hline $\mathrm{SiO}_{2}$ & 48.82 & 47.83 & 49.00 & 49.66 & 47.25 & 45.21 & 45.05 & 50.75 & 48.26 & 48.68 & 44.29 & 46.73 & 43.52 & 36.82 & 49.96 & 49.31 & 44.13 & 47.88 & 50.81 & 48.85 \\
\hline $\mathrm{TiO}_{2}$ & 0.30 & 0.29 & 0.30 & 0.30 & 0.33 & 0.33 & 0.31 & 0.47 & 0.23 & 0.26 & 0.32 & 0.21 & 0.32 & 0.72 & 0.18 & 0.17 & 0.26 & 0.27 & 0.11 & 0.12 \\
\hline $\mathrm{Al}_{2} \mathrm{O}_{3}$ & 10.08 & 9.10 & 8.94 & 8.96 & 9.49 & 9.70 & 10.47 & 2.93 & 8.84 & 10.00 & 12.37 & 13.37 & 14.51 & 16.07 & 9.01 & 8.29 & 8.59 & 9.26 & 3.83 & 13.36 \\
\hline $\mathrm{Fe}_{2} \mathrm{O}_{3 \mathrm{~T}}$ & 10.09 & 9.60 & 10.00 & 10.12 & 9.82 & 9.85 & 9.71 & 16.30 & 9.71 & 9.36 & 12.14 & 11.42 & 10.67 & 16.36 & 10.16 & 10.51 & 9.71 & 10.00 & 11.09 & 6.58 \\
\hline Mno & 0.24 & 0.25 & 0.27 & 0.27 & 0.23 & 0.23 & 0.20 & 0.60 & 0.17 & 0.15 & 0.20 & 0.11 & 0.15 & 0.20 & 0.25 & 0.26 & 0.20 & 0.21 & 0.18 & 0.11 \\
\hline $\mathrm{MgO}$ & 17.02 & 18.31 & 17.83 & 17.03 & 48.02 & 18.86 & 18.74 & 18.88 & 18.53 & 18.30 & 15.97 & 17.17 & 18.61 & 12.73 & 17.95 & 16.05 & 18.04 & 18.96 & 24.68 & 16.14 \\
\hline $\mathrm{CaO}$ & 5.34 & 6.58 & 6.65 & 6.71 & 5.92 & 6.04 & 5.07 & 4.27 & 8.08 & 5.84 & 1.98 & 0.26 & 1.00 & 0.14 & 9.85 & 10.33 & 5.09 & 4.91 & 4.22 & 5.87 \\
\hline $\mathrm{Na}_{2} \mathrm{O}$ & 0.77 & 0.70 & 0.79 & 0.80 & 0.60 & 0.61 & 0.59 & 0.23 & 0.63 & 0.49 & 0.35 & 0.55 & 0.67 & 0.51 & 0.93 & 1.13 & 0.20 & 0.22 & 0.52 & 1.69 \\
\hline $\mathrm{K}_{2} \mathrm{O}$ & 4.07 & 3.23 & 3.34 & 3.22 & 3.53 & 3.72 & 4.28 & 1.17 & 1.47 & 2.82 & 6.17 & 7.97 & 7.94 & 5.79 & 1.66 & 1.18 & 1.60 & 1.64 & 0.00 & 0.78 \\
\hline $\mathrm{P}_{2} \mathrm{O}_{5}$ & 0.03 & 0.02 & 0.04 & 0.03 & 0.01 & 0.01 & 0.04 & 0.01 & 0.04 & 0.03 & 0.04 & 0.00 & 0.05 & 0.04 & 0.03 & 0.04 & 0.02 & 0.02 & 0.02 & 0.03 \\
\hline $\mathrm{H}_{2} \mathrm{O}$ & 0.39 & 0.64 & 0.36 & 0.36 & 0.73 & 0.46 & 0.36 & 0.33 & 0.67 & 0.78 & 1.07 & 1.48 & 1.65 & 0.01 & 1.49 & 0.07 & 5.17 & 5.27 & 3.80 & 0.10 \\
\hline $\mathrm{LOI}$ & 1.56 & 3.12 & 1.61 & 1.61 & 3.00 & 3.29 & 3.07 & 1.89 & 2.54 & 3.44 & 3.82 & 1.70 & 1.93 & 8.64 & 1.62 & 0.87 & 11.01 & 6.27 & 3.98 & 5.01 \\
\hline Total & 98.71 & 99.67 & 99.13 & 99.07 & 98.93 & 98.31 & 97.86 & 97.83 & 99.17 & 100.15 & 98.72 & 100.97 & 101.02 & 98.03 & 103.09 & 98.21 & 104.02 & 104.91 & 103.24 & 98.64 \\
\hline $\mathrm{Cr}_{\mathrm{r}}$ & 2259.00 & 2176.00 & 2230.00 & 2235.00 & 2402.00 & 2268.00 & 2431.00 & 1797.00 & 1944.00 & \begin{tabular}{|l|}
2138.00 \\
\end{tabular} & 2601.00 & 1385.00 & 1962.00 & 4713.00 & 6015.00 & 6451.00 & 2172.00 & 2345.00 & 3672.00 & 1874.00 \\
\hline $\mathrm{Ni}$ & 327.00 & 301.00 & 325.00 & 336.00 & 315.00 & 296.00 & 298.00 & 1219.00 & 274.00 & 308.00 & 249.00 & 283.00 & 342.00 & 382.00 & 445.00 & 439.00 & 307.00 & 334.00 & 587.00 & 215.00 \\
\hline$C_{0}$ & 55.00 & 77.00 & 53.00 & 54.00 & 63.00 & 59.00 & 74.00 & 57.00 & 77.00 & 77.00 & 46.00 & 58.00 & 69.00 & 119.00 & 70.00 & 51.00 & 63.00 & 59.00 & 78.00 & 59.00 \\
\hline Sc & 32.00 & n.a. & 27.00 & 26.00 & n.a. & n.a. & n.a. & n.a. & ก.a. & n.a. & n.a. & ก.a. & n.a. & 39.00 & n.a. & 20.00 & n.a. & 26.00 & n.a. & 22.00 \\
\hline $\mathrm{v}$ & 123.00 & 94.00 & 109.00 & 113.00 & 92.00 & 99.00 & 94.00 & 107.00 & 92.00 & 84.00 & 101.00 & 101.00 & 98.00 & 208.00 & 122.00 & 140.00 & 60.00 & 81.00 & 63.00 & 60.00 \\
\hline $\mathrm{Cu}$ & 15.00 & 11.00 & 15.00 & 15.00 & 12.00 & 22.00 & 9.00 & 24.00 & 17.00 & 6.00 & 4.00 & 8.00 & 11.00 & 20.00 & 6.00 & 15.00 & 13.00 & 15.00 & 43.00 & 15.00 \\
\hline $\mathrm{Pb}$ & n.a. & 17.00 & n.a. & n.a. & 15.00 & 9.00 & 17.00 & 11.00 & 12.00 & 15.00 & 20.00 & 7.00 & 1.00 & n.a. & 14.00 & 19.00 & 15.00 & n.a. & 9.00 & n.a. \\
\hline $\mathrm{Zn}$ & 504.00 & 539.00 & 467.00 & 468.00 & 540.00 & 523.00 & 498.00 & 428.00 & 162.00 & 169.00 & 497.00 & 434.00 & 517.00 & 583.00 & 343.00 & 235.00 & 294.00 & 302.00 & 60.00 & 52.00 \\
\hline$\overline{R b}$ & n.a. & 416.00 & n.a. & B.a. & 457.00 & 483.00 & 566.00 & 170.00 & 162.00 & 324.00 & 941.00 & 1292.00 & 1150.00 & n.a. & 200.00 & n.a. & 170.00 & n.a. & n.d. & n.a. \\
\hline $\mathrm{Ba}$ & 129.00 & 92.00 & 102.00 & 103.00 & 105.00 & 96.00 & 121.00 & 38.00 & 48.00 & 116.00 & 178.00 & 341.00 & 319.00 & 639.00 & 31.00 & 19.00 & 75.00 & 87.00 & n.d. & 38.00 \\
\hline $\mathrm{Sr}$ & 5.00 & 3.00 & 5.00 & 5.00 & 2.00 & n.d. & 2.00 & n.d. & n.d. & 1.00 & 2.00 & 11.00 & 4.00 & 5.00 & 200.00 & 5.00 & 200.00 & 5.00 & n.d. & 37.00 \\
\hline $\mathrm{Ga}$ & n.a. & 22.00 & ก.a. & n.a. & 19.00 & 18.00 & 19.00 & 11.00 & 15.00 & 14.00 & 17.00 & 27.00 & 21.00 & n.a. & 20.00 & n.a. & 14.00 & n.a. & 1.00 & n.a. \\
\hline $\mathrm{Nb}$ & n.a. & 22.00 & n.a. & ก.a. & 24.00 & 7.00 & 19.00 & 31.00 & 17.00 & 20.00 & 24.00 & 12.00 & 0.00 & n.a. & 25.00 & n.a. & 5.00 & n.a. & 12.00 & n.a. \\
\hline $\mathrm{Zi}$ & 30.00 & 25.00 & 25.00 & 25.00 & 23.00 & 22.00 & 30.00 & 31.00 & 18.00 & 21.00 & 22.00 & n.d. & n.d. & 28.00 & 17.00 & 25.00 & 20.00 & 25.00 & n.d. & 25.00 \\
\hline $\bar{Y}$ & 40.00 & 146.00 & 28.00 & 29.00 & 124.00 & 147.00 & 160.00 & 59.00 & 65.00 & 88.00 & 171.00 & 17.00 & 1.00 & 302.00 & 128.00 & 43.00 & 82.00 & 11.00 & n.d. & 10.00 \\
\hline$T h$ & n.a. & 5.00 & n.a. & n.a. & 5.00 & 4.00 & 3.00 & 2.00 & 2.00 & 3.00 & 7.00 & 6.00 & 9.00 & ก.a. & 3.13 & n.a. & 1.00 & n.a. & n.d. & n.a. \\
\hline $\mathrm{U}$ & n.a. & 16.00 & n.a. & n.a. & 12.00 & 3.00 & 8.00 & 5.00 & 8.00 & 11.00 & 6.00 & 23.00 & 9.00 & n.a. & 200.00 & n.a. & 2.00 & n.a. & 2.00 & n.a. \\
\hline $\mathrm{La}$ & 15.00 & n.d. & 15.00 & 15.00 & n.d. & n.d. & n.d. & n.d. & n.d. & n.d. & n.d. & n.d. & n.d. & 102.00 & 3.13 & 15.00 & 200.00 & 15.00 & n.d. & 15.00 \\
\hline $\mathrm{Ce}$ & n.a. & n.d. & n.a. & n.a. & n.d. & 18.00 & n.d. & n.d. & 5.00 & n.d. & n.d. & 35.00 & n.d. & n.a. & 21.91 & n.a. & 200.00 & n.a. & n.d. & n.a. \\
\hline Nd & n.a. & 35.00 & n.a. & n.a. & 29.00 & 29.00 & 33.00 & 34.00 & 26.00 & 30.00 & 27.00 & 17.00 & n.d. & n.a. & 25.04 & n.a. & 24.00 & n.a. & n.d. & n.a. \\
\hline $\mathrm{Be}$ & 28.00 & n.a. & 28.00 & 29.00 & n.a. & n.a. & n.a. & n.a. & n.a. & n.a. & n.a. & n.a. & n.a. & 10.00 & n.a. & 97.00 & n.a. & 23.00 & n.a. & 2.00 \\
\hline
\end{tabular}

Tabela A2.4: Dados analíticos de rochas metaultramáficas, cromititos e equivalentes metassomáticos. 


\begin{tabular}{|c|c|c|c|c|c|c|c|c|c|c|c|c|c|c|c|c|c|c|c|}
\hline Amostra & $G-150 b(2)$ & G-159 & G.185 & $G-159 b$ & G-159e & G-159d(1) & $G-159 d(2)$ & $1^{*}$ & $1^{*}+a$ & BE- 01 & G-150c(1) & G-150c(2) & $G-158 c$ & A16-C & B-15 & Cap 5 & NE-3 & $N E-3(1)$ & NE-20 \\
\hline Litotipo & TAX & TAX & TAX & TAX & $\mathrm{ACX}$ & $\mathrm{CLT}$ & $\mathrm{CLT}$ & CRT & CRT & CRT & CRT & CRT & CRT & CRTM & CRTM & CRTM & CRTM & CRTM & CRTM \\
\hline Análise & ICP-AES & ICP-AES & ICP-AES & ICP-AES & ICP+AES & ICP-AES & ICP-AES & FRX & FRX & FRX & ICP-AES & ICP-AES & ICP+AES & $F R X$ & $F R X$ & FRX & FRX & ICP-AES & $F R X$ \\
\hline Mointho & Aqata & Ágata & Agata & Agata & Aggata & Agate & Agata & Ágata & Ágata & Aqaata & Agata & Ágata & Agata & Agata & Ágata & Ágata & Ágata & Agata & Agata \\
\hline $\mathrm{SiO}_{2}$ & 48.78 & 52.66 & 48.83 & 52.79 & 48.21 & 39.85 & 39.90 & 46.11 & 46.63 & 51.85 & 42.87 & 43.21 & 51.42 & 44.64 & 42.60 & 47.07 & 46.93 & 47.96 & 24.57 \\
\hline $\mathrm{TiO}_{2}$ & 0.13 & 0.32 & 0.19 & 0.36 & 0.30 & 0.29 & 0.27 & 0.19 & 0.17 & 0.18 & 0.24 & 0.23 & 0.24 & 0.22 & 0.18 & 0.24 & 0.20 & 0.21 & 0.26 \\
\hline $\mathrm{Al}_{2} \mathrm{O}_{3}$ & 13.43 & 1.87 & 5.61 & 2.59 & 9.70 & 12.59 & 12.69 & 9.78 & 9.64 & 6.35 & 12.62 & 12.62 & 8.44 & 11.04 & 6.85 & 9.76 & 8.95 & 8.84 & 12.91 \\
\hline $\mathrm{Fe}_{2} \mathrm{O}_{3 T}$ & 6.57 & 15.00 & 9.61 & 13.24 & 10.11 & 9.08 & 9.28 & 11.13 & 11.36 & 10.76 & 9.91 & 10.23 & 8.79 & 10.13 & 16.96 & 10.71 & 9.93 & 10.42 & 15.64 \\
\hline Mno & 0.11 & 0.30 & 0.27 & 0.25 & 0.15 & 0.15 & 0.15 & 0.35 & 0.36 & 0.15 & 0.17 & 0.16 & 0.17 & 0.25 & 0.45 & 0.21 & 0.33 & 0.35 & 0.32 \\
\hline $\mathrm{MgO}$ & 16.13 & 24.64 & 25.17 & 24.54 & 15.86 & 22.89 & 23.52 & 14.65 & 14.67 & 27.27 & 14.76 & 14.89 & 18.05 & 16.78 & 18.47 & 15.03 & 16.69 & 16.99 & 12.13 \\
\hline $\mathrm{CaO}$ & 5.97 & 1.25 & 3.32 & 3.61 & 11.54 & 6.10 & 6.19 & 11.45 & 11.53 & 3.35 & 10.31 & 10.11 & 8.15 & 8.24 & 1.81 & 1.52 & 9.43 & 9.50 & 3.00 \\
\hline $\mathrm{Na}_{2} \mathrm{O}$ & 1.68 & 0.00 & 0.10 & 0.10 & 1.30 & 0.45 & 0.45 & 1.45 & 1.19 & 0.08 & 1.25 & 1.25 & 0.70 & 1.02 & 0.53 & 0.33 & 1.04 & 1.15 & 0.52 \\
\hline $\mathrm{K}_{2} \mathrm{O}$ & 0.70 & 0.07 & 0.07 & 0.08 & 0.18 & 0.11 & 0.09 & 0.47 & 0.47 & 0.00 & 0.11 & 0.11 & 0.07 & 2.54 & 3.42 & 5.71 & 1.44 & 1.43 & 0.98 \\
\hline$\overline{P_{2} \mathrm{O}_{5}}$ & 0.03 & 0.03 & 0.03 & 0.03 & 0.06 & 0.04 & 0.04 & 0.01 & 0.00 & 0.01 & 0.04 & 0.05 & 0.03 & 0.02 & 0.02 & 0.02 & 0.01 & 0.02 & 0.03 \\
\hline $\mathrm{H}_{2} \mathrm{O}$ & 0.09 & 0.21 & 0.16 & 0.19 & 0.39 & 0.40 & 0.40 & 0.28 & 0.72 & 0.40 & 0.06 & 0.06 & 0.42 & 0.67 & 2.62 & 0.39 & 0.27 & 0.25 & 4.45 \\
\hline $\mathrm{LOI}$ & 5.07 & 2.73 & 4.59 & 3.14 & 2.04 & 7.26 & 7.24 & 1.25 & 1.00 & 4.91 & 1.31 & 1.26 & 2.74 & 2.67 & 2.94 & 1.60 & 1.76 & 1.42 & 9.06 \\
\hline Total & 98.69 & 99.08 & 97.95 & 100.92 & 99.84 & 99.21 & 100.22 & \begin{tabular}{|l|}
97.12 \\
\end{tabular} & 97.74 & 105.31 & 93.65 & 94.18 & 99.22 & 98.22 & 96.85 & 92.59 & 96.98 & 98.54 & 83.87 \\
\hline $\mathrm{Cr}$ & 1924.00 & 1694.00 & 3898.00 & 1749.00 & 1933.00 & 1967.00 & 2062.00 & 12597.00 & 10985.00 & 11243.00 & 40962.00 & 41298.00 & 11426.00 & 11525.00 & 27639.00 & 26212.00 & 11665.00 & 9804.00 & 110921.00 \\
\hline $\mathrm{Ni}$ & 223.00 & 601.00 & 460.00 & 666.00 & 259.00 & 425.00 & 427.00 & 247.00 & 188.00 & 538.00 & 219.00 & 214.00 & 321.00 & \begin{tabular}{|l|}
241.00 \\
\end{tabular} & 726.00 & 218.00 & 240.00 & 264.00 & 214.00 \\
\hline$c_{0}$ & 63.00 & 24.00 & 51.00 & 40.00 & 53.00 & 70.00 & 67.00 & 89.00 & 47.00 & 88.00 & 73.00 & 73.00 & 52.00 & 66.00 & 87.00 & 41.00 & 58.00 & 53.00 & 92.00 \\
\hline Sc & 22.00 & 10.00 & 27.00 & 10.00 & 29.00 & 33.00 & 32.00 & n.a. & n.a. & n.a. & 15.00 & 15.00 & 30.00 & n.a. & n.a. & n.a. & n.a. & 30.00 & $n, a$ \\
\hline $\mathrm{V}$ & 70.00 & 29.00 & 56.00 & 49.00 & 116.00 & 109.00 & 100.00 & 118.00 & 161.00 & 128.00 & 226.00 & 215.00 & 147.00 & 97.00 & 176.00 & 135.00 & 121.00 & 156.00 & 152.00 \\
\hline $\mathrm{Cu}$ & 15.00 & 103.00 & 15.00 & 96.00 & 15.00 & 15.00 & 15.00 & 15.00 & 1.00 & 14.00 & 15.00 & 15.00 & 15.00 & 12.00 & 4.00 & 5.00 & 10.00 & 15.00 & 3.00 \\
\hline $\mathrm{Pb}$ & n.a. & n.a. & n.a. & n.a. & n.a. & B. $a$ & n.a. & 24.00 & n.d. & 4.00 & n.a. & ก.a. & n.a. & 18.00 & 0.00 & 18.00 & 17.00 & n. & 19.00 \\
\hline $\mathrm{Zn}$ & 53.00 & 171.00 & 144.00 & 132.00 & 69.00 & 113.00 & 99.00 & 536.00 & 578.00 & 153.00 & 544.00 & 553.00 & 122.00 & 681.00 & 1207.00 & 1716.00 & 1007.00 & 750.00 & 7878.00 \\
\hline $\mathbf{R b}$ & n.a. & n.a. & n.a. & n.a. & n.a. & n.a. & ก.a. & 18.00 & 1.00 & 1.00 & n.a. & n.a. & n.a. & 337.00 & 548.00 & 845.00 & 164.00 & n.a. & 130.00 \\
\hline $\mathrm{Ba}$ & 45.00 & 10.00 & 10.00 & 10.00 & 27.00 & 27.00 & 10.00 & n.d. & 7.00 & 1.00 & 10.00 & 10.00 & 10.00 & 28.00 & 157.00 & 169.00 & 30.00 & 46.00 & 23.00 \\
\hline Sr & 40.00 & 5.00 & 5.00 & 5.00 & 21.00 & 21.00 & 5.00 & 2.00 & n.d. & n.d. & 5.00 & 5.00 & 5.00 & 1.00 & n.d. & 2.00 & 2.00 & 5.00 & $n . d$ \\
\hline $\mathrm{Ga}$ & ก.a. & n.a. & ก.a. & n.a. & n.a. & n.a. & n.a. & 31.00 & 14.00 & 4.00 & n.a. & n.a. & n.a. & 24.00 & 19.00 & 25.00 & 25.00 & n.a. & 38.00 \\
\hline $\mathrm{Nb}$ & n.a. & n.a. & n.a. & n.a. & ก.a. & n.a. & ก.a. & 18.00 & 21.00 & 10.90 & n.a. & n.a. & n.a. & 37.00 & 7.00 & 54.00 & 19.00 & ก.a. & 14.00 \\
\hline $\mathrm{Zr}$ & 25.00 & 25.00 & 25.00 & 25.00 & 25.00 & 25.00 & 25.00 & 13.00 & n.d. & 8.00 & 25.00 & 25.00 & 25.00 & 12.00 & n.d. & 15.00 & 14.00 & 25.00 & 14.00 \\
\hline $\bar{Y}$ & 10.00 & 10.00 & 10.00 & 10.00 & 10.00 & 10.00 & 12.00 & 66.00 & 29.00 & 15.00 & 10.00 & 10.00 & 10.00 & 233.00 & 13.00 & 190.00 & 110.00 & 41.00 & 30.00 \\
\hline Th & n.a. & n.a. & n.a. & ก.a. & n.a. & n.a. & n.a. & 3.00 & n.d. & 2.19 & ก.a. & n.a. & n.a. & 5.00 & 4.00 & 8.00 & 3.00 & n.a. & 4.00 \\
\hline$U$ & B.a. & n.a. & n.a. & n.a. & n.a. & n.a. & n.a. & 7.00 & n.d. & 5.47 & n.a. & n.a. & n.a. & 8.00 & n.d. & 10.00 & 10.00 & ก.a. & 7.00 \\
\hline $\mathrm{La}$ & 15.00 & 15.00 & 15.00 & 15.00 & 24.00 & 28.00 & 32.00 & n.d. & n.d. & 3.28 & 15.00 & 15.00 & 15.00 & n.d. & 24.00 & 8.00 & n.d. & 15.00 & 15.00 \\
\hline $\mathrm{Ce}$ & n.a. & n.a. & n.a. & n.a. & n.a. & B.a. & n.a. & 49.00 & n.d. & 41.57 & n.a. & n.a. & n.a. & 23.00 & n.d. & 98.00 & 42.00 & n.a. & 565.00 \\
\hline Nd & n.a. & n.a. & n.a. & n.a. & n.a. & n.a. & ก.a. & 52.00 & n.d. & 40.48 & n.a. & n.a. & n.a. & 49.00 & n.d. & 73.00 & 52.00 & n.a. & 221.00 \\
\hline Bo & 2.00 & 3.00 & 3.00 & 3.00 & 6.00 & 5.00 & 2.00 & n.a. & ก.a. & n.a. & 1.00 & 3.00 & 6.00 & n.a. & n.a. & n.a. & n.a. & 87.00 & n.a \\
\hline
\end{tabular}

Tabela A2.4: Dados analíticos de rochas metaultramáficas, cromititos e equivalentes metassomáticos. 


\begin{tabular}{|c|c|c|c|c|c|c|c|c|c|c|c|c|c|c|c|c|c|c|c|c|}
\hline Amostra & $\bar{A}-7 \mathrm{~b}$ & BT-03 & BE-02 & Cap-4 & C-01 & G-52a & G-50a & G-52i & $G-64 b$ & $\mathrm{HC}-3 \mathrm{a}$ & NE-21 & NE-26 & C-1a & $B-10$ & $G-54 b$ & G-238 & G.37b & G-52j & $G-54 b(1)$ & G-37a \\
\hline Litotipo & $A B$ & $\mathrm{AB}$ & $A B$ & $A B$ & $A B$ & $A B$ & $\mathrm{AB}$ & $A B$ & $A B$ & $\mathrm{AB}$ & $A B$ & $\mathrm{AB}$ & $A B G$ & $A B G$ & $A B G$ & $A B G$ & $A B G$ & $A B G$ & $A B G$ & ABET \\
\hline Análise & FRX & FRX & FRX & FRX & FRX & FRX & $F R X$ & FRX & $F R X$ & $F R X$ & FRX & $F R X$ & $F R X$ & FRX & FRX & ICP-AES & ICP-AES & ICP-AES & ICP-AES & FRX \\
\hline Moinho & Agata & Agata & Agata & Ágata & Agata & Agata & Ágada & Agata & Agata & Agata & Agata & Ágata & Agata & Ágata & Agata & Agata & Agata & Agata & Agata & Agata \\
\hline $\mathrm{SiO}_{2}$ & 45.92 & 51.10 & 50.14 & 46.75 & 54.09 & 50.68 & 52.72 & 52.66 & 45.97 & 48.79 & 48.75 & 52.53 & 59.95 & 51.09 & 65.67 & 53.74 & 53.81 & 52.19 & 53.91 & 49.40 \\
\hline $\mathrm{TiO}_{2}$ & 0.91 & 0.33 & 1.31 & 1.39 & 0.46 & 1.10 & 1.10 & 0.66 & 1.84 & 0.53 & 1.06 & 1.58 & 1.63 & 1.13 & 1.31 & 2.25 & 0.97 & 1.11 & 2.12 & 1.42 \\
\hline $\mathrm{Al}_{2} \mathrm{O}_{3}$ & 13.71 & 14.22 & 15.89 & 15.00 & 16.17 & 44.74 & 15.96 & 15.96 & 16.52 & 12.07 & 14.82 & 14.59 & 13.06 & 13.94 & 10.53 & 11.86 & 18.79 & 14.12 & 14.04 & $\frac{1.42}{14.12}$ \\
\hline $\mathrm{Fe}_{2} \mathrm{O}_{3 \mathrm{~T}}$ & 10.58 & 9.59 & 14.69 & 14.33 & 8.22 & 12.67 & 13.49 & 9.80 & 16.55 & 12.31 & 12.03 & 10.34 & 12.74 & 12.26 & 9.71 & 16.81 & 10.80 & 13.07 & 14.19 & 15.55 \\
\hline MnO & 0.17 & 0.17 & 0.21 & 0.19 & 0.12 & 0.14 & 0.19 & 0.13 & 0.18 & 0.27 & 0.14 & 0.21 & 0.32 & 0.18 & 0.09 & 0.43 & 0.14 & 0.15 & 0.14 & 0.17 \\
\hline $\mathrm{MgO}$ & 11.19 & 10.86 & 7.60 & 8.19 & 6.86 & 8.08 & 7.18 & 7.83 & 6.66 & 9.41 & 8.99 & 6.47 & 3.03 & 7.50 & 3.92 & 3.49 & 3.24 & 7.07 & 5.48 & 5.66 \\
\hline $\mathrm{CaO}$ & 7.59 & 9.47 & 8.83 & 8.84 & 8.66 & 8.87 & 8.06 & 7.89 & 9.71 & 9.16 & 8.67 & 7.41 & 5.68 & 8.11 & 6.19 & 8.39 & 3.73 & 8.71 & 8.10 & 8.83 \\
\hline $\mathrm{Na}_{2} \mathrm{O}$ & 1.63 & 2.49 & 0.93 & 2.12 & 3.57 & 2.48 & 0.85 & 3.62 & 2.17 & 2.20 & 2.46 & 2.50 & 2.35 & 0.81 & 1.89 & 0.78 & 5.18 & 2.59 & 2.53 & 2.88 \\
\hline $\mathrm{K}_{2} \mathrm{O}$ & 0.83 & 0.72 & 0.19 & 1.41 & 0.26 & 1.09 & 0.24 & 1.35 & 0.37 & 1.46 & 0.43 & 1.31 & 0.15 & 0.38 & 0.25 & 0.29 & 2.84 & 0.34 & 0.26 & 1.84 \\
\hline $\mathrm{P}_{2} \mathrm{O}_{5}$ & 0.41 & 0.04 & 0.21 & 0.17 & 0.07 & 0.15 & 0.22 & 0.11 & 0.04 & 0.05 & 0.14 & 0.67 & 0.34 & 0.18 & 0.44 & 0.34 & 0.14 & 0.15 & 0.52 & 0.12 \\
\hline $\mathrm{LO}$ & 6.40 & 1.10 & 3.81 & 1.15 & 1.28 & 1.20 & 5.14 & 1.41 & 2.78 & 1.55 & 1.57 & 1.56 & 0.44 & 3.95 & 0.66 & 1.18 & 1.29 & 0.94 & 0.39 & 0.98 \\
\hline Total & 99.34 & 100.09 & 103.81 & 99.54 & 99.76 & 101.20 & 105.15 & 101.42 & 102.79 & 97.80 & 99.06 & 99.17 & 99.69 & 99.53 & 100.66 & 99.56 & 100.93 & 100.44 & 101.68 & 100.97 \\
\hline $\mathrm{Cr}$ & 712.00 & 622.00 & 212.00 & 258.00 & 88.00 & 418.00 & 131.00 & 33.00 & 99.00 & 704.00 & 351.00 & 367.00 & 43.00 & 304.00 & 84.00 & 15.00 & 15.00 & 192.00 & 115.00 & 71.00 \\
\hline$\overline{\mathrm{Ni}}$ & 196.00 & 142.00 & 82.00 & 107.00 & 210.00 & $\$ 14.00$ & 73.00 & 103.00 & 57.00 & 199.00 & 174.00 & 81.00 & 32.00 & 72.00 & 68.00 & 25.00 & 17.00 & 130.00 & 130.00 & 51.00 \\
\hline Co & 44.00 & 54.00 & 26.00 & 39.00 & 47.00 & 45.00 & 29.00 & 49.00 & 44.00 & 38.00 & 73.00 & 23.00 & 28.00 & 45.00 & 22.00 & 117.00 & 50.00 & 101.00 & 82.00 & 50.00 \\
\hline Sc & n.a. & n.a. & n.a. & n.a. & n.a. & n.a. & n.a. & n.a. & n.a. & n.a. & n.a. & n.a. & n.a. & n.a. & n.a. & 40.00 & 17.00 & 30.00 & 28.00 & n.a. \\
\hline $\mathrm{V}$ & 158.00 & 78.00 & 241.00 & 229.00 & 94.00 & 228.00 & 210.00 & 148.00 & 302.00 & 158.00 & 192.00 & 192.00 & 245.00 & 219.00 & 329.00 & 453.00 & 227.00 & 261.00 & 313.00 & 300.00 \\
\hline $\mathrm{Cu}$ & 8.00 & 11.00 & 4.00 & 17.00 & 41.00 & 17.00 & 89.00 & 11.00 & 6.00 & 11.00 & 11.00 & 10.00 & 15.00 & n.d. & 11.00 & 183.00 & 16.00 & 166.00 & 15.00 & 83.00 \\
\hline$P b$ & 21.00 & 20.00 & 17.00 & 12.00 & 17.00 & 8.00 & 15.00 & 16.00 & 27.00 & 19.00 & 15,00 & 22.00 & 15.00 & 2.00 & 10.00 & n.a. & ก.a. & n.a. & n.a. & 72.00 \\
\hline $\mathrm{Zn}$ & 214.00 & 162.00 & 181.00 & 177.00 & 136,00 & 135.00 & 135.00 & 95.00 & 315.00 & 360.00 & 119.00 & 106.00 & 75.00 & 135.00 & 127.00 & 176.00 & 372.00 & 135.00 & 484.00 & 373.00 \\
\hline $\mathrm{Rb}$ & 97.00 & 64.00 & 3.00 & 109.00 & 19.00 & 81.00 & 2.00 & 113.00 & 5.00 & 93.00 & 36.00 & 128.00 & 11.00 & 3.00 & 12.00 & n.a. & n.a. & n.a. & n.a. & 327.00 \\
\hline $\mathrm{Ba}$ & 112.00 & 22.00 & 118.00 & 232.00 & 22.00 & 123.00 & 84.00 & 134.00 & 115.00 & 104.00 & 82.00 & 214.00 & 78.00 & 131.00 & 109.00 & 73.00 & 288.00 & 32.00 & 73.00 & 310.00 \\
\hline $\mathrm{Sr}$ & 21.00 & 73.00 & 10.00 & 71.00 & 149.00 & 102.00 & 6.00 & 91.00 & 96.00 & 102.00 & 70.00 & 100.00 & 76.00 & 17.00 & 108.00 & 51.00 & 247.00 & 97.00 & 130.00 & 95.00 \\
\hline $\mathrm{Ga}$ & 17.00 & 23.00 & 19.00 & 21.00 & 23.00 & 16.00 & 19.00 & 15.00 & 20.00 & 24.00 & 27.00 & 25.00 & 16.00 & 16.00 & 18.00 & n.a. & ก.a. & n.a. & n.a. & 19.00 \\
\hline $\mathrm{Nb}$ & 14.00 & 12.00 & 14.60 & 17.00 & 7.00 & 11.20 & 13.60 & 10.30 & 12.20 & 13,00 & 14.00 & 67.00 & 20.00 & 11.00 & 10.10 & n.a. & n.a. & n.a. & n.a. & 10.20 \\
\hline $\mathrm{Zr}$ & 87.00 & 46.00 & 122.00 & 112.00 & 52.00 & 44.00 & 139.00 & 61.00 & 64.00 & 37.00 & 55.00 & 321.00 & 296.00 & 81.00 & 115.00 & 230.00 & 83.00 & 78.00 & 168.00 & 93.00 \\
\hline $\mathrm{Y}$ & 54.00 & 29.00 & 20.00 & 40.00 & 9.00 & 27.00 & 20.00 & 25.00 & 13.00 & 30.00 & 26.00 & 148.00 & 46.00 & 24.00 & 19.00 & 53.00 & 14.00 & 25.00 & 37.00 & 71.00 \\
\hline $\mathrm{Th}$ & 2.00 & 6.00 & 7.30 & 6.00 & 4.00 & 2.04 & 8.37 & 3.08 & 8.16 & 4.00 & 4.00 & 15.00 & 16.00 & n.d. & 8.07 & n.a. & n.a. & n.a. & ก.a. & 10.23 \\
\hline U & 4.00 & 9.00 & 2.09 & 6.00 & 7.00 & 3.06 & 2.09 & 4.11 & 6.12 & 8.00 & 9.00 & 7.00 & 8.00 & n.d. & 6.05 & n.a. & n.a. & n.a. & ก.a. & 5.12 \\
\hline La & 3.00 & n.d. & 3.13 & 5.00 & n.d. & 3.06 & 3.14 & 3.08 & 3.06 & n.d. & n.d. & 21.00 & 42.00 & n.d. & 3.03 & 29.00 & 15.00 & 15.00 & 19.00 & 3.07 \\
\hline $\mathrm{Ce}$ & 16.00 & n.d. & 10.43 & 31.00 & n.d. & 8.16 & 13.60 & 21.59 & 31.62 & 13.00 & 20.00 & 77.00 & 84.00 & n.d. & 21.18 & n.a. & n.a. & n.a. & n.a. & 21.48 \\
\hline Nd & 42.00 & 27.00 & 15.65 & 45.00 & 33.00 & 12.24 & 28.25 & 8.22 & 15.30 & 29.00 & 33.00 & 59.00 & 68.00 & 22.00 & 14.12 & n.a. & n.a. & n.a. & n.a. & 13.30 \\
\hline$\overline{B \theta}$ & n.a. & n.a. & n.a. & n.a. & n.a. & n.a. & n.a. & n.a. & n.a. & n.a. & n.a. & n.a. & n.a. & n.a. & n.a. & 3.00 & 2.00 & 4.00 & 1.00 & n.a. \\
\hline
\end{tabular}

Tabela A2.5: Dados analiticos de anfibolitos ( $A B, A B E T, A B G, A B / T T G, A F F$ e AC) e gnaisses da SVS (Gn/SVS). 


\begin{tabular}{|c|c|c|c|c|c|c|c|c|c|c|c|c|c|}
\hline Amostra & G-56 & $G-168 a(1)$ & G-168a(2) & G-168a & G-231c & G-250a & NE-23 & NE-23a & NE-23b & $1-01$ & $\mathrm{NE}-22$ & NE-22a & NE-27 \\
\hline Litotipo & ABET & $A B / T T G$ & AB/TTG & $\mathrm{AB} / \mathrm{TTG}$ & AFF & AFF & $A C$ & $A C$ & $A C$ & Gn/SVS & GnSVS & Gn/SVS & GnSVS \\
\hline Análise & FRX & ICP-AES & ICP-AES & ICP-AES & ICP-AES & ICP-AES & FRX & FRX & FRX & FRX & FRX & $F R X$ & $F R X$ \\
\hline Moinho & Agata & Ágata & Agata & WC & Agata & Agata & Agata & Agata & Agata & Agata & Agata & Ágała & Ágata \\
\hline $\mathrm{SiO}_{2}$ & 50.56 & 52.05 & 52.25 & 51.50 & 42.21 & 47.62 & 64.16 & 49.00 & 50.77 & 64.03 & 69.19 & 67.63 & 68.78 \\
\hline $\mathrm{TiO}_{2}$ & 7.28 & 0.52 & 0.51 & 0.52 & 1.93 & 2.88 & 1.13 & 0.94 & 0.95 & 0.75 & 1.27 & 1.20 & 1.03 \\
\hline $\mathrm{Al}_{2} \mathrm{O}_{3}$ & 15.61 & 11.57 & 11.81 & 11.72 & 11.83 & 7.60 & 13.76 & 20.86 & 20.36 & 12.80 & 12.20 & 12.41 & 12.69 \\
\hline $\mathrm{Fe}_{2} \mathrm{O}_{3 \mathrm{I}}$ & 12.39 & 13.30 & 13.26 & 13.24 & 21.67 & 24.25 & 8.13 & 13.01 & 11.93 & 8.23 & 6.61 & 6.90 & 6.72 \\
\hline $\mathrm{MnO}$ & 0.18 & 0.30 & 0.29 & 0.29 & 0.22 & 0.26 & 0.06 & 0.12 & 0.08 & 0.16 & 0.09 & 0.10 & 0.09 \\
\hline$\overline{\mathrm{MgO}}$ & 5.88 & 8.81 & 8.77 & 8.85 & 8.19 & 6.92 & 2.60 & 1.64 & 1.17 & 3.77 & 3.56 & 3.03 & 2.32 \\
\hline $\mathrm{CaO}$ & 10.01 & 9.44 & 9.41 & 9.34 & 11.21 & 8.26 & 6.30 & 12.80 & 13.31 & 5.37 & 4.16 & 4.20 & 3.41 \\
\hline $\mathrm{Na}_{2} \mathrm{O}$ & 3.17 & 2.18 & 2.20 & 2.18 & 1.15 & 0.84 & 2.25 & 0.89 & 0.65 & 3.19 & 2.38 & 2.93 & 2.81 \\
\hline $\mathrm{K}_{2} \mathrm{O}$ & 0.69 & 1.33 & 1.35 & 1.36 & 0.74 & 0.33 & 0.24 & 0.15 & 0.16 & 0.70 & 0.61 & 0.65 & 1.03 \\
\hline$P_{2} \mathrm{O}_{5}$ & 0.22 & 0.03 & 0.03 & 0.02 & 0.04 & 0.13 & 0.22 & 0.21 & 0.20 & 0.10 & 0.27 & 0.24 & 0.21 \\
\hline LOI & 1.20 & 0.81 & 0.78 & 0.95 & 1.17 & 1.75 & n.d. & n.d. & 0.83 & 1.22 & n.d. & 0.45 & 0.75 \\
\hline Total & 101.19 & 100.34 & 100.66 & 99.97 & 100.36 & 100.84 & 98.85 & 99.62 & 100.41 & 100.32 & 100.34 & 99.74 & 99.84 \\
\hline $\mathrm{Cr}$ & 157.00 & 655.00 & 667.00 & 667.00 & 82.00 & 279.00 & 65.00 & 28.00 & 22.00 & 60.00 & 22.00 & 10.00 & 11.00 \\
\hline $\mathrm{Ni}$ & 74.00 & 200.00 & 210.00 & 209.00 & 225.00 & 339.00 & 39.00 & 28.00 & 23.00 & 74.00 & 29.00 & 21.00 & 18.00 \\
\hline Co & 38.00 & 35.00 & 32.00 & 76.00 & 102.00 & 100.00 & 6.00 & 9.00 & 28.00 & 35.00 & 13.00 & 18.00 & 2.00 \\
\hline Sc & ก.a. & 33.00 & 33.00 & 33.00 & 45.00 & 41.00 & n.a. & n.a. & n.a. & n.a. & n.a. & n.a. & n.a. \\
\hline $\mathrm{V}$ & 220.00 & 217.00 & 216.00 & 213.00 & 872.00 & 501.00 & 87.00 & 75.00 & 71.00 & 162.00 & 83.00 & 168.00 & 143.00 \\
\hline $\mathrm{Cu}$ & 77.00 & 15.00 & 2.00 & 15.00 & 12.00 & 279.00 & 174.00 & 72.00 & 193.00 & 50.00 & 16.00 & 16.00 & 120.00 \\
\hline $\mathrm{Pb}$ & 86.00 & ก.a. & ก.a. & n.a. & n.a. & n.a. & 23.00 & 22.00 & 36.00 & 17.00 & 27.00 & 17.00 & 18.00 \\
\hline $\mathrm{Zn}$ & 301.00 & 370.00 & 370.00 & 365.00 & 182.00 & 256.00 & 142.00 & 76.00 & 70.00 & 193.00 & 63.00 & 65.00 & 59.00 \\
\hline $\mathrm{Rb}$ & 23.00 & n.a. & ก.a. & n.a. & n.a. & n.a. & 9.00 & 7.00 & 14.00 & 50.00 & 57.00 & 67.00 & 119.00 \\
\hline $\mathrm{Ba}$ & 120.00 & 100.00 & 407.00 & 103.00 & 27.00 & 16.00 & 75.00 & n.d. & 37.00 & 86.00 & 213.00 & 268.00 & 272.00 \\
\hline $\mathrm{Sr}$ & 123.00 & 99.00 & 100.00 & 98.00 & 21.00 & 9.00 & 457.00 & 641.00 & 715.00 & 132.00 & 146.00 & 156.00 & 135.00 \\
\hline $\mathrm{Ga}$ & 23.00 & n.a. & n.a. & n.a. & n.a. & n.a. & 15.00 & 46.00 & 61.00 & 28.00 & 14.00 & 19.00 & 16.00 \\
\hline $\mathrm{Nb}$ & 13.20 & n.a. & n.a. & n.. & n.a. & n.a. & 15.00 & 9.00 & 9.00 & 19.00 & 22.00 & 29.00 & 28.00 \\
\hline$Z_{r}$ & 152.00 & 25.00 & 25.00 & 25.00 & 25.00 & 118.00 & 502.00 & 501.00 & 426.00 & 333.00 & 368.00 & 330.00 & 357.00 \\
\hline$Y$ & 32.00 & 13.00 & 10.00 & 16.00 & 15.00 & 81.00 & 80.00 & 93.00 & 60.00 & 52.00 & 106.00 & 61.00 & 64.00 \\
\hline Th & 9.13 & n.a. & n.a. & n.a. & n.a. & n.a. & 7.00 & 29.00 & 15.00 & 7.00 & 0.00 & 14.00 & 13.00 \\
\hline $\bar{U}$ & 5.07 & n.a. & ก.a. & n.a. & n.a. & n.a. & n.d. & n.d. & 6.00 & 3.00 & 10.00 & 9.00 & 8.00 \\
\hline La & 3.04 & 15.00 & 15.00 & 15.00 & 15.00 & 229.00 & 20.00 & 30.00 & 33.00 & 19.00 & 11.00 & 33.00 & 15.00 \\
\hline $\mathrm{Ce}_{0}$ & 25.36 & n.a. & n.a. & n.a. & ก.a. & n.a. & 75.00 & 103.00 & 123.00 & 66.00 & 84.00 & 70.00 & 66.00 \\
\hline $\mathrm{No}$ & 23.33 & n.a. & n.a. & n.a. & n.a. & ก.a. & 63.00 & 59.00 & 88.00 & 60.00 & 58.00 & 63.00 & 54.00 \\
\hline$\overline{B e}$ & n.a. & 2.00 & 2.00 & 2.00 & 5.00 & 3.00 & n.a. & ก.a. & n.a. & n.a. & n.a. & n.a. & n.a. \\
\hline
\end{tabular}

Tabela A2.5: Dados analíticos de anfibolitos ( $A B, A B E T, A B G, A B / T T G, A F F$ e AC) e gnaisses da SVS (Gn/SVS) 
Tabela A.2.6: Normas CIPW

\begin{tabular}{|c|c|c|c|c|c|c|c|c|c|c|c|c|c|c|c|}
\hline Amostra & G-18 & G-18(1) & G-18(2) & $G-60$ & $G-62$ & $G-65$ & G.74 & $\mathrm{G}-88$ & G-144a(1) & G-144a(2) & $\mathrm{G}-144 \mathrm{a}(3)$ & $G-144 d(1)$ & $G-144 d(2)$ & G-240a(1) & G-240a(2) \\
\hline Litotipo & $\pi G$ & TTG & TTG & TTG & $T T G$ & $\pi G$ & TTG & TTG & TTG & TTG & TTG & TTG & TIG & TTG & TTG \\
\hline Quartzo & 35.91 & 36.32 & 36.46 & 33.93 & 27.45 & 35.05 & 38.91 & 36.11 & 28.89 & 3060 & 30.13 & 62.74 & 64.20 & 29.61 & 29.07 \\
\hline Corindon & 0.94 & 0.01 & 0.17 & 0.72 & 1.10 & 1.34 & 1.0 & 1.47 & 0.18 & 0.45 & 0.60 & 0.36 & 0.33 & 0.44 & 0.53 \\
\hline Zircáo & 0.06 & 0.05 & 0.05 & 0.04 & 0.01 & 0.02 & 0.08 & 0.01 & 0.01 & 0.01 & 0.01 & 0.01 & 0.01 & 0.01 & 0.01 \\
\hline Ortoclásio & 30.77 & 28.49 & 29.14 & 34.65 & 37.46 & 27.26 & 32.00 & 25.70 & 51.48 & 51.54 & 50.53 & 13.42 & 12.35 & 21.04 & 21.22 \\
\hline Albita & 24.20 & 25.81 & 26.06 & 27.24 & 30.12 & 31.76 & 22.25 & 32.32 & 16.08 & 15.57 & 15.74 & 21.58 & 21.24 & 40.70 & 40.78 \\
\hline Anortita & 3.35 & 4.66 & 4.92 & 1.50 & 3.18 & 2.58 & 1.53 & 3.89 & 1.17 & 1.32 & 1.33 & 1.09 & 1.04 & 5.77 & 5.78 \\
\hline Hiperstênio & 2.68 & 0.50 & 0.50 & 1.23 & 0.63 & 1.27 & 1.87 & 0.36 & 0.20 & 0.22 & 0.22 & 0.07 & 0.10 & 0.55 & 0.5 \\
\hline Magnetita & 1.35 & 0.00 & 0.00 & 0.53 & 0.17 & 0.49 & 1.07 & 0.16 & 0.0 & 0.00 & 0.00 & 0.03 & 0.00 & 0.00 & 0.00 \\
\hline Cromita & 0.00 & 0.00 & 0.00 & $0 . \infty$ & 0.00 & 0.00 & 0.0 & 0.00 & 0.0 & 0.06 & 0.07 & 0.0 & 0.08 & 0.00 & 0.06 \\
\hline Hematita & 0.00 & 2.60 & 2.5 & 0.0 & 0.00 & 0.00 & 0.00 & 0.00 & 0.59 & 0.97 & 0.95 & 0.33 & 0.80 & 0.79 & 1.09 \\
\hline Iimenita & 0.53 & 0.09 & 0.13 & 0.13 & 0.04 & 0.15 & 0.40 & 0.06 & 0.05 & 0.00 & 0.00 & 0.06 & 0.00 & 0.04 & 0.00 \\
\hline Esfeno & 0.00 & 0.00 & 0.00 & 0.0 & 0.00 & 0.00 & 0.0 & 0.00 & 0.00 & 0.0 & 0.00 & 0.00 & 0.00 & 0.00 & 0.00 \\
\hline Rutilo & 0.00 & 0.22 & 0.19 & 0.0 & 0.0 & 0.00 & 0.0 & 0.0 & 0.04 & 0.07 & 0.08 & 0.00 & 0.04 & 0.08 & 0.10 \\
\hline Apatita & 0.15 & 0.10 & 0.07 & 0.02 & 0.03 & 0.12 & 0.05 & 0.08 & 0.33 & 0.29 & 0.30 & 0.02 & 0.02 & 0.10 & 0.07 \\
\hline Total & 99.94 & 98.85 & 100.31 & 100.07 & 100.20 & 100.10 & 100.12 & 100.17 & $99 . \infty$ & 101.10 & 99.95 & 99.72 & 100.21 & 99.11 & 99.26 \\
\hline
\end{tabular}

\begin{tabular}{|c|c|c|c|c|c|c|c|c|c|c|c|c|}
\hline Amostra & G-2400(1) & $G-240 b(2)$ & $G-240 b(3)$ & $G-240 b(4)$ & G-103a & G-103b(1) & G-103b(2) & G-106 & G-111 & $G-112$ & G-113 & G-123 \\
\hline Litotipo & TTG & TTG & TTG & TTG & GnM & $\mathrm{GnM}$ & $\mathrm{GnM}$ & $\mathrm{GnM}$ & $\mathrm{GnM}$ & $\mathrm{GnM}$ & $\mathrm{GnM}$ & $\mathrm{GnM}$ \\
\hline Quartzo & 29.73 & 29.90 & 30.58 & 30.09 & 36.78 & 48.09 & 48.91 & 34.22 & 37.5 & 37.06 & 32.36 & 68.54 \\
\hline Córindon & 1.38 & $1 . \mathfrak{3}$ & 1.5 & 1.57 & 0.47 & 7.22 & 7.15 & 0.2 & 3.14 & 0.00 & 2.56 & 5.21 \\
\hline Zircẫo & 0.01 & 0.01 & 0.01 & 0.01 & $0 . \infty$ & 0.09 & 0.10 & 0.09 & 0.02 & 0.09 & 0.15 & 0.01 \\
\hline Ortoclásio & 24.00 & 23.76 & 23.82 & 23.64 & 29.85 & 32.27 & 32.69 & 29.14 & 25.42 & 24.71 & 26.66 & 16.5 \\
\hline Albita & 37.90 & 38.41 & 37.82 & 37.74 & 24.28 & 3.47 & 3.5 & 25.97 & 28.68 & 23.86 & 25.04 & 5.16 \\
\hline Anortita & 4.28 & 4.33 & 4.27 & 4.10 & 4.76 & 0.23 & 0.23 & 5.21 & 2.43 & 7.54 & 4.36 & 0.01 \\
\hline Hiperstênio & 0.37 & 0.37 & 0.35 & 0.35 & 0.25 & 0.05 & 0.05 & 0.12 & 0.45 & 0.35 & 1.27 & 0.75 \\
\hline Magnetita & 0.00 & 0.00 & 0.00 & $0 . \infty$ & 0.00 & 0.00 & 0.0 & 0.00 & 0.00 & 0.00 & 0.0 & 0.00 \\
\hline Cromita & 0.00 & 0.0 & 0.07 & 0.07 & 0.00 & 0.00 & 0.0 & 0.0 & 0.0 & 0.00 & 0.00 & 0.00 \\
\hline Hematita & 0.70 & 0.70 & 1.06 & 1.07 & 2.71 & 3.42 & 3.57 & 3.41 & 1.07 & 4.67 & 6.15 & 1.07 \\
\hline Ilmenita. & 0.06 & 0.03 & 0.00 & 0.00 & 0.14 & 0.09 & 0.08 & 0.12 & 0.05 & 0.15 & 0.14 & 0.12 \\
\hline Esfeno & 0.00 & 0.0 & 0.00 & 0.00 & 0.00 & 0.0 & 0.0 & 0.00 & 0.00 & 0.6 & 0.0 & 0.00 \\
\hline Rutilo & 0.06 & 0.08 & 0.09 & 0.10 & 0.22 & 0.26 & 0.25 & 0.23 & 0.11 & 0.11 & 0.44 & 0.02 \\
\hline Apatita & 0.05 & 0.05 & 0.05 & 0.10 & 0.05 & 0.04 & 0.04 & 0.05 & 0.03 & 0.22 & 0.10 & 0.43 \\
\hline Total & 98.54 & 90.28 & 99.66 & 98.83 & 99.61 & 95.22 & 96.62 & 98.85 & 98.93 & 99.40 & 99.23 & 97.86 \\
\hline
\end{tabular}

Tabela A2.6.1: Normas CIPW de TTG e GnM. 


\begin{tabular}{|c|c|c|c|c|c|c|c|c|c|c|c|c|c|c|c|c|}
\hline Amostra & G-26 & $\mathrm{G}-29 \mathrm{a}$ & $G-29 b$ & $G-29 c$ & $G-29 d$ & G.29e & G-31 & G-2a & $\mathrm{G}-2 \mathrm{~b}(1)$ & $G+2 b(2)$ & G-3a & G-9 & G-11a & G-11d & G-13a & $G-68$ \\
\hline itotipo & GB & GB & $\mathrm{GB}$ & GB & GB & GB & GB & MGF & MGF & MGF & MGF & MGF & MGF & MGF & MGF & MGF \\
\hline Quartzo & 32.30 & 33.50 & 36.08 & 30.86 & 38.61 & 40.58 & 33.10 & 41.33 & 20.70 & 35.90 & 40.48 & 40.11 & 45.80 & 36.70 & 37.79 & 36.19 \\
\hline Córindon & 0.00 & 0.23 & 0.00 & 0.06 & 0.0 & 0.00 & 0.00 & 0.00 & 0.00 & $0 . \infty$ & 0.00 & 0.83 & 0.54 & 0.01 & 0.03 & 0.00 \\
\hline Zircáo & 0.08 & 0.06 & 0.07 & 0.07 & 0.07 & 0.07 & 0.12 & 0.07 & 0.07 & 0.06 & 0.07 & 0.07 & 0.07 & 0.09 & 0.06 & 0.14 \\
\hline Ortoclásio & 29.09 & 35.67 & 33.19 & 33.48 & 26.38 & 27.86 & 26.76 & 27.01 & 30.82 & 39.18 & 26.72 & 30.51 & 21.25 & 26.97 & 31.54 & 33.51 \\
\hline Albita & 28.01 & 24.79 & 22.84 & 26.06 & 25.56 & 23.36 & 24.37 & 26.31 & 37.31 & 17.26 & 27.07 & 24.11 & 26.48 & 30.04 & 24.45 & 17.85 \\
\hline Anortita & 5.88 & 3.30 & 3.87 & 5.54 & 5.48 & 4.16 & 6.76 & 2.33 & 4.40 & 3.36 & 2.24 & 1.57 & 2.36 & 2.63 & 3.23 & 4.85 \\
\hline Diopsidio & 0.81 & 0.0 & 0.77 & 0.00 & 0.38 & 0.58 & 0.26 & 0.33 & 3.73 & 0.67 & 0.59 & 0.00 & 0.00 & 0.00 & $0 . \infty$ & 0.45 \\
\hline Hiperstênio & 2.24 & 1.53 & 1.83 & 2.47 & 2.10 & 1.96 & 5.23 & 1.59 & 7.25 & 2.25 & 1.67 & 1.37 & 2.23 & 2.27 & 1.96 & 3.59 \\
\hline Magnetita & 1.05 & 0.63 & 0.91 & 0.98 & 0.92 & 0.92 & 2.07 & 0.70 & 1.12 & 0.85 & 0.79 & 1.09 & 0.85 & 0.87 & 0.66 & 2.13 \\
\hline limenita & 0.46 & 0.27 & 0.35 & 0.42 & 0.40 & 0.40 & 0.93 & 0.27 & 0.42 & 0.32 & 0.28 & 0.28 & 0.27 & 0.30 & 0.21 & 0.93 \\
\hline Apatita & 0.10 & 0.05 & 0.05 & 0.10 & 0.07 & 0.07 & 0.30 & 0.02 & 0.05 & 0.05 & 0.02 & 0.02 & 0.05 & 0.05 & 0.02 & 0.25 \\
\hline Total & 100.01 & 100.02 & 99.97 & 100.03 & 99.97 & 100.25 & 99.89 & 99.96 & 99.96 & 99.99 & 99.94 & 100.10 & 99.91 & 99.93 & 99.96 & 100.33 \\
\hline
\end{tabular}

Tabela A2.6.2: Normas CIPW de GB e MGF. 


\section{ANEXo 3: Elementos Traço, incluindo ETR, por ICP-MS.}

* TABela 3.1: Dados analíticos de Elementos Traço e ETR de GB e MGF.

* TABELA 3.2: Dados analíticos de Elementos Traço e ETR de Esmeraldas e Águas-Marinhas.

Abreviações: $\mathrm{GB}=$ Metagranitóides Borrachudos; $\mathrm{MGF}=$ Metagranitóides Foliados com Fluorita; $\mathrm{EX}=$ Esmeraldas de xistos; $\mathrm{EVQ}=$ Esmeraldas de Veios de Quartzo; EVP = Esmeraldas de Veios Pegmatóides; AMP = Águas Marinhas da Porção Pegmatóide de Pegmatito em MGF; AMQ = Águas Marinhas da Porção Quartzosa. 
Tabela A.3: Elementos Traço e ETR, por ICP-MS.

\begin{tabular}{|c|c|c|c|c|c|c|c|c|c|}
\hline Amostra & 03 & $\mathrm{~B}-20$ & G-26 & G-29a & $G-29 b$ & G-29c & G-29d & $\mathrm{G}-29 \mathrm{e}$ & G-31 \\
\hline Litotipo & GB & GB & GB & $\mathrm{GB}$ & GB & GB & $\mathrm{GB}$ & GB & $\mathrm{GB}$ \\
\hline $\mathrm{Cr}$ & 39.39 & 25.60 & 43.64 & 35.35 & 13.91 & 12.87 & 12.53 & 49.98 & 54.59 \\
\hline $\mathrm{Ni}$ & 68.43 & 60.15 & 77.24 & 71.03 & 56.99 & 60.77 & 60.28 & 74.28 & 76.71 \\
\hline $\mathrm{Co}$ & 1.01 & 3.69 & 1.62 & 0.81 & 0.79 & 1.39 & 0.78 & 0.86 & 3.09 \\
\hline Sc & 40.17 & 54.41 & 40.38 & 37.57 & 33.90 & 34.96 & 33.99 & 33.03 & 52.23 \\
\hline $\mathrm{V}$ & 1.53 & 4.10 & 1.36 & 0.70 & 0.62 & 1.88 & 0.66 & 0.47 & 3.23 \\
\hline $\mathrm{Cu}$ & 4.58 & 30.48 & 9.59 & 11.66 & 18.55 & 8.60 & 27.02 & 6.49 & 18.73 \\
\hline $\mathrm{Pb}$ & 2018.00 & 39.44 & 49.10 & 31.74 & 47.01 & 43.84 & 51.70 & 46.97 & 34.82 \\
\hline $\mathrm{Zn}$ & 3575.00 & 123.10 & 97.51 & 64.18 & 87.49 & 104.60 & 75.05 & 62.32 & 141.60 \\
\hline $\mathrm{Bi}$ & 0.33 & 0.08 & 0.37 & 0.16 & 2.84 & 0.21 & 1.34 & 0.68 & 0.13 \\
\hline $\mathrm{Cd}$ & 4.16 & 0.36 & 0.31 & 0.29 & 0.29 & 0.52 & 0.29 & 0.33 & 0.54 \\
\hline $\bar{W}$ & 1.70 & 0.39 & 1.16 & 2.89 & 1.84 & 1.61 & 2.00 & 2.24 & 0.83 \\
\hline Mo & 0.67 & 0.84 & 1.09 & 2.07 & 2.87 & 0.93 & 3.89 & 5.60 & 0.63 \\
\hline$s$ & 0.00 & 0.00 & 0.00 & 0.00 & 0.00 & 0.00 & 0.00 & 0.00 & 0.00 \\
\hline As & 0.18 & 2.93 & 1.49 & 36.18 & 12.29 & 3.02 & 89.17 & 5.22 & 2.55 \\
\hline Se & 2.70 & 0.94 & 1.22 & 2.12 & 2.72 & 6.03 & 0.95 & 0.44 & 2.37 \\
\hline $\mathrm{Sb}$ & 0.02 & 0.09 & 0.03 & 0.24 & 0.27 & 0.11 & 0.27 & 0.16 & 0.04 \\
\hline $\mathrm{Te}$ & 0.03 & 0.06 & 0.04 & 0.00 & 0.07 & 0.00 & 0.00 & 0.00 & 0.09 \\
\hline $\mathrm{Ru}$ & 0.01 & 0.01 & 0.00 & 0.01 & 0.00 & 0.01 & 0.00 & 0.00 & 0.00 \\
\hline $\mathrm{Rh}$ & 0.19 & 0.08 & 0.17 & 0.08 & 0.17 & 0.14 & 0.06 & 0.14 & 0.20 \\
\hline$P d$ & 6.05 & 6.39 & 7.09 & 13.47 & 10.04 & 33.51 & 10.03 & 8.07 & 8.81 \\
\hline $\mathrm{Ag}$ & 1.63 & 1.47 & 1.12 & 1.20 & 1.58 & 1.77 & 1.72 & 1.03 & 1.55 \\
\hline Re & 0.00 & 0.00 & 0.00 & 0.00 & 0.00 & 0.00 & 0.00 & 0.00 & 0.00 \\
\hline Os & 0.00 & 0.00 & 0.00 & 0.00 & 0.00 & 0.00 & 0.00 & 0.00 & 0.01 \\
\hline ir & 0.12 & 0.16 & 0.11 & 0.08 & 0.09 & 0.15 & 0.12 & 0.10 & 0.21 \\
\hline $\mathrm{Pt}$ & 2.88 & 3.39 & 1.90 & 3.78 & 3.48 & 2.55 & 3.32 & 5.49 & 6.61 \\
\hline $\mathrm{Hg}$ & 0.09 & 0.03 & 0.03 & 0.06 & 0.00 & 0.00 & 0.30 & 0.00 & 0.05 \\
\hline $\mathrm{K}$ & 36650.00 & 20255.00 & 27403.00 & 16794.00 & 21691.00 & 18620.00 & 19882.00 & 18852.00 & 28872.00 \\
\hline $\mathrm{Rb}$ & 371.30 & 131,30 & 194.40 & 148.70 & 223.50 & 212.50 & 229.90 & 192.50 & 102.60 \\
\hline Cs & 2.29 & 2.55 & 3.60 & 2.78 & 5.74 & 4.67 & 5.87 & 5.04 & 1.35 \\
\hline $\mathrm{Ba}$ & 624.30 & 1323.00 & 1022.00 & 424.70 & 592.30 & 875.00 & 581.70 & 578.50 & 1467.00 \\
\hline $\mathrm{Sr}$ & 41.44 & 176.20 & 131.50 & 66.85 & 78.60 & 97.51 & 81.52 & 84.19 & 214.30 \\
\hline $\mathrm{Ga}$ & 23.13 & 24.37 & 25.09 & 25.08 & 22.14 & 23.53 & 24.82 & 22.06 & 25.92 \\
\hline $\mathrm{Ta}$ & 3.32 & 2.10 & 2.26 & 3.71 & 2.52 & 3.80 & 5.85 & 2.39 & 2.17 \\
\hline $\mathrm{Nb}$ & 42.52 & 35.37 & 29.01 & 24.22 & 28.96 & 44.22 & 35.24 & 23.08 & 29.93 \\
\hline $\mathrm{Hf}$ & 9.24 & 13.71 & 11.48 & 9.05 & 10.67 & 17.15 & 13.21 & 10.66 & 19.20 \\
\hline $\mathrm{Zr}$ & 288.60 & 466.80 & 361.40 & 237.50 & 330.40 & 551.00 & 371.10 & 295.50 & 669.70 \\
\hline $\mathrm{Ti}$ & 696.00 & 1379.00 & 905.00 & 341.00 & 558.00 & 817.00 & 538.00 & 403.00 & 1498.00 \\
\hline$Y$ & 71.30 & 77.28 & 85.43 & 158.10 & 107.40 & 334.00 & 110.60 & 86.07 & 92.50 \\
\hline Th & 28.09 & 20.81 & 31.28 & 34.00 & 33.64 & 32.32 & 32.99 & 42.62 & 19.13 \\
\hline $\mathrm{U}$ & 4.78 & 2.42 & 3.35 & 7.82 & 6.58 & 7.84 & 9.02 & 7.03 & 2.64 \\
\hline La & 116.90 & 120.10 & 65.59 & 196.80 & 124.80 & 285.80 & 122.10 & 180.90 & 113.30 \\
\hline $\mathrm{Co}$ & 222.20 & 229.20 & 132.80 & 283.60 & 243.50 & 255.50 & 238.60 & 333.50 & 154.50 \\
\hline $\mathrm{Pr}$ & 26.37 & 27.76 & 16.70 & 41.11 & 29.20 & 58.48 & 29.92 & 38.27 & 26.48 \\
\hline $\mathrm{Nd}$ & 91.65 & 99.99 & 63.16 & 135.70 & 106.00 & 226.20 & 105.60 & 128.80 & 101.00 \\
\hline $\mathrm{Sm}$ & 17.19 & 18.69 & 15.08 & 26.27 & 21.62 & 46.69 & 21.72 & 23.49 & 20.45 \\
\hline $\mathrm{Eu}$ & 1.48 & 3.64 & 2.72 & 1.85 & 1.85 & 5.17 & 1.69 & 1.80 & 4.86 \\
\hline Gd & 17.64 & 19.04 & 15.50 & 29.87 & 23.51 & 64.57 & 23.15 & 25.08 & 20.97 \\
\hline $\mathrm{Tb}$ & 2.79 & 2.76 & 2.68 & 5.24 & 4.07 & 11.85 & 4.10 & 3.67 & 3.14 \\
\hline Dy & 14.75 & 13.78 & 15.20 & 28.60 & 22.62 & 68.15 & 22.56 & 18.56 & 16.68 \\
\hline Ho & 2.86 & 2.78 & 3.33 & 6.04 & 4.78 & 14.82 & 4.94 & 3.94 & 3.43 \\
\hline $\mathrm{Er}$ & 8.50 & 7.98 & 9.72 & 17.96 & 13.28 & 42.05 & 15.01 & 10.89 & 10.07 \\
\hline $\mathrm{Tm}$ & 1.20 & 1.11 & 1.30 & 2.61 & 1.84 & 6.09 & 2.38 & 1.38 & 1.39 \\
\hline $\mathrm{Yb}$ & 7.65 & 6.95 & 8.50 & 15.91 & 11.54 & 38.29 & 16.29 & 8.52 & 8.98 \\
\hline Lu & 1.07 & 1.04 & 1.19 & 2.32 & 1.61 & 5.50 & 2.31 & 1.16 & 1.43 \\
\hline$F$ & 0.00 & 0.00 & 0.00 & 0.00 & 0.00 & 0.00 & 0.00 & 0.00 & 19.20 \\
\hline $\mathrm{Cl}$ & 0.00 & 9496.00 & 0.00 & 1444.00 & 0.00 & 0.00 & 0.00 & 0.00 & 598.10 \\
\hline $\mathrm{Br}$ & 0.90 & 0.00 & 12.31 & 0.00 & 0.00 & 0.00 & 0.00 & 0.00 & 0.00 \\
\hline 1 & 0.00 & 0.00 & 0.00 & 0.00 & 0.00 & 0.00 & 0.00 & 0.00 & 0.00 \\
\hline
\end{tabular}

Tabela A3.1: Dados analíticos de elementos traço e ETR de GB e MGF, por ICP-MS. 
Tabela A.3: Elementos Traço e ETR, por ICP-MS

\begin{tabular}{|c|c|c|c|c|c|c|c|}
\hline Amostra & G-2a & G-3a & $G-3 b$ & G-9 & G-11a & G-11d & $\mathrm{G}-13 \mathrm{a}$ \\
\hline Litotipo & MGF & MGF & MGF & MGF & MGF & MGF & MGF \\
\hline $\mathrm{Cr}$ & 78.26 & 31.96 & 42.95 & 21.02 & 27.33 & 33.88 & 118.30 \\
\hline $\mathrm{Ni}$ & 85.53 & 64.55 & 71.28 & 46.75 & 60.70 & 90.35 & 137.80 \\
\hline $\mathrm{Co}$ & 1.04 & 0.44 & 0.54 & 0.61 & 0.37 & 0.47 & 2.13 \\
\hline Sc & 43.35 & 43.26 & 41.03 & 36.42 & 43.22 & 46.88 & 48.99 \\
\hline$V$ & 0.15 & 0.04 & 0.00 & 0.77 & 1.35 & 1.32 & 1.68 \\
\hline $\mathrm{Cu}$ & 21.36 & 7.97 & 7.53 & 26.30 & 54.75 & 8.59 & 18.21 \\
\hline $\mathrm{Pb}$ & 818.70 & 66.08 & 46.54 & 60.23 & 51.85 & 85.52 & 47.69 \\
\hline $\mathrm{Zn}$ & 545.10 & 130.20 & 64.16 & 126.20 & 425.20 & 102.90 & 234.30 \\
\hline $\mathrm{Bi}$ & 0.17 & 0.05 & 0.09 & 0.06 & 0.18 & 0.15 & 0.16 \\
\hline $\mathrm{Cd}$ & 5.08 & 0.36 & 0.30 & 0.24 & 0.95 & 0.31 & 0.51 \\
\hline$W$ & 1.14 & 0.87 & 1.39 & 1.74 & 1.04 & 1.24 & 0.00 \\
\hline Mo & 2.26 & 4.63 & 0.54 & 1.16 & 1.12 & 1.43 & 3.32 \\
\hline$S$ & 0.00 & 0.00 & 0.00 & 0.00 & 0.00 & 23330.00 & 34140.00 \\
\hline As & 1.06 & 2.78 & 2.59 & 0.47 & 0.27 & 0.51 & 3.13 \\
\hline Se & 2.85 & 0.00 & 1.72 & 1.90 & 2.70 & 1.35 & 11.37 \\
\hline $\mathrm{Sb}$ & 0.07 & 0.02 & 0.06 & 0.03 & 0.02 & 0.09 & 0.21 \\
\hline$T \theta$ & 0.03 & 0.10 & 0.09 & 0.08 & 0.00 & 0.05 & 0.83 \\
\hline $\mathrm{Ru}$ & 0.00 & 0.00 & 0.00 & 0.02 & 0.00 & 0.01 & 0.15 \\
\hline $\mathrm{Rh}$ & 0.14 & 0.08 & 1.48 & 0.23 & 0.16 & 0.17 & 0.09 \\
\hline $\mathrm{Pd}$ & 19.06 & 10.52 & 10.23 & 10.61 & 13.15 & 7.89 & 6.38 \\
\hline $\mathrm{Ag}$ & 1.24 & 2.25 & 1.12 & 2.18 & 2.64 & 1.30 & 1.42 \\
\hline $\mathrm{Re}$ & 0.00 & 0.00 & 0.00 & 0.00 & 0.00 & 0.00 & 0.03 \\
\hline Os & 0.01 & 0.00 & 0.00 & 0.01 & 0.00 & 0.00 & 0.06 \\
\hline Ir & 0.08 & 0.17 & 0.11 & 0.17 & 0.22 & 0.07 & 0.03 \\
\hline $\mathrm{Pt}$ & 4.45 & 1.80 & 50.75 & 2.55 & 2.63 & 3.35 & 2.12 \\
\hline $\mathrm{Hg}$ & 0.00 & 0.96 & 0.08 & 0.00 & 0.00 & 0.07 & 0.20 \\
\hline$K$ & 38518.00 & 28797.00 & 22629.00 & 20562.00 & 19624.00 & 41930.00 & 102189.00 \\
\hline $\mathrm{Rb}$ & 283.80 & 316.10 & 223.10 & 319.70 & 196.40 & 353.20 & 586.80 \\
\hline Cs & 1.37 & 3.22 & 1.64 & 4.25 & 1.55 & 2.39 & 2.35 \\
\hline $\mathrm{Ba}$ & 587.00 & 128.40 & 93.33 & 161.60 & 49.65 & 181.00 & 120.90 \\
\hline $\mathrm{Sr}$ & 56.26 & 11.60 & 16.51 & 11.67 & 19.93 & 16.43 & $\uparrow 2.56$ \\
\hline $\mathrm{Ga}$ & 22.88 & 26.50 & 27.54 & 26.97 & 31.76 & 33.64 & 54.43 \\
\hline$T \mathbf{a}$ & 2.85 & 3.81 & 4.02 & 5.51 & 3.27 & 5.66 & 5.18 \\
\hline $\mathrm{Nb}$ & 31.18 & 57.22 & 28.49 & 56.09 & 63.35 & 67.40 & 91.77 \\
\hline $\mathrm{Hf}$ & 6.71 & 13.63 & 11.94 & 16.19 & 16.69 & 8.17 & 9.58 \\
\hline $\mathrm{Zr}$ & 231.70 & 357.20 & 310.60 & 432.90 & 403.80 & 204.20 & 348.70 \\
\hline $\mathrm{Ti}$ & 691.00 & 450.00 & 291.00 & 473.00 & 459.00 & 409.00 & 784.00 \\
\hline$Y$ & 208.10 & 114.90 & 106.50 & 121.30 & 158.20 & 119.10 & 156.70 \\
\hline Th & 30.09 & 38.64 & 45.81 & 53.78 & 49.42 & 35.84 & 35.49 \\
\hline $\mathrm{U}$ & 5.39 & 9.19 & 9.94 & 8.46 & 17.16 & 16.21 & 8.04 \\
\hline $\mathrm{La}$ & 217.60 & 118.10 & 124.30 & 150.10 & 176.40 & 114.10 & 118.70 \\
\hline $\mathrm{C} \theta$ & 262.60 & 228.60 & 245.90 & 128.90 & 309.00 & 226.90 & 230.90 \\
\hline $\mathrm{Pr}$ & 38.06 & 27.34 & 29.41 & 52.35 & 37.10 & 24.68 & 23.46 \\
\hline Nd & 132.60 & 91.65 & 101.00 & 95.88 & 123.60 & 90.39 & 71.35 \\
\hline $\mathrm{Sm}$ & 24.50 & 18.33 & 20.25 & 18.62 & 26.06 & 17.43 & 16.86 \\
\hline $\mathrm{Eu}$ & 1.99 & 0.47 & 0.47 & 0.52 & 0.36 & 0.60 & 0.23 \\
\hline Gd & 31.74 & 20.31 & 21.60 & 23.83 & 27.67 & 19.57 & 17.16 \\
\hline $\mathrm{Tb}$ & 5.37 & 3.51 & 3.47 & 3.82 & 4.64 & 3.61 & 3.42 \\
\hline Dy & 33.74 & 20.11 & 19.30 & 22.60 & 27.89 & 23.48 & 18.74 \\
\hline $\mathrm{Ho}$ & 7.42 & 4.32 & 3.83 & 4.94 & 5.91 & 4.96 & 4.80 \\
\hline Er & 22.18 & 13.16 & 11.20 & 16.29 & 17.37 & 14.95 & 11.88 \\
\hline $\mathrm{Tm}$ & 3.23 & 1.92 & 1.69 & 2.57 & 2.65 & 2.28 & 1.93 \\
\hline $\mathrm{Yb}$ & 20.15 & 12.60 & 10.46 & 16.92 & 16.37 & $\$ 4.65$ & 11.78 \\
\hline Lu & 2.94 & 1.72 & 1.56 & 2.33 & 2.34 & 2.11 & 1.57 \\
\hline$F$ & 0.00 & 0.00 & 0.00 & 0.00 & 0.00 & 0.00 & 0.00 \\
\hline $\mathrm{Cl}$ & 86.28 & 0.00 & 0.00 & 348.90 & 0.00 & 1871.00 & 23620.00 \\
\hline $\mathrm{Br}$ & 0.00 & 0.00 & 0.00 & 0.00 & 0.00 & 4.94 & 36.89 \\
\hline 7 & 0.00 & 0.00 & 0.00 & 0.00 & 0.00 & 0.02 & 0.38 \\
\hline
\end{tabular}

Tabela A3.1: Dados analiticos de elementos traço e ETR de GB e MGF, por ICP-MS. 
Tabela A.3: Elementos Traço e ETR, por ICP-MS.

\begin{tabular}{|c|c|c|c|c|c|c|c|c|c|}
\hline Amostra & $B E-04$ & BE-08a & $\mathrm{G}-260$ & B-21 & B-22 & B-22(2) & $\mathrm{NE}-34$ & NE-36a1 & NE-36a2 \\
\hline Litotipo & EX & $E X$ & EX & EVQ & EVQ & EVQ & EVQ & EVQ & EVQ \\
\hline $\mathrm{Cr}$ & 3453.00 & 2189.00 & 726.00 & 2960.00 & 1563.00 & 1165.00 & 996.80 & 430.30 & 898.10 \\
\hline $\mathrm{Ni}$ & 109.30 & 98.37 & 61.21 & 101.20 & 134.90 & 74.36 & 78.80 & 85.05 & 89.79 \\
\hline $\mathrm{Co}$ & 6.73 & 4.52 & 3.58 & 3.81 & 3.78 & 2.93 & 2.59 & 3.12 & 3.13 \\
\hline Sc & 66.94 & 52.49 & 119.50 & 131.20 & 106.10 & 89.37 & 119.50 & 138.00 & 222.80 \\
\hline $\mathrm{V}$ & 158.90 & 104.90 & 67.94 & 124.40 & 121.90 & 103.10 & 82.68 & 91.07 & 132.10 \\
\hline $\mathrm{Cu}$ & 7.17 & 14.71 & 13.98 & 18.85 & 8.32 & 9.82 & 9.98 & 3.30 & 9.03 \\
\hline $\mathrm{Pb}$ & 3.07 & 1.25 & 3.46 & 1.60 & 13.82 & 1.84 & 0.69 & 4.65 & 3.45 \\
\hline $\mathrm{Zn}$ & 113.50 & 77.75 & 63.93 & 62.18 & 153.60 & 80.75 & 107.00 & 153.80 & 119.00 \\
\hline $\mathrm{Bi}$ & 0.40 & 0.18 & 0.25 & 0.68 & 0.16 & 0.14 & 0.02 & 1.19 & 2.85 \\
\hline $\mathrm{Cd}$ & 0.06 & 0.30 & 0.20 & 0.14 & 0.28 & 0.25 & 0.04 & 0.00 & 0.28 \\
\hline $\mathrm{Sn}$ & 3.93 & 1.77 & 3.28 & 3.52 & 3.76 & 0.86 & 2.02 & 3.28 & 2.21 \\
\hline$w$ & 14.46 & 6.84 & 7.55 & 20.04 & 0.30 & 0.34 & 7.75 & 6.16 & 9.39 \\
\hline Mo & 0.40 & 0.53 & 0.70 & 0.41 & 0.42 & 0.39 & 0.18 & 0.13 & 0.41 \\
\hline$S$ & 25770.00 & 24170.00 & 6450.00 & 33210.00 & 42750.00 & 0.00 & 10410.00 & 21560.00 & 34020.00 \\
\hline As & 2.20 & 1.82 & 1.24 & 2.99 & 1.55 & 0.56 & 0.79 & 0.51 & 0.84 \\
\hline $\mathrm{Se}$ & 1.29 & 1.80 & 2.12 & 2.55 & 2.06 & 0.00 & 1.44 & 1.48 & 2.13 \\
\hline $\mathrm{Sb}$ & 0.31 & 0.34 & 0.27 & 0.60 & 0.15 & 0.04 & 0.06 & 0.08 & 0.18 \\
\hline $\mathrm{Te}$ & 0.00 & 0.02 & 0.00 & 0.00 & 0.00 & 0.07 & 0.00 & 0.00 & 0.01 \\
\hline $\mathrm{Ru}$ & 0.02 & 0.00 & 0.00 & 0.00 & 0.00 & 0.00 & 0.00 & 0.00 & 0.00 \\
\hline $\mathrm{Rh}$ & 0.07 & 0.19 & 0.04 & 0.20 & 0.22 & 0.30 & 0.03 & 0.10 & 0.38 \\
\hline $\mathrm{Pd}$ & 0.22 & 0.17 & 0.99 & 0.16 & 0.47 & 0.25 & 0.13 & 0.14 & 0.13 \\
\hline $\mathrm{Ag}$ & 0.29 & 0.85 & 1.01 & 0.46 & 0.35 & 0.44 & 0.36 & 0.07 & 0.14 \\
\hline $\mathrm{Re}$ & 0.00 & 0.00 & 0.00 & 0.00 & 0.00 & 0.00 & 0.00 & 0.00 & 0.00 \\
\hline Os & 0.00 & 0.00 & 0.00 & 0.00 & 0.00 & 0.00 & 0.00 & 0.00 & 0.00 \\
\hline Ir & 0.01 & 0.00 & 0.04 & 0.03 & 0.06 & 0.08 & 0.01 & 0.01 & 0.01 \\
\hline$P t$ & 0.97 & 3.04 & 0.79 & 5.43 & 7.89 & 8.19 & 1.28 & 0.85 & 0.90 \\
\hline $\mathrm{Au}$ & 0.00 & 0.00 & 0.00 & 0.00 & 0.01 & 0.00 & 0.00 & 0.01 & 0.00 \\
\hline $\mathrm{Hg}$ & 0.45 & 0.15 & 0.38 & 0.78 & 0.10 & 0.00 & 0.25 & 0.06 & 0.21 \\
\hline $\mathrm{K}$ & 2433.00 & 723.00 & 306.00 & 337.00 & 965.00 & 167.00 & 966.00 & 1190.00 & 1484.00 \\
\hline$R b$ & 63.74 & 32.61 & 37.11 & 30.80 & 24.41 & 23.45 & 100.90 & $\$ 22.70$ & 99.93 \\
\hline Cs & 72.25 & 77.65 & 78.96 & 45.88 & 37.81 & 39.12 & 213.20 & 244.10 & 266.90 \\
\hline $\mathrm{Ba}$ & 15.17 & 7.64 & 9.81 & 7.46 & 77.54 & 43.66 & 3.37 & 3.79 & 3.75 \\
\hline $\mathrm{Sr}$ & 1.14 & 0.91 & 40.91 & 1.98 & 2.58 & 1.80 & 0.37 & 1.01 & 0.65 \\
\hline $\mathrm{Ga}$ & 12.91 & 12.06 & 16.83 & 10.83 & 13.40 & 12.23 & 9.37 & 9.10 & 12.13 \\
\hline $\mathrm{Ta}$ & 0.23 & 0.13 & 0.86 & 0.30 & 0.04 & 0.26 & 1.21 & 0.15 & 0.20 \\
\hline $\mathrm{Nb}$ & 2.82 & 0.56 & 26.91 & 1.31 & 1.08 & 0.47 & 3.30 & 0.98 & 1.12 \\
\hline $\mathrm{Hf}$ & 0.28 & 0.22 & 2.12 & 0.72 & 5.49 & 5.41 & 0.04 & 0.05 & 0.05 \\
\hline $\mathrm{Zr}$ & 19.30 & 13.01 & 159.40 & 44.04 & 236.00 & 227.40 & 1.26 & 0.83 & 1.74 \\
\hline $\mathrm{Ti}$ & 146.00 & 90.00 & 158.00 & 100.00 & 103.00 & 22.00 & 34.00 & 71.00 & 125.70 \\
\hline$Y$ & 1.34 & 0.77 & 14.31 & 1.12 & 2.40 & 2.27 & 0.32 & 0.46 & 0.63 \\
\hline Th & 0.68 & 0.14 & 4.41 & 0.44 & 0.92 & 0.46 & 0.08 & 0.18 & 0.20 \\
\hline $\mathrm{U}$ & 0.37 & 0.23 & 1.68 & 1.13 & 0.23 & 0.19 & 1.32 & 0.39 & 0.44 \\
\hline La & 5.61 & 0.27 & 42.08 & 0.99 & 2.35 & 2.29 & 0.12 & 0.12 & 0.73 \\
\hline $\mathrm{Ce}$ & 6.74 & 0.90 & 84.26 & 2.09 & 2.89 & 2.57 & 0.24 & 0.22 & 0.13 \\
\hline $\mathrm{Pr}$ & 0.99 & 0.08 & 8.00 & 0.35 & 0.53 & 0.52 & 0.04 & 0.03 & 0.07 \\
\hline $\mathrm{Nd}$ & 2.64 & 0.30 & 22.05 & 1.20 & 1.90 & 1.81 & 0.13 & 0.10 & 0.08 \\
\hline $\mathrm{Sm}$ & 0.34 & 0.05 & 2.71 & 0.25 & 0.42 & 0.39 & 0.04 & 0.03 & 0.03 \\
\hline $\mathrm{Eu}$ & 0.09 & 0.01 & 0.83 & 0.03 & 0.14 & 0.08 & 0.00 & 0.00 & 0.00 \\
\hline $\mathrm{Gd}$ & 0.45 & 0.07 & 3.35 & 0.16 & 0.40 & 0.37 & 0.08 & 0.04 & 0.04 \\
\hline$T b$ & 0.07 & 0.01 & 0.43 & 0.04 & 0.08 & 0.05 & 0.02 & 0.01 & 0.01 \\
\hline Dy & 0.24 & 0.07 & 2.42 & 0.14 & 0.30 & 0.40 & 0.06 & 0.06 & 0.08 \\
\hline $\mathrm{Ho}$ & 0.04 & 0.02 & 0.49 & 0.04 & 0.08 & 0.07 & 0.01 & 0.01 & 0.01 \\
\hline Er & 0.13 & 0.12 & 1.70 & 0.13 & 0.21 & 0.22 & 0.03 & 0.05 & 0.05 \\
\hline $\mathrm{Tm}$ & 0.01 & 0.01 & 0.23 & 0.02 & 0.03 & 0.04 & 0.01 & 0.01 & 0.02 \\
\hline $\mathrm{Yb}$ & 0.14 & 0.10 & 1.53 & 0.14 & 0.25 & 0.26 & 0.21 & 0.35 & 0.31 \\
\hline Lu & 0.03 & 0.02 & 0.29 & 0.03 & 0.05 & 0.05 & 0.09 & 0.19 & 0.17 \\
\hline $\mathrm{Cl}$ & 549.00 & 1541.00 & 0.00 & 1319.00 & 3328.00 & 0.00 & 0.00 & 256.70 & 1441.00 \\
\hline $\mathrm{Br}$ & 0.00 & 0.00 & 0.00 & 0.00 & 0.00 & 0.00 & 0.00 & 0.00 & 0.00 \\
\hline$T$ & 0.00 & 0.00 & 0.00 & 0.00 & 0.00 & 0.00 & 0.00 & 0.00 & 0.00 \\
\hline
\end{tabular}

Tabela A3.2.1: Dados analíticos de elementos traço e ETR de esmeraldas de xistos (EX), veios de quartzo (EVQ) e veios pegmatóides (EVP), por ICP-MS

Nota: B-21 e B-22: EVQ polideformados; NE-34 e NE-36a,b: EVQ pouco deformados. 
Tabela A.3: Elementos Traço e ETR, por ICP-MS.

\begin{tabular}{|c|c|c|c|c|c|c|c|}
\hline Amostra & NE-36b & Gal 1/2a & NE-30c & NE-31.01 & NE-31-02 & NE-31-03 & NE-31-06 \\
\hline Litotipo & EVQ & EVP & EVP & EVP & EVP & EVP & EVP \\
\hline $\mathrm{Cr}$ & 284.90 & 782.90 & 442.50 & 227.20 & 343.60 & 181.90 & 562.60 \\
\hline $\mathrm{Ni}$ & 66.62 & 73.89 & 90.16 & 77.15 & 79.37 & 88.21 & 79.17 \\
\hline Co & 2.56 & 2.14 & 6.80 & 3.20 & 2.73 & 2.87 & 2.74 \\
\hline $\mathrm{Sc}$ & 80.67 & 137.10 & 113.10 & 107.60 & 59.50 & 63.55 & 76.96 \\
\hline $\mathrm{V}$ & 59.01 & 85.42 & 78.08 & 68.21 & 44.42 & 45.74 & 60.69 \\
\hline $\mathrm{Cu}$ & 2.53 & 2.80 & 4.51 & 12.09 & 7.79 & 7.93 & 1.04 \\
\hline $\mathrm{Pb}$ & 1.82 & 6.08 & 3.67 & 1.35 & 1.52 & 0.78 & 0.75 \\
\hline $\mathrm{Zn}$ & 112.50 & 118.60 & 177.00 & 164.70 & 148.80 & 184.90 & 140.60 \\
\hline $\mathrm{Bi}$ & 0.10 & 0.31 & 0.14 & 0.01 & 0.00 & 0.00 & 0.03 \\
\hline $\mathrm{Cd}$ & 0.04 & 0.11 & 0.18 & 0.11 & 0.14 & 0.07 & 0.09 \\
\hline Sn & 3.15 & 1.94 & 4.25 & 3.08 & 1.01 & 2.31 & 1.31 \\
\hline $\bar{W}$ & 12.62 & 0.61 & 5.17 & 4.72 & 15.51 & 3.96 & 9.80 \\
\hline Mo & 0.29 & 0.29 & 0.18 & 0.49 & 0.27 & 0.94 & 0.34 \\
\hline 5 & 0.00 & 3315.00 & 17510.00 & 9138.00 & 0.00 & 6086.00 & 9236.00 \\
\hline As & 0.15 & 0.49 & 0.47 & 0.36 & 0.58 & 0.08 & 0.32 \\
\hline $\mathrm{Se}$ & 0.62 & 0.23 & 1.44 & 0.00 & 1.23 & 0.91 & 1.69 \\
\hline $\mathrm{sb}$ & 0.07 & 0.07 & 0.03 & 0.11 & 0.15 & 0.07 & 0.06 \\
\hline $\mathrm{Te}$ & 0.00 & 0.00 & 0.00 & 0.00 & 0.00 & 0.00 & 0.00 \\
\hline $\mathrm{Ru}$ & 0.00 & 0.00 & 0.00 & 0.00 & 0.00 & 0.00 & 0.00 \\
\hline Rh & 0.04 & 0.32 & 0.08 & 0.04 & 0.06 & 0.06 & 0.08 \\
\hline $\mathrm{Pd}$ & 0.16 & 0.67 & 0.87 & 0.36 & 0.17 & 0.13 & 0.09 \\
\hline$\overline{\mathrm{Ag}}$ & 0.14 & 0.20 & 0.12 & 0.30 & 0.31 & 0.23 & 0.07 \\
\hline $\operatorname{Re}$ & 0.00 & 0.00 & 0.00 & 0.00 & 0.00 & 0.00 & 0.00 \\
\hline $\mathrm{Os}$ & 0.00 & 0.00 & 0.00 & 0.00 & 0.00 & 0.00 & 0.00 \\
\hline $\mathrm{Ir}$ & 0.00 & 0.01 & 0.01 & 0.01 & 0.02 & 0.00 & 0.01 \\
\hline $\mathrm{Pt}$ & 1.14 & 1.56 & 2.19 & 0.64 & 0.45 & 1.94 & 0.79 \\
\hline$\overline{A u}$ & 0.00 & $0 . \infty$ & 0.00 & 0.00 & 0.00 & 0.00 & 0.00 \\
\hline $\mathrm{Hg}$ & 0.44 & 0.00 & 0.15 & 0.13 & 0.46 & 0.09 & 0.33 \\
\hline $\mathrm{K}$ & 509.00 & 2326.00 & 2462.00 & 750.00 & 446.00 & 783.00 & 832.00 \\
\hline$\overline{R b}$ & 90.97 & 77.82 & 76.66 & 58.21 & 50.45 & 59.80 & 61.03 \\
\hline Cs & 212.30 & 157.80 & 159.60 & 170.00 & 138.60 & 142.80 & 150.10 \\
\hline $\mathrm{Ba}$ & 2.95 & 60.92 & 15.65 & 3.35 & 3.30 & 2.94 & 6.28 \\
\hline $\mathrm{Sr}$ & 0.59 & 4,45 & 0.91 & 1.02 & 1.00 & 0.46 & 1.51 \\
\hline $\mathrm{Ga}$ & 7.41 & 12.79 & 12.83 & 11.58 & 9.99 & 9.30 & 12.05 \\
\hline $\mathrm{Ta}$ & 6.30 & 0.03 & 0.56 & 6.81 & 6.18 & 0.92 & 0.46 \\
\hline $\mathrm{Nb}$ & 19.34 & 0.80 & 2.78 & 20.15 & 16.97 & 2.53 & 9.31 \\
\hline $\mathrm{Hf}$ & 0.09 & 0.23 & 0.08 & 0.06 & 0.12 & 0.06 & 0.07 \\
\hline $\mathrm{Zr}$ & 2.23 & 7.96 & 0.99 & 1.51 & 3.51 & 0.87 & 1.83 \\
\hline $\mathrm{Ti}$ & 17.00 & 31.00 & 86.00 & 42.00 & 20.00 & 29.00 & 44.00 \\
\hline $\bar{Y}$ & 0.72 & 5.03 & 11.99 & 3.30 & 1.86 & 0.60 & 0.71 \\
\hline Th & 0.38 & 0.19 & 0.22 & 0.16 & 0.25 & 0.03 & 0.15 \\
\hline $\mathrm{U}$ & 2.74 & 0.16 & 1.39 & 2.09 & 3.57 & 0.42 & 0.70 \\
\hline $\mathrm{La}$ & 0.26 & 1.13 & 0.62 & 0.73 & 0.39 & 0.10 & 0.43 \\
\hline $\mathrm{Ce}$ & 0.44 & 3.29 & 7.64 & 2.01 & 0.82 & 0.28 & 0.94 \\
\hline $\mathrm{Pr}$ & 0.05 & 0.34 & 0.20 & 0.29 & 0.09 & 0.03 & 0.10 \\
\hline $\mathrm{Nd}$ & 0.22 & 1.67 & 0.76 & 1.13 & 0.36 & 0.05 & 0.25 \\
\hline $\mathrm{Sm}$ & 0.05 & 0.39 & 0.42 & 0.34 & 0.09 & 0.01 & 0.04 \\
\hline $\mathrm{Eu}$ & 0.00 & 0.08 & 0.05 & 0.05 & 0.00 & 0.00 & 0.02 \\
\hline $\mathrm{Gd}$ & 0.07 & 0.46 & 0.58 & 0.32 & 0.20 & 0.05 & 0.07 \\
\hline Tb & 0.02 & 0.09 & 0.23 & 0.07 & 0.04 & 0.01 & 0.01 \\
\hline Dy & 0.12 & 0.55 & 2.48 & 0.49 & 0.35 & 0.10 & 0.08 \\
\hline Ho & 0.03 & 0.13 & 0.61 & 0.10 & 0.06 & 0.04 & 0.02 \\
\hline Er & 0.07 & 0.40 & 2.28 & 0.31 & 0.19 & 0.12 & 0.08 \\
\hline $\mathrm{Tm}$ & 0.01 & 0.07 & 0.49 & 0.04 & 0.04 & 0.03 & 0.02 \\
\hline$Y b$ & 0.24 & 0.47 & 3.45 & 0.51 & 0.38 & 0.33 & 0.20 \\
\hline Lu & 0.13 & 0.16 & 0.53 & 0.17 & 0.09 & 0.10 & 0.06 \\
\hline $\mathrm{Cl}$ & 0.00 & 2627.00 & 0.00 & 0.00 & 112.10 & 588.00 & 179.10 \\
\hline $\mathrm{Br}$ & 0.00 & 0.00 & 0.00 & 0.00 & 0.00 & 0.00 & 0.00 \\
\hline$T$ & 0.00 & 0.00 & 0.00 & 0.00 & 0.00 & 0.00 & 0.00 \\
\hline
\end{tabular}

Tabela A3.2.1: Dados analíticos de elementos traço e ETR de esmeraldas de xistos (EX), veios de quartzo (EVQ) e veios pegmatóides (EVP), por ICP-MS. 
Tabela A.3: Elementos Traço e ETR, por ICP-MS.

\begin{tabular}{|c|c|c|c|c|}
\hline Amostra & G-39a & G-39b & $G-39 b(2)$ & G-39c \\
\hline Litotipo & AMP & AMP & AMP & AMQ \\
\hline $\mathrm{Cr}$ & 35.02 & 29.83 & 33.16 & 31.37 \\
\hline $\mathrm{Ni}$ & 77.77 & 84.76 & 60.61 & 73.87 \\
\hline Co & 1.98 & 1.13 & 0.94 & 0.58 \\
\hline Sc & 35.87 & 46.11 & 43.05 & 36.89 \\
\hline $\mathrm{V}$ & 22.09 & 23.17 & 22.63 & 1.89 \\
\hline $\mathrm{Cu}$ & 9.89 & 4.87 & 4.01 & 13.02 \\
\hline $\mathrm{Pb}$ & 5.61 & 22.16 & 22.36 & 1070.00 \\
\hline $\mathrm{Zn}$ & 331.80 & 376.70 & 351.90 & 25.15 \\
\hline $\mathrm{Bi}$ & 1.96 & 0.26 & 0.28 & 0.38 \\
\hline Cd & 0.19 & 0.14 & 0.09 & 0.86 \\
\hline Sn & 0.00 & 1.99 & 1.02 & 1.65 \\
\hline$W$ & 13.74 & 5.12 & 4.85 & 5.13 \\
\hline Mo & 0.88 & 0.44 & 0.54 & 0.43 \\
\hline$S$ & 2007.00 & 22550.00 & 18270.00 & 36820.00 \\
\hline As & 2.47 & 0.55 & 0.56 & 0.82 \\
\hline Se & 0.00 & 0.00 & 0.77 & 0.13 \\
\hline $\mathrm{Sb}$ & 0.41 & 0.05 & 0.10 & 0.15 \\
\hline Te & 0.00 & 0.00 & 0.00 & 0.02 \\
\hline $\mathrm{Ru}$ & 0.00 & 0.00 & 0.00 & 0.00 \\
\hline $\mathrm{Rh}$ & 1.65 & 0.19 & 0.11 & 0.16 \\
\hline $\mathrm{Pd}$ & 1.14 & 0.59 & 0.76 & 0.69 \\
\hline $\mathrm{Ag}$ & 0.21 & 0.20 & 0.13 & 0.21 \\
\hline$R \theta$ & 0.00 & 0.00 & 0,00 & 0.00 \\
\hline Os & 0.00 & 0.00 & 0.00 & 0.00 \\
\hline Ir & 0.01 & 0.00 & 0.01 & 0.02 \\
\hline$\overline{P t}$ & 116.50 & 1.60 & 1.54 & 3.25 \\
\hline $\mathrm{Au}$ & 0.00 & 0.00 & 0.00 & 0.01 \\
\hline $\mathrm{Hg}$ & 0.22 & 0.20 & 0.16 & 0.05 \\
\hline $\mathrm{K}$ & 367.00 & 873.00 & 786.00 & 61297.00 \\
\hline$R b$ & 31.73 & 32.34 & 31.44 & 205.70 \\
\hline Cs & 40.12 & 21.92 & 21.71 & 1.10 \\
\hline $\mathrm{Ba}$ & 11.54 & 17.92 & 18.77 & 1278.00 \\
\hline $\mathrm{Sr}$ & 2.99 & 1.34 & 1.19 & 95.25 \\
\hline $\mathrm{Ga}$ & 18.01 & 15.65 & 14.64 & 13.00 \\
\hline Ta & 0.62 & 0.07 & 0.07 & 0.18 \\
\hline $\mathrm{Nb}$ & 1.16 & 1.17 & 0.45 & 1.11 \\
\hline $\mathrm{Hf}$ & 0.19 & 0.18 & 0.03 & 1.58 \\
\hline $\mathrm{Zr}$ & 13.41 & 5.53 & 2.72 & 62.72 \\
\hline $\mathrm{Ti}$ & 36.00 & 64.00 & 52.00 & 62.00 \\
\hline$Y$ & 2.80 & 7.46 & 7.22 & 6.86 \\
\hline Th & 0.53 & 0.77 & 0.55 & 2.53 \\
\hline U & 1.19 & 0.27 & 0.28 & 0.49 \\
\hline La & 1.34 & 6.47 & 6.15 & 13.78 \\
\hline $\mathrm{C}_{\theta}$ & 1.49 & 5.63 & 5.37 & 28.14 \\
\hline $\mathrm{Pr}$ & 0.47 & 1.62 & 2.17 & 3.62 \\
\hline $\mathrm{Nd}$ & 1.48 & 6.05 & 6.17 & 14.36 \\
\hline $\mathrm{Sm}$ & 0.42 & 1.48 & 1.39 & 8.36 \\
\hline Eu & 0.12 & 0.40 & 0.38 & 8.57 \\
\hline $\mathrm{Gd}$ & 0.47 & 1.42 & 1.35 & 3.76 \\
\hline $\mathrm{Tb}$ & 0.06 & 0.25 & 0.24 & 0.57 \\
\hline Dy & 0.39 & 1.28 & 1.37 & 2.02 \\
\hline Ho & 0.11 & 0.26 & 0.27 & 0.30 \\
\hline Er & 0.24 & 0.71 & 0.72 & 0.59 \\
\hline $\mathrm{Tm}$ & 0.03 & 0.09 & 0.10 & 0.07 \\
\hline $\mathrm{Yb}$ & 0.27 & 0.68 & 0.66 & 0.55 \\
\hline Lu & 0.04 & 0.11 & 0.11 & 0.08 \\
\hline $\mathrm{Cl}$ & 0.00 & 352.10 & 0.00 & 2159.00 \\
\hline $\mathrm{Br}$ & 0.00 & 0.00 & 0.00 & 4.45 \\
\hline 1 & 0.00 & 0.00 & 0.00 & 0.00 \\
\hline
\end{tabular}

Tabela A3.2.2: Dados analiticos de elementos traço e ETR de águas marinhas, por ICP-MS. 


\title{
ANEXo 4: Química Mineral por MSE e FRX
}

\author{
* TABELA 4.1: Biotita. \\ * Tabela 4.2: Anfibólio. \\ * TABela 4.3: Plagioclásio. \\ * TABELA 4.4: K-feldspato. \\ * TABELA 4.5: Granada. \\ * Tabela 4.6: Cordierita. \\ * TABELA 4.7: Estaurolita. \\ * TABela 4.8: Clorita. \\ * TABEla 4.9: Esmeralda. \\ * Tabela 4.10: Outros Minerais.
}

\section{Símbolos/Abreviações:}

Local (Ponto de Análise no Mineral): $\mathrm{C}=$ centro; $\mathrm{B}=$ borda; $\mathrm{B}(\mathrm{i})=$ borda interna; $\mathrm{B}(\mathrm{e})=$ borda externa; $\mathrm{B}(\mathrm{ee})=$ borda externa extrema; $\mathrm{PIn}=$ parte interna; $\mathrm{PIm}=$ parte intermediária; Lente $\mathrm{Bt}=$ lente em biotita esfoliada; Lente $\mathrm{Flo}=$ lente em flogopita esfoliada; Média $4=$ média de 4 análises; n.a. = não analisado.

Minerais: $\mathrm{BT}=$ biotita; $\mathrm{FLO}=$ flogopita; $\mathrm{ANF}=$ anfibólio; $\mathrm{A} . \mathrm{V} .=$ anfibólio verde; A.I. $=$ anfibólio incolor; PLA = plagioclásio; $\mathrm{KF}=$ feldspato potássico; $\mathrm{GR}=$ granada $\mathrm{CD}=$ cordierita; $\mathrm{STAU}=$ estaurolita; $\mathrm{CLO}=$ clorita; $\mathrm{ESM}=$ esmeralda, tipo: $\mathrm{EX}=$ esmeralda de xisto; $\mathrm{EVQ}=$ esmeralda de veio de quartzo; $\mathrm{EVP}=$ esmeralda de veio pegmatóide; $\mathrm{S} / \mathrm{ID}$ = esmeralda sem identificação paragenética; $\mathrm{ILM}=$ ilmenita; $\mathrm{AP}=$ apatita; $\mathrm{CRT}=$ cromita; $\mathrm{EP}=$ epidoto; TIT = titanita $\mathrm{MGT}=$ magnetita; $\mathrm{RU}=$ rutilo; $\mathrm{KY}=$ cianita; $\mathrm{TC}=$ talco; $\mathrm{MU}=$ muscovita $\mathrm{ZEOL}=$ zeólita.

Litotipo: TTG $=$ gnaisse da associação tonalito-trondhjemito-granodiorito; $\mathrm{GB}=$ Metagranitóide Borrachudos; MGF = Metagranitóide Foliado com Fluorita; PGD = Pegmatóide intrusivo em rochas da SVS; UM = Rocha Metaultramáfica, Cromitito e Equivalentes Metassomáticos; $\mathrm{AB}=$ Anfibolito Metabásico; $\mathrm{ABET}=$ Anfibolito Metabásico com Epidoto e/ou Titanita; $\mathrm{ABG}=$ Anfibolito Metabásico com Granada; $\mathrm{MP}=$ Metapelito; $\mathrm{MG}=$ Metagrauvaca . 
Tabela A4.1: Biotitas/Flogopitas - BT/FLO

\begin{tabular}{|c|c|c|c|c|c|c|c|c|c|c|c|c|c|c|c|c|c|c|}
\hline Amostras & G-168g & G-108g & G-168g & G-168g & G-26 & G-26 & G-26 & G-26 & $G-20 c$ & $G-29 c$ & $G-29 d$ & $G-29 d$ & $G-29 d$ & $G-29 d$ & G-113 & G-113 & G-113 & G-113 \\
\hline Análises & $5 / 1 / 1$ & $5 / 1 / 2$ & $5 / 1 / 3$ & $5 / 1 / 4$ & $3 / 1 / 77$ & $3 / / 78$ & $6 / 2 / 24$ & $6 / 2 / 25$ & $6 / 1 / 33$ & 61134 & $4 / 25$ & $4 / 2 / 6$ & $4 / 3 / 10$ & $43 / 11$ & $5 / 3 / 10$ & $5 / 3 / 11$ & $5 / 3 / 14$ & $5 / 3 / 15$ \\
\hline Mineral & BT & BT & BT & BT & BT & BT & BT & BT & BT & BT & BT & BT & BT & BT & BT & BT & BT & BT \\
\hline Local & $\mathrm{C}$ & $B$ & $\mathrm{C}$ & B & $\mathrm{C}$ & $\mathrm{C}$ & $\mathrm{B}$ & $\mathrm{C}$ & $\mathrm{C}$ & $B$ & C & $B$ & C & B & $B$ & c & $\mathrm{B}$ & $c$ \\
\hline Litotipo & $\pi \mathrm{TG}$ & TTG & TTG & TTG & $\mathrm{GB}$ & $\mathrm{GB}$ & $\mathrm{GB}$ & $\mathrm{GB}$ & GB & $\mathrm{GB}$ & $\mathrm{GB}$ & $\mathrm{GB}$ & $\mathrm{GB}$ & $\mathrm{GB}$ & $\mathrm{GB}$ & GB & $\mathrm{GB}$ & GB \\
\hline $\mathrm{SiO}_{2}$ & 35.77 & 35.66 & 35.42 & 35.60 & 33.99 & 32.41 & 32.28 & 32.77 & 35.08 & 33.34 & 34.85 & 34.09 & 34.40 & 31.73 & 33.89 & 33.90 & 33.46 & 33.44 \\
\hline $\mathrm{TiO}_{2}$ & 259 & 2.41 & 2.56 & 2.60 & 1.81 & 1.56 & 0.83 & 0.96 & 2.14 & 2.20 & 2.70 & 2.41 & 1.08 & 1.46 & 1.87 & 2.8 & 1.16 & 1.00 \\
\hline $\mathrm{Al}_{2} \mathrm{O}_{3}$ & 15.81 & 16.0 & 15.90 & 15.67 & 16.25 & 15.72 & 16.79 & 17.19 & 15.83 & 15.67 & 15.42 & 15.55 & 16.96 & 17.13 & 16.68 & 15.25 & 16.66 & 15.74 \\
\hline $\mathrm{Cr}_{2} \mathrm{O}_{3}$ & 0.00 & 0.01 & 0.02 & 0.00 & 0.02 & 0.01 & 0.04 & 0.02 & 0.00 & 0.01 & 0.00 & 0.00 & 0.00 & 0.00 & 0.00 & 0.00 & 0.00 & 0.00 \\
\hline $\mathrm{ZnO}$ & n.a. & n.a. & ก.a. & n.a. & 0.15 & 0.07 & n.a. & n.a. & n.a. & n.a. & 0.08 & 0.14 & 0.11 & 0.10 & 0.20 & 0.13 & 0.15 & 0.18 \\
\hline $\mathrm{FeO}$ & 21.67 & 21.41 & 21.87 & 21.76 & 34.52 & 31.51 & 34.15 & 32.76 & 33.86 & 32.79 & 33.50 & 33.61 & 33.04 & 35.56 & 33.63 & 33.01 & 34.43 & 34.56 \\
\hline MnO & 0.34 & 0.27 & 0.30 & 0.25 & 0.39 & 0.28 & 0.33 & 0.32 & 0.29 & 0.34 & 0.31 & 0.33 & 0.34 & 0.41 & 0.41 & 0.38 & 0.35 & 0.36 \\
\hline $\mathrm{MgO}$ & 9.81 & 9.73 & 9.86 & 9.85 & 0.98 & 0.94 & 0.96 & 0.96 & 0.98 & 0.93 & 0.79 & 0.81 & 0.73 & 0.78 & 0.73 & 0.73 & 0.58 & 0.58 \\
\hline NiO & ก.a. & n.a. & n.a. & n.a. & 0.00 & 0.00 & n.a. & n.a. & n.a. & n.a. & 0.00 & 0.02 & 0.04 & 0.00 & 0.02 & 0.00 & 0.00 & 0.00 \\
\hline $\mathrm{CaO}$ & 0.00 & 0.00 & 0.00 & 0.00 & 0.00 & 0.07 & 0.09 & 0.03 & 0.00 & 0.00 & 0.00 & 0.00 & 0.00 & 0.03 & 0.03 & 0.01 & 0.04 & 0.07 \\
\hline $\mathrm{Na}_{2} \mathrm{O}$ & 0.08 & 0.06 & 0.09 & 0.08 & 0.07 & 0.37 & 0.18 & 0.22 & 0.04 & 0.07 & 0.10 & 0.12 & 0.09 & 0.10 & 0.04 & 0.07 & 0.06 & 0.01 \\
\hline $\mathrm{K}_{2} \mathrm{O}$ & 9.51 & 9.54 & 9.44 & 9.52 & 9.24 & 8.29 & 8.53 & 8.69 & 9.11 & 9.13 & 9.35 & 9.20 & 9.41 & 6.56 & 9.21 & 9.08 & 9.02 & 8.50 \\
\hline $\mathrm{BaO}$ & 0.14 & 0.25 & 0.26 & 0.25 & n.a. & n.a. & 0.07 & 0.02 & 0.22 & 0.17 & n.a. & n.a. & n.a. & n.a. & n.a. & n.a. & n.a. & n.a. \\
\hline$F$ & 0.19 & 0.14 & 0.10 & 0.26 & ก.a. & n.a. & 0.09 & 0.03 & 0.29 & 0.15 & n.a. & n.a. & n.a. & n.a. & ก.a. & n.a. & n.a. & n.a. \\
\hline Cl & n.a. & ก.a. & ก.a. & n.a. & n.a. & n.a. & n.a. & n.a. & n.a. & n.a. & n.a. & n.a. & n.a. & n.a. & n.a. & n.a. & ก.a. & ก.a. \\
\hline $\mathrm{H}_{2} \mathrm{O}$ & 1.77 & 1.79 & 1.81 & 1.73 & 1.78 & 1.8 & 1.67 & 1.71 & 1.65 & 1.66 & 1.78 & 1.76 & 1.78 & 1.72 & 1.77 & 1.74 & 1.75 & 1.72 \\
\hline Total & 97.68 & 97.27 & $97 . \approx$ & 97.57 & 99.20 & 92.91 & 96.01 & 95.67 & 99.49 & 96.46 & 98.88 & 98.04 & 96.58 & 95.57 & 98.48 & 96.98 & 97.6 & 96.19 \\
\hline Si & 5.77 & 5.77 & 5.73 & 5.76 & 5.74 & 5.79 & 5.64 & 5.70 & 5.88 & 5.78 & 5.87 & 5.81 & 5.80 & 5.55 & 5.74 & 5.83 & 5.74 & 5.83 \\
\hline$A I^{N}$ & 2.23 & 2.23 & 2.27 & 2.24 & 2.26 & 2.21 & 2.36 & 2.30 & 2.13 & 2.22 & 2.13 & 2.19 & 2.21 & 2.45 & 2.26 & 2.17 & 2.26 & 2.17 \\
\hline$A 1^{\sqrt{3}}$ & 0.77 & 0.82 & 0.75 & 0.75 & 0.97 & 1.10 & 1.10 & 1.22 & 1.00 & 0.97 & 0.93 & 0.93 & 1.16 & 1.07 & 1.07 & 0.92 & 1.11 & 1.06 \\
\hline $\mathrm{Ti}$ & 0.31 & 0.29 & 0.31 & 0.32 & 0.23 & 0.21 & 0.11 & 0.12 & 0.27 & 0.29 & 0.34 & 0.31 & 0.21 & 0.19 & 0.24 & 0.35 & 0.15 & 0.14 \\
\hline $\mathrm{Fe}^{+2}$ & 2.92 & 2.90 & 2.96 & 2.94 & 488 & 4.71 & 4.90 & 4.76 & 4.74 & 4.75 & 4.72 & 4.79 & 4.66 & 5.20 & 4.77 & 4.75 & 4.94 & 5.04 \\
\hline $\mathrm{Cr}$ & 0.0 & 0.00 & 0.00 & 0.00 & 0.00 & 0.00 & 0.01 & 0.00 & 0.00 & 0.00 & 0.00 & 0.00 & 0.0 & 0.0 & 0.00 & 0.00 & 0.00 & 0.00 \\
\hline $\mathrm{Zn}$ & - & - & $-\quad$ & -1 & 0.02 & 0.01 & - & - & -1 & $-\quad$ & 0.01 & 0.02 & 0.01 & 0.01 & 0.03 & 0.02 & 0.02 & 0.02 \\
\hline $\mathrm{Mn}$ & 0.05 & 0.04 & 0.04 & 0.03 & 0.06 & 0.04 & 0.05 & 0.05 & 0.04 & 0.05 & 0.04 & 0.05 & 0.05 & 0.06 & 0.06 & 0.06 & 0.06 & 0.05 \\
\hline $\mathrm{Mg}$ & 2.36 & 2.35 & 2.38 & 2.38 & 0.25 & 0.25 & 0.25 & 0.25 & 0.25 & 0.24 & 0.20 & 0.21 & 0.18 & 0.20 & 0.18 & 0.19 & 0.15 & 0.15 \\
\hline $\mathrm{Ni}$ & $-\quad$ & $-\quad$ & -1 & \begin{tabular}{l|l}
- & \\
\end{tabular} & 0.00 & 0.00 & $-\quad 1$ & - & -1 & $-\quad$ & 0.00 & 0.00 & 0.01 & 0.00 & $0 . \infty$ & 0.00 & 0.00 & 0.00 \\
\hline $\mathrm{Ca}$ & 0.00 & 0.00 & 0.00 & 0.0 & 0.00 & 0.01 & 0.02 & 0.01 & 0.00 & $0 . \infty$ & 0.00 & 0.00 & 0.00 & 0.01 & 0.01 & 0.00 & 0.01 & 0.01 \\
\hline $\mathrm{Na}$ & 0.03 & 0.02 & 0.03 & 0.03 & 0.02 & 0.13 & 0.06 & 0.07 & 0.01 & 0.02 & 0.03 & 0.04 & 0.03 & 0.03 & 0.01 & 0.02 & 0.02 & 0.00 \\
\hline$K$ & 1.96 & 1.97 & 1.95 & 1.97 & 1.99 & 1.89 & 1.90 & 1.93 & 1.95 & 2.02 & 201 & 2.00 & 2.02 & 1.46 & 1.99 & 1.99 & 1.98 & 1.89 \\
\hline $\mathrm{Ba}$ & 0.01 & 0.02 & 0.02 & 0.02 & $-\quad$ & - & 0.01 & 0.0 & 0.01 & 0.01 &. & $-\quad$ & -1 & -1 & - & - & -1 & - \\
\hline Cátions & 16.40 & 16.40 & 16.43 & 16.42 & 16.42 & 16.35 & 16.49 & 16.41 & 16.27 & 16.36 & 16.28 & 16.34 & 16.33 & 16.24 & 16.36 & 16.29 & 16.42 & 16.36 \\
\hline \#. $\mathrm{Fe}^{+2}$ & 0.50 & 0.56 & 0.55 & 0.56 & 0.95 & 0.95 & 0.95 & 0.95 & 0.95 & 0.95 & 0.96 & 0.96 & 0.96 & 0.96 & 0.96 & 0.96 & 0.97 & 0.97 \\
\hline
\end{tabular}

Tabela A4.1.1: Dados analiticos de biotitas de TTG, GB, MGF e PGD intrusivos na SVS. Fórmula estrutural: $24(O)$. 
Tabela A4.1: Biotitas/Flogopitas - BT/FLO

\begin{tabular}{|c|c|c|c|c|c|c|c|c|c|c|c|c|c|c|c|c|c|}
\hline \begin{tabular}{|l|} 
Amostras \\
Análises
\end{tabular} & $\frac{G-113}{5 / 18}$ & G-113 & G-166b & G-165b & $\mathrm{G}-16 \% \mathrm{~b}$ & $G-16 \sigma b$ & G-1बab & $G-160 b$ & $\mathbb{0 3}$ & G-2a & G-2a & G-2a & G-2b & $G-2 b$ & G-2b & $G-2 b$ & $G-2 b$ \\
\hline & & & & $4 / 151$ & $4 / 1 / 62$ & $4 / 1 / \mathfrak{3}$ & $4 / 256$ & $4 / 257$ & $223 \mathrm{BO} 1$ & $161 \mathrm{BO} 1$ & $16 / 2 \mathrm{BO}$ & $16 / 2802$ & $4 / 1 / 15$ & $4 / 1 / 16$ & $4 / 2 / 40$ & $4 / 2 / 41$ & $4 \sqrt{3 / 22}$ \\
\hline Mineral & BT & BT & 8T & BT & $\mathrm{BT}$ & BT & BT & BT & BT & $\mathrm{BT}$ & BT & BT-CLO & BT & BT-ANF & BT & BT & BT-ANF \\
\hline Local & $\mathrm{B}$ & C & $B$ & $\mathrm{C}$ & $B$ & C & $B$ & $\mathrm{c}$ & $C$ & $\mathrm{C}$ & $c$ & $\mathrm{~B}$ & C & $B$ & C & $B$ & B \\
\hline Litotipo & GB & GB & GB & GB & GB & GB & GB & $\mathrm{GB}$ & $\mathrm{GB}$ & MGF & MGF & MGF & MGF & MGF & MGF & MGF & MGF \\
\hline $\mathrm{SiO}_{2}$ & 33.93 & 35.20 & 33.80 & 34.12 & 34.20 & 33.97 & 33.83 & 34.58 & 30.85 & 32.54 & 33.05 & 27.04 & 33.60 & 31.09 & 33.81 & 33.09 & 26.13 \\
\hline $\mathrm{TiO}_{2}$ & 2.12 & 2.03 & 0.38 & 0.47 & 0.29 & 0.43 & 0.66 & 0.60 & 1.48 & 1.54 & 1.43 & 0.83 & 1.75 & 10.78 & 1.72 & 1.83 & 0.50 \\
\hline $\mathrm{Al}_{2} \mathrm{O}_{3}$ & 16.40 & 17.88 & $16 . \varpi$ & 15.90 & 16.98 & 16.30 & 17.92 & 16.13 & 14.24 & 14.77 & 14.89 & 15.03 & 15.71 & 11.18 & 15.18 & 15.29 & 16.00 \\
\hline $\mathrm{Cr}_{2} \mathrm{O}_{3}$ & 0.08 & 0.00 & 0.02 & 0.00 & 0.02 & 0.00 & 0.01 & 0.00 & 0.00 & 0.00 & 0.00 & 0.00 & 0.00 & 0.00 & 0.01 & 0.01 & 0.01 \\
\hline $\mathrm{ZnO}$ & 0.12 & 0.09 & 0.58 & 0.56 & 0.61 & 0.58 & 0.55 & 0.62 & n.a. & n.a. & n.a. & ก.a. & 0.92 & 1.03 & 0.85 & 0.78 & 1.78 \\
\hline $\mathrm{FeO}$ & 32.53 & 30.31 & 32.90 & 34.44 & 31.02 & 33.07 & 30.76 & 34.34 & 32.83 & 32.22 & 31.43 & 36.43 & 33.38 & 26.93 & 31.47 & 32.93 & 40.30 \\
\hline $\mathrm{MnO}$ & 0.35 & 0.20 & 0.82 & 0.81 & 0.85 & 0.75 & 0.70 & 0.79 & 0.77 & 0.99 & 0.88 & 1.03 & 1.17 & 0.77 & 0.95 & 0.96 & 1.38 \\
\hline $\mathrm{MgO}$ & 0.42 & 0.35 & 0.98 & 1.06 & 0.95 & 1.01 & 0.99 & 1.06 & 2.57 & 1.26 & 1.53 & 1.85 & 1.54 & 1.10 & 1.78 & 1.81 & 1.60 \\
\hline NiO & 0.00 & 0.00 & 0.0 & 0.00 & 0.0 & 0.00 & 0.00 & 0.00 & 0.00 & 0.00 & 0.00 & 0.00 & 0.03 & 0.00 & 0.00 & 0.00 & 0.00 \\
\hline $\mathrm{CaO}$ & 0.11 & 0.05 & 0.02 & 0.0 & 0.02 & 0.09 & 0.02 & 0.00 & 0.00 & 0.00 & 0.00 & 0.16 & 0.03 & 9.67 & 0.00 & 0.02 & 0.21 \\
\hline $\mathrm{Na}_{2} \mathrm{O}$ & 0.00 & 0.06 & 0.00 & 0.02 & 0.07 & 0.04 & 0.10 & 0.04 & 0.80 & 0.79 & 0.80 & 1.14 & 0.08 & 0.06 & 0.09 & 0.08 & 0.11 \\
\hline $\mathrm{K}_{2} \mathrm{O}$ & 9.29 & 8.12 & 9.06 & 9.42 & 8.87 & 9.14 & 8.28 & 9.03 & 6.73 & 9.10 & 9.11 & 3.10 & 8.33 & 0.47 & 8.79 & 8.02 & 0.89 \\
\hline $\mathrm{BaO}$ & n.a. & n.a. & n.a. & n.a. & n.a. & n.a. & n.a. & n.a. & ก.a. & n.a. & n.a. & n.a. & n.a. & n.a. & n.a. & n.a. & n.a. \\
\hline$F$ & n.a. & n.a. & ก.a. & n.a. & n.a. & n.a. & n.a. & ก.a. & ก.a. & n.a. & n.a. & n.a. & n.a. & n.a. & n.a. & ก.a. & ก.a. \\
\hline Cl & n.a. & n.a. & n.a. & n.a. & n.a. & n.a. & n.a. & n.a. & 0.14 & 0.12 & 0.06 & 0.00 & n.a. & n.a. & n.a. & n.a. & n.a. \\
\hline $\mathrm{H}_{2} \mathrm{O}$ & 1.75 & 1.78 & 1.74 & 1.75 & 1.74 & 1.74 & 1.75 & 1.77 & 1.60 & 1.66 & 1.6 & 1.55 & 1.76 & 1.75 & 1.74 & 1.73 & 1.57 \\
\hline Total & 97.20 & 96.07 & 96.93 & 96.55 & 95.62 & 97.03 & 95.57 & 98.96 & 91.71 & 94.99 & 94.87 & 88.16 & 98.30 & 94.83 & 96.39 & 96.55 & 90.48 \\
\hline Si & 5.80 & 5.93 & 5.82 & 5.83 & 5.91 & 5.85 & 5.81 & 5.86 & 5.5 & 5.77 & 5.83 & 5.22 & 5.73 & 5.32 & 5.84 & 5.73 & 4.98 \\
\hline$A I^{\mathrm{N}}$ & 2.20 & 2.07 & 2.18 & 2.17 & 2.09 & 2.15 & 2.19 & 214 & 2.35 & 2.23 & 2.17 & 2.79 & 2.27 & 2.25 & 2.16 & 2.27 & 3.02 \\
\hline $\mathrm{Al}^{\mathrm{M}}$ & 1.11 & 1.48 & 1.20 & 1.03 & 1.36 & 1.16 & 1.43 & 1.07 & 0.72 & 0.85 & 0.92 & 0.03 & 0.88 & 0.00 & 0.93 & 0.85 & 0.56 \\
\hline Ti & 0.27 & 0.26 & 0.05 & 0.06 & 0.04 & 0.06 & 0.09 & 0.08 & 0.16 & 0.21 & 0.19 & 0.12 & 0.22 & 1.39 & 0.22 & 0.24 & 0.07 \\
\hline $\mathrm{Fe}^{+2}$ & 4.67 & 4.27 & 4.74 & 4.92 & 4.48 & 4.77 & 4.42 & 4.86 & 5.03 & 4.78 & 4.5 & 5.88 & 4.76 & 3.85 & 4.55 & 4.77 & 6.42 \\
\hline $\mathrm{Cr}$ & 0.01 & 0.00 & 0.00 & 0.00 & 0.00 & $0 . \infty$ : & 0.00 & 0.0 & 0.00 & 0.00 & 0.00 & 0.00 & 0.00 & 0.00 & $0 . \infty$ & 0.00 & 0.00 \\
\hline $\mathrm{Zn}$ & 0.02 & 0.01 & 0.07 & 0.07 & 0.08 & 0.07 & 0.07 & 0.08 & $-\quad 1$ & - & $-\quad$ & -1 & 0.12 & 0.13 & 0.11 & 0.10 & 0.25 \\
\hline $\mathrm{Mn}$ & 0.05 & 0.03 & 0.12 & 0.12 & 0.12 & 0.11 & 0.10 & 0.11 & 0.12 & 0.15 & 0.13 & 0.17 & 0.17 & 0.11 & 0.14 & 0.14 & 0.22 \\
\hline $\mathrm{Mg}$ & 0.11 & 0.09 & 0.25 & 0.27 & 0.25 & 0.26 & 0.25 & 0.27 & 0.70 & 0.33 & 0.40 & 0.53 & 0.39 & 0.28 & 0.46 & 0.47 & 0.45 \\
\hline $\mathrm{Ni}$ & 0.00 & 0.00 & 0.00 & 0.00 & 0.00 & 0.0 & 0.00 & 0.00 & 0.00 & 0.00 & 0.00 & 0.00 & 0.00 & 0.00 & 0.00 & 0.00 & 0.00 \\
\hline $\mathrm{Ca}$ & 0.02 & 0.01 & 0.00 & 0.00 & 0.00 & 0.00 & 0.00 & 0.00 & 0.00 & 0.00 & 0.00 & 0.03 & 0.01 & 1.77 & 0.00 & 0.00 & 0.04 \\
\hline $\mathrm{Na}$ & 0.00 & 0.02 & 0.00 & 0.01 & 0.02 & 0.01 & 0.03 & 0.01 & 0.28 & 0.27 & 0.27 & 0.43 & 0.03 & 0.02 & 0.03 & 0.03 & 0.04 \\
\hline$K$ & 2.03 & 1.75 & 1.90 & 2.05 & 1.96 & 2.01 & 1.81 & 1.95 & 1.57 & 2.06 & 2.05 & 0.76 & 1.81 & 0.10 & 1.94 & 1.77 & 0.22 \\
\hline $\mathrm{Ba}$ & - & - & - & $-\quad$ & $=$ & - & - & $-\quad 1$ & - & $-\quad$ & $-\quad$ & $-\quad-\quad t$ & - & $-\quad$ & $-\quad-$ & - & \\
\hline Cátions & 16.28 & 15.91 & 16.43 & 16.53 & 16.31 & 16.44 & 16.21 & 16.44 & 16.58 & 16.65 & 16.60 & 16.55 & 16.38 & 15.23 & 16.37 & 16.37 & 16.28 \\
\hline$\# \mathrm{Fe}^{+2}$ & 0.98 & 0.98 & 0.96 & 0.95 & 0.95 & 0.96 & 0.95 & 0.95 & 0.88 & 0.93 & 0.92 & 0.92 & 0.92 & 0.93 & 0.91 & 0.91 & 0.5 \\
\hline
\end{tabular}

Tabela A4.1.1: Dados analiticos de biotitas de TTG, GB, MGF e PGD intrusivos na SVS. Fórmula estrutural: $24(0)$.

Nota: G-2a (16/2B02): biotita alterando em clorita; G-2b (4/1/16, 4/3/22 e 4/3/23): biotitas em reação para anfibólios. 
Tabela A4.1: Biotitas/Flogopitas - BT/FLO

\begin{tabular}{|c|c|c|c|c|c|c|c|c|c|c|c|c|c|c|c|c|c|}
\hline Amostras & $G-2 b$ & G-2b & $G-2 b$ & G-2b & G-3a & G-3a & G-3a & $G-3 a$ & G3a & G-3a & $G-3 a$ & G $3 \mathbf{a}$ & G-3a & G-3a & G-3a & G-3a & G-11a \\
\hline Análises & $4 / 3 / 23$ & $6 / 1 / 15$ & $6 / 1 / 16$ & $6 / 1 / 17$ & $39 / 1 \mathrm{~B} 1.1$ & $39 / 1 B 1.2$ & $39 / 1 \mathrm{~B} 1.3$ & 39/1B2.1 & $39 / 1 \mathrm{~B} 2.2$ & $39 / 182.3$ & $39 / 1 \mathrm{~B} 3.1$ & 39/1B3.2 & $39 / 2 \mathrm{~B} 1.1$ & $39 / 281.2$ & $39 / 2 \mathrm{~B} 2.1$ & $39 / 2 \mathrm{~B} 2.2$ & $5 / 2 / 18$ \\
\hline Mineral & BT-ANF & BT/ANF & BT/ANF & BT/ANF & BT & BT & BT & BT & BT & $B T$ & BT & BT & BT & BT & BT & BT & $\mathrm{BT}$ \\
\hline Local & $c$ & $\mathrm{C}$ & $B$ & $B$ & 8 & $\mathrm{Plm}$ & $\mathrm{C}$ & $\mathrm{C}$ & $\mathrm{C}$ & B & $c$ & B & C & B & C & B & c \\
\hline Litotipo & MGF & MGF & MGF & MGF & MGF & MGF & MGF & MGF & MGF & MGF & MGF & MGF & MGF & MGF & MGF & MGF & MGF \\
\hline $\mathrm{SiO}_{2}$ & 27.25 & 28.87 & 3169 & 46.49 & 32.26 & 32.52 & 32.85 & 32.5 & 32.45 & 32.39 & 32.47 & 32.53 & 32.50 & 32.84 & 32.78 & 33.09 & 34.89 \\
\hline $\mathrm{TiO}_{2}$ & 0.79 & 0.54 & 0.59 & 0.23 & 2.25 & 2.54 & 2.6 & 256 & 2.52 & 2.40 & 2.56 & 2.56 & 2.78 & 2.78 & 2.82 & 2.56 & 2.46 \\
\hline $\mathrm{Al}_{2} \mathrm{O}_{3}$ & 16.45 & 16.08 & 16.07 & 18.81 & 14.71 & 14.44 & 14.55 & 14.88 & 14.73 & 14.99 & 14.5 & 15.09 & 14.85 & 14.83 & 14.72 & 14.44 & 17.14 \\
\hline $\mathrm{Cr}_{2} \mathrm{O}_{3}$ & 0.01 & 0.02 & 0.04 & 0.03 & 0.00 & 0.00 & 0.00 & 0.00 & 0.00 & 0.00 & 0.00 & 0.00 & 0.00 & 0.00 & 0.00 & 0.0 & 0.00 \\
\hline $\mathrm{ZnO}$ & 1.46 & n.a. & n.a. & n.a. & n.a. & n.a. & ก.a. & n.a. & n.a. & n.a. & ก.a. & n.a. & n.a. & n.a. & n.a. & n.a. & n.a. \\
\hline $\mathrm{FeO}$ & 38.21 & 36.26 & 34.40 & 21.07 & 33.41 & 33.23 & 33.22 & 33.54 & 33.23 & 33.25 & 32.93 & 32.61 & 33.23 & 33.18 & 33.08 & 32.75 & 29.74 \\
\hline $\mathrm{MnO}$ & 1.42 & 1.53 & 1.31 & 0.71 & 0.47 & 0.41 & 0.38 & 0.50 & 0.45 & 0.50 & 0.49 & 0.51 & 0.44 & 0.50 & 0.47 & 0.44 & 0.59 \\
\hline $\mathrm{MgO}$ & 1.51 & 1.63 & 1.53 & 0.78 & 0.00 & 0.17 & 0.13 & 0.12 & 0.25 & 0.30 & 0.19 & 0.31 & 0.18 & 0.21 & 0.23 & 0.26 & 1.6 \\
\hline NiO & 0.00 & n.a. & n.a. & n.a. & 0.0 & $0 . \infty$ & 0.00 & 0.00 & 0.00 & 0.00 & 0.00 & 0.00 & 0.00 & 0.0 & 0.00 & 0.00 & ก.a. \\
\hline $\mathrm{CaO}$ & 0.25 & 0.19 & 0.08 & 0.09 & 0.00 & 0.00 & 0.00 & 0.00 & 0.00 & 0.00 & 0.00 & 0.00 & 0.00 & 0.00 & 0.11 & 0.00 & 0.00 \\
\hline $\mathrm{Na}_{2} \mathrm{O}$ & 0.20 & 0.14 & 0.16 & 0.12 & 0.34 & 0.41 & 0.33 & 0.34 & 0.58 & 0.49 & 0.47 & 0.30 & 0.39 & 0.31 & 0.36 & 0.33 & 0.04 \\
\hline $\mathrm{K}_{2} \mathrm{O}$ & 1.27 & 5.14 & 7.57 & 8.63 & 9.40 & 9.29 & 9.41 & 9.15 & 9.06 & 9.28 & 9.32 & 9.23 & 9.51 & 9.52 & 9.40 & 9.37 & 9.50 \\
\hline $\mathrm{BaO}$ & n.a. & 0.0 & 0.05 & 0.10 & ถ.a. & n.a. & n.a. & n.a. & n.a. & n.a. & n.a. & n.a. & n.a. & n.a. & n.a. & n.a. & 0.04 \\
\hline$F$ & n.a. & 0.00 & 0.00 & 0.05 & n.a. & n.a. & n.a. & n.a. & n.a. & n.a. & n.a. & n.a. & n.a. & n.a. & n.a. & n.a. & 0.90 \\
\hline $\mathrm{Cl}$ & ก.a. & n.a. & n.a. & n.a. & 0.16 & 0.22 & 0.19 & 0.19 & 0.22 & 0.25 & 0.20 & 0.25 & 0.22 & 0.24 & 0.23 & 0.21 & n.a. \\
\hline $\mathrm{H}_{2} \mathrm{O}$ & 160 & 1.61 & 1.69 & 1.95 & 1.64 & 1.63 & 1.65 & 1.6 & 1.63 & 1.63 & 1.63 & 1.63 & 1.64 & 1.65 & 1.6 & 1.64 & 1.37 \\
\hline Total & 90.42 & 91.01 & 95.18 & 99.06 & 94.64 & 94.86 & 95.36 & 95.58 & 95.12 & 95.48 & 94.89 & 9.02 & 95.74 & 96.06 & 95.85 & 95.09 & 98.30 \\
\hline Si & 5.11 & 5.36 & 5.61 & 7.05 & 5.77 & 5.79 & 5.81 & 5.76 & 5.76 & 5.73 & 5.78 & 5.76 & 5.74 & 5.77 & 5.77 & 5.85 & 5.83 \\
\hline$A 1^{N}$ & 2.89 & 2.64 & 2.39 & 0.95 & 2.23 & 2.21 & 2.19 & 2.24 & 2.24 & 2.27 & 2.22 & 2.24 & 2.26 & 2.23 & 2.23 & 2.15 & 2.17 \\
\hline$A I^{V}$ & 0.75 & 0.88 & 0.96 & 2.40 & 0.87 & 0.82 & 0.84 & 0.86 & 0.84 & 0.86 & 0.84 & 0.90 & 0.82 & 0.84 & 0.82 & 0.86 & 1.20 \\
\hline $\mathrm{Ti}$ & 0.11 & 0.08 & 0.08 & 0.03 & 0.30 & 0.34 & 0.35 & 0.34 & 0.34 & 0.32 & 0.34 & 0.34 & 0.37 & 0.37 & 0.37 & 0.34 & 0.31 \\
\hline $\mathrm{Fe}^{+2}$ & 6.00 & 5.48 & 5.09 & 2.67 & 5.00 & 4.96 & 4.91 & 4.95 & 4.93 & 4.92 & 4.90 & 4.83 & 4.91 & 4.87 & 4.87 & 4.85 & 4.15 \\
\hline $\mathrm{Cr}$ & 0.00 & 0.00 & 0.01 & 0.0 & 0.00 & 0.00 & 0.00 & 0.00 & 0.00 & 0.00 & 0.00 & 0.00 & 0.00 & 0.00 & 0.00 & 0.00 & 0.00 \\
\hline $\mathrm{Zn}$ & 0.20 & $-\quad$ & - &.$\quad$ & $-\quad$ & & - & -1 & $\therefore$ & - & $-\quad$ & -4 & - & -1 & - & - & - \\
\hline $\mathrm{Mn}$ & 0.23 & 0.24 & 0.20 & 0.09 & 0.07 & 0.06 & 0.06 & 0.08 & 0.07 & 0.08 & 0.07 & 0.08 & 0.07 & 0.07 & 0.07 & 0.07 & 0.08 \\
\hline $\mathrm{Mg}$ & 0.42 & 0.45 & 0.40 & 0.18 & 0.00 & 0.05 & 0.03 & 0.03 & 0.07 & 0.08 & 0.05 & 0.08 & 0.05 & 0.06 & 0.06 & 0.07 & 0.41 \\
\hline $\mathrm{Ni}$ & 0.00 & - & - & - & 0.00 & 0.00 & 0.00 & 0.00 & 0.00 & $0 . \infty$ & 0.00 & 0.00 & 0.00 & 0.00 & 0.00 & 0.00 & $=$ \\
\hline $\mathrm{Ca}$ & 0.05 & 0.04 & 0.02 & 0.02 & 0.00 & 0.00 & 0.00 & 0.00 & 0.00 & 0.00 & $0 . \infty$ & 0.00 & 0.00 & 0.00 & 0.02 & 0.00 & 0.00 \\
\hline $\mathrm{Na}$ & 0.07 & 0.05 & 0.06 & 0.04 & 0.12 & 0.14 & 0.11 & 0.12 & 0.20 & 0.17 & 0.16 & 0.10 & 0.13 & 0.11 & 0.12 & 0.11 & 0.01 \\
\hline$K$ & 0.30 & 1.22 & 1.71 & 1.67 & 2.15 & 2.11 & 2.12 & 2.06 & 2.05 & 2.10 & 2.12 & 2.08 & 2.14 & 2.13 & 2.11 & 2.12 & 2.02 \\
\hline $\mathrm{Ba}$ & \begin{tabular}{l|l}
- & \\
\end{tabular} & 0.00 & 0.00 & 0.01 & $-\quad$ & $-\quad$ & -1 & $\therefore$ & $-\quad$ & - & $-\quad 7$ & -7 & - & .7 &.- & - & 0.00 \\
\hline Cátions & 16.14 & 16.43 & 16.52 & 15.10 & 16.51 & 16.47 & 16.44 & 16.43 & 16.49 & 16.51 & 16.48 & 16.42 & 16.48 & 16.45 & 16.44 & 16.41 & 16.19 \\
\hline$\# \mathrm{Fe}^{+2}$ & 0.93 & 0.92 & 0.93 & 0.94 & 1.00 & 0.99 & 0.99 & 0.99 & 0.99 & 0.98 & 0.99 & 0.98 & 0.90 & 0.90 & 0.99 & 0.99 & 0.91 \\
\hline
\end{tabular}

Tabela A4.1.1: Dados analíticos de biotitas de TTG, GB, MGF e PGD intrusivos na SVS. Fórmula estrutural: 24(O).

Nota: G-2b (6/1/15, 6/1/16 e 6/1/17): biotitas em contato com anfibólios. 
Tabela A4.1: Biotitas/Flogopitas - BT/FLO

\begin{tabular}{|c|c|c|c|c|c|c|c|c|c|c|c|c|}
\hline Amostras & G-11a & G-11a & G-11a & G-68 & $G-\infty$ & G-68 & $G-68$ & $G-68$ & Astro 1 & Astro 1 & M-5 & M-5 \\
\hline Análises & $5 / 2 / 19$ & $5 / 2 / 20$ & $5 / 2 / 21$ & $32 / 1 \mathrm{B1.1}$ & $32 / 1 B 1.2$ & $32 / 2 \mathrm{~B} 1.1$ & $32 / 282.1$ & $32 / 2 \mathrm{~B} 2.2$ & $401 \mathrm{~B} 1.1$ & $40 / 1 \mathrm{~B} 1.2$ & $3 \sqrt{3 / 13}$ & $3 / 3 / 14$ \\
\hline Mineral & BT & BT & BT & BT & BT & BT & BT & $\mathrm{BT}$ & $B T$ & $\mathrm{BT}$ & BT & BT \\
\hline Local & B & C & $\bar{B}$ & B & $\mathrm{C}$ & $\mathrm{B}$ & B & C & $\mathrm{C}$ & B & B & $c$ \\
\hline Litotipo & MGF & MGF & MGF & MGF & MGF & MGF & MGF & MGF & PGD & PGD & PGD & PGD \\
\hline $\mathrm{SiO}_{2}$ & 34.57 & 34.83 & 34.95 & 32.60 & 32.53 & 32.59 & 31.97 & 32.58 & 38.90 & 39.19 & 35.50 & 36.05 \\
\hline $\mathrm{TiO}_{2}$ & 2.43 & 2.41 & 2.50 & 1.93 & 1.93 & 2.85 & $1 . \circledast$ & 1.74 & 0.66 & 0.68 & 0.81 & 0.83 \\
\hline $\mathrm{Al}_{2} \mathrm{O}_{3}$ & 17.13 & 16.84 & 17.24 & 15.26 & 15.22 & 14.23 & 15.43 & 14.78 & 14.67 & 14.85 & 17.98 & 17.76 \\
\hline $\mathrm{Cr}_{2} \mathrm{O}_{3}$ & 0.00 & 0.00 & 0.00 & 0.00 & 0.00 & 0.00 & 0.00 & 0.00 & 0.00 & 0.00 & 0.31 & 0.33 \\
\hline $\mathrm{ZnO}$ & n.a. & n.a. & n.a. & n.a. & n.a. & n.a. & n.a. & n.a. & n.a. & n.a. & 0.03 & 0.01 \\
\hline $\mathrm{FeO}$ & 29.26 & 29.59 & 29.61 & 32.06 & 31.87 & 31.57 & 32.26 & 33.18 & 14.13 & 14.36 & 12.53 & 12.35 \\
\hline Mino & 0.53 & 0.57 & 0.60 & 0.23 & 0.37 & 0.28 & 0.27 & 0.33 & 0.00 & 0.0 & 0.06 & 0.03 \\
\hline $\mathrm{MgO}$ & 1.66 & 1.0 & 1,63 & 1.33 & 1.24 & 1.24 & 1.19 & 1.14 & 15.98 & 16.07 & 21.01 & 20.57 \\
\hline $\mathrm{NiO}$ & ก.a. & n.a. & n.a. & 0.00 & 0.0 & 0.00 & 0.00 & 0.00 & $0 . \infty$ & 0.0 & 0.03 & 0.07 \\
\hline $\mathrm{CaO}$ & 0.00 & 0.00 & 0.00 & $0 . \infty$ & 0.00 & 0.00 & 0.00 & 0.00 & 0.00 & 0.00 & 0.05 & 0.03 \\
\hline $\mathrm{Na}_{2} \mathrm{O}$ & 0.00 & 0.05 & 0.04 & 0.32 & 0.31 & 0.23 & 0.00 & 0.22 & 0.36 & 0.44 & 0.11 & 0.06 \\
\hline $\mathrm{K}_{2} \mathrm{O}$ & 9.44 & 9.29 & 9.35 & 9.48 & 9.49 & 9.39 & 9.37 & 9.48 & 8.55 & 8.17 & 5.04 & 5.46 \\
\hline $\mathrm{BaO}$ & 0.01 & 0.02 & 0.01 & n.a. & n.a. & n.a. & n.a. & n.a. & n.a. & n.a. & n.a. & n.a. \\
\hline$F$ & 0.82 & 0.83 & 0.91 & n.a. & n.a. & ก.a. & n.a. & n.a. & n.a. & n.a. & ก.a. & n.a. \\
\hline $\mathrm{Cl}$ & n.a. & n.a. & ก.a. & 0.00 & 0.00 & 0.00 & 0.00 & 0.00 & 0.10 & 0.06 & ก.a. & n.a. \\
\hline $\mathrm{H}_{2} \mathrm{O}$ & 1.39 & 1.39 & 1.37 & 1.70 & 1.70 & 1.69 & 1.68 & 1.69 & 1.88 & 1.90 & 1.95 & 1.96 \\
\hline Total & 97.34 & 97.42 & 98.21 & 94.91 & 94.60 & 94.07 & 93.86 & 96.14 & 95.23 & 96.72 & 95.41 & 55.50 \\
\hline Si & 5.82 & 5.86 & 5.83 & $5 . \overline{75}$ & 5.75 & 5.80 & 5.71 & 5.77 & 5.87 & 5.87 & 5.46 & 5.54 \\
\hline $\mathrm{Af}^{\mathrm{N}}$ & 2.18 & 2.14 & 2.17 & 2.25 & 2.25 & 2.20 & 2.29 & 2.23 & 2.13 & 2.13 & 254 & 2.47 \\
\hline $\mathrm{Al}^{\mathrm{V}}$ & 1.22 & 1.20 & 1.22 & 0.92 & 0.92 & 0.78 & 0.96 & 0.85 & 0.47 & 0.49 & 0.71 & 0.75 \\
\hline $\mathrm{Ti}$ & 0.31 & 0.31 & 0.31 & 0.26 & 0.26 & 0.38 & 0.23 & 0.23 & 0.08 & 0.08 & 0.09 & 0.10 \\
\hline $\mathrm{Fe}^{+2}$ & 4.12 & 4.17 & 4.13 & 4.73 & 4.71 & 4.70 & 4.82 & 4.91 & 1.78 & 1.80 & 1.61 & 1.58 \\
\hline $\mathrm{Cr}$ & 0.00 & 0.00 & $0 . \infty$ & 0.00 & 0.00 & 0.00 & 0.00 & 0.00 & $0 . \infty$ & 0.00 & 0.04 & 0.04 \\
\hline $\mathrm{Zn}$ & $-\quad$ & $-\quad \mid$ & - & $-\quad$ & - & - & -7 & \begin{tabular}{l|l}
- \\
\end{tabular} & $=$ & $-\quad 1$ & 0.00 & 0.00 \\
\hline $\mathrm{Mn}$ & 0.09 & 0.08 & 0.09 & 0.03 & 0.06 & 0.04 & 0.04 & 0.05 & 0.00 & 0.00 & 0.01 & 0.00 \\
\hline $\mathrm{Mg}$ & 0.42 & 0.40 & 0.41 & 0.35 & 0.33 & 0.33 & 0.32 & 0.30 & 3.59 & 3.59 & 4.81 & 4.74 \\
\hline $\mathrm{Ni}$ & - & $-\quad 1$ & - & 0.00 & $0 . \infty$ & 0.00 & 0.00 & 0.00 & 0.00 & 0.00 & 0.00 & 0.01 \\
\hline $\mathrm{Ca}$ & 0.00 & 0.0 & 0.00 & 0.00 & $0 . \infty$ & $0 . \infty$ & 0.00 & 0.00 & 0.00 & 0.0 & 0.01 & 0.01 \\
\hline $\mathrm{Na}$ & 0.00 & 0.02 & 0.01 & 0.11 & 0.11 & 0.08 & 0.00 & 0.08 & 0.11 & $\begin{array}{l}0.13 \\
\end{array}$ & 0.03 & 0.02 \\
\hline$K$ & 203 & 2.00 & 1.99 & 2.13 & 2.14 & 2.13 & 2.14 & 2.14 & 1.65 & 1.56 & 0.99 & 1.07 \\
\hline $\mathrm{Ba}$ & 0.00 & 0.00 & 0.00 & & - & $-\quad$ & $-\quad 1$ & $=$ & - & - & - & - \\
\hline Cátions & 16.18 & 16.16 & 16.16 & 16.53 & 16.52 & 16.43 & 16.50 & 16.56 & 15.68 & 15.64 & 16.30 & 16.28 \\
\hline$\# \mathrm{Fe}^{+2}$ & 0.91 & 0.91 & 0.91 & 0.93 & 0.94 & 0.93 & 0.94 & 0.94 & 0.33 & $\begin{array}{l}0.33 \\
\end{array}$ & 0.25 & 0.25 \\
\hline
\end{tabular}

Tabela A4.1.1: Dados analíticos de biotitas de TTG, GB, MGF e PGD intrusivos na SVS. Fórmula estrutural: 24(O). 
Tabela A4.1: Biotitas/Flogopitas - BT/FLO.

\begin{tabular}{|c|c|c|c|c|c|c|c|c|c|c|c|c|c|c|c|c|c|c|}
\hline \begin{tabular}{|l|} 
Amostras \\
Análises \\
\end{tabular} & $\frac{1^{*}}{53 / 2 \mathrm{~B} 01}$ & $\frac{1^{*}}{53 / 2802}$ & $\begin{array}{c}1^{*} \\
53 / 2 \mathrm{BCO} \\
\end{array}$ & $\frac{B E-06}{3 / 1 / 38}$ & $\frac{B E-06}{3 / 1 / 39}$ & $\frac{\overline{B E-06}}{3 / 2 / 46}$ & $\frac{B E-06}{3 \sqrt{3 / 48}}$ & $\frac{B E-06}{6 / 15}$ & $\frac{B E-06}{6 / 1 / 6}$ & \begin{tabular}{c|} 
BE-08 \\
$37 / 1 F 1.1$
\end{tabular} & \begin{tabular}{|l|} 
BE-DB \\
$37 / 4 F 1.2$ \\
\end{tabular} & \begin{tabular}{|c|}
$\mathrm{BE}-08$ \\
$37 / / \mathrm{F} 2.1$ \\
\end{tabular} & \begin{tabular}{|l|}
$\mathrm{BE}-\mathrm{DB}$ \\
$37 / 1 \mathrm{~F} 2.2$ \\
\end{tabular} & \begin{tabular}{|c|}
$B E-0 B$ \\
$37 / 1 F 2.3$
\end{tabular} & \begin{tabular}{|c|} 
BE-08 \\
$37 / 2$ F1.1 \\
\end{tabular} & $\frac{\mathrm{BE}-08}{37 / 2 \mathrm{~F} 2.1}$ & \begin{tabular}{|c|} 
BE-D8 \\
$37 / 2 F 2.2$ \\
\end{tabular} & \begin{tabular}{|c|}
$\mathrm{BE}-08$ \\
$37 / 3 F 1.1$
\end{tabular} \\
\hline Mineral & $\mathrm{FlO}$ & FLO & FLO & FLO & FLO & FLO & FLO & FLO & FLO & FLO & FLO & FLO & FLO & FLO & FLO & FLO & FLO & FLO \\
\hline Local & $\bar{B}$ & $\mathrm{C}$ & $B$ & B & $\mathrm{C}$ & $B$ & $\mathrm{C}$ & $\mathrm{B}$ & $\mathrm{C}$ & $\mathrm{B}$ & $\mathrm{C}$ & $B$ & PIm & $\mathrm{C}$ & $\mathrm{C}$ & $B$ & $c$ & $\mathrm{C}$ \\
\hline Litotipo & UM & UM & UM & UM & UM & UM & UM & UM & UM & UM & UM & UM & UM & UM & UM & UM & UM & UM \\
\hline $\mathrm{SiO}_{2}$ & 39,29 & 39,30 & 39,80 & 39,54 & 40,27 & 39,76 & 41,6 & 40,06 & 40,5 & 40,14 & 40,11 & 40,22 & 40,43 & 40,13 & 40,13 & $40, \infty$ & 40,08 & 40,11 \\
\hline $\mathrm{TiO}_{2}$ & 0,45 & 0,61 & 0,44 & 0,93 & 0,97 & 0,73 & 0,82 & 0,88 & 0,87 & 0,91 & 0,86 & 0,80 & 0,88 & 0,74 & 0,72 & 0,85 & 0.74 & 0.72 \\
\hline $\mathrm{Al}_{2} \mathrm{O}_{3}$ & 13,85 & 14,04 & 14,32 & 14,41 & 14,28 & 14,09 & 15,19 & 14,21 & 14,37 & $14, \infty$ & 14,05 & 14,38 & 14,11 & 14,41 & 14,05 & 14,16 & 14,06 & 14,02 \\
\hline $\mathrm{Cr}_{2} \mathrm{O}_{3}$ & 1,21 & 1,23 & 1,18 & 0,35 & 0,46 & 0,38 & 0,54 & 0,31 & 0,32 & 0,34 & 0,29 & 0,42 & 0,51 & 0,37 & 0,38 & 0,48 & 0,58 & 0,36 \\
\hline $\mathrm{ZnO}$ & n.a. & n.a. & n.a. & $0, \infty$ & 0,04 & 0,04 & 0,05 & n.a. & n.a. & n.a. & n.a. & n.a. & n.a. & n.a. & n.a. & n.a. & n.a. & n.a. \\
\hline $\mathrm{FeO}$ & 9,74 & 10,01 & 9,77 & 10,95 & 10,82 & 10,83 & 11,16 & 10,62 & 10,82 & 10,83 & 10,62 & 11,13 & 11,17 & 11,23 & 11,21 & 11,36 & 11,15 & 10,91 \\
\hline MnO & $0, \infty$ & 0,00 & 0,00 & 0,05 & 0,08 & 0.07 & 0,04 & 0,06 & 0,08 & 0,00 & 0,00 & 0,00 & 0,0 & $0, \infty$ & 0.00 & 0,00 & 0,00 & 0,00 \\
\hline $\mathrm{MgO}$ & 18,82 & 18,89 & 19,44 & 20,27 & 19,92 & 20,01 & 19,79 & 20,19 & 20,30 & 18,96 & 18,74 & 18,73 & 18,84 & 18,61 & 19,00 & 18,53 & 18,75 & 18,34 \\
\hline $\mathrm{NiO}$ & 0,00 & 0,00 & 0,00 & 0.12 & 0,06 & 0,10 & 0,08 & n.a. & n.a. & 0,00 & 0,00 & 0,00 & 0,00 & $0, \infty$ & 0,00 & 0,00 & 0.00 & 0,00 \\
\hline $\mathrm{CaO}$ & 0,00 & 0,00 & 0,00 & 0,00 & 0,01 & 0,00 & 0,06 & 0,02 & $0, \infty$ & 0,00 & 0,00 & 0,00 & $0, \infty$ & $0, \infty$ & 0,00 & 0,00 & 0,00 & 0,00 \\
\hline $\mathrm{Na}_{2} \mathrm{O}$ & 0,33 & 0,46 & 0,30 & 0,66 & 0,59 & 0,54 & $0, \mathbb{3}$ & 0,55 & 0,57 & 0,68 & 0,71 & 0,73 & 0,65 & 0,64 & 0,72 & 0,51 & 0,77 & 0,56 \\
\hline $\mathrm{K}_{2} \mathrm{O}$ & 7,12 & 7,04 & 7,52 & 8,70 & 8,90 & 8,75 & 8,40 & 8,45 & 8,70 & 8,78 & 8,66 & 8,81 & 8,91 & 8,89 & 8,88 & 8,61 & 8,89 & 8,65 \\
\hline$\frac{\mathrm{BaO}}{\mathrm{D}}$ & n.e. & n.a. & n.a. & n.a. & n.a. & n.a. & n.a. & 0,04 & 0,08 & n.a. & n.a. & n.a. & n.a. & n.a. & n.a. & n.a. & n.a. & n.a. \\
\hline$F$ & n.a. & n.a. & n.a. & ก.a. & n.a. & n.a. & n.a. & 1.71 & 1,79 & n.a. & n.a. & n.a. & n.a. & n.a. & ก.a. & n.a. & ก.a. & n.a. \\
\hline Cl & 0,00 & 0,00 & 0,0 & n.a. & n.a. & n.a. & n.a. & n.a. & n.a. & 0,00 & 0,00 & $0, \infty$ & 0,00 & $0, \infty$ & 0,00 & 0,00 & 0,00 & 0,00 \\
\hline $\mathrm{H}_{2} \mathrm{O}$ & 3,99 & 4,01 & 4,07 & 4,15 & 4,17 & 4,12 & 4,28 & 3,30 & 3,34 & 4,10 & 4,08 & 4,12 & 4,13 & 4,11 & 4,11 & 4,09 & 4,10 & 4,06 \\
\hline Total & 94,80 & 95,59 & 96,84 & 100,13 & 100,57 & 99,42 & 102,70 & 100,43 & 101,77 & 98,82 & 98,12 & 99,34 & 99,63 & 99,13 & 99,20 & 98,59 & 99,12 & 97,73 \\
\hline $\mathrm{Si}$ & 5,91 & 5,87 & 5,87 & 5,72 & 5,79 & 5,79 & 5,84 & 5,80 & 5,80 & 5,87 & 5,89 & 5,86 & 5,87 & 5,86 & 5,86 & 5,87 & 5,86 & 5,92 \\
\hline$A I^{N}$ & 209 & 2,13 & 2,13 & 2,28 & 2,21 & 2,21 & 2,16 & 2,20 & 2,20 & 2,13 & 2,11 & 2,15 & 2,13 & 2,14 & 2,14 & 2,13 & 2,14 & 2,08 \\
\hline$\Delta \|^{\sqrt{1}}$ & 0,36 & 0,34 & 0,35 & 0,18 & 0,21 & 0,20 & 0,34 & 0.22 & 0,23 & 0,29 & 0,32 & 0,32 & 0,29 & 0,34 & 0,27 & 0,31 & 0,28 & 0,36 \\
\hline Ti & 0,05 & 0,07 & 0,06 & 0,10 & 0,11 & 0,08 & 0,09 & 0,10 & 0,09 & 0,10 & 0,10 & 0,09 & 0,10 & 0,08 & 0,08 & 0,09 & 0,08 & 0,08 \\
\hline $\mathrm{Fe}^{+2}$ & 1,23 & 1,25 & 1,21 & 1,33 & 1,30 & 1,32 & 1,31 & 1,29 & 1,30 & 1,32 & 1,31 & 1,36 & 1,36 & 1,37 & 1,37 & 1,39 & 1,36 & 1,35 \\
\hline $\mathrm{Cr}$ & 0,14 & 0,15 & 0,14 & 0,04 & 0,05 & 0,04 & 0,06 & 0,04 & 0,04 & 0,04 & 0,03 & 0,05 & 0,06 & 0,04 & 0,04 & 0,06 & 0,07 & 0,04 \\
\hline $\mathrm{Zn}$ & & & & 0,00 & 0,0 & 0,00 & 0,01 & - & & & & - & - & - & -9 & - & - & - \\
\hline $\mathrm{Mn}$ & 0,00 & 0,00 & $0, \infty$ & 0,01 & 0,01 & 0,01 & 0,01 & 0.01 & 0,01 & 0,00 & $0, \infty$ & 0,00 & 0,00 & $0, \infty$ & $0, \infty$ & 0,00 & 0,00 & 0,00 \\
\hline $\mathrm{Mg}$ & 4,22 & 4,21 & 4,27 & 4,37 & 4,27 & 4,34 & 4,13 & 4,36 & 4,33 & 4,13 & 4,11 & 4,07 & 4,08 & 4,05 & 4,14 & 4,05 & 4,09 & 4,04 \\
\hline $\mathrm{Ni}$ & 0,00 & 0,00 & 0,00 & 0,01 & 0,01 & 0,01 & 0,01 & - & $-\quad$ & 0,00 & 0,00 & 0,00 & 0,00 & 0,0 & 0,00 & 0,00 & 0,00 & 0,00 \\
\hline $\mathrm{Ca}$ & 0,00 & 0,00 & 0,00 & 0,00 & 0,00 & 0,00 & 0,01 & $0, \infty$ & $0, \infty$ & $0, \infty$ & 0,00 & 0,00 & $0, \infty$ & $0, \infty$ & 0,00 & $0, \infty$ & $0, \infty$ & 0,00 \\
\hline $\mathrm{Na}$ & 0,10 & 0,13 & 0,09 & 0,19 & 0.17 & 0,15 & 0,17 & 0,15 & 0,16 & 0,19 & 0,20 & 0,21 & 0,18 & 0,18 & 0,20 & 0,15 & 0,22 & 0,16 \\
\hline $\mathrm{K}$ & 1,37 & 1,34 & 1,41 & 1,61 & $1, \mathbb{G}$ & 1,63 & 1,50 & 1,56 & 1,59 & 1,64 & 1,62 & 1,64 & 1,6 & 1,66 & 1,65 & 1,61 & 1,66 & 1,63 \\
\hline $\mathrm{Ba}$ & & & & & -1 & & - & 0,00 & 0,01 & -1 & - & -1 & - & - & -9 & - & $-\quad$ & - \\
\hline Cátions & 15,47 & 15,49 & 15,52 & 15,82 & 15,76 & 15,78 & $15, \widetilde{3}$ & 15,73 & 15,74 & 15,71 & 15,09 & 15,72 & 15,71 & 15,72 & 15,76 & 15,66 & 15.75 & 15,65 \\
\hline FMg & 0.78 & 0.77 & 0.78 & 0.77 & 0.77 & 0,77 & 0.76 & 0.77 & 0,77 & 0.76 & 0.76 & 0.75 & 0,75 & 0.75 & 0.75 & 0.74 & 0.75 & 0,75 \\
\hline
\end{tabular}

Tabela 4.1.2: Dados analíticos de flogopitas de UM. Fórmula estrutural: 24(O). 
Tabela A4.1: Biotitas/Flogopitas - BT/FLO.

\begin{tabular}{|c|c|c|c|c|c|c|c|c|c|c|c|c|c|c|c|c|c|c|}
\hline \begin{tabular}{|l} 
Amostras \\
Análises
\end{tabular} & $\frac{B E-D}{}$ & CAP5 & CAP5 & CAP5 & CAP-5 & CAP-5 & CAP-5 & CAP-5 & CAP 5 & NE-12 & NE-12 & NE-12 & NE-3 & $\mathrm{NE-3}$ & NE-3 & NE-3 & NE3 3 & NE-3 \\
\hline \begin{tabular}{|l} 
Análises \\
Mineral
\end{tabular} & $37 / 3 F 2.1$ & 49/1FOI & 49/1F02 & 49/1FO3 & 4Q/1FO4 & $49 / 2 \mathrm{FO}$ & 49/2FO2 & 49/2F03 & $49 / 2 \mathrm{FO4}$ & $4 / 1 / 66$ & $4 / 1 / 67$ & $4 / 1 / 68$ & $48 / 2 \mathrm{FO}$ & $48 / 2 \mathrm{FO} 2$ & $48 / 2 \mathrm{FO3}$ & $48 / 2 F 04$ & $48 / 2 F 05$ & $48 / 2 \mathrm{FO} 6$ \\
\hline$\frac{\text { Mineral }}{\text { Local }}$ & FLO & FLO & FLO & FLO & FLO & FLO & FLO & FLO & FLO & FLO & FLO & FLO & FLO & FLO & FLO & FLO & FLO & FLO \\
\hline $\begin{array}{l}\text { Local } \\
\text { Lutotipo }\end{array}$ & C & $\frac{\mathrm{c}}{\mathrm{UM}}$ & $\begin{array}{c}\mathrm{B} \\
\mathrm{UM}\end{array}$ & $\mathrm{C}$ & $\frac{B}{U M}$ & $\begin{array}{c}\mathrm{C} \\
\mathrm{UM}\end{array}$ & $\frac{\mathrm{B}}{\mathrm{DM}}$ & $\begin{array}{l}\mathrm{C} \\
\mathrm{UMM}\end{array}$ & $\frac{B}{U M}$ & $\begin{array}{c}c \\
\text { UM }\end{array}$ & $\mathrm{C}$ & B & 8 & PIn & $\mathrm{C}$ & $\mathrm{B}$ & $\mathrm{C}$ & $\mathrm{B}$ \\
\hline $\mathrm{SiO}_{2}$ & 39,96 & 40,40 & 40,49 & 40,43 & 40,27 & 39,92 & 40,03 & 39.85 & $40, \infty$ & 40,83 & 41,58 & 40,96 & 39,99 & 39, & 39,85 & $\frac{\mathrm{UM}}{40,45}$ & $\frac{U M}{40,05}$ & $\frac{U M}{40.20}$ \\
\hline $\mathrm{TiO}_{2}$ & 0,81 & 0,00 & 0,00 & 0,00 & 0,00 & 0,14 & 0,00 & 0,00 & 0,14 & 0,44 & 0,60 & 0,43 & 0,27 & 0,28 & 0,29 & 0,36 & 0,32 & $\frac{4,24}{0,33}$ \\
\hline $\mathrm{Al}_{2} \mathrm{O}_{3}$ & 14,01 & 13,01 & 13,28 & 13,17 & 13,18 & 13,70 & 13,63 & 13,72 & 13,75 & 15,92 & 16,09 & 15,98 & 14,01 & 13,85 & 14,03 & 14,09 & 14,05 & 14,02 \\
\hline $\mathrm{Cr}_{2} \mathrm{O}_{3}$ & 0,38 & 0,61 & 0,62 & 0,03 & 0,44 & 0,03 & 0,57 & 0,67 & 0,70 & 0,39 & 0,30 & 0,30 & 0,93 & 0,83 & 1,03 & 0,90 & 0,95 & 0.86 \\
\hline $\mathrm{ZnO}$ & n.a. & n.a. & n.a. & n.a. & n.a. & n.a. & ก.a. & n.a. & n.a. & 0,0 & 0,06 & 0,02 & n.a. & n.a. & n.a. & ก.a. & n.a. & n.a. \\
\hline $\mathrm{FeO}$ & 11,06 & 10,09 & 10,05 & 10,09 & 9,59 & 10,6 & 10,78 & 10,46 & 10,57 & 9,44 & 9,26 & 9,59 & 9,13 & 8,91 & 9,25 & 9,23 & 9.05 & 9,26 \\
\hline Mno & 0,00 & $0, \infty$ & 0,00 & $0, \infty$ & $0, \infty$ & 0,00 & 0,17 & 0,18 & 0,00 & 0,02 & 0,04 & 0,06 & 0,00 & 0,00 & 0,00 & 0,00 & $0, \infty$ & 0,00 \\
\hline $\mathrm{MgO}$ & 18,37 & 19,67 & 19,82 & 19,74 & 19,68 & 19,12 & 19,16 & 19,13 & 18,97 & 20,67 & 20,97 & 20,86 & 19,85 & 19,52 & 19,64 & 19,92 & 19,68 & 19,46 \\
\hline NIO & $0, \infty$ & $0, \infty$ & $0, \infty$ & 0,00 & 0,00 & $0, \infty$ & $0, \infty$ & $0, \infty$ & 0,00 & 0,05 & 0,03 & 0,05 & 0,00 & 0,0 & 0,00 & 0,00 & $0, \infty$ & 0,00 \\
\hline $\mathrm{CaO}$ & $0, \infty$ & 0,00 & 0,0 & $0, \infty$ & 0,00 & 0,0 & 0,00 & $0, \infty$ & 0,00 & 0,06 & 0,09 & 0,14 & 0,00 & 0,00 & 0,00 & 0,0 & $0, \infty$ & 0,00 \\
\hline $\mathrm{Na}_{2} \mathrm{O}$ & 0,64 & 0,28 & 0,44 & 0,45 & 0,32 & 0,42 & 0,46 & 0,44 & 0,50 & 0,64 & 0,46 & 0,39 & 0,58 & 0,48 & 0,71 & 0,53 & 0,59 & 0,52 \\
\hline $\mathrm{K}_{2} \mathrm{O}$ & 8,69 & 7,83 & 7,91 & 7,90 & 7,55 & 8,01 & 7,97 & 7,63 & 7,84 & 8,31 & 7,71 & 8,09 & 7,43 & 7,53 & 7,44 & 7,53 & 7,47 & 7,39 \\
\hline $\mathrm{BaO}$ & n.a. & n.a. & n.a. & n.a. & n.a. & n.a. & n.a. & n.a. & ก.a. & n.a. & n.a. & n.a. & n.a. & n.a. & n.a. & n.a. & n.a. & n.a. \\
\hline$F$ & n.a. & n.a. & ก.a. & n.a. & n.a. & n.a. & n.a. & ก.a. & n.a. & n.a. & ก.a. & n.a. & n.a. & n.a. & n.a. & ก.a. & n.a. & n.a. \\
\hline $\mathrm{Cl}$ & $0, \infty$ & 0,0 & 0,0 & 0,06 & 0,00 & 0,00 & $0, \infty$ & 0,00 & 0,00 & n.a. & n.a. & n.a & 0,00 & $0, \infty$ & 0,00 & 0,00 & 0,00 & 0,00 \\
\hline $\mathrm{H}_{2} \mathrm{O}$ & 4,07 & 4,02 & 4,05 & 4,03 & 4,00 & 4,03 & 4,04 & 4,02 & 4,03 & 4,25 & 4,29 & 4,25 & 4,06 & 4,00 & 4,05 & 4,09 & 4,06 & 4,05 \\
\hline Total & 98,01 & 96,91 & 96,66 & 96,50 & 96,03 & 96,57 & 96,81 & 96,10 & 96,50 & 101,11 & 101,48 & 101,11 & 96,25 & 94,92 & 96,29 & 97,09 & 96,22 & 96,09 \\
\hline Si & 5,90 & 6,02 & 5,99 & 6,00 & 6,03 & 5,94 & 5,95 & 5,96 & 5,96 & 5,77 & 5,81 & 5,77 & 5,91 & 5,92 & 5,90 & 5,93 & 5,92 & 5,95 \\
\hline $\mathrm{Al}^{\mathrm{N}}$ & 2,11 & 1,98 & 2,01 & 2,00 & 1,97 & 2,06 & 2,05 & 2,06 & 2,05 & 2,23 & 2,19 & 2,23 & 2,09 & 2,08 & 2,10 & 2,07 & 2,08 & 2.05 \\
\hline$A 1^{n}$ & 0,33 & 0,31 & 0,31 & 0,30 & 0,36 & 0,34 & 0,33 & 0,36 & 0,36 & 0,42 & 0,46 & 0,43 & 0,35 & 0,37 & 0,35 & 0,36 & 0,37 & 0,39 \\
\hline $\mathrm{Ti}$ & 0,09 & 0,00 & 0,00 & 0,00 & 0,00 & 0,02 & 0,0 & $0, \infty$ & 0,02 & 0,05 & 0,06 & 0,05 & 0,03 & 0,03 & 0,03 & 0,04 & 0,04 & 0,04 \\
\hline $\mathrm{Fe}^{+2}$ & 1,36 & 1,26 & 1,24 & 1,25 & 1,20 & 1,32 & 1,34 & 1,31 & 1,31 & 1,12 & 1,08 & 1,13 & 1,13 & 1,12 & 1,15 & 1,13 & 1,12 & 1,15 \\
\hline Cr & 0,04 & 0,07 & 0,07 & 0,07 & 0,05 & 0,07 & 0,07 & 0,08 & 0,08 & 0,04 & 0,03 & 0,03 & 0,11 & 0,10 & 0,12 & 0,10 & 0,11 & 0,10 \\
\hline $\mathrm{Zn}$ & $=$ & - & $-\quad 1$ & $-\quad$ & $-\quad \mid$ & -1 & $-\quad$ & $-\quad$ & - & 0,01 & 0,01 & $0, \infty$ & - & $-\quad \mid$ & & & - & - \\
\hline $\mathrm{Mn}$ & 0,00 & $0, \infty$ & $0, \infty$ & $0, \infty$ & $0, \infty$ & 0,00 & 0,02 & 0,02 & 0,0 & 0,00 & 0,01 & 0,01 & 0,00 & $0, \infty$ & $0, \infty$ & 0,00 & 0,00 & 0,00 \\
\hline $\mathrm{Mg}$ & 4,04 & 4,37 & 4,37 & 4,37 & 4,40 & 4,24 & 4,24 & 4,26 & 4,21 & 4,35 & 4,37 & 4,38 & 4,38 & 4,36 & 4,33 & 4,35 & 4,34 & 4,29 \\
\hline $\mathrm{Ni}$ & 0,0 & 0,00 & $0, \infty$ & 0,00 & 0,00 & 0,00 & $0, \infty$ & 0,00 & 0,00 & 0,01 & 0,00 & 0,01 & 0,00 & $0, \infty$ & 0,0 & 0,00 & 0,00 & 0,00 \\
\hline $\mathrm{Ca}$ & $0, \infty$ & 0,00 & 0,00 & 0,0 & 0,00 & 0,00 & 0,00 & 0,00 & $0, \infty$ & 0,01 & 0,01 & 0,02 & 0,00 & $0, \infty$ & 0,00 & 0,00 & 0,00 & 0,00 \\
\hline $\mathrm{Na}$ & 0,18 & 0,08 & 0,13 & 0,13 & 0,09 & 0,12 & 0,13 & 0,13 & 0,14 & 0,18 & 0,13 & 0,11 & 0,17 & 0,14 & 0,20 & 0,15 & 0.17 & 0,15 \\
\hline$K$ & 1,64 & 1,49 & 1,49 & 1,50 & 1,44 & 1,52 & 1,51 & $\{, 45$ & 1,49 & 1,50 & 1,37 & 1,46 & 1,40 & 1,44 & 1,41 & 1,41 & 1,41 & 1,40 \\
\hline $\mathrm{Ba}$ & & $-\quad$ & - & & & & & & & & & & & & & - & 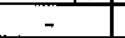 & - \\
\hline Cátions & 15,68 & 15,58 & 15,62 & 15,62 & 15,54 & 15,63 & 15,65 & 15,60 & 15,60 & $15, \infty 8$ & 15,53 & 15,62 & 15,56 & 15,56 & 15,59 & 15,54 & 15,55 & 15,51 \\
\hline $\mathrm{AMg}$ & 0,75 & 0.78 & 0.78 & 0.78 & 079 & 0.76 & 0,76 & 0.77 & 0.76 & 0.80 & 0.80 & 0.79 & 0.79 & 0,80 & 0,79 & 0,79 & 0,79 & 0.79 \\
\hline
\end{tabular}

Tabela 4.1.2: Dados analiticos de flogopitas de UM. Fórmula estrutural: 24(O) 
Tabela A4.1: Biotitas/Flogopitas - BT/FLO.

\begin{tabular}{|c|c|c|c|c|c|c|c|c|c|c|c|c|c|}
\hline Amostras & NE-30 & NE-30 & NE-31 & NE-31-06 & NE-31-06 & NE-31-O6 & NE-31-06 & SUL-01 & SUL-01 & SUL-01 & SUL-01 & SUL-01 & SUL-01 \\
\hline Análises & $6 / 1 / 50$ & $6 / 1 / 51$ & $6 / 3 / 62$ & $3 / 3 / 26$ & $3 / 4 / 30$ & $3 / 4 / 32$ & $3 / 4 / 34$ & $2 / \sqrt{7}$ & $2 / 1 / 8$ & $2 / 6 / 16$ & $2 / 6 / 17$ & $6 / 6 / 65$ & $6 / 6 / 66$ \\
\hline Mineral & FLO & FLO & FLO-CLO & FLO & FLO & $F L O$ & FLO & FLO & FLO & FLO & FLO & FLO & FLO \\
\hline Local & $c$ & $\mathrm{~B}$ & $\mathrm{~B}$ & C & $c$ & $\mathrm{C}$ & C & $\mathrm{C}$ & $\mathrm{B}$ & $c$ & B & $\mathrm{C}$ & B \\
\hline Litotipo & UM & UM & UM & UM & UM & UM & UM & $\mathrm{UM}$ & UM & UM & UM & UM & UM \\
\hline $\mathrm{SiO}_{2}$ & 38,92 & 40,19 & 33,63 & 39,42 & 40,73 & 39,32 & 39,33 & 40,29 & 39,86 & 40,06 & 40,50 & 38,54 & 39,26 \\
\hline $\mathrm{TiO}_{2}$ & 0,34 & 0,41 & 0,02 & 0,40 & 0,39 & 0,41 & 0,39 & 0,52 & 0,45 & 0,55 & 0,53 & 0,44 & 0,47 \\
\hline $\mathrm{Al}_{2} \mathrm{O}_{3}$ & 15,32 & 15,39 & 17,42 & 15,50 & 18,97 & 15,30 & 15,42 & 15,01 & 15,15 & 15,28 & 15,34 & 15,01 & 14,86 \\
\hline $\mathrm{Cr}_{2} \mathrm{O}_{3}$ & 0,25 & 0,26 & 0,17 & 0,29 & 0,23 & 0.28 & 0,20 & 0,17 & 0.22 & 0,27 & 0,31 & 0.27 & 0,30 \\
\hline 2 no & n.a. & n.a. & n.a. & 0,11 & 0,05 & 0,05 & 0,05 & 0,02 & 0,06 & 0,06 & 0,08 & n.a. & n.a. \\
\hline $\mathrm{FeO}$ & 10,26 & 10,28 & 10,75 & 10,12 & 8,65 & 9,84 & 9,98 & 10,59 & 10,69 & 10,80 & 10,75 & 10,76 & 10,12 \\
\hline MnO & 0,03 & 0,06 & 0,05 & 0,0 & 0,06 & 0,08 & 0,0 & 0,08 & 0,09 & 0,08 & 0,06 & 0,08 & 0,09 \\
\hline $\mathrm{MgO}$ & 20,16 & 20,56 & 21,22 & 20,32 & 17,67 & 20,57 & 20,36 & 20,36 & 20,13 & 19,59 & 19,81 & 19,92 & 19,93 \\
\hline $\mathrm{NiO}$ & n.a. & n.a. & n.a. & 0,01 & 0,06 & 0,06 & $0, \infty$ & 0,05 & 0,02 & 0.04 & 0,04 & n.a. & n.a. \\
\hline $\mathrm{CaO}$ & 0,00 & 0,00 & 0,42 & 0,02 & 0,07 & 0,00 & $0, \infty$ & 0,02 & 0,02 & 0,01 & 0,04 & 0,01 & 0,00 \\
\hline $\mathrm{Na}_{2} \mathrm{O}$ & 0,51 & 0,44 & 0,03 & $0, \infty$ & 0,47 & 0,59 & 0,57 & 0,44 & 0,40 & 0,33 & 0,32 & 0,37 & 0,38 \\
\hline$\overline{\mathrm{K}_{2} \mathrm{O}}$ & 8,54 & 8,25 & 0,12 & 8,45 & 7,02 & 8,61 & 8,43 & 8,90 & 8,65 & 8,74 & 8,85 & 8,50 & 8,54 \\
\hline $\mathrm{BaO}$ & 0,04 & 0,01 & 0,02 & n.a. & n.a. & n.a. & n.a. & n.a. & n.a. & n.a. & n.a. & 0,08 & 0,00 \\
\hline$F$ & 0,72 & 0,84 & 0,28 & n.a. & n.a. & n.a. & ก.a. & n.a. & n.a. & n.a. & n.a. & 1,05 & 1,01 \\
\hline Cl & n.a. & n.a. & n.a. & n.a. & n.a. & n.a. & ก.a. & n.a. & n.a. & n.a. & n.a. & n.a. & n.a. \\
\hline $\mathrm{H}_{2} \mathrm{O}$ & 3,76 & 3,79 & 3,67 & 4,15 & 4,21 & 4,14 & 4,13 & 4,19 & 4,16 & 4,16 & 4,20 & 3,57 & 3,61 \\
\hline Total & 98,85 & 100,48 & 87,80 & 99,48 & 98,58 & 99,25 & 98,94 & 100,64 & 99,90 & 99,97 & 100,83 & 98,6 & 98,57 \\
\hline$\widehat{\mathrm{Si}}$ & 5,70 & 5,76 & 5,30 & 5,70 & 5,80 & 5,70 & 5,71 & 5,77 & 5,75 & 5,78 & 5,79 & 5,68 & 5,76 \\
\hline$|A|^{N}$ & 2,31 & 2,24 & 2,70 & 2,30 & 2,20 & 2,30 & 2,29 & 2,23 & 2,25 & 2,22 & 2,21 & 2,32 & 2,24 \\
\hline$A l^{V}$ & 0,34 & 0,36 & 0,54 & 0,34 & 0,98 & 0,31 & 0,36 & 0,30 & 0,33 & 0,37 & 0,37 & 0,29 & 0,33 \\
\hline Ti & 0,04 & 0,04 & 0,00 & 0,04 & 0,04 & 0,05 & 0,04 & 0,06 & 0,05 & 0,06 & 0,06 & 0,05 & 0,05 \\
\hline $\mathrm{Fe}^{+2}$ & 1,26 & 1,23 & 1,42 & 1,22 & 1,03 & 1,19 & 1.21 & 1,27 & 1,29 & 1,30 & 1,29 & 1,33 & 1,24 \\
\hline $\mathrm{Cr}$ & 0,03 & 0,03 & 0,02 & 0,03 & 0,03 & 0,03 & 0,02 & 0,02 & 0,03 & 0,03 & 0,04 & 0,03 & 0,04 \\
\hline $\mathrm{Zn}$ & - & - & - & 0,01 & 0.01 & 0,01 & 0,01 & 0,00 & 0,01 & 0,01 & 0,01 & - & - \\
\hline $\mathrm{Mn}$ & 0,00 & 0,01 & 0,01 & 0,01 & 0,01 & 0.01 & 0,01 & 0,01 & 0,01 & 0,01 & 0,01 & 0,01 & 0,01 \\
\hline$\overline{\mathrm{Mg}}$ & 4,40 & 4,39 & 4,99 & 4,38 & 3,75 & 4,45 & 4,41 & 4,35 & 4,33 & 4,21 & 4,22 & 4,38 & 4,36 \\
\hline $\mathrm{Ni}$ & - & - & - & 0,00 & 0,01 & 0,01 & $0, \infty$ & 0,01 & $0, \infty$ & 0,00 & 0,00 & - & - \\
\hline $\mathrm{Ca}$ & 0,0 & 0,00 & 0,07 & 0,00 & 0.01 & 0,00 & 0,0 & 0,00 & 0,0 & 0,0 & 0,01 & 0,0 & 0,00 \\
\hline $\mathrm{Na}$ & 0,15 & 0,12 & 0,01 & 0,17 & 0,13 & 0,17 & 0,16 & 0,12 & 0.11 & 0,09 & 0,09 & 0,11 & 0.11 \\
\hline $\mathrm{K}$ & 1,59 & 1,51 & 0,02 & 1,56 & 1,28 & 1,59 & 1,56 & $1, \mathfrak{3}$ & 1,59 & 1,61 & 1,61 & 1,60 & $1, \infty 0$ \\
\hline $\mathrm{Ba}$ & $0, \infty$ & $0, \infty$ & 0,00 & - & - & $-\quad$ & - & - & - & - & - & 0,01 & $0, \infty$ \\
\hline Cátions & 1580 & 15,69 & 15,08 & 15,77 & 45,27 & 15,82 & 15,78 & 15,77 & 15,75 & 15,70 & 15,69 & 15,80 & 15,74 \\
\hline \#Mg & 0.78 & 0.78 & 0.78 & 0.78 & 0.78 & 0.79 & 0.78 & 0.77 & 0.77 & 0,76 & 0.77 & 0.77 & 0.78 \\
\hline
\end{tabular}

Tabela 4.1.2: Dados analíticos de flogopitas de UM. Fórmula estrutural: $24(0)$

Nota: As análises da amostra NE-31-06 säo de flogopitas com lentes de K-feldspato 
Tabela A4.1: Biotitas/Flogopitas - BT/FLO.

\begin{tabular}{|c|c|c|c|c|c|c|c|c|c|c|c|c|c|c|c|c|c|}
\hline Amostras & CAP-4 & CAP-4 & CAP-4 & $\mathrm{HC}-3 \mathrm{a}$ & $\mathrm{HC}-39$ & $\mathrm{HC}-3 \mathrm{a}$ & $\mathrm{HC}-3 \mathrm{a}$ & HC-3a & $\mathrm{HC}-3 \mathrm{a}$ & G-37a & G-37a & G-37a & G-37a & G-37a & $\mathrm{G}-37 a$ & $G-37 a$ & G-37a \\
\hline Análises & $28 / 1 \mathrm{~B} 1.1$ & $28 / 1 \mathrm{~B} 2.1$ & $28 / 381.1$ & $27 / 1 \mathrm{~B} 1.1$ & $27 / 1 \mathrm{~B} 4.2$ & 27/1B21 & $2711 \mathrm{~B} 2.2$ & $27 / 2 \mathrm{~B} 1.1$ & $27 / 2 \mathrm{~B} 1.2$ & $29 / 1 \mathrm{~B} 1.1$ & $29 / 1$ B1.2 & $29 / 2 \mathrm{~B} 1.1$ & $29 / 2 \mathrm{~B} 1.2$ & $29 / 2 \mathrm{~B} 1.3$ & 29/2B2.1 & $29 / 2 B 2.2$ & $29 / 3 B 1.1$ \\
\hline Mineral & BT & BT & BT & BT & $\mathrm{BT}$ & BT & BT & BT & BT & BT & $\mathrm{BT}$ & $\mathrm{BT}$ & BT & $\mathrm{BT}$ & $\mathrm{BT}$ & BT & BT \\
\hline Local & $\mathrm{B}$ & $\mathrm{C}$ & $\mathrm{B}$ & 8 & C & $B$ & $\mathrm{C}$ & $B$ & $\mathrm{C}$ & C & $B$ & $c$ & B & $\mathrm{C}$ & C & B & $\mathrm{PIm}$ \\
\hline Litotipo & $\mathrm{AB}$ & $\overline{A B}$ & $\overline{A B}$ & $\overline{A B}$ & $\overline{\mathrm{AB}}$ & $\overline{A B}$ & $\overline{A B}$ & $\overline{A B}$ & $\overline{A B}$ & ABET & ABET & ABET & ABET & ABET & ABET & ABET & ABET \\
\hline $\mathrm{SiO}_{2}$ & 30.33 & 30.26 & 29.83 & 36.51 & 36.39 & 36.33 & 36.29 & 36.69 & 36.38 & 38.73 & 38.94 & 36.15 & 37.07 & 36.14 & 36.5 & 37.05 & 36.60 \\
\hline $\mathrm{TiO}_{2}$ & 0.82 & 0.00 & 0.80 & 2.00 & 1.97 & 1.70 & 1.83 & 1.64 & 1.96 & 0.78 & 0.48 & 1.12 & 1.43 & 1.27 & 1.13 & 1.07 & 1.07 \\
\hline $\mathrm{Al}_{2} \mathrm{O}_{3}$ & 14.91 & 14.41 & 15.61 & 14.62 & 14.61 & 14.54 & 14.32 & 15.02 & 14.46 & 13.10 & 13.10 & 13.15 & 13.33 & 13.43 & 13.05 & 12.77 & 13.01 \\
\hline $\mathrm{Cr}_{2} \mathrm{O}_{3}$ & 0.17 & 0.00 & 0.00 & 0.00 & 0.00 & 0.00 & 0.00 & 0.00 & 0.00 & 0.00 & 0.00 & 0.00 & 0.00 & 0.00 & 0.00 & 0.00 & 0.00 \\
\hline $\mathrm{ZnO}$ & n.a. & n.a. & n.a. & n.a. & n.a. & n.a. & n.a. & n.a. & n.a. & n.a. & n.a. & n.a. & n.a. & n.a. & n.a. & n.a. & n.a. \\
\hline $\mathrm{FeO}$ & 18.83 & 20.78 & 18.82 & 15.49 & 15.96 & 15.78 & 15.99 & 15.90 & 16.05 & 18.44 & 17.40 & 19.31 & 20.21 & 19.71 & 19.26 & 18.83 & 19.36 \\
\hline $\mathrm{MnO}$ & 0.00 & 0.00 & 0.00 & 0.26 & 0.00 & 0.18 & 0.00 & 0.16 & 0.00 & 0.00 & 0.00 & 0.00 & 0.00 & 0.00 & 0.00 & 0.00 & 0.16 \\
\hline $\mathrm{MgO}$ & 18.05 & 18.00 & 18.01 & 12.89 & 12.96 & 13.00 & 12.91 & 13.12 & 12.81 & 14.09 & 14.03 & 11.78 & 11.88 & 11.74 & 12.44 & 12.61 & 12.38 \\
\hline $\mathrm{NiO}$ & 0.00 & 0.00 & 0.00 & 0.00 & $0 . \infty$ & 0.00 & 0.00 & 0.00 & 0.00 & 0.00 & 0.00 & 0.00 & 0.00 & 0.00 & 0.00 & 0.00 & 0.00 \\
\hline $\mathrm{CaO}$ & 0.25 & 0.35 & 0.00 & 0.00 & 0.00 & 0.00 & $0 . \infty$ & 0.00 & 0.00 & 0.00 & 0.0 & 0.00 & 0.00 & 0.00 & 0.00 & 0.15 & 0.00 \\
\hline $\mathrm{Na}_{2} \mathrm{O}$ & 0.30 & 0.31 & 0.15 & 0.00 & 0.00 & 0.15 & 0.00 & 0.25 & 0.27 & 0.44 & 0.24 & 0.33 & 0.50 & 0.49 & 0.45 & 0.38 & 0.61 \\
\hline $\mathrm{K}_{2} \mathrm{O}$ & 1.25 & 0.13 & 0.79 & 9.72 & 9.81 & 10.00 & 9.61 & 9.71 & 9.96 & 8.28 & 8.86 & 8.32 & 8.46 & 8.63 & 8.45 & 8.66 & 8.53 \\
\hline $\mathrm{BaO}$ & n.a. & n.a. & n.a. & n.a. & n.a. & n.a. & n.a. & n.a. & n.a. & n.a. & n.a. & n.a. & n.a. & n.a. & n.a. & n.a. & n.a. \\
\hline$F$ & ก.a. & n.a. & ก.a. & n.a. & n.a. & n.a. & n.a. & n.a. & n.a. & n.a. & n.a. & n.a. & n.a. & n.a. & n.a. & ก.a. & n.a. \\
\hline $\mathrm{Cl}$ & 0.00 & 0.00 & 0.00 & 0.00 & 0.00 & 0.00 & 0.00 & 0.00 & 0.13 & 0.00 & 0.0 & 0.00 & 0.00 & 0.00 & 0.00 & 0.00 & 0.00 \\
\hline $\mathrm{H}_{2} \mathrm{O}$ & 1.73 & 1.71 & 1.72 & 1.83 & 1.83 & 1.83 & 1.82 & 1.85 & 1.80 & 1.88 & 1.88 & 1.78 & 1.83 & 1.80 & 1.81 & 1.81 & 1.81 \\
\hline Total & 86.64 & 85.95 & 85.73 & 93.41 & 93.52 & 93.51 & 92.77 & 94.34 & 93.82 & 95.74 & 95.53 & 91.94 & 94.71 & 93.21 & 93.24 & 93.33 & 93.53 \\
\hline Si & 5.27 & 5.31 & 5.21 & 5.97 & 5.96 & 5.96 & 5.99 & 5.95 & 5.96 & 5.93 & 5.96 & 5.83 & 5.82 & 5.78 & 5.83 & 5.88 & 5.82 \\
\hline $\overrightarrow{A l^{N}}$ & 2.73 & 2.09 & 2.79 & 2.03 & 2.04 & 204 & 2.01 & 2.05 & 2.04 & 2.07 & 2.04 & 2.17 & 2.18 & 2.22 & 2.17 & 2.12 & 2.18 \\
\hline$A M^{M}$ & 0.32 & 0.29 & 0.42 & 0.79 & 0.78 & 0.77 & 0.77 & 0.82 & 0.75 & 0.29 & 0.32 & 0.33 & 0.29 & 0.30 & 0.28 & 0.27 & 0.26 \\
\hline Ti & 0.11 & 0.00 & 0.11 & 0.26 & 0.24 & 0.21 & 0.23 & 0.20 & 0.24 & 0.09 & 0.06 & 0.14 & 0.17 & 0.15 & 0.14 & 0.13 & 0.13 \\
\hline $\mathrm{Fe}^{+2}$ & 2.73 & 3.05 & 2.75 & 2.12 & 2.19 & 2.17 & 2.21 & 2.16 & 2.20 & 2.36 & 2.23 & 2.61 & 2.65 & 2.63 & 2.56 & 250 & 2.57 \\
\hline $\mathrm{Cr}_{\mathrm{T}}$ & 0.02 & 0.00 & 0.00 & 0.00 & 0.00 & 0.00 & 0.00 & 0.00 & 0.00 & 0.00 & 0.00 & 0.00 & 0.00 & 0.00 & 0.00 & 0.00 & 0.00 \\
\hline $\mathrm{Zn}$ & - & $-\quad$ & $-\quad$ & - & -1 & $-\quad$ & - & - & -1 & $-\quad$ & - & $-\quad$ & - & -1 & $-\quad \mid$ & - & - \\
\hline $\mathrm{Mn}$ & 0.00 & 0.00 & 0.00 & 0.04 & 0.00 & 0.03 & 0.00 & 0.02 & 0.00 & 0.00 & 0.00 & 0.00 & 0.00 & 0.00 & 0.00 & 0.00 & 0.02 \\
\hline $\mathrm{Mg}$ & 4.67 & 4.71 & 4.6 & 3.14 & 3.16 & 3.18 & 3.18 & 3.17 & 3.13 & 3.22 & 3.34 & 2.83 & 2.78 & 2.80 & 2.95 & 2.98 & 2.93 \\
\hline $\mathrm{Ni}$ & 0.00 & 0.00 & 0.00 & 0.00 & 0.00 & 0.00 & 0.00 & 0.00 & 0.00 & 0.00 & 0.00 & 0.00 & 0.00 & 0.00 & 0.00 & 0.00 & 0.00 \\
\hline $\mathrm{Ca}$ & 0.05 & 0.07 & 0.00 & 0.00 & 0.0 & 0.0 & 0.00 & 0.00 & $0 . \infty$ & 0.00 & 0.00 & 0.00 & 0.00 & 0.00 & 0.00 & 0.03 & 0.00 \\
\hline $\mathrm{Na}$ & 0.10 & 0.11 & 0.05 & 0.00 & 0.00 & 0.05 & 0.00 & 0.08 & 0.09 & 0.13 & 0.07 & 0.10 & 0.15 & 0.15 & 0.14 & 0.12 & 0.19 \\
\hline $\mathrm{K}$ & 0.28 & 0.03 & 0.18 & 2.03 & 2.05 & 200 & 2.02 & 2.01 & 2.08 & 1.62 & 1.73 & 1.71 & 1.70 & 1.76 & 1.72 & 1.75 & 1.73 \\
\hline $\mathrm{Ba}$ & - & - & - & - & - & - & - & - & & - & & & - & $-\quad$ & - & - & - \\
\hline Cátions & 16.28 & 16.26 & 16.19 & 16.37 & 16.41 & 16.49 & 16.40 & 16.46 & 16.48 & 15.71 & 15.74 & 15.73 & 15.74 & 15.80 & 15.78 & 15.77 & 1583 \\
\hline \#Fe ${ }^{+2}$ & 0.37 & 0.39 & 0.37 & 0.40 & 0.41 & 0.41 & 0.41 & 0.40 & 0.41 & 0.43 & 0.40 & 0.48 & 0.49 & 0.48 & 0.46 & 0.46 & 0.47 \\
\hline
\end{tabular}

Tabela A4.1.3: Dados analiticos de biotitas de anfibolitos metabásicos AB, ABET e ABG. Fórmula estrutural: 24(O). 
Tabela A4.1: Biotitas/Flogopitas - BT/FLO.

\begin{tabular}{|c|c|c|c|c|c|c|c|c|c|c|c|c|c|c|c|c|c|}
\hline \begin{tabular}{|l|} 
Amostras \\
Análises
\end{tabular} & $\frac{G-37 a}{29 / 3 B 1.2}$ & $\frac{G-56}{35 / 1 B 1.1}$ & $\frac{G-56}{35 / 2 B 4}$ & $\frac{\mathrm{G}-56}{35 / 2 \mathrm{~B} 12}$ & G-56 & $\frac{G-56}{350922}$ & $1-01$ & 1.01 & $1-01$ & $1-01$ & $1-01$ & $1-01$ & $1-01$ & $1-01$ & $1-01$ & $1-01$ & $1-01$ \\
\hline Mineral & BT & BT & BT & $\frac{20 / 2 B 1.2}{B T}$ & $\frac{3 / 282.7}{R T}$ & $\frac{35 / 2 B 2.2}{B T}$ & $10 / 2801$ & $10 / 2 \mathrm{BO} 2$ & $10 / 2 B C 3$ & $10 / 2 \mathrm{BOA}$ & $10 / 2 \mathrm{~B} 1.1$ & $10 / 3 \mathrm{BO} 1$ & $10 / 3 B O 2$ & $10 / 3 \mathrm{~B} 03$ & $1013 \mathrm{BO} 4$ & $10 / 332.1$ & $10 / 4801$ \\
\hline Local & B & C & C & $\frac{1}{B}$ & $\frac{D_{1}}{c}$ & $\frac{\mathrm{BT}}{\mathrm{B}}$ & $\frac{B T}{C}$ & BT & BT & $B T$ & BT & BT & BT & BT & BT & BT & BT \\
\hline Litotipo & ABET & ABET & ABET & ABET & $\overline{A B E T}$ & ABET & $\frac{C}{A B G}$ & $\frac{\text { B }}{\text { ABG }}$ & $\frac{C}{A B G}$ & $\frac{B}{A B G}$ & $\frac{C}{A R G}$ & $\frac{C}{A B C}$ & $\frac{\mathrm{B}}{\mathrm{AB}}$ & $\mathrm{C}$ & $B$ & $c$ & B \\
\hline $\mathrm{SiO}_{2}$ & 36.77 & 36.54 & 36.74 & 36.97 & 36.50 & 36.37 & 35.40 & 34.95 & 35.82 & 35.80 & $\frac{A D C}{36.38}$ & $\frac{A B 5}{36.10}$ & $\frac{A B S}{36.17}$ & $\frac{A B G}{3421}$ & $\frac{A B G}{3588}$ & $\frac{A B G}{3651}$ & $\frac{A B G}{3585}$ \\
\hline $\mathrm{TiO}_{2}$ & 0.85 & 1.14 & 1.20 & 0.96 & 1.22 & 1.04 & 2.04 & 1.91 & 1.92 & 1.80 & 2.04 & 1.47 & 1.00 & $\frac{04.41}{1.56}$ & $\frac{5.80}{1.56}$ & $\frac{36.51}{1.56}$ & $\frac{35.85}{158}$ \\
\hline $\mathrm{Al}_{2} \mathrm{O}_{3}$ & 12.94 & 14.04 & 14.36 & 14.40 & 14.27 & 14.31 & 15.02 & 15.15 & 15.24 & 15.21 & 15.37 & 15.31 & 15.44 & 15.38 & 15.26 & $\begin{array}{r}1.50 \\
15.44\end{array}$ & $\frac{1.58}{15.18}$ \\
\hline $\mathrm{Cr}_{2} \mathrm{O}_{3}$ & 0.00 & 0.00 & 0.00 & 0.00 & 0.00 & 0.00 & 0.00 & $0 . \infty$ & 0.00 & 0.00 & 0.00 & 0.00 & 0.00 & 0.00 & 0.00 & $0 . \infty$ & 0.00 \\
\hline $\mathrm{ZnO}$ & n.a. & n.a. & n.a. & ก.a. & n.a. & n.a. & n.a. & n.a. & n.a. & n.a. & n.a. & ก.a. & ก.a. & n.a. & n.a. & n.a. & n.a. \\
\hline FeO & 19.46 & 16.81 & 16.75 & 16.38 & 16.5 & 16.30 & 17.94 & 18.83 & 18.39 & 18.34 & 18.93 & 17.20 & 17.43 & 19.58 & 18.27 & 17.86 & 17.54 \\
\hline $\mathrm{MnO}$ & 0.00 & 0.00 & 0.00 & 0.26 & 0.00 & 0.00 & 0.0 & 0.18 & 0.00 & 0.00 & 0.17 & 0.00 & 0.00 & 0.00 & 0.14 & 0.00 & 0.00 \\
\hline $\mathrm{MgO}$ & 12.55 & 13.56 & 13.38 & 13.72 & 13.50 & 13.50 & 11.79 & 11.91 & 12.17 & 12.07 & 12.19 & 13.04 & 12.79 & 13.32 & 12.89 & 12.88 & 12.91 \\
\hline $\mathrm{NiO}$ & 0.00 & 0.00 & 0.00 & $0 . \infty$ & 0.00 & 0.00 & 0.00 & 0.00 & 0.00 & 0.00 & 0.00 & 0.00 & 0.00 & 0.00 & 0.0 & 0.00 & 0.00 \\
\hline $\mathrm{CaO}$ & 0.00 & 0.00 & 0.0 & 0.10 & 0.00 & 0.00 & $0 . \infty$ & 0.15 & 0.00 & 0.00 & 0.0 & 0.00 & 0.00 & $0 . \infty$ & $0 . \infty$ & 0.00 & 0.00 \\
\hline $\mathrm{Na}_{2} \mathrm{O}$ & 0.44 & 0.29 & 0.31 & 0.25 & 0.26 & 0.37 & 0.25 & 0.39 & 0.29 & 0.28 & 0.21 & 0.34 & 0.39 & 0.36 & 0.35 & 0.41 & 0.33 \\
\hline $\mathrm{K}_{2} \mathrm{O}$ & 8.50 & 9.31 & 9.61 & 9.58 & 9.49 & 9.39 & 7.58 & 7.27 & 7.93 & 7.81 & 7.90 & 8.21 & 8.17 & 6.54 & 8.36 & 7.83 & 8.21 \\
\hline $\mathrm{BaO}$ & n.a. & n.a. & n.a. & n.a. & n.a. & n.a. & n.a. & n.a. & n.a. & n.a. & ก.a. & n.a. & n.a. & n.a. & n.a. & n.a. & n.a. \\
\hline$F$ & n.a. & n.a. & n.a. & n.a. & n.a. & n.a. & n.a. & n.a. & n.a. & n.a. & n.a. & n.a. & n..8. & n.a. & n.a. & n.a. & n.a. \\
\hline Cl & $0 . \infty$ & 0.00 & 0.00 & 0.00 & 0.00 & 0.00 & 0.12 & 0.12 & 0.11 & 0.10 & 0.08 & 0.00 & 0.06 & 0.12 & 0.13 & 0.10 & 0.08 \\
\hline $\mathrm{H}_{2} \mathrm{O}$ & 1.81 & 1.83 & 1.84 & 1.85 & 1.83 & 1.82 & 1.77 & 1.77 & 1.80 & 1.80 & 1.84 & 1.81 & 1.83 & 1.78 & 1.81 & 1.83 & 1.81 \\
\hline Total & 93.32 & 93.52 & 94.19 & 94.49 & 93.62 & 93.10 & 91.91 & 92.63 & 93.67 & 93.21 & 95.11 & 93.57 & 93.88 & 92.85 & 94.64 & 94.41 & 93.49 \\
\hline $\mathrm{Si}$ & 5.85 & 6.00 & 5.99 & 6.00 & 5.96 & 5.99 & 5.90 & 5.81 & 5.87 & 5.89 & 5.88 & 5.89 & 5.89 & 5.67 & 5.84 & 5.91 & 5.87 \\
\hline $\mathrm{Al}^{\mathrm{N}}$ & 2.15 & 2.00 & 2.01 & 2.00 & 2.02 & 2.04 & 2.10 & 2.19 & 2.13 & 2.11 & 2.12 & 2.11 & 2.11 & 2.33 & 2.16 & 2.09 & 2.13 \\
\hline $\mathrm{Al}^{\mathrm{k}}$ & 0.27 & 0.71 & 0.75 & 0.75 & 0.74 & 0.76 & 0.84 & 0.77 & 0.81 & 0.84 & 0.80 & 0.84 & 0.85 & 0.68 & 0.76 & 0.85 & 0.80 \\
\hline $\mathrm{Ti}$ & 0.10 & 0.14 & 0.15 & 0.12 & 0.15 & 0.13 & 0.26 & 0.24 & 0.24 & 0.22 & 0.25 & 0.18 & 0.20 & 0.20 & 0.19 & 0.19 & 0.20 \\
\hline $\mathrm{Fe}^{+2}$ & 2.59 & 231 & 2.28 & 2.22 & 2.27 & 2.24 & 2.50 & 2.62 & 2.52 & 2.52 & 2.56 & 2.35 & 2.37 & 2.72 & 2.49 & 2.42 & 2.40 \\
\hline $\mathrm{Cr}$ & 0.00 & 0.00 & 0.00 & 0.00 & 0.00 & 0.00 & 0.00 & 0.00 & 0.0 & 0.00 & 0.00 & 0.00 & 0.00 & 0.00 & 0.00 & 0.00 & 0.00 \\
\hline $2 n$ & $-\quad$ & $-\quad$ & - & - & - & $=1$ & - & - & $-\quad$ & - & - & $\div$ & - & $-\quad$ & -4 & - & - \\
\hline $\mathrm{Mn}$ & 0.00 & 0.00 & 0.00 & 0.04 & 0.00 & 0.00 & 0.0 & 0.03 & 0.00 & 0.00 & 0.02 & 0.00 & 0.00 & 0.00 & 0.02 & 0.0 & 0.00 \\
\hline $\mathrm{Mg}$ & 2.98 & 3.32 & 3.25 & 3.32 & 3.30 & 3.31 & 2.93 & 2.95 & 2.97 & 2.96 & 2.94 & 3.17 & 3.10 & 3.20 & 3.13 & 3.11 & 3.15 \\
\hline $\mathrm{Ni}$ & 0.0 & 0.00 & 0.00 & 0.00 & 0.00 & 0.00 & $0 . \infty$ & 0.00 & 0.00 & 0.00 & 0.00 & 0.00 & $0 . \infty$ & 0.00 & 0.00 & $0 . \infty$ & 0.00 \\
\hline $\mathrm{Ca}$ & 0.00 & 0.00 & 0.00 & 0.02 & 0.00 & 0.00 & 0.00 & 0.03 & 0.00 & 0.0 & 0.00 & 0.00 & 0.00 & $0 . \infty$ & 0.00 & 0.00 & 0.00 \\
\hline $\mathrm{Na}$ & 0.14 & 0.09 & 0.10 & 0.08 & 0.08 & 0.12 & 0.08 & 0.13 & 0.00 & $0 . \infty$ & 0.07 & 0.11 & 0.12 & 0.12 & 0.11 & 0.13 & 0.11 \\
\hline$K$ & 1.73 & 1.95 & 2.00 & 1.98 & 1.96 & 1.97 & 1.61 & 1.54 & 1.66 & 1.64 & $1 . \mathfrak{3}$ & 1.71 & 1.70 & 1.38 & 1.74 & 1.62 & 1.72 \\
\hline $\mathrm{Ba}$ & - & - & - & - & - & - & - & - & $-\quad$ & - & - & - & -7 & - & - & - & - \\
\hline Cátions & 15.80 & 16.52 & 16.53 & 16.53 & 16.52 & 16.54 & 16.22 & 16.30 & 16.29 & 16.27 & 16.26 & 16.36 & 16.34 & 16.38 & 16.43 & 16.30 & 16.37 \\
\hline 桂Fe $\mathrm{Fe}^{+2}$ & 0.47 & 0.41 & 0.41 & 0.40 & 0.41 & 0.40 & 0.46 & 0.47 & 0.46 & 0.46 & 0.47 & 0.43 & 0.43 & 0.45 & 0.44 & 0.44 & 0.43 \\
\hline
\end{tabular}

Tabela A4.1.3: Dados analiticos de biotitas de antibolitos metabásicos AB, ABET e ABG. Fórmula estrutural: 24(O). 
Tabela A4.1: Biotitas/Flogopitas - BT/FLO.

\begin{tabular}{|c|c|c|c|c|c|c|}
\hline Amostras & 101 & $1-01$ & 101 & $1-04$ & 1.01 & $1-01$ \\
\hline Análises & $1014 \mathrm{BO} 2$ & $10 / 4 \mathrm{~B} 03$ & $10 / 4804$ & 10/4BO5 & $10 / 4 \mathrm{~B} 06$ & 10/4BO7 \\
\hline Mineral & $\mathrm{BT}$ & BT & BT & BT & BT & BT \\
\hline Local & $\mathrm{C}$ & $\mathrm{C}$ & $B$ & $\mathrm{C}$ & $\mathrm{B}$ & PI \\
\hline Litotipo & $\overline{A B G}$ & ABG & $A B G$ & ABG & ABG & $\overline{A B G}$ \\
\hline $\mathrm{SiO}_{2}$ & 36.38 & $36 . \Subset$ & 34.70 & 34.18 & 36.16 & 36.57 \\
\hline $\mathrm{THO}_{2}$ & 1.54 & 1.64 & 1.50 & 1.47 & 1.34 & 1.66 \\
\hline $\mathrm{Al}_{2} \mathrm{O}_{3}$ & 15.38 & 15.38 & 15.33 & 15.43 & 15.59 & 15.48 \\
\hline $\mathrm{Cr}_{2} \mathrm{O}_{3}$ & 0.00 & 0.00 & 0.00 & 0.00 & 0.00 & 0.00 \\
\hline $\mathrm{Zno}$ & ก.a. & n.a. & n.a. & n.a. & n.a. & n.a. \\
\hline Feo & 17.46 & 16.88 & 18.59 & 18.42 & 17.42 & 17.15 \\
\hline $\mathrm{MnO}$ & 0.00 & 0.00 & 0.00 & 0.00 & $0 . \infty$ & 0.00 \\
\hline $\mathrm{MgO}$ & 12.91 & 13.21 & 13.54 & 13.49 & 13.12 & 12.91 \\
\hline $\mathrm{NiO}$ & 0.0 & 0.00 & $0 . \infty$ & 0.00 & $0 . \infty$ & 0.00 \\
\hline $\mathrm{CaO}$ & 0.00 & 0.00 & 0.00 & 0.00 & 0.00 & 0.00 \\
\hline $\mathrm{Na}_{2} \mathrm{O}$ & 0.33 & 0.31 & 0.30 & 0.27 & 0.32 & 0.38 \\
\hline $\mathrm{K}_{2} \mathrm{O}$ & 8.38 & 8.48 & 6.77 & 6.34 & 8.03 & 8.53 \\
\hline $\mathrm{BaO}$ & n.a. & n.a. & n.a. & n.a. & n.a. & n.a. \\
\hline$F$ & n.a. & ก.a. & ก.a. & n.a. & n.a. & n.a. \\
\hline $\mathrm{Cl}$ & 0.12 & 0.13 & 0.08 & 0.11 & 0.07 & 0.12 \\
\hline $\mathrm{H}_{2} \mathrm{O}$ & 1.82 & 1.82 & 1.79 & 1.77 & 1.83 & 1.83 \\
\hline Total & 94.32 & 94.48 & 92.60 & 91.48 & 93.88 & 94.63 \\
\hline $\mathrm{Si}$ & 5.90 & 5.92 & 5.74 & 5.71 & 5.88 & 5.91 \\
\hline$A \mathrm{~N}^{\mathrm{N}}$ & 2.10 & 2.00 & 2.26 & 2.29 & 2.12 & 2.09 \\
\hline$A I^{n}$ & 0.84 & 0.84 & 0.72 & 0.75 & 0.86 & 0.85 \\
\hline $\mathrm{Ti}$ & 0.19 & 0.20 & 0.19 & 0.19 & 0.16 & 0.20 \\
\hline $\mathrm{Fe}^{+2}$ & 2.37 & 2.28 & 2.57 & 2.57 & 2.37 & 2.32 \\
\hline $\mathrm{Cr}_{\mathrm{r}}$ & 0.00 & 0.00 & 0.00 & 0.00 & 0.00 & 0.00 \\
\hline $\mathrm{Zn}$ & $-\quad$ & $-\quad$ & - & $-\quad$ & $-\quad$ & - \\
\hline$M n$ & 0.00 & 0.00 & 0.00 & 0.00 & 0.00 & 0.00 \\
\hline $\mathrm{Mg}$ & 3.12 & 3.18 & 3.34 & 3.36 & 3.18 & 3.11 \\
\hline $\mathrm{Ni}$ & $0 . \infty$ & 0.00 & 0.00 & 0.0 & 0.00 & 0.00 \\
\hline $\mathrm{Ca}$ & 0.00 & 0.00 & 0.00 & 0.00 & 0.00 & 0.00 \\
\hline $\mathrm{Na}$ & 0.10 & 0.10 & 0.10 & 0.0 & 0.10 & 0.12 \\
\hline $\mathrm{K}$ & 1.73 & 1.75 & 1.43 & 1.35 & 1.67 & 1.76 \\
\hline $\mathrm{Ba}$ & - & & - & - & $-\quad 1$ & - \\
\hline Cátions & 16.36 & 16.34 & 16.34 & 16.30 & 16.34 & 16.35 \\
\hline$\# \mathrm{Fe}^{+2}$ & 0.43 & 0.42 & 0.44 & 0.43 & 0.43 & 0.43 \\
\hline
\end{tabular}

Tabela A4.1.3: Dados analíticos de biotitas de anfibolitos metabásicos $A B, A B E T$ e $A B G$. Fórmula estrutural: 24(O). 
Tabela A4.1: Biotitas/Flogopitas - BT/FLO.

\begin{tabular}{|c|c|c|c|c|c|c|c|c|c|c|c|c|c|c|c|c|c|c|}
\hline Amostras & $\mathrm{AP}-2$ & $\mathrm{AP}-2$ & $\mathrm{AP} 3$ & AP-3 & AP 3 & AP-3 & $\mathrm{AP} 3$ & AP3 & G-52c & G.52c & G-52c & 6520 & G.52c & G52c & G-85a & G-85a & G-85a & $\frac{G-85 a}{1 / 2120}$ \\
\hline Análises & $3 / 1 / 18$ & $3 / 4 / 19$ & $1 / 1 / 43$ & $1 / 1 / 44$ & $4 / 457$ & $1 / 250$ & $1 / 251$ & $21 / 1$ & $2 / 1 / 29$ & $2 / 1 / 30$ & $2 / 2 / 35$ & $2 / 238$ & Q/1/8 & 6/19 & $1 / 1 / 6$ & $1 / 1 / 7$ & $1 / 1 / 8$ & $1 / 2 / 20$ \\
\hline Mineral & $\mathrm{BT}$ & $\mathrm{BT}$ & BT & BT & $\mathrm{BT}$ & BT & BT & BT & $\mathrm{BT}$ & BT & BT & BT & $\mathrm{BT}$ & BT & BT & BT & BT & BT \\
\hline Local & $\mathrm{B}$ & C & 8 & C & $\mathrm{C}$ & $B$ & C & $B$ & C & B & $\mathrm{B}$ & B & B & C & B & C & C & $\mathrm{B}$ \\
\hline Litotipo & MP & MP & $\mathrm{MP}$ & MP & MP & MP & MP & $\mathrm{MP}$ & MP & MP & MP & MP & MP & MP & MP & MP & MP & $\mathrm{MP}$ \\
\hline $\mathrm{SiO}_{3}$ & 38,07 & 38,67 & 37,73 & 37.98 & 37,87 & 37,15 & 37,37 & 37,97 & 26,36 & 25,78 & 38,27 & 38,91 & 39,18 & 38,19 & 39,23 & 39,49 & 39,69 & 39,08 \\
\hline $\mathrm{TIO}_{2}$ & 1,31 & 1,32 & 159 & 1,55 & 1,50 & 1,42 & 1,39 & 1,32 & 0,01 & 0,02 & 0,59 & 0,53 & 0,68 & 0,91 & 0,85 & 0,94 & 1,20 & 0,89 \\
\hline $\mathrm{Al}_{2} \mathrm{O}_{3}$ & 17,77 & 18,05 & 18,09 & 17,53 & 17,85 & 18,18 & 17,34 & 17,96 & 22,31 & 22,00 & 14.58 & 14,78 & 15,87 & 16,02 & 16,38 & 16,59 & 16,92 & 16,40 \\
\hline $\mathrm{Cr}_{2} \mathrm{O}_{3}$ & 0,00 & 0,00 & 0,01 & 0,00 & $0, \infty$ & 0,00 & $0, \infty$ & 0,01 & 0,02 & 0,09 & 0,02 & 0,08 & 0,05 & 0,07 & 0,02 & 0,01 & $0, \infty$ & 0,01 \\
\hline $\mathrm{ZnO}$ & $0, \infty$ & 0,00 & 0,04 & $0, \infty$ & $0, \infty$ & 0,02 & 0,00 & 0,00 & 0,08 & 0,02 & 0,0 & 0,0 & n.a. & n.a. & 0,02 & 0,07 & $0, \infty$ & $0, \infty$ \\
\hline $\mathrm{FeO}$ & 14,11 & 14,39 & 14,70 & 14,92 & 15,03 & 14,84 & 14,88 & 15,07 & 19,79 & 18,93 & 10,97 & 10,59 & 11,86 & 12,66 & 12,31 & 12,39 & 12,41 & 11,88 \\
\hline $\mathrm{MnO}$ & 0,01 & 0,04 & 0,04 & 0,04 & 0,06 & 0,08 & 0,01 & $0, \infty$ & $0, \infty$ & 0,03 & 0,01 & 0,00 & $0, \infty$ & 0,02 & 0,05 & 0,01 & 0,03 & $0, \infty$ \\
\hline $\mathrm{MgO}$ & 16,39 & 16,14 & 15,44 & 15,61 & 15,51 & 15,83 & 15,43 & 15,40 & 19,63 & 20,24 & 18,21 & 19,33 & 18,34 & 18,71 & 17,93 & 17,86 & 17,56 & 17,92 \\
\hline NiO & $0, \infty$ & $0, \infty$ & $0, \infty$ & 0,01 & 0,00 & 0,00 & 0,00 & 0,00 & 0,00 & 0,01 & $0, \infty$ & $0, \infty$ & n.a. & n.a. & 0,01 & $0, \infty$ & 0,02 & $0, \infty$ \\
\hline $\mathrm{CaO}$ & $0, \infty$ & $0, \infty$ & $0, \infty$ & $0, \infty$ & $0, \infty$ & $0, \infty$ & 0,01 & $0, \infty$ & 0,04 & 0,05 & $0, \infty$ & $0, \infty$ & 0,02 & 0,00 & $0, \infty$ & $0, \infty$ & $0, \infty$ & 0,00 \\
\hline $\mathrm{Na}_{2} \mathrm{O}$ & 0,74 & 0,66 & 0,60 & 0,66 & 0,68 & 0,60 & 0,72 & 0,65 & 0,06 & 0,06 & 0,11 & 0,10 & 0,12 & 0,12 & 0,82 & 0,86 & 0,94 & 0,85 \\
\hline $\mathrm{K}_{2} \mathrm{O}$ & 8,07 & 7,91 & 8,41 & 8,32 & 8,10 & 7,62 & 8,07 & 8,05 & 0,08 & 0,02 & 8,97 & 877 & 9,01 & 8,20 & 7,66 & 7,75 & 7.71 & 7,91 \\
\hline $\mathrm{BaO}$ & n.a. & n.a. & n.a. & n.a. & n.a. & n.a. & n.a. & n.a. & n.a. & n.a. & n.a. & n.a. & 0,22 & 0,12 & n.a. & n.a. & n.a. & ก.a. \\
\hline$F$ & n.a. & n.a. & n.a. & n.a. & n.a. & n.a. & n.a. & ก.a. & n.a. & n.a. & n.a. & n.a. & 1,75 & 1,53 & n.a. & n.a. & n.a. & n.a. \\
\hline $\mathrm{Cl}$ & n.a. & n.a. & n.a. & n.a. & n.a. & n.a. & ח.a. & n.a. & n.a. & n.a. & n.a. & n.a. & n.a. & n.a. & n.a. & n.a. & n.a. & n.a. \\
\hline $\mathrm{H}_{2} \mathrm{O}$ & 4,13 & 4,17 & 4,12 & 4,12 & 4,12 & $4, \infty$ & 4,06 & 4,12 & 3,77 & 3,73 & 3,96 & 4,04 & 3,28 & 3,36 & 4,13 & 4,16 & 4,18 & 4,12 \\
\hline Total & $100, \infty$ & 101,35 & 100,77 & 100,74 & 100,75 & 99,83 & 99,28 & 100,55 & 92,15 & 90,98 & 95,69 & 97,13 & 100,38 & 99,91 & 99,41 & 100,13 & 100,66 & 99,06 \\
\hline Si & 5,52 & 5,56 & 5,49 & 5,53 & 5,51 & 5,44 & 5,53 & 5,53 & 4,20 & 4,15 & 5,79 & 5,78 & 5,72 & 5,60 & 5,70 & 5,69 & 5,69 & 5,69 \\
\hline$\left.A\right|^{\mathrm{N}}$ & 2,48 & 2,44 & 2,51 & 2,47 & 2,49 & 2,56 & 2,48 & 2,47 & 3,81 & 3,85 & 2,21 & 2,22 & 2,28 & 2,40 & 2,30 & 2,31 & 2,31 & 2,31 \\
\hline$A \|^{n}$ & 0,56 & 0,61 & 0,59 & 0,54 & 0,57 & 0,58 & 0,54 & 0,61 & 0,38 & 0,31 & 0,39 & 0,36 & 0,45 & 0,37 & 0,50 & 0,51 & 0,54 & 0,51 \\
\hline Ti & 0,14 & 0,14 & 0,17 & 0,17 & 0,16 & 0,16 & 0,16 & 0,15 & 0,00 & $0, \infty$ & 0,07 & 0,06 & 0,08 & 0,10 & 0,09 & 0,10 & 0,13 & 0,10 \\
\hline $\mathrm{Fe}^{+2}$ & 1,71 & 1,73 & 1,79 & 1,82 & 1,83 & 1,82 & 1,84 & 1,84 & $2, \pi$ & 2.55 & 1,39 & 1,32 & 1.45 & 1,55 & 1,50 & 1,49 & 1,49 & 1,45 \\
\hline $\mathrm{Cr}$ & $0, \infty$ & $0, \infty$ & $0, \infty$ & 0,00 & $0, \infty$ & $0, \infty$ & $0, \infty$ & $0, \infty$ & 0,0 & 0,01 & 0,00 & 0,01 & 0,01 & 0,01 & 0,00 & $0, \infty$ & $0, \infty$ & $0, \infty$ \\
\hline $\mathrm{Zn}$ & $0, \infty$ & $0, \infty$ & $0, \infty$ & $0, \infty$ & $0, \infty$ & $0, \infty$ & $0, \infty$ & $0, \infty$ & 0,01 & 0,00 & 0,00 & $0, \infty$ & & - & 0,00 & 0,01 & $0, \infty$ & 0,00 \\
\hline $\mathrm{Mn}$ & $0, \infty$ & 0,01 & 0,01 & 0,01 & 0,01 & 0,01 & 0,00 & 0,00 & 0,00 & $0, \infty$ & $0, \infty$ & 0,0 & $0, \infty$ & 0,00 & 0,01 & $0, \infty$ & 0,00 & 0,00 \\
\hline$\overline{\mathrm{Mg}}$ & 3,5 & 3,46 & 3,35 & 3,39 & 3,37 & 3,46 & 3,40 & 3,34 & 4,66 & 4,85 & 4,11 & 4,28 & 3,99 & 4,09 & 3,88 & 3,84 & 3,75 & 3,89 \\
\hline $\mathrm{Ni}$ & $0, \infty$ & $0, \infty$ & $0, \infty$ & $0, \infty$ & $0, \infty$ & $0, \infty$ & $0, \infty$ & $0, \infty$ & 0,0 & 0,00 & $0, \infty$ & 0,00 & & - & $0, \infty$ & 0,00 & $0, \infty$ & $0, \infty$ \\
\hline $\mathrm{Ca}$ & $0, \infty$ & $0, \infty$ & 0,00 & $0, \infty$ & $0, \infty$ & $0, \infty$ & $0, \infty$ & 0,00 & 0,01 & 0,01 & $0, \infty$ & $0, \infty$ & 0,00 & 0,0 & $0, \infty$ & $0, \infty$ & $0, \infty$ & $0, \infty$ \\
\hline $\mathrm{Na}$ & 0,21 & 0,18 & 0,17 & 0,19 & 0,19 & 0,17 & 0,21 & 0.18 & 0,02 & 0,02 & 0,03 & 0,03 & 0,03 & 0,03 & 0,23 & 0,24 & 0,26 & 0,24 \\
\hline $\mathrm{K}$ & 1,49 & 1,45 & 1,56 & 1,5 & 1,50 & 1,43 & 1,52 & 1,50 & 0,02 & 0,00 & 1,73 & 1,66 & 1,68 & 1,53 & 1,42 & 1,43 & 1,41 & 1,47 \\
\hline $\mathrm{Ba}$ & & & & & & & & & & & & & 0,01 & 0,01 & - & & & \\
\hline Cátions & 15,66 & 15,58 & 15,64 & 15,66 & 15,63 & 15,62 & 15,67 & 15,62 & 15,72 & 15,76 & 15,72 & 15,71 & 15,69 & 15,69 & 15,63 & 15,62 & 15,58 & 15,65 \\
\hline $\mathrm{Mg}$ & 0,67 & 0,67 & $0, \mathbb{E}$ & $0, \Phi$ & 0,65 & 0,60 & 0,65 & $0, \mathbb{E}$ & 0,64 & 0,66 & 0.75 & 0,76 & 0,73 & 0,72 & 0,72 & 0,72 & 0,72 & 0,73 \\
\hline
\end{tabular}

Tabela 4.1.4: Dados analiticos de biotitas de MP e MG. Fórmula estrutural: 24(O).

Nota: As análises 2/1/29 e 2/1/30 (G-52c) são de biotita alterando para clorita. 
Tabela A4.1: Biotitas/Flogopitas - BT/FLO.

\begin{tabular}{|c|c|c|c|c|c|c|c|c|c|c|c|c|c|c|c|c|c|c|}
\hline $\begin{array}{l}\text { Amostras } \\
\text { Análises }\end{array}$ & $\frac{G-85 a}{1 / 2 / 21}$ & $\frac{G-85 a}{1 / 2 / 22}$ & $\frac{G-85 a}{3 / 373}$ & $\frac{G-85 a}{3 / 3 / 74}$ & $\frac{G-85 a}{5 / 2 / 24}$ & $\frac{G-85 a}{5 / 2 / 25}$ & $\frac{G-89}{2 / 1 / 61}$ & $\frac{G-89}{2 / 1 / 62}$ & $\frac{G-89}{2 / 2 / 68}$ & $\frac{G-69}{2 / 2 / 69}$ & $\frac{286 \mathrm{~A}}{1251}$ & $\begin{array}{l}286 \mathrm{~A} \\
1252\end{array}$ & $\frac{286 \mathrm{~A}}{1253}$ & $\frac{286 C}{3310}$ & $\frac{286 C}{3312}$ & $\frac{286 C}{3315}$ & $\frac{286 L}{1221}$ & $\frac{286 L}{1226}$ \\
\hline Mineral & BT & BT & $\mathrm{BT}$ & BT & BT & BT & BT & BT & BT & BT & BT & $\mathrm{BT}$ & $B T$ & BT & BT & BT & BT & BT \\
\hline Local & C & $c$ & B & $c$ & B & C & $\mathrm{C}$ & B & $B$ & C & Media4 & Media4 & Media4 & Media4 & Media4 & Media4 & Media4 & Media4 \\
\hline Litotipo & $M P$ & MP & MP & MP & MP & MP & MP & MP & $\mathrm{MP}$ & MP & $\mathrm{MP}$ & $\mathrm{MP}$ & $\mathrm{MP}$ & MP & MP & MP & MP & $\mathrm{MP}$ \\
\hline $\mathrm{SiO}_{2}$ & $\mathbf{3 9 , 6 0}$ & 39,61 & 40,35 & 38,90 & 39,09 & 39,09 & 36,39 & 36,62 & 36,51 & 37,20 & 40,29 & 39,77 & 39,47 & 39,11 & 40,09 & 40,21 & 39,71 & 39,17 \\
\hline $\mathrm{TiO}_{2}$ & 0,89 & 0,90 & 0,50 & 1,04 & 0,99 & 0,87 & 1,49 & 1,27 & 1,37 & 1,32 & 1,36 & 1,03 & 1,17 & 1,71 & 1,68 & 1,46 & 1,09 & 1.46 \\
\hline $\mathrm{Al}_{2} \mathrm{O}_{3}$ & 16,67 & 16,74 & 2135 & 16,63 & 16,46 & 16,69 & 18,13 & 18,29 & 18,21 & 18,20 & 17,08 & 17,51 & 17,42 & 17,58 & 16,59 & 16,98 & 17,27 & 17,36 \\
\hline $\mathrm{Cr}_{2} \mathrm{O}_{3}$ & 0,00 & 0,01 & 0,00 & 0,01 & 0,01 & 0,03 & 0,08 & 0,00 & 0,00 & 0,00 & n.a. & n.a. & n.a. & n.a. & n.a. & n.a. & n.a. & n.a. \\
\hline $\mathrm{ZnO}$ & $0, \infty$ & $0, \infty$ & 0,05 & 0,00 & n.a. & n.a. & 0,08 & 0,10 & 0,13 & 0,00 & n.a. & n.a. & n.a. & n.a. & n.a. & ก.a. & n.a. & ก.a. \\
\hline $\mathrm{FeO}$ & 11,75 & 11,85 & 10,88 & 12,20 & 12,14 & 11,61 & 17,81 & 17,83 & 18,38 & 18,81 & 7,81 & 8,05 & 8,10 & 8,24 & 8,64 & 8,43 & 8,06 & 8,32 \\
\hline Mno & $0, \infty$ & 0,03 & 0,00 & 0,00 & $0, \infty$ & 0,00 & 0,00 & 0,01 & 0,01 & 0,01 & 0,02 & 0,04 & 0.02 & 0,04 & 0,06 & $0, \infty$ & $0, \infty$ & 0,08 \\
\hline $\mathrm{MgO}$ & 17,87 & 18,22 & 12,37 & 17,77 & 1782 & 18,21 & 13,59 & 13,70 & 12,77 & 12,44 & 18,45 & $18, \sqrt[5]{5}$ & 18.51 & 18,06 & 17,51 & 17,68 & 18,42 & 18,17 \\
\hline $\mathrm{NiO}$ & 0,01 & $0, \infty$ & 0,00 & 0,00 & n.a. & n.a. & 0,00 & 0,01 & 0,01 & 0,00 & n.a. & n.a. & n.a. & n.a. & n.a. & n.a. & n.a. & ก.a. \\
\hline $\mathrm{CaO}$ & 0,01 & $0, \infty$ & 0,04 & 0,01 & 0.01 & $0, \infty$ & $0, \infty$ & $0, \infty$ & 0,06 & 0,05 & 0,25 & 0,20 & 0,45 & 0,31 & 0,32 & 0,41 & 0,00 & 0,28 \\
\hline $\mathrm{Na}_{2} \mathrm{O}$ & 0,83 & 0,80 & 0,45 & 0,90 & 0.94 & 0,86 & 0,43 & 0,43 & 0,38 & 0,46 & $0, \infty$ & 0,31 & $0, \infty$ & 0.61 & 0,48 & 0,52 & 0.46 & 0,51 \\
\hline $\mathrm{K}_{2} \mathrm{O}$ & 7,79 & 7,85 & 6,42 & 7,75 & 7.78 & 7,63 & 8,76 & 8,49 & 8,62 & 8,59 & 8,96 & 9,00 & 9,02 & 9,24 & 9,14 & 8,64 & 9,24 & 8,97 \\
\hline $\mathrm{BaO}$ & n.a. & n.a. & n.a. & n.a. & 0,14 & 0,15 & n.a. & ก.a. & n.a. & n.a. & n.a. & n.a. & n.a. & n.a. & n.a. & n.a. & n.a. & n.a. \\
\hline$F$ & n.a. & n.a. & ก.a. & ก.a. & 0,83 & 0,82 & n.a. & n.a. & n.a. & n.a. & 0,24 & 0,40 & 0,36 & 0,56 & 0,39 & 0,46 & 0,64 & 0,47 \\
\hline $\mathrm{Cl}$ & n.a. & n.a. & n.a. & n.a. & n.a. & n.a. & n.a. & $\begin{array}{l}\text { n.a. } \\
\end{array}$ & n.a. & n.a. & n.a. & n.a. & ก.a. & n.a. & n.a. & n.a. & n.a. & n.a. \\
\hline $\mathrm{H}_{2} \mathrm{O}$ & 4,15 & 4,17 & 4,13 & 4,12 & 3,73 & 3,74 & 4,04 & 4,05 & 4,03 & 4,06 & 4,05 & 3,97 & 3,97 & 3,89 & 3,96 & 3,94 & 3,84 & 3,92 \\
\hline Total & 99,65 & 100,18 & 96,54 & 99,33 & 99,94 & 99,70 & 100,80 & 100,80 & 100,48 & 101,14 & 96,51 & 98,93 & 98,19 & 99,35 & 96,86 & 98,81 & 98,78 & 98,71 \\
\hline Si & 5,72 & $5, \infty$ & 5,87 & 5,66 & 5,68 & 5,67 & 5,40 & 5,42 & 5,44 & 5,50 & 5,80 & 5,73 & 5,72 & 5,64 & 5,80 & 5,80 & 5,74 & 5,67 \\
\hline$\overline{A \mathbb{I}^{\mathrm{V}}}$ & 2,28 & 2,31 & 2,14 & 2,34 & 2,32 & 2,33 & 2,61 & 2,58 & 2,56 & 2,50 & 2,20 & 2,27 & 2.28 & 2,36 & 2,20 & 2,20 & 2,26 & 2,33 \\
\hline$\left.A\right|^{n}$ & 0,55 & 0,53 & 1,52 & 0,50 & 0,50 & 0,52 & 0,56 & 0,60 & 0,63 & 0,67 & 0,69 & 0,70 & 0,69 & 0,63 & $0, \sqrt{3}$ & 0,68 & 0,68 & 0,64 \\
\hline $\mathrm{Ti}$ & 0,10 & 0,10 & 0,06 & 0,11 & 0,11 & 0,10 & 0,17 & 0,14 & 0.15 & 0,15 & 0,15 & 0,11 & 0,13 & 0,19 & 0,18 & 0,16 & 0,12 & 0,16 \\
\hline $\mathrm{Fe}^{+2}$ & 1,42 & 1,42 & 1,32 & 1,48 & 1,48 & 1,41 & 2,21 & 2,21 & 2,29 & 2,33 & 0,94 & 0,97 & 0,98 & 0,99 & 1,05 & 1,02 & 0,97 & 1,01 \\
\hline $\mathrm{Cr}$ & $0, \infty$ & $0, \infty$ & 0,00 & 0,00 & 0,00 & 0,00 & 0,01 & 0,00 & 0,00 & 0,00 & -1 &.- & - & - & - & $-\quad$ & $=$ & - \\
\hline $\mathrm{Zn}$ & 0,01 & $0, \infty$ & 0,01 & $0, \infty$ & & & 0,01 & 0,01 & 0,01 & 0,00 & & $=$ & -1 & - & - & & & - \\
\hline$\overline{M n}$ & $0, \infty$ & 0,00 & 0,00 & 0,00 & 0,00 & 0,00 & 0,00 & 0,00 & 0,00 & 0,00 & 0,0 & 0,01 & $0, \infty$ & 0,01 & 0,01 & 0,01 & 0,01 & 0,01 \\
\hline $\mathrm{Mg}$ & 3,85 & 3,90 & 2,6 & 3,85 & 3,86 & 3,94 & 3,00 & 3,02 & 2,84 & 274 & 3,96 & 3,98 & $4, \infty$ & 3,88 & 3,78 & 3,80 & 3,97 & 3,92 \\
\hline $\mathrm{Ni}$ & $0, \infty$ & $0, \infty$ & 0,00 & 0,00 & $-\quad \mid$ & $-\quad$ & 0,0 & $0, \infty$ & 0,00 & 0,00 & -1 & $-\quad$ & $-\quad$ & & & & & \\
\hline $\mathrm{Ca}$ & $0, \infty$ & $0, \infty$ & 0,01 & 0,00 & $0, \infty$ & 0,0 & 0,00 & $0, \infty$ & 0,01 & 0,01 & 0,04 & 0,03 & 0,02 & 0,05 & 0,05 & 0,06 & 0,00 & 0,04 \\
\hline $\mathrm{Na}$ & 0,23 & 0,22 & 0,13 & 0,25 & 0,27 & 0,24 & 0,12 & 0,12 & 0.11 & 0,13 & $0, \infty$ & 0,09 & 0,00 & 0,17 & 0,14 & 0,15 & 0,13 & 0,14 \\
\hline $\mathrm{K}$ & 1,44 & 1,44 & 1,19 & 1,44 & 1,44 & 1,41 & 1,66 & 1,60 & 1,64 & 1,62 & 1,65 & 1,65 & 1,67 & 1,70 & $1, \infty 9$ & 1,59 & 1,70 & 1,66 \\
\hline$\overline{B a}$ & & -7 & -1 & \begin{tabular}{l|l}
- &
\end{tabular} & 0,01 & 0,01 & - & $-\quad 1$ & - & - & & - & $-\quad \mid$ & & & & & \\
\hline Cátions & 15,60 & 15,62 & 44,91 & 15,6 & 15,66 & 15,63 & 15,74 & 15,71 & 15,68 & 15,64 & 15,42 & 15,54 & 15,50 & 15,61 & 15,51 & 15,46 & 15,58 & 15,58 \\
\hline mg & 0,73 & 0,73 & 0,67 & 0.72 & 0.72 & 0.74 & 0.58 & 0.58 & 0,55 & 0.54 & 0,81 & 0.80 & 080 & 0,80 & 0,78 & 0,79 & 0,80 & 0,80 \\
\hline
\end{tabular}

Tabela 4.1.4: Dados analíticos de biotitas de MP e MG. Fórmula estrutural: 24(0).

Nota: Media 4 = média de 4 análises. 
Tabela A4.2: Anfibólios - ANF.

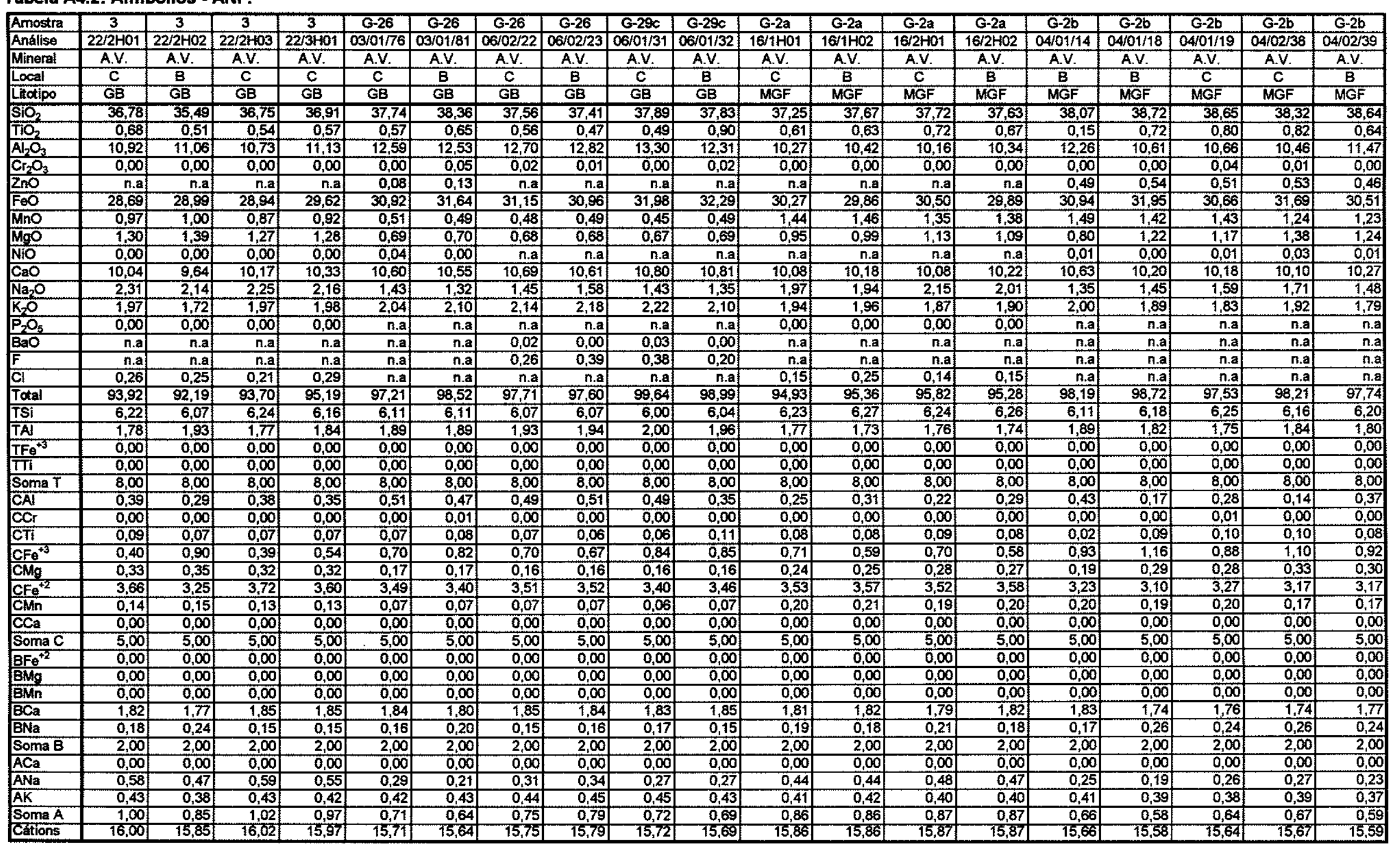

Tabela A4.2.1: Dados analiticos de anfibólios verdes (A.V.) de GB e MGF. Fórmula estrutural: 23(O). 
Tabela A4.2: Anfibólios - ANF.

\begin{tabular}{|c|c|c|c|c|c|c|c|c|c|c|c|c|c|}
\hline Arnostra & G-2b & G-2b & $\mathrm{G}-2 \mathrm{~b}$ & G-2b & $G-68$ & G-68 & G-68 & G-68 & G-68 & G-68 & $G-68$ & G-68 & G-68 \\
\hline Análise & $04 / 03 / 20$ & $04 / 03 / 21$ & $06 / 01 / 13$ & $06 / 01 / 14$ & $32 / 1 \mathrm{H} 1.1$ & $32 / 1+11.2$ & $32 / 1 \mathrm{H} 1.3$ & $32 / 1+12.1$ & $32 / 1 \mathrm{H} 2.2$ & $32 / 1 \mathrm{H} 2.3$ & $32 / 2 \mathrm{H1} .1$ & $32 / 2 \mathrm{H} 1.2$ & $32 / 2 \mathrm{H} 1.3$ \\
\hline Mineral & A.V. & A.V. & A.V. & A.V. & A.V. & A.V. & A.V. & A.V. & A.V. & A.V. & A.V. & A.V. & A.V. \\
\hline Local & $\mathrm{c}$ & B & $c$ & $\mathrm{~B}$ & B & Pin & C & $\mathrm{B}$ & Pln & $\mathrm{C}$ & $B$ & $P \ln$ & $c$ \\
\hline Litotipo & MGF & MGF & MGF & MGF & MGF & MGF & MGF & MGF & MGF & MGF & MGF & MGF & MGF \\
\hline $\mathrm{SiO}_{2}$ & 38,28 & 38.26 & 38,67 & 38,80 & 36,81 & 36,99 & 37,16 & 36,50 & 37,26 & 36,73 & 36,96 & 36,79 & 36,89 \\
\hline $\mathrm{TiO}_{2}$ & 0,98 & 0,79 & 0,8 & 0.85 & 1,30 & 0,90 & 0,90 & 0,64 & 0,77 & 0,62 & 0,50 & 0,74 & 0,69 \\
\hline $\mathrm{Al}_{2} \mathrm{O}_{3}$ & 10,65 & 10,47 & 10,66 & 11,03 & 119,21 & 11,11 & 11.22 & 10,51 & 10,89 & 10,89 & 11,80 & 11,30 & 11,03 \\
\hline $\mathrm{Cr}_{2} \mathrm{O}_{3}$ & 0,01 & 0.02 & 0,00 & 0,00 & 0,00 & 0,00 & 0,00 & 0,0 & 0,00 & $0, \infty$ & 0,00 & 0,00 & 0,00 \\
\hline $2 \mathrm{nO}$ & 0,53 & 0,53 & n.a & n.a & n.a & ก.a & n.a & n.a & n.a & n.a & n.a & n.a & ก.a \\
\hline $\mathrm{FeO}$ & $3 \%$ & 34,34 & 30,58 & 30,42 & 30,49 & 30,27 & 30,78 & 30,38 & 30,64 & 30,79 & 30,57 & 31,00 & 31,05 \\
\hline $\mathrm{MnO}$ & 1,65 & 1,54 & 1,53 & 1,54 & 0,45 & 0,44 & 0,54 & 0,50 & 0,46 & 0,44 & 0,53 & 0,54 & 0,48 \\
\hline $\mathrm{MgO}$ & 1,01 & 0,97 & 1,14 & 1,00 & 1,10 & 1,12 & 1,10 & 0,85 & 0,87 & 0,92 & 0,92 & 0,93 & 0.91 \\
\hline Nio & 0,00 & 0,00 & n.a & n.a & 0,00 & 0,00 & 0,00 & 0,00 & 0,00 & 0,00 & 0,00 & 0,00 & 0,00 \\
\hline $\mathrm{CaO}$ & 10,29 & 10,15 & 10,23 & 10,35 & 10,52 & 10,37 & 10,65 & 10,15 & 10,38 & 10,40 & 10,54 & 10,35 & 10,44 \\
\hline $\mathrm{Na}_{2} \mathrm{O}$ & 1,61 & 1,51 & 1,58 & 1,38 & 1,34 & 1,45 & 1,33 & 1,49 & 1,56 & 1,52 & 1,29 & 1,61 & 1,56 \\
\hline $\mathrm{K}_{2} \mathrm{O}$ & 1,92 & 1,85 & 3,84 & 1,91 & 1,93 & 1,96 & 1,93 & 1,98 & 2,01 & 1,94 & 1,90 & 2,03 & 1,92 \\
\hline $\mathrm{P}_{2} \mathrm{O}_{5}$ & n.a & n.a & n. & n.a & 0,00 & 0,00 & 0,00 & 0,00 & 0,00 & 0,00 & 0,00 & 0,00 & 0,00 \\
\hline $\mathrm{BaO}$ & n.a & n.a & 0,00 & 0,00 & $\begin{array}{ll}\text { n.a } \\
\end{array}$ & ก.a & n.a & n.a & n.a & n.a & n.a & n.a & n.a \\
\hline$F$ & n.a & n.a & 0,19 & 0,21 & n.a & n.a & n.a & n.a & n.a & n.a & n.a & n.a & n.a \\
\hline $\mathrm{Cl}$ & n.a & n.a & n.a & n.a & 0,00 & 0,08 & 0,11 & 0,11 & 0,09 & 0,09 & 0,09 & 0,13 & 0,09 \\
\hline Total & 98,01 & 97,43 & 97,31 & 97,49 & 95,15 & 94,69 & 95,72 & 93,11 & 94,90 & 94,34 & 95,10 & 95,42 & 95,06 \\
\hline $\mathrm{TSi}$ & 6,19 & 6,21 & 6,25 & 6,25 & 6,10 & 6,16 & 6.12 & 6,21 & 6,21 & 6,16 & 6,31 & 6,10 & 6,14 \\
\hline TAl & 1,82 & 1,80 & 1,75 & 1,75 & 1,91 & 1,84 & 1,88 & 1,79 & 1,79 & 1,84 & 1.89 & 1,90 & 1,86 \\
\hline $\mathrm{TFe}^{+3}$ & 0,00 & 0,00 & 0,00 & 0,00 & 0,00 & 0,00 & 0,00 & 0,00 & 0,00 & 0,00 & 0,00 & 0,00 & 0,00 \\
\hline TTi & 0,00 & 0,00 & 0,00 & 0,00 & 0,00 & 0,00 & 0,00 & 0,00 & 0,00 & 0,00 & 0,00 & 0,00 & 0,00 \\
\hline Soma T & 8,00 & 8,00 & 8,00 & 8,00 & 8,00 & 8,00 & 8,00 & 8,00 & 8,00 & 8,00 & 8,00 & 8,00 & 8,00 \\
\hline CA & 0,21 & 0,20 & 0,28 & 0,35 & 0,28 & 0,33 & 0,30 & 0,31 & 0,35 & 0,31 & 0,41 & 0,31 & 0,30 \\
\hline $\mathrm{CCr}$ & 0,00 & 0,00 & 0,00 & 0,00 & 0,00 & 0,00 & 0,00 & 0,00 & 0,00 & $0, \infty$ & 0,00 & 0,00 & 0,00 \\
\hline CTi & 0,12 & 0,10 & 0,11 & 0,10 & 0,16 & 0,11 & 0,11 & 0,08 & 0,10 & 0,08 & 0,06 & 0,09 & 0,09 \\
\hline $\mathrm{CFe}^{+3}$ & 0,90 & 1,01 & 0,84 & 0,80 & 0,73 & 0,70 & 0,76 & 0,70 & 0,60 & 0,73 & 0,81 & 0,79 & 0,76 \\
\hline $\mathrm{CMg}$ & 0,24 & 0,24 & 0,28 & 0,24 & 0,27 & 0,28 & 0,27 & 0,22 & 0,22 & 0,23 & 0,23 & 0,23 & 0,23 \\
\hline $\mathrm{CFe}^{+2}$ & 3,30 & 3,24 & 3,29 & 3,30 & 3,49 & 3,51 & 3,48 & 3,62 & 3,67 & 3,59 & 3,42 & 3,51 & 3,56 \\
\hline $\mathrm{CMn}$ & 0,23 & 0,21 & 0,21 & 0,21 & 0,06 & 0,06 & 0,08 & 0,07 & 0,07 & 0,06 & 0,07 & 0,08 & 0,07 \\
\hline $\mathrm{CCa}$ & 0,00 & $0, \infty$ & 0,00 & 0,00 & 0,00 & 0,00 & 0,00 & 0,00 & 0,00 & 0,00 & 0,00 & 0,00 & 0,00 \\
\hline Soma C & 5,00 & 5,00 & 5,00 & 5,00 & 5,00 & 5,00 & 5,00 & 5,00 & 5,00 & 5,00 & 5,00 & 5,00 & 5,00 \\
\hline $\mathrm{BFe}^{+2}$ & 0,00 & 0,00 & 0,00 & 0,00 & 0,00 & 0,00 & 0,00 & 0,00 & 0,00 & 0,00 & 0,00 & 0,00 & 0,00 \\
\hline $\mathrm{BMg}$ & 0,00 & 0,00 & 0,00 & 0,00 & 0,00 & 0,00 & 0,00 & 0,00 & 0,00 & $0, \infty$ & 0,00 & 0,00 & 0,00 \\
\hline BMn & 0,00 & 0,00 & 0,00 & 0,00 & 0,00 & 0,00 & 0,00 & 0,00 & 0,00 & 0,00 & 0,00 & 0,00 & 0,00 \\
\hline $\mathrm{BCa}$ & 1,78 & 1,76 & 1,77 & 1,79 & 1,87 & 1,85 & 1,88 & 1,85 & 1,86 & 1.87 & 1,87 & 1,84 & 1,86 \\
\hline $\mathrm{BNa}$ & 0,22 & 0,24 & 0,23 & 0,21 & 0,13 & 0,15 & 0,12 & 0,15 & 0,15 & 0,13 & 0,13 & 0,16 & 0,14 \\
\hline Soma B & 2,00 & 2,00 & 2,00 & 2,00 & 2,00 & 2,00 & 2,00 & 2,00 & 2,00 & 2,00 & 2,00 & 2,00 & 2,00 \\
\hline$\overline{A C a}$ & 0,00 & 0,00 & 0,00 & 0,00 & 0,00 & 0,00 & 0,00 & 0,00 & 0,00 & 0,00 & 0,00 & 0,00 & 0,00 \\
\hline $\mathrm{ANa}$ & 0,29 & 0,24 & 0,27 & 0,22 & 0,30 & 0,32 & 0,31 & 0,34 & 0,36 & 0,36 & 0,28 & 0,36 & 0,37 \\
\hline AK & 0,40 & 0,38 & 0,38 & 0,39 & 0,41 & 0,42 & 0,41 & 0,43 & 0,43 & 0,42 & 0,40 & 0,43 & 0,41 \\
\hline Soma A & 0,68 & 0,62 & $\begin{array}{ll}0,65 \\
\end{array}$ & 0,61 & 0,71 & 0,73 & 0,71 & 0,77 & 0,79 & 0,78 & 0,68 & 0,79 & 0,77 \\
\hline Cations & 15,68 & 15,62 & 15,65 & 15,61 & 75,71 & 15,73 & 15,71 & 15,77 & 15,79 & 15,78 & 15,68 & 15,79 & 15,77 \\
\hline
\end{tabular}

Tabela A4.2.1: Dados analíticos de anfibólios verdes (A.V.) de GB e MGF. Formula estrutural: 23(O). 
Tabela A4.2: Anfibólios - ANF.

\begin{tabular}{|c|c|c|c|c|c|c|c|c|c|c|c|c|c|c|c|c|c|c|c|c|}
\hline$\frac{\text { Amostra }}{\text { Análise }}$ & $\frac{1^{2}}{53 / 1401}$ & $\frac{1^{*}}{5311+10}$ & $\frac{1^{*}}{53 / 1403}$ & $1^{*}$ & $1^{*}$ & $4^{*}$ & $1^{*}$ & $1^{*}$ & B-11 & B-11 & B-11 & B-11 & B-11 & B-11 & B-11 & B-11 & B-18 & B-18 & $\mathrm{B}-18$ & $\mathrm{~B}-18$ \\
\hline Mineral & A.V. & $\frac{23 / 7 \mathrm{HU}_{2}}{\text { A.V. }}$ & 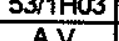 & $53 / 1 \mathrm{H} 04$ & $53 / 2 \mathrm{HO1}$ & $53 / 2 \mathrm{HO2}$ & $53 / 2 \mathrm{HO3}$ & $53 / 2 \mathrm{HO} 4$ & $2 / 4 A 01$ & $2 / 4 A O 2$ & $2 / 4 A 03$ & $2 / 5 A 01$ & $2 / 5 A 02$ & $2 / 5 A 03$ & $2 / 5 A 04$ & $2 / 5 \mathrm{~A} 05$ & $12 / 2 \mathrm{~A} 01$ & $12 / 2 \mathrm{AOO}$ & $12 / 2 \mathrm{AO}$ & $12 / 3 A 01$ \\
\hline Local & $\mathrm{C}$ & 8 & $\frac{\text { A.V. }}{B}$ & $\frac{\text { A.V. }}{\text { Pln }}$ & A.V. & A.V. & A.V. & A.V. & A.I. & A.I. & A.I. & A.I. & A.I. & A.I. & A.I. & A.I. & A.1. & A.I. & A.I. & A.I. \\
\hline Litotipo & UM & UM & UM & $\frac{\text { Pln }}{\text { UM }}$ & $\frac{B}{U M}$ & C & B & $\mathrm{c}$ & C & Pln & C & $\mathrm{C}$ & $B$ & $B(1)$ & PIn & 8 & $B(0)$ & $B(e)$ & Pln & C \\
\hline $\mathrm{SiO}_{2}$ & 45.62 & 45.75 & 45.99 & 45.72 & $\frac{u m}{45.29}$ & $\frac{U M}{4601}$ & $\frac{\text { UM }}{4527}$ & UM & UM & UM & UM & UM & UM & UM & UM & UM & UM & UM & UM & UM \\
\hline $\mathrm{TiO}_{2}$ & 0.00 & 0.00 & 0.00 & 0.00 & $\frac{N .20}{0.00}$ & $\frac{46.01}{0.00}$ & \begin{tabular}{r|}
$\frac{45.27}{0.00}$ \\
\end{tabular} & $\frac{45.20}{12}$ & 56.58 & 55.29 & 56.09 & 56.19 & 56.25 & 56.27 & 56.39 & 56.09 & 55.86 & 56.45 & 56.39 & 55.89 \\
\hline $\mathrm{Al}_{2} \mathrm{O}_{3}$ & 9.91 & 9.50 & 9.33 & 9.94 & 9.77 & $\begin{array}{l}0.00 \\
9.62\end{array}$ & $\begin{array}{l}0.00 \\
9.59\end{array}$ & 0.00 & 0.00 & 0.00 & 0.00 & 0.00 & 0.00 & 0.00 & 0.00 & 0.00 & 0.00 & 0.00 & 0.00 & 0.00 \\
\hline $\mathrm{Cr}_{2} \mathrm{O}_{3}$ & 1.78 & 1.78 & 1.67 & 1.65 & 2.06 & $\frac{7.02}{1.60}$ & $\frac{9.59}{1.88}$ & 9.84 & 0.68 & 1.38 & 0.03 & 0.60 & 0.65 & 0.46 & 0.77 & 0.65 & 0.69 & 0.84 & 0.67 & 0.74 \\
\hline $\mathrm{ZnO}$ & n.a. & n.a. & n.a. & n.a. & n.a. & n.a. & $\frac{1.68}{n . a}$ & 1.92 & 0.00 & 0.19 & 0.00 & 0.00 & 0.00 & 0.00 & 0.00 & 0.0 & 0.00 & 0.17 & 0.19 & 0.34 \\
\hline$F \in O$ & 9.91 & 10.09 & 9.95 & 10.08 & 9.92 & 9.98 & $\frac{\text { n.a. }}{10.04}$ & ก.a. & n.a. & n.a. & n.a. & n.a. & n.a. & n.a. & n.a. & n.a. & n.a. & n.a. & n.a. & n.a. \\
\hline $\mathrm{MnO}$ & 0.38 & 0.43 & 0.37 & 0.41 & 0.43 & 0.46 & $\frac{10.04}{0.44}$ & 10.16 & 13.89 & 11.85 & 14.43 & 13.17 & 13.99 & 43.39 & 13.57 & 13.97 & 14.45 & 13.97 & 14.29 & 14.10 \\
\hline $\mathrm{MgO}$ & 13.95 & 13.83 & 13.86 & 13.74 & 43.94 & 14.11 & \begin{tabular}{r|}
0.44 \\
13.88
\end{tabular} & $\begin{array}{r}0.45 \\
5\end{array}$ & 0.37 & 0.22 & 0.34 & 0.43 & 0.30 & 0.28 & 0.38 & 0.29 & 0.41 & 0.39 & 0.26 & 0.34 \\
\hline NiO & 0.00 & 0.00 & 0.00 & 0.00 & 0.00 & 0.00 & $\frac{13.88}{0.00}$ & $\frac{13.96}{000}$ & 23.84 & 21.82 & 24.17 & 25.00 & 24.39 & 24.71 & 24.61 & 24.43 & 24.06 & 24.47 & 24.27 & 24.04 \\
\hline $\mathrm{CaO}$ & 11.58 & 11.54 & 11.50 & 11.53 & 11.52 & 11.49 & 11.53 & $\begin{array}{r}0.00 \\
1161\end{array}$ & 0.00 & 0.00 & 0.00 & 0.00 & 0.00 & 0.00 & 0.00 & 0.00 & 0.00 & 0.00 & 0.00 & 0.00 \\
\hline $\mathrm{Na}_{2} \mathrm{O}$ & 1.76 & 1.65 & 1.54 & 1.73 & 1.70 & 1.76 & $|1.74|$ & $\frac{11.61}{171}$ & 0.76 & 4.91 & 0.35 & 0.45 & 0.37 & 0.49 & 0.50 & 0.44 & 0.45 & 0.48 & 0.40 & 0.45 \\
\hline$K_{2} \mathrm{O}$ & 0.46 & 0.34 & 0.32 & 0.49 & 0.39 & 0.42 & 0.38 & $\frac{1.74}{0.42}$ & 0.27 & 0.24 & 0.00 & 0.29 & 0.24 & 0.18 & 0.18 & 0.20 & 0.22 & 0.38 & 0.24 & 0.22 \\
\hline$P_{2} \mathrm{O}_{5}$ & 0.00 & 0.00 & 0.00 & 0.00 & 0.00 & 0.00 & 0.00 & $\frac{0.42}{0.00}$ & 0.00 & 0.00 & 0.00 & 0.00 & 0.00 & 0.00 & 0.00 & 0.00 & 0.00 & 0.00 & 0.00 & 0.00 \\
\hline $\mathrm{BaO}$ & n.a. & n.a. & n.a. & n.a. & n.a. & n.a. & n.a. & $\frac{0.00}{\text { n.a. }}$ & 0.00 & 0.00 & 0.00 & 0.00 & 0.00 & 0.00 & $0 . \infty$ & 0.00 & 0.00 & 0.00 & 0.00 & 0.00 \\
\hline$F$ & n.a. & ก.a. & n.a. & n.a. & ก.อ. & ก.а. & n.a. & n.a. & n.a. & n.a. & n.a. & n.a. & n.a. & n.a. & n.a. & n.a. & n.a. & n.a. & n.a. & n.a. \\
\hline $\mathrm{Cl}$ & 0.00 & 0.00 & 0.00 & 0.00 & 0.00 & 0.00 & 0.00 & $\begin{array}{l}\text { n.a. } \\
0.00\end{array}$ & n.a. & n.a. & n.a. & ก.a. & n.a. & n.a. & n.a. & n.a. & n.a. & n.a. & n.a. & n.a. \\
\hline Total & 95.35 & 94.91 & 94.53 & 95.29 & 95.02 & 95.45 & 94.55 & $\frac{0.00}{95.30}$ & 0.00 & 0.00 & 0.00 & 0.00 & 0.00 & 0.00 & 0.00 & 0.00 & 0.00 & 0.00 & 0.00 & 0.00 \\
\hline TSi & 6.81 & 6.85 & 6.90 & 6.84 & 6.78 & 6.86 & 6.81 & $\frac{90.30}{6.75}$ & 96.39 & 95.90 & 96.01 & 96.13 & 96.19 & 95.78 & 96.40 & 96.07 & 96.14 & 97.15 & 96.71 & 96.12 \\
\hline TAI & 4.19 & 1.45 & 1.10 & 1.17 & 1.22 & 1.15 & 1.19 & $\frac{6.10}{1.25}$ & 8.03 & 7.90 & 7.97 & 7.95 & 7.98 & 7.99 & 7.97 & 7.96 & 7.95 & 7.95 & 7.97 & 7.95 \\
\hline $\mathrm{TFe}^{+3}$ & 0.00 & 0.00 & 0.00 & 0.00 & 0.00 & $0 . \infty$ & 0.00 & 0.20 & 0.00 & 0.10 & 0.03 & 0.05 & 0.02 & 0.01 & 0.04 & 0.04 & 0.05 & 0.06 & 0.03 & 0.05 \\
\hline $\mathrm{TTi}$ & 0.00 & 0.00 & 0.00 & 0.00 & 0.00 & 0.00 & 0.00 & 0.00 & $\frac{0.00}{0.01}$ & 0.00 & 0.00 & 0.00 & 0.00 & 0.00 & 0.00 & 0.00 & 0.00 & 0.00 & 0.00 & 0.00 \\
\hline Soma T & 8.00 & 8.00 & 8.00 & 8.00 & 8.00 & 8.00 & 8.00 & 8.00 & $\begin{array}{l}0.00 \\
8.03\end{array}$ & 0.00 & 0.00 & 0.00 & 0.00 & 0.00 & 0.00 & 0.00 & 0.00 & 0.00 & 0.00 & 0.00 \\
\hline $\mathrm{CAl}$ & 0.55 & 0.53 & 0.55 & 0.58 & 0.50 & 0.54 & 0.51 & 0.48 & $\begin{array}{l}8.03 \\
0.11\end{array}$ & 8.00 & 8.00 & 8.00 & 8.00 & 8.00 & 8.00 & 8.00 & 8.00 & 8.00 & 8.00 & 8.00 \\
\hline $\mathrm{CCr}$ & 0.21 & 0.21 & 0.20 & 0.20 & 0.24 & 0.19 & 0.20 & 0.23 & $\frac{0.11}{0.00}$ & 0.14 & 0.07 & 0.05 & 0.09 & 0.07 & 0.09 & 0.07 & 0.06 & 0.08 & 0.08 & 0.08 \\
\hline $\mathrm{CTi}$ & 0.00 & 0.00 & 0.00 & 0.00 & 0.00 & 0.00 & 0.00 & 0.00 & $\frac{0.00}{0.00}$ & 0.02 & 0.00 & 0.0 & 0.00 & 0.00 & 0.00 & 0.0 & 0.00 & 0.02 & 0.02 & 0.04 \\
\hline $\mathrm{CFe}^{+3}$ & 0.00 & 0.00 & 0.00 & 0.00 & 0.00 & 0.00 & 0.00 & 0.00 & 0.00 & 0.00 & 0.00 & 0.0 & 0.00 & 0.00 & 0.00 & $0 . \infty$ & 0.00 & 0.00 & 0.00 & 0.00 \\
\hline $\mathrm{CMg}$ & 3.10 & 3.09 & 3.10 & 3.06 & 3.11 & 3.13 & 311 & 311 & $\frac{0.00}{489}$ & 0.00 & 0.00 & 0.00 & 0.00 & 0.00 & 0.00 & 0.00 & 0.00 & 0.00 & 0.00 & 0.00 \\
\hline $\mathrm{CFe}^{+2}$ & 1.14 & 9.17 & 1.15 & 1.16 & 1.14 & 1.14 & 1.18 & 1.18 & $\begin{array}{l}4.89 \\
0.00\end{array}$ & 4.65 & 4.93 & 4.95 & 4.91 & 4.93 & 4.91 & 4.93 & 4.94 & 4.90 & 4.90 & 4.89 \\
\hline $\mathrm{CMn}$ & 0.00 & 0.00 & 0.00 & 0.00 & 0.00 & 0.00 & 0.00 & 0.00 & 0.00 & 0.20 & 0.00 & 0.00 & 0.00 & 0.00 & 0.00 & 0.00 & 0.00 & 0.00 & 0.00 & 0.00 \\
\hline $\mathrm{CCa}$ & 0.00 & 0.00 & 0.00 & 0.00 & 0.00 & 0.00 & 0.00 & 0,00 & 0.00 & 0.00 & 0.00 & 0.00 & 0.00 & 0.00 & 0.00 & 0.00 & 0.00 & 0.00 & 0.00 & 0.00 \\
\hline Soma C & 5.00 & 5.00 & 5.00 & 5.00 & 5.00 & 5.00 & 5.00 & 5.00 & $\begin{array}{l}0.00 \\
5.00\end{array}$ & 0.00 & 0.00 & 0.00 & 0.00 & 0.00 & 0.00 & 0.00 & 0.00 & 0.00 & 0.00 & 0.00 \\
\hline $\mathrm{BFe}^{+2}$ & 0.10 & 0.09 & 0.10 & 0.10 & 0.10 & 0.11 & 0.09 & 0.09 & $\begin{array}{l}5.00 \\
1.65\end{array}$ & 5.00 & 5.00 & 5.00 & 5.00 & 5.00 & 5.00 & 5.00 & 5.00 & 5.00 & 5.00 & 5.00 \\
\hline $\mathrm{BMg}$ & 0.00 & 0.00 & 0.00 & 0.00 & 0.00 & 0.00 & 0.00 & 0.00 & $\frac{1.00}{0.16}$ & 1.22 & 1.71 & 1.56 & 1.66 & 1.59 & 1.60 & 1.66 & 1.72 & 1.64 & 1.69 & 1.68 \\
\hline$B M n$ & 0.05 & 0.06 & 0.05 & 0.05 & 0.06 & 0.06 & 0.06 & 0.06 & 0.76 & 0.00 & 0.19 & 0.32 & 0.25 & 0.30 & 0.28 & 0.24 & 0.16 & 0.24 & 0.22 & 0.21 \\
\hline $\mathrm{BCa}$ & 4.85 & 1.85 & 1.85 & 1.85 & 1.85 & 1.83 & 1.86 & 1.86 & $\frac{0.04}{0.12}$ & 0.03 & 0.04 & 0.05 & 0.04 & 0.03 & 0.05 & 0.04 & 0.05 & 0.05 & 0.03 & 0.04 \\
\hline $\mathrm{BNa}$ & 0.00 & 0.00 & 0.00 & 0.00 & 0.00 & 0.00 & 0.00 & 0.00 & $\frac{.12}{0.03}$ & 0.75 & 0.05 & 0.07 & 0.06 & 0.08 & 0.08 & 0.07 & 0.07 & 0.07 & 0.06 & 0.07 \\
\hline Soma B & 2.00 & 2.001 & 2.00 & 2.00 & $2 . \infty$ & 2.00 & 2.00 & 2.00 & 2.00 & 0.00 & 0.0 & 0.00 & 0.00 & 0.00 & 0.00 & 0.00 & 0.00 & 0.00 & 0.00 & 0.00 \\
\hline $\mathrm{ACa}$ & 0.00 & 0.00 & 0.00 & 0.00 & 0.00 & 0.00 & 0.00 & 0.00 & 0.00 & 2.00 & 2.00 & 2.00 & 2.00 & 2.00 & 2.00 & 2.00 & 2.00 & 2.00 & 2.00 & 2.00 \\
\hline $\mathrm{ANa}$ & 0.51 & 0.48 & 0.45 & 0.50 & 0.49 & 0.51 & 0.51 & 0.50 & 0.04 & 0.00 & 0.00 & 0.00 & 0.00 & 0.00 & 0.00 & 0.00 & 0.00 & 0.00 & 0.00 & 0.00 \\
\hline AK & 0.09 & 0.07 & 0.06 & 0.09 & 0.07 & 0.08 & 0.07 & 0.08 & 0.00 & 0.07 & 0.00 & 0.08 & 0.07 & 0.05 & 0.05 & 0.06 & 0.06 & 0.10 & 0.07 & 0.06 \\
\hline Soma A & 0.60 & 0.54 & 0.51 & 0.59 & 0.57 & 0.59 & 0.58 & 0.58 & 0.04 & $\frac{0.00}{0.07}$ & 0.00 & 0.00 & 0.00 & 0.00 & 0.00 & 0.00 & 0.00 & 0.00 & 0.00 & 0.00 \\
\hline Cátions & 15.60 & 15.55 & 15.511 & 15.59 & 15.57 & 45.59 & 15.58 & 15.58 & 15.07 & $\frac{0.07}{15.07}$ & 0.00 & $\frac{0.08}{1509}$ & $\frac{0.07}{15.77}$ & $\begin{array}{r}0.05 \\
15.05\end{array}$ & 0.05 & 0.06 & 0.06 & 0.10 & 0.07 & 0.06 \\
\hline & & & & & & & & & & 10.01 & 15.00 & 15.08 & 15.07 ] & 15.05 & 15.05 & 15.06 & 15.06 & 15.10 & 15.07 & 15.06 \\
\hline
\end{tabular}


Tabela A4.2: Anfibólios - ANF.

\begin{tabular}{|c|c|c|c|c|c|c|c|c|c|c|c|c|c|c|c|c|c|c|c|c|}
\hline \begin{tabular}{|l|} 
Amostra \\
Análise \\
\end{tabular} & \begin{tabular}{|c|} 
BE-06 \\
$03 / 01 / 41$
\end{tabular} & \begin{tabular}{|c|} 
BE.06 \\
$03 / 02 / 42$
\end{tabular} & \begin{tabular}{c|}
$\mathrm{BE}-06$ \\
$03 / 02 / 45$
\end{tabular} & $\frac{B E-06}{03 / 04 / 49}$ & \begin{tabular}{|c|}
$B E-06$ \\
$06 / 01 / 01$
\end{tabular} & $\frac{B E-06}{06 / 01 / 02}$ & \begin{tabular}{|c|} 
BE-D6 \\
$06 / 01 / 03$ \\
\end{tabular} & \begin{tabular}{|c|}
$B E-06$ \\
$06 / 01 / 04$
\end{tabular} & \begin{tabular}{|c|}
$\mathrm{BE}-08$ \\
$37 / 1 \mathrm{H} 111$ \\
\end{tabular} & \begin{tabular}{|c|} 
BE- 08 \\
$37 / 1+11,2$
\end{tabular} & $\begin{array}{c}\mathrm{BE}-08 \\
37 / 1 \mathrm{H} 13 \\
\end{array}$ & $\frac{B E-08}{37 / 1414}$ & \begin{tabular}{|c|}
$\mathrm{BE}-08$ \\
$37 / 1 \mathrm{H} 21$ \\
\end{tabular} & $\frac{B E-08}{371+27}$ & \begin{tabular}{|c|}
$\mathrm{BE}-08$ \\
$37 / 1 \mathrm{H}^{3} 1$ \\
\end{tabular} & 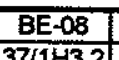 & BE-08 & BE-08 & \begin{tabular}{|l|} 
BE-08 \\
\end{tabular} & BE-08 \\
\hline Mineral & A.V. & A.V. & A.V. & A.V. & A.V. & A.V. & A.V. & A.V. & A.V. & A.V. & A.V. & $\frac{31 \mathrm{H} 1.4}{\text { A.V. }}$ & $\frac{37 / 1 \mathrm{H}^{2} .1}{\mathrm{~A} . \mathrm{V}}$ & $\frac{37 / 1 \mathrm{H} 2.2}{\mathrm{~A} . \mathrm{V} .}$ & $|37 / 1 \mathrm{H} 3.1|$ & $\frac{37 / 1 H 3.2}{A . V .}$ & $\frac{3 / 2 \mathrm{Al} .1}{\text { A.V. }}$ & $\frac{3 / 2 \mathrm{HI} .2}{\mathrm{~A} . \mathrm{V} .}$ & $\frac{37 / 2 \mathrm{H} 2.1}{\mathrm{~A} . \mathrm{V}}$ & $\frac{37 / 2 \mathrm{H} 2.2}{\mathrm{A.V}}$ \\
\hline Local & $B$ & C & $\mathrm{C}$ & $c$ & $c$ & $B$ & $\mathrm{C}$ & $B$ & $c$ & $c$ & $B(1)$ & $B(\theta)$ & $\mathrm{C}$ & $B$ & $\mathrm{c}$ & $\frac{1.0}{B}$ & $\mathrm{C}$ & $\frac{\text { A.V. }}{B}$ & $\frac{\text { A.V. }}{B}$ & $\frac{\text { A.V. }}{C}$ \\
\hline Litotipo & UM & $\overline{U M}$ & $\mathrm{UM}$ & UM & UM & UM & UM & UM & UM & $\overline{U M}$ & $\frac{U M}{U M}$ & Uू & UM & UM & UM & UM & UM & UM & $\mathrm{UM}$ & UM \\
\hline $\mathrm{SiO}_{2}$ & 45.20 & 45.25 & 44.01 & 43.95 & 44.86 & 44.90 & 44.86 & 44.85 & 43.87 & 44.10 & 43.58 & 44.75 & 44.48 & 44.51 & 44.81 & 43.81 & 44.08 & 44.39 & 44.77 & 44.71 \\
\hline $\mathrm{TMO}_{2}$ & 0.45 & 0.43 & 0.43 & 0.44 & 0.37 & 0.40 & 0.45 & 0.39 & 0.27 & 0.19 & 0.42 & 0.35 & 0.27 & 0.22 & 0.26 & 0.15 & 0.21 & 0.30 & 0.26 & 0.25 \\
\hline $\mathrm{Al}_{2} \mathrm{O}_{3}$ & 12.34 & 12.86 & 12.95 & 13.28 & 12.47 & 12.51 & 12.56 & 12.87 & 12.73 & 12.77 & 22.55 & 12.60 & 12.42 & 12.65 & 12.82 & 13.07 & 12.76 & 12.88 & 12.57 & 12.48 \\
\hline $\mathrm{Cr}_{2} \mathrm{O}_{3}$ & 0.94 & 0.58 & 0.79 & 1.54 & 0.69 & 1.06 & 1.05 & 1.57 & 1.42 & 1.32 & 1.78 & 1.19 & 1.28 & 0.88 & 0.81 & 0.83 & 0.68 & 1.16 & 0.54 & 0.57 \\
\hline $\mathrm{ZnO}$ & 0.04 & 0.00 & 0.03 & 0.06 & n.a. & n.a. & n.a. & n.a. & n.a. & n.a. & n.a. & ก.a. & n.a. & ก.a. & n.a. & n.a. & n.a. & n.a. & n.a. & n.a. \\
\hline $\mathrm{FeO}$ & 13.00 & 12.67 & 12.29 & 12.28 & 12.39 & 12.34 & 12.36 & 12.47 & 12.62 & 12.35 & 12.54 & 12.54 & 12.90 & 12.70 & 12.66 & 12.52 & 12.52 & 12.90 & 12.74 & 12.60 \\
\hline Mno & 0.29 & 0.26 & 0.27 & 0.24 & 0.28 & 0.31 & 0.34 & 0.27 & 0.39 & 0.26 & 0.32 & 0.30 & 0.30 & 0.19 & 0.36 & 0.40 & 0.32 & 0.34 & 0.34 & 0.29 \\
\hline MgO & 13.47 & 12.99 & 13.29 & 13.16 & 13.76 & 13.30 & 13.42 & 13.06 & 12.03 & 12.13 & 11.90 & 12.32 & 11.94 & 12.28 & 12.43 & 11.87 & 12.41 & 12.15 & 12.24 & 12.26 \\
\hline $\mathrm{NiO}$ & 0.06 & 0.07 & 0.02 & 0.06 & ก.a. & n.a. & ก.a. & n.a. & 0.00 & 0.00 & 0.00 & 0.00 & 0.00 & 0.00 & 0.00 & 0.00 & 0.00 & 0.00 & 0.00 & 0.00 \\
\hline $\mathrm{CaO}$ & 11.61 & 11.71 & 11.54 & 11.56 & 11.62 & 11.51 & 11.55 & 11.50 & 11.43 & 11.41 & 11.36 & 11.51 & 11.47 & 11.28 & 11.46 & 11.51 & 11.44 & 11.43 & 11.63 & 11.32 \\
\hline $\mathrm{Na}_{2} \mathrm{O}$ & 1.61 & 1.68 & 1.69 & 1.79 & 1.63 & 1.68 & 1.73 & $\begin{array}{l}1.74 \\
\end{array}$ & 1.88 & 1.86 & 2.01 & 1.94 & 1.90 & 1.89 & 1.85 & 1.97 & 1.76 & 1.97 & 1.91 & 1.79 \\
\hline $\mathrm{K}_{2} \mathrm{O}$ & 0.35 & 0.33 & 0.45 & 0.52 & 0.36 & 0.33 & 0.30 & 0.32 & 0.34 & 0.32 & 0.38 & 0.31 & 0.26 & 0.29 & 0.42 & 0.47 & 0.40 & 0.26 & 0.42 & 0.36 \\
\hline $\mathrm{P}_{2} \mathrm{O}_{5}$ & n.a. & n.a. & n.a. & n.a. & n.a. & n.a. & n.a. & n.a. & 0.00 & 0.00 & 0.00 & 0.00 & 0.00 & 0.00 & 0.00 & 0.00 & 0.00 & 0.00 & 0.00 & 0.00 \\
\hline $\mathrm{BaO}$ & n.a. & n.a. & n.a. & n.a. & 0.01 & 0.05 & 0.00 & 0.01 & n.a. & n.a. & n.a. & n.a. & n.a. & n.a. & n.a. & n.a. & n.a. & n.a. & n.a. & n.a. \\
\hline$F$ & n.a. & n.a. & n.a. & n.a. & 0.56 & 0.77 & 0.70 & 0.74 & n.a. & n.a. & n.a. & n.a. & n.a. & n.a. & n.a. & n.a. & n.a. & n.a. & n.a. & n.a. \\
\hline $\mathrm{Cl}$ & n.a & n.a. & n.a. & $\begin{array}{ll}\text { n.a. } \\
\end{array}$ & n.a. & n.a. & n.a. & n.a. & 0.00 & 0.00 & 0.00 & 0.00 & 0.00 & 0.00 & 0.00 & 0.00 & 0.00 & 0.00 & 0.00 & 0.00 \\
\hline Total & 99.36 & 98.83 & 97.76 & 98.88 & 99.00 & 99.16 & 99.29 & 99.79 & 96.98 & 96.71 & 96.84 & 97.81 & 97.19 & 96.89 & 97.88 & 96.60 & 96.58 & 97.78 & 96.79 & 96.63 \\
\hline TSi & 6.49 & 6.53 & 6.42 & 6.36 & 6.48 & 6.51 & 6.48 & 6.47 & 6.50 & 6.54 & 6.49 & 6.57 & 6.58 & 6.58 & 6.56 & 6.52 & 6.53 & 6.52 & 6.55 & 6.63 \\
\hline TAI & 1.51 & 1.47 & 1.58 & 1.64 & 1.53 & 1.49 & 1.52 & 1.53 & 1.50 & 1.46 & 1.51 & 1.43 & 1.42 & 1.42 & 1.44 & 1.48 & 1.47 & 1.48 & 1.45 & 1.38 \\
\hline $\mathrm{TFe}^{+3}$ & 0.00 & 0.00 & 0.00 & 0.00 & 0.00 & 0.00 & 0.00 & 0.00 & 0.00 & 0.00 & 0.00 & 0.00 & 0.00 & 0.00 & 0.00 & $0 . \infty$ & 0.00 & 0.00 & 0.00 & 0.00 \\
\hline$\pi i$ & 0.00 & 0.00 & 0.00 & 0.00 & 0.00 & 0.00 & 0.00 & 0.00 & 0.00 & 0.00 & 0.00 & 0.00 & 0.00 & 0.00 & 0.00 & 0.00 & 0.00 & 0.00 & 0.00 & 0.00 \\
\hline Soma T & 8.00 & 8.00 & 8.00 & 8.00 & 8.00 & 8.00 & 8.00 & 8.00 & 8.00 & 8.00 & 8.00 & 8.00 & 8.00 & 8.00 & 8.00 & 8.00 & 8.00 & 8.00 & 8.00 & 8.00 \\
\hline CAI & 0.58 & 0.72 & 0.64 & 0.63 & 0.59 & 0.64 & 0.62 & 0.66 & 0.72 & 0.77 & 0.69 & 0.74 & 0.74 & 0.78 & 0.77 & 0.81 & 0.75 & 0.75 & 0.74 & 0.80 \\
\hline $\mathrm{CCr}$ & 0.11 & 0.07 & 0.09 & 0.18 & 0.08 & 0.12 & 0.12 & 0.18 & 0.17 & 0.16 & 0.21 & 0.14 & 0.15 & 0.10 & 0.09 & 0.10 & 0.08 & 0.14 & 0.06 & 0.07 \\
\hline $\mathrm{CTI}$ & 0.05 & 0.05 & 0.05 & 0.05 & 0.04 & 0.04 & 0.05 & 0.04 & 0.03 & 0.02 & 0.05 & 0.04 & 0.03 & 0.02 & 0.03 & 0.02 & 0.02 & 0.03 & 0.03 & 0.03 \\
\hline $\mathrm{CFe}^{+3}$ & 0.22 & 0.06 & 0.20 & 0.14 & 0.25 & 0.11 & 0.14 & 0.07 & 0.00 & 0.00 & 0.00 & 0.00 & 0.00 & 0.00 & 0.00 & 0.00 & 0.01 & 0.00 & 0.00 & 0.00 \\
\hline $\mathrm{CMg}$ & 2.88 & 2.80 & 2.89 & 2.84 & 2.96 & 2.87 & 2.89 & 2.81 & 2.66 & 2.68 & 2.64 & 2.70 & 2.63 & 2.71 & 2.71 & 2.63 & 2.74 & 2.66 & 2.70 & 2.71 \\
\hline $\mathrm{CFe}^{+2}$ & 1.17 & 1.32 & 1.14 & 1.17 & 1.08 & 1.21 & 1.18 & 1.25 & 1.43 & 1.38 & 1.41 & 1.39 & 1.45 & 1.38 & 1.39 & 1.44 & 1.39 & 1.43 & 1.46 & 1.40 \\
\hline CMn & 0.00 & 0.00 & 0.00 & 0.00 & 0.00 & 0.00 & 0.00 & 0.00 & 0.00 & 0.00 & 0.00 & 0.00 & 0.00 & 0.00 & 0.00 & 0.00 & 0.00 & 0.00 & 0.00 & 0.00 \\
\hline $\mathrm{CCa}$ & 0.00 & 0.00 & 0.00 & 0.00 & 0.00 & 0.00 & 0.00 & 0.00 & 0.00 & 0.00 & 0.00 & 0.00 & 0.00 & 0.00 & 0.00 & 0.00 & 0.00 & 0.00 & 0.00 & 0.00 \\
\hline Soma C & 5.00 & 5.00 & 5.00 & 5.00 & 5.00 & 5.00 & 5.00 & 5.00 & 5.00 & 5.00 & 5.00 & 5.00 & 5.00 & 5.00 & 5.00 & 5.00 & 5.00 & 5.00 & 5.00 & 5.00 \\
\hline $\mathrm{BFe}^{+2}$ & 0.18 & 0.16 & 0.16 & 0.18 & 0.17 & 0.18 & 0.17 & 0.19 & 0.14 & 0.16 & 0.15 & 0.15 & 0.15 & 0.19 & 0.16 & 0.12 & 0.15 & 0.16 & 0.11 & 0.17 \\
\hline$B M g$ & 0.00 & 0.00 & 0.00 & 0.00 & 0.00 & 0.00 & 0.00 & 0.00 & 0.00 & 0.00 & 0.00 & 0.00 & 0.00 & 0.00 & 0.00 & 0.00 & 0.00 & 0.00 & 0.00 & 0.00 \\
\hline $\mathrm{BMn}$ & 0.04 & 0.03 & 0.03 & 0.03 & 0.03 & 0.04 & 0.04 & 0.03 & 0.05 & 0.03 & 0.04 & 0.04 & 0.04 & 0.02 & 0.05 & 0.05 & 0.04 & 0.04 & 0.04 & 0.04 \\
\hline $\mathrm{BCa}$ & 1.79 & 1.81 & 1.80 & 1.79 & 1.80 & 1.79 & 1.79 & 1.78 & 1.81 & 1.81 & 1.81 & 1.81 & 1.82 & 1.79 & 1.80 & 1.84 & 1.82 & 1.80 & 1.85 & 1.80 \\
\hline $\mathrm{BNa}$ & 0.00 & 0.00 & $0 . \infty$ & 0.00 & 0.00 & 0.00 & 0.00 & 0.00 & 0.00 & 0.00 & 0.00 & 0.00 & 0.00 & 0.00 & 0.00 & 0.00 & 0.00 & 0.00 & 0.00 & 0.00 \\
\hline Soma B & 2.00 & 2.00 & 2.00 & 2.00 & 2.00 & 2.00 & 2.00 & 2.00 & 2.00 & 2.00 & 2.00 & 2.00 & 2.00 & 2.00 & 2.00 & 2.00 & 2.00 & 2.00 & 2.00 & 2.00 \\
\hline $\mathrm{ACa}$ & 0.00 & 0.00 & 0.00 & 0.00 & 0.00 & 0.00 & 0.00 & 0.00 & 0.00 & 0.00 & 0.00 & 0.00 & 0.00 & 0.00 & 0.00 & 0.00 & 0.00 & 0.00 & 0.00 & 0.00 \\
\hline $\mathrm{ANa}$ & 0.45 & 0.47 & 0.48 & 0.50 & 0.46 & 0.47 & 0.49 & 0.49 & 0.54 & 0.54 & 0.58 & 0.55 & 0.55 & 0.54 & 0.53 & 0.57 & 0.51 & 0.56 & 0.55 & 0.51 \\
\hline AK & 0.06 & 0.06 & 0.08 & 0.10 & \begin{tabular}{l|l|}
0.07 \\
\end{tabular} & 0.06 & 0.06 & 0.06 & 0.06 & 0.06 & 0.07 & 0.06 & 0.05 & 0.06 & 0.08 & 0.09 & 0.08 & 0.05 & 0.08 & 0.07 \\
\hline Soma A & 0.51 & 0.53 & 0.56 & 0.60 & 0.52 & 0.53 & 0.54 & 0.55 & 0.60 & 0.60 & 0.65 & 0.61 & 0.59 & 0.60 & 0.60 & 0.66 & 0.58 & 0.61 & 0.63 & 0.58 \\
\hline Cátions & 15.51 & 15.53 & 15.56 & 15.60 & 15.52 & 15.53 & 15.54 & 15.55 & 15.60 & 15.60 & 15.65 & 15.61 & 15.60 & 15.60 & 15.61 & 15.66 & 15.58 & 15.61 & 15.63 & 15.58 \\
\hline
\end{tabular}


Tabela A4.2: Anfibólios - ANF.

\begin{tabular}{|c|c|c|c|c|c|c|c|c|c|c|c|c|c|c|c|c|c|c|c|c|}
\hline \begin{tabular}{|l} 
Amostra \\
Andílise
\end{tabular} & \begin{tabular}{|c|}
$\mathrm{BE}-08$ \\
$3712 \mathrm{H}^{-3} 1$ \\
\end{tabular} & $\frac{B E-O B}{3713+14}$ & \begin{tabular}{|l|}
$\mathrm{BEE}-08$ \\
$37 / \mathrm{H}^{191}$ \\
\end{tabular} & BE-08 & 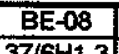 & \begin{tabular}{|c|}
$\mathrm{BE}-08$ \\
$37 / \mathrm{H}+24$
\end{tabular} & BE-08 & $\begin{array}{l}\text { BE-08 } \\
37 Y 4+14\end{array}$ & BE-08 & BE-08 & NE-12 & NE-12 & $\mathrm{NE}-3$ & NE-3 & NE-3 & NE-3 & $\mathrm{NE}-3$ & NE-3 & $\mathrm{NE}-3$ & NE-3 \\
\hline $\begin{array}{l}\text { Analise } \\
\text { Mineral }\end{array}$ & $\frac{37 / 2 \mathrm{H} .1}{\mathrm{~A} . \mathrm{V}}$ & $\frac{37 / 3 H 1.1}{\text { A.V. }}$ & $\frac{37 / 6 \mathrm{H} 1.1}{\mathrm{A.V}}$ & $\frac{37 / 6 \mathrm{H} 1.2}{\mathrm{AV}}$ & $\frac{37 / 6 \mathrm{H} 1.3}{\mathrm{AV}}$ & $\frac{37 / 6 \mathrm{H} 2.1}{\mathrm{AY}}$ & $\frac{37 / 6 H 2.2}{A V}$ & $37 / \times \mathrm{H}_{1.1}$ & $37 / \times H 2.1$ & $37 / \times+2.2$ & $04 / 01 / 69$ & $04 / 01 / 70$ & $48 / 1+101$ & $48 / 1 \mathrm{HO2}$ & $48 / 1 \mathrm{HO}$ & $48 / 1+104$ & $48 / 2 \mathrm{HO1}$ & $48 / 2 \mathrm{HO}$ & $48 / 2 \mathrm{HO3}$ & $48 / 2 H 04$ \\
\hline Local & C & $\mathrm{C}$ & $c$ & Plm & $\frac{M . v .}{B}$ & $\frac{\text { A.V. }}{C}$ & $B$ & $\frac{\text { A.V. }}{P \mid m}$ & A.V. & A.V. & A.V. & A.V. & A.V. & A.V. & A.V. & A.V. & A.V. & A.V. & A.V. & A.V. \\
\hline Litotipo & UM & UM & $\overline{U M}$ & UM & UM & UM & UM & UM & $\frac{P \ln }{U M}$ & $B(e)$ & C & 8 & c & B & C & B & C & B & B & C \\
\hline $\mathrm{SiO}_{2}$ & 44.36 & 44.34 & 44.06 & 4427 & 4384 & 43.83 & 1515 & ans & UM & $\mathrm{UM}$ & UM & UM & UM & UM & UM & UM & UM & UM & UM & UM \\
\hline $\mathrm{TiO}_{2}$ & 0.16 & 0.27 & 0.19 & 0.23 & 0.29 & 0.30 & $\frac{45.15}{0.23}$ & 43.69 & 44.61 & 45.08 & 53.99 & 53.52 & 48.22 & 48.57 & 48.34 & 48.07 & 48.15 & 47.96 & 49.01 & 48.75 \\
\hline $\mathrm{Al}_{2} \mathrm{O}_{3}$ & 12.70 & 12.83 & 12.97 & 13.23 & 13.10 & 13.10 & $\frac{0.23}{12.17}$ & 0.17 & 0.25 & 0.29 & 0.06 & 0.07 & 0.00 & 0.00 & 0.00 & 0.00 & 0.00 & 0.00 & 0.00 & 0.00 \\
\hline $\mathrm{Cr}_{2} \mathrm{O}_{3}$ & 0.39 & 0.74 & 0.93 & 1.37 & 4.56 & 148 & $\frac{12.17}{1.13}$ & 13.36 & 12.20 & 12.08 & 5.43 & 5.86 & 7.80 & 7.65 & 7.55 & 7.76 & 7.71 & 7.71 & 7.57 & 7.69 \\
\hline $\mathrm{ZnO}$ & n.a. & n.a. & n.a. & n.a. & $n a$ & $n a t$ & 1.13 & 1.17| & 1.17 & 0.82 & 0.28 & 0.17 & 1.49 & 1.30 & 1.18 & 1.42 & 1.33 & 1.35 & 1.21 & 1.48 \\
\hline $\mathrm{FeO}$ & 12.66 & 13.08 & 12.78 & 12.73 & 12.67 & 12.59 & $\frac{n . a .}{12.33}$ & n.a. & ก.a. & n.a. & 0.03 & 0.06 & n.a. & n.a. & ก.a. & n.a. & n.a. & n.a. & n.a. & n.a. \\
\hline $\mathrm{MnO}$ & 0.32 & 0.40 & \begin{tabular}{l|l|}
0.33 \\
\end{tabular} & 0.23 & 0.30 & 0.37 & $\begin{array}{r}12.33 \\
0.40\end{array}$ & 12.71 & 12.24 & 12.31 & 8.59 & 10.16 & 9.24 & 8.78 & 8.96 & 8.94 & 9.11 & 8.94 & 8.87 & 8.91 \\
\hline $\mathrm{MgO}$ & 12.20 & 12.25 & 12.15 & 12.00 & 11.81 & 12.14 & $\frac{0.40}{1257}$ & 0.23 & 0.27 & 0.35 & 0.29 & 0.37 & 0.48 & 0.40 & 0.41 & 0.38 & 0.38 & 0.44 & 0.46 & 0.40 \\
\hline NiO & 0.00 & 0.00 & 0.00 & 0.00 & 0.00 & 0.00 & $\frac{12.52}{0.00}$ & 11.87| & 12.56 & 12.60 & 18.74 & 18.37] & 15.56 & 15.42 & 15.49 & 15.50 & 15.32 & 15.36 & 15.99 & 15.59 \\
\hline $\mathrm{CaO}$ & 11.44 & 11.50 & 11.48 & 11.26 & 11.38 & 11.57 & $\frac{0.00}{1128}$ & 0.00 & $0 . \infty$ & 0.00 & 0.01 & 0.05 & 0.00 & 0.00 & 0.00 & 0.00 & $0 . \infty$ & 0.00 & 0.00 & 0.00 \\
\hline $\mathrm{Na}_{2} \mathrm{O}$ & 1.82 & 1.96 & 1.82 & 1.88 & 1.95 & 2.11 & $\frac{11.28}{1.90}$ & 11.36 & 11.53 & 11.58 & 11.40 & 10.23 & 11.33 & 11.38 & 11.35 & 11.29 & 11.11 & 11.26 & 11.44 & 11.54 \\
\hline $\mathrm{K}_{2} \mathrm{O}$ & 0.34 & 0.37 & 0.43 & 0.50 & 0.42 & 0.48 & $\begin{array}{l}1.90 \\
0.23\end{array}$ & 1.87 & 1.85 & 1.91 & 0.67 & 0.69 & 1.55 & 1.47 & 1.45 & 1.33 & 1.46 & 1.43 & 1.44 & 1.59 \\
\hline $\mathrm{P}_{2} \mathrm{O}_{5}$ & 0.00 & 0.00 & 0.00 & 0.00 & 0.00 & 000 & 0.23 & 0.39 & 0.31 & 0.32 & 0.12 & 0.11 & 0.30 & 0.16 & 0.15 & 0.23 & 0.22 & 0.16 & 0.25 & 0.30 \\
\hline $\mathrm{BaO}$ & n.a. & n.a. & n.a. & n.a. & n.a. & & 0.00 & 0.00 & 0.00 & 0.001 & n.a. & n.a. & 0.00 & 0.00 & 0.00 & 0.00 & 0.00 & 0.00 & 0.00 & 0.00 \\
\hline$F$ & ก.a. & n.a. & n.a. & n.a. & $n . a_{1}$ & & n.a. & n.a. & n.a. & n.a. & n.a. & n.a. & ก.a. & n.a. & n.a. & n.a. & п.a. & п.a. & n.a. & n.a. \\
\hline CI & 0.00 & 0.00 & 0.00 & 0.00 & & 11.. & n.a. & n.a. & n.a. & n.a. & n.a. & n.a. & n.a. & ก.a. & n.a. & n.a. & n.a. & n.a. & n.a.] & ก.a. \\
\hline Tokal & 96.39 & 97.74 & 97.14 & 97.70 & & 0.00 & 0.00 & 0.00 & 0.00 & 0.00 & n.a. & n.a. & 0.00 & 0.00 & 0.00 & 0.00 & 0.00 & 0.00 & $0 . \infty$ & 0.00 \\
\hline TSi & 6.59 & 6.51 & 6.51 & 652 & 64 & 97.97 & 97.34 & 96.82 & 96.99 & 97.34 & $99.61]$ & 99.66 & 95.97 & 95.13 & 94.88 & 94.92 & 94.79 & 94.61 & $96.24 \mid$ & 96.25 \\
\hline TAl & 4.42 & 1.49 & 150 & 148 & & 6.45 & 6.64 & 6.48 & 6.58 & 6.63 & 7.48 & 7.45 & 7.09 & 7.18 & 7.16 & 7.12 & 7.15 & 7.13 & 7.15 & 7.14 \\
\hline $\mathrm{TFe}^{+3}$ & 0.00 & 0.00 & 0.00 & 0.00 & 0.00 & 1.55 & 1.36 & 1.52 & 1.42 & 1.37 & 0.52 & 0.55 & 0.91 & 0.82 & 0.84 & 0.88 & 0.85 & 0.87 & 0.85 & 0.86 \\
\hline $\mathrm{TTi}$ & 0.00 & 0.00 & 0.00 & 0.00 & 0.00 & 0.00 & 0.00 & 0.00 & 0.00 & 0.00 & 0.00 & 0.00 & 0.00 & 0.00 & 0.00 & 0.00 & 0.00 & 0.00 & 0.00 & 0.00 \\
\hline Soma T & 8.00 & 8.00 & 8.00 & 8.00 & 8.00 & 8.00 & 8.00 & $\frac{0.00}{8.00}$ & 8.00 & 0.00 & 0.00 & 0.00 & 0.00 & 0.00 & 0.00 & 0.00 & 0.00 & 0.00 & $0 . \infty$ & 0.00 \\
\hline CAI & 0.81 & 0.73 & 0.76 & 0.81 & 0.77 & 0.72 & 0.75 & 0.81 & 0.71 & 0.00 & 0.04 & 8.00 & 8.00 & 8.00 & 8.00 & 8.00 & 8.00 & 8.00 & 8.00 & 8.00 \\
\hline $\mathrm{CCr}$ & 0.05 & 0.09 & 0.11 & 0.16 & 0.18 & 017 & 0.13 & 014 & 0.14 & 0.64 & 0.01 & 0.41 & 0.44 & 0.51 & 0.48 & 0.47 & 0.50 & 0.48 & 0.45 & 0.47 \\
\hline $\mathrm{CTi}$ & 0.02 & 0.03 & 0.02 & 0.03 & 0,03 & 0.03 & 003 & 002 & 0.14 & 0.10 & 0.03 & 0.02 & 0.17 & 0.15 & 0.14 & 0.17 & 0.16 & 0.16 & 0.14 & 0.17 \\
\hline $\mathrm{CFe}^{+3}$ & $0 . \infty$ & 0.00 & 0.00 & 0.00 & 0.00 & $0 \mathrm{~cm}$ & $0 \mathrm{~m}$ & & & 0.03 & 0.011 & $0.01]$ & 0.00 & 0.00 & $0 . \infty 0$ & 0.00 & 0.00 & 0.00 & 0.00 & 0.00 \\
\hline $\mathrm{CMg}$ & 270 & 268 & 2.67 & 263 & 361 & 266 & 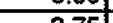 & 0.00 & 0.00 & 0.00 & 0.00 & 0.00 & 0.00 & 0.00 & 0.00 & 0.00 & 0.00 & 0.00 & 0.00 & 0.00 \\
\hline $\mathrm{CFe}^{+2}$ & 1.43 & 1.47 & 1.44 & 1.37 & 141 & $\frac{1.00}{1.42}$ & 2.19 & 2.62 & 2.76 & 2.76 & 3.87 & 3.81| & 3.41 & 3.40 & 3.42 & 3.42 & 3.39 & 3.40 & 3.48 & 3.41 \\
\hline & & & & & & & 1.35 & 1.411 & 1.37| & 1.38 & 0.72 & 0.75 & 0.98 & 0.94 & 0.96 & 0.95 & 0.95 & 0.96 & 0.93 & 0.95 \\
\hline $\mathrm{CCa}$ & 0.00 & 0.00 & 0.00 & 0.0 & u.us & 0.00 & 0.00 & 0.00 & 0.00 & 0.00 & $0 . \infty$ & 0.00 & 0.00 & 0.00 & 0.00 & 0.00 & 0.00 & 0.00 & 0.00 & 0.00 \\
\hline Soma C & 5.00 & 5.00 & 5.00 & & ..u & 0.00 & 0.00 & 0.00 & 0.00 & 0.00 & 0.00 & 0.00 & 0.00 & 0.00 & $0 . \infty$ & 0.00 & 0.00 & 0.00 & 0.00 & 0.00 \\
\hline $\mathrm{BFe}^{+2}$ & 0.14 & 0.14 & 0.14 & $\frac{3.00}{0.20}$ & 0.00 & 5.00 & 5.001 & 5.00 & 5.00 & 5.00 & 5.00 & 5.00 & 5.00 & 5.00 & 5.00 & 5.00 & 5.00 & 5.00 & 5.00 & 5.00 \\
\hline $\mathrm{BMg}$ & 0.00 & 0.00 & 0.00 & $\frac{0.20}{0.00}$ & 0.16 & 0.13 & 0.17 & 0.17 & 0.14 & 0.13 & 0.27 & 0.43 & 0.16 & 0.15 & 0.15 & 0.16 & 0.18 & 0.15 & 0.15 & 0.14 \\
\hline BMn & 0.04 & 0.05 & 0.04 & 0.03 & 0.00 & 0.00 & 0.00 & 0.00 & 0.00 & 0.00 & 0.00 & 0.00 & 0.00 & 0.00 & 0.00 & 0.00 & 0.00 & 0.00 & 0.00 & 0.00 \\
\hline $\mathrm{BCa}$ & 1.82 & 1.81 & 1.82 & $\frac{0.05}{1.78}$ & 0.04 & 0.05 & 0.05 & 0.03 & 0.03 & 0.04 & 0.03 & 0.04 & 0.06 & 0.05 & 0.05 & 0.05 & 0.05 & 0.06 & 0.06 & 0.05 \\
\hline $\mathrm{BNa}$ & 0.00 & 0.00 & 0.00 & 0.00 & 7.00 & 1.82 & 1.78 & 1.81 & 1.82 & 1.83 & 1.69 & 1.53 & 1.78 & 1.80 & 1.80 & 1.79 & 1.77 & 1.79 & 1.79 & 1.81 \\
\hline Soma B & 2.00 & 200 & 20 & 0.00 & 0.00 & 0.00 & 0.00 & 0.00 & 0.00 & 0.00 & 0.00 & 0.00 & 0.00 & 0.00 & 0.00 & 0.00 & 0.00 & 0.00 & 0.00 & 0.00 \\
\hline $\mathrm{ACa}$ & 0.00 & & & 2.00 & 2.00 & 2.00 & 2.00 & 2.00 & 2.00 & 2.00 & 2.00 & 2.00 & 2.00 & 2.00 & 2.00 & 2.00 & 2.00 & 2.00 & 2.00 & 2.00 \\
\hline $\mathrm{ANa}$ & 0.52 & 0.56 & 0.52 & 0.00 & 0.00 & 0.00 & $0 . \infty$ & 0.00 & 0.00 & 0.00 & 0.00 & 0.00 & 0.00 & 0.00 & 0.00 & 0.00 & 0.00 & 0.00 & 0.00 & 0.00 \\
\hline$\overline{A K}$ & 0.06 & 0.07 & 0.08 & u.54 & 0.56 & 0.60 & 0.54 & 0.54 & 0.53 & 0.55 & 0.18 & 0.19 & 0.44 & 0.42 & 0.42 & 0.38 & 0.42 & 0.41 & 0.41 & 0.45 \\
\hline Soma $A$ & 0.59 & 0.63 & 0.60 & $\frac{0.09}{0.63}$ & 0.08 & 0.09 & 0.04 & 0.07 & 0.06 & 0.06 & 0.02 & 0.02 & 0.06 & 0.03 & 0.03 & 0.04 & 0.04 & 0.03 & 0.05 & 0.06 \\
\hline Cations & 15.59 & 15.63 & 15.60 & 15.63 & $\frac{0.69}{15.64}$ & $\frac{0.69}{15.69}$ & $\frac{0.59}{15.58}$ & $\frac{0.61}{15.61}$ & $\frac{0.59}{15.50}$ & 0.61 & 0.20 & 0.21 & 0.50 & 0.45 & 0.45 & 0.43 & 0.46 & 0.44 & 0.45 & 0.51 \\
\hline & & & & & & 10.0 & 10.00 & 80.01 & 10.25 & 10.011 & $15.20 \mid$ & 15.21 & 15.50 & 15.45 & 15.44 & 15.43 & 15.46 & 15.44 & 15.45 & 15.51 \\
\hline
\end{tabular}


Tabela A4.2: Antibolios - ANF.

\begin{tabular}{|c|c|c|c|c|c|c|c|c|c|c|c|c|c|c|c|c|c|c|c|}
\hline \begin{tabular}{|l|} 
Amostra \\
Análise \\
\end{tabular} & \begin{tabular}{|l|} 
CAP-4 \\
$2 B / 1 H 1.1$ \\
\end{tabular} & $\begin{array}{l}\text { CAP-4 } \\
28 / 1 \mathrm{H}^{-12} \\
\end{array}$ & \begin{tabular}{|c|} 
CAP-4 \\
$28 / 1 \mathrm{H} 1.3$ \\
\end{tabular} & \begin{tabular}{|c|} 
CAP-4 \\
$28 / 3 \mathrm{H} 1.1$ \\
\end{tabular} & \begin{tabular}{|c|} 
CAP-4 \\
$28 / 3 H 1.2$ \\
\end{tabular} & \begin{tabular}{|c|} 
CAP-4 \\
$28 / 4 H 1.1$ \\
\end{tabular} & \begin{tabular}{|c|} 
CAP-4 \\
$28 / 4 \mathrm{H} 1.2$ \\
\end{tabular} & \begin{tabular}{|c|} 
HC-3a \\
$27 / 1 \mathrm{H} 1.1$ \\
\end{tabular} & $\begin{array}{c}\mathrm{HC}-3 \mathrm{a} \\
27 / 4 \mathrm{H} 1.2 \\
\end{array}$ & \begin{tabular}{|c|}
$\mathrm{HC}-3 \mathrm{a}$ \\
$27 / 1 \mathrm{H} 1.3$ \\
\end{tabular} & \begin{tabular}{|c|}
$\mathrm{HC}-3 \mathrm{a}$ \\
$27 / 1 \mathrm{H} 2.1$ \\
\end{tabular} & \begin{tabular}{|c|}
$\mathrm{HC}-3 \mathrm{a}$ \\
$27 / 2 \mathrm{H}+1.1$ \\
\end{tabular} & \begin{tabular}{|c|}
$\mathrm{HC}-3 \mathrm{a}$ \\
$27 / 2 \mathrm{H} 1.2$ \\
\end{tabular} & \begin{tabular}{|c|}
$\mathrm{HC}-3 \mathrm{a}$ \\
$27 / 2 \mathrm{H} 2.1$ \\
\end{tabular} & \begin{tabular}{|c|}
$H C-3 a$ \\
$27 / 2 H 2.2$ \\
\end{tabular} & \begin{tabular}{|c|}
$\mathrm{HC}-3 \mathrm{a}$ \\
$27 / 2 \mathrm{H} 2.3$ \\
\end{tabular} & \begin{tabular}{|c|}
32,20 \\
$06101 / 41$ \\
\end{tabular} & $\begin{array}{c}32,20 \\
06 / 01 / 42 \\
\end{array}$ & $\frac{G-37 a}{29 / 1 \mathrm{H} 1.1}$ \\
\hline Mineral & A.V. & A.V. & A.V. & A.V. & A.V. & A.V. & A.V. & A.V. & A.V. & $\begin{array}{c}\text { A.V. } \\
\end{array}$ & A.V. & A.V. & A.V. & A.V. & \begin{tabular}{|l|} 
A.V. \\
\end{tabular} & \begin{tabular}{|c|} 
A.V. \\
\end{tabular} & \begin{tabular}{|l|} 
A.V. \\
\end{tabular} & A.1. & A.V. \\
\hline Local & $\mathbf{B}$ & Pln & C & 8 & C & $B$ & $\mathrm{C}$ & B & C & $B$ & c & B & c & $\mathrm{C}$ & C & $B$ & $\mathrm{C}$ & C & $c$ \\
\hline Litotipo & $\mathrm{AB}$ & $\overline{A B}$ & $\overline{A B}$ & $A B$ & $A B$ & $\mathrm{AB}$ & $A B$ & $A B$ & $A B$ & $A B$ & $\mathrm{AB}$ & $A B$ & $\overline{A B}$ & $\mathrm{AB}$ & $\overline{A B}$ & $A B$ & ABET & ABET & ABET \\
\hline $\mathrm{SiO}_{2}$ & 42.67 & 42.39 & 42.54 & 42.23 & 41.84 & 42.81 & 41.75 & 44.38 & 44.61 & 44.74 & 45.13 & 49.34 & 46.25 & 44.28 & 45.37 & 44.57 & 42.58 & 51.90 & 41.15 \\
\hline $\mathrm{TiO}_{2}$ & 0.38 & 0.50 & 0.43 & 0.48 & 0.48 & \begin{tabular}{l|l|}
0.44 \\
\end{tabular} & 0.59 & 0.46 & 0.41 & 0.34 & 0.41 & 0.00 & 0.20 & 0.41 & 0.23 & 0.37 & 0.95 & 0.07 & 0.28 \\
\hline $\mathrm{Al}_{2} \mathrm{O}_{3}$ & 13.70 & 13.43 & 13.58 & 13.38 & 14.11 & 13.44 & 14.11 & 9.12 & 9.34 & 9.32 & 9.07 & 5.18 & 8.08 & 9.23 & 8.10 & 8.92 & 12.74 & 0.08 & 12.84 \\
\hline $\mathrm{Cr}_{2} \mathrm{O}_{3}$ & 0.00 & 0.00 & 0.00 & 0.00 & 0.00 & 0.00 & 0.00 & 0.00 & 0.00 & 0.00 & 0.00 & 0.00 & 0.00 & 0.00 & 0.00 & 0.00 & 0.00 & 0.04 & 0.00 \\
\hline $\mathrm{ZnO}$ & n.a. & n.a. & n.a. & \begin{tabular}{|c|} 
n.a. \\
\end{tabular} & n.a. & n.a. & n.a. & n.a. & n.a. & n.a. & n.a. & n.a. & n.a. & n.a. & n.a. & n.a. & n.a. & n.a. & n.a. \\
\hline $\mathrm{FeO}$ & 15.07 & 15.05 & 15.63 & 15.42 & 15.70 & 15.15 & 15.92 & 14.10 & 14.40 & 14.55 & 14.05 & 12.39 & 14.10 & 14.36 & 13.97 & 13.86 & 18.01 & 22.79 & 21.00 \\
\hline MnO & 0.32 & 0.32 & \begin{tabular}{l|}
0.27 \\
\end{tabular} & 0.26 & 0.26 & 0.24 & 0.22 & 0.31 & 0.47 & 0.42 & $\begin{array}{l}0.37 \\
\end{array}$ & 0.37 & 0.36 & 0.33 & 0.37 & 0.41 & 0.25 & 0.69 & 0.33 \\
\hline $\mathrm{MgO}$ & 9.94 & 9.84 & 9.89 & 10.03 & 9.85 & 10.20 & 9.75 & 11.42 & 11.50 & 11.31 & 11.42 & 13.62 & 12.14 & 11.24 & 11.72 & 11.46 & 9.42 & 8.92 & 7.48 \\
\hline NiO & 0.00 & 0.00 & 0.00 & 0.00 & 0.00 & 0.00 & 0.00 & 0.00 & 0.00 & 0.00 & 0.00 & 0.00 & 0.00 & 0.00 & 0.00 & 0.00 & n.a. & n.a. & 0.00 \\
\hline $\mathrm{CaO}$ & 10.85 & 10.94 & 10.93 & 10.77 & 10.50 & 10.79 & 10.66 & 11.71 & 11.67 & 11.68 & 11.76 & 12.09 & 11.85 & 11.81 & 11.66 & 11.80 & 11.71 & 12.12 & 11.40 \\
\hline $\mathrm{Na}_{2} \mathrm{O}$ & 1.58 & 1.48 & 1.44 & 1.57 & \begin{tabular}{|c|}
1.55 \\
\end{tabular} & 1.46 & 1.69 & 1.32 & 1.41 & 1.16 & 1.10 & 0.79 & 1.16 & 1.25 & 1.01 & 1.15 & 1.33 & 0.00 & 1.84 \\
\hline $\mathrm{K}_{2} \mathrm{O}$ & 0.29 & 0.20 & 0.27 & 0.37 & 0.42 & 0.26 & 0.40 & 0.95 & 1.09 & 0.96 & 0.88 & 0.39 & 0.78 & 0.96 & 0.86 & 0.90 & 1.07 & 0.04 & 1.53 \\
\hline $\mathrm{P}_{2} \mathrm{O}_{5}$ & $0 . \infty$ & 0.00 & 0.00 & 0.00 & 0.00 & 0.00 & 0.00 & 0.00 & 0.00 & 0.00 & 0.00 & 0.00 & 0.00 & 0.00 & 0.00 & 0.00 & n.a. & n.a. & 0.00 \\
\hline $\mathrm{BaO}$ & n.a. & n.a. & ก.a. & n.a. & n.a. & ก.a. & ก.a. & n.a. & n.a. & n.a. & n.a. & n.a. & n.a. & n.a. & n.a. & n.a. & 0.02 & 0.01 & ก.a. \\
\hline $\mathbf{F}$ & n.a. & n.a. & n.a. & n.a. & n.a. & n.a. & n.a. & n.a. & n.a. & n.a. & n.a. & n.a. & n.a. & ก.a. & n.a. & n.a. & 0.00 & 0.18 & n.a. \\
\hline CI & 0.08 & 0.05 & 0.00 & 0.05 & $\begin{array}{l}0.07 \\
\end{array}$ & 0.00 & 0.00 & 0.00 & 0.00 & 0.00 & 0.00 & 0.00 & 0.00 & 0.00 & 0.00 & 0.00 & n.a. & n.a. & 0.00 \\
\hline Total & 94.88 & 94.20 & 94.98 & 94.56 & 94.78 & 94.79 & 95.09 & 93.77 & 94.90 & 94.48 & 94.19 & 94.17 & 94.92 & 93.87 & 93.29 & 93.44 & 98.08 & 96.84 & 97.85 \\
\hline TSi & 6.50 & 6.50 & 6.47 & \begin{tabular}{|l|}
6.47 \\
\end{tabular} & 6.40 & 6.51 & 6.37 & 6.86 & 6.83 & 6.86 & 6.92 & 7.45 & 7.02 & \begin{tabular}{|c|}
6.84 \\
\end{tabular} & 7.01 & 6.89 & \begin{tabular}{|l|}
6.38 \\
\end{tabular} & 7.94 & 6.32 \\
\hline TAI & 1.50 & 1.50 & 1.53 & 1.53 & 1.60 & 1.49 & 1.63 & 1.14 & 1.17 & 1.14 & 1.08 & 0.55 & 0.98 & 1.16 & 0.99 & 1.11 & 1.62 & 0.01 & 1.68 \\
\hline $\mathrm{TFe}^{+3}$ & 0.00 & 0.00 & 0.00 & 0.00 & 0.00 & 0.00 & 0.00 & 0.00 & 0.00 & 0.00 & 0.00 & 0.00 & 0.00 & 0.00 & 0.00 & 0.00 & 0.00 & 0.04 & 0.00 \\
\hline TTi & 0.00 & 0.00 & 0.00 & 0.00 & 0.00 & 0.00 & 0.00 & 0.00 & 0.00 & 0.00 & 0.00 & 0.00 & 0.00 & 0.00 & 0.00 & 0.00 & 0.00 & 0.00 & 0.00 \\
\hline Soma T & 8.00 & 8.00 & 8.00 & 8.00 & 8.00 & 8.00 & 8.00 & 8.00 & 8.00 & 8.00 & 8.00 & 8.00 & 8.00 & 8.00 & 8.00 & 8.00 & 8.00 & 8.00 & 8.00 \\
\hline CAI & 0.96 & 0.93 & 0.90 & 0.88 & 0.94 & 0.92 & 0.91 & 0.52 & 0.51 & 0.54 & 0.56 & 0.37 & 0.47 & 0.52 & 0.49 & 0.52 & 0.62 & 0.00 & 0.64 \\
\hline $\mathrm{CCr}$ & 0.00 & 0.00 & 0.00 & 0.00 & 0.00 & 0.00 & 0.00 & 0.00 & 0.00 & 0.00 & 0.00 & 0.00 & 0.00 & 0.00 & 0.00 & 0.00 & 0.00 & 0.01 & 0.00 \\
\hline CTi & 0.04 & 0.06 & 0.05 & 0.06 & 0.06 & 0.05 & 0.07 & 0.05 & 0.05 & 0.04 & 0.05 & 0.00 & 0.0 & 0.05 & 0.03 & 0.0 & 0.11 & 0.01 & 0.03 \\
\hline $\mathrm{CFe}^{+3}$ & 0.00 & 0.00 & 0.05 & 0.01 & 0.01 & 0.00 & 0.00 & 0.00 & 0.00 & 0.00 & 0.00 & 0.00 & 0.00 & 0.00 & 0.00 & 0.00 & 0.20 & 0.03 & 0.13 \\
\hline $\mathrm{CMg}$ & 2.26 & 2.25 & 2.24 & 2.29 & 2.25 & 2.31 & 2.22 & 2.63 & 2.62 & 2.58 & 2.61 & 3.07 & 2.75 & 2.59 & 2.70 & 2.64 & 2.10 & 2.04 & 1.71 \\
\hline $\mathrm{CFe}^{+2}$ & 1.73 & 1.77 & 1.76 & 1.77 & 1.75 & 1.72 & 1.80 & 1.80 & 1.82 & 1.84 & 1.7 & 1.56 & 1.7 & 1.85 & 1.79 & 1.79 & 1.97 & 2.85 & 2.49 \\
\hline $\mathrm{CMn}$ & 0.00 & 0.00 & 0.00 & 0.00 & 0.00 & 0.00 & 0.00 & 0.00 & 0.00 & 0.00 & 0.00 & 0.00 & 0.00 & 0.00 & 0.00 & 0.01 & 0.00 & 0.08 & 0.00 \\
\hline $\mathrm{CCa}$ & 0.00 & 0.00 & 0.00 & 0.00 & 0.00 & 0.00 & 0.00 & 0.00 & 0.00 & 0.00 & 0.00 & 0.00 & 0.00 & 0.00 & 0.00 & 0.00 & 0.00 & 0.00 & 0.00 \\
\hline Soma C & 5.00 & 5.00 & 5.00 & 5.00 & 5.00 & 5.00 & 5.00 & 5.00 & 5.00 & 5.00 & 5.00 & 5.00 & 5.00 & 5.00 & 5.00 & 5.00 & 5.00 & 5.00 & 5.00 \\
\hline $\mathrm{BFe}^{+2}$ & 0.19 & 0.16 & 0.18 & 0.20 & 0.25 & 0.21 & 0.23 & 0.02 & 0.03 & 0.03 & 0.02 & 0.00 & 0.03 & 0.00 & 0.02 & 0.00 & 0.09 & 0.00 & 0.08 \\
\hline $\mathrm{BMg}$ & 0.00 & 0.00 & 0.00 & 0.00 & 0.00 & 0.00 & 0.00 & 0.00 & 0.00 & 0.00 & 0.00 & 0.00 & 0.00 & 0.00 & 0.00 & 0.00 & 0.00 & 0.00 & 0.00 \\
\hline $\mathrm{BMn}$ & 0.04 & 0.04 & 0.04 & 0.03 & 0.03 & 0.03 & 0.03 & 0.04 & 0.06 & & 0.05 & 0.05 & 0.05 & 0.04 & 0.05 & 0.05 & 0.03 & 0.01 & 0.04 \\
\hline $\mathrm{BCa}$ & 1.77 & 1.80 & 1.78 & 1.77 & 1.72 & 1.76 & 1.74 & 1.94 & 1.91 & 1.92 & 1.93 & 1.96 & 1.93 & 1.95 & 1.93 & 1.96 & 1.88 & 1.99 & 1.88 \\
\hline BNa & 0.00 & 0.00 & 0.00 & 0.00 & 0.00 & 0.00 & 0.00 & 0.00 & 0.00 & 0.00 & 0.00 & 0.00 & 0.00 & 0.00 & 0.00 & 0.00 & 0.00 & 0.00 & 0.00 \\
\hline Soma B & 2.00 & 2.00 & 2.00 & 2.00 & 2.00 & 2.00 & 2.00 & 2.00 & 2.00 & 2.00 & & & & 2.00 & 2.00 & 2.00 & 2.00 & 2.00 & 2.00 \\
\hline $\mathrm{ACa}$ & 0.00 & 0.00 & 0.00 & 0.00 & 0.00 & 0.00 & 0.00 & 0.00 & 0.00 & 0.00 & 0.00 & 0.00 & 0.00 & 0.00 & 0.00 & 0.00 & 0.00 & 0.00 & 0.00 \\
\hline $\mathrm{ANa}$ & 0.47 & 0.44 & 0.43 & 0.47 & 0.46 & 0.43 & 0.50 & 0.40 & 0.42 & 0.35 & 0.33 & 0.23 & 0.34 & 0.37 & 0.30 & 0.35 & 0.39 & 0.00 & 0.55 \\
\hline$A K$ & 0.06 & 0.04 & 0.05 & 0.07 & 0.08 & 0.05 & 0.08 & 0.19 & 0.21 & 0.19 & 0.17 & 0.08 & 0.15 & 0.19 & 0.17 & 0.18 & 0.20 & 0.01 & 0.30 \\
\hline Soma A & 0.52 & 0.48 & 0.48 & 0.54 & 0.54 & 0.48 & 0.58 & 0.58 & 0.63 & 0.53 & 0.50 & \begin{tabular}{l|}
0.31 \\
\end{tabular} & 0.49 & 0.56 & 0.47 & 0.52 & 0.59 & 0.01 & 0.85 \\
\hline Cátions & \begin{tabular}{|l|}
15.52 \\
\end{tabular} & 15.48 & 15.48 & 15.54 & 15.54 & 15.48 & 15.58 & 15.58 & 15.63 & 15.53 & 15.50 & 15.31 & 55.49 & 15.56 & 45.47 & 15.52 & 45.59 & 15.01 & 45.85 \\
\hline
\end{tabular}


Tabela A4.2: Anfibólios - ANF.

\begin{tabular}{|c|c|c|c|c|c|c|c|c|c|c|c|c|c|c|c|c|c|c|}
\hline Amostra & G-37a & G-37a & G-37a & G-37a & G-37a & G-37a & G-37a & G-37a & G-37a & G-56 & G-56 & G-56 & G-56 & G-56 & G-56 & G-56 & B-10 & $\mathrm{B}-10$ \\
\hline Análise & \begin{tabular}{|l|}
$29 / 1 \mathrm{H} 1.2$ \\
\end{tabular} & 29/1H1.3 & $29 / 2 \mathrm{H} 1.1$ & $29 / 2 \mathrm{H} 1.2$ & $29 / 2 \mathrm{H} 2.1$ & $29 / 2 \mathrm{H} 2.2$ & $29 / 3 \mathrm{H} 1.1$ & $29 / 3 \mathrm{H} 1.2$ & $29 / 3 \mathrm{H} 1.3$ & $35 / 1 \mathrm{H} 1.1$ & $35 / 1 \mathrm{H} 1.2$ & $35 / 2 \mathrm{H} 1.1$ & $35 / 2 \mathrm{H} 1.2$ & $35 / 2 \mathrm{H} 2.1$ & $35 / 2 \mathrm{H} 2.2$ & $35 / 2 \mathrm{H} 2.3$ & $26 / 2 A 01$ & $26 / 2 \mathrm{AO} 2$ \\
\hline Mineral & \begin{tabular}{|l|} 
A.V. \\
\end{tabular} & A.V. & A.V. & A.V. & A.V. & A.V. & A.V. & A.V. & A.V. & A.V. & A.V. & A.V. & A.V. & A.V. & A.V. & A.V. & A.I. & A.I. \\
\hline Local & $P \ln$ & $\mathrm{B}$ & $\mathrm{B}$ & C & B & $\mathrm{C}$ & $B$ & C & Pln & B & $\mathrm{C}$ & $B$ & C & B & Pln & $\mathrm{C}$ & $B$ & $\mathrm{C}$ \\
\hline Litotipo & ABET & ABET & ABET & ABET & ABET & ABET & ABET & ABET & ABET & ABET & ABET & ABET & ABET & ABET & ABET & ABET & $A B G$ & ABG \\
\hline $\mathrm{SiO}_{2}$ & 41.33 & 40.75 & 39.72 & 39.84 & 39.58 & 39.14 & 39.60 & 39.57 & 39.47 & 41.19 & 41.04 & 40.96 & 40.52 & 41.38 & 41.71 & 41.41 & 52.82 & 52.83 \\
\hline $\mathrm{TiO}_{2}$ & 0.30 & 0.19 & 0.16 & 0.33 & 0.33 & 0.30 & 0.28 & 0.27 & 0.36 & 0.48 & 0.44 & 0.51 & 0.33 & 0.31 & 0.36 & 0.41 & 0.00 & 0.00 \\
\hline $\mathrm{Al}_{2} \mathrm{O}_{3}$ & 12.79 & 12.81 & 12.64 & 12.45 & 12.09 & 12.37 & 12.14 & 12.08 & 12.20 & 12.37 & 12.46 & 12.42 & 12.69 & 11.91 & 11.80 & 12.31 & 1.29 & 1.45 \\
\hline $\mathrm{Cr}_{2} \mathrm{O}_{3}$ & 0.00 & 0.00 & 0.00 & 0.00 & 0.00 & 0.00 & 0.00 & 0.00 & 0.00 & 0.00 & 0.00 & 0.00 & 0.00 & 0.00 & 0.00 & 0.00 & 0.00 & 0.00 \\
\hline $\mathrm{ZnO}$ & n.a. & n.a. & n.a. & n.a. & n.a. & n.a. & n.a. & n.a. & n.a. & n.a. & n.a. & n.a. & n.a. & n.a. & n.a. & n.a. & n.a. & n.a. \\
\hline $\mathrm{FeO}$ & 20.90 & 20.69 & 21.13 & 21.07 & 20.75 & 20.40 & 20.99 & 21.19 & 21.37 & 17.54 & 17.64 & 17.68 & 17.61 & 17.36 & 17.72 & 17.48 & 21.95 & 22.97 \\
\hline $\mathrm{MnO}$ & 0.34 & 0.20 & 0.34 & 0.30 & 0.24 & 0.26 & 0.40 & 0.28 & 0.32 & 0.38 & 0.29 & 0.34 & 0.32 & 0.34 & 0.34 & 0.36 & 0.54 & 0.48 \\
\hline $\mathrm{MgO}$ & 7.52 & 7.33 & 6.72 & 6.98 & 6.90 & 6.86 & 6.73 & 6.63 & 6.79 & 8.65 & 8.96 & 8.72 & 8.69 & 8.90 & 8.95 & 8.77 & 17.30 & 17.15 \\
\hline $\mathrm{NiO}$ & 0.00 & 0.00 & 0.00 & 0.00 & 0.00 & 0.00 & 0.00 & 0.00 & 0.00 & 0.00 & 0.00 & 0.00 & 0.00 & 0.00 & 0.00 & 0.00 & 0.00 & 0.00 \\
\hline $\mathrm{CaO}$ & 11.64 & 11.55 & 11.05 & 11.01 & 11.20 & 11.09 & 11.19 & 11.23 & 11.26 & 11.49 & 11.29 & 11.44 & 11.36 & 11.51 & 11.42 & 11.54 & 0.64 & 0.66 \\
\hline $\mathrm{Na}_{2} \mathrm{O}$ & 1.93 & 1.87 & 1.84 & 1.91 & 1.79 & 1.84 & 1.71 & 1.86 & 1.81 & 1.62 & 1.68 & 1.71 & 1.81 & 1.88 & 1.87 & 1.68 & 0.26 & 0.19 \\
\hline $\mathrm{K}_{2} \mathrm{O}$ & 1.69 & 1.60 & 1.23 & 1.63 & 1.59 & 1.50 & 1.46 & 1.58 & 1.63 & 1.07 & 1.13 & 1.24 & 1.22 & 0.91 & 0.96 & 1.11 & 0.00 & 0.00 \\
\hline $\mathrm{P}_{2} \mathrm{O}_{5}$ & 0.00 & 0.00 & 0.00 & 0.00 & 0.00 & 0.00 & 0.00 & 0.00 & 0.00 & 0.00 & 0.00 & 0.00 & 0.00 & 0.00 & 0.00 & 0.00 & 0.00 & 0.00 \\
\hline $\mathrm{BaO}$ & n.a. & n.a. & n.a. & n.a. & n.a. & n.a. & n.a. & n.a. & n.a. & n.a. & n.a. & n.a. & n.a. & n.a. & n.a. & n.a. & n.a. & n.a. \\
\hline$F$ & n.a. & n.a. & n.a. & n.a. & n.a. & n.a. & n.a. & n.a. & n.a. & n.a. & n.a. & n.a. & n.a. & n.a. & n.a. & n.a. & n.a. & n.a. \\
\hline $\mathrm{Cl}$ & 0.00 & 0.00 & 0.00 & 0.00 & 0.00 & 0.00 & 0.00 & 0.00 & 0.00 & 0.06 & 0.07 & 0.00 & 0.00 & 0.00 & 0.00 & 0.00 & 0.00 & 0.00 \\
\hline Total & 98.44 & 96.99 & 94.83 & 95.52 & 94.47 & 93.76 & 94.50 & 94.69 & 95.21 & 94.85 & 95.00 & 95.02 & 94.55 & 94.50 & 95.13 & 95.07 & 94.80 & 95.73 \\
\hline TSi & 6.32 & 6.32 & 6.30 & 6.30 & 6.32 & 6.29 & 6.32 & 6.32 & 6.27 & 6.42 & 6.38 & 6.38 & 6.34 & 6.46 & 6.48 & 6.43 & 7.95 & 7.89 \\
\hline TAl & 1.68 & 1.68 & 1.70 & 1.70 & 1.68 & 1.71 & 1.68 & 1.68 & 1.73 & 1.59 & 1.62 & 1.62 & 1.66 & 1.54 & 1.52 & 1.57 & 0.05 & 0.11 \\
\hline $\mathrm{TFe}^{+3}$ & 0.00 & 0.00 & 0.00 & 0.00 & 0.00 & 0.00 & 0.00 & 0.00 & 0.00 & 0.00 & 0.00 & 0.00 & 0.00 & 0.00 & 0.00 & 0.00 & 0.00 & 0.00 \\
\hline $\mathrm{TTi}$ & 0.00 & 0.00 & 0.00 & 0.00 & 0.00 & 0.00 & 0.00 & 0.00 & 0.00 & 0.00 & 0.00 & 0.00 & 0.00 & 0.00 & 0.00 & 0.00 & 0.00 & 0.00 \\
\hline Soma T & 8.00 & 8.00 & 8.00 & 8.00 & 8.00 & 8.00 & 8.00 & 8.00 & 8.00 & 8.00 & 8.00 & 8.00 & 8.00 & 8.00 & 8.00 & 8.00 & 8.00 & 8.00 \\
\hline CAI & 0.63 & 0.66 & 0.66 & 0.62 & 0.60 & 0.63 & 0.60 & 0.60 & 0.55 & 0.68 & 0.66 & 0.66 & 0.68 & 0.65 & 0.64 & 0.68 & 0.18 & 0.15 \\
\hline $\mathrm{CCr}$ & 0.00 & 0.00 & 0.00 & 0.00 & 0.00 & 0.00 & 0.00 & 0.00 & 0.00 & 0.00 & 0.00 & 0.00 & 0.00 & 0.00 & 0.00 & 0.00 & 0.00 & 0.00 \\
\hline CTi & 0.04 & 0.02 & 0.02 & 0.04 & 0.04 & 0.04 & 0.03 & 0.03 & 0.04 & 0.06 & 0.05 & 0.06 & 0.04 & 0.04 & 0.04 & 0.05 & 0.00 & 0.00 \\
\hline $\mathrm{CFe}^{+3}$ & 0.08 & 0.10 & 0.18 & 0.08 & 0.12 & 0.12 & 0.19 & 0.12 & 0.21 & 0.09 & 0.13 & 0.08 & 0.11 & 0.06 & 0.05 & 0.06 & 0.00 & 0.00 \\
\hline $\mathrm{CMg}$ & 1.72 & 1.69 & 1.59 & 1.65 & 1.64 & 1.64 & 1.60 & 1.58 & 1.61 & 2.01 & 2.08 & 2.03 & 2.03 & 2.07 & 2.07 & 2.03 & 3.88 & 3.82 \\
\hline $\mathrm{CFe}^{+2}$ & 2.54 & 2.52 & 2.55 & 2.61 & 2.60 & 2.57 & 2.58 & 2.67 & 2.59 & 2.17 & 2.09 & 2.18 & 2.15 & 2.18 & 2.20 & 2.18 & 0.94 & 1.04 \\
\hline CMn & 0.00 & 0.00 & 0.00 & 0.00 & 0.00 & 0.00 & 0.00 & 0.00 & 0.00 & 0.00 & 0.00 & 0.00 & 0.00 & 0.00 & 0.00 & 0.00 & 0.00 & 0.00 \\
\hline $\mathrm{CCa}$ & 0.00 & 0.00 & 0.00 & 0.00 & 0.00 & 0.00 & 0.00 & 0.00 & 0.00 & 0.00 & 0.00 & 0.00 & 0.00 & 0.00 & 0.00 & 0.00 & 0.00 & 0.00 \\
\hline Soma C & 5.00 & 5.00 & 5.00 & 5.00 & 5.00 & 5.00 & 5.00 & 5.00 & 5.00 & 5.00 & 5.00 & 5.00 & 5.00 & 5.00 & 5.00 & 5.00 & 5.00 & 5.00 \\
\hline $\mathrm{BFe}^{+2}$ & 0.05 & 0.06 & 0.08 & 0.09 & 0.05 & 0.06 & 0.03 & 0.04 & 0.04 & 0.03 & 0.08 & 0.05 & 0.05 & 0.03 & 0.06 & 0.03 & 1.83 & 1.83 \\
\hline $\mathrm{BMg}$ & 0.00 & 0.00 & 0.00 & 0.00 & 0.00 & 0.00 & 0.00 & 0.00 & 0.00 & 0.00 & 0.00 & 0.00 & 0.00 & 0.00 & 0.00 & 0.00 & 0.00 & 0.00 \\
\hline BMn & 0.04 & 0.03 & 0.05 & 0.04 & 0.03 & 0.04 & 0.05 & 0.04 & 0.04 & 0.05 & 0.04 & 0.05 & 0.04 & 0.05 & 0.05 & 0.05 & 0.07 & 0.06 \\
\hline $\mathrm{BCa}$ & 1.91 & 1.92 & 1.88 & 1.87 & 1.92 & 1.91 & 1.91 & 1.92 & 1.92 & 1.92 & 1.88 & 1.91 & 1.91 & 1.93 & 1.90 & 1.92 & 0.10 & 0.11 \\
\hline $\mathrm{BNa}$ & 0.00 & 0.00 & 0.00 & 0.00 & 0.00 & 0.00 & 0.00 & 0.00 & 0.00 & 0.00 & 0.00 & 0.00 & 0.00 & 0.00 & 0.00 & 0.00 & 0.00 & 0.00 \\
\hline Soma B & 2.00 & 2.00 & 2.00 & 2.00 & 2.00 & 2.00 & 2.00 & 2.00 & 2.00 & 2.00 & 2.00 & 2.00 & 2.00 & 2.00 & 2.00 & 2.00 & 2.00 & 2.00 \\
\hline $\mathrm{ACa}$ & 0.00 & 0.00 & 0.00 & 0.00 & 0.00 & 0.00 & 0.00 & 0.00 & 0.00 & 0.00 & 0.00 & 0.00 & 0.00 & 0.00 & 0.00 & 0.00 & 0.00 & 0.00 \\
\hline $\mathrm{ANa}$ & 0.57 & 0.56 & 0.57 & 0.59 & 0.55 & 0.57 & 0.53 & 0.58 & 0.56 & 0.49 & 0.51 & 0.52 & 0.55 & 0.57 & 0.56 & 0.51 & 0.08 & 0.06 \\
\hline AK & 0.33 & 0.32 & 0.25 & 0.33 & 0.32 & 0.31 & 0.30 & 0.32 & 0.33 & 0.21 & 0.22 & 0.25 & 0.24 & 0.18 & 0.19 & 0.22 & 0.00 & 0.00 \\
\hline Soma A & 0.90 & 0.88 & 0.82 & 0.92 & 0.88 & 0.88 & 0.83 & 0.90 & 0.89 & 0.70 & 0.73 & 0.76 & 0.79 & 0.75 & 0.75 & $\begin{array}{l}0.73 \\
\end{array}$ & 0.08 & 0.06 \\
\hline Cátions & 15.90 & 15.88 & 15.82 & 15.91 & 15.88 & 15.88 & 15.83 & 15.90 & 15.89 & 15.70 & 15.73 & 15.76 & 15.79 & 15.75 & 15.75 & 15.73 & 15.08 & 15.06 \\
\hline
\end{tabular}


Tabela A4.2: Anfibólios - ANF.

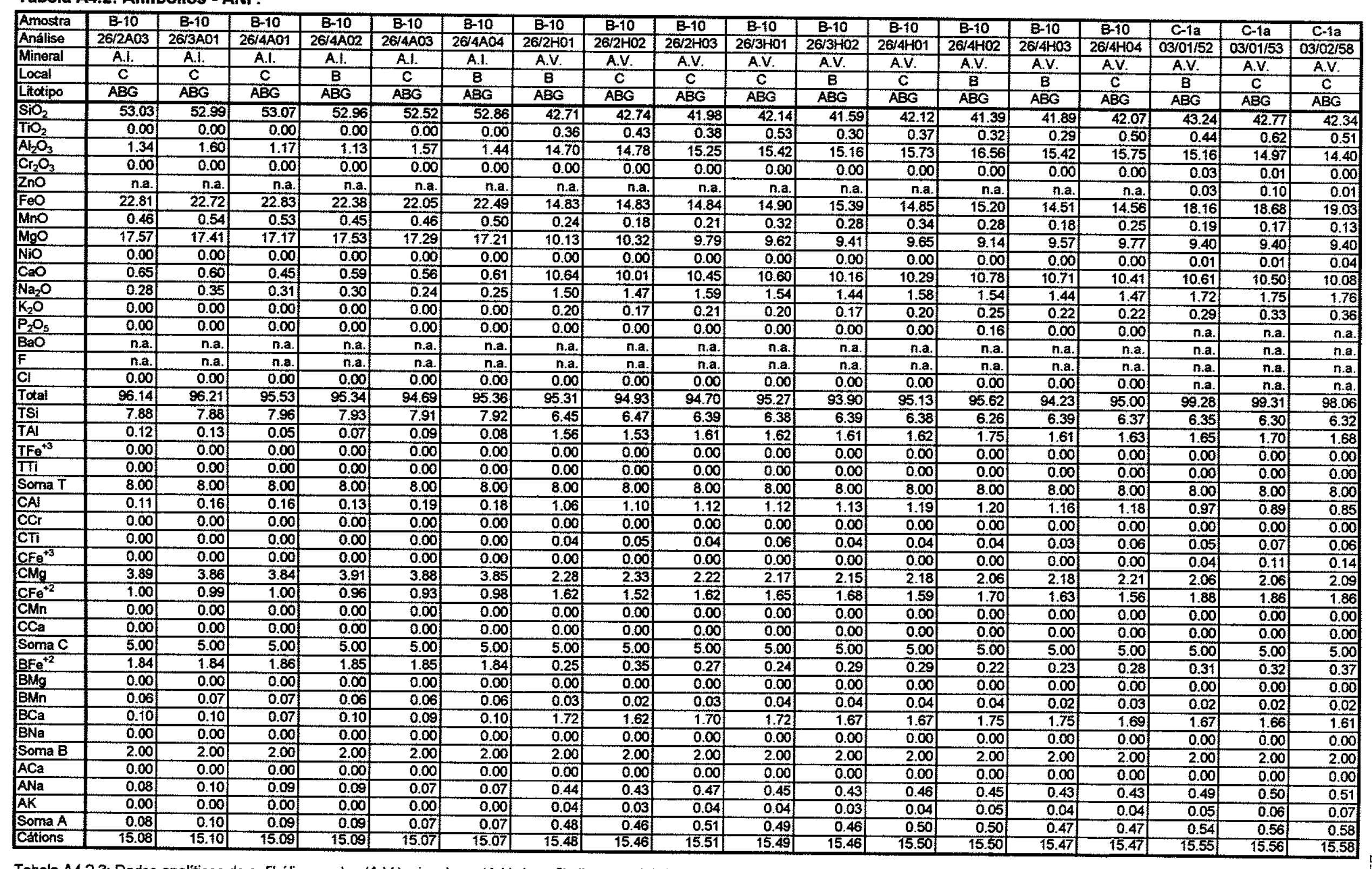

Tabela A4.2.3: Dados analíticos de anfibólios verdes (A.V.) e incolores (A.I.) de anfibolitos metabásicos $A B, A B E T$ e $A B G$. Fórmula estrutural: $23(O)$. 
Tabela A4.2: Anfibólios - ANF.

\begin{tabular}{|c|c|c|c|c|c|c|c|c|c|c|c|c|c|c|c|c|c|c|}
\hline Amostra & C-1a & C-1a & G-54b & G-54b & G.54b & G-54b & G-54b & G-54b & G-54b & G-54b & $G-54 b$ & $G-54 b$ & G-54b & $G-54 b$ & G-54b & $G-54 b$ & $G-54 b$ & G-54b \\
\hline Anatise & $03 / 04 / 62$ & $03 / 04 / 63$ & 6/1H1.1 & 61H1.2 & $6 / 1 \mathrm{H} 1.3$ & $6 / 1 \mathrm{H} 1.4$ & 6/1H1.5 & $6 / 1+2.1$ & $6 / 1 \mathrm{H} 2.2$ & $6 / 1 \mathrm{H} 2.3$ & $6 / \mathrm{HO1} .1$ & $6 / 1+01.2$ & 6/H01.3 & $6 / H 02.1$ & $6 / 1+02.2$ & $6 / H 02.3$ & $6 / 1+03.1$ & G/H03.2 \\
\hline Local & $\frac{\text { A.V. }}{B}$ & A.V. & A.V. & A.V. & A.V. & A.V. & A.V. & A.V. & A.V. & A.V. & A.V. & A.V. & A.V. & A.V. & A.V. & A.V. & A.V. & A.V. \\
\hline Litotipo & $\frac{\mathrm{D}}{\mathrm{ABG}}$ & $\frac{C}{A B G}$ & $\frac{B}{A R G}$ & 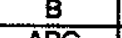 & Pim & Pln & C & B & Pin & C & B & $B$ & Pln & B & B & $c$ & $B$ & Pin \\
\hline $\mathrm{SiO}_{2}$ & 40.96 & 42.14 & 40.34 & ABG & $A B G$ & $A B G$ & $A B G$ & ABG & ABG & $A B G$ & $\mathrm{ABG}$ & $A B G$ & $A B G$ & $A B G$ & $A B G$ & $\overline{A B G}$ & $\overline{A B G}$ & $\overline{A B G}$ \\
\hline $\mathrm{TiO}_{2}$ & 0.35 & 0.51 & 0.49 & $\frac{41.07}{0.37}$ & 40.05 & 40.10 & 40.22 & 40.54 & 40.41 & 40.40 & 40.50 & 40.56 & 40.12 & 41.78 & 41.31 & 41.35 & 40.67 & 40.76 \\
\hline $\mathrm{Al}_{2} \mathrm{O}_{3}$ & 16.43 & 15.31 & 15.01 & 14.50 & $\frac{0.20}{14.92}$ & 0.43 & $\frac{0.52}{15.39}$ & 0.31 & 0.42 & 0.49 & 0.42 & 0.50 & 0.45 & 0.40 & 0.41 & $0.44]$ & 0.20 & 0.53 \\
\hline $\mathrm{Cr}_{2} \mathrm{O}_{3}$ & 0.01 & 0.04 & 0.00 & 0.00 & $\frac{11.05}{0.00}$ & 14.95 & $\frac{15.26}{0 \mathrm{~m}}$ & 14.33 & 14.74 & 15.00 & 14.74 & 14.58 & 14.99 & 14.15 & 14.22 & 14.09 & 14.95 & 14.62 \\
\hline $\mathrm{ZnO}$ & 0.00 & 0.00 & n.a. & n.a. & $n$ & 0.00 & 0.00 & 0.00 & 0.00 & 0.00 & 0.00 & 0.00 & 0.00 & 0.00 & $0 . \infty$ & 0.00 & 0.00 & 0.00 \\
\hline $\mathrm{FeO}$ & 19.98 & 18.33 & 18.32 & 17.39 & 18.13 & 18.3. & n.a. & n.a. & n.a. & n.a. & n.a. & n.a. & n.a. & n.a. & ก.a. & n.a. & ก.a. & n.a. \\
\hline $\mathrm{MnO}$ & 0.16 & 0.19 & 0.00 & 0.00 & & 0.04 & 18.06 & $\{7.68$ & 18.07] & 18.04 & 18.10 & 17.47 & 18.02 & 17.82 & 18.28 & 18.01 & 17.85 & 18.01 \\
\hline $\mathrm{MgO}$ & 7.59 & 9.17 & 766 & 810 & & 0.76 & 0.00 & 0.00 & 0.00 & 0.23 & 0.00 & 0.00 & 0.17 & 0.00 & 0.16 & 0.15 & 0.17 & 0.00 \\
\hline NiO & 0.00 & 0.00 & 0.00 & 0.00 & $\frac{1.6}{n m}$ & 7.80 & 7.72 & 8.03 & 7.93 & 7.97 & 7.92 & 7.97 & 8.00 & 8.47 & 8.36 & 8.39 & 7.64 & 8.01 \\
\hline $\mathrm{CaO}$ & 10.67 & 10.79 & 10.38 & 10.22 & 10.00 & 0.00 & 0.00 & 0.00 & 0.00 & 0.00 & 0.00 & 0.00 & 0.00 & 0.00 & 0.00 & 0.00 & 0.00 & 0.00 \\
\hline $\mathrm{Na}_{2} \mathrm{O}$ & 1.68 & 172 & 1.74 & 171 & 10.30 & 10.21 & 10.24 & 10.22 & 10.30 & 10.31 & 10.17 & 10.21 & 10.29 & 9.93 & 9.91 & 10.21 & 10.56 & 10.53 \\
\hline $\mathrm{K}_{2} \mathrm{O}$ & 0.29 & 0.25 & 0.31 & 0.33 & $\frac{1.81}{0.40}$ & 7.10 & 1.88 & 1.75 & 1.90 & 1.84 & 4.81 & 1.82 & 1.84 & 1.64 & 1.64 & 1.62 & 1.72 & 1.84 \\
\hline $\mathrm{P}_{2} \mathrm{O}_{5}$ & n.a. & ก.a. & 0.00 & 0.00 & 0.00 & $0 .+1$ & 0.49 & 0.25 & 0.40 & 0.48 & 0.35 & 0.37 & 0.42 & 0.31 & 0.39 & 0.33 & 0.29 & 0.30 \\
\hline $\mathrm{BaO}$ & n.a. & n.a. & n.a. & n.a. & n.a. & n.a. & $\frac{0.00}{n a}$ & $\frac{0.00}{n a}$ & 0.00 & 0.00 & 0.00 & 0.00 & 0.00 & 0.00 & 0.00 & 0.00 & 0.00 & 0.00 \\
\hline $\mathbf{F}$ & n.a. & ก.a. & n.a. & n.a. & n.a. & n.a. & $\frac{n . a .}{n . a}$ & 0 & n.a. & n.a. & n.a. & n.a. & ก.a. & n.a. & n.a. & n.a. & n.a. & n.a. \\
\hline $\mathrm{Cl}$ & n.a. & n.a. & 0.00 & 0.00 & 0.00 & 0.00 & 000 & 000 & n.a. & n.a. & n.a. & n.a. & n.a. & n.a. & n.a. & ก.a. & n.a. & n.a. \\
\hline Total & 98.12 & 98.45 & 94.25 & 9369 & 9383 & 9408 & 0.00 & 0.00 & 0.00 & 0.00 & 0.00 & 0.00 & 0.00 & 0.00 & 0.00 & 0.00 & 0.00 & 0.00 \\
\hline $\mathrm{TSi}$ & 6.13 & \begin{tabular}{|c|}
6.24 \\
\end{tabular} & 6.29 & 6.42 & 6.27 & 6.26 & 6.27 & 639 & 94.17 & 94.76 & 94.01 & 93.48 & 94.30 & 94.50 & 94.68 & 94.59 & 94.05 & 94.60 \\
\hline TAN & 4.87 & 1.76 & 1.71 & 1.58 & 1.73 & 1.74 & & & 6.37 & 6.27 & 6.33 & 6.37 & 6.25 & 6.47 & 6.40 & 6.40 & 6.34 & 6.33 \\
\hline $\mathrm{TFe}^{+3}$ & 0.00 & 0.00 & 0.00 & 0.00 & 0,00 & 000 & 1.13 & 0.02 & 1.69 & 1.73 & 1.67 & 1.63 & 1.75 & 1.53 & 1.60 & 1.60 & 1.66 & 1.68 \\
\hline$\pi$ & 0.00 & 0.00 & 0.00 & 0.00 & 0.00 & 0.00 & 0.00 & 0.00 & 0.0 & 0.00 & 0.00 & 0.00 & 0.00 & 0.00 & 0.00 & 0.00 & 0.00 & 0.00 \\
\hline Soma T & 8.00 & 8.00 & 8.00 & 8.00 & 8.00 & 8.00 & 8.00 & 8.00 & 0.00 & 0.00 & 0.00 & 0.00 & 0.00 & 0.00 & 0.00 & 0.00 & 0.00 & 0.00 \\
\hline CAI & 1.03 & 0.91 & 1.04 & 1.09 & 1.03 & 101 & 108 & 103 & $\frac{8.00}{100}$ & 8.00 & 8.00 & 8.00 & 8.00 & 8.00 & 8.00 & 8.00 & 8.00 & 8.00 \\
\hline $\mathrm{CCr}$ & 0.00 & 0.01 & 0.00 & 000 & 0,00 & 0,00 & 000 & 000 & $\frac{1.02}{0.00}$ & 1.01[ & 1.04 & 1.06 & 1.00 & 1.05 & 0.99 & 0.97 & 1.09 & 1.00 \\
\hline CTi & 0.04 & 0.06 & 0.06 & & & & & & 0.00 & 0.00 & 0.00 & 0.00 & 0.0 & 0.00 & 0.00 & 0.00 & 0.00 & 0.00 \\
\hline $\mathrm{CFe}^{+3}$ & 0.21 & 0.19 & 0.00 & & 000 & & 0.00 & 0.04 & 0.05 & 0.06 & 0.05 & 0.06 & 0.05 & 0.05 & 0.05 & 0.05 & 0.02 & 0.06 \\
\hline & & & & & & & 0.00 & 0.00 & 0.00 & 0.00 & 0.00 & 0.00 & 0.00 & 0.00 & 0.00 & 0.00 & 0.00 & 0.00 \\
\hline $\mathrm{CFe}^{+2}$ & 2.02 & 181 & 212 & & 1.01 & 1.82 & 1.80 & 1.88 & 1.85 & 1.84 & 1.85 & 1.87 & 1.86 & 1.95 & 1.93 & 1.94 & 1.78 & 1.85 \\
\hline CMn & 0.00 & 0.00 & 0.00 & 0.00 & 2.11 & $2.0 \mathrm{~g}$ & 2.07 & 2.05 & 2.08 & 2.09| & 2.07 & 2.01 & 2.09] & 1.95 & 2.03 & 2.04 & 2.11 & 2.09 \\
\hline $\mathrm{CCa}$ & 0.00 & 0.00 & 0.00 & 0.00 & 0.00 & 0.0 & 0.00 & 0.00 & 0.00 & 0.00 & 0.00 & 0.00 & 0.00 & 0.00 & 0.00 & 0.00 & 0.00 & 0.00 \\
\hline Soma C & 5.00 & 500 & 5.00 & 5.00 & 0.00 & 0.001 & 0.00 & 0.00 & 0.00 & 0.00 & 0.00 & 0.00 & 0.00 & 0.00 & 0.00 & 0.00 & 0.00 & 0.00 \\
\hline $\mathrm{BFe}^{+2}$ & 0.27 & 0.26 & 0.27 & $\frac{5.00}{0.29}$ & 5.00 & 5.00 & 5.00 & 5.00 & 5.00 & 5.00 & 5.00 & 5.00 & 5.00 & 5.00 & 5.00 & 5.00 & 5.00 & 5.00 \\
\hline$B M g$ & 0.00 & 0.00 & 0.00 & $0 . \infty$ & 0.20 & 0.27 & 0.29 & 0.28 & 0.28 & 0.26 & 0.30 & 0.28 & 0.26 & 0.35 & 0.34 & 0.29 & 0.21 & 0.25 \\
\hline $\mathrm{BMn}$ & 0.02 & 0.02 & 0.00 & $0 . \infty$ & 0.00 & 0.02 & $\frac{0.00}{0.00}$ & o.00 & 0.00 & 0.00 & 0.00 & 0.00 & 0.00 & 0.00 & 0.00 & 0.00 & 0.00 & 0.00 \\
\hline $\mathrm{BCa}$ & 1.71 & 1.71 & 173 & 1.71 & 1.74 & 1.71 & 1.71 & 1.00 & 1.90 & 1.03 & 0.00 & 0.00 & 0.02 & 0.00 & 0.02 & 0.02 & 0.02 & 0.00 \\
\hline $\mathrm{BNa}$ & 0.00 & 0.00 & 0.00 & 0.00 & 0.00 & 0.00 & 000 & $0 \mathrm{mt}$ & & 1.14 & 3.70 & 1.72 & $1 . / 2$ & 1.65 & 1.64 & 1.69 & 1.76 & 1.75 \\
\hline Sorma B & 2.00 & 2.00 & 2.00 & 200 & 200 & 200 & $2 m$ & $\frac{0.00}{200}$ & o.w & 0.00 & 0.00 & 0.00 & 0.00 & 0.00 & 0.00 & 0.00 & 0.00 & 0.00 \\
\hline $\mathrm{ACa}$ & 0.00 & 0.00 & 0.00 & & & & & 2.04 & 2.00 & 2.0 & 2.00 & 2.00 & 2.00 & 2.00 & 2.00 & 2.00 & 2.00 & 2.00 \\
\hline$\overline{\mathrm{ANa}}$ & 0.49 & & 053 & & & 0.0 & 0.0 & 0.00 & 0.00 & 0.00 & 0.00 & 0.00 & 0.00 & 0.00 & 0.00 & 0.00 & 0.00 & 0.00 \\
\hline AK & 0.06 & 0.05 & 0.06 & $\begin{array}{l}0.02 \\
0.07\end{array}$ & 0.00 & 0.52 & 0.57 & 0.53 & 0.58 & 0.55 & 0.55 & 0.55 & 0.56 & 0.49 & 0.49 & 0.49 & 0.52 & 0.55 \\
\hline Soma A & 0.54 & 0.54 & 0.59 & 0.58 & 0.00 & 0.00 & $\frac{0.70}{0.67}$ & 0.05 & 0.08 & 0.10 & 0.07 & 0.07 & 0.08 & 0.06 & 0.08 & 0.07 & 0.06 & 0.06 \\
\hline Cátions & 15.54 & 15.54 & 15.59 & 15.58 & 15.63 & 15.60 & $\frac{0.67}{15.67}$ & \begin{tabular}{r|}
0.58 \\
1558
\end{tabular} & $\frac{0.66}{15.65}$ & 0.65 & 0.62 & 0.63 & 0.64 & 0.55 & 0.57 & 0.55 & 0.58 & 0.61 \\
\hline & & & & & & 0.00 & 15.08 & 75.50 & 15.65 & 15.65 & $15.62]$ & 15.63 & 15.64 & 15.55 & 15.57 & 15.55 & 15.58 & 15.61 \\
\hline
\end{tabular}


Tabela A4.2: Anfibólios - ANF.

\begin{tabular}{|c|c|c|c|c|c|c|c|c|c|c|c|c|c|c|c|c|c|c|}
\hline \begin{tabular}{|l|} 
Amostra \\
Análise
\end{tabular} & G-54b & G-54b & $1-01$ & $\frac{1-01}{101}$ & $\frac{1-01}{1}$ & $1-01$ & $1-01$ & $1-01$ & $1-01$ & $1-01$ & $1-01$ & 1.01 & $1-01$ & $1-01$ & T-01 & $1-01$ & $1-01$ & $1-01$ \\
\hline Mineral & A.V. & AV & AV & AY & AVITUS & TO1H04 & $10011+105$ & 10/2H+01 & $10 / 2+102$ & $10 / 2 H_{03}$ & 10/2HO4 & $10 / 2+405$ & $10 / 2 \mathrm{H} 06$ & $10 / 21707$ & $10 / 2 \mathrm{H} 08$ & $10 / 2 H 1.1$ & $10 / 2 \mathrm{H} 1.2$ & $10 / 2 \mathrm{H} 1.4$ \\
\hline Local & PIn & $\frac{M \cdot v}{P \text { in }}$ & $\frac{\text { A.V. }}{B}$ & $\frac{\text { A.V. }}{P \ln }$ & $\frac{\text { A.V. }}{\text { C }}$ & A.V. & A.V. & A.V. & A.V. & A.V. & A.V. & A.V. & A.V. & A.V. & A.V. & A.V. & A.V. & A.V. \\
\hline Litotipo & $\overline{A B G}$ & $A B G$ & $A B G$ & $A B G$ & $\frac{C}{A B G}$ & $\frac{B}{A B C}$ & C & $\mathrm{C}$ & $\mathrm{B}$ & $\mathrm{C}$ & $\mathrm{c}$ & $B$ & $\mathrm{~B}$ & B & B & B & $\mathrm{Pln}$ & $\mathrm{B}$ \\
\hline $\mathrm{SiO}_{2}$ & 40.76 & 41.33 & 41.94 & 42.15 & 41.73 & $\frac{A B G}{41.52}$ & $A B G$ & $A B G$ & $A B G$ & ABG & $A B G$ & $A B G$ & $A B G$ & ABG & $\mathrm{ABG}$ & $\mathrm{ABG}$ & ABG & ABG \\
\hline $\mathrm{THO}_{2}$ & 0.42 & 0.46 & 0.38 & 0.41 & 0.35 & $\begin{array}{r}41.52 \\
0.43\end{array}$ & 41.53 & 41.37 & 40.35 & 41.29 & 41.49 & 43.31 & 41.68 & 41.57 & 43.38 & 41.30 & 41.99 & 41.27 \\
\hline $\mathrm{Al}_{2} \mathrm{O}_{3}$ & 14.59 & 14.37 & 12.64 & 12.68 & 12.64 & $\begin{array}{r}0.43 \\
12.80\end{array}$ & 0.51 & 0.53 & 0.53 & 0.58 & 0.55 & 0.50 & 0.57 & 0.42 & 0.37 & 0.48 & 0.50 & 0.35 \\
\hline $\mathrm{Cr}_{2} \mathrm{O}_{3}$ & 0.00 & 0.00 & 0.00 & 0.00 & 0.00 & $\frac{12.80}{0.00}$ & 13.04 & 13.64 & 14.03 & 13.39 & 13.27 & 13.25 & 12.62 & 12.56 & 13.29 & 13.85 & 12.76 & 14.48 \\
\hline $2 \mathrm{nO}$ & n.a. & n.a. & n.a. & n.a. & n.a. & $\frac{0.00}{\text { n.a. }}$ & 0.00 & 0.00 & 0.00 & 0.00 & 0.00 & 0.00 & 0.00 & 0.00 & 0.00 & 0.00 & 0.00 & 0.00 \\
\hline $\mathrm{FeO}$ & 17.63 & 17.94 & 17.20 & 17.43 & 17.35 & $\frac{\text { n.a. }}{17.53}$ & n.a. & n.a. & n.a. & n.a. & n.a. & n.a. & n.a. & n.a. & n.a. & n.a. & n.a. & n.a. \\
\hline $\mathrm{MnO}$ & 0.00 & 0.00 & 0.32 & 0.37 & \begin{tabular}{|c|}
0.34 \\
\end{tabular} & 0.39 & $\frac{17.55}{0.46}$ & 18.17 & 18.08 & 18.29 & 17.59 & 18.46 & 17.88 & 17.44 & 18.29 & 18.07 & 18.14 & 17.77 \\
\hline $\mathrm{MgO}$ & 8.17 & 8.35 & 9.19 & 9.10 & 9.12 & 9.08 & 0.46 & 0.39 & 0.47 & 0.37 & 0.33 & 0.29 & 0.42 & 0.41 & 0.35 & 0.32 & 0.38 & 0.36 \\
\hline $\mathrm{NiO}$ & 0.00 & 0.00 & 0.00 & 0.00 & 0.00 & 0.00 & $\frac{9.03}{0.00}$ & 8.48 & 8.53 & 8.53 & 8.47 & 8.96 & 8.69 & 8.85 & 9.05 & 8.32 & 8.61 & 8.33 \\
\hline $\mathrm{CaO}$ & 10.42 & 10.40 & 10.46 & 10.44 & 10.48 & 10.57 & 10.66 & $\frac{0.00}{10.30}$ & 0.00 & 0.00 & 0.00 & 0.00 & 0.00 & 0.00 & 0.00 & 0.00 & 0.00 & 0.00 \\
\hline $\mathrm{Na}_{2} \mathrm{O}$ & 1.67 & 1.61 & 1.81 & 1.92 & 1.81 & 1.91 & $\frac{1.00}{1.83}$ & $\frac{10.30}{1.85}$ & 10.40 & 10.47 & 10.86 & 10.78 & 10.47 & 10.49 & 10.87 & 10.53 & 10.61 & 10.48 \\
\hline $\mathrm{K}_{2} \mathrm{O}$ & 0.27 & 0.29 & 0.38 & 0.45 & 0.34 & 0.43 & 0.47 & $\frac{1.85}{0.44}$ & 1.87 & 1.81 & 1.77 & 1.97 & 1.95 & 1.76 & 1.97 & 1.89 & 1.92 & 1.96 \\
\hline $\mathrm{P}_{2} \mathrm{O}_{5}$ & 0.00 & 0.00 & 0.00 & 0.00 & 0.00 & 0.00 & 0.00 & $\frac{0.44}{0.00}$ & 0.47 & 0.45 & 0.38 & 0.40 & 0.38 & 0.30 & 0.36 & 0.44 & 0.36 & 0.31 \\
\hline $\mathrm{BaO}$ & ก.a. & n.a. & n.a. & n.a. & n.a. & n.a. & n.a. & 0.00 & 0.00 & 0.00 & 0.00 & 0.00 & 0.00 & 0.00 & $0 . \infty$ & 0.00 & 0.00 & 0.00 \\
\hline$F$ & ก.ล. & n.a. & n.a. & ก.a. & n.a. & ก.a. & n.a. & n.a. & n.a. & n.a. & n.a. & n.a. & n.a. & n.a. & n.a. & ก.a. & n.a. & n.a. \\
\hline $\mathrm{Cl}$ & 0.00 & 0.00 & 0.00 & 0.09 & 0.07 & 0.11 & 0.14 & n.a. & n.a. & n.a. & n.a. & n.a. & n.a. & n.a. & n.a. & n.a. & n.a. & n.a. \\
\hline Total & 93.93 & 94.75 & 94.32 & 95.04 & 94.23 & 94.77 & 9523 & 0.10 & 0.14 & 0.12 & 0.10 & 0.08 & 0.12 & 0.06 & 0.07 & 0.12 & 0.07 & 0.11 \\
\hline TSi & 6.35 & 6.38 & 6.51 & \begin{tabular}{l|}
6.52 \\
\end{tabular} & \begin{tabular}{|c|}
6.49 \\
\end{tabular} & 6.44 & 6.41 & $\frac{50.41}{6.40}$ & 94.81 & 95.30 & 94.81 & 98.00 & 94.78 & 93.86 & 98.00 & 95.32 & 95.34 & 95.42 \\
\hline TAI & 1.65 & 1.62 & 1.49 & 1.48 & $1.51]$ & 1.56 & 159 & $\frac{0.40}{1.61}$ & 6.26 & 6.38 & 6.43 & 6.50 & 6.48 & 6.49 & 6.50 & 6.38 & 6.49 & 6.36 \\
\hline $\mathrm{TFe}^{+3}$ & 0.00 & 0.00 & 0.00 & 0.00 & 0.00 & 0.00 & 0.00 & $\frac{1.61}{0.00}$ & 1.74 & 1.62 & 1.57 & 1.50 & 1.52 & 1.51 & 1.50 & 1.62 & 1.51 & 1.64 \\
\hline TTi & 0.00 & 0.00 & 0.00 & 0.00 & 0.00 & 0.00 & 0.00 & & 0.00 & 0.00 & 0.00 & 0.00 & 0.00 & 0.00 & 0.00 & 0.00 & 0.00 & 0.00 \\
\hline Soma T & 8.00 & 8.00 & 8.00 & 8.00 & 8.00 & 8.00 & 8.00 & $\frac{0.00}{8.00}$ & 0.00 & 0.00 & 0.00 & 0.00 & 0.00 & 0.00 & 0.00 & 0.00 & 0.00 & 0.00 \\
\hline CAI & 1.02 & 0.99 & 0.82 & 0.82 & 0.80 & 0.77 & 0.78 & $\frac{0.00}{0.88}$ & 8.00 & 8.00 & 8.00 & 8.00 & 8.00 & 8.00 & 8.00 & 8.00 & 8.00 & 8.00 \\
\hline $\mathrm{CCr}$ & 0.00 & 0.00 & 0.00 & 0.00 & 0.00 & 0,00 & 0.00 & 0.80 & 0.85 & 0.82 & 0.85 & 0.85 & 0.79 & 0.80 & 0.85 & 0.91 & 0.81 & 0.98 \\
\hline CTi & 0.05 & 0.05 & & 0.05 & & 005 & & 0.00 & 0.00 & 0.00 & 0.00 & 0.00 & 0.00 & 0.00 & $0 . \infty$ & 0.00 & 0.00 & 0.00 \\
\hline $\mathrm{CFe}^{+3}$ & 0.00 & 0.00 & 0.00 & 0.00 & 0.02 & 0.00 & 0.00 & 0.06 & 0.06 & 0.07 & 0.06 & 0.06 & 0.07 & 0.05 & 0.04 & 0.06 & 0.06 & 0.04 \\
\hline $\mathrm{CMg}$ & 1.90 & 1.92 & 2.13 & 2.10 & 2.11 & $\begin{array}{l}0.03 \\
2.10\end{array}$ & $\frac{0.00}{2.08}$ & 0.00 & 0.13 & 0.03 & 0.00 & 0.00 & 0.00 & 0.01 & 0.00 & 0.00 & 0.00 & 0.00 \\
\hline $\mathrm{CFe}^{+2}$ & 2.03 & 2.04 & 2.01 & 2.03 & 2.03 & $\frac{2.10}{2.05}$ & $\frac{2.00}{2.03}$ & $\frac{1.95}{2.11}$ & 1.97 & 1.97 & 1.96 & 2.01 & 2.02 & 2.06 & 2.02 & 1.92 & 1.98 & 1.91 \\
\hline CMn & 0.00 & 0.00 & 0.00 & 0.00 & 0.00 & 0.00 & 0.00 & $\frac{2.11}{0.00}$ & 2.01 & 2.12 & 2.13 & 2.09 & 2.13 & 2.07 & 2.08 & 2.12 & 2.15 & 2.07 \\
\hline $\mathrm{CCa}$ & 0.00 & 0.00 & 0.00 & 0.00 & 0.00 & 0.00 & 0.00 & 0.00 & 0.00 & 0.00 & 0.00 & 0.00 & 0.00 & $0 . \infty$ & 0.00 & 0.00 & 0.00 & 0.00 \\
\hline Soma C & $5 . \infty 0$ & 5.00 & 5.00 & 5.00 & 5.00 & 500 & 500 & $\frac{0.00}{5 m}$ & 0.00 & 0.00 & 0.00 & 0.00 & 0.00 & 0.00 & 0.00 & 0.00 & 0.00 & 0.00 \\
\hline $\mathrm{BFe}^{+2}$ & 0.26 & 0.28 & 0.22 & 0.22 & 0.21 & 0.19 & 0.18 & $\frac{5.00}{0.24}$ & 5.00 & 5.00 & 5.00 & 5.00 & 5.00 & 5.00 & 5.00 & 5.00 & 5.00 & 5.00 \\
\hline BMg & 0.00 & 0.00 & 0.00 & 0.00 & 0.00 & 0.00 & & 0.24 & 0.21 & 0.22 & 0.15 & 0.23 & 0.20 & 0.19 & 0.21 & 0.21 & 0.19 & 0.22 \\
\hline BMn & 0.00 & 0.00 & 0.04 & 0.05 & 0.05 & 0.05 & $\frac{.00}{0.06}$ & 0.00 & 0.00 & 0.00 & 0.00 & 0.00 & 0.00 & 0.00 & 0.00 & 0.00 & 0.00 & 0.00 \\
\hline $\mathrm{BCa}$ & 1.74 & 1.72 & 1.74 & 1.73 & 1.75 & 1.76 & $\frac{0.00}{1.76}$ & 0.05 & 0.06 & 0.05 & 0.04 & 0.04 & 0.06 & 0.05 & 0.04 & 0.04 & 0.05 & 0.05 \\
\hline $\mathrm{BNa}$ & 0.00 & 0.00 & 0.00 & 0.00 & 0.00 & 0.00 & 1.16 & 1.71 & 1.73 & 1.73 & 1.80 & 1.74 & 1.75 & 1.76 & 1.75 & 1.74 & 1.76 & 1.73 \\
\hline Soma B & 2.00 & 2.00 & 2.00 & 2.00 & 2.00 & 2.00 & $\frac{0.00}{2.00}$ & 0.00 & 0.00 & 0.00 & 0.00 & 0.00 & 0.00 & 0.00 & 0.00 & 0.00 & 0.00 & 0.00 \\
\hline $\mathrm{ACa}$ & 0.00 & 0.00 & 0.00 & 0.00 & 0.00 & 0.00 & $\frac{2.00}{0.00}$ & 2.00 & 2.00 & 2.00 & 2.00 & 2.00 & 2.00 & 2.00 & 2.00 & 2.00 & 2.00 & 2.00 \\
\hline $\mathrm{ANa}$ & 0.50 & 0.48 & 0.55 & 0.58 & 0.55 & 0.57 & 0.00 & $0 . \infty$ & 0.00 & 0.00 & 0.00 & 0.00 & 0.00 & 0.00 & 0.00 & 0.00 & 0.00 & 0.00 \\
\hline AK & 0.05 & 0.06 & 0.08 & 0.09 & 0.07 & 0.09 & $\frac{.00}{0.09}$ & 0.56 & 0.56 & 0.54 & 0.53 & 0.57 & 0.59 & 0.53 & 0.57 & 0.57 & 0.58 & 0.59 \\
\hline Soma A & 0.56 & 0.54 & 0.62 & 0.67 & \begin{tabular}{l|l|}
0.61 \\
\end{tabular} & 0.66 & 0.09 & 0.09 & 0.09 & 0.09 & 0.08 & 0.08 & 0.08 & 0.06 & 0.07 & 0.09 & 0.07 & 0.06 \\
\hline Cátions & 15.56 & 15.54 & 15.62 & 15.66 & 15.61 & 15.66 & 15.64 & $\frac{0.64}{1564}$ & 0.66 & 0.63 & 0.61 & 0.65 & 0.66 & 0.59 & 0.64 & 0.65 & 0.65 & 0.65 \\
\hline & & & & & & 10.00 & 10.04 & 15.64 & 15.66 & 15.63 & 15.61 & 15.65 & 15.66 & 15.59 & 15.64 & 15.65 & 15.65 & 15.65 \\
\hline
\end{tabular}


Tabela A4.2: Anfibólios - ANF.

\begin{tabular}{|c|c|c|c|c|c|c|c|}
\hline Amostra & $1-01$ & $1-01$ & $1-01$ & $1-01$ & $1-01$ & $1-01$ & $1-01$ \\
\hline Análise & $10 / 3 \mathrm{HOH}$ & $10 / 3 \mathrm{HO2}$ & $10 / 3 \mathrm{H} 03$ & $10 ; 3+104$ & $10 / 3+105$ & $10 / 4 \mathrm{H} 01$ & $10 / 4 \mathrm{HO}$ \\
\hline Mineral & A.V. & A.V. & A.V. & A.V. & A.V. & A.V. & A.V. \\
\hline Local & $B$ & c & $\mathrm{C}$ & $c$ & B & $B$ & c \\
\hline Litotipo & $\overline{A B G}$ & $\overline{A B G}$ & $\widehat{A B G}$ & $A B G$ & $\overline{A B G}$ & $\overline{A B G}$ & $A B G$ \\
\hline $\mathrm{SKO}_{2}$ & 42.06 & 41.27 & 41.60 & 41.34 & 41.63 & 42.34 & 42.04 \\
\hline $\mathrm{TiO}_{2}$ & 0.42 & 0.48 & 0.52 & 0.55 & 0.52 & 0.34 & 0.41 \\
\hline $\mathrm{Al}_{2} \mathrm{O}_{3}$ & 12.82 & 13.08 & 12.90 & 12.84 & 12.74 & 12.49 & 12.55 \\
\hline $\mathrm{C}_{2} \mathrm{O}_{3}$ & 0.00 & 0.00 & 0.00 & 0.00 & 0.00 & 0.00 & 0.00 \\
\hline $2 \pi 0$ & n.a. & n.a. & n.a. & n.a. & n.a. & ก.a. & n.a. \\
\hline$F \in O$ & 17.44 & 17.30 & 17.61 & 17.59 & 17.26 & 17.13 & 17.46 \\
\hline $\mathrm{MnO}$ & 0.34 & 0.34 & 0.34 & 0.33 & 0.36 & \begin{tabular}{l|}
0.31 \\
\end{tabular} & 0.32 \\
\hline MgO & 8.98 & 8.66 & 9.02 & 8.86 & 8.83 & 9.36 & 9.15 \\
\hline NiO & 0.00 & 0.00 & 0.00 & 0.00 & 0.00 & 0.00 & 0.00 \\
\hline $\mathrm{COO}$ & 10.37 & 10.50 & 10.43 & 10.29 & 10.50 & 10.64 & 10.35 \\
\hline $\mathrm{Na}_{2} \mathrm{O}$ & 1.75 & 1.78 & 1.92 & 1.88 & 1.91 & 1.72 & 1.96 \\
\hline $\mathrm{K}_{2} \mathrm{O}$ & 0.43 & 0.45 & 0.38 & 0.38 & 0.34 & 0.30 & 0.38 \\
\hline $\mathrm{P}_{2} \mathrm{O}_{5}$ & 0.00 & 0.00 & 0.00 & 0.00 & 0.00 & 0.00 & 0.00 \\
\hline $\mathrm{BaO}$ & ก.a. & n.a. & n.a. & n.a. & n.a. & n.a. & n.a. \\
\hline$F$ & ก.a. & n.a. & n.a. & n.a. & n.a. & ก.a. & n.a. \\
\hline $\mathrm{Cl}$ & 0.09 & 0.07 & 0.06 & 0.00 & 0.00 & \begin{tabular}{l|}
0.07 \\
\end{tabular} & 0.08 \\
\hline Total & 94.70 & 93.93 & 94.78 & 94.06 & 94.09 & 94.70 & 94.70 \\
\hline TSi & 6.52 & 6.45 & 6.45 & 6.45 & 6.49 & 6.53 & 6.52 \\
\hline SAl & 1.49 & 1.55 & 1.56 & 1.55 & 1.51 & 1.47 & 1.48 \\
\hline $\mathrm{FFe}^{+3}$ & 0.00 & 0.00 & 0.00 & 0.00 & 0.00 & 0.00 & 0.00 \\
\hline TTi & 0.00 & 0.00 & 0.00 & 0.00 & 0.00 & 0.00 & 0.00 \\
\hline Soma T & 8.00 & 8.00 & 8.00 & 8.00 & 8.00 & 8.00 & 8.00 \\
\hline CAl & 0.85 & 0.86 & 0.80 & 0.81 & 0.83 & 0.80 & 0.81 \\
\hline $\mathrm{CCr}$ & 0.00 & 0.00 & 0.00 & 0.00 & 0.00 & 0.00 & 0.00 \\
\hline CTi & 0.05 & 0.06 & 0.06 & 0.07 & 0.06 & 0.04 & 0.05 \\
\hline $\mathrm{CFe}^{+3}$ & 0.0 & 0.00 & 0.00 & 0.00 & 0.00 & 0.02 & 0.00 \\
\hline $\mathrm{CMg}$ & 2.07 & 2.02 & 2.08 & 2.06 & 2.05 & 2.15 & 2.12 \\
\hline $\mathrm{CFe}^{+2}$ & 2.03 & 2.07 & 2.06 & 2.06 & 2.05 & 1.99 & 2.03 \\
\hline $\mathrm{CMn}$ & 0.00 & 0.00 & 0.00 & 0.00 & 0.00 & 0.00 & 0.00 \\
\hline $\mathrm{CCa}$ & 0.00 & 0.00 & 0.00 & 0.00 & 0.00 & 0.00 & 0.00 \\
\hline Soma C & 5.00 & 5.00 & 5.00 & 5.00 & 5.00 & 5.00 & 5.00 \\
\hline $\mathrm{BF}_{\theta}+2$ & 0.23 & 0.20 & 0.22 & 0.24 & 0.20 & 0.20 & 0.24 \\
\hline $\mathrm{BMg}$ & 0.00 & 0.00 & 0.00 & 0.00 & 0.00 & 0.00 & 0.00 \\
\hline BMn & 0.05 & 0.05 & 0.05 & 0.04 & 0.05 & 0.04 & 0.04 \\
\hline $\mathrm{BCa}$ & 1.72 & 1.76 & 1.73 & 1.72 & 1.76 & 1.76 & 1.72 \\
\hline $\mathrm{BNa}$ & 0.00 & 0.00 & 0.00 & 0.00 & 0.00 & 0.00 & 0.00 \\
\hline Soma B & 2.00 & 2.00 & 2.00 & 2.00 & 2.00 & 2.00 & 2.00 \\
\hline $\mathrm{ACa}$ & 0.00 & 0.00 & 0.00 & 0.00 & 0.00 & 0.00 & 0.00 \\
\hline$\overline{\mathrm{ANa}}$ & 0.53 & 0.54 & 0.58 & 0.57 & 0.58 & 0.51 & 0.59 \\
\hline AK & 0.09 & 0.09 & 0.08 & 0.08 & 0.07 & 0.06 & 0.08 \\
\hline Soma A & 0.61 & 0.63 & 0.65 & 0.65 & 0.65 & 0.57 & 0.66 \\
\hline Cátions & 15.61 & 15.63 & 15.65 & 15.65 & 15.65 & 15.57 & 15.66 \\
\hline
\end{tabular}

Tabela A4.2.3: Dados analíticos de anfibólios verdes (A.V.) e incolores (A.I.) de anfibolitos metabásicos $A B, A B E T$ e $A B G$. Fórmula estrutural: 23(O). 
Tabela A4.2: Anfibólios - ANF.

\begin{tabular}{|c|c|c|c|c|c|c|c|c|c|c|c|c|c|c|c|c|c|c|c|}
\hline \begin{tabular}{|l} 
Amostra \\
Análise
\end{tabular} & $\frac{G-52 c}{02 / 01 / 26}$ & $\frac{G-52 c}{02 / 01 / 27}$ & \begin{tabular}{|c|}
$G-52 c$ \\
$02 / 02 / 37$ \\
\end{tabular} & $\frac{G-52 c}{02 / 01 / 42}$ & \begin{tabular}{|c|} 
G-52c \\
$02 / 01 / 44$ \\
\end{tabular} & \begin{tabular}{|c|}
$G-52 c$ \\
$02 / 02 / 47$ \\
\end{tabular} & $\frac{G-52 c}{02 / 02 / 51}$ & \begin{tabular}{|c|} 
G-52c \\
$02 / 03 / 52$ \\
\end{tabular} & $\frac{G-52 c}{02 / 03 / 55}$ & \begin{tabular}{|c|} 
G-52c \\
$00 / 01 / 10$
\end{tabular} & \begin{tabular}{|c|}
$G-52 c$ \\
$06 / 04 / 11$
\end{tabular} & \begin{tabular}{|c|}
$G-52 c$ \\
$06101 / 12$ \\
\end{tabular} & \begin{tabular}{|c|}
$G-85 a$ \\
$01 / 02 / 10$ \\
\end{tabular} & $\frac{G-85 a}{01 / 02 / 23}$ & $\begin{array}{c}G-85 a \\
0102 / 24\end{array}$ & $\frac{G-85 a}{01 / 02 / 09}$ & \begin{tabular}{c|}
$-85 a$ \\
$05 / 02122$ \\
\end{tabular} & \begin{tabular}{c|}
$.85 a$ \\
0502123
\end{tabular} & \begin{tabular}{|c|}
$M-5$ \\
$03 / 03 / 10$ \\
\end{tabular} \\
\hline Minera! & A.I. & A.I. & A.I. & A.I. & A.I. & \begin{tabular}{|l|} 
A.I. \\
\end{tabular} & A.1. & \begin{tabular}{|l|l|} 
A.1. \\
\end{tabular} & A.I. & A.1. & $\frac{06 / 01 / 11}{A . I .}$ & $\frac{0}{\text { A.I. }}$ & A.1. & $\frac{01 / 021<3}{A .1}$ & $\frac{07102724}{A .1}$ & $\frac{07 / 02209}{A .1 .}$ & $\frac{05 / 02 / 22}{A .1}$ & $\frac{05 / 02 / 23}{A !}$ & $\frac{03 / 03510}{A . V .}$ \\
\hline Local & $\mathrm{C}$ & B & $B$ & c & B & C & C & $\mathrm{c}$ & $c$ & $\mathrm{c}$ & $\mathrm{C}$ & 8 & $\mathrm{~B}$ & $\mathrm{c}$ & $\mathrm{B}$ & $\mathrm{C}$ & $\mathrm{C}$ & B & $\frac{\pi .1}{c}$ \\
\hline Litotipo & $\overline{M P}$ & $\overline{M P}$ & $\overline{M P}$ & MP & MP & MP & MP & MP & MP & MP & MP & $\overline{M P}$ & $M P$ & MP & $\overline{M P}$ & MP & MP & $M P$ & MP \\
\hline $\mathrm{SiO}_{2}$ & 54.83 & 53.66 & 52.16 & 54.04 & 54.45 & 54.45 & 54.97 & 54.42 & 55.40 & 51.39 & 53.18 & 52.01 & 43.48 & 42.97 & 42.92 & 43.71 & 42.25 & 43.74 & 45.72 \\
\hline $\mathrm{TiO}_{2}$ & 0.03 & 0.08 & 0.00 & 0.01 & 0.02 & 0.08 & 0.03 & 0.01 & 0.00 & 0.10 & 0.00 & 0.07 & 0.14 & 0.21 & 0.20 & 0.22 & 0.18 & 0.24 & 0.46 \\
\hline $\mathrm{Al}_{2} \mathrm{O}_{3}$ & 1.39 & 2.92 & 2.50 & 1.94 & 0.96 & 1.27 & 0.97 & 1.94 & 1.37 & 4.12 & 2.69 & 2.69 & 17.69 & 16.30 & 17.20 & 16.81 & 16.03 & 66.41 & 14.28 \\
\hline $\mathrm{Cr}_{2} \mathrm{O}_{3}$ & 0.01 & 0.06 & 0.00 & 0.01 & 0.01 & 0.02 & 0.06 & 0.03 & 0.04 & 0.00 & 0.03 & 0.07 & 0.01 & 0.01 & 0.01 & 0.00 & 0.00 & 0.00 & 0.26 \\
\hline $\mathrm{ZnO}$ & 0.13 & 0.00 & 0.00 & 0.00 & 0.02 & 0.00 & 0.04 & 0.00 & 0.07 & n.a. & n.a. & n.a. & 0.01 & 0.00 & 0.02 & 0.02 & n.a. & n.a. & 0.00 \\
\hline $\mathrm{FeO}$ & 23.81 & 23.12 & 21.08 & 24.70 & 24.44 & 23.69 & 24.53 & 24.42 & 23.76 & 22.42 & 22.45 & 22.51 & 20.66 & 20.20 & 21.09 & 20.55 & 20.45 & 20.87 & 10.79 \\
\hline Mno & 0.24 & 0.22 & 0.23 & 0.38 & 0.41 & 0.36 & 0.39 & 0.42 & 0.35 & 0.21 & 0.16 & 0.19 & 0.07 & 0.05 & 0.08 & 0.04 & 0.05 & 0.06 & 0.21 \\
\hline $\mathrm{MgO}$ & 19.10 & 19.06 & 18.80 & 17.67 & 18.17 & 18.40 & 18.21 & 18.17 & 19.12 & 18.34 & 18.88 & 18.98 & 14.44 & 14.68 & 14.33 & 14.91 & 14.89 & 14.79 & 14.34 \\
\hline $\mathrm{NiO}$ & 0.03 & 0.01 & 0.01 & 0.00 & 0.00 & 0.01 & 0.00 & 0.04 & 0.04 & n.a. & n.a. & n.a. & 0.00 & 0.00 & 0.03 & 0.03 & n.a. & ก.a. & 0.03 \\
\hline $\mathrm{CaO}$ & 0.43 & 0.30 & 0.28 & 0.36 & 0.26 & 0.29 & 0.31 & 0.37 & 0.30 & 0.34 & 0.29 & 0.31 & 0.44 & 0.44 & 0.42 & 0.42 & $0 . \overline{44}$ & 0.40 & 10.86 \\
\hline $\mathrm{Na}_{2} \mathrm{O}$ & 0.07 & 0.11 & 0.06 & 0.08 & 0.04 & 0.08 & 0.02 & 0.04 & 0.00 & 0.15 & 0.11 & 0.12 & 1.72 & 1.71 & 1.79 & 9.60 & 1.72 & 1.62 & 1.51 \\
\hline $\mathrm{K}_{2} \mathrm{O}$ & 0.02 & 0.06 & 0.01 & 0.03 & 0.01 & 0.02 & 0.02 & 0.00 & 0.02 & 0.02 & 0.00 & 0.03 & 0.02 & 0.03 & 0.00 & 0.00 & 0.00 & 0.01 & 0.10 \\
\hline $\mathrm{P}_{2} \mathrm{O}_{5}$ & n.a. & n.a. & n.a. & n.a. & n.a. & n.a. & n.a. & n.a. & n.a. & n.a. & n.a. & n.a. & n.a. & n.a. & n.a. & n.a. & n.a. & n.a. & n.a. \\
\hline $\mathrm{BaO}$ & n.a. & n.a. & ก.a. & n.a. & n.a. & ก.a. & n.a. & n.a. & n.a. & 0.00 & 0.02 & 0.01 & n.a. & n.a. & n.a. & n.a. & 0.02 & 0.00 & n.a. \\
\hline$F$ & n.a. & n.a. & n.a. & n.a. & n.a. & n.a. & n.a. & n.a. & n.a. & 0.49 & 0.42 & 0.46 & n.a. & n.a. & n.a. & n.a. & 0.41 & 0.33 & n.a. \\
\hline CI & n.a. & n.a. & $\begin{array}{ll}\text { n.a. } \\
\end{array}$ & n.a. & n.a. & n.a. & n.a. & n.a. & n.a. & n.a. & n.a. & n.a. & n.a. & h.a. & ก.a. & n.a. & n.a. & n.a. & n.a. \\
\hline Total & 100.09 & 99.60 & 95.13 & 99.22 & 98.79 & 98.67 & 99.55 & 99.86 & 100.47 & 97.58 & 98.23 & 97.45 & 98.68 & 96.60 & 98.09 & 98.31 & 96.44 & 98.47 & 98.56 \\
\hline TSi & 7.78 & 7.62 & \begin{tabular}{l|}
7.72 \\
\end{tabular} & 7.78 & 7.87 & 7.85 & 7.89 & 7.77 & 7.84 & 7.47 & 7.67 & 7.57 & 6.09 & 6.14 & 6.06 & 6.15 & 6.07 & 6.17 & 6.51 \\
\hline TAl & 0.22 & 0.38 & 0.28 & 0.22 & 0.13 & 0.15 & 0.11 & 0.23 & 0.16 & 0.53 & 0.33 & 0.44 & 1.91 & 1.86 & 1.95 & 1.85 & 1.93 & 1.83 & 1.49 \\
\hline $\mathrm{TFe}^{+3}$ & 0.00 & 0.00 & 0.00 & 0.00 & 0.00 & 0.00 & 0.00 & 0.00 & 0.00 & 0.00 & 0.00 & 0.00 & 0.00 & 0.00 & 0.00 & 0.00 & 0.00 & 0.00 & 0.00 \\
\hline$T T i$ & 0.00 & 0.00 & 0.00 & 0.00 & 0.00 & 0.00 & 0.00 & 0.00 & 0.00 & 0.00 & 0.00 & 0.00 & 0.00 & 0.00 & 0.00 & 0.00 & 0.00 & 0.00 & 0.00 \\
\hline Soma T & 8.00 & 8.00 & 8.00 & 8.00 & 8.00 & 8.00 & 8.00 & 8.00 & 8.00 & 8.00 & 8.00 & 8.00 & 8.00 & 8.00 & 8.00 & 8.00 & 8.00 & 8.00 & 8.00 \\
\hline CAI & 0.02 & 0.11 & 0.15 & 0.11 & 0.03 & 0.07 & 0.05 & 0.10 & 0.07 & 0.17 & 0.13 & 0.03 & 1.01 & 0.89 & 0.91 & 0.93 & 0.78 & 0.89 & 0.91 \\
\hline $\mathrm{CCr}$ & 0.00 & 0.01 & 0.00 & 0.00 & 0.00 & 0.00 & 0.01 & 0.00 & 0.00 & 0.00 & 0.00 & 0.01 & 0.00 & 0.00 & 0.00 & 0.00 & 0.00 & 0.00 & 0.03 \\
\hline CTi & 0.00 & 0.01 & 0.00 & 0.00 & 0.00 & 0.01 & 0.00 & 0.00 & 0.00 & 0.01 & 0.00 & 0.01 & 0.02 & 0.02 & 0.02 & 0.02 & 0.02 & 0.03 & 0.05 \\
\hline $\mathrm{CFe}^{+3}$ & 0.21 & 0.27 & 0.14 & 0.13 & 0.11 & 0.08 & 0.05 & 0.14 & 0.09 & 0.38 & 0.22 & 0.42 & 1.34 & 1.39 & 1.48 & 1.31 & 1.59 & 1.33 & 0.02 \\
\hline $\mathrm{CMg}$ & 4.04 & 4.03 & 4.15 & 3.79 & 3.91 & 3.96 & 3.90 & 3.87 & 4.03 & 3.97 & 4.06 & 4.12 & 2.64 & 2.70 & 2.59 & 2.73 & 2.61 & 2.75 & 3.05 \\
\hline $\mathrm{CF}^{+2}$ & 0.73 & 0.57 & 0.56 & 0.97 & 0.95 & 0.89 & 0.99 & 0.89 & 0.81 & 0.47 & 0.58 & 0.43 & 0.00 & 0.00 & 0.00 & 0.00 & 0.00 & 0.00 & 0.95 \\
\hline $\mathrm{CMn}$ & 0.00 & 0.00 & $0 . \infty$ & 0.00 & 0.00 & 0.00 & 0.00 & 0.00 & 0.00 & 0.00 & 0.00 & 0.00 & 0.00 & 0.00 & 0.00 & 0.00 & 0.00 & 0.00 & 0.00 \\
\hline $\mathrm{CCa}$ & 0.00 & 0.00 & 0.00 & 0.00 & 0.00 & 0.00 & 0.00 & 0.00 & 0.00 & 0.00 & 0.00 & 0.00 & 0.00 & 0.00 & 0.00 & 0.00 & 0.00 & 0.00 & 0.00 \\
\hline Soma C & 5.00 & 5.00 & 5.00 & 5.00 & 5.00 & 5.00 & 5.00 & 5.00 & 5.00 & 5.00 & 5.00 & 5.00 & 5.00 & 5.00 & 5.00 & 5.00 & 5.00 & 5.00 & 5.00 \\
\hline $\mathrm{BFe}^{+2}$ & 1.89 & 1.90 & 1.91 & 1.88 & 1.90 & 1.89 & 1.90 & 1.88 & 1.91 & 1.88 & 1.91 & 1.89 & 1.09 & 1.02 & 1.01 & 1.10 & 0.87 & 1.13 & 0.32 \\
\hline BMg & 0.00 & 0.00 & 0.00 & 0.00 & 0.00 & 0.00 & 0.00 & 0.00 & 0.00 & 0.00 & 0.00 & 0.00 & 0.37 & 0.43 & 0.43 & 0.39 & 0.58 & 0.36 & 0.00 \\
\hline BMn & 0.03 & 0.03 & 0.03 & 0.05 & 0.05 & 0.04 & 0.05 & 0.05 & 0.04 & 0.03 & 0.02 & 0.02 & 0.01 & 0.01 & 0.01 & 0.01 & 0.01 & 0.01 & 0.03 \\
\hline $\mathrm{BCa}$ & 0.07 & 0.05 & 0.04 & 0.06 & 0.04 & 0.05 & 0.05 & 0.06 & 0.05 & 0.05 & 0.05 & 0.05 & 0.07 & 0.07 & 0.06 & 0.06 & 0.07 & 0.06 & 1.66 \\
\hline $\mathrm{BNa}$ & 0.02 & 0.03 & 0.02 & 0.02 & 0.01 & 0.02 & 0.01 & 0.01 & 0.00 & 0.04 & 0.03 & 0.03 & 0.47 & 0.47 & 0.49 & 0.44 & 0.48 & 0.44 & 0.00 \\
\hline Soma B & 2.00 & 2.00 & 2.00 & 2.00 & 2.00 & 2.00 & 2.00 & 2.00 & 2.00 & 2.00 & 2.00 & 2.00 & 2.00 & 2.00 & $2 . \infty$ & 2.00 & 2.00 & 2.00 & 2.00 \\
\hline $\mathrm{ACa}$ & 0.00 & 0.00 & 0.00 & 0.00 & 0.00 & 0.00 & 0.00 & 0.00 & 0.00 & 0.00 & 0.00 & 0.00 & 0.00 & 0.00 & 0.00 & 0.00 & 0.00 & 0.00 & 0.00 \\
\hline $\mathrm{ANa}$ & 0.00 & 0.00 & 0.00 & 0.00 & 0.00 & 0.00 & 0.00 & 0.00 & 0.00 & 0.00 & $0 . \infty$ & 0.00 & 0.00 & 0.00 & 0.00 & 0.00 & 0.00 & 0.00 & 0.42 \\
\hline$\overline{A K}$ & 0.00 & 0.01 & 0.00 & 0.01 & 0.00 & 0.00 & 0.00 & 0.00 & 0.00 & 0.00 & 0.00 & 0.01 & 0.00 & 0.01 & 0.00 & 0.00 & 0.00 & 0.00 & 0.02 \\
\hline Soma A & 0.00 & 0.01 & 0.00 & $\begin{array}{l}0.01 \\
\end{array}$ & 0.00 & 0.00 & 0.00 & 0.00 & 0.00 & 0.00 & 0.00 & 0.01 & 0.00 & 0.01 & 0.00 & 0.00 & 0.00 & 0.00 & 0.44 \\
\hline Cátions & 15.00 & 15.01 & 15.00 & 15.01 & 15.00 & 15.00 & 15.00 & 15.00 & 15.00 & 15.00 & 15.00 & 15.01 & 15.00 & 15.01 & 15.00 & 15.00 & 15.00 & 15.00 & 15.43 \\
\hline
\end{tabular}

Tabela A4.2.4: Dados analíticos de anfibólios incolores (A.I) e verde (A.V.) de MP. Fórmula estrutural recalculada com base em 23(O). 
Tabela A4.3: Plagioclásios - PLA.

\begin{tabular}{|c|c|c|c|c|c|c|c|c|c|c|c|c|c|c|c|c|c|}
\hline Amostra & $G-168 g$ & $G-168 g$ & 03 & $\mathbb{3}$ & 03 & $\mathbb{1 3}$ & G-26 & G-26 & G-26 & G-26 & G-26 & $\mathrm{G}-29 \mathrm{c}$ & $G-290$ & G-29d & $G-29 d$ & G-29d & G-29d \\
\hline Análise & $5 / 3 / 6$ & $5 / 3 / 7$ & $223 \mathrm{PO}$ & $223 \times 02$ & $22 / 2 \mathrm{PO} 1$ & $22 / 2 \mathrm{PO}$ & $3 / 179$ & $3 / 1 / 13$ & $62 / 26$ & $6 / 2 / 29$ & $6 / 2 \sqrt{30}$ & $\alpha / 130$ & $6 / 1 / 40$ & $4 / 1 / 2$ & $4 / 1 / 3$ & $4 \sqrt{3 / 12}$ & $4 / 3 / 13$ \\
\hline Mineral & PLA & PLA & PLA & PLA & PLA & PLA & PLA & PLA & PLA & $P L A$ & PLA & PLA & PLA & PLA & PLA & PLA & PLA \\
\hline Local & $B$ & $\mathrm{C}$ & $\mathrm{C}$ & $B$ & Pln & $B$ & $\mathrm{C}$ & $c$ & Lente $B t$ & $B$ & C & $B$ & $c$ & B & $\mathrm{C}$ & $c$ & $\mathrm{~B}$ \\
\hline Litotipo & ITG & TTG & $\mathrm{GB}$ & $\mathrm{GB}$ & $G B$ & GB & $\mathrm{GB}$ & $\mathrm{GB}$ & $\mathrm{GB}$ & GB & GB & $\mathrm{GB}$ & GB & $\mathrm{GB}$ & $\overline{G B}$ & $\mathrm{~GB}$ & $\mathrm{~GB}$ \\
\hline $\mathrm{SiO}_{2}$ & 61.70 & 60.67 & 67.29 & 67.89 & 67.50 & 67.79 & 64.34 & 6.35 & 67.31 & $64 . \infty$ & 6.52 & 66.11 & 66.74 & 6.95 & 66.27 & 6.41 & 65 \\
\hline $\mathrm{TiO}_{2}$ & 0.03 & 0.04 & 0.0 & 0.00 & 0.00 & 0.00 & 0.06 & 0.03 & 0.00 & $0 . \infty$ & 0.00 & 0.01 & 0.02 & 0.00 & 0.00 & 0.09 & 0.01 \\
\hline $\mathrm{Al}_{2} \mathrm{O}_{3}$ & 24.32 & 24.50 & 21.03 & 20.54 & 20.18 & 20.04 & 22.34 & 21.36 & 20.85 & 22.11 & 22.00 & 22.88 & 22.42 & 22.41 & 21.59 & 21.84 & 22.06 \\
\hline $\mathrm{Cr}_{2} \mathrm{O}_{3}$ & 0.00 & 0.00 & 0.00 & $0 . \infty$ & 0.00 & $0 . \infty$ & $0 . \infty$ & 0.00 & 0.01 & 0.00 & 0.00 & 0.00 & 0.0 & 0.00 & 0.01 & 0.00 & 0.02 \\
\hline $\mathrm{ZnO}$ & n.a. & n.a. & n.a. & n.a. & n.a. & n.a. & 0.00 & 0.0 & ก.a. & ก.a. & n.a. & n.a. & n.a. & 0.00 & 0.00 & 0.0 & 0.00 \\
\hline $\mathrm{FeO}$ & 0.05 & 0.07 & 0.0 & 0.25 & 0.00 & 0.0 & 0.06 & 0.08 & 0.59 & 0.03 & 0.03 & 0.16 & 0.12 & 0.06 & 0.06 & 0.08 & 0.03 \\
\hline MnO & 0.00 & 0.00 & 0.0 & 0.0 & 0.00 & 0.13 & 0.01 & 0.00 & 0.0 & 0.01 & 0.01 & $0 . \infty$ & 0.00 & 0.03 & 0.00 & 0.01 & 0.00 \\
\hline $\mathrm{MgO}$ & 0.03 & 0.01 & 0.00 & 0.00 & $0 . \infty$ & 0.00 & 0.01 & 0.0 & 0.02 & 0.01 & 0.00 & 0.02 & 0.01 & 0.00 & 0.0 & 0.00 & 0.01 \\
\hline NiO & n.a. & n.a. & 0.00 & 0.0 & 0.00 & 0.00 & 0.00 & 0.00 & n.a. & n.a. & n. $a$. & n.a. & n.a. & $0 . \infty$ & 0.00 & 0.02 & 0.00 \\
\hline $\mathrm{CaO}$ & 5.56 & 6.06 & 1.07 & 0.61 & 0.45 & 0.22 & 3.05 & 2.62 & 1.25 & 2.98 & 2.87 & 2.6 & 2.54 & 2.49 & 2.54 & 2.76 & 2.50 \\
\hline $\mathrm{Na}_{2} \mathrm{O}$ & 8.32 & 7.70 & 11.26 & 11.33 & 11.45 & 11.61 & 9.50 & 9.79 & 10.25 & 9.31 & 9.30 & 9.50 & 9.66 & 9.92 & 9.79 & 9.6 & 9.94 \\
\hline $\mathrm{K}_{2} \mathrm{O}$ & 0.18 & 0.14 & 0.12 & 0.00 & 0.14 & 0.15 & 0.22 & 0.15 & 0.14 & 0.21 & 0.30 & 0.18 & 0.18 & 0.24 & 0.20 & 0.19 & 0.16 \\
\hline $\mathrm{P}_{2} \mathrm{O}_{5}$ & n.a. & n.a. & 0.00 & 0.00 & 0.00 & 0.00 & n.a. & n.a. & n.a. & n.a. & n.a. & n.a. & n.a. & n.a. & n.a. & n.a. & n.a. \\
\hline $\mathrm{BaO}$ & 0.02 & 0.0 & n.a. & n.a. & n.a. & n.a. & n.a. & n.a. & 0.01 & 0.02 & 0.02 & 0.02 & 0.02 & n.a. & n.a. & n.a. & n.a. \\
\hline$F$ & 0.13 & 0.01 & n.a. & n.a. & n.a. & n.a. & n.a. & n.a. & 0.0 & 0.00 & 0.00 & 0.05 & 0.00 & n.a. & n.a. & n.a. & n.a. \\
\hline Cl & n.a. & n.a. & 0.00 & 0.00 & 0.00 & 0.0 & n.a. & n.a. & n.a. & n.a. & n.a. & n.a. & n.a. & n.a. & n.a. & n.a. & n.a. \\
\hline Total & 100.33 & 99.20 & 100.77 & 100.62 & 99.72 & 100.10 & 99.59 & 99.38 & 100.43 & 99.36 & 100.14 & 101.67 & 101.71 & 102.10 & 100.46 & 100.05 & 100.78 \\
\hline $\mathrm{Si}$ & 10.93 & 10.86 & 11.71 & 11.81 & 11.85 & 11.85 & 11.38 & 11.56 & 11.75 & 11.44 & 1150 & 11.43 & 11.51 & 11.52 & 11.58 & 11.49 & 11.50 \\
\hline $\mathbf{A l}$ & 5.07 & 5.16 & 4.31 & 4.21 & 4.17 & 4.13 & 4.6 & 4.45 & 4.28 & 4.61 & 4.55 & 4.66 & 4.56 & 4.54 & 4.44 & 4.52 & 4.53 \\
\hline $\mathrm{Ti}$ & 0.0 & 0.01 & 0.0 & 0.00 & 0.00 & 0.00 & 0.01 & 0.00 & 0.00 & 0.0 & 0.00 & 0.00 & 0.00 & 0.0 & 0.0 & 0.01 & 0.00 \\
\hline $\mathrm{Fe}^{2}$ & 0.01 & 0.01 & 0.00 & 0.04 & 0.00 & 0.0 & 0.01 & 0.01 & 0.09 & 0.00 & 0.00 & 0.02 & 0.02 & 0.01 & 0.01 & 0.01 & 0.00 \\
\hline $\mathrm{Mn}$ & 0.00 & 0.0 & 0.00 & 0.00 & 0.00 & 0.02 & 0.00 & 0.00 & 0.00 & 0.00 & 0.00 & 0.00 & $0 . \infty$ & 0.00 & 0.00 & 0.00 & 0.00 \\
\hline $\mathrm{Mg}$ & 0.01 & 0.00 & $0 . \infty$ & 0.00 & 0.00 & 0.00 & 0.0 & 0.00 & 0.01 & 0.00 & 0.00 & 0.01 & 0.00 & $0 . \infty$ & 0.0 & 0.00 & 0.00 \\
\hline $\mathrm{Ba}$ & 0.00 & 0.0 & & - & & & & - & 0.00 & 0.00 & 0.00 & 0.0 & 0.0 & & & & \\
\hline $\mathrm{Ca}$ & 1.05 & 1.16 & 0.20 & 0.11 & 0.09 & 0.04 & 0.58 & 0.50 & 0.23 & 0.57 & 0.54 & 0.49 & 0.47 & 0.46 & 0.48 & 0.52 & 0.48 \\
\hline $\mathrm{Na}$ & 2.86 & 2.67 & 3.80 & 3.82 & 3.90 & 3.94 & 3.26 & 3.36 & 3.47 & 3.19 & 3.20 & 3.21 & 3.23 & 3.31 & 3.32 & 3.29 & 3.36 \\
\hline K & 0.04 & 0.03 & 0.03 & 0.00 & 0.03 & 0.03 & 0.05 & 0.03 & 0.03 & 0.05 & 0.07 & 0.04 & 0.04 & 0.05 & 0.05 & 0.04 & 0.04 \\
\hline Cations & 19.97 & 19.90 & 20.04 & 19.99 & 20.03 & 20.02 & 19.94 & 19.91 & 19.85 & 19.87 & 19.85 & 19.86 & 19.84 & 19.89 & 19.87 & 19.89 & 19.92 \\
\hline$A b$ & 72.3 & 69.1 & 94.400 & 97.100 & 97.100 & 98.200 & 83.8 & 86.4 & 92.9 & 83.9 & 84.0 & 85.8 & 86.4 & 86.6 & 86.4 & 85.4 & 86.6 \\
\hline$A n$ & 26.7 & 30.1 & 4.900 & 2.900 & 2.100 & 1.000 & 14.9 & 12.8 & 6.3 & 14.8 & 14.2 & 13.1 & 12.6 & 12.0 & 12.4 & 13.5 & 12.5 \\
\hline Or & 1.0 & 0.8 & 0.700 & 0.000 & 0.800 & 0.800 & 1.3 & 0.9 & 0.8 & 1.2 & 1.8 & 1.1 & 1.1 & 1.4 & 1.2 & 1.1 & 0.9 \\
\hline
\end{tabular}

Tabela A4.3.1: Dados analiticos de plagioclásios de TTG, GB, MGF e PGD intrusivos na SVS. Fórmula estrutural: 32(O)

Nota: Lente $\mathrm{Bt}=$ lente em biotita esfoliada. 
Tabela A4.3: Plagioclásios - PLA.

\begin{tabular}{|c|c|c|c|c|c|c|c|c|c|c|c|c|c|c|c|c|c|}
\hline Amostra & $\mathrm{G}-113$ & G-113 & G-16्6 & $G-16 \sigma b$ & $G-166$ & $G-2 a$ & G-2a & $\mathrm{G}-2 \mathrm{a}$ & G-2a & $G-2 b$ & G-2b & $G-2 b$ & $G-2 b$ & $\mathrm{G}-2 \mathrm{~b}$ & G-2b & G-3a & G-3a \\
\hline Análise & $5 / 1 / 6$ & $5 / 17$ & $4 / 1 / 54$ & $4 / 1 / 5$ & $4 / 250$ & 16/1PO1 & $1611 \mathrm{PO2}$ & 16/2P01 & $16 / 2 P O 2$ & $4 / 2 / 44$ & $4 / 2 / 45$ & $4 / 3 / 26$ & $4 / 3 / 27$ & $63 / 18$ & $6 / 3 / 49$ & $39 / 1 \mathrm{P} 4.1$ & $39 / 1$ P1.2 \\
\hline Mineral & PLA & PLA & PLA & PLA & PLA & PLA & PLA & $P L A$ & PLA & PLA & PLA & PLA & PLA & PLA & PLA & PLA & PLA \\
\hline Local & $B$ & $\mathrm{C}$ & $B$ & $\mathrm{C}$ & $C$ & C & $B$ & $\mathrm{C}$ & B & $c$ & B & $c$ & $B$ & $c$ & $B$ & PIn & Pln \\
\hline Litotipo & $\mathrm{GB}$ & GB & GB & GB & GB & MGF & MGF & MGF & MGF & MGF & MGF & MGF & MGF & MGF & MGF & MGF & MGF \\
\hline $\mathrm{SiO}_{2}$ & 66.63 & 66.45 & 6.45 & 67.83 & 5.6 & 67.43 & 67.88 & 67.75 & 68.24 & 67.54 & 68.65 & 66.78 & 6.02 & 65.62 & 68.52 & 66.98 & 67.04 \\
\hline $\mathrm{TiO}_{2}$ & 0.00 & 0.00 & 0.00 & 0.00 & 0.01 & $0 . \infty$ & $0 . \infty$ & $0 . \infty$ & 0.00 & 0.0 & 0.00 & 0.04 & 0.0 & 0.01 & $0 . \infty$ & 0.00 & 0.00 \\
\hline $\mathrm{Al}_{2} \mathrm{O}_{3}$ & 21.92 & 22.00 & 20.39 & 20.99 & 21.07 & 20.76 & 20.13 & 20.53 & 20.23 & 20.26 & 20.75 & 21.16 & 20.23 & 21.82 & 20.01 & 20.53 & 20.49 \\
\hline $\mathrm{Cr}_{2} \mathrm{O}_{3}$ & 0.00 & 0.05 & 0.00 & 0.00 & 0.00 & 0.00 & 0.00 & 0.00 & 0.00 & 0.02 & 0.00 & 0.02 & 0.00 & 0.00 & 0.0 & 0.00 & 0.00 \\
\hline $\mathrm{ZnO}$ & 0.01 & 0.00 & 0.0 & 0.0 & 0.00 & n.a. & n.a. & n.a. & n.a. & 0.00 & 0.00 & 0.0 & 0.00 & n.a. & n.a. & n.a. & n.a. \\
\hline $\mathrm{FeO}$ & 0.08 & 0.0 & 0.16 & 0.06 & 0.01 & 0.00 & 0.18 & 0.17 & 0.00 & 0.07 & 0.05 & 0.08 & 0.04 & 0.11 & 0.04 & 0.00 & 0.00 \\
\hline $\mathrm{MnO}$ & 0.0 & 0.02 & 0.02 & 0.00 & 0.00 & 0.00 & $0 . \infty$ & 0.00 & 0.0 & 0.00 & 0.04 & 0.00 & 0.00 & 0.00 & 0.03 & $0 . \infty$ & 0.00 \\
\hline $\mathrm{MgO}$ & 0.00 & 0.01 & 0.01 & 0.00 & $0 . \infty$ & $0 . \infty$ & 0.00 & 0.00 & 0.00 & 0.0 & 0.00 & 0.02 & $0 . \infty$ & 0.00 & 0.00 & 0.00 & 0.00 \\
\hline $\mathrm{NiO}$ & $0 . \infty$ & 0.0 & 0.00 & 0.00 & 0.01 & 0.0 & 0.0 & 0.00 & 0.0 & 0.00 & 0.01 & 0.00 & 0.02 & n.a. & n.a. & 0.0 & 0.00 \\
\hline $\mathrm{CaO}$ & 2.44 & 2.61 & 0.25 & 1.74 & 1.87 & 1.05 & 0.54 & 0.00 & 0.14 & 0.65 & 0.6 & 2.28 & 0.33 & 2.27 & 0.20 & 0.89 & 0.99 \\
\hline $\mathrm{Na}_{2} \mathrm{O}$ & $9 . \tilde{3}$ & 9.59 & 10.74 & 9.82 & 9.93 & 11.08 & 11.38 & 11.33 & 11.85 & 10.79 & 10.47 & 9.85 & 10.91 & 9.83 & 11.18 & 11.10 & 11.06 \\
\hline $\mathrm{K}_{2} \mathrm{O}$ & 0.14 & 0.20 & 0.16 & 0.24 & 0.12 & 0.08 & 0.16 & 0.26 & 0.11 & 0.18 & 0.17 & 0.26 & 0.13 & 0.21 & 0.14 & 0.16 & 0.12 \\
\hline $\mathrm{P}_{2} \mathrm{O}_{5}$ & n.a. & n.a. & n.a. & n.a. & n.a. & 0.00 & 0.00 & 0.00 & 0.00 & n.a. & n.a. & n.a. & n.a. & n.a. & n.a. & 0.00 & 0.00 \\
\hline $\mathrm{BaO}$ & n.a. & ก.a. & n.a. & n.a. & n.a. & n.a. & n.a. & n.a. & n.a. & n.a. & n.a. & n.a. & n.a. & 0.01 & $0 . \infty$ & n.a. & n.a. \\
\hline$F$ & n.a. & n.a. & n.a. & n.a. & n.a. & n.a. & n.a. & n.a. & n.a. & n.a. & n.a. & n.a. & n.a. & 0.00 & 0.11 & n.a. & n.a. \\
\hline $\mathrm{Cl}$ & ก.a. & n.a. & n.a. & n.a. & n.a. & 0.00 & 0.00 & 0.00 & 0.00 & n.a. & n.a. & n.a. & n.a. & n.a. & n.a. & 0.00 & 0.00 \\
\hline Total & 100.85 & 100.93 & 101.18 & 100.68 & 98.71 & 100.40 & 100.27 & 100.76 & 100.57 & 99.51 & 100.79 & 100.49 & 100.68 & 99.88 & 100.23 & 99.66 & 99.70 \\
\hline Si & 11.58 & 11.55 & 11.96 & 11.77 & 11.65 & 11.76 & 11.86 & 11.78 & 11.87 & 11.86 & 11.87 & 11.66 & 11.95 & 11.54 & 11.94 & 11.77 & 11.78 \\
\hline Al & 4.49 & 4.50 & 4.13 & 4.20 & 4.40 & 4.26 & 4.14 & 4.21 & 4.14 & 4.19 & 4.23 & 4.35 & 4.12 & 4.52 & 4.11 & 4.25 & 4.24 \\
\hline$T i$ & 0.00 & 0.00 & 0.0 & 0.00 & $0 . \infty$ & $0 . \infty$ & 0.00 & 0.00 & $0 . \infty$ & 0.0 & 0.00 & 0.01 & 0.0 & 0.0 & $0 . \infty$ & 0.00 & 0.0 \\
\hline $\mathrm{Fe}^{2}$ & 0.01 & 0.00 & 0.02 & 0.01 & $0 . \infty$ & 0.00 & 0.03 & 0.03 & $0 . \infty$ & 0.01 & 0.01 & 0.01 & 0.01 & 0.02 & 0.01 & 0.00 & 0.00 \\
\hline$M n$ & 0.00 & 0.00 & $0 . \infty$ & 0.0 & 0.0 & 0.00 & 0.00 & 0.0 & 0.00 & 0.00 & 0.01 & 0.00 & 0.00 & 0.00 & 0.00 & 0.0 & 0.00 \\
\hline $\mathrm{Mg}$ & 0.00 & 0.00 & 0.00 & 0.00 & 0.0 & 0.0 & 0.00 & 0.00 & $0 . \infty$ & 0.0 & 0.00 & 0.01 & 0.00 & 0.00 & 0.00 & 0.00 & 0.00 \\
\hline $\mathrm{Ba}$ & & & -1 & -1 & & & -1 & 4 & 7 & & & -1 & & 0.00 & 0.0 & & \\
\hline $\mathrm{Ca}$ & 0.45 & 0.49 & 0.05 & 0.32 & 0.36 & 0.20 & 0.10 & 0.11 & 0.03 & 0.12 & 0.12 & 0.43 & 0.06 & 0.43 & 0.04 & 0.17 & 0.19 \\
\hline $\mathrm{Na}$ & 3.25 & 3.23 & 3.5 & 3.31 & 3.42 & 3.75 & 3.85 & 3.82 & 4.00 & 3.67 & 3.51 & 3.33 & 3.66 & 3.35 & 3.78 & 3.78 & 3.77 \\
\hline $\mathrm{K}$ & 0.03 & 0.04 & 0.04 & 0.06 & 0.03 & 0.02 & 0.04 & 0.06 & 0.02 & 0.04 & 0.04 & 0.06 & 0.03 & 0.06 & 0.03 & 0.04 & 0.03 \\
\hline Cátions & 19.81 & 19.83 & 19.78 & 19.75 & 19.86 & 19.99 & 20.01 & 20.02 & 20.06 & 19.89 & 19.78 & 19.85 & 19.83 & 19.90 & 19.90 & 20.01 & 20.00 \\
\hline$A b$ & 87.0 & 85.9 & 97.8 & 89.8 & 89.9 & 94.6 & 96.6 & 95.7 & 98.8 & 95.8 & 95.7 & 87.3 & 97.6 & 87.6 & 98.2 & 94.9 & 94.6 \\
\hline $\mathrm{An}$ & 12.2 & 12.9 & 1.3 & 8.8 & 9.3 & 4.9 & 2.5 & 2.8 & 0.6 & 3.2 & 3.3 & 11.2 & 1.6 & 11.2 & 1.0 & 4.2 & 4.7 \\
\hline Or & 0.8 & $\begin{array}{l}1.2 \\
\end{array}$ & 1.0 & 1.4 & 0.7 & 0.5 & 0.9 & 1.5 & 0.6 & 1.0 & 1.0 & 1.5 & 0.8 & 1.2 & 0.8 & 0.9 & 0.7 \\
\hline
\end{tabular}

Tabela A4.3.1: Dados analíticos de plagioclásios de TTG, GB, MGF e PGD intrusivos na SVS. Fórmula estrutural: 32(O) 
Tabela A4.3: Plagioclásios - PLA.

\begin{tabular}{|c|c|c|c|c|c|c|c|c|c|c|c|c|c|c|c|c|c|}
\hline Amostra & G3a & G-33 & G-3a & G.3a & G-3a & G-3a & 6-3a & G-3a & G-3a & G-11a & G-11a & G-11a & G-11a & $G-11 a$ & G-11a & $G-68$ & $G-68$ \\
\hline Análise & $39 / 1 P 1.3$ & $39 / 1 P 1.4$ & $39 / 1 P 1.5$ & $39 / 1 \mathrm{P} 1.6$ & $39 / 1 \mathrm{P} 2.1$ & $39 / 4 P 2.2$ & $39 / 1 \mathrm{P} 2.3$ & $39 / 2 \mathrm{P} 1.1$ & $39 / 2 \mathrm{P} 1.2$ & $5 / 1 / 8$ & $5 / 19$ & $5 / 2 / 12$ & $5 / 2 / 13$ & $5 / 2 / 16$ & $5 / 217$ & $32 / 1 \mathrm{P} 1.1$ & $3211 \mathrm{P} 1.2$ \\
\hline $\begin{array}{l}\text { Mineral } \\
\text { Local }\end{array}$ & PLA & PLA & PLA & PLA & PLA & PLA & PLA & PLA & PLA & PLA & PLA & PLA & PLA & PLA & PLA & PLA & PLA \\
\hline Local & $\mathrm{B}$ & Pln & B & $B$ & $\mathrm{C}$ & $c$ & B & $\mathrm{B}$ & $c$ & C & $\mathrm{B}$ & B & $\mathrm{C}$ & $B$ & $C$ & B & Plm \\
\hline Litotipo & MGF & MGF & MGF & MGF & MGF & MGF & MGF & MGF & MGF & $\mathrm{MGF}$ & MGF & MGF & MGF & MGF & MGF & MGF & MGF \\
\hline $\mathrm{SiO}_{2}$ & 67.75 & 66.94 & 67.54 & 68.23 & 68.06 & 67.16 & 68.34 & 66.68 & 67.60 & 66.66 & 66.89 & 65.46 & 65.44 & 67.73 & 68.56 & 66.71 & 66.71 \\
\hline $\mathrm{TiO}_{2}$ & 0.00 & 0.0 & 0.00 & 0.00 & 0.00 & 0.0 & 0.00 & 0.00 & 0.00 & 0.00 & 0.02 & 0.0 & 0.00 & $0 . \infty$ & 0.03 & 0.00 & 0.00 \\
\hline $\mathrm{Al}_{2} \mathrm{O}_{3}$ & 20.46 & 20.48 & 20.19 & 20.37 & 21.07 & 20.65 & 19.97 & 20.64 & 20.71 & 21.33 & 20.40 & 20.67 & 21.27 & 20.21 & 20.67 & 20.71 & 20.51 \\
\hline $\mathrm{Cr}_{2} \mathrm{O}_{3}$ & 0.00 & 0.00 & 0.00 & 0.00 & 0.00 & 0.00 & 0.00 & 0.00 & 0.00 & 0.0 & 0.01 & 0.01 & 0.0 & 0.03 & 0.02 & 0.00 & 0.00 \\
\hline $\mathrm{Zno}$ & n.a. & n.a. & n.a. & n.a. & n.a. & n.a. & n.a. & n.a. & n.a. & n.a. & n.a. & ก.a. & n.a. & n.a. & n.a. & n.a. & n.a. \\
\hline $\mathrm{FeO}$ & 0.00 & 0.21 & 0.45 & 0.41 & $0 . \infty$ & 0.16 & 0.21 & $0 . \infty$ & 0.0 & 0.03 & 0.07 & 0.07 & 0.00 & 0.05 & 0.02 & 0.00 & 0.00 \\
\hline Mino & 0.00 & 0.13 & 0.00 & 0.15 & 0.00 & 0.00 & $0 . \infty$ & 0.0 & $0 . \infty$ & 0.03 & $0 . \infty$ & $0 . \infty$ & 0.00 & 0.03 & 0.01 & 0.15 & 0.00 \\
\hline Mgo & 0.00 & $0 . \infty$ & 0.00 & $0 . \infty$ & 0.00 & 0.00 & 0.00 & 0.00 & 0.00 & 0.01 & 0.0 & 0.01 & 0.00 & 0.00 & 0.00 & $0 . \infty$ & 0.00 \\
\hline NiO & 0.00 & 0.0 & 0.00 & 0.00 & 0.00 & 0.0 & 0.00 & 0.00 & 0.00 & n.a. & n.a. & n.a. & n.a. & n.a. & n.a. & $0 . \infty$ & 0.00 \\
\hline $\mathrm{CaO}$ & 0.68 & 0.91 & 0.44 & 0.47 & 0.92 & 0.83 & 0.20 & 0.95 & 1.05 & 1.56 & 0.68 & 0.76 & 1.38 & 0.28 & 0.33 & 1.12 & 0.92 \\
\hline $\mathrm{Na}_{2} \mathrm{O}$ & 11.33 & 11.34 & 11.32 & 9.72 & 8.61 & 11.19 & 11.50 & 10.92 & 11.03 & 10.08 & 10.75 & 10.78 & 10.30 & 10.75 & 10.67 & 11.11 & 11.21 \\
\hline $\mathrm{K}_{2} \mathrm{O}$ & 0.11 & 0.17 & 0.09 & 0.14 & 0.18 & 0.16 & 0.12 & 0.15 & 0.24 & 0.24 & 0.22 & 0.15 & 0.12 & 0.15 & 0.10 & 0.12 & 0.11 \\
\hline $\mathrm{P}_{2} \mathrm{O}_{5}$ & 0.15 & 0.16 & 0.00 & 0.00 & 0.00 & $0 . \infty$ & 0.0 & 0.00 & 0.00 & n.a. & n.a. & n.a. & n.a. & n.a. & n.a. & 0.00 & 0.00 \\
\hline $\mathrm{BaO}$ & n.a. & n.a. & n.a. & n.a. & n.a. & n.a. & n.a. & n.a. & n.a. & 0.00 & 0.0 & 0.04 & 0.01 & $0 . \infty$ & 0.0 & n.a. & n.a. \\
\hline$F$ & n.a. & B.a. & n.a. & ก.a. & n.a. & n.a. & n.a. & n.a. & n.a. & $0 . \infty$ & 0.12 & 0.00 & 0.00 & 0.00 & 0.00 & n.a. & n.a. \\
\hline $\mathrm{Cl}$ & 0.00 & $0 . \infty$ & 0.00 & 0.00 & 0.00 & 0.00 & 0.00 & 0.0 & $0 . \infty$ & n.a. & n.a. & n.a. & n.a. & n.a. & n.a. & 0.00 & 0.00 \\
\hline Total & 100.48 & 100.34 & 100.03 & 99.49 & 98.84 & 100.15 & 100.34 & 99.34 & 100.63 & 99.94 & 99.16 & 97.95 & 98.52 & 99.23 & 100.41 & 99.92 & 99.46 \\
\hline $\mathrm{Si}$ & 11.80 & 11.72 & 11.83 & 11.93 & 11.91 & 11.76 & 11.91 & 14.75 & 11.77 & 11.68 & 11.81 & 11.71 & 11.63 & 11.90 & 11.89 & 11.72 & 11.75 \\
\hline AI & 4.20 & 4.22 & 4.17 & 4.20 & 4.34 & 4.26 & 4.10 & 4.28 & 4.25 & 4.40 & 4.24 & 4.35 & 4.45 & 4.18 & 4.22 & 4.28 & 4.26 \\
\hline $\mathrm{Ti}$ & 0.00 & $0 . \infty$ & 0.00 & 0.0 & 0.00 & 0.00 & 0.00 & 0.00 & 0.0 & $0 . \infty$ & $0 . \infty$ & 0.00 & 0.00 & 0.00 & 0.00 & 0.00 & 0.00 \\
\hline $\mathrm{Fe}^{2}$ & 0.0 & 0.03 & 0.07 & 0.06 & $0 . \infty$ & 0.02 & 0.08 & $0 . \infty$ & $0 . \infty$ & 0.00 & 0.01 & 0.01 & 0.00 & 0.01 & 0.00 & 0.00 & 0.00 \\
\hline $\mathrm{Mn}$ & 0.00 & 0.02 & 0.00 & 0.02 & 0.00 & 0.00 & 0.00 & 0.00 & 0.0 & 0.00 & 0.00 & 0.0 & 0.00 & 0.00 & $0 . \infty$ & 0.02 & 0.00 \\
\hline $\mathrm{Mg}$ & 0.00 & 0.00 & 0.00 & 0.00 & $0 . \infty$ & 0.00 & 0.00 & 0.00 & $0 . \infty$ & 0.00 & 0.00 & 0.00 & 0.00 & 0.00 & 0.00 & 0.00 & 0.00 \\
\hline $8 a$ & & & & & & & & -1 & & 0.0 & 0.00 & 0.00 & 0.00 & 0.00 & 0.00 & & \\
\hline $\mathrm{Ca}$ & 0.13 & 0.17 & 0.08 & 0.09 & 0.17 & 0.16 & 0.04 & 0.18 & 0.20 & 0.29 & 0.13 & 0.15 & 0.26 & 0.05 & 0.06 & 0.21 & 0.17 \\
\hline $\mathrm{Na}$ & 3.83 & 3.85 & 3.85 & 3.30 & 2.92 & 3.80 & 3.89 & 3.73 & 3.72 & 3.42 & 3.68 & 3.74 & 3.55 & 3.66 & 3.50 & 3.78 & 3.83 \\
\hline $\mathrm{K}$ & 0.02 & 0.04 & 0.02 & 0.03 & 0.04 & 0.04 & 0.03 & 0.03 & 0.05 & 0.05 & 0.06 & 0.03 & 0.03 & 0.03 & 0.02 & 0.00 & 0.03 \\
\hline Cátions & 19.99 & 20.07 & 20.01 & 19.63 & 19.39 & 20.03 & 19.99 & 19.98 & 19.99 & 19.86 & 19.92 & 19.99 & 19.92 & 19.84 & 19.79 & 20.04 & 20.04 \\
\hline$A B$ & 96.2 & 94.8 & 97.4 & 96.5 & 93.2 & 95.2 & 98.4 & 94.6 & 93.7 & 90.8 & 95.4 & 95.4 & 92.4 & 97.7 & 97.7 & 94.1 & 95.1 \\
\hline $\mathrm{An}$ & 3.2 & 4.2 & 2.1 & 2.6 & 5.5 & 3.9 & 0.9 & 4.5 & 4.9 & 7.8 & 3.3 & 3.7 & 6.8 & 1.4 & 1.7 & 5.2 & 4.3 \\
\hline Or & 0.6 & 0.9 & 0.5 & 0.9 & 1.3 & 0.9 & 0.7 & 0.9 & 1.3 & 1.4 & 1.3 & 0.9 & 0.7 & 0.9 & 0.6 & 0.7 & 0.6 \\
\hline
\end{tabular}

Tabela A4.3.1: Dados analiticos de plagioclásios de TTG, GB, MGF e PGD intrusivos na SVS. Fórmula estrutural: $32(O)$. 
Tabela A4.3: Plagioclásios - PLA.

\begin{tabular}{|c|c|c|c|c|c|c|c|c|c|c|c|c|c|c|c|c|}
\hline Amostra & $G-68$ & $G-68$ & $G-68$ & ASTRO-01 & ASTRO-01 & ASTRO-01 & ASTRO-01 & ASTRO-01 & |ASTRO-01 & ASTRO-01 & ASTRO-01 & ASTRO-01 & $\mathrm{M}-5$ & M5 & M-5 & M-5 \\
\hline Análise & $32 / 2 \mathrm{P} 1.1$ & $32 / 2 \times 1.2$ & $32 / 2 P 1.3$ & $401 P 1.1$ & $401 P 1.2$ & $40 / 1 P 1.3$ & 40/1P2.1 & 4Q/1P2.2 & $40 / 2 \mathrm{P} 1.1$ & $40 / 2 P 2.1$ & $40 / 3 P 1.1$ & $4013 P 1.2$ & $3 / 28$ & $3 / 3 / 11$ & $3 / 3 / 12$ & $3 / 4 / 16$ \\
\hline Mineral & PLA & PLA & PLA & PLA & PLA & PLA & PLA & PLA & PLA & PLA & PLA & PLA & PLA & PLA & PLA & PLA \\
\hline Local & B & PIn & $\mathrm{C}$ & $B$ & PIn & PIn & 8 & Pin & Pln & PIn & B & Pin & $c$ & $\mathrm{C}$ & B & $\mathrm{C}$ \\
\hline Litotipo & MGF & MGF & MGF & PGD & $P G D$ & PGD & PGD & PGD & PGD & PGD & PGD & PGD & PGD & PGD & PGD & PGD \\
\hline $\mathrm{SiO}_{2}$ & 67.61 & 67.39 & 66.71 & 63.5 & 63.16 & 64.70 & 62.75 & 63.42 & 63.20 & 62.89 & 66.47 & 63.5 & 57.28 & 58.01 & 57.36 & 58.27 \\
\hline $\mathrm{TiO}_{2}$ & 0.00 & 0.00 & 0.0 & 0.00 & 0.00 & 0.00 & 0.00 & 0.00 & 0.00 & 0.00 & 0.00 & 0.0 & 0.03 & 0.00 & 0.03 & 0.02 \\
\hline $\mathrm{Al}_{2} \mathrm{O}_{3}$ & 20.30 & 20.28 & 20.73 & 24.82 & 24.84 & 25.20 & 24.58 & 24.83 & 24.95 & 25.05 & 23.91 & 24.78 & 27.74 & 27.11 & 27.30 & 26.71 \\
\hline $\mathrm{Cr}_{2} \mathrm{O}_{3}$ & 0.00 & $0 . \infty$ & 0.00 & 0.00 & 0.00 & 0.00 & 0.0 & $0 . \infty$ & 0.00 & 0.00 & 0.00 & 0.00 & 0.03 & 0.00 & 0.03 & 0.00 \\
\hline $\mathrm{ZnO}$ & n.a. & n.a. & ก.a. & n.a. & n.a. & n.a. & n.a. & n.a. & ก.a. & n.a. & n.a. & n.a. & 0.00 & 0.00 & 0.01 & 0.00 \\
\hline $\mathrm{FeO}$ & 0.00 & 0.00 & $0 . \infty$ & 0.24 & 0.00 & 0.00 & 0.15 & 0.00 & 0.0 & 0.00 & 0.00 & 0.00 & 0.01 & 0.10 & 0.05 & 0.01 \\
\hline $\mathrm{MnO}$ & 0.00 & 0.0 & 0.00 & 0.00 & 0.15 & 0.00 & 0.0 & $0 . \infty$ & 0.00 & 0.00 & 0.00 & 0.16 & 0.01 & 0.00 & 0.01 & $0 . \infty$ \\
\hline $\mathrm{MgO}$ & 0.00 & 0.00 & 0.0 & 0.00 & 0.00 & 0.00 & 0.00 & 0.00 & 0.00 & 0.00 & 0.00 & $0 . \infty$ & 0.00 & 0.00 & 0.00 & 0.00 \\
\hline $\mathrm{NiO}$ & 0.00 & 0.00 & 0.00 & 0.00 & 0.00 & 0.00 & 0.00 & 0.00 & 0.00 & 0.00 & 0.00 & 0.00 & 0.05 & 0.02 & 0.00 & 0.00 \\
\hline $\mathrm{CaO}$ & 0.40 & 0.69 & 0.73 & 5.22 & 5.32 & 5.41 & 5.01 & 5.22 & 5.29 & 5.58 & 3.80 & 5.22 & 9.46 & 8.82 & 9.12 & 8.30 \\
\hline $\mathrm{Na}_{2} \mathrm{O}$ & 11.40 & $\$ 1.31$ & 11.11 & 7.72 & 8.91 & 7.15 & 8.82 & 8.76 & 8.89 & 8.89 & 7.26 & 7.03 & 6.04 & 6.27 & 6.28 & 6.78 \\
\hline $\mathrm{K}_{2} \mathrm{O}$ & 0.14 & 0.00 & 0.10 & 0.00 & 0.00 & 0.09 & 0.00 & 0.00 & 0.00 & 0.00 & 0.00 & 0.0 & 0.04 & 0.03 & 0.03 & 0.03 \\
\hline$\overline{\mathrm{P}_{2} \mathrm{O}_{5}}$ & 0.00 & 0.16 & 0.00 & 0.00 & 0.00 & 0.00 & 0.00 & 0.00 & 0.00 & 0.00 & 0.00 & 0.00 & n.a. & n.a. & n.a. & n.a. \\
\hline $\mathrm{BaO}$ & n.a. & n.a. & ก.a. & n.a. & n.a. & n.a. & n.a. & n.a. & n.a. & n.a. & n.a. & n.a. & n.a. & n.a. & n.a. & n.a. \\
\hline$F$ & n.a. & ก.a. & n.a. & ก.a. & n.a. & n.a. & ก.a. & ก.a. & ก.a. & n.a. & n.a. & n.a. & n.a. & n.a. & n.a. & n.a. \\
\hline $\mathrm{Cl}$ & 0.00 & 0.00 & 0.00 & $0 . \infty$ & 0.00 & 0.00 & 0.0 & 0.00 & $0 . \infty$ & 0.00 & $0 . \infty$ & $0 . \infty$ & n.a. & n.a. & n.a. & n.a. \\
\hline Total & 99.85 & 99.92 & 99.38 & 101.55 & 102.38 & 102.55 & 101.31 & 102.23 & 102.42 & 102.50 & 101.44 & 100.74 & 100.60 & 100.36 & 100.22 & 100.12 \\
\hline $\mathrm{Si}$ & 11.84 & 11.80 & 11.75 & 11.04 & 10.94 & 11.00 & 10.97 & 10.98 & 10.95 & 10.89 & 11.42 & 11.09 & 10.20 & 10.34 & 10.25 & 10.40 \\
\hline$\overline{\mathrm{Al}}$ & 4.19 & 4.18 & 4.30 & 5.08 & 5.07 & 5.00 & 5.06 & 5.06 & 5.08 & 5.11 & 4.84 & 5.09 & 5.82 & 5.0 & 5.75 & 5.61 \\
\hline $\mathrm{Ti}$ & 0.00 & 0.00 & 0.00 & 0.00 & 0.00 & 0.00 & 0.00 & $0 . \infty$ & 0.00 & 0.00 & 0.00 & 0.00 & 0.0 & 0.00 & 0.00 & 0.00 \\
\hline $\mathrm{Fe}^{2}$ & 0.00 & $0 . \infty$ & 0.00 & 0.04 & 0.0 & 0.00 & 0.02 & 0.00 & 0.00 & 0.0 & 0.00 & 0.00 & 0.00 & 0.02 & 0.01 & 0.00 \\
\hline$M n$ & 0.00 & 0.00 & 0.00 & 0.00 & 0.02 & 0.00 & 0.00 & 0.0 & 0.00 & 0.00 & 0.00 & 0.02 & 0.00 & 0.00 & 0.00 & 0.0 \\
\hline $\mathrm{Mg}$ & 0.00 & 0.0 & 0.00 & 0.00 & 0.00 & $0 . \infty$ & $0 . \infty$ & $0 . \infty$ & 0.00 & 0.00 & 0.00 & 0.00 & 0.00 & 0.00 & 0.00 & 0.00 \\
\hline $\mathrm{Ba}$ & & & & & & & & & & & & & & & - & \\
\hline $\mathrm{Ca}$ & 0.08 & 0.13 & 0.14 & 0.97 & 0.99 & 0.99 & 0.94 & 0.97 & 0.98 & 1.04 & 0.70 & 0.98 & 1.80 & $1 . \infty 8$ & 1.75 & 1.59 \\
\hline $\mathrm{Na}$ & 3.87 & 3.84 & 3.79 & 2.60 & 2.9 & 2.38 & 2.90 & 2.94 & 2.98 & 2.99 & 2.42 & 2.38 & 2.09 & 2.17 & 2.18 & 2.35 \\
\hline $\mathrm{K}$ & 0.08 & 0.02 & 0.02 & $0 . \infty$ & 0.00 & 0.02 & 0.00 & 0.00 & 0.0 & 0.02 & $0 . \infty$ & $0 . \infty$ & 0.01 & 0.01 & 0.01 & 0.01 \\
\hline Cátions & 20.01 & 19.9 & 20.00 & 19.72 & 20.01 & 19.56 & 19.9 & 19.95 & 19.90 & 20.05 & 19.37 & 19.55 & 19.93 & 19.90 & 19.95 & 19.96 \\
\hline$A B$ & 97.3 & 96.3 & 96.0 & 72.8 & 75.2 & 70.1 & 76.1 & 75.2 & 75.3 & 73.9 & 77.6 & 70.9 & 53.5 & 56.2 & 55.4 & 59.5 \\
\hline $\mathrm{An}$ & 1.9 & 3.2 & 3.5 & 27.2 & 24.8 & 29.3 & 23.9 & 24.8 & 24.7 & 25.6 & 22.4 & 29.1 & 46.3 & 43.7 & 44.4 & 40.3 \\
\hline Or & 0.8 & 0.5 & 0.6 & 0.0 & 0.0 & 0.6 & 0.0 & 0.0 & 0.0 & 0.5 & 0.0 & 0.0 & 0.2 & 0.2 & 0.2 & 0.2 \\
\hline
\end{tabular}

Tabela A4.3.1: Dados analíticos de plagioclásios de TTG, GB, MGF e PGD intrusivos na SVS. Fórmula estrutural: 32(O). 
Tabela A4.3: Plagioclásios - PLA.

\begin{tabular}{|c|c|c|c|c|c|c|c|c|c|c|}
\hline Amostra & NE- 30 & NE 30 & NE-31 & NE-31-06 & NE-31.06 & $\mathrm{NE}-31-06$ & NE-31-O6 & SUL-01 & SUL-01 & SUL-01 \\
\hline Análise & $6 / 1 / 48$ & $6 / 1 / 49$ & $62 \sqrt{58}$ & $3 / 1 / 24$ & $3 / 3 / 28$ & $3 / 4 / 29$ & $3 / 4 / 31$ & $2 / 1 / 9$ & $6 / 5 / 63$ & $65 / 64$ \\
\hline Mineral & PLA & PLA & PLA & PLA & PLA & PLA & $\mathrm{PLA}$ & PLA & PLA & PLA \\
\hline Local & B & C & $\mathrm{C}$ & $\mathrm{C}$ & $C$ & Lente Fio & $\mathrm{C}$ & Lente Flo & $\mathrm{C}$ & $B$ \\
\hline Litotipo & PGD-UM & PGD-UM & PGD-UM & $\mid$ PGDUM & PGD-UM & PGD-UM & PGD-UM & PGD-UM & PGDUUM & PGD-UM \\
\hline $\mathrm{SiO}_{2}$ & ธ3.66 & 63.02 & 61.05 & 61.92 & 59.47 & 68.64 & 60.63 & 67.48 & 61.07 & 61.65 \\
\hline $\mathrm{TiO}_{2}$ & $0 . \infty$ & 0.00 & $0 . \infty$ & 0.04 & 0.00 & 0.00 & 0.03 & 0.00 & 0.05 & 0.01 \\
\hline $\mathrm{Al}_{2} \mathrm{O}_{3}$ & 23.27 & 24.02 & 24.25 & 23.73 & 25.43 & 19.67 & 25.05 & 20.04 & 25.25 & 24.41 \\
\hline $\mathrm{Cr}_{2} \mathrm{O}_{3}$ & 0.03 & 0.02 & 0.00 & $0 . \infty$ & 0.00 & 0.00 & 0.01 & 0.02 & 0.00 & 0.00 \\
\hline $\mathrm{ZnO}$ & n.a. & n.a. & ก.a. & 0.00 & $0 . \infty$ & 0.0 & 0.0 & 0.00 & n.a. & n.a. \\
\hline $\mathrm{FeO}$ & 0.05 & 0.0 & 0.0 & 0.05 & 0.02 & 0.06 & 0.05 & 0.30 & 0.05 & 0.00 \\
\hline Mno & 0.0 & 0.02 & 0.04 & 0.03 & 0.00 & 0.02 & 0.01 & 0.00 & 0.02 & 0.00 \\
\hline $\mathrm{MgO}$ & 0.01 & 0.01 & $0 . \infty$ & 0.00 & 0.02 & 0.01 & 0.01 & 0.00 & 0.01 & 0.01 \\
\hline $\mathrm{NiO}$ & n.a. & n.a. & ก.a. & 0.00 & 0.02 & 0.03 & 0.01 & 0.00 & n.a. & n.a. \\
\hline $\mathrm{CaO}$ & 4.42 & 5.30 & 5.71 & 4.73 & 6.97 & 0.02 & 6.45 & 0.73 & 6.91 & 6.29 \\
\hline $\mathrm{Na}_{2} \mathrm{O}$ & 8.67 & 8.11 & 7.91 & 8.53 & 7.54 & 11.03 & 7.77 & 10.57 & 7.27 & 7.66 \\
\hline $\mathrm{K}_{2} \mathrm{O}$ & 0.03 & 0.11 & 0.06 & 0.14 & 0.06 & 0.02 & 0.06 & 0.05 & 0.09 & 0.10 \\
\hline $\mathrm{P}_{2} \mathrm{O}_{5}$ & ก.a. & n.a. & n.a. & n.a. & n.a. & n.a. & n.a. & ก.a. & n.a. & n.a. \\
\hline $\mathrm{BaO}$ & 0.00 & 0.00 & 0.0 & n.a. & ก.a. & n.a. & n.a. & n.a. & 0.02 & 0.0 \\
\hline$F$ & 0.14 & 0.00 & 0.00 & n.a. & n.a. & n.a. & n.a. & n.a. & 0.04 & 0.00 \\
\hline $\mathrm{Cl}$ & n.a. & n.a. & n.a. & n.a. & n.a. & n.a. & n.a. & n.a. & n.a. & n.a. \\
\hline Total & 100.28 & 100.61 & 99.02 & 9.17 & 99.53 & 99.50 & 100.08 & 99.19 & 100.78 & 100.13 \\
\hline Si & 11.21 & 11.07 & 10.92 & 11.05 & 10.64 & 12.01 & 10.77 & 11.88 & 10.77 & 10.92 \\
\hline Al & 4.83 & 4.97 & 5.11 & 4.99 & 5.36 & 4.05 & 5.24 & 4.16 & 5.24 & 5.09 \\
\hline Ti & $0 . \infty$ & 0.00 & $0 . \infty$ & 0.01 & 0.00 & 0.0 & 0.00 & 0.00 & 0.01 & 0.00 \\
\hline $\mathrm{Fe}^{2}$ & 0.01 & 0.00 & 0.00 & 0.01 & 0.00 & 0.01 & 0.01 & 0.04 & 0.01 & 0.00 \\
\hline $\mathrm{Mn}$ & 0.00 & 0.00 & 0.01 & 0.01 & $0 . \infty$ & 0.0 & 0.00 & 0.00 & $0 . \infty$ & 0.00 \\
\hline $\mathrm{Mg}$ & 0.00 & 0.00 & 0.00 & $0 . \infty$ & 0.01 & 0.00 & 0.00 & 0.00 & 0.00 & 0.00 \\
\hline $\mathrm{Ba}$ & 0.00 & 0.00 & 0.00 & & & & & & 0.00 & 0.0 \\
\hline $\mathrm{Ca}$ & 0.83 & 1.00 & 1.10 & 0.90 & 1.34 & 0.00 & 1.23 & 0.14 & 1.31 & 1.19 \\
\hline $\mathrm{Na}$ & 2.96 & 2.76 & 2.74 & 2.96 & 2.62 & 3.74 & 2.68 & 3.61 & 2.49 & 2.63 \\
\hline K & 0.01 & 0.03 & 0.01 & 0.03 & 0.01 & 0.00 & 0.01 & 0.01 & 0.02 & 0.02 \\
\hline Cátions & 19.85 & 19.83 & 19.89 & 19.94 & 19.98 & 19.83 & 19.94 & 19.84 & 19.85 & 19.86 \\
\hline$A b$ & 77.9 & 73.0 & 71.2 & 75.9 & 66.0 & 99.8 & 68.3 & 96.0 & $\overline{6.2}$ & 68.4 \\
\hline$A n$ & 21.9 & 26.3 & 28.4 & 23.3 & 33.7 & 0.1 & 31.3 & 3.7 & 34.3 & 31.0 \\
\hline Or & 0.2 & 0.7 & 0.4 & 0.8 & 0.4 & 0.1 & 0.4 & 0.3 & $\begin{array}{l}0.5 \\
\end{array}$ & 0.6 \\
\hline
\end{tabular}

Tabela A4.3.2: Dados analíticos de plagioclásios de veios pegmatóides mineralizados em rochas metaultramáficas (PGD-UM). Fórmula estrutural: 32(O). Nota: Lente Flo = lente em flogopita esfoliada. 
Tabela A4.3: Plagioclásios - PLA.

\begin{tabular}{|c|c|c|c|c|c|c|c|c|c|c|c|c|c|c|c|c|c|c|}
\hline $\begin{array}{l}\text { Amostra } \\
\text { Análise }\end{array}$ & \begin{tabular}{|c|}
$\mathrm{HC}-3 \mathrm{a}$ \\
$27 / 1 \mathrm{P} 1.1$
\end{tabular} & $\frac{\mathrm{HC}-3 \mathrm{a}}{271 \mathrm{P} 12}$ & $\frac{\mathrm{HC} 3 \mathrm{a}}{272011}$ & $\frac{\mathrm{HC}_{3} \mathrm{a}}{27 \mathrm{PA} 2}$ & $\frac{\mathrm{HC}-3 \mathrm{a}}{270 \mathrm{C}^{3}}$ & $\mathrm{HC} 3 \mathrm{a}$ & $\mathrm{HC}-3 \mathrm{a}$ & HC-3a & CAP-4 & CAP-4 & \begin{tabular}{|c|} 
CAP-4 \\
\end{tabular} & \begin{tabular}{|c|} 
CAP-4 \\
\end{tabular} & CAP 4 & G.37a & G-37a & G-37a & G $37 a$ & G.37a \\
\hline Mineral & PLA & PLA & PLA & $\frac{2 m \angle r T .2}{\text { PLA }}$ & $\frac{211281.3}{P L A}$ & $\frac{27 / 2 \mathrm{P} 2.1}{\mathrm{PLA}}$ & $27 / 2 \mathrm{P} 2.2$ & $27 / 2 \mathrm{P} 2.3$ & 28/1P1.1 & 28/1P2.1 & 28/1P3.1 & 28/4P1.1 & $28 / 4 P 1.2$ & 29/4P2.1 & $29 / 1 P 2.2$ & $2911 P 2.3$ & 29/1P3.1 & $29 / 1 \mathrm{P} 3.2$ \\
\hline Local & $\mathrm{C}$ & B & $\mathrm{C}$ & Pin & $\mathrm{B}(\mathrm{e})$ & $\mathrm{C}$ & $\frac{F}{B}$ & PIm & $\frac{P L A}{C}$ & $\frac{P L A}{C}$ & $\frac{\text { PLA }}{C}$ & $\frac{\text { PLA }}{B}$ & PLA & $\frac{\text { PLA }}{r}$ & PLA & PLA & PLA & PLA \\
\hline Litotipo & $A B$ & $\overline{A B}$ & $\overline{A B}$ & $\overline{A B}$ & $\mathrm{AB}$ & $\overline{A B}$ & $A B$ & $A B$ & $A B$ & $\overline{A B}$ & $\overline{A B}$ & $\frac{8}{A B}$ & $\frac{C}{A B}$ & $\frac{\mathrm{C}}{\mathrm{ABET}}$ & $\frac{B}{A B F T}$ & $\frac{\mathrm{B}(\mathrm{e})}{\mathrm{ARFT}}$ & $\frac{\mathrm{C}}{\mathrm{ARET}}$ & $\frac{\mathrm{B}}{\mathrm{ABET}}$ \\
\hline $\mathrm{SiO}_{2}$ & 60.33 & 59.64 & 59.78 & 60.04 & 60.32 & 61.25 & 60.10 & 60.87 & 66.42 & 67.50 & 58.55 & 68.55 & 69.08 & 65.49 & $\approx 3.08$ & ธ3.22 & 64.17 & 62.54 \\
\hline $\mathrm{TiO}_{2}$ & 0.00 & 0.00 & 0.00 & 0.00 & 0.00 & 0.00 & 0.00 & 0.00 & 0.00 & 0.00 & $0 . \infty$ & 0.00 & 0.00 & 0.00 & 0.00 & $0 . \infty$ & 0.00 & 0.00 \\
\hline $\mathrm{Al}_{2} \mathrm{O}_{3}$ & 24.55 & 25.24 & 25.27 & 25.10 & 25.28 & 24.31 & 24.85 & 24.40 & 20.38 & 20.27 & 26.31 & 20.01 & 20.02 & 23.74 & 25.13 & 25.58 & 24.53 & 25.67 \\
\hline $\mathrm{Cr}_{2} \mathrm{O}_{3}$ & 0.00 & 0.00 & 0.00 & 0.00 & 0.00 & 0.00 & 0.00 & 0.00 & 0.00 & 0.00 & $0 . \infty$ & 0.00 & 0.00 & 0.00 & 0.00 & 0.00 & 0.00 & 0.00 \\
\hline $\mathrm{ZnO}$ & n.a. & ก.a. & n.a. & n.a. & ก.a. & n.a. & n.a. & n.a. & n.a. & ก.a. & n.a. & n.a. & ก.a. & n.a. & n.a. & n.a. & n.a. & A.a. \\
\hline $\mathrm{FeO}$ & 0.0 & 0.19 & 0.00 & 0.26 & 0.29 & 0.0 & 0.22 & 0.0 & 0.28 & 0.21 & 0.19 & 0.26 & 0.15 & 0.17 & 0.18 & 0.32 & 0.22 & 0.17 \\
\hline $\mathrm{MnO}$ & 0.00 & 0.00 & 0.00 & 0.0 & 0.00 & 0.0 & $0 . \infty$ & 0.00 & 0.0 & $0 . \infty$ & 0.00 & 0.0 & 0.16 & 0.00 & 0.00 & 0.00 & 0.00 & 0.00 \\
\hline $\mathrm{MgO}$ & 0.00 & 0.00 & 0.00 & 0.00 & 0.00 & 0.00 & 0.00 & 0.00 & 0.0 & 0.00 & $0 . \infty$ & 0.00 & 0.0 & 0.00 & 0.00 & $0 . \infty$ & 0.00 & 0.00 \\
\hline NiO & 0.00 & 0.00 & 0.00 & 0.00 & 0.00 & $0 . \infty$ & 0.00 & 0.00 & 0.00 & 0.00 & 0.00 & 0.0 & 0.00 & 0.00 & 0.00 & 0.0 & 0.00 & 0.00 \\
\hline $\mathrm{CaO}$ & 5.64 & 6.14 & 6.09 & 6.15 & 6.02 & 5.38 & 6.02 & 5.12 & 1.08 & 0.50 & 7.42 & 0.16 & 0.00 & 3.87 & 5.43 & 5.79 & 4.92 & 6.14 \\
\hline $\mathrm{Na}_{2} \mathrm{O}$ & 8.16 & 7.86 & 7.95 & 8.19 & 7.82 & 8.62 & 8.25 & 8.49 & 10.90 & 11.26 & 6.28 & 11.64 & 9.47 & 9.98 & 8.ळ & 7.14 & 9.01 & 8.43 \\
\hline $\mathrm{K}_{2} \mathrm{O}$ & 0.21 & 0.23 & 0.15 & 0.16 & 0.17 & 0.25 & 0.25 & 0.23 & 0.20 & 0.16 & 0.08 & 0.00 & 0.00 & 0.00 & 0.00 & 0.00 & 0.08 & 0.00 \\
\hline $\mathrm{P}_{2} \mathrm{O}_{5}$ & 0.00 & 0.0 & 0.00 & $0 . \infty$ & 0.00 & 0.0 & 0.00 & 0.00 & 0.0 & 0.00 & 0.00 & 0.00 & 0.0 & 0.00 & 0.00 & 0.00 & 0.0 & 0.00 \\
\hline $\mathrm{BaO}$ & n.a. & n.a. & n.a. & n.a. & ก.. & n.a. & n.a. & n.a. & ก.a. & n.a. & n.a. & n.a. & n.a. & n.a. & n.a. & n.a. & ก.a. & n.a. \\
\hline $\mathbf{F}$ & n.a. & n.a. & n.a. & n.a. & n.a. & n.a. & n.a. & n.a. & n.a. & n.a. & n.a. & n.a. & n.a. & n.a. & п.a. & n.a. & n.a. & ก.a. \\
\hline $\mathrm{Cl}$ & 0.0 & 0.00 & 0.0 & 0.00 & 0.00 & 0.0 & $0 . \infty$ & 0.00 & $0 . \infty$ & 0.00 & 0.00 & 0.00 & $0 . \infty$ & 0.00 & $0 . \infty$ & $0 . \infty$ & $0 . \infty$ & 0.00 \\
\hline Total & 98.89 & 99.30 & 99.24 & 99.90 & 99.90 & 99.81 & 99.6 & 99.11 & 99.26 & 99.99 & 98.83 & 100.62 & 98.88 & 103.25 & 102.47 & 102.05 & 102.93 & 102.95 \\
\hline Si & 10.84 & 10.70 & 10.71 & 10.72 & 10.74 & 10.90 & 10.75 & 10.90 & 11.75 & 11.84 & 10.53 & 11.91 & 12.08 & 11.21 & 10.91 & 10.93 & 11.04 & 10.80 \\
\hline Al & 5.19 & 5.33 & 5.33 & 5.28 & 5.30 & 5.10 & 5.23 & 5.14 & 4.24 & 4.18 & 5.57 & 4.10 & 4.12 & 4.79 & 5.12 & 5.21 & 4.97 & 5.22 \\
\hline $\mathrm{Ti}$ & 0.0 & 0.00 & 0.00 & 0.0 & 0.00 & 0.0 & 0.00 & 0.00 & 0.0 & 0.00 & 0.00 & $0 . \infty$ & 0.00 & 0.0 & 0.00 & 0.00 & 0.00 & 0.00 \\
\hline $\mathrm{Fe}^{2}$ & 0.00 & 0.03 & 0.00 & 0.04 & 0.04 & 0.0 & 0.03 & $0 . \infty$ & 0.04 & 0.00 & 0.03 & 0.04 & 0.02 & 0.02 & 0.03 & 0.05 & 0.03 & 0.03 \\
\hline $\mathrm{Mn}$ & 0.00 & $0 . \infty$ & 0.0 & 0.0 & 0.00 & 0.00 & 0.00 & 0.00 & 0.0 & 0.00 & 0.00 & 0.00 & 0.02 & 0.0 & 0.0 & 0.00 & 0.00 & 0.00 \\
\hline $\mathrm{Mg}$ & 0.00 & 0.00 & $0 . \infty$ & 0.00 & 0.00 & 0.00 & 0.00 & 0.00 & 0.00 & 0.00 & 0.00 & 0.00 & 0.00 & 0.00 & 0.0 & 0.00 & 0.00 & 0.00 \\
\hline $\mathrm{Ba}$ & & & & & & & & & & & & & & & & & & \\
\hline $\mathrm{Ca}$ & 1.09 & 1.18 & 1.17 & 1.18 & 1.15 & 1.03 & 1.15 & 0.98 & 0.21 & 0.09 & 1.43 & 0.03 & 0.00 & 0.71 & 1.01 & 1.07 & 0.91 & 1.14 \\
\hline $\mathrm{Na}$ & 2.84 & 2.73 & 2.76 & 2.83 & 2.70 & 2.98 & 2.86 & 2.95 & $\begin{array}{l}3.74 \\
\end{array}$ & 3.82 & 2.19 & 3.92 & 3.21 & 3.31 & 2.90 & 2.39 & 3.01 & 2.82 \\
\hline $\mathrm{K}$ & 0.05 & 0.05 & 0.03 & 0.04 & 0.04 & 0.06 & 0.06 & 0.06 & 0.05 & 0.04 & 0.02 & 0.00 & 0.00 & 0.00 & $0 . \infty$ & 0.00 & 0.02 & 0.00 \\
\hline Cátions & 20.00 & 20.02 & 20.01 & 20.08 & 19.97 & 20.06 & 20.09 & 20.02 & 20.02 & 20.00 & 19.78 & 20.00 & 19.46 & 20.04 & 19.97 & 19.65 & 19.98 & 20.00 \\
\hline $\mathrm{Ab}$ & 71.5 & 68.9 & 6.7 & 70.0 & 09.5 & 73.3 & 70.3 & 74.0 & 93.7 & 96.7 & 60.2 & 99.2 & 100.0 & 82.4 & 74.2 & 69.1 & 76.5 & 71.3 \\
\hline An & 27.3 & 29.7 & 29.5 & 29.1 & 29.5 & 25.3 & 28.3 & 24.7 & 5.1 & 2.4 & 39.3 & 0.8 & 0.0 & 17.6 & 25.8 & 30.9 & 23.1 & 28.7 \\
\hline Or & 1.2 & 1.3 & 0.9 & 0.9 & 1.0 & 1.4 & 1.4 & 1.3 & 1.1 & 0.9 & 0.5 & 0.0 & 0.0 & 0.0 & 0.0 & 0.0 & 0.5 & 0.0 \\
\hline
\end{tabular}

Tabela A4.3.3: Dados analíticos de plagioclásios de anfibolitos metabásicos $A B, A B E T$ e ABG. Fórmula estrutural: 32(O) 


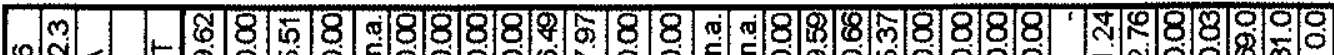

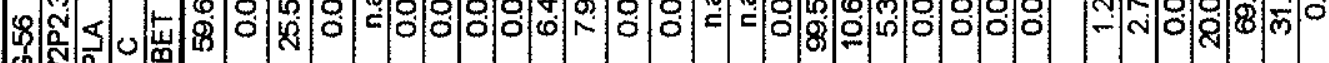

3
3

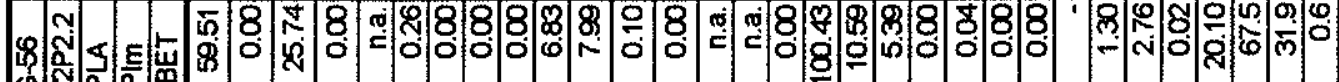

oิ

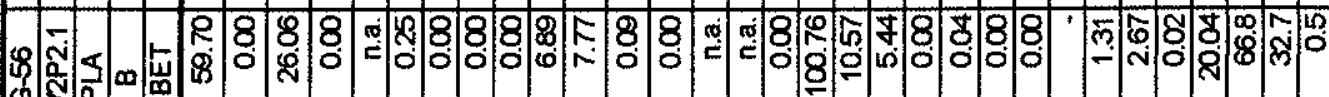

今 N

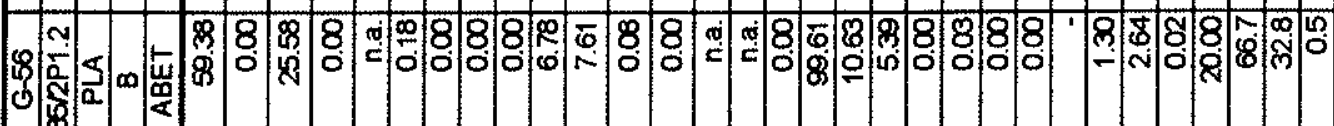

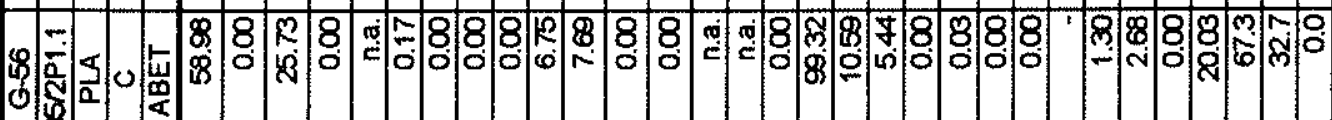

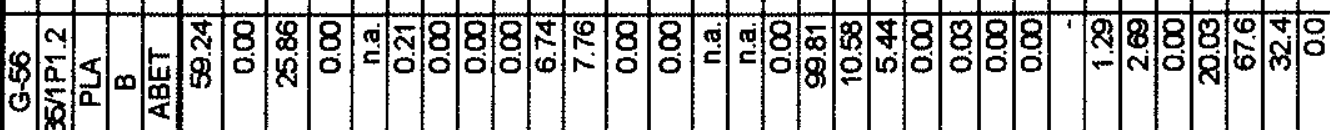

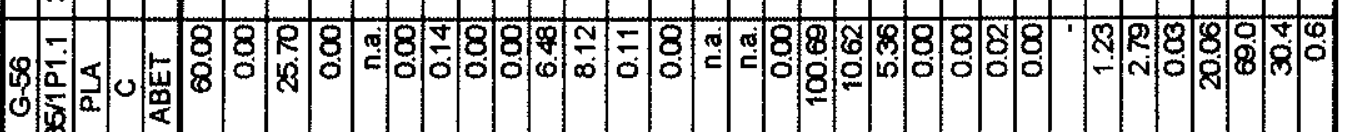

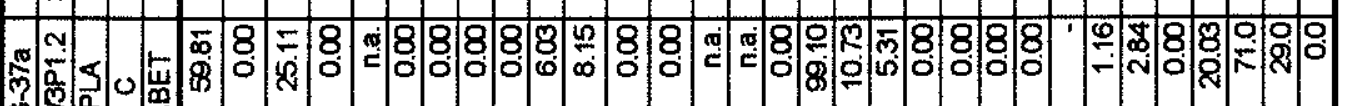
b.

(ุ)

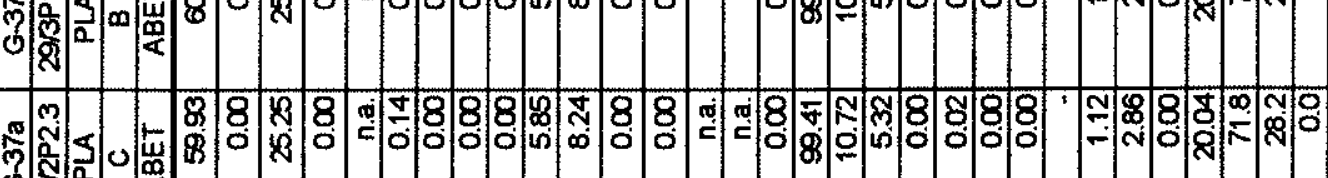
$\mathcal{O}$ 응

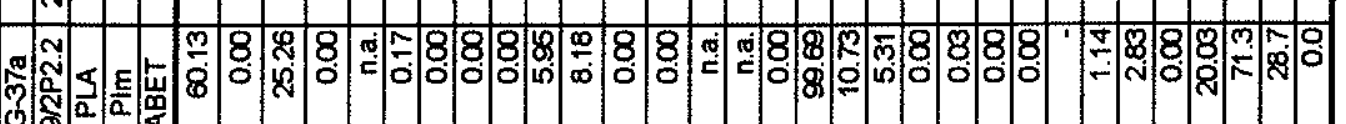

- 8 3.

S ॐ నু

S 了)

(F) (5)

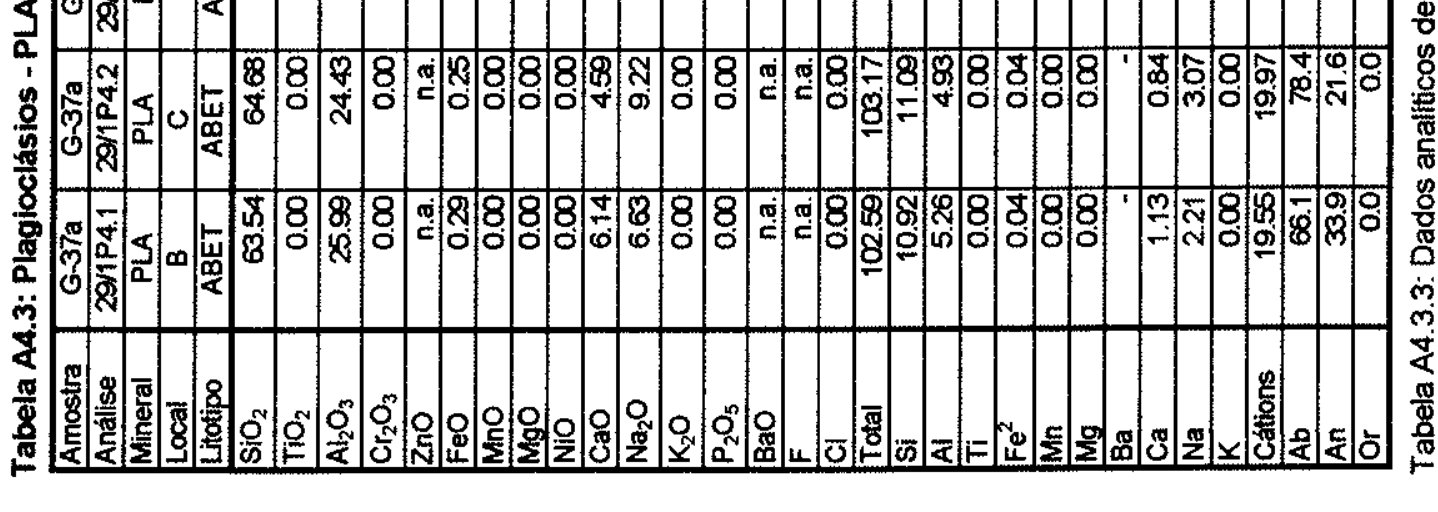


Tabela A4.3: Plagioclásios - PLA.

\begin{tabular}{|c|c|c|c|c|c|c|c|c|c|c|c|c|c|c|c|c|c|}
\hline Amostra & G.56 & G-56 & C-1a & C-1a & C-1a & $G-54 b$ & G-54b & $\mathrm{G}-54 \mathrm{~b}$ & G-54b & $\mathrm{G} 54 \mathrm{~b}$ & $\mathrm{G}-54 \mathrm{~b}$ & $G-54 b$ & G.54b & $6.54 b$ & $G-54 b$ & G-54b & $G 54 b$ \\
\hline Análise & $35 / 2 \mathrm{P} 3.1$ & $35 / 2$ P3.2 & $3 / 154$ & $3 / 359$ & $3 / 4 / 64$ & 6/PL1.1 & 6/PL1.2 & 6/PL1.3 & GPL1.4 & 6PL1.5 & 6P12.1 & GPL2.2 & 6/PL2.3 & 6/1P1.1 & G1P1.2 & $6 / 1 \mathrm{P} 1.3$ & 6/4P1.4 \\
\hline Mineral & PLA & PLA & PLA & PLA & PLA & PLA & PLA & PLA & PLA & PLA & PLA & PLA & PLA & PLA & PLA & PLA & PLA \\
\hline Local & $\mathrm{C}$ & B & $\mathrm{C}$ & $\mathrm{C}$ & C & PIn & $B(i)$ & $\mathrm{B}(\mathrm{e})$ & C & Pln & $B$ & Plm & $\mathrm{C}$ & 80 & Plm & Pin & $\mathrm{Pln}$ \\
\hline Litotipo & ABET & ABET & ABG & $A B G$ & $A B G$ & $A B G$ & $\mathrm{ABG}$ & $A B G$ & $\overline{A B G}$ & $A B G$ & $A B G$ & ABG & $A B G$ & $A B G$ & ABG & $A B G$ & $A B G$ \\
\hline $\mathrm{SiO}_{2}$ & 59.51 & 59.18 & 60.05 & 57.17 & 60.77 & 59.6 & 58.20 & 58.10 & 60.58 & 58.26 & 58.78 & 58.54 & 58.62 & 58.26 & 58.47 & $58 . \infty 5$ & 58.56 \\
\hline $\mathrm{TiO}_{2}$ & 0.00 & 0.00 & 0.06 & 0.00 & 0.00 & 0.0 & 0.00 & 0.00 & 0.0 & 0.00 & 0.00 & 0.00 & 0.00 & 0.0 & 0.00 & 0.00 & 0.00 \\
\hline $\mathrm{Al}_{2} \mathrm{O}_{3}$ & 25.64 & 25.74 & 26.09 & 28.02 & 25.86 & 25.63 & 25.71 & 26.58 & 25.03 & 26.60 & 26.08 & 26.24 & 26.22 & 26.72 & 26.71 & 26.67 & 26.35 \\
\hline $\mathrm{Cr}_{2} \mathrm{O}_{3}$ & $0 . \infty$ & 0.00 & 0.02 & 0.00 & 0.05 & 0.00 & 0.00 & 0.00 & $0 . \infty$ & 0.00 & 0.00 & 0.00 & 0.00 & 0.00 & 0.00 & 0.00 & 0.00 \\
\hline $\mathrm{ZnO}$ & n.a. & n.a. & 0.00 & 0.00 & 0.00 & n.a. & n.a. & ก.a. & n.a. & n.a. & n.a. & n.a. & n.a. & n.a. & n.a. & n.a. & n.a. \\
\hline $\mathrm{FeO}$ & 0.18 & 0.25 & 0.09 & 0.01 & 0.06 & 0.00 & 0.00 & 0.18 & 0.0 & 0.0 & 0.00 & 0.00 & 0.0 & 0.18 & 0.19 & 0.15 & 0.00 \\
\hline MnO & $0 . \infty$ & 0.00 & 0.00 & 0.0 & $0 . \infty$ & 0.00 & 0.00 & $0 . \infty$ & 0.00 & 0.00 & $0 . \infty$ & 0.00 & 0.00 & 0.0 & 0.00 & $0 . \infty$ & 0.00 \\
\hline $\mathrm{MgO}$ & 0.00 & 0.00 & 0.01 & $0 . \infty$ & 0.00 & $0 . \infty$ & 0.00 & 0.00 & 0.0 & 0.00 & 0.00 & 0.0 & $0 . \infty$ & 0.00 & $0 . \infty$ & 0.00 & 0.00 \\
\hline $\mathrm{NiO}$ & 0.00 & 0.00 & 0.0 & 0.03 & 0.01 & 0.00 & 0.0 & $0 . \infty$ & 0.00 & 0.00 & 0.00 & 0.00 & 0.0 & 0.00 & 0.00 & 0.00 & 0.00 \\
\hline $\mathrm{CaO}$ & 6.60 & 6.84 & 7.56 & 9.60 & 7.28 & 6.66 & 7.12 & 7.70 & 5.72 & 7.32 & 7.22 & 7.40 & 7.40 & 7.52 & 7.74 & 7.75 & 7.25 \\
\hline $\mathrm{Na}_{2} \mathrm{O}$ & 7.83 & 7.88 & 6.89 & 5.92 & 7.24 & 7.66 & 7.56 & 7.32 & 8.23 & 7.24 & 7.57 & 7.53 & 7.40 & 7.27 & 7.32 & 7.27 & 7.41 \\
\hline $\mathrm{K}_{2} \mathrm{O}$ & 0.00 & 0.00 & 0.04 & 0.03 & 0.04 & 0.00 & 0.0 & 0.00 & 0.00 & 0.10 & 0.00 & 0.00 & 0.00 & 0.00 & 0.00 & 0.00 & 0.00 \\
\hline $\mathrm{P}_{2} \mathrm{O}_{5}$ & 0.0 & 0.00 & n.a. & n.a. & n.a. & 0.00 & 0.00 & 0.00 & 0.00 & 0.00 & $0 . \infty$ & 0.00 & 0.00 & 0.00 & 0.00 & 0.0 & 0.0 \\
\hline $\mathrm{BaO}$ & n.a. & n.a. & n.a. & n.a. & n.a. & n.a. & n.a. & n.a. & n.a. & n.a. & n.a. & n.a. & n.a. & n.a. & n.a. & n.a. & ก.a. \\
\hline $\mathbf{F}$ & n.a. & n.a. & n.a. & n.a. & n.a. & n.a. & n.a. & n.a. & n.a. & n.a. & n.a. & n.a. & n.a. & n.a. & n.a. & n.a. & n.a. \\
\hline $\mathrm{Cl}$ & 0.00 & 0.00 & n.a. & n.a. & n.a. & 0.0 & 0.00 & 0.00 & 0.00 & 0.00 & 0.00 & 0.0 & 0.00 & 0.00 & 0.0 & 0.00 & 0.00 \\
\hline Total & 99.76 & 99.89 & 100.80 & 100.84 & 101.31 & 99.58 & 98.59 & 99.88 & 99.56 & 99.52 & 99.65 & 99.71 & 99.64 & 99.95 & 100.43 & 100.49 & 99.57 \\
\hline $\mathrm{Si}$ & 10.6 & 10.58 & 10.60 & 10.16 & 10.67 & 10.65 & 10.53 & 10.40 & 10.80 & 10.45 & 10.52 & 10.48 & 10.50 & 10.41 & 10.41 & 10.43 & 10.49 \\
\hline AI & 5.39 & 5.42 & 5.43 & 5.87 & 5.35 & 5.39 & 5.48 & 5.61 & 5.25 & 5.62 & 5.50 & 5.53 & 5.53 & 5.63 & 56 & 5.59 & 5.56 \\
\hline $\mathrm{Ti}$ & 0.00 & 0.00 & 0.01 & 0.0 & 0.00 & 0.0 & 0.00 & 0.0 & 0.00 & 0.0 & 0.0 & 0.00 & 0.0 & 0.0 & 0.00 & 0.00 & 0.00 \\
\hline $\mathrm{Fe}^{2}$ & 0.03 & 0.04 & 0.01 & 0.00 & 0.01 & 0.00 & 0.00 & 0.03 & 0.00 & 0.00 & $0 . \infty$ & $0 . \infty$ & 0.00 & 0.03 & 0.03 & 0.02 & $0 . \infty$ \\
\hline $\mathrm{Mn}$ & 0.00 & 0.00 & $0 . \infty$ & 0.00 & 0.00 & 0.00 & 0.00 & 0.0 & 0.00 & 0.0 & 0.00 & 0.00 & 0.0 & $0 . \infty$ & 0.00 & 0.0 & 0.00 \\
\hline $\mathrm{Mg}$ & 0.00 & 0.00 & $0 . \infty$ & 0.00 & 0.0 & 0.00 & 0.00 & 0.0 & 0.00 & 0.0 & 0.00 & 0.0 & 0.00 & 0.0 & 0.00 & 0.00 & 0.00 \\
\hline $\mathrm{Ba}$ & & & & & & & 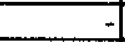 & & & & 7 & -1 & & -1 & & -1 & \\
\hline $\mathrm{Ca}$ & 1.26 & 1.31 & 1.43 & 1.84 & 1.37 & 1.28 & 1.38 & 1.48 & 1.09 & 1.41 & 1.39 & 1.42 & 1.42 & 1.44 & \begin{tabular}{|c|}
1.48 \\
\end{tabular} & 1.48 & 1.39 \\
\hline $\mathrm{Na}$ & 2.71 & 2.73 & 2.36 & 2.04 & 2.47 & 2.65 & 2.5 & 2.54 & 2.84 & 2.52 & $2 . \mathfrak{3}$ & 2.61 & 2.57 & 2.52 & 2.53 & 2.51 & 2.57 \\
\hline $\mathrm{K}$ & 0.00 & 0.00 & 0.01 & 0.01 & 0.01 & 0.00 & 0.00 & 0.00 & 0.00 & 0.02 & 0.0 & 0.00 & $0 . \infty$ & 0.00 & 0.00 & 0.00 & 0.00 \\
\hline Cátions & 20.02 & 20.07 & 19.85 & 19.92 & 19.88 & 19.97 & 20.05 & 20.06 & 19.99 & 20.01 & 20.03 & 20.05 & 20.02 & 20.03 & 20.04 & 20.02 & 20.01 \\
\hline$A b$ & 68.2 & 67.6 & 62.1 & 52.5 & 64.1 & 67.5 & 65.8 & 63.2 & 72.3 & 63.8 & 65.5 & 64.8 & 64.4 & 63.6 & 63.1 & 62.9 & 64.9 \\
\hline An & 31.8 & 32.4 & 37.7 & 47.3 & 35.6 & 32.5 & 34.2 & 36.8 & 27.7 & 35.6 & 345 & 35.2 & 35.6 & 36.4 & 36.9 & 37.1 & 35.1 \\
\hline Or & 0.0 & 0.0 & 0.2 & 0.2 & 0.2 & 0.0 & 0.0 & 0.0 & 0.0 & 0.6 & 0.0 & 0.0 & 0.0 & 0.0 & 0.0 & 0.0 & 0.0 \\
\hline
\end{tabular}

Tabela A4.3.3: Dados analíticos de plagioclásios de anfibolitos metabásicos $A B, A B E T$ e $A B G$. Fórmula estrutural: $32(O)$ 


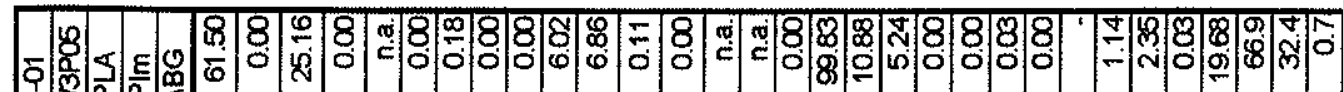

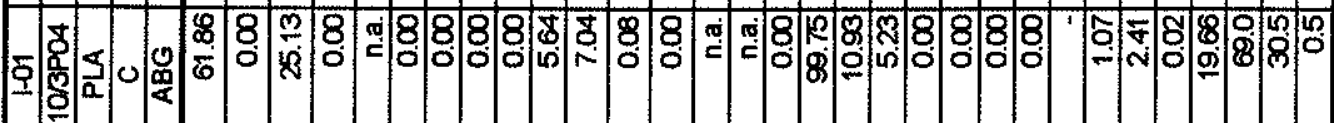

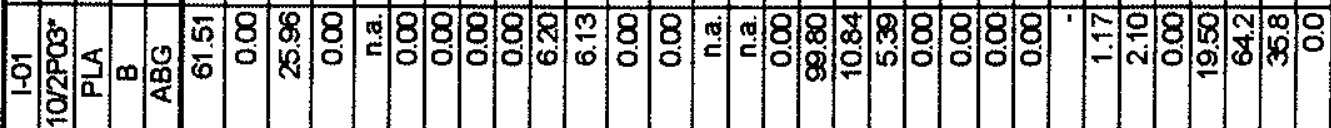

- 5 5

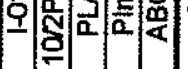

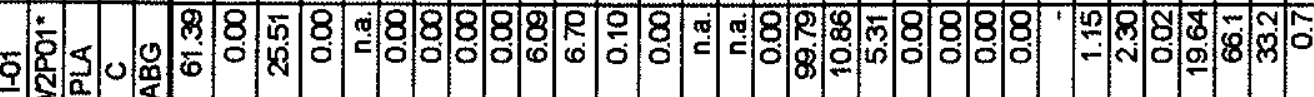

- 4 (8) 8 8 8 8

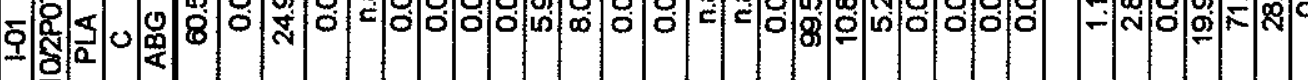

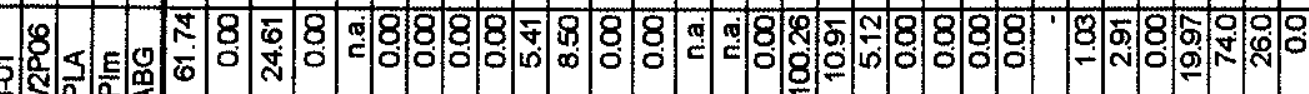

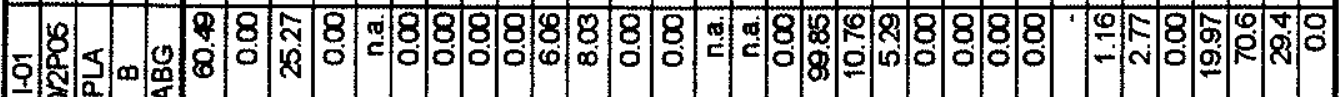

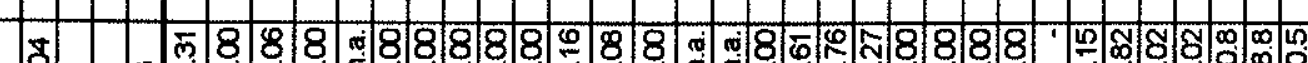

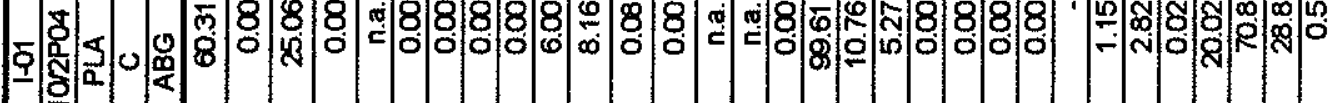

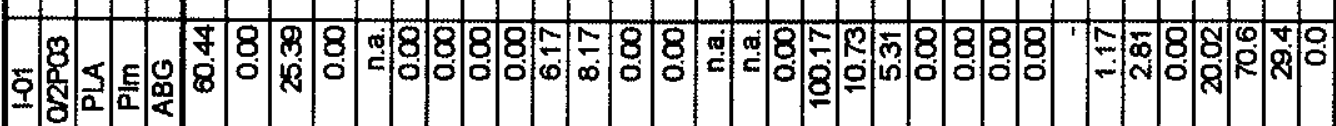

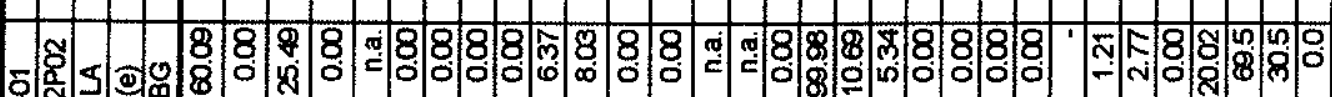
S $0.0 \%$

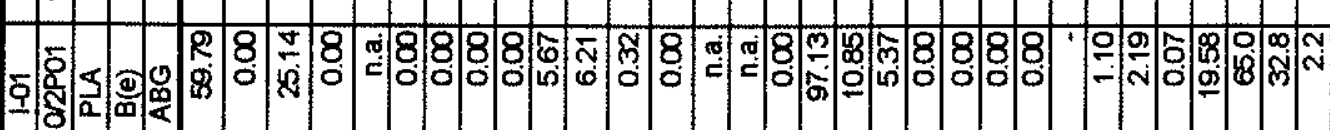

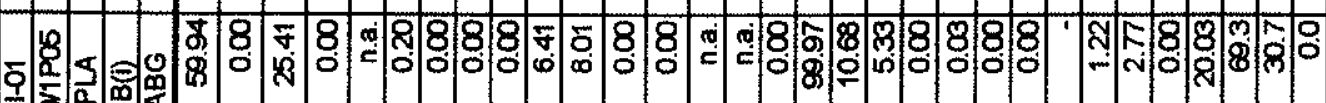

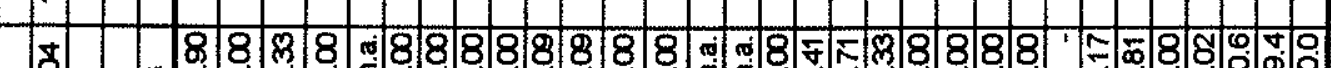

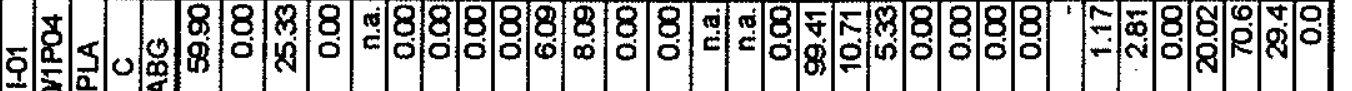

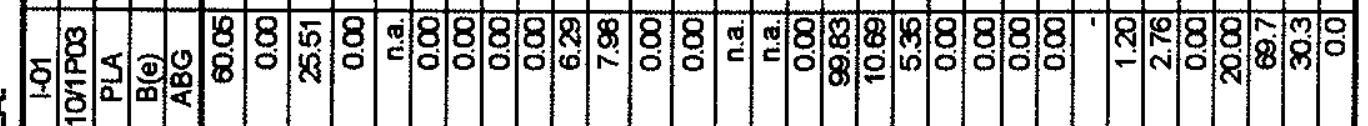

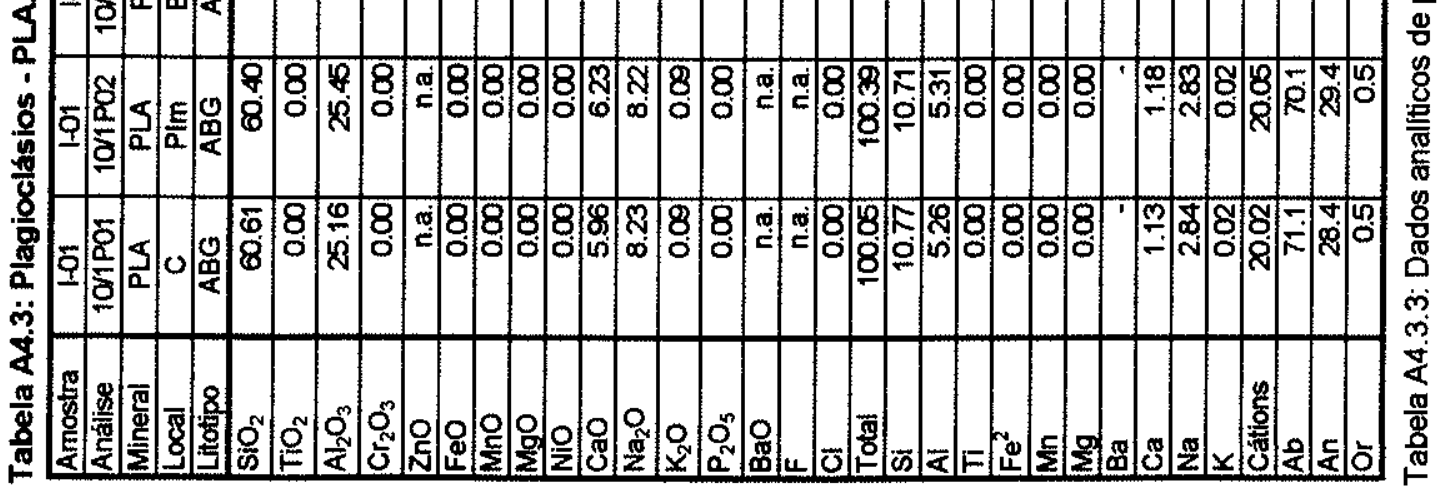


Tabela A4.3: Plagioclásios - PLA

\begin{tabular}{|c|c|c|c|c|c|c|c|c|}
\hline Amostra & $1-01$ & $1-01$ & 1.01 & $1-01$ & 101 & $1-01$ & $1-01$ & $\frac{1-01}{104 P 02}$ \\
\hline Análise & 10/3P06 & $10 / 3 P^{\prime \prime} 1^{*}$ & $1033 P 02^{*}$ & $103 \mathrm{PCO}$ & $103 P^{2} 4^{*}$ & $103 P 05$ & $10 / 4 \mathrm{PO1}$ & $10 / 4 \mathrm{PO} 2$ \\
\hline Mineral & PLA & PLA & PLA & PLA & PLA & PLA & PLA & PLA \\
\hline Local & $B(0)$ & $B(\mathrm{e})$ & $\mathrm{PIm}$ & C & B & $\mathrm{C}$ & $\mathrm{B}(\mathrm{e})$ & $\mathrm{C}$ \\
\hline Litotipo & $\overline{A B G}$ & $\overline{A B G}$ & $\overline{A B G}$ & $\overline{A B G}$ & $\overline{A B G}$ & $\overline{A B G}$ & $\overline{A B G}$ & $\overline{A B G}$ \\
\hline $\mathrm{SiO}_{2}$ & 60.97 & 59.93 & 60.99 & 62.20 & 60.09 & 6.32 & 60.41 & 60.31 \\
\hline $\mathrm{TiO}_{2}$ & 0.00 & 0.00 & 0.00 & 0.00 & 0.00 & 0.00 & $0 . \infty$ & 0.00 \\
\hline $\mathrm{Al}_{2} \mathrm{O}_{3}$ & 25.25 & 25.46 & 24.75 & 24.04 & 25.43 & 25.08 & 25.12 & 25.33 \\
\hline$\overline{\mathrm{Cr}_{2} \mathrm{O}_{3}}$ & 0.00 & 0.00 & 0.00 & 0.0 & 0.0 & $0 . \infty$ & 0.0 & 0.00 \\
\hline Zno & n.a. & na. & n.a. & n.a. & n.a. & n.a. & n.a. & n.a. \\
\hline $\mathrm{FeO}$ & 0.17 & 0.0 & 0.00 & 0.00 & 0.22 & 0.0 & 0.28 & 0.00 \\
\hline $\mathrm{MnO}$ & 0.17 & 0.00 & $0 . \infty$ & 0.00 & 0.00 & 0.00 & 0.00 & 0.00 \\
\hline $\mathrm{MgO}$ & 0.00 & $0 . \infty$ & $0 . \infty$ & 0.0 & 0.00 & 0.00 & $0 . \infty$ & 0.00 \\
\hline $\mathrm{NiO}$ & 0.0 & 0.0 & $0 . \infty$ & 0.00 & 0.00 & 0.0 & 0.0 & 0.00 \\
\hline $\mathrm{CaO}$ & 6.11 & 6.48 & 5.33 & 4.95 & 6.39 & 6.03 & 6.24 & 6.16 \\
\hline $\mathrm{Na}_{2} \mathrm{O}$ & 6.84 & 8.12 & 8.65 & 8.68 & 7.94 & 8.00 & 8.26 & 8.15 \\
\hline $\mathrm{K}_{2} \mathrm{O}$ & 0.00 & 0.00 & 0.11 & 0.00 & 0.11 & 0.00 & 0.00 & $0 . \infty$ \\
\hline $\mathrm{P}_{2} \mathrm{O}_{5}$ & 0.00 & 0.00 & $0 . \infty$ & 0.00 & 0.00 & 0.00 & 0.00 & 0.00 \\
\hline $\mathrm{BaO}$ & n.a. & n.a. & n.a. & ก.a. & n.a. & п.а. & n.a. & n.a. \\
\hline$F$ & n.a. & n.a. & n.a. & n.a. & n.a. & n.a. & ก.a. & n.a. \\
\hline $\mathrm{Cl}$ & 0.00 & $0 . \infty$ & 0.00 & 0.00 & 0.0 & 0.00 & 0.00 & 0.00 \\
\hline Total & 99.51 & 99.99 & 99.83 & 99.87 & 100.18 & 99.43 & 100.31 & 100.03 \\
\hline Si & 10.84 & 10.67 & 10.85 & 11.02 & 10.69 & 10.77 & 10.73 & 10.72 \\
\hline Al & 5.29 & 5.34 & 5.18 & 5.02 & 5.33 & 5.27 & 5.25 & 5.30 \\
\hline $\mathrm{Ti}$ & 0.00 & 0.00 & 0.00 & 0.0 & $0 . \infty$ & $0 . \infty$ & 0.00 & 0.00 \\
\hline $\mathrm{Fe}^{2}$ & 0.03 & $0 . \infty$ & 0.00 & 0.00 & 0.03 & 0.0 & 0.04 & 0.00 \\
\hline Mn & 0.03 & 0.00 & 0.00 & 0.00 & 0.00 & 0.00 & 0.00 & 0.00 \\
\hline $\mathrm{Mg}$ & 0.00 & 0.00 & $0 . \infty$ & $0 . \infty$ & 0.00 & 0.00 & 0.00 & 0.00 \\
\hline \multicolumn{9}{|l|}{$\mathrm{Ba}$} \\
\hline $\mathrm{Ca}$ & 1.16 & 1.24 & 1.02 & 0.94 & 1.22 & 1.15 & 1.19 & 1.17 \\
\hline $\mathrm{Na}$ & 2.36 & 2.80 & 2.98 & 298 & 2.74 & 2.77 & 2.85 & 2.81 \\
\hline $\mathrm{K}$ & 0.0 & 0.00 & 0.03 & 0.0 & 0.03 & 0.00 & 0.00 & 0.02 \\
\hline Cátions & 19.69 & 20.05 & 20.06 & 19.96 & 20.03 & 19.97 & 20.06 & 20.03 \\
\hline$A b$ & 67.0 & 69.4 & 74.1 & 76.0 & $\varnothing 8$ & 70.6 & 70.6 & 70.2 \\
\hline$A n$ & 33.0 & 30.6 & 25.2 & 24.0 & 30.6 & 29.4 & 29.4 & 29.3 \\
\hline Or & 0.0 & 0.0 & 0.6 & 0.0 & 0.6 & 0.0 & 0.0 & 0.4 \\
\hline
\end{tabular}

Tabela A4.3.3: Dados analíticos de plagioclásios de anfibolitos metabásicos AB, ABET e ABG. Fórmula estrutural: $32(0)$. 
Tabela A4.3: Plagioclásios - PLA.

\begin{tabular}{|c|c|c|c|c|c|c|c|c|c|c|c|c|c|c|}
\hline Amostra & AP-2 & $286 \mathrm{~A}$ & $286 \mathrm{~A}$ & 2864 & $286 \mathrm{C}$ & $286 \mathrm{C}$ & $286 C$ & $286 t$ & $286 \mathrm{~L}$ & $286 \mathrm{~L}$ & CAP- 3 & CAP-3 & CAP 3 & CAP 3 \\
\hline Análise & $3 / 4 / 20$ & 1131 & 1137 & 1139 & 3242 & 3243 & 3245 & 12148 & 12149 & 12154 & $4 / 1 / 34$ & $4 / 1 / 35$ & $4 / 1 / 36$ & $41 / 37$ \\
\hline Mineral & PLA & PLA & PLA & PLA & PLA & PLA & PLA & PLA & PLA & PLA & PLA & PLA & PLA & PLA \\
\hline Local & C & Média 4 & Média 4 & Média 4 & Média 4 & Média 4 & Média 4 & Média 4 & Média 4 & Média 4 & $\mathrm{C}$ & B & $c$ & B \\
\hline Litotipo & MP & MP & MP & MP & MP & $\mathrm{MP}$ & $M P$ & MP & MP & MP & MG & MG & $M G$ & MG \\
\hline $\mathrm{SiO}_{2}$ & 66.62 & 60.91 & $\infty 0.36$ & 60.18 & 60.95 & 60.73 & 60.84 & 60.88 & 61.20 & 6.76 & 65.11 & 63.56 & 63.93 & 63.22 \\
\hline $\mathrm{TiO}_{2}$ & 0.04 & 0.04 & 0.03 & 0.04 & 0.03 & 0.02 & 0.03 & 0.03 & 0.01 & 0.04 & 0.05 & 0.02 & 0.00 & 0.00 \\
\hline $\mathrm{Al}_{2} \mathrm{O}_{3}$ & 22.19 & 24.57 & 25.31 & 25.28 & 24.03 & 23.87 & 25.26 & 25.01 & 24.42 & 24.27 & 22.80 & 23.34 & 23.17 & 22.88 \\
\hline $\mathrm{Cr}_{2} \mathrm{O}_{3}$ & 0.02 & n.a. & n.a. & n.a. & ก.a. & n.a. & n.a. & n.a. & n.a. & n.a. & 0.00 & 0.00 & 0.00 & 0.00 \\
\hline $\mathrm{ZnO}$ & 0.0 & n.a. & n.a. & n.a. & n.a. & n.a. & n.a. & n.a. & ก.a. & n.a. & 0.00 & 0.00 & 0.00 & 0.01 \\
\hline $\mathrm{FeO}$ & 0.03 & 0.04 & 0.02 & 0.03 & 0.17 & 0.15 & 0.14 & 0.01 & 0.01 & 0.02 & 0.02 & 0.0 & $0 . \infty$ & 0.00 \\
\hline $\mathrm{MnO}$ & 0.03 & n.a. & n.a. & ก.a. & n.a. & n.a. & n.a. & n.a. & n.a. & n.a. & 0.00 & 0.00 & 0.00 & 0.00 \\
\hline $\mathrm{MgO}$ & 0.00 & 0.03 & 0.02 & 0.02 & 0.02 & 0.06 & 0.02 & 0.01 & 0.02 & 0.03 & 0.00 & 0.00 & 0.00 & 0.00 \\
\hline NiO & 0.01 & n.a. & n.a. & n.a. & ก.a. & n.a. & n.a. & n.a. & n.a. & ก.a. & 0.0 & 0.03 & 0.00 & 0.03 \\
\hline $\mathrm{CaO}$ & 2.71 & 5.56 & 5.96 & 6.39 & 6.30 & 6.11 & 5.92 & 5.87 & 5.44 & 6.40 & 3.75 & 3.75 & 3.6 & 3.68 \\
\hline $\mathrm{Na}_{2} \mathrm{O}$ & 9.71 & 8.76 & 8.42 & 8.17 & 8.13 & 8.42 & 8.79 & 8.66 & 8.92 & 9.12 & 8.83 & 8.97 & 9.03 & 8.88 \\
\hline $\mathrm{K}_{2} \mathrm{O}$ & 0.04 & 0.34 & 0.28 & 0.38 & 0.03 & 0.16 & 0.18 & 0.31 & 0.22 & 0.10 & 0.14 & 0.09 & 0.13 & 0.10 \\
\hline $\mathrm{P}_{2} \mathrm{O}_{5}$ & n.a. & n.a. & n.a. & n.a. & n.a. & n.a. & n.a. & n.a. & ก.a. & ก.a. & n.a. & n.a. & n.a. & n.a. \\
\hline $\mathrm{BaO}$ & n.a. & n.a. & n.a. & n.a. & ก.a. & ก.a. & n.a. & n.a. & n.a. & n.a. & n.a. & n.a. & n.a. & n.a. \\
\hline$F$ & n.a. & n.a. & ก.a. & n.a. & n.a. & n.a. & n.a. & n.a. & n.a. & n.a. & n.a. & n.a. & n.a. & n.a. \\
\hline $\mathrm{Cl}$ & n.a. & n.a. & n.a. & n.a. & n.a. & n.a. & n.a. & n.a. & n.a. & п.a. & ก.a. & n.a. & n.a. & n.a. \\
\hline Total & 101.40 & 100.25 & 100.40 & $100.4 \theta$ & 99.66 & 99.52 & 104.18 & 100.78 & 100.24 & 100.74 & 100.70 & 99.76 & 99.95 & 98.80 \\
\hline Si & 11.53 & 10.82 & 10.71 & 1069 & 10.88 & 10.87 & 10.73 & 10.77 & 10.87 & 10.78 & 11.37 & 11.22 & 11.26 & 11.27 \\
\hline AI & 4.52 & 5.14 & 5.29 & 5.29 & 5.05 & 5.03 & 5.24 & 5.21 & 5.11 & 5.07 & 4.6 & 4.85 & 4.81 & 4.80 \\
\hline $\mathrm{Ti}$ & 0.01 & 0.01 & 0.00 & 0.01 & 0.0 & 0.0 & 0.00 & 0.00 & 0.00 & 0.01 & 0.01 & 0.00 & 0.00 & 0.00 \\
\hline $\mathrm{Fe}^{2}$ & 0.00 & 0.01 & 0.00 & 0.00 & 0.03 & 0.02 & 0.02 & 0.00 & 0.00 & 0.00 & 0.00 & 0.0 & 0.00 & 0.00 \\
\hline $\mathrm{Mn}$ & 0.00 & 0.00 & 0.00 & 0.00 & 0.00 & 0.0 & 0.00 & 0.00 & 0.00 & 0.00 & 0.00 & 0.00 & 0.00 & 0.00 \\
\hline $\mathrm{Mg}$ & 0.00 & 0.01 & 0.01 & 0.01 & 0.01 & 0.02 & 0.01 & 0.09 & 0.01 & 0.01 & 0.00 & 0.00 & 0.00 & 0.00 \\
\hline $\mathrm{Ba}$ & & & & & - & -1 & & -1 & - & -1 & - & - & - & \\
\hline $\mathrm{Ca}$ & 0.50 & 1.06 & 1.13 & 1.22 & 1.21 & 1.17 & 1.12 & 1.11 & 1.04 & 1.22 & 0.70 & 0.71 & 0.70 & 0.70 \\
\hline $\mathrm{Na}$ & 3.26 & 3.02 & 2.90 & 2.81 & 2.81 & 2.92 & 3.01 & 2.97 & 3.07 & 3.14 & 299 & 3.07 & 3.09 & 3.07 \\
\hline K & 0.01 & 0.08 & 0.06 & 0.09 & 0.01 & 0.04 & 0.04 & 0.07 & 0.05 & 0.02 & 0.03 & 0.02 & 0.03 & 0.02 \\
\hline Cátions & 19.83 & 20.14 & 20.11 & 20.10 & 19.99 & 20.08 & 20.16 & 20.14 & 20.13 & 20.25 & 19.79 & 19.88 & 19.88 & 19.87 \\
\hline$A b$ & 86.4 & 72.7 & 70.8 & 68.4 & 69.9 & 70.7 & 72.2 & 71.5 & 73.9 & 71.7 & 80.3 & 80.8 & 80.9 & 80.9 \\
\hline An & 13.3 & 25.5 & 27.7 & 29.6 & 29.9 & 28.4 & 26.9 & 26.8 & 24.9 & 27.8 & 18.8 & 18.7 & 18.3 & 18.5 \\
\hline Or & 0.2 & 1.9 & 1.5 & 2.1 & 0.2 & 0.9 & 1.0 & 1.7 & 1.2 & 0.5 & 0.8 & 0.5 & 0.8 & 0.6 \\
\hline
\end{tabular}

Tabela A4.3.4: Dados analíticos de plagioclásios de MP e MG. Fórmula estrutural: $32(\mathrm{O})$.

Nota: Média 4 = média de 04 análises. 
Tabela A4.4: Feldspatos Potássicos - KF.

\begin{tabular}{|c|c|c|c|c|c|c|c|c|c|c|c|c|c|c|c|c|c|}
\hline Amostra & 3 & 3 & 3 & 3 & G-26 & G-26 & G-26 & G-29c & G-29c & G-20c & G-29d & G-29d & $\mathrm{G}-113$ & G-113 & G-166 & G-166b & G-166b \\
\hline Análise & $22 / 2 \mathrm{KF} .1$ & $22 / 2$ KF. 2 & $22 / 3 \mathrm{KF} .1$ & $22 / 3 \mathrm{KF} .2$ & $03 / 01 / 82$ & $06 / 02 / 27$ & $06 / 02 / 28$ & $06 / 01 / 35$ & $06101 / 36$ & $06 / 01 / 37$ & $04 / 01 / 01$ & $04 / 02 / 07$ & $05 / 01 / 08$ & $05 / 01 / 09$ & $04 / 01 / 52$ & $04 / 01 / 53$ & $04 / 02 / 58$ \\
\hline Mineral & KF & \begin{tabular}{|l|}
$\mathrm{KF}$ \\
\end{tabular} & $\mathrm{KF}$ & $\mathrm{KF}$ & $\mathrm{KF}$ & $\mathrm{KF}$ & $\mathrm{KF}$ & $\mathrm{KF}$ & $\mathrm{KF}$ & KF & $\mathrm{KF}$ & $\mathrm{KF}$ & $\mathrm{KF}$ & $\mathrm{KF}$ & \begin{tabular}{|l|}
$\mathrm{KF}$ \\
\end{tabular} & $\mathrm{KF}$ & $\mathrm{KF}$ \\
\hline Local & $B$ & $\mathrm{C}$ & Pin & $B$ & C & B & $\mathrm{C}$ & $C$ & B & $B$ & C & B & B & C & B & C & $\mathrm{C}$ \\
\hline Litotipo & GB & $\mathrm{GB}$ & $\mathrm{GB}$ & GB & $\mathrm{GB}$ & GB & $\mathrm{GB}$ & GB & GB & $\mathrm{GB}$ & GB & $\mathrm{GB}$ & $\mathrm{GB}$ & GB & GB & $\mathrm{GB}$ & GB \\
\hline $\mathrm{SiO}_{2}$ & 64.38 & 63.77 & 64.43 & 64.28 & 64.60 & 63.21 & 63.84 & 63.53 & 64.55 & 63.17 & 64.52 & 64.74 & 64.58 & 64.85 & 64.40 & 64.55 & 64.06 \\
\hline $\mathrm{TiO}_{2}$ & 0.00 & 0.00 & 0.00 & 0.00 & 0.03 & 0.00 & 0.02 & 0.00 & 0.00 & 0.00 & 0.06 & 0.00 & 0.01 & 0.04 & 0.02 & 0.00 & 0.00 \\
\hline $\mathrm{Al}_{2} \mathrm{O}_{3}$ & 18.82 & 18.69 & 18.89 & 18.68 & 18.40 & 18.57 & 18.71 & 18.37 & 18.51 & 18.86 & 18.97 & 18.69 & 18.59 & 18.49 & 18.47 & 18.64 & 18.28 \\
\hline $\mathrm{Cr}_{2} \mathrm{O}_{3}$ & 0.00 & 0.00 & 0.00 & 0.00 & 0.00 & 0.00 & 0.00 & 0.00 & 0.00 & 0.00 & 0.00 & 0.02 & 0.02 & 0.00 & 0.00 & 0.02 & 0.00 \\
\hline ZnO & n.a. & n.a. & n.a. & n.a. & 0.00 & n.a. & ก.a. & n.a. & n.a. & ก.a. & 0.00 & 0.00 & 0.00 & 0.00 & 0.00 & 0.00 & 0.02 \\
\hline $\mathrm{FeO}$ & 0.00 & 0.00 & 0.00 & 0.00 & 0.00 & 0.03 & 0.08 & 0.07 & 0.00 & 0.07 & 0.06 & 0.22 & 0.00 & 0.06 & 0.00 & 0.03 & 0.07 \\
\hline $\mathrm{MnO}$ & 0.00 & 0.00 & 0.00 & 0.00 & 0.03 & 0.00 & 0.00 & 0.02 & 0.00 & 0.00 & 0.00 & 0.01 & 0.03 & 0.02 & 0.00 & 0.00 & 0.00 \\
\hline $\mathrm{MgO}$ & 0.00 & 0.00 & 0.00 & 0.00 & 0.00 & 0.00 & 0.01 & 0.02 & 0.01 & 0.0 & 0.01 & 0.03 & 0.00 & 0.00 & 0.00 & 0.00 & 0.00 \\
\hline $\mathrm{NiO}$ & 0.00 & 0.00 & 0.00 & 0.00 & 0.00 & n.a. & n.a. & n.a. & n.a. & ก.a. & 0.03 & 0.01 & 0.04 & 0.01 & 0.02 & 0.00 & 0.00 \\
\hline $\mathrm{CaO}$ & 0.00 & 0.00 & 0.00 & 0.00 & 0.00 & 0.00 & 0.00 & 0.00 & 0.00 & 0.00 & 0.00 & 0.00 & 0.00 & 0.00 & 0.00 & 0.00 & 0.00 \\
\hline $\mathrm{Na}_{2} \mathrm{O}$ & 0.60 & 0.85 & 0.74 & 0.57 & 0.50 & 0.68 & 0.51 & 0.65 & 0.46 & 0.68 & 0.44 & 0.57 & 0.58 & 0.60 & 0.35 & 0.49 & 0.61 \\
\hline $\mathrm{K}_{2} \mathrm{O}$ & 15.86 & 15.59 & 16.26 & 16.38 & 15.90 & 15.90 & 16.17 & 15.67 & 16.14 & 15.57 & 16.23 & 16.47 & 15.91 & 16.17 & 16.65 & 16.07 & 16.15 \\
\hline $\mathrm{P}_{2} \mathrm{O}_{5}$ & 0.00 & 0.00 & 0.00 & 0.00 & ก.a. & & & 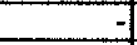 & & & n.a. & n.a. & ก.a. & n.a. & n.a. & n.a. & n.a. \\
\hline $\mathrm{BaO}$ & n.a. & n.a. & n.a. & ก.a. & n.a. & 0.47 & 0.45 & 0.41 & 0.43 & 0.46 & n.a. & n.a. & ก.a. & n.a. & n.a. & n.a. & n.a. \\
\hline$F$ & n.a. & n.a. & n.a. & ก.a. & n.a. & 0.08 & 0.10 & 0.04 & 0.02 & 0.03 & п.а. & n.a. & ก.a. & n.a. & n.a. & n.a. & n.a. \\
\hline $\mathrm{Cl}$ & 0.00 & 0.00 & 0.00 & 0.00 & n.a. & n.a. & ก.a. & ก.a. & n.a. & n.a. & n.a. & n.a. & n.a. & n.a. & n.a. & n.a. & n.a. \\
\hline Total & 99.66 & 98.90 & 100.32 & 99.91 & 99.46 & 98.94 & 99.89 & 98.78 & 100.12 & 98.84 & 100.32 & 100.76 & 99.76 & 100.24 & 99.91 & 99.80 & 99.19 \\
\hline $\mathrm{Si}$ & 11.93 & 11.91 & 11.89 & 11.92 & 11.99 & 11.88 & 11.89 & 11.93 & 11.96 & 11.86 & 11.90 & 11.92 & 11.96 & 11.97 & 11.95 & 11.95 & 11.96 \\
\hline Ti & 0.00 & 0.00 & 0.00 & 0.00 & 0.00 & 0.00 & 0.00 & 0.00 & 0.00 & 0.00 & 0.01 & 0.00 & 0.00 & 0.01 & 0.00 & 0.00 & 0.00 \\
\hline A & 4.11 & 4.11 & 4.11 & 4.08 & 4.02 & 4.11 & 4.10 & 4.06 & 4.04 & 4.17 & 4.12 & 4.05 & 4.05 & 4.02 & 4.04 & 4.06 & 4.02 \\
\hline $\mathrm{Fe}^{+2}$ & 0.00 & 0.00 & 0.00 & 0.00 & 0.00 & 0.01 & 0.01 & 0.01 & 0.00 & 0.01 & 0.01 & 0.03 & 0.00 & 0.01 & 0.00 & 0.01 & 0.01 \\
\hline $\mathrm{Mn}$ & 0.00 & 0.00 & 0.00 & 0.00 & 0.00 & 0.00 & 0.00 & 0.00 & 0.00 & 0.00 & 0.00 & 0.00 & 0.00 & 0.00 & 0.00 & 0.00 & 0.00 \\
\hline $\mathrm{Mg}$ & 0.00 & 0.00 & 0.00 & 0.00 & 0.00 & 0.00 & 0.00 & 0.01 & 0.00 & 0.00 & 0.0 & 0.01 & 0.00 & 0.00 & 0.00 & 0.00 & 0.00 \\
\hline $\mathrm{Ca}$ & 0.00 & 0.00 & 0.00 & 0.00 & 0.00 & 0.00 & 0.00 & 0.00 & 0.00 & 0.00 & 0.00 & 0.00 & 0.00 & 0.00 & 0.00 & 0.00 & 0.00 \\
\hline $\mathrm{Na}$ & 0.22 & 0.31 & 0.27 & 0.21 & 0.18 & 0.25 & 0.18 & 0.24 & 0.17 & 0.25 & 0.16 & 0.20 & 0.21 & 0.22 & 0.13 & 0.18 & 0.22 \\
\hline $\mathrm{K}$ & 3.75 & 3.71 & 3.83 & 3.87 & 3.76 & 3.81 & 3.84 & 3.75 & 3.81 & 3.73 & 3.82 & 3.87 & 3.76 & 3.81 & 3.94 & 3.80 & 3.85 \\
\hline $\mathrm{Ba}$ & & & & & & 0.03 & 0.03 & 0.03 & 0.03 & 0.03 & & & - & & -1 & - & \\
\hline Cátions & 20.00 & 20.04 & 20.10 & 20.08 & 19.95 & 20.09 & 20.06 & 20.03 & 20.00 & 20.04 & 20.01 & 20.08 & 19.99 & 20.02 & 20.05 & 19.99 & 20.06 \\
\hline $\mathrm{Ab}$ & 5.4 & 7.7 & 6.5 & 5.0 & 4.6 & 6.1 & 4.6 & 5.9 & 4.1 & 6.2 & 3.9 & 5.0 & 5.2 & 5.3 & 3.1 & 4.4 & 5.4 \\
\hline$A_{n}$ & 0.0 & 0.0 & 0.0 & 0.0 & 0.0 & 0.0 & 0.0 & 0.0 & 0.0 & 0.0 & 0.0 & 0.0 & 0.0 & 0.0 & 0.0 & 0.0 & 0.0 \\
\hline Or & 94.6 & 92.3 & 93.5 & 95.0 & 95.4 & 93.9 & 95.4 & 94.1 & 95.9 & 93.8 & 96.1 & 95.0 & 94.8 & 94.7 & 96.9 & 95.6 & 94.6 \\
\hline
\end{tabular}

Tabela A4.4.1: Dados analíticos de feldspatos potássicos de GB e MGF. Fórmula estrutural: 32(O). 
Tabela A4.4: Feldspatos Potássicos - KF.

\begin{tabular}{|c|c|c|c|c|c|c|c|c|c|c|c|c|c|c|c|}
\hline Amostra & G-11a & G-11a & G-11a & G-11a & G-2a & G-2a & G-2a & $\mathrm{G}+2 \mathrm{a}$ & G-20 & $G-2 b$ & G-2b & G-2b & G-2b & $G-2 b$ & G-3a \\
\hline Análise & $05 / 01 / 10$ & $05 / 01 / 11$ & $05 / 02 / 14$ & $05 / 02 / 15$ & $16 / 1 \mathrm{KF} 1$ & $16 / 1 \mathrm{KF} 2$ & $16 / 2 \mathrm{KF} 1$ & $16 / 2 \mathrm{KF} 2$ & $04 / 02 / 42$ & $04 / 02 / 43$ & $04 / 03 / 28$ & $04 / 03 / 29$ & $06 / 03 / 20$ & $06 / 03 / 21$ & $39 / 1 \mathrm{~K} 1.1$ \\
\hline Mineral & $\mathrm{KF}$ & $\mathrm{KF}$ & $\mathrm{KF}$ & $\mathrm{KF}$ & $\mathrm{KF}$ & $\mathrm{KF}$ & $\mathrm{KF}$ & $\mathrm{KF}$ & $\mathrm{KF}$ & $\mathrm{KF}$ & $\mathrm{KF}$ & $\mathrm{KF}$ & $\mathrm{KF}$ & $\mathrm{KF}$ & $\mathrm{KF}$ \\
\hline Local & $\mathrm{B}$ & C & $B$ & $\mathrm{C}$ & $\mathrm{C}$ & $\mathrm{B}$ & $C$ & B & B & c & B & C & $\mathrm{C}$ & $\mathrm{B}$ & C \\
\hline Lifotipo & MGF & MGF & MGF & MGF & MGF & MGF & MGF & MGF & MGF & MGF & MGF & MGF & MGF & MGF & MGF \\
\hline $\mathrm{SiO}_{2}$ & 62.70 & 63.33 & 63.14 & 63.34 & 65.01 & 64.47 & 64.59 & 64.84 & 64.17 & 64.61 & 65.02 & 64.66 & 64.79 & 63.86 & 64.74 \\
\hline $\mathrm{TiO}_{2}$ & 0.08 & 0.00 & 0.03 & 0.00 & 0.00 & 0.00 & 0.00 & 0.00 & 0.00 & 0.03 & 0.03 & 0.02 & 0.01 & 0.04 & 0.00 \\
\hline $\mathrm{Al}_{2} \mathrm{O}_{3}$ & 18.71 & 18.35 & 18.24 & 18.18 & 18.77 & 18.87 & 18.76 & 18.89 & 18.77 & 18.41 & 18.31 & 18.59 & 18.66 & 18.36 & 18.43 \\
\hline $\mathrm{Cr}_{2} \mathrm{O}_{3}$ & 0.00 & 0.00 & 0.00 & 0.00 & 0.00 & 0.00 & 0.00 & 0.00 & 0.00 & 0.05 & 0.00 & 0.00 & 0.01 & 0.02 & 0.00 \\
\hline $\mathrm{ZnO}$ & n.a. & n.a. & n.a. & n.a. & n.a. & n.a. & ก.a. & n.a. & 0.00 & 0.00 & 0.00 & 0.00 & n.a. & n.a. & n.a. \\
\hline $\mathrm{FeO}$ & 0.05 & 0.01 & 0.06 & 0.02 & 0.00 & 0.00 & 0.00 & 0.00 & 0.21 & 0.03 & 0.07 & 0.07 & 0.02 & 0.06 & 0.00 \\
\hline $\mathrm{MnO}$ & 0.00 & 0.00 & 0.01 & 0.02 & 0.00 & 0.00 & 0.00 & 0.00 & 0.00 & 0.01 & 0.00 & 0.00 & 0.03 & 0.02 & 0.00 \\
\hline $\mathrm{MgO}$ & 0.00 & 0.00 & 0.00 & 0.00 & 0.00 & 0.00 & 0.00 & 0.00 & 0.00 & 0.00 & 0.00 & 0.00 & 0.00 & 0.01 & 0.00 \\
\hline NiO & n.a. & n.a. & n.a. & n.a. & 0.00 & 0.00 & 0.00 & 0.00 & 0.00 & 0.03 & 0.00 & 0.00 & ก.a. & n.a. & 0.00 \\
\hline $\mathrm{CaO}$ & 0.00 & 0.00 & 0.00 & 0.00 & 0.00 & 0.00 & 0.00 & 0.00 & 0.00 & 0.00 & 0.00 & 0.00 & 0.00 & 0.00 & 0.00 \\
\hline $\mathrm{Na}_{2} \mathrm{O}$ & 0.60 & 0.58 & 0.57 & 0.63 & 0.56 & 0.46 & 0.65 & 0.59 & 0.50 & 0.62 & 0.56 & 0.56 & 0.69 & 0.45 & 0.56 \\
\hline $\mathrm{K}_{2} \mathrm{O}$ & 15.90 & 15.82 & 16.04 & 16.11 & 16.06 & 16.13 & 15.85 & 16.61 & 16.21 & 16.06 & 16.23 & 16.31 & 15.81 & 16.42 & 16.21 \\
\hline $\mathrm{P}_{2} \mathrm{O}_{5}$ & n.a. & n.a. & n.a. & ก.a. & 0.00 & 0.00 & 0.00 & 0.00 & n.a. & n.a. & ก.a. & n.a. & n.a. & n.a. & 0.00 \\
\hline $\mathrm{BaO}$ & 0.04 & 0.03 & 0.05 & 0.04 & n.a. & n.a. & n.a. & n.a. & n.a. & n.a. & n.a. & n.a. & 0.18 & 0.27 & n.a. \\
\hline$F$ & 0.00 & 0.00 & 0.12 & 0.00 & n.a. & ก.a. & n.a. & n.a. & n.a. & ก.a. & n.a. & n.a. & 0.07 & 0.02 & n.a. \\
\hline $\mathrm{Cl}$ & n.a. & n.a. & n.a. & n.a. & 0.00 & 0.00 & 0.00 & 0.00 & n.a. & n.a. & ก.a. & n.a. & n.a. & n.a. & 0.00 \\
\hline Total & 98.08 & 98.12 & 98.26 & 98.34 & 100.40 & 99.93 & 99.85 & 100.93 & 99.86 & 99.85 & 100.22 & 100.21 & 100.27 & 99.53 & 99.94 \\
\hline Si & 11.85 & 11.94 & 11.92 & 11.94 & 11.96 & 11.92 & 11.94 & 11.91 & 11.90 & 11.97 & 12.00 & 11.95 & 11.95 & 11.93 & 11.98 \\
\hline $\mathrm{Ti}$ & 0.01 & 0.00 & 0.00 & 0.00 & 0.00 & 0.00 & 0.00 & 0.00 & 0.00 & 0.00 & 0.00 & 0.00 & 0.00 & 0.01 & 0.00 \\
\hline $\mathrm{Al}$ & 4.16 & 4.07 & 4.06 & 4.04 & 4.07 & 4.11 & 4.08 & 4.09 & 4.10 & 4.02 & 3.98 & 4.04 & 4.05 & 4.04 & 4.02 \\
\hline $\mathrm{Fe}_{2}$ & 0.01 & 0.00 & 0.01 & 0.00 & 0.00 & 0.00 & 0.00 & 0.00 & 0.03 & 0.01 & 0.01 & 0.01 & 0.00 & 0.01 & 0.00 \\
\hline $\mathrm{Mn}$ & 0.00 & 0.00 & 0.00 & 0.00 & 0.00 & 0.00 & 0.00 & 0.00 & 0.00 & 0.00 & 0.00 & 0.00 & 0.00 & 0.00 & 0.00 \\
\hline $\mathrm{Mg}$ & 0.00 & 0.00 & 0.00 & 0.00 & 0.00 & 0.00 & 0.00 & 0.00 & 0.00 & 0.00 & 0.00 & 0.00 & 0.00 & 0.00 & 0.00 \\
\hline $\mathrm{Ca}$ & 0.00 & 0.00 & 0.00 & 0.00 & 0.00 & 0.00 & 0.00 & 0.00 & 0.00 & 0.00 & 0.00 & 0.00 & 0.00 & 0.00 & 0.00 \\
\hline $\mathrm{Na}$ & 0.22 & 0.21 & 0.21 & 0.23 & 0.20 & 0.17 & 0.23 & 0.21 & 0.18 & 0.22 & 0.20 & 0.20 & 0.25 & 0.16 & 0.20 \\
\hline $\mathrm{K}$ & 3.83 & 3.80 & 3.87 & 3.87 & 3.77 & 3.81 & 3.74 & 3.89 & 3.84 & 3.80 & 3.82 & 3.84 & 3.72 & 3.91 & 3.83 \\
\hline $\mathrm{Ba}$ & 0.00 & 0.00 & 0.00 & 0.00 & & & & & & & & & 0.01 & 0.02 & \\
\hline Cátions & 20.08 & 20.03 & 20.06 & 20.08 & 19.99 & 20.00 & 20.00 & 20.09 & 20.05 & 20.01 & 20.01 & 20.05 & 19.99 & 20.08 & 20.02 \\
\hline$A b$ & 5.4 & 5.3 & 5.1 & 5.6 & 5.0 & 4.2 & 5.9 & 5.1 & 4.5 & 5.6 & 5.0 & 5.0 & 6.2 & 4.0 & 5.0 \\
\hline $\mathrm{An}$ & 0.0 & 0.0 & 0.0 & 0.0 & 0.0 & 0.0 & 0.0 & 0.0 & 0.0 & 0.0 & 0.0 & 0.0 & 0.0 & 0.0 & 0.0 \\
\hline Or & 94.6 & 94.7 & 94.9 & 94.4 & 95.0 & 95.8 & 94.1 & 94.9 & 95.5 & 94.4 & 95.0 & 95.0 & 93.8 & 96.0 & 95.0 \\
\hline
\end{tabular}

Tabela A4.4.1: Dados analíticos de feldspatos potássicos de GB e MGF. Fórmula estrutural: 32(O). 
Tabela A4.4: Feldspatos Potássicos - KF.

\begin{tabular}{|c|c|c|c|c|c|c|c|c|c|c|c|c|}
\hline Amostra & G-3a & G-3a & G-3a & G-3a & G-3a & G-3a & $G-68$ & $\mathrm{G}-68$ & $G-68$ & $\mathrm{G}-68$ & $\mathrm{G}-68$ & $G-68$ \\
\hline Análise & $39 / 1 \mathrm{~K} 1.2$ & $39 / 1 \mathrm{~K} 2.1$ & $39 / 1 \mathrm{~K} 2.2$ & $39 / 2 \mathrm{~K} 1.1$ & $39 / 2 \mathrm{~K} 1.2$ & $39 / 2 \mathrm{~K} 1.3$ & $32 / 1 \mathrm{~K} 1.1$ & $32 / 1 \mathrm{~K} 1.2$ & $3211 \mathrm{~K} 2.1$ & $32 / 1 \mathrm{~K} 2.2$ & $32 / 2 \mathrm{~K} 1.1$ & $32 / 2 \mathrm{~K} 1.2$ \\
\hline Mineral & $\mathrm{KF}$ & $\mathrm{KF}$ & $\mathrm{KF}$ & $\mathrm{KF}$ & $\mathrm{KF}$ & $\mathrm{KF}$ & KF & $\mathrm{KF}$ & KF & $\mathrm{KF}$ & $\mathrm{KF}$ & $\mathrm{KF}$ \\
\hline Local & $B$ & $\mathrm{C}$ & $\mathrm{B}$ & $B$ & $\mathrm{C}$ & $\mathrm{C}$ & B & $\mathrm{C}$ & $\mathrm{B}$ & Pln & B & $\mathrm{C}$ \\
\hline Litotipo & MGF & MGF & MGF & MGF & MGF & MGF & MGF & MGF & MGF & MGF & MGF & MGF \\
\hline $\mathrm{SiO}_{2}$ & 64.87 & 64.94 & 64.65 & 63.81 & 64.60 & 64.28 & 63.90 & 64.31 & 63.97 & 64.20 & 64.07 & 64.12 \\
\hline $\mathrm{TiO}_{2}$ & 0.00 & 0.00 & 0.00 & 0.00 & 0.00 & 0.00 & 0.00 & 0.00 & 0.00 & 0.00 & 0.00 & 0.00 \\
\hline $\mathrm{Al}_{2} \mathrm{O}_{3}$ & 18.81 & 18.69 & 18.57 & 18.46 & 18.67 & 18.60 & 18.78 & 18.72 & 18.59 & 18.43 & 18.61 & 18.40 \\
\hline $\mathrm{Cr}_{2} \mathrm{O}_{3}$ & 0.00 & 0.00 & 0.00 & 0.00 & 0.00 & 0.00 & 0.00 & 0.00 & 0.00 & 0.00 & 0.00 & 0.00 \\
\hline $\mathrm{ZnO}$ & n.a. & n.a. & n.a. & n.a. & n.a. & n.a. & n.a. & n.a. & n.a. & n.a. & n.a. & n.a. \\
\hline $\mathrm{FeO}$ & 0.00 & 0.00 & 0.00 & 1.12 & 0.47 & 0.48 & 0.00 & 0.00 & 0.00 & 0.00 & 0.00 & 0.00 \\
\hline $\mathrm{MnO}$ & 0.00 & 0.00 & 0.00 & 0.00 & 0.00 & 0.00 & 0.00 & 0.00 & 0.00 & 0.00 & 0.00 & 0.00 \\
\hline $\mathrm{MgO}$ & 0.00 & 0.00 & 0.00 & 0.00 & 0.00 & 0.00 & 0.00 & 0.00 & 0.00 & 0.00 & 0.00 & 0.00 \\
\hline $\mathrm{NiO}$ & 0.00 & 0.00 & 0.00 & 0.00 & 0.00 & 0.00 & 0.00 & 0.00 & 0.00 & 0.00 & 0.00 & 0.00 \\
\hline $\mathrm{CaO}$ & 0.00 & 0.00 & 0.00 & 0.00 & 0.00 & 0.00 & 0.00 & 0.00 & 0.00 & 0.00 & 0.00 & 0.00 \\
\hline $\mathrm{Na}_{2} \mathrm{O}$ & 0.60 & 0.54 & 0.54 & 0.00 & 0.14 & 0.00 & 0.42 & 0.70 & 0.42 & 0.50 & 0.30 & 0.43 \\
\hline $\mathrm{K}_{2} \mathrm{O}$ & 16.34 & 16.24 & 16.29 & 15.52 & 16.85 & 16.84 & 16.18 & 15.96 & 16.18 & 16.19 & 16.55 & 16.24 \\
\hline $\mathrm{P}_{2} \mathrm{O}_{5}$ & 0.00 & 0.00 & 0.00 & 0.00 & 0.00 & 0.00 & 0.00 & 0.00 & 0.00 & 0.00 & 0.00 & 0.00 \\
\hline $\mathrm{BaO}$ & n.a. & n.a. & n.a. & n.a. & n.a. & ก.a. & n.a. & n.a. & n.a. & n.a. & n.a. & n.a. \\
\hline $\mathrm{F}$ & n.a. & n.a. & n.a. & n.a. & n.a. & n.a. & n.a. & n.a. & n.a. & n.a. & n.a. & n.a. \\
\hline $\mathrm{Cl}$ & 0.00 & 0.00 & 0.00 & 0.00 & 0.00 & 0.00 & 0.00 & 0.00 & 0.00 & 0.00 & 0.00 & 0.00 \\
\hline Total & 100.62 & 100.41 & 100.05 & 98.91 & 100.73 & 100.20 & 99.28 & 99.69 & 99.16 & 99.32 & 99.53 & 99.19 \\
\hline$S i$ & 11.93 & 11.96 & 11.96 & 11.93 & 11.92 & 11.92 & 11.91 & 11.92 & 11.93 & 11.96 & 11.93 & 11.96 \\
\hline$\pi$ & 0.00 & 0.00 & 0.00 & 0.00 & 0.00 & 0.00 & 0.00 & 0.00 & 0.00 & 0.00 & 0.00 & 0.00 \\
\hline A & 4.07 & 4.05 & 4.04 & 4.07 & 4.06 & 4.06 & 4.12 & 4.09 & 4.08 & 4.04 & 4.08 & 4.04 \\
\hline $\mathrm{Fe}_{2}$ & 0.00 & 0.00 & 0.00 & 0.18 & 0.07 & 0.07 & 0.00 & 0.00 & 0.00 & 0.00 & 0.00 & 0.00 \\
\hline $\mathrm{Mn}$ & 0.00 & 0.00 & 0.00 & 0.00 & 0.00 & 0.00 & 0.00 & 0.00 & 0.00 & 0.00 & 0.00 & 0.00 \\
\hline $\mathrm{Mg}$ & 0.00 & 0.00 & 0.00 & 0.00 & $0 . \infty$ & 0.00 & 0.00 & 0.00 & 0.00 & 0.00 & 0.00 & 0.00 \\
\hline $\mathrm{Ca}$ & 0.00 & 0.00 & 0.00 & 0.00 & 0.00 & 0.00 & 0.00 & 0.00 & 0.00 & 0.00 & 0.00 & 0.00 \\
\hline $\mathrm{Na}$ & 0.21 & 0.19 & 0.19 & 0.00 & 0.05 & 0.00 & 0.15 & 0.25 & 0.15 & 0.18 & 0.11 & 0.16 \\
\hline $\mathrm{K}$ & 3.83 & 3.81 & 3.84 & 3.70 & 3.97 & 3.98 & 3.85 & 3.78 & 3.85 & 3.85 & 3.93 & 3.87 \\
\hline $\mathrm{Ba}$ & & & & & & & & & & & & \\
\hline Cations & 20.05 & 20.02 & 20.04 & 19.88 & 20.06 & 20.04 & 20.03 & 20.04 & 20.02 & 20.03 & 20.05 & 20.02 \\
\hline$\overline{A B}$ & 5.3 & 4.8 & 4.8 & 0.0 & 1.2 & 0.0 & 3.8 & 6.3 & 3.8 & 4.5 & 2.7 & 3.9 \\
\hline$A_{n}$ & 0.0 & 0.0 & 0.0 & 0.0 & 0.0 & 0.0 & 0.0 & 0.0 & 0.0 & 0.0 & 0.0 & 0.0 \\
\hline Or & 94.7 & 95.2 & 95.2 & 100.0 & 98.8 & 100.0 & 96.2 & 93.7 & 96.2 & 95.5 & 97.3 & 96.1 \\
\hline
\end{tabular}

Tabela A4.4.1: Dados analiticos de feldspatos potássicos de GB e MGF. Fórmula estrutural: 32(0). 
Tabela A4.4: Feldspatos Potássicos - KF.

\begin{tabular}{|c|c|c|c|c|c|c|c|c|c|c|c|c|c|}
\hline Amostra & CAP-4 & CAP-4 & CAP-4 & CAP-4 & $\mathrm{CAP}-4$ & CAP-4 & CAP-4 & CAP-4 & CAP-4 & CAP-4 & CAP-4 & $1-01$ & $1-01$ \\
\hline Análise & $28 / 1 \mathrm{~K} 1.1$ & $28 / 1 \mathrm{~K} 1.2$ & $28 / 1 \mathrm{~K} 2.1$ & $28 / 1 \mathrm{~K} 2.2$ & $28 / 1 \mathrm{~K} 3.1$ & $28 / 1 \mathrm{~K} 4.1$ & $28 / 1 \mathrm{~K} 5.1$ & $28 / 3 \mathrm{~K} 1.1$ & $28 / 3 K_{2} .1$ & $28 / 4 \mathrm{~K} 1.1$ & $28 / 4 \mathrm{~K} 1.2$ & $10 / 3 \mathrm{KO1}$ & 10/3K02 \\
\hline Mineral & $\mathrm{KF}$ & $\mathrm{KF}$ & $\mathrm{KF}$ & $\mathrm{KF}$ & KF & $\mathrm{KF}$ & $\mathrm{KF}$ & KF & $\mathrm{KF}$ & $\mathrm{KF}$ & $\mathrm{KF}$ & $\mathrm{KF}$ & KF \\
\hline Local & C & B & C & $\bar{B}$ & $\mathrm{C}$ & C & $\mathrm{C}$ & C & C & B & $\mathrm{C}$ & 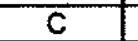 & $\mathrm{C}$ \\
\hline Litotipo & $\overline{A B}$ & $\overline{A B}$ & $\overline{A B}$ & $\overline{\mathrm{AB}}$ & $\overline{A B}$ & $\overline{A B}$ & $\overline{A B}$ & $\overline{A B}$ & $\overline{A B}$ & $A B$ & $\overline{A B}$ & ABG & $\overline{A B G}$ \\
\hline $\mathrm{SiO}_{2}$ & 65.19 & 64.47 & 64.93 & 64.84 & 65.00 & 65.36 & 68.45 & 64.73 & 66.27 & 67.18 & 67.16 & 64.67 & 65.20 \\
\hline $\mathrm{TiO}_{2}$ & 0.00 & 0.00 & 0.00 & 0.00 & 0.00 & $0 . \infty$ & 0.00 & $0 . \infty$ & 0.00 & 0.00 & 0.00 & 0.00 & 0.00 \\
\hline $\mathrm{Al}_{2} \mathrm{O}_{3}$ & 18.51 & 18.74 & 18.71 & 18.70 & 18.68 & 18.56 & 19.69 & 18.86 & 19.23 & 19.45 & 19.42 & 18.80 & 18.68 \\
\hline $\mathrm{Cr}_{2} \mathrm{O}_{3}$ & 0.00 & 0.00 & 0.00 & 0.00 & 0.00 & 0.00 & 0.00 & 0.00 & 0.00 & 0.00 & 0.00 & 0.00 & 0.00 \\
\hline Zno & n.a. & n.a. & n.a. & n.a. & n.a. & ก.a. & n.a. & n.a. & n.a. & n.a. & n.a. & n.a. & n.a. \\
\hline $\mathrm{FeO}$ & 0.00 & 0.49 & 0.00 & 0.00 & 0.20 & 0.22 & 0.00 & 0.28 & 0.00 & 0.17 & 0.00 & 0.00 & 0.00 \\
\hline $\mathrm{MnO}$ & 0.00 & 0.00 & 0.00 & 0.00 & $0 . \infty$ & 0.00 & 0.00 & 0.00 & $0 . \infty$ & 0.00 & 0.00 & 0.00 & 0.00 \\
\hline $\mathrm{MgO}$ & 0.00 & 0.00 & 0.00 & 0.00 & 0.00 & 0.00 & 0.00 & 0.00 & $0 . \infty$ & 0.00 & 0.00 & 0.00 & 0.00 \\
\hline NiO & 0.00 & 0.00 & 0.00 & 0.00 & 0.00 & 0.00 & 0.00 & 0.00 & 0.00 & 0.00 & 0.00 & 0.00 & 0.00 \\
\hline $\mathrm{CaO}$ & 0.00 & 0.00 & 0.00 & 0.00 & 0.00 & 0.00 & 0.00 & 0.00 & 0.00 & 0.00 & 0.00 & 0.00 & 0.00 \\
\hline $\mathrm{Na}_{2} \mathrm{O}$ & 0.00 & 0.00 & 0.00 & 0.00 & 0.00 & 0.00 & 0.14 & 0.22 & 0.00 & 0.00 & 0.15 & 0.15 & 0.00 \\
\hline $\mathrm{K}_{2} \mathrm{O}$ & 17.28 & 16.78 & 16.92 & 17.06 & 16.89 & 16.97 & 11.99 & 17.07 & 17.32 & 13.49 & 13.41 & 17.28 & 17.29 \\
\hline $\mathrm{P}_{2} \mathrm{O}_{5}$ & 0.00 & 0.00 & 0.00 & 0.00 & 0.00 & 0.00 & 0.00 & 0.00 & 0.00 & 0.00 & 0.00 & 0.00 & 0.00 \\
\hline $\mathrm{BaO}$ & ค.a. & n.a. & n.a. & n.a. & n.a. & n.a. & n.a. & n.a. & n.a. & n.a. & n.a. & n.a. & n.a. \\
\hline $\mathrm{F}$ & n.a. & ก.a. & n.a. & n.a. & n.a. & ก.a. & n.a. & n.a. & n.a. & n.a. & n.a. & n.a. & n.a. \\
\hline Cl & 0.00 & 0.00 & 0.00 & 0.00 & 0.00 & 0.00 & 0.00 & 0.00 & 0.00 & $0 . \infty$ & 0.00 & 0.00 & 0.00 \\
\hline Total & 100.98 & 100.48 & 100.56 & 100.60 & 100.77 & 101.11 & 100.27 & 101.16 & 102.82 & 100.29 & 100.14 & 100.90 & 101.17 \\
\hline Si & 11.98 & 11.91 & 11.96 & 11.95 & 11.96 & 11.98 & 12.20 & 11.89 & 11.94 & 12.11 & 12.12 & 11.91 & 11.96 \\
\hline Ti & 0.00 & 0.00 & 0.00 & 0.00 & 0.00 & 0.00 & 0.00 & 0.00 & 0.00 & 0.00 & 0.00 & 0.00 & 0.00 \\
\hline Al & 4.01 & 4.08 & 4.06 & 4.06 & 4.05 & 4.01 & 4.13 & 4.08 & 4.08 & 4.13 & 4.13 & 4.08 & 4.04 \\
\hline$\overline{\mathrm{Fe}^{+2}}$ & 0.00 & 0.08 & 0.00 & 0.00 & 0.03 & 0.03 & 0.00 & 0.04 & 0.00 & 0.03 & 0.00 & 0.00 & 0.00 \\
\hline $\mathrm{Mn}$ & 0.00 & 0.00 & 0.00 & 0.00 & 0.00 & 0.00 & 0.00 & 0.00 & 0.00 & 0.00 & 0.00 & 0.00 & 0.00 \\
\hline $\mathrm{Mg}$ & 0.00 & 0.00 & 0.00 & 0.00 & 0.00 & 0.00 & 0.00 & 0.00 & 0.00 & 0.00 & 0.00 & 0.00 & 0.00 \\
\hline $\mathrm{Ca}$ & 0.00 & 0.00 & 0.00 & 0.00 & $0 . \infty$ & 0.00 & $0 . \infty$ & 0.00 & 0.00 & 0.00 & 0.00 & 0.00 & 0.00 \\
\hline $\mathrm{Na}$ & 0.00 & 0.00 & 0.00 & 0.00 & 0.00 & 0.00 & 0.05 & 0.08 & 0.00 & 0.00 & 0.05 & 0.05 & 0.00 \\
\hline $\mathrm{K}$ & 4.05 & 3.96 & 3.98 & 4.01 & 3.96 & 3.97 & 2.73 & 4.00 & 3.98 & 3.10 & 3.09 & 4.06 & 4.05 \\
\hline $\mathrm{Ba}$ & & & & & & & & & & 4 & & & \\
\hline Cátions & 20.04 & 20.02 & 19.99 & 20.02 & 20.00 & 19.99 & 19.11 & 20.10 & 20.00 & 19.37 & 19.38 & 20.10 & 20.04 \\
\hline$\overline{A b}$ & 0.0 & 0.0 & 0.0 & 0.0 & 0.0 & 0.0 & 1.7 & 1.9 & 0.0 & 0.0 & 1.7 & 1.3 & 0.0 \\
\hline$A n$ & 0.0 & 0.0 & 0.0 & 0.0 & 0.0 & 0.0 & 0.0 & 0.0 & 0.0 & 0.0 & 0.0 & 0.0 & 0.0 \\
\hline Or & 100.0 & 100.0 & 100.0 & 100.0 & 100.0 & 100.0 & 98.3 & 98.1 & 100.0 & 100.0 & 98.3 & 98.7| & 100.0 \\
\hline
\end{tabular}

Tabela A4.4.2: Dados analíticos de feldspatos potássicos de anfibolitos metabásicos AB e ABG. Fórmula estrutural: $32(0)$. 
Tabela A4.4: Feldspatos Potássicos - KF.

\begin{tabular}{|c|c|c|c|c|c|c|c|c|}
\hline Amostra & $\mathrm{G}-168 \mathrm{~g}^{\star}$ & $B E-04$ & NE-31-06 & NE-31-06 & NE-31-06 & $1-01$ & $1-01$ & $1-01$ \\
\hline Análise & $05 / 03 / 05$ & $45 / 1 \mathrm{KO}$ & $03 / 03 / 27$ & $03 / 04 / 33$ & $03 / 04 / 35$ & 10/4K01 & $10 / 4 \mathrm{KO} 2$ & $10 / 4 \mathrm{KO3}$ \\
\hline Mineral & $\mathrm{KF}$ & $\mathrm{KF}$ & KF & $\mathrm{KF}$ & $\mathrm{KF}$ & KF & $\mathrm{KF}$ & $\mathrm{KF}$ \\
\hline Local & Lente Bt & Lente Flo & Lente Flo & Lente Flo & Lente Flo & Lente Bt & Lente Bt & Lente $\mathrm{Bt}$ \\
\hline Litotipo & TTG & UM & UM & UM & UM & ABG & ABG & ABG \\
\hline $\mathrm{SiO}_{2}$ & 63.65 & 64.87 & 64.70 & 62.68 & 63.84 & 65.63 & 64.97 & 64.69 \\
\hline $\mathrm{TIO}_{2}$ & 0.04 & 0.00 & 0.00 & 0.00 & 0.02 & 0.00 & 0.00 & 0.00 \\
\hline $\mathrm{Al}_{2} \mathrm{O}_{3}$ & 18.50 & 18.51 & 18.29 & 18.05 & 18.60 & 18.78 & 19.00 & 18.58 \\
\hline $\mathrm{Cr}_{2} \mathrm{O}_{3}$ & 0.00 & 0.00 & 0.00 & 0.03 & 0.00 & 0.00 & 0.00 & 0.00 \\
\hline Zno & n.a. & n.a. & 0.00 & 0.00 & 0.02 & n.a. & n.a. & n.a. \\
\hline $\mathrm{FeO}$ & 0.20 & 0.00 & 0.14 & 0.17 & 0.18 & 0.36 & 0.00 & 0.00 \\
\hline $\mathrm{MnO}$ & 0.00 & 0.00 & 0.02 & 0.00 & 0.00 & 0.00 & 0.00 & 0.00 \\
\hline $\mathrm{MgO}$ & 0.00 & 0.00 & 0.01 & 0.02 & 0.00 & 0.00 & 0.00 & 0.00 \\
\hline $\mathrm{NiO}$ & n.a. & 0.00 & 0.00 & 0.02 & 0.00 & 0.00 & 0.00 & 0.00 \\
\hline $\mathrm{CaO}$ & 0.00 & 0.00 & 0.00 & 0.00 & 0.00 & 0.00 & 0.00 & 0.00 \\
\hline $\mathrm{Na}_{2} \mathrm{O}$ & 0.08 & 0.00 & 0.38 & 0.08 & 0.38 & 0.00 & 0.00 & 0.00 \\
\hline $\mathrm{K}_{2} \mathrm{O}$ & 16.53 & 16.44 & 16.34 & 16.94 & 16.30 & 17.06 & 17.05 & 17.09 \\
\hline $\mathrm{P}_{2} \mathrm{O}_{5}$ & n.a. & 0.00 & n.a. & n.a. & n.a. & 0.00 & 0.00 & 0.00 \\
\hline $\mathrm{BaO}$ & 0.42 & n.a. & n.a. & n.a. & n.a. & ก.a. & n.a. & n.a. \\
\hline$F$ & $0 . \infty$ & n.a. & n.a. & n.a. & n.a. & n.a. & n.a. & n.a. \\
\hline $\mathrm{Cl}$ & ก.a. & 0.00 & n.a. & n.a. & n.a. & 0.00 & 0.00 & 0.00 \\
\hline Total & 99.42 & 99.82 & 99.88 & 97.99 & 99.34 & 101.83 & 101.02 & 100.36 \\
\hline Si & 11.91 & 12.00 & 11.99 & 11.91 & 11.91 & 11.96 & 11.92 & 11.96 \\
\hline $\mathrm{Ti}$ & 0.01 & 0.00 & 0.00 & 0.00 & 0.00 & 0.00 & 0.00 & 0.00 \\
\hline A) & 4.08 & 4.03 & 3.99 & 4.04 & 4.09 & 4.03 & 4.11 & 4.04 \\
\hline $\mathrm{Fe}^{+2}$ & 0.03 & 0.00 & 0.02 & 0.03 & 0.03 & 0.06 & 0.00 & 0.00 \\
\hline$\overline{M n}$ & 0.00 & 0.00 & 0.00 & 0.00 & 0.00 & 0.00 & 0.00 & 0.00 \\
\hline $\mathrm{Mg}$ & 0.00 & 0.00 & 0.00 & 0.01 & 0.00 & 0.00 & 0.00 & 0.00 \\
\hline $\mathrm{Ca}$ & 0.00 & 0.00 & 0.00 & 0.00 & 0.00 & 0.00 & 0.0 & 0.00 \\
\hline $\mathrm{Na}$ & 0.03 & 0.00 & 0.14 & 0.03 & 0.14 & 0.00 & 0.00 & 0.00 \\
\hline $\mathrm{K}$ & 3.95 & 3.88 & 3.86 & 4.11 & 3.88 & 3.97 & 3.99 & 4.03 \\
\hline $\mathrm{Ba}$ & 0.03 & & & & & & & \\
\hline Cátions & 20.03 & 19.92 & 20.00 & 20.13 & 20.04 & 20.01 & 20.02 & 20.03 \\
\hline$\overline{A b}$ & 0.7 & 0.0 & 3.4 & 0.7 & 3.4 & 0.0 & 0.0 & 0.0 \\
\hline$A_{n}$ & 0.0 & 0.0 & 0.0 & 0.0 & 0.0 & 0.0 & 0.0 & 0.0 \\
\hline Or & 99.3 & 100.0 & 96.6 & 99.3 & 96.6 & 100.0 & 100.0 & 100.0 \\
\hline
\end{tabular}

Tabela A4.4.3: Dados analiticos de feldspatos potássicos de lentes em biotitas (Bt)/flogopitas (Flo) esfoliadas de TTG, UM e ABG. Fórmula estrutural com base em 32(O). 
Tabela A4.5: Granadas - GR.

\begin{tabular}{|c|c|c|c|c|c|c|c|c|c|c|}
\hline Amostra & G-113 & $G-113$ & $G-113$ & $G-113$ & $G-166 b$ & $G-168 b$ & $G-166 b$ & $G-166 b$ & $G-166 b$ & G-166b \\
\hline Análise & $5 / 3 / 12$ & $5 / 3 / 13$ & $5 / 3 / 16$ & $5 / 3 / 17$ & $4 / 1 / 46$ & $4 / 1 / 47$ & $4 / 1 / 48$ & $4 / 1 / 50$ & $4 / 1 / 60$ & $4 / 1 / 61$ \\
\hline Mineral & GR & GR & GR & GR & GR & GR & GR & GR & GR & GR \\
\hline Local & $\mathrm{C}$ & B & $c$ & $B$ & $\mathrm{C}$ & B & $\mathrm{C}$ & 8 & $\mathrm{~B}$ & $\mathrm{C}$ \\
\hline Litotipo & $\mathrm{GB}$ & GB & GB & GB & $\overline{\mathrm{GB}}$ & GB & $\mathrm{GB}$ & $\mathrm{GB}$ & GB & GB \\
\hline $\mathrm{SiO}_{2}$ & 37.53 & 37.69 & 37.13 & 37.52 & 36.81 & 37.05 & 36.68 & 37.57 & 37.77 & 36.96 \\
\hline $\mathrm{TiO}_{2}$ & 0.00 & 0.01 & 0.00 & 0.04 & 0.00 & 0.00 & 0.04 & 0.00 & 0.00 & 0.03 \\
\hline $\mathrm{A}_{2} \mathrm{O}_{3}$ & 20.49 & 20.45 & 20.18 & 20.23 & 20.39 & 20.70 & 20.66 & 20.84 & 20.94 & 20.15 \\
\hline $\mathrm{Cr}_{2} \mathrm{O}_{3}$ & 0.03 & 0.01 & 0.00 & 0.01 & 0.00 & 0.02 & 0.01 & 0.05 & 0.00 & 0.00 \\
\hline Zno & 0.00 & 0.00 & 0.04 & 0.02 & 0.14 & 0.04 & 0.01 & 0.02 & 0.05 & 0.01 \\
\hline $\mathrm{FeO}$ & 26.79 & 27.22 & 25.07 & 25.39 & 29.21 & 27.45 & 30.84 & 30.28 & 29.84 & 30.97 \\
\hline $\mathrm{MnO}$ & 4.93 & 5.14 & 6.18 & 6.40 & 10.56 & 12.19 & 9.02 & 9.64 & 9.67 & 8.73 \\
\hline $\mathrm{MgO}$ & 0.05 & 0.06 & 0.03 & 0.05 & 0.11 & 0.10 & 0.13 & 0.13 & 0.11 & 0.11 \\
\hline $\mathrm{NiO}$ & 0.00 & 0.06 & 0.00 & 0.00 & 0.05 & 0.00 & 0.00 & 0.00 & 0.01 & 0.00 \\
\hline $\mathrm{CaO}$ & 10.45 & 10.49 & 10.39 & 10.07 & 3.02 & 2.84 & 3.04 & 2.97 & 3.15 & 3.39 \\
\hline $\mathrm{Na}_{2} \mathrm{O}$ & 0.00 & 0.07 & 0.07 & 0.12 & 0.03 & 0.06 & 0.06 & 0.04 & 0.00 & 0.02 \\
\hline $\mathrm{K}_{2} \mathrm{O}$ & 0.00 & 0.01 & 0.00 & 0.02 & 0.00 & 0.00 & 0.00 & 0.01 & 0.00 & 0.00 \\
\hline $\mathrm{P}_{2} \mathrm{O}_{5}$ & n.a. & n.a. & n.a. & n.a. & n.a. & n.a. & n.a. & n.a. & n.a. & n.a. \\
\hline Total & 100.27 & 101.21 & 99.09 & 99.87 & 100.32 & 100.45 & 100.49 & 101.55 & 101.54 & 100.37 \\
\hline $\mathrm{TS}_{\mathrm{i}}$ & 3.02 & 3.03 & 3.03 & 3.04 & 3.02 & 3.01 & 3.00 & 3.01 & 3.01 & 3.03 \\
\hline TAl & 0.00 & 0.00 & 0.00 & 0.00 & 0.00 & 0.00 & 0.00 & 0.00 & 0.00 & 0.00 \\
\hline Soma T & 3.02 & 3.03 & 3.03 & 3.04 & 3.02 & 3.01 & 3.00 & 3.01 & 3.01 & 3.03 \\
\hline AIV & 1.94 & 1.94 & 1.94 & 1.93 & 1.97 & 1.98 & 1.99 & 1.97 & 1.97 & 1.94 \\
\hline $\mathrm{Fe}^{3}$ & 1.60 & 1.65 & 1.69 & 1.70 & 1.72 & 1.68 & 1.71 & 1.65 & 1.59 & 1.62 \\
\hline $\mathrm{Ti}$ & 0.00 & 0.00 & 0.00 & 0.00 & 0.00 & 0.00 & 0.00 & 0.00 & 0.00 & 0.00 \\
\hline $\mathrm{Cr}$ & 0.00 & 0.00 & 0.00 & 0.00 & 0.00 & 0.00 & 0.00 & 0.00 & 0.00 & 0.00 \\
\hline Soma A & 3.55 & 3.59 & 3.63 & 3.63 & 3.68 & 3.67 & 3.71 & 3.62 & 3.55 & 3.57 \\
\hline $\mathrm{Fe}^{2}$ & 1.79 & 1.76 & 1.68 & 1.69 & 2.00 & 1.90 & 2.08 & 2.08 & 2.08 & 2.11 \\
\hline $\mathrm{Mg}$ & 0.01 & 0.01 & 0.00 & 0.01 & 0.01 & 0.01 & 0.02 & 0.02 & 0.01 & 0.01 \\
\hline $\mathrm{Mn}$ & 0.34 & 0.35 & 0.43 & 0.44 & 0.73 & 0.84 & 0.63 & 0.66 & 0.65 & 0.61 \\
\hline $\mathrm{Ca}$ & 0.90 & 0.90 & 0.91 & 0.87 & 0.27 & 0.25 & 0.27 & 0.26 & 0.27 & 0.30 \\
\hline $\mathrm{Na}$ & 0.00 & 0.01 & 0.01 & 0.02 & 0.01 & 0.01 & 0.01 & 0.01 & 0.00 & 0.00 \\
\hline Soma B & 3.03 & 3.03 & 3.03 & 3.03 & 3.02 & 3.01 & 3.00 & 3.01 & 3.02 & 3.03 \\
\hline Cations & 9.60 & 9.65 & 9.69 & 9.70 & 9.72 & 9.68 & 9.71 & 9.65 & 9.58 & 9.62 \\
\hline$\overline{A l m}$ & 57.41 & 56.65 & 54.01 & 54.49 & 65.76 & 63.10 & 69.66 & 68.73 & 68.32 & 68.59 \\
\hline And & 0.00 & 0.00 & 0.00 & 0.00 & 0.00 & 0.00 & 0.00 & 0.00 & 0.00 & 0.00 \\
\hline Gross & 30.77 & 31.04 & 31.20 & 30.12 & 8.97 & 8.24 & 8.88 & 8.46 & 9.12 & 10.19 \\
\hline Piropo & 0.21 & 0.25 & 0.13 & 0.21 & 0.46 & 0.41 & 0.53 & 0.53 & 0.44 & 0.46 \\
\hline Espess & 11.51 & 12.04 & 14.67 & 15.15 & 24.81 & 28.19 & 20.90 & 22.12 & 22.12 & 20.75 \\
\hline Uvaro & 0.10 & 0.03 & 0.00 & 0.03 & 0.00 & 0.07 & 0.03 & 0.16 & 0.00 & 0.00 \\
\hline
\end{tabular}

Tabela A4.5.1: Dados analíticos de granadas de GB. Fórmula estrutural: 12(O). 
Tabela A4.5: Granadas - GR.

\begin{tabular}{|c|c|c|c|c|c|c|c|c|c|c|c|c|c|c|c|c|c|}
\hline Amostra & B-10 & 8-10 & $\mathrm{B}-10$ & B-10 & B-10 & $\mathrm{B}-10$ & $B-10$ & $B-10$ & $\mathrm{~B}-10$ & $8-10$ & $\mathrm{C}-1 \mathrm{a}$ & $\overline{C-1 a}$ & C-1a & $\mathrm{C}-1 \mathrm{a}$ & $\mathrm{C}-1 \mathrm{a}$ & C-1a & $\mathrm{C}-1 \mathrm{a}$ \\
\hline Análise & $26 / 3 \mathrm{GO1}$ & $26 / 3 G 02$ & $26 / 3 G 03$ & $26 / 3 \mathrm{GO} 4$ & 263605 & $26 / 3 G 06$ & $26 / 4 \mathrm{GO} 1$ & $26 / 4 \mathrm{GO2}$ & $26 / 4 \mathrm{GO3}$ & $26 / 4 G 04$ & $3 / 1 / 50$ & $3 / 1 / 51$ & $3 / 2 / 55$ & $3 / 2 / 56$ & $3 / 2 / 57$ & $3 / 4 / 60$ & $3 / 4 / 61$ \\
\hline Mineral & GR & $\begin{array}{ll}\text { GR } \\
\end{array}$ & GR & GR & GR & GR & GR & GR & GR & GR & GR & GR & GR & GR & $\mathrm{GR}$ & GR & $\mathrm{GR}$ \\
\hline Local & C & PIm & $\mathrm{Plm}$ & $B(i)$ & $B(e)$ & $\mathrm{B}(\boldsymbol{\theta})$ & $C$ & PIm & $B(i)$ & $\mathrm{B}$ & C & B & Pln & B & C & C & 8 \\
\hline Litotipo & $\overline{A B G}$ & ABG & ABG & $A B G$ & $\mathrm{ABG}$ & $A B G$ & $A B G$ & ABG & $A B G$ & $A B G$ & $A B G$ & $A B G$ & ABG & $\overline{A B G}$ & ABG & $A B G$ & ABG \\
\hline $\mathrm{SiO}_{2}$ & 36.67 & 36.56 & 36.89 & 37.04 & 37.19 & 36.93 & 37.34 & 36.71 & 36.54 & 37.04 & 37.81 & 38.10 & 37.87 & 37.83 & 38.94 & 38.10 & 38.48 \\
\hline $\mathrm{TiO}_{2}$ & 0.00 & 0.00 & 0.00 & 0.00 & 0.00 & 0.00 & 0.00 & 0.00 & 0.00 & 0.00 & 0.06 & 0.00 & 0.00 & 0.00 & 0.07 & 0.02 & 0.00 \\
\hline $\mathrm{Al}_{2} \mathrm{O}_{3}$ & 21.07 & 21.01 & 20.99 & 21.32 & 21.30 & 21.22 & 21.43 & 21.15 & 20.99 & 21.33 & 21.13 & 21.64 & 21.11 & 21.55 & 21.76 & 21.39 & 21.45 \\
\hline $\mathrm{Cr}_{2} \mathrm{O}_{3}$ & 0.00 & 0.00 & $0 . \infty$ & 0.00 & 0.00 & 0.00 & 0.00 & 0.00 & 0.00 & 0.00 & 0.00 & 0.00 & 0.02 & 0.01 & 0.00 & 0.02 & 0.00 \\
\hline $\mathrm{ZnO}$ & n.a. & n.a. & n.a. & n.a. & n.a. & ก.a. & n.a. & n.a. & n.a. & n.a. & 0.00 & 0.05 & 0.00 & 0.00 & 0.00 & 0.00 & 0.04 \\
\hline $\mathrm{FeO}$ & 29.33 & 28.15 & 27.74 & 28.46 & 29.17 & 30.11 & 28.20 & 28.67 & 29.69 & 29.01 & 29.94 & 32.70 & 31.89 & 31.92 & 31.18 & 31.05 & 30.81 \\
\hline MnO & 2.58 & 2.90 & 2.76 & 1.79 & 1.78 & 2.32 & 1.74 & 1.70 & 1.46 & 1.67 & 1.30 & 1.63 & 1.20 & 1.26 & 1.05 & 0.85 & 0.58 \\
\hline $\mathrm{MgO}$ & 4.42 & 3.98 & 3.71 & 4.58 & 4.57 & 4.01 & 4.76 & 4.93 & 4.95 & 4.71 & 3.86 & 3.66 & 3.91 & 3.81 & 3.86 & 4.05 & 3.74 \\
\hline $\mathrm{NiO}$ & 0.00 & 0.00 & 0.00 & 0.00 & 0.00 & 0.00 & 0.00 & 0.00 & 0.00 & 0.00 & 0.00 & 0.02 & 0.00 & 0.00 & 0.00 & 0.01 & 0.00 \\
\hline $\mathrm{CaO}$ & 4.87 & 5.94 & 6.32 & 5.36 & 4.76 & 4.46 & 5.31 & 4.91 & 4.68 & 4.96 & 5.43 & 4.55 & 4.84 & 5.25 & 6.05 & 5.50 & 6.66 \\
\hline $\mathrm{Na}_{2} \mathrm{O}$ & 0.23 & 0.25 & 0.00 & 0.35 & 0.22 & 0.23 & 0.22 & 0.00 & 0.27 & 0.34 & 0.00 & 0.00 & 0.00 & 0.00 & 0.06 & 0.03 & 0.05 \\
\hline $\mathrm{K}_{2} \mathrm{O}$ & 0.0 & 0.00 & 0.00 & 0.00 & 0.00 & 0.00 & 0.00 & 0.00 & 0.00 & 0.00 & 0.00 & 0.00 & 0.00 & 0.00 & 0.00 & 0.02 & 0.01 \\
\hline $\mathrm{P}_{2} \mathrm{O}_{5}$ & 0.17 & 0.00 & 0.00 & 0.00 & 0.00 & 0.00 & 0.12 & 0.00 & 0.00 & 0.00 & n.a. & n.a. & n.a. & n.a. & n.a. & n.a. & n.a. \\
\hline Total & 99.34 & 98.79 & 98.41 & 98.90 & 98.99 & 99.28 & 99.12 & 98.07 & 98.58 & 99.06 & 99.53 & 102.35 & 100.84 & 101.63 & 102.97 & 101.04 & 101.82 \\
\hline TSi & 3.00 & 3.00 & 2.99 & 3.01 & 3.00 & 3.00 & 3.00 & 2.98 & 3.00 & 3.01 & 3.01 & 3.00 & 3.01 & 299 & 3.01 & 3.00 & 3.01 \\
\hline TAl & 0.00 & 0.00 & 0.01 & 0.00 & 0.00 & 0.00 & 0.00 & 0.02 & 0.00 & 0.00 & 0.0 & 0.04 & 0.00 & 0.01 & 0.00 & 0.00 & 0.00 \\
\hline Soma T & 3.00 & 3.00 & 3.0 & 3.01 & 3.00 & 3.00 & 3.00 & 3.00 & 3.00 & 3.01 & 3.01 & 3.00 & 3.01 & 3.00 & 3.01 & 3.00 & 3.01 \\
\hline AIVI & 2.03 & 2.03 & 2.00 & 2.04 & 2.03 & 2.03 & 2.03 & 2.01 & 2.03 & 2.04 & 1.98 & 2.00 & 1.98 & 2.00 & 1.98 & 1.99 & 1.98 \\
\hline $\mathrm{Fe}^{3}$ & 0.21 & 0.41 & 0.47 & 0.62 & 0.71 & 0.84 & 0.91 & 1.00 & 1.18 & 1.30 & 1.27 & 1.30 & 1.36 & 1.41 & 1.41 & 1.46 & 1.48 \\
\hline $\mathrm{Ti}$ & 0.00 & 0.0 & 0.00 & 0.00 & 0.00 & 0.0 & 0.00 & 0.00 & 0.00 & 0.00 & 0.00 & 0.00 & 0.00 & 0.00 & 0.00 & 0.00 & 0.00 \\
\hline $\mathrm{Cr}$ & 0.00 & 0.00 & 0.00 & 0.00 & 0.00 & 0.00 & 0.00 & 0.00 & 0.00 & 0.00 & 0.00 & 0.00 & 0.00 & 0.00 & 0.00 & 0.00 & 0.00 \\
\hline Soma A & 2.24 & 2.44 & 2.47 & 2.66 & 2.74 & 2.87 & 2.94 & 3.01 & 3.22 & 3.34 & 3.25 & 3.30 & 3.33 & 3.42 & 3.39 & 3.45 & 3.46 \\
\hline $\mathrm{Fe}^{2}$ & 1.79 & 1.72 & 1.81 & 1.76 & 1.86 & 1.90 & 1.79 & 1.85 & 1.80 & 1.79 & 2.01 & 2.08 & 2.06 & 2.02 & 1.99 & 2.01 & 1.97 \\
\hline $\mathrm{Mg}$ & 0.54 & 0.49 & 0.45 & 0.55 & 0.55 & 0.49 & 0.57 & 0.60 & 0.61 & 0.57 & 0.46 & 0.43 & 0.46 & 0.45 & 0.44 & 0.48 & 0.44 \\
\hline $\mathrm{Mn}$ & 0.18 & 0.20 & 0.19 & 0.12 & 0.12 & 0.16 & 0.12 & 0.12 & 0.10 & 0.12 & 0.09 & 0.11 & 0.08 & 0.08 & 0.07 & 0.06 & 0.04 \\
\hline $\mathrm{Ca}$ & 0.43 & 0.52 & 0.55 & 0.47 & 0.41 & 0.39 & 0.46 & 0.43 & 0.41 & 0.43 & 0.46 & 0.38 & 0.41 & 0.45 & 0.50 & 0.47 & 0.56 \\
\hline $\mathrm{Na}$ & 0.04 & 0.04 & 0.00 & 0.06 & 0.03 & 0.04 & 0.03 & 0.00 & 0.04 & 0.05 & 0.00 & 0.00 & 0.00 & 0.00 & 0.01 & 0.01 & 0.01 \\
\hline Soma B & 2.97 & 2.97 & 3.00 & 2.96 & 2.97 & 2.97 & 2.97 & 2.99 & 2.97 & 2.96 & 3.01 & 3.00 & 3.02 & 3.00 & 3.01 & 3.01 & 3.01 \\
\hline Cations & 8.21 & 8.41 & 8.47 & 8.62 & 8.72 & 8.84 & 8.91 & 9.00 & 9.18 & 9.30 & 9.27 & 9.30 & 9.36 & 9.41 & 9.41 & 9.46 & 9.48 \\
\hline Alm & 60.97 & 58.63 & 50.58 & 60.61 & 63.14 & 64.77 & 61.00 & 52.56 & 61.68 & 61.59 & 66.08 & 60.18 & 67.79 & 58.11 & 65.89 & 66.58 & 65.19 \\
\hline And & 0.00 & 0.00 & 0.00 & 0.00 & 0.00 & 0.00 & 0.00 & 0.00 & 0.00 & 0.00 & 0.00 & 0.00 & 0.00 & 0.00 & 0.00 & 0.00 & 0.00 \\
\hline Gross & 14.55 & 17.85 & 22.86 & 16.06 & 14.01 & 13.23 & 15.56 & 17.76 & 14.10 & 14.85 & 15.57 & 16.57 & 13.82 & 19.00 & 16.85 & 15.51 & 18.81 \\
\hline Piropo & 18.38 & 16.64 & 18.67 & 19.09 & 18.71 & 16.55 & 19.41 & 24.82 & 20.75 & 19.62 & 15.40 & 18.55 & 15.61 & 19.23 & 14.96 & 15.95 & 14.70 \\
\hline Espess & 6.10 & 6.89 & 7.89 & 4.24 & 4.14 & 5.44 & 4.03 & 4.86 & 3.48 & 3.95 & 2.95 & 4.69 & 2.72 & 3.61 & 2.31 & 1.90 & 1.30 \\
\hline Uvaro & 0.00 & 0.00 & $0 . \infty$ & 0.00 & 0.00 & 0.00 & 0.00 & 0.00 & 0.00 & 0.00 & 0.00 & 0.00 & 0.06 & 0.04 & 0.00 & 0.06 & 0.00 \\
\hline
\end{tabular}

Tabela A4.5.2: Dados analíticos de granadas de anfibolitos metabásicos ABG. Fórmula estrutural: 12(O). 


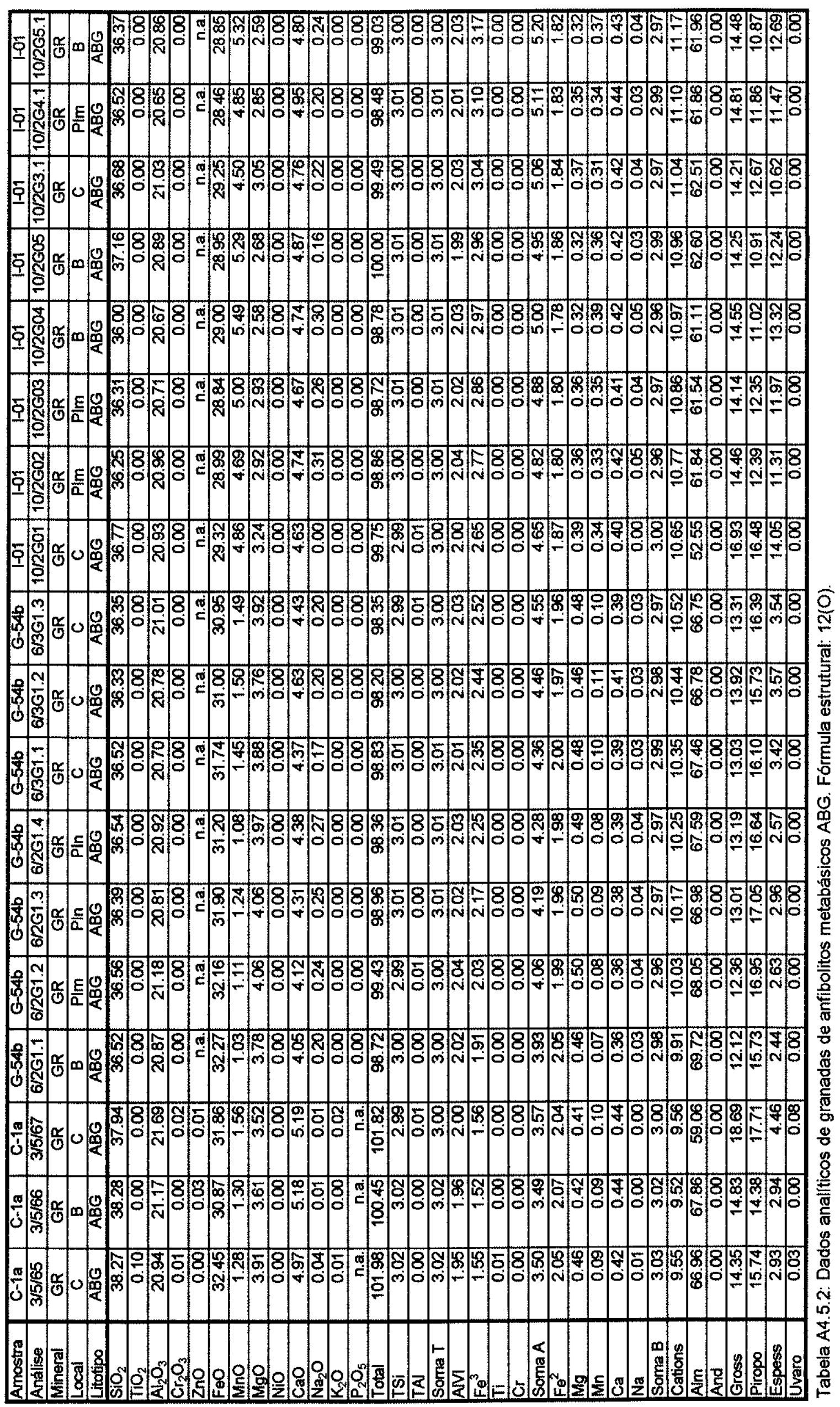


Tabela A4.5: Granadas - GR.

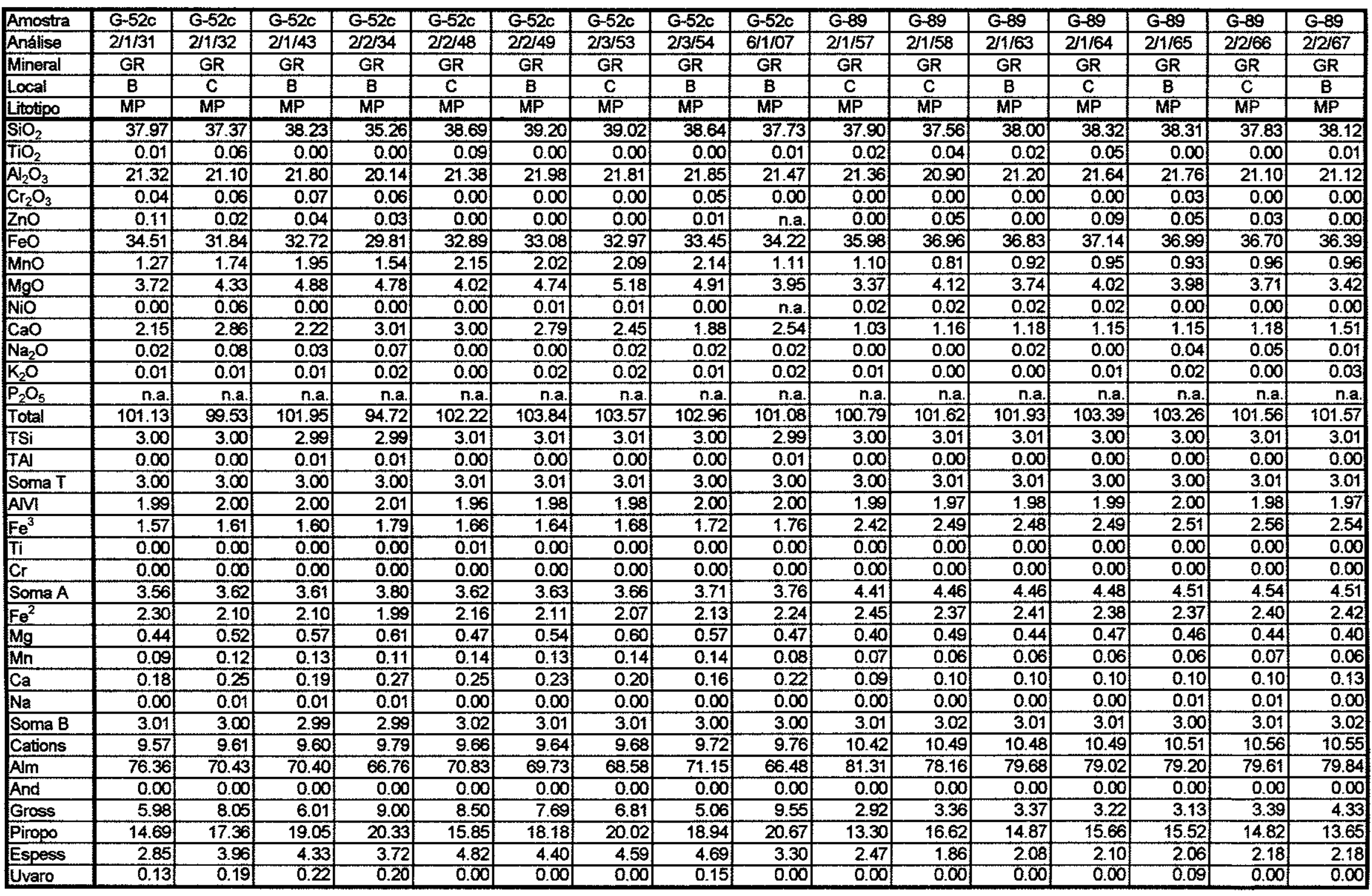

Tabela A4.5.3: Dados analíticos de granadas de MP. Fórmula estrutural: 12(O). 
Tabela A4.6: Cordieritas - CD.

\begin{tabular}{|c|c|c|c|c|c|c|c|c|c|c|c|c|c|c|c|c|}
\hline Amostra & AP-3 & $\mathrm{AP}+3$ & AP-3 & AP-3 & AP-3 & G-85a & G-85a & $G-85 a$ & G-85a & G-85a & $G-85 a$ & $G-85 a$ & G-85a & G-85a & $G-85 a$ & G-85a \\
\hline Análise & $1 / 1 / 40$ & $1 / 1 / 55$ & $1 / 1 / 56$ & $1 / 2 / 49$ & $2 / 1 / 2$ & $1 / 1 / 1$ & $1 / 1 / 2$ & $1 / / / 3$ & $1 / 1 / 4$ & $1 / 1 / 5$ & $1 / 2 / 12$ & $1 / 2 / 13$ & $1 / 2 / 14$ & $1 / 2 / 18$ & $1 / 2 / 19$ & $1 / 3 / 27$ \\
\hline Mineral & $C D$ & $C D$ & CD & $C D$ & $\mathrm{CD}$ & $C D$ & $C D$ & $\mathrm{CD}$ & $C D$ & $\mathrm{CD}$ & $\mathrm{CD}$ & $\mathrm{CD}$ & $C D$ & $\mathrm{CD}$ & $\mathrm{CD}$ & $\mathrm{CD}$ \\
\hline Local & $B$ & C & $\mathrm{C}$ & $B$ & $B$ & $\mathrm{C}$ & $\mathrm{C}$ & B & $B$ & PIm & B & $\mathrm{C}$ & $\mathrm{C}$ & $\mathrm{C}$ & B & $C$ \\
\hline Litotipo & MP & MP & MP & MP & MP & $M P$ & MP & $M P$ & MP & MP & $\mathrm{MP}$ & MP & MP & MP & MP & $\mathrm{MP}$ \\
\hline $\mathrm{SiO}_{2}$ & 48.05 & 49.02 & 49.49 & 49.88 & 49.60 & 49.25 & 48.81 & 48.57 & 48.89 & 48.73 & 49.00 & 48.19 & 48.88 & 47.92 & 48.68 & 49.10 \\
\hline $\mathrm{TiO}_{2}$ & 0.00 & 0.00 & 0.07 & 0.06 & 0.00 & 0.00 & 0.00 & 0.00 & 0.00 & 0.00 & 0.00 & 0.00 & 0.00 & 0.00 & 0.00 & 0.06 \\
\hline $\mathrm{Al}_{2} \mathrm{O}_{3}$ & 33.64 & 33.73 & 33.18 & 33.92 & 33.63 & 31.74 & 31.46 & 32.21 & 32.59 & 31.97 & 32.07 & 31.26 & 31.57 & 31.09 & 31.52 & 31.32 \\
\hline $\mathrm{Cr}_{2} \mathrm{O}_{3}$ & 0.00 & 0.04 & 0.00 & 0.00 & 0.07 & 0.00 & 0.03 & 0.01 & 0.00 & 0.01 & 0.00 & 0.01 & 0.00 & 0.00 & 0.00 & 0.00 \\
\hline $\mathrm{ZnO}$ & 0.00 & 0.01 & 0.01 & 0.00 & 0.01 & 0.04 & 0.03 & 0.00 & 0.01 & 0.01 & 0.01 & 0.00 & 0.00 & 0.01 & 0.00 & 0.02 \\
\hline $\mathrm{FeO}$ & 5.60 & 5.85 & 5.68 & 5.15 & 5.62 & 6.18 & 5.91 & 5.59 & 5.92 & 5.75 & 5.62 & 5.79 & 5.77 & 5.91 & 5.79 & 5.66 \\
\hline $\mathrm{MnO}$ & 0.08 & 0.07 & 0.04 & 0.07 & 0.07 & 0.02 & 0.02 & 0.03 & 0.00 & 0.00 & 0.02 & 0.00 & 0.00 & 0.04 & 0.02 & 0.00 \\
\hline $\mathrm{MgO}$ & 10.41 & 10.38 & 10.23 & 10.43 & 10.36 & 10.41 & 10.22 & 10.18 & 10.18 & 10.30 & 10.52 & 10.28 & 10.29 & 10.26 & 10.22 & 10.34 \\
\hline NiO & 0.00 & 0.02 & 0.00 & 0.00 & 0.00 & 0.05 & 0.00 & 0.00 & 0.01 & 0.00 & 0.01 & 0.02 & 0.00 & 0.06 & 0.01 & 0.00 \\
\hline $\mathrm{CaO}$ & 0.00 & 0.01 & 0.01 & 0.00 & 0.01 & 0.04 & 0.04 & 0.03 & 0.02 & 0.02 & 0.03 & 0.04 & 0.02 & 0.03 & 0.03 & 0.03 \\
\hline $\mathrm{Na}_{2} \mathrm{O}$ & 0.48 & 0.51 & 0.46 & 0.54 & 0.47 & 1.18 & 1.16 & 0.75 & 0.78 & 1.01 & 1.06 & 1.26 & 1.24 & 1.18 & 1.11 & 1.30 \\
\hline $\mathrm{K}_{2} \mathrm{O}$ & 0.01 & 0.00 & 0.02 & 0.00 & 0.01 & 0.02 & 0.0 & 0.01 & 0.01 & 0.00 & 0.02 & 0.02 & 0.01 & 0.00 & 0.00 & 0.01 \\
\hline Total & 98.27 & 99.64 & 99.19 & 100.05 & 99.85 & 98.93 & 97.68 & 97.38 & 98.41 & 97.80 & 98.36 & 96.87 & 97.78 & 96.50 & 97.38 & 97.84 \\
\hline $\mathrm{Si}$ & 4.91 & 4.94 & 5.00 & 4.98 & 4.98 & 5.02 & 5.03 & 5.00 & 4.99 & 5.01 & 5.01 & 5.01 & 5.03 & 5.01 & 5.03 & 5.05 \\
\hline $\mathrm{Ti}$ & 0.00 & 0.00 & 0.01 & 0.01 & 0.00 & 0.00 & 0.00 & 0.00 & 0.00 & 0.00 & 0.00 & 0.00 & 0.00 & 0.00 & 0.00 & 0.01 \\
\hline Al & 4.04 & 4.00 & 3.95 & 3.99 & 3.97 & 3.81 & 3.82 & 3.91 & 3.92 & 3.87 & 3.86 & 3.83 & 3.83 & 3.83 & 3.83 & 3.79 \\
\hline $\mathrm{Cr}$ & 0.00 & 0.00 & 0.00 & 0.00 & 0.01 & 0.00 & 0.00 & 0.00 & 0.00 & 0.00 & 0.00 & 0.00 & 0.00 & 0.00 & 0.00 & 0.00 \\
\hline $\mathrm{Fe}^{+2}$ & 0.48 & 0.49 & 0.48 & 0.43 & 0.47 & 0.53 & 0.51 & 0.48 & 0.51 & 0.49 & 0.48 & 0.50 & 0.50 & 0.52 & 0.50 & 0.49 \\
\hline $\mathrm{Mn}$ & 0.01 & 0.01 & 0.00 & 0.01 & 0.01 & 0.00 & 0.00 & 0.00 & 0.00 & 0.00 & 0.00 & 0.00 & 0.00 & 0.00 & 0.00 & 0.00 \\
\hline $\mathrm{Mg}$ & 1.58 & 1.56 & 1.54 & 1.55 & 1.55 & 1.58 & 1.57 & 1.56 & 1.55 & 1.58 & 1.60 & 1.59 & 1.58 & 1.60 & 1.57 & 1.58 \\
\hline $\mathrm{Ca}$ & 0.00 & 0.00 & 0.00 & 0.00 & 0.00 & 0.00 & 0.00 & 0.00 & 0.00 & 0.00 & 0.00 & 0.00 & 0.00 & 0.00 & 0.00 & 0.00 \\
\hline $\mathrm{Na}$ & 0.10 & 0.10 & 0.09 & 0.11 & 0.09 & 0.23 & 0.23 & 0.15 & 0.15 & 0.20 & 0.21 & 0.25 & 0.25 & 0.24 & 0.22 & 0.26 \\
\hline $\mathrm{K}$ & 0.00 & 0.00 & 0.00 & 0.00 & 0.00 & 0.00 & 0.00 & 0.00 & 0.00 & 0.00 & 0.00 & 0.00 & 0.00 & 0.00 & 0.00 & 0.00 \\
\hline Cátions & 11.11 & 11.10 & 11.06 & & 11.08 & 11.18 & 11.17 & 11.11 & 11.12 & 11.15 & 11.16 & 11.19 & 11.18 & 11.19 & 11.16 & 11.18 \\
\hline$\# \mathrm{Mg}$ & 0.77 & 0.76 & 0.76 & 0.78 & 0.77 & 0.75 & 0.76 & 0.76 & 0.75 & 0.76 & 0.77 & 0.76 & 0.76 & 0.76 & 0.76 & 0.77 \\
\hline
\end{tabular}

Tabela A4.6.1: Dados analíticos de cordieritas de MP. Fórmula estrutural: 18(0). 
Tabela A4.6: Cordieritas - CD.

\begin{tabular}{|c|c|c|c|c|c|c|c|c|c|c|c|c|}
\hline Amostra & G-85a & G-85a & $G-85 a$ & $286 \mathrm{~A}$ & $286 \mathrm{~A}$ & $286 A$ & $286 \mathrm{C}$ & $286 C$ & $286 C$ & $286 \mathrm{~L}$ & $286 \mathrm{~L}$ & 2866L \\
\hline Análise & $1 / 3 / 28$ & $3 / 3 / 72$ & $3 / 3 / 75$ & 1133 & 1232 & 1233 & 3251 & 3253 & 3254 & 1241 & 1242 & 1243 \\
\hline Mineral & $C D$ & $\mathrm{CD}$ & $C D$ & $\mathrm{CD}$ & CD & $\mathrm{CD}$ & CD & $C D$ & $C D$ & $\mathrm{CD}$ & $C D$ & $C D$ \\
\hline Local & C & $\mathrm{C}$ & PIm & Média 4 & Média 4 & Média 4 & Média 4 & Média 4 & Média 4 & Média 4 & Média 4 & Média 4 \\
\hline Litotipo & MP & $\mathrm{MP}$ & $\mathrm{MP}$ & MP & $\mathrm{MP}$ & MP & MP & MP & MP & MP & MP & $M P$ \\
\hline $\mathrm{SiO}_{2}$ & 48.82 & 50.28 & 49.74 & 48.80 & 47.88 & 48.36 & 48.29 & 48.78 & 48.88 & 48.65 & 48.60 & 48.98 \\
\hline $\mathrm{TiO}_{2}$ & 0.02 & 0.00 & 0.00 & 0.30 & 0.24 & 0.20 & 0.57 & 0.23 & 0.15 & 0.18 & 0.13 & 0.10 \\
\hline $\mathrm{Al}_{2} \mathrm{O}_{3}$ & 31.20 & 33.24 & 33.49 & 33.85 & 34.16 & 34.04 & 34.08 & 33.92 & 33.83 & 33.76 & 33.91 & 33.32 \\
\hline $\mathrm{Cr}_{2} \mathrm{O}_{3}$ & 0.00 & 0.00 & 0.01 & n.a. & n.a. & n.a. & n.a. & n.a. & n.a. & n.a. & n.a. & n.a. \\
\hline $\mathrm{ZnO}$ & 0.00 & 0.02 & 0.00 & n.a. & n.a. & n.a. & n.a. & n.a. & n.a. & n.a. & n.a. & n.a. \\
\hline $\mathrm{FeO}$ & 5.84 & 6.03 & 5.83 & 4.25 & 4.51 & 4.60 & 4.47 & 4.81 & 4.77 & 4.21 & 4.16 & 4.20 \\
\hline $\mathrm{MnO}$ & 0.00 & 0.04 & 0.02 & 0.13 & 0.14 & 0.11 & 0.07 & 0.08 & 0.07 & 0.09 & 0.08 & 0.11 \\
\hline $\mathrm{MgO}$ & 10.49 & 10.29 & 10.66 & 9.94 & 9.80 & 10.09 & 9.66 & 9.87 & 9.71 & 9.92 & 9.91 & 10.04 \\
\hline $\mathrm{NO}$ & 0.02 & 0.01 & 0.00 & n.a. & n.a. & n.a. & n.a. & n.a. & n.a. & n.a. & n.a. & n.a. \\
\hline $\mathrm{CaO}$ & 0.01 & 0.02 & 0.01 & 0.46 & 0.63 & 0.12 & 0.32 & 0.26 & 0.30 & 0.21 & 0.32 & 0.14 \\
\hline $\mathrm{Na}_{2} \mathrm{O}$ & 1.22 & 0.64 & 0.60 & ก.a. & n.a. & n.a. & n.a. & n.a. & n.a. & n.a. & n.a. & n.a. \\
\hline $\mathrm{K}_{2} \mathrm{O}$ & 0.01 & 0.00 & 0.01 & 0.11 & 0.04 & 0.27 & 0.00 & 0.00 & 0.07 & 0.82 & 0.78 & 0.80 \\
\hline Total & 97.63 & 100.57 & 100.37 & 97.84 & 97.40 & 97.79 & 97.46 & 97.95 & 97.78 & 97.84 & 97.89 & 97.69 \\
\hline $\mathrm{Si}$ & 5.03 & 5.02 & 4.97 & 5.00 & 4.93 & 4.95 & 4.96 & 4.98 & 5.01 & 5.01 & 5.00 & 5.04 \\
\hline $\mathrm{Ti}$ & 0.00 & 0.00 & 0.00 & 0.02 & 0.02 & 0.02 & 0.04 & 0.02 & 0.01 & 0.01 & 0.01 & 0.01 \\
\hline A & 3.79 & 3.91 & 3.94 & 4.08 & 4.14 & 4.10 & 4.12 & 4.08 & 4.08 & 4.09 & 4.11 & 4.04 \\
\hline $\mathrm{Cr}$ & 0.00 & 0.0 & 0.00 & 0.00 & 0.00 & 0.00 & 0.00 & 0.00 & 0.00 & 0.00 & 0.00 & 0.00 \\
\hline $\mathrm{Fe}^{2+}$ & 0.51 & 0.50 & 0.49 & 0.36 & 0.39 & 0.39 & 0.38 & 0.41 & 0.41 & 0.36 & 0.36 & 0.36 \\
\hline $\mathrm{Mn}$ & 0.00 & 0.00 & 0.00 & 0.01 & 0.01 & 0.04 & 0.01 & 0.01 & 0.01 & 0.01 & 0.01 & 0.01 \\
\hline $\mathrm{Mg}$ & 1.61 & 1.53 & 1.59 & 1.52 & 1.51 & 1.54 & 1.48 & 1.50 & 1.48 & 1.52 & 1.52 & 1.54 \\
\hline $\mathrm{Ca}$ & 0.00 & $0 . \infty$ & 0.00 & 0.05 & 0.07 & 0.01 & 0.04 & 0.03 & 0.03 & 0.02 & 0.04 & 0.02 \\
\hline $\mathrm{Na}$ & 0.25 & 0.12 & 0.12 & 0.00 & 0.00 & 0.00 & 0.00 & 0.00 & 0.00 & 0.0 & 0.00 & 0.00 \\
\hline$K$ & 0.00 & 0.00 & 0.00 & 0.01 & 0.01 & 0.04 & 0.00 & 0.00 & 0.01 & 0.11 & 0.10 & 0.11 \\
\hline Cátions & 11.19 & 11.08 & 11.11 & 11.06 & 11.08 & 11.05 & 11.04 & 11.03 & 11.04 & 11.13 & 11.14 & 11.12 \\
\hline$\# \mathrm{Mg}$ & 0.76 & 0.75 & 0.77 & 0.81 & 0.79 & 0.80 & 0.79 & 0.79 & 0.78 & 0.81 & 0.81 & 0.81 \\
\hline
\end{tabular}

Tabela A4.6.1: Dados analiticos de cordieritas de MP. Fórmula estrutural: 18(O).

Nota: Média 4: média de 4 análises. 
Tabela A4.7: Estaurolitas - STAU.

\begin{tabular}{|c|c|c|c|c|c|c|c|c|c|c|c|c|c|c|c|c|c|}
\hline Amostra & AP-2 & AP-3 & AP-3 & AP-3 & AP-3 & AP-3 & AP-3 & $\mathrm{AP}-3$ & $G-52 c$ & G-52C & G-52c & G-89 & G-89 & G-89 & G-89 & $M-5$ & $M-5$ \\
\hline Análise & $3 / 1 / 17$ & $1 / 1 / 38$ & $1 / 1 / 39$ & $1 / 1 / 41$ & $1 / 1 / 53$ & $1 / 1 / 54$ & $1 / 2 / 47$ & $1 / 2 / 48$ & $2 / 1 / 41$ & $2 / 2 / 45$ & $2 / 3 / 56$ & $2 / 1 / 59$ & $2 / 1 / 60$ & 212770 & $2 / 2 / 71$ & $3 / 1 / 3$ & $3 / 1 / 4$ \\
\hline Mineral & STAU & STAU & STAU & STAU & STAU & STAU & STAU & STAU & STAU & STAU & STAU & STAU & STAU & STAU & STAU & STAU & STAU \\
\hline Local & C & $c$ & B & $c$ & $\mathrm{C}$ & B & $C$ & B & $\mathrm{C}$ & C & $\mathrm{C}$ & B & $\mathrm{C}$ & B & $\mathrm{C}$ & $\mathrm{C}$ & $\mathrm{C}$ \\
\hline Litotipo & MP & MP & MP & MP & MP & $\overline{M P}$ & $\mathrm{MP}$ & MP & MP & MP & MP & MP & MP & MP & MP & MP & $\overline{M P}$ \\
\hline $\mathrm{SiO}_{2}$ & 27.94 & 27.35 & 27.70 & 28.65 & 28.27 & 27.60 & 27.72 & 28.60 & 27.70 & 28.45 & 28.55 & 27.95 & 27.59 & 27.93 & 27.46 & 27.45 & 27.48 \\
\hline $\mathrm{TiO}_{2}$ & 0.72 & 0.95 & 0.77 & 0.84 & 0.71 & 0.48 & 0.73 & 0.77 & 0.66 & 0.54 & 0.49 & 0.60 & 0.61 & 0.69 & 0.60 & 0.15 & 0.22 \\
\hline $\mathrm{Al}_{2} \mathrm{O}_{3}$ & 52.90 & 51.11 & 52.37 & 52.81 & 52.07 & 53.28 & 51.87 & 53.75 & 53.45 & 54.56 & 54.74 & 52.44 & 52.84 & 53.83 & 53.11 & 57.25 & 57.35 \\
\hline $\mathrm{Cr}_{2} \mathrm{O}_{3}$ & 0.03 & 0.00 & 0.01 & 0.00 & 0.03 & 0.02 & 0.00 & 0.00 & 0.03 & 0.00 & 0.03 & 0.03 & 0.00 & 0.02 & 0.01 & 0.17 & 0.21 \\
\hline $\mathrm{ZnO}$ & 0.32 & 0.21 & 0.24 & 0.23 & 0.18 & 0.20 & 0.18 & 0.18 & 0.39 & 0.38 & 0.34 & 2.90 & 2.96 & 3.08 & 3.10 & 0.41 & 0.48 \\
\hline $\mathrm{FeO}$ & 14.13 & 15.03 & 14.58 & 14.27 & 14.53 & 14.62 & 14.19 & 14.23 & 14.01 & 14.13 & 13.83 & 12.50 & 12.51 & 12.58 & 12.65 & 10.14 & 10.76 \\
\hline MnO & 0.15 & 0.08 & 0.08 & 0.13 & 0.13 & 0.12 & 0.12 & 0.09 & 0.12 & 0.14 & 0.11 & 0.01 & 0.01 & 0.05 & 0.09 & 0.13 & 0.12 \\
\hline $\mathrm{MgO}$ & 2.79 & 3.07 & 2.81 & 2.95 & 2.92 & 2.82 & 2.89 & 2.72 & 2.13 & 2.25 & 2.33 & 2.42 & 2.44 & 1.98 & 2.04 & 3.11 & 2.74 \\
\hline $\mathrm{NiO}$ & 0.01 & 0.00 & 0.01 & 0.01 & 0.01 & 0.01 & 0.00 & 0.00 & 0.00 & 0.02 & 0.01 & 0.00 & 0.01 & 0.00 & 0.01 & 0.00 & 0.01 \\
\hline $\mathrm{CaO}$ & 0.01 & 0.00 & 0.00 & 0.01 & 0.00 & 0.00 & $0 . \infty$ & 0.01 & 0.06 & 0.03 & 0.02 & 0.00 & 0.00 & 0.00 & 0.00 & 0.00 & 0.02 \\
\hline $\mathrm{Na}_{2} \mathrm{O}$ & 0.00 & 0.00 & 0.03 & 0.00 & 0.00 & 0.00 & 0.00 & 0.00 & 0.00 & 0.01 & 0.00 & 0.00 & 0.00 & 0.00 & 0.00 & 0.00 & 0.00 \\
\hline $\mathrm{K}_{2} \mathrm{O}$ & 0.02 & 0.00 & 0.01 & 0.00 & 0.00 & 0.00 & 0.00 & 0.00 & 0.02 & 0.00 & 0.02 & 0.00 & 0.00 & 0.00 & 0.02 & 0.00 & 0.00 \\
\hline Total & 99.02 & 97.80 & 98.61 & 99.90 & 98.85 & 99.15 & 97.70 & 100.35 & 98.57 & 100.51 & 100.47 & 98.85 & 98.97 & 100.16 & 99.09 & 98.81 & 99.39 \\
\hline $\mathrm{Si}$ & 8.035 & 8.011 & 8.017 & 8.158 & 8.151 & 7.940 & 8.080 & 8.005 & 7.995 & 8.042 & 8.06 & 8.09 & 7.99 & 7.99 & 7.95 & 7.75 & 7.74 \\
\hline $\bar{A}$ & 17.92 & 17.63 & 17.85 & 17.71 & 17.68 & 18.05 & 17.81 & 17.92 & 18.17 & 18.16 & 18.19 & 17.88 & 18.01 & 18.12 & 18.11 & 19.03 & 19.01 \\
\hline Ti & 0.16 & 0.21 & 0.17 & 0.18 & 0.15 & 0.10 & 0.16 & 0.16 & 0.14 & 0.12 & 0.10 & 0.13 & 0.13 & 0.15 & 0.13 & 0.03 & 0.05 \\
\hline $\mathrm{Cr}$ & 0.01 & 0.00 & 0.00 & 0.00 & 0.01 & 0.01 & 0.00 & 0.00 & 0.01 & 0.00 & 0.01 & 0.01 & 0.00 & 0.01 & 0.00 & 0.04 & 0.05 \\
\hline $\mathrm{Zn}$ & 0.07 & 0.05 & 0.05 & 0.05 & 0.04 & 0.04 & 0.04 & 0.04 & 0.08 & 0.08 & 0.07 & 0.62 & 0.63 & 0.65 & 0.66 & 0.09 & 0.10 \\
\hline $\mathrm{Fe}^{+2}$ & 3.40 & 3.68 & 3.53 & 3.40 & 3.50 & 3.52 & 3.46 & 3.37 & 3.38 & 3.34 & 3.26 & 3.03 & 3.03 & 3.01 & 3.06 & 2.39 & 2.53 \\
\hline $\mathrm{Mn}$ & 0.04 & 0.02 & 0.02 & 0.03 & 0.03 & 0.03 & 0.03 & 0.02 & 0.03 & 0.03 & 0.03 & 0.00 & 0.00 & 0.01 & 0.02 & 0.03 & 0.03 \\
\hline $\mathrm{Mg}$ & 1.20 & 1.34 & 1.21 & 1.25 & 1.26 & 1.21 & 1.26 & 1.15 & 0.92 & 0.95 & 0.98 & 1.05 & 1.05 & 0.84 & 0.88 & 1.31 & 1.15 \\
\hline $\mathrm{Ca}$ & 0.00 & 0.00 & 0.00 & 0.00 & 0.00 & 0.00 & 0.00 & 0.00 & 0.02 & 0.01 & 0.01 & 0.00 & 0.00 & 0.00 & 0.00 & 0.00 & 0.01 \\
\hline $\mathrm{Na}$ & 0.00 & 0.00 & 0.02 & 0.00 & 0.00 & 0.00 & 0.00 & 0.00 & 0.00 & 0.01 & 0.00 & 0.00 & 0.00 & 0.00 & 0.00 & 0.00 & 0.00 \\
\hline$K$ & 0.01 & 0.00 & 0.00 & 0.00 & 0.00 & 0.00 & 0.00 & 0.00 & 0.01 & 0.00 & 0.01 & 0.00 & 0.00 & 0.00 & 0.01 & 0.00 & 0.00 \\
\hline Cátions & 30.83 & 30.94 & 30.87 & 30.78 & 30.82 & 30.90 & 30.83 & 30.76 & 30.75 & 30.74 & 30.71 & 30.81 & 30.84 & 30.78 & 30.83 & 30.67 & 30.66 \\
\hline$* \mathrm{Mg}$ & 0.17 & 0.17 & 0.16 & 0.17 & 0.17 & 0.16 & 0.17 & 0.16 & 0.13 & 0.14 & 0.14 & 0.16 & 0.16 & 0.14 & 0.14 & 0.23 & 0.20 \\
\hline
\end{tabular}

Tabela A4.7.1: Dados analíticos de estaurolitas de MP. Fórmula estrutural: $48(0)$. 
Tabela A4.8: Cloritas - CLO.

\begin{tabular}{|c|c|c|c|c|c|c|c|c|c|c|c|c|c|c|c|c|c|}
\hline Amostra & $B-11$ & $\mathrm{~B}-11$ & $\mathrm{~B}-11$ & $B-11$ & $\mathrm{~B}-11$ & $8-11$ & $\mathrm{~B}-11$ & B-11 & $\mathrm{B}-18$ & B-18 & B-18 & $\mathrm{B}-18$ & B-18 & NE-31 & NE-31 & SUL-01 & $286 \mathrm{~A}$ \\
\hline Análise & $2 / 1 \mathrm{CL} 1$ & $2 / 1 \mathrm{CL} 2$ & $2 / 2 \mathrm{CL1}$ & $2 / 3 C L 1$ & $2 / 5 \mathrm{CL} 1$ & $2 / 5 \mathrm{CL} 2$ & $2 / 5 \mathrm{CL} 3$ & $2 / 5 \mathrm{CL} 4$ & $12 / 2 \mathrm{CL} 1$ & $12 / 2 \mathrm{CL} 2$ & $12 / 2 \mathrm{CL} 3$ & $12 / 2 \mathrm{CL} 4$ & $12 / 3 \mathrm{CL} 1$ & $06 / 03 / 61$ & $06 / 03 / 62$ & $02 / 01 / 05$ & 1121 \\
\hline Mineral & CLO & $\mathrm{ClO}$ & CLO & CLO & CLO & $\mathrm{CLO}$ & CLO & $\mathrm{CLO}$ & CLO & CLO & CLO & CLO & ClO & CLO & $\mathrm{CLO}$ & CLO & CLO \\
\hline Local & PIn & PIn & Pln & PIn & PIn & Pln & PIn & Pin & Pln & PIn & PIn & $\mathrm{Pln}$ & Pin & Alt. Fl & Alt $\mathrm{FI}$ & Alt. FI & Média 4 \\
\hline Litotipo & UM & UM & UM & UM & UM & UM & UM & UM & UM & UM & UM & $\mathrm{UM}$ & UM & UM & UM & UM & MP \\
\hline $\mathrm{SiO}_{2}$ & 27.17 & 27.33 & 28.16 & 27.14 & 27.15 & 27.32 & 27.04 & 27.34 & 26.96 & 27.05 & 27.15 & 27.55 & 27.27 & 28.83 & 33.63 & 28.23 & 27.83 \\
\hline $\mathrm{TiO}_{2}$ & 0.00 & 0.00 & 0.00 & 0.00 & 0.00 & 0.00 & 0.00 & 0.00 & 0.00 & 0.00 & 0.00 & 0.00 & 0.00 & 0.08 & 0.02 & 0.09 & 0.04 \\
\hline $\mathrm{Al}_{2} \mathrm{O}_{3}$ & 18.73 & 18.60 & 18.09 & 18.06 & 18.70 & 18.91 & 18.63 & 18.95 & 18.63 & 18.57 & 19.05 & 18.59 & 18.80 & 19.84 & 17.42 & 20.68 & 23.77 \\
\hline $\mathrm{Cr}_{2} \mathrm{O}_{3}$ & 1.85 & 1.83 & 1.76 & 1.58 & 1.72 & 1.70 & 1.82 & 1.87 & 1.68 & 1.60 & 1.88 & 1.60 & 1.62 & 0.20 & 0.17 & 0.28 & n.a. \\
\hline $\mathrm{FeO}$ & 7.30 & 7.55 & 7.42 & 7.41 & 8.20 & 8.27 & 8.33 & 8.32 & 7.30 & 7.29 & 7.54 & 7.56 & 7.38 & 13.63 & 10.75 & 14.62 & 10.84 \\
\hline $\mathrm{NiO}$ & 0.26 & 0.00 & 0.00 & 0.00 & 0.00 & 0.00 & 0.00 & 0.00 & 0.00 & 0.00 & 0.00 & 0.00 & 0.00 & n.a. & n.a. & 0.04 & n.a. \\
\hline Mno & 0.00 & 0.00 & 0.00 & 0.17 & 0.00 & 0.00 & 0.00 & 0.00 & 0.00 & 0.00 & 0.00 & 0.00 & 0.00 & 0.10 & 0.05 & 0.16 & 0.06 \\
\hline $\mathrm{MgO}$ & 28.23 & 28.01 & 29.75 & 28.24 & 27.81 & 27.73 & 27.98 & 27.69 & 28.07 & 28.25 & 28.23 & 27.90 & 28.47 & 23.59 & 21.22 & 24.53 & 25.03 \\
\hline $\mathrm{CaO}$ & 0.08 & 0.00 & 0.00 & 0.00 & 0.00 & 0.00 & 0.00 & 0.00 & 0.00 & 0.00 & 0.00 & 0.00 & 0.00 & 0.07 & 0.42 & 0.04 & 0.20 \\
\hline $\mathrm{Na}_{2} \mathrm{O}$ & 0.32 & 0.19 & 0.20 & 0.15 & 0.28 & 0.00 & 0.15 & 0.19 & 0.30 & 0.00 & 0.00 & 0.23 & 0.18 & 0.01 & 0.03 & 0.02 & n.a. \\
\hline $\mathrm{K}_{2} \mathrm{O}$ & 0.00 & 0.00 & 0.00 & 0.00 & 0.00 & 0.00 & 0.00 & 0.00 & 0.00 & 0.00 & 0.00 & 0.00 & 0.00 & 0.04 & 0.12 & 0.01 & 0.00 \\
\hline $\mathrm{P}_{2} \mathrm{O}_{5}$ & 0.00 & 0.00 & 0.00 & 0.00 & 0.00 & 0.00 & 0.00 & 0.00 & 0.16 & 0.00 & 0.00 & 0.15 & 0.00 & n.a. & n.a. & n.a. & n.a. \\
\hline $\mathrm{Cl}$ & 0.00 & 0.00 & 0.00 & 0.00 & 0.00 & 0.00 & 0.00 & 0.00 & 0.00 & 0.00 & 0.00 & 0.00 & 0.00 & n.a. & ก.a. & n.a. & n.a. \\
\hline $\mathrm{F}$ & n.a. & n.a. & n.a. & n.a. & n.a. & n.a. & n.a. & n.a. & n.a. & n.a. & n.a. & n.a. & n.a. & 0.34 & 0.28 & n.a. & 0.00 \\
\hline $\mathrm{H}_{2} \mathrm{O}$ & 11.86 & 11.82 & 12.09 & 11.71 & 11.82 & 11.85 & 11.82 & 11.89 & 11.77 & 11.74 & 11.87 & 11.85 & 11.86 & 11.82 & 11.82 & 12.21 & 12.37 \\
\hline Total & 95.80 & 95.33 & 97.47 & 94.46 & 95.68 & 95.78 & 95.77 & 96.25 & 94.87 & 94.50 & 95.72 & 95.43 & 95.58 & 98.55 & 95.93 & 100.91 & 100.14 \\
\hline $\mathrm{Si}$ & 5.50 & 5.55 & 5.59 & 5.56 & 5.51 & 5.53 & 5.49 & 5.51 & 5.49 & 5.53 & 5.49 & 5.58 & 5.51 & 5.77 & 6.75 & 5.55 & 5.40 \\
\hline$|\mathrm{Al}|^{\mathrm{N}}$ & 2.51 & 2.45 & 2.41 & 2.44 & 2.49 & 2.47 & 2.51 & 2.49 & 251 & 2.47 & 2.52 & 2.42 & 2.49 & 2.23 & 1.25 & 2.45 & 2.60 \\
\hline Soma T & 8.00 & 8.00 & 8.00 & 8.00 & 8.00 & 8.00 & 8.00 & 8.00 & 8.00 & 8.00 & 8.00 & 8.00 & 8.00 & 8.00 & 8.00 & 8.00 & 8.00 \\
\hline $\mathrm{Al}^{\mathrm{v}}$ & 1.96 & 1.99 & 1.81 & 1.92 & 1.98 & 2.04 & 1.94 & 2.02 & 1.96 & 200 & 2.02 & 2.01 & 1.99 & 2.45 & 2.87 & 2.33 & 2.83 \\
\hline $\mathrm{Ti}$ & 0.00 & 0.00 & 0.00 & 0.00 & 0.00 & 0.00 & 0.00 & 0.00 & 0.00 & 0.00 & 0.00 & 0.00 & 0.00 & 0.01 & 0.00 & 0.01 & 0.01 \\
\hline $\mathrm{Fe}^{+2}$ & 1.24 & 1.28 & 1.23 & 1.27 & 1.39 & 1.40 & 1.41 & 1.40 & 1.24 & 1.25 & 1.27 & 1.28 & 1.25 & 2.28 & 1.80 & 2.40 & 1.76 \\
\hline $\mathrm{Cr}$ & 0.30 & 0.29 & 0.28 & 0.26 & 0.28 & 0.27 & 0.29 & 0.30 & 0.27 & 0.26 & 0.30 & 0.26 & 0.26 & 0.03 & 0.03 & 0.04 & 0.00 \\
\hline $\mathrm{Mn}$ & 0.00 & 0.00 & 0.00 & 0.03 & 0.00 & 0.00 & 0.00 & 0.00 & 0.00 & 0.00 & 0.00 & 0.00 & 0.00 & 0.02 & 0.01 & 0.03 & 0.01 \\
\hline $\mathrm{Mg}$ & 8.51 & 8.47 & 8.80 & 8.63 & 8.41 & 8.37 & 8.46 & 8.33 & 8.53 & 8.60 & 8.50 & 8.42 & 8.58 & 7.04 & 6.35 & 7.18 & 7.24 \\
\hline $\mathrm{Ca}$ & 0.02 & 0.00 & 0.00 & 0.00 & 0.00 & 0.00 & 0.00 & 0.00 & 0.00 & 0.00 & 0.00 & 0.00 & 0.00 & 0.02 & 0.09 & 0.01 & 0.04 \\
\hline $\mathrm{Na}$ & 0.13 & 0.08 & 0.08 & 0.06 & 0.11 & 0.00 & 0.06 & 0.07 & 0.12 & 0.00 & 0.00 & 0.09 & 0.07 & 0.00 & 0.01 & 0.01 & 0.00 \\
\hline $\mathrm{K}$ & 0.00 & 0.00 & $0 . \infty$ & 0.00 & 0.00 & 0.00 & 0.00 & 0.00 & 0.00 & 0.00 & 0.00 & 0.00 & $0 . \infty$ & 0.01 & 0.03 & 0.00 & 0.00 \\
\hline Cations & 20.14 & 20.11 & 20.19 & 20.16 & 20.17 & 20.07 & 20.16 & 20.12 & 20.12 & 20.10 & 20.09 & 20.05 & 20.15 & 19.86 & 19.19 & 20.02 & 19.88 \\
\hline$\# \mathrm{Mg}$ & 0.87 & 0.87 & 0.88 & 0.87 & 0.86 & 0.86 & 0.86 & 0.86 & 0.87 & 0.87 & 0.87 & 0.87 & 0.87 & 0.76 & 0.78 & 0.75 & 0.80 \\
\hline
\end{tabular}

Tabela A4.8.1: Dados analíticos de cloritas de UM e MP. Formula estrutural: $36(0)$.

Nota: As cloritas das amostras NE-31 e Sul 01 são retrometamórficas da transformação da flogopita; Média 4 = média de 4 análises. 
Tabela A4.8: Cloritas - CLO.

\begin{tabular}{|c|c|c|c|c|c|c|c|c|}
\hline Amostra & $286 \mathrm{~A}$ & 2864 & $286 C$ & $286 C$ & $286 C$ & $286 \mathrm{~L}$ & 2861 & $286 \mathrm{~L}$ \\
\hline Análise & 1122 & 1223 & 3111 & 3112 & 3113 & 1232 & 1234 & 1235 \\
\hline Mineral & $\mathrm{CLO}$ & CLO & CLO & CLO & CLO & CLO & $\mathrm{CLO}$ & $\mathrm{CLO}$ \\
\hline Local & Média 4 & Média 4 & Média 4 & Média 4 & Média 4 & Média 4 & Média 4 & Média 4 \\
\hline Litotipo & MP & MP & MP & MP & MP & MP & MP & $\mathrm{MP}$ \\
\hline $\mathrm{SiO}_{2}$ & 28.25 & 28.61 & 28.56 & 28.40 & 27.59 & 28.75 & 28.82 & 28.49 \\
\hline $\mathrm{TiO}_{2}$ & 0.26 & 0.07 & 0.12 & 0.10 & 0.04 & 0.05 & 0.08 & 0.05 \\
\hline $\mathrm{A}_{2} \mathrm{O}_{3}$ & 24.60 & 23.35 & 25.62 & 24.06 & 24.19 & 24.26 & 23.94 & 24.41 \\
\hline $\mathrm{Cr}_{2} \mathrm{O}_{3}$ & n.a. & n.a. & n.a. & na. & n.a. & n.a. & n.a. & n.a. \\
\hline $\mathrm{FeO}$ & 11.14 & 10.44 & 10.20 & 10.36 & 9.99 & 9.27 & 10.81 & 9.76 \\
\hline $\mathrm{NiO}$ & n.a. & n.a. & n.a. & n.a. & n.a. & n.a. & n.a. & n.a. \\
\hline MnO & 0.15 & 0.05 & 0.07 & 0.07 & 0.07 & 0.06 & 0.08 & 0.06 \\
\hline $\mathrm{MgO}$ & 26.04 & 24.11 & 25.33 & 25.01 & 25.22 & 24.82 & 24.54 & 24.37 \\
\hline $\mathrm{CaO}$ & 0.18 & 0.12 & 0.14 & 0.17 & 0.08 & 0.20 & 0.08 & 0.09 \\
\hline $\mathrm{Na}_{2} \mathrm{O}$ & n.a. & n.a. & n.a. & n.a. & n.a. & n.a. & n.a. & n.a. \\
\hline $\mathrm{K}_{2} \mathrm{O}$ & 0.07 & 0.01 & 0.03 & 0.02 & 0.01 & 0.01 & 0.00 & 0.01 \\
\hline $\mathrm{P}_{2} \mathrm{O}_{5}$ & ก.a. & n.a. & n.a. & n.a. & n.a. & n.a. & n.a. & n.a. \\
\hline $\mathrm{Cl}$ & n.a. & n.a. & n.a. & n.a. & n.a. & n.a. & n.a. & n.a. \\
\hline$F$ & 0.43 & 0.00 & 0.00 & 0.11 & 0.03 & 0.28 & 0.01 & 0.21 \\
\hline $\mathrm{H}_{2} \mathrm{O}$ & 12.55 & 12.29 & 12.78 & 12.43 & 12.33 & 12.33 & 12.49 & 12.31 \\
\hline Total & 103.67 & 99.05 & 102.85 & 100.73 & 99.55 & 100.03 & 100.85 & 99.76 \\
\hline Si & 5.31 & 5.58 & 5.36 & 5.46 & 5.36 & 5.53 & 5.53 & 5.51 \\
\hline $\mathrm{Al}^{\mathrm{N}}$ & 2.69 & 2.42 & 2.64 & 2.54 & 2.64 & 2.47 & 2.47 & 2.49 \\
\hline Soma T & 8.00 & 8.00 & 8.00 & 8.00 & 8.00 & 8.00 & 8.00 & 8.00 \\
\hline$A \|^{n}$ & 2.76 & 2.95 & 3.03 & 2.90 & 2.90 & 3.03 & 2.94 & 3.06 \\
\hline $\mathrm{Ti}$ & 0.04 & 0.01 & 0.02 & 0.01 & 0.01 & 0.01 & 0.01 & 0.01 \\
\hline $\mathrm{Fe}^{+2}$ & 1.75 & 1.70 & 1.60 & 1.67 & 1.62 & 1.49 & 1.74 & 1.58 \\
\hline $\mathrm{Cr}$ & 0.00 & 0.00 & 0.00 & 0.00 & 0.00 & 0.00 & 0.00 & 0.00 \\
\hline $\mathrm{Mn}$ & 0.02 & 0.01 & 0.01 & 0.01 & 0.01 & 0.01 & 0.01 & 0.01 \\
\hline $\mathrm{Mg}$ & 7.30 & 7.02 & 7.09 & 7.17 & 7.31 & 7.12 & 7.02 & 7.02 \\
\hline $\mathrm{Ca}$ & 0.04 & 0.03 & 0.03 & 0.04 & 0.02 & 0.04 & 0.02 & 0.02 \\
\hline $\mathrm{Na}$ & 0.00 & 0.00 & 0.00 & 0.00 & 0.0 & 0.00 & 0.00 & 0.00 \\
\hline $\mathrm{K}$ & 0.02 & 0.00 & 0.01 & 0.01 & 0.00 & 0.00 & 0.00 & 0.00 \\
\hline Cations & 19.93 & 19.72 & 19.78 & 19.80 & 19.86 & 19.70 & 19.74 & 19.70 \\
\hline$\# \mathrm{Mg}$ & 0.81 & 0.80 & 0.82 & 0.81 & 0.82 & 0.83 & 0.80 & 0.82 \\
\hline
\end{tabular}

Tabela A4.8.1: Dados analíticos de cloritas de UM e MP. Fórmula estrutural: 36(O). 
Tabela A4.9: Esmeraldas - ESM.

\begin{tabular}{|c|c|c|c|c|c|c|c|c|c|c|c|c|c|c|c|c|c|c|c|}
\hline Amostra & $\mathrm{BE}-04$ & BE-O4 & $\mathrm{BE}-04$ & $\mathrm{BE}-04$ & BE-04 & $\begin{array}{l}\mathrm{BE}-04 \\
\end{array}$ & BE-04 & BE-04 & BE-04 & $\mathrm{BE}-\mathrm{OA}$ & $\mathrm{BE}-04$ & BE-04 & BE-04 & $8 E-04$ & $\mathrm{BE}-04$ & $\mathrm{BE}-04$ & $\mathrm{BE}-04$ & BE-04 & $\frac{B E-04}{45 / 2 S 13}$ \\
\hline Análise & $45 / 1501$ & $45 / 1502$ & 4511503 & $45 / 1504$ & 451505 & $45 / 1506$ & $45 / 2501$ & $46 / 2 \mathrm{SO}$ & $45 / 2503$ & $45 / 2504$ & $45 / 2505$ & $45 \sqrt{2506}$ & $45 \sqrt{2 S 07}$ & $45 / 2508$ & $45 / 2509$ & $45 / 2510$ & $45 / 2 S 11$ & $45 / 2512$ & $\frac{45 / 2 S 13}{F X}$ \\
\hline Mineral & $\mathrm{EX}$ & EX & EX & $E X$ & $E X$ & EX & EX & EX & EX & EX & $E X$ & EX & EX & EX & $E X$ & $E X$ & EX & EX & EX \\
\hline Local & $c$ & $B(e)$ & PIn & Pln & Pln & $B(i)$ & PIn & Pin & PIn & PIn & PIn & $\overline{P l n}$ & PIn & Pin & Pin & Pin & Pin & PIn & Pin \\
\hline $\mathrm{SiO}_{2}$ & 64.91 & 64.90 & 64.09 & 64.48 & 6.12 & 64.74 & 64.89 & 5.15 & 64.73 & 65.50 & 6.34 & 64.83 & 6.12 & 65.08 & 64.56 & 64.26 & 64.79 & 65.03 & 64.62 \\
\hline $\mathrm{TiO}_{2}$ & 0.00 & 0.00 & $0 . \infty$ & $0 . \infty$ & 0.00 & 0.00 & 0.00 & $0 . \infty$ & 0.00 & 0.00 & $0 . \infty$ & $0 . \infty$ & 0.00 & $0 . \infty$ & 0.0 & 0.00 & 0.0 & 0.00 & 0.00 \\
\hline $\mathrm{Al}_{2} \mathrm{O}_{3}$ & 17.01 & 17.04 & 16.37 & 16.66 & 16.92 & 16.58 & 16.99 & 16.42 & 16.57 & 16.73 & 16.94 & 16.70 & 16.30 & 17.09 & 16.75 & 16.69 & 16.74 & 16.70 & 16.28 \\
\hline $\mathrm{Cr}_{2} \mathrm{O}_{3}$ & 0.0 & 0.31 & 0.16 & 0.00 & 0.19 & 0.27 & 0.20 & 0.18 & 0.18 & 0.16 & 0.23 & 0.23 & 0.31 & 0.18 & 0.14 & 0.25 & 0.19 & 0.15 & 0.23 \\
\hline $\mathrm{ZnO}$ & ก.a. & n.a. & n.a. & n.a. & n.a. & n.a. & n.a. & n.a. & n.a. & n.a. & n.a. & n.a. & n.a. & n.a. & n.a. & n.a. & n.a. & n.a. & n.a. \\
\hline FeO & 0.38 & 0.52 & 0.52 & 0.58 & 0.44 & 0.57 & 0.49 & 0.44 & 0.50 & 0.61 & 0.66 & 0.78 & 0.49 & 0.69 & 0.60 & 0.64 & 0.46 & 0.59 & 0.55 \\
\hline Mno & 0.00 & 0.00 & 0.00 & 0.00 & 0.00 & 0.0 & $0 . \infty$ & $0 . \infty$ & 0.00 & $0 . \infty$ & 0.18 & 0.0 & 0.00 & 0.0 & 0.0 & 0.00 & 0.00 & 0.0 & 0.00 \\
\hline MgO & 1.20 & 1.43 & 1.75 & 1.75 & 1.44 & 1.49 & 1.50 & 1.48 & 1.36 & 1.49 & 1.44 & 1.61 & 1.64 & 1.52 & 1.33 & 1.42 & 1.36 & 1.43 & 1.61 \\
\hline NiO & 0.00 & 0.0 & 0.00 & 0.00 & 0.00 & 0.00 & 0.00 & $0 . \infty$ & $0 . \infty$ & 0.00 & $0 . \infty$ & 0.00 & 0.0 & $0 . \infty$ & 0.00 & 0.00 & 0.00 & 0.00 & 0.00 \\
\hline $\mathrm{CaO}$ & 0.00 & 0.00 & 0.09 & $0 . \infty$ & 0.00 & 0.00 & 0.0 & 0.0 & 0.00 & 0.08 & 0.09 & 0.00 & 0.00 & 0.0 & 0.00 & 0.0 & 0.00 & 0.0 & 0.00 \\
\hline $\mathrm{Na}_{2} \mathrm{O}$ & 1.27 & 1.33 & 1.59 & 1.61 & 1.41 & 1.32 & 0.92 & 0.93 & 1.35 & 0.89 & 1.04 & 1.08 & 0.88 & 0.96 & 1.37 & 1.36 & 1.43 & 1.33 & 1.50 \\
\hline $\mathrm{K}_{2} \mathrm{O}$ & 0.00 & 0.00 & 0.00 & 0.00 & $0 . \infty$ & 0.00 & $0 . \infty$ & 0.00 & 0.0 & 0.00 & 0.0 & 0.0 & 0.00 & 0.00 & 0.00 & 0.0 & 0.0 & 0.00 & 0.00 \\
\hline $\mathrm{P}_{2} \mathrm{O}_{5}$ & $0 . \infty$ & 0.00 & 0.12 & 0.00 & 0.00 & 0.00 & $0 . \infty$ & 0.00 & 0.00 & 0.0 & $0 . \infty$ & 0.0 & 0.00 & 0.0 & $0 . \infty$ & 0.00 & 0.00 & 0.00 & 0.00 \\
\hline $\mathrm{BaO}$ & n.a. & n.a. & n.a. & n.a. & n.a. & n.a. & n.a. & n.a. & n.a. & n.a. & n.a. & n.a. & n.a. & n.a. & n.a. & n.a. & n.a. & n.a. & n.a. \\
\hline $\mathrm{F}$ & ก.a. & n.a. & n.a. & n.a. & n.a. & ก.a. & n.a. & n.a. & n.a. & n.a. & ก.a. & n.a. & n.a. & n.a. & n.a. & ก.a. & n.a. & n.a. & n.a. \\
\hline$\widehat{\mathrm{SO}_{3}}$ & 0.0 & 0.00 & 0.0 & 0.00 & 0.00 & $0 . \infty$ & $0 . \infty$ & 0.00 & $0 . \infty$ & 0.0 & 0.00 & 0.00 & 0.0 & 0.0 & 0.00 & 0.00 & 0.00 & 0.00 & 0.0 \\
\hline $\mathrm{Cl}$ & 0.00 & 0.00 & 0.0 & 0.0 & 0.00 & $0 . \infty$ & 0.05 & 0.00 & 0.0 & 0.0 & 0.0 & 0.00 & 0.00 & $0 . \infty$ & 0.00 & 0.00 & 0.00 & 0.00 & 0.00 \\
\hline Total & 84.77 & 85.53 & 84.9 & 85.17 & 85.52 & 84.97 & 85.13 & 84.60 & 84.78 & 85.46 & 85.92 & 85.23 & 84.74 & 85.52 & 84.81 & 84.61 & 84.97 & 85.23 & 84.79 \\
\hline $\mathrm{Si}$ & 14.315 & 14.233 & 14.220 & 14.226 & 14.271 & 14.200 & 14.270 & 14.387 & 14.313 & 14.338 & 14.268 & 14.269 & 14.370 & 14.254 & 14.279 & 14.255 & 14.292 & 14.300 & 14.306 \\
\hline $\mathrm{Ti}$ & 0.000 & 0.00 & 0.000 & 0.000 & 0.000 & 0.000 & 0.000 & 0.000 & 0.000 & 0.000 & 0.000 & 0.000 & 0.000 & 0.000 & 0.000 & 0.000 & 0,000 & 0.000 & 0.000 \\
\hline Al & 4.418 & 4.401 & 4.277 & 4.320 & 4.367 & 4.310 & 4.400 & 4.270 & 4.315 & 4.313 & 4.356 & 4.329 & 4.236 & 4.408 & 4.363 & 4.360 & 4.349 & 4.326 & 4.244 \\
\hline $\mathrm{Cr}$ & 0.000 & 0.054 & 0.028 & 0.000 & 0.033 & 0.047 & 0.050 & 0.031 & 0.031 & 0.028 & 0.040 & 0.040 & 0.054 & 0.031 & 0.024 & 0.044 & 0.033 & 0.026 & 0.040 \\
\hline $\mathrm{Zn}$ & 0.000 & 0.000 & 0.000 & 0.000 & 0.000 & 0.000 & 0.000 & 0.000 & 0.00 & 0.000 & 0.000 & 0.000 & 0.000 & 0.000 & 0.000 & 0.000 & 0.000 & 0,00 & 0.000 \\
\hline $\mathrm{Fe}^{+2}$ & 0.070 & 0.095 & 0.096 & 0.107 & 0.081 & 0.105 & 0.090 & 0.081 & 0.109 & 0.112 & 0.121 & 0.144 & 0.000 & 0.126 & 0.122 & 0.119 & 0.085 & 0.100 & 0.102 \\
\hline$M n$ & 0.000 & 0.000 & 0.000 & 0.000 & 0.000 & 0.00 & 0.000 & 0.000 & 0.000 & 0.000 & 0.033 & 0.000 & 0.000 & 0.000 & 0.000 & 0.000 & 0.000 & 0.00 & 0.000 \\
\hline$\overline{\mathrm{Mg}}$ & 0.336 & 0.468 & 0.579 & 0.576 & 0.470 & 0.490 & 0.492 & 0.487 & 0.448 & 0.486 & 0.460 & 0.528 & 0.540 & 0.496 & 0.439 & 0.470 & 0.447 & 0.469 & 0.531 \\
\hline $\mathrm{Na}$ & 0.543 & 0.566 & 0.684 & 0.689 & 0.590 & 0.565 & 0.392 & 0.398 & 0.579 & 0.378 & 0.440 & 0.461 & 0.377 & 0.408 & 0.588 & 0.581 & 0.612 & 0.567 & 0.644 \\
\hline $\mathrm{Ni}$ & 0.000 & 0.000 & 0.000 & 0.000 & 0.000 & 0.000 & 0.000 & 0.000 & 0.000 & 0.000 & 0.000 & 0.000 & 0.000 & 0.000 & 0.000 & 0.000 & 0.000 & 0.000 & 0.000 \\
\hline $\mathrm{Ca}$ & 0.00 & 0.000 & 0.021 & 0.021 & 0.000 & 0.000 & 0.000 & 0.000 & 0.000 & 0.019 & 0.021 & 0.000 & 0.000 & 0.000 & 0.000 & 0.000 & 0.000 & 0.000 & 0.000 \\
\hline K & 0.000 & 0.000 & 0.000 & 0.000 & 0.000 & 0.00 & 0.000 & 0.000 & 0.000 & 0.000 & 0.000 & 0.000 & 0.000 & 0.000 & 0.000 & 0.000 & 0.000 & 0.000 & 0.000 \\
\hline $\mathrm{P}$ & 0.000 & 0.000 & 0.020 & 0.000 & 0.000 & 0.000 & 0.000 & 0.000 & 0.000 & 0.000 & 0.000 & 0.000 & 0.000 & 0.000 & 0.000 & 0.000 & 0.000 & 0.000 & 0.000 \\
\hline $\mathrm{Ba}$ & 0.000 & 0.000 & 0.000 & 0.000 & 0.000 & 0.000 & 0.000 & 0.000 & 0.000 & 0.000 & 0.000 & 0.000 & 0.000 & 0.000 & 0.000 & 0.000 & 0.00 & 0.000 & 0.000 \\
\hline Cátions & 19.741 & 19.817 & 19.925 & 19.948 & 19.821 & 19.807 & 19.694 & 19.654 & 19.795 & 19.674 & 19.748 & 19.771 & 99.667 & 19.723 & 19.815 & 19.820 & 19.818 & 19.800 & 19.867 \\
\hline
\end{tabular}

Tabela A4.9.1: Dados anailiticos de esmeraldas de xistos (EX), veios de quartzo (EVQ) e veios pegmatóides (EVP). Fórmula estrutural: 36(O). 
\& 嵌

88R@

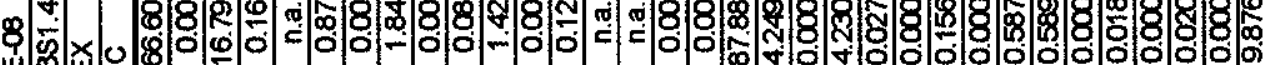
岗)

桶

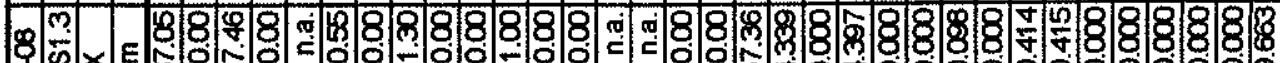
出

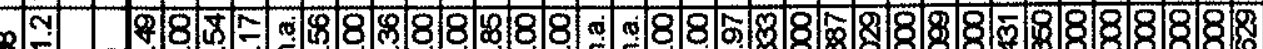

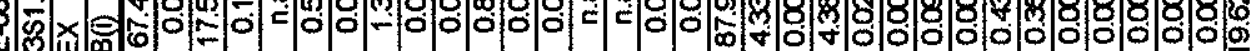

希 $\infty$ 这 $\infty$

8 -

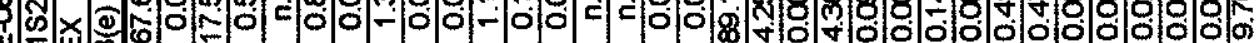

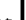

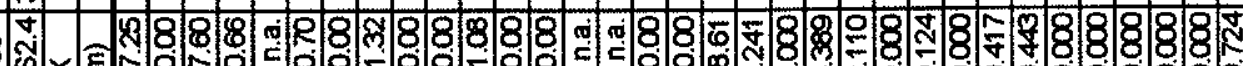

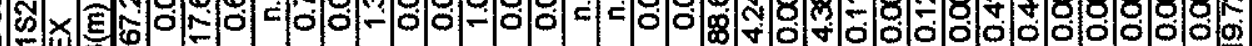
洒

管 8 8

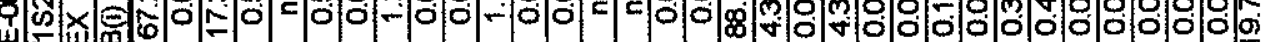

त 8 -

N $\times$ 틍

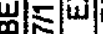

৪ ल)

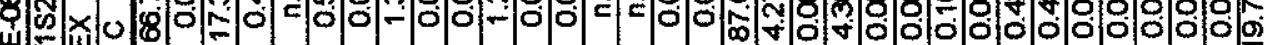

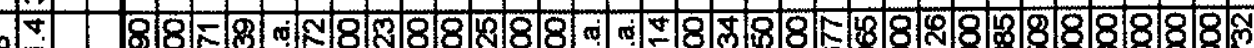

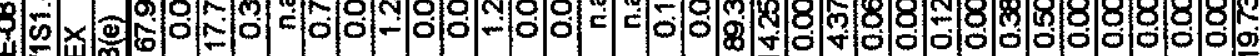

$m$ -

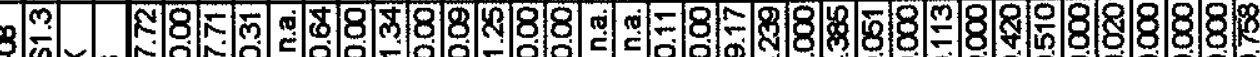

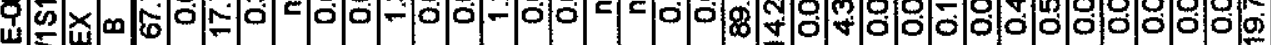

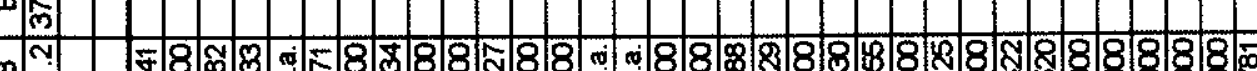

$\$$ 象 $\times$ E .

$9=58$ \% 9

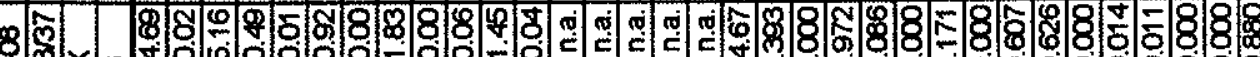
(x) \& 8 8 \$.

8 B 原

$8 M$ R

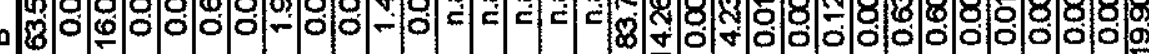
ஜ 8 8

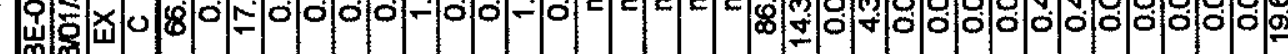


Tabela A4.9: Esmeraldas - ESM.

\begin{tabular}{|c|c|c|c|c|c|c|c|c|c|c|c|c|c|c|c|c|c|c|c|}
\hline $\begin{array}{l}\text { Amostra } \\
\text { Anślise }\end{array}$ & \begin{tabular}{|c|} 
BE-DB \\
$37 / 451 / 2$
\end{tabular} & \begin{tabular}{|c|}
$B E-\infty$ \\
$37 / 4 S 13$ \\
\end{tabular} & \begin{tabular}{|c|}
$B E-\infty 8$ \\
$37 / 4 S 21$
\end{tabular} & \begin{tabular}{|c|} 
BE.- 08 \\
$37 / 4531$ \\
\end{tabular} & \begin{tabular}{|c|}
$B E-\infty 8$ \\
$37 / 4 S 41$
\end{tabular} & $\frac{B-21}{0501 / 01}$ & \begin{tabular}{|c|}
$8-21$ \\
$0501 / 02$ \\
\end{tabular} & \begin{tabular}{|c|}
$\mathrm{B}-21$ \\
$0501 / 03$ \\
\end{tabular} & \begin{tabular}{|c|}
$\mathrm{B}-22$ \\
$0501 / 21$
\end{tabular} & \begin{tabular}{|c|}
$\mathrm{B}-22$ \\
$0501 / 22$
\end{tabular} & \begin{tabular}{c|}
$\mathrm{B}-22$ \\
$05102 / 23$
\end{tabular} & \begin{tabular}{|c|}
$\mathrm{B}-22$ \\
$0502 / 24$
\end{tabular} & \begin{tabular}{|c|} 
BE-05 \\
$0101 / 29$
\end{tabular} & $\frac{B E-05}{010130}$ & \begin{tabular}{|c|} 
BE.05 \\
010131
\end{tabular} & \begin{tabular}{|c|}
$\mathrm{BE}-0 \mathrm{~S}$ \\
01,02133
\end{tabular} & \begin{tabular}{|c|}
$B E-\infty 5$ \\
$01 / 04 / 34$ \\
\end{tabular} & \begin{tabular}{|c|} 
NE-36a \\
$0201 / 21$
\end{tabular} & \begin{tabular}{|l|}
$\mathrm{NE}-36 \mathrm{a}$ \\
$0201 / 22$ \\
\end{tabular} \\
\hline Mineral & $E X$ & $E X$ & EX & EX & EX & EVQ & EVQ & EVQ & EVQ & EVQ & $\mathrm{EVQ}$ & EVQ & $E V Q$ & EVQ & EVQ & EVQ & $\mathrm{EVQ}$ & EVQ & EVQ \\
\hline Local & Pin & C & $\mathrm{C}$ & $C$ & $\mathrm{C}$ & $\mathrm{C}$ & Plm & $\mathrm{B}$ & B & $c$ & $c$ & Pin & $\mathrm{C}$ & B & $\mathrm{C}$ & B & Plm & $\bar{B}$ & B \\
\hline $\mathrm{SiO}_{2}$ & 67.20 & 67.26 & 67.25 & 67.10 & 67.37 & 64.81 & 64.45 & 66.22 & 66.49 & 6.28 & 65.36 & 65.71 & 65.02 & 66.44 & 6.09 & 65.01 & 65.23 & 65.26 & 5.97 \\
\hline $\mathrm{TiO}_{2}$ & 0.0 & 0.0 & 0.0 & 0.00 & 0.00 & 0.01 & 0.00 & 0.0 & $0 . \infty$ & 0.00 & 0.00 & 0.03 & 0.00 & 0.01 & 0.0 & 0.01 & 0.00 & 0.02 & 0.00 \\
\hline $\mathrm{Al}_{2} \mathrm{O}_{3}$ & 16.67 & 17.23 & 17.22 & 17.31 & 17.05 & 15.45 & 15.80 & 16.58 & 16.88 & 16.84 & 16.41 & 16.69 & 15.80 & 16.60 & 16.43 & $15 . \infty$ & 15.73 & 14.90 & 15.21 \\
\hline $\mathrm{Cr}_{2} \mathrm{O}_{3}$ & 0.00 & 0.00 & 0.15 & 0.00 & 0.00 & 0.28 & 0.22 & 0.33 & 0.21 & 0.22 & 0.15 & 0.14 & 0.17 & 0.20 & 0.21 & 0.26 & 0.25 & 0.09 & 0.08 \\
\hline $\mathrm{Zno}$ & n.a. & n.a. & n.a. & n.a. & n.a. & 0.00 & $0 . \infty$ & 0.00 & $0 . \infty$ & 0.02 & 0.00 & 0.00 & 0.02 & 0.00 & 0.05 & 0.04 & 0.00 & $0 . \infty$ & 0.02 \\
\hline $\mathrm{FeO}$ & 0.79 & 0.74 & 0.72 & 0.66 & 0.75 & 0.66 & $0 . \mathbb{3}$ & $0 . \mathbb{3}$ & 0.59 & 0.80 & 0.90 & 0.82 & 0.62 & 0.55 & 0.48 & 0.67 & 0.88 & 0.84 & 0.82 \\
\hline Mno & 0.00 & 0.00 & 0.0 & 0.0 & $0 . \infty$ & $0 . \infty$ & 0.00 & 0.03 & 0.01 & 0.0 & 0.04 & 0.03 & 0.01 & 0.03 & 0.0 & 0.0 & 0.01 & 0.02 & 0.00 \\
\hline $\mathrm{MgO}$ & 1.82 & 1.68 & $1 . \infty$ & 1.81 & 1.70 & 2.23 & 2.15 & 1.45 & 1.15 & 1.26 & 1.27 & 1.31 & 1.6 & 1.45 & 1.45 & 1.74 & 1.79 & 2.78 & 2.79 \\
\hline NiO & 0.00 & 0.00 & 0.00 & 0.00 & 0.00 & 0.0 & 0.00 & 0.00 & 0.0 & 0.00 & $0 . \infty$ & 0.03 & 0.01 & $0 . \infty$ & 0.01 & 0.01 & 0.0 & 0.0 & $0 . \infty$ \\
\hline $\mathrm{CaO}$ & 0.08 & 0.00 & 0.13 & 0.00 & 0.0 & 0.04 & 0.05 & 0.06 & 0.01 & 0.05 & 0.05 & 0.02 & 0.03 & 0.03 & 0.03 & 0.01 & 0.04 & 0.10 & 0.10 \\
\hline $\mathrm{Na}_{2} \mathrm{O}$ & 1.19 & 1.16 & 1.11 & 1.06 & 1.06 & 1.45 & 1.44 & 1.10 & 0.76 & 0.94 & 0.89 & 0.94 & 1.04 & 1.03 & 0.96 & 1.26 & 1.27 & 1.64 & 1.71 \\
\hline $\mathrm{K}_{2} \mathrm{O}$ & 0.00 & 0.00 & 0.00 & 0.00 & 0.00 & 0.05 & 0.05 & 0.05 & 0.01 & 0.05 & 0.03 & 0.04 & 0.04 & 0.0 & 0.01 & 0.03 & 0.02 & 0.08 & 0.06 \\
\hline$\overline{\mathrm{P}_{2} \mathrm{O}_{5}}$ & 0.00 & 0.14 & 0.0 & $0 . \infty$ & 0.00 & n.a. & n.a. & n.a. & n.a. & n.a. & n.a. & n.a. & n.a. & n.a. & ก.a. & n.a. & n.a. & n.a. & n.a. \\
\hline $\mathrm{BaO}$ & n.a. & n.a. & n.a. & n.a. & n.a. & n.a. & ก.a. & n.a. & n.a. & n.a. & ก.a. & n.a. & n.a. & n.a. & n.a. & n.a. & n.a. & n.a. & n.a. \\
\hline$F$ & n.a. & ก.a. & ก.a. & n.a. & n.a. & n.a. & ก.a. & n.a. & n.a. & n.a. & n.a. & ก.a. & n.a. & n.a. & n.a. & n.a. & n.a. & n.a. & п.a. \\
\hline $\mathrm{SO}_{3}$ & 0.00 & 0.13 & 0.0 & $0 . \infty$ & 0.00 & n.a. & n.a. & n.a. & n.a. & ก.a. & n.a. & ก.a. & n.a. & n.a. & n.a. & n.a. & n.a. & n.a. & n.a. \\
\hline $\mathrm{Cl}$ & 0.00 & $0 . \infty$ & 0.00 & 0.00 & $0 . \infty$ & n.a. & n.a. & n.a. & n.a. & ก.a. & n.a. & n.a. & n.a. & n.a. & n.a. & n.a. & n.a. & n.a. & n.a. \\
\hline Total & 87.75 & 88.43 & 88.27 & 87.94 & 87.93 & 84.98 & 84.79 & 86.45 & 86.11 & 86.46 & 85.10 & 85.76 & 84.39 & 86.34 & 84.71 & 84.9 & 85.22 & 85.73 & 86.76 \\
\hline Si & 14.358 & 14.253 & 14.286 & 14.286 & 14.344 & 14.345 & 14.295 & 14.359 & 14.415 & 14.360 & 14.389 & 14.356 & 14.429 & 14.395 & 14.371 & 14.406 & 14.383 & 14.350 & 14.342 \\
\hline$\pi$ & 0.000 & 0.000 & 0.000 & 0.000 & 0.000 & 0.000 & 0.000 & 0.000 & 0.000 & 0.000 & 0.000 & 0.000 & 0.000 & 0.000 & 0.000 & 0.000 & 0.000 & 0.000 & 0.000 \\
\hline$\overline{A !}$ & 4.195 & 4.300 & 4.308 & 4.340 & 4.275 & 4.027 & 4.127 & 4.234 & 4.310 & 4.297 & 4.254 & 4.294 & 4.129 & 4.235 & 4.272 & 4.064 & 4.085 & 3.861 & 3.894 \\
\hline $\mathrm{Cr}$ & 0.000 & 0.000 & 0.025 & 0.000 & 0.000 & 0.049 & 0.039 & 0.057 & 0.006 & 0.038 & 0.026 & 0.024 & 0.030 & 0.034 & 0.037 & 0.045 & 0.044 & 0.016 & 0.014 \\
\hline $\mathrm{Zn}$ & 0.000 & 0.000 & 0.000 & 0.000 & 0.00 & 0.000 & 0.000 & 0.000 & 0.000 & 0.000 & 0.00 & 0.000 & 0.000 & 0.000 & 0.010 & 0.010 & 0.000 & 0.000 & 0.000 \\
\hline $\mathrm{Fe}^{+2}$ & 0.141 & 0.131 & 0.128 & 0.118 & 0.134 & 0.122 & 0.117 & 0.114 & 0.107 & 0.145 & 0.166 & 0.150 & 0.115 & 0.100 & 0.089 & 0.124 & 0.162 & 0.155 & 0.149 \\
\hline $\mathrm{Mn}$ & 0.000 & 0.000 & 0.000 & 0.000 & 0.000 & 0.000 & 0.000 & 0.006 & 0.002 & 0.000 & 0.007 & 0.006 & 0.002 & 0.006 & 0.000 & 0.000 & 0.002 & 0.004 & 0.000 \\
\hline $\mathrm{Mg}$ & 0.580 & 0.531 & 0.536 & 0.574 & 0.540 & 0.736 & 0.711 & 0.469 & 0.372 & 0.407 & 0.417 & 0.427 & 0.539 & 0.468 & 0.477 & 0.575 & 0.588 & 0.912 & 0.904 \\
\hline $\mathrm{Na}$ & 0.493 & 0.477 & 0.457 & 0.438 & 0.438 & 0.622 & 0.619 & 0.462 & 0.319 & 0.396 & 0.380 & 0.398 & 0.448 & 0.433 & 0.407 & 0.541 & 0.543 & 0.700 & 0.721 \\
\hline Ni & $0 . \infty \infty$ & 0.000 & 0.000 & 0.000 & 0.000 & 0.000 & 0.000 & 0.000 & 0.000 & 0.000 & 0.000 & 0.010 & 0.000 & 0.000 & 0.000 & 0.000 & 0.000 & 0.000 & 0.000 \\
\hline $\mathrm{Ca}$ & 0.018 & 0.000 & 0.000 & 0.000 & 0.000 & 0.009 & 0.012 & 0.014 & 0.002 & 0.012 & 0.012 & 0.005 & 0.007 & 0.007 & 0.007 & 0.002 & 0.000 & 0.024 & 0.023 \\
\hline $\mathrm{K}$ & 0.000 & 0.024 & 0.000 & 0.000 & 0.000 & 0.014 & 0.014 & 0.014 & 0.003 & 0.014 & 0.008 & 0.011 & 0.011 & 0.000 & 0.003 & 0.008 & 0.006 & 0.022 & 0.017 \\
\hline P & 0.000 & 0.090 & 0.000 & 0.000 & 0.000 & 0.000 & 0.000 & 0.000 & 0.000 & 0.000 & 0.000 & 0.000 & 0.000 & 0.000 & 0.000 & 0.000 & 0.000 & 0.000 & 0.000 \\
\hline $\mathrm{Ba}$ & 0.000 & 0.000 & 0.000 & 0.000 & 0.000 & 0.000 & 0.000 & 0.000 & 0.000 & 0.000 & 0.000 & 0.000 & 0.000 & 0.000 & 0.000 & 0.000 & 0.000 & 0.000 & 0.000 \\
\hline Cátions & 19.785 & 19.766 & 19.760 & 19.756 & 19.731 & 19.924 & 19.934 & 19.720 & 19.566 & 19.668 & 19.659 & 19.680 & 19.710 & 19.678 & 19.673 & 19.796 & 19.822 & 20.053 & 20.064 \\
\hline
\end{tabular}

Tabela A4.9.1: Dados analíticos de esmeraldas de xistos (EX), veios de quartzo (EVQ) e veios pegmatóides (EVP). Fórmula estrutural: $36(O)$.

Nota: As amostras B-21, B-22 e BE-05 são de veios de quartzo polideformados e NE-36a de veio de quartzo pouco deformado. 
Tabela A4.9: Esmeraldas - ESM.

\begin{tabular}{|c|c|c|c|c|c|c|c|c|c|c|c|c|c|c|c|c|c|c|c|}
\hline Amostra & NE.369 & NE-36a & NE-36a & $\mathrm{NE}-36 \mathrm{a}$ & NE-36a & NE $36 a$ & $\mathrm{NE}-\mathbf{3 0}^{*}$ & NE $30^{\circ}$ & NE $30^{\circ}$ & $N E-31^{*}$ & \begin{tabular}{|l|} 
NE-31* \\
\end{tabular} & $\mathrm{NE}-31^{*}$ & NE-31* & NE-31.02 & NE-31-O2 & $\mathrm{NE}-31.02$ & $\mathrm{NE}-31-02$ & NE-31-O2 & NE-31-06 \\
\hline Análise & $0201 / 23$ & $0202 / 18$ & $0202 / 19$ & 020220 & $02103 / 24$ & $02 / 03 / 25$ & 060253 & 060254 & 060255 & $0602 / 56$ & $06 / 0257$ & 060250 & 060260 & $0501 / 26$ & $0501 / 27$ & $05102 / 28$ & $0502 / 29$ & $0502 \sqrt{30}$ & $0301 / 21$ \\
\hline Mineral & $\mathrm{EVQ}$ & EVQ & EVQ & \begin{tabular}{|l|}
$E V Q$ \\
\end{tabular} & EVQ & \begin{tabular}{|l|} 
EVQ \\
\end{tabular} & EVP & EVP & EVP & \begin{tabular}{|l|} 
EVP \\
\end{tabular} & EVP & EVP & EVP & EVP & EVP & EVP & EVP & EVP & EVP \\
\hline Local & B & C & $\mathrm{C}$ & $c$ & $\mathrm{Plm}$ & PIm & $\mathrm{B}$ & C & B & $\mathrm{B}$ & $\mathrm{c}$ & B & $c$ & $\mathrm{C}$ & $\mathrm{C}$ & $\mathrm{C}$ & $\mathrm{C}$ & $P \ln$ & B \\
\hline $\mathrm{SiO}_{2}$ & 65.53 & 64.22 & 64.62 & 65.39 & 64.87 & 63.67 & 66.25 & 65.87 & 65.65 & 64.79 & Б5.84 & 66.86 & 64.60 & 65.43 & 66.22 & $\overline{65.6}$ & 65.59 & 6.50 & 65.26 \\
\hline $\mathrm{TiO}_{2}$ & 0.00 & $0 . \infty$ & $0 . \infty$ & 0.04 & 0.02 & 0.0 & 0.00 & 0.03 & 0.02 & 0.00 & 0.01 & 0.00 & 0.00 & 0.0 & 0.03 & $0 . \infty$ & 0.00 & 0.10 & 0.01 \\
\hline $\mathrm{Al}_{2} \mathrm{O}_{3}$ & 15.08 & 14.62 & 14.84 & 14.94 & 14.71 & 14.23 & 15.93 & 15.72 & 15.6 & 15.36 & 15.85 & 15.91 & 15.26 & 15.36 & 15.82 & 15.05 & 14.88 & 15.02 & 15.93 \\
\hline $\mathrm{Cr}_{2} \mathrm{O}_{3}$ & 0.08 & 0.08 & 0.06 & 0.11 & 0.05 & 0.04 & 0.06 & 0.09 & 0.11 & 0.17 & 0.10 & 0.14 & 0.12 & 0.05 & 0.05 & 0.01 & 0.07 & 0.00 & 0.11 \\
\hline $\mathrm{ZnO}$ & $0 . \infty$ & $0 . \infty$ & 0.06 & 0.0 & 0.06 & 0.04 & n.a. & n.a. & n.a. & n.a. & n.a. & n.a. & n.a. & 0.00 & 0.00 & 0.04 & 0.0 & 0.02 & 0.00 \\
\hline $\mathrm{FeO}$ & 0.75 & 0.80 & 0.79 & 0.71 & 0.71 & 0.72 & 0.8 & 0.70 & 0.66 & 0.64 & 0.75 & 0.63 & 0.68 & 0.62 & 0.56 & 0.91 & 0.96 & 0.94 & 0.62 \\
\hline $\mathrm{MnO}$ & 0.01 & $0 . \infty$ & 0.0 & 0.00 & 0.00 & $0 . \infty$ & 0.0 & 0.00 & 0.01 & 0.02 & 0.00 & 0.0 & 0.02 & 0.01 & 0.00 & 0.0 & 0.0 & 0.03 & 0.03 \\
\hline $\mathrm{MgO}$ & 2.78 & 2.82 & 2.82 & 2.85 & 3.05 & 3.08 & 2.04 & 2.08 & 2.19 & 2.26 & 2.03 & 2.29 & 2.24 & 2.18 & 2.18 & 2.59 & 2.51 & 2.53 & 2.06 \\
\hline NiO & 0.00 & 0.00 & $0 . \infty$ & 0.04 & 0.00 & 0.02 & n.a. & n.a. & n.a. & n.a. & n.a. & n.a. & n.a. & 0.03 & 0.0 & 0.01 & 0.02 & 0.01 & 0.01 \\
\hline $\mathrm{CaO}$ & 0.06 & 0.09 & 0.11 & $0 . \infty$ & 0.10 & 0.06 & 0.01 & 0.04 & 0.02 & 0.03 & 0.04 & 0.04 & 0.04 & 0.03 & 0.02 & 0.06 & 0.04 & 0.08 & 0.03 \\
\hline $\mathrm{Na}_{2} \mathrm{O}$ & 1.76 & 1.67 & 1.67 & 1.74 & 1.73 & 1.88 & 1.31 & 1.38 & 1.46 & 1.52 & 1.37 & 1.41 & 1.44 & 1.54 & 1.0 & 1.55 & 1.76 & 1.5 & 1.25 \\
\hline $\mathrm{K}_{2} \mathrm{O}$ & 0.06 & 0.13 & 0.14 & 0.11 & 0.07 & 0.05 & 0.05 & 0.05 & 0.02 & 0.05 & 0.07 & 0.04 & 0.03 & 0.02 & 0.02 & 0.12 & 0.06 & 0.11 & 0.07 \\
\hline $\mathrm{P}_{2} \mathrm{O}_{5}$ & n.a. & n.a. & n.a. & n.a. & n.a. & n.a. & ก.a. & n.a. & n.a. & n.a. & n.a. & n.a. & n.a. & n.a. & n.a. & n.a. & n.a. & n.a. & ก.a. \\
\hline $\mathrm{BaO}$ & n.a. & n.a. & n.a. & n.a. & n.a. & n.a. & 0.0 & 0.00 & 0.07 & 0.00 & 0.02 & 0.00 & 0.00 & n.a. & n.a. & n.a. & n.a. & n.a. & n.a. \\
\hline$F$ & n.a. & n.a. & n.a. & n.a. & n.a. & n.a. & 0.05 & 0.10 & 0.03 & 0.0 & 0.00 & 0.0 & 0.08 & n.a. & n.a. & n.a. & ก.a. & n.a. & n.a. \\
\hline $\mathrm{SO}_{3}$ & n.a. & ก.a. & n.a. & n.a. & n.a. & n.a. & n.a. & n.a. & n.a. & n.a. & n.a. & n.a. & n.a. & n.a. & n.a. & ก.a. & n.a. & n.a. & n.a. \\
\hline $\mathrm{Cl}$ & n.a. & n.a. & ก.a. & n.a. & n.a. & n.a. & n.a. & n.a. & n.a. & n. & n.a. & n.a. & n.a. & n.a. & n.a. & n.a. & n.a. & n.a. & n.a. \\
\hline Total & 86.11 & 84.43 & 85.11 & 86.02 & 85.37 & 83.79 & 86.38 & 86.06 & 85.87 & 84.84 & 86.08 & 87.32 & 84.51 & 85.27 & 86.50 & 86.02 & 85.89 & 85.98 & 85.38 \\
\hline Si & 14.349 & 14.35 & 14.335 & 14.344 & 14.340 & 14.352 & 14.397 & 14.390 & 14.376 & 14.362 & 14.372 & 14.379 & 14.381 & 14.414 & 14.376 & 14.392 & 14.405 & 14.384 & 14.348 \\
\hline$\pi$ & 0.000 & 0.000 & 0.000 & 0.010 & 0.000 & 0.00 & 0.000 & 0.000 & 0.000 & 0.000 & 0.000 & 0.000 & 0.000 & 0.000 & 0.000 & 0.000 & 0.000 & 0.020 & 0.000 \\
\hline AI & 3.889 & 3.848 & 3.877 & 3.859 & 3.829 & 3.777 & 4.077 & 4.044 & 4.031 & 4.010 & 4.075 & 4.029 & 4.001 & 3.985 & 4.045 & 3.884 & 3.848 & 3.879 & 4.124 \\
\hline $\mathrm{Cr}$ & 0.014 & 0.014 & 0.011 & 0.019 & 0.000 & 0.007 & 0.010 & 0.016 & 0.019 & 0.030 & 0.017 & 0.024 & 0.021 & 0.009 & 0.009 & 0.002 & $\overline{0.012}$ & 0.000 & 0.019 \\
\hline $\mathrm{Zn}$ & 0.000 & 0.000 & 0.010 & 0.000 & 0.010 & 0.010 & 0.000 & 0.000 & 0.000 & 0.000 & 0.000 & 0.000 & 0.000 & 0.000 & 0.000 & 0.010 & 0.000 & 0.000 & 0.000 \\
\hline $\mathrm{Fe}^{+2}$ & 0.137 & 0.150 & 0.147 & 0.130 & 0.131 & 0.136 & 0.124 & 0.128 & 0.121 & 0.119 & 0.137 & 0.113 & 0.127 & 0.114 & 0.102 & 0.167 & 0.176 & 0.172 & 0.114 \\
\hline $\mathrm{Mn}$ & 0.002 & 0.000 & 0.000 & 0.000 & 0.000 & 0.000 & 0.000 & 0.00 & 0.002 & 0.004 & 0.000 & 0.000 & 0.004 & 0.002 & 0.000 & 0.000 & 0.000 & 0.006 & 0.006 \\
\hline $\mathrm{Mg}$ & 0.907 & 0.940 & 0.933 & 0.932 & 1.005 & 1.005 & 0.661 & 0.677 & 0.715 & 0.747 & 0.661 & 0.734 & 0.743 & 0.716 & 0.706 & 0.846 & 0.822 & 0.827 & 0.675 \\
\hline $\mathrm{Na}$ & 0.747 & 0.724 & 0.718 & 0.740 & 0.742 & 0.822 & 0.552 & 0.585 & 0.620 & 0.653 & 0.580 & 0.588 & 0.522 & 0.658 & 0.674 & 0.659 & 0.749 & 0.659 & 0.533 \\
\hline $\mathrm{Ni}$ & 0.000 & 0.000 & 0.000 & 0.010 & 0.000 & 0.000 & 0.000 & 0.000 & 0.000 & 0.000 & 0.00 & 0.000 & 0.000 & 0.010 & 0.000 & 0.000 & 0.000 & 0.000 & 0.000 \\
\hline $\mathrm{Ca}$ & 0.014 & 0.022 & 0.026 & 0.021 & 0.024 & 0.014 & 0.002 & 0.009 & 0.005 & 0.007 & 0.000 & 0.009 & 0.010 & 0.007 & 0.005 & 0.014 & 0.009 & 0.019 & 0.007 \\
\hline $\mathrm{K}$ & 0.017 & 0.037 & 0.040 & 0.031 & 0.020 & 0.014 & 0.014 & 0.014 & 0.006 & 0.014 & 0.019 & 0.011 & 0.009 & 0.006 & 0.006 & 0.034 & 0.017 & 0.031 & 0.020 \\
\hline $\mathbf{P}$ & 0.000 & 0.000 & 0.000 & 0.000 & 0.000 & 0.000 & 0.000 & 0.000 & 0.000 & 0.000 & 0.000 & 0.00 & 0.000 & 0.000 & 0.000 & 0.000 & 0.000 & 0.000 & 0.000 \\
\hline $\mathrm{Ba}$ & 0.000 & 0.000 & 0.000 & 0.000 & 0.000 & 0.000 & 0.000 & 0.000 & 0.010 & 0.000 & 0.000 & 0.000 & 0.000 & 0.000 & 0.000 & 0.000 & 0.000 & .0 .000 & 0.000 \\
\hline Cations & 20.076 & 20.000 & 20.097 & 20.006 & 20.110 & 20.167 & 19.837 & 19.863 & 19.905 & 19.946 & 99.870 & 19.887 & 99.918 & 19.921 & 19.923 & 20.008 & 20.038 & 19.997 & 19.846 \\
\hline
\end{tabular}

Tabela A4.9.1: Dados analíticos de esmeraldas de xistos (EX), veios de quartzo (EVQ) e veios pegmatóides (EVP). Fórmula estrutural: 36(O).

Nota: A amostra NE-36a é de veio de quartzo pouco deformado. 
Tabela A4.9: Esmeraldas - ESM.

\begin{tabular}{|c|c|c|c|c|c|c|c|c|}
\hline Amostra & NE 31-OG & NE-31-0 & SUL-O1 & SULLOI & SULOI & SUL-01 & SUL-01 & SUL-01 \\
\hline Análise & $0301 / 23$ & $0301 / 25$ & $0201 / 11$ & 0202003 & 020204 & $0203 / 12$ & $0200 / 13$ & $02103 / 14$ \\
\hline Mineral & EVP & EVP & EVP & EVP & EVP & EVP & $E V P$ & EVP \\
\hline Local & B & $\mathrm{C}$ & B & $\mathrm{C}$ & B & $\mathrm{C}$ & B & Plm \\
\hline $\mathrm{SiO}_{2}$ & $\omega . \infty$ & 64.74 & 64.64 & 6.79 & 64.66 & 65.34 & 65.75 & 65.98 \\
\hline $\mathrm{TiO}_{2}$ & $0 . \infty$ & 0.00 & 0.06 & $0 . \infty$ & 0.03 & 0.0 & 0.01 & 0.01 \\
\hline $\mathrm{Al}_{2} \mathrm{O}_{3}$ & 15.81 & 16.00 & 15.77 & 15.51 & 15.86 & 15.47 & 15.62 & 15.62 \\
\hline $\mathrm{Cr}_{2} \mathrm{O}_{3}$ & 0.09 & 0.10 & 0.23 & 0.19 & 0.14 & 0.20 & 0.19 & 0.23 \\
\hline ZnO & 0.02 & 0.00 & 0.02 & 0.00 & 0.01 & $0 . \infty$ & 0.07 & 0.0 \\
\hline $\mathrm{FeO}$ & 0.59 & 0.52 & 0.57 & 0.62 & 0.64 & 0.66 & 0.55 & 0.64 \\
\hline $\mathrm{MnO}$ & 0.04 & $0 . \infty$ & 0.05 & 0.02 & $0 . \infty$ & $0 . \infty$ & 0.00 & 0.00 \\
\hline $\mathrm{MgO}$ & 1.96 & 1.80 & 2.06 & 1.97 & 2.00 & 1.89 & 2.18 & 2.11 \\
\hline NiO & 0.00 & 0.01 & 0.00 & 0.02 & 0.00 & 0.02 & 0.0 & 0.01 \\
\hline $\mathrm{CaO}$ & 0.03 & 0.04 & 0.03 & 0.05 & 0.04 & 0.05 & 0.05 & 0.05 \\
\hline $\mathrm{Na}_{2} \mathrm{O}$ & 1.50 & 1.33 & 1.41 & 1.42 & 1.30 & 1.46 & 1.57 & 1.42 \\
\hline $\mathrm{K}_{2} \mathrm{O}$ & 0.02 & 0.04 & 0.04 & 0.04 & 0.06 & 0.07 & 0.02 & 0.06 \\
\hline $\mathrm{P}_{2} \mathrm{O}_{5}$ & n.a. & n.a. & n.a. & n.a. & n.a. & n.a. & n.a. & n.a. \\
\hline $\mathrm{BaO}$ & n.a. & n.a. & n.a. & n.a. & n.a. & n.a. & n.a. & n.a. \\
\hline$F$ & n.a. & n.a. & n.a. & n.a. & n.a. & ก.a. & n.a. & n.a. \\
\hline $\mathrm{SO}_{3}$ & n.a. & n.a. & n.a. & n.a. & n.a. & ก.a. & n.a. & n.a. \\
\hline Cl & n.a. & n.a. & n.a. & n.a. & n.a. & n.a. & n.a. & n.a. \\
\hline Total & 85.75 & 84.67 & 84.88 & 85.63 & 84.83 & 85.16 & 86.01 & 86.12 \\
\hline Si & 14.384 & 14.339 & 14.315 & 14.426 & 14.322 & 14.416 & 14.371 & 14.394 \\
\hline Ti & 0.00 & 0.000 & 0.010 & 0.000 & 0.000 & 0.000 & 0.000 & 0.000 \\
\hline $\mathrm{Al}$ & 4.07 & 4.197 & 4.113 & 4.005 & 4.137 & 4.019 & 4.021 & 4.013 \\
\hline$\overline{C r}$ & 0.016 & 0.017 & 0.040 & 0.033 & 0.024 & 0.035 & 0.033 & 0.040 \\
\hline $2 n$ & 0.000 & 0.000 & 0.000 & 0.000 & 0.000 & 0.000 & 0.010 & 0.000 \\
\hline $\mathrm{Fe}^{+2}$ & 0.108 & 0.096 & 0.106 & 0.114 & 0.119 & 0.122 & 0.101 & 0.117 \\
\hline $\mathrm{Mn}$ & 0.007 & 0.000 & 0.000 & 0.004 & 0.000 & 0.000 & 0.000 & 0.000 \\
\hline$\overline{\mathrm{Mg}}$ & 0.640 & 0.594 & 0.60 & 0.644 & 0.660 & 0.622 & 0.710 & 0.686 \\
\hline $\mathrm{Na}$ & 0.637 & 0.571 & 0.605 & 0.604 & 0.597 & 0.625 & 0.665 & 0.601 \\
\hline $\mathrm{Ni}$ & 0.000 & 0.000 & 0.000 & 0.000 & 0.000 & 0.000 & 0.000 & 0.000 \\
\hline $\mathrm{Ca}$ & 0.007 & 0.009 & $0 . \infty 7$ & 0.012 & 0.000 & 0.012 & 0.012 & 0.012 \\
\hline $\mathrm{K}$ & 0.006 & 0.011 & 0.011 & 0.011 & 0.017 & 0.020 & 0.006 & 0.014 \\
\hline$P$ & 0.00 & 0.000 & 0.000 & 0.000 & 0.000 & 0.000 & 0.000 & 0.000 \\
\hline $\mathrm{Ba}$ & 0.000 & 0.000 & 0.000 & 0.000 & 0.000 & 0.000 & 0,000 & 0.000 \\
\hline Cátions & 19.882 & 19.834 & 19.896 & 19.853 & 19.885 & 19.871 & 19.929 & 19.877 \\
\hline
\end{tabular}

Tabela A4.9.1: Dados analíticos de esmeraldas de xistos (EX), veios de quartzo (EVQ) e veios pegmatóides (EVP). Fórmula estrutural: 36(O). 
Tabela A4.9: Esmeraldas - ESM.

\begin{tabular}{|c|c|c|c|c|c|c|c|c|c|c|c|c|c|}
\hline Amostra & B-28(10) & $\mathrm{B}-28(10)$ & B-28(2) & $\mathrm{B}-28(3)$ & B-28(4) & $8-28(5)$ & $8-28(6)$ & $B-28(6)$ & $\mathrm{B}-28(7)$ & $8-28(7)$ & B-28(8) & B-28(9) & B-28(9) \\
\hline Análise & 189 & $189^{*}$ & 181 & 182 & 183 & 184 & 185 & $185^{\star}$ & 186 & $186^{*}$ & 187 & 188 & $188^{*}$ \\
\hline Mineral & ESM & ESM & ESM & ESM & ESM & ESM & ESM & ESM & ESM & ESM & ESM & ESM & ESM \\
\hline Local & SAD & SAD & S/D & S/D & SAD & SAD & SAD & Sno & S/D & S/D & SAD & SID & SRD \\
\hline $\mathrm{SiO}_{2}$ & డ5.25 & 64.83 & 65.58 & 65.82 & 64.82 & 65.02 & 65.04 & 64.76 & 65.08 & 64.79 & 65.18 & 64.75 & 64.64 \\
\hline $\mathrm{TiO}_{2}$ & 0.02 & 0.02 & 0.01 & 0.01 & 0.02 & 0.02 & 0.02 & 0.02 & 0.02 & 0.02 & 0.01 & 0.03 & 0.03 \\
\hline $\mathrm{Al}_{2} \mathrm{O}_{3}$ & 16.03 & 15.94 & 17.45 & 17.60 & 15.44 & 16.06 & 15.65 & 15.48 & 15.53 & 15.46 & 15.84 & 15.90 & 15.84 \\
\hline $\mathrm{Cr}_{2} \mathrm{O}_{3}$ & 0.30 & 0.32 & 0.02 & 0.02 & 0.05 & 0.08 & 0.08 & 0.09 & 0.07 & 0.07 & 0.14 & 0.17 & 0.18 \\
\hline Zno & & & & & & & & & & & & & \\
\hline $\mathrm{FeO}$ & 0.93 & 0.91 & 0.81 & 0.75 & 1.35 & 0.98 & 0.99 & 0.99 & 1.20 & 1.15 & 1.01 & 1.01 & 0.97 \\
\hline Mno & 0.01 & 0.00 & 0.01 & 0.01 & 0.01 & 0.01 & 0.01 & 0.00 & 0.01 & 0.00 & 0.01 & 0.01 & 0.00 \\
\hline $\mathrm{MgO}$ & 1.49 & 1.48 & 0.54 & 0.53 & 1.71 & 1.56 & 1.81 & 1.78 & 1.77 & 1.69 & 1.09 & 2.01 & 1.94 \\
\hline $\mathrm{NiO}$ & & & & & & -1 & - & & & & & & \\
\hline $\mathrm{CaO}$ & 0.04 & 0.05 & 0.02 & 0.02 & 0.06 & 0.06 & 0.06 & 0.07 & 0.06 & 0.07 & 0.06 & 0.06 & 0.07 \\
\hline $\mathrm{Na}_{2} \mathrm{O}$ & 1.06 & 1.04 & 0.56 & 0.47 & 1.29 & 1.09 & 1.33 & 1.34 & 1.32 & 1.36 & 1.24 & 1.25 & 1.27 \\
\hline $\mathrm{K}_{2} \mathrm{O}$ & 0.05 & 0.06 & 0.0 & 0.0 & 0.04 & 0.03 & 0.04 & 0.04 & 0.04 & 0.04 & 0.04 & 0.15 & 0.15 \\
\hline $\mathrm{P}_{2} \mathrm{O}_{5}$ & 0.02 & 0.01 & 0.02 & 0.01 & 0.01 & 0.01 & 0.01 & 0.01 & 0.01 & 0.01 & 0.02 & 0.01 & 0.01 \\
\hline $\mathrm{BaO}$ & & & & & & & & & & & & 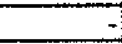 & \\
\hline$F$ & & & & 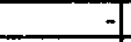 & $=$ & - & + & & & & & & \\
\hline $\mathrm{SO}_{3}$ & 0.04 & 0.02 & 0.01 & 0.02 & 0.02 & 0.04 & 0.02 & 0.02 & 0.02 & 0.02 & 0.02 & 0.02 & 0.02 \\
\hline $\mathrm{Cl}$ & & & & & & & & & & & & & \\
\hline Total & 85.24 & 84.68 & 85.02 & 85.26 & 84.82 & 84.96 & 85.06 & 84.60 & 85.13 & 84.68 & 85.26 & 85.37 & 85.12 \\
\hline $\mathrm{Si}$ & 14.369 & 14.372 & 14.381 & 14.381 & 14.393 & 14.363 & 14.377 & 14.393 & 14.389 & 14.396 & 14.369 & 14.287 & 14.301 \\
\hline $\mathrm{Ti}$ & 0.000 & 0.000 & 0.000 & 0.000 & 0.000 & 0.000 & 0.000 & 0.000 & 0.000 & 0.000 & 0.000 & 0.000 & 0.000 \\
\hline$\overline{A l}$ & 4.157 & 4.162 & 4.506 & 4.520 & 4.038 & 4.178 & 4.074 & 4.052 & 4.044 & 4.046 & 4.112 & 4.132 & 4.127 \\
\hline $\mathrm{Cr}$ & 0.052 & 0.056 & 0.003 & 0.003 & 0.009 & 0.014 & 0.014 & 0.016 & 0.012 & 0.012 & 0.024 & 0.090 & 0.031 \\
\hline$Z_{n}$ & 0.000 & 0.000 & 0.000 & 0.000 & 0.000 & 0.000 & 0.000 & 0.000 & 0.000 & 0.000 & 0.000 & 0.000 & 0.000 \\
\hline $\mathrm{Fe}^{2}$ & 0.171 & 0.169 & 0149 & 0.137 & 0.251 & 0.181 & 0.183 & 0.184 & 0.222 & 0.214 & 0.186 & 0.186 & 0.179 \\
\hline $\mathrm{V}$ & 0.000 & 0.000 & 0.000 & 0.000 & 0.000 & 0.000 & 0.000 & 0.000 & 0.000 & 0.000 & 0.000 & 0.000 & 0.000 \\
\hline $\mathrm{Mn}$ & 0.002 & 0.000 & 0.002 & 0.002 & 0.002 & 0.002 & 0.002 & 0.000 & 0.002 & 0.000 & 0.002 & 0.002 & 0.000 \\
\hline $\mathrm{Mg}$ & 0.489 & 0.489 & 0.177 & 0.173 & 0.566 & 0.514 & 0.596 & 0.590 & 0.583 & 0.560 & 0.555 & 0.661 & 0.640 \\
\hline $\mathrm{Na}$ & 0.453 & 0.447 & 0.234 & 0.199 & 0.555 & 0.467 & 0.570 & 0.577 & 0.566 & 0.586 & 0.530 & 0.535 & 0.545 \\
\hline $\mathrm{Ni}$ & 0.000 & 0.000 & 0.000 & 0.000 & 0.000 & 0.000 & 0.000 & 0.000 & 0.000 & 0.000 & 0.000 & 0.000 & 0.000 \\
\hline $\mathrm{Ca}$ & 0.009 & 0.012 & 0.005 & 0.005 & 0.014 & 0.014 & 0.014 & 0.017 & 0.014 & 0.017 & 0.014 & 0.014 & 0.017 \\
\hline $\mathrm{K}$ & 0.014 & 0.017 & 0.000 & 0.000 & 0.041 & 0.008 & 0.011 & 0.011 & 0.011 & 0.011 & 0.011 & 0.042 & 0.042 \\
\hline $\mathrm{P}$ & 0.000 & 0.000 & 0.000 & 0.000 & 0.000 & 0.000 & 0.000 & 0.000 & 0.000 & 0.000 & 0.000 & 0.000 & 0.000 \\
\hline $\mathrm{Ba}$ & 0.000 & 0.000 & 0.000 & 0.000 & 0.000 & 0.000 & 0.000 & 0.000 & 0.000 & 0.000 & 0.000 & 0.000 & 0.000 \\
\hline Cátions & 19.726 & 19.724 & 19.457 & 19.420 & 19.839 & 19.751 & 19.841 & 19.840 & 19.843 & 19.844 & 19.8003 & 19.889 & 19.882 \\
\hline
\end{tabular}

Tabela A4.9.2: Dados analíticos de esmeraldas da jazida Belmont, selecionadas segundo critérios de cor, sem identificação paragenética (S/D). Fórmula estrutural: $36(0)$. Nota: Cores: (2) e (3) = verde muito claro (sem inclusões); (4) a $(8)=$ verde médio (com poucas inclusões); $(9)$ e $(10)=$ verde intenso (com maior número de inclusõ $\epsilon$ 
Tabela A4.9: Esmeraldas - ESM.

\begin{tabular}{|c|c|c|c|c|c|c|c|c|c|c|c|c|c|}
\hline Amostra & $8-28(10)$ & B-28(10) & $\mathrm{B}-28(2)$ & $B-28(3)$ & B-28(4) & $B-28(5)$ & B-28(6) & $B-28(6)$ & $8-28(7)$ & $B-28(7)$ & B-28(8) & B-28(9) & B-28(9) \\
\hline Análise & 189 & $189^{*}$ & 181 & 182 & 183 & 184 & 185 & $185^{*}$ & 186 & $186^{*}$ & 187 & 188 & $188^{*}$ \\
\hline Mineral & ESM & ESM & ESM & ESM & ESM & ESM & ESM & ESM & ESM & ESM & ESM & ESM & ESM \\
\hline Local & SID & S/L & S/ID & S/ID & S/D & S/D & S/ID & S/ID & S $I D$ & S/D & SID & S/ID & S/D \\
\hline $\mathrm{SiO}_{2}$ & 65.25 & 64.83 & 65.58 & 65.82 & 64.82 & 65.02 & 65.04 & 64.76 & 65.08 & 64.79 & 65.18 & 64.75 & 64.64 \\
\hline $\mathrm{TiO}_{2}$ & 0.02 & 0.02 & 0.01 & 0.01 & 0.02 & 0.02 & 0.02 & 0.02 & 0.02 & 0.02 & 0.01 & 0.03 & 0.03 \\
\hline $\mathrm{Al}_{2} \mathrm{O}_{3}$ & 16.03 & 15.94 & 17.45 & 17.60 & 15.44 & 16.06 & 15.65 & 15.48 & 15.53 & 15.46 & 15.84 & 15.90 & 15.84 \\
\hline $\mathrm{Cr}_{2} \mathrm{O}_{3}$ & 0.30 & 0.32 & 0.02 & 0.02 & 0.05 & 0.08 & 0.08 & 0.09 & 0.07 & 0.07 & 0.14 & 0.17 & 0.18 \\
\hline FeO & 0.93 & 0.91 & 0.81 & 0.75 & 1.35 & 0.98 & 0.99 & 0.99 & 1.20 & 1.15 & 1.01 & 1.01 & 0.97 \\
\hline Mno & 0.01 & 0.00 & 0.01 & 0.01 & 0.01 & 0.01 & 0.01 & 0.00 & 0.01 & 0.00 & 0.01 & 0.01 & 0.00 \\
\hline $\mathrm{MgO}$ & 1.49 & 1.48 & 0.54 & 0.53 & 1.71 & 1.56 & $1.8 \mathrm{f}$ & 1.78 & 1.77 & 1.69 & 1.69 & 2.01 & 1.94 \\
\hline $\mathrm{CaO}$ & 0.04 & 0.05 & 0.02 & 0.02 & 0.06 & 0.06 & 0.06 & 0.07 & 0.06 & 0.07 & 0.06 & 0.06 & 0.07 \\
\hline $\mathrm{Na}_{2} \mathrm{O}$ & 1.06 & 1.04 & 0.55 & 0.47 & 1.29 & 1.09 & 1.33 & 1.34 & 1.32 & 1.36 & 1.24 & 1.25 & 1.27 \\
\hline $\mathrm{K}_{2} \mathrm{O}$ & 0.05 & 0.06 & 0.00 & 0.00 & 0.04 & 0.03 & 0.04 & 0.04 & 0.04 & 0.04 & 0.04 & 0.15 & 0.15 \\
\hline $\mathrm{P}_{2} \mathrm{O}_{5}$ & 0.02 & 0.01 & 0.02 & 0.01 & 0.01 & 0.01 & 0.01 & 0.04 & 0.01 & 0.01 & 0.02 & 0.01 & 0.01 \\
\hline $\mathrm{SO}_{3}$ & 0.04 & 0.02 & 0.01 & 0.02 & 0.02 & 0.04 & 0.02 & 0.02 & 0.02 & 0.02 & 0.02 & 0.02 & 0.02 \\
\hline Total & 85.24 & 84.68 & 85.02 & 85.26 & 84.82 & 84.96 & 85.06 & 84.60 & 85.13 & 84.68 & 85.26 & 85.37 & 85.12 \\
\hline $\mathrm{Ba}$ & 3.00 & 0.00 & 0.00 & 9.00 & 6.00 & 6.00 & 8.00 & 0.00 & 5.00 & 0.00 & 8.00 & 0.00 & 0.00 \\
\hline $\mathrm{Ce}$ & 21.00 & 0.00 & 0.00 & 0.00 & 11.00 & 11.00 & 0.00 & 3.00 & 17.00 & 0.00 & 9.00 & 10.00 & 200 \\
\hline Co & 0.00 & 0.00 & 0.00 & 0.00 & 8.00 & 2.00 & 0.0 & 0.00 & 11.00 & 0.00 & 0.00 & 19.00 & 10.00 \\
\hline Cu & 4.00 & 6.00 & 0.00 & 0.00 & 76.00 & 0.00 & 0.00 & 3.00 & 19.00 & 13.00 & 1.00 & 2.00 & 3.00 \\
\hline $\mathrm{Ga}$ & 20.00 & 11.00 & 40.00 & 38.00 & 23.00 & 23.00 & 17.00 & 11.00 & 23.00 & 13.00 & 21.00 & 19.00 & 10.00 \\
\hline La & 0.00 & 0.00 & 0.00 & 0.00 & 0.00 & 9.00 & 0.00 & 0.00 & 0.00 & 0.00 & 5.00 & 0.00 & 0.00 \\
\hline $\mathrm{Nb}$ & 0.00 & 0.00 & 1.00 & 0.00 & 0.00 & 0.00 & 0.00 & 0.00 & 0.00 & 0.00 & 0.00 & 0.00 & 0.00 \\
\hline Nd & 8.00 & 29.00 & 8.00 & 8.00 & 8.00 & 8.00 & 8.00 & 20.00 & 8.00 & 25.00 & 8.00 & 8.00 & 24.00 \\
\hline$\overline{\mathrm{Ni}}$ & 8.00 & 6.00 & 6.00 & 3.00 & 8.00 & 8.00 & 7.00 & 11.00 & 10.00 & 10.00 & 6.00 & 16.00 & 12.00 \\
\hline$\overline{\mathrm{Pb}}$ & 1.00 & 4.0 & 0.00 & 0.00 & 227.00 & 0.00 & 0.00 & 6.00 & 20.00 & 40.00 & 0.00 & 0.00 & 6.00 \\
\hline$\overline{R b}$ & 21.00 & 31.00 & 14.00 & 12.00 & 44.00 & 28.00 & 30.00 & 36.00 & 38.00 & 53.00 & 29.00 & 41.00 & 52.00 \\
\hline $\mathrm{Sr}$ & 0.00 & 0.00 & 0.00 & 0.00 & 0.00 & 0.00 & 0.00 & 0.00 & 0.00 & 0.00 & 0.00 & 0.00 & 0.00 \\
\hline Th & 0.00 & 4.00 & 0.00 & 1.00 & 4.00 & 7.00 & 0.00 & 1.00 & 1.00 & 4.00 & 2.00 & 0.00 & 2.00 \\
\hline $\mathrm{U}$ & 3.00 & 0.00 & 0.00 & 2.00 & 0.00 & 2.00 & 0.00 & 0.00 & 4.00 & 0.00 & 4.00 & 0.00 & 0.00 \\
\hline 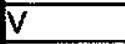 & 90.00 & 39.00 & 16.00 & 17.00 & 163.00 & 120.00 & 109.00 & 51.00 & 145.00 & 68.00 & 104.00 & 56.00 & 23.00 \\
\hline$Y$ & 1.00 & 0.00 & 3.00 & 2.00 & 4.00 & 4.00 & 4.00 & 0.00 & 3.00 & 0.00 & 3.00 & 2.00 & 1.00 \\
\hline $\mathrm{Zn}$ & 42.00 & 49.00 & 84.00 & 85.00 & 108.00 & 74.00 & 63.00 & 65.00 & 72.00 & 70.00 & 48.00 & 62.00 & 70.00 \\
\hline $\mathrm{Zr}$ & 5.00 & 6.00 & 6.00 & 8.00 & 18.00 & 4.00 & 3.00 & 4.00 & 17.00 & 11.00 & 4.00 & 7.00 & 7.00 \\
\hline
\end{tabular}

Tabela A4.9.3: Dados analíticos (por FRX) de esmeraldas da jazida Belmont, selecionadas segundo critérios de cor, sem identificação paragenética (S/ID). Nota: Cores: $(2)$ e $(3)=$ verde muito claro (sem inclusões); (4) a (8) = verde médio (com poucas inclusões); $(9)$ e (10) $=$ verde intenso (com maior núme 
Tabela A4.10: Outros Minerals.

\begin{tabular}{|c|c|c|c|c|c|c|c|c|c|c|c|c|c|c|c|c|c|}
\hline Amostra & CAP-4 & CAP-4 & CAP-4 & CAP-4 & CAP-4 & CAP-4 & CAP-4 & G-37 & G-37 & G-37 & G-37 & G-56 & G-56 & B-10 & B-10 & B-10 & $B-10$ \\
\hline Análise & $28 / 111.1$ & $28 / 112.1$ & $28 / 112.2$ & $28 / 411.1$ & $28 / 311.1$ & $28 / 2 ! 1.1$ & $28 / 2 / 1.2$ & $29 / 1 / 1.1$ & $29 / 311.1$ & $29 / 3 ! 2.1$ & $29 / 312.2$ & $35 / 1 E 1.1$ & 35/1E1.2 & 26/4/E01 & $26 / 4 / E 02$ & 26/4/E03 & $26 / 4 / \mathrm{EO} 4$ \\
\hline Mineral & ILM & ILM & ILM & $\mathrm{ILM}$ & ILM & $\mathrm{ILM}$ & $\mathrm{ILM}$ & ILM & ILM & ILM & ILM & $\mathrm{ILM}$ & ILM & $\mathrm{ILM}$ & ILM & $\mathrm{ILM}$ & ILM \\
\hline Local & $c$ & $\mathrm{C}$ & $\mathrm{B}$ & C & C & C & $\mathrm{B}$ & C & C & C & $\mathrm{B}$ & $C$ & B & $\mathrm{C}$ & $\mathrm{C}$ & $B$ & $B$ \\
\hline Litotipo & $A B$ & $A B$ & $A B$ & $\overline{A B}$ & $\overline{A B}$ & $\overline{A B}$ & $\overline{A B}$ & ABET & ABET & ABET & ABET & ABET & ABET & $\overline{A B G}$ & $\overline{A B G}$ & $\overline{A B G}$ & $\overline{A B G}$ \\
\hline $\mathrm{SiO}_{2}$ & 0.00 & 0.17 & 0.00 & 0.00 & 0.18 & 0.14 & 0.00 & 0.15 & 0.00 & 0.22 & 0.16 & 0.17 & 0.14 & 0.00 & 0.00 & 0.00 & 0.22 \\
\hline $\mathrm{TiO}_{2}$ & 51.22 & 51.89 & 51.51 & 51.53 & 52.54 & 52.25 & 52.33 & 51.97 & 51.07 & 51.31 & 50.98 & 53.62 & 53.49 & 53.70 & 52.30 & 51.94 & 51.86 \\
\hline $\mathrm{Al}_{2} \mathrm{O}_{3}$ & 0.00 & 0.00 & 0.00 & 0.00 & 0.12 & 0.23 & 0.14 & 0.00 & 0.00 & 0.22 & 0.15 & 0.00 & 0.00 & 0.00 & 0.00 & 0.00 & 0.20 \\
\hline $\mathrm{Cr}_{2} \mathrm{O}_{3}$ & 0.00 & 0.00 & 0.00 & 0.00 & 0.00 & 0.00 & 0.00 & 0.00 & 0.00 & 0.0 & 0.00 & 0.00 & 0.00 & 0.00 & 0.00 & 0.00 & 0.00 \\
\hline $\mathrm{ZnO}$ & n.a. & ก.a. & n.a. & n.a. & n.a. & n.a. & n.a. & n.a. & n.a. & ก.a. & n.a. & n.a. & n.a. & n.a. & n.a. & n.a. & ก.a. \\
\hline$F \in O$ & 45.76 & 46.04 & 45.29 & 45.16 & 45.99 & 46.48 & 46.52 & 46.46 & 45.33 & 45.60 & 45.55 & 39.77 & 39.37 & 44.21 & 45.39 & 44.20 & 44.70 \\
\hline $\mathrm{V}_{2} \mathrm{O}_{3}$ & 0.00 & 0.00 & 0.00 & 0.00 & 0.00 & 0.52 & 0.33 & 0.00 & 0.00 & 0.00 & 0.00 & 0.00 & 0.00 & 0.00 & 0.00 & 0.00 & 0.00 \\
\hline MnO & 1.03 & 1.12 & 1.28 & 1.54 & 1.98 & 1.09 & 1.17 & 1.30 & 1.20 & 1.06 & 1.03 & 1.58 & 1.77 & 0.69 & 0.56 & 0.63 & 0.56 \\
\hline $\mathrm{MgO}$ & 0.49 & 0.36 & 0.14 & 0.31 & 0.16 & 0.60 & 0.47 & 0.16 & 0.17 & 0.23 & 0.22 & 0.00 & 0.14 & 0.67 & 0.79 & 0.68 & 0.76 \\
\hline $\mathrm{NiO}$ & 0.00 & 0.00 & 0.00 & 0.00 & 0.00 & 0.00 & 0.00 & 0.00 & 0.00 & 0.00 & 0.00 & 0.00 & 0.00 & 0.00 & 0.00 & 0.00 & 0.00 \\
\hline $\mathrm{CaO}$ & 0.14 & 0.14 & 0.11 & 0.25 & 0.24 & 0.15 & 0.32 & 0.45 & 0.21 & 0.20 & 0.22 & 0.62 & 0.60 & 0.11 & 0.11 & 0.10 & 0.15 \\
\hline $\mathrm{Na}_{2} \mathrm{O}$ & 0.00 & 0.00 & 0.00 & 0.00 & 0.00 & 0.18 & 0.00 & 0.00 & $0 . \infty$ & 0.00 & 0.00 & 1.03 & 1.17 & 0.00 & 0.00 & 0.00 & 0.00 \\
\hline $\mathrm{K}_{2} \mathrm{O}$ & 0.00 & 0.00 & 0.00 & 0.00 & 0.00 & 0.00 & 0.00 & 0.00 & 0.00 & 0.00 & 0.00 & 0.00 & 0.00 & 0.00 & $0 . \infty$ & 0.00 & 0.00 \\
\hline $\mathrm{P}_{2} \mathrm{O}_{5}$ & 0.00 & 0.00 & 0.00 & 0.00 & 0.00 & 0.00 & 0.00 & 0.00 & 0.00 & 0.13 & 0.00 & 0.00 & 0.00 & 0.00 & 0.00 & 0.00 & 0.00 \\
\hline $\mathrm{SO}_{3}$ & 0.00 & 0.00 & 0.00 & 0.00 & 0.00 & 0.00 & 0.00 & 0.00 & 0.00 & 0.00 & 0.00 & 0.00 & 0.00 & 0.00 & 0.00 & 0.00 & 0.00 \\
\hline Total & 98.64 & 99.72 & 98.33 & 98.79 & 101.21 & 101.64 & 101.28 & 100.49 & 97.98 & 98.97 & 98.31 & 96.79 & 96.68 & 99.38 & 99.15 & 97.55 & 98.45 \\
\hline
\end{tabular}

Tabela A4.10.1: Dados analíticos de ilmenitas (ILM). 


\begin{tabular}{|c|c|c|c|c|c|c|c|c|c|c|c|c|c|c|c|c|c|}
\hline Amostra & B-10 & $B-10$ & $B-10$ & G-54b & G-54b & G-54b & G-54b & G-54b & G-54b & G-54b & G-54b & $G-54 b$ & $G-54 b$ & $G-54 b$ & G-54b & $G-54 b$ & G-54b \\
\hline Análise & 26/2/E01 & 26/2/EO2 & 26/3E01 & 6/L1.2 & 6/LL1.3 & G/L2.1 & G/L2.2 & 6/LL2.3 & 6/L2.4 & G/L3.1 & G/L3.2 & 6/L3.3 & 6/L3.4 & $6 / 1 / 1.1$ & $6 / 111.2$ & $6 / 111.3$ & $6 / 111.4$ \\
\hline Mineral & ILM & ILM & $\mathrm{ILM}$ & ILM & $\mathrm{ILM}$ & $\mathrm{ILM}$ & ILM & ILM & ILM & ILM & ILM & ILM & ILM & IIM & ILM & ILM & ILM \\
\hline Local & B & $\mathrm{C}$ & $c$ & $\mathrm{C}$ & $B$ & $B$ & PIm & $\mathrm{C}$ & $\mathrm{C}$ & $\mathrm{B}$ & $B$ & $\mathrm{C}$ & C & B & Pim & $C$ & $\mathrm{C}$ \\
\hline Litotipo & $\overline{A B G}$ & $\overline{A B G}$ & $\overline{A B G}$ & $\overline{A B G}$ & $\overline{A B G}$ & $A B G$ & $A B G$ & $\overline{A B G}$ & $A B G$ & $\overline{A B G}$ & $A B G$ & $\overline{A B G}$ & $A B G$ & $A B G$ & $A B G$ & $A B G$ & $A B G$ \\
\hline $\mathrm{SiO}_{2}$ & 0.00 & 0.11 & 0.13 & 0.15 & 0.12 & 0.00 & 0.00 & 0.00 & 0.00 & 0.00 & 0.29 & 0.00 & 0.00 & 0.00 & 0.00 & 0.14 & 0.18 \\
\hline $\mathrm{TiO}_{2}$ & 52.41 & 52.74 & 52.87 & 51.04 & 51.21 & 50.97 & 51.04 & 51.32 & 50.80 & 51.44 & 50.53 & 51.82 & 51.16 & 51.12 & 51.48 & 51.04 & 51.21 \\
\hline $\mathrm{Al}_{2} \mathrm{O}_{3}$ & 0.17 & 0.00 & 0.13 & 0.00 & 0.14 & 0.00 & 0.00 & 0.00 & 0.12 & 0.14 & 0.18 & 0.00 & 0.00 & 0.00 & 0.00 & 0.00 & 0.14 \\
\hline $\mathrm{Cr}_{2} \mathrm{O}_{3}$ & 0.00 & 0.00 & 0.00 & 0.00 & 0.00 & 0.00 & 0.00 & 0.00 & 0.00 & 0.00 & 0.00 & 0.00 & 0.00 & 0.00 & 0.00 & 0.00 & 0.00 \\
\hline Zno & n.a. & n.a. & n.a. & n.a. & n.a. & n.a. & n.a. & n.a. & n.a. & n.a. & n.a. & n.a. & n.a. & ก.a. & n.a. & n.a. & n.a. \\
\hline FeO & 44.32 & 44.66 & 44.64 & 46.20 & 46.56 & 46.94 & 46.42 & 46.40 & 46.83 & 46.41 & 45.61 & 46.47 & 46.54 & 46.83 & 46.58 & 46.64 & 46.60 \\
\hline $\mathrm{V}_{2} \mathrm{O}_{3}$ & 0.00 & 0.00 & 0.00 & 0.00 & 0.00 & 0.00 & 0.00 & 0.00 & 0.00 & 0.00 & 0.00 & 0.00 & 0.00 & 0.00 & 0.00 & 0.00 & 0.00 \\
\hline Mno & 0.73 & 0.54 & 0.74 & 0.34 & 0.27 & 0.43 & 0.37 & 0.30 & 0.29 & 0.29 & 0.35 & 0.36 & 0.30 & 0.29 & 0.33 & 0.35 & 0.46 \\
\hline $\mathrm{MgO}$ & 0.78 & 0.81 & 0.17 & 0.48 & 0.39 & 0.52 & 0.47 & 0.40 & 0.53 & 0.43 & 0.51 & 0.55 & 0.46 & 0.60 & 0.59 & 0.41 & 0.46 \\
\hline NiO & 0.00 & 0.00 & 0.00 & 0.00 & 0.00 & 0.00 & 0.00 & 0.00 & $0 . \infty$ & 0.00 & 0.00 & 0.00 & 0.00 & 0.00 & 0.00 & 0.00 & 0.00 \\
\hline $\mathrm{CaO}$ & 0.16 & 0.11 & 0.14 & 0.16 & 0.00 & 0.27 & 0.16 & 0.14 & 0.18 & 0.19 & 0.62 & 0.21 & 0.10 & 0.17 & 0.12 & 0.13 & 0.17 \\
\hline $\mathrm{Na}_{2} \mathrm{O}$ & 0.00 & 0.00 & 0.00 & 0.00 & 0.00 & 0.00 & 0.00 & 0.00 & 0.00 & 0.00 & 0.00 & 0.00 & 0.00 & 0.00 & 0.00 & 0.00 & 0.00 \\
\hline $\mathrm{K}_{2} \mathrm{O}$ & 0.00 & 0.00 & 0.00 & 0.00 & 0.00 & 0.00 & 0.00 & 0.00 & 0.00 & 0.00 & 0.00 & 0.00 & 0.00 & 0.00 & 0.00 & 0.00 & 0.00 \\
\hline $\mathrm{P}_{2} \mathrm{O}_{5}$ & 0.00 & 0.00 & 0.00 & 0.00 & 0.00 & 0.00 & 0.00 & 0.00 & 0.00 & 0.00 & 0.00 & 0.00 & 0.00 & 0.00 & 0.00 & 0.00 & 0.00 \\
\hline $\mathrm{SO}_{3}$ & 0.00 & 0.00 & 0.00 & 0.00 & 0.00 & 0.00 & 0.00 & 0.00 & 0.00 & 0.0 & 0.00 & 0.00 & 0.00 & 0.00 & 0.00 & 0.00 & 0.15 \\
\hline Total & 98.57 & 98.97 & 98.82 & 98.37 & 98.69 & 99.13 & 98.46 & 98.56 & 98.75 & 98.90 & 98.09 & 99.41 & 98.56 & 99.01 & 99.10 & 98.71 & 99.37 \\
\hline
\end{tabular}

Tabela A4.10.1: Dados analíticos de ilmenitas (ILM). 


\begin{tabular}{|c|c|c|c|c|c|c|c|c|c|c|c|c|c|c|c|c|c|}
\hline Amostra & G-54b & G-54b & G-54b & G-54b & $G-54 b$ & $G-54 b$ & $1-01$ & $1-01$ & $1-01$ & $1-01$ & $1-01$ & $1-01$ & $1-01$ & $1-01$ & $1-01$ & G-52c & G-85a \\
\hline Analise & $6 / 2 \mid 1.1$ & $6 / 2 / 1.2$ & $6 / 2121$ & $6 / 212.2$ & $6 / 3 \mid 1.1$ & $6 / 311.2$ & 10/2/EOT & 10/3/E01 & $10 / 3 / \mathrm{EO} 2$ & 10/3/E03 & 10/3E04 & 10/1/E01 & 10/1/EO2 & 10/1/E03 & 10/1/EO4 & $02102 / 36$ & $01 / 02 / 15$ \\
\hline Mineral & $\mathrm{LM}$ & ILM & $\mathrm{ILM}$ & ILM & ILM & ILM & ILM & ILM & ILM & ILM & ILM & ILM & ILM & ILM & $\mathrm{ILM}$ & $\mathrm{ILM}$ & ILM \\
\hline Local & Pim & $\mathrm{B}$ & $\mathrm{B}$ & $C$ & $B$ & $B$ & $c$ & $\mathrm{C}$ & B & $C$ & $B$ & $\mathrm{C}$ & $\mathrm{B}$ & $\mathrm{C}$ & $\mathrm{B}$ & $C$ & C \\
\hline Litotipo & $A B G$ & $A B G$ & $A B G$ & $A B G$ & ABG & $A B G$ & $A B G$ & $A B G$ & $A B G$ & ABG & $A B G$ & $A B G$ & $A B G$ & $A B G$ & ABG & MP & MP \\
\hline $\mathrm{SiO}_{2}$ & 0.14 & 0.13 & 0.13 & 0.00 & 0.16 & 0.00 & 0.0 & 0.13 & 0.25 & 0.16 & 0.13 & 0.14 & 0.24 & 0.11 & 0.21 & 0.15 & 0.10 \\
\hline $\mathrm{TiO}_{2}$ & 50.68 & 50.02 & 51.05 & 50.75 & 51.04 & 51.76 & 49.42 & 51.06 & 50.24 & 51.27 & 51.03 & 51.65 & 51.35 & 51.24 & 50.95 & 41.55 & 45.20 \\
\hline $\mathrm{A}_{2} \mathrm{O}_{3}$ & 0.00 & 0.00 & 0.20 & 0.15 & 0.00 & 0.19 & 0.00 & 0.11 & 0.13 & 0.00 & 0.00 & 0.13 & 0.22 & 0.16 & 0.11 & 0.08 & 0.05 \\
\hline $\mathrm{Cr}_{2} \mathrm{O}_{3}$ & 0.00 & 0.00 & 0.00 & 0.00 & 0.00 & 0.00 & 0.00 & 0.00 & 0.00 & 0.00 & 0.00 & 0.00 & 0.00 & 0.00 & 0.00 & 0.09 & 0.03 \\
\hline $\mathrm{ZnO}$ & n.a. & n.a. & n.a. & n.a. & n.a. & n.a. & n.a. & n.a. & n.a. & n.a. & n.a. & n.a. & n.a. & n.a. & n.a. & 0.00 & 0.00 \\
\hline $\mathrm{FeO}$ & 46.92 & 46.80 & 46.67 & 46.63 & 46.28 & 46.75 & 46.61 & 46.02 & 45.62 & 45.96 & 45.92 & 46.07 & 46.05 & 46.13 & 46.22 & 45.82 & 48.16 \\
\hline $\mathrm{V}_{2} \mathrm{O}_{3}$ & 0.00 & 0.00 & 0.00 & 0.00 & 0.00 & 0.00 & 0.00 & 0.00 & 0.00 & 0.00 & 0.00 & 0.00 & 0.00 & 0.00 & 0.00 & n.a. & n.a. \\
\hline $\mathrm{MnO}$ & 0.23 & 0.22 & 0.35 & 0.31 & 0.35 & 0.21 & 1.35 & 1.52 & 1.52 & 1.46 & 1.67 & 1.28 & 1.28 & 1.32 & 1.38 & 0.17 & 0.08 \\
\hline $\mathrm{MgO}$ & 0.87 & 0.71 & 0.51 & 0.40 & 0.76 & 0.75 & 0.33 & 0.46 & 0.43 & 0.45 & 0.30 & 0.40 & 0.38 & 0.43 & 0.41 & 0.44 & 0.08 \\
\hline $\mathrm{NiO}$ & 0.00 & 0.00 & 0.00 & 0.00 & 0.00 & 0.00 & 0.00 & 0.00 & 0.00 & 0.00 & 0.00 & 0.00 & 0.00 & 0.00 & 0.00 & 0.00 & 0.00 \\
\hline $\mathrm{CaO}$ & 0.00 & 0.19 & 0.23 & 0.14 & 0.00 & 0.17 & 0.42 & 0.35 & 0.43 & 0.22 & 0.26 & 0.13 & 0.26 & 0.16 & 0.32 & 0.04 & 0.02 \\
\hline $\mathrm{Na}_{2} \mathrm{O}$ & 0.00 & 0.00 & 0.00 & 0.00 & 0.00 & 0.00 & 0.00 & 0.00 & 0.00 & 0.00 & 0.00 & 0.00 & 0.00 & 0.00 & 0.00 & 0.13 & 0.07 \\
\hline $\mathrm{K}_{2} \mathrm{O}$ & 0.00 & 0.00 & 0.00 & 0.00 & 0.00 & 0.00 & 0.00 & 0.00 & 0.00 & 0.00 & 0.00 & 0.00 & 0.00 & $0 . \infty$ & 0.00 & 0.03 & 0.01 \\
\hline $\mathrm{P}_{2} \mathrm{O}_{5}$ & 0.00 & 0.00 & 0.00 & 0.00 & 0.00 & 0.00 & 0.00 & 0.00 & 0.00 & 0.00 & 0.00 & 0.00 & 0.16 & 0.00 & 0.00 & n.a. & n.a. \\
\hline $\mathrm{SO}_{3}$ & 0.00 & 0.00 & 0.00 & 0.00 & 0.00 & 0.00 & 0.00 & 0.00 & 0.00 & 0.00 & 0.00 & 0.00 & 0.13 & 0.00 & 0.00 & n.a. & n.a. \\
\hline Total & 98.84 & 98.07 & 99.14 & 98.38 & 98.59 & 99.83 & 98.13 & 99.65 & 98.62 & 99.52 & 99.31 & 99.80 & 100.07 & 99.55 & 99.60 & 88.50 & 93.80 \\
\hline
\end{tabular}

Tabela A4.10.1: Dados analíticos de ilmenitas (ILM). 


\begin{tabular}{|c|c|c|}
\hline Amostra & G-85a & G-85a \\
\hline Análise & $01 / 02 / 16$ & $01 / 03 / 26$ \\
\hline Mineral & ILM & ILM \\
\hline Local & C & $\mathrm{C}$ \\
\hline Litotipo & MP & MP \\
\hline $\mathrm{SiO}_{2}$ & 0.01 & 0.01 \\
\hline $\mathrm{TiO}_{2}$ & 44.47 & 45.88 \\
\hline $\mathrm{Al}_{2} \mathrm{O}_{3}$ & 0.00 & 0.01 \\
\hline $\mathrm{Cr}_{2} \mathrm{O}_{3}$ & 0.00 & 0.03 \\
\hline $\mathrm{ZnO}$ & 0.00 & 0.06 \\
\hline $\mathrm{FeO}$ & 47.34 & 47.36 \\
\hline $\mathrm{V}_{2} \mathrm{O}_{3}$ & n.a. & n.a. \\
\hline Mno & 0.05 & 0.11 \\
\hline $\mathrm{MgO}$ & 0.56 & 0.14 \\
\hline NiO & 0.03 & 0.03 \\
\hline $\mathrm{CaO}$ & 0.01 & 0.04 \\
\hline $\mathrm{Na}_{2} \mathrm{O}$ & 0.08 & 0.03 \\
\hline $\mathrm{K}_{2} \mathrm{O}$ & 0.00 & 0.0 \\
\hline $\mathrm{P}_{2} \mathrm{O}_{5}$ & n.a. & n.a. \\
\hline $\mathrm{SO}_{3}$ & n.a. & n.a. \\
\hline Total & 92.55 & 93.70 \\
\hline
\end{tabular}

Tabela A4.10.1: Dados analíticos de ilmenitas (ILM). 


\begin{tabular}{|c|c|c|c|c|c|c|c|c|c|c|c|c|}
\hline Amostra & $1-01$ & BE- 06 & BE-08 & BE-08 & \begin{tabular}{|l|} 
BE- 08 \\
\end{tabular} & BE-08 & BE-08 & NE-12 & NE-12 & NE-12 & G-85a & G-85a \\
\hline Análise & $10 / 4$ AP1 & $03 / 03 / 47$ & $37 / 1 \mathrm{A1.1}$ & 37/1A1.2 & $37 / 1 \mathrm{A2} .1$ & 37/2A1.1 & $37 / 2 A 1.2$ & $04 / 01 / 64$ & $04 / 01 / 65$ & 040377 & $03 / 03 / 69$ & $03 / 03 / 70$ \\
\hline Minera! & $A P$ & $\mathrm{AP}$ & AP & $\mathrm{AP}$ & AP & $\mathrm{AP}$ & $A P$ & $\mathrm{AP}$ & $A P$ & AP & $A P$ & $A P$ \\
\hline Local & $c$ & $\mathrm{c}$ & C & C & $B$ & C & $c$ & $\mathrm{C}$ & $\mathrm{B}$ & $\bar{B}$ & 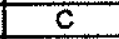 & $\mathrm{B}$ \\
\hline Litotipo & ABG & UM & $\mathrm{UM}$ & UM & UM & UM & UM & UM & $\mathrm{UM}$ & UM & $\mathrm{MP}$ & $\mathrm{MP}$ \\
\hline $\mathrm{SiO}_{2}$ & 0.00 & 0.05 & 0.00 & 0.00 & 0.00 & 0.00 & 0.00 & 0.03 & 0.00 & 0.01 & 0.00 & 0.00 \\
\hline $\mathrm{TiO}_{2}$ & 0.00 & 0.03 & 0.00 & 0.00 & 0.00 & 0.00 & 0.00 & 0.00 & 0.01 & 0.02 & 0.00 & 0.03 \\
\hline $\mathrm{Al}_{2} \mathrm{O}_{3}$ & 0.11 & 0.00 & 0.00 & 0.00 & 0.00 & 0.00 & 0.11 & 0.01 & 0.00 & 0.01 & 0.00 & 0.00 \\
\hline $\mathrm{Cr}_{2} \mathrm{O}_{3}$ & 0.00 & 0.03 & 0.00 & 0.00 & 0.00 & 0.00 & 0.00 & 0.00 & 0.00 & 0.00 & 0.00 & 0.00 \\
\hline $\mathrm{ZnO}$ & n.a. & 0.46 & n.a. & n.a. & n.a. & ก.a. & n.a. & 0.47 & 0.49 & 0.46 & 0.59 & 0.4 \\
\hline$F_{0 O}$ & 0.00 & 0.06 & 0.00 & 0.00 & 0.00 & 0.00 & 0.00 & 0.05 & 0.07 & 0.12 & 0.07 & 0.07 \\
\hline $\mathrm{V}_{2} \mathrm{O}_{3}$ & 0.00 & n.a. & 0.00 & 0.00 & 0.00 & 0.00 & 0.00 & n.a. & n.a. & n.a. & ก.a. & n.a. \\
\hline $\mathrm{MnO}$ & 0.00 & 0.08 & 0.00 & 0.00 & 0.00 & 0.00 & 0.00 & 0.03 & 0.04 & 0.04 & 0.03 & 0.01 \\
\hline $\mathrm{MgO}$ & 0.00 & 0.01 & 0.00 & 0.00 & 0.00 & 0.00 & 0.11 & 0.00 & 0.00 & 0.01 & 0.04 & 0.04 \\
\hline $\mathrm{NOO}$ & 0.00 & 0.00 & 0.00 & 0.00 & 0.00 & 0.00 & 0.00 & 0.02 & 0.05 & 0.00 & 0.05 & 0.00 \\
\hline $\mathrm{CaO}$ & 55.54 & 55.48 & 57.06 & 56.68 & 56.68 & 56.94 & 56.86 & 55.21 & 55.02 & 55.05 & 55.45 & 55.40 \\
\hline $\mathrm{Na}_{2} \mathrm{O}$ & 0.00 & 0.00 & 0.00 & 0.00 & 0.00 & 0.00 & 0.00 & 0.00 & 0.00 & 0.00 & 0.00 & 0.00 \\
\hline $\mathrm{K}_{2} \mathrm{O}$ & 0.00 & 0.00 & 0.00 & 0.00 & 0.00 & 0.00 & 0.00 & 0.01 & 0.01 & 0.02 & 0.01 & 0.02 \\
\hline $\mathrm{P}_{2} \mathrm{O}_{5}$ & 43.82 & n.a. & 44.85 & 44.72 & 44.62 & 44.81 & 44.90 & n.a. & n.a. & B.a. & n.a. & n.a \\
\hline $\mathrm{SO}_{3}$ & 0.00 & n.a. & 0.00 & 0.00 & 0.00 & 0.00 & 0.00 & n.a. & n.a. & n.a. & n.a. & n.a \\
\hline Total & 99.47 & 56.20 & 101.94 & 101.40 & 101.30 & 101.75 & 101.98 & 55.83 & 55.69 & 55.74 & 56.24 & 56.01 \\
\hline
\end{tabular}

Tabela A4.10.2: Dados analificos de apatita (AP).

\begin{tabular}{|c|c|c|c|c|c|c|c|c|c|}
\hline Amostra & BE-08 & BE-08 & \begin{tabular}{|l|} 
BE-08 \\
\end{tabular} & BE-08 & BE-08 & BE-08 & BE-08 & BE-08 & \begin{tabular}{|l} 
BE. 08 \\
\end{tabular} \\
\hline Análise & $37 / \times C 1.1$ & $37 / \times C 1.2$ & $37 / \times C 1.3$ & $37 / 6 \mathrm{C} 1.1$ & $37 / 6 \mathrm{C} 1.2$ & $37 / 6 C 1.3$ & $37 / 6 \mathrm{C} 2.1$ & $37 / 6 \mathrm{C} 2.2$ & $37 / 6 \mathrm{C} 3.1$ \\
\hline Mineral & CRT & CRT & CRT & \begin{tabular}{|c|} 
CRT \\
\end{tabular} & CRT & CRT & CRT & CRT & CRT \\
\hline Local & UM & UM & UM & UM & UM & UM & UM & UM & UM \\
\hline $\mathrm{SiO}_{2}$ & 0.00 & 0.15 & 0.12 & 0.00 & 0.00 & 0.19 & 0.18 & 0.00 & 0.00 \\
\hline $\mathrm{THO}_{2}$ & 0.35 & 0.35 & 0.38 & 0.33 & 0.30 & 0.47 & 0.49 & 0.30 & 0.26 \\
\hline $\mathrm{Al}_{2} \mathrm{O}_{3}$ & 14.03 & 13.71 & 13.32 & 14.32 & 12.60 & 13.89 & 14.68 & 12.97 & 11.33 \\
\hline $\mathrm{Cr}_{2} \mathrm{O}_{3}$ & 45.24 & 45.74 & 45.59 & 44.42 & 47.17 & 45.31 & 43.68 & 46.17 & 48.82 \\
\hline $\mathrm{ZnO}$ & n.a. & n.a. & n.a. & n.a. & n.a. & n.a. & n.a. & n.a. & n.a. \\
\hline $\mathrm{FeO}$ & 37.46 & 38.50 & 38.16 & 37.69 & 37.54 & 37.90 & 37.78 & 37.78 & 36.57 \\
\hline$\overline{\mathrm{V}_{2} \mathrm{O}_{3}}$ & 0.00 & 0.00 & 0.15 & 0.15 & 0.00 & 0.00 & 0.00 & 0.00 & 0.15 \\
\hline $\mathrm{MnO}$ & 0.91 & 1.02 & 0.82 & 1.05 & 1.09 & 9.13 & 1.03 & 0.81 & 0.94 \\
\hline$\overline{\mathrm{MgO}}$ & 0.67 & 0.84 & 0.65 & 0.54 & 0.59 & 0.58 & 0.60 & 0.54 & 0.52 \\
\hline Nio & 0.00 & 0.00 & 0.00 & 0.00 & 0.00 & 0.00 & 0.00 & 0.00 & 0.00 \\
\hline $\mathrm{CaO}$ & 0.00 & 0.00 & 0.18 & 0.09 & 0.25 & 0.00 & 0.00 & 0.00 & 0.29 \\
\hline $\mathrm{Na}_{2} \mathrm{O}$ & 2.10 & 2.45 & 1.92 & 2.37 & 2.37 & 2.50 & 2.52 & 2.28 & 2.50 \\
\hline $\mathrm{K}_{2} \mathrm{O}$ & 0.00 & 0.00 & 0.00 & 0.00 & 0.00 & 0.00 & 0.00 & 0.00 & 0.00 \\
\hline $\mathrm{P}_{2} \mathrm{O}_{5}$ & 0.00 & 0.00 & 0.00 & 0.00 & 0.00 & 0.00 & 0.00 & 0.00 & 0.00 \\
\hline $\mathrm{SO}_{3}$ & 0.00 & 0.00 & 0.00 & 0.00 & 0.00 & 0.00 & 0.00 & 0.00 & 0.00 \\
\hline Total & 100.76 & 102.46 & 101.29 & 100.96 & 101.91 & 101.97 & 100.96 & 100.85 & 101.38 \\
\hline
\end{tabular}

Tabela A4.10.3: Dados analiticos de cromita (CRT). 


\begin{tabular}{|c|c|c|c|c|c|c|c|c|c|c|c|c|c|c|c|c|c|c|c|c|}
\hline \begin{tabular}{|l|} 
Amostra \\
Analise \\
\end{tabular} & $\begin{array}{c}\text { G-2a } \\
16 / 1 E 01 \\
\end{array}$ & $\begin{array}{c}\mathrm{G}-2 \mathrm{a} \\
16 / 1 \mathrm{EO} 2 \\
\end{array}$ & \begin{tabular}{|l|} 
101 \\
$1012 \sqrt{E 05}$ \\
\end{tabular} & \begin{tabular}{|c|} 
G-37 \\
$29 / 1 E 1.1$ \\
\end{tabular} & \begin{tabular}{|c|}
3 \\
$22 / 3 / 701$ \\
\end{tabular} & $\begin{array}{c}\text { G-2a } \\
6 / 1 T 01\end{array}$ & $\begin{array}{l}\text { G-2a } \\
161 T 02\end{array}$ & $\frac{G-2 b}{04 / 03 / 24}$ & $\frac{G-2 b}{04103 / 25}$ & \begin{tabular}{|c|}
$G-29 c$ \\
$06 / 01 / 47$
\end{tabular} & \begin{tabular}{|c|} 
G-68 \\
$32 / 1 T / 1.1$ \\
\end{tabular} & \begin{tabular}{|c|}
$G-68$ \\
$32 / 1 T 1.2$ \\
\end{tabular} & $\frac{H C-3 a}{27 / 2 T 1.1}$ & \begin{tabular}{|c|}
$\mathrm{MC}-3 \mathrm{a}$ \\
$27 / 2 T 1.2$ \\
\end{tabular} & \begin{tabular}{|c|}
$G-37$ \\
$29 / 1 T 1.1$ \\
\end{tabular} & \begin{tabular}{|c|} 
G-37 \\
$29 / 4 T 2.1$
\end{tabular} & \begin{tabular}{|c|} 
G.37 \\
$29 / 2 T 1.1$ \\
\end{tabular} & \begin{tabular}{|c|}
$G-56$ \\
$35 / 2 T 1.1$ \\
\end{tabular} & \begin{tabular}{|c|}
$G-56$ \\
$35 / 2 T 2.1$ \\
\end{tabular} & \begin{tabular}{|c|} 
G-56 \\
$35 / 1 T 1.1$
\end{tabular} \\
\hline Mineral & $E P$ & $E P$ & $E P$ & EP & TIT & TII & TIT & TIT & TIT & TIT & TIT & $\pi T$ & TIT & $\frac{T T}{T T}$ & $\frac{2017}{\text { TIT }}$ & TIT & TाT & TIT & TT & TIT \\
\hline Local & $\mathrm{c}$ & $\mathrm{C}$ & C & $\mathrm{C}$ & 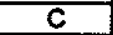 & C & C & $\mathrm{c}$ & B & C & Plm & $B(\theta x)$ & $\mathrm{C}$ & B & $\mathrm{c}$ & $\mathrm{C}$ & $\mathrm{C}$ & PIm & $\mathrm{PIm}$ & Pim \\
\hline Litotipo & MGF & MGF & ABG & ABET & GB & MGF & MGF & MGF & MGF & $G B$ & MGF & MGF & $A B$ & $\overline{A B}$ & ABET & ABET & ABET & ABET & ABET & ABET \\
\hline $\mathrm{SiO}_{2}$ & 27.99 & 26.02 & 30.85 & 34.61 & 31.09 & 30.47 & 30.54 & 29.97 & 30.61 & 30.18 & 30.11 & 30.15 & 30.47 & 30.39 & 31.69 & 31.37 & 30.68 & 30.47 & 30.76 & 3077 \\
\hline $\mathrm{THO}_{2}$ & 1.14 & 1.26 & 0.46 & 0.00 & 25.68 & 27.93 & 28.08 & 26.40 & 27.05 & 25.93 & 29.33 & 29.49 & 34.19 & 33.45 & 29.20 & 28.80 & 28.82 & 31.55 & 31.42 & 31.48 \\
\hline $\mathrm{Al}_{2} \mathrm{O}_{3}$ & 10.56 & 9.92 & 14.95 & 19.48 & 7.45 & 5.08 & 5.20 & 5.66 & 5.45 & 7.01 & 4.68 & 4.67 & 2.61 & 3.02 & 6.93 & 7.51 & 6.87 & 4.18 & 4.80 & 4.90 \\
\hline $\mathrm{Cr}_{2} \mathrm{O}_{3}$ & 0.65 & 0.57 & 1.02 & 0.74 & 0.00 & 0.00 & 0.00 & 0.04 & 0.04 & 0.00 & 0.00 & 0.00 & 0.00 & 0.00 & 0.00 & 0.00 & 0.00 & 0.00 & 0.00 & 0.00 \\
\hline $\mathrm{ZnO}$ & n.a. & n.a. & n.a. & n.a. & n.a. & n.a. & n.a. & 0.00 & 0.02 & ก.a. & n.a. & n.a. & n.a. & n.a. & n.a. & n.a. & n.a. & n.a. & n.a. & n.a. \\
\hline $\mathrm{FeO}$ & 12.34 & 42.30 & 6.84 & 8.66 & 1.40 & 2.53 & 2.32 & 2.48 & 2.53 & 1.43 & 1.93 & 1.97 & 0.67 & 0.74 & 1.15 & 0.69 & 0.75 & 0.71 & 0.46 & 0.31 \\
\hline $\mathrm{V}_{2} \mathrm{O}_{3}$ & 1.44 & 1.52 & 2.13 & 1.40 & 0.00 & 0.00 & 0.00 & n.a. & n.a. & n.a. & 0.00 & 0.00 & 0.00 & 0.00 & 0.00 & 0.00 & 0.00 & 0.00 & 0.00 & 0.00 \\
\hline $\mathrm{MnO}$ & 0.81 & 0.78 & 0.65 & 0.35 & 0.24 & 0.33 & 0.36 & 0.29 & 0.29 & 0.14 & 0.00 & 0.17 & 0.00 & 0.00 & 0.00 & 0.00 & 0.00 & 0.00 & 0.00 & 0.00 \\
\hline $\mathrm{MgO}$ & 0.00 & 0.00 & 0.00 & 0.00 & 0.13 & 0.00 & 0.13 & 0.05 & 0.04 & 0.00 & 0.00 & 0.00 & 0.00 & 0.00 & 0.00 & 0.00 & 0.00 & 0.00 & 0.00 & 0.00 \\
\hline NiO & 0.00 & 0.00 & 0.00 & 0.00 & 0.00 & 0.00 & 0.00 & 0.00 & 0.00 & n.a. & 0.00 & 0.00 & 0.00 & 0.00 & 0.00 & 0.00 & 0.00 & 0.00 & 0.00 & 0.00 \\
\hline $\mathrm{CaO}$ & 8.57 & 7.78 & 10.65 & 16.60 & 28.07 & 27.14 & 26.98 & 27.46 & 27.21 & 27.43 & 27.08 & 27.11 & 28.62 & 28.66 & 29.48 & 29.68 & 28.86 & 28.37 & 28.80 & 28.83 \\
\hline $\mathrm{Na}_{2} \mathrm{O}$ & 0.00 & 0.72 & 0.24 & 0.30 & 0.23 & 0.00 & 0.15 & 0.16 & 0.11 & 0.04 & 0.00 & 0.00 & 0.00 & 0.00 & 0.00 & 0.00 & 0.00 & 0.00 & $\frac{0.00}{0.0}$ & 0.00 \\
\hline $\mathrm{K}_{2} \mathrm{O}$ & 0.00 & 0.00 & 0.00 & 0.00 & 0.00 & 0.00 & 0.00 & 0.01 & 0.03 & 0.00 & 0.00 & 0.00 & 0.00 & 0.00 & 0.00 & 0.00 & 0.00 & 0.00 & 0.00 & 0.00 \\
\hline $\mathrm{P}_{2} \mathrm{O}_{5}$ & 0.00 & 5.42 & 0.00 & 0.00 & 0.47 & 0.71 & 0.74 & n.a. & n.a. & 0.00 & 0.50 & 0.55 & 0.00 & 0.00 & 0.00 & 0.00 & 0.00 & 0.00 & 0.00 & 0.00 \\
\hline $\mathrm{SO}_{3}$ & 3.36 & 3.36 & 0.00 & 0.00 & 0.45 & 0.13 & 0.18 & n.a. & n.a. & 0.00 & 0.00 & 0.00 & 0.00 & 0.00 & 0.00 & 0.00 & 0.00 & 0.00 & 0.00 & 0.00 \\
\hline 800 & n.a. & ก.a. & n.a. & n.a. & n.a. & n.a. & n.a. & n.a. & na. & 0.37 & n.a. & n.a. & n.a. & n.a. & n.a. & n.a. & n.a. & ก.a. & n.a. & n.a. \\
\hline$F$ & n.a. & n.a. & n.a. & n.a. & n.a. & n.a. & n.a. & n.a & n.a. & 0.69 & n. & n.a. & n.a. & n.a. & n.a. & n.a. & n.a. & ก.a. & n.a. & n.a. \\
\hline Total & 37.73 & 42.17 & 36.48 & 47.53 & 95.21 & 94.32 & 94,68 & 92.52 & 93.33 & 93.22 & 93.63 & 94.11 & 96.56 & 56.26 & 37.56 & 37.88 & 95.98 & 95.28 & 36.24 & 96.29 \\
\hline
\end{tabular}

Tabela A4.10.4: Dados analíticos de epidoto (EP) e titanita (TIT).

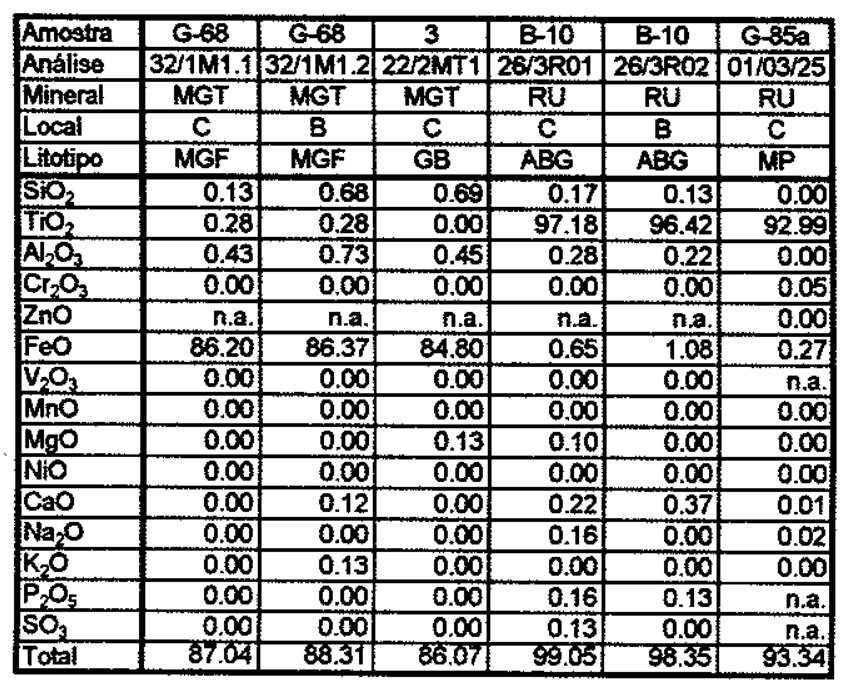

Tabela A4.10.5: Dados analíticos de magnetita (MGT) e rutilo (RU). 


\begin{tabular}{|c|c|c|c|c|c|c|c|c|c|c|c|c|c|c|c|c|c|c|c|c|}
\hline Amostra & M-5 & $M-5$ & $M-5$ & $M-5$ & M.5 & $\mathrm{M}-5$ & B-18 & B-18 & $\mathrm{B}-18$ & B-18 & B-18 & $B-11$ & $\mathrm{~B}-11$ & Aिstro 01 & Astro 01 & 2866 & 2861 & $286 \mathrm{~L}$ & $286 \mathrm{~L}$ & $286 \mathrm{~L}$ \\
\hline Análise & $03 / 01 / 01$ & $03 / 01 / 02$ & $03 / 02 / 06$ & $03 / 02 / 07$ & $03 / 03 / 09$ & $03 / 04 / 15$ & $12 / 1 \mathrm{~T} 01$ & $12 / 1 \mathrm{TO2}$ & $12 / 2 T 01$ & $12 / 2 \mathrm{TO2}$ & $12 / 3 \mathrm{TO}$ & $2 / 5101$ & $2 / 5 \mathrm{TO} 2$ & 40/3M1.1 & $40 / 3 M 1.2$ & 1 & 2 & 3 & 4 & 5 \\
\hline Mineral & KY & $\mathrm{KY}$ & $K \gamma$ & $K Y$ & $K Y$ & $\mathrm{KY}$ & TC & TC & TC & TC & TC & TC & TC & $M U$ & $\mathrm{MU}$ & MU & MU & $\mathrm{MU}$ & MU & MU \\
\hline Local & c & B & c & C & c & $\mathrm{C}$ & $\mathrm{C}$ & $\mathrm{C}$ & PIm & PIm & Pim & $\mathrm{C}$ & $\mathrm{C}$ & $\mathrm{c}$ & $\mathrm{c}$ & Pln & Pln & Att. Caol. & All Caol. & Aft. Caol. \\
\hline Lifotipo & MP & MP & MP & MP & $M P$ & MP & UM & UM & UM & UM & $\mathrm{UM}$ & UM & UM & $\overline{P G D}$ & PGD & MP & $M P$ & MP & $\mathrm{MP}$ & MP \\
\hline $\mathrm{SiO}_{2}$ & 37.64 & 37.18 & 37.53 & 36.92 & 37.40 & 38.13 & 60.79 & 62.21 & 61.43 & 60.90 & 61.41 & 60.55 & 61.76 & 49.90 & 49.50 & 47.06 & 46.84 & 44.55 & 45.35 & 44.60 \\
\hline $\mathrm{TiO}_{2}$ & 0.04 & 0.03 & 0.05 & 0.02 & 0.01 & 0.06 & 0.00 & 0.00 & 0.00 & 0.00 & 0.00 & 0.00 & 0.00 & 0.00 & 0.00 & 0.06 & 0.05 & 0.00 & 0.00 & 0.02 \\
\hline $\mathrm{A}_{2} \mathrm{O}_{3}$ & 62.96 & 63.58 & 63.41 & 63.25 & 63.11 & 63.28 & 0.53 & 0.65 & 0.84 & 0.74 & 0.96 & 1.31 & 0.68 & 39.64 & 40.34 & 38.31 & 38.07 & 41.00 & 41.32 & 40.13 \\
\hline $\mathrm{Cr}_{2} \mathrm{O}_{3}$ & 0.08 & 0.15 & 0.11 & 0.09 & 0.02 & 0.04 & 0.00 & 0.00 & 0.00 & 0.00 & 0.00 & 0.17 & 0.00 & 0.00 & 0.00 & n.a. & n.a. & n.a. & n.a. & ก.a. \\
\hline $\mathrm{ZnO}$ & 0.00 & 0.04 & 0.01 & 0.00 & 0.00 & 0.00 & n.a. & n.a. & n.a. & n.a. & n.a. & n.a. & n.a. & n.a. & n.a. & n.a. & n.a. & n.a. & n.a. & n.a. \\
\hline $\mathrm{FeO}$ & 0.23 & 0.32 & 0.29 & 0.33 & 0.30 & 0.26 & 3.11 & 3.22 & 3.36 & 3.05 & 3.23 & 3.46 & 3.31 & 1.20 & 0.90 & 0.28 & 0.26 & 0.22 & 0.23 & 0.21 \\
\hline $\mathrm{V}_{2} \mathrm{O}_{3}$ & n.a. & n.a. & n.a. & n.a. & n.a. & n.a. & 0.00 & 0.00 & 0.00 & 0.00 & 0.00 & 0.00 & 0.00 & 0.00 & 0.00 & n.a. & n.a. & n.a. & n.a. & n.a. \\
\hline Mno & 0.00 & 0.01 & 0.00 & 0.00 & 0.00 & 0.00 & 0.00 & 0.00 & 0.00 & 0.00 & 0.00 & 0.00 & 0.00 & 0.00 & 0.00 & 0.03 & 0.02 & 0.01 & 0.00 & 0.00 \\
\hline MgO & 0.00 & 0.02 & 0.00 & 0.02 & 0.02 & 0.02 & 27.93 & 28.96 & 28.47 & 27.74 & 29.03 & 27.65 & 28.38 & 0.18 & 0.15 & 0.33 & 0.26 & 0.12 & 0.80 & 0.25 \\
\hline $\mathrm{CaO}$ & 0.00 & 0.01 & 0.00 & 0.00 & 0.01 & 0.00 & 0.00 & 0.00 & 0.00 & 0.00 & 0.00 & 0.00 & 0.09 & 0.00 & 0.10 & ก.a. & n.a. & n.a. & n.a. & n.a. \\
\hline $\mathrm{Na}_{2} \mathrm{O}$ & 0.00 & 0.00 & 0.00 & 0.01 & 0.00 & 0.00 & 0.18 & 0.31 & 0.14 & 0.29 & 0.37 & 0.38 & 0.26 & 1.01 & 1.37 & n.a. & n.a. & n.a. & n.a. & ก.a. \\
\hline $\mathrm{K}_{2} \mathrm{O}$ & 0.01 & 0.00 & 0.00 & 0.02 & 0.01 & 0.00 & 0.00 & 0.00 & 0.00 & 0.00 & 0.00 & 0.00 & 0.00 & 6.79 & 6.72 & 9.70 & 9.64 & 4.70 & 3.47 & 2.60 \\
\hline $\mathrm{P}_{2} \mathrm{O}_{5}$ & n.a. & n.a. & n.a. & n.a. & n.a. & n.a. & 0.00 & 0.00 & 0.00 & 0.00 & 0.00 & 0.00 & 0.00 & 0.00 & 0.00 & n.a. & n.a. & n.a. & n.a. & ก.a. \\
\hline $\mathrm{SO}_{3}$ & n.a. & ก.a. & ก.a. & n.a. & ก.a. & n.a. & 0.00 & 0.00 & 0.00 & 0.00 & 0.00 & 0.00 & 0.00 & 0.00 & 0.00 & n.a. & n. & ก.a. & n.a. & n.a. \\
\hline$F$ & n.a. & n.a. & ก.a. & n.a. & n.a. & n.a. & n.a. & n.a. & n.a. & n.a. & n.a. & n.a. & n.a. & n.a. & n.a. & 0.04 & 0.06 & 0.02 & 0.02 & 0.02 \\
\hline Total & 100.96 & 101.34 & 101.40 & 100.66 & 100.88 & 101.79 & 92.54 & 95.35 & 94.24 & 92.72 & 95.00 & 93.52 & 94.48 & 98.72 & 99.08 & 95.81 & 95.20 & 90.62 & 91.19 & 87.83 \\
\hline
\end{tabular}

Tabela A4.10.6: Dados analíticos de cianitas (KY), talco (TC) e muscovita (MU).

\begin{tabular}{|c|c|c|c|}
\hline Amostra & 32.20 & 32.20 & 32.20 \\
\hline Análise & $06 / 01 / 43$ & $06 / 01 / 44$ & $06 / 01 / 45$ \\
\hline Mineral & ZEOL & ZEOL & ZEOL \\
\hline Local & B do veio & C do veio & $B$ do veio \\
\hline Litotipo & ABET & ABET & ABET \\
\hline $\mathrm{SiO}_{2}$ & 58.55 & 50.71 & 60.69 \\
\hline $\mathrm{TiO}_{2}$ & 0.00 & 0.03 & 0.00 \\
\hline $\mathrm{Al}_{2} \mathrm{O}_{3}$ & $\$ 7.53$ & 21.52 & 16.74 \\
\hline $\mathrm{Cr}_{2} \mathrm{O}_{3}$ & 0.00 & 0.00 & 0.02 \\
\hline $\mathrm{FeO}$ & 0.02 & 0.07 & 0.00 \\
\hline MnO & 0.00 & 0.00 & 0.03 \\
\hline Mgo & 0.27 & 0.00 & 0.02 \\
\hline $\mathrm{CaO}$ & 8.08 & 11.10 & 6.80 \\
\hline $\mathrm{Na}_{2} \mathrm{O}$ & 0.36 & 0.00 & 0.05 \\
\hline $\mathrm{K}_{2} \mathrm{O}$ & 0.58 & 0.66 & 1.36 \\
\hline $\mathrm{BaO}$ & 0.04 & 0.00 & 0.10 \\
\hline$F$ & 0.01 & 0.00 & 0.00 \\
\hline Total & 85.50 & 84.10 & 85.82 \\
\hline
\end{tabular}

Tabela A4.10.7: Dados analíticos de zeólitas (ZEOL) de um micro-veio em ABET.

Nota: $B$ do veio $=$ borda do veio; $C$ do veio $=$ centro do veio. 


\section{ANEXo 5: Cálculos Geotermobarométricos}

Abreviações: $\mathrm{MP}=$ Metapelitos da SVS; $\mathrm{ABG}=$ Anfibolitos Metabásicos com Granada da SVS; GB = Metagranitóides Borrachudos; MGF = Metagranitóides Foliados com Fluorita. 


\begin{tabular}{|c|c|c|c|c|c|c|c|c|c|c|c|}
\hline $\begin{array}{l}\text { GEOTERMOMETROS } \\
\text { (bar) }=6000 \\
\text { Granada-Biotita }\end{array}$ & & & & & & & & & & & \\
\hline Amostras & G-52c (C) & $G-52 c(B)$ & $G-52 c(C)$ & $G-52 c(B)$ & G-52c (B) & $\mathrm{G}-52 \mathrm{C}(\mathrm{B})$ & $G-89(C)$ & $G-89(B)$ & $G-89(C)$ & G-89(B) & $G-166 b(C)$ \\
\hline Análises (Gr) & $2 / 2 / 48(\mathrm{Gr})$ & $2 / 2 / 49(\mathrm{Gr})$ & $2 / 1 / 32(\mathrm{Gr})$ & $2 / 1 / 31(\mathrm{Gr})$ & $2 / 2 / 34(\mathrm{Gr})$ & $6 / 1 / 7(\mathrm{Gr})$ & $2 / 1 / 64(\mathrm{Gr})$ & $2 / 1 / 63(\mathrm{Gr})$ & $2 / 2 / 66(\mathrm{GT})$ & $2 / 2 / 67(\mathrm{Gr})$ & $4 / 1 / 48(\mathrm{Bt})$ \\
\hline Análises (Bt) & $2 / 1 / 29(\mathrm{Bt})$ & $2 / 1 / 30(\mathrm{~B} t)$ & $2 / 1 / 29(\mathrm{Bt})$ & $2 / 1 / 30(\mathrm{BT})$ & $2 / 2 / 35(\mathrm{Bt})$ & $6 / 1 / 8(B t)$ & $2 / 1 / 61(\mathrm{Bt})$ & $2 / 1 / 62(\mathrm{Bt})$ & $2 / 2 / 69(\mathrm{Bt})$ & $2 / 2 / 68(\mathrm{Bt})$ & $4 / 1 / 51(\mathrm{Bt})$ \\
\hline Litotipo & MP & $M P$ & MP & MP & MP & $M P$ & MP & $\mathrm{MP}$ & $\mathrm{MP}$ & MP & GB \\
\hline Ferry \& Spear, 1978 (I) & 467.0 & 494.0 & 507 & 423 & 429 & 365 & 518 & 495 & 539 & 496 & 508 \\
\hline indares \& Martignote, $1985^{1}$ (1) & 510.0 & 530.0 & 547.0 & 445.0 & 449.0 & 365.0 & 468.0 & 451.0 & 488.0 & 453.0 & 612.0 \\
\hline Indares \& Martignole, $1985^{2}(1)$ & 528.0 & 548.0 & 566.0 & 460.0 & 472.0 & 388.0 & 502.0 & 485.0 & 527.0 & 488.0 & 647.0 \\
\hline Thompson, $1976(\mathrm{l})$ & 507.0 & 529.0 & 543.0 & 473.0 & 478.0 & 422.0 & 552.0 & 533.0 & 569.0 & 534.0 & 544.0 \\
\hline Holdaway \& Lee, 1977 (1) & 500.0 & 520.0 & 530.0 & 468.0 & 472.0 & 422.0 & 538.0 & 521.0 & 553.0 & 522.0 & 530.0 \\
\hline Battacharya ot al., $1992^{1}$ (i) & 562.0 & 572.0 & 580.0 & 533.0 & 529.0 & 498.0 & 572.0 & 560.0 & 585.0 & 564.0 & 528.0 \\
\hline Battacharya et al., $1992^{2}$ (i) & 601.0 & 605.0 & 614.0 & 575.0 & 560.0 & 542.0 & 600.0 & 590.0 & 612.0 & 596.0 & 497.0 \\
\hline Perchuk \& Lavrenteva, $1983^{4}$ (I) & 527.0 & 543.0 & 543.0 & 491.0 & 495.0 & 451.0 & 549.0 & 536.0 & 562.0 & 537.0 & 543.0 \\
\hline Hoinkes, 1986 (1) & 526.0 & 551.0 & 568.0 & 472.0 & 484.0 & 412.0 & 545.0 & 522.0 & 569.0 & 530.0 & 575.0 \\
\hline Ganguly, $1979(1)$ & 536.0 & 558.0 & 572.0 & 481.0 & 492.0 & 423.0 & 547.0 & 524.0 & 570.0 & 531.0 & 659.0 \\
\hline Goldman \& Albeo, $1977^{1}$ (i) & 481.0 & 500.0 & 507.0 & 440.0 & 484.0 & 424.0 & 481.0 & 468.0 & 494.0 & 468.0 & 411.0 \\
\hline $\operatorname{Ln} \mathrm{Kd}(\mathrm{Gr}-\mathrm{Bi})(\mathrm{ll})$ & 21 & 2.0 & 2.0 & 2.3 & 2.3 & 2.6 & 1.9 & 2.0 & 1.9 & 2.0 & 20 \\
\hline Thompson, 1976 (il) & 513.0 & 534.9 & 542.5 & 472.8 & 477.9 & 422.0 & 551.8 & 533.1 & 568.9 & 534.1 & 543.5 \\
\hline Goldman \& Albee, $1977^{1}$ (il) & 465.3 & 479.7 & 484.7 & 439.0 & 442.4 & 405.9 & 490.8 & 478.5 & 502.1 & 479.1 & 485.3 \\
\hline Goldman \& Albee, $1977^{2}$ (il) & 479.8 & 500.4 & 507.9 & 429.7 & 484.5 & 413.7 & 481.0 & 467.7 & 494.0 & 467.2 & 410.7 \\
\hline Holdaway \& Lee, 1977 (II) & 503.4 & 522.8 & 529.5 & 467.7 & 472.2 & 421.8 & 537.7 & 521.3 & 552.7 & 522.1 & 530.4 \\
\hline Ferty \& Spear, 1978 (II) & 470.8 & 497.4 & 506.7 & 423.3 & 429.2 & 364.8 & 518.1 & 495.3 & 539.4 & 496.4 & 507.9 \\
\hline Lavrent'eva \& Perchuk, 1981 (II) & 536.0 & 552.6 & 558.2 & 505.2 & 509.2 & 464.9 & 565.1 & 551.3 & 577.7 & 552.0 & 559.0 \\
\hline Hodges \& Spear, 1982 (il) & 501.7 & 526.3 & 538.1 & 445.2 & 462.5 & 389.7 & 530.5 & 508.0 & 552.6 & 512.6 & 541.9 \\
\hline Pigage \& Greenwood, 1982 (II) & 537.5 & 561.1 & 572.9 & 466.4 & 492.9 & 408.4 & 546.8 & 523.7 & 570.2 & 530.4 & 658.8 \\
\hline Perchuk \& Lavrent'eva, $1983^{\dagger}$ (II) & 520.9 & 537.1 & 542.7 & 490.6 & 494.5 & 451.1 & 549.4 & 535.8 & 561.8 & 536.5 & 543.4 \\
\hline Ganguly \& Saxena, 1984 (il) & 426.4 & 424.6 & 439.8 & 385.3 & 343.8 & 3226 & 460.2 & 449.1 & 490.8 & 465.1 & 653.0 \\
\hline Ganguly \& Saxena, 1984 (ii) & 422.3 & 420.7 & 436.1 & 383.0 & 340.8 & 320.7 & 458.3 & 447.3 & 488.7 & 463.2 & 633.9 \\
\hline Perchuk et al., 1985 (ii) & 560.1 & 573.8 & 582.6 & 518.6 & 537.0 & 482.9 & 565.2 & 552.0 & 578.5 & 557.1 & 586.6 \\
\hline Indares \& Martignole, $1985^{1}$ (II) & 494.5 & 519.2 & 530.6 & 438.8 & 442.3 & 369.4 & 485.4 & 468.6 & 508.4 & 470.3 & 517.3 \\
\hline Indares \& Martignole, $1985^{2}$ (II) & 513.5 & 538.2 & 547.3 & 445.2 & 449.6 & 365.3 & 468.5 & 451.3 & 488.4 & 453.2 & 612.1 \\
\hline Williams \& Grembling, 1990 (II) & 533.9 & 554.0 & 567.8 & 465.8 & 479.6 & 404.3 & 550.4 & 528.0 & 576.5 & 536.8 & 671.1 \\
\hline Dasgupta et al., 1991 (ii) & 553.0 & 584.5 & 586.3 & 503.1 & 511.8 & 431.2 & 498.1 & 479.0 & 499.1 & 473.2 & 406.9 \\
\hline Battacharya et al., $1992^{1}$ (II) & 520.8 & 536.5 & 542.5 & 493.6 & 487.1 & 447.4 & 530.4 & 517.9 & 540.6 & 519.1 & 416.2 \\
\hline Battacharya et al., $1992^{2}$ (ii) & 518.7 & 534.1 & 537.9 & 500.1 & 475.9 & 445.5 & 510.5 & 500.5 & 516.4 & 500.1 & 266.0 \\
\hline
\end{tabular}

Tabela A5.1: Resultado dos cálculos geotermométricos, utilizando-se planilhas I - de Rettinger (1994; dados nåo publicados) e II - de Reche e Martinez (1996).

Simbolos: $C=$ centros; e $B=$ bordas de pares de minerais. 


\begin{tabular}{|c|c|c|c|c|c|c|c|}
\hline $\begin{array}{l}\text { GEOTERMOMETROS } \\
\text { P(bar) }=6000 \\
\text { Granada-Blotta }\end{array}$ & & & & & & & \\
\hline Amostras & G-166b(B) & $G-166 b(B)$ & $G-166 b(C)$ & G-113(C) & $\mathrm{G}-113(\mathrm{~B})$ & $G-113(C)$ & $G-113(B)$ \\
\hline Simbolos & $4 / 1 / 50(\mathrm{Gr})$ & $4 / 1 / 60(\mathrm{Gr})$ & $4 / 1 / 61(\mathrm{Gr})$ & $5 / 3 / 12(\mathrm{Gr})$ & $5 / 3 / 13(\mathrm{Gr})$ & $5 / 3 / 16(\mathrm{Gr})$ & $5 / 3 / 17(\mathrm{Gr})$ \\
\hline & $4 / 1 / 49(B t)$ & $4 / 1 / 62(\mathrm{Bt})$ & $4 / 1 / 63(\mathrm{Bt})$ & $5 / 3 / 15(\mathrm{Bt})$ & $5 / 3 / 14(\mathrm{Bt})$ & $5 / 3 / 19(\mathrm{Bt})$ & $5 / 3 / 18(B t)$ \\
\hline Litotipo & GB & GB & GB & $\mathrm{GB}$ & $\mathrm{GB}$ & $\mathrm{GB}$ & $\mathrm{GB}$ \\
\hline Ferry \& Spear, $1978(1)$ & 517 & 454 & 452 & 449 & 494 & 458 & 537 \\
\hline Indares \& Martignole, $1985^{4}$ (i) & 619.0 & 543.0 & 543.0 & 586.0 & 637.0 & 565.0 & 669.0 \\
\hline Indares \& Martignole, $1985^{2}$ (i) & 660.0 & 586.0 & 580.0 & 621.0 & 676.0 & 618.0 & 714.0 \\
\hline Thompson, $1976(1)$ & 551.0 & 499.0 & 497.0 & 495.0 & 532.0 & 502.0 & 568.0 \\
\hline Holdaway \& Lee, 1977 (I) & 537.0 & 491.0 & 489.0 & 488.0 & 520.0 & 494.0 & 551.0 \\
\hline Battacharya et al., $1992^{1}(1)$ & 532.0 & 486.0 & 489.0 & 561.0 & 598.0 & 565.0 & 627.0 \\
\hline Battacharya et al., $1992^{2}(1)$ & 503.0 & 449.0 & 453.0 & 550.0 & 597.0 & 554.0 & 630.0 \\
\hline Perchuk \& Lavrent'eva, $1983^{1}$ (1) & 549.0 & 510.0 & 509.0 & 508.0 & 535.0 & 513.0 & 561.0 \\
\hline Hoinkes, 1986 (l) & 583.0 & 513.0 & 517.0 & 548.0 & 605.0 & 558.0 & 665.0 \\
\hline Ganguly, $1979(1)$ & 673.0 & 601.0 & 598.0 & 665.0 & 726.0 & 691.0 & 793.0 \\
\hline Goldman \& Albee, $1977^{1}(1)$ & 424.0 & 396.0 & 387.0 & 426.0 & 463.0 & 458.0 & 495.0 \\
\hline $\operatorname{Ln} \mathrm{Kd}(\mathrm{Gr}-\mathrm{Bi})(\mathrm{II})$ & 1.9 & 2.2 & 2.2 & 22 & 2.0 & 2.2 & 1.9 \\
\hline Thompson, 1976 (II) & 551.0 & 497.3 & 498.8 & 495.2 & 525.5 & 501.9 & 567.4 \\
\hline Goldman \& Albeo, $1977^{1}$ (II) & 490.3 & 455.0 & 456.0 & 453.6 & 477.8 & 458.1 & 501.1 \\
\hline Goldman \& Albee, $1977^{2}$ (ii) & 423.4 & 384.8 & 394.7 & 421.9 & 457.5 & 452.5 & 488.1 \\
\hline Holdaway \& Lee, 1977 (II) & 537.0 & 489.5 & 490.9 & 487.6 & 517.2 & 493.6 & 551.4 \\
\hline Ferry \& Spear, 1978 (II) & 517.1 & 452.1 & 453.9 & 449.6 & 490.6 & 457.6 & 537.5 \\
\hline Lavient'eva \& Perchuk, 1981 (H) & 564.5 & 524.1 & 525.3 & 522.5 & 547.9 & 527.6 & 576.6 \\
\hline Hodges \& Spear, 1982 (II) & 549.6 & 488.1 & 486.8 & 553.5 & 598.0 & 563.2 & 643.7 \\
\hline Pigage \& Greenwood, 1982 (II) & 671.4 & 593.0 & 597.6 & 657.4 & 714.6 & 683.3 & 783.4 \\
\hline Perchuk \& Lavrent'eva, $1983^{1}$ (11) & 548.9 & 509.2 & 510.3 & 507.6 & 541.0 & 512.7 & 560.7 \\
\hline Ganguly \& Saxena, 1984 (II) & 664.4 & 588.1 & 590.9 & 597.3 & 647.6 & 610.8 & 705.9 \\
\hline Ganguly \& Saxena, 1984 (II) & 644.2 & 571.1 & 5725 & 587.9 & 637.2 & 598.7 & 692.0 \\
\hline Perchuk et al., 1985 (II) & 590.1 & 555.1 & 552.1 & 643.1 & 667.5 & 650.4 & 699.6 \\
\hline Indares \& Martignode, $1985^{1}$ (II) & 524.4 & 464.3 & 463.2 & 519.2 & 558.3 & 500.4 & 577.0 \\
\hline Indares \& Martignole, $1985^{2}$ (II) & 619.3 & 543.7 & 543.5 & 586.6 & 634.0 & 566.0 & 670.1 \\
\hline Williams \& Grembling, 1990 (II) & 683.4 & 602.9 & 606.2 & 674.7 & 734.5 & 698.4 & 804.0 \\
\hline Dasgupta et al. 1991 (ii) & 401.9 & 354.3 & 341.0 & 416.0 & 448.1 & 382.4 & 474.6 \\
\hline Battacharya et al., $1992^{1}$ (II) & 418.5 & 381.3 & 376.5 & 416.7 & 445.4 & 409.8 & 462.4 \\
\hline Battacharya et al., $1992^{2}$ (II) & 265.0 & 233.5 & 224.4 & 264.4 & 290.0 & 245.3 & 296.5 \\
\hline
\end{tabular}

Tabela A5.1: Resultado dos cálculos geotermométricos, utilizando-se planilhas I - de Rettinger (1994; dados não publicados) e II - de Reche e Martinez (1996). Simbolos: $C=$ centros; e $B=$ bordas de pares de minerais. 


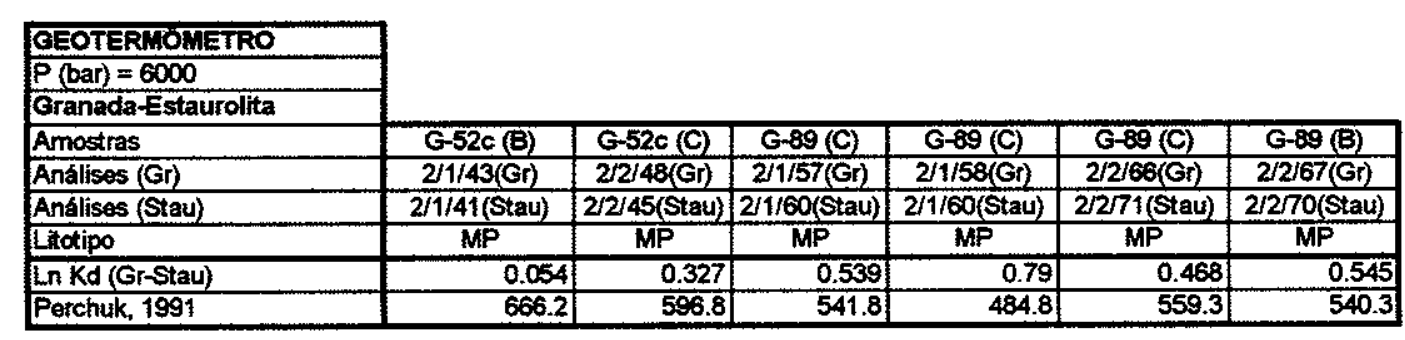

\begin{tabular}{|c|c|c|c|c|c|c|c|}
\hline $\begin{array}{l}\text { GEOTERMONMETRO } \\
\text { P (bar) = } 6000 \\
\text { Granada-Anfibólio }\end{array}$ & & & & & & & \\
\hline Amostras & $G-52 c(C)$ & $\mathrm{G}-52 \mathrm{c}(\mathrm{B})$ & C-1a(C) & C-ta (B) & $\mathrm{C}-1 \mathrm{a}(\mathrm{C})$ & $\mathrm{C}-1 \mathrm{e}(\mathrm{C})$ & $\mathrm{C}-1 \mathrm{a}(\mathrm{B})$ \\
\hline Análises (G:) & $2 / 2 / 48(G)$ & $2 / 1 / 43\left(G_{r}\right)$ & $3 / 1 / 50(G)$ & $3 / 1 / 51(\mathrm{Gr})$ & $3 / 2 / 57(\mathrm{Gr})$ & $3 / 460(\mathrm{Gr})$ & $3 / 4 / 61(G r)$ \\
\hline Análises (Anf) & $2 / 2 / 51$ (Anf) & $2 / 1 / 44$ (Ann) & 3/4/53(Ant) & 3/1/52(Anf) & 3/2/58(Anf) & 3/4/63(Ant) & $3 / 4 / 62$ (Ant) \\
\hline Litotipo & $\mathrm{MP}$ & MP & $A B G$ & ABG & $A B G$ & ABG & ABG \\
\hline Graham \& Powell, 1984 & 1.84 & 1.64 & 1.45 & $\begin{array}{r}1.53 \\
\end{array}$ & 1.46 & 1.46 & 1.26 \\
\hline Ln Kd (GI-Ant) & 468 & 483 & 602 & 593 & 609 & 599 & 676 \\
\hline
\end{tabular}

\begin{tabular}{|c|c|c|c|c|c|c|c|c|}
\hline \multirow{2}{*}{$\begin{array}{l}\text { GEOTERMOMETRO } \\
\text { P(bar) }=6000 \\
\text { Dois Feldspatos }\end{array}$} & & & & & & & & \\
\hline & & & & & & & & \\
\hline Amostra & $G-26(C)$ & G-26(B) & $\mathrm{G}-26(\mathrm{C})$ & $\mathrm{G}-166 \mathrm{~b}(\mathrm{C})$ & $\mathrm{G}-166 \mathrm{~b}(\mathrm{~B})$ & $\mathrm{G}-16 \mathrm{bb}(\mathrm{C})$ & $\mathrm{G}=113(\mathrm{C})$ & $G-113(B)$ \\
\hline Análises (Pla) & $3 / 1 / 83(\mathrm{Pla})$ & 6/2/29(P/a) & $6 / 2 / 30(\mathrm{Pla})$ & $4 / 1 / 55$ (Pla) & $4 / 1 / 54$ (Pla) & $4 / 2 / 59(\mathrm{Pla})$ & $5 / 4 / 7(\mathrm{Pla})$ & 5/1/6(Pla) \\
\hline Análises (Kf) & $3 / 1 / 82(\mathrm{~K} f)$ & $6 / 2 / 27(\mathrm{Kf})$ & $6 / 2 / 28(\mathrm{Kf})$ & $4 / 1 / 53(\mathrm{~K})$ & $4 / 1 / 52(\mathrm{~K})$ & $4 / 2 / 58(\mathrm{~K})$ & $5 / 4 / 9(K f)$ & $5 / 1 / 8(\mathrm{Kf})$ \\
\hline Litotipo & $G B$ & $\mathrm{~GB}$ & $\mathrm{~GB}$ & $\mathrm{~GB}$ & $G B$ & $\mathrm{~GB}$ & $\mathrm{~GB}$ & $\mathrm{~GB}$ \\
\hline Nekvazil \& Bumham, 1987 & 376.0 & & 413.2 & 364.0 & 330.1 & 314.5 & 427.5 & 418.7 \\
\hline Elkins \& Grove, 1990 & 271.7 & 319.9 & 309.3 & 296.8 & 260.8 & 330.5 & 425.4 & 323.0 \\
\hline Lindstey \& Nekvasil, 1989 & 265.8 & 313.5 & 289.3 & 280.2 & 254.8 & 309.2 & 305.7 & 291.9 \\
\hline Ghiorso, 1984 & 346.0 & 314.7 & & 394.4 & 283.2 & 393.2 & 396.6 & 390.3 \\
\hline Fuhmman \& Lindsley, 1988 & & 327.8 & 297.3 & 289.8 & 253.2 & 316.3 & 310.9 & 307.1 \\
\hline
\end{tabular}

\begin{tabular}{|c|c|c|c|c|c|c|c|c|c|c|c|c|c|}
\hline $\begin{array}{l}\text { CEOTERMOMETRO } \\
P \text { (bar) }=6000 \\
\text { Dois Feldspatos }\end{array}$ & & & & & & & & & & & & & \\
\hline Amostra & $G-2 b(C)$ & $\mathrm{G}-2 \mathrm{~b}(\mathrm{~B})$ & $G-2 b(C)$ & $G-2 b(B)$ & $G-2 b(C)$ & $G-2 b(B)$ & G11a(C) & $G-11 a(B)$ & $G-11 a(C)$ & G-t1a (B) & G-11a (C) & G-11a (B) & NE-31-06 \\
\hline Análises (Pla) & 4/3/26(Pla) & 4/3/27(Pia) & 4/2/44(Pla) & 4/2/45(Pla) & $6 / 3 / 48(\mathrm{Pla})$ & 6/3/19(Pla) & $5 / 1 / 8(\mathrm{Pla})$ & $5 / 1 / 9(\mathrm{Pla})$ & $5 / 2 / 13$ (Pla) & $5 / 2 / 12(\mathrm{Pla})$ & 5/2/17(Pla) & $5 / 2 / 16(\mathrm{Pla})$ & $3 / 3 / 28(\mathrm{Pla})$ \\
\hline Análises (Ko) & $4 / 3 / 29(\mathrm{~K})$ & $4 / 3 / 28(\mathrm{Kf})$ & $4 / 2 / 43(\mathrm{~K})$ & $4 / 2 / 42(K f)$ & $6 / 3 / 20(\mathrm{~K})$ & $6 / 3 / 21(\mathrm{Kf})$ & $5 / 1 / 19(\mathrm{~K})$ & $5 / 1 / 10(\mathrm{KS})$ & $5 / 2 / 15(\mathrm{Ki})$ & $5 / 2 / 44(\mathrm{KN})$ & $5 / 2 / 15(\mathrm{KI})$ & $5 / 2 / 44(\mathrm{~K})$ & $3 / 3 / 27(\mathrm{~K})$ \\
\hline Litotipo & MGF & MGF & MGF & MGF & MGF & MGF & MGF & MGF & MGF & MGF & MGF & MGF & UMM \\
\hline Nekvazil \& Burnham, 1987 & 394.0 & 362.9 & 382.2 & 378.8 & 444.2 & 378.4 & 418.5 & 399.0 & 393.8 & 384.1 & 371.0 & 365.8 & 394.4 \\
\hline Elkins \& Grove, 1990 & 315.4 & 306.2 & 323.7 & 299.3 & 333.5 & 287.6 & 321.3 & 321.5 & 323.1 & 313.6 & 327.8 & 316.9 & 282.0 \\
\hline Lindśsley \& Nekvasil, 1988 & 301.5 & 296.7 & 320.3 & 299.0 & 330.0 & 282.0 & 308.2 & 314.0 & 311.4 & 307.3 & 321.2 & 310.8 & \\
\hline Ghiorso, 1984 & 414.3 & 363.7 & 388.1 & 379.1 & 426.9 & 348.0 & 408.1 & 397.7 & 387.8 & 387.3 & 371.4 & 366.1 & 338.6 \\
\hline Fuhrman \& Lindsfey, 1988 & 302.1 & 304.1 & 317.5 & 291.6 & 331.6 & 279.7 & 313.0 & 312.2 & 317.8 & 305.5 & 316.9 & 307.1 & 336.4 \\
\hline
\end{tabular}

Tabela A5.2: Resultado dos cálculos geotermométricos utilizando-se as planithas de Reche e Martinez (1996) e Wen Nekvasil (1994). Símbolos: $C=$ centros; e $B=$ bordas de pares de minerais. 


\begin{tabular}{|c|c|c|c|c|c|c|c|c|c|c|c|c|}
\hline \multicolumn{13}{|l|}{$\begin{array}{l}\text { GEOBAROMETROS } \\
T=600^{\circ} \mathrm{C} \\
\text { Gr-Als-Qtz-Plg (GASP) }\end{array}$} \\
\hline Amostras & $G-165(C)$ & $G-1660(B)$ & $G-1660(C)$ & G-1660(B) & G-106 (C) & $G-113(C)$ & G-113(B) & $G-113(C)$ & $G-113(B)$ & C-1a(C) & C-1a(C) & $\mathrm{C}-1 \mathrm{a}(\mathrm{C})$ \\
\hline Análises (Gr) & $4 / 1 / 46 \mathrm{Gr})$ & $4 / 1 / 47(\mathrm{Gr})$ & $4 / 1 / 48(\mathrm{Gr})$ & $4 / 1 / 47(\mathrm{Gr})$ & $4 / 1 / 61(\mathrm{Gr})$ & $5 / 312(\mathrm{GT})$ & $5 / 3 / 13(\mathrm{Gr})$ & $5 / 3 / 6(\mathrm{Gr})$ & $53 / 17(\mathrm{Gr})$ & $3 / 150(\mathrm{Gr})$ & $3 / 257(\mathrm{Gr})$ & $3 / 4 / 60(\mathrm{Gr})$ \\
\hline Análises (Pla) & $4 / 15$ (Pla) & $41 / 54(\mathrm{Pla})$ & $4 / 155(\mathrm{Pla})$ & $4 / 154(\mathrm{Pla})$ & $4 / 159$ (Pla) & $5 / 1 / 7(\mathrm{Pla})$ & $5 / 1 / 6$ (Pla) & $5 / 17$ (Pla) & $5 / 1 / 6(\mathrm{Pla})$ & $3 / 54(\mathrm{Pla})$ & $33 \mathrm{se}$ (Pla) & $3 / 4 / 64(\mathrm{Pla})$ \\
\hline Litotipo & $\mathrm{GB}$ & $\mathrm{GB}$ & $\mathrm{GB}$ & GB & GB & $\mathrm{GB}$ & $\mathrm{GB}$ & GB & GB & $A B G$ & $A B G$ & $A B G$ \\
\hline GASP (1) & - & - & - & - & - & - & 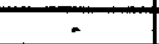 & - & - & - & - & - \\
\hline Hodges \& Spear, $1982(1)$ & 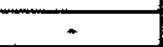 & - & $=$ & - & - & - & - & - & $\tau$ & - & - & - \\
\hline Hodges \& Crowley, $1985(1)$ & - & - & $=$ & - & - & - & - & - & $=$ & - & - & - \\
\hline Newton \& Haselton, 1981 (il) & 12618.9 & 25642.1 & 12713.2 & 25642.1 & 12778.5 & 15444.4 & 15787.5 & 15474.2 & 15648.7 & 8618.0 & 8275.51 & 8942.0 \\
\hline Newton \& Haselton, 1981 (ii) & 13281.3 & 27159.8 & 13383.7 & 27159.8 & 13453.4 & 16291.4 & 16556.9 & 16322.2 & 16508.3 & 9038.4 & 86698 & 53876 \\
\hline Newton \& Haselton, 1981 (ii) & 11404.2 & 22134.7 & 11479.1 & 22134.7 & 11532.8 & 13733.3 & 61 & 13759.4 & 13002.7 & 8089.3 & 7812.2 & 8351.0 \\
\hline Hodges \& Spear, 1982(ii) & 10903.3 & 22711.6 & 10993.5 & 22711.6 & 11129.9 & 14219.5 & 14483.0 & 14250.4 & 14345.2 & 8285.0 & 7612.0 & 86325 \\
\hline Hodges \& Spear, 1982(II) & 11451.9 & 24036.0 & 11549.6 & 24036.0 & 11635.1 & 14065.5 & 15266.3 & 15017.6 & 15118.8 & 8682.1 & 79500 & 9056.3 \\
\hline Hodges \& Spear, 1982 (II) & 9992.5 & 19721.2 & 10064.7 & 19721.2 & 10176.9 & 12724.8 & 12942.1 & 12754.7 & 12829.4 & 7818.0 & 7271.0 & 8090.0 \\
\hline Ganguly \& Saxena, 1984 (ii) & 10887.3 & 24955.9 & 10933.0 & 249659 & 11192.3 & 16030.1 & 16917.1 & 16632.8 & 16663.2 & 9434.3 & 9064.6 & 9815.8 \\
\hline Ganguly \& Saxena, $1984(1)$ & 11434.9 & 26428.4 & 11485.1 & 26428.4 & 117761.7 & 17565.1 & 17861.2 & 17557.3 & 17589.9 & 9942.1 & 95140 & 10323.1 \\
\hline Hodges \& Crowley, 1985 (II) & 9979.3 & 21569.6 & 100149 & 21569.6 & 10228.2 & 14717.0 & 14946.2 & 14713.4 & 14738.2 & 8754.6 & 8456 & 9062.4 \\
\hline Hodges \& Crowley, 1985 (11) & 11853.3 & 24144.8 & 11942.4 & 24144.8 & 12273.1 & 15192.4 & 15457.4 & 15232.8 & 15346.1 & 9412.2 & 8728.7 & 9720.7 \\
\hline Hodges \& Crowley, 1985 (II) & 11661.9 & 23450.1 & 11722.8 & 23450.1 & 11857.2 & 14983.0 & 15247.7 & 150289 & 15120.1 & 8646.6 & 8051.8 & 89316 \\
\hline Hodges \& Crowley, 1965 (II) & 12567.7 & 25699.8 & 12664.5 & 25699.8 & 13030.1 & 16127.0 & 16409.4 & $161 \approx 9.7$ & 16291.9 & 10005.9 & 9271.0 & 10336.4 \\
\hline Hodges \& Crowley, 1985 (II) & 12351.5 & 249119 & 12416.4 & 24911.9 & 12559.6 & 15890.1 & 16172.2 & 15939.0 & 16036.2 & 9438.7 & 8504.9 & 9442.4 \\
\hline Hodges \& Crowley, 1985 (II) & 10941.9 & 21014.0 & $110\{3.4$ & 21014.0 & 11272.2 & 13690.1 & 13908.3 & 13723.8 & 13815.2 & 8907.6 & 8353.9 & 9158.1 \\
\hline Hodges \& Crowley, 1985 (Ii) & 10796.3 & 20515.5 & 10846.5 & 20515.5 & 10057.3 & 13534.5 & 13752.7 & 13572.3 & 13647.5 & 8310.2 & 7819.8 & 8545.2 \\
\hline Koziol, 1969 (II) & 12872.9 & 26501.0 & 12948.2 & 26501.0 & 13048.9 & 16471.4 & 16816.9 & 16528.3 & 16672.7 & 8986.0 & 8651.7 & 9227.8 \\
\hline Koziol, 1969 (i) & 12619.9 & 26739.5 & 12698.0 & 26739.5 & 12802.3 & 16348.2 & 16706.1 & 16407.2 & 1656.7 & 8592.8 & 8246.5 & 88434 \\
\hline Koziol, 1989(II) & 116559 & 22931.9 & 11758.0 & 22931.9 & 11841.0 & 14662.8 & 14947.6 & 14709.7 & 14828.7 & 8491.3 & 8215.7 & 8690.7 \\
\hline Koziol \& Newton, 1988 (ii) & 12555.8 & 23676.3 & 12630.1 & 23676.3 & 12850.0 & 14899.5 & 15183.6 & 14933.1 & 15091.7 & 9337.1 & 9000.8 & 9563.7 \\
\hline Kaziol \& Newton, 1988 (ii) & 13783.1 & 27357.3 & 13876.4 & 27357.3 & 14164.6 & 16529.8 & 16974.9 & 16670.0 & 16865.2 & 9901.6 & 9559.8 & 10180.1 \\
\hline
\end{tabular}

Tabela A5.3: Resultado dos cálculos geobarométricos, utilizando-se planilhas 1- de Rettinger (1994; dados não publicados) e II - de Reche e Martinez (1996). Símbolos: C = centros; e $B=$ bordas de pares de minerais. 


\section{ANEXo 6: Termogravimetria (TG) e Análise Térmica Diferencial (DTA) de Esmeraldas}

(Manuscrito de trabalho de autoria de G.A.A. Machado, A.M.L. da Silva e H.D. Schorscher, aceito para publicação na Revista da Associação Brasileira de Química). 
TERMOGRAVIMETRIA (TG) E ANÁLISE TÉRMICA DIFERENCIAL (DTA) EM ESMERALDAS DAS JAZIDAS DE CAPOEIRANA E BELMONT (MG)

\author{
GEYSA ANGELIS ABREU MACHADO ${ }^{1}$, ADÉLIA MARIA LIMA DA SILVA ${ }^{2}$, \\ HANS DANIEL SCHORSCHER ${ }^{1}$
}

${ }^{1}$ Departamento de Mineralogia e Petrologia - Instituto de Geociências - USP Rua do Lago, 562, Cidade Universitária. São Paulo - SP. CEP 05508-900 e-mail: geysa@usp.br

${ }^{2}$ Departamento de Química Fundamental - Instituto de Química - USP Av. Prof. Lineu Prestes, 748, Cidade Universitária. São Paulo - SP. CEP 05508-900 e-mail: amisilva@quim.iq.usp.br

SYNOPSIS - Machado, G. A. A., Silva, A. M. L. \& Schorscher, H. D. Thermogravimetry (TG) and differential thermal analysis (DTA) of emeralds from the Capoeirana and Belmont mines (MG).

\title{
ABSTRACT
}

Thermogravimetry (TG) and differential thermal analysis (DTA) are applied to various fields of mineral science. The present work illustrates the importance of the application of thermal analysis in the study of emeralds for the determination of water content and thermal behaviour. Genetically different emerald samples were investigated in this study.

Keywords: emerald, thermogravimetry, differential thermal analysis 


\section{INTRODUÇÃO}

A esmeralda é uma variedade verde de berilo, $\mathrm{Be}_{3} \mathrm{Al}_{2} \mathrm{Si}_{6} \mathrm{O}_{18}$, formada através da interação de fluidos ricos em berílio relacionados a granitos, com rochas metaultramáficas ricas em crômio. Sua estrutura cristalina consiste de anéis de tetraedros $\mathrm{SiO}_{4}$ e $\mathrm{BeO}_{4}$ ligados a octaedros $\mathrm{AlO}_{6}$, na razão Al:O:Si $=6: 3: 1$. . Os anéis de $\mathrm{SiO}_{4}$ estão empilhados formando uma série de canais estruturais (C.E.), abertos, paralelos ao eixo " $\mathrm{c}$ " do retículo cristalino. Moléculas de água e $\mathrm{CO}_{2}$ e íons de metais alcalinos podem ser aprisionados nestes canais. A água aprisionada pode ser de dois tipos: (a) tipo I, em coordenação estrutural, com orientação dos eixos H$\mathrm{H}$ dos dipolos paralela ao eixo "c" do cristal; (b) tipo II, em coordenação eletrolítica, com os eixos $\mathrm{H}-\mathrm{H}$ dos dipolos perpendiculares ao eixo "c" do cristal, pela ação do campo elétrico dos íns alcalinos associados (Figura 1) [1-2]. A água pode, ainda, ocorrer como "inclusões fluidas" (I.F.), representando pequenas porções de fluidos inclusos durante a cristalização das esmeraldas.

Machado [3] caracterizou, por espectroscopia de absorção na região do infravermelho, amostras de esmeraldas de diferentes associações genéticas (xistos, veios de quartzo e pegmatóides), determinando qualitativamente água do tipo // com álcalis associados e, subordinadamente, água do tipo $\mathrm{I}$.

O presente trabalho tem como objetivo determinar o teor de água nos C.E. e nas I.F. de esmeraldas, bem como avaliar a estabilidade térmica destes minerais, por Termogravimetria/Termogravimetria Derivada e Análise Térmica Diferencial (TG/DTG-DTA). Na literatura, existem excelentes artigos que relatam o uso das técnicas termoanalíticas no estudo de propriedades físicas e químicas de argilas e outros minerais [4-8], sem, no entanto, fazer referências às esmeraldas/ berilos. 


\section{MATERIAIS E MÉTODOS}

\section{Amostras de Esmeraldas}

Fragmentos de cristais centimétricos de esmeraldas, de diferentes ambientes petrogenéticos, tais como, xistos, veios de quartzo e veios pegmatóides, das jazidas de Capoeirana e Belmont (MG) foram selecionados e submetidos a moagem em cadinhos de cerâmica até granulometria silte $(<0,062 \mathrm{~mm}-2 \mu \mathrm{m})$.

Os códigos relatados no artigo são:

- $\mathrm{EX}=$ esmeraldas de xistos (BE-08 e G-260);

- $\mathrm{EVQ}=$ esmeraldas de veios de quartzo (B-21 e NE-34);

- $E V P=$ esmeraldas de veios pegmatóides (NE-31-01, 02 e 06);

- C.E. = canais estruturais;

- I.F. = inclusões fluidas.

Termogravimetria/Termogravimetria Derivada - Análise Térmica Diferencial (TG/DTG-DTA)

As curvas TG/DTG-DTA foram obtidas no sistema SDT 2960 da TA Instruments, sob atmosfera estática, no intervalo de temperatura de 25 a $1100^{\circ} \mathrm{C}$, utilizando-se razão de aquecimento igual a $10^{\circ} \mathrm{C} \mathrm{min}^{-1}$, massas de amostras da ordem de 14 a $20 \mathrm{mg}$ e $\alpha-\mathrm{Al}_{2} \mathrm{O}_{3}$ altamente sinterizada como material de referência (na quantidade de $\sim 18 \mathrm{mg}$ ). 


\section{RESULTADOS E DISCUSSÃO}

As composições isotópicas da água da esmeralda de diferentes associações foram medidas diretamente da água preservada como I.F. e nos C.E. do mineral (Machado et al., em preparação). A água liberada durante 0 aquecimento apresentou duas composições isotópicas distintas: abaixo de $800^{\circ} \mathrm{C}$ (sendo considerada como água derivada das I.F.) e acima de $800^{\circ} \mathrm{C}$ (sendo considerada como a água de formação, contida nos C.E. da esmeralda). Os teores de água obtidos por estas análises foram de, aproximadamente, 0,05 a $0,16 \%$ para a água das I.F. e de 1,08 a 2,16 \% para a água dos C.E. Estes resultados serão, no que se segue, comparados com os dados deste trabalho, obtidos por TG/DTG-DTA.

O comportamento térmico das esmeraldas de xistos (EX), de veios de quartzo (EVQ) e de veios pegmatóides (EVP), não mostraram diferenças significativas nas curvas TG/DTG-DTA (Figuras 2-7).

O processo térmico ocorreu em três etapas principais, evidenciadas por picos nas curvas DTG em $\sim 150^{\circ} \mathrm{C}$ (água livre), $\sim 300^{\circ} \mathrm{C}$ (água das I.F.) e $\sim 900^{\circ} \mathrm{C}$ (água dos C.E.). As curvas DTA para todas as amostras evidenciaram um pico endotérmico largo, no intervalo de 100 a $1100^{\circ} \mathrm{C}$ (com máximo em $\sim 860^{\circ} \mathrm{C}$ ), relativo ao processo de liberação de toda a água contida nas esmeraldas.

Os teores de água de umidade (água livre), das inclusões fluidas (I.F.) e dos canais estruturais (C.E.), dos três tipos genéticos de esmeraldas, determinados por TG/DTG-DTA, são apresentados na Tabela 1. Considerando que a força de aprisionamento e retenção da água nas esmeraldas cresce na ordem, água livre < água intersticial < água coordenada e, com base nos picos das curvas DTG, foram adotados os seguintes intervalos de temperatura para os cálculos de perda de 
massa: de 25 a $200^{\circ} \mathrm{C}$ para água livre (umidade), de 200 a $500^{\circ} \mathrm{C}$ para água das I.F. e de 500 a $1100^{\circ} \mathrm{C}$ para água dos C.E. (água coordenada).

As curvas TG indicaram perdas de massa de $\sim 1,95$ a $2,56 \%$ como somatórias da desidratação das I.F. e dos C.E.. Em média, as esmeraldas de xistos perderam $1,52 \%$, as de veios de quartzo $2,08 \%$ e as de veios pegmatóides $2,07 \%$ de água acima de $500^{\circ} \mathrm{C}$, considerada, principalmente, dos C.E.. Esses teores estão dentro da faixa daqueles obtidos pelas análises isotópicas.

\section{CONCLUSÕES}

A água de importância para a gênese das mineralizações ocorre, nas esmeraldas, como "inclusões fluidas" (IF) e nos canais estruturais (C.E.). A água nos C.E. representa uma pequena porção do fluido original, a partir do qual o mineral se formou; a água das I.F. pode sofrer contaminações posteriores e, assim, não necessariamente, indica a composição do fluido original. Determinados por TG/DTGDTA, os teores de água das I.F. e dos C.E., associados a outros dados termodinâmicos e metalogenéticos (tais como temperatura, quimismo e pressão parcial de fluidos no meio mineralizante, entre outros), poderão contribuir para a melhor compreensão da formação desse valioso mineral-gema e seus depósitos. A relação de proporcionalidade direta, simples, entre a pressão total na formação do mineral e seus teores de água nos C.E., conforme às vezes aceita na literatura [9], ainda não foi verificada. 


\section{AGRADECIMENTOS}

Os autores agradecem ao CNPq pelas bolsas concedidas, à Verônica Gabriel dos Santos pelo apoio técnico, à Maria de Fátima Vitória de Moura pelas sugestões e ao LATIG-IQ-USP.

\section{REFERÊNCIAS BIBLIOGRÁFICAS}

1 - WOOD, D. L. \& NASSAU, K. 1968. American Mineralogist., 53 (5-6), 777.

2 - AINES, R.D. \& ROSSMAN, G.R. 1984. American Mineralogist, 69, 319.

3- MACHADO, G. A. A. 1994. Dissertação de Mestrado, DMP/IG/USP.

4- LE CHATELIER, H. 1887. Bull. Soc. Franc. Mineral. Cryst., 10, 204.

5- PAULIK, F. \& ARNOLD, M. 1993. J. Thermal Anal., 39, 1079.

6- STOCH, L. 1997. J. Thermal Anal., 48, 121.

7- ABDEL-REHIM, A. M. 1997. J. Thermal Anal., 48, 177.

8 - DE, K., GERTH, K., BÜCHEL, G. \& HARTMANM, E. 1997. J. Thermal Anal., 48, 73.

9 - CORREIA NEVES, J.M., MONTEIRO, R.L.B.B., DUTRA, C.V. 1984. Revista Brasileira de Geociências, 14 (3), 137. 


\section{TABELA 1}

Dados termoanalíticos da água nas esmeraldas das Jazidas de Capoeirana e Belmont (MG)

\section{TG}

DTA

\begin{tabular}{cccccc}
\cline { 3 - 6 } Esmeraldas & Amostras & $\%$ Água & $\%$ Água & \% Água & $\mathbf{T}_{\mathbf{p}}\left({ }^{\circ} \mathrm{C}\right)$ \\
& Livre & I.F. & C.E. & \\
\hline G-260 & 0,06 & 0,38 & 1,57 & 864
\end{tabular}

Xistos

BE-08

0,14

0,37

1,46

859

Veios de

\section{B-21}

0,18

0,57

1,81

870

Quartzo

NE-34

0,21

2,35

871

NE-31-01

0,13

2,20

871

Veios

Pegmatóides

NE-31-02

0,12

0,58

1,92

867

NE-31-06

0,02

0,39

2,09

857

Agua: Livre $\left(\Delta T=25-200^{\circ} \mathrm{C}\right)$; Inclusóes fluidas, I. F. $\left(\Delta T=200-500^{\circ} \mathrm{C}\right)$; Canais estruturais,

C. $E .\left(\Delta T=500-1100^{\circ} \mathrm{C}\right) ; T_{p}$ : temperatura de pico na curva DTA 


\section{Lista de Figuras}

FIG.1 - Seção transversal esquemática do canal estrutural da esmeralda, mostrando os dois tipos de água e a posição dos íons alcalinos, associados a água do Tipo II, nas partes mais estreitas do canal [2].

FIG.2 - Curvas TG de esmeraldas de xistos (insert DTG).

FIG.3 - Curvas DTA de esmeraldas de xistos.

FIG.4 - Curvas TG de esmeraldas de veios de quartzo (insert DTG).

FIG.5 - Cunvas DTA de esmeraldas de veios de quartzo.

FIG.6 - Curvas TG de esmeraldas de veios pegmatóides (insert DTG).

FIG.7 - Curvas DTA de esmeraldas de veios pegmatoides. 

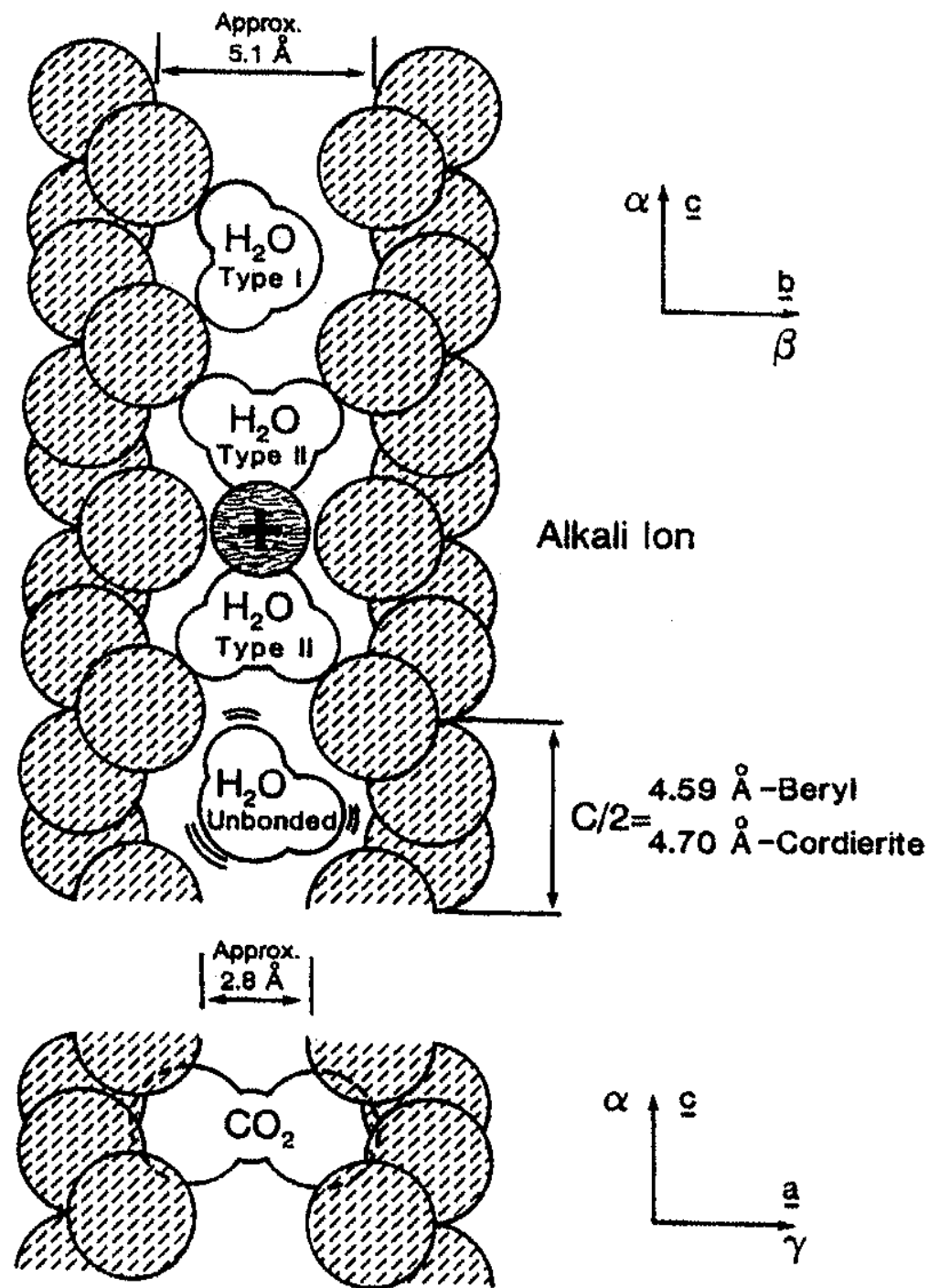

Figura 1: Seção transversal esquemática do canal estrutural da esmeralda, mostrando os dois tipos de água e a posição dos íns alcalinos, associados a água do Tipo II, nas partes mais estreitas do canal, segundo Aines \& Rossman [2]. 


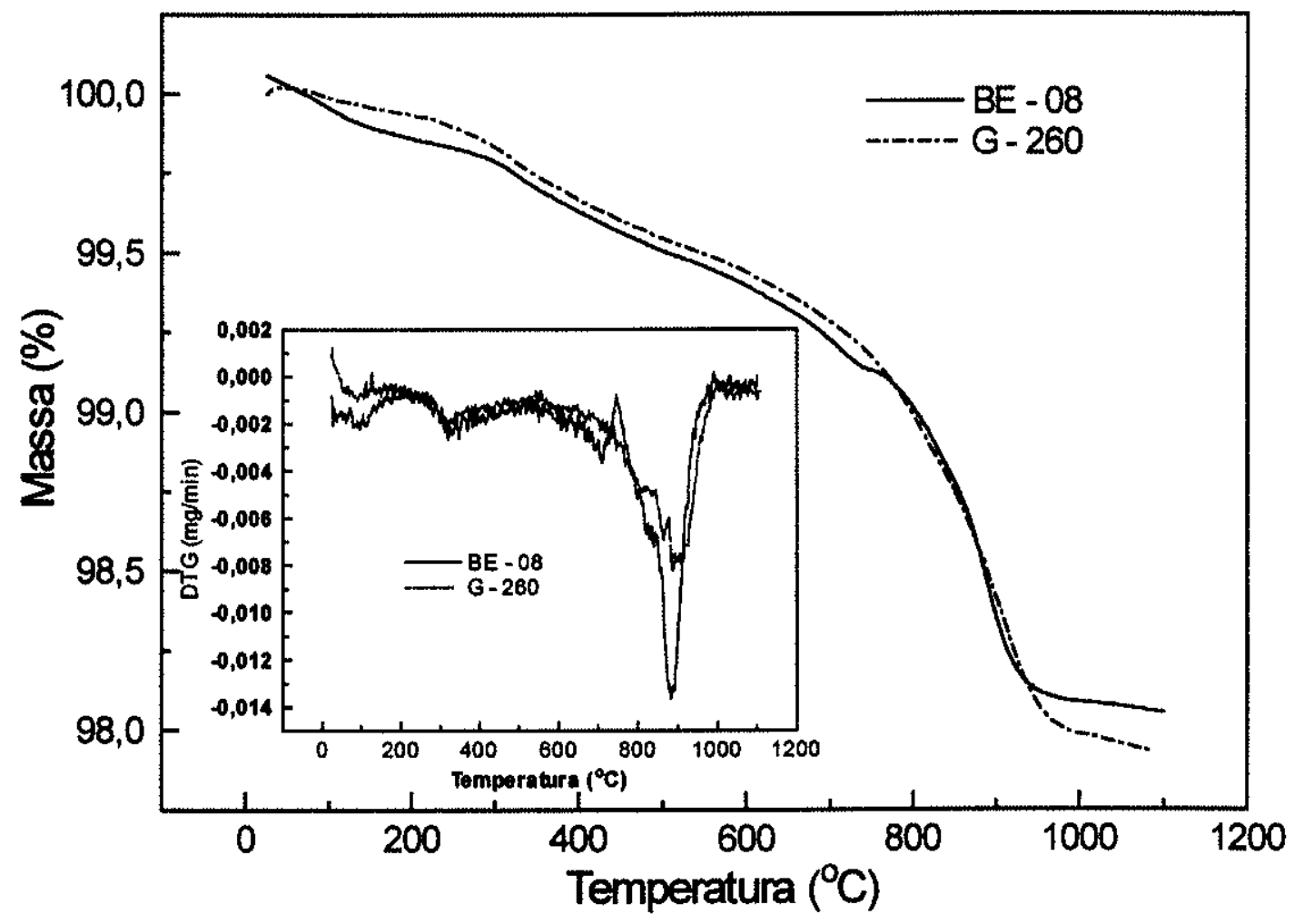

Figura 2: Curvas TG de esmeraldas de xistos (insert DTG). 


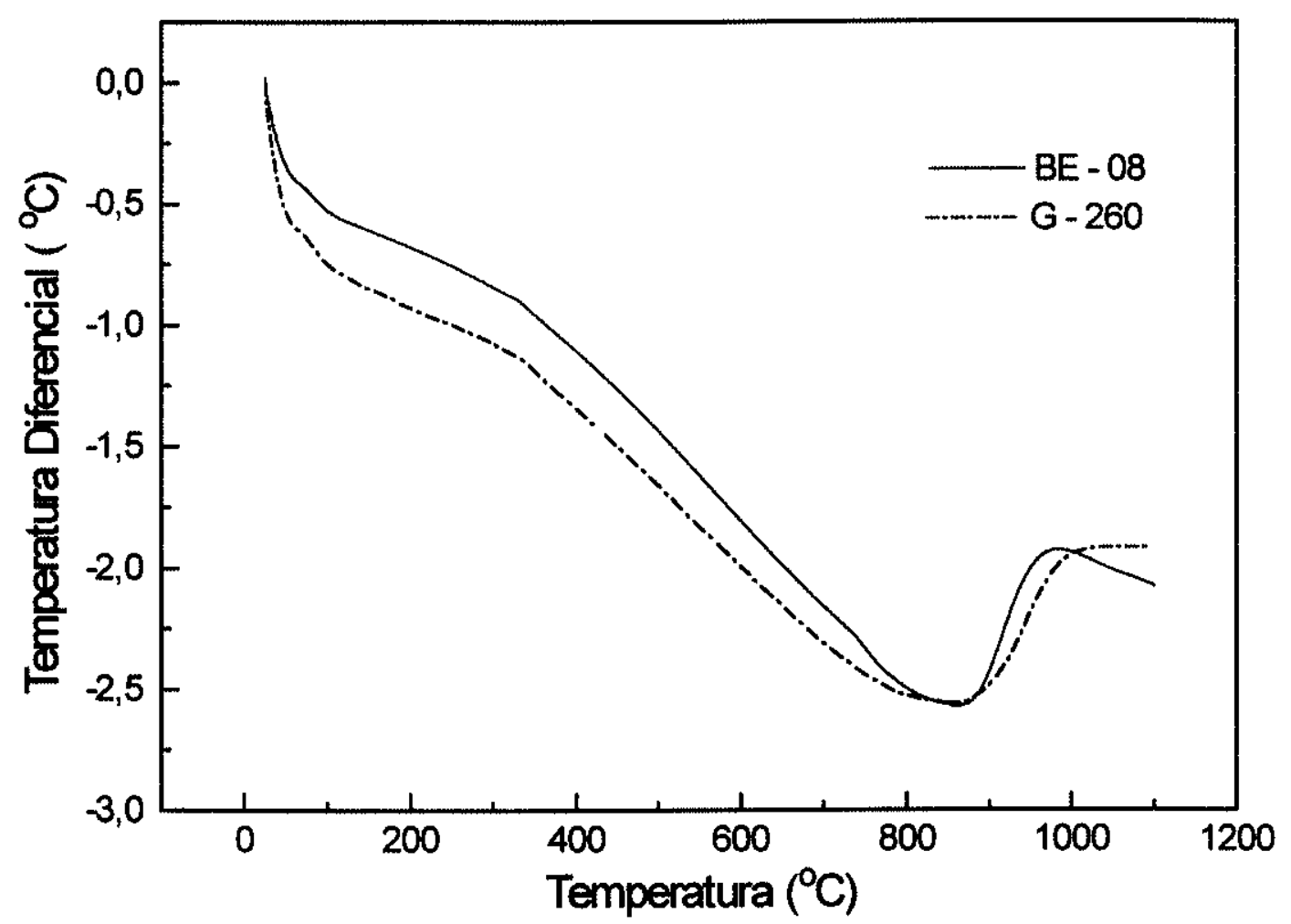

Figura 3: Curvas DTA de esmeraldas de xistos. 


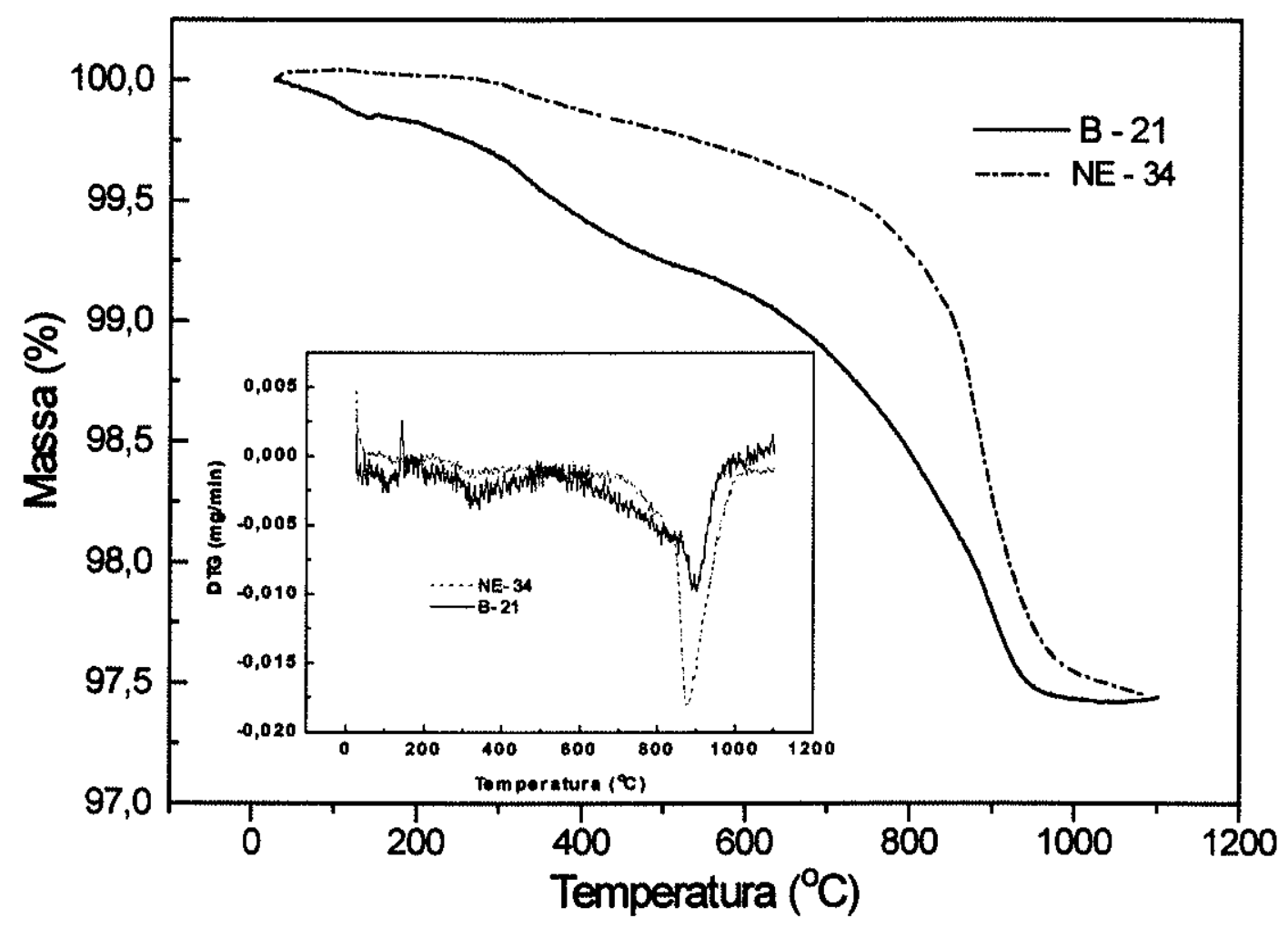

Figura 4: Curvas TG de esmeraldas de veios de quartzo (insert DTG). 


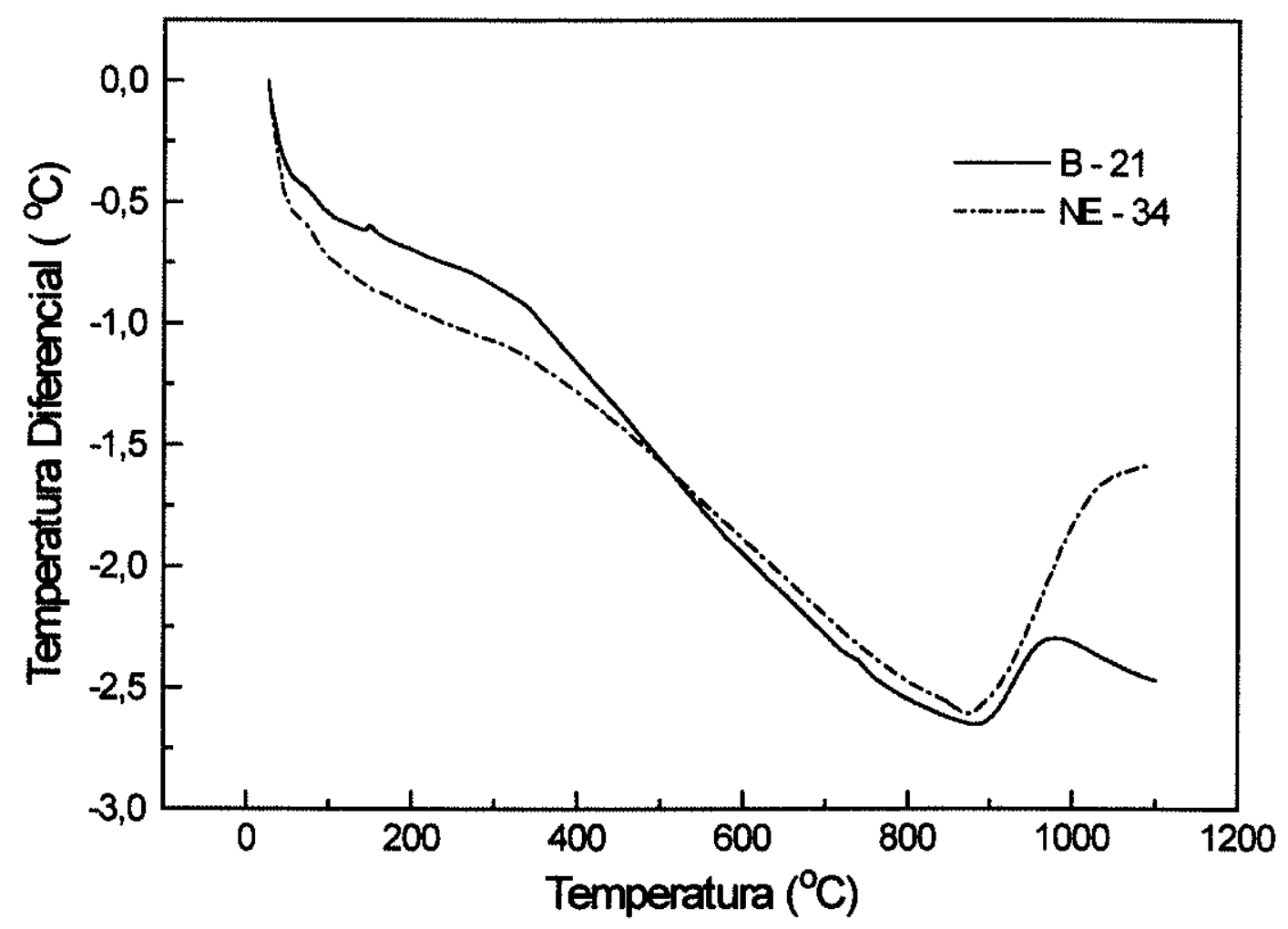

Figura 5: Curvas DTA de esmeraldas de veios de quartzo. 


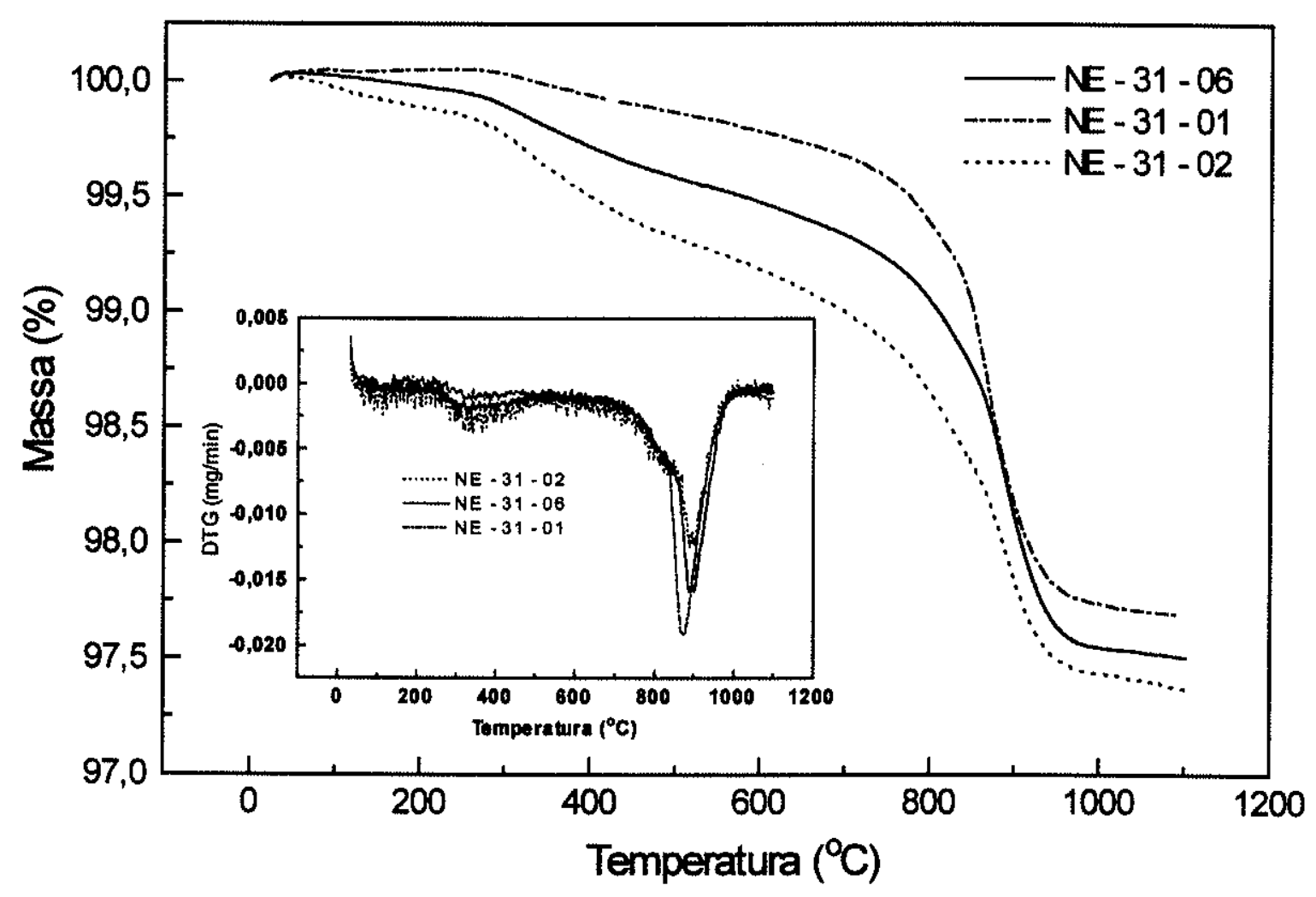

Figura 6: Curvas TG de esmeraldas de veios pegmatóides (insert DTG). 


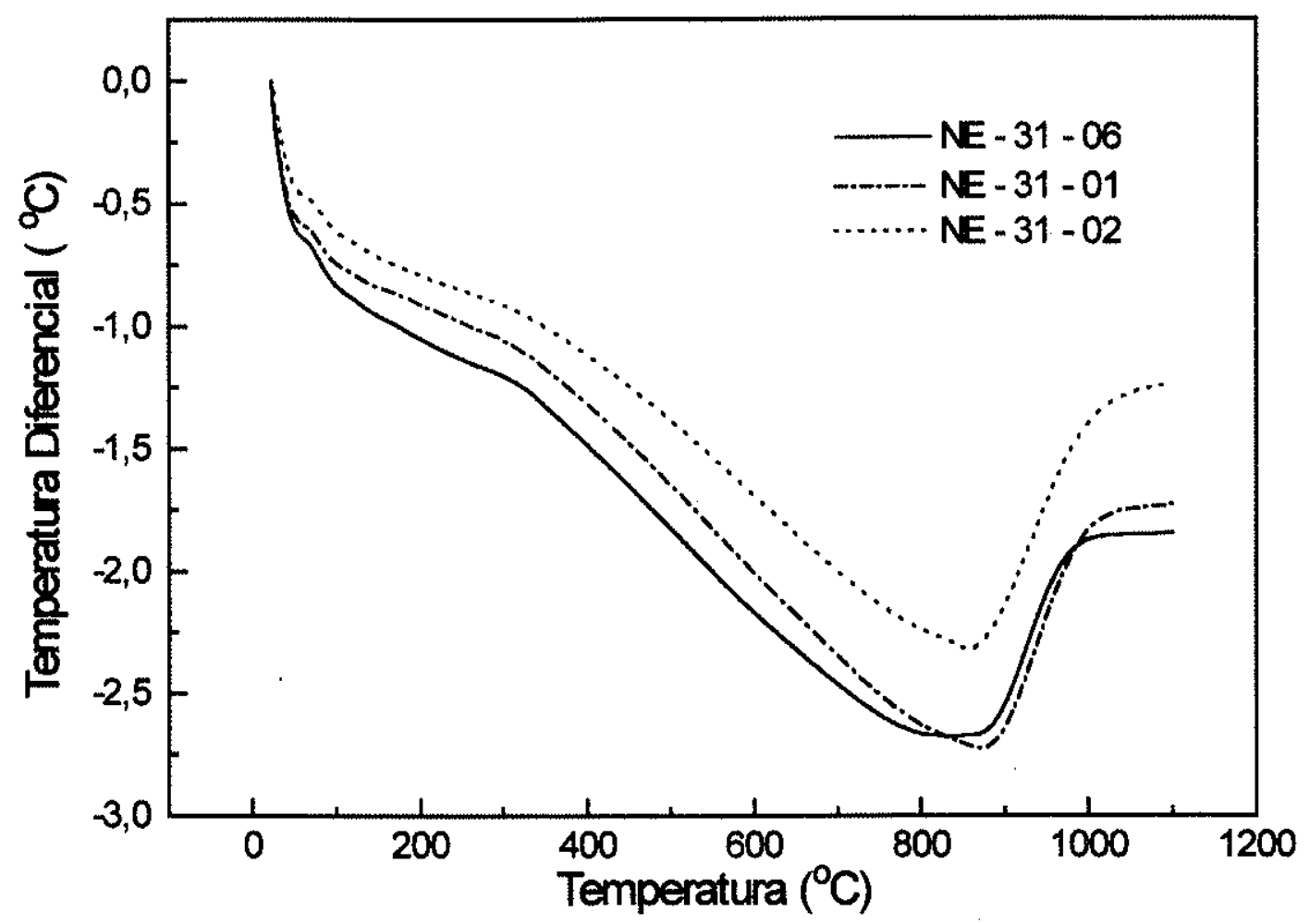

Figura 7: Curvas DTA de esmeraldas de veios pegmatoides. 